\title{
Het collectief actierecht voor consumentenorganisaties op het terrein van de algemene voorwaarden
}

Citation for published version (APA):

Mölenberg, L. J. H. (1995). Het collectief actierecht voor consumentenorganisaties op het terrein van de algemene voorwaarden. [Doctoral Thesis, Maastricht University]. Gouda Quint. https://doi.org/10.26481/dis.19950406lm

Document status and date:

Published: 01/01/1995

DOI:

10.26481/dis.19950406lm

Document Version:

Publisher's PDF, also known as Version of record

Please check the document version of this publication:

- A submitted manuscript is the version of the article upon submission and before peer-review. There can be important differences between the submitted version and the official published version of record.

People interested in the research are advised to contact the author for the final version of the publication, or visit the DOI to the publisher's website.

- The final author version and the galley proof are versions of the publication after peer review.

- The final published version features the final layout of the paper including the volume, issue and page numbers.

Link to publication

\footnotetext{
General rights rights.

- You may freely distribute the URL identifying the publication in the public portal. please follow below link for the End User Agreement:

www.umlib.nl/taverne-license

Take down policy

If you believe that this document breaches copyright please contact us at:

repository@maastrichtuniversity.nl

providing details and we will investigate your claim.
}

Copyright and moral rights for the publications made accessible in the public portal are retained by the authors and/or other copyright owners and it is a condition of accessing publications that users recognise and abide by the legal requirements associated with these

- Users may download and print one copy of any publication from the public portal for the purpose of private study or research.

- You may not further distribute the material or use it for any profit-making activity or commercial gain

If the publication is distributed under the terms of Article $25 \mathrm{fa}$ of the Dutch Copyright Act, indicated by the "Taverne" license above, 
Het collectief actierecht voor

consumentenorganisaties op het terrein

van de algemene voorwaarden 


\section{Het collectief actierecht $v$ consumentenorganisaties $o_{\mathrm{p}}$
terrein van de algemene voor}

\section{PROEFSCHRIFT}

ter verkrijging van de graad van docto aan de Rijksuniversiteit Limburg te Maast ${ }_{\text {richt }}$ op gezag van de rector magnificus, prof.mr M.J. Cohen, volgens het besluit van het College van Dekanen, in het openbaar te verdedigen op donderdag 6 aprill 1995 om 16.00 uur

door

Leonardus Johannes Henricus Mölenberg

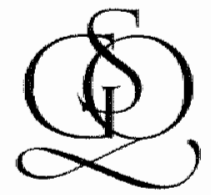

Gouda Quint bv

(S. Gouda Quint - D. Brouwer en Zoon)

Arnhem 
Promotores: Prof. mr G.J. Rijken

Prof. mr J.L.M. Elders

Leescommissie:

Prof. dr G.R. de Groot (voorzitter)

Prof. mr E.H. Hondius (Universiteit Utrecht) Prof. dr G.W. Mincke 


\section{Voorwoord}

Het schrijven van een proefschrift is een eenzame aangelegenheid. Meer dan eens kwam bij mij de gedachte op, dat $i k$, voor de keuze geplaatst om het nog eens te doen, zeker zou weigeren. Deze keuzemogelijkheid deed zich echter niet voor en nu het resultaat er ligt, stemt dat uiteraard tot tevredenheid.

Er is een aantal mensen die ik graag zou willen bedanken voor de steun die ik van hen kreeg bij het schrijven van dit boek. Allereerst zijn dat mijn promotores, prof. mr G.J. Rijken en prof. mr. J.L.M. Elders, voor hun nimmer aflatend geduld en hun stimulerende begeleiding. Voorts de leden van de beoordelingscommissie, prof. mr G.R. de Groot, prof. mr E.H. Hondius en prof. dr. G.W. Mincke. Dan zijn er nog mijn collega's van het "Iens Verburgh Instituut voor Consumentenrecht" (IVIC). De sfeer binnen deze sectie is zeer prettig en stimulerend, hetgeen, mede omdat zij geregeld bereid waren om mij vrij te houden van de werkzaamheden van het instituut, zeker heeft bijgedragen aan de succesvolle afronding van dit werk. Ine Corstjens, secretaresse van het IVIC en de vakgroep privaatrecht, verdient bijzondere lof voor de zorg die zij heeft besteed aan het "camera-ready" maken van het manuscript. Een woord van dank is eveneens op zijn plaats voor Sebastian Krause en mijn kamergenoot Harald Quaedvlieg voor hun onschatbare hulp bij de vertaling van de samenvatting. Er is én collega die ik apart wil vermelden. Dat is Sjaak Verstappen. Vanaf het eerste moment tot aan de voltooiing van mijn proefschrift heeft hij kritisch meegedacht en vond ik bij hem steeds een gewillig oor. Zijn bereidheid om hele middagen en avonden met mij te discussiëren zijn een enorme stimulans voor mij geweest. Sjaak ik ben je daarvoor buitengewoon dankbaar.

Aparte vermelding verdienen ook Els en Guus. Samenleven met iemand die een proefschrift schrijft, is niet altijd even leuk. Lieve Els en Guus bedankt voor jullie steun en geduld.

Het manuscript van dit boek werd in de nazomer van 1994 voltooid. Na dit tijdstip gepubliceerde wetgeving, rechtspraak en literatuur kon slechts incidenteel worden verwerkt.

Léon Mölenberg 



\section{Inhoud}

Lijst van afkortingen

\section{INLEIDEND GEDEELTE}

Hoofdstuk 1

Inleiding

1.1 Algemeen 3

1.2 Doelstelling van het onderzoek 5

1.3 Afbakening van het onderwerp 6

1.4 Onderzoeksmethode 7

1.5 Terminologie 11

1.5.1 Algemene voorwaarden 11

$\begin{array}{lll}1.5 .2 & \text { Consument } & 14\end{array}$

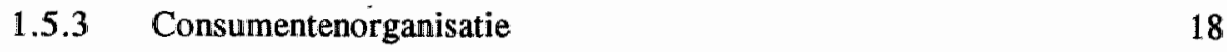

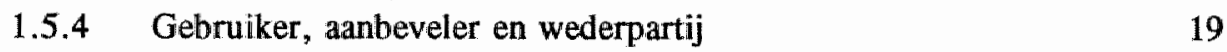

$\begin{array}{ll}\text { 1.5.5 Rechterlijke controle op algemene voorwaarden } & 20\end{array}$

$\begin{array}{ll}\text { 1.5.5.1 Aanvaardings- en gebondenheidstoets } & 21\end{array}$

$\begin{array}{ll}\text { 1.5.5.2 Informatietoets } & 23\end{array}$

1.5.5.3 Inhoudstoets, concrete en abstracte inhoudstoetsing 23

1.5.6 Individueel belang, groepsbelang, algemeen belang,

$\begin{array}{ll}\text { 1.5.7 Individuele actie, collectieve actie en actierecht } & 27\end{array}$

$\begin{array}{lll}1.6 & \text { Opzet van het onderzoek } & 29\end{array}$ 


\section{Hoofdstuk 2}

Algemene aspecten van het verschijnsel algemene woorwaarden en de procesrechtelijke positie van de consument op dit terrein

2.1 Inleiding

2.2 Algemene voorwaarden

2.2.1 Ontstaansgeschiedenis van algemene voorwaarden

2.2.2 Functie van het gebruik van algemene voorwaarden

2.2.3 Omvang van het gebruik van algemene voorwaarden

2.3 De juridische status van algemene voorwaarden in het burgerlijk recht

2.3.1 De beginselen van het contractenrecht, het klassieke contractsmodel

2.3.2 Vermaatschappelijking van het privaatrecht

2.3.3 De theoretische rechtvaardiging van de verbindende kracht van algemene voorwaarden

2.3.3.1 De aanvaarding van de gelding van algemene voorwaarden

2.3.3.2 Gebondenheid aan algemene voorwaarden met een onredelijk bezwarende inhoud

$2.4 \quad$ Individuen en organisaties als partijen in het burgerlijk proces

2.4.1 Beginselen van het burgerlijk procesrecht

2.4.2 Ongelijke kansen in het burgerlijk proces

2.4.2.1 Sociaal-economische ongelijkheid en procesrechtelijke uitgangspunten

24.2.2 Ongelijksoortigheid van partijen; individuen versus organisaties

2,4.2,3 Repeat Players versus One Shotters

2.4.2.4 De niet-unieke en asymmetrische relatie

2.4.3 De consument als partij in het burgerlijk proces

2.5 Nadelen voor de consument van het gebruik van algemene voorwaarden en de beschermingsbehoefte van de consument

2.5.1 Onredelijk bezwarende inhoud van algemene voorwaarden

2.5.2 Snelle primaire gebondenheid

2.5.3 Kennisname van de inhoud van algemene voorwaarden

2.5.4 Versluiering van de inhoud van algemene voorwaarden

2.5.5 Het ontbreken van individuele invloed van de consument

2.5.6 Toegang tot de rechter en procesrechtelijk positie 82

2.6 Behoefte aan rechtsbescherming bij de consument 


\section{Hoofdstuk 3}

Rechtspraak op het terrein van de algemene voorwaarden vobr de totstandkoming van de wet algemene voorwaarden

$\begin{array}{lll}3.1 & \text { Inleiding } & 85\end{array}$

3.2 Toepasselijkheid $\quad 85$

3.2.1 Uitdrukkelijke of stilzwijgende partijbedoeling 85

3.2.2 Gebruik en bestendig gebruikelijk beding $\quad 88$

$\begin{array}{lll}3.3 & \text { Versluiering van de contractsinhoud } & 88\end{array}$

$\begin{array}{lll}3.4 & \text { Inhoudstoetsing } & 89\end{array}$

$\begin{array}{ll}3.4 .1 & \text { Uitleg van algemene voorwaarden }\end{array}$

$\begin{array}{ll}3.4 .2 & \text { Inhoudstoetsing van algemene voorwaarden }\end{array}$

3.5 Beperkingen van de rechterlijke controle op algemene voorwaarden 97

$\begin{array}{lll}3.5 .1 & \text { Toegang tot de burgerlijke rechter } & 97\end{array}$

3.5.1.1 Consumenten $\quad 98$

3.5.1.2 Consumentenorganisaties 99

3.5.2 Beperkte reikwijdte van de rechtspraak inzake algemene
voorwaarden

3.5.3 Het ontbreken van preventieve werking van de rechtspraak op het terrein van de algemene voorwaarden 103

$\begin{array}{ll}3.6 & \text { Particuliere geschillenbeslechting } \\ 3.6 .103\end{array}$

$\begin{array}{ll}\text { 3.6.1 Branchegeschillencommissies } & 104\end{array}$

3.6.2 Erkende geschillencommissies en de Stichting Geschillencommissies voor Consumentenzaken 104

3.6.3 Voor- en nadelen van geschillencommissies vergeleken met de burgerlijke rechter

Hoofdstuk 4

De wetgever en algemene voorwaarden; het collectief actierecht voor consumentenorganisaties

$\begin{array}{lll}4.1 & \text { Inleiding } & 109\end{array}$

4.2 Beleidsinstrumenten van de centrale overheid 110

4.2.1 Zelfregulering 111

4.2.2 Zelfregulering als instrument in het consumentenbeleid van de overheid

4.3 Beleidsdoelen en beleidsinstrumentenkeuze van de centrale overheid op het terrein van de algemene voorwaarden

4.3.1 Beleidsdoelen van de centrale overheid op het terrein van de algemene voorwaarden 


\subsubsection{Beleidsinstrumentenkeuze van de overheid ter}

bescherming van het consumentenbelang op het terrein van de algemene voorwaarden

4.4 Invulling van de gekozen beleidsinstrumenten ter bescherming van het consumentenbelang op het terrein van de

algemene voorwaarden

4.4.1 Wetgeving

4.4.2 Zelfregulering

4.4.3 Subsidiëring

4.4.4 Het optreden van de overheid als moderator

4.4.5 Voorlichting

4.5 Knelpunten in de algemene voorwaardenproblematiek die door de gekozen beleidsinstrumenten worden bestreken

4.6 Collectief actierecht voor consumentenorganisaties op het terrein van de algemene voorwaarden als ongelijkheidscompensatie 130

4.6.1 Collectieve procesbevoegdheid van consumentenorganisaties in de Nederlandse wetgeving vór de inwerkingtreding van afdeling 6.5.3 BW

4.6.2 Collectieve procesbevoegdheid op het terrein van de algemene voorwaarden

4.6.3 Collectieve procesbevoegdheid in andere Nederlandse wetgeving

4.6.4 Het collectief actierecht voor consumentenorganisaties op het terrein van de algemene voorwaarden als ongelijkheidscompensatie

\section{DE WETTELIJKe REgELING VAN DE PROBLEMATIEK VAN DE ALGEMENE VOORWAARDEN}

\section{Hoofdstuk 5}

De wet algemene voorwaarden

5.1 Inleìding

5.1.1 Ontstaansgeschiedenis van de Wet algemene voorwaarden

5.1.2 Uitgangspunten van de wettelijke regeling

5.1.3 Plaats van de wettelijke regeling

5.1.4 Indeling van de Wet algemene voorwaarden

5.2.1 Bereik van de wet

5.2.1.1 Het materiële bereik 
5.2.3 Het toepasselijkheidsvraagstuk, de snelle primaire gebondenheid aan algemene voorwaarden

5.2.4 Informatieplicht van de gebruiker

5.2.4.1 Terhandstelling

5.2.4.2 Mededeling

5.2.4.3 Toezending redelijkerwijs onmogelijk

5.2.4.4 Bewijs

5.2.5 De inhoudstoetsing

5.2.5.1 Uitlegregels voor algemene voorwaarden

5.2.5.2 De open norm van artikel 6:233 sub a BW

5.2.5.3 De lijsten van de artikelen 6:236 en 6:237 BW

5.2.5.4 De Haagse lijst, artikel 6:243 BW

5.2.6 Verjaring en verval

5.2.7 Internationale aspecten

$\begin{array}{ll}\text { 5.2.7.1 Het EEG-verbintenissenverdrag } & 227\end{array}$

$\begin{array}{ll}\text { 5.2.7.2 Handelstransacties } & 228\end{array}$

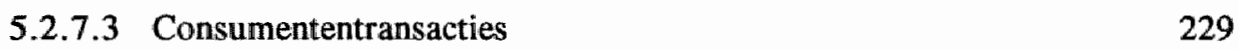

5.2.7.4 Forumkeuze 231

5.3 Collectieve actie en procesrechtelijke bepalingen 234

5.3.1 De hoofdvordering 236

$\begin{array}{ll}\text { 5.3.2 De toetsnorm } & 239\end{array}$

$\begin{array}{ll}\text { 5.3.2.1 Abstracte inhoudstoets } & 239\end{array}$

$\begin{array}{ll}\text { 5.3.2.2 Strijd met een dwingende wetsbepaling } & 247\end{array}$

$\begin{array}{lll}5.3 .3 & \text { De bevoegde organisaties } & 250\end{array}$

5.3.4 Instemming van belangenorganisaties met het gebruik van bedingen in algemene voorwaarden $\quad 258$

$\begin{array}{ll}\text { 5.3.5 Overlegverplichting } & 260\end{array}$

$\begin{array}{ll}\text { 5.3.6 Algemene ontvankelijkheidsvereisten } & 270\end{array}$

$\begin{array}{lll}\text { 5.3.7 De geadresseerden van de vorderingen } & 275\end{array}$

$\begin{array}{lll}\text { 5.3.8 De nevenvorderingen } & 279\end{array}$

5.3.8.1 Verbod van gebruik of aanbeveling 280

$\begin{array}{ll}\text { 5.3.8.2 Gebod tot herroeping van de aanbeveling } & 287\end{array}$

$\begin{array}{ll}\text { 5.3.8.3 Publikatie van de uitspraak } & 289\end{array}$

$\begin{array}{ll}\text { 5.3.8.4 Dwangsom } & 291\end{array}$

$\begin{array}{lll}5.3 .9 & \text { Verjaring } & 295\end{array}$

$\begin{array}{ll}\text { 5.3.10 De rechtsgang } & 297\end{array}$

$\begin{array}{ll}\text { 5.3.10.1 De bevoegde rechter } & 298\end{array}$

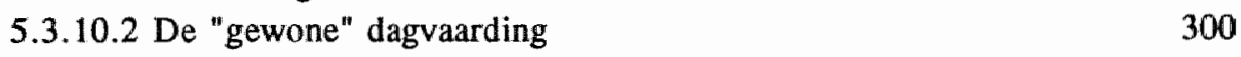

$\begin{array}{ll}\text { 5.3.10.3 De collectieve dagvaarding } & 302\end{array}$ 
Verstek en verzet 308

Vaeging, tussenkomst en derdenverzet $\quad 312$

$\begin{array}{ll}4 \text { Voorlopige voorziening } & 315\end{array}$

$\begin{array}{ll}\text { De uitspraak } & 317\end{array}$

Hoger beroep en cassatie $\quad 332$

q De kosten van de procedure $\quad 334$

$\begin{array}{ll}\text { Overheidssubsidie } & 337\end{array}$

De verhouding tussen artikel 6:240 BW en artikel 3:305a BW 339

pik 6

isetz zur Regelung des Rechts der allgemeinen

fsbedingungen"

Inleiding $\quad 345$

Ontstaansgeschiedenis $\quad 346$

De doelstelling en verwachtingen van de wet 353

Plaats en indeling van de wet $\quad 356$

Materieelrechtelijke bepalingen $\quad 357$

$\begin{array}{ll}\text { Bereik van de wet } & 357\end{array}$

$\begin{array}{ll}\text { Het materiële bereik } & 357\end{array}$

2 Het personele bereik 366

Het toepasselijkheidsvraagstuk $\quad 367$

I Verwijzing naar de toepasselijke algemene voorwaarden $\quad 369$

2. Informatieplicht van de gebruiker ten aanzien van de inhoud 371

3 Aanvaarding van de gelding $\quad \therefore \quad 372$

4 De gevolgen van niet-toepasselijkheid 374

De inhoudstoetsing $\quad 376$

I. Uitlegregels voor algemene voorwaarden 376

2 De open norm van \& 9 AGBG $\quad 379$

3 De lijsten van \& 10 en 11 AGBG 394

$\begin{array}{ll}\text { Internationale aspecten } & 397\end{array}$

Procesrechtelijke bepalingen $\quad 400$

De vorderingen $\quad 403$

1 De hoofdvorderingen 404

2 De nevenvorderingen $\quad 409$

$\begin{array}{ll}\text { De toetsnorm } & 412\end{array}$

1 De uitleg van algemene voorwaarden in de abstracte procedure 412

2 Abstracte inhoudstoets $\quad 414$

3 Strijd met een dwingende wetsbepaling 416

$\begin{array}{ll}\text { De bevoegde organisaties } & 418\end{array}$ 
6.3.4 De geadresseerden van de vorderingen

6.3.5 Declaratoire uitspraak ten behoeve van de gebruiker of aanbeveler 424

6.3.6 Verjaring

425

6.3.7 De rechtsgang

6.3.7.1 De Abmahnung

6.3.7.2 De bevoegde rechter

6.3.7.3 Voorlopige voorziening

434

6.3.7.4 Het horen van toezichthoudende instanties

436

6.3.7.5 De waarde van het geschil 436

6.3.7.6 Het vonnis $\quad 438$

6.3.7.7 Hoger beroep, bezwaar, cassatie en verzet 443

6.3.7.8 De kosten van de procedure 444

Hoofdstuk 7

De wet algemene voorwaarden vergeleken met het AGB-Gesetz

7.1 Inleiding

7.2 Materieelrechtelijke bepalingen

7.2.1 Definitie van het begrip algemene voorwaarden en het toepassingsbereik van de wet

7.2.2 De gebondenheid en de informatieplicht

7.2.3 Verrassende bedingen

7.2.4 Leesbaarheid en duidelijkheid

7.2.5 Uitlegregels

7.2.6 Inhoudstoets en toetsnorm 453

7.2.7 De lijsten 456

7.2.8 Nietigheid versus vernietigbaarheid 456

7.2.9 De kosten van de procedure 458

$\begin{array}{lll}7.3 & \text { Procesrechtelijke bepalingen } & 459\end{array}$

7.3.1 De bevoegde organisaties $\quad 459$

$\begin{array}{lll}7.3 .2 & \text { De toetsnorm } & 459\end{array}$

$\begin{array}{lll}\text { 7.3.3 De vorderingen } & 460\end{array}$

7.3.4 De geadresseerden van de vorderingen 461

7.3.5 Overlegverplichting versus Abmahnung 461

7.3.6 De rechtsgang 463

7.3.7 De werking van het verbodsvonnis 464

7.3.8 De registratie van collectieve procedures en vonnissen 464

7.3.9 De kosten van de procedure 465

7.4 Conclusie 465 
III PRAKTISCHE ERVARINGEN VAN CONSUMENTENORGANISATIES MET HET COLLECTIEF ACTIERECHT ALS BEDOELD IN 13 AGB-GESETZ

\section{Hoofdstuk 8}

De rol van de Duitse consumentenorganisaties in de praktijk van het AGB-Gesetz

8.1 Inlleiding

8.2 Consumentenorganisaties in Duitsland

8.2.1 Verbraucherschutzverein e.V.

8.2.2 Verbraucherzentrale Baden-Württemberg e.V.

8.2.3 Andere actieve consumentenorganisaties

8.3 De uitoefening van het klachtrecht als bedoeld in $\$ \$ 13$ e.v. AGBG door consumentenorganisaties

8.3.1 De beginjaren

8.3.2 De gerechtelijke handhaving in de periode 1977-1992

8.3.3 Het aandeel in de AGB-controle van de meest actieve consumentenorganisaties van 1977-1992

8.3.3.1 VSV Berlijn

8.3.3.2 Verbraucherzentrale Baden-Württemberg

8.3.3.3 Andere actieve consumentenorganisaties

\section{Hoofdstuk 9}

Handhavingsprocedure en strategie

9.1 Inleiding

9.2 Het collectieve rechtshandhavingsmodel op het terrein van de algemene voorwaarden

$\begin{array}{lll}9.3 & \text { Opsporingsactiviteiten en strategie : } & 502\end{array}$

9.3.1 De VSV

9.3.2 Verbraucherzentrale Baden-Württemberg
504

$\begin{array}{ll}9.4 \text { Abmahnung } & 504 \\ & 506\end{array}$

$\begin{array}{ll}\text { 7.4.1 De VSV } & 506\end{array}$

$\begin{array}{ll}\text { 7.4.2 De Verbraucherzentrale Baden-Württemberg } & 506 \\ & 509\end{array}$

$\begin{array}{ll}7.5 & \text { Voorlopige voorziening } \\ 512\end{array}$

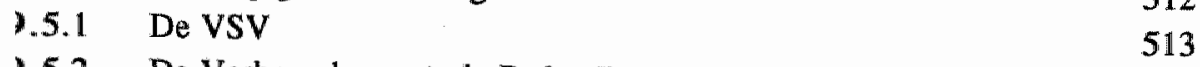

$\begin{array}{ll}\text { 1.5.2 De Verbraucherzentrale Baden-Württemberg } & 513\end{array}$

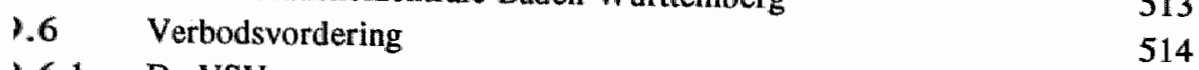

$\begin{array}{lll}\text { 1.6.1 De VSV } & 514 \\ & 514\end{array}$ 
9.6.2 Verbraucherzentrale Baden-Württemberg 516

$\begin{array}{lll}9.7 & \text { Gebodswordering } & 518\end{array}$

$\begin{array}{lll}9.8 & \text { Vertragsstrafeklage } & 518\end{array}$

$\begin{array}{lll}9.9 & \text { Ordnungsgeldverfahren } & 519\end{array}$

9.10 Registratie als bedoeld in \& 20 AGBG $\quad 519$

Hoofdstuk 10

Toepassingsgebieden en spreiding van de AGB-rechtshandhaving

$10.1 \quad$ Inleiding

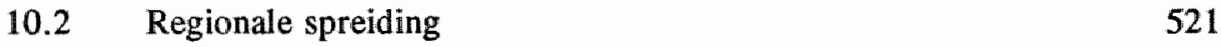

10.3 Branchegewijze spreiding $\quad 522$

10.4 Spreiding naar soort onredelijk bezwarend beding $\quad 525$

10.4.1 De beginjaren 1977-1983 526

10.4.2 Recentere cijfers over de spreiding naar soort onredelijk bezwarend beding $\quad 533$

$\begin{array}{lll}10.5 & \text { Conclusies } & 542\end{array}$

Hoofdstuk 11

Knelpunten in de collectieve AGB-rechtshandhaving door consumentenorganisaties

$\begin{array}{lll}11.1 & \text { Inleiding } & 545\end{array}$

11.2 De ervaringen met het AGB-Gesetz 546

11.2.1 De algemene regels van de $\$ \S 1$ tot en met 7 AGBG 547

11.2.2 De inhoudscontrole van de $\$ \S 9$ tot en met 11 AGBG 549

11.2.3 De procesrechtelijke voorschriften van de $\S 13$ tot en met 22 AGBG 551

11.3 De zuiverende werking van het AGB-Gesetz 553

11.4 Effectiviteit van het collectieve actierecht als middel ter compensatie van de ongelijkheid van partijen 


\section{NIEUWE WEGEN}

Hoofdstuk 12

De Duitse ervaringen vertaald naar de Nederlandse situatie

12.1 Inleiding

563

12.2 Te verwachten effectiviteit van de Wet algemene voorwaarden

12.2.1 De verwachte directe individuele bescherming van de Wet algemene voorwaarden

12.2.2 De aanpassing door gebruikers en aanbevelers van hun algemene voorwaarden aan de nieuwe wetgeving

12.2.3 Te verwachten effectiviteit van het collectieve actierecht

Hoofdstuk 13

Slotbeschouwing en suggesties

Samenvatting

Zusammenfassung

Wet algemene voorwaarden

Gesetz zur Regelung des Rechts der Allgemeinen Geschäftsbedingungen (AGB-Gesetz) vom 9. 12. 1976 (BGB1. I 3317)

Lijst van verkort aangehaalde literatuur 


\section{Lijst van afkortingen}

$\begin{array}{ll}\text { AA } & \text { Ars Aequi } \\ \text { Abs. } & \text { Absatz } \\ \text { AbzG } & \text { Abzahlungsgesetz } \\ \text { AcP } & \text { Archiv für die civilistische Praxis } \\ \text { AGB } & \text { Allgemeine Geschäftsbedingungen } \\ \text { AGBE } & \text { Allgemeine Geschäftsbedingungen Entscheidung } \\ \text { AGBG } & \text { Gesetz zur Regelung des Rechts der Allgemeinen Geschäftsbe- } \\ & \text { dingungen } \\ \text { AGV } & \text { Arbeitsgemeinschaft der Verbraucher } \\ \text { A-G } & \text { Advocaat-Generaal } \\ \text { AMvB } & \text { Algemene Maatregel van Bestuur } \\ \text { ANVR } & \text { Algemene Nederlandse Vereniging van Reisbureaus } \\ \text { AnwBl } & \text { Anwaltsblatt } \\ \text { ASJ } & \text { Arbeitsgemeinschaft sozialdemokratischer Juristen } \\ \text { Aufl. } & \text { Auflage } \\ \text { BB } & \text { Betriebs Berater } \\ \text { Bb } & \text { Nieuwsbrief Bedrijfsjuridische berichten } \\ \text { BGB } & \text { Bürgerliches Gesetzbuch } \\ \text { BGBI } & \text { Bundesgesetzblatt } \\ \text { BGH } & \text { Bundesgerichtshof } \\ \text { BGHZ } & \text { Entscheidungen des Bundesgerichtshof in Zivilsachen } \\ \text { BJM } & \text { Bundesjustizminister } \\ \text { BKA } & \text { Bundeskartellamt } \\ \text { BMJ } & \text { Bundesministerium der Justiz } \\ \text { BMWi } & \text { Bundesministerium für Wirtschaft } \\ \text { BRat } & \text { Bundesrat } \\ \text { BT } & \text { Bundestag } \\ \text { BW } & \text { Burgerlijk Wetboek } \\ \text { BW(oud) } & \text { Oud Burgerlijk Wetboek } \\ \text { CCA } & \text { Commissie voor consumentenaangelegenheden } \\ \text { Ch. } & \text { Chapter } \\ & \end{array}$


casu quo

Der Betrieb

3

dissertatie

r Deutscher Juristentag

I Deutsche Mark

V Deutsche Reisebüro-Verband e.V.

r.z. dat will zeggen

etcetera

G Europese Economische Gemeenschap

$V$ EEG-verbintenissenverdrag

X EEG-executieverdrag

Europese Gerneenschap

f. Einführung

l. Einleitung

Europese Unie

eingetragener Verein

en verder

Eindverslag van de vaste Commissie voor Justitie (Tweede Kamer)

I Verslag van het mondeling overleg, tevens Eindverslag van de Bijzondere Commissie (Eerste Kamer)

Europese Gemeenschap

-Com Commissie van de Europese Gemeenschappen

B Gesetz gegen Wettbewerbsbeschränkungen

G Gerichtsverfassungsgesetz

W Gewijzigd Voorstel van Wet

B Gesetz gegen Wettbewerbsbeschränkungen

B Handelsgesetzbuch

IV Handelingen Nederlandse Juristenvereniging

Hoge Raad

Interdepartementale Coördinatiecommissie voor Consumentenzaken

Internationaal privaatrecht

C Iens Verburgh Instituut voor Consumentenrecht

Juristische Arbeitsblätter

Journal for Consumer Policy

Journal Officiel

Juristische Rundschau

juncto

Kammergericht

Kommanditgesellschaft 
$\mathrm{KG}$

KvK

KwNBW

LG

LM

LV

L\&SR

m.m.

MvA

MvA I

MvT

NBW

NEV

NJ

NJB

NJV

NJW

nl.

nr.

Nr.

nrs.

NVW I

NVW II

$0 . \mathrm{a}$.

OLG

OLGZ

ONBW

OS

o.m.

OvW

pag.

Rb.

RBerG

RM

RM-Themis

Rndnr.

RP

Rv

SEW

SR
Kort Geding

Kamer van Koophandel en Fabrieken

Kwartaalbericht Nieuw BW

Landgericht

Lindenmaier - Möhring, Nachschlagewerk des BGH

Landesverband

Law and Society Review

mutatis mutandis

Memorie van Antwoord (Tweede Kamer)

Memorie van Antwoord in de Eerste Kamer

Memorie van Toelichting

Nieuw Burgerlijk Wethoek

Nota naar aanleiding van het Eindverslag van de vaste Commissie voor Justitie

Nederlandse Jurisprudentie

Nederlands Juristenblad

Nederlandse Juristenvereniging

Neue Juristische Wochenschrift

namelijk

nummer

Nummer

nummers

Eerste Nota van Wijziging

Tweede Nota van Wijziging

onder andere

Oberlandesgericht

Rechtsprechung der Oberlandesgerichte in Zivilsachen

Overgangswet Nieuw Burgerlijk Wetboek

One Shotter

onder meer

Ontwerp van Wet

pagina

Rechtbank

Rechtsberatungsgesetz

Rechtsgeleerd Magazijn

Rechtsgeleerd Magazijn Themis

Randnummer

Repeat Player

Wetboek van Burgerlijke Rechtsvordering

Sociaal Economisch Weekblad

Sociaal Recht 


$\begin{array}{ll}\text { b. } & \text { Staatsblad } \\ \text { NOKA } & \text { Stichting Wetenschappelijk Onderzoek Konsumentenaangelegen- } \\ & \text { heden } \\ \text { kV } & \text { Stichting \& Vereniging } \\ \text { MA } & \text { Tijdschrift voor Milieuaansprakelijkheid } \\ \text { b. } & \text { Tractatenblad } \\ \text { IC } & \text { Tijdschrift voor Consumentenrecht } \\ \text { VVS } & \text { Tijdschrift voor vennootschappen, verenigingen en stichtingen } \\ \text { CV I } & \text { Uitgebreide commissie vergadering van 1 oktober 1984 } \\ \text { CV II } & \text { Uitgebreide commissie vergadering van 24 januari 1985 } \\ \text { WG } & \text { Gesetz gegen den unlauteren Wettbewerb } \\ \text { srsR } & \text { Versicherungsrecht } \\ \text { KV } & \text { Verein Konsumenten und Verbraucherschutz } \\ \text { NG } & \text { Vereniging van Nederlandse Gemeenten } \\ \text { SV } & \text { Verbraucherschutzverein e.V. Berlin } \\ \text { U } & \text { Vrije Universiteit } \\ \text { JR } & \text { Verbraucher und Recht } \\ \text { V } & \text { Voorlopig verslag van de vaste Commissie voor Justitie (Tweede } \\ & \text { Kamer) } \\ \text { V I } & \text { Voorlopig Verslag van de Bijzondere Commissie voor de herzie- } \\ & \text { ning van het Burgerlijk Wetboek (Eerste Kamer) } \\ \text { VG } & \text { Versicherungsvertragsgesetz } \\ \text { WVfG } & \text { Verwaltungsverfahrensgesetz } \\ \text { M } & \text { Wertpapier-Mitteilungen } \\ \text { PNR } & \text { Weekblad voor Privaatrecht, Notariaat en Registratie } \\ \text { RP } & \text { Wettbewerb in Recht und Praxis } \\ \text { P } & \text { Zeitschrift für Wirtschaftsrecht und Insolvenzpraxis } \\ \text { ?O } & \text { Zivilprozeßordnung } \\ \text { RP } & \text { Zeitschrift für Rechtspolitik } \\ \text { VP } & \text { Zeitschrift für Verbraucherpolitik }\end{array}$


I INLEIDEND GEDEELTE 
Stb. Staatsblad

SWOKA Stichting Wetenschappelijk Onderzoek Konsumentenaangelegenheden

S\&V Stichting \& Vereniging

TMA Tijdschrift voor Milieuaansprakelijkheid

Trb. Tractatenblad

TvC Tijdschrift voor Consumentenrecht

TVVS Tijdschrift voor vennootschappen, verenigingen en stichtingen

UCV I Uitgebreide commissie vergadering van 1 oktober 1984

UCV II Uitgebreide commissie vergadering van 24 januari 1985

UWG Gesetz gegen den unlauteren Wettbewerb

VersR Versicherungsrecht

VKV Verein Konsumenten und Verbraucherschutz

VNG Vereniging van Nederlandse Gemeenten

VSV Verbraucherschutzverein e.V. Berlin

VU Vrije Universiteit

VuR Verbraucher und Recht

VV Voorlopig verslag van de vaste Commissie voor Justitie (Tweede Kamer)

VV I Voorlopig Verslag van de Bijzondere Commissie voor de herziening van het Burgerlijk Wetboek (Eerste Kamer)

VVG Versicherungsvertragsgesetz

VwVfG Verwaltungsverfahrensgesetz

WM Wertpapier-Mitteilungen

WPNR Weekblad voor Privaatrecht, Notariaat en Registratie

WRP Wettbewerb in Recht und Praxis

ZIP Zeitschrift für Wirtschaftsrecht und Insolvenzpraxis

ZPO Zivilprozeßordnung

ZRP Zeitschrift für Rechtspolitik

ZVP Zeitschrift für Verbraucherpolitik 
I INLEIDEND GEDEELTE 


\section{Inleiding}

\subsection{Algemeen}

De op 1 januari 1992 ingevoerde boeken 3, 5, 6 en delen van boek 7 van het nieuwe Burgerlijk Wetboek (BW) bevatten voor een groot deel een hercodificatie van reeds onder het oude Burgerlijk Wetboek (BW (oud)) bestaande wetgeving en de naar aanleiding van deze regelgeving ontwikkelde jurisprudentie. Deels bevat het nieuwe Burgerlijk Wetboek echter ook geheel nieuwe regelgeving. Zo ook op het terrein van de algemene voorwaarden waar afdeling 6.5.3 BW voorziet in een geheel nieuwe regeling.

Waar de rechtspraktijk zich onder het oude Burgerlijk Wetboek moest "behelpen" met de algemene vermogensrechtelijke regelgeving inzake o.a. de ongeoorloofde oorzaak (artikel $1356 \mathrm{j}^{\circ} 1371$ e.v. BW (oud)) ${ }^{1}$, misbruik van omstandigheden $^{2}$, de wilsovereenstemming (artikel $1356 \mathrm{BW}$ (oud)) ${ }^{3}$, en later met de beperkende werking van de goede trouw (artikel $1374 \mathrm{BW}$ (oud)) ${ }^{4}$, biedt het nieuwe Burgerlijk Wetboek een specifiek op algemene voorwaarden gericht materieelrechtelijk regelcomplex: de Wet algemene voorwaarden. ${ }^{5}$

Niet alleen materieelrechtelijk is de Wet algemene voorwaarden nieuw, ook procesrechtelijk getuigt zij van zin voor vernieuwing. De reeds eerder bij de

1 HR 26 maant 1920, NJ 1920, 476 (Surinaamse Postbode); HR 14 april 1950, NJ 1951, 17, m.nt. Ph.A.N.H. (Röntgenbehandeling).

2. HR 11 januari 1957, NJ 1957, 37 (BOVAG II).

3 HR 20 november 1981, NJ 1982, 517, m.nt. C.J.H.B., A.A 1982, pag. 247, m.nt. G. (Holleman/De Klerk).

4 HR 19 mei 1967, NJ 1967, 261, m.nt. G.J.S., AA 1967, pag. 214, m.nt. P.A.S. (Saladir/HBU); HR 20 februari 1976, NJ 1976, 486, mint. G.J.S, AA 1976, pag. 467, m.nt. G.

(Pseudo-Vogellpest); HR 25 april 1986, NJ 1986, 714, m.nt. G., AA 1986, pag. 816, m.nt. v.Sch., TwC 1986, pag. 361, m.nt. Rijken (Van der Meer/Smilde); HR 16 januari 1987, NJ 1987, 553, m.nt. G., KwNBW 1987/2, pag. 63, m.nt. Hondius, TwC 1987, pag. 263 (Hoolijen/De Tilburgsche Hypotheekbank); HR 23 maart 1990, NJ 1991, 214, m.nt. H.J.S. (Botman/Van Haaster); HR 8 maart 1991, N\$1991, 396 (De Kleijn/Van der Ende).

5 Wet van 18 juni 4987, houdende invoeringswet Boeken 3,5 en 6 wan het nieuwe Burgerlijk Wetboek (tweede gedeelte) (aigemene voorwaanden), Stb. 1987, nr. 327. 
Wet Misleidende Reclame ${ }^{6}$, alsook in wetgeving van ons omringende landen en in vastgestelde EG-wetgeving, ingeslagen weg wan een individueel actierecht geflankeerd door een collectief actierecht voor bellangenorganisaties, wordt in afdeling 6.5.3 $\mathrm{BW}$ voortgezet. In artikel 6:240 BW wordt onder andere aan belangenorganisaties van beroeps- of bedrijfsgenoten enerzijds en belangenorganisaties van eindgebruikers van diensten en produkten (consumenten) anderzijds het ius agendi uitdrukkelijk toegekend. Om dit actierecht mogelijk te maken heeft de "klassieke" procedurele regelgeving van het Wetboek voor Burgerlijke Rechtsvordering de nodige wijzigingen ondergaan.

Materieelrechtelijke en procesrechtelijke vernieuwingen op het terrein van de algemene voorwaarden worden natuurlijk niet zonder reden door de wetgever geintroduceerd. Zo beoogt de Nederlandse wetgever door middel van de materieelrechtelijke regels van afdeling 6.5.3 BW met name consumenten een verhoogde bescherming te bieden op het terrein van de algemene voorwaarden. Eén van de instrumenten die beogen deze materieelrechtelijke bescherming ook daadwerkelijk te realiseren, is het collectief actierecht voor consumentenorganisaties zoals neergelegd in artikel 6:240 e.v. BW.

Waar moet de consument tegen beschermd worden en wat heeft de wetgever er in een era van deregulering toe aangezet de consument deze bescherming te bieden met een geheel nieuwe regeling die zowel materieelrechtelijke als

6. Wet van 6 juni 1980 , Stb. 1980, nr. 304; artikelen 1416a tot en met $1416 \mathrm{c}$ BW(oud), thans de artikelen 6:194 tot en met 6:196 BW.

7 Zie o.A. voor: België, "Wet betreffende de handelspraktijken en de voorlichting en bescherming van de consument" van 14 juli 1991, artikel 98, Belgisch Staatsblad 29 augustus 1991, pag. 18712-18766; Duitsland, "Gesetz zur Regelung des Reehts der Allgemeinen Geschäftsbedingungen" van 9 december 1976, \& 13, Bundesgesetzblatt Teil I, pag. 3317; Duitsland, "Gesetz gegen den Unlauteren Wettbewerb"' (wetswijziging) van 21 juli $1965, \S 13$, Bundesgesetzblatt Teil I, pag. 625; Frankrijk, "Loi sur la protection et l'information des consommateurs de produits et de services" (wetswijziging) van 5 jantuari 1988, No. 88-14, artt. 35-38, J.0. 6 januari 1988; Luxemburg, "Loi relative la protection juridique du consommateur" (wetswijziging) van 15 mei 1987, artikel 5, Mémorial 1987; Oostenrijk, "Konsumentenschutzgesetzes" wan 8 maart 1979, 28 e.v., Bundesgesetzblatt 140; Portugal, Wet Algemene Voorwaarden 1985 , artikel 3 lid 2 en artikel 25 lid 1 sub a, Decreto-Lei no 446/85 wan 25 oktober 1985 (zie RIW 1987, 111); Spanje; "Ley generall para la defensa de los consumidores y usuarios" (1984), No. 26/1984, artikel 8 lid 3; Zwitserland, Bundesgesetz gegen den unlauteren Wettbewerb (UWG) van 19 december 1986, artikel 10 lid 2 sub b.

8. Ruchtijin 93/13/EEG van de Raad van 5 april 1993, betreffende oneerlijke bedingen in consumentenovereenkomsten, Publikatieblad EG 21 april 1993, Nr. L 95/29, artikel 7 lid 2. Artikell 10 lid I wan deze richtlijn bepaalt dat de wetgeving van de Lid-Staten uiterlijk op 31 december 1994 man de bepalingen van deze richtlijn dienen te voldoen. Zie uitgebreid over deze richtlijn onder andere: H.J. Bakker en R.H.C. Jongeneel, Een rechtlijnige richtlijn, TvC 1992, pag. 4-18; Jongeneel, TvC 1993, pag. 117-130; Jongeneel en Wessels, NJB 1993, pag. 897899; E.H. Hondius, Nuar een Eunopees Contractenrecht: de richtlijn oneerlijke bedingen in consumentenowereenkomsten, NTBR 1993/6, pag. 108-112; Bultmann, VuR 1994, pag. 137145; Eckert, pag. 1986-1991; Woll, AGBG Kommentar, pag. 1869-2008. Zie voor een eender stadium in de EEG-historie: "Resolution (76) 47 on unfair terms in consumer contracts and an appropriate method of control" van 16 november 1976, Appendix, Principles II. 
procesrechtelijke nova biedt? Wat is de inhoud van het nieuwe regelcomplex? Hoe verhoudt de nieuwe regeling zich tot de algemene leerstukken, wat is haar bereik en welke is haar praktische relevantie?

Vragen te over die er toe nopen deze nieuwe regeling en haar consequenties nader onder de loep te nemen. Anderen en ook ik hebben reeds op de nieuwe wet ingehaakt. Te noemen zijn in dat verband: Wessels en Jongeneel, "Algemene voorwaarden" (1987, 1989 en 1992); Hartkamp, in "Asser-Hartkamp II, Hoofdstuk 17. Algemene voorwaarden en standaardregelingen" (1989 en 1993); Verhoeven, "Algemene voorwaarden getoetst" (1989); Van Erp, "Contract als rechtsbetrekking, Een rechtsvergelijkende studie" (1990); Rijken, Mölenberg en Verstappen, "Algemene voorwaarden in het toeristisch-recreatieve verkeer" (1990); Mölenberg en Rijken, "De ervaringen van de Duitse consumentenorganisaties met het AGB-Gesetz" (1991); Van Dunné, "Verbintenissenrecht, deel 1, Hoofdstuk 4. Belangrijke clausules in overeenkomsten" en met name de dissertatie van Jongeneel, "De Wet algemene yoorwaarden en het AGB-Gesetz" (1990), waarin deze de materieelrechtelijke regeling van afdeling 6.5.3 BW vergelijkt met het Duitse AGB-Gesetz. Van iets eerdere datum, maar daarom niet minder relevant voor de problematiek van de algemene voorwaarden, zijn onder andere te noteren de dissertaties van: Hondius, "Standaardvoorwaarden, Rechtsvergelijkende beschouwingen over standaardisering van kontraktsbedingen en overheidstoezicht daarop" (1978); Nieuwenhuis, "Drie beginselen van contractenrecht" (1979); Van der Werf, "Gebondenheid aan standaardvoorwaarden, Standaardvoorwaarden in het rechtsverkeer met particuliere en professionele contractanten" (1980); Rijken, "Exoneratieclausules" (1983); Gras, "De sociale werkelijkheid van het standaardcontract" (1984) en de preadviezen van Hondius en Dalhuisen voor de Nederlandse Juristen-Vereniging, respectievelijk "Naar een wettelijke regeling van algemene voorwaarden" en "Algemene voorwaarden" (1979).

Daarmee kom ik bij de doelstelling van mijn onderzoek. Deze en cle daaruit voortvloeiende probleemstelling zet ik uiteen in $\mathrm{nr} .1 .2$ hierna. In $\mathrm{nr} .1 .3$ baken ik het onderwerp nader af en in de nrs. 1.4, 1.5 en 1.6 geef ik respectievelijk de onderzoeksmethode, de gehanteerde terminologie en de opzet van het onderzoek weer.

\subsection{Doelstelling van het onderzoek}

De doelstelling van mijn onderzoek is drieërlei. Het eerste doel is te achterhalen welke de motieven van de wetgever waren om op het terrein van de algemene voorwaarden een collectief actierecht voor consumentenorganisaties te introduceren en welke doeleinden hij met dit actierecht nastreeft. 
Het tweede doel van het onderzoek is het bespreken en nader analyseren van de wettelijke regeling inzake het collectief actierecht voor consumentenorganisaties en de daarmee gepaard gaande abstracte inhoudstoetsing op het terrein van de algemene voorwaarden zoals neergelegd in afdeling 6.5.3 BW. Het collectief actierecht is een naar Nederlandse begrippen vrij nieuw actierecht. In algemene zin, als reactie op jurisprudentiële ontwikkelingen met name op het terrein van de onrechtmatige daad, is dit actierecht weliswaar onderwerp geweest van diverse publikaties; specifiek op de collectieve actie op het terrein van de algemene voorwaarden gerichte literatuur is echter slechts mondjesmaat voorhanden. Een grondige bestudering van de wettelijke grondslagen van dit actierecht en de abstracte inhoudstoetsing is derhalve gewenst. Aangezien het collectief actierecht (mede) gestalte geeft aan de materieelrechtelijke regeling, mag ook een bespreking van deze laatste regels in dit onderzoek niet ontbreken.

Derde doelstelling van het onderzoek is een beeld te verschaffen van de praktische werking van het collectief actierecht op het terrein van de algemene voorwaarden. Heeft afdeling 6.5 .3 en dan met name het daarin opgenomen collectief actierecht ook werkelijk de potentie te voldoen aan de verwachtingen en doeleinden die de wetgever nastreeft? Welke omstandigheden en factoren zijn voor het bereiken van deze doeleinden bepalend?

Deze vragen zal ik trachten te beantwoorden door middel van een vooruitblik naar de werking van dit collectief actierecht in de praktijk. Deze vooruitblik zal voor een groot deel gebaseerd zijn op de praktische ervaringen die Duitse consumentenorganisaties - sinds 1 april 1977 - hebben opgedaan met het Gesetz zur Regelung des Rechts der Allgemeinen Geschäftsbedingungen (AGB-Gesetz). Het AGB-Gesetz voorziet eveneens in een collectief actierecht voor consumentenorganisaties op het terrein van de algemene voorwaarden en heeft nadrukkelijk mede model gestaan voor de Nederlandse Wet algemene voorwaarden. Aan de hand van de zo verkregen uitkomsten wil ik dan komen tot een prognose omtrent de in Nederland te verwachten effectiviteit van het collectief actierecht op het terrein van de algemene voorwaarden. Leidraad hierbij zal steeds de vraag zijn in hoeverre de consumentenbescherming die de overheid op het terrein van de algemene voorwaarden voor ogen stond ook daadwerkelijk door het collectief actierecht wordt gerealiseerd.

\subsection{Afbakening van het onderwerp}

Ten einde dit boek binnen een voor mij werkbare omvang te houden en om een tijdige verschijning ervan te verzekeren, was het voor mij noodzakelijk de te behandelen stof nader af te bakenen. Het onderzoek richt zich op het collectief actierecht voor consumentenorganisaties als gegeven in afdeling 6.5.3 $\mathrm{BW}$ en daarmee voornamelijk op de procesrechtelijke regels van deze afdeling. De 
materieelrechtelijke regels die enkel betrekking hebben op het individuele actierecht van artikel 6:233 sub a en b BW worden alleen besproken voor zover van belang voor het collectief actierecht en de daarmee gepaard gaande abstracte inhoudstoets. Voor het overige verwijs ik naar de vrij recente werken van Wessels en Jongeneel ${ }^{9}$, Verhoeven ${ }^{10}$ en Jongeneel ${ }^{11}$ en de Parlementaire Geschiedenis ${ }^{12}$.

Een tweede afbakening is gelegen in het feit dat ik mij expliciet richt op het terrein van de algemene voorwaarden en daarmee heb afgezien van een uitgebreide behandeling van het collectief actierecht voor consumentenorganisaties op andere territoria van het vermogensrecht. Daarbij valt met name te denken aan de wet inzake vorderingsrechten voor belangenorganisaties zoals vastgelegd in de artikelen 3:305a en 3:305b BW. ${ }^{13}$ Daar waar dit nuttig is voor de te behandelen stof wordt uiteraard nader op deze wet ingegaan. Voor het overige wil ik verwijzen naar de publikaties dienaangaande van met name Rodrigues $^{14}$ en Frenk $^{15}$.

Een derde beperking ligt besloten in mijn kewze om als invalshoek voor het onderzoek de positie van de consument te nemen. Daardoor beperkt het onderzoek zich tot consumenten en consumentenorganisaties als onderwerp van deze studie. Het collectief actierecht zoals dat door afdeling 6.5.3 BW is toegekend aan organisaties die de belangen behartigen van personen die een beroep of bedrijf uitoefenen en het beroep van niet-consumenten op artikel 6:233 $\mathrm{BW}$, zullen derhalve slechts zijdelings worden aangestipt.

\subsection{Onderzoeksmethode}

Het onderzoek geschiedt in de eerste plaats aan de hand van wetgeving en literatuur. Nederlandse jurisprudentie is van minder belang nu het collectief actierecht op het terrein van algemene voorwaarden eerst onlangs gestalte heeft gekregen en van enige jurisprudentie betreffende het collectief actierecht zoals neergelegd in afdeling 6.5.3 BW nog geen sprake is. Procedures waarin de

9 Algemene woorwarden (1992).

10 Algemene woorwarirden getoetst (1989).

11 De Wet algemene voorwaarden en het AGB-Gesetz (dissertatie 1991).

12 Parlementaïre Geschiedenis (Inv, 3, 5 en 6), pag. 1450-1817.

13 Wet van 6 april 1994 tot regeling van de bevoegdheid van bepaalde rechtspersonen om ter bessheming van de belangen van andere personen een rechtsvordering in te stellien, Stb. 1994, 269. In werking getreden op 1 juli 1994. Zie: Besluit van 27 mei 1994 tot inwerkingtreding van de Wet van 6 april 1994, Stb 1994, 391.

14 Collectieve consumentenacties, SWOKA-onderzoeksrapport (1988); Procesrecht en collectief actierecht (1988); Het wetswoorstel inzake vorderingsnechten voor belangenorganisaties, Sociaal Recht 1992,4 , pag. 108 e.v.

15 RM-Themis 1989, pag. 372-389; diss.; TvC 1990, pag. 203-216; Jaarboek konsumentenrecht $1990-1993$. 
inhoud van algemene voorwaarden abstract wordt getoetst op grond van afdeling 6.5.3 BW zijn nog niet voorhanden. Nederlandse jurisprudentie is dan ook voornamelijk van belang ter illustratie en duiding van het oude recht en de daaruit overgenomen begrippen in het huidige recht.

Een rijke schaar van jurisprudentie aangaande het collectief actierecht voor consumentenorganisaties op het terrein van de algemene voorwaarden is echter direct voorhanden bij onze oosterburen. Het Duitse AGB-Gesetz - dat voor een aanzienlijk deel model heeft gestaan voor de Nederlandse regeling en daarmee dan ook voor een deel vergelijkbaar is - trad reeds in 1977 in werking en kan inmiddels bogen op haar derde lustrum. De afgelopen zestien jaar heeft het AGB-Gesetz een schat aan publikaties en jurisprudentie opgeleverd. Daarmee diende zich een vergelijking aan van het Nederlandse recht met het Duitse recht.

Rechtsvergelijking moet echter geen doel op zichzelf zijn. Rechtsvergelijking dient meer te omvatten dan alleen een bestudering van buitenlands recht "sec" en de vaststelling en verklaring van overeenkomsten en verschillen tussen twee of meer rechtsstelsels, wil het niet blijven steken in zogenaamde "Auslandsrechtskunde" ${ }^{16}$ In dit onderzoek is het doel van de rechtsvergelijking dan ook dieper gelegen, namelijk het, aan de hand van de in Duitsland ontwikkelde doctrine met betrekking tot het AGB-Gesetz en de praktische ervaringen met deze regelling, blootleggen en analyseren van de grondslagen van het collectief actierecht en de abstracte inhoudstoetsing zoals deze in Nederland hun werking zullen hebben.

Het blootleggen van deze grondslagen zal voor een deel zeker kunnen geschieden aan de hand van de Nederlandse wetshistorie. ${ }^{17}$ Gezien de slechts summiere omvang van de toelichtende parlementaire stukken zal een aantal vragen onbeantwoord blijven indien we enkel te rade gaan bij deze weerslag van de parlementaire discussie inzake de Wet algemene voorwaarden. Deze vragen kunnen mogelijk een oplossing vinden in de doctrine die zich heeft ontwikkeld naar aanleiding van een vergelijkbare regeling in een ander rechtsstelsel.

Hoe meer overeenkomst deze regeling, het vreemde rechtsstelsel en de samenleving waarin deze functioneren, vertoont met de Nederlandse regeling, rechtsstelsel en samenleving, hoe meer de in het buitenland ontwikkelde theorieên toepasbaar zijn op de Nederlandse regeling. ${ }^{18}$ Het AGB-Gesetz dient zich dan bij uitstek aan als een verantwoorde keuze. Niet alleen vertonen de materiële en processuele regels van het AGB-Gesetz sterke overeenkomsten met

Kokkini-latridou, pag. 12; De Boer, pag. 41.

17. Overigens is het gezag var parlementaire stukken slechts betrekkelijk, het is een "bron wan argumenten", een van de geaceepteende kenbronnen. Zie hienover onder meer: Lokin "pag. 257259, Jongeneel, diss., pag. 3.

De Boer, pag. 47. 
haar tegenhangers in de Nederlandse Wet algemene voorwaarden, ze zijn bovendien ingebed in een rechtsstelsel en samenleving die in hoge mate overeenkomen met ons rechtsstelsel ${ }^{19}$ en onze samenleving.

Het ligt dan ook voor de hand dat gedurende de meer dan 15 jaar dat de theorie naar aanleiding van het AGB-Gesetz zich heeft kunnen ontwikkelen, antwoorden zijn gevonden op vragen en knelpunten waar de Nederlandse rechtspraktijk (nog) niet aan toe is gekomen. Dit ligt te meer voor de hand nu zowel het Duitse als het Nederlandse collectief actierecht gebaseerd zijn op een zogenaamde "open norm" (Generalklausel) die, onder andere, nader wordt ingevuld door de gewoonte, de redelijkheid en de billijkheid en de eisen van maatschappelijke betamelijkheid. De rechter komt deswege weliswaar een grote vrijheid toe; hij heeft echter tegelijkertijd juist vanwege de openheid van deze normen ook weinig houvast. ${ }^{20}$ Veel vragen zullen derhalve vooreerst open blijven. ${ }^{21}$ Deze open normen krijgen hun concrete invulling eerst in de rechtspraak. Pas als deze rechtspraak gevormd is kunnen hieruit algemene regels ten aanzien van de invulling van deze normen gedestilleerd worden en krijgt men zicht op knelpunten in de toepassing van de wet. In dat licht lijkt het mij nuttig nu reeds inspiratie op te doen uit de overvloedige bron aan Duitse jurisprudentie en literatuur. Een deel van mijn onderzoek beslaat derhalve een rechtsvergelijkende beschouwing van de Duitse regeling aan de hand van (Duitse) wetgeving, literatuur en jurisprudentie.

De Duitse en Nederlandse rechtsstelsels vertonen aan de andere kant ook aanzienlijke verschillen in zowel het systeem van privaatrecht als de rechtscultuur. De Duitse oplossingen kunnen derhalve niet altijd zonder meer toegepast worden in Nederland. $\mathrm{Zij}_{\mathrm{ij}}$ zullen steeds op hun bruikbaarheid voor Nederland getoetst moeten worden. ${ }^{22}$ Of zoals de toenmalige minister van justitie bij de totstandkoming van afdeling 6.5.3 opmerkte: "Overigens is het daarbij gegaan zoals meestal met rechtsvergelijking het geval is: zij vormt een waardevolle bron van inspiratie, maar reikt zelden pasklare oplossingen aan"23. Als leidraad neem ik daarbij de door De Groot in dit verband aangehaalde bijbeltekst: "Vergelijkt alles en behoudt het goede".

Een andere factor die voor mij heeft meegewogen in de keuze voor het Duitse rechtsstelsel als object van rechtsvergelijking is gelegen in de geografische en linguïstische toegankelijkheid daarvan. Niet elk rechtsstelsel leent zich

19 Hondius, diss., pag. 160.

20 Zie in dit verband: Barendrecht, diss., pag. 6, 70-71, 105-109, 241-252 en pag. 271 e.v.

21 Hairkamp, inaug, rede, pag. 21.

22 Zie ook: Jongeneel, diss., pag. 5.

23 MvT, Parlementaire Geschiedenis, Inv. 3, 5 en 6, pag. 1455.

24 De Groot, inaugurele rede. 
daardoor voor rechtsvergelijking. ${ }^{25}$ Daarmee komen we aan bij de problematiek van het juridisch vertalen. ${ }^{26}$ Een aantal opmerkingen vooraf is hier op $z$ 'n plaats.

Juridische terminologie wijkt doorgaans sterk af van het algemeen woordgebruik en is sterk systeem gebonden. Bij vertaling van juridische teksten moet in de brontekst geformuleerde juridische informatie worden hergeformuleerd in de juridische terminologie van de doeltaal. Kort gezegd komt het er op neer dat van rechtstaal naar rechtstaal moet worden vertaald. Niet altijd zijn echter equivalente juridische begrippen in de doeltaal voorhanden. In dat geval bieden zich drie oplossingen aan:

-de niet te vertalen term in de oorspronkelijke taal laten staan, eventueel met de letterlijke vertaling of een omschrijving tussen haakjes toegevoegd;

-de term omschrijven;

-in de doeltaal een nieuw woord creẽren, eventueel met toelichting.

In dit boek heb ik zoveel mogelijk gebruik gemaakt van Nederlandse equivalenten van Duitse juridische begrippen; dit verhoogt naar ik vertrouw de leesbaarheid van dit werk. Daar waar dit niet te vermijden viel heb ik zoveel mogelijk gekozen voor het onvertaald laten van terminologie. Uiteraard wordt deze terminologie in Nederlandse begrippen nader omschreven.

Naast een vergelijking van de Duitse en Nederlandse materieel- en procesrechtelijke regelgeving wordt in deze dissertatie mede een overzicht gegeven van het functioneren van het collectief actierecht voor consumentenorganisaties in de praktijk. Daartoe worden de ervaringen van Duitse consumentenorganisaties met het collectief actierecht geĭnventariseerd. De rol van de Duitse consumentenorganisaties in de (consumenten)rechtshandhaving op het gebied van algemene voorwaarden en de ervaringen van de Duitse consumentenorganisaties met het collectief actierecht worden beschreven aan de hand van literatuuronderzoek, jaarverslagen van de desbetreffende consumentenorganisaties, enquêtes en interviews met medewerkers van de Verbraucherschutzverein e.V. (VSV) te Berlijn en de Verbraucherzentrale Baden-Württemberg te Stuttgart en onderzoek in de archieven van de VSV te Berlijn. Uit de literatuur ${ }^{27}$ was bekend dat het collectief actierecht als bedoeld in $\$ 13$ AGB-Gesetz voornamelijk gehanteerd werd door de VSV te Berlijn en de Verbraucherzentrale Baden-Württemberg te

25 De Boer, pag. 46.

26 Zie hienover meer uitgebreid: Balkema en De Groot, Recht en vertalen (1987); Mincke, Die Problematik von Recht und Sprache in der Ubersetzung von Rechtstexten (1991); Kolkinilatridou, pag. 94-102.

27 Bunte, AeP 1982, pag. 31; Bunte, DB 1982, pag. 2; Ulmer, BB 1982, pag. 584; Bohle en Micklitz, pag. 1; Schlosser, ZIP 1985, pag. 449; Bunte, NJW 1987, pag. 921; Schlosser P., 10 Jahre AGB-Gesetz, JR 1988, pag. 1; Bunte, JA 1988, pag. 311. 
Stuttgart. Beide consumentenorganisaties is in het kader van het onderhavige onderzoek een lijst met vragen voorgelegd ${ }^{28}$ en zij zijn vanaf 1989 door mij diverse malen bezocht. Tijdens deze bezoeken zijn medewerkers geïnterviewd die direct betrokken zijn bij de uitvoering van het collectief actierecht als bedoeld in $\$ 13$ AGB-Gesetz, zijn lijsten met vragen beantwoord en heeft onderzoek plaatsgevonden in de omvangrijke archieven van de VSV te Berlijn. De andere consumentenorganisaties op deelstaatniveau (Verbraucherzentralen), uitgezonderd de deelstaten in de voormalige DDR, zijn in de zomer van 1990 door middel van een vragenlijst ${ }^{29}$ geënquêteerd. De resultaten van dit onderzoek zijn grotendeels reeds gepubliceerd in het SWOKA-onderzoeksrapport "De ervaringen van de Duitse consumentenorganisaties met het AGB-Gesetz" ${ }^{130}$.

\subsection{Terminologie}

Alvorens over te gaan tot de opzet van het onderzoek, ga ik eerst in op een aantal basisbegrippen en leg ik uit in welke betekenis ik deze gebruik. Dit zijn achtereenvolgens de termen: algemene voorwaarden, consument, consumentenorganisaties, gebruikers van algemene voorwaarden, aanbevelers van algemene voorwaarden, gebondenheidstoets, aanvaardingstoets, informatietoets, inhoudstoets, individueel belang, groepsbelang, algemeen en collectief belang, consumentenbelang, individuele actie, collectieve actie en actierecht. Overigens beoog ik met deze aandacht voor de terminologie enkel de lezer enig houvast te bieden bij het lezen van dit boek en pretendeer ik niet een bijdrage te leveren tot unificatie van deze termen.

Bij die omschrijving is zoveel mogelijk aansluiting gezocht bij de terminologie zoals die door de Nederlandse wetgever in afdeling 6.5.3 BW wordt gehanteerd, mede omdat de systematiek van het nieuwe Burgerlijk Wetboek met zich brengt dat eenmaal door de wetgever gekozen terminologie consequent door het hele Burgerlijk Wetboek wordt gehanteerd.

\subsubsection{Algemene voorwaarden}

In de Nederlandse rechtsliteratuur ${ }^{31}$ inzake algemene voorwaarden werd tot voor kort een grote verscheidenheid aan termen gebezigd ter aanduiding van het verschijnsel van schriftelijke concept-bedingen die zijn opgesteld om zonder

28 Mölenberg en Rijken, Bijlage 4.

29 Mölenberg en Rijken, Bijlage 4.

30 Mälenberg en Rijken, SWOKA-onderzoeksrapporten 1991, 115.

31 In de literatuur is hierop reeds herhaaldelijk gewezen. Zie bijwoorbeeld: Zeylemaker, pag. 67 e.v.; Jansma, pag. 126-127; Brens, pag. 199; Brack, Kernpunten, pag. 12; Sluyter, pag. 6; Hondius, diss., pag. 227 e.v.; Van der Werf, diss., pag. 7 e.w.. 
onderhandelingen omtrent hun inhoud te worden opgenomen in een gewoonlijk onbepaald aantal nog te sluiten overeenkomsten van bepaalde aard ${ }^{32}$. Om er enkele te noemen: adhesiecontracten, algemene voorwaarden, consumentenvoorwaarden, contractmodellen, formuliercontracten, standaardvoorwaarden, standaardbepalingen, standaardovereenkomsten, toetredingscontracten, standaardcontracten etc. ${ }^{33}$

Grofweg werd een onderscheid gemaakt in drie verschillende categorieën: contractmodellen, de eenzijdig door eén partij of haar organisatie opgestelde en de in tweezijdig overleg tussen partijen of hun organisaties vastgestelde algemene voorwaarden. ${ }^{34}$ Contractmodel staat dan voor het reeds voorgeformuleerde en afgedrukte contract waarop nog slechts de essentialia en handtekeningen op stippellijntjes of iets dergelijks behoeven te worden ingevuld. Algemene voorwaarden behelzen daarentegen het samenstel van voorgeformuleerde bedingen dat door toepasselijk verklaring contractsinhoud wordt. ${ }^{35}$

Op de wenselijkheid van een uniforme hantering van terminologie in deze omdat dit de inzichtelijkheidl en duidelijkheid en daarmee een juiste beroepsuitoefening ten goede komt - is reeds gewezen door Hondius ${ }^{36}$ en Van der Werf ${ }^{37}$. $\mathrm{Zij}$ stelden voor de term standaardvoorwaarden als uniform begrip te hanteren ${ }^{38}$. De Nederlandse wetgever heeft, in navolging van de Duitse terminologie, echter gekozen voor de term algemene voorwaarden.

In navolging van de keuze die de Nederlandse wetgever maakt in artikel 6:231 BW én omdat de term algemene voorwaarden in de recente literatuur inzake algemene voorwaarden, mede door de keuze van de wetgever, algemeen is geaccepteerd, wordt in deze dissertatie gekozen voor de term "algemene voorwaarden ${ }^{39}$ en wordt hieronder verstaan:

een of meer schriffelijke bedingen die zijn opgesteld teneinde in eem cantal overeenkomsten te warden opgenomen, met witzondering van bedingen die die kem van de prestatie acangeven.

Deze algemene voorwaarden kunnen dan weer, afhankelijk van wie ze heeft geconcipieerd, worden onderscheiden in nul-, een- en tweezijdige algemene

32 Deze definitie is ontleend an Hondius, diss., pag. 243; zie ook CCA-advies, pag. 4 en Van der Werf, diss. . pag. 9.

33 Zie meer uitgebreid: Hondius diss., pag. 227 e.v.; Van der Werf, diss., pag. 7 e.v.

34 Zeylemaker 1948, 72-78; Hondius diss., pag. 96.

35 Zeylemaker, pag. 67 en 72.

36 Hondius, diss., pag. 228 e.v.; Hondius, preadwies, pag. 98.

37 Van der Werf, diss,, pag. 7 e.v..

38 Van der Werf, diss., pag: 9; Hondius, diss., pag. 241.

39 Zie ook: Jongeneel, diss., pag. 4. 
voorwaarden. ${ }^{40}$ De term eenzijdige algemene voorwaarden staat voor algemene voorwaarden die geheel zijn opgesteld door de gebruiker of zijn belangenorganisatie zonder dat de wederpartij van de gebruiker daar invloed op heeft gehad. Tweezijdige algemene voorwaarden zijn de voorwaarden die tot stand zijn gekomen in onderling overleg tussen gebruiker en wederpartij of hun respectievelijke belangenorganisaties. In Nederland valt daarbij te denken aan de algemene voorwaarden die in het kader van het CCA-overleg gezamenlijk worden vastgesteld door branche-organisaties enerzijds en consumentenorganisaties anderzijds. Nulzijdige algemene voorwaarden zijn die algemene voorwaarden die gebruikt worden door contractspartijen zonder dat zij zelf invloed hebben gehad op de inhoud van deze bedingen. $\mathrm{Zij}$ zijn meestal opgesteld door van partijen onafhankelijke derden. Bij voorbeeld algemene voorwaarden in modelcontracten gehanteerd door advocaten of notarissen ten behoeve van hun cliëntèle. De wettelijke definitie omvat alle hiervoor genoemde versehijningsvormen zonder daar een onderscheid tussen te maken. De wettelijke definitie hanteert het meervoud "algemene voorwaarden" zowel voor én beding als voor een samenstel van bedingen. ${ }^{41}$ Dit lijkt mij taalkundig onjuist. Daar waar ik spreek over één enkel beding of - in termen van Hondius ${ }^{42}$ - één standaardvoorwaarde bezig ik het enkelvoud "algemene voorwaarde".

Van "algemene voorwaarden" dient men goed te onderscheiden de in artikel 6:214 BW opgenomen "standaardregeling". Algemene voorwaarden zijn immers contractuele bedingen die slechts gelden tussen de partijen die dit overeenkomen. Bij de standaardregeling gaat het daarentegen om materiële wetgeving die voorziet in een voor een bepaalde bedrijfstak of bepaald beroep algemeen verbindende regeling voor een bepaald soort overeenkomst. De standaardregeling geldt daarmee van rechtswege voor de overeenkomsten waarop zij ziet, dus ook zonder dat partijen haar uitdrukkelijk in deze overeenkomsten hebben opgenomen. De standaardregeling bevat dan ook geen algemene voorwaarden als bedoeld in afdeling 6.5.3 $\mathrm{BW}$ en is derhalve ook niet aan de rechterlijke controle van afdeling 6.5.3 BW onderworpen maar aan die van 6:248 lid 2 en $6: 258$ BW. ${ }^{43}$

40 E.H. Hondius, diss., pag 256 e.v. en Jongeneel, diss., pag. 11. Vergelijk ook: Van der Werf, diss., pag. 12 en 107; Van der Werf, Advocatenblad 1982, pag. 113; Verhoeven, pag. 2. Deze leatsten hanteren de term onzijdig in plasts van nulzijdig.

41 MvT, Parlementaire Geschiedenis, Inv. 3, 5 en 6, pag. 1519; MvA, Parlementaire Geschiedenis, Inv. 3, 5 en 6, pag. 1528.

42 Hondius, diss., pag. 241.

43 MvT, Parlementaire Geschiedenis, Inv, 3, 5 en 6, pag. 1457-1458; zie ook: Van Heijningen, pag. 369 e.v.; Rijken, KwNBW 1986, pag. 6 e.v.; Engelen, pag. 200 e.v.; Wolthers, pag. 27 e.v.; Hondius en Van Wassenaer, pag. 6-7 en pag. 52; Asser-Hartkamp II, 1993, nrs. 376 en 377 . 


\subsubsection{Consument}

Met - in navolging van internationale tendensen - de opkomst, in de jaren vijftig/zestig, van de beweging die we kunnen aanduiden als consumentisme ${ }^{44}$ in Nederland, heeft de, uit de economische wetenschap afkomstige ${ }^{45}$, term "consument" ook voor de rechtswetenschap, en dan met name met betrekking tot het contractenrecht, in toenemende mate aan betekenis gewonnen.

Economisch gezien is de consument gepositioneerd aan het einde van het economische proces. Hij is de eindverbruiker van consumptiegoederen en diensten. Door dit eindwerbruik onttrekt de consument de goederen en diensten meestal voorgoed aan het economische verkeer. Het produkt of de dienst bereikt bij de consument zijn finale bestemming.

In de rechtswetenschap is dit uit de economische wetenschap stammend begrip niet zonder meer te hanteren. In de rechtswetenschap en in het recht wordt de term consument voornamelijk gebruikt ter aanduiding van een wisselende groep van rechtssubjecten die vanuit hun bijzondere positie in het rechtsverkeer bijzondere bescherming verdienen. De groep is wisselend al naar gelang de beschermingsbehoefte.

De term consument wordt verder voornamelijk gehanteerd om aan te geven dat een der partijen (de consument) niet beroeps- of bedrijfsmatig handelt. ${ }^{46}$ Zodioende onderscheidt men aan de ene kant de consument en aan de andere kant de ondernemer. In dat verband ziet het begrip consument in de Nederlandse wetgeving dan op een natuurlijk persoon ${ }^{47}$ en het begrip ondernemer door-

44 Hondius, Konsumentenrecht, pag. 14 e.v.; Brack, Consument, recht en koopkracht, pag, 55 e.v.; Brack, diss., pag. 58 ; Van Driel, pag. $₫ 8$ e.v.; Rijken, inaug. rede, pag. 11 .

45 Brack, diss., pag. 17 e.v. en pag. 115; Hondius, preadvies, pag. 101; Verhoewen, pag. 26.

46 Hondius, preadvies, pago, 101; Brack, diss. pag. 137 e.v.; Rodrigues, SWOKA-onderzoeksrapport, pag. 3.

47 Anders bij voorbeeld: Artikel 1 lid 7 van de (Belgische) Wet betreffende de handelspraktijken en bescherming van de eonsument, was consument gedefinieerd wordt als "iedere natuurlijke of rechtspersioon die, uitsluitend voor niet beroepsmatige doeleinden, op de markt gebrachte produkten of diensten verwerft of gebruikt; Artikel 2 lid 2 van het (eenste) Gewijzigd voorstel voor een EG-richtlijn betreffende oneerlijke bedingen in consumentenowereenkomsten $(92 / \mathrm{C}$ $73 / 05$, Publikatieblad EG 24 maart 1992, Nr. C $73 / 7$ ) wasr consument in de Engelse versie gedefinicend wondt als "any natural or legall person who, in transactions covered by this Directive, is acting for purposes which can be reganded as outside his trade, business or profesaion". Opmerkelijk is dat in de Nederlandse versie het begrip consument is beperkt tot alleen natuurlijke pensonen. In de uiteindelijke richtlijn van 5 april 1993 betreffende oneerlijke bedingen in consumentenovereenkomsten is zowel in de Engelse als de Nederlandse versie de definitie van consument in artikel 2 sub b - geheel in overeenstemming met de jurisprudentie van het Europese Hof van Justitie (14 mast 1991, C-361/89, Di Pinto) - beperkt tot natuurlijke personen. 
gaans op een rechtspersoon of een natuurlijk persoon die een bedrijf of een beroep uitoefent ${ }^{48}$.

Bij de omschrijving van het begrip consument heeft de wetgever de keuze tussen een drietal benaderingswijzen. Te onderscheiden zijn:

1."objectieve" criteria, waarbij niet de partijen bij de transactie, maar de transactie zelf het aanknopingspunt van de wettelijke regeling is;

2.een negatieve definitie van consumenten door het uitsluiten van professionele activiteiten van de werkingssfeer van de regeling;

3.een positieve definitie van de consument als subject van bepaalde beschermende maatregelen. ${ }^{49}$

Bij de positieve definitie kan vervolgens gekozen worden voor het begrip consument in "engere" zin: uitsluitend natuurlijke personen, of het begrip consument in "ruimere" zin: naast natuurlijke personen ook bepaalde rechtspersonen en beoefenaren van een vrij beroep. ${ }^{50}$

Ofschoon de introductie van een uniform begrip consument reeds langere tijd wordt bepleit, is de Nederlandse wetgever daarin slechts gedeeltelijk geslaagd. Het Burgerlijk Wetboek en de Wet op het Consumentenkrediet hanteren bij voorbeeld uiteenlopende beschrijvingen. ${ }^{51}$ Het Burgerlijk Wetboek zelf hanteert echter wél een uniforme beschrijving van het begrip consument. In het kader van deze dissertatie wordt voor het begrip consument dan ook aangesloten bij de omschrijving zoals die is neergelegd in de artikelen 6:236, 237 aanhef en 240 lid 3 BW (algemene voorwaarden), artikel 7:5 lid 1 BW (koop en ruil), artikel 7:414 lid 3 BW (lastgeving) en artikel 7:857 BW (borgtocht) en welke doorgaans gehanteerd wordt in de literatuur. Consument is dan:

de matumrlijke persoon die een goed of een dienst betrekt en die niet handelt in de willoefening van een beroep of bedrijf.

48 Zie voor een opsomming van bedrijfsbeoefentars: Jangeneel, Koop en consumentenkoop, Zwolle 1990, pag. 96.

49 Zie ook Brack, diss, pag. 146 ; Brack moemt hierin als vierde mogelijkheid "de wetgever knoopt vast an collectieve consumentenbelangen". Het komt mij echter voor dat deze mogelijkheid afhankelijk is wan een pasitieve of negatieve definitie wan het begrip consument (zie de arti. 6:196 lid 2 en 6:240 lid $3 \mathrm{BW}$; ".... of van eindgebruikers van niet voor een beroep of bedrijf bestemde goederen of diensten) zodal deze cattegorie als zodanig geen onderscheidend vermogen heeft.

50 Brack, diss., pag. 147. Zie voor het begrip consument in numere zin: Th. Bourgoignie, pag. 54. Bourgoignie verstal onder het begrip consument niet alleen "personnes physiqueg" matr eveneens "personnes morales (homes, écoles, associations sans but lucratif, sociétés, groupements, .....) ; Von Hippel, pag. 3, noot 1.

51 E.H. Hondius, Konsumentenrecht algemeen, Jearboek konsumentienrecht 1991, Deventer 1991, pag. 2 . 
Consument in die zin is de eindgebruiker van een goed of dienst. ${ }^{52}$ Het goed of de dienst wordt door de consument aangewend "à son usage privé". ${ }^{53}$ Consument is dus de natuurlijke persoon die hetzij geen vrij beroep of bedrijf uitoefent hetzij overeenkomsten sluit die met zijn beroeps- of bedrijfsactiviteiten geen verband hebben. ${ }^{54}$ De consument in "engere" zin.

Doorgaans zal het niet moeilijk zijn te bepalen of de wederpartij een consument is of niet. De vraag of de wederpartij een natuurlijk persoon is en de vraag of hij een beroep of bedrijf uitoefent leveren meestal geen problemen op. Afbakeningsproblemen doen zich echter voor bij de vraag of een natuurlijk persoon die een beroep of bedrijf uitoefent bij het sluiten van een overeenkomst handelt in de uitoefening van dat beroep of bedrijf en bij de vraag of een natuurlijk persoon die niet handelt in de uitoefening van een beroep of bedrijf maar wél goederen of diensten betrekt die zijn bestemd voor beroeps- of bedrijfsuitoefening gezien kan worden als consument. ${ }^{55}$ Zo kan er met name twijfel zijn indien:

-de overeenkomst weliswaar is gesloten ten behoeve van het beroep of bedrijf maar niet de uitoefening van het beroep of bedrijf uitmaakt en deze overeenkomst niet verschilt van overeenkomsten die ook door particulieren plegen te worden gesloten; bij voorbeeld de ondernemer die zijn bedrijfspand laat schilderen of tegen brand verzekert of een tandarts die een fauteuil koopt voor zijn wachtkamer ${ }^{56}$;

-de overeenkomst deels ten behoeve van de beroeps- of bedrijfsuitoefening wordt gesloten en deels voor privégebruilk; bij voorbeeld de winkelier die zijn woon/winkelpand laat schilderen ${ }^{57}$;

-de overeenkomst door een particulier is gesloten maar een professionele dienst of goed betreft; bij voorbeeld de amateurfotograaf die een professionele panoramacamera $k_{0 o p t}{ }^{\text {si }}$.

Met betrekking tot deze grensgevallen wordt in de parlementaire stukken het volgende vermeld:

52 Rodugues, SWOKA-ondernoeksrapport, pag. 3, Boer, pag. 6.

53 Demeullenaere, diss, pag. 140-142.

54 MvT, Parhementaire Geschiedenis, Inv. 3, 5 en 6, pag. 1650-1651; Asser-Hartkamp II, 1993, nrs 366 en 367 , Iongeneel, diss., pag: 79 .

55 Asser-Hartkamp 1I, 1993, nr. 367; Van Delft-Baas, pag. 15-16; Hujma, WPNR 1990, pag. 734; Hijma, WPNR 1992 , pag. $387-388$.

56 Do voorbelden zijn ontleend aan. Asser-Hartkamp II, 1993, nr. 367 en Hijma, WPNR 1990, pag. 734 .

57 Voorteeld ontleend aan UCV I (Salomong), Parlementaire Gesehiedenis, Inv, 3, 5 en 6, pag. 1669.

58 Voorbeeld ontleend aan: Hijma, WPNR 1992, pag. 387. 
"In verreweg de meeste gevallen zal reeds wil de aard van de prestatie die het onderneen vorms van de overeenkomst, of wit het tussen de gebruiker c.q. diens personeel en de wedenpartij gevoende (werkooplgesprek duidelijk zijn of de gebruiker al dan niet met een consument te maken heef. Uitercard is denkbaar dat een bij de witoefening wan haar beroep of bedrijf handelende wedenpartij wan een ondememer die ook met consumenten contracteen, een prestatie bedingt die zich miet onderscheidt wan wat conswmenten plegen te bedingen, maar ook dan zal de hoedarigheid van die wederpartij de gebruiker veelal duidelijk zijn, bij voorbeeld uit de gegevens die zijn vermeld op de betaalkaan of -cheque waarmee wordt afgerekend, de plaats waarheen de rekening moer worden gestuurd of de zaak moet wordem afgeleverd, enz. Tegen deze achtergrond zal her door de commissile gevreesde probleem zich in een relatief beperk acantal gevallen kanmen woordoen. Alsdam rust bij een beroep van de gebraiker op zijn algemene voorwaarden op de wederpartij de bewijslast van het feit dat hij als consument heeft gecontracteerd. Hierbij vall dan nog te bedenken enerzijds diat de gebruiker deze onzekerheid kan voorkomen door zich, indien dit vaor hern wan belang is, bij het sluiten wan de overeenkomst woor Rees: van; LJHM) de hoedanigheid wan zijn whederpartij te vergewissen ... w9

De twijfel bij de eerstgenoemde situatie is daarmee opgelost. In het daar genoemde geval moet het begrip handelen in de uitoefening van beroep of bedrijf ruim worden uitgelegd en vallen ook de overeenkomsten die zich niet onderscheiden van die welke gewoonlijk worden gesloten door consumenten daaronder. ${ }^{60}$ Alhoewel de minister van mening is dat in de meeste gevallen reeds de aard van de prestatie die het onderwerp vormt van de overeenkomst bepalend kan zijn voor de vraag of de wederpartij een consument is, is toch vooral de subjectieve bedoeling van de wederpartij - de gebruiker dient zich immers zelf van de hoedanigheid van de wederpartij te vergewissen indien hij daar belang bij heeft - doorslaggevend. Dit betekent ook dat de particulier die professionele diensten of goederen betrekt onder het begrip consument valt. ${ }^{61}$

Met betrekking tot de genoemde tweede situatie merkt de minister in de uitgebreide commissievergadering op:

59 MvA, Parlementaire Geschiedenis, Inv, 3, 5 en 6, pag. 1655.

60 Asser-Hartkamp II, 1993, nr. 367; Jongeneel, diss., pag. 79; Van Delft-Bans, pag. 16. Andars: Hijmm, WPNR 1990, pag. 734 en WPNR 1992, pag. 388. De laultste is voor een objectiverende benadering die enerzijds voontwloeit uil de ratio van de (koop)regeling - daar waar een nietdeskundig te achten wederpartij handelt met een desikundig te achten gebruiker doet zich een feitelijke evenwichtsverstoring woor ten gunste van de gebruiker, die juridiseh door een bescherming van de wedemartij dient te worden gecompenseerd - en anderijdis omdat de gebruiker zijn contractuele mogelijkheden en onmogelijkheden op het moment wan het aangaan wan de oveneenkomst afdoende behoort te kunneru inschatten. In zijn visie gaat het er niet om wast te stellen waartoe de koper de zaak heeft bestemd, mar komt de vraag centraal te staan hoe de wederpartij zich objectief gezien heeft opgestell en welke nol hij naar matschappelijke maststaven speelt. In zijn objectiverende optiek dient de ondememer in de exste situatie als consument behandeld te worden en in de derde situatie dient de particulier als thardelende in de witoefening van beroep of bedrif beschouwd te worden.

61 Anders: Hijma, WPNR 1992, pag. 388. De particulier die professionele goederen of diensten betrekt beschouwt hij niet als consument. 
EF zullen altijid, hoe dan ook, van die grensgewallen zijn, watabij geoordeeld zal moeten worden of sprake dient te zijn van een extenstieve of een beperkende uitleg, die grensgevallen zijn er inderdaad, wamneer iemavid (..) zowel prive als zakelijk een opdracht geeft. Zolang her fiscale regime in Nederiand is zoals het is, zal het altijd wel een zakelijke opdracht zijn. It weet echter wiet, of dit de zank ciniel rechueliyk oplost! inte

De minister is dus van mening dat aan de wijze waarop de wederpartij zich fiscaal presenteert een belangrijke doch mogelijk niet beslissende betekenis toekomt. ${ }^{63}$ Het vinden van een oplossing in de tweede situatie wordt daarmee uiteindelijk overgelaten aan de rechter.

\subsubsection{Consumentenorganisatie}

"Een consumentenorganisatie is een rechtspersoon die zich (statutair) ten doel heeft gesteld de belangen van bepaalde consumenten of de consument in het algemeen te behartigen en deze belangen ook feitelijk behartigt", aldus de definitie van Rodrigues ${ }^{64}$. De Nederlandse wetgever hanteert zowel in de Wet misleidende reclame als in de Wet algemene voorwaarden nagenoeg dezelfde terminologie ter aanduiding van consumentenorganisaties:

rechtspersonen met walledige rechtsbevaegdheid die ten doel hebben de behartiging wan belangen van eindgebruikers wan niet voor een beroep of bedrijf bestemde goederien of diensten.

Bij deze definitie wil ik mij aansluiten. Opvallend, doch naar mijn mening voor de praktijk zonder importantie, is dat in deze definitie de neutrale term "eindgebruikers" wordt gehanteerd. Deze omvat naar mijn mening zowel natuurlijke personen als rechtspersonen en wijkt in die zin af van het begrip consument zoals dat in het Burgerlijk Wetboek wordt gehanteerd.

Consumentenorganisaties kunnen weer nader worden onderverdeeld in enerzijds algemene consumentenorganisaties die zich richten op de belangen van consumenten in de ruimste zin van het woord zoals bij voorbeeld de Consumentenbond en het (onlangs opgeheven ${ }^{65}$ ) Konsumenten Kontakt en anderzijds categoriale consumentenorganisaties die zich slechts richten op de belangen van een bepaalde categorie of specifieke groep eindgebruikers zoals bij voorbeeld de ANWB, Vereniging Eigen Huis, het Landelijk Patiëntenplatform maar ook bij

62. UCV I, Parlementaine Geschiedenis, Inv. 3, 5 en 6, pag. 1669-1670.

63 Wessels, WPNR 1990 ; pag. 722.

64 Rodrigues, SWOKA-onderzocksrapport; pag. 3.

65 Het Konsumenten Kontakt is per 1 janumin 1994 opgeheven, Zie: Rijken, NJB 1994, pag. 645, noot 10. In TVC 1994, pag. 334, wordt melding gemalkt van beëindiging van de werkzaamheden van KK per 1 juni 1994 
voorbeeld de Moto Guzzi Club Nederland als behartiger van de belangen van eindgebruikers van een specifiek merk Italiaanse motorrijwielen.

\subsubsection{Gebruiker, aanbeveler en wederpartij}

Voor wat betreft de termen gebruiker en wederpartij wordt in deze dissertatie aangesloten bij de wettelijke betekenis zoals deze is neergelegd in artikel $6: 231$ BW. Gebruiker is dan:

degene die algemene voorwourden in een owereenkomst gebruilat.

In die zin is de gebruiker degene door wie de algemene voorwaarden "in de overeenkomst worden ingeschakeld, daarop toepasselijk worden verklaard". 6 De partij dus, die het initiatief neemt tot het opnemen van algemene voorwaarden in de overeenkomst. ${ }^{67}$ Het begrip omvat niet alleen personen die een beroep of bedrijf uitoefenen of overheidslichamen. Ook een particulier die niet handelt in de uitoefening van een beroep of bedrijf kan gebruiker van algemene voorwaarden zijn in de zin van afdeling 6.5.3 $\mathrm{BW}{ }^{*}$ Zowel natuurlijke personen als rechtspersonen kunnen gebruiker zujjn.

In een aantal gevallen zal niet direct duidelijk zijn welke contractspartij gebruiker van algemene voorwaarden is. Met name bij de hantering van nulzijdige algemene voorwaarden opgesteld door een onpartijdige derde of door organisaties van belanghebbenden is niet altijd uit te maken welke partij gebruiker is ${ }^{69}$. Bij voorbeeld indien de contractspartijen gezamenlijk besluiten een in een boekhandel verkrijgbaar modelcontract te gebruiken voor hun overeenkomst.

Degene jegens wie algemene voorwaarden in een contractuele relatie worden gebezigd is de wederpartij. In de wettelijke definitie is de wederpartij:

degene die door ondertekening van een geschrift of op andere wijze de gelding wan algemene woorwaarden heeft canwaard.

In deze definitie komt duidelijk naar voren dat de wederpartij de tegenpool is van de gebruiker als initiatiefnemer. De wederpartij is immers degene die

66 MvA, Parlementaire Geschiedenis, Inv. 3, 5 en 6, pag. 1526.

67 Jongeneel, diss., pag. 69.

68 Asser-Hartkamp II, 1993, nr. 347; Jongeneel, WPNR 1991, prg. 814.

69. VV, Parlementaire Geschiedenis, Inw. 3, 5 en 6, pag. 1522. Zie hierover: Jongeneel, WPNR 1991 , pag. 813 e.v. 
algemene voorwaarden aanvaardt, hetgeen een voorafgaand initiatief - een aanbod - van de andere contractspartij (de gebruiker) veronderstelt.

Wederpartif in die zin ziet behalve op consumenten ook op professionele contractanten. Ook hier geldt dat bij het gebruik van nulzijdige algemene voorwaarden opgesteld door een onpartijdige derde of organisaties van belanghebbenden niet altijd is uit te maken welke partij wederpartij is.

De term "aanbeveler" komt in de Wet algemene voorwaarden niet voor. Ik kan, voor wat betreft de inhoud van deze term, echter aansluiten bij het bepaalde in artikel 6:240 lid $2 \mathrm{BW}$ dat het vorderingsrecht van consumentenorganisaties mede richt tot:

¿.. een rechispersoon met volledige rechisbevoegdheid die ten doel heeft de behartiging van belangen van persomen die een beroep of bedriff uitoefenen, indien hij het gebruik wan algemene voorwaarden door die persoon bewordert.

De term "aanbeveler" sluit daarbij dan nauw aan bij het bepaalde in artikel $6: 241$ lid 3 sub b BW dat aan de uitspraak op vordering van de eiser kan worden verbonden

... een gebod om een anubeveling tor het gebruik wan dege bedingen te herropen.

\subsubsection{Rechterlijke controle op algemene voorwaarden}

De rechterlijke controle op algemene voorwaarden beperkt zich niet tot de controle als bedoeld in afdeling 6.5.3 BW. Algemene voorwaarden maken integraal deel uit van de overeenkomst en zijn derhalve deels onderworpen aan dezelfde rechterlijke controle als die op overeenkomsten in het algemeen. "Deels" omdat de open norm van artikel 6:233 sub a BW voor het door haar bestreken gebied een lex specialis is van de algemene regel inzake de beperkende werking van de redelijkheid en billijkheid van artikel $6: 248$ lid 2 BW. ${ }^{70}$

Voor wat betreft de rechterlijke controle op het terrein van de algemene voorwaarden wordt traditioneel een onderscheid gemaakt tussen enerzijds de vraag of algemene voorwaarden toepasselijkheid zijn op de overeenkomst omdat zij door de wederpartij zijn aanvaard en anderzijds de vraag of deze aanvaarde voorwaarden gezien hun inhoud bindend zijn voor de wederpartij.

Door de nieuwe wettelijke regeling valt de rechterlijke controle van algemene voorwaarden uiteen in vier fasen: 
-de vraag of de wederpartij de gelding van algemene voorwaarden heeft aanvaard (de artikelen 6:231 sub c, 3:33 en 3:35 $\mathrm{BW}$ );

-de vraag of de gebruiker de wederpartij een redelijke mogelijkheid heeft geboden om van de algemene voorwaarden kennis te nemen (de artikelen 6:233 sub b en 6:234 BW);

-de vraag of de inhoud van de aanvaarde algemene voorwaarden bewerkstelligt dat bepaalde bedingen (ver)nietig(baar) zijn (de artikelen 3:40, 6:233 sub a, 6:236 en 6:237 BW);

-de vraag of de beperkende werking van de redelijkheid en billijkheid met zich brengt dat het aanvaarde beding in de concrete omstandigheden van het geval niet van toepassing is (artikell 6:248 lid $2 \mathrm{BW}$ ).

\subsubsection{Aanvaardings- en gebondenheidstoets}

Zoals reeds hiervoor vermeld wordt traditioneel in de literatuur ten aanzien van de rechterlijke controle op algemene voorwaarden een onderscheid gemaakt tussen enerzijds de zogenaamde gebondenheidsvraag ${ }^{71}$, de vraag of de wederpartij de toepasselijkheid (gelding) van de algemene voorwaarden op de overeenkomst heeft aanvaard, en anderzijds de inhoudstoets, de vraag of de betreffende voorwaarden gezien hun inhoud voor de wederpartij bindend zijn ${ }^{72}$.

Bij de rechterlijke controle van algemene voorwaarden gaat het logischerwijs primair om de vraag of de desbetreffende algemene voorwaarden op grond van het feit dat zij door de wederpartij - die al dan niet kennis heeft genomen van de inhoud van de betreffende bedingen - zijn aanvaard, deel zijn gaan uitmaken van de overeenkomst. Bij ontkennende beantwoording van deze vraag maken de desbetreffende algemene voorwaarden immers geen deel uit van de overeenkomst tussen partijen en dient de rechter deze bedingen buiten beschouwing te laten bij de beoordeling van de rechtsgevolgen van deze overeenkomst.

In deze opvatting wordt daarbij in eerste instantie niet gekeken naar de inhoud van die algemene voorwaarden of naar de (on)mogelijkheid van de wederpartij om van de inhoud van deze algemene voorwaarden kennis te nemen. Het betreft dan ook slechts de vraag of de wederpartij de toepasselijkheid, de

71 Zie bijvoorbeld: MNT, Parlementaire Gesehiedenis, Inv. 3, 5 en 6, pag. 1455-1456, Hondius, diss., pag. 391 e.v.; Van der Werf, diss., pag. 32 e.v.; Rijken, diss., 78 e.v.; Verhoeven, pag 40 e.v.; Jongeneel, diss., pag. 87 e.v.; Asser-Hartkamp II, 1993, ar. 349 e.v.; Mölenberg en Rijken, pag. 1; Rjjken, Mölenberg en Verstappen, pag. 4; Wetsels en Jongeneel, 1992, pag. 1. 43 en 49 ;

72 Zie bijwoorbeeld: Hondius, diss, pag. 454 e.v.; Van der Werf, diss., pag. 69 e.v.; Rjken, diss., pag. 79 e.v.; Asser-Hartkamp II, 1993, nr. 355 e.v.; Verhoeven, pag. 53 a. Jongeneel, diss., pag. 143 e.v.; Mölenberg en Rijken, pag. 2; Rijken, Mölenberg en Verstappen, pag. 5; Wessels en Jongeneel, 1992 , pag. 49 e.v. 
gelding van algemene voorwaarden heeft aanvaard. Voor deze toets wordt in deze dissertatie derhalve het begrip aanvaardingstoets gehanteerd. In de literatuur wordt deze toets meestal gekoppeld aan de term gebondenheid. Ik geef echter de voorkeur aan de term aanvaardingstoets. Dit om twee redenen.

Allereerst omdat in de literatuur het onderscheid tussen het gebondenheidsvraagstuk door de verschillende auteurs niet altijd wordt gehanteerd in die zin dat er een onderscheid wordt gemaakt tussen het toepasselijkheidsvraagstuk aan de ene kant en de inhoudstoets aan de andere kant. In de visie van degenen die het onderscheid niet hanteren is gebondenheid aan een beding immers mede afhankelijk van de inhoud daarvan en vallen bij de toetsing van de gebondenheid de aanvaardingstoets en de inhoudstoets samen. ${ }^{\text {th }}$

Ten tweede omdat ik het beperken van de term gebondenheidstoets tot alleen, wat ik noem, de aanvaardingstoets taalkundig gezien te beperkt vindt. De vraag of de wederpartij "gebonden" is aan algemene voorwaarden is immers niet alleen afhankelijk van zijn wél of niet aanvaarding van de gelding van algemene voorwaarden. Ook op andere wijze komt de "gebondenheid" aan de orde in de rechterlijke controle. Bij voorbeeld indien op grond van de controlle van de inhoud van een beding de rechter tot de conclusie komt dat een beding nietig of vernietigbaar is of dat het beding buiten toepassing dient te blijven op grond van de redelijkheid en billijkheid. Ook dan komt de rechter tot de conclusie dat het beding de wederpartij in de concrete omstandigheden uiteindelijk niet bindt. ${ }^{74}$ Elke rechterlijke controle op het terrein van de algemene voorwaarden ziet uiteindelijk dan ook altijd op de vraag of de gebruiker op de te controleren voorwaarden een beroep kan doen jegens zijn wederpartij. Met andere woorden de vraag of het betreffende beding in het concrete geval verbindende kracht heeft voor de wederpartij. De rechterlijke controlle is dus strikt genomen altijd een gebondenheidstoets. Aan een nietig of buiten toepassing verklaard beding is men immers per definitie niet (meer) gebonden, omdat dat beding ofwel geacht wordt nooit deel te hebben uitgemaakt van de overeenkomst (nietigheid van rechtswege) ofwel na een aanvankelijk bestaan, op vordering van een der partijen, alsnog met terugwerkende kracht uit de overeenkomst is gelicht (vernietigbaarheid) ofwel nooit bindende werking heeft gehad in de bijzondere omstandigheden van het concrete geval (buiten toepassing). De aanvaardingstoets en de in de volgende (sub)paragrafen aan de orde komende informatie- en inhoudstoets zijn dus in die zin allemaal species van het genus gebondenheidstoets.

Zie hiema paragraf 2.3.3.

74 In dezelfde zin: Asser-Hartkamp 4-II, 1993, nrs. 353 en 353a. 
De aanvaardingstoets is dan de primaire gebondenheidstoets die in het systeem van het nieuwe Burgerlijk Wetboek plaats vindt aan de hand van de bepalingen van de artikelen 6:231 sub $\mathrm{c} j^{\circ}$ 3:33 en 3:35 BW.

\subsubsection{Informatietoets}

De rechterlijke controle, als bedoeld in artikel 6:233 sub b BW, betreft de vraag of de gebruiker de wederpartij een redelijke mogelijkheid heeft geboden om van de algemene voorwaarden kennis te nemen en ziet op de informatieplicht die de gebruiker van algemene voorwaarden heeft jegens zijn wederpartij. Om die reden wordt deze toets in deze dissertatie aangeduid met het begrip informatietoets. Aan deze toets komt de rechter pas toe indien hij heeft vastgesteld dat de gelding van de betreffende algemene voorwaarden is aanvaard.

\subsubsection{Inhoudstoets, concrete en abstracte inhoudstoetsing}

In de controle op de inhoud van de algemene voorwaarden is in de nieuwe regeling op twee manieren voorzien. In de eerste plaats in een individuele procedure op vordering of bij wege van verweer van een individuele wederpartij als bedoeld in artikel 6:233 BW en in de tweede plaats in een bijzondere procedure op vordering van een belangenorganisatie als bedoeld in artikel 6:240 BW.

Voor de rechterlijke controle op de inhoud van algemene voorwaarden in het algemeen wordt in deze dissertatie de term inhoudstoets gebruikt. De term inhoudstoets omvat in die zin zowel de inhoudstoets in de individuele als die in de bijzondere procedure. De term ziet in zijn algemeenheid eveneens op de rechterlijke toets van de inhoud van algemene voorwaarden aan dwingende wetsbepalingen, de goede zeden of de openbare orde als bedoeld in artikel 3:40 BW. De toets vindt logischerwijs eerst plaats indien de rechter geconstateerd heeft dat de gelding van de algemene voorwaarden door de wederpartij is aanvaard.

In de individuele procedure als bedoeld in artikel 6:233 sub a BW - de koper van een gebrekkig woonhuis legt bij voorbeeld de exoneratieclausule waarop de verkoper zich beroept, ter beoordeling voor aan de rechter - vindt de inhoudstoetsing plaats aan de hand van de concrete omstandigheden van het individuele geval. In navolging van de wetgever wordt deze rechterlijke toets de concrete inhoudstoets genoemd. ${ }^{75}$ De concrete inhoudstoets kan zowel op

75 MvT, Parlementaire Geschiedenis, Inv. 3, 5 en 6, pag. 1580. 
verzoek van de individuele consument als op verzoek van de individuele professionelle wederpartij plaatsvinden.

De bijzondere procedure als voorzien in artikel 6:240 BW - de Consumentenbond legt een door een landelijke witgoedketen gehanteerd (verlenging van de) leveringstijdbeding voor aan de bijzondere rechter - heeft betrekking op een meer abstracte toetsing. De inhoud van de ter toetsing voorliggende algemene voorwaarden wordt in zulk een procedure beoordeeld met het oog op hun gebruik in het algemeen, ongeacht de persoon van de wederpartij en ongeacht de gedragingen wan de partijen bij of na het sluiten van de overeenkomst. ${ }^{76}$ In navolging van de wetgever tijdens de parlementaire behandeling van het wetsontwerp wordt deze rechterlijke toets de abstracte inhoudstoets genoemd. ${ }^{n}$

\subsubsection{Individueel belang, groepsbelang, algemeen belang, collectief belang en consumentenbelang}

Indien het subject van de met belang aangeduide relatie éen persoon is, is er sprake van een individueel belang. ${ }^{7}$ Naast het individuele belang wordt in de literatuur een aantal categorieën van gebundelde belangen onderscheiden: groepsbelangen, collectieve belangen en algemene belangen. ${ }^{79}$

Algemene belangen zijn die belangen die gemeenschappelijk zijn aan een zo grote groep dat deze praktisch ieder lid omvat van een samenleving die een staatkundige eenheid vormt, zij vormen een facet van vrijwel ieders bestaan en de betrokkenen zijn niet te individualiseren. Voorbeelden van dit type belangen zijn verkeersveiligheid, werkgelegenheid, volksgezondheid en het (algemene) consumentenbelang. Groepsbelangen daarentegen zijn dan de belangen waarbij de betrokken personen well zijn te individualiseren als specifieke groep. ${ }^{80}$

Groenendijk hanteert daarnaast nog een derde categorie: de collectieve bellangen, waarbij het gaat om de relatie tot een gemeenschappelijk object van een verzameling van mensen die tenminste eén sociaal kenmerk gemeen

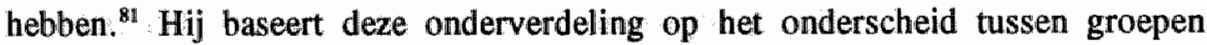
en sociale categorieën (collectieven). Het verschil tussen een groep en een sociale categorie schuilt dan met name in het onderling contact van de betrokke-

76 MvT, Parlementaire Gesehiedenis, Inv. 3, 5 en 6, pag. 1763.

77 MvT, Parlementaire Geschiedenis, Inv. 3, 5 en 6, pag. 1456, 1649 en 1763.

78 Groenendijk, diss., pag. 47 .

79 Verburgh, inaug. rede, pag. 8; Groenendijk, diss., pag. 48; Rodrigues, SWOKA-onderzoeksrapport, pag. 6, Frenk, diss. "pag. 6.

80 Verturgh, inaug. rede, pag. 8-9; Groenendijk, disis, pag. 48-49; Rodrigues, SWOKAonderzoeksrapport, pag. 6; Rodrigues, Procesnecht en collectief actierecht, pag. 18; Frenk, disss., pag. 6-7.

81 Groenendijk, diss., pag. 48. 
nen, de mate van invloed die deze hebben op de besluitvorming ten aanzien van het betrokken belang en de individualiseerbaarheid. ${ }^{82}$

De term groep veronderstelt dat de betrokkenen contact met elkaar onderhouden, dat er individuele invloed op de besluitvorming ten aanzien van het belang is, dat de "leden" zich als groep presenteren en dat de leden van de groep met naam kunnen worden aangewezen. Bij voorbeeld de huurders van een bepaald flatgebouw, de bewoners van een specifieke wijk, de leden van een bepaalde vereniging, etc. $\mathrm{Bij}$ een sociale categorie is het onderlinge contact onmogelijk of van incidentele aard en directe deelname aan de besluitvorming omtrent het collectieve belang is doorgaans dan ook niet mogelijk.. De besluitvorming ten aanzien van dit collectieve belang verloopt vaak via (particuliere) organisaties. Voorbeelden van dergelijke collectieve belangen zijn: werknemers-, studenten-, ondernemers-, ouderen- en consumentenbelangen ${ }^{83}$.

De term collectieve belangen die Groenendijk hanteert voor de belangen van een sociale categorie is mijns inziens nogal verwarrend omdat deze te weinig onderscheidend vermogen heeft. Groepsbelangen en algemene belangen zijn immers per definitie eveneens collectieve belangen. Spraakverwarring ligt dan voor de hand. Mijn voorkeur ter aanduiding van dit soort belangen gaat dan ook uit naar een term die meer aansluit bij het begrip sociale categorie, namelijk "categoriale belangen". Logische consequentie is dat in deze visie de term collectieve belangen dan zowel groeps-, categoriale- als algemene belangen omvat.

De term consumentenbelang heeft in het licht van de voorgaande onderverdeling van soorten belangen weinig onderscheidend vermogen. Als algemene term is het een diffuus begrip. Het ziet, afhankelijk van het aantal betrokkenen en de aard van het belang, zowel op het individuele, het groeps-, het categoriaal alls het algemeen belang. Het begrip is dus afhankelijk van de context waarin het wordt gebruikt en de waardering daarvan.

Iedereen is consument. Daar waar het belangen aangaat die zo algemeen zijn dat nagenoeg iedereen in zijn hoedanigheid als consument erbij betrokken is, is sprake van algemene belangen. ${ }^{84} \mathrm{Bij}$ voorbeeld het (algemene) belang van consumenten bij niet-misleidende reclame, eerlijke produktvoorlichting of veilige produkten. Indien de term consumentenbellang echter ziet op het belang van de consument in de concrete contractuele relatie, bij voorbeeld in de situatie van

82. Groenendijk, diss., pag. 51 .

83 Opvallend is mijns inziens dat Groenendijk het consumentenbelang niet noemt als woorbeeld wan een collectief belang maar enkel als voorbeeld van een algemeen belang. Zie Groenendijk, disis., pag. 49 .

84 Zie meer uitgebreid over de term "algemeen belang" en "het algemeen belang": Groenendijk, diss., pag. 53 e.v. 
de toerist wiens gereserveerde hotelkamer overboekt is, dan beherbergt het begrip een individueel belang. Wordt het begrip in de ruimere context van een groep gebruikt, bij voorbeeld in de context van een groep consumenten die eenzelfde reis onderneemt, dan is het betreffende consumentenbelang een groepsbelang. Analoog geredeneerd komt het consumentenbelang in een categoriaal perspectief te staan indien het wordt gebruikt in een categoriale context, bij voorbeeld in de context van de reizende consument in het algemeen.

In het kader van het begrip belang moet hier tevens het begrip belang aan de orde komen zoals het gehanteerd wordt in het adagium "point d'intérêt, point d'action" oftewel "geen belang, geen actie".s Het begrip belang in dit adagium ziet op een zuiver processueel belang. Het betreft de vraag of de eisende partij bij toewijzing van het door haar gevorderde enig belang heeft; de vraag of met de vordering eisers recht en belang te verwezenlijken zijn. Bij het ontbreken van dit processueel belang is de betreffende partij niet ontvankelijk. ${ }^{86}$ Een voorbeeld van een ontbrekend processueel belang is het (nogmaals) instellen van een reeds eerder toegewezen vordering. ${ }^{87}$ Het adagium "point d'intérêt, point d'action" kan volgens Van Baars het best vertaald worden met: "geen processueel belang, geen actie" ${ }^{\prime 2}$ Het geeft uitdrukking aan de gedachte dat men de overheidsrechter niet onnodig moet inschakelen en de tegenpartij niet moet lastig vallen met een onnodig proces. ${ }^{99}$ In ons recht is deze processuele regel neergelegd in artikel 3:303 BW:

Zonder woldounde belang kom niemand een rechtswordering toe ${ }^{\text {wi }}$

Opmerking verdient dat artikel 3:303 BW niet alleen de eis stelt dat eiser een processueel belang dient te hebben, maar tevens dat zijn materiële belang voldoende is om een procedure te rechtvaardigen. ${ }^{90}$ In deze dissertatie wordt in de hierboven beschreven termen individueel belang, groepsbelang, etc., de term belang gehanteerd in de betekenis van het "materieel belang". Het moet goed onderscheiden worden van het begrip processueel belang. Het begrip materieel

85 Zie hierover Van Baars, dissertatie 1971; Rodrigues, Procesrecht en collectief actierecht, pag. 31, Frenk, TwC 1990, pag. 206-208; Frenk, diss, pag. 27-32.

86 Frenk, diss., pag. 27.

87 Stein, compendium, pag. 164.

88 Van Baars, diss., pag. 153, 160 en 165.

89 Van Baars, diss., pug. 155; Frenk, diss, pag. 28.

90 Parlementaine Geschiedenis, Boeken 3, 5 en 6, pag. 302-303; Rodirigues, Procesrecht en collectiof actierecht, pag. 31; Frenk, TrC 1990, pag. 207; Frenk, diss., pag. 32 e.v.. Frenk vrangt zich zelfs of of in artikel 3:303 BW niet tevens het "eigen-belangvereiste" (de eis dat men in rechte slechts kan opkomen voor zijn eigen belangen) is opgenomen; zie: TvC 1990 , pag. 207. 
belang wordt bij voorbeeld gehanteerd in het (achterhaalde ${ }^{91}$ ) procesrechtelijk beginsel dat een eiser in een civiele procedure slechts voor zijn eigen belangen kan opkomen; zijn eigen materiële belangen.

\subsubsection{Individuele actie, collectieve actie en actierecht}

Artikel 3:296 BW bepaalt dat degene die jegens een ander verplicht is iets te geven, te doen of na te laten daartoe door de rechter op vordering van de gerechtigde veroordeeld kan worden. In dit artikel komt het nawwe verband tussen subjectief recht (vorderingsrecht) en rechtsvordering tot uitdrukking. ${ }^{92}$ Het recht om in rechte op te komen voor zijn belangen wordt als algemene term aangeduid met "actierecht" of "ius agendi". In het verlengde daarvan liggen termen als "individueel en collectief actierecht".

Het onderscheid tussen de termen individueel actierecht en collectief actierecht dient mijns inziens gebaseerd te zijn op het belang dat in de betreffende procedure in het geding is en valt niet noodzakelijkerwijs samen met het onderscheid tussen individu en collectief. De onderscheidende factor is of het belang dat wordt vertegenwoordigd het eigen belang is of de gebundelde belangen van anderen ${ }^{93}$.

De term individueel actierecht ziet dan op de bevoegdheid om als natuurlijk of rechtspersoon op te komen voor een eigen concreet belang. Onder collectief actierecht wordt dan begrepen het recht van natuurlijke of rechtspersonen om in rechte op te komen voor de krachtens hun doelstelling te behartigen collectieve belangen van anderen..$^{94}$

De uitoefening van het actierecht, de rechtshandhaving is de actie. In het verlengde van de termen individueel en collectief actierecht liggen dan de termen individuele actie en collectieve actie. ${ }^{95} \mathrm{De}$ termen collectieve actie en collectief actierecht zien dan zowel op de handhaving van groeps- en categoriale belangen als algemene belangen.

Een prachtig voorbeeld van (consumenten) actie waarin de onderscheiden vormen van actie en consumentenbelang aan bod komen, is te vinden in de procedure omtrent de tellefoontarieven zoals deze gespeeld heeft tussen enerzijds de Staat der Nederlanden (PTT) als gedaagde en anderzijds de Consumentenbond, de Algemene Nederlandse Bond voor Ouderen (ANBO) en de consument

91 Frenk, diss., pag. 77.

92 Harkamp, Compendium, pag. 161.

93 Aan dit laatste doet niet af dat de behartiging van dit collectieve belang een "eigen" belang is geworden omdat men zich dit belang heeft angetrokken. Zie in dit verband: Frenk, diss., pag. $37-42$ en HR 18 december 1992, NJ 1994, 139 (Kuumders/Stichting Natuur en Miliou).

94 Rodrigues, SWOKA-onderzoeksrapport, pag. 3.

95 De term actie beperkt zich overigens niet tot de gerechtelijke fase. 
als eisers " Eisers vorderden een verklaring voor recht dat het bestrepindelen van de PTT een aan de PTT toerekenbare tekortkoming of ftmatige daad was en dat de PTT derhalve in beginsel gehouden was tot $j \mathrm{~g}$ van schadevergoeding. $\mathrm{Zij}$ vorderden de uitspraak primair met betrekt alle telefoonabonnees, subsidiair ten behoeve van de leden van ANBO psumentenbond en meer subsidiair met betrekking tot de eigen telefoontíngen van ANBO, Consumentenbond en Meijer.

- primaire en subsidiaire vorderingen zijn duidelijke voorbeelden van feve acties. Hoewel het betroffen belang mede dat van eisers omvat is het pmelijk dat van anderen dan van eisers zelf. Opmerkelijk is dat ook de juele consument als eiser heeft deelgenomen aan de collectieve actie. Hij gen vordering ingesteld namens alle telefoonabonnees en namens de leden NBO en Consumentenbond, een zuivere "actio popularis"197?

a primaire vordering ziet op alle telefoonabonnees en daarmee mijns is hoofdzakelijk op een categoriaal belang. De subsidiaire vordering betreft juidelijk groepsbelang. Het betreft het belang van de leden van ANBO ctievelijk Consumentenbond, en daarmee het belang van een groep an de leden gemakkelijk te identificeren zijn. De meer subsidiaire vordepetreft drie (gebundelde) individuele acties en dlaarmee gepaard gaande duele eigen belangen van enerzijds een natuurlijk persoon en anderzijds rechtspersonen. Deze vordering ziet op drie concrete gevallen. Dat overiaok de individuele procedure uiteindelijk toch collectieve (in casu categorirevolgen kan hebben (precedentwerking) blijkt wel uit het feit dat tussen en, ofschoon eisers enkel ontvankelijk werden verklaard in hun uiterst Jiaire individuele vordering en die ook kregen toegewezen, na afloop van ocedure een schikking is getroffen voor alle telefoonabonnees. ${ }^{98}$

de Wet algemene voorwaarden is zowel in een individuele actie (artikel BW) als in een collectieve actie (artikel 6:240 BW) voorzien. In die at staat de term individuele actie voor de rechtshandhaving door de consuof professionele wederpartij in het concrete, individuele geval als bedoeld ikel 6:233 sub a en b BW. De term collectieve actie is dan gereserveerd de rechtshandhaving door belangenorganisaties in de abstracte procedure doeld in artikel $6: 240 \mathrm{BW}$. Voor zover het betreft consumenten, gaat het individuele actie om het eigen belang van de consument, bij de collectieve Saat het om zowel het algemene als het categoriale consumentenbelang.

\footnotetext{
1. Den Haag, 15 februari 1989, TvC 1989, pag. 76-84, m.nt P.R. Rodrigues.

Wers dan bij het proefproces, was formeel een individu procespartij is doch materieel ook

Mre dan diens belangen in het spel zijn, is het uitgangspunt van de "actio popularis" juist dat

individu voor andere dan alleen thet eigen belang kan ageren. Zie hierover meer uitgebreid:

mendijk, diss, pag. 271-309.

4rigues, TwC 1989, pag, 84.
} 


\subsection{Opzet van het onderzoek}

Het onderhavige onderzoek is gesplitst in vier gedeelten: een inleidend deel waarin het verschijnsel algemene voorwaarden in zijn maatschappelijk kader wordt geplaatst; een tweede deel waarin de te onderzoeken wetgeving wordt besproken en vergeleken; een derde deel waarin de werking van het collectief actierecht op het terrein van de algemene voorwaarden in de praktijk aan de orde komt en een laatste deel met conclusies en voorstellen.

Ter verdieping van het inzicht in het collectief actierecht op het terrein van de algemene voorwaarden wordt het inleidend gedeelte in de volgende hoofdstukken voortgezet met een generieke beschrijving van het verschijnsel algemene voorwaarden, de procesrechtelijke positie van de consument op dit terrein en de reactie van de Nederlandse wetgever het fenomeen algemene voorwaarden.

In hoofdstuk 2 wordt het verschijnsel algemene voorwaarden nader uitgediept en gerelateerd aan de grondbeginselen van ons contractenrecht en burgerlijk procesrecht. Uitgangspunt is daarbij de rol die zowel de individuele consument als zijn vertegenwoordigende organisaties hierin spelen. Vanuit deze beschrijving en een inventarisatie van de ontwikkelingen in de rechtspraak op dit terrein in hoofdstuk 3, wordt blootgelegd welke mechanismen zowel de Nederlandse wetgever als buitenlandse wetgevers er toe heeft gebracht de consument op het terrein van de algemene voorwaarden nader te beschermen. Voor deze bescherming staan de wetgevers diverse beleidsinstrumenten ter beschikking. In het vierde en tevens laatste hoofdstuk van het inleidend gedeelte wordt op deze beleidsinstrumenten nader ingegaan. Afgesloten wordt dit hoofdstuk met een beschrijving van de keuze (en het karakter daarvan) van de Nederlandse wetgever voor dwingende wetgeving waarin opgenomen een repressieve inhoudstoetsing op instigatie van consumentenorganisaties. ${ }^{99}$ Getoond zal worden dat het collectief actierecht op het terrein van de algemene voorwaarden een compensatie beoogt te bieden voor de ongelijke positie van de consument in het rechtsverkeer met professionele aanbieders.

In het tweede deel "De wettelijke regeling van de problematiek van de algemene voorwaarden" komen in de hoofdstukken 5 en 6 de materieel- en procesrechtelijke bepalingen van respectievelijk de Nederlandse Wet algemene voorwaarden en het Duitse AGB-Gesetz aan de orde. Het tweede deel wordt in hoofdstuk 7 afgesloten met een vergelijking van beide regelingen waarbij uiteraard de nadruk zal liggen op een vergelijking van de materieel- en procesrechtelijke bepalingen en de juridische knelpunten daarin. 
behandelt de praktische ervaringen van Duitse consumentenorga-

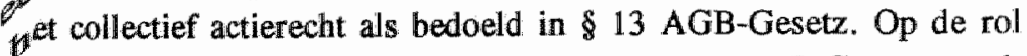
consumentenorganisaties in de praktijk van het AGB-Gesetz wordt 8 ingegaan. Daarbij zullen de activiteiten van de meest actieve grganisaties nader worden onderzocht. De handhavingsprocedures

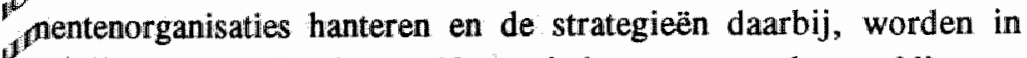

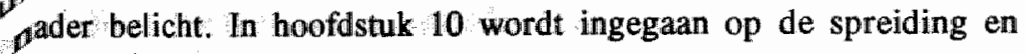

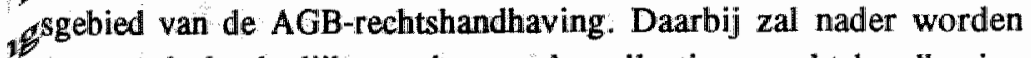
pet materieelrechtelijk gevolg van de collectieve rechtshandhaving

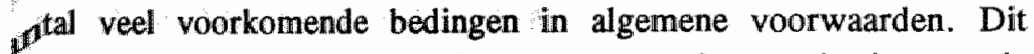
wordt in hoofdstuk 11 afgesloten met een inventarisatie van de $p$ de collectieve AGB-rechtshandhaving door Duitse consumentenen wordt een oordeel gegeven over de effectiviteit van het collectief ; middel ter compensatie van ongelijkheid tussen marktpartijen zoals and in de praktijk is gebracht.

, en laatste deel "Nieuwe wegen" worden allereerst in hoofdstuk 12 3rvaringen vertaald naar de Nederlandse situatie en wordt een * gemaakt van de in Nederland te verwachten knelpunten in de echtshandhaving door consumentenorganisaties op het terrein van de ,orwaarden en de factoren die deze knelpunten beïnvloeden. In , draag ik mogelijke oplossingen aan voor deze knelpunten. Daarbij en inspireren door de Duitse ervaringen. Het boek wordt afgesloten envatting in het Nederlands en het Duits. 


\section{Algemene aspecten van het verschijnsel algemene voorwaarden en de procesrechte、 lijke positie van de consument op dit terre $i_{h}$}

\subsection{Inleiding}

Het onderhavige onderzoek richt zich op de regeling van algemene voorwaarden en de door de Nederlandse en Duitse wetgever gekozen wijze van bescherming van consumenten op dit gebied. Beide wetgevers hebben in respectievelijk het AGB-Gesetz en de Wet algemene voorwaarden gekozen voor dwingend recht dat uitgaat van een repressieve ${ }^{1}$ inhoudstoetsing te entameren door zowel individuele wederpartijen als belangenorganisaties.

Voor een beter begrip van deze keuze is allereerst vereist vertrouwd te raken met het verschijnsel algemene voorwaarden, de ontstaansgeschiedenis, de ratio, het standaardkarakter en de kenmerken ervan zoals gehanteerd tegenover consumenten. Daarbij wordt nader ingegaan op de juridische status van algemene voorwaarden en is van belang de vraag, in hoeverre het gebruik hiervan in overeenstemming is te brengen met de beginselen van ons contractenrecht en procesrecht. Algemene voorwaarden zijn immers:

een of meer schriftelijke bedingen die zijn opgesteld temeinde in een aantal overeenkomsten te worden opgenomen, met witzondering van bedingen die de kem wan de prestatie aangeven.

Nog fraaier komt het karakter van algemene voorwaarden tot uitdrukking in de definitie van Hondius:

1 De toetsing vindt in beide systemen immers plats nadat de te toetsen algeneme voorwasrien zijn sanbevolen, gebruikt of thun gebruik is aangekondigd. De term "repressieve inhoudstoetsing" staat in de hier bedoelde betekenis tegenover de zogenaumde "preventieve inhoudistoetsing". Preventieve inhoudstoetsing ziet dan op de inhoudstoets die plaatsvindt voordat algemente voorwasden (mogen) worden aambevolen, gebruikt of het gebnik daarvan wordt angekondigd, zoals bij voorbeeld bij voorafgaande overtieidsgoedkeuring. De term repressieve inhoudgto et in deze betekenis shuit niet uit dat deze ook een zekere preventiewe werking heeft, bij voot beld door precedentwerking, door verbod van verder gebnik of omdat de toutsing plantsvindt direct wa de aankondiging van gebruik en deze toetsing daadwerkelijk gebnik belet. 
"schriffielijke koncept-bedingen, welke zijn opgesteld om zonder onderhandelingen ontrent hun inhowd opgenomen te worden in een gewoonlijk onbepaald aantal nog te sluiten overeenkomsten wan bepacalde card: ${ }^{2}$

Zo ontbeert met name bij eenzijdig opgestelde algemene voorwaarden de consument enige invloed op de inhoud daarvan. Zijn contractsvrijheid beperkt zich in deze tot het wel of niet ongewijzigd aanvaarden van de gereedliggende algemene voorwaarden. De consument heeft slechts de keuze tussen wél of niet contracteren; aan de inhoud van de algemene voorwaarden valt niet te tornen. Tevens speelt een rol dat de consument bij het contracteren in hoge mate te maken heeft met organisaties en collectieven - bij voorbeeld banken, verzekeringsmaatschappijen, detailhandelketens, winkels, etcetera - als tegenpartij en er zowel in als buiten rechte sprake is van sociale ongelijkheid. Als reactie op deze ongelijkheid zijn consumenten overgegaan tot bundeling van hun belangen in organisaties en collectieven, de consumentenorganisaties.

Centraal staat de vraag in hoeverre de individuele consument met betrekking tot overeenkomsten die hij sluit toegang heeft tot het recht en rechter, gevolgd door de vraag welke rol consumentenorganisaties daarin kunnen spelen. In dit hoofdstuk wordt daartoe in de volgende paragraaf (2.2) ingegaan op de ontstaansgeschiedenis, functie en omvang van het gebruik van algemene voorwaarden. Vervolgens wordt in paragraaf 2.3 het rechtskarakter van algemene voorwaarden behandeld. Aan de hand van de beginselen van ons contractenrecht en de vermaatschappelijking en collectivering van het privaatrecht wordt, zoals Gras dat noemt, de "sociale werkelijkheid" van algemene voorwaarden blootgelegd. Met name waar het de verbindende kracht van, in de literatuur ook wel aangeduid met gebondenheid aan, algemene voorwaarden betreft, schiet het "klassieke" contractsmodel namelijk te kort. Daarbij gaat het om de vraag of deze gebondenheid gerechtvaardigd dient te worden vanuit de klassieke grondslagen van het contractenrecht of vanuit de behoeften van het moderne maatschappelijk verkeer.

In paragraaf $2.4 \mathrm{komt}$, aan de hand van de beginselen van het burgerlijk procesrecht, de positie van de consument als individu in het juridisch proces aan de orde. Conflicten, dus ook conflicten met betrekking tot algemene voorwaarden, worden deels beslist door de overheidsrechter. Daarbij wordt ingegaan op de rol die collectieven in dit proces spelen.

2. Hondius, diss., pag. 243. Ziv in dit verband ook: artikel 3 van EEG-Richtlijin betreffende oneerlijke bedingen in consumentenoveneenkomsten waarin bepalend is voor de vraag of men met een algemene voorwande te doen heeft of het beding voorwerp is geweest van afzonderlijke onderthandeling.

$3 \quad$ Zie de titel wam zijin dissertaltie: 
Paragraaf 2.5 bevat een (samenvattende) inventarisatie van de nadelen van het gebruik van algemene voorwaarden voor de consument. Vanuit deze inventarisatie wordt in de laatste paragraaf (2.6) nagegaan waar de consument op dit terrein bescherming behoeft en waar niet.

\subsection{Algemene voorwaarden}

Algemene voorwaarden - de zogenaamde kleine lettertjes - zijn in ons contractenrecht gemeengoed geworden en de consument gaat in de vervulling van zijn levensbehoeften veelvuldig overeenkomsten aan die grotendleels bepaald worden door deze algemene voorwaarden. Hoe is dit algemene gebruik van gestandaardiseerde contractsbedingen ontstaan, wat zijn de gronden van dit gebruik en in welke omvang worden algemene voorwaarden gebruikt? Vragen waar ik in de volgende (sub)paragrafen kort op zal ingaan.. Voor meer uitgebreide behandeling verwijs ik naar de dissertatie van Hondius. ${ }^{4}$

\subsubsection{Ontstaansgeschiedenis van algemene voorwaarden}

Het gebruik van algemene voorwaarden in overeenkomsten voert terug tot ruim vór onze jaartellings. Daar waar een samenleving zich verder ontwikkelt, vindt een zekere standaardisering van verhoudingen plaats. Standaardformulieren en gestandaardiseerde teksten worden dan ook reeds aangetroffen in de oude Babylonische-, Egyptische-, Griekse-, Romeinse en Germaanse beschavingen. ${ }^{6}$ In de $11 \mathrm{e}$ en $12 \mathrm{e}$ eeuw leidde de opbloei van de handel in sommige delen van Europa met name in Italië tot een hernieuwde aandacht voor contractsmodellen en formulierverzamelingen en komen in Italië de eerste assurantiecontracten tot ontwikkeling. ${ }^{7}$ De Italiaanse notariële handleidingen en modellenverzamelingen hebben vanaf de $14 \mathrm{e}, 15 \mathrm{e}$ eeuw over heel Europa algemeen navolging gevonden en tot op heden wordt in het handelsverkeer gebruik gemaakt van modellenverzamelingen.. ${ }^{8}$

Algemene voorwaarden zijn als algemeen maatschappelijk verschijnsel echter pas tot ontwikkeling gekomen en een rol van betekenis gaan spelen met de opkomst van de moderne industriële maatschappij". De industriële ontwikkeling en de daarmee gepaard gaande welvaart hebben geleid tot massaproduktie en

4 Hondius, diss., hoofdstuk 3.

5 Hondius, diss, pag. 98 e.v.; Van der Werf, disis. pag. 21.

6 Hondius, diss, , pag. 98-108; Van der Werf, diss., pag. $2 l_{\text {. }}$

7 Hondius, diss, pag. 109 e.v.; Van der Werf, diss., pag. 21.

8. Hondius, diss., pag. 110-116; Van der Werf, diss., pag. 22-23.

9 Hondius, diss., pag. 16 e.v. en pag 123 e.v.; Grag, Standaardkontrakten, pag. 8-9; Van der Werf, diss., pag. 16,23 en 24 ; Dalhuisen, pag. 63 ; Rijken, inaug. rede, pag. 7-8. 
massaconsumptie van goederen en diensten en daarmee tot standaardisering. In dezelfde zin veranderde ook het karakter van het handels- en rechtsverkeer tussen professionele aanbieders van goederen en diensten onderling en tussen professionele aanbieders en de consument. Ook hier deden zich standaardisering, schaalvergroting en concentratie voor, hetgeen gepaard ging met een groeiende behoefte aan uniformering van de daarop betrekking hebbende overeenkomsten.

In het professionele handelsverkeer leidde dit er toe, mede vanwege de instorting van bet gildewezen dat in zijn tijd voorzag in de benodigde uniforme reglementering, dat vanaf de $18 \mathrm{e}$ eeuw handelsbeurzen en verenigingen steeds meer overgingen tot standaardisering van hun contracten en dat de eerste tweezijdige algemene voorwaarden tot stand kwamen. ${ }^{10}$

In die tijd komen eveneens de eenzijdige algemene voorwaarden in zwang. Met name in het rechtsverkeer met consumenten leidde de standaardisering en massaconsumptie tot gebruik van eenzijdig door de professionele aanbieders opgestelde algemene voorwaarden. Een van de eerste contracten waarvoor algemene voorwaarden grote betekenis kregen was de verzekeringsovereenkomst. ${ }^{11}$ Sindsdien hebben algemene voorwaarden een hoge vlucht genomen en zich met de ontwikkeling van de industriële samenleving uitgebreid tot nagenoeg alle takken van het economisch rechtsverkeer waar vrijwell iedereen regelmatig mee in aanraking komt. ${ }^{12}$

\subsubsection{Functie van het gebruik van algemene voorwaarden}

Juridisch gezien hebben algemene voorwaarden geen andere functie dan obligatoire overeenkomsten in het algemeen hebben. $\mathrm{Zij}$ geven een (nadere) regeling voor de uitwisseling van goederen en/of diensten tussen partijen. ${ }^{13}$

Praktisch gezien is de functie van algemene voorwaarden tweeledig en (beknopt) te omschrijven als enerzijds het vereenvoudigen van het aangaan van telkens terugkerende overeenkomsten en anderzijds het vastleggen van de rechtspositie van partijen. Algemene voorwaarden kunnen of een specifiek op de overeenkomst toegesneden afwijking van het regelende recht bevatten of voorzien in (aanvullende) regels voor contractstypen die in de wet geen nadere regeling vinden. ${ }^{14} \mathrm{Zij}$ bevorderen daarmee een vlot en behoorlijk functioneren

10 Hondius, diss., pag. 116-122.

11 Hondius, diss., pag. 123 en 365 e.v.

12 W.G. Verknisen, Standaandeontracten, Ars Aequi VI (1957), pag. 166; Gras, Standaardkontrakten, pag. 1, 46 e.v.; Gras, diss., pag. 23-29; Verhoeven, pag. 2; Jongeneel, diss., pag. 1.

13 Van der Werf, diss." pag 16.

14 Nieuwenhuis, diss, pag. 134. 
van het economisch verkeer. ${ }^{\text {is }}$ Doordat onderhandelingen over de verdere inhoud van de overeenkomst achterwege kunnen blijven, leiden algemene voorwaarden tot tijd- en daarmee kostenbesparing voor zowel de consument als de gebruiker. De gebruiker kan aan minder gekwalificeerd personeel de contractssluiting overlaten en de consument kan zich concentreren op de hoofdzaak.

Algemene voorwaarden zijn in die zin te vergelijken met het regelend recht. ${ }^{16}$ Partijen kunnen zich concentreren op de essentialia van de overeenkomst - de rompovereenkomst - en de modaliteiten net zoals bij het regelende recht overlaten aan het toepasselijk verklaarde regelcomplex van algemene voorwaarden. ${ }^{17}$ Algemene voorwaarden zijn in beginsel dan ook opgesteld om ongelezen te worden aanvaard door de wederpartij. In het niet (hoeven) lezen van de algemene voorwaarden ligt immers hun mut.

Algemene voorwaarden bieden het voordeel dat zij actueel zijn en toegesneden op een bepaalde overeenkomst of een specifiek produkt. $\mathrm{Zij}$ kunnen meer dan het regelende recht rekening houden met de kenmerken van die overeenkomst of dat produkt. Doordat de inhoud (en daarmee de risico's) van overeen* komsten van te voren vaststaat, verhoogt het gebruik van algemene voorwaarden de berekenbaarheid van de kosten van toekomstige transacties en wordt de rechtszekerheid voor partijen vergroot. ${ }^{18}$ Volgens Gras zijn zij een organisatietechniek ter bereiking van het ondernemingsdoel waar de moderne grote onderneming niet meer buiten kan en zijn zij onlosmakelijk met bepaalde produkten of diensten verbonden. ${ }^{19}$ Vanuit de optiek van de ondernemer zijn algemene voorwaarden en de uniforme toepassing daarvan dan ook vooral van belang voor de rationalisering van zijn onderneming. ${ }^{20}$

Algemeen wordt aangenomen dat het gebruik van (redelijke en evenwichtige) algemene voorwaarden in ons economisch verkeer onontbeerlijk is bij de regulering van de stroom van goederen en diensten aan de consument. ${ }^{21}$ Het economisch verkeer zou danig ontwricht raken indien over de modaliteiten van alke overeenkomst apart onderhandeld zou moeten worden of, in de woorden van Nieuwenhuis:

CCA-Advies, pag. 4-5; Van der Werf, pag. 16-17; Nieuwenhuis, diss., pag. 135; AsserHartkamp II, 1993, nr. 342.

16 Hondius, diss., pag. 270 e.v.; CCA-Advies, pag. 4-5.

17 Nieuwenthuis; diss., pag. 134.

18 Hondius, diss., pag. 227; CCA-Advies, pag. 5; Gras, diss., pag. 38; Van der Werf, pag. 16.

19 Gras, diss., pag. 12-15.

20 Hondius, diss., pag. 267 e.v.; Rijken, diss., pag. 60-63; Verhoeven, pag. $25-26$.

21 Stein, diss., pag. 152; Verburgh, NJB 1979, pag. 530; Gras, Standaurdkontrakten, pag. 1; Van der Werf, diss., pag. 2 en 17; Gras, diss., pag. 13 e.v. en 38; Hondius, diss., pag. 267 e.v.; Hondius, preadvies, pag. 108; Nieawenhuis, diss., pag. 134; CCA-advies, pag. 4 en 5 ; AsserHartkamp II, 1993, nr. 342; Jongeneel, diss., pag. 1; Verhoeven, pag. 2 en pag. 25-26; MVT Inv., Parl. Gesch. Boek 6 (Inv. 3, 5 en 6), pag. 1451 en 1452. 
"Het contractenrecht zou spoedig dol draaien als het niet kon terugvallen op woorgevormude en gereedliggende parronen ". 22

\section{2,3 Omvang van het gebruik van algemene voorwaarden}

Naar de omvang van het gebruik van algemene voorwaarden in Nederland is rechtssociologisch onderzoek gedaan door Gras. Deze onderzocht bij een groot aantal sectoren van het Nederlandse bedrijfsleven:

-het percentage ondernemingen dat bij in- of verkoop gebruik maakt van algemene voorwaarden (verbreiding van het gebruik);

-de frequentie van gebruik van algemene voorwaarden (groot-, respectievelijk kleinverbruik), en

-het geschatte percentage van de transacties waarbij ondernemingen algemene voorwaarden gebruiken (intensiteit van het gebruik). ${ }^{23}$

Op grond van zijn onderzoek komt hij tot de gevolgtrekking dat zowel in het Nederlandse bedrijfsleven als geheel als in de afzonderlijke bedrijfstakken:

-het percentage "verbreiding van gebruik" overal, zowel bij de afzonderlijke inkoopcategorieën als bij de verkoop groter is dan $50 \%$, meestal zelfs groter dan $80 \%$;

-het percentage "grootgebruik" groter is dan het "kleingebruik". Dat wil zeggen dat verreweg het merendeel van de ondernemingen met hoge frequentie algemene voorwaarden gebruikt; en

-de intensiteit van gebruik groter is dan $50 \%$. Dat wil zeggen dat het geschatte percentage transaeties waarbij algemene voorwaarden worden gebruikt praktisch overal groter is dan $50 \%$.

Gras komt tot de conclusie dat bij de transacties van het Nederlandse bedrijfsleven "het kontraktenrecht in feite standaardkontraktenrecht is geworden". ${ }^{24}$ Daarbij moet opgemerkt worden dat een aantal sectoren niet bij het onderzoek betrokken werd omdat bekend is dat deze vrijwel geheel beheerst worden door algemene voorwaarden. Het betreft met name de overheidsbedrijven (inclusief de nutsbedrijven), vervoer en transport, verzekerings- en bankwezen. ${ }^{25}$ Daaruit mag derhalve worden afgeleid dat de omvang van het gebruik van algemene voorwaarden in het bedrijfsleven groter is dan de onderzoekscijfers van Gras laten zien. ${ }^{20}$

22. Nieuwenhus diss pag: 134. Z ie eveneens: Van Schaick, diss,, pag. 165.

23. Gras, diss, pag. 23 .

24 Gras, diss, pag. 26.

25 Gras, Standaurdkontrakten, pag. 32 en de noten 41 en 42 ; Gras, diss., pag.. 22.

26 Verhoeven, pag. 3 . 
De omvang van het gebruik van algemene voorwaarden in het rechtsverkeer met consumenten is door Gras niet onderzocht. Wel neemt deze aan, en hij vindt daarvoor ook indicaties in zijn onderzoek ${ }^{27}$, dat bij veel transacties van ondernemingen met de consument, vooral de zogenaamde "quick-hand" transacties, geen gebruik wordt gemaakt van algemene voorwaarden:

"Waarde, kwaliteit en kwantiteit zijn bij deze transalkties veelal zo eennowdig te beoordeten dar algemene woonwarden hier slechts een storende rol zouden spelen. Bij de zogenaande duurzame produkten ligt dat anders". 28

Ofschoon exacte cijfers ontbreken mag desondanks gevoeglijk worden aangenomen dat ook het gebruik van algemene voorwaarden jegens consumenten wijd verbreid is. ${ }^{29}$ In nagenoeg alle takken van produktie, dienstverlening en handel worden algemene voorwaarden gebruikt. ${ }^{30}$ Wie om zich heen kijkt, consument zijn we immers allemaal, kan dit zonder meer beamen. Duidelijke indicaties hiervoor zijn onder meer ook te vinden in het feit dat blijkens de Consumentenbond ruim $15 \%$ van de klachten die haar bereiken betrekking hebben op (onredelijk bezwarende) bedingen in algemene voorwaarden ${ }^{31}$, het tot stand komen van steeds meer - in het kader van het CCA-overleg tussen branche- en consumentenorganisaties - tweezijdige algemefie voorwaarden ${ }^{32}$ en de - niet uitputtende - lijst van algemene voorwaarden van leveranciersorganisaties waarmee consumenten blijkens de ervaringen van Consumentenbond en Konsumenten Kontakt te maken kregen ${ }^{33}$.

\subsection{De juridische status van algemene voorwaarden in het burgerlijk recht}

Algemene voorwaarden hebben een standaardkarakter. Dit komt tot uiting in enerzijds het feit dat zij zijn opgesteld om zonder onderhandelingen in een (groot) aantal overeenkomsten te worden opgenomen en anderzijds het feit dat zij meestal een zeer ruime werkingssfeer hebben, het bijzondere geval moet

27 Gras, diss., pag. 26-27.

28 Gras, diss., pag. 26.

29 Zie ook de opsomming door Rijken van rechterlijke uitspraken met betrekking tot exoneratieclausulles en het voorkomen van deze bedingen in gedeponeerde algemene voorwaarden. Rijken, diss., pag. 32-33 en 35-36.

30 Zeylemaker, pag. 78; Jansma, pag. 127-129; Polak, pag. 95; Gras, diss., pag. 24 en 25; Gras, Standaardkontrakten, pag. 46 en 47 ; Hondius, diss. pag. 16 e.v.; Hondius, preadvies, pag. 104; Rijken, diss., pag. 63; Asser-Hartkamp 11, 1993, nr. 342; Verhoeven, pag. 3 en 4; zie ook CCA-advies, bijlage 1 .

31 Verhoeven, pag. 3-4, noot 12.

32. CCA, Van consument en consumptic, bijlage 3, pag. 70.

33. CCA-Advies, Bijlage 1, pag. 52 e.v. 
immers passen in het algemene kader dat algemene voorwaarden bieden. ${ }^{34}$ Partijen kunnen zich door gebruik te maken van algemene voorwaarden beperken tot de essentialia van de overeenkomst en kunnen de nadere invulling van hun overeenkomst overlaten aan het toepasselijk verklaarde complex algemene voorwaarden. Zoals reeds vermeld, ligt in de tijd- en kostenbesparing die dit oplevert voor een groot deel de ratio van het gebruik van algemene voorwaarden. Dat maakt ook. waarom zij maatschappelijk gezien zulk een nuttige en onmisbare functie vervullen. ${ }^{35}$ Daarvoor wordt echter een prijs betaald: de vrijheid om zelf de inhoud van contractuele betrekkingen in te vullen komt doorgaans sllechts toe aan één der partijen. De keuze van de consument is dan ook doorgaans beperkt tot het al clan niet contracteren, "take it or leave it"36. De contractsvrijheid is, althans voor één der partijen, in naam van dezelfde contractsvrijheid teruggedrongen. ${ }^{37}$ In dit verband worden algemene voorwaarden ook wel eens getypeerd als particuliere wetgeving. ${ }^{38}$

In het rechtsverkeer met zowel consumenten als professionele wederpartijen worden algemene voorwaarden doorgaans in de overeenkomst geïncorporeerd zonder dat de wederpartij kennis neemt van hun inhoud. ${ }^{39}$ Vaak ook zonder dat deze zich bewust is van het feit dat hij er mee heeft ingestemd dat zij contractsinhoud worden. Indien de wederpartij al kennis neemt van de inhoud - meestal pas op het moment dat zich problemen voordoen bij de uitvoering van de overeenkomst - zal hij doorgaans niet begrijpen wat er in geregeld staat. Zo hij al in staat is de juridische merites van de voorwaarden te doorzien, zal veelal spoedig blijken dat enerzijds de algemene voorwaarden een in vergelijking met het regelende recht voor hem ongunstige juridische positie creëren en anderzijds dat de gebruiker van die algemene voorwaarden alleen maar wenst te contracteren op basis van die algemene voorwaarden. Ook de vlucht naar een andere (diensten)leverancier is vaak een illusie omdat deze eveneens algemene voorwaarden hanteert, die weer nagenoeg of geheel identiek zijn aan de voorwaarden die men probeerde te vermijden. De wederpartij wordt dus meestal voor het blok gesteld, contracteren onder het regime van de toepasselijke algemene voorwaarden of niet.

34 Gras, disis, pag. 38.

35. Gras, diss, pag. 51 .

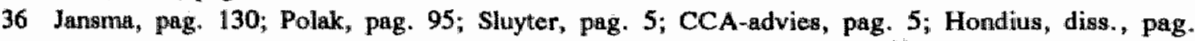
305 e.v.; Hondius, preadvies NJV, pag. 112 e.v.; Gras, Standaardkontrakten, pag. 1 en 26; Gras, diss., pag. 9 en 41 ; Rijken, diss., pag. 71 en 72; 'Tweede Kamer, zitting 1981, 16983 , nrs. 1-3 (MvT), pag. 9; Dalhuisen, pag. 59; Van der Werf, diss., pag. 27.

37 Gras, diss., pag. 10.

38 Sluyter, pag. 8 e.v.; Verburgh, NJB 1979, pag. 528; Schut, pag. 89. Zie ook: Nieuwenhuis, diss., 133 e.v.; Rijken, diss., pag. 72, Verhoeven, pag. 20.

39 Gras, diss., pag. 53. 
Deze situatie is moeilijk in overeenstemming te brengen met de "klassieke" beginselen van ons contractenrecht: contractsvrijheid, consensualisme en de daarop berustende verbindende kracht van de overeenkomst. Het daarop gebaseerde contractsmodel gaat immers uit van gelijkwaardige partijen die in vrijheid bepalen waar zij zich aan wensen te binden en zodoende komen tot een evenwichtige overeenkomst die op billijke wijze tegemoet komt aan de wederzijdse belangen. Gelijkheid en contractsvrijheid waarborgen in dit model een contractsinhoud die recht doet aan de belangen van beide partijen en legitimeren daarmee tevens de verbindende kracht daarvan.

De feitelijke gang van zaken bij algemene voorwaarden strookt echter niet met deze uitgangspunten ${ }^{41}$ of zoals Knieper het uitdrukt:

"Die Rechtstatsachen sprechen machdricklich gegen die Vertragstheorie: "AGB (allgemeine Geschäfisbedingungen, LJHM) werden ohne Rücksicht auf eine konkrete Vertragssituation als in sich geschlossene, standardisierende Regeln aufgestell, in der Absicht, eine umbestimmte Anzahl zukiznftiger Geschafte wit ihnen abzuschliessen und grumdsatzlich keine Ausnahmern zuzulassen". 42

Van gelijkheid der partijen of contractsvrijheid bij beide partijen is in de praktijk bij algemene voorwaarden immers geen sprake.

De juridische status van algemene voorwaariven en met name de grondslag van de gebondenheid van de consument aan algemene voorwaarden is in de rechtsliteratuur dan ook een veelvuldig ter hand genomen onderwerp. Daarbij zijn grofweg twee kampen te onderscheiden: enerzijds schrijvers die het verschijnsel algemene voorwaarden en de gebondenheid daaraan verklaren vanuit het "klassieke" contractsmodel en anderzijds auteurs die, vanuit de constatering dat de "klassieke" grondslagen te kort schieten, de verklaring van (gebondenheid aan) het verschijnsel algemene voorwaarden zoeken in de behoeften van het maatschappelijk verkeer. . $^{43}$

Alvorens in paragraaf 2.3.3 tot een bespreking van deze standpunten te komen, passeren in de volgende paragrafen de beginselen van ons contractenrecht en het klassieke contractsmodel kort de revue. Daarbij wordt ingegaan op de invloed hierop van de zogenaamde collectivering en publicering van het privaatrecht, tezamen aangeduid met "de vermaatschappelijking van het privaatrecht".

40 Asser-Hankamp II, 1993, nrs. 34 e.v.

41 Gras, diss., pag. 39; Verhoeven, pag. 25.

42 Knieper, pag. 60.

43 Met name Gras acht het vasthouden an het klassieke contractsmodel ter verklaring van het verschijinsel algemene voorwarden eem onkenning van de "maatschappelijke werkelijkheid", diss., parg. 57. 


\subsubsection{De beginselen van het contractenrecht, het klassieke contractsmodel}

De drie belangrijkste beginselen van ons contractenrecht zijn consensualisme, contractsvrijheid en de verbindende kracht van de overeenkomst.

Consensualisme is het beginsel dat overeenkomsten in de regel niet formeel, doch consensueel worden aangegaan. Dit betekent dat overeenkomsten tot stand komen door de wilsovereenstemming van partijen allén. Daarmee wordt bedoeld dat wederzijdse toestemming van partijen niet alleen essentieel is maar bowendien voldoende is voor het tot stand komen van de overeenkomst. De wilsovereenstemming is in beginsel vormvrij en hoeft niet omkleed te zijn met een eed, een handeling of een formaliteit teneinde een rechtens bindende overeenkomst te vormen. ${ }^{44}$ Het beginsel vond in het oude recht uitdrukking in artikel $1356 \mathrm{BW}$ (oud) en in het huidige recht in de artikelen $3: 33,3: 35,3: 37$ en 6:217 BW. Het beginsel van consensualiteit is een uiting van de vrijheids- en gelijkheidsgedachte die aan ons rechtsstelsel ten grondslag ligt.

Contractsvrijheild is het beginsel dat het in het algemeen een ieder vrij staat met willekeurig welke partij, onder welke condities of met welke inhoud men maar wil en naar eigen inzicht, een overeenkomst aan te gaan. ${ }^{45}$ Contractsvrijheid is als beginsel niet met zoveel woorden in de wet vastgellegd. Gewezen kan echter worden op de artikelen 1:1 BW, 1:121 BW, 6:248 lid 1 BW, 3:33 BW en artikel 3:40 BW, welk laatste bepaalt dat overeenkomsten niet in strijd mogen zijn met een dwingende wetsbepaling, de openbare orde of goede zeden, waaruit a contrario valt af te leiden dat andere overeenkomsten in beginsel vrijelijk kunnen worden aangegaan. ${ }^{46}$ Ondanks het feit dat het beginsel niet gecodificeerd is in de wet, is ons gehele privaatrecht op dit beginsel gegrond ${ }^{47}$ en is het eveneens een uitvloeisel van het vrijheids- en gelijkheidsbeginsel dat aan ons rechtssysteem ten grondslag ligt. Een samenleving gebaseerd op een ruilsysteem van zaken en diensten is ondenkbaar zonder een bepaalde vrijheid tot het aangaan van die overeenkomsten en moet de contractsvrijheid als beginsel erkennen. Een - in beginsel - op een vrije markt gebaseerde economie kan niet zonder deze vrijheid. Het algemeen belang vereist contractsvrijheid maar geeft tevens ook aan waar de grenzen daarvan liggen.

De verbindende kracht van de overeenkomst, het beginsel dat partijen datgene wat zij zijn overeengekomen, moeten nakomen, of zoals artikel 1374 BW (oud) bepaalde:

Asser-Hartkamp II, 1993, nrs. 34 e.v.; Rutten-Roos, pag. 175.

Asser-Hartkamp 11, 1993, nr. 34; Rutten-Roos, pag. 175.

Asser-Hartkamp II, 1993 , nr, 42 .

Elders, preadvies, pag. 13 .

Asser-Hartkamp II, 1993, nr. 38. Zie in dit verband: Van Schaick, diss, Deel I. 
In het huidige recht ligt dit beginsel mede besloten in artikel $6: 248$ lid 1 BW. ${ }^{49}$ Ook dit beginsel vindt zijn grondsllag in de eisen van onze samenleving. In elke tot een zekere mate van ontwikkeling gekomen samenleving worden zaken en diensten geruild. Gepaard daarmee gaat een behoefte aan afspraken. Deze hebben echter nawwelijks nut als men er niet op kan vertrouwen dat deze ook worden nagekomen. Zonder het vertrouwen en de zekerheid, dat gemaakte afspraken worden nagekomen, kan geen enkele samenleving tot economische ontwikkeling komen. ${ }^{50}$

Ofschoon deze drie beginselen naww met elkaar zijn verweven, moeten zij rechtstheoretisch zorgvuldig worden gescheiden. Consensualisme ziet op het totstandkomen van de overeenkomst. De verbindende kracht van de overeenkomst ziet daarentegen op het gevolg van de totstandgekomen overeenkomst. Daarbij veronderstellen consensualisme en de verbindende kracht van de overeenkomst weer contractsvrijheid, de vrijheid om zich te binden. ${ }^{51}$

Consensualiteit, contractsvrijheid en de verbindende kracht van de overeenkomst hebben van oudsher gegolden als belangrijke fundamenten van het overeenkomstenrecht. In het huidige recht is de algemene geldingskracht van deze beginselen mede door een aantal maatschappelijke ontwikkelingen echter tot op zekere hoogte in het gedrang gekomen. De wil is weliswaar nog steeds de basis voor de totstandkoming van overeenkomsten (artikel 3:33 BW), maar ten behoeve van de rechtszekerheid wordt eveneens de in het maatschappelijk verkeer gewekte schijn van wil, zelfs als die wil in werkelijkheid niet bij de declarant aanwezig is, rechtens als wilsuiting aan de verklarende toegerekend (artikel 3:35 BW). Het beginsel van de verbindende kracht van overeenkomsten wordt tegelijkertijd in toenemende mate gerelativeerd door de redelijkheid en billijkheid (artikelen 6:2 en 6:248 BW) en de individuele contractswrijheid is danig onder druk komen te staan doordat ook het privaatrecht meer en meer wordt beheerst door regels van dwingend recht. Deze teruggang in de individuele vrijheid en autonomie vindt zijn verklaring in het verschijnsel dat wordt aangeduid met "vermaatschappelijking van het privaatrecht".

49 Asser-Hartkamp 11, 1993, nr. 34; Rijken, Redelijkheid en billijkheid, pag. 11-12 en 26.

50 Asser-Hartkamp II, 1993, nr. 37; Niewwenhuis, dissi, , pag. 45.

51 Asser-Hartkamp II, 1993, nr. 36. 


\subsubsection{Vermaatschappelijking van het privaatrecht}

De liberale maatschappijvisie die aan ons, uit de eerste helft van de $19 \mathrm{e}$ eeuw stammende, Burgerlijk Wetboek en procesrecht ten grondslag ligt en waarin sterke nadruk wordt gelegd op de klassieke beginselen van contractsvrijheid en autonomie van de individuele burgers, werd steeds meer achterhaald door de maatschappelijke werkelijkheid. ? $^{52}$

De liberale maatschappijvisie van die tijd ging uit van een samenleving bestaande uit mondige, rationeel handelende en gelijkwaardige individuen die hun onderlinge rechtsbetrekkingen naar eigen inzicht en op voet van gelijkheid vormgeven zonder dat de overheid zich daar onnodig mee bemoeit. ${ }^{53} \mathrm{Het}$ contractsmodel baseerde zich op gelijkheid, vrijheid en op het vertrouwen dat op die basis contractuele rechtsbetrekkingen tot billijke resultaten zouden leiden. Van uit die liberale optiek diende het privaatrecht derhalve zo weinig mogelijk regels van dwingend recht te bevatten. Binnen de grenzen van het publieke belang diende de individuele (contracteer)vrijheid voorop te staan.

Het vrijheidsbeginsel is echter niet absoluut. Inherent aan het vrijheidsbeginsel is het (materiële) gelijkheidsbeginsel. Daarmee wordt bedoeld dat de aanspraak op vrijheid in gelijke mate aan iedereen toekomt. Gevolg hiervan is dat de vrijheid van de eén beperkt wordt door de vrijheid van de ander. Een absolute vrijheid zou een ongebreidelde vrijheid van de sterkere en een feitelijke onvrijheid van de zwakkere betekenen. Het recht dient derhalve rekening te houden met de bestaande feitelijke ongelijkheid tussen de rechtssubjecten en deze zo mogelijk op te heffen om aldus het vrijheidsbeginsel te realiseren. ${ }^{54}$

Het realiseren van dit materiële gelijkheidsbeginsel was van oudsher weggelegd voor het publiekrecht.

De maatschappelijke structuur van de eerste helft van de negentiende eeuw is sindsdien echter ingrijpend gewijzigd. De toenmalige samenleving kende nog nauwelijks de verschijnselen "organisatie", "kartel", "grote onderneming" of "N.V." s" en was lang zo gecompliceerd niet als de huidige samenleving. ss Schaalvergroting en concentratie hebben geleid tot een hedendaagse samenleving waarin het collectieve element steeds sterker naar voren komt: de moderne samenleving is een samenleving van organisaties geworden waarop het individu nog slechts in beperkte mate directe invloed heeft". Het "vrije" contract wordt vaak niet meer afgesloten door de individuen afzonderlijk, maar door organisa- 
ties die dat veelal reeds namens of voor hem hebben gedaan. ${ }^{57}$ Aan de inhoud valt voor het individu niets te veranderen. Typische voorbeelden hiervan zijn de collectieve arbeidsovereenkomsten, verzekeringsovereenkomsten en algemene voorwaarden.

Zo is ook het privaatrecht niet meer te typeren als het recht dat uitsluitend gericht is op de individuele mens. Er is sprake van een collectivering van het privaatrecht. Het individu als uitgangspunt van het contractenrecht is verdrongen door groepen en organisaties. Het individu moet zich aanpassen aan de structuren waarbinnen deze groepen en organisaties functioneren en zich daarbij conformeren aan de door deze gehanteerde contracten. De individuele contractsvrijheid is in naam van de contractsvrijheid teruggedrongen. ${ }^{58}$

Zoals hiervoor reeds opgemerkt was het realiseren van het materiële gelijkheidsbeginsel van oudsher weggelegd voor het publiekrecht. Steeds vaker wordt echter ook in het privaatrecht rekening gehouden met de door collectivering en schaalvergroting ontstane feitelijke ongelijkheid van partijen en wordt het traditionele publiekrechtelijke belang bij de realisatie van het materiële gelijkheidsbeginsel in toenemende mate via de privaatrechtelijke weg verwerkelijkt. Vanuit het inzicht dat formeel-juridische gelijkheid bij ongelijke positie en machtsverhoudingen leidt tot een praktisch-matschappelijke ongelijkheid wordt бók via de privaatrechtelijke weg getracht het evenwicht in de maatschappelijke machtsverhoudingen te herstellen. ${ }^{59}$ Naast de bescherming van individuen ligt de nadruk daarbij vooral op de bescherming van bepaalde categorieën rechtssubjecten. Expliciete voorbeelden van dit ingrijpen zijn de wettelijke bepalingen inzake de arbeids-, de pacht-, de huur-, de reis- en de consumentenkoopovereenkomst. Private partijen dienen in de regulering van hun onderlinge betrekkingen daardoor steeds meer rekening te houden met dit publieke belang. De contractsvrijheid wordt beperkt door algemene belangen. De tendens in het overheidsingrijpen is dan ook in overwegende mate gericht op het beperken van de individuele vrijheid, of, zoals Hartkamp het uitdrukt:

"Het aantal wetten, wasardoor de wrijheid van het individu, om maar eigen inzicht zijn betrekkingen re regelen, werd belonot, is aangegrowid tot een zwellende stroom". ${ }^{60}$

De toenemende invloed van het publieke belang op het privaatrecht wordt aangeduid met "publicering van privaatrecht" en "instroming van het publiekrecht in het privaatrecht". ${ }^{11}$ Het terugdringen van de individuele contracts-

57 Gras, diss., pag. 8.

58 Gras, diss., pag. 10. Zic in dit verband eveneens: Van Sehaick, diss. pag. 65 e.v..

59 Verhoeven, pag. 27.

60 Asser-Hartkamp II, 1993, nr. 43.

61 Rutten-Roos, pag. 122 e.v.; Verhoeven, pag. 18; Gras, diss., pag. 10. 
vrijheild door enerzijds de publicering van het privaatrecht en anderzijds de collectivering van het privaatrecht wordt aangeduid met "vermaatschappelijking van het privaatrecht" ${ }^{62}$

Op het terrein van de overeenkomsten komt de collectivering en de daarmee gepaard gaande tanende invloed van het individu op de vormgeving van zijn overeenkomsten met name tot uiting bij het verschijnsel algemene voorwaarden. ${ }^{13}$

Zoals reeds eerder vermeld gaat de individuele consument als natuurlijk persoon grotendeels overeenkomsten aan met professionele organisaties (rechtspersonen) of samenwerkingsverbanden, waarbij van de zijde van de consument nauwelijks nog sprake is van contractsvrijheid in de zin dat hij mede gestalte geeft aan de inhoud van zijn rechtsbetrekkingen of van een werkelijk vrije individuele wilsvorming. ${ }^{64}$ In nagenoeg alle takken van produktie, dienstverlening en handel hebben door professionele organisaties opgestelde algemene voorwaarden en standaardcontracten immers de plaats ingenomen van op basis van onderhandelingen tussen contractspartijen tot stand gekomen overeenkomsten. ${ }^{65}$ De consument heeft daardoor veelal slechts de keuze tussen wel of niet contracteren. ${ }^{66}$ Het feit dat de professionele gebruiker de algemene voorwaarden "dicteert" aan de consument is het gevolg van het rechtseconomisch machtsverschil tussen ondernemer en consument, tussen organisatie en individu. Het "klassieke" contractsmodel dat uitgaat van twee gelijkwaardige partijen (burgers) die in vrijheid hun onderlinge rechtsbetrekking invullen, valt hierop moeilijk toe te passen en is door de veranderde maatschappelijke verhoudingen achterhaald.

Het collectieve element van algemene voorwaarden, de vermaatschappelijking van het privaatrecht en het ontbreken van individuele invloed zijdens de consument op de inhoud van algemene voorwaarden, komen eveneens tot uiting in het feit dat aanbieders- en consumentenorganisaties in toenemende mate overleggen en akkoorden aangaan over de door de aanbieders in hun overeenkomsten met consumenten te hanteren algemene voorwaarden. Dit proces aangeduid met de term zelfregulering - is, mede ingegeven door een streven naar deregulering in het beleid van de Nederlandse overheid, een toenemende rol gaan spelen als overheidsinstrument ter behartiging van algemene consumen-

62 Gras, diss., pag. 10.

63 Jansma, pag. 125; Gras, disss., pag. 9 e.v.; Van der Werf, diss., pag. 16; Van der Grinten, pag. 13.

64 Gras, Standaardkontrakten, pag. 5.

65 Zie hiervoor paragraf 2.2.3.

66 Zie hiervoor paragraaf 2.3.2. 
tenbelangen ${ }^{67}$ Sinds 1974 wordt onder auspiciën van de Commissie voor Consumentenaangelegenheden (CCA) van de Sociaal Economische Raad (SER) overleg gevoerd tussen consumenten- en branche-organisaties over door de leden van deze branche-organisaties tegenover consumenten te hanteren algemene voorwaarden. Het overleg heeft tot gevolg gehad dat sinds 1978 diverse branches tegenover consumenten algemene voorwaarden hanteren die zijn vastgesteld in overleg met consumentenorganisaties. ${ }^{*}$ Door dit collectieve onderhandelen verschuiven voor wat betreft algemene voorwaarden het consensualisme en de contractsvrijheid als het ware van individuele overeenstemming naar collectieve overeenstemming. Enige parallellen met de reeds geruime tijd geleden geïntroduceerde collectieve toestemming en contractsvorming tussen werkgevers en werknemers - de collectieve arbeidsovereenkomst - zijn hier ongetwijfeld aanwezig.

Algemeen wordt aangenomen dat het ontbreken van individuele invloed zijdens de consument op de inhoud van jegens hem gehanteerde algemene voorwaarden echter niet aan de verbindende kracht van deze voorwaarden in de weg staat. Is dit te rijmen met het klassieke contractsmodel waarin individuele contractsvrijheid en consensualisme de legitimatie vormen van de verbindende kracht van de overeenkomst of dient zij (mede) verklaard te worden vanuit de behoeften en mechanismen van het gecollectiveerde maatschappelijk verkeer?

\subsubsection{De theoretische rechtvaardiging van de verbindende kracht van algemene vaorwaarden}

Uitgangspunt bij het vraagstuk van de theoretische rechtvaardiging van de verbindende kracht van algemene voorwaarden dient te zijn, dat de wil van partijen of het wederzijds opgewekte vertrouwen daarvan in ieder geval overeenstemt voor wat betreft de hoofdzaken van de overeenkomst. ${ }^{\circ}$ Voor wat betreft deze "essentialia", de "romp"-overeenkomst, gelden de beginselen van consensualisme en contractsvrijheid vrijwel onverkort, waardoor de gebondenheid van partijen aan deze "romp"-overeenkomst in beginsel is gelegitimeerd. De discussie omtrent de rechtvaardiging van de verbindende kracht van algemene voorwaarden richt zich dan ook uitdrukkelijk alleen op de bijkomende

67 Tweede Kamer, vergaderjaar 1985-1986, 19 342, nr. 1. Zie verder onder meer: Brack, Consumentenbeleid, pag. 243 e.v.; Môlenberg en Van der Sluijg, pag. 265 e.w.; Van Driel, diss...

68 S.E.R. Commissie voor Consumentenhangelegenheden, Van consument en consunptie, Den Haag, september 1991, pag. 27 e.v.

69 Zie ook Asser-Hartkamp II, 1993, nr. 349. 
modaliteiten var de "romp"-overeenkomst:" de verbindende kracht van algemene voorwaarden.

De problematiek van de verbindende kracht van algemene voorwaarden spitst zich vooral toe op de onbekendheid van de wederpartij met de (soms onredelijk bezwarende) inhoud van de daarop toepasselijk verklaarde algemene voorwaarden. In het (uitzonderlijke) geval dat de wederpartij well bekend is met de inhoud van de algemene voorwaarden en uitdrukkelijk akkoord is gegaan met de gelding daarvan of het gerechtvaardigde vertrouwen daarvan bij de gebruiker heeft opgewekt, is de grondslag van de verbindende kracht immers onbetwist.

$Z_{i j}$ berust op de wil of het bij de wederpartij opgewekte vertrouwen daarvan.

Kennisname van de inhoud van algemene voorwaarden vóór de aanvaarding van de gelding daarvan is in de praktijk doorgaans echter niet het geval en zou ook in strijd zijn met de functie en ratio van het gebruik van algemene voorwaarden. Algemene voorwaarden zijn immers een van tevoren opgesteld regelcomplex dat bedoeld is om ongelezen door de wederpartij te worden aanwaard. Slechts dan vereenvoudigen zij het contracteren voor beide partijen. Het kennisnemen van de inhoud van algemene voorwaarden door de wederpartij is dan ook eerder uitzondering dan regel. ${ }^{71}$

Belangrijkste dogmatisch probleem is de vraag in hoeverre een wederpartij gebonden is aan algemene voorwaarden waarvan zij de gelding heeft aanvaard terwijl zij de inhoud daarvan niet kende en de gebruiker van zijn kant doorgaans zeer wel op de hoogte is van zowel het gegeven dat de wedlerpartij de inhoud van die algemene voorwaarden niet kent als van het feit dat in de betreffende algemene voorwaarden ongebruikelijke of zelfs onredelijk bezwarende bedingen zijn opgenomen. Anders gezegd: "kan men willen wat men niet kent?" en "mag de gebruiker erop vertrouwen dat de wederpartij heeft ingestemd met een bepaalde inhoud terwijl hij weet dat deze daarvan absoluut geen notie heeft én hij bovendien weet dat dle inhoud voor de wederpartij onredelijk bezwarend is?".

\subsubsection{De aanvaarding van de gelding van algemene voorwaarden}

Doorgaans wordt in de literatuur en rechtspraak ${ }^{72}$ aangenomen dat de omstandigheid dat de wederpartij niet op de hoogte was van de inhoud van de algemene voorwaarden die zij verklaarde te aanvaarden of waarvan zij het gerechtvaardigde vertrouwen opwekte, in beginsel niet in de weg staat aan haar gebonden-

71 Zie ook paragraaf 2.2 .2 .

72 Zie hiema paragmaf 3.2 .1 . 
heid aan die voorwaarden. Aan deze primaire gebondenheid aan ongezien aanvaarde algemene voorwaarden worden in de literatuur verschillende theorieën ten grondslag gelegd. ${ }^{\text {n }}$

Volgens de aanhangers van de wills- en verklaringstheorie is men primair gebonden omdat men wil ook al kent men niet. ${ }^{74}$

"Men will, ondat men woelt zich te onderwerpen acan een veilige regeling. deskundig en onpartijdig opgemaaka, of omdat men nu eenmal niat amders kan dan zich onderwerpen, maar men wil en mew weter wat men wil". 75

Een correctie op deze primaire gebondenheid teneinde de ongewenste gevolgen van onredelijke bedingen, door Zeijlemaker zeer toepasselijk "machtsbedingen" genoemd ${ }^{76}$, tegen te gaan, is volgens hen te vinden in de algemene regels van het verbintenissenrecht zoals onder andere de artikelen 1371 en $1373 \mathrm{BW}$ (oud) (geoorloofde oorzaak), artikel $1357 \mathrm{BW}$ (oud) (wilsgebreken), misbruik van recht en met name de artikelen 1374 lid $3 \mathrm{BW}$ (oud) (goede trouw) en $1375 \mathrm{BW}$ (oud) (aanvullende werking van wet, gewoonte en billijkheid). ${ }^{7}$

Andere auteurs gaan eveneens uit van de wilsleer maar dan gecorrigeerd door het vertrouwenselement en de goede trouw. ${ }^{78}$

"Volgens deze formule is degees die een kontraktsdokument ondertekent aum de daarin verwatte (verwijzing naor) standaardvoorwaarden gebonden indiem en voor zover hij bij de onderiekening op toerekenbare wijze bij de wederpartij het vertrowwen heeft opgewekt dat hij gebonden wilde zijn. Het antwoard op de wracag of her vertrouwen geacht mag worden te zijn opgewekt, hamg! af wan ale wardering man omstandigheden als de mate van akkoordverklaring, de gebruikelijkheid van de betreffende klausules in het licht wan de kontekst en de mogelijkheid voor de wederpartij om zich van

73 Zie voor en overzicht: Rijken, diss., pag. 72 e.v.; Jongeneel, disis., pag. 106 e.v..; Verthoeven, pag. 20 e.v.

74 Zeylemaker, pag. 85 e.v ; Asser-Rutten II, 1979, pag 77. Laatstgenoemde auteur spreckt van "algemene wilsonderwerping". Zle ook: Asser-Rutten II, 1982, pag. 85, wasrin hetzelfde standpunt wondt verwoord met die beperking, dat de uitdrukking "algemene wilsonderwerping" vemeden wordt. Zie eveneens: Wessels en Jongeneel, 1992 , pag. 46 en Jongeneel, diss. pag. 111, die als uitgengspunt een "risicoaanwaarding" zien. Volgens then is de rechtvandiging van de primaire gebondenheid an ongekend aanvanrde bedingen gelegem in het beginsel "... dat men de gevolgen moer dragen vas een door eïgen verzuim veroorzaak informatiegebrek. "..... "Hierbij moet wel warden opgemunila dat deze rechvaardiging alleen aanvaardbaar is indien het kemnisnemen wan de irthoud wan de algemene woorwaarden mogelijk is."

75 Zeylemaker, pag. 86.

76 Zeylemaker, pag. 111 :

77 Zeylemaker, pag. 111 e.v.

78 Hondius, dissi, pag. 408409; Van der Werf, diss., pag. 42; Nieuwenhuix, diss., pag. 144; Dalhuisen, preadvies: NJV, pag. 14 e.v., 30 e.v. en 84; Dalhuisen, NJB 1979, pag. 619. 
de kondities bewust te zijn In bijzondere gevallen zullen ook andere omstandigheden eem rol spelen." 79

Ook in deze visie is de grondslag voor de verbindende kracht aan ongekende algemene voorwaarden de wilsuiting of het daarvan opgewekte vertrouwen. In die visie heeft onderzoek naar de vraag of er sprake is van opgewekt vertrouwen, een drievoudige functie. In de eerste plaats een aanvaardingstoets betreffende de vraag of de gelding van het gehele complex algemene voorwaarden is aanvaard en vervolgens een beperking van de primaire gebondenheid tot die bedingen die men heeft kunnen kennen (informatietoets) en die gezien de omstandigheden niet ongebruikelijk zijn (inhoudstoets).

Een derde groep auteurs zoekt voor de primaire gebondenheid aan ongekend aanvaarde algemene voorwaarden aansluiting bij de behoeften van het rechtsverkeer. ${ }^{80}$ bil] voorbeeld Stein:

"mijins inziens dwingt de praktische behoefte van het verkeer tot de conclusie, dat de adherent acant alle bedingen wit het standiardcontract gebonden is, onverschillig of hij ze kende of niet, mils hij ze maar heeft kannen kennen ". 81

Verburgh en Rijken gaan daarbij van het standpunt uit dat de theoretische rechtvaardiging van de gebondenheid ontbreekt. ${ }^{82}$ Verburgh geeft de stand van zaken als volgt weer:

\footnotetext{
"We moeten in ieder geval constateren dat aan de huidige praktijk yant het op grote schaal aannemen van gebondenheid aan standaardvoorwaarden weliswar en theoretische rechtvaardiging ontbreekt, maar in het maxatschappelijk leven toch grote behoefte bestaat. De meest logische consequentie lijkt dan te zijn: hoe minder juridisch-theoretische rechtvacardiging, hoe meer inhoudscontrole " ${ }^{83}$.
}

Hij stelt dat er vanwege de behoeften van het rechtsverkeer geen bezwaar is tegen deze snelle primaire gebondenheid van de wederpartij ook aan die bedingen waarvan zij de inhoud niet kent of begrijpt, mits er maar tevens voorzien wordt in een afdoende inhoudscontrole. Met andere woorden: aan de aanvaarding van de gelding van de gehele set algemene voorwaarden moeten niet al te strenge eisen worden gesteld, op voorwaarde dat de wederpartij de

79 Hondius, diss, pag. $408-409$.

80 Stein, diss, pag. 155; Sluyter, pag. 13; Verburgh, NJB 1979, pag. 530, Rujken, diss,, pag. 7879; Van Dunné, Verbintenissenrecht, pag. 234.

81 Stein, diss., pag. 155.

82 Verburgh, N.H 1979, pag. 530, Rijken, diss , pag. 78-79.

83 Verburgh, NJB 1979, pag. 530. 
inhoud van bedingen kan aangrijpen om zich alsnog van zijn gebondenheid aan die bedingen te bevrijden.

In dezelfde zin Rijken die naar aanleiding van de opvattingen in de literatuur stelt dat de kloof tussen praktijk en de theorie niet te overbruggen schijnt. ${ }^{84} \mathrm{Hij}$ leidt uit de pogingen de gebondenheid aan algemene voorwaarden te verklaren vanuit de wils-, verklarings- of vertrouwenstheorie af dat:

"... men zich van bewust is dat standaardwownadrden in ons rechisverkeer een nuitige functie wervullen en daarwit niet meer weg te denken zijn, alsmede dat men (dawom) niev zozeer ageent vegen het snel gebonden raken cacu standaardvoonwaarden als zodanig; allswel en met name tegen een gebonden zijm acan ongekende en ombegrepen standaxardwoonwaarden die tevens het stempel ongebruikelijk, onbilijk etc. dragen. Praktisch gespraken zou er geen probleem zijn indien standaardvoorwaarden geen ongebruikelijke, ombilijke clausules zouden bevatren. In laatsibedaeld geval zou men zich miet druk (behoeven tel maken om het feit dat de Nederlandse rechtsprack sme! tot gebandenheid concludeert.

\section{Zo ook Van Dunnê:}

"Dit leidh dan tot de regel: nier. te moetilik doen (juridisch') ower de vraag of men aan een standarardcontract gebonden is, wel moeilijk doen als men op een abmormale, oneerlijke manier gebonden wordt, door middel van onereuze bepalingen. "86

De problemen van het verschijnsel algemene voorwaarden liggen, zoals Rijken $^{87}$ terecht opmerkte, voor de meeste auteurs dan ook niet bij de snelle primaire gebondenheid aan ongekende algemene voorwaarden sec. De meeste auteurs zijn het daar wel over eens, deze primaire gebondenheid berust op de wil van de wederpartij of het opgewekte vertrouwen daarvan om de gelding van het toepasselijk verklaarde regelcomplex te aanvaarden. Daarbij moet niet al te moeilijk worden gedaan over de vraag of de wederpartij de inhoud van de aanvaarde algemene voorwaarden kent. De ratio van algemene voorwaarden zit immers voornamelijk in het feit dat zij ongelezen worden aanvaard. Daardoor voorzien algemene voorwaarden in een matschappelijke behoefte. De basis voor de verbindende kracht van algemene voorwaarden, namelijk de aanvaarding van de gelding berust dus op de wil of het opgewekte vertrouwen daarvan, ook al heeft men onder omstandigheden niet veel te willen. Ook afdeling 6.5.3 BW gaat van dit standpunt uit. ${ }^{88}$ Bij de vraag of sprake is van aanvaarding van de gelding zijn de partijwil zoals die zich uit in een afgelegde verklaring en het

84 Rijken, diss., pag. 78.

85 Rijken, diss., pag. 79.

86 Van Dunne, Verbintenissenrecht, pag. 234.

87 Rijken, disq., pag. 78-79.

88 Zie hiema paragraf 4.4 en 5.1 .2 . 
opgewekte vertrouwen daarvan de enige criteria die het antwoord bepalen. Wil en vertrouwen zijn in die zin geen fictie ${ }^{29}$ en bepalend voor de toepasselijkheid van algemene voorwaarden.

Voor de beantwoording van de vraag of sprake is van aanvaarding van de gelding van algemene voorwaarden is irrelevant of de wederpartij kennis heeft genomen van de inhoud van die algemene voorwaarden. Doorslaggevend is enkel of de wederpartij kennis heeft kunnen nemen van de wil van de gebruiker om algemene voorwaarden toepasselijk te doen zijn op de te sluiten "romp"overeenkomst en of de wederpartij dit aanbod heeft aanvaard. Dat de individuele contractsvrijheid en consensus, daar waar het gaat om massaal gesloten (nagenoeg) identieke overeenkomsten, zich beperkt tot de hoofdzaken, de essentialia, en voor wat betreft de algemene voorwaarden tot de gelding, voorziet in een maatschappelijke behoefte en de behoefte van partijen om de regeling van modaliteiten over te laten aan een voorgevormd complex van regels en kan in beginsel niet als onjuist of ongewenst worden bestempeld. ${ }^{\circ}$ Zoals reeds gezegd hebben algemene voorwaarden als voorgevormd complex van regels dezelfde functie als het regelende recht, massaal contracteren wordt een stuk eenvoudiger doordat men zich kan beperken tot de hoofdzaken. Zoals Stein ${ }^{91}$ reeds verwoordde, is de onbekendheid van de wederpartij met de inhoud van de voorwaarden waarvan zij de gelding ongezien heeft aanvaard geen argument om haar primaire gebondenheid niet aan te nemen. Het is in het recht niet ongebruikelijk dat men bij een ("romp"-) overeenkomst verplichtingen op zich neemt zonder te weten waaruit die verplichtingen bestaan. ${ }^{92}$ Ook het systeem van dwingend en regelend burgerlijk recht is hierop gebaseerd. Daarbij valt niet te ontkennen, dat ook het regelend recht door slechts weinig justitiabelen wordt gelezen of gekend, laat staan begrepen. Dit is echter nooit reden geweest de toepasselijkheid van het regelende recht, dat immers verondersteld wordt te getuigen van een redelijke belangenafweging ${ }^{93}$, uit te sluiten. Het euvel van het ongeweten en onbegrepen (regelende) recht heeft ook nooit tot dezelfde discussie geleid als

89 Zie: Sluyter, pag. 13, die de vrang stelde: "Verdient het niet de voorkeur de "fictie wan will of vertrouwen" prijis te geven op grond vam de praktisehe behoeften wan het verkeer?".

90 Anders: Verhoeven, pag. 25. "Het argument van "de behoeften van de praktijk" kan wamuit rechtstheoretisch oogpunt principieel geen grond opleveren voor gebondenheid. aan algemene voorwararden." Hilj erkent echter tewens dat wils-, zuivene vertmouwens- en verklaringstheorieèn slechts onduidelijke theoretische grondslag zijn woor de gebondenheid aan algemene voorwaturden.

91 Stein, diss., pag. 155; Zie ook: Stuijter, pag. 14.

92 Asser-Hartikamp II, 1993 , nr. 350.

93 Asser-Scholten, pag. 22. 
het geval is bij, wat Marx noemt, het "euvel der ongeweten en onbegrepen bedingen"es.

Het is bovendien zeér de vraag of de wederpartij "überhaupt" behoefte heeft aan kennisname van algemene voorwaarden waarvan zij de juridische implicaties doorgaans niet doorziet. Indien de wederpartij consument is kan deze vraag mijns inziens ontkennend worden beantwoord. De ratio van het gebruik van algemene voorwaarden ligt immers ook voor de wederpartij in het gemak en de tijd-en dus kostenbesparing die het gebruik van algemene voorwaarden met zich brengt; in de snelle primaire gebondenheid dus. Deze ratio verdraagt zich niet met wederpartijen die vór het sluiten van de overeenkomst kennisnemen van de inhoud van algemene voorwaarden. Het gemak van algemene voorwaarden - als ook de regels van het aanvullend recht indien toepasselijk - ligt toch immers grotendeels opgesloten in het feit dat zij een sluimerend bestaan leiden en veelal pas relevant zijn voor de wederpartij op het moment dat er "problemen" zijn ten aanzien van de uitvoering van de overeenkomst. Onderzoek heeft bevestigd dat zowel de consument-wederpartij als de ondernemer-wederpartij er in de praktijk weinig aan gelegen is vór het sluiten van de overeenkomst van de inhoud van algemene voorwaarden kennis te nemen. ${ }^{95}$ De Nederlandse wetgever huldigt hetzelfde standpunt in het systeem van afdeling 6.5.3 BW, met name in de regeling van de verjaring van artikel 6:235 lid $4 \mathrm{BW}$, eveneens uit van het standpunt dat de wederpartij zich pas op het tijdstip waarop de gebruiker een beroep doet op het beding bewust wordt van het bestaan van het beding en zijn implicaties. $^{96}$

Voor zover de wederpartij er op kan vertrouwen dat de toepasselijk verklaarde algemene voorwaarden getuigen van een redelijke afweging van de belangen van beide partijen, is bij het sluiten van de overeenkomst, kennisname van de inhoud van die "faire" regeling overbodig. De wederpartij heeft enkel belang bij de mogelijkheid van eenvoudige kennisname van de inhoud van het toepasselijke regelcomplex op het moment dat hij dat wil. Dit niet ter legitimatie van de verbindende kracht daarvan ${ }^{97}$, maar omdat hij simpelweg de mogelijkheid dient te hebben om vast te kunnen stellen welke regel op een bepaalde omstandigheid bij de uitvoering van de overeenkomst toepasselijk is.

Buiten het geringe aantal wederpartijen dat zich beroepshalve met algemene voorwaarden bezig houdt, zullen er echter slechts weinigen zijn die reeds op eerder tijdstip behoefte voelen aan het raadplegen van de inhoud van de toepasselijke regels dan op het moment dat de uitvoering van de overeenkomst hen

94 Marx, NJB 1939, pag. 447.

95 Gras, diss., prg. 54-55; Hondius, diss., pag. 302.

96 Zie hierna de paragrafen 5.2 .4 .4 en 5.2 .6 .

97 Stein . diss., pag." 155. 
niet tot tevredenheid stemt. Er van uitgaande dat het merendeel van de enorme hoeveelheid overeenkomsten die dagelijks worden gesloten naar tevredenheid wordt uitgevoerd, is de behoefte aan kennisname van het regelcomplex naar mijn mening eerder uitzondering dan regel.

Terecht gaat de Nederlandse wetgever er in het stelsel van afdeling 6.5.3 BW dan ook van uit dat de vraag of er sprake is van aanvaarding van de gelding, de primaire gebondenheid, los staat van andere toetsen die nagaan of bedingen voor de wederpartij bindend zijn zoals de inhouds- en informatietoets.

De opvatting dat de primaire gebondenheid aan algemene voorwaarden in beginsel enkel en alleen berust op de toestemming met betrekking tot de essentialia van de overeenkomst, de maatschappelijke behoefte aan algemene voorwaarden en de aanvaarding door de wederpartij van de gelding van de algemene voorwaarden, dwingt tot de constatering dat voor primaire gebondenheid aan algemene voorwaarden in beginsel meestal voldoende is dat een der contractspartijen (de gebruiker) aan de andere partij (de wederpartij) vór het sluiten van de "romp"-overeenkomst duidelijk kenbaar aan de wederpartij] meedeelt dat een bepaald algemene voorwaardencomplex van toepassing is op deze overeenkomst. Het duidelijk kenbaar meedelen maakt dat het stilzwijgen van de wederpartij ten aanzien van de voorgestelde gelding van algemene voorwaarden uitgelegd mag worden als een aanvaarding van de gelding van de betreffende voorwaarden op welker aanvaarding van de gelding de gebruiker alsdan gerechtvaardigd mag vertrouwen. Van primaire en dus ook verdere gebondenheid aan algemene voorwaarden is in dat model in ieder geval absoluut geen sprake indien de wederpartij de gelding van deze voorwaarden uitdrukkelijk afwijst. In dat geval beperken de afspraken van partijen zich tot de "romp"-overeenkomst. In de praktijk komt het echter nauwelijks voor dat wederpartijen de gelding van algemene voorwaarden afwijzen. In de zeldzame gevallen dat zij dat wel doen is de gebruiker doorgaans in het geheel niet bereid om met deze wederpartijen een overeenkomst te sluiten. Take it or leave it!

Bij deze nagenoeg eemzijdlige toepasselijkverklaring doet zich hoogstens het probleem van de zogenaamde "battle of forms" 100 voor; de situatie dat beide partijen hun algemene voorwaarden toepasselijk hebben verklaard. Probleem bij dit vraagstuk is echter niet of partijen (primair) gebonden zijn aan algemene

98. Zive hierna paragraaif 5.2.3.

99 Hetgeen ook Rijken concludieert, diss., pag. 79.

100 Hondius, diss., pag. 424 e.v.; Van der Werf, diss., pag. 56; Verhoeven, pag. 13; AsserHaitkamp II, 1993, nr. 354; Jongeneel, diss., pag. 124 e.v.; Van Dunne, Verbintenissenrecht; pag. $250-253$. 
voorwaarden maar aan welke (set) algemene voorwaarden zij zich (primair) hebben gebonden ${ }^{101}$

\subsubsection{Gebondenheid aan algemene voorwaarden met een onredelijk bezwa- rende inhoud}

Zoals reeds aangeduid liggen de echte problemen ten aanzien van de gebondenheid bij de vraag of de toepasselijk verklaarde algemene voorwaarden inhoudelijk recht doen aan de belangen van beide partijen en met name recht doen aan de belangen van de partij die geen invloed heeft op de inhoud van die algemene voorwaarden. Het probleem ligt bij de verbindende kracht van ongebruikelijke of onredelijk bezwarende algemene voorwaarden die het belang en de verwachtingen van de wederpartij ten aanzien van de "romp"-overeenkomst op een onbillijke wijze frustreren. In de literatuur wordt algemeen erkend dat deze bedingen niet bindend dienen te zijn voor de wederpartij en dat er dus een correctie plaats dient te vinden met betrekking tot de verbindendheid van de algemene voorwaarden waarvan de gelding door de wederpartij is aanvaard. De wederpartij mag immers verwachten dat de gebruiker van algemene voorwaarden zich bij de vaststelling van de inhoud van zijn algemene voorwaarden heeft laten leiden door de eisen van redelijkheid en ojillijkheid (6:248 BW). Reeds in 1957 stelde de Hoge Raad buiten twijfel dat partijen door in onderhandeling te treden over het sluiten van een overeenkomst, tot elkaar komen te staan in een bijzondere, door de goede trouw (naar nieuw BW "redelijkheid en billijkheid") beheerste rechtsverhouding, medebrengende dat zij hun gedrag mede laten bepalen door de gerechtvaardigde belangen van de wederpartij. ${ }^{102}$ Deze norm geldt eveneens voor de gebruiker van algemene voorwaarden en diens wederpartij. Aan de ene kant mag de gebruiker er naar de eisen van redelijkheid en billijkheid op vertrouwen dat de wederpartij de gelding van algemene voorwaarden heeft aanvaard ook zonder kennis te nemen van de inhoud van die voorwaarden. Aan de andere kant mag de wederpartij die de gelding van algemene voorwaarden ongezien heeft aanvaard, er op zijn beurt op vertrouwen dat de gebruiker bij het opstellen van die algemene voorwaarden - bij de vaststelling van de inhoud dus - op een faire wijze rekening heeft gehouden met de gerechtvaardigde en voor de gebruiker kenbare belangen van de wederpartij. De redelijkheid en billijkheid zijn dus enerzijds de grondslag van de snelle primaire gebondenheid maar geven anderzijds ook de grenzen daarvan aan en daarmee de grondslag voor de inhoudstoetsing.

101 Zie ook artikel 6:225 lid $3 \mathrm{BW}$.

102 HR 15 november 1957, NJ 1958, 67, nt. L.E.H.R., AA 1957, pag, 103, m.nt. G. (Baris/ Riezenkamp). 
Aan de gebruiker mogen in dit verband op grond van redelijkheid en billijkheid hoge eisen worden gesteld. Bij algemene voorwaarden is de "klassieke" waarborg voor een redelijke contractsinhoud, te weten de individuele contractsvrijheid en de consensus van gelijkwaardige individuele partijen, immers grotendeels komen te vervallen. Dit omdat de gebruiker eenzijdig het gebruik ervan oplegt aan de wederpartij, de inhoud eenzijdig bepaalt ${ }^{103}$ en bovendien weet dat de wederpartij doorgaans niet overgaat tot kennisname van de inhoud van de betreffende algemene voorwaarden, hetgeen ook niet de bedoeling is van algemene voorwaarden.

Door het opnemen van bedingen die in dit licht qua inhoud onvoldoende rekening houden met de belangen van de doorsnee wederpartij bij de betreffende overeenkomsten handelt de gebruiker in strijd met hetgeen de redelijkheid en billijkheid van hem eist. In dat geval is het niet meer dan (redelijk en) billijk om de aanvaarding van de gelding van het gehele regelcomplex - de primaire gebondenheid - in die zin te corrigeren dat de wederpartij van haar gebondenheid aan de bedingen wordt bevrijd die onvoldoende blijk geven van een zorgvuldige wederzijdse belangenafweging door de gebruiker.

Over de wijze waarop die bindende kracht dient te worden geëcarteerd zijn in de literatuur twee benaderingen te onderscheiden.

In de eerste benadering wordt de correctie gezocht in het relativeren van de primaire gebondenheid aan dit soort bedingen op basis van de wil van de wederpartij of het daarvan opgewekte vertrouwen bij de gebruiker. Onderzocht wordt of de toestemming of de opgewekte schijn daarvan ook ten aanzien van dit soort bedingen mag worden aangenomen. Uitgangspunt daarbij is dat de wederpartij ongezien alleen die bedingen heeft gewild die gebruikelijk en redelijk zijn en dat de gebruiker er ook alleen op mag vertrouwen dat de toestemming van de wederpartij zich slechts uitstrekt over die bedingen. Daarbij wordt met name de nadruk gelegd op de positie van de gebruiker en het bij hem opgewekte gerechtvaardigde vertrouwen. Hij is immers degene bij wie de inhoud van een beding, dus ook een voor de wederpartij onredelijk bezwarende, bekend is of dient te zijn. In deze visie omvat de (primaire) gebondenheidstoets zowel de aanvaardingstoets als de inhoudstoets en hebben onredelijk bezwarende bedingen van begin af aan geen verbindende kracht omdat zij nooit zijn aanvaard. De gebruiker van de betreffende bedingen heeft immers bij het opstellen ervan onvoldoende rekening gehouden met de belangen van de wederpartij, hij

103 Dit is ook zo indien de gebruiker algemene woorwaarden thanteert die zjjn opgesteld in overleg met consumentenorganisaties. Uiteindelijk bepaalt de gebruiker of hij deze algemene voorwaar den wil hanteren of niet. De wederpartij heef in deze geen enkelle keuze. Ook voor nulzijdig en
tweezijdig opgestelde algernene voorwarden geldt doorggans: "graag of niet". 
weet dit of behoort dit te weten en mag er derhalve ook niet op vertrouwen dat ook maar éen wederpartij dit beding zou hebben gewild indien zij vrijelijk en vanuit een gelijkwaardige onderhandelingspositie had kunnen handelen. De aanvaarding van de gelding kan de gebruiker in redelijkheid (en billijkheid) dan ook nooit uitleggen als een aanvaarding van (ook) deze bedingen.

In de tweede benaderingswijze is het uitgangspunt dat er sprake is van toestemming of de opgewekte schijn daarvan ten aanzien van alle bedingen en dus in beginsel ook van primaire gebondenheid aan alle bedingen. In deze visie wordt de oplossing voor het probleem van de ongezien aanvaarde onredelijk bezwarende of ongebruikelijke bedingen gezocht in het achteraf toetsen van de inhoud van dit beding an de redelijkheid en de billijkheid, welke toets uiteindelijk ook kan leiden tot een alsnog niet-gebondenheid van de wederpartij aan dat bepaalde beding. In die visie is voor de primaire gebondenheid niet relevant of door de wederpartij kennis is genomen van de inhoud van de aanvaarde algemene voorwaarden. Bij algemene voorwaarden moet er immers per definitie van uit worden gegaan dat zij zijn bedoeld om ongezien te worden aanvaard. Reeds bij het opstellen van de algemene voorwaarden behoort de gebruiker daar van uit te gaan. Los van het feit dat in de praktijk kennisname van de inhoud van algemene voorwaarden voór de aanvaarding van de gelding daarvan welhaast niet plaatsvindt, verandert er door kennisname van de inhoud immers niets in de positie van de wederpartij. Het "take it or leave it"-karakter van algemene voorwaarden bewerkstelligt immers dat ook de wederpartij die de inhoud kent, daarin geen wijziging kan brengen. De inhoud van algemene voorwaarden is in die visie slechts relevant voor de vraag of de algemene voorwaarden waarvan de wederpartij de gelding (ongezien) heeft aanvaard vervolgens ook verbindende kracht hebben voor die wederpartij. De toets aan de redelijkheid en billijkheid is in het kader van algemene voorwaarden dan ook altijd te beschouwen als een toets van de verbindende kracht van de bedingen waaraan de wederpartij zich primair heeft gebonden. ${ }^{104}$ Het gaat steeds om de vraag of een bepaald beding naar zijn inhoud de wederpartij in een concrete situatie, gezien de eisen van redelijkheid en billijkheid, bindt.

Beide oplossingen leiden er uiteindelijk toe dat de betreffende clausules geen bindende werking hebben voor de wederpartij. De Nederlandse wetgever heeft in het stelsel van afdeling 6.5.3 BW gekozen voor het laatst genoemde uitgangspunt. Snelle gebondenheid aan algemene voorwaarden met een correctie achteraf door middel van twee vernietigingsgronden. ${ }^{105}$ In afdeling $6.5 .3 \mathrm{BW}$ gekozen voor een loskoppeling van de inhoudstoets en de aanvaardingstoets. In het stelsel van het nieuwe Burgerlijk wetboek heeft de inhoud van een beding in

104 Net als de (inhouds)toets aun de wet, goede zeden en openbare orde.

$105 \mathrm{Zie}$ hiema paragraaf 5.11 .2 . 
beginsel geen invloed op de vraag of sprake is van primaire gebondenheid, of dus sprake is van aanvaarding van de gelding van de algemene voorwaarden. De inhoud van algemene voorwaarden is daarentegen wel beslissend voor de vraag of zij vervolgens bindende kracht hebben jegens de wederpartij. In dat systeem wordt dus eerst bekeken of de gelding is aanvaard door de wederpartij. Indien dat niet het geval is, is geen sprake van primaire gebondenheid en heeft het beding dus geen bindende kracht. Pas als sprake is van aanvaarding van de gelding bestaat er een vermoeden dat deze algemene voorwaarden partijen binden. De vraag of de betreffende algemene voorwaarden de wederpartij werkelijk binden hangt vervolgens af van toetsen zoals de informatie- en de inhoudstoets. Pas nadat al deze toetsen zijn uitgevoerd heeft men het antwoord op de vraag of het concrete beding in de concrete omstandigheden van het geval bindend is voor de wederpartij.

\subsection{Individuen en organisaties als partijen in het burgerlijk proces}

Overheidsrechtspraak is én van de vele mechanismen die mensen bij conflictoplossing hanteren. Afgezet tegen andere mechanismen als overleg, loting, berusting, geweld, bemiddeling of niets doen, wordt slechts een relatief gering deel van de conflicten in de maatschappij aan de rechter voorgelegd. ${ }^{106}$

Net als het materiële privaatrecht is het formele burgerlijk procesrecht gebaseerd op het liberale maatschappijbeeld dat geënt is op het autonome individu en diens individuele vrijheid en welk beeld kenmerkend was voor het begin van de negentiende eeuw. In overeenstemming met dit liberale maatschappijbeeld was het model van het burgerlijk proces een conflict in een unieke relatie tussen twee individuele, min of meer gelijkwaardige burgers, dat op initiatief van eén van hen werd voorgelegd aan de van staatswege ingestelde rechter. ${ }^{107}$ Dit maatschappijbeeld komt tot uiting in "klassieke" beginselen van ons burgerlijk procesrecht als: openbaarheid van behandeling, onafhankelijkheid, onpartijdigheid en de lijdelijkheid van de overheidsrechter, het horen van beide partijen, verplichte procesvertegenwoordiging, niet-kosteloze rechtspraak en motivering van de beslissing.

De collectivering en standaardisatie van onze samenleving is niet ongemerkt voorbij gegaan aan het procesrecht. Ook daar hebben organisaties en gestandaardiseerde rechtsbetrekkingen hun intrede gedaan. Een prachtig voorbeeld hiervan is het Duitse "Mahnverfahren". ${ }^{108}$ Voor deze incassoprocedure, waarin de absolute competentie ligt bij het "Amtsgericht" ( $\$ 689$ Abs.1 ZPO), is bepaald

106 Elders, Minnelijke schikking, pag. 55 e.v.; Sarat, pag. 342.

107 Groenendijk, diss., pag. 7.

10\$ 688 tot en met $703 \mathrm{~d} \mathrm{ZPO}$. 
dat de rechter van de woonplaats van eiser relatief competent is ( $\$ 689$ Abs.2 $\mathrm{ZPO}$ ). Hierdoor is het voor "grootverbruikers" van deze incassoprocedure mogelijk om via elektronische gegevensverwerkingssystemen of computer de verschillende "Mahnanträge" bij één gerechtelijke instantie in te stellen. ${ }^{109}$

Het valt te constateren dat het individu in de gerechtelijke procedure in toenemende mate wordt geconfronteerd met organisaties en rechtspersonen als tegenpartij en steeds vaker treden collectieven, belangengroeperingen en organisaties in rechte op ter behartiging van individuele belangen, groeps- en algemene belangen in gestandaardiseerde rechtsbetrekkingen. Rechtshandhaving vindt als gevolg daarvan meer en meer plaats op het collectieve vlak. Het toenemende aantal collectieve acties is hiervan een duidelijke uiting.

Ook op het terrein van het consumentenrecht valt, zij het aarzelend, een toename van het aantal collectieve acties te bespeuren. Deze toename van het aantal collectieve acties wordt verklaard vanuit een toenemende behoefte aan rechtsbescherming van de individuele consument, welke onder de klassieke uitgangspunten van het burgerlijk procesrecht onvoldoende tot zijn recht komt. ${ }^{110}$ Afgezet tegen de klassieke uitgangspunten van het civiele procesrecht zal in deze paragraaf derhalve worden geïnventariseerd welke rol individuen - met name consumenten - en organisaties spelen in de civiele procedure.

\subsubsection{Beginselen van het burgerlijk procesrecht}

Als belangrijkste beginselen van het burgerlijk procesrecht worden genoemd: de openbaarheid van behandeling, onafhankelijkheid, onpartijdigheid en lijdelijkheid van de rechter, hoor en wederhoor, verplichte procesvertegenwoordiging, niet-kosteloze rechtspraak en motivering van de beslissing. ${ }^{111}$ Ons Wetboek van burgerlijke rechtsvordering dateert uit het begin van de negentiende eeuw. De liberale maatschappijopvatting van die tijd, die het concrete conflict tussen twee individuele en min of meer gelijkwaardige burgers als uitgangspunt hanteerde, drukt nog steeds haar stempel op ons burgerlijk procesrecht. In overeenstemming met dit negentiende eeuwse maatschappijbeeld was en is het model van het burgerlijk proces geënt op de volgende uitgangspunten:

1.De procesautonomie van de individuele burger. Iedereen bepaalt zelf of hij zijn geschil aan de rechter voorlegt. Het beginsel van de lijdelijkheid van de burgerlijke rechter is de weerslag van de partijautonomie. ${ }^{12}$ Ook het pro-

109 Zie hierover: M. Freudenthal, Het "Mahnverfahren': voorbeeld van een incassoprocedure, NJB 1992, 1333-1137.

110 Rodrigues, SWOKA-onderzoeksrapport, pag. 5.

111. Stein, compendium, pag. 33; Hugenholtz/Heemskerk, pag. 8; Groenendijk, diss., pag. 7.

112 Stein, compendium, pag. 46; Hugenholtz/Heemskerk, pag. 11; Groenendijk, diss., pag. 8; Rodrigues, SWOKA-onderzoeksrapport, pag. 5. 
cesrechtelijk beginsel dat men enkel kan opkomen voor zijn eigen belang is een uitvloeisel van de procesautonomie.

2.De formele gelijkheid van partijen. Ongeacht de status van partijen zijn de rechtsregels waaraan zij zijn onderworpen gelijk. Het uitgangspunt vindt zijn uitwerking in de beginselen van hoor en wederhoor, de openbaarheid van de rechtszitting, de verplichte procesvertegenwoordiging en de onafhankelijkheid en onpartijdigheild van de rechter. ${ }^{153}$

3 De unieke en op zichzelf staande relatie van partijen. Het conflict wordt, los van zijn sociale en maatschappelijk context, aan de hand van de concrete individuele omstandigheden beslecht. ${ }^{14}$ Iedere burger heeft recht op een afzonderlijk proces waarin zijn individuele rechtspositie wordt beoordeeld. Het uitgangspunt komt tot uitdrukking in enerzijds de grondwettelijke en volkenrechtelijke bepalingen die de toegang tot de rechter ter behartiging van burgerlijke rechten garanderen en anderzijds in de regel dat enkel de procespartijen gebonden zijjn door het gezag van gewijisde van de uitspraak. ${ }^{115}$

\subsubsection{Ongelijke kansen in het burgerlijk proces}

De consument treedt in het rechtsverkeer doorgaans op als individu. Contractuele wederpartij van de consument is daarbij veelal een professionele organisatie of samenwerkingsverband." 116

Ofschoon alle consumenten tezamen een sociale categorie vormen, komen individuele consumenten uit verschillende sociaal-economische groepen en zijn er grote verschillen te signaleren tussen de verschillende individuele consumenten. Deze sociale ongelijkheid heeft zijn invloed op de procesrechtelijke mogelijkheden van de diverse individuen. Daarnaast heeft ook de ongelijksoortigheild (individu-organisatie) van procespartijen haar uitwerking op deze mogelijkheden. In het navolgende wordt, aan de hand van de "klassieke" beginselen van burgerlijk procesrecht nagegaan in hoeverre deze sociale ongelijkheid en ongelijksoortigheid invloed hebben op de toegang tot en het gebruik van de burgerlijke rechter.

\subsubsection{Sociaal-economische ongelijkheid en procesrechtelijke uitgangspunten}

Keerzijde van het eerste uitgangspunt, de procesautonomie, is dat niemand gedwongen kan worden om zijn rechten via de rechter te handhaven. Het

113 Groenendijk, diss., pag, 8\%9, Rodrigues, swOKA-onderzoeksrapport, pag. 5; Hugenholot Heemskerk, payg. 8.

114 Rodrigues, sWOKA-onderzoeksrapport, pag. 5.

115 Groenendijk, diss:, pag. 9.

116 Bij voorbeeld: banken, verzekerwars, postorderbedrijven, detailhandelaren, nutsbedrijwen, etc. 
beginsel dat men slechts mag opkomen voor zijn eigem belang geeft hieraan uiting. Ook de lijdelijkheid van de rechterlijke macht en advocatuur is een uitvloeisel van deze procesautonomie. Het initiatief tot gerechtelijke belangenbehartiging ligt niet bij deze instituties maar bij de individuele partij zelf. Het gevolg van het uitgangspunt van de procesautonomie is derhalle dat indien een partij zelf geen initiatief onderneemt er geen (gerechtelijke) bescherming van zijn belangen plaatsvindt omdat de partij dit zelf kennelijk niet wenst.

Socialle verschillen tussen partijen zoals kennis, vaardigheid en vermogen hebben echter tot gevolg dat de toegangsdrempel tot de burgerlijke rechter voor de verschillende sociale groepen verschilt. Zo zullen partijen met een laag opleidingsniveau en dito inkomen, vanwege de sociale afstand die zij moeten overbruggen, doorgaans een grotere inspanning moeten leveren en lopen zij gezien hun kennisniveau en financiële positie grotere risico's dan mensen met hoger opleidingsniveau en betere financiële mogelijkheden. ${ }^{117}$ Vanwege dit verschil in toegangsmogelijkheden tot de burgerlijke rechter mag het ontbreken van het nemen van initiatief tot een procedure derhalve nooit zonder meer uitgelegd worden als een ontbrekende behoefte aan rechtsbescherming. Daarbij moet worden opgemerkt dat voor het overgrote deel van de individuele burgers het voeren van een civiele procedure voor eigen rekening voor een rechtbank nagenoeg onbetaalbaar is geworden.

Het tweede uitgangspunt, de formele gellikheid van procespartijen, schakelt de feitelijke (sociale) ongelijkheid van partijen bij het conflict op een aantal punten uit. Het stellen van gelijke regels voor beide partijen beoogt gelijke processuele kansen voor deze partijen.

Formele gelijkheid leidt echter niet zonder meer tot een feitelijk gelijke processuele positie. Met de ongelijke verdeling van een aantal, voor het voeren van een proces belangrijke, factoren als de mogelijkheid om kosten en risico's te dragen, het uithoudingsvermogen en de toegangsmogelijkheden tot relevante deskundigheid en informatie, wordt in het burgerlijk proces immers in beginsel geen rekening gehouden. Het scheppen van gelijke kansen voor partijen uit verschillende sociale groepen en met een ongel ijke uitgangspositie kan alleen tot een gelijkwaardig resultaat leiden bij ongelijke inspanning van de betrokkenen. ${ }^{118}$ Groenendijk haalt daarbij een aan Ehrlich ontleend citaat aan:

"Je meir reich und arm nach denselben Rechissatzen behandelt wird, um so mehr gewinnt die Oberlegenheit der Reichen an Gewicht"1199

117 Groenendijk, diss., pag. 10.

118 Groenendijk, diss., pag. 10.

119 Groenendijk, diss., pag. 10 en noot $27 \mathrm{a}$. 
De unieke en op zichzelf staande relatie van partijen, het derde uitgangspunt, bewerkstelligt dat het conflict tot op zekere hoogte los van de sociale factoren die het deden ontstaan, los van soortgelijke conflicten van anderen en los van de overige relaties van betrokkenen wordt beoordeeld. Het heeft als voordeel dat de rechter makkelijker tot een beslissing kan komen en dat de individueel betrokkenen de beslissing eerder aanvaarden. ${ }^{120}$ Deze individualisering van het (burgerlijke) conflict heeft echter gevolgen voor het soort conflicten dat voor berechting in aanmerking komt. Met name conflicten waarbij de waarde per individu te klein is om de kosten te rechtvaardigen (de zogenaamde "small claims"), waarbij de risico's van berechting te groot zijn om door én individu gedragen te worden ${ }^{121}$ of waarbij de uitspraak in het individuele gevall de oorzaak van het conflict niet kan wegnemen, komen in principe wél voor berechting in aanmerking, maar worden feitelijk niet aan de rechter voorgelegd. ${ }^{122}$ Daarnaast heeft deze individualisering gevolgen voor de werking van het vonnis. Het vonnis bezit slechts kracht van gewijsde tussen partijen. Andere justitiabelen kunnen geen directe rechten ontlenen aan het vonnis ook al verkeren zij in dezelfde situatie of omstandigheden. Afgezien van precedentwerking heeft het vonnis derhalve geen breedtewerking.

De bovengenoemde uitgangspunten van het burgerlijk procesmodel kunnen bij sociale diversiteit van partijen leiden tot een ongelijk gebruik van of ongelijke kansen in het juridisch proces. Leden van verschillende sociaal-economische groepen onderscheiden zich eveneens in de mogelijkheden om initiatief te nemen, om kosten en risico's van de procedure te dragen en om zich toegang te verschaffen tot de rechtshulp. ${ }^{123}$

Aangenomen wordt echter dat het verschil in toegangsmogelijkheden tot en kansen bij de burgerijjke rechter niet alleen voortvloeit uit individuele sociale verscheidenheid: Voor een deel wordt het verklaard vanuit het verschil tussen individuen en organisaties, vanuit de ongelijksoortigheid van partijen dus.

\subsubsection{Ongelijksoortigheid van partijen; individuen versus organisaties}

Het burgerlijk procesmodel is van oorsprong gericht geweest op de beslechting van een geschil tussen twee individuele natuurlijke personen. Tot halverwege de negentiende eeuw stemde dit model nagenoeg overeen met de maatschappelijke werkelijkheid. Buiten de staat, de kerk, de steden, de gilden en de handelsver-

120. Groenendijk, diss., pag. 11 .

121 Zie ook hiema $\mathbf{2 . 4 . 2 . 4}$ omtrient de asymmetrische relatie.

122 Groenendijk diss , pag. 11 .

123 Groenendijk $\mathrm{k}_{\text {, dissi. }}$, pag. 11. 
enigingen waren er nawwelijks organisaties die deelnamen aan het rechtsverkeer. Sinds de industriële revolutie echter, participeren organisaties in steeds sterkere mate in het rechtsverkeer en wordt het leven van het individu in de Westerse wereld in toenemende mate bepaald door zijn relaties tot organisaties. Deze organisaties zijn overwegend rechtspersonen ${ }^{124}$ en daarmee juridisch nagenoeg gelijkgesteld met natuurlijke personen. Het sociologisch begrip organisatie - een samenwerkingsverband van twee of meer natuurlijke personen met een bepaald doel - en het juridisch begrip rechtspersoon gaan in werkelijkheid nagenoeg samen. ${ }^{125}$

De formele juridische gelijkstelling van organisaties met individuen verhult echter de feitelijke ongelijkheid tussen organisaties en individuen bij deelname aan het rechtsverkeer. Het verschil in omvang en beschikbare middelen van organisaties en natuurlijke personen is voortdurend toegenomen waardoor het toekennen van gelijke rechten in de praktijk leidt tot een ongelijke realisatie van belangen. ${ }^{126}$ Bovendien beschikken organisaties, in vergelijking met natuurlijke personen, bij het aangaan en uitvoeren van overeenkomsten meestal over meer relevante informatie. $\mathrm{Zij}$ zijn voorts minder emotioneel en financieel betrokken bij de individuele overeenkomst en hebben veel minder, maar meer gespecificeerde, doelen om na te streven. ${ }^{127}$ Een en ander vergemakkelijkt het nemen van rationele beslissingen voor de organisatie.

De toegenomen rol van organisaties in het rechtsverkeer komt uiteraard ook tot uiting in het burgerlijk proces. Enerzijds doordat het individu in het burgerlijk proces steeds meer geconfronteerd wordt met een organisatie als tegenpartij en anderzijds doordat in steeds meer civiele procedures enkel nog organisaties tegenover elkaar staan.

Zowel Amerikaanse, Duitse als Nederlandse onderzoeken uit de jaren zeventig tonen dan ook aan dat in het merendeel van de in eerste instantie gevoerde civiele procedures (uitgezonderd familiezaken) én of beide procespartijen een organisatie is. ${ }^{128}$ Slechts in ongeveer $28 \%$ van de onderzochte procedures

124 Uitzonderingen zijn de firma en de matsehap.

125 Groenendijk, diss., pag. 13.

126 Coleman, pag. 76.

127 Groenendijk , diss., pag. 13.

128 Wanner, L\&SR 1974, pag. 424-437; Blankenburg, pag. 317; Galanter, L\&SR 1975, pag. 349; Groenendijk, diss., pag. 14-18; Rodrigues, SWOKA-onderzoksmapport, pag. 7-9. Zie voor eem overzicht van onderzoeken (en uitkomsten daarvan) betreffende small claims courts in (voomamelijk) de VS van wó́r 1975: Yngvesson en Hennesey. pag. 235 e.v.; Galanter, LdesR 1975, pag. 349-357. 
waren beide procespartijen individuele burgers. ${ }^{12}$ In ongeveer $50 \%$ van de gevallen stond een individu tegenover een organisatie, waarbij organisaties vaker als eiser optraden dan als gedaagde. ${ }^{130}$ In de resterende gevallen - iets meer dan ongeveer $20 \%$ - stonden twee organisaties tegenover elkaar.

Groenendijk's onderzoek naar het aandeel van individuen en organisaties in cassatieberoepen voor de Hoge Raad in 1927 en 1977 , bevestigt eveneens dat slechts een minderheid $(34 \%)$ van de procedures wordt gevoerd tussen twee individuen,

Onderzoeken uit de jaren tachtig naar de aard van partijen in de civiele procedure laten een zelfde beeld zien. ${ }^{132}$ Voor Nederland vond Van Duyne onder andere, dat in $42 \%$ van total 5724 onderzochte handelszaken die in 1983 dienden voor de rechtbanken te Breda, Den Haag en Rotterdam, een onderneming als eiser optrad tegen een natuurlijk persoon ${ }^{133}$. Ook onderzoek door Bruinsma en Welbergen, naar de partijsamenstelling in cassatieberoepen voor de Hoge Raad, laat dit beeld ongewijzigd. Zij onderzochten 58 arresten van de Hoge Raad en maakten daarbij onderscheid tussen formele procespartijen en feitelijke procespartijen. De formele (nominalle) procespartijen waren in 16 arresten twee natuurlijke personen $(27,5 \%)$, in 26 arresten een natuurlijk persoon en een organisatie $(44,8 \%)$ en in 16 uitspraken twee organisaties

$(27,5 \%)$. De feitelijke (reële) procespartijen waren in 12 arresten twee natuurlijke personen $(20,7 \%)$, in 19 arresten een natuurlijk persoon en een organisatie $(32,8 \%)$ en in 27 uitspraken twee organisaties $(46,5 \%) .{ }^{134}$

Het nog niet zo lang geleden gepubliceerde onderzoek van Van Koppen en Malsch naar ongeveer 740 in 1986 gewezen eindvonnissen van de rechtbanken te Rotterdam, Den Haag en Breda laat een zelfde verdeling zien. ${ }^{135}$ De 741 onderzochte eisers betroffen 471 organisaties en 244 individuen. Bij de 742

$\$ 29$ Dit cijfer is warsehijnlijlk nog te hoog omdat in veel procedures weliswas de formele procespartij een individu is, maar de feitelijke partij een organisatie is. Zie: Groenendijk, dissi." page 1 is.

130 Dat organisaties in vergellyking met individuen waker optreden als eiser dan als gedaagde blijkt ook uit reeds eender gedasn onderzoek wan Bloembergen e.a.. Zie: A.R. Bloembergen, J.C.. Hers-van Oven, P. Vinke en P.J.M. wan Werseh, Duizend botsingen., Deventer 1972, pag. 16. Zie meer uitgebreid: paragran $2,5.2 .3$.

131 Groenendijk, diss., pag, 17. Het hogere percentage in cassatie t.o.v. de procedures in eerste aanleg, wordt volgens Gmontendijk verklevard door hel feit dat in cassatie formeel een individu procespartij is, terwijl de procedure feitelijk door sen organisatie (assuradeur, valkbond etc.) wordt gevoend.

132 Vidmar, pag, 526-527, Zie woor een overzicht van Nederlands onderzoek: Rodrigues, SWOKA-onderzoeksrapport, pag. 7-8.

133 Van Duyne, pag. 73.

134 Bruinsma en Welbergen, pag. 51.

135 Van Koppen en Malseh, L\&SR 1991 , pag. 815 en NJB 1992, pag. 1103. 
onderzochte gedaagden is het beeld net andersom: 485 individuen en 257 organisaties. ${ }^{136}$

Gezien het voorgaande kan men stellen dat het klassieke procesmodel, dat slechts uitgaat van twee individuen als procespartij, beschouwd kan worden als grotendeels achterhaald door de werkelijkheid.

\subsubsection{Repeat Players versus One Shotters}

Opmerkelijke uitkomst van het onderzoek van Groenendijk naar de aard van procespartijen in cassatieberoepen was, dat organisaties anderhalf (1927) tot twee keer (1977) zo veel succes hadden als individuen. ${ }^{137}$ De hoogste successcores, $46 \%$ in 1927 en $63 \%$ in 1977 , werden daarbij behaald in procedures waarin organisaties als eisers optraden tegen individuele gedaagden. Ook Amerikaans onderzoek laat zien dat organisaties beter scoren dan individuen. ${ }^{138}$

Volgens de Amerikaanse rechtssocioloog Galanter is deze ongelijke vaardigheid om van het recht gebruik te maken, niet zozeer het gevolg van persoonlijke eigenschappen van procespartijen maar meer het gevolg van de relatie van partijen tot het systeem van rechtshulp en rechtspraak. ${ }^{139}$ Daarbij valt een onderscheid te maken tussen enerzijds de partij die meermaals en routinematig een beroep doet op rechtspraak, de Repeat Player (RP), en anderzijds de partij die slechts incidenteel een beroep daarop doet, de One Shotter (OS).$^{100}$

In vergelijking met de incidenteel optredende procespartij heeft de routinematig optredende procespartij zowel vóor ${ }^{141}$, tijdens als na de procedure, een groot aantal voordelen:

-de RP kan putten uit zijn ervaringen opgedaan in eerdere procedures en accumuleert deskundigheid. Hij kan zijn contractuele handelen daar - onder andere in algemene voorwaarden - op afstemmen;

136 Van Koppen en Malsch, LikSR 1991, pag. 815 en NJB 1992, pag. 1103; Vidmar, pag. 528.

137 Groenendijk, diss. , pag. 18. Zie in dezelfde zin: Galanter, L\&SR 1975, pag. 357 e.v.; Yngvesson en Hennessey, pag. 246.

138 Wanner, L\&SR 1975, pag. 300-306; Galanter, L\&SR 1975, pag. 357-360.

139 Galanter, L\&SR 1974, pag. 104, now 20 en L\&SR 1975, pag. 347.

140 Galanter, L\&SR 1974, pag. 97 en L\&SR 1975, pag. 347. Zie ook: Groenendijk, diss., pag. 19 en Rodrigues, SWOKA-onderzoeksrapport, pag. 7. Opvallend is dat zowel Groenendijk als Rodrigues de term "One Shooter" hanteren i.p.v. "One Shotter".

141 Partijen in een conflict kunnen de dreiging met en prowedure en het dagvanden ook hanteren om préprocessuele onderthandeling op gang te bremgen of te beïnvloeden. Repeat Players doen dit met meer succes dan One Shotters. Zie Sarat, pag. 347 e.v. 
-de RP heeft gemakkelijker toegang tot rechtshulpverleners en deskundigen. Bovendien hebben zij meer mogelijkheden om informele contacten in diverse circuits (rechterlijke macht, overheid) te onderhouden. Doordat hij meer procedures voert zijn de (aanloop)kosten per procedure geringer;

-de RP kan zich richten op gemiddelde uitkomsten in procedures. De RP kan, wetende dat hij de meerderheid der procedures zal winnen, verlies in individuele procedures op de koop toe nemen;

-de RP heeft meer financiële mogelijkheden ${ }^{142}$;

-de RP kan kosten en risico's over een groter aantal zaken spreiden. Het belang van de RP is daardoor relatief vaak klein terwijl dit voor de OS meestal relatief groot is. Daardoor kan de RP makkelijker risico"s nemen;

-de RP heeft meer mogelijkheden (bijv. lobbyen) om relevante regels zelf te veranderen;

-de RP kan een procedure zowel voeren met het oog op een beoogde precedentwerking voor volgende gevallen ("play for rules"143) als vanwege de toewijzing van een vordering ${ }^{144}$;

-bij de RP is sprake van minder persoonlijke betrokkenheid bij de uitkomst van de procedure dan de OS; en

-de RP kan zijn aandacht richten op de verwezenlijking van een beperkt aantal concrete doelen. Daardoor beschikt de RP vaak over middelen, kennis en continue aandacht die het mogelijk maken om de naleving van regels af te dwingen zonder gebruik te maken van (overheids)rechtspraak. ${ }^{145}$

Het onderscheid tussen One Shotter en Repeat Player valt meestal samen met dat tussen individuele procespartij en organisaties als procespartij. ${ }^{146}$ Gezien de strategische voordelen die de RP heeft ten opzichte van de OS lijkt het derhalve verklaarbaar waarom organisaties significant vaker succes in gerechtelijke procedures hebben dan natuurlijke personen.

Zo vond Groenendijk dat in éen op de zes van de 1779 door hem onderzochte (niet-familierechtelijke) burgerlijke procedures voor de rechtbank te Amsterdam uit 1978, een Repeat Player optrad. Bij de 101 door hem onderzochte cassatieberoepen bij de Hoge Raad was dit zelfs in éen op de vier beroepen thet geval. ${ }^{147}$ Vooral banken, verzekeringsmaatschappijen en over-

142 Zie ook: Van Koppen en Malsch, L\&SR 1991, pag. 804 en 814-815; NJB 1992, pag. 1103.

143 Galanter, L\&SR 1974 , pag. 100.

144 Zie hierover eveneens: Van Koppen en Malsch, L\&SR 19991, pag. 811.

145 Galanter, L\&SR 1974, pag. 98-103 en L\&SR 1975, pag. 347; Groenendijk, diss., pag. 19.20; Rodrigues; SWOKA-onderzoeksrapport, pag. 7 .

146 Yngvesson en Hennesey, pag. 236; Coleman, pag. 13-14; Galanter, L\&SR 1975, pag. 362-363

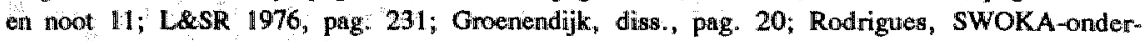
zoeksrapport, pag. 7 .

147 Groenendijk, diss., pag. 20-21. 
heidsinstanties bleken typische Repeat Players te zijnn. ${ }^{148}$ Bij de onderzochte rechtbankprocedures bleken individuele personen slechts enkele malen in twee en slechts zelden in meerdere procedures op te treden. Daaruit blijkt, en dat wordt ook door ander onderzoek ${ }^{149}$ bevestigd, dat van routine-matig gebruik van rechtspraak door natuurlijke personen nauwelijks sprake is en het individu slechts zelden in staat is de voordelen van de Repeat Player te verwerven. ${ }^{150}$

Het klassieke procesrechtelijke uitgangspunt van de formele gelijkheid van procespartijen en de juridische gelijkschakeling van natuurlijke personen en rechtspersonen houdt met deze feitelijke ongelijkheid tussen organisaties en individuen echter nauwelijks rekening.

Uit rechtssociologisch onderzoek naar de samenstelling van procespartijen blijkt dat organisaties in de civiele procedure significant vaker optreden als eiser dan als gedaagde. ${ }^{\text {is }}$ In 1559 door Vidmar onderzochte small claims, trad bijvoorbeeld in $76 \%$ (1188) van de gevallen een organisatie, in $14 \%$ (220) van de gevallen een énmanszaak en slechts in $10 \%$ (147) van de gevallen een individu als eiser op. Als gedaagde trad daarentegen slechts in 15\% (237) van de gevallen een organisatie, in $9 \%(145)$ van de gevallen een énmanszaak en in $76 \%$ (1177) van de gevallen een individu op. ${ }^{152}$

"Thus, like previous studies we find that the most common configuration in the court involves busimess plaintiffs suing individuals. "153

Van Koppen en Malsch concluderen aan de hand van Nederlands onderzoek eveneens dat van alle civiele gedingen, het geding waarin een organisatie als eiser tegenover een individu als gedaagde staat het meeste voorkomt. ${ }^{154}$ In hun onderzoek is van de eisers $67 \%$ een organisatie en $33 \%$ een individu. Van de gedaagden is $35 \%$ een organisatie en $65 \%$ een individu. ${ }^{155}$

148 Zie ook, in dezelfde zin: Francken, 1983, pag. 13-14 en 57.

149 Ongepubliceend onderzoek van Schuyt, Jettingthoff, Lambregts en $Z$ wart. Zie hierover: Groenendijk, diss., pag. 21, noot 57.

150 Groenendijik $k_{i}$ diss., pag. 21.

151 Yngresson and Hennesey, pag. 235-243; Wanner, L\&SR 1974, pag. 431-432; Blankenburg, pag. 317; Galanter, L\&SR 1975, pag. 349-357; Vidmar, pag. 526 e.v.; Van Koppen en Malseh, L\&SR 1991, pag. 815 en NJB 1992, pag. 1103.

152 De percentages en aantallen żjin door mij afgeleid uit cijfers van Vidmar, pag. 526-527.

153 Vidmar, pag. 528.

154 Van Koppen en Malsch, NJB 1992, pag. 1103.

155 Van Koppen en Malsch. L\&SR 1991, pag. 815 en NJB 1992, pag. 1103. 
Eisers winnen de gerechtelijke procedure vaker dan gedaagden. ${ }^{156}$ Het succes van de Repeat Players in de processuele fase lijkt derhalve gedeeltelijk te steunen op het feit dat deze vaker als eiser optreden. Het hebben van procedurele ervaring lijkt overigens ook voor gedaagden gunstig uit te pakken, met name als de eiser One Shotter is. ${ }^{157}$

Voor de hand liggend is, dat een deel van het succes van eisers en dus ook organisaties, is te wijten aan het feit dat gedaagden vaak verstek taat gaan. In verstekzaken krijgt eiser de vordering in beginsel immers altijd geheel toegewezen. Van Koppen en Malsch komen in hun onderzoek bijvoorbeeld tot de conclusie dat $48 \%$ van alle zaken die tot een procedure leidden een verstekzaak betrof. In total werd daardoor in $73 \%$ van alle gevallen de vordering van eiser geheel of gedeeltelijk toegewezen. ${ }^{158} \mathrm{Zo}$ ook Vidmar. Hij vond in zijn onderzoek, dat de 1559 zaken die uiteindelijk tot een procedure hadden geleid, bestonden uit $1126(72 \%)$ verstekzaken en $433(28 \%)$ zaken waarin de gedaagde verweer voerde. ${ }^{159}$ Uitgesplitst naar soort partij, trad in $84 \%$ van de gevallen een organisatie, in $13 \%$ van de gevallen een énmanszaak en slechts in $3 \%$ van de gevallen een individu als eiser op in een verstekprocedure. De niet verschenen gedaagde betrof in $11 \%$ van de gevallen een organisatie, in $6 \%$ van de gevallen een érnmanszaak en in $83 \%$ van de gevallen een individu. ${ }^{\text {tro }}$ Repeat Players zitten gemiddeld genomen dus relatief vaker dan One Shotters in de duidelijk comfortabelere procesrechtelijke positie van eiser.

De, in vergelijking met One Shotters, hogere succesquota van Repeat Players in de gerechtelijke procedure door het optreden als eiser, worden echter door de onderzoeken van Vidmar en Van Koppen en Malsch ook weer gerelativeerd. Wordt in het onderzoek naar de succesquota van eisers en gedaagden de fase voorafgaand aan de gerechtelijke procedure - de onderhandelingsfase - en de fase volgend op het vonnis - de executiefase - betrokken dan ontstaat een genuanceerder beeld.

Vidmar laat vanuit onderzoek naar de préprocessuele (onderhandelings-) fase zien, dat de succesquota van eisers gedeeltelijk gebaseerd zijn op optisch bedrog. ${ }^{161}$ In veel zaken waarin de gedaagde verweer voert, wordt de vordering van eiser slechts voor een deel toegewezen. Onderzoekers kwalificeren een

156 Van Koppen en Malsch, L\&SR 1991, pag. 818 en NJB 1992, pag. 1101; Yngvesson en Hennesey, pag. 243 e.v.; Sarat, pag. 364-366; Wanner, L\&SR 1975, pag. 300-305; Galanter, L\&SR 1975, pag. 357-360.

157 Sarat; pag: 364-366.

158 Van Koppen en Malsch, L\&SR 1991, pag. 818 en NJB 1992, pag. 1104.

159 Vidmar, pag. 525-527.

160 Vidmar, pag. 526-527.

161 Vidmar, The small claims court: a reconceptualization of disputes and empirical investigation, 1984. Zie hierover kort: Van Koppen en Malsch, NJB 1992, pag. 1101-1102. 
dergelijke gedeeltelijke toewijzing van eiser's vordering doorgaans als een overwinning van eiser. Vidmar komt echter tot de conclusie dat het toegewezen deel van de vordering vaak het bedrag (of zelfs een lager bedrag) is dan dat waarvan de gedaagde, in de aan de procedure voorafgaande onderhandelingen, al toegaf dat hij dat verschuldigd was. ${ }^{162}$ Een voorbeeld ${ }^{163}$ " eiser vordert $f 10.000$, $=$ en gedaagde heeft zich in het préprocessuele stadium bereid verklaard de helft daarvan (f $5.000,=$ ) te betalen, omdat hij dat deel van de vordering erkent. Als eiser zijn vordering van $f 10.000,=$ in de gerechtelijke procedure voor $f 5.000$, = toegewezen krijgt, wordt dit doorgaans geturfd als een overwinning van eiser; in feite heeft gedaagde echter gewonnen. Vidmar gaat er in een dergelijke situatie van uit dat het geschil miet $f 10.000,=$ maar slechts het betwiste deel van eiser's vordering van $f 5.000,=$ betreft. Er van uit gaande dat een toewijzing van eisers vordering van minder dan $50 \%$ van het betwiste deel beschouwd dient te worden als een overwinning voor de gedaagde, komt Vidmar tot de conclusie dat gedaagden, indien zij verweer voeren, méer procedures winnen dan eisers. ${ }^{164}$ In $59 \%$ van alle gevallen krijgt eiser minder dan $50 \%$ van het betwiste deel toegewezen en gemiddeld wordt slechts $41 \%$ van het betwiste deel van eiser's vordering toegewezen. ${ }^{165}$ Opmerkelijk is dat Vidmar in de zaken waarin verweer wordt gevoerd door gedaagden, geen enkel verband vond tussen enerzijds de status van Repeat Player of One Shotter en anderzijds de successcore. ${ }^{166}$

Indien men bovenstaande cijfers plaatst in het geheel van alle zaken levert dit de volgende cijfers op. Uitgaande van de veronderstelling dat in nagenoeg alle verstekzaken het betwiste deel van de vordering geheel wordt toegewezen en dus de eiser wint, worden $83,6 \%{ }^{167}$ van alle 1559 zaken door eisers gewonnen en wordt gemiddeld ook $83,6 \%$ van het betwiste deel van eisers vordering toegewezen. De succesquota van organisaties en Repeat Players lijken derhalve vooral gebaseerd op het feit dat zij in verstekprocedures meestall als eiser optreden.

Van Koppen en Malsch hebben de fase warin het wonnis moet worden uitgevoerd, de postprocessuele fase van het geschil, aan een nadere analyse onderworpen. ${ }^{168} \mathrm{Zij}$ onderzochten 4131 in 1986 gewezen eindvonnissen van de rechtbanken te Rotterdam, Den Haag en Breda en daarvan werd in 73\% (3031)

162 Vidmar, pag. 535 .

163 Voorbeeld ontleend an Van Koppen en Malsch, NJB 1992, pag. 1102.

164. Vidmar, pag. 533-535.

165 Vidmar, pag. 534.

166 Vidmar, pag. 535.

167 Verstekzaken $(72,2 \%)+$ door eiser gewonnen verweerzaken $(41 \%$ van $27,8 \%=11,4 \%)$.

168 Van Koppen en Malsch, L\&SR 1991, pag. 803-820 en NJB 1992, pag. $1101-1104$. 
van alle gevallen de vordering van eiser geheel of gedeeltelijk toegewezen en in de resterende $27 \%$ de vordering van eiser geheel afgewezen. ${ }^{169}$ Op het eerste gezicht dus duidelijke processuele voordelen voor de eisers, waarvan de meerderheid een organisatie is. Nader onderzoek naar het betalingsgedrag van gedaagden ná een woor hen ongunstig vonnis levert echter een geheel ander beeld op.

Van de 930 onderzochte zaken waarin de vordering van eiser geheel of gedeeltelijk werd toegewezen had drie jaar na het vonnis slechts $43 \%$ van de gedaagden geheel, $22 \%$ gedeeltelijk en $35 \%$ geheel niets betaald. ${ }^{170}$ Als geheel of gedeeltelijk betaald werd, ging dat meestal ook niet zonder problemen. ${ }^{\text {nt }}$ De $22 \%$ gedaagden die gedeeltelijk het vonnis nakwamen, betaalden gemiddeld $45 \%$ van de toegewezen vordering. ${ }^{172}$ Dit betekent dat in deze 930 onderzochte zaken, uiteindelijk gemiddeld slechts ongeveer $53 \%{ }^{173}$ van het totale toegewezen bedrag werd betaald.

Opgesplitst naar soort partij verschuift het beeld iets. De onderzochte 244 individuele eisers kregen hun vorderingen in $40 \%$ van de gevallen geheel niet, in $16 \%$ van de gevallen gedeeltelijk en in $43 \%$ van de gevallen geheel betaald. Bij de 497 onderzochte organisaties wordt in $35 \%$ van de gevallen geheel niet, in $25 \%$ van de gevallen gedeeltelijk en in $40 \%$ van de gevallen geheel betaald. De individuele eiser krijgt in $60 \%$ en de organisatie in $65 \%$ van de gevallen iets tot alles betaalld. ${ }^{174}$ Eisende organisaties behouden in de executiefase derhalve het succes dat zij tijdens de procedure hadden. Individuele eisers ontvangen daarentegen rellatief vaak weinig tot niets van de toegewezen vordering. ${ }^{175}$ Indien we in deze cijfers betrekken dat gemiddeld $45 \%$ van de toegewezen vordering wordt betaald indien sprake is van gedeeltelijke betaling, krijgen van alle toegewezen vorderingen individuen gemiddeld ongeveer $50,2 \% 176$ en organisaties gemiddeld ongeveer $51,6 \%^{177}$ van het totale bedrag betaald. Uiteindelijk is de Repeat Player als eiser dus ook hierin iets in het voordeel. Een mogelijke verklaring voor het succes van organisaties is volgens Van Koppen en Malsch dat organisaties over meer, vooral financiële, middelen beschikken om gedaagden tot betaling te bewegen. ${ }^{178}$

169 Van Koppen en Malsch, L\&SR 1991, pag. 806 en 818, NJB 1992, pag, 1102 en 1104.

170 Van Koppen en Malsch, L\&:SR 1991, pag. 810 en NJB 1992, pag. 1102.

171 Van Koppen en Malsch, NJB 1992, pag. 1103.

172 Van Koppen en Malsch, L\&SR 1991, pag. 809 en NJB 1992, pag. 1102.

$17343 \%+45 \%$ van $22 \%=43 \%+10 \%=53 \%$.

174 Van Koppen en Malsch, LdSR 1991, pag. 815; NJB 1992, pag. 1103.

175 Van Koppen en Malsch, LosiR 1991, pag. 819; NJB 1992, pag. 1103.

$17643 \%+45 \%$ van $16 \%=43 \%+7,2 \%=50,2 \%$

$17740,5 \%+45 \%$ van $24,7 \%=40,5 \%+11,1 \%=51,6 \%$.

178 Van Koppen en Malsch, NJB 1992, pag. 1103. 
Als bovenstaande uitkomsten worden toegepast op alle 4131 door Van Koppen en Malsch onderzochte zaken, dus inclusief die zaken waarin de vordering werd afgewezen, krijgen eisers in $53 \%$ van de gevallen niets, in $16 \%$ van de gevallen gedeeltelijk en in $32 \%$ van de gevallen alles betaald. ${ }^{17 \%}$ Uitgaande van het gegeven dat in de gevallen waarin gedeeltelijk wordt betaald slechts $45 \%$ van het toegekende bedrag wordt geïncasseerd, blijkt de gedaagde dus uiteindelijk "winnaar" te zijn.

Het (gedeeltelijk) niet betalen van de toegewezen vordering is voornamelijk (75\%) terug te voeren op financieel onvermogen van individuele gedaagden en faillissement van organisaties. In $13 \%$ van de gevallen werd alsnog een schikking getroffen tot een lager bedrag dan toegewezen door de rechter en in $12 \%$ van de gevallen werden andere redenen opgegeven. ${ }^{100}$ Daarbij valt op dat organisaties als gedaagden beter en gemiddeld meer van het toegewezen bedrag betalen dan individuele gedaagden. Organisaties betalen niets in $35 \%$, gedeeltelijk in $13 \%$ en geheel in $52 \%$ van de onderzochte gevallen. Individuen daarentegen betalen niets in $37 \%$, gedeeltelijk in $27 \%$ en geheel in $36 \%$ van de gevallen. ${ }^{181}$ De verklaring van het betere betalingsgedrag van organisaties dient daarbij gezocht te worden in de betere financiële positie van organisaties.

"gedaagde repeat players zijn eenvoudigweg vaker dan individuele gedaagden in staxt om te voldoen aan het wonnis "ils?

\subsubsection{De niet-unieke en asymmetrische relatie}

Een van de neveneffecten van het feit dat de distributie van goederen en diensten in toenemende mate geschiedt door organisaties is de standaardisering van de relaties tussen grote aantallen burgers, natuurlijke personen enerzijds en organisaties anderzijds. Massaproduktie van goederen en diensten heeft geleid tot een massale produktie van gestandaardiseerde civielrechtelijke relaties. ${ }^{183}$

Het veelvuldig gebruik van algemene voorwaarden geeft hieraan expliciet uitdrukking. In veel gevallen zal het dus zo zijn dat de rechtsrelatie die onderwerp is van een civielrechtelijke procedure geen unieke doch een gestandaardiseerde rechtsrelatie betreft. Het procesrechtelijke uitgangspunt dat het onderwerp van het geschil een unieke relatie tussen twee partijen is en derhalve alleen

179 Van Koppen en Malsch, LesR 1991, pag. 818 en NJB 1992, pag 1104.

180 Van Koppen en Malsch, LdsR 1991, pag. 809-810 en NIB 1992, pag. 1103 noot 7.

181 Van Koppen en Malsch, L\&SR 1991, pag. \$15 en NJB 1992, pag. 1103. Percentages voor organisaties zijn door mij afgeleid uit de onderzoeksmesultaten voor bedrijven en overheid.

182 Ven Koppen en Malsch, NDB 1992, pag. 1103.

183 Groenendijk, diss, pag. 28. 
die twee partijen gebonden zijn aan de uitspraak, houdt met deze standaardisering geen rekening. ${ }^{184}$

Het feit dat de rechtsrelatie tussen natuurlijk persoon en organisatie gestandaardiseerd is - en in de meeste gevallen dus alles behalve uniek is - brengt doorgaans ook een verschil in de betekenis van deze relatie voor partijen met zich. Doorgaans gaat het vanuit de optiek van het individu om een eenmalige relatie. Voor de organisatie is het vaak slechts én uit een groot aantal soortgelijke relaties. Dit leidt tot twee vormen van asymmetrie in de relatie tussen organisatie en individu. Aan de ene kant kan de betekenis van de relatie of de waarde van het conflict voor het individu te klein zijn zodat procederen niet loont, terwijl tegelijkertijd voor de organisatie gezien het grote aantal gelijke relaties het procederen wel de kosten en moeite loont. Aan de andere kant doet zich het tegenovergestelde voor. Omdlat de relatie voor het bedrijf er éen uit velen is kan het zo zijn dat de betekenis van deze relatie voor de organisatie aanmerkelijke geringer is dan voor het individu. Dit leidt er toe dat organisaties doorgaans gemakkelijker de aan het proces verbonden risico's kunnen dragen dan individuen. ${ }^{185}$ Bovendien kunnen organisaties/Repeat Players bepaalde (aanloop)kosten spreiden over meerdere procedures, waardoor de kosten per procedure geringer zijn. ${ }^{186}$

\subsubsection{De consument als partij in het burgerlijk proces}

In een deel van de gevallen zullen de individuen in de, in de vorige paragrafen aangehaalde, onderzoeken consumenten zijn. De procesrechtelijke (on)mogelijkheden die het individu in het burgerlijk proces heeft in vergelijking met organisaties zullen derhalve ook onverkort van toepassing zijn op de procesrechtelijke positie van de consument. De consument die via een beroep op de overheidsrechter verhaal tracht te vinden moet eveneens de bekende procesdrempels overwinnen. Deze liggen vooral in factoren als $\operatorname{kosten}^{187}$, tijd, moeite, onbekendheid met het recht en psychologische drempels. ${ }^{188}$ Algemeen wordt der-

184 Groenendijk, diss., prg. 29.

185 Groenendijk, diss., pag. 30-31.

186 Galanter, LLSR 1974, pag. 98.

187 Zie over kosten: Snijders, inaug. rede, pag. 9-10; Advocatenblad-special: Op prijs gesteld, Adwocatenblad 1994, pag. 629-679; A.F.M. Brenninkmeijer, Advocatentarieven: niet op prijs gesteld, NJB 1994, pag. 1239-1246. Volgens de latste, kunnen betalende cliënten, d.w.z. cliënten die geen bemep kunnen doen op door de overhieid gefinanciende nechitshulp, vanwege de kosten "voor procedures die over minder dan 20 tot 25 duizend gulden gaan maar beter hun rechtsaanspraken inslikken", a.w., pag. 1243.

188 EG-COM, 1985, pag, 6; Verburgh, Trechter, pag. 5-6; Konsumenten-blauwdruk, pag. 7-8; Hondüs, diss., pag. 489 e.v.; Rodrigues, sWoKA-rapport, pag. 7; Boer, pag. 15; Peeters, pag. 4; Weernekers, pag 244; Last, pag. 237. 
halve aangenomen dat de weg naar de burgerlijke rechter voor de consument niet gemakkelijk is. Dit blijkt ook uit (spaarzaam) onderzoek dat specifiek. gericht is op de rol van de consument in het burgerlijk proces.

Schuyt, Groenendijk en Sloot analyseerden in hun onderzoek 1087 rechtsproblemen. Daaruit komt naar voren dat $29 \%$ daarvan het consumentenrecht betreft. Over het totaal van de 1087 door deze auteurs onderscheiden rechtsproblemen genomen is de tegenpartij in $34,4 \%$ de overheid, in $28,8 \%$ particuliere organisaties en in $29 \%$ een individu. Particuliere organisaties zijn daarbij vooral tegenpartij bij de rechtsproblemen die door Schuyt c.s. worden gekwalificeerd als consumentenrechtelijke problemen. ${ }^{199}$

Uit onderzoek is gebleken dat de consument, als hij de weg naar de burgerlijke rechter al weet te vinden, dat meestal doet als gedaagde. Doorgaans ontmoet hij dan een organisatie als wederpartij. ${ }^{190}$ De Engelse "National Consumer Council" vestigde in haar rapport "Justice out of reach" (1976) onder meer de aandacht op het feit, dat in het merendeel van de zaken die voor de "County Courts" dienden professionele handelaren optraden als eiser en dat gewone particulieren slechts in $9 \%$ van de gevallen optraden als eiser. ${ }^{191}$ Voor Nederland constateert Peeters dat van de ruim 1200 zaken die hem als kantonrechter in 1987 werden voorgelegd slechts twee consumenten als eiser in conventie en twee consumenten als eiser in reconventie optraden. ${ }^{102}$

Onderzoek van Vidmar laat eveneens het vorengeschetste beeld zien. Van 1559 onderzochte procedures betroffen $53,2 \%$ (830) consumentenzaken. Van de eisers in deze $830(100 \%)$ consumentenzaken is $92,9 \%(771)$ een organisatie en $7,1 \%$ (59) een consument. Van de eisers in de 687 (100\%) consumentenverstekzaken is slechts $1,6 \%$ consument en $98,4 \%$ een organisatie. Van de eisers in consumentenzaken waarin verweer wordt gevoerd door gedaagde, is $33,6 \%$ een individu en $66,4 \%$ een organisatie. Van alle 1556 onderzochte procedures is slechts in $3,8 \%$ van de gevallen een consument eiser ${ }^{193}$ "De weg vinden" moet voor de consument overigens niet al te letterlijk genomen worden. De consument laat in veel gevallen verstek gaan. In het onderzoek van Vidmar in $44,1 \%$ van alle onderzochte 1559 zaken en in $82,8 \%$ van alle 830 consumentenzaken. ${ }^{194}$

189 Schuyt, pag. 141 en 161. Zie ook: Rodrigues, SWOKA-onderzocksrapport, pag. 8.

190 Zie voor een overzicht van Amerikatans onderzock van vớr 1975: Yngvesson en Hennesey, pug. 236.

191 Zie over dit rapport: Konsumenten-blauwdruk, pag. 7; EG-Com, 1985, pag. 20.

192 Peeters, pag. 3.

193 Percentages en aantallen zijn door mij afgeleid uit cijfers van Vidmar, pag. 526.

194 Vidmar, pag. 526. 
De uitkomsten worden voor Nederland onder andere ${ }^{195}$ bevestigd door onderzoek van Francken en van Blankenburg en Verwoerd.

Francken constateert dat $28,7 \%$ (459) van alle $( \pm 1.600)$ door het kantongerecht in Tilburg in 1980 gewezen eindvonnissen in civiele zaken, consumentenzaken betroffen. ${ }^{106}$ In 296 zaken liet de consument verstek gaan $(64,5 \%$ van de consumentenzaken en $18,5 \%$ van alle zaken), in 152 zaken voerde de consument verweer (33,1\% van de consumentenzaken en $9,5 \%$ van alle) en in slechts 11 procedures trad een consument op als eiser. ${ }^{197}$ In slechts $0,7 \%$ van alle zaken en $2,4 \%$ van alle consumentenzaken ging het initiatief tot de procedure dus uit van de consument. Tegenpartij van de (gedaagde) consument was ook in dit onderzoek nagenoeg altijd een organisatie. ${ }^{198}$ Blankenburg en Verwoerd komen tot de conclusie dat $80 \%$ van alle vorderingen in de door hen onderzochte koopzaken een verstekvonnis betrof, waarbij de eisers op een enkele uitzondering na verkopers waren. ${ }^{199}$

\subsection{Nadelen voor de consument van het gebruik van algemene voorwaar- den en de beschermingsbehoefte van de consument}

Algemene voorwaarden worden tegenover consumenten veel gebruikt en met name bij overeenkomsten betreffende duurzame goederen en dienstverlening. Bij de zogenaamde "quick hand" overeenkomsten komen ze nawwelijks voor. Alhoewel algemeen erkend wordt dat het gebruik van algemene voorwaarden een nuttige functie vervult in onze samenleving $k$ leven aan het feitelijk gebruik van algemene voorwaarden voor de consument ook een aantal negatieve aspecten. Genoemd is in dit verband de snelle gebondenheid aan ongekende contractsbedingen zonder dat daar uitdrukkelijk mee is ingestemd of kennis van is genomen, het ontbreken van individuele invloed op de contractsinhoud, het gebruik van voor de wederpartij onredelijk bezwarende voorwaarden en de moeilijkheden die de individuele consument ervaart bij een beroep op de burgerlijke rechter. Daarnaast wordt in de literatuur gewezen op het probleem

195 Zie ook: Konsumenten-blauwdnuk, pag. 7, warin gewng wordt gemalkt van het feit dat van de 75.135 eindwonnissen in $197180 \%$ verstekvonnissen betrof.

196 Francken, 1983, pag. 9.10 en 57. Consumentenzaken zijn zaken wagrbij sprake was van een conflict tusisen leverancier en consument (pag. 9\%. Het essentiele criterium is dat er torssen partijen cen overeenkomst is gesloten, die voor wat de én betreft behoort tot de uitoefening van zijn beroep of bedrijf en voor de ander juist niet (pag. 5). Zie voor de VS: Vidmar, pag. 531. Vidmar vond in zijn onderzoek dat 31 san de procedunes consumentenzaken betroffen.

197 Francken, 1983 , pag. 10 en 57.

198 Francken, 1983, prig. 13-14.

199 Blankenburg en Verwoen, pag. 28. 
van de versluiering van de contractsinhoud. ${ }^{200}$ In de volgende paragrafen zal ik, in het licht van hetgeen hiervoor in dit hoofdstuk reeds is beschreven, aangeven in hoeverre de genoemde negatieve aspecten van het gebruik van algemene voorwaarden de consument tot nadeel strekken en in hoeverre hij behoefte heeft aan rechtsbescherming op dit terrein.

\subsubsection{Onredelijk bezwarende inhoud van algemene voorwaarden}

Los van het antwoord op de vraag waaraan algemene voorwaarden moeten voldoen willen zij een redelijke inhoud hebben en hoe dit te waarborgen, wordt gebondenheid aan voor beide partijen evenwichtige algemene voorwaarden, ook zonder dat sprake is van kennisname van de inhoud van deze voorwaarden, gezien de voordelen die daaraan verbonden zijn, als maatschappelijk wenselijk ervaren. Tegenover deze voordelen staan echter ook duidelijke nadelen. Zoals hiervoor reeds aangegeven ligt het probleem daarbij niet bij de gebondenheid sec maar bij de inhoud van de algemene voorwaarden waaraan de wederpartij zich gebonden heeft.

Alhoewel de laatste jaren in toenemende mate algemene voorwaarden worden vastgesteld in onderling overleg tussen organisaties van gebruikers en organisaties van wederpartijen, worden algemene voorwaarden in de meeste gevallen eenzijdig opgesteld door de gebruiker of een groep van gebruikers. ${ }^{201}$ Algemeen wordt aangenomen dat met name deze eenzijdige invulling van contractsbedingen er toe geleid heeft, dat degene die de algemene voorwaarden opstelt deze vaak dusdanig concipieert dat de voordelen bij hem liggen en de nadelen bij de wederpartij. Van een evenwichtig regelcomplex ter completering van de "romp"-overeenkomst is op die wijze geen sprake. ${ }^{202}$ Het is dan ook niet verwonderlijk dat de aldus opgestelde algemene voorwaarden dikwijls bedingen bevatten die op een onredelijke wijze nadelig zijn voor de wederpartij of deze laatste zelfs vrijwel rechteloos overleveren aan de gebruiker. Niet zelden worden zowel het regelende als het dwingende recht op onbillijke wijze geëcarteerd ten faveure van de gebruiker/opsteller. Het regelcomplex dat door de gebruiker in de plaats wordt gesteld van het regelende of dwingende recht

200 Hondius, diss., pag. 300; CCA-advies, pag. 5 en 10; Rijken, diss., pag. 69-72; Verhowen, pag. 3.

201. Gras, Standaardkontrakten, pag. 74-75.

202 Zie onder andere: Zeylemaker, pag. 77 en 88; CCA-advies, pag. 5; Hondius, preadvies NJV, pag. 110 e.w.; Van der Werf, diss., pag. 26; Asser-Hartkamp II, 1993, nr. 343; Jongeneel, diss., pag. 9; Verhoeven, pag. 3 en 19. 
brengt de adherent dan in een ongunstigere positie dan zonder dit regelcomplex het geval zou zijn.

Het misbruik dat door gebruikers kan worden gemaakt door het hanteren van zulke onredelijk bezwarende algemene voorwaarden wordt in de juridische literatuur onderscheiden in misbruik in ruime en in enge zin. ${ }^{204}$ Onder misbruik in rüme zin wordt begrepen het enkele bestán in de overeenkomst van onevenwichtige, de wederpartij onredelijk benadelende bedingen, dus ongeacht of er beroep wordt gedaan op deze bedingen. Indien daadwerkelijk een beroep wordt gedaan op deze onereuze bedingen is sprake van misbruik in enge zin.

Het verschil tussen misbruik in ruime en enge zin wordt in de literatuur ook wel ondergebracht in het thema coulance van de gebruiker. ${ }^{205}$ In deze benadering gaat men uit van de stelling dat de meeste complexen van algemene voorwaarden niet uitgaan van de doorsnee wederpartij maar zijn toegespitst op de meest chicaneuze wederpartij en dusdanig zijn opgesteld dat alle mogelijke problemen die zich met deze wederpartij kunnen voordoen bij de uitvoering van die specificke overeenkomst, afdoende zijn geregeld. Onder coulance van de gebruiker wordt het verschijnsel verstaan dat de gebruiker van algemene voorwaarden doorgaans geen beroep doet op voor de wederpartij onereuze bedingen in algemene voorwaarden doch alleen teruggrijpt op deze bedingen bij chicaneuze wederpartijen, waardoor van misbruik in enge zin nauwelijks sprake is.

Een juridische rechtvaardiging van dit coulance-stelsel wordt in de rechtsliteratuur algemeen afgewezen. ${ }^{206}$ Vanuit het gezichtspunt van machtenscheiding wordt het ongewenst gevonden dat de "particuliere wetgever" ook nog eens optreedt als "particuliere rechter", 2077 Het coulance-stelsel bevordert daarnaast de rechtsonzekerheid omdat niet van te voren vaststaat welke gedragslijn de gebruiker tegenover de wederpartij zal volgen ${ }^{208}$. Voorts schept het stelsel rechtsongelijkheid omdat de gebruiker eerder coulance zal overwegen tegenover belangrijke wederpartijen die over goede relaties beschikken en waarmee de gebruiker dus graag verder zaken wil doen, dan tegenover voor de gebruiker

203 Zeylemaker, pag. 70, 77 en 108-110; Jansma, pag. 131-133; Sluyter, pag. 9; Hondius, preadvies, pag. 112; Hondius, diss, "pag. 294 en 300; CCA-advies, pag. 5-6; Van der Werf, diss., prig. 2 en 17; Gras, diss., pag. 4; Rijken, diss., pag. 62; Jongeneel, diss, , pag. 11-12; MvT Inv., Parlementaire Geschiedenis, Inv, 3, 5 en 6, pag. 1452; Asser-Hartkamp II, 1993. nr. 343; Heinrichs, BGB (Palandt), Einf. AGBG 1, Nr. 1; Kötz, Münchener Kommentar, Einl. AGBG Rndnr. 2 ; Hensen, JA 1981, pag. 133.

204 Hondüu, diss, pag. 310 ; Gras, diss., pag. 46.

205 Jansma, pag. 138 e.v.; Sluijter, pag. 10; CCA-advies, pag. 6; Hondius, diss., pag. 309; Hondius, preadvies N.JV, pag. 114 e.v.

206 Jansma, pag. 140-141; Sluijter, pag. 10; CCA-Advies, pag. 6-7; Hondius, diss. paug. 309; Hondius, preadvies, paig. 115 .

207 Sluijter, pag. 10 ; Hondius, preadvies NJV, pag. 115.

208 Hondus, diss., pag. 309; Hondius, preadvies; pag. 115. 
minder interessante wederpartijen. ${ }^{209}$ Verder is het stelsel onrechtvaardig omdat waarschijnlijk een aantal wederpartijen na lezing van een onredelijk bezwarend beding ten onrechte afziet van het indienen van een protest tegen dat beding ${ }^{210}$ en het aldus:

"de brutale wederpartij, die zich om geen algemene voonwaarden bekommert, beloont, tenwijl de goedgelovige lezer wan een - wolgens de algemene woorwaanden niet honorabele - claim op de ondentemer zal afilen".211

Op de Schriftglaubigkeit van de wederpartij met betrekking tot het geschreven woord wordt ook gewezen door Hondius:

"Een silandaardklausule moge nog zo onereus zijn, zij staat er toch maar, zwart op wit, gedrukr nog wel, gedeponeerd soms bij-dus kennelijk goedgekeund door - de rechbamk, zo abstrakt en moeilijk geformuleerd dar hat wel wan heel hoog moet komen. "212

Algemeen wordt derhalve aangenomen, en ik sluit mij hierbij aan, dat de bron van het euvel van onredelijk bezwarende algemene voorwaarden gezocht moet worden in misbruik dat in ruime zin wordt gemaakt van deze voorwaarden. De enkele aanwezigheid van onredelijk bezwarende voorwaarden in een algemene voorwaardencomplex moet worden gezien als een misstand. ${ }^{213}$ Zoals Jansma reeds verwoordde is het:

"... in strijd met het rechrvaandigheidsgevoel om acam én der partijen bij een overeenkomst eent onredelijk scherp wapen in handen te geven in het vertrouwen dat het niet anders dan met wijsheid zall worden gehanteend". 214

Met name de omstandigheid dat de consument geconfronteerd wordt met algemene voorwaarden met een onredelijk bezwarende inhoud vroeg derhalve om een oplossing. De Nederlandse wetgever heeft in de regeling van afdeling 6.5.3 BW dan ook niet de nadruk gelegd op het stellen van strenge eisen aan de inlassing van algemene voorwaarden in de overeenkomst maar op de inhoudelijke toets van die voorwaarden zoals neergelegd in de artikelen 6:233 sub a, $6: 236$ en $6: 237 \mathrm{BW}$. 


\subsubsection{Snelle primaire gebondenheid}

Het gebruik van algemene voorwaarden voorziet in een maatschappelijke behoefte aan standaardisatie. Zowel de gebruiker als de wederpartij hebben in beginsel voordeel bij het gebruik van redelijke en op de aard van de overeenkomst toegesneden algemene voorwaarden. Deze voordelen zijn grotendeels gebaseerd op de omstandigheid dat door de wederpartij geen kennis wordt genomen van de contractsinhoud en dat daar verder ook niet over wordt onderhandeld. Doorgaans heeft de wederpartij ook geen behoefte aan kennisname van de inhoud.

Een in beginsel snelle primaire gebondenheid van de wederpartij aan de gelding van algemene voorwaarden van de gebruiker, ook zonder dat de wederpartij kennis heeft genomen van de inhoud hiervan, is een essentiële voorwaarde voor een rationeel gebruik van algemene voorwaarden. Het komt mij voor dat het opwerpen van formele hindernissen met betrekking tot deze snelle primaire gebondenheid aan algemene voorwaarden afbreuk doet aan het profijt dat beide contractspartijen met het gebruik van algemene voorwaarden beogen. Strikt genomen kan mijns inziens dan ook niet worden beweerd dat het voor de consument nadelig is dat hij in beginsel snel gebonden is aan door de gebruiker gehanteerde algemene voorwaarden.

\subsubsection{Kennisname van de inhoud van algemene voorwaarden}

Voor aanvaarding van de gelding van algemene voorwaarden is allereerst vereist dat de wederpartij op een of andere manier vóor, bij of na het sluiten van de (romp-)overeenkomst door de gebruiker wordt geattendeerd op de toepasselijkheid, de gelding van bepaalde algemene voorwaarden. Voor aanvaarding van de gelding van algemene voorwaarden en dus primaire gebondenheid daaraan, is kennisname van de inhoud niet vereist. Dit is ook het uitgangspunt in de regeling van afdeling 6.5.3 $\mathrm{BW} .{ }^{215}$ De consument heeft in de praktijk doorgaans ook geen behoefte aan kennisname van de inhoud voór of bij het sluiten van de (romp)overeenkomst. Bovendien zou een van de voordelen van het gebruik van algemene voorwaarden - de eenvoudige en snelle wijze van contracteren - voor de consument grotendeels wegvallen indien hij alvorens te contracteren kennis neemt van de inhoud van de toepasselijke algemene voorwaarden. Algemene voorwaarden hebben in feite immers dezelfde functie als het regelend recht: partijen kunnen zich concentreren op de hoofdzaken en de bijzaken overlaten aan een gereedliggend regelcomplex. 
Strikt genomen brengt het feit dat de consument onbekend is met de inhoud van de toepasselijke algemene voorwaarden op het moment van het sluiten van de overeenkomst naar mijn mening dan ook geen nadelen mee voor de consument.

Hierbij dient echter uitdrukkelijk een kanttekening te worden gemaakt. In algemene voorwaarden komen vaak bedingen voor die de wederpartij verplichtingen opleggen die bij niet nakoming daarvan bewerkstelligen dat of de contractuele rechten van de wederpartij deels of geheel vervallen of de wederpartij in verzuim en daarmee schadeplichtig is. Voorbeelden van dergelijke clausules zijn: "Reclames binnen acht dagen", "Betaling binnen veertien dagen op straffe van een contractuele boete" etc.. De gebruiker kan en moet er van uitgaan dat de wederpartij de voorwaarden niet kent, leest, begrijpt of overziet, temeer omdat het ongekend aanvaarden een van de premisses is voor een rationeel gebruik van algemene voorwaarden. Bedingen in algemene voorwaarden die vervolgens bewerkstelligen dat de wederpartij in een nadeligere positie komt omdat hij van deze voorwaarden niet reeds vóor het sluiten van de overeenkomst heeft kennisgenomen doch bijvoorbeeld eerst op het moment dat hij een klacht heeft ten aanzien van de uitvoering van de overeenkomst of op het moment dat de gebruiker aanspraak maakt op een in die voorwaarden opgenomen boetebeding, zijn naar mijn mening derhalve qua inhoud onereus van karakter indien de gebruiker de wederpartij vóor het sluiten van de overeenkomst niet uitdrukkelijk op de gevolgen van die bedingen heeft gewezen. ${ }^{216}$

Het voorgaande laat echter onverlet dat de consument, indien hij dat wil, vớr of na het sluiten van de overeenkomst wél de mogelijkheid moet hebben om op eenvoudige wijze kennis te nemen van de inhoud van de toepasselijke voorwaarden. De consument moet, indien hij dat wil, te allen tijde de mogelijkheid hebben om de mogelijke contractuele risico's die voortvloeien uit de algemene voorwaarden, reeds voor het sluiten van de overeenkomst te overzien. Bovendien moet hij in staat zijn om na te gaan hoe hij bij (het misgaan van) de uitvoering van de overeenkomst dient te handelen.

Aan deze mogelijkheid van kennisname van de inhoud van algemene voorwaarden schort het in de praktijk nog wel eens vanwege de zogenaamde "versluiering" van de inhoud van algemene voorwaarden.

\subsubsection{Versluiering van de inhoud van algemene voorwaarden}

Aan het gestandaardiseerde gebruik van algemene voorwaarden is het verschijnsel verbonden, dat wordt aangeduid met "versluiering van de contractsin- 
houd". ${ }^{217}$ Hiermee wordt - kortweg - geduid op het feit dat het voor de doorsnee consument vaak moeilijk zo niet onmogelijk is de inhoud van algemene voorwaarden te achterhalen.

Sommige auteurs verstaan onder het begrip "versluiering" eveneens de onmogelijkheid van de zijde van de wederpartij om de algemene voorwaarden te wijzigen $^{218}$. Dit lijkt mij echter onjuist. Ook de niet-versluierde en volstrekt open en duidelijk ter hand gestelde algemene voorwaarden zijn doorgaans niet te veranderen door de wederpartij. De onveranderbaarheild van algemene voorwaarden vloeit voort uit hun standaardkarakter en staat mijns inziens volledig los van de vraag of de wederpartij de inhoud heeft kunnen achterhalen.

Voor de "versluiering van de contractsinhoud" is een aantal oorzaken aan te wijzen. Allereerst is het voor de wederpartij vaak moeilijk om achter de inhoud van toepasselijk verklaarde algemene voorwaarden te komen omdat vaak wordt verwezen naar elders gedeponeerde algemene voorwaarden. Will de wederpartij toch kennisnemen van de inhoud van deze algemene voorwaarden - meestal pas als er problemen zijn met de uitvoering van de overeenkomst - dan zal zij zich doorgaans moeten wenden tot de gebruiker, een kamer van koophandel of een griffie van een rechtbank. Geografisch gezien is dit vaak een hele opgave. ${ }^{219}$ Ook is het opvragen van fotokopieën van bij rechtbankgriffies of de kamers van koophandel gedeponeerde algemene voorwaarden bepaald niet kosteloos ${ }^{220}$ en is het opvragen van de voorwaarden bij de ondernemer zelf bemoeilijkt, omdat deze inmiddels van weder- in tegenpartij is veranderd ${ }^{221}$.

Indien de wederpartij de tekst van de algemene voorwaarden wél ontvangt wordt deze meestal niet gelezen. ${ }^{22}$ Het lettertype, de omvang en de vormgeving van de set algemene voorwaarden nodigen daar meestal ook niet toe uit. ${ }^{223}$ Algemene voorwaarden hebben bovendien voor de doorsnee wederpartij slechts zelden een tot kennisname uitnodigende amusementswaarde. Daarbij bewerkstelligt het feit dat sprake is van een asymmetrische relatie tussen gebruiker en wederpartij, dat, vanuit de optiek van de consument, het lezen van algemene voorwaarden verhoudingsgewijs te veel tijdsinvestering van hem vergt.

217 Hondius, diss., pag. 300; CCA-advies, pag. 5 en 10; Rijken, diss., pag. 71-72; Verthoeven, pag. 3; Jongeneel, diss., pag. 11-12.

218 Hondius, diss., pag. 305-307; Jongeneel, diss., pag. 12.

219 Asser-Hartkamp II, 1993, nr. 343.

220 Van Westerop, pag. 100 en 102; Hondius, diss., pag. 301.

221 Hondius, diss., pag. 301.

222 Hondius, diss., pag. 302; Gras, diss., pag. 54-55; Rijken, diss., pag. 71; CCA-adwies, pag. 10.

223 Hondius, diss., pag. 302 . 
Worden de algemene voorwaarden well gelezen dan zijn ze voor de (doorgaans) juridisch ongeschoolde wederpartij niet te begrijpen. ${ }^{224}$ Naar mijn mening geldt dit laatste in veel gevallen eveneens voor de doorsnee gebruiker. Dit niet begrijpen vindt in de eerste plaats zijn reden in het feit dat algemene voorwaarden zijn opgesteld in juridisch vakjargon dat voor de leek niet te begrijpen is. ${ }^{25}$. Op de tweede plaats is dit niet-begrijpen een gevolg van het ontbreken van de meest elementaire juridische kennis op het gebied van het contractenrecht. ${ }^{226}$ Dit is de doorsnee-consument overigens niet euvel te duiden, daar deze kennis niet hoort tot het educatieve basispakket. Het wordt hem gewoonweg niet geleerd. Mijns inziens een leemte in ons onderwijs- en rechtssysteem.

Voorts worden algemene voorwaarden niet begrepen omdat hierin, vanwege het gegeven dat zij niet alleen zien op het individuele geval maar ook op een hele reeks van (nagenoeg) identieke gevallen, veelal gebruik wordt gemaakt van abstracte formuleringen waarvan de betekenis voor het individuele geval niet (direct) duidelijk is. ${ }^{27}$ Daarbij komt nog dat sommige bedingen in algemene voorwaarden gewoonweg onduidelijk zijn of voor velerlei uitleg vatbaar. Verder zijn algemene voorwaarden (soms bewust) zo complex geredigeerd - verwijzingen, schakelbepalingen, uitzonderingen etc. - dat voor de doorsnee wederpartij moeilijk of niet te achterhalen valt, welke rechten en plichten zij op grond van deze algemene voorwaarden heeft. Daardoor is zij onmogelijk in staat de contractuele risico's waaraan zij zich blootstelt, te overzien.

Gezien mijn opvatting dat wederpartijen, indien zij dat wensen, te allen tijde kennis moeten kunnen nemen van de inhoud van toepasselijke algemene voorwaarden zal duidelijk zijn dat ik de versluiering van de inhoud van algemene voorwaarden beschouw als een duidelijk nadeel voor de consument.

\subsubsection{Het ontbreken van individuele invloed van de consument op de inhoud van algemene voorwaarden}

Formeel juridisch gezien heeft elke wederpartij het recht wijzigingen aan te brengen in de door de gebruiker voorgestelde contractsinhoud. Het door de consument gewijzigde aanbod wordt juridisch gezien als een nieuw aanbod (artikel 6:225 lid $1 \mathrm{BW}$ ) welk door de oorspronkelijke aanbieder aanvaard dient te worden wil sprake zijn van een overeenkomst (artikel 6:217 lid $1 \mathrm{BW}$ ). In de

224 Marx, pag. 424-425; Zeylemaker, pag. 85; CCA-advies, pag. 5 en 10; Hondius, preadvies, pag. 111; Hondius, diss., pag. 303-305; MvT Inv., Parlementaire Geschiedenis, Inv. 3, 5 en 6 , pag. 1452; Rijken, dis:s., pag. 71; Verhoeven, pag. 25; Asser-Hartkamp II, 1993, nr. 343; Jongeneel, diss., pag. 11-12; Hefermehl, Handkommentar zum BGB, Vor \& AGBG Rndnr. 2. 225 Hondius, diss., pag. 303; R.jken, diss., pag. 71 .

226 Zie ook: Verburgh, Trechter, pag. 5.

227 Hondius, diss., pag. 304. 
zeldzame gevallen dat de consument daadwerkelijk een wijziging in de algemene voorwaarden voorstelt, wordt hij doorgaans, veelal mede ingegeven door ontbrekende juridische kennis bij de gebruiker of diens personeel, met verbazing, onbegrip en zelfs meewarigheid geconfronteerd. Zoals reeds eerder is opgemerkt valt in de praktijk dan ook te constateren dat de individuele consument nauwelijks tot geen invloed heeft op de inhoud van algemene voorwaarden die gebruikers aan hem voorleggen.

Algemene voorwaarden worden voornamelijk eenzijdig vastgesteld door de gebruiker of diens belangenorganisatie en hebben, omdat zij zien op een groot aantal (nagenoeg) gelijke contractssituaties, een confectiekarakter. De consument kan ze accepteren of niet. ${ }^{228}$ Daar staat tegenover dat er in toenemende mate een verschuiving valt te constateren van individuele naar collectieve consensus. Steeds vaker worden algemene voorwaarden gehanteerd die tot stand zijn gekomen op grond van tweezijdig overleg tussen aanbiedersorganisaties en consumentenorganisaties. Ook voor deze tweezijdig vastgestelde algemene voorwaarden geldt de stelregel "take it or leave it" en ontbeert de consument directe individuele invloed op de inhoud van deze algemene voorwaarden. Individuele contractsvrijheid is op het terrein van de algemene voorwaarden dan ook doorgaans een fictie.

Vraag is of het ontbreken van deze individuele contractsvrijheid ten aanzien van algemene voorwaarden nadelen met zich brengt voor de consument.

Vooropgesteld zij, dat in de situatie waarin sprake is van evenwichtige algemene voorwaarden, die rekening houden met de gerechtvaardigde belangen van zowel de gebruiker als de wederpartij, het ontbreken van individuele invloed op die algemene voorwaarden van de zijde van de consument niet gezien kan worden als nadelig voor deze. Daarbij maakt het geen verschil of deze algemene voorwaarden nul-, eén- of tweezijdig zijn vastgesteld. Eenzijdige vaststelling zou in die situatie wellicht zelfs de voorkeur hebben. Vanwege het ontbreken van de noodzaak tot onderhandelen over de contractsinhoud zal de kostprijs van het produkt of de dienst waarvoor de betreffende algemene voorwaarden bestemd zijn, waarschijnlijk lager uitvallen. Dat zou uiteindelijk in het voordeel van de consument zijn. Daar komt bij dat de consument gewoonlijk de benodigde juridische kennis en het inzicht in de specifieke eigenaardigheden van de betreffende rechtsrellatie mist, om een evenwichtige overeenkomst te concipieren. Gebruikers of hun belangenorganisaties hebben op juridisch vlak meer (financiële) mogelijkheden en ook een beter beeld van de specifieke eigenschap-

228 Marx, pag. 425; Zeylemaker, pag. 70; Sluyter, pag. 5; CCA-Advies, pag. 5; Dalhuisen, pag. 59; Hondius, preadvies, pag. 111-112; Hondlius, diss., pag. 305; Gras, Standaardkontrakten pag. 1; Van der Werf, diss., pag. 16 en 27; Gras, diss., pag. 4; Rijken, diss., pag. 72; MvT Inv., Parlementaire Geschiedenis, Inv, 3, 5 en 6, pag. 1452; Verhoeven, pag. 25; Jongeneel, diss., pag. 10-11; Hefermehl, Handkommentar zum BGB, Vor \$1 AGBG Rndnr. 2. 
pen van hun produkt of dienst. Mede gezien het feit dat sprake is van een asymmetrische relatie tussen gebruiker en wederpartij, de kosten van het opstellen van algemene voorwaarden kunnen door de gebruiker worden uitgesmeerd over een groot aantal overeenkomsten, ligt het voor de hand dat de gebruiker of zijn belangenorganisatie de algemene voorwaarden concipieert. Indien deze algemene voorwaarden evenwichtig zijn is er voor de consument geen vuiltje aan de lucht.

Daar waar de consument geconfronteerd wordt met algemene voorwaarden die eenzijdig zijn opgesteld door de gebruiker of diens belangenorganisatie, Joert echter steeds het gevaar dat de algemene voorwaarden al te eenzijdig naar de belangen van de gebruiker zijn toe geschreven. Dit gevaar zal aanzienlijk geringer zijn als sprake is van tweezijdig, op basis van overleg waarin de wederpartij actief en als gelijke participeert, vastgestelde algemene voorwaarden. Individuele onderhandelingen verdragen zich echter niet met het standaardkarakter van algemene voorwaarden. Sterker: algemene voorwaarden en individuele invloed op de inhoud van deze voorwaarden gaan in het gestandaardiseerde rechtsverkeer niet samen.

De gemiddelde consument (en vaak ook de gebruiker) kent bovendien het civiele recht niet en weet niet welke zijn rechten en plichten zouden zijn indien niet algemene voorwaarden doch het aanvullend recht van toepassing zou zijn. Zoals reeds eerder gememoreerd valt dit ontbreken van kennis hem nauwelijks te verwijten. De doorsnee consument heeft nauwelijks toegang tot het civiele recht. Hij kent het niet en het wordt hern ook nauwelijks geleerd. Rechtskennis is een nagenoeg ontbrekend vak in de opleiding van de gemiddelde burger. Toegang tot het recht krijgt de consument doorgaans slechts door het kopen of inhuren van juridische kennis. De individuele consument heeft daar veelal de middelen niet voor omdat zijn belang, individueel gezien, vaak te gering is. Een eenvoudige kosten/baten-analyse doet de meeste consumenten dan ook meestal afzien van het binnenhalen van dure rechtskennis. Het gevolg is dat de consument (noodgedwongen) al datgene dat de gebruiker hem voorhoudt voor zoete koek slikt.

Daarenboven heeft de consument als individu, nog afgezien van het kostenaspect, niet de nodige "countervailing power" om zijn rechten, zo hij die al kent of de kennis daaromtrent heeft gekocht, door te zetten. De asymmetrische relatie werkt ook hier in het nadeell van de individuele consument. Een eenpersoons-boycot van de gebruiker bij voorbeeld, zal als gevolg van deze asymmetrie veelal weinig effect sorteren. 


\subsubsection{Toegang tot de rechter en procesrechtelijk positie}

De consument maakt in de praktijk slechts spaarzaam gebruik wan de burgerlijke rechter. De drempel tot de overheidsrechter is voor de gemiddelde consument vanwege zijn geringe kennis van het recht en de daarmee gepaard gaande kosten- en tijdsaspecten alsmede psychologische factoren te hoog. Met name bij de zogenaamde "small claims" maken het kosten/moeite-aspect en een daarop gebaseerde kosten/baten-analyse, dat de deur naar de overheidsrechter voor de consument in veel gevallen gesloten is. Vooral vanwege het feit dat, bij het gebruik van algemene voorwaarden, de rechtsrelatie tussen gebruiker en wederpartij vanuit het perspectief van de consument veelal een unieke en vanuit het perspectief van de gebruiker er én uit vele identieke rechtsrelaties betreft, werkt het kostenaspect verhoudingsgewijs bijzonder in het nadeel van de consument.

Als de consument al weet dat hij bij de rechter terecht kan en daar ook werkelijk bij terecht komt, is dit meestal als onervaren gedaagde en zijn er sterke indicaties dat hij, in verhouding tot de gebruiker, als One Shotter in de gerechtelijke procedure in een nadeligere positie verkeert. Er is geen reden om aan te nemen dat dit op het terrein van de algemene voorwaarden anders zou liggen.

\subsection{Behoefte aan rechtsbescherming bij de consument}

Het voorgaande overziende, ligt op het terrein van algemene voorwaarden de behoefte aan rechtsbescherming van de consument primair bij de gebondenheid aan qua inhoud onredelijke algemene voorwaarden. Maatregelen die beogen de consument te beschermen op het terrein van de algemene voorwaarden dienen dan ook op de eerste plaats te bewerkstelligen dat inhoudelijk onredelijk bezwarende bedingen jegens hem niet bindend zijn.

Ten tweede is het van belang dat de consument, zo hij dat wenst, op eenvoudige wijze, zowel vór als na het sluiten van de overeenkomst kennis kan nemen van de inhoud van de toepasselijke algemene voorwaarden. De rechtsbescherming van de consument dient derhalve mede gericht te zijn op het tegengaan van versluiering van de contractsinhoud.

Uiteraard biedt rechtsbescherming tegen gebondenheid aan onereuze algemene voorwaarden en tegen versluiering van de contractsinhoud de consument pas werkelijk soelaas, als hij zich bewust is van zijn recht op bescherming, de inhoud van dit recht kent en ook daadwerkelijk de mogelijkheid heeft deze bescherming bij de rechter af te dwingen. Daarmee zijn we meteen aanbeland bij het derde terrein waarop de consument bescherming behoeft. De toegang tot het recht en de rechter. De consument kent het recht niet en in verhouding tot 
gebruikers van algemene voorwaarden ondervindt de consument in het algemeen meer, niet alleen financiële, problemen bij het vinden van de weg naar het recht en rechter. Dit plaatst de consument reeds bij voorbaat in een nadeligere positie. Bij de (on)toegankelijkheid van het recht en rechtspraak ten aanzien van (niet alleen) algemene voorwaarden speelt de mate waarin wetgever en rechtspraak er in slagen duidelijke en toegankelijke regels te scheppen, uiteraard ook een rol. ${ }^{229}$

Dat de consument snel, dat wil zeggen ook zonder dat hij van de inhoud van de toepasselijke algemene voorwaarden op de hoogte is en zonder al te veel formele vereisten, in beginsel gebonden is aan algemene voorwaarden is inherent aan het karakter van algemene voorwaarden en werkt ook in zijn voordeel. Voor zover hij er op kan vertrouwen dat de inhoud van de toepasselijke algemene voorwaarden niet onredelijk is, vormt deze snelle primaire gebondenheid ook geen probleem en is slechts toe te juichen. Te dien aanzien bestaat bij de consument mijns inziens dan ook geen behoefte aan rechtsbescherming.

Hetzelfde geldt naar mijn mening voor het ontbreken van individuele invloed zijdens de consument op de inhoud van toepasselijk verklaarde algemene voorwaarden. Indien deze voorwaarden getuigen van een redelijke belangenafweging is er mijns inziens geen behoefte aan individuele invloed op de inhoud hiervan. 


\section{Rechtspraak op het terrein van de algemene voorwaarden vóór de totstandkoming van de wet algemene voorwaarden}

\subsection{Inleiding}

In dit hoofdstuk wordt geinnventariseerd hoe in de Nederlandse rechtspraak is omgegaan met het verschijnsel algemene voorwaarden vóor de totstandkoming en inwerkingtreding van de Wet Algemene Voorwaarden. Bekeken wordt op wellke wijze toen in de Nederlandse rechtspraak invulling werd gegeven aan de beschermingsbehoefte van de consument op het terrein van de algemene voorwaarden. Daarbij wordt niet alleen aandacht besteed aan de overheidsrechter maar tevens aan het particuliere alternatief daarvoor: de geschillenbeslechting door geschillencommissies.

Aan de hand van de hierboven reeds gehanteerde indeling zullen achtereenvolgens de in de jurisprudentie gevormde criteria ten aanzien van de toepasselijkheid, de versluiering van de contractsinhoud en de inhoudstoetsing van algemene voorwaarden aan de orde komen.

\subsection{Toepasselijkheid}

De toepasselijkheid op de "romp"-overeenkomst van algemene voorwaarden kon onder het oude BW gebaseerd zijn op twee verschillende grondslagen. Ten eerste op grond van de uitdrukkelijke of stilzwijgende afspraak tussen partijen (artikel $1356 \mathrm{sub} 1^{\circ} \mathrm{BW}$ (oud)) en ten tweede op grond van gebruik (artikel $1375 \mathrm{BW}$ (oud)) of bestendig gebruikelijk beding (artikel $1383 \mathrm{BW}$ (oud)).

\subsubsection{Uitdrukkelijke of stilzwijgende partijbedoeling}

Hoofdregel onder het oude recht was dat aan het bedingen van toepasselijkheid van algemene voorwaarden geen andere eisen behoren te worden gesteld dan in 
het algemeen gelden voor het totstandkomen van een overeenkomst." Dit betekent dat voor toepasselijkheid van algemene voorwaarden in beginsel vereist was dat de wederpartij de algemene voorwaarden voór, bij of zelfs na het sluiten van de "romp"-overeenkomst had aanvaard, althans het gerechtvaardigd vertrouwen daarvan bij de gebruiker had opgewekt. Voor aanvaarding is in beginsel minimaal vereist dat de (potentiële) wederpartij vóor, bij of na het siuiten vain de overeenkomst op de hoogte is van het voornemen van de gebruiker om bepaalde algemene voorwaarden van toepassing te doen zijn op de "romp ${ }^{\text {*H }}$-overeenkomst. Voor aanvaarding van de toepasselijkheid van algemene voorwaarden is derhalve niet vereist dat de gebruiker op de gelding van algemene voorwaarden wijst vór of bij het sluiten van de "romp"-overeenkomst. Echter, in het geval de gebruiker zijn wederpartij eerst ná het sluiten van de "romp" -overeenkomst wijst op de toepasselijkheïd van algemene voorwaarden, staat het de wederpartij zonder meer vrij de toepasselijkheïd van deze voorwaarden, met instandhouding van de "romp"-overeenkomst, af te wijzen. De gebruiker loopt in die gevallen dus het "risico" dat niet zijn algemene voorwaarden maar het aanvullende recht de rechtsbetrekking tussen hem en de wederpartij bepaalt.

Zoals reeds eerder opgemerkt, was het belangrijkste dogmatisch probleem gelegen in de vraag in hoeverre algemene voorwaarden waarvan de wederpartij de toepasselijkheid heeft aanvaard, verbindende kracht hebben als de wederpartij de inhoud daarvan niet kent en de gebruiker doorgaans zeer wel op de hoogte is van het feit dat de wederpartij de inhoud niet kent. Anders gezegd "kan men willen wat men niet kent?" of "mag de fidens erop vertrouwen dat de wederpartij heeft ingestemd met een bepaalde inhoud terwijl hij (de fidens) weet dat de declarant daarvan geen notie heeft?".

Doorgaans werd door de Hoge Raad aangenomen dat de omstandigheid dat de wederpartij niet op de hoogte was van de inhoud van de algemene voorwaarden die zij verklaarde te aanvaarden, niet in de weg stond aan toepasselijkheid van die voorwaardlen. ${ }^{2}$

Over het algemeen genomen, wordt in de Nederlandse rechtspraak dan ook wrij snel een primaire gebondenheid aan algemene voorwaarden aangenomen.

1 Zie o.a.: HR 9 december 1977, NJ 1978, 187, m. nit. G.J.S. (Towell/Janson); HR 20 november 1981, NJ 1982, 517, m.nt. C.J.H.B., AA 1982, pag. 247, m.nt. G. (Holleman/De Klerk); HR 18 oktober 1985, NJ 1987, 189, m. nit. J.C.S. (Galama/Filo Tecnica Spa); HR 21 november 1986, NJ 1987, 946, m.nt. C.J.H.B., KwNBW 1987, pag. 30, m.nt. Hondius (Tolbeckl Swindak); HR 1 juli 1993, NJ 1993, 688 (Bouma/Cavo).

2 HR 20 november 1981, NJ 1982, 517, m.nt. C.J.H.B., AA 1982, pag, 247, m.nt. G.

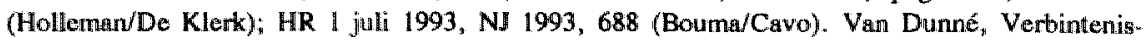
senrecht, pag. 245 en 249; Asserf-Hartkamp II, 1993, nr. 349.

3 Zie voor aen overzicht: Hondius, diss., pag. 397-438; Rjjken, diss., pag. 73-75; Contractenreeht VII (Hondius), nirs. 15-111. 
In sommige gevallen zelfs indien naar de toepasselijkheid van deze voorwaarden pas wordt verwezen ná het sluiten van de overeenkomst én de wederpartij vervolgens niet reageert. $Z$ o wordt bij woorbeeld volgens vaste rechtspraak degene die niet binnen korte tijd tegen de inhoud van een bevestigingsbrief bezwaar maakt, geacht met deze inhoud akkoord te gaan, althans bij de gebruiker het gerechtvaardigde vertrouwen daarvan te hebben opgewekt. ${ }^{5}$ In die visie is het toepasselijkheidsvraagstuk beperkt tot de aanvaardingstoets en staat zij los van de vraag of kennis is genomen van de inhoud van de betreffende algemene voorwaarden.

Tegenover deze snelle toepasselijkheid staat dat de Hoge Raad in zijn arrest inzake Holleman/De Klerk heeft beslist dat er zich onder de tussen gebruiker en wederpartij overeengekomen voorwaarden, mogelijk "... bepalingen bevinden van een zodanige inhoud dat de toestemming van de wederpartij niet kan worden geacht op toepasselijkverklaring ook daárvan gericht te zijn geweest"." In die visie behelst het toepasselijkheidsvraagstuk niet alleen de aanvaardingstoets maar tevens een inhoudstoets. Het is immers van de inhoud van bedingen afhankelijk of de wederpartij de toepasselijkheid van het beding aanvaard heeft. Zeer recent heeft de Hoge Raad deze formule nog eens bevestigd in zijn arrest inzake Bouma/Cavo:

"Het subanderdeel is evenwel gegrond, voor zover thet betaogt dal 's hofs opvating impliceent dat in het handelswerkeer tussen ondernemingen de toestemming van een contractspartij in het algemeen mede moet worden geacht gericht te zijn geweest op zeer vergaande exoneratieclausules in stilzwijgend aanvaardle maar niet gekende algemene poorwarden, en dat zulks blijk geeft van aen anjuiste rechtsopwathing. Indien een contractspartij de toepasselijkheid van door haar miet gekende algemene woonwarden stilzwiggend heeft anwaard, sluit dit immers miet wit dat er zich onder die voomwarden bepalingen bevinden van een zodanige inhoud, dat haar toestemming niet kan worden geacht op de toepasselijkverklaving ook dáarvan gerich se zijn geweest, ook al is het een feit van algemene bekendheid dat in algemene woorwaarden bepalingen van een dergelijke inhoud zo regelmatig woorkowen, dat men dacirmede rekening dien te houden. w7

Daarnaast is volgens de Hoge Raad "de wijze waarop het beding deel van de overeenkomst is geworden" ook één van de omstandigheden die een rol spelen

4 Zie Contractenrecht VII (Hondius), nr. 35 e.v.

5 HR 21 november 1986, NJ 1987, 946, m.nt. C.J.H.B., KwNBW 1987, pag. 30, m.nt. Hondius (Tolbeck/Swindak). Zie ook: Contractenrecht VII (Hondius), nrs. 40 e.v. Zie voor gebondenheid indien op factuur verwezen wordt naair algemene voorwarden: HR 15 maart 1991, NJ 1991,416 (Van Lente \& Visseher/Ossfloor); HR 7 juni 1991, NJ 1991, 525 (NWB/Codex); HR 5 juni 1992, NJ 1992, 565 (Lloyd/AEG); HR \uli 1993, NJ 1993, 688 (Bouma/Cavo); HR 10 juni 1994, NJ 1994, 611 (Van der Breggen/TNO). Dharcover uitwoerig: Van Dunne, Verbintemissenrecht, pag. 241 e.v.

6 HR 20 november 1981 , NJ 1982, 517, m.nt. C.J.H.B. (Holleman/De Klerk).

7 HR 1 juli 1993, NJ 1993, 688 (Bouma/Cawo). 
bij de beoordeling van de vraag of een gebruiker te goeder trouw een beroep op een bepaalld contractsbeding kan doen; bij de inhoudstoets dus. ${ }^{8}$

In de jurisprudentie naar aanleiding van het oude recht was het toepasselijkheidsvraagstuk dan ook nauw verweven met de inhoudstoetsing en andersom de inhoudstoetsing met het toepasselijkheidsvraagstuk."

\subsubsection{Gebruik en bestendig gebruikelijk beding}

Onder het oude recht werd onderscheid gemaakt tussen toepasselijkheid van algemene voorwaarden op grond van gebruik en toepasselijkheid krachtens bestendig gebruikelijk beding. ${ }^{10}$

Toepasselijkheid op grond van het gebruik (artikel 1375 BW (oud)) werd in de rechtspraak slechts zelden aangenomen. ${ }^{11}$ Daarentegen werd eerder aangenomen dat een beding toepasselijk was op grond van een bestendig gebruik (artikel $1383 \mathrm{BW}$ (oud)). ${ }^{12}$ Onderscheiden wordt daarbij tussen enerzijds bestendig gebruikelijke bedingen tussen partijen ${ }^{13}$ en anderzijds bestendig gebruikelijke bedingen in een bepaalde tak van handel, beroep of bedrijf. ${ }^{14}$ Voor toepasselijkheid krachtens bestendig gebruikelijk beding in een bepaalde bedrijfsof beroepsgroep is voldoende dat én der contractspartijen behoort tot de kring waarin dat beding algemeen en regelmatig toepasselijk wordt verklaard en de andere partij kan weten dat haar wederpartij tot die kring behoort. ${ }^{15}$

\subsection{Versluiering van de contractsinhoud}

Versluiering van de contractsinhoud lijkt in de Nederlandse rechtspraak nauwelijks een thema. Verwijzing vớr - en in bepaalde gevallen zelfs ná - de totstandkoming van de overeenkomst naar elders gedeponeerde voorwaarden is immers veelal voldoende om een primaire gebondenheid van de wederpartij te

$8 \mathbb{H R} 19 \mathrm{meil} 1967$, NJ 1976, 261, m.nt: G.J.S., AA 1967, pag. 214, m.nt. P.A.S. (Saladin/HBU); HR 14 december 1973, NJ 1974, 127, m.nt. G.J.S. (De Boer/Wittenberg); HR 20 febnuari 1976, NJ 76, 486, m.nt. G.J.S., AA 1976, pag. 467, m.nt. G. (Pseudo-yogelpest); HR 25 april 1986, NJ 1986, 714, m.nt. G., AA 1986, p8g. 816, m.mt. v. Sch., TvC 1986, pag. 361, m.nt. Rijken (Van der Meer/Smilde); HR 16 jenuari 1987, NJ 1987, 553, m.nt. Q., KwNBW 1987/2, pag. 63, m.nt. Hondius, TwC 1987, pag. 263 (Hooijen/de Tilburgsche). Uitgebreid over deze omstandigheid: Rijken, diss., pag. 146 e.v.

9 Jongeneel, diss., pag. 88 en $110_{\text {i }}$ Rijken, diss., pag. 81 en 150.

10 Asser-Rutten II, 1982, pag. 233-235; Contractenrecht VII (Hondius); nr. 104; Hondius, dissi, pag. 410-411; Van der Werf, diss, pag. 59-62; Rjjken, diss., pag. 78. Niet alle auteurs vinden dit onderseheid zinvol, Zie bij voorbeeld: Van der Werf, diss., pag. 59.

11 Contractenrecht VII (Hond ius), nrs. 104-106.

12. Hondius, diss, pag, 410411; Contractenrecht VII (Hondius), nrs. 78-98.

13 Contractenrecht VII (Hondius), nrs. 79-86.

14 Contractenrecht IV (De Klerk-Leenen), nrs. 161-179 en VII (Hondius), nrs. 87-98.

15 Contractenrecht VII (Hondius), nr. 88. 
bewerkstelligen tenzij de wederpartij uitdrukkelijk de gelding van algemene voorwaarden afwijst.

Toch komt versluiering van de contractsinhoud in de Nederlandse rechtspraak aan de orde en ook op dit terrein uit zich de nauwe verwevenheid van de aanvaardingstoets met de inhoudstoets. Voor het versluieringsvraagstuk heeft het Holleman/De Klerk-arrest ${ }^{16}$ eveneens betekenis. Onder omstandigheden kan een beding verrassend zijn - en kan de toestemming van de wederpartij niet worden geacht op toepasselijkverklaring ook dáárvan gericht te zijn geweest juist omdat het beding zit weggestopt tussen andere algemene voorwaarden of juist omdat de inhoud van het bewuste beding voor de wederpartij niet toegankelijk is. Indien het beding niet aan versluiering ten prooi zou zijn gevallen, zou het ook nooit verrassend c.q. ontoegankelijk zijn.

Versluiering speelt eveneens een rol bij de inhoudstoetsing aan de goede trouw. In het richtinggevende arrest inzake Saladin/HBU is de wijze waarop een bepaald beding in de overeenkomst is geïncorporeerd en de mate waarin de wederpartij zich van de strekking van een bepaald beding bewust is geweest immers één van de uitdrukkelijk genoemde omstandigheden die een rol spelen bij de toetsing aan de goede trouw ${ }^{17}$ De mate waarin de wederpartij zich van de strekking van een bepaald beding bewust is geweest hangt logischerwijs nauw samen met de mate van versluiering en daarmee (deels) met de wijze waarop het beding deel is gaan uitmaken van de overeenkomst. ${ }^{18}$ Een beroep van de gebruiker op een bepaalde clausule zal eerder in strijd met de goede trouw (redelijkheid en billijkheid) worden geacht, indien vaststaat dat de wederpartij zich bij het sluiten van de overeenkomst door versluiering niet bewust is geweest van de strekking van dit beding.

\subsection{Inhoudstoetsing}

Alvorens men een oordeel over de inhoud van een bepaald beding kan geven zal men moeten vaststellen welke de inhoud van dat beding is. Tot de inhoudstoetsing moet derhalve eveneens de uitleg van allgemene voorwaarden worden gerekend. Uitleg kan echter eveneens een rol spelen bij de (primaire) gebondenheid aan algemene voorwaarden. De inhoud van een beding kan er immers toe leiden dat de wederpartij niet geacht kan worden (ook) daar zijn toestemming aan te hebben verbonden. ${ }^{19}$

16 HR 20 november 1981, NJ 1982, 517, m.nt. C.J.H.B. (Holleman/De Klerk).

17 HR 19 mei 1967, NJ 1967, 261, m.nt. G.J.S., A.A 1967, 214, m.nt. P.A.S. (Saladin/HBU). Zie ook: Rijken, diss., pag. 97 en 154-156.

18 Rijken, diss., pag. 150-156.

19 HR 20 november 1981, NJ 1982, 517 (Holleman/De Klerk); HR 1 juli 1993, NJ 1993, 688 (Bouma/Cavo). 


\subsubsection{Vitleg van algemene voorwaarden}

Het uitleggen van een overeenkomst is het vaststellen van de rechtsinhoud van de contractuele verhouding ${ }^{x 0}$, het vaststellen van de betekenis van de door de contractanten afgelegde verklaringen en van de daardoor ontstane rechtsgevolgen aan de hand van de omstandigheden van het geval $^{2 \mathrm{t}}$.

Daarbij dient de uitleg van de partijverklaringen $\sec$ goed te worden onderscheiden van de uitleg van de overeenkomst. Bij de uitleg van de partijverklaring gaat het zuiver om de vaststelling van de inhoud van een schriftelijke of mondelinge partijverklaring. Uitleg van de overeenkomst heeft weliswaar ook als uitgangspunt de partijbedoeling welke blijkt uit hun verklaringen, maar gaat verder. Bij de uitleg van de overeenkomst wordt niet alleen vastgesteld wat de inhoud is van de partijverklaringen maar wordt tevens vastgesteld welke rechtsgevolgen voortvloeien uit deze partijafspraken, de daarop betrekking hebbende wettelijke voorschriften, de gewoonte en de aanvullende of beperkende werking van de redelijkheid en billijkheid. ${ }^{22}$ Onder het oude BW werd voor de vaststelling van de rechtsinhoud van de overeenkomst, in beginsel, de volgende volgorde gehanteerd:

-partijafspraken (artikel 1374 BW (oud));

-nietigheid c.q. vernietigbaarheid van partijafspraken wegens strijd met dwingend recht, openbare orde en goede zeden (artikel $1371 \mathrm{j}^{\circ} 1373 \mathrm{BW}$ (oud)); -aanvulling van partijafspraken door dwingend recht (artikel $1375 \mathrm{BW}$ (oud)); -bestendig gebruikelijk beding (artikel $1383 \mathrm{BW}$ (oud)); -aanvullend recht (artikel 1375 BW (oud));

-gebruik (artikel 1375 BW (oud)); -aanvullende werking van redelijkheid en billijkheid (artikel $1375 \mathrm{BW}$ (oud)).

In beginsel, omdat de uiteindelijke volgorde werd, en nog steeds wordt, bepaald door de redelijkheid en billijkheid..$^{23}$ Aan alle zo vastgestelde verbintenissen kan de regel van artikel 1374 lid' $3 \mathrm{BW}$ (oud) dat overeenkomsten te goeder trouw moeten worden uitgevoerd, dan weer derogeren. De zogenaamde derogerende werking van de goede trouw. ${ }^{24}$

20 Van der Werf, disss, pang. 63.

21 HR 22 maart 1974, NJ 1974, 265 m.nt. G.J.S. (Dusotrac); Asser-Hartkamp II, 1993, nur. 280; Verhoeven, pag. 14.

22 Door Rutten respectievelijk de aanvulling en beperking van de partijafspraken genoernd. Zie Asser-Rutten II, 1982, pag. 193 e.v. en 230 e.v.

23 Asser-Rutten II, 1982, pag. 240.

24 Abas, diss, pag. 109203; Asser-Rutten II, 1982, pag, 230 e.v.; H. Drion, Jac. Hujma en M.M. Otthof, Compendium van het Nederlands vernogensrecht, 7e druk, Kluwer Deventer, 1985, pag. 170; Rijken, Redelijkheid en billijkheid, pag. 2944. 
Indien partijen algemene voorwaarden toepasselijk verklaren op een overeenkomst maken deze, op schrift gestelde, woorwaarden deel uit van de overeenkomst. Samen met de verklaringen die de "romp"overeenkomst vormen zijn de algemene voorwaarden de partijverklaringen die de basis zijn voor de vaststelling van de inhoud van de overeenkomst. Bij de uitleg van algemene voorwaarden gaat het dus om het, aan de hand van de omstandigheden van het geval, vaststellen van de inhoud van een schriftelijke partijverklaring.

Vooropgesteld moet worden dat bij de uitleg geen onderscheid kan worden gemaakt tussen duidelijke en onduidelijke wilsverklaringen. De betekenis van elke partijverklaring wordt pas duidelijk door uitleg. ${ }^{25}$ Deze uitleg van algemene voorwaarden/overeenkomsten wordt beheerst door de redelijkheid en billijkheid ${ }^{26}$ en is derhalve altijd normatief. ${ }^{27}$ Het begrip normatieve uitleg hanteer ik in deze in "enge" zin. Ik versta hier dus niet onder de aanvulling of beperking van de partijafspraken door middel van wet, gebruik, redelijkheid en billijkheid, onvoorziene omstandigheden en overmacht, zoals onder meer voorgestaan door Van Dunné. ${ }^{28}$ In die zin werkt de redelijkheid en billijkheid bij de uitleg van de partijverklaring derhalve niet alleen als een aanvullende bron van verbintenissen maar tevens als dé maatstaf bij de uitleg van de partijafspraak.

Uitlegging is in eerste instantie een aangelegenheid van de contractspartijen zelf. Het wordt pas een taak voor de rechter als partijen het niet eens kunnen worden over de uitleg van de partijafspraak ${ }^{29}$ en dus sprake is van een belangenconflict $^{30}$. Meestal komt de rechter er niet aan te pas en zal het duiden van de partijafspraak niet al te veel moeilijkheden opleveren. Zinnen, woorden en formuleringen zijn echter op velerlei wijzen uit te leggen. De inhoud van sommige clausules is derhalve soms moeilijk vast te stellen. In thet oude BW waren in de tweede Titel van Boek 4 een aparte afdeling en regels gewijd aan "'de uitlegging der overeenkomsten" welke regels - hoewel formeel voorgeschreven - meer het karakter hadden van wenken en raadgevingen. ${ }^{31}$ In het huidige BW komen deze expliciete uitlegregels voorlopig niet terug ${ }^{32}$, met dien verstande dat in de artikelen 3:35 en 3:36 BW gekozen wordt voor het vertrou-

25 Asser-Hartkamp II, 1993, nr. 285.

26 HR 20 mei 1949, NJ 1950, 72, m.nt. Ph.A.N.H. (Rederij Koppe); Asser-Hartkamp II, 1993, nr. 281; Wessels en Jongeneel, pag. 15; Verhoeven, pag. 14.

27 Asser-Hartkamp II, 1993, nr. 281; Van der Werf, dis:, , pag. 63; Vertioewen, pag. 15 .

28 Van Dunne, diss.; Van Dunne, Verbintenissenrecht, pag. 119-168. Zie hierover (onder andere): Asser-Hartkamp II, 1989, pag. 255; Van der Werf, diss., pag. 63.

29 Asser-Hartkamp II, 1993, nr. 283; Van Dunné, Verbintenissenrecht, pag. 119.

30 Van Dunne, Verbintenissennecht, pag. 119.

31. Artikelen 1378 tot en met 1387 BW(oud). Zie Asser-Rutten II, 1982, pag. 225.

32 Hondius, preadvies, pag. 168-169; Asser-Hartkamp II, 1993, nr. 279; Jongeneel, diss., pag. 152; Parlementaire Geschiedenis Boek 6, pag. 916. 
wensbeginsel waarbij de omstandigheden van het geval en de maatschappelijke context mede bepalend zijn voor de zin die aan een verklaring of een gedraging mag worden toegekend. Voorlopig, omdat de EEG-richtlijn betreffende oneerlijke bedingen in consumentenovereenkomsten ${ }^{33}$ de Lid-Staten dwingt om uiterlijk op 31 december $1994^{34}$ de contra proferentem regel van artikel 5 van die richtlijn $\mathrm{n}^{35}$ in de nationale wetgeving te implementeren.

Volgens vaste rechtspraak is uitleg van contractsbepalingen een in hoofdzaak feitelijke werkzaamheid waarbij niet de letterlijke tekst en een zuiver taalkundige uitleg daarvan maatgevend zijn, maar "de zin die partijen in de gegeven omstandigheden over en weer redelijkerwijs aan deze bepalingen mochten toekennen" ${ }^{36}$. Mede van belang kan daarbij zijn tot welke maatschappelijke kringen partijen behoren en welke rechtskennis van zodanige partijen kan worden verwacht. ${ }^{37}$

Indien de uitleg een algemene voorwaarde betreft staan een aantal van de, voor uitleg, relevante omstandigheden reeds bij voorbaat vast. Zo is het beding standaard bedoeld voor meerdere nagenoeg gelijke transacties, naar alle waarschijnlijkheid opgesteld door éen der partijen en op initiatief van deze in de overeenkomst opgenomen. De wederpartij heeft dit beding doorgaans klakkeloos en zelfs ongelezen aanvaard. Vanwege dit standaardkarakter en de eenzijdige invulling van standaardvoorwaarden zijn op het gebied van de uitleg van algemene voorwaarden een drietal algemene regels in de jurisprudentie uitgekristalliseerd en algemeen aanvaard.

33 Richtlijn 93/13/EEG van de Raad van 5 april 1993, Publikatieblad EG 21 april 1993, Nr. L. 95/29.

34 Artikel 10 lid I Richtlijn oneerlijke bedingen in consumentenoveneenkomsten.

35 Artikel 5: In hel geval wan overeenkomsten wannan alle of bepaalde aan de consumemi voorgestelde bedingen schriftelijk zijn opgesteld, moeten deze bedingen steeds dwidelijk en begrijpelijk aijn opgesteld. In geval wan twijfel over de betekenis van een beding, prevaleent de voor de consument gunstigste interpretatie. Deze witleggingsregel is niet wan toepassing in thet koder wan de in artikel 7 , lid 2 , bedoelde procedures.

36 HR 13 maart 1981, NJ 1981, 635, m.nt.C.J.H.B., AA 1981, pag. 355, m.nt. Van Schilfgaar de (Haviltex).

37 Zie (onder" andere): HR 17 december 1976, NJ 1977, 241, m.nt. G.J.S., AA 1977, pag. 654" m.nt. v.Sch. (Bunde/Erokens); HR I juli 1977, NJ 1978, 125, m.nt. G.J.S. (Ram/Matger); HR 18 november 1983 , NJ 1984, 272, m.nt. G. (Kluft/B en W supermarkten); HR 20 januari 1984 , NJ 1987, 295 (Leutseher/Van Tuyn); HR 25 januari 1985, NJ 1985, 559, m.nt. P.A.S. (Patelski/Sittard); HR 1 juli 1985 , NJ 1986, 692, m.nt. C.J.H.B. (FrenkelKRO); HR 11 november 1988, NJ 1990, 440 (AMRO/NCM); HR 4 januari 1991, NJ 1991, 254 (AlC/VRG); HR 17 september 1993, RvdW 1993, 177 (Gerritse/HAS); HR 24 september 1993 , RWdW 1993, 186 (Hol en. FNV/EIM). Zie voor meer jurisprudentie en een overzicht van de stand van zaken met betrekking tot de uitleg van overeenkomsten: Van Dunné, Verbintenissenrecht, pag. 160-165; Tjittes, diss., pag. $135 \mathrm{ev}$. 
Volgens de eerste regel moeten algemene voorwaarden vanwege hun standaardkarakter in beginsel objectief worden uitgelegd. ${ }^{38}$ Uniformiteit is immers de ratio van het gebruik van algemene voorwaarden.

De tweede regel, strikt genomen geen uitleg- maar een voorrangsregel, bepaalt dat individuele afspraken boven standaardvoorwaarden gaan. ${ }^{39} \mathrm{Dit}$ vloeit logischerwijs voort uit enerzijds de functie van algemene voorwaarden, zij zijn immers een regelcomplex dat aanvullend werkt op de uitdrukkelijke partijafspraken, en anderzijds het feit dat individuele afspraken een uitdrukking zijn van een duidelijke wilsovereenstemming ten aanzien van de inhoud van het beding, terwijl bij algemene voorwaarden doorgaans enkel de wilsovereenstemming ten aanzien van de gelding daarvan vast staat.

De derde regel bepaalt dat clausules voorkomend in standaardvoorwaarden bij twijfel omtrent hun betekenis in beginsel moeten worden uitgelegd in het voordeel van de wederpartij. Dit als logisch gevolg van het feit dat de wederpartij op de inhoud van algemene voorwaarden geen invloed kan uitoefenen. Aan de uitleg ten gunste van de wederpartij kunnen een aantal interpretatiemethoden dienstig zijn. ${ }^{40}$ De meest bekende interpretatiemethode is de zogenaamde contra proferentem-regel, de regel dat onduidelijk bedingen moeten worden uitgelegd in het nadeel van degene die ze heeft geformuleerd of bedongen. ${ }^{41}$

Vermelding verdient ook hier dat ook op het terrein van de uitlegging van partijafspraken in de jurisprudentie de mogelijkheid is ontwikkeld om uitleg als controlemiddel en tegelijkertijd inhoudstoets te laten fungeren en zo de scherpe kantjes van bedingen weg te slijpen. ${ }^{42}$ Met name de uitleg van bedingen in het voordeel van de wederpartij is hier een duidelijk voorbeeld van. Al te onredelijke gevolgen van een beding worden door uitleg geëcarteerd. Daardoor is vaak geen scherpe lijn te trekken tussen uitleg en inhoudstoets.

38. Contratenrecht VII (Hondius), nrs. 183-190; Van der Werf, diss.; pag. 63-64; Jongeneel, diss. , pag. 161; Verhoeven, pag. 15.

39 Rijken, diss " pag. 104; Hondius, diss., pag. 443 e.v. en 590 e.v.; Honditus, preadvies, pag. 121; Contractenrecht VII (Hondius), nrs. 210-215; Wessels en Jongeneel, 1992, pag. 25; Verhoeven, pag. 15.

40 Zie voor een overzieht: Contractenrecht VII (Hondius), nrs. 204-205.

41 De contra proferentem-regel wordt overigens niet zondermeer aanvaand door de Hoge Raad. Zite o.a.: HR 1 juli 1977 , NJ 1978, 125 (Ram/Matser); HR 28 april 1989, NJ 1990, 583 (Liszkay/Harman) en HR 9 september 1994, RvdW 1994, 169C, NJB 1994, pag. 445 (Trousborst/Tollenaar en Wegener); Hondius, diss., pag. 450 e.v. en 588 e.v.; Hondius, preadvies, pag. 121; Asser-Hartkamp II, 1993, nr. 287; Jongeneel, diss., pag. 152 e.v.; Rijken, diss, pag. 159; Van der Werf, diss., pag. 65 e.v.; Contractenrechit VII (Hondius), nr. 206; Wessels en Jongeneel, 1992, pag, 25-26; Verhoeven, pag. 15; Van Dume, Verbintenissenrecht, pag. 151 .

42 Zie hierover: Hondius, diss.; peg. 450; Rijken, diss., pag. 25 en 104; Contractenrecht VII (Hondius), nr. 136; Asser-Hartkamp II, 1993, nr. 344; Van Dunne, Verbintenissenrecht, pagg. 151 en $262-263$. 


\subsubsection{Inhoudstoetsing van algemene voorwarden}

In de jurisprudentie is op verschillende grondslagen de inhoud van algemene voorwaarden getoetst. Met uitzondering van de hiervoor besproken rol die de inhoud van algemene voorwaarden speelt bij het (primaire) gebondenheidsvraagstuk of bij de uitleg van contractsbedingen, is de toets van de inhoud van algemene voorwaarden onder vigeur van het oude Burgerlijk Wetboek voornamelijk ${ }^{43}$ gebaseerd geweest op enerzijds de wet, de goede zeden en de openbare orde (artikel 1371 $\mathrm{j}^{\circ} 1373 \mathrm{BW}$ (oud)) ) $^{44}$ anderzijds - sinds het Saladin/ $\mathrm{HBU}$-arrest in $1967^{4.5}$ - de (objectieve) goede trouw (redelijkheid en billijkheid) van artikel 1374 lid $3 \mathrm{BW}$ (oud).

Bedingen in algemene voorwaarden konden op grond van artikel $1371 j^{\circ} 1373$ BW (oud) allereerst getoetst worden aan dwingende wetgeving. Indien een beding in strijd was met een dwingende wetsbepaling dan was het beding nietig tenzij uit de bepaling of haar strekking een andere sanctie voortvloei$\mathrm{de}^{47}$ (bij voorbeeld vernietigbaarheild) of de bepaling niet de strekking had de geldigheid van daarmee strijdige bedingen aan te tasten ${ }^{48}$. Het huidig BW heeft deze regel vastgelegd in artikel $3: 40$ lid 2 en lid $3 \mathrm{BW}$. Bedingen in strijd met dwingende wettelijke regels die beogen het belang van een der partijen te beschermen zijn doorgaans vernietigbaar op vordering van de beschermde partij. Algemeen is aanvaard dat de nietigheid van cén of meerdere bedingen in een overeenkomst wegens strijd met de wet, pas dán de nietigheid van de overeenkomst in haar geheel tengevolge zal hebben, indien aannemelijk is dat de partijen de overeenkomst zonder dat beding niet zouden hebben gesloten."

Op grond van dezelfde artikelen konden algemene voorwaarden ook getoetst worden aan de goede zeden of openbare orde. ${ }^{50}$ Indien een beding in strijd is met de goede zeden of de openbare orde heeft dit steeds nietigheid van het beding ten gevolge. Ook hier heeft nietigheid van eén of meerdere bedingen doorgaans niet tot gevolg dat de gehele overeenkomst nietig is . ${ }^{51}$ Goede zeden

Zie voor andere mogelijkheden voor rechterlijk ingrijpen zoals o. a. dwaling, bedrog, misbrilk van omstandigheden, afstand van recht ete: Contractenrecht VII (Hondius), nrs. 164-173.

44 Van der Werf, diss., pag. 69.

45 HR 19 mei 1967, NJ 1967, 261, m.nt. G.J.S., AA 1967, m.nt. P.A.S. (Saladiru/HBU).

46 Artikel 1371 BW(oud) spreekt van "krachteloos".

47 HR 20 april 1990, NJ 1990, 701, m.nt. P.A.S. (Huplkes/Coster Zonen B. V.).

48. HR 13 januari 1938, NJ 1938, 600 (Kluwer/N.V. Annsterdamsehe Bank); HR 11 mei 1951 , NJ 1952, 127, m.nt. Ph.A.N.H. (Florar Van der Kamp).

49 Asser-Rutten II, 1982, pag. 202.

50 HR 14 april 1950, NJ 1951, 17, m.nt. Ph.A.N.H. (Röntgenbehandeling); Comtractenrecht VII (Hondius), nr. 138, Zie voor een overzicht: Rijken, diss., pag. $86,174 \mathrm{en} 181$.

51 Hondius, diss., pag. 472. 
en openbare orde zijn nagenoeg gelijke begrippen die mede worden ingevuld aan de hand van regels van ongeschreven recht. Strijd met de openbare orde of goede zeden wordt aangenomen, naargelang een rechtsregel van algemeen belang dan wel een die vooral ziet op de zedelijke orde wordt geschonden. ${ }^{52}$

Voor wat betreft allgemene voorwaarden had de toets aan de goede zeden vooral betekenis voor de uitsluiting van aansprakelijkheid voor opzet en grove schuld van de exonerant. Deze aansprakelijkheidsuitsiuiting werd algemeen nietig geacht wegens strijd met de goede zeden. ${ }^{53}$

Sinds het Saladin/HBU-arrest uit 1967 is de inhoudstoetsing van algemene voorwaarden mogelijk op grond van de (objectieve) goede trouw van artikel 1374 lid $3 \mathrm{BW}$ (oud) ${ }^{54}$ De in dit arrest gehanteerde formule

"dar het antwoord op de wraag in welke gewallen (....) een beroep op dit beding miet wrijstaat, Ghankelijk kan zijn wan de watardering van tal van omstandigheden, zoals de zwourte roun de schwld, mede in werband met acard en de emst van de bij emige gedraging betrokken belangen, de aard en de werdere imhoud van de overeenkonst waarin hel beding woorkamt, de maatschappelijke positie en de onderlinge verhouding van partijen, de wijze warop het beding is tot stand gekomen, de mate warim de wederpartij zich wan de strekking van het beding bewust is geweest;"

is sindsdien in diverse uitvoeringen en meer en meer geënt op het systeem en de terminologie van het huidige Burgerlijk Wetboek - de HR hanteert bij voorbeeld sinds zijn arrest van 25 april 1986 (Van der Meer/Smilde) het begrip "onredelijk bezwarend' - herhaald door ons hoogste rechtscollege. ${ }^{55}$ Als een van de om-

52 Assser-Ruatten II, 1982 , parg. 196.

53 HR 3 juni 1938, NJ 1938, $920 \mathrm{~m}$ nt. E.M.M. (BOVAG I); HR 14 april 1950, NJ 1951, 17, m.nt. Ph.A.N.H. (Röntgenbehandeling).

54. Hondus, diss, pag. 471. e.w.; Rijken, diss., pag, $97-1.02$ en 133 e.v.; Contractenrecht VII (Hondus), nr. 138; Van der Werf, dis:s, pag. 69.71.

55 HR 19 mei 1967 , NJ 1976, 261, mnt. G.J.S., AA 1967, pag. 214, m.nt. P „A.S. (Saladin/HBLly: HR 14 december 1973, NJ 1974, 127 m.nt. G.J.S. (De Boer/Wittenberg); HR 20 febnari 1976, N. 1976, 486, m.nt. G.J.S. AA 1976, pag. 467, m.nt. G. (Piseudo-vogelpest); HR 18 december 1981, NJ 1982, 71 (Van KJeefMonster); HR 25 april 1986, NJ 1986, 714, m.nt. G., AA 1986, pag. 816, m.nt. v. Seh., TwC 1986, pag. 361, m.nt. Rijken (Van der Meer/Smilde); HR 16 janturi 1987, NJ 1987, 553, m.nt. G., KwWBW 1987/2, pag, 63 rint. nt. Hondius, TwC 1987, pag. 263, m.nt Rijken (Hooijen/de Tilburgsche); HR 10 juli 1989, NJ 1989, 840, m.nt. P.A.S. (Spenjaard/HBB); HR 3 november 1989, NJ 1991, 168, m.nt. E. A.A. (Prins en Spoelstra/Woningstichting St. Joseph); HR 23 mart 1990, NJ 1991, 214, m.nt. H.J.S. (Botman/Van Haaster); HR 20 april 1990, NJ 1990, 676, m.nt. P.A.S. (Van der Klugt/De Boer); HR 15 februari 1991, NJ 1991, 538 (Roelofi/Van Soest); HR 8 maart 1991, NI 1991, 396 (De Kleijn/Van der Ende); HR 8 juli 1991, NJ 1991, 691, m.nt. M.S. (Kunat - ent Antiekstudio); HR 9 oktober 1992, NJ 1994, 287 (Manssiluis/Pakwoningen); HR 31 december 1993, RwdW 1994, 21 (Matatag/De Schelde). 
standigheden die een rol spelen bij deze toets wordt met name ook genoemd de omstandigheid dat het een beding in algemene voorwaarden betreft. ${ }^{56}$

Gezien de omstandigheden die een rol spelen bij de toets op grond van de HBU-formule zal duidelijk zijn dat deze meer omvat dan een zuivere inhoudstoets; de toets behelst - zoals in de voorgaande paragrafen reeds opgemerkt mede de aanvaardingstoets en de informatietoets. ${ }^{57}$ De HBU-toets ormvat zoals Rijken het stelt:

"dan ook méer dan inhoudscontrole alleen: her hele maarschappelijke en juridische gebeuren rondom

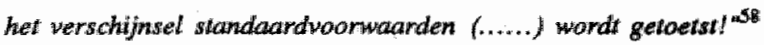

Het is dan ook niet verwonderlijk dat de op de beperkende werking van de goede trouw gebaseerde HBU-toets, zich ontwikkeld heeft tot het instrument bij uitstek voor de inhoudelijke toetsing van algemene voorwaarden en in feite de (inhouds-) toetsen op andere grondslagen in de schaduw heeft gezet. Het beroep op artikel 1374 lid 3 BW (oud), dat zich eigenlijk alleen maar richt tegen een onredelijke uitvoering van de overeenkomst in het concrete geval, heeft zich daarbij steeds meer ontwikkeld tot een allesomvattende toets naar de verbindende kracht van algemene voorwaarden. ${ }^{59}$ Daarbij abstraheert de Hoge Raad deels ook van de feitelijke omstandigheden die zich hebben voorgedaan bij de uitvoering van de in het geding zijnde overeenkomst. Een mooi voorbeeld hiervan is te vinden in het Botman/Van Haaster-arrest. ${ }^{6}$ In dat arrest werd de onredelijkheild van een arbitragebeding enkel en alleen gezocht in de inhoud van het beding. De verbindendheid van het beding

".. dient niet: te worden beoordeeld aan de hand van de madelen die zich bij de op grond van het beding aangespannen arbitrage daadwerkelijk hebben verwezenlijkt, mar acan de hand van de eventuele onredelijk bezwarende gevolgen waraan het beding, bij gebondenheid daaraan, Vars Haaster wam de acnwang af blooit stelde, waaronder ook de nadelen waanan de verwezenlibing bij handhaving van het beding slechts "mogelijk" was." wt

Bij de toets aan de goede trouw gaat het niet om de vraag of een beding nietig of vernietigbaar is, maar om de vraag of een beroep op het beding door een

56 HR 25 april 1986, NJ 1986, 714, m.nt. G., AA 1986, pag. 816, m.nt. v. Sch., TvC 1986, pag. 361, m. nt. Rijken (Van der Meer/Smilde); HR 16 januari 1987, NJ 1987, 553, m.nt. G KwNBW 1987/2, pag. $63 \mathrm{~m}$.nt. Hondius, TwC 1987 , pag. 263, m.nt. Rijken (Hooijen/de Tilburgsche).

57 Zie voor een nadere analyse vau de te waarderem omstandigheden: Rijken, dissi., pag. 133 e..." Contractenfecht VII (Hondius), ans. 140 e.w.

58 Rijken, diss., pag. 81 .

59 Asser-Hartksamp II, 1989, nr. 344.

60 HR 23 maart 1990, NJ 1991, 214, m.nt. H.J.S. (Botman/Van Haaster).

61 r.o. 3.4. 
partij, gezien de concrete omstandigheden van het geval, jegens zijn wederpartij in strijd is met de goede trouw. Indien het beroep op een beding in strijd komt met de goede trouw heeft dit een beperking van de toepasselijkheid van het beding tot gevolg ${ }^{62}$. Toepassing van artikel 1374 lid $3 \mathrm{BW}$ (oud) leidt dan tot niet-inroepbaarheid, niet-verbindendheid van het beding. ${ }^{63}$

\subsection{Beperkingen van de rechterlijke controle op algemene voorwaarden}

Ondanks het feit dat de rechter met de wet, de goede zeden en openbare orde en met name de toetsing aan de (objectieve) goede trouw prachtige materieelrechtelijke instrumenten in handen had ter bescherming van de consument tegen onredelijk bezwarende algemene voorwaarden, kleefden aan de rechterlijke controle op de algemene voorwaarden onder het BW (oud) een aantal bezwaren. De eerste beperking betreft de bereikbaarheid van de burgerlijke rechter voor de consument. De overige beperkingen vloeien voort uit de werking van het vonnis en het niet preventieve karakter van civiele procedure.

\subsubsection{Toegang tot de burgerlijke rechter}

Zoals reeds eerder aangehaald, maken consumenten en hun organisaties bij de beslechting van hun geschillen inzake algemene voorwaarden slechts zelden gebruik van de burgerlijke rechter en valt slechts een geringe bereidheid tot procederen te constateren. Voor deze onbereikbaarheid van de burgerlijke rechter zijn verschillende oorzaken aan te wijzen zoals onbekendheid met het recht, ontoereikendheid wan de rechtshulp, de kosten van rechtshulp, het nietontvankelijkheidsrisico van consumentenorganisaties bij collectieve belangenbehartiging, het procesrisico en psychologische factoren. ${ }^{64}$ Deels liggen deze oorzaken binnen de organisatie van de civiele rechtspraak, voor een deel liggen zij er echter ook buiten. Een onderscheid tussen individuele consumenten die recht zoeken en consumentenorganisaties is hier op zijn plaats. De hiervoor genoemde factoren gelden immers niet gelijkelijk voor consumenten en hun bellangenorganisaties.

62 Asser-Hartkamp II, 1993, pag. 315.

63 Snijders, noot (2.1) bij HR 23 mart 1990, NJ 1991, 214 (Botman/Ven Hatater). Rijken, disis., pag. $87-88$ en 98.

64 Zive hiervor onder 2.4.3. 


\subsubsection{Consumenten}

Strikt genomen kan elke consument zijn geschillen inzake algemene voorwaarden altijd voorleggen aan de burgerlijke rechter. Het materielle recht biedt hem ook voldoende mogelijkheden daartoe. Desalniettemin komt men in de Nederlandse rechtspraak inzake algemene voorwaarden slechts zelden consumenten tegen. Van de belangrijkste arresten door ons hoogste rechtscollege de laatste jaren op het terrein van de algemene voorwaarden gewezen ${ }^{65}$, zijn in slechts enkele procedures consumenten, soms mede gesteund door consumentenorganisaties, betrokken. ${ }^{6}$ Dat de individuele consument de weg naar de burgerlijke rechter niet weet te vinden, is enerzijds terug te voeren op oorzaken die buiten de organisatie van de civiele rechtspraak liggen en een aantal oorzaken die wél zijin terug te voeren op de organisatie en inrichting van de burgerlijke rechtspraak.

Ten eerste is de doorsnee consument onbekend met het materiële civiele recht in het algemeen en dus zeker ook met het materiële recht inzake algemene voorwaarden. ${ }^{67} \mathrm{Hij}$ is dus onbekend met zijn eigen rechtspositie en is er zich veelal niet van bewust dat het materiële recht hem bescherming biedt. Het inroepen van die bescherming bij de burgerlijke rechter komt dus vaak al niet eens bij hem op. Deze oorzaak ligt buiten de organisatie van onze civiele rechtspraak en kan derhalve moeilijk gezien worden als een tekortkoming daarvan. Hier ligt eerder een voorlichtende taak voor de centrale overheid.

Een tweede factor die bewerkstelligt dat de consument de burgerlijke rechter op het terrein van de algemene voorwaarden slechts sporadisch adieert, is gelegen in het feit dat veel algemene voorwaardlen voorzien in een andere vorm van geschillenbeslechting zoals arbitrage of bindend advies. ${ }^{68}$ Dit feit gecombineerd met zijn vaak geringe kennis van het civiele recht, maakt dat de consument (vaak onterecht) al snel tot de conclusie komt dat de in de voorwaarden voorziene vorm van geschillenbeslechting de enige is die voor hem open staat. Ook deze oorzaak van de beperkte werking van de rechterlijke controle ligt buiten de organisatie van het civielrechterlijk apparaat.

Als de consument zich er al van bewust is dat het materiële recht inzake algemene voorwaarden hem bescherming biedt dan bemoeilijken een aantal

65 Zie noot 55.

66 HR 25 april 1986, NI 1986, 714, m.nt. G., AA 1986, pag. 816, m.nt. v. Seh., TvC 1986, pag. 361, m.nt. Rijken (Van der Meer/Smilde); HR 10 juli 1989, NJ 1989, 840, m.nt. P.A.S. (Spanjikard/HBB); HR 3 november 1989, NJ 1991, 168, m.nt. E.A.A. (Prins en Spoelstra/Wonüngstichting St. Joseph); HR 20 april 1990, NJ 1990, 676, m.nt. P.A.S. (Van der Klugt/De Boer).

67 Hondius, diss., pag. 489.

68 Hondius, diss, png. 492. 
andere aspecten de toegang tot de rechter. Te noemen zijn hier psychische factoren, waarbij vooral sociale afstand een rol speelt, de hoge kosten, de lange duur, het moeiteaspect en de complexiteit en formaliteit van de civiele procedure. ${ }^{69}$ Een aantal van deze factoren vinden hun directe oorzaak in de organisatie en inrichting van de overheidsrechtspraak. Met name aspecten als hoge kosten, zelfs als de procedure wordt gewonnen en de andere partij in de kosten wordt veroordeeld ${ }^{70}$, lange duur, complexiteit en formaliteit van de procedure liggen naar hun aard besloten in de organisatie van de civiele rechtspraak.

\subsubsection{Consumentenorganisaties}

Een aantal van de hiervoor genoemde beperkingen gelden natuurlijk in mindere mate voor consumentenorganisaties. Het is niet al te gewaagd om te veronderstellen dat het materiële recht inzake algemene voorwaarden bij deze organisaties genoegzaam bekend is. Bovendien is een organisatie gemakkelijker dan de individuele consument in staat zich dergelijke kennis te verwerven. Psychische factoren die de gang naar de rechter voor de individuele consument bemoeilijken zijn voor consumentenorganisaties geen belemmering. Hoewel kostenaspecten voor consumentenorganisaties zeker ook een rol zullen spelen in de keuze voor de burgerlijke rechter, zijn deze voor consumentenorganisaties op weg naar de burgerlijke rechter een aanmerkelijk eenvoudiger te nemen hindernis dan voor individuele consumenten. Zo kunnen ook die belangen worden behartigd welke door hun algemeenheid van aard of de geringe individuele geldswaarde door individuele consumenten niet behartigd worden. ${ }^{71} \mathrm{De}$ complexiteit, de lange duur en de formaliteit van de procedure mogen voor een consumentenorganisatie eveneens niet beschouwd worden als al te grote obstakels voor een civiele procedure.

Gezien de zwakke processuele positie van de individuele consument en het feit dat consumentenorganisaties ten opzichte van deze beter voor het voeren van civiele procedures zijn toegerust, is het niet meer dan logisch dat consumentenorganisaties hun leden meer en meer zijn gaan bijstaan in civiele procedures. Zo besloot de Consumentenbond in 1969 haar tot dan toe aan haar leden verleende rechtshulp in de vorm van adviezen en bemiddeling bij consumentenklachten, uit te breiden met het verlenen van (kosteloze) bijstand in rechte. ${ }^{72}$ De overwegingen die tot dit besluit leidden waren: de ongelijke positie van de consument bij het aangaan van overeenkomsten waardoor deze zich vaak in een

69 Zie o.a.: Hondius, diss. 489 e.w.; Van der Worf, diss., pag. 70-72; Boer, pag. 15; Last, pag. 237.

70 Hugentaltz/Heemskerk, pag. 106; Stein, Compendium, pag. 175.

71 Hondius en Rodrigues, pag. 1212.

72 Zie 0.a.: Consumentenbond, Jaarverslag rechterlijke actie 1990, Den Hkag 1991, pag. 3. 
onbevredigende rechtspositie bevindt, het gevaar dat met deze toenemende ongelijkheid onvoldoende rekening werd gehouden in rechterlijke uitspraken, de in verhouding tot het belang vaak onevenredig hoge kosten verbonden aan een procedure en de wens om de effectiviteit van de buitengerechtelijke ledenservice te bevorderen. Doordat de Consumentenbond het procesrisico voor haar rekening neemt en daarmee de voor individuele consumenten remmende kostenfactor wordt weggenomen, wordt beoogd het procedleren op typische consumentenkwesties te stimuleren en aldus het tot stand komen van meer jurisprudentie op dit terrein te bevorderen. ${ }^{73}$

Ondanks het feit dat de consumentenorganisaties beter zijn toegerust voor hat voeren van civiele procedures is het aantal door hen gevoerde collectieve consumentenacties toch niet zo groot. ${ }^{74} \mathrm{Zo}$ heeft het ook tot 1982 geduurd alvorens de Consumentenbond haar eerste collectieve vordering op eigen naam instelde op het terrein van de algemene voorwaarden. ${ }^{75}$ Deze aarzelende houding werd bij de Consumentenbond voornamelijk veroorzaakt door de onzekerheid omtrent de vereisten voor ontvankelijkheid van belangenorganisaties in algemeen belang- en groepsbelangacties. Deze vereisten kregen immers eerst na die tijd zowel op het terrein van de onrechtmatige daad ${ }^{76}$ als op het terrein van het contractenrecht ${ }^{n}$ nader gestaite. De bond verzucht na het voeren van de eerste twee collectieve acties in haar Jaarverslag Rechtsbijstand 1983 dan ook:

"Het acantal kemen dar door ons een algemeen belcong of collectief belong actie is ondemomen is mog beperkt. De achtergrond hierwan is dat wij de kans op onwankelijkverklaring niet hoog inschattem en liever het risico niet wilden lopen. "78

De eerste collectieve actie inzake algemene voorwaarden, waarin de Consumentenbond ageerde tegen een kettingbeding in de gronduitgifte-voorwaarden van de gemeente Smilde ${ }^{79}$, werd echter meteen een teleurstelling. De Consumenten-

73 Consumentenbond; De rechtsbijstand van de consumentenbond in 1979, Den Hagg 1980.

74 Rodrigules, Ars Aequi Libri, pag. 51 .

75 Hondius en Rodrigues, pag. 1210 ; Verhoeven, pag, 116 e.v.

76 Zie met name: HR 1 julli 1983, NJ 1984, 360 (Staat der Nederlanden/LSV); HR 27 juni 1986, NJ 1987, 743, m.nt. W.H.H. (Nieuwe Meer); HR 11 december 1987, NJ 1990, 73, m.nt. W.H.H. en M.S. (Staat der Nederlanden/VEA); HR 18 december 1992, NJ 1993, 139 (Kuunders/Stichting Natuur en Miliew). Zie hierover uitgebneid: Frenk, diss.„pag. 81-102,

77 HR 30 november 1990, NJ 1991, 492, m.nt. M.s. (Vereniging assistent-geneeskundigen/gemeente "s-Gravenhage); HR 1 juli 1992, NJ 1993, 450, mint. H.S. (Abva-Kabo/Staat der Nederlanden); HR 1 juli 1993, NJ 1994, 461, m.nt: HI.S. (De drie HLO's Westland/gemeente "s-Gravenhage). Zie meer uitgebreid: Frenk, diss., pag. 83-1102.

78 Consumentenbond, Jaarverslag rechtsbijstand consumentenbond 1983, Den Haag 1984, pag. 15

79 HR 25 april 1986, NJ 1986, 742 (Consumentenbond/Gemeente Smilde). Zie hierower: Hondius en Rodrigues, pag. 1206-1214; Frenk, diss:, peg. 84-85. 
bond, anticiperend op (toentertijd nog) het wetswoorstel inzake afdeling 6.5.2A NBW, werd tot in hoogste instantie niet ontvankelijk verklaard. Toch was de afloop van deze procedure niet onverdeeld negatief voor de Consumentenbond. Weliswaar was de Hoge Raad niet bereid reeds op de, gedetailleerde en wezenlijk van het oude recht afwijkende, bepalingen van afdeling 6.5.2A NBW inzake het collectief actierecht te anticiperen, de afwijzing van de collectieve actiebevoegdheid werd echter uitdrukkelijk beperkt tot het terrein van de algemene voorwaarden. In de woorden van de Hoge Raad:

"Naar hwidig recht is voor een vordering wan een belcungenorganisatie als de Consumentenbond, sitrekkende tot een verklaring voor recht als hierboven in 3.1 onder a omschreven (een verklaring woor recht dar een beding anredelijk bezwarend is, toevoeging LJHM), geen placts." "

Met dit arrest sloot ons hoogste rechtscollege als het ware de deur naar collectieve inhoudstoetsing op het terrein van de algemene voorwaarden hermetisch af tot de invoering van het nieuwe $\mathrm{BW} .{ }^{\circ}$ Daarmee is grotendeels verklaard waarom consumentenorganisaties op het terrein van de algemene voorwaarden nauwelijks collectief zijn opgetreden.

Succesvoller was de Consumentenbond in 1986 met zijn tweede collectieve actie op het terrein van de algemene voorwaarden, gericht tegen de PTT. ${ }^{81}$ In deze procedure kwam de Consumentenbond gezamenlijk met een individueel lid op tegen de algemene voorwaarden van de PTT in verband met de weigering van de PTT om niet door haar geleverde telefoontoestellen aan te sluiten. Gevorderd werd onder meer een verklaring voor recht dat het de PTT niet vrij stond ten aanzien van deze weigering een beroep te doen op haar algemene voorwaarden. Hoewel de gevraagde collectieve verklaring voor recht op inhoudelijke gronden werd afgewezen, werd de Consumentenbond, mede vanwege het feit dat hij als overlegpartner fungeerde in de "Commissie voor Consumentenaangelegenheden Telefoonvoorwaarden", uitdrukkelijk ontvankelijk verklaard in zijn vordering. ${ }^{82}$

De eerstvolgende procedure waarin de Consumentenbond collectief is opgetreden inzake algemene voorwaarden vond plaats in $1991^{83}$ en was voor de bond succesvol. Niet alleen werd de Consumentenbond ontvankelijk verkllaard in zijn vordering gericht op ongedaanmaking van een eenzijdige wijziging

80 Zie ook: Hondius en Rodrigues, pag. 1211.

81 Rb. Den Haag 27 mant 1986, TrC 1986, pag. 371 e.v. (Consumentenbond/Staat der Nederianden (PTTD). Zie ook: Hondius en Rodrigues, pag. 1210; Verhoeven, pag. 117.

82 Rb. Den Haag 27 maart 1986, TwC 1986, pag. 372, r.0. 5.1 .

83 Pres. Rb. Den Hagg 17 aprill 1991, TvC 1991, pag. 312 e.v,, m.nt. Niels Frerik, Hof Den Hang 13 april 1993, TrC 1993, pag. 355 e.v., m. nt. Rijken; HR 2 september 1994, RvdW 1994, 165C, TwC 1994, pag. 369, m.nt. L.Dommering-van Rongen, NJB 1994, pag. 431432 (Congumentenbond/Nuts Ziektekostenwerzekering). 
van verzekeringswoorwaarden door een verzekeraar, de vorderingen van de Consumentenbond werden in hoofdzaak ook toegewezen.

Enkele dagen later was de laatste collectieve actie van de Consumentenbond op het terrein van de algemene voorwaarden van voor het in werking treden van het Nieuw $\mathrm{BW}{ }^{34}$ Ook in deze procedure waarin de Consumentenbond van de OV-Studentenkaart B.V. vorderde dat het deze laatste, ondanks andersluidende algemene voorwaarden; verboden werd een bepaalde gedragslijn te volgen, werd de bond ontvankelijk verklaard en werd de vordering in hoofdzaak toegewezen. Hoewel de actie wan de bond zich na de ervaringen in de zaak tegen de gemeente Smilde wijselijk niet toespitste op een inhoudelijke toets van een algemene voorwaarde doch op de gedraging van de OV-Studentenkaart B.V., was het resultaat dat het desbetreffende beding door de rechter feitelijk toch buiten werking werd gesteld.

\subsubsection{Beperkte reikwijdte van de rechtspraak inzake algemene voorwaarden}

Als de consument de weg naar de rechter weet te vinden en een voor hem gunstig vonnis weet te verkrijgen, dan heeft dit vonnis slechts een beperkte reikwijdte. Deze beperkte reikwijdte is een rechtstreeks gevolg van het feit dat op grond van artikel 67 Rv. het gezag van gewijsde enkel werking heeft ten aanzien van procespartijen en niet ten aanzien van niet in de procedure betrokken derden. ${ }^{85}$ Het is het gevolg van het beginsel dat slechts de concrete en unieke relatie van partijen ter beoordeling van de rechter ligt.

Buiten de gebruikelijke precedlentwerking ${ }^{86}$, die niet altijd even groot is ${ }^{87}$, heeft het vonnis derhalve geen breedtewerking. Dit is met name voor een gestandaardiseerd verschijnsel als algemene voorwaarden nadelig. Bij de beoordeling van algemene voorwaarden zullen de individuele omstandigheden vanwege het evildente standaardkarakter van deze voorwaarden meestal een ondergeschikte rol spelen en zal een beding in een bepaald soort overeenkomst dat jegens éen consument onredelijk bezwarend is bevonden, veelal eveneens onredelijk bezwarend zijn ten opzichte van alle andere consumenten die in dezelfde soort overeenkomsten met dit beding worden geconfronteerd. Toch kunnen de niet in de procedure betrokken consumenten, vanwege de beperkte werking van het gezag van gewijsde, geen (direct) beroep doen op een dergelijk uitspraak. Zij zijn afhankelijk van de wil van de gebruikers van dergelijke algemene voorwaarden. Indien dezen zich niet vrijwillig onderwerpen aan de

84. Pres. Rb. Rotterdam 24 april 1991, KG 1991, 179 (Consumentenbond/OV-Studentenkaart BV).

85 CCA-Advies, pag. 19; Van der Werf, diss, , pag. 71; Verhoeven, pag. 113; Rijken, TVVS 1986 , pag. 268 .

86 Van der Werf; diss., pag. $711-72$

87 Hondius, diss., pag. 493. 
rechterlijke uitspraak, gewezen weluswaar in een andere contractsrelatie máar ten aanzien van dezelfde soort overeenkomst en met dezelfde algemene voorwaarde, moet, voorzover consumentenorganisaties met een beroep op het vonnis er miet in slagen de gebruiker van zijn dwalingen te doen terugkeren, in beginsel iedere individuele consument voor zich een eigen procedure starten. Elke rechter, wiens uitspraak ten aanzien van een dergelijk beding wordt gevraagd, moet dan in beginsel telkens weer opnieuw vaststellen wat rechtens is tussen partijen.

\subsubsection{Het ontbreken van preventieve werking van de rechtspraak op het terrein van de algemene voorwaarden}

Een laatste beperking die kleeft aan de rechtspraak inzake algemene voorwaarden is gelegen in het feit dat de rechterlijke controle van algemene voorwarden naar haar aard repressief is. ${ }^{88}$ De rechterlijke controle vindt immers steeds achteraf plaats. Pas nadat onenigheid is ontstaan over een beding in algemene voorwaarden wordt het beding (soms) ter beoordeling voorgelegd aan de rechter. Voorwerp en tijdstip van controle liggen temporeel dan ook meestal ver uit elkaar. Algemene voorwaarden worden soms reeds jaren gehanteerd alvorens zij ter toetsing aan de rechter worden voorgelegd. Beziet men daarnaast dat rechterlijke vonnissen slechts werking hebben tussen de procespartijen, dat een eventuele precedentwerking naar haar aard slechts naar de toekomst toe werkt en dat consumenten nauwelijks op de hoogte zijn van rechtspraak op het terrein van algemene voorwaarden, dan is het niet te gewaagd om te stellen dat onredelijk bezwarende algemene voorwaarden lange tijd in het rechtsverkeer kunnen worden gehanteerd zonder aan rechterlijke controle onderhevig te zijn.

\subsection{Particuliere geschillenbeslechting}

Contractspartijen kunnen overeenkomen dat zij hun conflicten ten aanzien van de betreffende overeenkomst laten beslechten door anderen dan de overheidsrechter. Mede als gevolg van de moeilijke toegankelijkheid van de overheids-

88. Hondius, diss, pag. 494; Verhoeven, pag. 113; Rijken, TVVs 1986, pag. 268.

89 Zie ook: Hondius, diss., pag. 495; Rijken, inmug. rede, pag. 24. Lavatstgenoemdes haalt in dit werband de volgende vitspraak van Bultmann, directeur wan de Verbrauchersehutzwerein $e$. $V$. te Berlijn, an: "Der Salt: "Unlauterer Wewbewerb lohnt sich immer" gilt unwerändert. Alle Maßnahmen des Verbraucherschutzvereins sind nur Reaktionen, die für die betroffenen Firmen keine Folgen haben, wenn sie auf Abmahnung oder sonstige sehriftiche Auffordenung ihr unlauteres und gesetzwidriges Vertalten sofort einstellen. Bis zu diesem Zeitpunkt hat das unllatutere Verhaltem meist genug Vorteile gebracht." 
rechter is de consument zich op het terrein van de algemene voorwaarden in toenemende mate gaan wenden tot deze alternatieve - of zo men wil, aanvullende - vormen van geschillenbeslechting. ${ }^{90}$ Dit is een gevolg van enerzijds het feit dat algemene voorwaarden steeds meer tot stand komen in gemeenschappelijk overleg tussen aanbiedersorganisaties en consumentenorganisaties en deze in de aldus vastgestelde algemene voorwaarden in geschillenbeslechting door middel van bindend advies voorzien, en anderzijds van het gegeven dat deze vorm van particuliere rechtspraak voorziet in een eenvoudige, weinig kostbare en voor de consument toegankelijke vorm van geschillenbeslechting die door de overheidsrechter niet wordt geboden.

\subsubsection{Branchegeschillencommissies}

Branchegeschillencommissies zijn op een aantal wijzen te onderscheiden. ${ }^{91} \mathrm{Zo}_{0}$ is er onderscheid te maken naar de betrokkenen bij de oprichting en samenstelling van deze commissies. De branchegeschillencommissies zijn ofwel eenzijdig door het bedrijfsleven in het leven geroepen ofwel door het bedrijfsleven in samenwerking met consumentenorganisaties. Qua samenstelling kan verschil gemaakt worden tussen commissies die enkel zijn bezet met bedrijfs- of branchegenoten en commissies waarin, al dan niet onder leiding van een onpartijdige voorzitter, zowel vertegenwoordigers van aanbiederszijde als van consumentenzijde zitting hebben. ${ }^{92}$

Een verder onderscheid is te maken naar de oorsprong van de algemene voorwaarden waaraan de geschillencommissie haar bevoegdheid ontleent en die veelal ten grondslag liggen aan de uitspraken van deze commissies. Deze voorwaarden zijn ofwel eenzijdig door de branche zelf vastgesteld ofwel in overleg met consumentenorganisaties. ${ }^{\text {3 }}$

Voorts zijn de geschillencommissies te onderscheiden naar de vorm waarin zij uitspraak doen. Meestal geschiedt de uitspraak in consumentengeschillen bij wege van bindend advies maar soms ook door middel van arbitrage. ${ }^{94}$

\subsubsection{Erkende geschillencommissies en de Stichting Geschillencommissies voor Consumentenzaken}

Een belangrijk onderscheid tussen de verschillende geschillencommissies is voorts het verschil tussen erkende en niet erkende geschillencommissies.

90 Zie uitgebreider: Boer, pag. 17 e.v. en het Themanummer van TVC 1986, nr. 3.

91 Boer, pag. 17.

92 Boer, pag. 17 e.v.

93 Boer, pag. 17.

94 Hondius, TwC 1986, pag. 183. 
De erkende geschillencommissies, bijna alle ressorterend onder de Stichting Geschillencommissies voor Consumentenzaken (SGC) ${ }^{95}$, zijn erkend door de Nederlandse overheid op grond van de "Erkenningsregeling Geschillencommissies consumentenklachten" van 18 januari $1990^{\circ}$. Om erkend te worden moeten zij voldoen aan de voorwaarden vermeld in deze erkenningsregeling. Zo moeten onder meer de gebruikers aangesloten bij de betreffende geschillencommissie tot de zelfde branche behoren, een groep van voldoende betekenis vormen, dient de samenstelling van de geschillencommissie voldoende waarborgen te bieden voor een goede rechtsgang en onpartijdigheid en dient de geschillencommissie open te staan voor iedere tot de branche behorende ondernemer. ${ }^{97}$ Erkende geschillencommissies worden via de Stichting Geschillencommissies voor Consumentenzaken gesubsidieerd door het Ministerie van Economische Zaken. Het Ministerie heeft daarbij als "vaste" beleidslijn slechts die geschillencommissies te subsidiëren die ressorteren onder de SGC.98

Naast deze erkende geschillencommissies bestaat een aantal niet door de overheid erkende geschillencommissies. ${ }^{99}$ Bekende niet erkende geschillencommissies zijn bij voorbeeld de Geschillencommissie Bankbedrijf, de ANWBFOCWA Geschillencommissie en de Klachtencommissie effectenbedrijf. Het feit dat geen erkenning is aangevraagd kan verschillende oorzaken hebben. Zo kan het onder andere zijn, dat de betrokken branche-organisatie er niet in geslaagd is tot overeenstemming te komen met de Consumentenbond over de te hanteren voorwaarden of dat ook beroeps- of bedrijfsmatige afnemers kunnen klagen bij de commissie. ${ }^{100}$

Zoals reeds vermeld ressorteren de meeste van de erkende geschillencommissies onder de Stichting Geschillencommissies voor Consumentenzaken. ${ }^{101}$ Deze stichting, in maart 1970 opgericht onder de maam Stichting Consumentenklachten, is een samenwerkingsverband van de Consumentenbond en een aantal branche-organisaties. ${ }^{102} \mathrm{Zij}$ stelt zich ten doel het beslechten van tussen consumenten en ondernemers gerezen geschillen, die voortvloeien uit klachten van

95 Boer, pag. 20.

96 Staatscourant 19 januari 1990 , pag. 14 en 15 . Van 1975 to 1990 vond erkenning plats op grond van de Erkennings- en Subsidiëringsregeling Commissies Consumentenklachten, Statstscourant 26 november 1975, nr. 320. Zie hierover: Hondius, TvC 1986, pag. 184; Boer, pag. 20.

97 Artikelen 3 en 4 Erkenningsregeling geschillencommissien consumentenklachten.

98 Toelichting Erkenningsregeling geschillencommissies consumentenklachten. Zie ook: SGC 1990, pag. 11-13.

99 Zie voor een overzicht: Wegwijzer bij Consumentenkllachten, zesde herziene druk, C.C.A.publikstie 1992, uitgave van de (SER) Commissie voor Consumentenaangelegenheden, pag. 45 c.y.

100 Hondius, TvC 1986, pag. 184.

101 Stichting Geschillencommissies voor consumentenzaken; Surinamestraat 24,2585 GJ Den Haag.

102 In 1988 verkreeg de stichting haar huidige naam. 
consumenten over geleverde goederen en diensten. Het doel tracht de SGC te verwezenlijken door het oprichten en in stand houden van geschillencommissies, die, nadat zij partijen in het geschil de gelegenheid hebben gegeven hun standpunt toe te lichten, uitspraak doen bij wege van bindend advies. ${ }^{100}$

Voor oprichting van een geschillencommissie binnen de SGC geldt een. aantal voorwaarden ${ }^{104}$ :

-De branche-organisatie die wil komen tot oprichting van een geschillencommissie moet een behoorlijke organisatiegraad hebben en bereid zijn bij te dragen in de kosten van de geschillencommissie;

-De branche-organisatie moet bereid zijn de door haar leden gehanteerde leveringsvoorwaarden zodanig aan te passen dat sprake is van evenwichtige voorwaarden ${ }^{105}$;

-De branche-organisatie moet bereid zijn garant te staan voor de nakoming van de bindende adviezen door haar leden;

-De op te richten geschilleneommissie moet qua samenstelling en werkwijze voldoen aan de eisen gesteld in de Erkennings- en Subsidiëringsregeling Commissies Consumentenklachten ${ }^{\| 106}$.

Op 1 januari 1994 waren onder de paraplu van de SGC 18 geschillencommissies werkzaam. ${ }^{107}$

103 SGC 1990, pag. 5. Zie ook: Boer, pag. 19.

104 SGC 1990, pag, 10-11.

105 De SGC bemoeit zich niet met de inhoud van de algemene voorwaanden. Het overleg over dleze inhoud, dat in beginsel plaats windt onder auspiciën van de (SER) Commissie voor Consumentenaangelegenheden (CCA), wondt overgelaten aan de consumentenorganisaties en de brancheorganisaties.

106 De SGC neemt geen geschillencommissie onder haar hoede als het Ministerie van Economische Zaken niet bereid is deze commissie te erkennen en dus ook niet bereid is er subsidie asn te vertenen, Zie SGC 1990, pag. 11.

107 1. Chemisch reinigen, ingesteld in 1970 door Consumenteribond (CB) en Nederlandse Vereniging van Textielreinigers (Netex); 2. Natwas, ingesteld in 1971 door $\mathrm{CB}$ en Nederlandse Vereniging van Wasserijen (NWW); 3. Reizen, ingesteld in 1972 door CB en Algemeen Verbond van Reisondernemingen (ANVR); 4. Recreatie, ingestell in 1973 door Algemene Nederlandse Wielrijders Bond (ANWB)/CB en Organisatie van Recreatio Ondememers Nederland (RECRON)/Algemene Nederlandse Vereniging van VVV's; 5. Woninginrichting, ingesteld in 1976 door CB en Federatie van Meubileringsbonden; 6. Perket, ingesteld in 1979 door CB en Vereniging van Parketwloeren Leveranciers (VPL); 7. Keukens, ingesteld in 1979 door CB en Algemene Nederlandse Vereniging van Keukenspecialisten (ANVK); 8. Openbare Nutsbedrijven, ingesteld in 1980 door $\mathrm{CB}$ en de Verenigingen van Exploittanten van respectievelijk Elektriciteitsbedrijwen (VEEN), Gasbedrijven (VEGIN), Waterleidingbedrijwen (VEWIN) en Stadsverwarmingsbedrijven (VESTIN) in Nederland; 9. Bankzaken (Postbank). ingesteld in 1987 door CB en Postbank NV; 10. Post en Telecommunicatie, ingesteld in 1989 door CB en PTT Nederland NV; 11. Optiek, ingesteld in 1990 door CB en Vereniging Nederlandse Unie van Opticiens (NUVO); 12. Uitwartwezen, ingesteld in 1991 door CB en Landelijke Organisatie van Uitvaartverenigingen (LOVU)/Nederlandse Unie van Ondernemers in het Uitwartwerzorgingsbedriff (NUVU); 13. Verhuisbedrijwen, ingesteld in 1991 door CB en 


\subsubsection{Voor-en nadelen van geschillencommissies vergeleken met de burgerlijke rechter}

Aan geschillenbeslechting door particuliere geschillencommissies kleven vooren nadelen voor de consument. Als belangrijkste voordelen voor de consument van deze vorm van geschillenbeslechting ten opzichte van geschillenbeslechting door de overheidsrechter worden genoemd: grote technische deskundigheid, lage kosten, snelle rechtsgang, weinig psychologische belemmeringen, een weinig formele procedure en oordeel naar redelijkheid en billijkheid op basis van evenwichtige algemene voorwaarden. ${ }^{108}$

Natuurlijk heeft geschillenbeslechting door geschillencommissies ook nadelen voor de consument indien men deze vorm van geschillenbeslechting vergelijkt met die van de overheidsrechter. Genoemd worden: minder waarborgen voor een onpartijdige uitspraak, gecentraliseerde vestiging van geschillencommissies en daardoor een grotere geografische afstand, afhankelijkheid van de vrijwillige medewerking van de leverancier en van de organisatiegraad van de branche, geen waarborgen voor de continuïteit van de particuliere rechtsgang, verschil in toepassing van het recht, geen executoriale titel, geen hoger beroep en het ontbreken van de mogelijkheid een collectieve actie in te stellen. ${ }^{109}$

Ondanks de genoemde nadelen, die overigens niet voor elke geschillencommissie even sterk spelen, voorzien branchegeschillencommissies in een duidelijke behoefte van de consument aan een eenvoudige, snelle en goedkope geschillenbeslechtingsprocedure en spelen zij een belangrijke rol in het consumentenrecht. ${ }^{110}$ Dit moge duidelijk blijken uit de cijfers met betrekking tot het aantal bij de Stichting Geschillencommissies voor consumentenzaken ingediende klachten en door de geschillencommissies gedane uitspraken. Zo werden in de eerste vijftien jaar van het bestaan van de SGC - vanaf de oprichting in maart 1970 tot eind 1985 - circa 45.000 klachten ingediend en kwamen de geschillencommissies tot circa 26.000 uitspraken." Van 1986 tot en met 1991 werden

107(...vervollg)

Samenwerking Vakafdelingen Meubeltransport (SAVAM); 14. Openbaar Verwoer, ingesteld in 1992 door CB en NS; 15. Auto's, ingesteld in 1992 door ANWB/Konsumentenkontakt(KK)/CB en BOVAG; 16. Waternecreatie, ingesteld in 1992 door ANWB/CB en Nederlandse Vereniging ven Ondernemingen in de Bedrijfstak Waterrecreatie (HISWA); 17. Installerende Bedrijven, ingesteld in 1993 door $\mathrm{CB} / \mathrm{KK}$ en Vereniging van Nederlandse Installatiebedrijven (VNI); 18. Textiel, ingesteld in 1993 door CB en Vereniging van Ondememers in de Modedetailhandel (MITEX).

108 Verburgh, Trechter, pag. 6; Francken, 1982, pag. 54; Last, pag. 237-238; Boer, pag. 23 e.v.

109 Boer, pag. 26 e.v.; Weernekers, pag. 245-246; Last, pag. 240-242; Elders, Minnelijke schikking, pag. 69-70.

110 Verburgh, Trechter, pag. 5-6; Hondius, TwC 1986, pag. 183; Last, pag. 238-239.

111 Last, pag. 238. 
in totaal 29.485 klachten ingediend en kwamen de commissies tot 14.685 uitspraken. ${ }^{112}$ In 1992 en 1993 werden respectievelijk 6027 en 6594 nieuwe zaken aan de geschillencommissies voorgelegd en kwamen de commissies tot respectievelijk 2770 en 3169 einduitspraken. ${ }^{113}$ Ook de niet-erkende geschillencommissies staan in de belangstelling van de consument. Zo werden bij de Geschillencommissie Bankbedrijf in de periode van september 1985 tot en met december 19911742 klachten ingediend. ${ }^{14}$

112 Jaarverglagen SGC $1987,1988,1989,1990,1991$.

113 Jaarverslag Stichting Geschillencommissies woor Consumentenzaken 1992, pag. 20 en 1993. pag. 21 .

114 Jaarversilag Geschillencommissie Bankbedrijf, jamuari 1992 - december 1992, pag. 8. 


\section{De wetgever en algemene voorwaarden; het collectief actierecht voor consumentenorga- nisaties}

\subsection{Inleiding}

Algemeen wordt aanvaard dat redelijke algemene voorwaarden een nuttige en zelfs onmisbare rol in het rechtsverkeer kunnen spelen.' ${ }^{\prime}$ Het gebruik van algemene voorwaarden had en heeft echter ook zijn schaduwzijden. In praktisch alle standaardvoorwaarden wordt de rechtspositie van de ondernemer versterkt en worden de rechten van de consument (vaak ontoelaatbaar) beperkt. De risico's worden door ondernemers vaak afgewenteld op de consument. ${ }^{2} \mathrm{De}$ consument heeft nauwelijks invloed op de contractsinhoud ${ }^{3}$ en de gehanteerde algemene voorwaarden zijn voor de gemiddelde consument doorgaans onbegrijpelijk. $^{4}$

Vanaf de jaren vijftig groeide in Nederland dan ook geleidelijk het besef dat aan een aantal negatieve aspecten van het gebruik van algemene voorwaarden een halt moest worden toegeroepen. Aanvankelijk werd wettelijk ingrijpen afgewezen en zocht men een oplossing in instrumenten die door de rechtspraak werden aangeboden. ${ }^{5}$ Deze instrumenten werden echter gaandeweg als onbevredigend ervaren en de roep naar overheidsingrijpen werd steeds luider. ${ }^{6}$ Met de invoering van het nieuwe Burgerlijk Wetboek is dit overheidsingrijpen op het terrein van de algemene voorwaarden gerealiseerd.

1. Zie hiervoor paragrant 2.2.2.

2 Zie hiervoor paragraaf 2.5.1.

3 Zie hienvoor paragraaf 2.5 .5 .

4 Zie hierwoor paragrafi 2.5.4.

5 Zeijlemaker, pag. 123; Jansma, HNJV 1948, 1 (2e stuk), pag, 79; HNJV 1948, I (2c stuk), pag. 88-90; Van de Sande Bakhuijzen, pag. 281 e.w.; Dalhuisen, pag. $51-52$ en 82 ; Van der Werf, diss., pag. 90-91; Van der Werf, NJB 1980, pag. 682 e.v.; Vollebregt, pag. 809 e.v.

6 Hondius, diss., pag. 819. CCA-advïes, pag. 6 e.w.; Hondius, preadvies, pag. 198 e.v.; In navolging van het preadvies van Hondius beantwoondde een grote meerdertheid van de aanwezigen op de vergadering van de NJV hel vraggunt "Biedt de geldende wetgeving, mede gezien de ontwikkeling in de rechtspraak, voldoende bescherming aan de adherent en de gebruiker?" ontkennend. Zie: HNJV 1979, deel 2, pag. 146. 
Het inleidende deel $\mathbb{I}$ wordt in dit hoofdstuk derhalve afgerond met een inventarisatie van het beleid van de Nederlandse overheid op het terrein van de algemene voorwaarden, de instrumenten die de overheid ter beschikking staan ter bescherming van het consumentenbelang op dit terrein en de keuze die de Nederlandse overheid ter uitvoering van haar beleid daaruit heeft gemaakt.

Centraal daarbij staat uiteindelijk de keuze van de Nederlandse wetgever voor het collectief actierecht voor consumentenorganisaties op dit terrein. Allereerst zal daartoe in de volgende paragraaf aandacht worden besteed aan de beleidsinstrumenten die de overheid ter uitvoering van haar taak ter beschikking staan. Daarbij wordt met name aandacht besteed aan het verschijnsel dat bekend staat als zelfregulering en dat door de Nederlandse overheid als expliciet beleidsinstrument op het terrein van algemene voorwaarden is geadopteerd. In de artikelen 6:240 tot en met 6:243 BW is aan consumentenorganisaties het collectieve actierecht immers mede gegeven om het onderhandelingsproces tussen consumentenorganisaties en branche-organisaties inzake te hanteren algemene voorwaarden te stimuleren. ${ }^{7}$ In paragraaf 3 worden vervolgens de beleidsdoelen van de overheid op het terrein van de algemene voorwaarden geïnventariseerd en wordt nagegaan welke beleidsinstrumenten de overheid ter realisering deze doelen heeft gekozen. In paragraaf 4 wordt nagegaan hoe de Nederlandse wetgever de gekozen beleidsinstrumenten heeft ingevuld. In paragraaf 5 wordt nagegaan hoe de, in hoofdstuk 2 geïnventariseerde, knelpunten op het terrein van de algemene voorwaarden door de gekozen beleidsinstrumenten worden aangepakt. Het hoofdstuk wordt in paragraaf 6 afgesloten met een nadere beschouwing van de geschiedenis en de betekenis van het collectief actierecht voor consumentenorganisaties op het terrein van de algemene voorwaarden als beleidsinstrument van de overheid.

\subsection{Beleidsinstrumenten van de centrale overheid}

De overheid staan ter uitvoering van haar taak en het daartoe gekozen beleid slechts een beperkt aantal beleidsinstrumenten ter beschikking. Het beleidsinstrument bij uitstek van de centrale overheid is natuurlijk regelgeving.

Tot het klassieke beleidsinstrumentarium van de (Nederlandse) overheid kunnen verder worden gerekend: het verlenen van subsidies ${ }^{9}$ en voorlichting. ${ }^{10}$ Andere, meer moderne, ter beschikking staande beleidsinstrumenten zijn het

7 MvT Inv., Parlementaire Gegchiedenis, Inv. 3, 5 en 6, pag. 1457, 1762 en 1765.

8. Hondius, diss., pag. 363; ICC-eindrapport, pag. 10; Braclik, TwC 1987, pag. 244; Von Hippel, pag. 25.

9 Hondius, diss., pag. 362 en 727 e.v.; ICC-eindrapport, pag. 53-54; Brack, TwC 1987, pag. 244.

10. ICC-eindrapport, pag. II0; Brack, TvC 1987, pag. 244 e.v. 
optreden van de overheid als moderator bij onderhandelingen tussen marktpartijen $^{11}$ en (het stimuleren) van zelfregulering. ${ }^{12}$

\subsubsection{Zelfregulering}

Sinds 1974 vindt in ons land, onder andere onder auspiciën van de CCA, in toenemende mate overleg plaats tussen consumenten- en branche-organisaties over de inhoud van de door de leden van de betreffende branche-organisatie te hanteren algemene voorwaarden. ${ }^{13}$ In de literatuur wordt dit tussen marktpartijen plaatsvindende onderhandelingsproces - en de resultaten daarvan - doorgaans aangeduid met de term zelfregulering. Toch bestaat over de terminologie en de inhoud van het begrip zelfregulering geen eenstemmigheid. Termen als soft law $^{14}$, concerted action ${ }^{15}$, gedragscodes, zelfregulering ${ }^{16}$, branche-codes, gentlemen's agreements, para-legale normen ${ }^{17}$ en zelfdiscipline ${ }^{18}$ hebben alle betrekking op regelingen die door (organisaties van) ondernemers al dan niet in overleg met (organisaties van) consumenten zijn opgesteld. Gemeenschappelijk kenmerk is dat het opstellen van regels, de toepassing en de eventuele handhaving ervan door middel van sancties, niet geschiedt op basis van een wettelijke instelling of bevoegdheidsverlening, maar op strikt particuliere basis, meestal door middel van een overeenkomst en soms door eenzijdige afkondiging. ${ }^{19}$

Ondanks de verscheidenheid in terminologie en verschijningsvormen kiest men de laatste jaren in de literatuur in het algemeen voor zelfregulering als overkoepelend begrip. ${ }^{20} \mathrm{Bij}$ deze keuze sluit ik mij aan, temeer daar de Nederlandse wetgever eveneens consequent kiest voor de term zelfregulering.

11 Hondius, diss, pag. 362 en 731 e.v, ICC-eindrapport, pag. 52, Brack, TvC 1987, pag. 248.

12 Hondius, diss, pag. 349 e.v; ICC-eindrapport, pag. 11; Brack, TvC 1987, pag. 246; Von Mippeil, pag. $25-27$.

13 CC.A, Van consument en consumptie, pag. 27-28, pag. 46-48 en pag. 56-59.

14 Tala, pag. 341 e.v.; Bourgoignie, JCP 1984, pag. 307 e.v." Wan Driel, diss., pag. 14.

15 Hondius, JCP 1984, pag. 139, Wan Driel, diss, pag. 13 .

16 Hondius, diss., pag. 345; Kabel, pag. 151; Van Mierlo, 247; Huls, pag. 9" Van Driel, Regelmaat 1987, pag. 158; Mölenberg en Van der Sluijs, pag. 259; Van Driel, diss., pag. 2.

17 H. Bracekmans, Para-legale normen en Lex Mercatoria, Tijdsehurift voor Privatrecht 1986, nr. 3, pag. 8 e.v.

18 Stuyck, pag. 81 e.w.; Van Driel, diss., pag. 12.

19 Kabel, pag. 151; Van Driel, diss., pag. 14.

20 Hondius, diss., pag. 345 e.v.; Kabel, pag. 151 e.v.; Van Mierlo, pag. 247 e.v.; ICC-eindrapport; Huls, pag. 10; Van Driel, Regelmaat 1987, pag. 158 e.v.; Van Driel, diss.; Mölenberg en Van der Sluijs, pag. 259. Het Tijdschrift voor Congumentennecht had sinds de eerste aflevering tot het dende nummer in 1990 een nagenoeg vaste rubriek onder deze benaming. 
De dereguleringsdiscussie van de tachtiger jaren heeft in Nederland geleid tot een veranderde houding van de wetgever ten opzichte van het wetgevingsinstrument, in die zin dat de overheid streeft naar vermindering van wetgeving. Voor het consumentenbeleid betekent dit dat de overheid zal bezien in hoeverre haar toekomende taken en verantwoordelijkheden door andere dan regelgevende maatregelen vervuld en geëffectueerd kunnen worden. Bij deze andere maatregelen wordt daarbij nadrukkelijk ook aan zelfregulering gedacht.

De aanzetten voor deze terughoudende opstelling ten opzichte van het wetgevingsinstrument werden gegeven door de dereguleringsrapporten van de Commissies Van der Grinten en Geelhoed en de werkgroep Nicaise, welke laatste concrete voorstellen tot deregulering deed op de beleidsterreinen sociaal-economische ordening en kwaliteitsbevordering. ${ }^{21}$

Voor de vormgeving van het consumentenbeleid was vooral het hierop volgende eindrapport inzake dereguleringsinvloeden op het consumentenbeleid van de Werkgroep Dereguleringsinvloeden Consumentenbeleid (ook bekend als de Commissie Lukaçs) van de (inmiddels opgeheven) Interdepartementale Coördinatiecommissie voor Consumentenzaken (ICC) van belang. ${ }^{22}$ Met als uitgangspunt handhaving van de doelstellingen van het consumentenbeleid (zie hierna paragraaf 4.3.1), ging het toenmalige kabinet grotendeels akkoord met de in het ICC-eindrapport vervatte hoofdlijnen en benadering voor toekomstige beleidsinstrumentenkeuze. ${ }^{23}$

Uitgangspunt van het ICC-eindrapport is de noodzaak de taakverhouding tussen consumentenorganisaties en de overheid te herbezien in het licht van het overheidsstreven naar vermindering van regelgeving en de daarmee gepaard gaande oriëntatie op andere beleidsinstrumenten. De werkgroep stelt daarbij voorop dat terughoudendheid en soberheid bij wetgeving niet meebrengt dat regelgeving in de toekomst op voorhand wordt afgewezen. Wetgeving ter bescherming van consumentenbelangen blijft nog steeds mogelijk mits, na grondige toetsing, de noodzaak ertoe en de effectiviteit ervan vaststaan. Wetge-

21 Kamenstukkken 17931 , nr. 5, rapport Commissie Van der Grinten (1983); Kamersiukken 17 931, nr. 9, rapport Commissie Geelhoed (1984); Kamerstukken 17 931, nr. 10-11, rapport Werkgroep Nicaise (1984). Zie himover meer uitgebreid: Hondius, TrC 1985, pag. 76 e.w; Van Driel, diss., pag. 42 e. ...

22 Dereguleringsinvloeden op het consumentenbeleid. Een benadering voor toekomstige instrumentenkeuze, Eindrappont van de door de Interdepartementale Coördinatiecommissie voor Consumentenzaken (ICC) ingestelde Werkgroep Dereguleringsimvloeden Consumentenbeleid. Den Hagg, 18 september 1985. Zie hierower: Brack, TvC 1987, pag. 243-247; Van Driel, Regelmant 1987, pag. 158-159; Mölenberg en Van der Sluijs, pag. 265-266; Van Driel, diss., pag. 70 e.v.; Rijken, Mölenberg en Verstappen, pag. 10.14.

Kamerstukken 19342 , nr. 1 . 
ving ter bescherming van consumentenbelangen is echter niet op zijn plaats indien deze toetsing of afweging ertoe leidt dat uitsluitend eigen activiteiten van consumenten of hun organisaties, met of zonder ondersteuning in enigerlei vorm door de overheid, als adequate oplossingen gezien moeten worden. Indien zelfregulering effectiever is ter bescherming van consumentenbellangen dan wetgeving (of andere beleidsinstrumenten zoals voorlichting, subsidiëring of het optreden als moderator) en de noodzaak van wetgeving voor de bescherming van deze belangen niet aanwezig is, verdient zelfregulering als beleidsinstrument de voorkeur. ${ }^{24}$

Op zoek naar een methodische benaderingswijze van het beleidsinstrumentarium op consumententerrein verdeelde de werkgroep het terrein van de consumentenbelangen in drie aandachtsvelden die het rellevante terrein van de consumentenbelangen in voldoende mate afdekken:

a.de zorg voor het fysieke welzijn van de consument, waarbij belangen van gezondheid en veiligheid centraal staan;

b.de zorg voor de consument als zelfstandige marktpartij, te weten zijn economische belangen;

c.klachten en geschillen, als bijzonder onderdeel van het gestelde onder b., zijnde de mogelijkheden van de consument om zijn recht te halen na het sluiten van een contract, alsmede klachten inzake verkoopmethoden. ${ }^{25}$

Een indicatie van aard en reikwijdte van het overheidsoptreden op deze drie aandachtsvelden tracht de werkgroep te geven door een verdere systematisering in de vorm van drie beschermingsniveaus: een basisbeschermingsniveau gevolgd door een tweede en derde beschermingsniveau. ${ }^{26}$

Op het basisbeschermingsniveau acht de overheid het primair haar eigen verantwoordelijkheid om een optimale bescherming van consumentenbelangen te bewerkstelligen. De overheid vervult hierbij een actieve en initiërende rol. Als mogelijke beleidsinstrumenten komen wetgeving, zelfregulering, het optreden als moderator, voorlichting en subsidie in aanmerking, waarbij de keuze zal afhangen van de effectiviteit van het instrument. ${ }^{27}$

Op het tweede beschermingsniveau ligt volgens de overheid de primaire verantwoordelijkheid bij de betrokken marktpartijen zelf. Door middel van zelfregulering zullen deze marktpartijen tot adequate bescherming van consumentenbelangen op dit niveau dienen te komen. De overheid heeft op dit niveau 
weliswaar een eigen verantwoordelijkheid, doch deze is van secundaire aard: gestreefd wordt naar het bevorderen van zelfregulering vanuit een terughoudende opstelling, met dien verstande dat indien zelfregulering niet het gewenste resultaat oplevert, de overheid alsnog andere beleidsinstrumenten, waaronder wetgeving, zal kunnen inzetten. ${ }^{28}$

Op het derde beschermingsniveau ligt de uitsluitende verantwoordelijkheid voor belangenbescherming bij de betrokken marktpartijen. Ook indien zelfregulering geen adequaat resultaat oplevert acht de overheid zich op dit niveau niet geroepen om op te treden. ${ }^{29}$ Volgens de toenmalige staatssecretaris Van Zeil is deze categorie derhalve slechts genoemd voor de volledigheid en ter bescherming van particulier initiatief. ${ }^{30}$

Doel van de koppeling van aandachtsvelden aan beschermingsniveaus is, dat, als eenmaal bepaald is op welk niveau een aandachtsveld thuishoort, bekend is of de overheid op dit aandachtsveld een taak voor zichzelf ziet weggelegd en zo ja, of deze taak van primaire of secundaire aard is. Indien is vastgesteld dat de overheid op een specifiek aandachtsveld een taak heeft, zal vervolgens, mede aan de hand van de aard van die taak, bepaald moeten worden voor welke beleidsinstrumenten gekozen dient te worden om deze te taak te verwezenlijken. $^{31}$

\subsection{Beleidsdoelen en beleidsinstrumentenkeuze van de centrale overheid op het terrein wan de algemene woorwaarden}

Zoals reeds aangegeven in paragraaf 4.3.1 was thet uitgangspunt bij de beleidsinstrumentenkeuze van de overheid de doelstellingen van het consumentenbeleid te handhaven. Welke zijn echter de doelstellingen van dit beleid op het terrein van de algemene voorwaarden? In deze paragraaf worden de beleidsdoelen van de overheid op het terrein van de algemene voorwaarden geïnventariseerd en wordt nagegaan welke beleidsinstrumenten de overheid ter realisering van deze doelen heeft gekozen.

31 ICC-eindrapport, pag. 9.

\section{4}




\subsubsection{Beleidsdoelen van de centrale overheid op het terrein van de algemene voorwaarden}

Het verschijnsel algemene voorwaarden komt, met het voornemen om te komen tot een nieuw Burgerlijk Wetboek, in het begin van de jaren vijftig pas echt in de belangstelling van de Nederlandse overheid. Het overleg tussen regering en Staten-Generaal over dit nieuwe Burgerlijk Wetboek vond in de beginfase plaats aan de hand van door Meijers, in overleg met de Minister van Justitie, opgestelde vraagpunten. Van belang op het terrein van de algemene voorwaarden was vooral het op de standaardregeling gerichte vraagpunt 24.32

Moet meer dan thans de mogelijkheid geopend worden, dat voor bepaalde contracten de toepasselijke regels niet door de wet worden vastgesteld, maxar door de Kroon of een andere overheidsinstantie onder medewerking of ma raadpleging der belanghebbenden?

De vraag die door de regering en Staten-Generaal bevestigend werd beantwoord ${ }^{33}$, zij het met de restrictie dat standaardregelingen slechts bepalingen van aanvullend recht mogen bevatten, heeft uiteindelijk geleid tot het huidige artikel 6:214 BW inzake de standaardregeling.

Reeds in de discussie omtrent de standaardregeling stond de overheid een zekere bescherming van wederpartijen bij standaardregelingen, lees algemene voorwaarden, voor ogen. Gesteld wordt dat één van de voordelen van de (wettelijke) standaardregeling is te vinden in het feit dat

"... de tegenwoordige standaardregelingen weelal worden vastgesteld door ém groep der belanghebbenden, ondat de andere groep miet, of mier voldoende, is georganiseerd. De onder leiding van de Overheid tor stand gekomen standaardregelingen zullen in betere mate met de belangen van die andere groep en met het algemeen belang rekening kunnen houden. ${ }^{\text {34 }}$

Het ontwerp van wet van Boek 6 van het nieuwe Burgerlijk Wetboek bevatte in artikel 6.5.1.2 dan ook (nagenoeg) de huidige regeling van artikel 6:214 BW. Daarnaast was in artikel 6.5.1.3 van het ontwerp voorzien in een regeling ten aanzien van de gebondenheid aan algemene voorwaarden (lid 1) en, een op de dwalingsregeling geënte, vernietigingsgrond voor bedingen die ongebruikelijk of onereus zijn (lid 2). ${ }^{35}$

32 "Tweede Kamer 1952/1953, 2846, nurs. 4-5, pag. 2.

33 Tweede Kamer 1952/1953, 2846, nrs. 4-5, pag. 2; Tweede Kamer 1952/1953, 2846, nr. 33, pag. 2 .

34 Tweede Kamer $1952 / 1953,2846, n r .25$, pag 5 .

35 Toelichting ontwerp Boek 6 NBW, Parlementaine Geschiedenis, Boek 6, pag. 865. 
Arikel 6.5.1.3

1. Degene die door ondertekening of op andere wijze heeft te kennen gegeven de inhoud van ein geschinft of een verwijzing naar algemene woorwaanden te acanvaarden, is daaracan ook dan gebonden, als bij het sluiten wan de overeenkomust zijn wederpartij begreep of moest begrijpen dat hij de inhoud doarvan niet kende.

2. Niettemin is, onwerminderd het in artikel 3.2.10 (het hwidige artikel 3:44 BW, LJHM) bepaalde, een beding vernietigbaar, indien de wederpartij bij het sludten van de overeenkomut begreep of moest begrijpen dat de ander, indien hij het beding had gekend, deze overeenkiomst niet zou hebben aangegaan. 36

Volgens de toelichting op het ontwerp beoogden de artikelen 6.5.1.2 en 6.5.1.3 "bij te dragen tot een oplossing van het probleem der zogenaamde standaard-en formuliercontracten" ${ }^{37}$ Geconstateerd werd dat de bij deze regelingen gerezen moeilijkheden voornamelijk hieruit voortkomen dat:

-zij veelal eenzijdig door én partij of belangengroep worden opgesteld, terwijl de potentiële wedlerpartijen slechts de keuze hebben tussen aanvaarding van het gehele complex van voorwaarden en niet-contracteren;

-in vele gevallen de wederpartijen bovendien geen kennis nemen van de inhoud der regeling;

-onder deze omstandigheden er niet voldoende waarborgen zijn dat de regelingen niet een onbillijke bevoordeling van een der partijen in de hand werken of voor haar een dusdanige machtspositie opbouwen dat de andere contractant volledig aan haar coulance is overgeleverd;

-de huidige middelen die de rechter onder het geldende wetboek ter beschikking staan (artikelen 1356, 1371, 1373 en 1374 lid 3 BW (oud)) onvoldoende zijn. ${ }^{38}$

Vanuit deze constatering werd gekozen voor een oplossing van de problematiek van de algemene voorwaarden door middel van nieuwe wetgeving die gedeeltelijk algemeen gericht is en gedeeltelijk alleen op algemene voorwaarden is toegesneden.

In de regeling van artikel 6.5.1.3 lid 1 van het ontwerp NBW stond de rechtszekerheid voorop en koos de overheid voor snelle gebondenheid aan algemene voorwaarden. Door te bepalen dat de wederpartij ook aan algemene voorwaarden gebonden is indien de gebruiker begreep of moest begrijpen dat deze de inhoud daarvan niet kende, werd een duidelijk wettelijk antwoord gegeven op de, in de literatuur meermaals gestelde vraag in hoeverre een wederpartij gebonden is aan algemene voorwaarden waarvan zij de gelding heeft aanvaard

36 Tweede Kamer, Zitting 1963-1964, 7729, Nr. 2 (Ontwerp van Wet), pag. 27.

37 Toeilichting ontwerp Boek 6 NBW, Parlementaine Geschiedenis, Boek 6, pag. 851 .

38 Toelichting ontwep Boek 6 NBW, Parlementaire Geachiedenis, Boek 6 , pag 851. 
terwijl zij de inhoud daarvan niet kent en de gebruiker van dit niet-kennen op de hoogte is.

De regelingen van de artikelen 3.2.10 lid 4 (misbruik van omstandigheden), 6.5.1.3 lid 2 en 6.5.1.2 zien op de inhoud van de algemene voorwaarden. De tandem van enerzijds het repressieve toezicht van de rechter op de inhoud van algemene voorwaarden op grond van artikel 3.2.10 lid 4 en 6.5.1.3 lid 2 en anderzijds de standaardregeling van artikel 6.5.1.2 moest bewerkstelligen dat in de praktijk algemene voorwaarden worden gehanteerd

".... waanuan mag worden verwachu dat zij met de eisen wan de rechwocardigheid in overeenstemming zijim en wan praktische zin zullen getwigen. ${ }^{39}$

In de memorie van toelichting op het wetsontwerp ter vaststelling van de rijksbegroting voor het dienstjaar 1975 werd echter aangekondigd dat het Ministerie van Justitie voornemens is een nieuwe wettelijke regeling betreffende algemene voorwaarden tot stand te brengen ${ }^{40}$ en werd de beraadslaging omtrent de problematiek van de algemene voorwaarden en daarmee omtrent de regeling van artikel 6.5.1.3 van het ontwerp voorlopig in de ijskast gezet. ${ }^{41}$

Tegelijkertijd wordt in de Memorie van Antwoord benadrukt dat de regelgeving inzake de standaardregeling slechts indirect gericht is op de problematiek van de algemene voorwaarden. De strekking van de regeling is immers het vermijden van wettelijke regelingen van aanvullend recht door voor bepaalde overeenkomsten standaardregelingen op te stellen op een zodanige wijze, dat de kring van contractanten bij de opstelling ervan zoveel mogelijk betrokken is. Deze standaardregelingen kunnen weliswaar er toe bijdragen dat de behoefte aan algemene voorwaarden afneemt en zullen bij een eventuele toetsing van algemene voorwaarden van belang zijn voor de vraag wat binnen de betreffende kring van contractanten als een redelijke regeling beschouwd moet worden, dit zijn echter maar (wenselijke) neveneffecten. Mede omdat de standaardregeling in beginsel slechts van aanvullend recht is, leent het artikel 6.5.1.2 zich, in de opvatting van de wetgever, nauwelijks voor een effectieve bescherming van de consumenten tegen het euvel van eenzijdige of moeilijk kenbare algemene voorwaarden. ${ }^{42}$

39 Toelichting ontwerp Boek 6 NBW, Parlementaire Geschiedenis, Boek 6, pag. 852.

40 Tweede Kamer, 1974-1975, 13 100, hoofdstuk VI, nr. 2, pag. 7.

4) Tweede Kamer, 1975-1976, 7729, urs. 6-7 (MvA), pag. 196.

42 Tweede Kanner, 1975-1976, 7729, nirs. 6-7 (MvA), pag. 196. Zie ook: MVT Inv., Parlementaire Geschiedlenis, Inv. 3,5 en 6 , pag. 1458, alwar wordt opgemerkt "De functie van artikel 6.5.1.2 ligt niet in de cerste plaats op het gebied van de consumentenbescherming..." 
De eerste stappen op weg naar de in de rijksbegroting voor 1975 aangekondigde wettelijke regeling laten op zich wachten tot 1981, als het ontwerp voor het tweede gedeelte van de Invoeringswet Boeken 3-6 van het nieuwe Burgerlijk Wetboek met daarin een regeling met betrekking tot de algemene voorwaarden wordt ingediend. ${ }^{4}$ Zowel artikel 6.5.1.2 ontwerp NBW als het artikel 6.5:1.3 ontwerp NBW maken dan inmiddels deel uit van Boek 6 NBW dat in mei 1980, samen met de Boeken 3 en 5 door de Eerste Kamer werd aangenomen.4 De reden waarom het wetsontwerp pas in 1981 werd ingediend is gelegen in het feit: dat de wetgever in het ontwerp de adviezen van de CCA over respectievelijk de problematiek van de standaardwoorwaarden $(1978)^{45}$ en het voorontwerp van Boek 7 , titel 1 inzake de consumentenkoop. ${ }^{46}$

Het ontwerp van afdeling 6.5.2A en daarmee ook de huidige beleidsdoelen die de Nederlandse overheid op het terrein van de algemene voorwaarden nastreeft zijn, blijkens de toelichting, in essentie gebaseerd op het CCA-advies inzake het vraagstuk van de toepassing van standaardvoorwaarden bij transacties met de consument (CCA-advies), ${ }^{47}$

Uitgangspunt van de wetgever is dat algemene voorwaarden een nuttige rol spelen in het maatschappelijke verkeer en allerlei voordelen bieden. ${ }^{4}$ Daar staat echter tegenover dat de wetgever eveneens onderkent dat aan de hantering van algemene voorwaarden ook belangrijke nadelen kunnen zijn verbonden zoals:

-een zekere versluiering van de contractsinhoud; de consument kent dikwijls de inhoud van de voorwaarden niet en voor zover hij de beschikking heeft over de standaardvoorwaarden, zal hij er vaak nauwelijks kennis van nemen of de strekking ervan niet begrijpen;

-de consument heeft slechts de keus tussen aanvaarden van de algemene voorwaarden of niet-contracteren, van gelijkwaardigheid in de onderhandelingspositie is veelal geen sprake en in feite is van een echte onderhandelingspositie geen sprake;

-de consument wordt dikwijls geconfronteerd met bedingen die in onvoldoende mate rekening houden met zijn belangen. ${ }^{49}$

43 Tweede Kamer 1981,16983, nrs. 1-3 (Ontwerp van wel), pag. 1-8.

44 Stb. 1980, ans. 430-432.

45 Advies inzake het vraggstuk van de toepassing van standaardvoorwatirden bij transacties met de consument (CCA), SER-uitgave 1978, nr. 7 (CCA-rdvies).

46. Advies inzake het Voonontwerp van de wet Consumentenkoop (CCA), SER-uitgave 1980, nr. 6.

47 MvT Inv., Parlementsire Geschiedenis, Inv. 3, 5 en 6, pag. 1451 en 1456-1457.

48 MvT Inv., Parlementaire Geschiedenis, Inv, 3, 5 en 6, pag. 1451-1452.

49 MvT Inv., Parlementaire Geschiedenis, Inv. 3,5 en 6, pag. 1452-1453, Zie ook: CCA-advies, pegg. 42 . 
Vanuit het algemene beleidsstreven de positie van de consument in het privaatrecht te verbeteren ${ }^{50}$, is het beleid van de overheid op het terrein van de algemene voorwaarden derhalve erop gericht de consument een grotere bescherming te bieden tegen onereuze bedingen in standaardvoorwaarden ${ }^{51}$ en te komen tot een effectieve bestrijding van onereuze algemene voorwaarden die collectief worden gebruikt $t^{52}$. Het beleid is er niet op gericht het gebruik van algemene voorwaarden uit te bannen. Branchegenoten moet weliswaar de vrijheid worden gelaten zelf hun voorwaarden vast te stellen, maar deze vrijheid dient wel aan beperkingen te worden gebonden om niet de juridisch zwakkere partij het slachtoffer te laten worden. ${ }^{53}$ Uiteindelijk doel van de Nedlerlandse overheid op het terrein van de algemene voorwaarden is, dat in het verkeer met consumenten slechts algemene voorwaarden worden gehanteerd die op evenwichtige wijze met de wederzijdse belangen rekening houden ${ }^{54}$ of die, zoals de toenmalige staatssecretaris Van Zeil het zei,:

".... in overeenstemming zijn met de verdelende rechtvaardigheid".

Het voorgaande betekent dat de basisbescherming die de overheid voor de consument inzake algemene voorwaarden voor ogen staat, verder gaat dan het enkel uitbannen van onredelijk bezwarende algemene voorwaarden. Het overheidsstreven is immers tevens gericht op het uitbannen van onevenwichtige algemene voorwaarden in het rechtsverkeer met consumenten.

So CCA-advies, pag. 41.

51 MVT Inv., Parlementaire Geschiedenis, Inw. 3, 5 en 6, pag. 1453; (1CC) Jaarrappont Over. heidsbeleid Consumentenaangelegenheden 1975-1976, pag. 32; CCA-advies, pag. 4.

52. Mv'T Inw., Parlementaire Gesehiedenis, Inw. 3, 5 en 6, pag. 1764.

53 CC.A-advies, pag. 42; ICC-eindrapport, pag. 22.

54 MvT Inv., Parlementaire Geschiedenis, Inv. 3, 5 en 6, pag. 1765; CCA-advies, pag. 8.

55 Van Zeil, Inwoeringswet Boeken 3,5 en 6 van het nieuwe Burgerlijk Wetboek, Handelingen Tweede Kamer 1984-1985, UCV 5, 1 oktober 1984, pag. 5-13. 


\subsubsection{Beleidsinstrumentenkeuze van de overheid ter bescherming van het}

consumentenbelang op het terrein van de algemene voorwaarden

Voor wat betreft algemene voorwaarden leidt de in paragraaf 4.2 .2 genoemde koppeling tussen aandachtsvelden en beschermingsniveaus tot het volgende resultaat.

Algemene voorwaarden worden gerekend tot het aandachtsveld economische belangen van de consument, ${ }^{56}$ Uitgangspunt bij de benadering van dit aandachtsveld is dat het proces van produktie en consumptie in economische zin optimaal verloopt als het de resultante is van de individuele beslissingen van private marktpartijen, genomen binnen zekere, door de overheid te stellen randvoorwaarden. Belangrijke voorwaarde hierbij is een voldoende mate van gelijkwaardigheid van marktpartijen. Bij het stellen van die randvoorwaarden voor het aandachtsveld economische belangen kan de overheid kiezen voor het basisbeschermingsniveau, het tweede beschermingsniveau en soms zelfs het derde beschermingsniveau. ${ }^{57}$

Volgens de Commissie Lukaçs zijn vanuit de positie van de consument in het marktproces de volgende fasen te onderscheiden:

a.De précontractuele fase waarin de consument zich op de markt oriënteert en zich laat voorlichten en adviseren.

b. De contractuele fase waarin consument en aanbieder overeenstemming (proberen te) bereiken inzake de te sluiten overeenkomst.

c. Het gebied van de (onbehoorlijke) handelspraktijken. ${ }^{58}$

Algemene voorwaarden behoren tot de contractuele fase. De regulering van deze fase wordt gerekend tot het basisbeschermingsniveau. ${ }^{59}$ Uitgangspunt is het beginsel van contractswrijheid. De contractsvrijheid brengt weliswaar met zich dat partijen zelf de inhoud van hun overeenkomsten kunnen bepalen, maar dan wel binnen zekere, door de wetgever te stellen, grenzen. De basisbescherming van de consument inzake bij voorbeeld koop, dienstverlening en algemene voorwaarden dient dan bij voorkeur vast te liggen in regels van dwingend recht. Daarnaast wordt zelfregulering niet uitgesloten en op sommige terreinen zelfs

56 ICC-eindrapport, pag. 16.

57 ICC-eindrapport, pag. 15 e.v.

58 ICC-eindrapport, pag. 15-16. Het is overigens vreernd dat de Commissie heeft gekozen voor de term fasen. Het gebied van de (onbehoorljike) handelspraktijken kan men immens bezwatarlijk een fase noemen.

59 lCC-eindrapport, pag. 22; Brack, TwC 1987, pag 245; Möllenberg en Van der Sluijsi, pag. 266; Rijken; Mölenberg en Verstappen, pag. 12; Van Driel, diss., pag. 71. Anders: Van Driel, Regelmaat 1987, pag. 159. Zij platst de bescherming van economische belangen op het tweedie beschermingsniveau. 
bevorderd, bij voorbeeld het branchevoorwaardenoverleg. Indien zelfregulering onvoldoende resultaat oplevert kan de overheid ingrijpen middels wetgeving. ${ }^{60}$

De basisbescherming voor de consument op het terrein van de algemene voorwaarden zal dus enerzijds voor een deel gerealiseerd dienen te worden door de beleidsinstrumenten wetgeving, subsidie en voorlichting. Anderzijds voor een deel door het beleidsinstrument zelfregulering en well in de vorm van overleg en overeenstemming tussen consumentenorganisaties en branche-organisaties over te hanteren algemene voorwaarden in transacties met consumenten. ${ }^{61}$

\subsection{Invulling van de gekozen beleidsinstrumenten ter bescherming van het consumentenbelang op het terrein van de algemene voorwaarden}

Het beleidsvoornemen inzake de basisbescherming voor de consument inzake algemene voorwaarden komt in het tot nu toe door de overheid gevoerde beleid alsmede in de keuze van de bijbehorende instrumenten duidelijk naar voren. Enerzijds een strikt stelsel van dwingende rechtsregels die beogen de rechterlijke controle op algemene voorwaarden te versterken en onredelijk bezwarende algemene voorwaarden uit te bannen zoals afd. 6.5.3 BW, titel 7.1 BW en artikel 6:214 BW en anderzijds een eigen verantwoordelijkheid voor marktpartijen om middels zelfregulering, op haar beurt weer gestimuleerd door wetgeving, te komen tot algemene voorwaarden die op evenwichtige wijze met de wederzijdse belangen rekening houden en in overeenstemming zijn met de verdelende rechtvaardigheid.

Zowel het zelfreguleringsproces als de rechtshandhaving door middel van collectieve actie worden daarbij gestimuleerd doordat de overheid subsidies verleent en optreedt als moderator. In de volgende (sub)paragrafen komt de invulling van de verschillende beleidsinstrumenten aan de orde. Het feit dat deze beleidsinstrumenten afzonderlijk aan de orde komen, wil niet zeggen dat zij ook los en geïsoleerd van elkaar staan. Er bestaat een zekere wisselwerking en samenhang tussen de verschillende beleidsinstrumenten op het terrein van de algemene voorwaarden.

\subsubsection{Wetgeving}

Wetgeving kan op een aantal manieren en gebieden voorzien in consumentenbescherming op het terrein van de algemene voorwaarden. De wetgever had de

60 ICC-eindrapport, pag. 22.

61 Rijken, Mölenberg en Verstappen, pag. 12. 
keuze uit een veelheid van in de literatuur aangedragen mogelijkheden ${ }^{62}$. Genoemd worden onder andere versterking van de repressieve rechterlijke controle, het bevorderen van concurrentie, het opnemen van meer dwingende rechtsregels, standaardregelingen, zelfregulering, preventief en repressief toezicht door de overheid, het instellen van een consumentenombudsman en zelfs een algeheel verbod van algemene voorwaarden.

De Nederlandse overheidl heeft, met de invoering van het nieuwe Burgerlijke Wetboek, een viertal regelingen specifiek gericht op het verschijnsel algemene voorwaarden zijn intrede laten doen in het Nederlandse privaatrecht:

-de Wet algemene voorwaarden, afdeling 6.5.3 BW, de artikelen 6:231 tot en met 6:247 BW;

-titel 7.1 BW inzake Koop en ruil, artikel 7:6 en artikel 7:25 lid $2 \mathrm{BW}$;

-de Standaardregeling, artikel 6:214 BW;

-artikel 6:225 lid $3 \mathrm{BW}$.

In artikel 6:225 lid $3 \mathrm{BW}$, dat zich naar alle waarschijnlijkheid niet richt op de individuele consument (consumenten zullen zelf niet contracteren onder gebruikmaking van algemene voorwaarden ${ }^{63}$ ), is een regel van aanvullend recht opgenomen met betrekking tot de toepasselijkheid van algemene voorwaarden. Voorts is de overheid bij de in artikel 6:214 BW neergelegde standaardregeling, direct betrokken bij het opstellen van deze regelingen van aanvullend recht voor een bepaalde categorie overeenkomsten en kan zij daar preventief toezicht op uitoefenen. Het meeste gewicht dient echter ongetwijfeld toegekend te worden aan de beide overige regelingen: de dwingendrechtelijke regelgeving inzake algemene voorwaarden en de nagenoeg geheel dwingendrechtelijke regeling inzake de consumentenkoop.

De regeling inzake de consumentenkoop is vooral van belang voor de problematiek van de algemene voorwaarden omdat zij, met ingang van 1 januari 1992, krachtens het bepaalde in artikel 7:6 BW het gebruik van algemene voorwaarden bij de meest frequente overeenkomst waarin consumenten partij zijn, de consumentenkoop, nagenoeg onmogelijk maakt. ${ }^{64}$ Daarmee heeft de Nederlandse overheid, ter bescherming van de consument, niet alleen gekozen voor dwingende regelgeving op dit deelterrein waarop algemene voorwaarden

62 Zie onder andere: Von Hippel, pag. 127-136; CCA-advies, pag. 8 e.v.; Hondius, preadviess NJV, pag, 141 e. $\mathrm{v}_{* ;}$ Jongeneel, diss., pag. 12 e.v.; Asser-Hartkamp II, 1993, nr. 344.

63 Afgezien wellicht van die consumenten die nog steeds de door de Consumentenbond in 1973 opgestelde Consumentenwoorwarden hanteren. Consurnentengids 1973 , pag. $1888-189$. Zie over deze voorwaarden onder andere: Hondius, diss., pag. 21, noot 23 en pag. 326 e.v.

64 Bij cen consumentenkoop kan niet wordem afgeweken wan de afdelingen 1 tot en met 7 van Titel $7.1 \mathrm{BW}$, met vitzondering wan de artikelen $11,12,13,26$ en 35 . Algemene voonwararden die afwijken van het bepaalde in deze artikelen zijn echter vernietigbaar (artikel 7:6 lid $2 j^{\circ} 6: 233$ sub a $B W$. 
frequent worden gehanteerd en daarmee dus voor een versterking van de rechterlijke controle, maar eveneens voor een nagenoeg algeheel verbod van het gebruik van algemene voorwaarden op het terrein van de consumentenkoop.

Het belang van de Wet algemene voorwaarden ligt voornamelijk op de andere terreinen van het (consumenten)contractenrecht. ${ }^{65}$ Vanaf de invoering op 1 januari 1992 van de Boeken 3, 5, 6 en gedeelten van Boek 7 van het nieuw Burgerlijk Wetboek is deze nieuwe regeling in werking getreden. ${ }^{6}$ Daarmee is voor het eerst in de geschiedenis van de Nederlandse privaatrechtelijke wetgeving, een regeling van kracht geworden die zich uitsluitend richt op de problematiek van de algemene voorwaarden.

De ratio van afdeling 6.5.3 $\mathrm{BW}$ betreffende de bestrijding van onredelijk bezwarende bedingen in algemene voorwaarde ${ }^{67}$ is gelegen in de eenzijdige inhoud van algemene voorwaarden, in verband met het gemak waarmee deze voorwaarden de wederpartij die geen invloed op de (vaak onereuze) inhoud heeft en daarmee zelfs meestentijds onbekend is, worden opgedrongen. ${ }^{68}$ Tegen die achtergrond heeft het wetsontwerp de volgende oogmerken:

-versterking van de rechterlijke controle op de inhoud van algemene voorwaarden ter bescherming van wederpartijen, daar dezen op de inhoud van die voorwaarden in de regel geen invloed hebben, deze vaak niet eens kennen of begrijpen of het risico onderschatten dat de gebruiker jegens hen een beroep doet op deze voorwaarden;

-het bieden van zoveel mogelijk rechtszekerheid, zowel ten aanzien van de toepasselijkheid van algemene voorwaarden als ten aanzien van de (on)geoorloofdheid van hun inhoud;

-het verplichten of stimuleren van overleg tussen belanghebbenden over de inhoud van algemene voorwaarden. ${ }^{69}$

\subsubsection{Zelfregulering}

Zoals reeds aangegeven in de vorige paragrafen is het beleid van de Nederlandse overheid op het terrein van de algemene voorwaarden mede gericht op het

65 Met uitzondering wan de arbeidsovereenkomst. Zie artikel 6:245 BW. Bij deze overeenkomsten zijn consumenten echter ook niet partij in hun hoedanigheid alsi consument.

66 Op algemene voorwaarden die vór de inwerkingtreding nog niet werden gebruikt is afdeling 6.5.3 BW onmiddellijk van toepassing (art. 68a OW). Op algemene voorwarden die op 1 januari 1992 reeds door cen partij in has overeenkomsten worden gebruikt, alsmede op wijzigingen in die voorwaarden na 1 januari 1992 , is afdeling $6.5 .3 \mathrm{BW}$ eerst op 1 januari 1993 van toepassing (art. 191 Ow).

67 Zie de anhef van de wet zoals gepubliceerd in het Staatsblad 1987, nr. 327.

68 MvT Inv., Parlementaire Geschiedenis, Inv. 3, 5 en 6, pag. 1453.

69 MvT Inv, Parlementaire Geschiedenis, Inv. 3, 5 en 6, pag. 1455. Zie hierover: Rijken, KaiNBW 1984, pag. 120 e.v. 
verplichten of stimuleren van zelfregulering door marktpartijen. Sinds 1974 wordt dit overleg door marktpartijen dan ook actief gesteund door de Nederlandse overheid. ${ }^{*}$ De overheid, in de hoedanigheid van de CCA, treedt sinds die tijd op als moderator en effent de weg voor dit overleg door het verschaffen van de materiële voorzieningen zoals vergaderruimte, secretariële ondersteuning: Daarnaast worden aan consumentenorganisaties gerichte subsidies verleend om dit overleg te stimuleren.

Het zelfreguleringsoverleg inzake algemene voorwaarden wordt tevens ondersteund door wetgeving. Zo is in de artikelen 6:240 tot en met 6:243 BW aan consumentenorganisaties het collectief actierecht vooral toegekend in de verwachting, dat consumentenorganisaties met alleen al de dreiging van een gerechtelijke procedure, de (organisaties van) gebruikers van algemene voorwaarden aan de onderhandelingstafel kunnen brengen. ${ }^{71}$ Het onderhandelingsproces wordt daarnaast nog eens "extra" gestimuleerd door enerzijds de "overlegverplichting" van artikel 6:240 lid 4 BW en anderzijds de beloning die de (organisaties van) gebruikers van algemene voorwaarden voor succesvol onderhandelen krijgen, doordat de actiebevoegdheid van consumentenorganisaties vervalt, zodra deze met het gebruik van bedingen in algemene voorwaarden hebben ingestemd (artikel 6:240 lid 5 BW).

Strikt genomen houdt het bepaalde in artikel 6:240 lid 4 BW geen verplichting tot overleg in. Het verplicht de eisende (consumenten)organisaties enkel om - op straffe van niet-ontvankelijkheid - de inbreukmakende (organisatie van) gebruikers de gelegenheid te bieden om in onderling overleg de algemene voorwaarden zodanig te wijzigen dat de bezwaren die grond voor de vordering zouden opleveren, zijn weggenomen. ${ }^{n}$ Hoewel (organisaties van) gebruikers van algemene voorwaarden niet verplicht zijn on tot overleg over te gaan is de verwachting van de wetgever dat zij dit, mede omdat hen anders een rechterlijk verbod boven het hoofd hangt, wel zullen doen. Als consumentenorganisaties en branche-organisaties eenmaal samen aan de onderhandelingstafel zitten verwacht de wetgever dat niet alleen de jegens consumenten onredelijk bezwarende bedingen uitgebannen zullen worden maar dat tevens verder onderhandeld wordt om uiteindelijk te komen tot algemene voorwaarden die op evenwichtige wijze met de wederzijdse belangen rekening houden. Dit laatste is immers de uiteindelijke basisbescherming die de overheid voor ogen staat. Waar dit evenwicht ligt, wordt door de overheid niet aangegeven. Dit is ook niet verwonderlijk omdat dit evenwicht per branche, per produkt en per soort transactie anders kan liggen en

70. CCA, Vas consument en consumptie; pag. 27.

71 CCA-adwies, pag. 8-9 en 26; MvT Inv, Parlementaire Geschiedenis, Inv “ 3, 5 en 6, pag. 1455 , 1515 en 1764-1765; Rijken, KwNBW 1984, pag. 128.

72 Mölenberg en Rijken, pag. 64-65. 
het meer op de weg ligt van branche-organisaties en consumentenorganisaties om in onderling overleg dit evenwicht te bepalen. Alhoewel de term zelfregulering een zekere vrijblijvendheid van marktpartijen om dit evenwicht te bereiken impliceert, houdt de overheid toch nog een stok achter de deur voor het geval het branchevoorwaardenoverleg onvoldoende resultaten oplevert. Algemene voorwaarden behoren immers tot het basisbeschermingsniveau en dat is het niveau waarop de overheid zelf de eerst verantwoordelijke is. In het ICC-eindrapport wordt derhalve uitdrukkelijk gesteld dat de overheid met wetgeving kan ingrijpen als blijkt dat het overleg tussen partijen onvoldoende resultaten oplevert. ${ }^{73}$ Dit overheidsingrijpen zou echter eveneens kunnen bestaan uit het vaststellen van een standaardregeling voor de betreffende branche. In die zin heeft de standaardregeling eveneens te maken met zelfregulering. Zij kan een reactie zijn op falende zelfregulering van marktpartijen. Daarbij komt dat de standaardregeling zelf, gezien het feit dat marktpartijen worden betrokken bij het opstellen van een dergelijke regeling, natuurlijk ook zekere zelfreguleringsaspecten in zich bergt, uiteraard met dien verstande dat de overheid uiteindelijk de beslissende stem heeft. Door de overheid geleide zelfregulering dus.

\subsubsection{Subsidiering}

Het beleidsinstrument subsidiëring wordt door de Nederlandse overheid op het terrein van de algemene voorwaarden op een aantal manieren gehanteerd. Zo ontvangen consumentenorganisaties bij voorbeeld jaarlijks financiële bijdragen van de centrale overheid. Hoewel deze subsidies grotendeels algemeen van aard zijn, komen deze ongetwijfeld ook de voorlichting en belangenbehartiging op het terrein van de algemene voorwaarden ten goede.

Meer specifiek op het terrein van de algemene voorwaarden toegesneden zijn de subsidies die consumentenorganisaties ontvangen of zullen ontvangen in het kader van de hun in de Wet algemene voorwaarden toebedachte taak als collectieve rechtshandhaver op grond van artikel 6:240 $\mathrm{BW}$. In het CCA-advies wordt hierover het volgende opgemerkt:

"Wat de withoering van de regeling betmeft, stack wast dat de controle op onereuze bedüngen, het plegen wan overleg en het voeren van processmen ter zake, aanzienlijke kosten voor de consumentenorgowisaties zal meebrengen.

Een deel wan de commissie wijst erop dat het toewertrouwen wan de controletaak aan consumentemorganisaties op en praktische heuze berust: zij zijn reedis vertrouwd met de problemariek en aldus' wordt een kostbare owerheidsicontrole overbodig. Dit rechnaardigt wolgens deze leden dat de desbetreffende kosten van de consumentenorganisaties door de overheid warden gedragen. "74

74 CCA advies, pag. 50. 
De Nederlandse overheid stelt zich, in navolging wan dit standpunt, derhalve in beginsel op het standpunt dat de in deze wet aan consumentenorganisaties toegekende taak "door de regering geheel of ten dele behoort te worden gesubsidieerd"7s zodat zij in de gelegenheid zijn "om op efficiënte wijze de in de wet neergellegde bevoegdheid ten nutte te maken" ${ }^{* 76}$.

Tijdens de parlementaire behandeling van deze wet is in dit verband toegezegd dat voor de inwerkingtreding getracht zou worden om te komen tot een goede subsidieregeling. ${ }^{n}$ Om enerzijds zoveel mogelijk onzekerheid bij consumentenorganisaties omtrent de inhoud van een dergelijke subsidieregeling weg te nemen en anderzijds vanaf de inwerkingtreding van de Wet algemene voorwaarden en direct adequaat optreden van deze organisaties mogelijk te maken is vanaf 1985 subsidie aan consumentenorganisaties verstrekt voor werkzaamheden ter voorbereiding van de hun toebedachte taak. Bij deze voorbereidende werkzaamheden moet worden gedacht aan het doen van onderzoek, het opbouwen van expertise en goodwill en het voeren van overleg. ${ }^{78}$

Een andere specifiek op algemene voorwaarden gerichte subsidie is de bijdrage van de overheid aan erkende geschillencommissies. Het is vast beleid dat slechts die erkende geschillencommissies woor subsidie in aanmerking komen die werkzaam zijn onder de paraplu van de Stichting Geschillencommissies voor consumentenzaken. ${ }^{79}$ De SGC gaat echter eerst tot oprichting van een geschillencommissie over indien de branehe-organisatie bereid is evenwichtige algemene voorwaarden te hanteren die het resultaat zijn van overleg tussen consumenten- en branche-organisaties. ${ }^{80}$

\subsubsection{Het optreden van de overheid als moderator}

Het optreden als moderator bij het overleg tussen branche- en consumentenorganisaties over algemene voorwaarden wordt door de Nederlandse overheid sinds 1974 als beleidsinstrument gehanteerd. Vanaf die tijd treedt de overheid, in de hoedanigheid van de $\mathrm{CCA}^{\mathrm{s1}}$, op als moderator en verschaft een kader voor dit overleg door materiële voorzieningen zoals vergaderruimte ter beschikking te stellen, secretariële ondersteuning door het SER-secretariaat en het uitvoeren van een aantal procedurele taken zoals het benoemen - in overleg met

76 Nota II Inv., Parlementaire Geschiedenis, Inv, 3, 5 en 6, pag. 1772.

77 Mva Inw., Parlementaire Geschiedenis, Inv. 3, 5 en 6, pag. 1170; Nota II Inv., Parlementaire Geschiedenis, Inv. 3, 5 en 6, pag. 1772.

78 Nota II Inv., Parlementaire Geschiedenis, Inv. 3, 5 en 6, pag. 1772.

79 SGC 1990, pag. 13.

80 SGC 1990, pag. 10-11.

81 Het CCA is cen commissie van de SER. 
partijen - van een onafhankelijke voorzitter en bemiddeling bij conflicten ${ }^{82}$ Sinds 1988 vindt het overleg onder auspiciën van de CCA plaats aan de hand van het Protocol zelfregulering dat procedures en spelregels bevat voor het overleg. ${ }^{83}$

\subsubsection{Voorlichting}

Reeds in 1976 deed de CCA voorstellen aan de regering om te komen tot meer en betere consumentenvoorlichting, welke onder meer ook gericht zou moeten zijn op een vergroting van het inzicht van de consument in misleidende en agressieve verkooppraktijken en vergroting van de kennis van de consument over zijn rechten en plichten ${ }^{84}$. In het eerstvolgende advies van de CCA werd er vervolgens op aangedrongen dat "consumentenopvoeding" zowel in het basisonderwijs als in het voortgezet onderwijs een vaste plaats dient te krijgen. ${ }^{85}$ In 1987 wordt, met overheidssubsidie, door de Consumentenbond, het Konsumenten Kontakt en de Stichting Ombudsman het Coördinatiepunt Massamediale Consumentenvoorlichting (COMAC) opgericht. Met het stopzetten van de overheidsfinanciering is de COMAC in 1992 echter weer opgeheven.

Expliciete voorbeelden van het hanteren door de centrale overheid van voorlichting als beleidsinstrument op het terrein van de algemene voorwaarden zijn echter zeldzaam. De enige, specifiek op de consument gerichte, overheidsvoorlichting die mij op dit terrein tot nu toe heeft bereikt is de uitgave van de Directies Voorlichting van respectievelijk het Ministerie van Justitie en van Economische Zaken van januari 1992 "Consument \& Recht na januari 1992". In deze brochure wordt in een viertal pagina's zeer oppervlakkig op de nieuwe regelgeving inzake algemene voorwaarden ingegaan. ${ }^{86}$

\subsection{Knelpunten in de algemene voorwaardenproblematiek die door de gekozen beleidsinstrumenten worden bestreken}

Zoals in de voorgaande hoofdstukken reeds beschreven zijn bij de algemene woorwaardenproblematiek de volgende knelpunten aan te wijzen: de toepasse-

82 Zie hierover onder meer: CCA, Van consument en consumptic; Van der Graf, Van der Meer en Van Mierlo, pag. 48 e.w.

83 Protocol zelfregulering 1988. Het protocol is in 1989 vanwege een aantal in de praktijk gebleken tekortkomingen op een drietal punten herzien. Zie: CCA, Van consument en consumptie, pag. 56.

84 Advies inzake de voorlichting aan de consument wia radio en televisie (CCA), SER-uitgave 1976, nr. 16.

85 Adwies inzake consumentenopvoeding op scholen, SER-uitgave 1977, nr. 8.

86 Consument \& Recht na januari 1992, Uitgave van de Ministeries wan Justitie en Economische Zaken, januari 1992, pag. 12-14. 
lijkheid, de versluiering van de contractsinhoud, onduidelijk taalgebruik en ondoorzichtigheid van bedingen in algemene voorwaarden, de uitleg van contractsbedingen, de (vaak) onereuze inhoud, de ontoegankelijkheid van de overheidsrechter voor individuele consumenten en de weinig effectieve werking van het rechterlijk vonnis inzake algemene voorwaarden. In deze paragrafen wordt geïnventariseerd of, en zo ja hoe, deze knelpunten worden aangepakt in de door de Nederlandse overheid gekozen beleidsinstrumenten.

De toepasselijkheid van algemene voorwaarden wordt in beginsel overgelaten aan de algemene regels omtrent de totstandkoming van overeenkomsten, het aanbod en de aanvaarding daarvan zoals neergelegd in de artikelen 6:217 e.v., 3:33 en $3: 35 \mathrm{BW}$. Met als doel rechtszekerheid ${ }^{37}$ en als uitgangspunt een snelle primaire gebondenheid van de wederpartij aan algemene voorwaarden is de oorspronkelijk in artikel 6.5.1.3 lid 1 Ontwerp NBW opgenomen regeling overgenomen in artikel 6:232 $\mathrm{BW}^{\mathrm{gs}}$ Met de bepaling dat de wederpartij ook gebonden is aan algemene voorwaarden waarvan hij de gelding zonder de inhoud te kennen heeft aanvaard (6:231 sub c BW), is een duidelijk wettelijk antwoord gegeven op de, in de literatuur meermalen gestelde vraag in hoeverre een wederpartij gebonden kan zijn aan algemene voorwaarden waarvan zij de gelding heeft aanvaard terwijl zij de inhoud daarvan niet kent en de gebruiker van dit niet-kennen op de hoogte is.

Tegenover deze snelle primaire gebondenheid van de wederpartij staat echter dat de wetgever in de artikelen 6:233 sub $b$ en 6:234 $\mathrm{BW}$ een regeling heeft opgenomen die moet bewerkstelligen dat de wederpartij van de gebruiker van algemene voorwaarden, voór of bij het sluiten van de overeenkomst een redelijke mogelijkheid heeft zich op de hoogte te stellen van de inhoud van de betreffende algemene voorwaarden. Het niet bieden van een redelijke mogelijkheid om zich te informeren over de inhoud leidt via de weg van vernietiging tot niet-gebondenheid van de wederpartij aan die allgemene voorwaarden. Een regeling dus waarmee de overheid het probleem van de versluiering van algemene voorwaarden deels heeft aangepakt. Deels, omdat het probleem van de versluiering van algemene voorwaarden meer omvat dan het enkele niet-ontvangen van algemene voorwaarden. Ook de vaak onduidelijke redactie en het moeilijk toegankelijke taalgebruik dragen bij tot de versluiering van de inhoud van algemene voorwaarden. Hoewel de Nederlandse wetgever dit probleem 
heeft onderkend ${ }^{89}$ is er van afgezien regels met betrekking tot de redactie en het taalgebruik van algemene voorwaarden in de wet op te nemen..$^{90}$

Nauw verbonden met de onduidelijke redactie en het moeilijke taalgebruik van algemene voorwaarden is de uitleg daarvan. Zoals reeds aangegeven in paragraaf 3.4.1 zijn in het huidige Burgerlijk Wetboek geen bijzondere regels opgenomen met betrekking tot de uitleg van contractsbedingen in het algemeen of algemene voorwaarden in het bijzonder. ${ }^{91}$

Belangrijkste knelpunt in de algemene voorwaardenproblematiek is ongetwijfeld het feit dat tegenover (niet alleen) consumenten veelvuldig algemene voorwaarden worden gehanteerd met een onredelijk bezwarende inhoud en dat de consument geen of nauwelijks invloed heeft op de inhoud van deze bedingen. Dit knelpunt wordt door de Nederlandse overheid met een aantal beleidsmiddelen bestreden. Allereerst valt hier uiteraard wetgeving te noemen:

-de algemene regel van artikel 3:40 (Strijd met de wet, openbare orde of goede zeden);

-de specifiek op algemene voorwaarden gerichte individuele inhoudstoets van artikel 6:233 sub a $\mathrm{BW}$ en (voor consumenten) de artikelen 6:236 en 6:237 BW; -de collectieve inhoudstoets te entameren door belangenorganisaties van artikel 6:240 BW waarin de open norm van artikel 6:233 sub a BW en de artikelen 6:236 en 6:237 BW analoog worden toegepast.

Daarnaast kunnen genoemd worden: zelfregulering en het stimuleren daárvan middels wetgeving (artikel 6:240 BW), subsidiëring en het optreden als moderator.

Nagenoeg even grote knelpunten in de algemene voorwaardenproblematiek zijn de ontoegankelijkheid van de overheidsrechter voor individuele consumenten en de weinig effectieve werking van het rechterlijk vonnis inzake algemene voorwaarden. Het, niet-exclusief voor algemene voorwaarden geldende, knelpunt van de ontoegankelijkheid van de overheidsrechter voor individuele consumenten wordt door de Nederlandse overheid op twee manieren aangepakt. Enerzijds wordt door middel van wetgeving zoals deze gestalte heeft gekregen

89 MvT Inv., Parlementaire Geschiedenis, Inv. 3, 5 en 6, pag. 1452; CCA-advies, pag. 9-10.

90 Jongeneel, diss., pag. 135. Richtlijn 93/13/EEG betreffende oneerlijke bedingen in consumentenovereenkomsten verplicht de Nederlandse wetgever on op uiterlijk 31 december 1994 do regell van artikel 5 van die richtlijn dat schriftelijke bedingen steeds duidelijk en begrijpelijk moeten zijm opgesteld, in de Nederlandse wetgeving te implementeren. Zle: paragraaf $3.4 .1 \mathrm{en}$ noten 33-35 van hoofdstuk 3; Jongeneel, TrC 1993, pag. 130, Jongeneel en Wessels, NJB 1993, pag. 899.

91 De in de vorige noot genoemde Richtijn 93/13/EEG verplicht de Nederlandse wetgever eveneens om uiterlijk op 31 december 1994 de contra proferentem-regel van artikel 5 van die richtlijn in de Nederlandse wetgeving to implementeren. Zie: paragraaf 3.4.1 en noten 33-35 van hoofdstuk 3; Jongeneel, TvC 1993, pag. 130; Jongeneel en Wessels, NJB 1993, pag. 899. 
in de recente, mijns inziens zeer summiere, vereenvoudiging van de kantongerechtsprocedure, de toegang tot de overheidsrechter iets eenvoudiger gemaakt voor de consument. Anderzijds wordt de totstandkoming van voor de consument eenvoudig toegankelijke particuliere geschillenbeslechting bevorderd. Hiertoe wordt zelfregulering gestimuleerd, wordt opgetreden als moderator in het zelfreguleringsproces en worden particuliere geschillenbeslechtingsinstanties erkend en gesubsidieerd. Het zelfreguleringsproces op zichzelf wordt daarbij dan weer gestimuleerd door het collectief actierecht van consumentenorganisaties op grond van artikel 6:240 $\mathrm{BW}$ en de in de in dit artikel opgenomen prikkels tot onderhandelen.

Het probleem van de weinig effectieve werking van het rechterlijk vonnis wordt eveneens middels wetgeving aangepakt. Als voornaamste oorzaken van het geringe effect van rechterlijke uitspraken op het terrein van de algemene voorwaarden, zijn de beperkte reikwijdte van het vonnis en het ontbreken van preventieve werking van rechtspraak aan te wijzen. ${ }^{92}$ Beide knelpunten worden te lijf gegaan. Allereerst door het opnemen van de lijsten van de artikelen 6:236 en 6:237 BW die het gebruik van bepaalde algemene voorwaarden tegenover alle consumenten verbieden en rechtszekerheid verschaffen omtrent het al dan niet geoorloofd zijn van bepaalde algemene voorwaarden. Vervolgens door wettelijke regeling van de abstracte toetsing van algemene voorwaarden op grond artikel 6:240 $\mathrm{BW}$ en de daaraan gekoppelde collectieve verbodsmogelijkheid en vereenvoudiging van de mogelijkheid een collectief van gebruikers van algemene voorwaarden te dagvaarden (artikel $1003 \mathrm{Rv}$ ).

\subsection{Collectief actierecht voor consumentenorganisaties op het terrein van de algemene voorwaarden als ongelijkheidscompensatie}

Zoals hiervoor reeds aangegeven speelt het collectieve actierecht voor belangenorganisaties een belangrijke rol in de door de Nederlandse overheid gekozen beleidsmiddelen op het terrein van de algemene voorwaarden. Daar het collectief actierecht voor consumentenorganisaties het centrale thema van deze dissertatie is wordt in de volgende paragrafen, ter afronding en afsluiting van het inleidend deel, nader hierop ingegaan. Daartoe wordt allereerst aangegeven op welke terreinen consumentenorganisaties een wettelijk actierecht hadden vór de inwerkingtreding van afdeling 6.5.3 $\mathrm{BW}$. Vervolgens waar en hoe de collectieve actiebevoegdheid is gerealiseerd in afdeling 6.5.3 BW en de relatie met andere collectieve acties in de Nederlandse wetgeving. Besloten wordt met een beschrijving van de ratio en het doel van de collectieve actie voor consumen- 
tenorganisaties op het terrein van de algemene voorwaarden, zoals geregeld in de artikelen 6:240 e.v. BW.

\subsubsection{Collectieve procesbevoegdheid van consumentenorganisaties in de Nederlandse wetgeving wö́r de inwerkingtreding van afdeling $6.5 .3 \mathrm{BW}$}

Ruim anderhalf decennium nadat Slagter als eerste een voorzichtig pleidooi hield voor de toekenning van een collectieve actie aan consumentenorganisaties $^{93}$ werd in 1980 voor het eerst in de Wet Misleidende Reclame (artikelen $1416 \mathrm{a}$ tot en met 1416c BW (oud), thans de artikelen 6:194 tot en met 6:196 $\mathrm{BW}$ ) aan consumentenorganisaties een wettelijk collectief actierecht toegekend. $^{94}$ De actiebevoegdheid is beperkt tot het vorderen van een verbod of van een rectificatie.

De door deze wet aan consumentenorganisaties toegekende bevoegdheid wordt vooral gemotiveerd met de verwachting dat hiermee de mogelijkheden worden verbeterd om op effectieve wijze het verschijnsel van misleidende reclame tegen te gaan. Van consumentenorganisaties wordt een doelmatig en alert optreden verwacht. Dit wordt niet verwacht van de individuele consumenten omdat deze "in het algemeen ieder voor zich hetzij te weinig materieel belang, hetzij onvoldoende financiële middelen hebben om een gerechtelijke actie te voeren, nog daargelaten de prealabele vraag of zij zich wel altijd van het gevaar van misleiding bewust zijn".." Overgelaten aan de individuele consument zou de misleidende reclame slechts zeer incidenteel worden aangepakt. ${ }^{96}$ Voor de kosten van gevoerde procedures komen de consumentenorganisaties het Konsumenten Kontakt (KK) en Consumentenbond (CB) in aanmerking voor subsidie. ${ }^{97}$

Het aantal collectieve gerechtelijke acties gevoerd door consumentenorganisaties op het terrein van de misleidende reclame is echter zeer beperkt gebleven. Als redenen voor dit beperkte gebruik van dit actiemiddel door consumentenorganisaties worden aangegeven:

93 Slagter, pag. 223,248 en 251.

94 Rodrigues, SWOKA-onderzoeksrapport, pag. 25; Dommering-van Rongen, pag. 137.

95 Tweede Kamer, zitting 1975-1976, 13 611, mr. 1-4 (MvT), pag. 8; Tweede Karner, zitting 1978-1979, nr. 6 (MvA), pag. 3-4.

96 Tweede Kamer, zitting 1975-1976, 13611 , nrs. $1-4$ (MvT), pag. 8.

97 Voor subsidiëring was in de jaren 1980 en 1981 een bedrag van $f 50000$ besehikbaar. Vanaf 1982 is $f 70000$ per jaar beschikbaar. Zie: Wet misleidende reclame voldoet aan doelstellingen, NJB 1984, pag. 774: Rodrigues, SWOKA-onderzoeksrapport, pag. 25. Zoals reeds vermeld is het Konsumenten Kontakt is per 1 januari 1994 opgehevem. Zie paragraaf 1.5 .3 noot 65.

98 Dommering-van Rongen pag. 141 en 147; Rodrigues, SWOKA-onderzoeksrapport, pag. 25; Mölenberg en Rijken, pag. 4. Zie ook: Wet misleidende reclame voldoet an doetstellingen, NJB 1984, pag. 773 e.v. 
-de personele belasting die deze procedures voor consumentenorganisaties betekenen;

-een dreiging met deze actie leidde in een aanzienlijk aantal gevallen tot buitengerechtelijk succes (schikking);

-de beschikbaarheid van efficiënte(re) particuliere geschillenbeslechting bij de Reclame Code Commissie. ${ }^{99}$

Vanaf 1 juli 1989 kunnen consumentenorganisaties ook van de in de Wet persoonsregistratie opgenomen collectieve actiebevoegdheid gebruik maken. Daar is bij mijn weten tot op heden door consumentenorganisaties echter nog geen gebruik van gemaakt.

Wél wordt door consumentenorganisaties in toenemende mate gebruik gemaakt van de collectieve actiemogellikheden op het terrein van de onrechtmatige daad en recentelijk lijken de consumentenorganisaties de eerste collectieve successen te boeken op het terrein van het contractenrecht. ${ }^{101}$

\subsubsection{Collectieve procesbevoegdheid op het terrein van de algemene voor- waarden}

Bijzonder aan afdeling 6.5.3 BW is niet alleen dat deze zich door middel van een repressieve rechterlijke controle, te entameren door (individuele) wederpartijen van gebruilkers van algemene voorwaarden, specifiek richt op de problematiek van algemene voorwaarden, doch ook dat in de artikelen 6:240 BW aan belangenorganisaties en met name aan consumentenorganisaties een collectief actierecht op dit terrein wordt toegekend.

\section{Artikel 6.240 BW:}

1. Op vordering wan een rechtspersoon als bedoeld in lid 3 kumen bepaalde bedingen in bepaalde algemene voorwadurden onredelijk bezwarend worden verkloward; de artikelen 233 onder $a_{2}, 236$ w 237 zin van overeenkomstige toepassing. Voor de toepassing van de vorige zin wordt een beding in algemene voorwaarden dat in strijd is met een dwingende wetsbepaling, als onredelijk bezwarend aungemerkt.

2. De wordering kan worden ingesteld tegen de gebruiker, alsmede tegen een rechtspersoon thet volledige rechtshevoegdheid die ten doel heef de behartiging wan belangen wan personen die een beroup of bedriff witoefenen, indien hij het gebrwik van de algemene voarwaralen door die personwen bevordert.

99 Dommering-van Rongen pag. 141; Rodrigues, SWOKA-onderzoeksmppont, pag. 9 en 25.

100 Frenk, Jaarboek konsumentenrecht 1990, pag. 323.

101 Pres. Rb. Den Haag, 17 april 1991, TvC 1991, pag. 312-317, m.nt. Niels Frenk. Zie eveneens: Rb. Den Haag, 15 februari 1989. TrC 1989 , pag. 76-84, m.nt. P.R. Rodrigues, inzake PTT/ANBO en Consumentenbond, waarin de rechter niet bereid: was wonderingen op het terrein van het contractenrecht toe te stanan. 
3. De vandering komt toe aan rechtspersonen met wolledige rechisbevoegdheid die ten doel hebben de behartiging van belangen van personen die een beroep of bedrijf uitoufenen of van eindgebrukers wan niet woor een beroep of bedriff bestemde goederen of diensten. $\mathrm{Zij}_{\mathrm{j}}$ kcon slechts betrekking hebbers op algemene voorwaarden die worden gebruikt of bestemd ajn te wordem gebruikt in overeenkomsten met personien wier belangen door de rechtspersoon wonden behartigd.

4. De eiser is miet onvvankelijk indien niet blifkt dar hij, alvorens de pordering in te stellen, de gebruiker of, in thet geval bedoeld in artikel 1003 wan het Werboek van Burgerlijke Rechtswondering, de aldwar bedoelde veremiging, de gelegenheid heeft gebaden am in onderling overleg de algemente woorwarden zodanig te wijzigen dat de bezwaren die grond woor de vordering zouden opleveren. zäjn weggenomen. Een termijn van zes maandem na schriffelijke kennisgeving wan de bezwaren is daarroe in elk geval valdoende.

5. Woor zover een rechtspersoon met het gebruik wan bedingen in algemene voonwaarden heeft ingestemd, komt hem geen vordering als bedoeld in lid 1 toe.

De artikelen 6:240 tot en 6:243 BW openen voor consumentenorganisaties als collectiviteit de mogelijkheid, te vorderen dat bedingen in algemene voorwaarden, gehanteerd door zowel individuele gebruikers als door een collectiviteit van gebruikers, door een bijzondere rechter onredelijk bezwarend worden verklaard.

De Nederlandse wetgever heeft met deze collectieve vordering beoogd, mede door de prikkel tot onderhandelen die zij vormt, een collectief controlemechanisme te bieden tegen het in wezen collectieve verschijnsel der algemene voorwaarden. ${ }^{102}$

\section{Artikel 6:241 BW:}

1. Hel Gerechishof te "s-Gravenhage is bij witsluiting bevoegd ror kennismeming van vorderingen als in het worige artikel bedoeld.

2. De in het vorige artikel bedolde rechtspersonen hebben de bevoegdheden, geregeld in de artiketen 285 en 376 van het Wetboek van Burgerlijke Rechtsvardering; artikel 379 van dat Wetboek is niet van roepassing.

3. Op vordering van de eiser kan aan de witspraak worden verbonden

a. een verbod' van het gebruik wan de door de witspraak geiroffen bedingen of van het bevorderen dianoran;

b. een gebod am een aambeveling tot het gebruik wan deze bedingen te herroepen;

c. en veroordeling tot het opembar maken of laten openbaar maken wan de witspraak, zulks op door de rechter te bepalen wijze en op kosten van de door de rechter aan te geven partij of partijen.

4. De rechter kan in zijn sitspraak axangeven op welke wijze het onredelijk bezwarend karakter wan de bedingen waarop de uitspraak betrekking heeft, kan worden weggenomen.

5. Geschillen terzake wan de tenuitvoerlegging wan de in lid 3 bedoelde veroordelingen, alsmede van de veroordeling tot betaling van een dwangsom, zo deze is opgelegd, worden bij witsluting door het Gerechushof te 's-Gravenhage besist.

Consumentenorganisaties kunnen bij het Gerechtshof te 's-Gravenhage een vordering instellen tegen gebruikers van algemene voorwaarden en tegen

102 MvT Inv., Perlementaire Geschiedenis, Inv. 3, 5 en 6, pag. 1762. Zie ook: Rijken, KwNBW 1984 , pag. 121. 
ondernemers- of beroepsorganisaties die het gebruik van algemene voorwaarden door hun leden bevorderen (artikel 6:240 lid 2 en $3 \mathrm{BW}$ ). Wordt de vordering tegen een branche-organisatie ingesteld dan kunnen de leden van die organisatie als collectiviteit in de procedure worden betrokken zonder hen afzonderlijk te dagvaarden (artikel $1003 \mathrm{Rv}$ ).

Gevorderd kan worden een specifiek beding in bepaalde algemene voorwaarden onredelijk bezwarend te verklaren. De zogenaamde "open norm" van artikel 6:233 sub a BW en de lijsten van de artikelen 6:236 en 6:237 BW zijn van overeenkomstige toepassing, waarbij tevens bepaald wordt dat bedingen in algemene voorwaarden die in strijd zijn met een dwingende wetsbepaling, als onredelijk bezwarend worden aangemerkt (artikel 6:240 lid $1 \mathrm{BW}$ ).

Daarnaast kan gevorderd worden aan de uitspraak dat een beding in algemene voorwaarden onredelijk bezwarend is, te verbinden een verbod van gebruik, een gebod om een aanbeveling tot gebruik te herroepen, een veroordeling tot openbaar maken van de uitspraak en een dwangsom (artikel 6:241 NBW).

Gebruik van een beding in algemene voorwaarden door degene jegens wie een verbod tot gebruik ervan is uitgesproken, leidt in de individuele procedure ex artikel 6:243 BW altijd tot vernietigbaarheid van dat beding.

Artikel $6.243 \mathrm{BW}$

Een beding in algemene woonwarden dat door degente jegens wie een verbad not gebruik erwan is uitgesproken, in strijd met het verbod in een avereenkonst wordt opgenamen, is vemietigbar. Artikel 235 is wan overienkomsitige roepassing.

Het vorderingsrecht van artikel 6:240 $\mathrm{BW}$ - en de daaraan verbonden nevenvorderingen - is aan consumentenorganisaties vooral toegekend in de verwachting dat de dreiging met een gerechtelijke inhoudstoetsing de (organisaties) van gebruikers van algemene voorwaarden aan de onderhandelingstafel zal brengen en op die wijze algemene voorwaarden tot stand komen die op evenwichtige wijze rekening houden met de wederzijdse belangen. ${ }^{100}$ Rijken drukt het aldus uit:

"De consumententorganisaties krijgen het ius agendi in de verbodsprocedure, hetwelk hen de madige countemailing power oplevert. Voor de gebruikers van algemene voorwaarden en de brancheorganisaties zal de dreiging wan een verbodsprocedure de nodige prikkel sot anderhandelingen wormen. Alkhs wordt een kltwaat geschapen waarin her mogelijk moet zijn om met vruch overleg te plegent over de inhoud wan algemene voorwarden. De acanzet tot bedoeld overleg wordt in genaemd artikellid gegeven:" "104

103 MvT Inv, Parlementaire Geschiedenis, Inv, 3, 5 en 6, pag. 1455 en 1765; CCA-advies, pag. 8-9.

104 Rijken, KwNBW 1984, pag. 128 . 
Het belang dat de wetgever hecht aan deze onderhandelingen op het terrein van de algemene voorwaarden wordt uitdrukkelijk onderstreept door de leden 4 en 5 van artikel 6:240 BW. Lid 4 legt op consumentenorganisaties een overlegverplichting op straffe van niet-ontvankelijkheid en lid 5 stimuleert de (organisaties van) gebruikers om succesvol te onderhandelen doordat de actiebevoegdheid van een consumentenorganisatie vervalt zodra deze met het gebruik van bepaalde bedingen in door (organisaties van) gebruikers jegens consumenten te hanteren algemene voorwaarden heeft ingestemd.

\subsubsection{Collectieve procesbevoegdheid in andere Nederlandse wetgeving}

De collectieve procesbevoegdheid zoals die aan onder andere consumentenorganisaties is toegekend in artikel 6:240 BW is in Nederland niet geheel nieuw en staat dan ook niet alleen. Een collectieve procesbevoegdheid is in diverse wetten en wetsvoorstellen ter hand genomen. De argumenten voor een collectieve actiebevoegdheid liggen daarbij in de volgende omstandigheden:

-belangenorganisaties kunnen in rechte optreden in aangelegenheden waar per individu geringe, maar in hun totaliteit aanzienlijke belangen in het spel zijn die, indien het initiatief aan ieder individu zelf wordt overgelaten, niet of onvoldoende worden beschermd;

-de drempels in de toegang tot de rechter zijn voor belangenorganisaties minder hoog dan voor het individu;

-van het collectief actierecht kan een belangrijke preventieve werking uitgaan. ${ }^{105}$

In dit kader verdient met name de eerst recentelijk op 1 juli $1994^{106}$ in werking getreden Wet van 6 april 1994 tot regeling van de bevoegdheid van bepaalde rechtspersonen om ter bescherming van de belangen van andere personen een rechtsvordering in te stellen (Wet vorderingsrecht belangenorganisaties) ${ }^{107}$ nadere aandacht. ${ }^{108}$

Met deze wet wordt uitvoering gegeven aan het, naar aanleiding van de motie Groenman ${ }^{109}$, gedane verzoek van de Tweede Kamer van 9 december 1986 om op zo kort mogelijk termijn een algemeen collectief actierecht voor consumentenorganisaties wettelijk te regelen. Ook buiten de met name in de diverse wettelijke regelingen genoemde specifieke terreinen bleken belangenorganisaties immers in steeds meer gevallen behoefte te hebben aan de bevoegd-

105 Tweede Kamer, vergaderjaar 1991-1992, 22 486, nir. 3 (MvT), pag. 2.

106 Sib. 1994, 391.

107 Staatsblad $1994,269$.

108 Zie meer uitgebreid: Frenk, diss., pag. 103-162; Mölenberg, pag. 275-288.

109 Tweede Kamer 1986-1987, 19 754, nr. 6, pag. 1. 
heid om in rechte op te treden, welke behoefte ook in toenemende mate in de rechtspraak werd gehonoreerd "ta Op 11 februari 1988 werd dan ook aan de S.E.R. en de Adviescommissie Burgerlijk Procesrecht het Voorontwerp varderingsrecht belangenorganisaties ${ }^{111}$ ter advies voorgelegd. Het voorontwerp behelsde slechts eén artikel:

Een rechtspersoon met volledige rechtsbevoegdheid die in overeenstemming met zijn statuten belangen van anderen behartigt, kan, indien de bescherning wan die belangen dit rechruacrdigt, its: rechte vorderen dat een gedraging onrechtonatig wortt verklaard of dat een onrechtmatige gedraging wordit verboden.

Op dit voorontwerp werd verdeeld gereageerd. ${ }^{112}$ Enerzijds werd bezwaar gemaakt tegen de inbreuk die het collectief actierecht maakt op het individuele karakter van het burgerlijk procesrecht, ${ }^{13}$ anderzijds werd gesteld dat het voorontwerp vergeleken met de ontwikkelingen in de rechtspraak te veel beperkingen inhield en dat met name niet was voorzien in een mogelijkheid van een collectieve schadevergoedingsactie. ${ }^{114}$ Een, naar aanleiding van de gerezen kritiek, gewijzigd Voorontwerp vorderingsrecht belangenorganisaties werd door de regering in 1990 als wetsvoorstel voor advies toegezonden aan de Raad van State $^{115}$ en begin 1992 aan de Tweede Kamer voorgelegd. ${ }^{116}$ Na twee Nota's

$110 \mathrm{Zie}$ woor een overzicht van de rechtspraak: Tweede Kamer, vergaderjaar 1991-1992, 22 486, nr. 3 (MVT), pag. 3-7; Rodrigues, SWOKA-onderzoeksrapport, pag. 19-23; Rodrigues, Procesrecht en collectief actierecht, pag. 33 e.v.; Van Nispen, nr. 219 a.

111 Vorderingsrecht belangenorganisaties, Voorontwerp van wet met toelichting, Ministerie vant Justitie 1988.

112 Frenk, RM-Themis 1989, pag. 372-389; Frenk, TvC 1990, pag. 203-217; Hondius, rechtspositie van de consument, pag. 336 .

113 Advies Vorderingsrecht belangenorganisaties, Adviescommissic Burgerlijk Procesrecht, 3\| januari 1990.

114 Zie meer uitgebreid onder andere: Advies inzake thet voonontwerp van Wet regeling vorderingsrecht belangenorganisaties, (SER-)Commissie Vorderingsrecht Belangenorganisaties, SERPublikatio nr. 1 - 19 januari 1990 (90/01); J.E.A.A. ten Berg-Koolen en R.Ch. Versehuur, Verdediging van collectieve bellangem voor de rechter, TvC 1988, pag. 306-308; D.W.J.M. Pessers, Behartiging van collectieve belangen, NJB 1988, pag. 605-607; P.R. Rodrigues; SWOKA-onderzoekisrapport, pag. 29-33; K. Rozennond, Het voonontwerp Vorderingerechi belangenorganisaties, Rechtshulp 1989, pag. 8-19; D. van der Meijden en M. Robesin, Helt voorontwerp vorderingsrecht: cen stap terug voor milieuorganisaties, NJB 1989, pag. 855-856; Th.G. Drupsteen, Voorontwerp vorderingsrecht belangenorganisaties, Milieu \& Recht 1989. pag. 345; E.H. Hondius, Het vorderingsrecht voor consumentenorganisaties in rechtsvergelijkkend perspectief - Kanttekeningen bij het voorgestelde art. 3.11.8a NBW, in "Het Nieuw BW in perspectief", Zwolle 1990, pag. 109-127; Frenk, RM-Themis 1989, pag. 372-389; Frenk, TvC 1990, pag. 203-217.

115 Het advies van de Raad van State beperkte zĭch tot opmerkingen van redactionele aard. Zie: NJB 1990, pag. 1294; Frenk, Jaarboek konsumentenrecht 1991, pag. 307.

116. Tweede Kamer, vergaderjar 1991-1992, 22 486, nrs. 1-2. Zie over het wetsvoorstel o.a.: Van Dam-Lely, pag. 39 e.v.; Frenk, Jaarbwek konsumentenrecht 1992, pag. 327-331. 
van wijziging ${ }^{117}$ en amendering ${ }^{118}$ van het Gewijzigd voorstel van wet ${ }^{119}$, werd het nader gewijzigd voorstel wan wet op 2 november 1993 door de Tweede Kamer $^{120}$ en op 29 maart 1994 door de Eerste Kamer ${ }^{121}$ aangenomen. Het bellangrijkste artikel in de nieuwe wet is artikel $3: 305 \mathrm{a} \mathrm{BW} .^{122}$

\section{Artikel 3:305a BW:}

1. Een stichting of vereniging met volledige rechtsbevoegdheid kan een rechtswordering instellen die streka tor bescherming van gelijksoortige belangen van andere personen, voorzover zij deze belangen ingevolge haar statuten behartigt.

2. Een rechtspersoon als bedoeld in lid 1 is niet ontvankelijk, indien hij in de gegeven omstandigheden onvoldoende heeft getracht het gevorderde door het voeren van overleg met de gedaagde te bereiken.

3. Een rechusvardering als bedoeld in lid 1 kan niet strekken tot schadevergoeding te voldoen in geld.

4. Een gedraging kan niet ten grondslag worden gelegd aan een rechtswardering als bedoeld in lid

1, woor zover degene die door deze gedraging wordt getroffen, daartegen bezwaar maaks.

5. Een rechterlijke witspraak heeft geen gevolg tem aanzien van een persoon tot bescherming van wiens belang de rechtsvordering strekt en die zich verzet tegen werking van de witsprack ten opzichte van hem, tenzij de aard wan de witspraak meebrengt dat de werking riet slechts ten opzichre van deze persaon kan worden uitgesloten. ${ }^{123}$

De Wet vorderingsrecht belangenorganisaties is met name ook van belang omdat het er aanvankelijk naar uitzag dat de Nederlandse wetgever niet van zins was

117 Tweede Kamer, vergaderjaar 1992-1993, 22 486, nrs. 6 en 9; Frenk, Jaarboek konsumentenrecht 1993, pag. 199 .

118 Er werden in total 5 amendementen ingediend (Tweede Kamer, vergaderjaar 1993-1994, 22 486, nrs. 12-16) waarvan er een door de regering werd overgenomen (nr. 16) en twee (nns. 14 en 15) door de Kamer werden aangenomen.

119 Tweede Kamer, vergaderjatar 1992-1993, 22 486, nr. 10.

120 Handelingen Tweede Kamer, 2 nowember 1993, pag. 19-1350 en 19-1351. Zie hienover: Klik, pag. 34 e.v."Frenk, S\&V 1994, pag. 35 e.v.; Bierbows en De Vries, pag. 96-97.

121 Handelingen Eenste Kamer, 29 maart 1994, pag. 26-1385 tot en met 26-1389.

122 In artikel $3: 305 \mathrm{~b} \mathrm{BW}$ is aan publiekrechtelijke rechtspersonen eveneens het collectief actierecht toegekend. Zie hierover o.a.: J.M.H.F. Teunissen en A.Q.C. Tak, Recht ist was der Umwelt nülzt?, NJB 1994 , pag 612 e.v.

123. Zie over de totstandkoming wan de wet o.a.: Rodrigues, SR 1992, pag. 108 e.v.; Rozemond, pag. 13 e.v.; Frenk, Jaarboek konsumentenrecht, 1990-1993; E. Bauw en N. Frenk, Nieuwe perspectieven voor milieuorganisaties, NJB 1991, pag. 1259-1263; N. Frenk en W. Messer, Ongekende mogelijkheden woor milieuorganisaties!?; KwNBW 1991, pag. 14-17; J.H. van Dam-Lely, Wetsvoorstel regeling bevoegdheid belangenorganisaties tot instellen collectieve acties, Stichting \& Vereniging 199.2, pag. 39-44; P.A. Kottenhagen-Edxes, Onrechtmatige daad en milieu, dissi. Rottendam, Amhem 1992, pag. 104 124; A.F "Klamer, Wetsvoorstel collectief actierecht woor belangenorganisaties, TVVS 1992, pag. 116-118; R.Ch. Verschuur, Kroniek Titel 3.11 Rechtsworderingen, NTBR 1992, pag. $165-167 ; \mathrm{H}$. wan den Berg; Het wetsvorstel collectieve acties en de millienorganisatjes, Rechtshulp 1992, nr. 8, pag. $8-9$ en nr. 9, pag. 167; P.F.A. Biertbooms en L.J.A. de Vries, Collectief aktierecht en milieubelangen: de stand wan zaken in Nederland, Tijdschrift voor Milieurecht 1993, pag. 293-299; Bierbooms en De Wries, pag. 96-97; Frenk, Stichting \&ereniging 1994, pag. 35-38; Klïk, pag. 34-42; Mölenberg. pag. 277 e.v.; Frenk, diss. pag. 105 e.v. 
aan consumenten- en andere belangenorganisaties een algemeen collectief actierecht toe te kennen. Tot 1986 gaf de Nederlandse wetgever er immers de voorkeur aan slechts beperkt actiebevoegdheid aan belangenorganisaties toe te kennen in specifieke wetten. ${ }^{124}$ In diverse bijzondere wetten werd speciaal ten behoeve van veelal met name genoemde collectieven, voorzien in specifieke acties ter behartiging van de belangen die deze organisaties zich ten doel stellen ${ }^{125}$. Zo bijvoorbeeld in:

artikel 79 Wet algemene bepalingen milieuhygiene voor "privaatrechielijke organisaties" die met het. oog op het willeubelang in het leven zijn geroepen;

-artikel 3 lid 5 en artikel 20a lid I Wet gellike behandeling wan mannen en vrowwen voor "rechtsper. sonen met wolledige rechtsbevoegdheid' die ten doel hebben de behartiging van de belangen was diegenen die een beroep zouden kunnen doen op her in artikel 1637ji wan het Burgerlijk Wetboek ent het in deze wet bepaalde" "126;

artikel 10 lid 2 Wet persoonsregistraties voor de "rechuspersoon met volledige rechtsbevoegdheid. die krachtens zijn doelstelling en blijkens zijn feitelijke werkaamheden de beiangen behartigt van de: personen die door het gedrag van die houder of de bewerker (van een persoonsregistratie, roevoeging WWHM) schade lijden of dreigen te lijden ${ }^{\text {i.27; }}$;

artikel $2: 346$ sub $b$ BW en $2: 347$ sub b $B W$ voor de "vereniging van werknemers, die in de onderneming werkzame persomen onder haar leden telt en ten minste wwee jaren volledige rechtsbevoegdheid: bezit, mits zij krachiens haar statuten ten doel heeft de belangen van hat leden als werknemers we behartigen en als zadanig in de bedriffstak of onderneming werkzaam is";

-artikel 5.126 BW lid 2 en lid 3 (artikel 876a BW (owd)) voor de vereniging van appartementseigenaars;

-artikel 6:196 lid' 2 sub a BW (Wet misleidende reclame, artikel 1416 lid 2 sub a BW (oud)) voor "rechispersonen met volledige rechtsbevoegdheid, die ten doel hebben, de behartiging wan belangen van persomen die een beroep of bedrijf uitoefenen of van eindgebruikers van niet voor een beroep of bedrijf bestemde goederen of diensten, indien deze belangen door het openbaar maken van de (misleidende, toevoeging $L J H M$ ) mededeling zijn of dreigen te worden aangetast ${ }^{\text {"128. }}$;

-artikel 6:196 lid 2 sub b BW (Wet misleidende reclame, artikel 1416 c lid 2 sub b BW (oud)) woor "andere rechtspersonen met volledige rechtsbevoegdheid" wier doel door het openbaar maken vant een misteidende mededeling words of dreigt te worden aangetast;

-artiket 15 Wet op de collectieve arbeidsovereenkonst voor de vereniging wan werkgevers of werlonemers;

124 ICC-eindrapport, pag. 39; Tweede Kamer, vergaderjaar 1991-1992, 22 486. nr. 3, pag. 2-3; Hondius en Rodrigues, pag. 1213; Rodrigues, sWOKA-onderzocksrapport, pag. 24 e.v.

125 Hondius en Rodrigues, pag. 1213, noot 52 en 54; Van Nispen, $\mathrm{nr}, 219 \mathrm{a}$; Rodrigues, SWOKAonderzcelksrapport, pag. 24-27; Frenk, Jaarboek konsumentenrecht 1990, pag. 321-324; Frenk, Jaarboek konsumentenrecht 1991, pag. 307-309; Frenk, diss., pag. 103; Tweede Kamer, vergaderjaar 1991-1992, 22 486, nr. 3 (MvT), pag. 2.

126 Ingevoegd bij de Wet van 27 april 1989, Stb. 1989, nr. 168; Zie nader P.F. van der Heijden, De mieuwe wet gelijke behandeling m/v, NJB 1989, pag. 1033-1038; I.P. Asseher-Vonk, Vorderingen tot naleving van do Wet gelijke hehandeling van mannen en vrouwen, SMA 1980, pag. 510.

127 Wet pentoonsnegistraties wan 28 december 1988, Stb. 1988, nr. 665, op 1 juli 1989 in werking getreden.

128 Wet van 6 juni 1980 , Stb. 1980, nr. 304. 
-artikel 3 lid 2 en lid 4 Wet op het algemeen verbindend en he' omverbindend verklaren wan bepalingem wan collectiewe arbeidsovereenkomstem voor de wereniging met wolledige rechibewaegdheid wan witemgevers of anbeiders:

artikel 26 Wet op de ondememingsraden voor de ondennemingsraden;

-artikel 36 Wet op de ondermemingstaden voor de vakveranigingen;

artikel 29 a Auteurswet woor "de door onze minister wan Justitie an te wijzen rechtsporsonten met walledige rechsbevoegdheid die ten doel hebben de behartiging van de belangen wan makers van werken of hun rechrwerkijgenden "120;

-artikel 12 lid 2 Watboek van Strafiordering can de "rectitspersoon die krachtens zijn doelstelling en bljkens zijn feitelijke werkzacumheden een belang behartigt dat door de beslissing rot niet vervolging of niet vendere venwolging rechtstreeks wordt getroffen";

artikel 30a onder a Vestigingswet Bedrijuen 1954 en antikel 57 a onder a Drank- en Horecawer woor verenigingen van ondememers met wolledige rechisbevoegdheid en stichtingen, die in overeenstemming met hus statuten belangen behartigem van hen, die een zelfide of verwant bedrijt witheyfienen ${ }^{\text {w } 130 \text {; }}$

wartikel 26 onder a Vestigingswet detailhandel woor "verenigingen van derailhandelaren met wolledige rechisbevoegdheid en stichtingen, die in overeenstemuming met hun statuten belangen wan detailhandelaren behartigen";

-artikel 30 a onder vesrigingswet Bedrijen 1954 en arrikel 26 onder $c$ Vestigingswet detaithardet woor "werenigingen met wolledige rechtsbevoegdheid en stichtingen, die in overeenstemming met hun statutten belangen van consumenten behartigen ${ }^{\text {1313 }}$;

-artikel 57 a onder c Drank- en Horecawet voor "verenigingen met volledige rechusbevoegdheid en stichtingen, die in overeenstemming met hun statuten belanger van comsumenten, watronder de beperking van risico's voor de gezondheid", voortuloeiende wit het gebruik van alcohol, behartigen"; -artikel 30 a onder d Vestigingswer Bedrijuen 1954, artikel 26 onder d Vestigingswer detailhandel en arwikel 57 a onder $d$ wan de Drank- en Horecawet voor "verenigingen met volledige rechtsbewoegdheid, die in overeenstemming met han statuten belangen wan werkomers behartigen";

-artikel 18 wan de op 1 jult 1993 in werking getreden Wet op de naburige rechten voor organisaties wan wirvoerende kanstemaars, producenten van fonogrammen en omroeporganisaties ${ }^{132}$;

-amikel 10 Algemene wet gelijke behandeling voor "belangenorganisaties" ${ }^{\text {133; }}$

-artikel 128 Gezandheids-en welzijnswet voor dieren voor "belangenorganisaties "134.

-arrikel 2 metswoorstel Groepsacties gelijke behandeling aanhangig waarin is woorziem in een collecriewe actie ${ }^{\mathrm{is}}$.

129 Wet van 30 mei 1985 , Stb. 1985 , nr. 307 .

130 Wet tot wijziging van de Vestigingswet Bedrijven 1954, de Vestigingswet detailhandel en de Drank-en Horecawet, Tweede Kamer 1986.1987, 19 743, Stb. 1990, nr. 19. In werking getreden op $\|$ oktober 1990 (zie KB van 12-9-1990, Stb. 1990, nr. 483).

131 Zie nader P.R. Rodrigues, Beunhazerij, pag. $471-480$.

132. Wet op de naburige rechten, Stb 1993, 178, gewijzigd bij wet van 8 november 1993, Stb. $1993,598$.

133 Wet van 2 maart 1994, houdende algemene negels ter bescherming tegen discriminatie op grond wan godsdienst, levensovertuiging, politieke gezindheid, ras, geslacht, nationaliteit, heterow of homoseksuele gerichtheid of burgerlijke stast (Algemene wet gelijke behandeling), Staatsblad 1994, 230. Zie ook: Frenk, Jaurboek konsumentenrecht 1991, pag. 309.

134 In werking getreden op 8 juni 1994.

135 Gewijzigd initiatiefvoorstel-Groenman, Tweede Kamer, vergaderjaar 1986-1987, 19507 , nr. 6. 
Met de toekenning van het algemene collectieve actierecht aan belangenorganisaties in de artikelen 3:305a en 3:305b BW heeft de wetgever het echter onnodig geacht om verschillende, in vergelijking met dit algemene collectieve actierecht, beperktere actiebevoegdheden in de diverse specifieke wetten te handhaven. Met de inwerkingtreding van de artikelen 3:305a en 3:305b BW op 1 juli 1994 zijn de volgende bepalingen derhalve vervallen:

-artikel 6:196 lid $2 \mathrm{BW}$;

-artikel 29a Auteurswet;

-artikel 10 lid 2 Wet persoonsregistraties;

-artikel 30a Vestigingswet Bedrijven 1954;

-artikel 26 Vestigingswet detailhandel;

-artikel 57a Drank- en Horecawet;

-artikel 20a Wet gelijke behandeling mannen en vrouwen;

-artikel 10 Algemene wet gelijke behandeling;

-artikel 18 Wet op de naburige rechten;

-artikel 128 van de Gezondheids- en welzijnswet voor dieren. ${ }^{136}$

Tijdens de parlementaire behandeling was tevens voorzien in een wijziging van artikel 6:240 lid $3 \mathrm{BW}$ in die zin, dat het vereiste van volledige rechtsbevoegdheid zou komen te vervallen omdat dit vereiste oorspronkelijk ook niet zou gelden voor de actiebevoegdheid van artikel 3:305a BW. ${ }^{137}$ Met de terugkeer van de eis van volledige rechtsbevoegdheid in het uiteindelijke artikel 3:305a BW is aanpassing van artikel 6:240 lid 3 BW aan artikel 3:305a BW onnodig. ${ }^{138}$

\subsubsection{Het collectief actierecht voor consumentenorganisaties op het terrein van de algemene voorwaarden als ongelijkheidscompensatie}

De knelpunten inzake het gebruik van algemene voorwaarden vinden hun oorzaak voornamelijk in de ongelijke positie waarin gebruikers van algemene voorwaarden en consumenten-wederpartijen zich ten opzichte van elkaar bevinden. Het collectief actierecht voor consumentenorganisaties beoogt de ongewenste resultaten van deze ongelijkheid tegen te gaan en kan derhalve gezien worden als een middel ter compensatie van deze ongelijkheid.

136 Artikelen II tot en met IX Wet vorderingsrecht belangenorganisaties.

137 Artikel III wan het wetswoonstel, Tweede Kamer, vergaderjaar 1991-1992, 22,486 , nrs. 1-2.

138 Zie voor de verhouding tussen het collectieve actierecht op het terrein van de algemene voorwasurdern als bedoeld in artikel 6:240 BW en het algemene collectieve actierecht als bedoeld in artikel 6:305a BW hiema paragraaf 5.3.12. 
"De natio wan de bescherming tegen algemene voonwarden is immers mede te winden in de

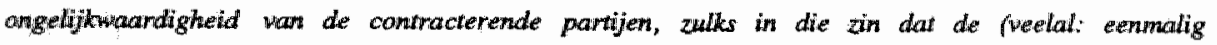
eomitracterende) wederpartij staat tegenover een gebruiker die de voorwaarden toepast bij (neelal: hereff opgesteld woor) de wele transacties wan hetzelyde type die hij pleegr te sluaten. "139

Vanuit de individuele consument gezien compenseert het collectief actierecht voor consumentenorganisaties op twee terreinen (indirect) de ongelijkheid ten opzichte van de gebruiker van algemene voorwaarden.

Ten eerste de ongelijkheid ten aanzien van de vaststelling van de inhoud van algemene voorwaarden. De consument is vanwege het feit dat hij ten opzichte van de gebruiker van algemene voorwaarden doorgaans in een ongelijke positie verkeert, niet in staat over de inhoud van algemene voorwaarden te onderhandelen. Van echte consensus bij de individuele consument ten aanzien van de inhoud van algemene voorwaarden is doorgaans geen sprake. Hierin brengt de Wet algemene voorwaarden direct geen verandering. Ook na invoering hiervan zall de individuele consument, als hij daar al behoefte an heeft, geen invloed hebben op de inhoud van de jegens hem gehanteerde algemene voorwaarden. Door het toekennen van het ius agendi zullen consumentenorganisaties echter beter in staat zijn om enerzijds door middel van overleg en anderzijds door het uitlokken van gerechtelijke verboden te bewerkstelligen dat de inhoud van jegens consumenten gehanteerde algemene voorwaarden een meer evenwichtige inhoud krijgen. Van individuele consensus dus naar collectieve consensus, waardoor de contractuele positie van de consument gelijkwaardiger wordt en dus meer in evenwicht komt. Ook in een ander opzicht draagt het collectief actierecht van consumentenorganisaties bij tot een meer evenwichtige inhoud van algemene voorwaarden. De weinig preventieve werking en de geringe breedtewerking van het rechterlijk vonnis zijn aanzienlijk verbeterd. Uiteindelijk zal dit moeten resulteren in een meer evenwichtige inhoud van algemene voorwaarden in individuele overeenkomsten en wordt ook op deze wijze de ongelijke positie van de individuele consument, collectief gecompenseerd.

Ten tweede de ongelijkheid ten aanzien van de toegankelijkheid van het recht en de overheidsrechter. De consument heeft immers doorgaans geen of nauwelijks toegang tot het recht en rechter. De situatie van de individuele consument zal door het vaststellen van specifieke wetgeving met daarin opgenomen een individueel actierecht niet echt verbeteren, als hij niet tegelijkertijd ook toegang krijgt tot het recht en de rechter. De positie van de individuele consument is in dit opzicht echter niet direct verbeterd. De toegankelijkheid van het recht en de rechter zal voor individuele consumenten ook na inwerkingtreding van afdeling 6.5.3 BW en andere consumentenbeschermende wetgeving een 
praktisch niet te nemen hindernis blijven. Daar staat tegenover dat voor consu mentenorganisaties de toegang tot de rechter is verbeterd. Van de consumentent organisaties kan worden verwacht dat zij well toegang hebben tot het recht en de rechter omdat woor hen de beperkingen van de individuele consument niet of althans in mindere mate gelden. Zij zijn immers, al dan niet na verloop van tijd, Repeat Player. De toekenning van het collectieve actierecht aan consumentenor ganisaties moet dan ook mede gezien worden als een compensatie voor het feitelijk ontbreken van het actierecht bij de individuele consument. ${ }^{100} \mathrm{Collec}$ tieve actie in plaats van individuele actie. De consumentenorganisatie is als collectief immers een betere procespartij dan de individuele consument. In die zin is procesrechtelijk gezien sprake van een "upgrading". ${ }^{141}$

Ook vanuit het (collectieve) perspectief van consumentenorganisaties gezien heeft het collectief actierecht een ongelijkheidscompenserende werking. Eén van de knelpunten bij zelfregulering is immers vaak de geringe bereidheid van het bedrijfsleven om mee te werken aan het voorwaardenoverleg. Dit werd vooral geweten aan het feit dat bij de consumentenorganisaties een "stok achter de deur" ontbrak." ${ }^{142}$ Het collectief actierecht beoogt deze stok achter de deur te bieden. ${ }^{143}$ De consumentenorganisaties hebben door de expliciete mogelijkheid van een beroep op de overheidsrechter meer "countervailing power". ${ }^{144}$ Daardoor wordt in het onderhandelingsproces over de te hanteren algemene voorwaarden de positie van consumentenorganisaties ten aanzien van aanbiedersorganisaties gelijkwaardiger en zijn zij beter in staat de beoogde bescherming van de belangen van de individuele consument te realiseren.

140 Zie ook: CCA-advies, pag. 26 noot 1 .

141 Galanter, L\&SR 1974, pag. 141 e.v.; Gallanter, LeSR 1976, pag. 231 e.v.

142. ICC-eindrapport, pag. 22-23; CCA-advies, pag. 8-9 en 26; MvT Inv, Parlementaire Gieschiedenis, Inv. 3, 5 en 6, pag. 1762, 1764.

143 CCA-advies, pag. 38; MvA I Inw., Parlementaire Geschiedenis, Inv, 3, 5 en 6, pag. 1780.

144 Hondius, diss, , pag. 330-331; Von Hippel, pag. 27 e.v; Rijken, diss., pag. 226 en 230. 
II DE WETTELIJKE REGELING VAN DE PROBLEMATIEK VAN DE ALGEMENE VOORWAARDEN 


\section{De wet algemene voorwaarden}

\subsection{Inleiding}

Op 16 juni 1987 is, als vrucht van het groeiende besef dat het gebruik van algemene voorwaarden (voor de consument) niet alleen voordelen doch ook nadelen met zich bracht ${ }^{1}$, door de Eerste Kamer het wetsvoorstel inzake algemene voorwaarden (afdeling 6.5.2A NBW) aangenomen. ${ }^{2}$ De Wet algemene voorwaarden is op 1 januari 1992 in werking getreden en de overgangstermijn als bedoeld in artikel 191 Overgangswet NBW is inmiddels verstreken, waardoor de regeling in beginsel van toepassing is op alle in Nederland gehanteerde algemene voorwaarden. ${ }^{3}$

Met de invoering van afdeling 6.5.3 $\mathrm{BW}$ en de bijbehorende veranderingen en toevoegingen in de Wet op de Rechterlijke Organisatie (RO) en het Wetboek van Burgerlijke Rechtsvordering (Rv), heeft de Nederlandse wetgever gekozen voor een stelsel van regels waarin een expliciete dwingendrechtelijke stellingname wordt gegeven ten aanzien van:

- de problematiek van de toepasselijkheid (primaire gebondenheid) van algemene voorwaarden (ook indien de wederpartij de gelding daarvan heeft aanvaard zonder de inhoud te kennen);

- de wijze waarop de gebruiker van algemene voorwaarden an zijn wederpartij de mogelijkheid dient te verschaffen van deze voorwaarden kennis te nemen;

- de geoorloofdheid van de inhoud van algemene voorwaarden;

- de toegang tot de overheidsrechter.

1 MvT, Parlementaire Geschiedenis, Inv. 3, 5 en 6, pag. 1454.

2 Wet van 18 juni 1987, houdende inwoeringswet Boeken 3,5 en 6 van het nieuwe Burgerlijk Wetboek (tweede gedeelte) (algemene voorwaarden), Staatsblad 1987, 327.

3 In beginsel, omdat een uitzondering moet worden gemaakt voor de toepassing van de vemietigbaarheid van artikel $6: 233$ sub $b j^{\circ} 6: 234$ BW op algemene voorwarden die reeds wó́r $\|$ januari 1992 deel uit makten van de overeenkomst. Zie hierover: Van der Beek, diss,", pag. 100-102. 
De invulling wan deze stellingname zoals deze uiteindelijk vorm heeft gekregen in de regeling van afdeling 6.5.3 BW, komt in dit hoofdstuk aan de orde: Daarbij wordt allereerst (kort) ingegaan op de ontstaansgeschiedenis van afdeling 6.5.3 BW, de plaats in het (nieuwe) Burgerlijk Wetboek, de uitgangspunten van de wettelijke regeling en de indeling van de Wet algemene voorwaarden. Vervolgd wordt met een, eveneens beknopte, bespreking van de materieelrechtelijke bepalingen van de artikelen 6:230 tot en met $6: 239$ en $6: 245$ tot en met 6:247 BW in paragraaf 5.2. De nadruk komt uiteraard te liggen op het procesrechtelijk deel van de regeling en de bepalingen omtrent het collectief actierecht woor consumentenorganisaties zoals voorzien in de artikelen 6:240 tot en met 6:244 BW en de artikelen 4 sub $13^{\circ}, 9$ lid 3,67 en 1003 tot en met 1006 van het Wetboek van Burgerlijke Rechtsvordering. Deze materie wordt uitvoerig besproken in paragraaf 5.3.

\subsubsection{Ontstaansgeschiedenis van de Wet algemene voorwaarden}

Nadat de in het Ontwerp-Meijers van 1961 voorziene regelgeving inzake de problematiek van de algemene voorwaarden, bestaande uit de bepalingen van de (ontwerp) artikelen 6.5.1.2 (het latere 6:214) en 6.5.1.3 NBW, voor wat betreft de regeling voorzien in het laatste artikel, in 1975 was verlaten, zijn de eerste stappen gezet op weg naar de huidige wettelijke regeling van afdeling $6.5 .3 \mathrm{BW}$ inzake algemene voorwaarden.

Het eerste ontwerp van de in 1975, ter vervanging van artikel 6.5.1.3 NBW, aangekondigde wettelijke regeling werd op 28 juli 1981 aan de Tweede Kamer der Staten-Generaal aangeboden onder de titel: Invoeringswet Boeken 36 van het nieuwe Burgerlijk Wetboek (tweede gedeelte) (algemene voorwaarden). Dit ontwerp van wet voorzag in:

- schrapping van het (ontwerp) artikel 6.5.1.3 NBW en wijziging van het (ontwerp) artikel 6.5.1.9 NBW, het huidige artikel 6:216 BW;

- invoeging van een nieuwe regeling, na afdeling 6.5.2 NBW (Het tot stand komen van overeenkomsten), in de afdeling 6.5.2A NBW, getiteld "Algemene voorwaarden"; 6

- invoeging van een nieuw artikel 67 in de Wet op de Rechterlijke Organisatie;

- wijziging van de artikelen 4 en 9 van het Wetboek van Burgerlijke Rechtsvordering; ${ }^{:}$

4 Tweede Kanner, zitting 1981, 16, 983, nrs. 1-3, pag. 1.

5 Artikel IOntwerp van wet, Tweede Kamer, zitting 1981, 16983 , nrs. 1-3, pag. I.

6 Artikel II Ontwerp van wet, Tweede Kamer, zitting 1981, 16983 , nrs. 1-3, pag. 1-6.

7 Artikel III Ontwerp van wet, Tweede Kamer, zitting 1981, 16 983, nrs. 1-3, pag. 6-7.

8. Artikel IV Ontwerp van wet, Tweede Kamer, zitting 1981, 16 983, nrs. 1-3, pag. 7. 
- toevoeging van een Twaalfde Titel aan het Derde Boek van het Wetboek van Burgerlijke Rechtsvordering, getiteld "Van rechtspleging in zaken betreffende onredelijk bezwarende bedingen in algemene voorwaarden ${ }^{\text {m9; }}$;

- vaststelling van een overgangsregeling ${ }^{10}$.

Bij het opstellen van het wetsontwerp is onder meer acht geslagen op:

- het (ontwerp van) artikel 6.5.1.3; ${ }^{11}$

- het CCA-advies inzake het vraagstuk van de toepassing van standaardvoorwaarden bij transacties met de consument ${ }^{12}$ en het CCA-advies inzake het Voorontwerp van de wet Consumentenkoop ${ }^{13}$ en dan vooral het eerstgenoemde CCA-advies dat uitdrukkelijk de basis is van het ingediende wetsontwerp; ${ }^{14}$

- de Nederlandse literatuur inzake algemene voorwaarden, met name de dissertatie van Hondius ${ }^{15}$ en de preadviezen van Hondius $^{16}$ en Dalhui$\operatorname{sen}^{17}$ voor de Nederlandse Juristenvereniging; ${ }^{18}$

- wetten (en ontwerpen daarvan) van Nederland omringende landen en de Europese Gemeenschap zoals het Duitse AGB-Gesetz uit $1976^{19}$, het Oostenrijkse Konsumentenschutzgesetz uit $1979^{20}$, de Britse Unfair Contract Terms Act uit $1977^{21}$, de Franse Loi sur la protection et l'information des consommateurs de produits et de services uit $1978^{22}$ en de Europese Resolutie inzake Unfair Terms in Consumer Contracts and an Appropriate Method of Control ${ }^{23}$;

9 Artikel III Ontwerp wan wet, Tweede Kamer, zitting 1981, 16 983, nrs. 1-3, pag. 6-7.

10 Artikel V Ontwerp van wet, Tweede Kamer, zutting 1981, 16983 , nrs. 1-3, pag. 8.

11. MvT; Parlementaire Geschiedenis, Inw, 3, 5 en 6, pag. 1450.

12 SER-uitgave 1978 , nr. 7.

13 SER-Uitgave 1980, nr. 6.

14 MvT, Parlementaire Geschiedenis, Inv. 3, 5 en 6, pag "1451.

15 E.H. Hondius, Standaandwoorwaanden, Rechtsvergelijkende beschouwingen over standandisering wan kontraktsbedingen en overheidstrexicht dsamop, diss. Leiden, Deventer 1978.

16 E.H. Hondius, Newar een wettelijke regeling van algemene voorwaanden, preadvies voor de Nederlandse Juristen-Veneniging, HNJV 1979, deel 1, pag. 91-290.

17 J.H. Dallhuisen, Algemene voorwalarden, preadvies voor de Nederlandse Juristen-Vereniging, HNJV 1979 , deel 1 , pag. 5im 89.

18 MVT, Parlementaire Gesshiedenis, Inv. 3, 5 en 6, pag. 1454.

19 Wet van 9 december 1976, BGBI. 1976, nr. 142.

208 malart 1979, BGBl. 1979, nr. 140.

2126 oktober 1977, Elizabeth II 1977, Ch. 50.

2210 januari 1978, JO 1978, 301 .

2316 november 1976, Resolution (76) 47. Zie voor de authertieke Franse en Engelse tekist respectievelijk Hondius, preadvies, paig. 216-220 en Contractennecht VII (Hondius), nr. 133. 
- de visies van onafhankelijke deskundigen, consumenten- en ondernemersorganisaties op het begin 1980 aan hen voorgelegde voorontwerp van wet inzake algemene voorwaarden ${ }^{24}$.

Het eerste ontwerp van afdeling 6.5.2A NBW, dat oorspronkelijk slechts 13 artikelen telde, werd in de literatuur verdeeld ontvangen, waarbij vooral thet bedrijfsleven een afwijzend standpunt innam. ${ }^{25}$ Op weg naar goedkeuring door de Eerste Kamer der Staten-Generaal op 16 juni $1987^{26}$ en publikatie in het Staatsblad op 18 juni $1987^{27}$ heeft het ontwerp dan ook een betrekkelijk turbulente periode gekend. ${ }^{28}$

Allereerst overleefde het in september 1983 de zogenoemde "Operatie stofkam". ${ }^{29}$ Vervolgens de in juni 1983 gepubliceerde dereguleringsvoorstellen van de Commissie Van der Grinten die voorzagen in intrekking van het wetsontwerp ${ }^{30}$. Deze dereguleringsvoorstellen op het terrein van de algemene voorwaarden werden begin 1984 echter resoluut van de hand gewezen door het Kabinet. ${ }^{31}$ Ook in de Tweede en Eerste Kamer werd het ontwerp bepaald niet

24 Rede van de toenmalige minister van Justitie J. de Ruiter bij het 50-jarig bestaan wan het: Nederlands Genootschap van Bedrijfsjuristen, NJB 1980, 1116-1117. Het voorontwerp kreeg een goed onthaal van de consumentenorganisaties en de Raad voor het Midden- en Kleinbedrijf. Van de zijde van andere organisaties van ondememers werd vooral kritiek op en onvredle met het voorontwerp genit.

25 Kritisch doch overwegend positief werd het oorspronkelijke ontwerp (en de gewijzigde versies daarvan) ontvangen door: Serraris-Perrick, Bouwrecht 1982, pag. 380-282; Hondius, AA 1982, pag. 45-47; Serraris-Perrick, NJB 1983, pag. 472-478; Hondius, KWNBW 1984, Algemene voorwaarden, pag. 29-30.

Afwijzend: Göbbels, pag. 217-226; Vollebregt, NJB 1984, pag. 809-815; Het Nederlands Genootschap van Bedrijfsjuristen, zie: Spier, KwNBW 1984, pag. 129-131; Spier, KwNBW 1985 , pag. 6-10.

26 Handelingen Eerste Kamer, vergaderjaar 1986-1987, pag. 1565-1566.

27 Wet van 18 juli 1987, houdende Invoeringswet Boeken 3,5 en 6 wan het nieuwe Burgerlijk Wetboek (tweede gedeelte) (algemene voorwaanden), Stastablad 1987, 327.

28 Zie voor een overzicht van de parlementaire behandeling: Parlementaire Geschiedenis, Inv, 3, 5 en 6, pag. XXIV-XXXI; G.J. Rijken, KwNBW 1984, pag. 121-129 en van dezelfde auteur: NJB 1984, pag. 1413-1417; KwNBW 1985, pag. 79-80; TVVS 1986, 265-270.

29 Nota van 29 september 1983, betreffende de voortgang van de Invoeringswet Boeken 3-6 Nieuw BW, eerste tot en met zevende gedeelte. Het twweede gedeelte (16 983 - ilgemene voorwaarden) was niet in de wijzigings- en temporiseringsvoorstellen, de zogenoemde "Operatie stofkam", betrokken. Zie: Hondius, KwNBW 1984, Operatie stofkam, pag. 2.

30 Rapport van de Commissie Van der Grinten, Tweede Kamer, zitting 1982-1983, 17 931, nr. 5. Wegens bezwaren tegen de lijsten van de artikelen 6.5.2A.3 en 6.5.2A.4 Olnv en de abstracte inhoudstoetsing door het Haagse Hof en omdat naar de mening van de commissie de leden 2 van de artikelen 6.5.1.3 en 6.5.3.1 van het nieuwe Burgerlijk Wetboek voldoende bescherming bieden, werd aanbevolen het wetsontwerp inzake algemene voorwaarden in te trekken. Zie:

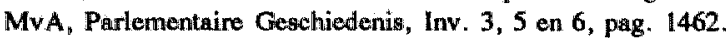

31 Zie: MvA, Parlementaire Geschiedenis, Inv. 3, 5 en 6, pag. 1462-1463; Hondius, Deregulering, KWNBW 1984, pag. 17-18. 
zonder kritiek en vragen ontvangen. ${ }^{32}$ Toch is het in grote lijnen door de volksvertegenwoordiging overgenomen en zijn in de loop van de parlementaire behandeling inhoudelijk slechts geringe wijzigingen aangebracht in het oorspronkelijke ontwerp.

De vooral voor het onderhavige onderzoek relevante bepalingen omtrent de abstracte inhoudstoetsing door het Haagse Hof op vordering van belangenorganisaties, hebben de twee Nota's van Wijziging ${ }^{33}$ en de aangenomen amendementen $^{34}$ vrijwel ongeschonden doorstaan. De uiteindelijke bepalingen inzake het ius agendi voor consumenten- en ondernemersorganisaties zoals neergelegd in de huidige afdeling 6.5.3 $\mathrm{BW}$ en de daarbij behorende wijzigingen en aanvullingen in de Wet op de Rechterlijke Organisatie en het Wetboek van Burgerlijke Rechtsvordering, wijken, afgezien van enige redactionele wijzigingen, inhoudelijk slechts op één punt af van het oorspronkelijk ontwerp. Het betreft de laatste volzin van artikel 6:240 lid $1 \mathrm{BW}$ :

Voor de toepassing van de vorige zin wordt een beding in algemene voorwaarden dat in strijd is met een dwingende wetsbepaling, als onredelijk bezwarend aangemerkt.

Deze tekst werd, in goed overleg tussen de Minister van Justitie en de vaste Commissie voor Justitie reeds in de eerste Nota van wijziging, samen met de

32 Zie: Voorlopig Verslag van de vaste Commissie voor Justitie (VV) van 30 juni 1983, Tweede Kamer, zitting 1982-1983, 16983 , nr. 4, pag. 1-26; Eindverslag van de vaste Cammissie voor Justitie (EV) van 16 mei 1984, Tweede Kamer, vergaderjaar 1983-1984, 16983 , nr. 7, pag. 124: Uitgebreide Commissievergaderingen van 1 oktober 1984 (UCV I), Handelingen Tweede Kamer, 1984-1985, 5de uitgebreide commissievergadering, pag. 5-1 $t / m 5-31$, en wan 28 januari 1985, Handelingen Tweede Kamer, 1984-1985, 40ste uitgebreide commissievergadering, pag. $40-1 \mathrm{v} / \mathrm{m}$ 40-28; Voorlopig Verslag van de Bijzondere Commissie voor de herziening van het Burgerlijk Wetboek (VV I), Eerste Kamer, vergaderjaar 1985-1986, 16 983, nr. 139, pag. $1-10$.

33. Nota van Wijziging (NwW I) van 2 januari 1984, Tweede Kamer, vergaderjaar 1983-1984, 16 983, nr. 6, pag. 1-3; Tweede Nota van Wijziging (Nvw II) van 20 augustus 1984, Tweede Kamer, vergaderjaar 1983-1984, 16983 , nr. 9, pag. 1-3.

34 Er werden in total 57 amendementen ingediend. Zie: Tweede Kamer, vergaderjaar 1984-1985, 16983 , nrs. 12-43. Darrvan kwamen uiteindelijk slechts 32 amendementen in stemming omdat de kamerieden Salomons en Schutte alanog 25 amendementen introkken. Van deze 32 amendementen werden uiteindelijk 4 amendementen angenomen, welke zijn vervat in de Kamerstukken 16983 , nrs. 18, 28, 30 en 33. Zie: Handelingen Tweede Kamer, vergaderjaar 19841985, pag. 4825-4826; G.J. Rijken, Het wetsvoorstel algemene voorwharden door de Tweede Kamer aanvaand, KwNBW 1985, pag. 79-80. 
daar uit voortvloeiende wijziging van lid 4 van artikel 6.5.2A.7 OvW (het huidige $6: 241 \mathrm{BW})^{35}$, toegevoegd aan het oorspronkelijke ontwerp. ${ }^{36}$

Op 1 januari 1992 is de Wet algemene voorwaarden - als onderdeel van de nieuwe Boeken 3, 5 en 6 - in werking getreden . ${ }^{37}$ Het ten aanzien van afdelling 6.5.3 vastgestelde overgangsrecht in artikel 191 ONBW, voorzag in een uitgestelde werking van een jaar voor algemene voorwaarden die op 1 januari 1992 reeds door een partij in haar overeenkomsten werden gebruikt en de tot 1 januari 1993 aangebrachte wijzigingen in die voorwaarden. ${ }^{38} \mathrm{Na} 1$ januari 1993 kunnen in beginsel ${ }^{39}$ alle algemene voorwaarden overeenkomstig afdeling 6.5.3 BW worden vernietigd met dien verstande dat deze vernietiging ten hoogste kan terugwerken tot het tijdstip waarop afdeling 6.5.3 van toepassing werd. ${ }^{\text {to }}$ Bovendien heeft artikel 191 ONBW geen betrekking op de vernietigingsgrond van artikel 6:233 sub b BW. Voor de regeling van artikel 6:233 sub b BW geldt artikel 79 ONBW. ${ }^{41}$

\subsubsection{Uitgangspunten van de wettelijke regeling}

Zoals reeds aangegeven in paragraaf 4.3.1 gaat de Nederlandse wetgever er van uit dat algemene voorwaarden een nuttige rol kunnen spelen in het economische verkeer. Daarbij wordt in de eerste plaats gedacht aan de besparing van tijd en kosten voor zowel de gebruiker als de wederpartij, omdat niet meer bij elke transactie over de voorwaarden behoeft te worden onderhandeld en deze voorwaarden kunnen worden afgestemd op de specifieke geaardheid van de transactie in een bepaalde branche. ${ }^{42}$ In de tweede plaats dragen algemene voorwaarden bij tot een grotere rechtszekerheid voor beide partijen omdat zij de wederzijdse rechten en plichten duidelijk vastleggen. ${ }^{43}$ Voor de ondernemer

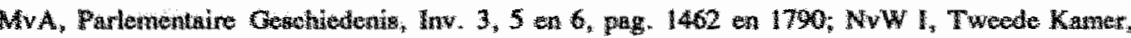

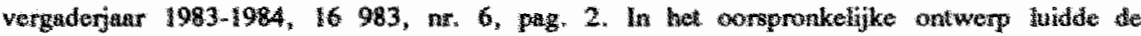

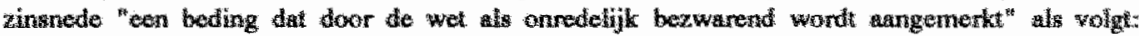

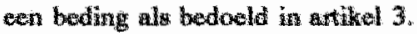

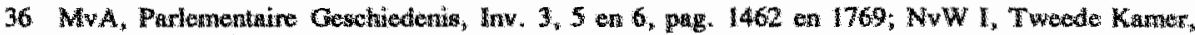
vergaderjuar 1993-1984, 16983, nr. 6, pag. 2 .

37 Konimklyk Besluit van 20 rebneri 1990, Stantsbidd 1990, 90.

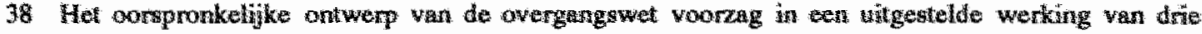
jaar. Ontwerp Inworingswet Boeken 3,5 en 6 new Burgerlijk Welwek, elfde gedeclte, bewattende anwhing van de Overgangwet niew Wugerlyk Wethow, Tweede Kamer, 1984 1985,18998

39 Zine kiterboven noot 3.

40 Zis ankel 19 hd 2 ONBW. Zie witgebreid over het avergangrecht indake addeling 6.5.3 BW. Van der Beek, diss, pag, 98-102, Harkamp, WPNR 1992, pag. 327-328.

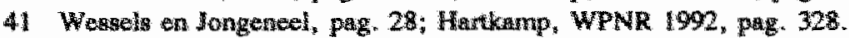

42 MVT, Parlenentaire Gesehiedusis, Iow, 3,5 en 6, poge, 1452 .

$43 \mathrm{MV}$, Parlementaic Geschiederis, Inv, 3,5 en $6, p a g, 1452$. 
heeft het gebruik van algemene voorwaarden tevens het voordeel dat zijn personeel rechtstreeks transacties op basis van die voorwaarden kan afsluiten. ${ }^{44}$ Redelijke algemene voorwaarden hebben bovendien als voordeel dat de wederpartij zich bij de vergelijking van diverse aanbiedingen kan beperken tot essentialia zoals prijs en kwaliteit. is $^{\text {s }}$

Daar staat het uitgangspunt van de Nederlandse wetgever tegenover dat aan de hantering van algemene voorwaarden ook belangrijke nadelen zijn verbonden. Daarbij wordt met name gedacht aan enerzijds een zekere versluiering van de contractsinhoud omdat de wederpartij nauwelijks kennis neemt van de inhoud van de algemene voorwaarden én anderzijds het gebruik van (onereuze) bedingen die in onvoldoende mate rekening houden met de belangen van de wederpartij.

Vanuit bovenstaande optiek is het stelsel van afdeling 6.5.3 BW gebaseerd op de volgende uitgangspunten:

- gezien de voordelen die het hanteren van algemene voorwaarden voor beide partijen heeft moeten niet al te strenge eisen worden gesteld aan de inlassing van die algemene voorwaarden in de overeenkomst ${ }^{47}$;

- de nadelen (versluiering en onereuze inhoud) van het hanteren van algemene voorwaarden voor de wederpartij moeten echter op een doeltreffende wijze worden bestreden ${ }^{48}$.

\subsubsection{Plaats van de wettelijke regeling}

De wet algemene voorwaarden bestrijkt het gehele vermogensrecht en is derhalve opgezet als aanvulling van Boek 6 van het nieuwe BW (Algemeen gedeelte van het verbintenissenrecht). De wetgever ging er van uit dat van een nieuw verbintenissenrecht mag worden verwacht dat het een passende regeling geeft voor het belangrijke fenomeen algemene voorwaarden. ${ }^{49}$

De wet is als derde afdeling (na)geplaatst in de vijfde titel van Boek 6 (Overeenkomsten in het algemeen). $\mathrm{Zij}$ is geplaatst ma afdeling 6.5.2 BW betreffende het tot stand komen van overeenkomsten en voor afdeling 6.5.4 BW betreffende de rechtsgevolgen van overeenkomsten. De plaatsing van de wet algemene voorwaarden tussen deze afdelingen is een logische als men bedenkt dat de wet algemene voorwaarden met beide afdelingen duidelijke raakvlakken heeft. Aan de ene zijde geeft afdeling 6.5.3 $\mathrm{BW}$ nadere regels met betrekking

44 MvT, Parlementaire Gegchiedenis, Inv. 3, 5 en 6, pag. 1452.

45 MWT, Parlementaire Geschiedenis, Inv. 3, 5 en 6 , pag. 1452.

46. MVT, Parlementaire Geschiedenis, Inv. 3, 5 en 6 pag. 1452.

47 MvT, Parlementaire Geschiedenis, Inv. 3, 5 en 6, pag. 1581 .

48 MvT, Parlementaire Geschiedenis, Inv. 3, 5 en 6, pag. 1481.

49 MvT, Parlementsire Geschiedenis, Inv, 3, 5 en 6, pag. 1451. 
tot de aanvaarding van de gelding van de algemene voorwaarden en de daarmee samenhangende problematiek van de versluiering van algemene voorwaarden en vindt bovendien de rechterlijke controle op de inhoud haar motivering in de wijze waarop de wederpartij in beginsel aan de algemene voorwaarden wordt gebonden. Aan de andere zijde heeft de inhoudelijke toetsing van algemene voorwaarden zoals voorzien in afdeling 6.5.3 BW grote verwantschap met de toetsing aan de redelijkheid en de billijkheid als voorzien in afdeling 6.5.4 BW. . $^{\text {so }}$

De Wet algemene voorwaarden is geplaatst binnen de wettelijke regeling voor overeenkomsten in het algemeen. ${ }^{{ }^{51}} \mathrm{Zij}$ is dus zonder meer van toepassing op de obligatoire of verbintenisscheppende overeenkomsten. Door de schakelbepaling van artikel 6:216 $\mathrm{BW}$ is het bepaalde in afdeling 6.5.3 BW van overeenkomstige toepassing op andere meerzijdige vermogensrechtelijke rechtshandelingen, als de zakelijke, de procesrechtelijke en familierechtelijke overeenkomst. Een en ander, voor zover de strekking van de betrokken bepalingen in verband met de aard van de rechtshandeling zich daartegen niet verzet. Als voorbeelden worden in de MvT genoemd: de afstand van een vorderingsrecht (artikel 6:160 $\mathrm{BW}$ ), de vestiging van beperkte rechten (artikelen 3:84 en 3:98 BW), de verdeling van een gemeenschap (artikelen 3:178 e.v. BW) ${ }^{52}$ Verder kunnen onder andere worden genoemd: schuld- en contractsoverneming (artikel 6:155 e.v. BW), de vaststellings- en bewijsovereenkomst (artikel 7.15.1 NBW), kwijtschelding, erfpachtvoorwaarden, hypotheekvoorwaarden en de omzetting van een natuurlijke overeenkomst in een rechtens afdwingbare (artikel 6:5 BW) ${ }^{53}$

Volgens de Memorie van Toelichting op artikel 6.5.2A.1 OvW kunnen de bepalingen van afdeling $6.5 .3 \mathrm{BW}$ en met name de artikelen 6:233 tot en met 6:238 BW, zo nodig ook overeenkomstig worden toegepast op eenzijdige rechtshandelingen (Titel 2 van Boek $3 \mathrm{BW}$ ), bij voorbeeld verklaringen gericht tot een contractspartij die de verklaring van tevoren heeft opgesteld en aan de andere partij ter ondertekening geeft of een aanbod of aanvaarding van de kant van de gebruiker, waarbij de algemene voorwaarden restricties bevatten ten aanzien van de geldigheid..$^{54}$ Verder is volgens de Memorie van Toelichting overeenkomstige toepassing buiten het vermogensrecht denkbaar, deze is echter

50 MvT, Parlementaire Geschiedenis, Inv, 3, 5 en 6, pag. 1458. Zie hierover: Wessels en. Jongeneel, 1992, pag. 11-12; Rijken, KwNBW 1984, pag. 121; Verhoewen, pag. 8.

51 Op oveneenkomsten zijn uiterasd primair de bepalingen van Boek 3 BW van toepassing.

52 MvT, Parlementaire Geschiedenis, Inv, 3, 5 en 6, pag. 1521 .

53 Zie verder: Asser-Hartkamp II, 1993, nr. 373; Wessels en Jongeneel, 1992, pag. 13-15; Verthoeven, pag. 9.

54 MvT, Parlementaire Geschiedenis, Inv. 3, 5 en 6, pag. 1521 en 1713. 
geheel aan het inzicht van de rechter overgelaten ${ }^{55}$ en ook op de publiekrechtelijke overeenkomst wordt analoge toepassing mogelijk geacht ${ }^{56}$.

\subsubsection{Indeling van de Wet algemene voorwaarden}

Een kort en duidelijk overzicht van de inhoud van afdeling 6.5.3 BW wordt in de Memorie van Toelichting gegeven ${ }^{57}$ en luidt, door mij ietwat aangepast en omgezet naar de uiteindelijke artikelnummering, als volgt.

Uitgaande van een ruime omschrijving van algemene voorwaarden (artikel 6:231 BW) en een snelle toepasselijkheid daarvan in de overeenkomst (artikel 6:231 sub $c j^{\circ} 3: 33$ en $3: 35 j^{\circ} 6: 232$ BW) - beide in het belang van de rechtszekerheid -, biedt artikel 6:233 onder a BW voor alle bedingen in algemene voorwaarden die in een overeenkomst zijn opgenomen en niet als kernbedingen kunnen worden beschouwd (ongeacht of de wederpartij ze kende of niet) een ruime maatstaf voor inhoudelijke toetsing: vernietigbaar is elk beding dat, kort gezegd, onredelijk bezwarend voor de wederpartij is. Voorts is vernietigbaar een beding in algemene voorwaarden die de wederpartij niet op eenvoudige wijze kan kennen omdat de gebruiker haar geen redelijke mogelijkheid daartoe heeft geboden (artikel 6:233 sub b j 6:234 BW). De vernietigbaarheid kan steeds buitengerechtelijk worden ingeroepen (artikel 6:246 BW).

De algemene norm van artikel 6:233 onder a BW wordt, voor transacties met consumenten, uitgewerkt in twee lijsten met clausules. De eerste (artikel 6:236 $\mathrm{BW}$ ) somt bedingen op die steeds onredelijk bezwarend zijn, de tweede (artikel 6:237 $\mathrm{BW}$ ) geeft een voor tegenbewijs vatbaar vermoeden daarvan. (...) Een tweetal bepalingen die de wederpartij beogen te beschermen bij vertegenwoordiging is opgenomen in artikel 6:238 BW. Overigens kent artikel 6:239 BW de mogelijkheid om bij Algemene Maatregel van Bestuur de onderdelen van artikel 6:237 BW te wijzigen of hun toepassingsgebied te beperken.

De artikelen 6:240 tot en met 6:242 $\mathrm{BW}$ regelen een andere, meer abstracte vorm van rechterlijke inhoudstoetsing: een bijzondere rechter (het Gerechtshof te 's-Gravenhage) kan op vordering van organisaties van ondernemers of consumenten bedingen in algemene voorwaarden onredelijk bezwarend verklaren en het gebruik daarvan verbieden. De vordering kan ook tegen organisaties worden ingesteld, indien deze het gebruik van de voorwaarden bevorderen. Voor dat geval wordt aan het Wetboek van Burgerlijke Rechtsvordering een aantal bepalingen toegevoegd (artikelen 1003 tot en met $1006 \mathrm{Rv}$ ), die het mogelijk maken dat de organisatie en haar leden te zamen in rechte worden

55 MVT, Parlementaire Geschiedenis, Inv. 3, 5 en 6, pag. 1521.

56 Asser-Hartkamp II, 1993, mrs, 31 en 373; Wessels en Jongeneel, 1992, prg. 13.

57 MvT, Partementaire Gesehiedenis, Inv. 3, 5 en 6, pag. 1456. 
betrokken. Ook artikel 6:240 $\mathrm{BW}$ bevat weer bepalingen inzake het overleg tussen belanghebbenden: men zie de leden 4 en 5 . Artikel 6:242 BW regelt de mogelijkheid dat een uitspraak van de bijzondere rechter op grond van gewijzigde omstandigheden wordt gewijzigd of opgeheven.

Indien een beding ondanks het verbod opnieuw wordt gebruikt, is het steeds (buitengerechtelijk) vernietigbaar: artikel 6:243 BW. De uitspraak van de bijzondere rechter dient de rechtszekerheid dus op dezelfde wijze als de lijst wan artikel 6:236 BW.

Een ondernemer mag niet in de knel raken doordat hij van de zijde van zijn afnemer door een verbod of vernietiging wordt getroffen, terwijl hij zelf op gelijksoortige wijze jegens zijn voorschakel verbonden is. Soms zal hij zich op artikel 6:233 onder a BW kunnen beroepen, maar dit is niet steeds mogelijk. Artikel 6:244 BW helpt hem uit dit dilemma.

In artikel 6:245 $\mathrm{BW}$ is de toepasselijkheid van de regeling geheel uitgesloten voor bepaalde overeenkomsten. Artikel 6:246 $\mathrm{BW}$ verklaart de regeling tot dwingend recht. Ten slotte is artikel 6:247 BW gewijd aan de toepasselijkheid van de regeling in internationale gevallen.

Tot zover de Memorie van Toelichting. Opgemerkt dient te worden dat in een latere fase van het wetgevingsproces artikel 6:235 lid $1 \mathrm{BW}$ is toegevoegd. Deze bepaling sluit een beroep op de vernietigingsgronden voor bepaalde soorten wederpartijen uit.

\subsection{Materieelrechtelijke bepalingen}

Op de abstracte inhoudstoetsing door het Haagse hof zijn de artikelen 6:233 onder a, 6:236 en 6:237 BW van overeenkomstige toepassing. Alvorens op de regeling van de abstracte inhoudstoets in te gaan is het derhalve nuttig de materieelrechtelijke bepalingen van de Wet algemene voorwaarden zoals vervat in de artikelen 6:231 tot en met 6:239 BW en de artikelen 6:243 tot en met 6:247 BW aan een korte nadere beschouwing te onderwerpen. Daarbij komt, vanwege het nauwe verband met de collectieve actie zoals voorzien in de artikelen 6:240 tot en met $6: 242 \mathrm{BW}$, de nadruk te liggen op de inhoudstoets als voorzien in artikel 6:233 onder a, 6:236 en 6:237 $\mathrm{BW}$. Achtereenvolgens komen aan de orde: het bereik van de wet, het dwingendrechtelijk karakter daarvan, de primaire gebondenheid ofwel het toepasselijkheidsvraagstuk, de informatieplicht van de gebruiker, de inhoudstoets, de verjaring en de internationale aspecten van de regeling. 


\subsubsection{Bereik van de wet}

Het bereik van afdeling 6.5.3 BW wordt op tweeërlei wijze beperkt. Te onderscheiden vallen beperkingen ten aanzien van het materiële bereik en het personele bereik. ${ }^{58}$ De materiële beperkingen zijn te vinden in respectievelijk de artikelen 6:231 sub a, 6:245 en 6:246 BW, de personele beperkingen in de artikelen $6: 233$ en 6:235 BW.

\subsubsection{Het materiële bereik}

Materieel gezien is het toepassingsbereik van afdeling 6.5.3 BW beperkt tot bedingen in algemene voorwaarden in obligatoire overeenkomsten en, op grond van het bepaalde in artikel $6: 216 \mathrm{BW}$, andere meerzijdige vermogensrechtelijke rechtshandelingen ${ }^{59}$ Op grond van artikel 6:245 $\mathrm{BW}$ is afdeling 6.5.3 $\mathrm{BW}$ niet van toepassing op arbeidsovereenkomsten of collectieve arbeidsovereenkomsten en volgens artikel 6:247 BW is de afdeling niet van toepassing op overeenkomsten tussen professionele partijen die niet beide in Nederland gevestigd zijn.

Algemene voorwaarden zijn in de wettelijke definitie (art. 6:231 sub a BW):

een of meer schriftelijke bedingen die zijn opgesteld teneinde in een aantal overeenkomsten te worden opgenomen, met uitzondering van bedingen die de kern van de prestatie aangeven.

De afdeling ziet dus zowel op algemene voorwaarden bij consumententransacties als transacties tussen professionele contractanten, maar niet op mondelinge bedingen, niet op individuele bedingen en niet op kernbedingen. Voor de vraag of sprake is van algemene voorwaarden is zonder belang de vorm waarin de overeenkomst is gegoten en evenmin de herkomst (nul-, een- of tweezijdig vastgesteld) van de algemene voorwaarden. ${ }^{60}$

Volgens de wettelijke definitie moet allereerst sprake zijn van een beding. Daarmee wordt aangeduid dat het moet gaan om een voorwaarde van contractuele aard. Dit betekent dat toelichtende teksten, consideransen etcetera geen algemene voorwaarden kunnen zijn om de eenvoudige reden dat zij niet gekwalificeerd kunnen worden als een beding. ${ }^{61}$ Verder vallen ook regels die van rechtswege deel uitmaken van de overeenkomst, zoals bij voorbeeld de stan-

58 Asser-Hartkamp II, 1993, nr. 358; Verhoeven, pag. 62.

59 Zie hiervoor paragraat 5.1.3.

60 MvT, Parlementaire Geschiedenis, Inv. 3, 5 en 6, pag. 1519.

61 Wessels en Jongeneel, pag. 32-33; Verhoeven, pag; 30. 
daardregeling woorzien in artikel 6:214 BW, niet onder het begrip beding en dus ook niet onder het begrip algemene voorwaarde(n). ${ }^{62}$ Indien wettelijke bepalingen in algemene voorwaarden zijn overgenomen of krachtens enige wettelijke regeling zijn goedgekeurd of zelfs zijn voorgeschreven, zijn het echter wel contractsbedingen en dus algemene voorwaarden in de zin van artikel 6:231 BW. ${ }^{3}$ Ook verordeningen opgesteld door een ander orgaan dan de formele wetgever en niet berustend op een wet in formele $z^{1 n^{64}}$, zoals gas-, exploitatieen gronduitgifteverordeningen, zijn, wanneer ze als bedingen zijn opgenomen in een overeenkomst, te beschouwen als algemene voorwaarden. ${ }^{65}$

Verder kunnen alleen schriftelijke bedingen onder de definitie van algemene voorwaarden worden gevangen en vallen mondelinge bedingen buiten de regeling. ${ }^{66}$ Onder het begrip "schriftelijk beding" worden echter ook de bedingen begrepen die op schrift zijn gesteld en vervolgens aan de wederpartij mondeling worden meegedeeld. ${ }^{67}$

Vereist is voorts dat de bedingen zijn opgesteld ten einde in een aantal overeenkomsten te worden opgenomen. Bepalend is dus het zogenoemde "bestemmingscriterium". ${ }^{68}$ Volgens de toelichting op het amendement van het kamerlid Korthals ${ }^{69}$ wordt de bestemming geacht aanwezig te zijn:

a. indien een persoon de bedingen in een aantal overeenkomsten heeft gebruikt;

b. indien een persoon kenbaar heeft gemaakt dat hij de bedingen in overeenkomsten zal gaan gebruiken;

c. indien het gebruik van de bedingen wordt bevorderd door een rechtspersoon als bedoeld in artikell 6:240 lid $2 \mathrm{BW}$.

62 MvT, Parlementaire Geschiedenis, Inv. 3, 5 en 6, pag. 1420 en 1457 ; Jongeneel, diss, , pag. 37; Wessels en Jongeneel, pag. 32-33; Verhoeven, pag. 30.

63 MvT, Parlementaire Geschiedenis, Inw, 3, 5 en 6, pag. 1519-1520; Jongeneel, diss., pag. 37; Weskels en Jongeneel, 1992, pag. 32; Verhoeven, pag. 30.

64 Artikel 107 Grondwet.

65 MvA 1, Parlementaire Gesehiedenis, Inv, 3, 5 en 6, pag. 1565-1566; EV 1, Parlementaire Geschiedenis, Inv. 3, 5 en 6, pag. 1570-1571; Spier, KwNBW 1985, pag. 8; Verhoeven, pag. 30.

66 In het oorspronkelijke ontwerp werd geen onderscheid gemakt tussen mondelinge en schriftelijke bedingen. Zie: OvW, Tweedle Kamer, zitting 1981, 16983 , nrs. 1-3, pag. 2. Vanuit de gedachte dat mondelinge bedingen in de praktijk, mede gezien de bewijspmblematisek, nauwelijks een rol van betekenis zullen spelen én om enigermate toe te geven ain de deregulleringsvoorstellen van de Commissie van der Grinten is besloten de definitie van algemene voorwaarden te beperken tot schriftelijke bedingen. Zie: MvA, Parlementaine Geschiedenis, Inv. 3,5 en 6 , pag. 1462-1463.

67 NEV, Parlementaire Geschiedenis, Inw. 3, 5 en 6, pag. 1541; UCV II, Parlementaire Geschiedenis, Inv. 3, 5 en 6, pag. 1553. Zie ook: Jongeneel, diss., pag. 34-35; Wessels en Jongeneel, 1992, pag. 32-33; Verthoeven, 30-31.

68 Zie hierover: Jongeneel, dis8., pag. 41-42 en 70-71; Wessels en Jongeneel, 1992, pag, 33-35; Asser-Hartkamp II, 1993, nrs. 346-347; Verhoeven, pag. 31-32.

69 Tweede Kamer, vergaderjaar 1984-1985, 16983 , nr. 28; Parlementaire Geschiedenis, Inv. 3, 5 en 6, pag. 1557. 
Eenmalige contractuele afspraken (individuele bedingen) zijn derhalve geen algemene voorwaarden.

In het oorspronkelijke ontwerp was eerst sprake van algemene voorwaarden indien deze "geregeld" en later "meermalen" in overeenkomsten zijn gebruikt. $^{\text {}}$ Het criterium meermalen gebruikt kan echter nog steeds een rol spelen bij de vaststelling van de bestemming. Dat sprake is van algemene voorwaarden moet in een procedure - in geval van betwisting - immers worden aangetoond door de wederpartij. Niet altijd is echter sprake van bedingen waarvan het gebruik door een ondernemersorganisatie wordt bevorderd of van bedingen waarvan door de gebruiker kenbaar is gemaakt dat hij ze in een aantal overeenkomsten zal gaan gebruiken. In die gevallen staat de bestemming immers vast, ook indien de voorwaarden nog niet daadwerkelijk zijn gebruikt of door de gebruiker pas voor de eerste keer in een overeenkomst worden opgenomen. Het kenbaar maken van het (voorgenomen) gebruik van algemene voorwaarden moet ruim worden uitgelegd. Het omvat niet alleen het expliciete aankondigen maar ook het op andere wijze aanduiden van bedingen als algemene voorwaarden, bij voorbeeld door de presentatie, lay-out of redactie van de betreffende bedingen. Als de bestemming duidelijk en dus bepalend is, is zij doorslaggevend bij de bewijslevering. ${ }^{71}$

Indien de bestemming van een beding niet uit de wijze van presentatie of anderszins kenbaar is, staat de bestemming van algemene voorwaarde vast indien de wederpartij kan aantonen dat een beding reeds meermalen door de gebruiker is opgenomen in overeenkomsten. Daarvoor is niet vereist dat het beding meermalen in dezelfde bewoordingen wordt gehanteerd door de gebruiker. Ook van bedingen die onderling slechts verschillen van ondergeschikte betekenis vertonen krijgen de bestemming algemene voorwaarde door herhaaldelijk gebruik. ${ }^{72}$ Onder "meermalen" wordt volgens de toenmalige Minister van Justitie, in navolging van de Duitse literatuur, vijf keer begrepen ofschoon hij niet uitsluit dat vier keer ook voldoende kan zijn. ${ }^{73}$ Een beding dat oorspronkellijk slechts met de bedoeling is opgesteld te worden gebruikt in slechts én of enkele overeenkomsten kan op grond van herhaaldelijk gebruik dus van individueel beding veranderen in een algemene voorwaarde. Vanaf ongeveer de vierde

70 Zie respectievelijk: OvW, Parlementaire Geschiedenis, Inv, 3, 5 en 6, pag. 1518 en NwW II, Parlementaire Geschiedenis, Inv. 3, 5 en 6, pag. 1542.

71. UCV II, Parlementaire Geschiedenis, Inv. 3, 5 en 6, pag. 1547.

72 NEV, Parlementaire Geschiedenis, Inv. 3, 5 en 6, plag, 1636-1639; UCV II, Partementaine Geschiedenis, Inv. 3, 5 en 6, paug. 1546-1548; Jongeneel, diss., pag. 41-42; Wessels en Jongemeel, pag. 34; Verhoeven, pag. 31-32.

73 UCV II, Parlementaine Geschiedenis, Inv. 3, 5 en 6, pag. 1546-1547. Zie hierover nader: Jongeneel, diss., pag. 41. 
owereenkomst moet het beding beschouwd worden als een algemene voorwaarde in de zin van artikel 6:231 sub a BW. Dit betekent echter niet dat daarmee ook dezelfde bedingen in de eerste drie overeenkomsten achteraf gekwalificeerd worden als algemene voorwaarden vanaf het moment dat duidelijk wordt dat hetzelfde beding meermalen is gebruikt. Deze bedingen blijven individueel overeengekomen en zijn dus niet te beschouwen als algemene voorwaarden. ${ }^{74}$

Naar de letter van de definitie van algemene voorwaarden in artikel 6:231 sub a $B W$, vallen hieronder ook bedingen die niet door eén der partijen doch door een derde - bij voorbeeld een notaris, advocaat, makelaar of auteur van modelcontracten - zijn opgesteld om in meerdere overeenkomsten te worden gebruikt doch door de uiteindelijke contractspartijen of én der partijen slechts én keer worden gebruikt. ${ }^{75}$ Dit was het gevolg van het hiervoor vermelde amendement van het kamerlid Korthals. Op deze consequentie is in de UCV van 28 januari 1985 herhaaldelijk uitdrukkelijk gewezen en zij is, ook door de Minister wan Justitie die tegen deze uitbreiding ten opzichte van de eerdere voorstellen waarschuwde, erkend. ${ }^{76}$ Ook de Tweede Kamer had kennelijk geen moeite met deze uitbreiding en nam het amendement van het kamerlid Korthals aan. ${ }^{77}$ In de Eerste Kamer stuitte deze uitbreiding van het begrip algemene voorwaarden echter op ernstige bezwaren. ${ }^{72}$ Het antwoord van de Minister op deze bezwaren luidde als volgt:

"Het kan immers moeilijk wordien wolgehouden dat een zodanige uitbreiding wan de definitie wan het begrip algemene poorwaarden in owereenstemming is met de strekking wan het onderhawge wetsontwerp. Het wetsontwerp is, (....), gericht op bescherming van een contractant tegen. algemene voomaarden die door belanghebbenden - veelal de andere contractant of dients branchearganisatie - zijh opgesteld en die door deze herkomst het gevaar in zich bergen wan een onredelijk bezwarende eenzijdigheid. In de voormelde discussie - die niet geheel wrij wain verwarring was omdat tij over verschillende amendementen ging en waarin bovendien de wradg mespeelde welke consequenties de voorgestelde formulering had woor de "verbodsactie van artiket 6.5.2A.6 - is maar het ons voorkont de problematiek niet in haar wolle scherple onderkend. Wy constateren dat art. 1 onder a tegen deze ackutergrond geenszins noopt tor het actnvaarden van cen resultaat dat door ons in gelijke mate mordt afgekeurd als door de commissie. Von algemene voorwarden is naar onze mening in elk geval geen sprake indien aen advocaat of notaris bij het opstellen van een overeenkomst gebraik maakt van door hesm zelf wervaardigde of a mon mollenboeken ontleende madellen, ook al is duidelijk dat hajj die, indien

74 NEV, Parlementaire Gesehiedenis, Inv 3 , 5 en 6, pag. 1539; Jongeneel, diss., pag. 42.

75 UCV II, Parlementaire Geschiedenis, lnv. 3, 5 en 6, pag. 1559-1561; Jongeneel, diss., pag. 70-72; Wessels en Jongeneel, 1992, pag. 35; Asser-Hartkamp 11, 1993, nr. 347.

76 UCV II, Parlementaire Geschiedenis, Inv. 3, 5 en 6, pag. 1559-1561; Jongeneel, diss., pag. $70-71$.

77 Handelingen Tweede Kamer, vergaderjaar 1984-1985, pag. 4825; Parlementaine Geschiedenis, Inv, 3, 5 en 6, pag. 1561.

78 VV I, Parlementaire Geschiedenis, Inv, 3, 5 en 6, pag. 1563. 
thet unithom, ook voor andere clienten zal gebruikem. Daarentegen is de afdeling wel toepasselijk indien de advocaut of notaris duidelijk als zodanig kenbare standaardbedingen gebnuiks, bijp. affomstig van de cliênt of opgesteld doar een brancheorganisatie; aok indien de client zelf de overeenkomst zou shuiten, zou afd. 6.5.2A hier immers steeds van toepassing zijn. De rechter zal hier zo nodig de juiste begrenzing kurnen acangeven. "xo

Met dit antwoord ging de Minister voorbij aan de opvatting van de Tweede Kamer en zette hij, wellicht onbewust, de Eerste Kamer op een verkeerd been. In de eerste plaats omdat vast staat dat van onduidelijkheid omtrent de ruime strekking van het amendement van het kamerlid Korthals geen sprake was en de Minister de beslissing hieromtrent overliet aan de Tweede Kamer. In de tweede plaats omdat ook van de zijde van de Tweede Kamer reeds uitdrukkelijk twijfels waren geuit omtrent de onafhankelijkheid en neutraliteit van de derden die de bedingen opstelden, zodat er geen grond was voor een uitzonderingspositie vanwege het gegeven dat de betreffende (algemene) voorwaarden niet zouden zijn opgesteld door belanghebbenden. ${ }^{81}$ Ten derde omdat de Minister ietwat al te stellig is in zijn bewoordingen. De minister stelt namelijk dat van algemene voorwaarden in elk geval geen sprake is indien een advocaat of notaris bij het opstellen van een overeenkomst gebruik maakt van door hem zelf vervaardigde of aan modellenboeken ontleende modellen, ook al is duidelijk dat hij die, indien het uitkomt, ook voor andere cliënten zal gebruiken. Dezelfde Minister verwoordde tijdens de behandeling in de Tweede Kamer echter reeds de stellige opvatting dat wanneer de cliënt van de advocaat of de cliënt van de notaris die voorwaarden meermalen zal gebruiken en de bestemming dus vast staat, de definitie van algemene voorwaarden rechtstreeks van toepassing is op de cliënt. ${ }^{82}$

Ondertussen moet echter ook worden toegegeven dat de discussie omtrent de verschillende amendementen inderdaad nogal complex en verwarrend is geweest. Met Jongenee ${ }^{83}$ ben ik desalniettemin van mening dat aan het feit dat het amendement van het kamerlid Korthals is aangenomen, meer gewicht toekomt dan aan de woorden van de Minister ${ }^{84}$ Betekent dit dan ook, zoals Jongeneel in zijn dissertatie betoogts, dat bedingen die zijn opgesteld door een derde teneinde meerdere malen in overeenkomsten te worden gebruikt, door deze bestemming, altijd en zondermeer te beschouwen zijn als algemene

MWA 1, Parlementaire Geschiedenis, Inw. 3, 5 en 6, pag. 1567 en 1568.

so UCW II, Parlementaire Geschiedenis, Inv, 3, 5 en 6, pag. 1559-1560. Zie ook: Jongeneel, dista, pag. 72 .

31 UCV II, Parlementaire Geschiedenis, Inw, 3, 5 en 6, pag. $1550-1551$.

82 UCV II, Parlementaire Geschiedenis, Inw. 3, 5 en 6, pag. 1551.

83 Jongencel, disss, pag. 72.

84 Anders: Asser-Hartkamp II, 1993, nr. 347.

35 Jongeneel, diss., pag. 74. 
voorwaarden indien deze vervolgens, op aanraden van deze derde, door een of beiđe partijen worden opgenomen in één overeenkomst? Mij lijkt niet dat dit altijd het geval is en wel om de volgende reden.

Gedurende de parlementaire behandeling van artikel 6:231 BW is de bestemming van contractsbedingen altijd gekoppeld geweest aan de partij of de persoon die deze voorwaarden gebruikte. Indien die partij kenbaar maakte dat zij algemene voorwaarden gebruikte of zou gebruiken of indien die partij een bepaald beding daadwerkelijk meermalen had gebruikt was sprake van algemene voorwaarden. Een uitzondering werd enkel gemaakt voor het geval dat brancheorganisaties het gebruik van algemene voorwaarden aanbevelen. Tegen de branche-organisaties kan dan toch een vordering als bedoeld in artikel 6:240 BW worden ingesteld ondanks het feit dat de algemene voorwaarden nog niet daadwerkelijk door de branche-organisatie of haar leden zijn gebruikt. Ook staat dan de bestemming van de bedingen als algemene voorwaarden vast, zodat het lid van de branche-organisatie ook reeds bij het eerste gebruik van door de organisatie gepropageerde bedingen, gebruiker is van algemene voorwaarden. ${ }^{86}$ Hetzelfde geldt waarschijnlijk voor de particulier die slechts eenmalig (de als zodanig bestempelde) algemene voorwaarden van een branche-organisatie gebruikt. De particulier bijvoorbeeld die zijn woonhuis verkoopt met gebruikmaking van door de NVM (makelaarsbond) opgestelde algemene voorwaarden gebruikt. ${ }^{87}$ Dit past ook in de opzet van afdeling 6.5.3 BW: het wetsontwerp is immers "gericht op bescherming van een contractant tegen algemene voorwaarden die door belanghebbenden - veelal de andere contractant of diens brancheorganisatie - zijn opgesteld en die door deze herkomst het gevaar in zich bergen van een onredelijk bezwarende eenzijdigheid".

Door overname van het amendement van het kamerlid Korthals is in de tekst van de wet de koppeling van de bestemming aan de intentie van de gebruiker echter komen te vervallen. Toch houdt deze koppeling mijns inziens materieel gezien zijn betekenis. Een beroep op afdeling 6.5.3 BW kan, buiten het geval van een collectieve actie als bedoeld in artikel 6:240 BW, immers alleen worden gedaan door een wederpartij jegens een gebruiker zoals respectievelijk bedoeld in artikel 6:231 sub b en sub c BW. De wederpartij moet dus aantonen dat de betreffende bedingen door de gebruiker als algemene voorwaarden zijn gebruikt of dat deze kenbaar heeft gemaakt dat hij deze bedingen als algemene voorwaarden gebruikt of zal gebruiken. Indien het herhaaldelijk gebruik vaststaat of vaststaat dat de bestemming als algemene voorwaarde door de gebruiker kenbaar is gemaakt, is sprake van algemene voorwaarden. De herkomst van het beding

(8) A 
dat aldus gekwalificeerd moet worden als een algemene voorwaarde is daarbij irrelevant. Het maakt niet uit of deze algemene voorwaarde door de gebruiker zelf of een, al dan niet onafhankelijke, derde is opgesteld.

Daar waar sprake is van bedingen die door een derde zijn opgesteld ten behoeve van de tot zijn beroepsuitoefening horende taak van het maken van contracten voor anderen, staat vast dat deze derde deze bedingen heeft gemaakt om die (mogelijk) in een aantal overeenkomsten van zijn cliënten op te nemen. Dit zijn door deze bestemming echter nog geen algemene voorwaarden. De bedingen zijn immers niet opgesteld door de derde om deze zelf als gebruiker in de zin van artikel 6:231 BW te hanteren in overeenkomsten die hij zelf sluit, doch met de bedoeling die bedingen op te nemen in overeenkomsten van zijn cliënten. Hij heeft deze bedingen als het ware reeds gereedliggen, echter zonder hun definitieve bestemming te weten. De bedingen zijn op dat moment derhalve te beschouwen als onbestemd. Dat deze bedingen in sommige overeenkomsten van die cliënten mogelijk dienst gaan doen als algemene voorwaarde doet daar niet aan af, dit is immers niet afhankelijk van de wil van de opsteller. Ook van het bevorderen van gebruik door de derde zoals branche-organisaties dit jegens hun leden doen is mijns inziens geen sprake. ${ }^{20}$ De derde maakt weliswaar in zijn beroepsuitoefening gebruik van deze bedingen, maar niet als gebruiker of aanbeveler als bedoeld in afdeling 6.5.3 BW. Aan het bestemmingscriterium zoals vervat in artikel 6:231 sub a BW is met het gegeven dat het beding niet uniek is, dan ook (nog) niet voldaan.

De vraag naar de bestemming van het beding wordt naar mijn mening ook pas relevant als het beding is opgenomen in een overeenkomst van de cliënt van de opsteller. Dan pas moet beoordeeld worden of het beding, zoals het gebruikt wordt door die cliënt, een algemene voorwaarde is. Daarvoor zal beoordeeld moeten worden of de cliënt naar zijn wederpartij toe op enigerlei wijze kenbaar heeft gemaakt dat het beding een algemene voorwaarde is of dat de cliënt het betreffende beding reeds meermalen in zijn overeenkomsten heeft gebruikt. Daarbij is het zeer wel mogelijk dat eenzelfde beding door verschillende cliënten gebruikt, zelfs als dit maar én enkele keer is, in het ene geval wél en in het andere geval niet bestempeld kan worden als algemene voorwaarde. De intentie van de ontwerper van het beding ten aanzien van de bestemming van dit beding is daarbij niet relevant om de eenvoudige reden dat hij als derde geen partij is in de betreffende contractsrelatie. De derde kan hoogstens gezien worden als een soort hulppersoon van de gebruiker van het beding of zelfs van beide contractspartijen bij het opstellen van het contract. Het feit dat de opsteller als opdrachtnemer gebruik maakt van een kant en klaar beding mag naar mijn mening niet 
worden meegewogen bij de vraag of de opdrachtgever dat beding in zija overeenkomst gebruikt als algemene voorwaarde in de zin van artikel 6:231 sub a BW.

Uitgesloten van de werking van afdeling 6.5.3 $\mathrm{BW}$ zijn verder de zogenoemde kernbedingen, de bedingen die de kern van de prestaties aangeven. ${ }^{90}$ De ratio van deze bepaling is gelegen in het voorkomen van de introductie van de iustum pretium-regel. Voorkomen moet worden dat de inhoudscontrole van de artikelen 6:233 en 6:240 BW ook zou worden toegepast op kernbedingen. Dit zou immers neerkomen op "de - gedeeltelijke - introductie van een iustum pretiumregel over de gehele linie van het contractenrecht" hetgeen niet gewenst werd geacht. ${ }^{\text {91 }}$

Kernbedingen zijn in beginsel die bedingen die de zogenaamde essentialia van de overeenkomst vormen. Met de essentialia zijn bedoeld de bestanddelen zonder welke de overeenkomst vanwege onvoldoende bepaalbaarheid van de verbintenissen niet tot stand komt, of, in de woorden van de toenmalige Minister van Justitie de bedingen in welker afwezigheid niet afdoende kan worden voorzien door het aanvullende recht, de gewoonte of de redelijkheid en billijkheid. Als voorbeelden van kernbedingen worden genoemd: de prijs, de hoeveelheid, het gewicht of de kwaliteit van de gekochte goederen, het middel van vervoer bij de reisovereenkomst, de dekking bij een verzekeringsovereenkomst. ${ }^{92}$ Het begrip kernbeding is echter niet alleen beperkt tot de essentialia van de overeenkomst, soms kan het ook ruimer zijn en omvat het tevens bedingen zonder welke de overeenkomst toch bepaalbaar zou zijn. Als voorbeeld worden genoernd de prijs bij een koopovereenkomst ${ }^{93}$, welke altijd een kernbeding is ${ }^{94}$, en sommige bedingen in verzekeringsovereenkomsten die de omvang van de dekking bepalen. Ook bedingen die bepalen dat een derde de prijs vaststelt, dat de prijs vrijblijvend is of dat de prijs eerst later wordt bepaald, zijn kernbedingen ${ }^{95}$.

Het begrip kernbeding moet echter zo beperkt mogelijk worden opgevat. Daarbij is niet bepalend of het beding in kwestie een voor de gebruiker of beide partijen belangrijk punt regelt, maar of het beding van zo wezenlijke betekenis

90 Zie hienover ook: Wessels en Jongeneel, 1992, pag. 35-37; Jongeneel, diss., pag. 42 e.w.; Verhoeven pag. 33-34.

91 MvT, Parlementaire Geschiedenis, Inv, 3, 5 en 6, pag. 1521.

92 MvT, Parlementaire Geschiedenis, Inv. 3, 5 en 6, pag. 1521; NEV, Parlementaire Geschiedenis, Inv, 3, 5 en 6, pag. 1541, EV I, Parlementaire Geschiedenis, Inv. 3, 5 en 6, pag. 1571.

93. Op grond van artikel 7:4 BW is de koper immers cen redelijke prijs verschuldigt indien de koop is gesloten zonder dat de prijs is bepauld.

94 MvT, Parlementaire Geschiedenis, Inv. 3, 5 en 6, pag. 1521; NEV, Parlementaire Geschiedenis, Inv, 3, 5 en 6, pag. 1541

95 MvT, Parlementaire Geschiedenis, Inv, 3, 5 en 6, pag. 1761. 
is dat de overeenkomst zonder dat beding niet tot stand gekomen zou zijn of er van wilsovereenstemming omtrent het wezen van de overeenkomst geen sprake zou zijn. ${ }^{\%}$ Onder kernbedingen vallen niet die bedingen die de modaliteiten, zelfs de belangrijkste, van de prestaties (nader) bepalen zoals bedingen inzake prijsverandering, levertijd, plaats en tijdstip van de prestatie, aansprakelijkheidsuitsluiting, annulering, verlenging, incassokosten, rente bij vertraging, boetes, etcetera. Bij twijfel bieden de lijsten van de artikelen 6:236 en 6:237 BW houvast. Bedingen die op deze lijsten voorkomen zijn per definitie niet te kwalificeren als kernbeding ${ }^{97}$ ook niet indien partijen zulk een beding of een ander niet-kernbeding uitdrukkelijk tot kernbeding bestempelen ${ }^{98}$.

Onder algemene voorwaarden kunnen ook worden begrepen die algemene woorwaarden waarover onderhandeld is en die vervolgens door partijen uitdrukkelijk worden aanvaard. Meestal worden over de inhoud van algemene voorwaarden geen onderhandelingen gevoerd, daar zijn ze immers niet voor bedoeld. Indien wel wordt onderhandeld over de inhoud van de algemene voorwaarden kan dit consequenties hebben voor de status van het betreffende beding."9

Indien de onderhandelingen niet voeren tot enige wijziging van het beding en ook indien de wederpartij uitdrukkelijk instemt met het beding waarover is onderhandeld, blijft het een (ongewijzigde) algemene voorwaarde. Daar doet niet aan af dat mogelijk elders in de overeenkomst compenserend voordeel is bedongen. Deze compensatie kan echter wel door de rechter worden meegewogen bij de inhoudstoetsing aan de open norm en de grijze lijst. Relevante omstandigheden bij deze inhoudstoets zijn immers ook de wijze waarop het beding tot stand is gekomen en de overige contractsinhoud. Evident is dat wegens het ontbreken van enige speelruimte bij de rechter, een dergelijk compenserend voordeel niet meeweegt bij de beoordeling van zwarte bedingen. ${ }^{100}$

Indien het beding door de onderhandelingen wel wordt gewijzigd en daardoor tot een eenmalige afspraak wordt, is het niet meer te beschouwen als een algemene voorwaarde maar als een individueel beding, een eenmalige afspraak. ${ }^{101}$ Is het beding na de wijziging echter nog steeds bestemd om in

96 MwT, Parlementaire Geschiedenis, lnv, 3, 5 en 6, pag 1521; MvA, Parlementaire Geschiede nis, Inv. 3, 5 en 6, pag. 1566.

97 MNA, Parlementaine Geschiedenis, Inv. 3, 5 en 6, pag. 1527.

98 MwA 1, Parlementaire Geschiedenis, Inv. 3, 5 en 6, pag. 1566; EV 1. Parlementaire Geschiedenis, Inv, 3, 5 en 6, pag. 1571-1572.

99 Zie hierover ook: Asser-Hartkamp II, 1993, nr. 348; Jongeneel, diss., pag. 54-61; Wessels en Jongeneel, 1992, pag. 37-38; Verhoeven, pag. 35.

100 MvA, Parlementaire Gegchiedenis, Inv. 3, 5 en 6, pag. 1528; MvA I, Parlementaire Geschiedenis, $\operatorname{lnw}_{m} 3,5$ en 6 , pag. 1565 .

101 MvT, Parlementaire Geschiedenis, Inv. 3, 5 en 6, pag- 1453. 
meerdere overeenkomsten te worden opgenomen, dan is uiteraard ook het nieuwe beding een algemene voorwaarde. ${ }^{\text {in }}$

Omtrent de bewijslast vermeldt de Memorie van Toelichting het volgende:

".. de bewijslast van het feit dat bepaalde bedingen algemene woorwaarden zijn, benust op degerse die zich daarop beroept, dethalve biju, de wederpartij die zich op de vemietighaarheid wan en beding beraept of de organisatie die een vordering krachtens artikel 6 instelt. (...) De bewijslast wan de stelling dat een bepaald beding de kem wan een prestatie acangeeft rust op de partij die de algemene voonwaarden heeft gebezigd c.q. het gebruit daarvan in de zin van artikel 6 heeft bevorderd. " 100

De wederpartij kan volstaan met het bewijs dat er sprake is van een beding dat is opgesteld om een aantal malen te worden gebruikt, zonder dat de wederpartij hoeft te bewijzen dat het beding in kwestie een niet-kernbeding is. De gebruiker die stelt dat het beding een kernbeding is, moet vervolgens bewijzen dat het beding ondanks die bestemming toch geen algemene voorwaarde is omdat het een kernbeding is. Derhalwe is een beding waarvan de wederpartij heeft bewezen dat het bestemd is om meermalen te worden gebruikt, behoudens tegenbewijs van de gebruiker dat het een kernbeding is, een algemene voorwaarde.

Indien een beding niet als allgemene voorwaarde kan worden beschouwd, is afdeling 6.5.3 BW niet van toepassing en gelden doorgaans de algemene regels van het verbintenissenrecht. ${ }^{104}$ Dit betekent met name:

- dat de regel van artikel 6:232 $\mathrm{BW}$, die het verweer van de wederpartij dat zij niet gebonden is omdat zij de inhoud van de betreffende (algemene) voorwaarden niet kende, afsnijdt, niet van toepassing is. Het feit dat de gebruiker begreep of moest begrijpen dat de wederpartij de inhoud van de betreffende bedingen niet kende kan in die gevallen derhalve een beletsel zijn om primaire gebondenheid van de wederpartij aan de betreffende bedingen aan te nemen ${ }^{105}$;

- dat de regels omtrent de informatieplicht van de gebruiker zoals neergelegd in artikel 6:233 sub $\mathrm{b} \mathrm{j}^{\circ}$ 6:234 BW niet van toepassing zijn;

- dat de inhoudelijke toetsing van het beding op grond van artikel $6: 233$ sub a $j^{\circ} 6: 236$ en $6: 237 \mathrm{BW}$ is uitgesloten. ${ }^{106}$

102 Jongeneel, diss., pag. 59; Weasels en Jongereel, 1992, pag. 38.

103 MvT, Parlementaire Gesthiedenis, Inv, 3, 5 en 6, pag. 1522.

104. Rechtspmoblemen ten aanzien van deze bedingen worden met name beheerst door de titel 3.2 en 6.1 BW en de afdelingen $1,2,4$ en 5 van titel $6.5 \mathrm{BW}$.

105 Anders: Jongeneel, diss., pag. 112, die artikel 6:232 BW ook van toepassing acht op (standarad) kembedingen die deel uitmaken van de set algemene voorwaarden.

106 Zie ook: Jongeneel, diss., pag. 54; Verhoeven, pag. 33-34; Wessells en Jongeneel, 1992, pag. 37. 
Vanuit personeel oogpunt gezien wordt de Wet algemene voorwaarden allereerst en in beginsel beperkt tot wederpartijen. Immers alleen wederpartijen, of organisaties daarvan, kunnen een beroep doen op de vermietigingsgronden van afdeling 6.5.3 BW. In beginsel, omdat ook de gebruiker of zijn belangenorgamisatie op grond van artikel 6:242 BW kunnen ageren tegen uitspraken van het Haagse hof en de gebruiker tevens een beroep op artikel 6:244 BW kan doen. Ook kent artikel 6:235 lid 2 BW aan de gebruiker een beroep op de vernietigingsgrond van artikel 6:233 onder a BW toe.

Verder wordt op grond van artikel 6:235 lid 1 BW een deel van de werking van afdeling 6.5.3 BW beperkt tot de zogenaamde kleine partijen. Uitgesloten van een beroep op de vernietigingsgronden bedoeld in de artikelen 6:233 en 6:234 BW zijn:

a. rechtspersonen als bedoeld in artikel 2:360 BW, die ten tijde van het sluiten van de overeenkomst laatstelijk hun jaarrekening openbaar hebben gemaakt, of ten aanzien waarvan op dat tijdstip laatstelijk artikel $2 * 403$ lid $1 \mathrm{BW}$ is toegepast;

b. partijen die ten tijde van het sluiten van de overeenkomst meer dan vijftig personen in dienst hadden of waar blijkens het Handelsregister op dat tijdstip meer dan vijftig personen werkzaam waren ${ }^{108}$.

De uitsluiting beperkt zich slechts tot het beroep op de artikelen 6:233 en 6:234 BW en ziet slechts op de "grote" contractspartij in haar hoedanigheid als wederpartij. Op alle andere bepalingen kan de grotere contractspartij zich dus wel beroepen, bij voorbeeld op de snelle primaire gebondenheid aan algemene voorwaarden op basis van de artikelen $6: 231$ sub $c j^{\circ} 3: 33$ en $3: 35 j^{\circ} 6: 232$ BW.

Voorts is, op grond van het bepaalde in artikel 6:235 lid $3 \mathrm{BW}$, het beroep op de vernietigingsgronden van de artikelen 6:233 en 6:234 $\mathrm{BW}$ uitgeslloten voor de wederpartij, die zelf meermalen dezelfde of nagenoeg dezelfde voorwaarden in haar overeenkomsten heeft gebruikt. De bepaling is een uitvloeise] wan het algemeen aanvaarde beginsel dat men niet terug mag komen op eigen gedragingen en zich evenmin tegenover anderen kan beklagen over gedragingen die men zelf ook verricht. ${ }^{10 s}$

107 Zie meer uitgebreid: Jongeneel, diss, pag. 80-81; Verhoeven, pag. 68-69; Wessels en Jongeneel, 1992 , pag. 68-69.

108 Verhowen, pag. 69-70; Wessels en Jongeneel, 1992, pag. 69.

109 MvT, Parlementaire Geschiedenis, Inv. 3,5 en 6, pag. 1625. Zie meer witgebreid: Wesgels em Jongeneel, 1992, pag. 74-75; Verhoeven, pag. 71.73. 


\subsubsection{Dwingend recht}

De met afdeling 6.5.3 $\mathrm{BW}$ beoogde bescherming zou illusoir zijn indien van de bepalingen van die afdeling zou kunnen worden afgeweken. Artikel 6:246 BW verklaart de artikelen 6:231 tot en met 6:244 BW en de bepalingen van de in artikel 6:239 lid 1 BW bedoelde algemene matregelen van bestuur daarom tot dwingend recht. ${ }^{110}$

Afwijking van een dwingende wetsbepaling leidt op grond van artikel 3:40 lid 2 BW tot nietigheid, tenzij de bepaling waarvan wordt afgeweken uitsluitend strekt ter bescherming van ến der partijen bij een meerzijdige rechtshandeling. In het laatste geval is de afwijkende rechtshandeling vernietigbaar. Indien uit de strekking wan de overtreden bepaling anders voortvloeit kan geen beroep worden gedaan op nietigheid of vernietigbaarheid.

De meeste dwingendrechtelijke bepalingen van afdeling 6.5.3 $\mathrm{BW}$ strekken ter bescherming van eén der partijen en dan meestal de wederpartij. Afwijking van deze bepalingen leidt op grond van artikel 3:40 lid 2 BW derhalve tot een vernietigbaarheid in te roepen door de door de overtreden bepaling beschermde partij. Zo voorzien de artikelen 6:233, 6:234, 6:235 lid 4, 6:236, 6:237, 6:238 en 6:243 $\mathrm{BW}$ in bescherming van de wederpartij. Bescherming van anderen dan de wederpartij bieden de artikelen 6:232 BW (gebruiker), 6:235 lid $2 \mathrm{BW}$ (volmachtgever), 6:235 lid $3 \mathrm{BW}$ (gebruiker), 6:240 lid 4 en $5 \mathrm{BW}$ (gebruiker of aanbeveler), 6:242 lid $1 \mathrm{BW}$ (gebruiker) en 6:244 (de "beknelde" gebruiker en eerdere voorschakels). ${ }^{111}$

Voor een beroep op artikel $6: 246 \mathrm{j}^{\circ} 3: 40$ en $3: 49 \mathrm{BW}$ is niet vereist dat het beding warvan vernietiging wordt gevraagd een algemene voorwaarde is. ${ }^{112}$ Wanneer echter in een algemene voorwaarde als bedoeld in artikel 6:231 BW wordt afgeweken van de bepalingen van afdeling 6.5.3 $\mathrm{BW}$ is zulk een beding vernietigbaar wegens strijd met de wet. Aan een vernietigbaarheid van het beding op grond van het feit dat zulk een beding tevens beschouwd kan worden als onredelijk bezwarend zoals bedoeld in artikel 6:233 sub a BW komt men dan niet toe. Zo zal een beding dat de wederpartij de bevoegdheid om een onredelijk bezwarend beding te vernietigen ontneemt of beperkt, vernietigbaar zijn op grond van artikel $6: 246 j^{\circ} 3: 40$ en 3:49 BW. Indien een beding in algemene voorwaarden vernietigbaar is op grond van het bepaalde in de artikelen 6:233, 6:234 en 6:243 BW, is het echter niet getroffen met deze sanctie omdat wordt

110 MvT, Parlementaine Geschiedenis, lnw. 3, 5 en 6, pag. 1805. Zie ook: Wessels en Jongemeel, 1992, pag. 18-19; Verthoeven, pag. 139-140; Asser-Hartkamp II, 1993, nr. 374.

111 MvT, Parlementaine Geschiedenis, Inv. 3, 5 en 6, pag. 1805.

112 MWA, Parlementaine Geschiedenis, Inv. 3, 5 en 6, pag. 1806. 
afgeweken van de bepalingen van afdeling 6.5.3 BW, maar omdat de voorschriften van artikel 6.5.3 $\mathrm{BW}$ meebrengen dat op bepaalde gedragingen van gebruikers de sanctie vernietigbaarheid rust. In dat geval wordt geen beroep gedaan op de vernietigingsgrond van artikel 3:40 lid $2 \mathrm{BW}$ maar rechtstreeks op de vernietigingsgronden van artikel 6:233, 6:234 of 6:243 BW. Zo is bij voorbeeld een beding dat de ontbindingsbevoegdheid van consumenten uitsluit of beperkt, niet te beschouwen als in strijd met het bepaalde in de artikelen 6:231 tot en met 6:243 BW. Het beding is echter toch vernietigbaar omdat artikel 6:236 BW bepaalt dat een beding met een dergelijke inhoud jegens consumenten onredelijk bezwarend is en artikel 6:233 sub a BW vervolgens daaraan de sanctie van vernietigbaarheid verbindt.

De artikelen 6:231 tot en met 6:244 BW strekken ter bescherming van de economisch zwakkere partij jegens wie algemene voorwaarden worden gebruikt. Volgens de Memorie van Antwoord moet artikel 6:246 BW derhalve ruim worden uitgelegd.

"De bepaling richt zich tegen alle bedingen die ertae strekken de door de wet geboden bescherming we verijdelen, en zulks ongeacht of zo'm beding de toepasselijkheid wan de regeling als geheel of wan harer bepalingen beoogt wit te siluiten. "113

Zo zijn in het voorbeeld van de Minister niet alleen vernietigbaar (wegens strijd met een dwingende wetsbepaling) bedingen die een beroep op artikel 6:233 $\mathrm{BW}$ uitsluiten, maar ook de bedingen die inhouden dat vernietiging van een beding leidt tot ontbinding van de overeenkomst of een schadevergoedingsplicht van de wederpartij en bedingen die bepalen dat een onredelijk bezwarend beding wordt omgezet in een wettelijk toelaatbaar beding.

Het dwingendrechtelijk karakter van de afdeling wordt enigszins beperkt indien in een andere wettelijke bepaling wordt toegestaan dat van de voorschriften van afdeling 6.5.3 BW wordt afgeweken. In dat geval prevaleert deze andere wettelijke bepaling. ${ }^{114}$ Tijdens de parlementaire behandeling wordt daarbij gewezen op prijsverhogingen waartoe de gebruiker op grond van wettelijke bepalingen verplicht of bevoegd is zoals de Wet op de omzetbelasting en prijsbeschikkingen op grond van de Prijzenwet. ${ }^{115}$

113 MWA, Parlementaine Geschiedenis, Inv. 3, 5 en 6, pag. 1806.

114 VV en MvA, Parlementaire Geschiedenis, Inv. 3, 5 en 6, pag. 1806.

$115 \mathrm{MWA}$, Parlementaire Geschiedenis, Inv. 3, 5 en 6, peg. 1702. 
Ofschoon dit niet uitdrukkelijk is bepaald, zijn ook de artikelen 6:245 en 6:247 leden 1, 3 en 4 BW bepalingen van bijzonder dwingend recht. ${ }^{116}$

Voor artikel 6:245 BW geldt dat partijen afdeling 6.5.3 BW niet bij overeenkomst van toepassing kunnen verklaren op arbeidsovereenkomsten. Als reden wordt aangegeven dat de wettellijke regels inzake de totstandkoming van overeenkomsten, de vernietigingsgronden en de collectieve actie zoals neergelegd in respectievelijk de artikelen 6:232, 6:233-234 en 6:240-241 BW, niet ter vrije beschikking staan van partijen. ${ }^{117}$

Artikel 6:247 lid 2 BW is in beginsel ook dwingendrechtelijk van karakter. ${ }^{118}$ Voor het internationale handelsverkeer werd het wenselijk geacht om een duidelijke regel op te nemen. Een van de beweegredenen om de toepasselijkheid van de afdeling op internationale transacties tussen ondernemers uit te sluiten was gelegen in het streven om voor (Nederlandse) ondernemers de keuze voor toepasselijkheid van het Nederlandse recht niet onaantrekkelijker te maken. Dit streven verzet zich volgens de Minister derhalve niet tegen toepasselijkheid van afdeling 6.5.3 BW ook op internationale overeenkomsten tussen ondernemers indien dit in het kader van een rechtskeuzeclausule uitdrukkelijk wordt overeengekomen. ${ }^{119}$

Om te vermijden dat de wederpartij voor de vernietiging op een gerechtelijke procedure is aangewezen bepaalt artikel 6:246 BW dat de bevoegdheid om ook buitengerechtelijk te vernietigen, zoals voorzien in artikel 3:49 $\mathrm{BW}$, niet kan worden uitgesloten. ${ }^{120}$

\subsubsection{Het toepasselijkheidsvraagstuk, de snelle primaire gebondenheid aan algemene voorwaarden}

Hoofdregel is, net als onder het oude recht, dat aan het bedingen van toepasselijkheid van algemene voorwaarden geen andere eisen behoren te worden gesteld dan in het algemeen gelden voor het totstandkomen van een overeenkomst. ${ }^{121}$ Dit betekent, dat op grond van de artikelen $6: 231$ sub $c j^{\circ} 6: 217 j^{\circ} 3: 33$ en 3:35 BW voor primaire gebondenheid aan algemene voorwaarden in beginsel

116 MvA I, Parlememtaire Geschiedenis, Inv. 3, 5 en 6, pag. 1815.

117 MvA I, Parlementaire Geschiedenis, Inv. 3, 5 en 6, pag. 1815.

118. Verthoeven, pag. 142.

119 MvA 1, Parlementaire Gesehiedenis, Inv. 3, 5 en 6, pag. 1815-1816.

120 MvT, Parlementaine Geschiedenis, Inv, 3, 5 en 6, pag. 1805-1806.

121 Zie 0.a.: HR 9 december 1977, NJ 1978, 187, m.nt. G.J.S. (Towell/Janson); HR 20 november 1981, NJ 1982, 517, m.nt. C.J.H.B., AA 1982, pag. 247, m.nt. G. (Holleman/De Klerk); HR 18 oktiober 1985, NJ 1987, 189, m.nt. J.C.S. (Galama/Filo Teenica Spa); HR 21 nowember 1986, NJ 1987, 946, m.nt. C.J.H.B., KwNBW 1987, pag. 30, m.nt. Hondius (Tolbeck/ Swindak); HR 1 juli 1993, NJ 1993, 688 (Bouma/Cavo). 
vereist is dat de wederpartij de algemene voorwaarden vớr, bij of na het sluiten van de (romp-) overeenkomst heeft aanvaard, althans het gerechtvaardigd vertrouwen daarvan bij de gebruiker heeft opgewekt.

Zoals reeds aangegeven in paragraaf 2.3.3 opteert de Nederlandse wetgever in afdeling 6.5.3 BW voor een strikte scheiding van de aanvaardings- en de inhoudstoets. Uitgangspunt van de regeling is dat "men misstanden waartoe het gebruik van algemene voorwaarden soms leidt, niet moet willen bestrijden door strenge eisen te stellen voor de inlassing daarvan in de overeenkomst". ${ }^{122}$ Mede in het belang van de rechtszekerheid wordt derhalve uitgegaan van de wenselijkheid van een snelle primaire gebondenheid van de wederpartij aan algemene voorwaarden, ook indien vaststaat dat deze de inhoud van de algemene voorwaarden waarvan zij de gelding heeft aanvaard, niet kende (artikel 6:232 $\mathrm{BW}$ ). Tegenover deze snelle toepasselijkheid staat immers een "ruime mogelijkheid om bedingen uit die algemene voorwaarden te vernietigen" (artikel 6:233 en 6:234 BW) ${ }^{123}$, waarmee de wederpartij zich van haar gebondenheid aan die algemene voorwaarden kan bevrijden ${ }^{124}$.

Daarmee geeft de wetgever een duidelijk ontkennend antwoord op de vraag of een wederpartij zich kan beroepen op het feit dat de gebruiker zich niet op een bepaald beding kan beroepen omdat deze begreep dat zij niet wist wat zij aanvaardde en daarom volgens de vertrouwensleer (artikel 3:35 BW) niet gebonden is. Artikel 6:232 BW geeft een helder antwoord op deze vraag, of, zoals raadadviseur Hartkamp het tijdens de mondelinge behandeling verwoordde:

Dit artikel swijdt dit probleem af en geeft een duidelijke regel, dat algemene voorwaarden reeds van wopassing zijn zodra de wederpartij weet dat ze ingeschakeld worden. Deze regel geeft duidelijkheid en getat ook verder dan het huidige recht. Uit de rechuspraak blijkt dat het betoog van de wederpartij

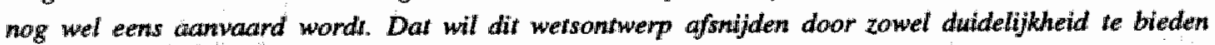
over de toepasselyjkheid als juist bescherming te bieden tegen de toepasselijkheid van onredelijke bedingen. 125

Zoals in artikel 6:231 sub $\mathfrak{c}$ BW aangegeven, hoeft de wederpartij nog slechts de gelding van algemene voorwaarden te aanvaarden, de inhoud van die voorwaarden of kennis daaromtrent bij de adherent speelt daarbij geen enkele rol. ${ }^{126}$ Wederpartij is immers "degene die door ondertekening van een ge-

122 MvT, Parlementaire Geschiedenis, Inv. 3, 5 en 6, pag. 1573 .

123 MvT, Parlementaire Geschiedenis, Inv, 3, 5 en 6, pag. 1573.

124 Asser-Hartkamp II, 19931, nr. 353.

125 UCV II, Parlementaire Geschiedenis, lnw. 3, 5 en 6, pag. 1577.

$126 \mathrm{MvT}$, Parlementaire Gegchiedenis, Inv. 3, 5 en 6, pag. 1573. 
schrift of op andere wijze de gelding van algemene voorwaarden heeft aan vaard" (cursivering LJHM).

Dat de inhoud van de bedingen waarvan de gelding wordt aanvaard niet: relevant is, blijkt uit artikel $6: 232 j^{\circ} 6: 217 j^{\circ} 3: 33$ en 3:35 BW. Dit artikel bepaalt immers dat een wederpartij in beginsel ook dan aan de algemene voorwaarden is gebonden, als bij het sluiten van de overeenkomst de gebruiker begreep of moest begrijpen dat de wederpartij de inhoud van die voorwaarden niet kende. De bepaling stelt buiten twijfel dat ook degene die zich aan door de wederpartij opgestelde bedingen onderwerpt zonder het vertrouwen te wekken dat hij van die bedingen heeft kennis genomen, daaraan in beginsel gebonden is. ${ }^{127}$ Dat de wederpartij niet op de hoogte is van de inhoud van algemene voorwaarden waarvan zij de gelding heeft aanvaard, is in het systeem van afdeling 6.5.3 BW ook verder geen probleem. De wederpartij kan bij onereuze bedingen de inhoud immers aangrijpen om een - ook buitengerechtelijke - vernietiging op grond van artikel 6:233 sub a BW te bewerkstelligen.

Naar huidig recht ligt de snelle primaire gebondenheid aan algemene voorwaarden duidelijk verankerd in de wet (artikel 6:232 BW). Zij vindt haar rechtvaardiging enerzijds in de nuttige functie die algemene voorwaarden in het rechtsverkeer kunnen vervullen ${ }^{128}$ en de rechtszekerheid die snelle gebondenheid biedt, en anderzijds in de daar tegenover staande inhoudstoets. Daarmee wordt bij de toepasselijkheid van algemene voorwaarden impliciet gekozen voor de eisen van het rechtsverkeer.

Onjuist is volgens mij dan ook de opvatting van Wessels en Jongeneel dat de rechtvaardiging van deze snelle primaire gebondenheid moet worden gezocht in het beginsel dat men de gevolgen moet dragen van een door eigen verzuim veroorzaakt informatiegebrek. ${ }^{12 \%}$ Onjuist alleen al vanwege het feit dat algemene voorwaarden zijn opgesteld om ongelezen te worden aanvaard en in de praktijk doorgaans ook ongelezen worden aanvaard. Ook de wetgever gaat daarvan uit. ${ }^{30}$ Pas dan hebben algemene voorwaarden hun optimale nut. Het zou vervolgens onjuist zijn om het risico van het niet lezen van de algemene voorwaarden bij de partij te leggen, waarvan men feitelijk en rechtens verwacht dat deze geen kennis neemt van de inhoud. Dat zou de wederpartij in feite verplichten om wél daadwerkelijk kennis te nemen van de algemene voorwaarden voordat zij de gelling daarvan aanvaardt. De genoemde visie is voorts onjuist omdat de wederpartij mag verwachten dat de gebruiker slechts bedingen

127 MvT, Parlementaire Geschicdenis, Inv. 3, 5 en 6, pag. 1573, Zie ook: Jongeneel, diss."pag. 88; Verhoeven, pag. 40-41; Wesisels en Jongeneel, 1992, pag. 43.

128 MvT, Parlementaire Geschiedenis, Inv. 3, 5 en 6, pag. 1580 .

129. Wessels en Jongeneel, 1992, pag. 46; Jongeneel, diss., pag. 111.

130 Zie bij voorbeeld: MvA, Parlementaire Geschiedenis, Inv. 3, 5 en 6, pag. 1629. 
gebruikt die - ook ongelezen vớr de aanvaarding daarvan - niet onredelijk bezwarend zijn jegens haar. De wetgever gaat daar eveneens van uit. Het is niet voor niets dat tegelijkertijd met het vastleggen van de snelle primaire gebondenheid ook een regeling is opgenomen die de gebruiker, op straffe van vernietigbaarheid, verplicht slechts die bedingen in zijn algemene voorwaarden op te nemen die rekening houden met de kenbare en gerechtvaardigde belangen van de wederpartij.

Of de wederpartij de gelding van bepaalde algemene voorwaarden heeft aanvaard moet naar huidig recht worden beoordeeld aan de hand van de algemene regels voor het tot stand komen van overeenkomsten van afdeling 6.5.2 $\mathrm{BW}$ en de artikelen 3:33 en 3:35 BW. ${ }^{131}$ Aanvaarding van de gelding van algemene voorwaarden door de wederpartij veronderstelt dat de gebruiker op enigerlei wijze aan de wederpartij het aanbod doet de algemene voorwaarden op te nemen in de overeenkomst en dat dit aanbod de wederpartij bereikt. Dit betekent dat de wederpartij de gelding van algemene voorwaarden op elk moment kan aanvaarden, dus vó́r, bij of na het sluiten van de "romp"-overeenkomst.

Hierbij dient goed te worden onderscheiden tussen enerzijds de "romp"overeenkomst die bestaat uit de uitdrukkelijk door partijen overeengekomen essentialia, de kernbedingen, en anderzijds de daarop toepasselijk te verklaren algemene voorwaarden die als gereedliggend regelcomplex de modaliteiten regelen. De "romp"-overeenkomst vormt ook zonder daarop toepasselijk verklaarde algemene voorwaarden een bepaalbare en zelfstandige overeenkomst.

Tezamen vormen de "romp"-overeenkomst en de algemene voorwaarden de door partijen vastgelegde contractsinhoud, de uiteindelijke overeenkomst tussen gebruiker en wederpartij. Strikt genomen is het dan ook onjuist om te spreken van toepasselijkheid van algemene voorwaarden op de overeenkomst, alsof het twee verschillende entiteiten zouden zijn waarvan er eén buiten de overeenkomst zou liggen. Algemene voorwaarden worden door aanvaarding immers integraal deel van de uiteindelijke overeenkomst. Binnen deze (uiteindelijke) overeenkomst zijn twee afzonderlijke entiteiten te onderscheiden, enerzijds de uitdrukkelijk overeengekomen bedingen die de "romp"-overeenkomst vormen - meestal de kernbedingen - en anderzijds het van te voren opgestelde regelcomplex dat de modaliteiten van de "romp"-overeenkomst regelt, de algemene voorwaarden.

De aanvaarding van "romp"-overeenkomst en algemene voorwaarden hoeft in tijd niet samen te vallen. Dit betekent dat het zeer wel mogelijk is, en in de

131 MvT, Parlementaire Geschiedenis, Inv. 3, 5 en 6, pag. 1573. Zie ook: Asser-Hautkamp II, 1989, 324-325; Jongeneel, diss., pag. 88; Verhoeven, pag. 41; Wesisels en Jongeneel, 1992, pag. 43. 
praktijk gebeurt dit ook frequent, dat partijen eerst overeenstemming bereiken over de "romp"-overeenkomst en pas op een later tijdstip, meestal op initiatief van één der partijen (de gebruiker in spe), daarop algemene voorwaarden toepasselijk verklaren.

Voor gebondenheid van de wederpartij aan de algemene voorwaarden van de gebruiker, is derhalve vereist dat de gebruiker aan zijn wederpartij vớr, bij of na het sluiten van de "romp"-overeenkomst kenbaar maakt ${ }^{132}$ dat hij zijn algemene voorwaarden wil laten gelden voor deze overeenkomst en dat de wederpartij daarmee akkoord is gegaan of althans bij de gebruiker het gerechtvaardigde vertrouwen daarvan heeft gewekt. ${ }^{133}$ De aanvaarding van de gelding van algemene voorwaarden is niet aan een bepaalde vorm gebonden en kan liggen opgesloten in elke gedraging van de wederpartij maar ook in een nalaten. Artikel 6:231 sub c BW bepaalt derhalve dat de wederpartij de gelding van algemene voorwaarden "door ondertekening van een geschrift of op andere wijze" kan aanvaarden.

Indien de gebruiker eerst na het sluiten van de "romp"-overeenkomst te kennen geeft dat hij zijn algemene voorwaarden toepasselijk wil doen zijn op die "romp"-overeenkomst, moet dit worden beschouwd als een eenzijdig aanbod van de gebruiker, gericht tot zijn wederpartij, om de bestaande "romp"-overeenkomst in die zin te wijzigen dat daarin alsnog zijn algemene voorwaarden worden opgenomen. ${ }^{134}$ Indien de wederpartij dit aanbod aanvaardt of althans bij de gebruiker het gerechtvaardigd vertrouwen daarvan wekt, ontstaat daardoor een nieuwe, althans gewijzigde, overeenkomst. ${ }^{135}$ Het staat de wederpartij echter ook geheel vrij de gelding van de algemene voorwaarden op de reeds gesloten "romp"-overeenkomst af te wijzen, hetgeen betekent dat tussen partijen slechts de "romp"-overeenkomst en het daarop toepasselijke wettelijk regelcomplex (artikel 6:248 lid $1 \mathrm{BW}$ ) bindend is en niet de door de gebruiker gewenste algemene voorwaarden.

Of sprake is van een als zodanig door de wederpartij te begrijpen aanbod van de gebruiker (in spe) tot wijziging van de bestaande "romp"-overeenkomst in de zin dat zijn algemene voorwaarden (alsnog) toepasselijk zijn en of sprake

132 Voor een overzicht wan de verschillende wijzen van bekendmaking: Rijken, diss, pag. $73-78$; Jongeneel, diss., pag. 911.98.

133 Zie voor de omstandigheden wasonder gebondenheid wordt aangenomen: Contractenrecht VI, pag. 7-134h; Jongeneel, dissi., pag. 90-97; Wessels en Jongeneel, 1992, pag. 43-46; Verthoeven, pag. $41-43$.

134 Zie ook Jongeneel, diss. , pag. 94.

135 Zie voor dezelfde gedachte, maar dan maar aanleiding van kamerwragen over de verwijzing naar de toepasselijkheüd van algemene voorwaarden in de onderbewestiging: MvA I, Parlementaine Geschiedenis, Inv. 3, 5 en 6, pag. 1620. Zie ook Jongeneel, diss., pag. 94; Wiessels en Jongeneel, 1992, pag. 45 . 
is van aanwaarding van dit aanbod door deze wederpartij, dient te worden beoordeeld aan de hand van de gewone regels van de artikelen $3: 33$ en $3: 35$ BW. Ook hier geldt de regel van artikel 6:232 $\mathrm{BW}$ dat onbekendheid van de wederpartij met de inhoud van de alsnog in te voegen algemene voorwaarden geen beletsel voor (primaire) gebondenheid daaraan vormt. Bij de beantwoording van de vraag of sprake is van alsnog aamvaarding van de gelding van deze algemene voorwaarden, is vooral van belang of de wederpartij er rekening mee moest houden dat er een aanbod zou komen van de gebruiker om de "romp"overeenkomst alsnog te completeren of te wijzigen en of de gebruiker in de gegeven omstandigheden van het geval daarop mocht vertrouwen. ${ }^{136}$ Indien de wederpartij niet behoefde te verwachten dat er een aanbod zou komen tot alsnog wijziging van de reeds gesioten "romp"-overeenkomst alsnog, mag mijns inziens niet al te snel worden aangenomen dat het enkele niet reageren van de wederpartij op een wijzigingsvoorstel, ook automatisch leidt tot primaire gebondenheid van die wederpartij aan de in het wijzigingsvoorstel bedoelde allgemene voorwaarden. ${ }^{137}$

In dit verband dient te worden gewezen op het feit dat het niet ongebruikelijk is, dat gebruikers in hun algemene voorwaarden verwijzen naar andere algemene voorwaarden. ${ }^{138}$ Mijns inziens mag niet al te snel worden aangenomen dat de wederpartij zich ook aan die laatste voorwaarden heeft willen binden. ${ }^{39}$ Ten eerste is het namelijk zeer de vraag of het aanbod van de gebruiker tot toepasselijkverklaring van andere algemene voorwaarden in algemene voorwaarden de wederpartij bereikt. Algemene voorwaarden worden doorgaans immers ongelezen aanvaard, hetgeen ook de gebruiker weet of behoort te weten. Ten tweede hoeft de wederpartij niet te verwachten dat in de algemene voorwaarden die hij heeft aanvaard, ook nog eens andere algemene voorwaarden toepasselijk worden verklaard. In dat licht mag, naar mijn mening, de gebruiker er niet op vertrouwen dat de aanvaarding van de gelding van de algemene voor-

136. Jomgeneel, disa., pag. 94.

1372 ie voor een voorbeeld waarin de wederpartij wel kon verwachten dat er cen wijzigingsvoorstel gedaan zou worden: Jongencel, diss., pag. 94. Zie ook over het niet-reageren op cen wijzigingsvoorstel, manr dan voor wat betreft rechtswerwerking: Hof Amhem 8 maart 1994, TvC 1944, pag. 128-136, m.nt. J.G.J. Rinkes.

138 Zie bij voorbeeld artikel 1 hid 2 van de door de Nederlandse banken (in overleg met de Consumentenbond en het Konsumenten Kontakt vast gesteld) gehanteerde "Voorwanirden gebruik geid- en betalautomaten" van 1 juli 1989: De vopasselijke Algentene Voorwardem en ander, op de bankpas betrekking hebbende, voorwaanden gelden voor zover daar in deze voorwaarden niet wan wordt afgeweken. Blijkens de toellichting wordt hierbij met name gedoeld op de "Algemene Bankwoorwarinden".

$139 Z^{2}$ in dit verband evencens: Hof Amhem 19 olktober 1993, TwC 1994, pag. 27-30, m.mt. J.G.J. Rinkes. Het Hof achtte een verwijzing nan de "Algemene bankvoorwanden" in de door de wederpartij aanvaarde "Algemene voorwarden voor sparrekeningen" onvoldoende om gebondenheid aan de "Algemene bankwoorwarnden" te bewerkstelligen. 
waarden die wel kenbaar waren voor de wederpartij tevens ook is gericht op aanvaarding van dle "orbekende" allgemene voorwaarden.

Of sprake is van aanvaarding door de wederpartij van de gelding van algemene voorwaarden is een feitelijke vraag die uiteindelijk door de rechter moet worden beslist. Daarbij dient in beginsel het bewijs van de aanvaarding van de gelding van algemene voorwaarden door de wederpartij, te worden geleverd door degene die zich op de betreffende voorwaarden beroept en dat is de gebruiker. Mijns inziens moeten door de rechter echter niet al te strenge eisen worden gesteld aan dit bewijs. Dit vanwege het nut van (redelijke) algemene voorwar den voor beide partijen en de uitgangspunten van afdeling $6.5 .3 \mathrm{BW}$ inhoudende dat enerzijds in het belang van de rechtszekerheid sprake moet zijn van een snelle primaire gebondenheid van de wederpartij aan de algemene voorwaarden en anderzijds dat de misstanden waartoe het gebruik van algemene voorwaarden soms leidt, niet moeten worden bestreden door het stellen van strenge eisen voor de inlassing daarvan in de overeenkomst. ${ }^{140}$

\subsubsection{Informatieplicht wan de gebruiker}

Het uitgangspunt van de wenselijkheid van snelle inlassing van de algemene voorwaarden in de overeenkomst, heeft de wetgever er niet alleen toe gebrachi de rechter een vergaande mogelijkheid te bieden om op grond van artikel 6:233 sub a BW de inhoud van algemene voorwaarden te toetsen, maar tevens om in de artikelen 6:233 sub b en 6:234 BW expliciete eisen te stellen aan de informatieplicht van de gebruiker. ${ }^{141}$ De snelle toepasselijkheid van algemene voor waarden is in dle visie van de wetgever alleen aanvaardbaar indien er tevens een inhoudstoets en stringente informatieplicht bestaan. Ook de gedachte dat in het stelsel van afdeling $6.5 .3 \mathrm{BW}$ bij de bestrijding van het misbruik van onredelijk bezwarende algemene voorwaarden het accent behoort te vallen op een toetsing van de inhoud daarvan door de rechter en het gegeven dat de wedlerpartij zelfs als zij tijdig over de algemene voorwarden beschikt, deze meestentijds toch niet zal lezen dan wel begrijpen, hebben de wetgever er niet van weerhouden een regeling op te nemen die ten doel heeft te waarborgen dat de wederpartij de gelegenheid heeft om werkelijk kennis te nemen van de inhoud van die algemene voorwaarden. ${ }^{142}$ Dit doel wordt bereikt door op de gebruiker, op straffe

140 MvT, Parlementaine Geschiedenia, Inw, 3, 5 en 6, pag. 1572-1573 en 1581.

141 MvT, Parlementaine Geschiedenis, Inv. 3, 5 en 6, pag. 1459.

142 MvT, Pariementaine Geschiedenis, Inv. 3, 5 en 6, pag. 1581. 
wan vernietigbaarheid van het beding, een indirecte ${ }^{143}$ verplichting te leggen zijn wederpartij een exemplaar van de voorwaarden te verschaffen. ${ }^{144}$

Artikel 6:233 sub b BW bepaait derhalve, dat de gebruiker de wederpartij een "redelijke mogelijkheid" dient te bieden van de algemene voorwaarden kennis te nemen. Voldoet de gebruiker niet aan deze informatieplicht jegens zijn wederpartij dan kan deze laatste ${ }^{145}$ een beding in algemene voorwaarden, ongeacht de inhoud daarvan, alleen al op die grond - ook buitengerechtelijk vernietigen. In artikel 6:234 $\mathrm{BW}$ wordt, gelet op de parlementaire behandeling, enuntiatief $^{146}$ aangegeven op welke wijze de gebruiker kan voldoen aan zijn informatieplicht.

\subsubsection{Terhandstelling}

Op grond van het bepaalde in artikel 6:234 lid 1 sub a en b BW is de hoofdregel dat de gebruiker de algemene voorwaarden, indien dit redelijkerwijs mogelijk is, voór of bij het sluiten van de overeenkomst aan de wederpartij ter hand moet stellen. Doorgaans zal dit betekenen dat in de gevallen waarin aan het sluiten van de overeenkomst persoonlijk of schriftelijk contact tussen gebruiker en wederpartij voorafgaat, de gebruiker de plicht heeft de algemene voorwaarden vór of bij het sluiten van die overeenkomst aan de wederpartij te owerhandigen. ${ }^{147}$. Het vooraf toezenden wordt met terhandstellen gelijkgesteld. ${ }^{148}$ De toevoeging bij het sluiten van de overeenkomst ziet op een soort van samenval van momenten waarin sprake is van een (nagenoeg) gelijktijdige aanvaarding en terhandstelling en is opgenomen om bewijsproblemen te vermijden. Ook indien de set algemene voorwaarden pas bij het sluiten van de overeenkomst wordt overhandigd, moet de wederpartij - zo zij dat wil - echter de gelegenheid hebben de aanvaarding van het aanbod uit te stellen om kennis te

143 Indirect omdat de gebruiker strikt genomen geen directe wettelijke verpliehting heeft tot informaltieverstrekking. Het niet-verstrekken van informatie wordt eehter gesanetioneeru door eem vemietigbuarheid ten behoeve wan degene an wie de gewengte informatie is onthouden. Via deze omweg wordt als het ware een verplichting voor de gebniker gecreëerd. Een zogenamude Obliegrenheit. Zie hierover ook: Wessels en Jongeneel, 1992, pag 100 .

144 MVT, Parlementaire Geschiedenis, Inv. 3, 5 en 6, pag. 1581.

145 Indien het betreft een wederpartij als bedoeld in artikel 6.235 BW kan deze geen beroep doen op de vemietigingsgronden wan artikel $6: 233 \mathrm{NBW}$.

146 Dit neemt niet weg dat op grond wan de beperkende werking van de redelijkheid en billijkheild (6:248 lid 2 BW) de wettelijke regeling onder omstandigheden wel eens miet zou kunnen gelden. Bij voorbeeld indien de gebnsiker op een voor de wederpartij duidelijk zichtbare en duidelijk leesbare wijze zijn algemene voorwaanden theeft afgedrukt op een bord. Bij voorbeeld een bord bij een garderobe of bij de ingang van cen fietsenstalling.

147 Wessels en Jongeneel, 1992, pag. 58-59; Verhoeven, pag. 47-48; Jongeneel, disty., pag. 113 114.

148 NEV, Parlementaire Geschiedenis, Inv. 3, 5 en 6, pag. 1594. 
nemen van die algemene voorwaarden. ${ }^{149}$ Feitelijk komt de zinsnede "voor of bij" in artikel 6:234 lid 1 sub a BW dus neer op voor het sluiten van de overeenkomst.." ${ }^{150}$ Bij terhandstelling na het totstandkomen van de wilsovereenstemming is in ieder geval niet voldaan aan de informatieplicht ${ }^{151}$, of zoals de Minister het verwoordde:

"Als men uitgaat wan de formulering "woor of bij, maar in elk geval daama nilet meer", is de sitwatite voor en ieder duidelijk. Op het moment waarop de wilsovereenstemming tot stand komt, dus op dat ondeelbare agenblik, moet de terhandstelling hebben plaatsgevonden. "152

Het onderscheid tussen de aanvaarding van de "romp"-overeenkomst en de aanvaarding van de gelding van algemene voorwaarden is ook in verband met de informatieplicht van belang en met name voor de vraag op welk tijdstip aan deze informatieplicht moet zijn voldaan. Zoals in de vorige paragraaf reeds aangegeven, is het zeer wel mogelijk dat het moment van aanvaarding van de essentialia niet samenvalt met de aanvaarding van de gelding van de daarop toepasselijke allgemene voorwaarden. Welk tijdstip wordt in dit licht in artikel 6:234 lid 1 sub a BW bedoeld met vór of bij het sluiten van de overeenkomst? Is dat het moment waarop overeenstemming wordt bereikt over de essentialia of het tijdstip waarop de gelding van algemene voorwaarden wordt aanvaard?

Indien, bij voorbeeld, omtrent de gelding van algemene voorwaarden eerst na het sluiten van de "romp"-overeenkomst overeenstemming wordt bereikt en de algemene voorwaarden op dat moment in de bestaande overeenkomst worden geïncorporeerd, moet er mijns inziens van worden uitgegaan dat het moment van het sluiten van de overeenkomst als bedoeld in artikel 6:234 BW het moment is waarop de wederpartij alsnog de gelding van algemene voorwaarden aanvaardt. In het geval dat overeenstemming over de "romp"-overeenkomst en overeenstemming over de gelding van daarop toepasselijke algemene voorwaarden temporeel niet samenvallen, moet onder voór of bij het sluiten van de overeenkomst worden begrepen voór of bij de aanvaarding van de gelding van algemene voorwaarden. ${ }^{\text {is }}$

149 UCV II, Parlementaine Geschiedenis, Imv. 3, 5 en 6, pag. 1600 en 1602-1603.

150 Zie in dezelfide zin: Wessels en Jongeneel, 1992 , pag. 59.

151 Wessels en Jongeneel, 1992 , pag. 59; Verhoeven, paig. 48.

152 UCV II, Parlementaire Geschiedenis, Inv. 3, 5 en 6, pag. 1602-1603.

153 Zie in dezelfde zin de vaste Commissie voor Justitie: VV, Parlementaire Geschiedenis, Inv. 3, 5 en 6 , pag. 1583 ; EV, Parlementaire Geschiedenis, Inv. 3, 5 en 6, pag. 1588 en 1599. Do commissie gaat or van uit dat vóor de aanvaarding van de gelding van de algemene voorwaratden voldaan moet zijn aan de informatieplicht. De Minister nam dit standpunt over. Zie NwW 11. Parlementaire Geschiedenis, Inv. 3, 5 en 6, pag. 1594. 
Het komt geregeld voor dat in algemene voorwaarden, andere algemene voorwaarden door de gebruiker toepasselijk worden verklaard. Zo dit al zou leiden tot primaire gebondenheid van de wederpartij ook aan die laatste voorwaarden, hetgeen ik doorgaans niet voor mogelijk houd, ${ }^{154}$ geldt ook voor deze voorwaarden dat de gebruiker, op straffe van vernietigbaarheid, aan zijn informatieplicht moet voldoen. Dat betekent mijns inziens, dat ook de algemene voorwaarden waarnaar wordt verwezen in algemene voorwaarden, op straffe van vernietigbaarheid, ter hand moeten worden gesteld vór of bij de aanvaarding van de gelding van de voorwaarde waarin wordt verwezen naar de toepasselijkheid van die voorwaarden.

\subsubsection{Mededeling}

Voor het geval terhandstelling redelijkerwijs niet mogelijk is, kan de gebruiker, op grond van het bepaalde in artikel 6:234 lid 1 sub b BW, volstaan met aan de wederpartij - vóór het sluiten van de overeenkomst - mee te delen dat de voorwaarden ter inzage liggen bij de gebruiker zelf, of zijn gedeponeerd bij een Kamer van Koophandel en Fabrieken of een griffie van een gerecht, mits hij daarbij tevens meedeelt dat de voorwaarden op verzoek zullen worden toegezonden.

Ofschoon de tekst van artikel 6:234 lid 1 sub b BW anders doet vermoeden, moeten de algemene voorwaarden in ieder geval (ook) ter inzage liggen bij de gebruiker zelf. Dit is immers, om met de woorden van de toenmalige Minister van Justitie te spreken, $z \sigma$ voor de hand liggend dat het niet nodig is dit expliciet te regelen. ${ }^{1 s s}$

De regel van artikel 6:234 lid 1 sub b BW is uitdrukkelijk slechts bedoeld een uitzondering te vormen op de hoofdregel van voorafgaande terhandstelling, voor het geval dat deze terhandstelling of toezending vooraf redelijkerwijs niet mogelijk is. Indien voorafgaande terhandstelling of toezending redelijkerwijs mogelijk is, geldt onverkort de hoofdregel van 6:234 lid 1 sub a BW. Onder "redelijkerwijs niet mogelijk" dient te worden verstaan:

- feitelijke onmogelijkheid van terhandstelling, men denke aan het geval dat de overeenkomst wordt gesloten per automaat of per telefoon ${ }^{156}$;

$154 \mathrm{Z}$ ie hierwoor paragraf 5.2 .3 .

155 UCV II, Parlementaire Gesehiedenis, Inv. 3, 5 en 6, pag. 1608.

156 MvT, Parlementaire Geschiedenis, Inv. 3, 5 en 6, pag. 1581; MvA, Parlementaire Geschiedenis, Inv. 3, 5 en 6, pag. 1585. 
- praktische onmogelijkheid, bij voorbeeld bij massaal gesloten overeenkomsten zoals vervoerovereenkomsten voor tram of bus. ${ }^{157}$

Artikel 6:234 lid 2 BW bepaalt vervolgens, dat indien de wederpartij toezending verzoekt, die toezending - op straffe van vernietigbaarheid van de betreffende algemene voorwaarden - onverwijld ${ }^{158}$ en op kosten van de gebruiker dient te geschieden.

\subsubsection{Toezending redelijkerwijs onmogelijk}

In uitzonderingsgevallen kan toezending van de algemene voorwaarden redelijkerwijs niet van de gebruiker worden gevergd; men denke aan zeer omvangrijke, soms boekwerken vullende complexen van algemene voorwaarden. ${ }^{139}$ Op grond van het bepaalde in artikel 6:234 lid $3 \mathrm{BW}$ vervalt in dat geval de verplichting van de gebruiker tot toezending als bedoeld in de leden 1 en 2 van artikel 6:234 BW. Echter alleen "voor zover" dit redelijkerwijs niet van hem kan worden gevergd. De woorden "voor zover" geven aan dat

"het onder omstandigheden mogelijk en redelijk kan zijn de wederpartij een uittreksel of een samenvatting wan de voor deze vooral relevante bedingen te daen toekomen". ${ }^{160}$

Een tekortschieten van de gebruiker ten aanzien van de kosteloze verzending van dit uittreksel of samenvatting leidt eveneens tot een vernietigbaarheid van de betreffende algemene voorwaarde(n).

157 MvA, Parlementaire Geschiedenis, Inv, 3, 5 en 6, pag. 1585. Pensoonlijk vind ik hell voorbeld van massual gesloten verwowrovereenkomsten per bus, tram of trein ongelukküg gekozen. Dezie overeenkomsten worden grotendeels heheerst door bijzondere wetgeving zodat het gebruik war algemene voorwatuden bij dit soont vervoerovereenkomsten nagenoeg volstrekt overbodig üs.. Voor de massainl gesloten vervoerovereenkomsten als bedoeld in de kamerstukken wordt in de praktijk dan ook enkel gebruik gemaakt van algemene voorwaanden bij de zogenalamde abonnementen en kortingskaarten en miet bij het sluitem van eenmalige vervoerovereenkomstem (het ter afstempeling anbieden van een strippenkmart of het kopen van een enkeltje of een retourtje). In die gevallen is, mede vanwege het, voorafgand aan de contractssluiting, peraoonlijke contact met het personeel van de gebruiker, naar mijn mening een aan de contractssluiting voorafgaande terhandstelling van de algemene voorwasarden alleszins "redelijikerwijks mogelijk". Anders: Wessels en Jongeneel, 1992, pag. 60-61.

I58 Onverwijld bettkent hier: zonder vertraging. Zie MwA II, Parlementaire Geschiedenis, Imv. 3, 5 6, pag. 1585.

159 MvT, Parlementaire Geschiedenis, Inv, 3, 5 en 6, pag. 1581; Als voorbeeld wondt in de MvT genoemd de algemene voorwaanden wan openbare nutsbedrijven met bijbehorende normworrwhiften.

160 MvT, Parlementsire Geschiedenis, Inv. 3,5 en 6 , payg. 1582. 


\subsubsection{Bewijs}

De verdeling van de bewijslast is, voor zover de wet daar niet in voorziet ${ }^{161}$, aan de rechter toevertrouwd. Voor de vraag op welke partij de rechter de bewijslast legt, zijn diverse theorieën ontwikkeld. ${ }^{162}$ In de jurisprudentie en in artikel $177 \mathrm{Rv}$ wordt echter niet uitdrukkelijk voor toepassing van eén theorie gekozen. ${ }^{163}$ Op grond van artikel $177 \mathrm{Rv}$ en de algemeen aanvaarde regel ${ }^{164}$ dat een partij in beginsel slechts belast kan worden met het bewijs van positieve feiten, mag aangenomen worden dat de bewijslast van het feit dat de algemene voorwaarden toepasselijk zijn en het feit dat de wederpartij een redelijke mogelijkheid heeft gehad om van de algemene voorwaarden kennis te nemen, in beginsel rust op de gebruiker. ${ }^{165}$ Dit beginsel kan door de rechter terzijde worden gesteld indien uit enige bijzondere regel of uit de eisen van redelijkheid en billijkheid een andere verdeling van de bewijslast voortvloeit.

Dit betekent dat doorgaans de gebruiker zal moeten aantonen:

1. dat indien er een redelijke mogelijkheid is geweest om de algemene voorwaarden ter hand te stellen als bedoeld in artikel 6:234 lid 1 sub a BW, hij zijn algemene voorwaarden daadwerkelijk vóor of bij het sluiten van de overeenkomst aan de wederpartij heeft overhandigd of indien sprake is van schriftelijk contact vooraf heeft toegezonden;

2. dat indien deze redelijke mogelijkheid zich miet heeft voorgedaan, hij de wederpartij voór het sluiten van de overeenkomst heeft medegedeeld:

a. dat zijn algemene voorwaarden toepasselijk zijn;

b. deze bij hem, een K.v.K. of een griffie van een gerecht ter inzage liggen;

c. dat zij op verzoek van de wederpartij zullen worden toegezonden;

en dat de wederpartij hetzij heeft afgezien van toezending, hetzij, indien de wederpartij om toezending heeft gevraagd, dat de algemene voorwaarden daadwerkelijk en kosteloos aan de wederpartij zijn toegezonden;

3. dat voor zover toezending redelijkerwijze niet van de gebruiker kan worden gevergd als bedoeld in artikel 6:234 lid $3 \mathrm{BW}$, hij de wederpartij vór het sluiten van de overeenkomst heeft medegedeeld dat zijn algemene voorwaarden toepasselijk zijn én deze bij hem, een K.v.K. of een griffie van een gerecht ter inzage liggen.

In de hierboven onder 1 genoemde situatie hoeft de bewijslast voor de gebruiker geen onoverkomelijke problemen op te leveren. Hij kan immers vóor of bij de

161 Zie bij voorbeld artikel 6:195 BW (misleidende reclame).

162 Stein, Compendium, pag. 119-124.

163 Stein, Compendium, pag. 124.

164 Stein, Compendium, pag. 123; Hugenholtz/Heemskerk, prg. 146.

165 Jongeneel, diss., pag. 114; Wessels en Jongeneel, 1992, pag. 65; Verhoeven, pag. 46. 
totstandkoming van de overeenkomst de terhandstelling van de algemene voorwaarden schriftelijk laten bevestigen door de wederpartij. Dit kan hij echter mijns inziens niet doen in een algemene voorwaarde. Een algemene voorwaarde waarin de wederpartij verklaart de algemene voorwaarden te hebben ontvangen (fictieve verklaring) is jegens consumenten onredelijk bezwarend op grond vam het bepaalde in de artikel 236 sub 1 of sub k BW. ${ }^{106}$

Het zal aanstonds duidelijk zijn dat in de hierboven onder 2 en 3 genoemde situaties, het bewijs van het feit dat aan de informatieplicht is voldaan, de gebruiker voor hetere vuren zal plaatsen. Hoe dient de gebruiker bij voorbeeld te bewijzen dat de wederpartij bij een telefonische opdracht heeft afgezien van toezending van de algemene voorwaarden? ?67 $^{167}$

De rechter kan in die gevallen weliswaar kiezen voor een bewijsopdracht aan de wederpartij doch dat zal er veelal alleen toe leiden dat de bewijsnood zich verplaatst van de gebruiker naar de wederpartij. Naar mijn mening zal in dat soort gevallen soms ook een terzijdestelling van een beroep van de wederpartij op artikel 6:233 sub $b j^{\circ}$ 6:234 BW op basis van de beperkende werking van de redelijkheid en billijkheid (artikel 6:248 lid 2 BW) op zijn plaats zijn. Hoe de rechter echter met dit probleem zal omgaan is voorshands ongewis.

In ieder geval kan mijns inziens geconcludeerd worden, dat het uitgangspunt dat "men misstanden waartoe het gebruik van algemene voorwaarden soms leidt, niet moet willen bestrijden door strenge eisen te stellen voor de inlassing daarvan in de overeenkomst" enigszins op losse schroeven komt te staan. Van de gebruiker zijn op het vlak van het bewijs immers de nodige inspanningen vereist teneinde te voorkomen, dat deze snelle inlassing weer even snel ongedaan wordt gemaakt door een beroep van de wederpartij op de vernietigingsgrond van artikel 6:233 sub b BW. De inlassingseisen zijn dan weliswaar niet streng, de bewijseisen met betrekking tot artikel 6:233 sub $b \mathrm{j}^{\circ} 6: 234 \mathrm{BW}$ daarentegen wel. Daarmee wordt een deel van de voordelen die algemene voorwaarden bieden, namelijk het eenvoudig contracteren zonder dat men veel aandacht hoeft te schenken aan die algemene voorwaarden en de tijdsbesparing die dit oplevert, teniet gedaan. Daardoor en mede vanwege de onzekerheid over de lijn die de rechter in deze zal volgen, wordt de rechtszekerheid die wordt geboden door het uitgangspunt van de snelle primaire gebondenheid, voor een aanzienlijk deel uitgehold. Het komt mij dan ook voor dat de uitwerking van de

166 Zie ook parlementaire behandeling artikel 236 sub 1 BW. Parlementaire Gesehiedenis, lnv. 3,5 en 6, pag. 1711-1715.

167 Zie ook: UCV II, Parlementaire Gesehiedenis, Inv. 3, 5 en 6, pag. 1613; Wessels en Jongeneel, 1992, pag. 62-63. 
informatieplicht van de gebruiker zoals neergelegd in artikel 6:234 BW, kan worden bestempeld als onredelijk bezwarend voor de gebruiker.

Bovendien kan ik mij, net als Jongeneel ${ }^{168}$, niet aan de indruk onttrekken dat de wetgever in de regeling van de informatieplicht van de gebruiker zich in haar ijver schuldig heeft gemaakt aan "overkill". De wederpartij heeft doorgaans pas behoefte aan kennisname van de inhoud van algemene voorwaarden op het moment dat er iets mis gaat bij de uitvoering van de "romp"-overeenkomst. Dit is ook de ratio van algemene voorwaarden. Het is een sluimerend regelcomplex dat eerst aan de oppervlakte komt op het moment dat daar behoefte aan is, meestal dus als zich problemen voor doen bij de uitvoering van de uitdrukkelijk overeengekomen "romp"-overeenkomst. Deze gedachtengang komt ook tot uitdrukking in artikel 6:235 lid $4 \mathrm{BW}$. Hierin wordt bepaald dat de verjaringstermijn bij de vernietigbaarheid van algemene voorwaarden eerst aanvangt op de dag volgend op die waarop de gebruiker een beroep doet op een beding in zijn algemene voorwaarden. De ratio van deze bepaling is gelegen in

"'... het moment waarop de tot vernietiging bevoegde kennis heeft gekregen wan de vernietigingsgrond. Wat de onderhavige situatie betreft zal dit veelal miet zijn het mament waarop de overeenkomut gesloten is, doch een later ogenblik; te denken is in het bijzonder aan het tijdstip watarop de wrederpartij (...) met een beroep op het beding wordt geconfronteerd, aangezien hij zich pas op dat ogemblik van het beding en zijn implicaties bewrust zal worden. "169

Daarbij moet uitdrukkelijk worden aangetekend dat in de praktijk de uitvoering van het merendeel der overeenkomsten niet tot problemen leidt. Wat is vanuit dat gezichtspunt dan het nut van informatie, die in het merendeel van de gevallen niet gebruikt zal worden, op een tijdstip dat de wederpartij daar niet om vraagt en die vervolgens, mede omdat de wederpartij op dat moment totaal geen behoefte heeft aan kennisname, in nagenoeg alle gevallen, ongelezen, in de prullenbak verdwijnt?

Het komt mij voor dat in dat licht het opleggen van een stringente informatieplicht op de gebruiker ook voor het geval dat de wederpartij daar niet om vraagt, vrij nutteloos is. Het is niet alleen een onzinnige verspilling van grondstoffen en een onverantwoorde bijdrage aan de toename van afvalbergen, maar tevens een miskenning van de functie en ratio van algemene voorwaarden. Door deze te vergaande betutteling van contractspartijen, worden voor het (nuttige) gebruik van algemene voorwaarden immers onnodige obstakels opgeworpen.

168 Jongeneel, diss., pag. 120.

169 MWA, Parlementaire Geschiedenis, Inv. 3, 5 en 6, pag. 1629. 
Onnodige obstakels ook, omdat afdeling 6.5.3 BW voorziet in een vergaande inhoudstoetsing van algemene voorwaarden en zodoende afdoende bescherming: biedt tegen ongezien aanvaarde algemene voorwaarden. De versluiering van de inhoud van algemene voorwaarden is immers voornamelijk een probleem indien: de inhoud van de betreffende algemene voorwaarden bij een beroep daarop door de gebruiker onredelijk bezwarend blijkt te zijn voor de wederpartij. Het accent van een wettelijke regeling op het terrein van de algemene voorwaarden behoon derhalve, zoals de wetgever zelf opmerkte, te liggen op de toetsing van de inhoud daarvan. ${ }^{170}$

In het voorgaande is tevens reeds aangegeven waar volgens mij de grenzen van een informatieplicht van de gebruiker behoren te liggen. $\mathrm{Zij}$ behoren te worden gekoppeld aan het verzoek van de wederpartij. Voorop staat immers, als een contractueel "grondrecht"171, dat de wederpartij, indien zij dat wi], te allen tijde, of dat nu vóor of na het sluiten van de "romp"-avereenkomst of voor of na de aanvaarding van de gelding van de algemene voorwarden is, de mogelijkheid moet hebben om van de inhoud van deze voorwaarden kennis te nemen. In mijn visie voldoet een gebruiker derhalve aan zijn informatieplicht als hij de wederpartij de toepasselijke algemene voorwaarden op diens verzoek overhandigt of kosteloos toezendt onverwijld nadat de wederpartij hem daarom heeft verzocht. Indien, en voorzover, deze overhandiging of toezending praktisch onmogelijk is, voldoet de gebruiker aan zijn informatieplicht als de wedlerpartij onverwijld de mogelijkheid wordt geboden de algemene voorwaarden bij de gebruiker te raadplegen. ${ }^{172}$

De, mijns inziens, te vergaande informatieplicht ${ }^{173}$ van de gebruiker stuit bovendien nog op een ander bezwaar. Indien de gebruiker slaagt in het bewijs dat hij aan zijn informatieplicht heeft voldaan, staat vast dat de wederpartij een redelijke mogelijkheid heeft gehad om van de inhoud van die voorwaarden kennis te nemen. Feitelijk is het echter zo dat de wederpartij ondanks de redelijke mogelijkheid om kennis te nemen van de inhoud van de algemene voorwaarden vóor de aanvaarding van de gelding daarvan - bij voorbeeld ondat zij haar zijn overhandigd - daar veelal toch geen gebruik van maakt. ${ }^{174}$ Het

170 Zie hierna paragraaf 5.2 .5 .

171 Jongeneell, diss. pag. 120 .

172 Zie het oorspronkelijk ontwerp van wet, artikel $6.5 .2 \mathrm{~A} .2$, lid 2 , sub b NBW.

173 Zie ook paragraaf 2.5.3.

174 Jongeneel, diss., pag. 120 , spreekt wan meer dan $99 \%$ van de gevallen. Zie ook de opmerking van de Minister tijdens de mondelinge behandeling (UCV 1, Parlementaire Gesehiedenis, Inw.

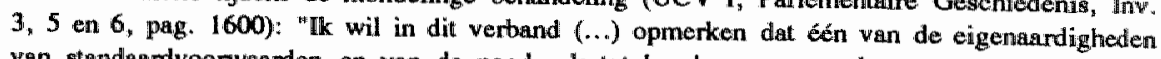
wan standaardvoorwaanden en van de noodzaak to beschermen van de consument is, diat dit laatsite er geen kennis wan pleegt te nemen. Dit heeft de noodzaak tot zijn beseherming in het (wordt vervolgd...) 
verkeer van goederen en diensten zou overigens een onaanvaardbare vertraging ondergaan indien wederpartijen daar wél gebruik van zouden gaan maken. Algemene voorwaarden zijn ook niet bedoeld on te worden gelezen. Meestal komt de wederpartij aan dit lezen pas toe op het moment dat er problemen zijn bij de uitvoering van de overeenkomst. Dan kan echter blijken dat men te laat is met zijn klacht of dat men bij de verkeerde instantie klaagt, hetgeen men had kunnen weten als men de voorwaarden vooraf had bestudeerd. ${ }^{175}$ Vaststaat dat kennisname van de inhoud van de voorwaarden feitelijk mogelijk was, de gebruiker heeft immers aan zijn informatieplicht voldaan. De verleiding is dan groot om bij een beroep van de wederpartij op het onredelijk bezwarende karakter van bij voorbeeld verval- of verjaringsbedingen, het risico van het niet lezen wan zulk een beding te leggen bij de wederpartij en wel op grond van het beginsel, dat men de gevolgen moet dragen van een door eigen verzuim veroorzaakt informatiegebrek.. ${ }^{176}$ De wederpartij had immers duidelijk de gelegenheid om van de voorwaarden kennis te nemen. Toch moet naar mijn mening in het geval van algemene voorwaarden aan deze verleiding niet worden toegegeven. Het is immers een feit van algemene bekendheid dat bijna elke wederpartij de toepasselijke algemene voorwaarden niet leest voordat $z i j$ de gelding van deze aanvaard. De gebruiker weet dit ook of behoort dit althans te weten. Algemene voorwaarden zijn naar hun aard, bedingen die ongelezen worden aanvaard en pas bedoeld zijn om te worden gelezen op het moment (of wlak daarna) dat zich problemen voordoen bij de uitvoering van de overeenkomst. Bovendien is het zo, dat als men de algemene voorwaarden al leest, deze als gevolg van de "take it or leave it" opstelling van de meeste gebruikers, nilet te veranderen zijn door de wederpartij. Algemene voorwaarden zijn naar hun aard ook niet bedoeld om gewijzigd te worden.

Onder die omstandigheden is het rechtens onjuist de wederpartij tegen te werpen dat zij kennis had kunnen nemen van het betreffende beding vóor de aanwaarding van de gelding. Bedingen in algemene voorwaarden die bewerkstelligen dat de wederpartij in een nadeliger positie komt omdat zij eerst kennis neemt van de algemene voorwaarden op het moment dat er problemen zijn met de uitvoering van de "romp"-overeenkomst, zijn naar mijn mening derhalve onredelijk bezwarend indien de gebruiker de wederpartij vóor de aanvaarding

174 (...vervolg)

leven geroepen. Als wij ervan uitgaan dat in de praktijk door de wederpartij wan de gebniker, geen kennis wordt genomen van de voorwaanden, dan is het vereivte dat de voorwaarden tevoren moesten zijn overhandigd of toegezonden ook niet wezenlijk voor de vrang of die voorwarden van toepassing zijn."

$175 \mathrm{Zie}$ ook: Jongeneel "disi., pag. 120.

176 Zie ower dit beginsel: Wessels en Jongeneel, 1992, pag. 46, Jongentel, diss., pag. 111. 
van de gelding van die bedlingen niet uitdrukkelijk op de inhoud daarvan heeft gewezen. ${ }^{17}$

\subsubsection{De inhoudstoetsing}

Belangrijkste steunpunt van de nieuwe wet is ongetwijfeld de uitdrukkelijke mogelijkheid om de inhoud van algemene voorwaarden ter toetsing voor te leggen aan de overheidsrechter, zoals deze is neergelegd in artikel 6:233 sub a $\mathrm{BW}$. Uitgangspunt van afdeling 6.5.3 $\mathrm{BW}$ is immers

"de gedachite dat het accent van eem regeling ter bestrijding van misbruik van onerewze algemutit

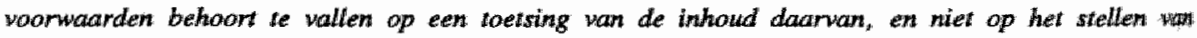
strenge eisen woor de inlassing van die woonwaarden in de overeenkomst". ${ }^{178}$

Ter onderstreping van deze gedachte worden de rechter ruime mogelijkheden gegeven de inhoud van een beding op redelijkheid en evenwichtigheid te toetsen. ${ }^{170}$ Enerzijds de algemene norm van artikel 6:233 sub a BW die bepaalt dat algemene voorwaarden vernietigbaar zijn indien deze onredelijk bezwarend zijn voor de wederpartij. Anderzijds een uitwerking van deze norm in twee lijsten van bedingen die indien zij gebruikt worden in overeenkomsten met consumenten, ofwel altijd geacht worden onredelijk bezwarend te zijn jegens de wederpartij omdat zij voorkomen op de zogenoemde zwarte lijst van artikel 6:236 BW, ofwel vermoed worden onredelijk bezwarend te zijn omdat zij zijn geplaatst op de zogenoemde grijze lijst van artikel 6:237 BW. Voordat ik deze toetsnorm en de uitwerking daarvan nader beschouw ga ik eerst nog even kort in op de uitleg van algemene voorwaarden. Ook naar huidig BW zal de rechter immers voorafgaande aan de inhoudstoetsing van een beding, de inhoud daarvan moeten vaststellen.

\subsubsection{Uitlegregels voor algemene voorwaarden}

Bij het uitleggen van algemene voorwaarden door de rechter gaat het om de vaststelling van de inhoud van een beding; om de vaststelling van de betekenis van de door contractanten afgelegde verklaring. ${ }^{120}$ De partijbedoeling is derhalve het uitgangspunt, of, zoals Hondius het weergeeft:

177 Zie in dezelfde zin: MvA, Parlementaire Geschiedenis, Inv. 3, 5 en 6, pag. 1585-1586. Zie hiema paragraaf 5:2.5.2 warin de betreffende tekat is opgenomen.

178 MvT, Parlementaire Geschiedenis, Inv. 3, 5 en 6, pag. 1456, 1573 en 1581.

179 Asser-Hartkanp II, 1993 , n.r. 355.

180 Zie thiervoor paragraaf 3.4.1. 
Thdien partijen menen dat olifanten ingevolge de AVC 1950 werpakt moeten worden, dam moet dat: oxis

Zoals reeds eerder vermeld hebben de regels inzake de uitleg van overeenkomsten zoals neergelegd in de artikelen 1378 tot en met 1387 van het oude BW hebben in het huidig BW geen plaats meer gekregen. ${ }^{182} \mathrm{Zij}$ werden ten dele als overbodig en ten dele, vanwege hun te grote algemeenheid, onjuist geacht. ${ }^{13}$ Ook achtte de wetgever het niet nodig speciale uitlegregels vast te stellen voor het terrein van de algemene voorwaarden. ${ }^{184}$

Hondius heeft in het verleden codificatie van een antal uitlegregels, zoals de contra proferentem regel en de regel dat het individueel overeengekomene prevaleert boven algemene voorwaarden, bepleit. ${ }^{\text {tas }}$

"Deze acmbeveling wordt niet zozeer ingegeven uit ontevredentheid met de strekking en duidelijkheid wan de thans door de rechispraak gehanteerde witlegregels en -methodien, als wel door de gedachte dat geldend rechit ook aan anderen dan rechter en overige kenners van rechtsrituelen kenthaar dient te zijin." (...) "De wet is er niet alleen voor de rechter, maar ook voor de burger, "186

Ook Jongeneel is de opvatting toegedaan dat vanuit het oogpunt van kenbaarheid het opnemen van uitlegregels in de wet de voorkeur lijkt te verdienen. Tegelijkertijd betwijfelt hij echter het praktische nut van codificatie van uitlegregels. De doorsnee contractant heeft immers onvoldoende toegang tot het burgerlijk wetboek. Bovendien kan de rechter goed uit de voeten met de in de rechtspraak ontwikkelde uitlegregels en zouden wettelijke regels diens speelruimte mogelijk kunnen beperken. ${ }^{187}$

Dat het burgerlijk wetboek vrijwel ontoegankelijk is voor de doorsnee contractant is helaas waar. Desalniettemin is ook voor de doorsnee contractant de wet de meest aangewezen bron om van het recht kennis te nemen. Bovendien heeft de wet, ondanks de geringe toegankelijkheid daarvan voor de doorsnee justitiabele, juist voor deze een grotere kracht van argument dan welke andere bron van rechtsvinding ook. Juist vanwege deze uitstraling van gecodificeerde regels naar het doorsnee publiek, verdient het mijns inziens aanbeveling een aantal in de rechtspraak uitgekristalliseerde en in de doctrine algemeen aanvaar-

181 Hondius, preadvies NJV, pag. 168.

182 Zile hierwoor peragraf 3.4 .1 .

183 Toelichting-Mejjers baj Bioek 6, Parlementaire Gesehiedenis, Boek 6, pag. 916.

184 VV, Parlementaire Gieschiedenis, Inv, 3, 5 en 6, pag. 1461; MvA, Parlementaire Gesehiedenis, Inv, 3, 5 en 6, pag. 1462 .

185 Hondus, preadvies NJV, pag, 168-169; Hondius, Unfair Terms in Comsumer Contracts, pag. $232-235$.

186 Hondius, preadvies NIV, pag. 168-169.

187 Jongeneel, diss., pag. 152. 
de uitlegregels in de wet op te nemen. Te denken valt in de eerste plaats aande contra proferentem regel en de regell dat individuele afspraken prevaleren bowen algemene voorwaarden. Dit te meer, omdat artikel 5 van de EEG-richtliji betreffende oneerlijke bedingen de Nederlandse wetgever dwingt tot het opne men van de contra proferentem regel in de nationale wetgeving. ${ }^{188}$ Uiteraand is het daarbij zeer gewenst dat de overheid zich meer moeite getroost de kennis omtrent het recht bij de doorsnee burger te activeren en uit te bouwen. Het argument van Jongeneel dat codificatie van rechtsregels voor de rechter weinig nut heeft omdat deze goed uit de voeten kan met de in de jurisprudentie ontwikkelde regels doet daar niet an af. De wet is immers in de eerste plaats geschreven voor de burger en niet voor de rechter. Niet voor niets is de naam Burgerlijk Wetboek gekozen. Bovendien biedt een duidelijke wettelijke regel het voordeel dat daardoor onnodige procedures worden voorkomen, hetgeen naar mijn mening niet alleen een ontlastend effect heeft op de werklast van de rechter maar tevens aanzienlijk voordeliger is voor de betrokken partijen. Jongeneel's argument dat de rechter door codificatie van uitlegregels in zijn speelruimte zal worden beknot wordt aanzienlijk gerelativeerd, indien men bedenkt dat de redelijkheid en billijkheid van artikel 6:248 lid $2 \mathrm{BW}$ onder omstandigheden ook derogeren aan wettelijke uitlegregels.

Algemeen wordt aanvaard dat de rechter zich bij de uitleg van overeenkomsten en dus ook van algemene voorwararden moet laten leiden door algemene rechtsbeginselen als de redelijkheid en billijkheid van artikel 6:248 $\mathrm{BW}$ en het vertrouwensbeginsel van artikel 3:35 BW. ${ }^{189}$ Daarmee wordt de lijn, die in de jurisprudentie onder het oude BW is ontwikkeld, in het huidige BW onverkort voortgezet. Door de Hoge Raad wordt deze lijn duidelijk geillustreerd in zijn, sindsdien als meest richtinggevend in deze materie beschouwde, arrest van 13 maart 1981. ${ }^{190}$ Sedertdien is het vaste regel dat bij de uitleg van contractsbepalingen niet de letterlijke tekst en een zuiver taalkundige uitleg daarvan bepalend is maar:

188 Jongeneel, TwC 1993, pag. 130; Jongeneel en Wessels, NJB 1993, pag. 899. Zie eweneens: hierwoor paragraaf 3.4 .1 .

189 Asster-Hartkamp 11, 1993, nr, 281; Wessels en Jongeneel, 1992, pag. 24; Verhoeven, pag. 14.

190 HR 13 masrt 1981, NJ 1981,635 , m.nt. C.J.H.B., A.A 1981, pag. 355, m.nt. Van Schilfgar de (Hawiltex). Zie ook: HR 17 december 1976, NJ 1977, 241, m.nt. G.J.S. AA 1977, pag, 654, m.nt. v.Seh. (Bunde/Erckens); HR 1 juli 1977, NJ 1978, 125, m.nt, G.J.S. (Ram/Matser); HR 18 november 1983, NJ 1984, 272, m.nt. G. (Kluft/B en W supermarkten); HR 20 janwari 1984, NJ 1987, 295 (Leutscher/Van Tuyn); HR 25 januari 1985, NJ 1985, 559, m.nt. P.A.S. (Patelski/Sittard); HR I juli 1985, NJ 1986, 692, m.nt. C.J.H.B. (Frenkel/KRO); HR. 11 nowember 1988, NJ 1990, 440 (Amo/NCM). Zie voor meer jurisprudentie en een owerzicht van de stand van zaken met betrekking tot de uitleg van overeenkomsten: Van Dunne; Verbintenissenrecht, pag. 160-165. 
-.... de zin die partijen in de gegeven omstandigheden over en weer redelijkerwijs aan deze bepalingen mochtem toekennen en op hetgeen zij te dien aanzien redelijkerwijs. wan elkaar mochten wenwachten. Dasubij kan mede van belang zijn tot welke matschappelijke kringen partijen behoren en welke rechtskennis vam zodanige partijem kan wonden werwachs."

Voortbouwend op dit arrest is in de rechtspraak en doctrine een aantal uitlegregels voor algemene voorwaarden ontwikkeld:

- algemene voorwaarden moeten objectief worden uitgelegd;

- de taalkundige betekenis is niet doorslaggevend;

- individuele afspraken gaan altijd voor algemene voorwaarden;

- bij twijfel dient een onduidelijk beding in beginsel ten nadele van de professionele opsteller te worden uitgelegd. ${ }^{191}$

Mede gezien deze laatste regel geldt mijns inziens voor de uitleg van algemene voorwaarden in consumententransacties dat zij moeten worden uitgelegd overeenkomstig de zin die de (consument-)wederpartij in de gegeven omstandigheden redelijkerwijs aan zulk een beding mag toekennen. De bedingen zijn door de gebruiker immers bedoeld om door de consument te worden begrepen. Daarbij ligt in elk gevall vast dat van de doorsnee consument nauwelijks enige rechtskennis mag worden verwacht.

\subsubsection{De open norm van artikel 6:233 sub a BW}

Zoals reeds eerder gezegd moet de inhoudstoets van artikel 6:233 sub a BW beschouwd worden als het hart ${ }^{192}$ van de nieuwe regelgeving inzake algemene voorwaarden. Dit is niet meer dan logisch indien men bedenkt dat het belangrijkste probleem bij algemene voorwaarden juist deze (onredelijk bezwarende) inhoud is.

\section{Uitgangspunten}

Artikel 6:233 sub a BW legt de inhoudstoetsing vast in een algemene bepaling, met ruim omschreven criteria, een zogenaamde "open norm". ${ }^{193}$

191 Zie paragraf 3.4.1. Zie voor een verder overzicht van de in de rechtspraak ontwikkelde uitlegregels bi algemene voonwaarden: Jongeneel, diss., pag. 152 e.w.; Wessels en Jongeneel, 1992 , pag. 25-26, Verhoeven, pag. 15-16.

192 NEV, Parlementaire Geschiedenis, Inw. 3, 5 en 6, pag. 1596; Verhoeven, pag. 53.

193 De therm "open norm" alsmede de termen "zwarte lijst" en "grijze lijst" zijn teng te voeren op Hondüus. In zxjn dissertatie maakt hij gewag van een zogenaamde zwarte lijst en cen "blanketnorm" die hij naar Duits voorbeeld "Generalklausel" noemt. Zie bij woorbeeld pag. 613 (zwarte lijst) en pag. $585-586$ (Generalkfausel, blanketnormi). In zijn preadvies voor de NVV introduceerde hij de termen "open norm", "Zwarte lijst" en "grijze lijst". Zie: Hondius, preadvies,

(wordt wervolgd....) 
Een beding in algemene moonwardien is vemietigbaar (...) indien het, getet op de aard en de overige inhoud van de overeenkowst, de wijze warop de voonwarden zijn tot stand gekomem dy wederzifls kenbare belangen wan partijen en de overige omstandigheden wan het geval, onrededija: bezwarend is voor de wederpartiy.

De bepaling is opgenomen in de regeling van afdeling 6.5.3 $\mathrm{BW}$ ter vervanging van de oorspronkelijk voorziene vernietigingsgrond in artikel 6.5.1.3 lid 2 ontwerp NBW. Dit omdat de huidige bepaling meer rechtstreeks, effectiever en bruikbaarder wordt geacht ${ }^{194}$. Op de vraag van de vaste Commissie voor Justitie, wat zich verzet tegen handhaving van artikel 6.5.1.3, lid 2 ontwerp NBW ${ }^{195}$ gaf de Minister dan ook het volgende, voor de uitgangspunten van de inhoudstoets verhelderende, antwoord (door mij aangepast aan de huidige artikelnummering van afdeling 6.5.3 BW):

"Vooreerst is de door artikel 6:233 sub a BW geboden bescherming meer rechtstreeks. Zij is meer rechitstreeks, omdat de norm direct de inhoud van het beding op de voorgrond stelt "zodat de rechisstrijd tussien partijen en het eventueel te leveren bewijs zich daarop moet concentreren, en miet op de afgeleide en naar haar aurd maeilijker te bewijzen, immers nimmer grijpbare uraag, wat partijen over en weer omirent elkaars kennis of intenties begrepen of moesten begrijpen.

Voorts is die bescherming effectiever. Antikel 6:233 sub a BW vereist immers niet dat de wederpartij het onereuze beding niet kende, al zal dit veelal het gewal zijn; moch dat de wederpartij de overeenkomst niet zou hebben aangegaan, indien zij het wel gekend had. Dit laatste vereiste, dat in artikel 6.5.1.3, lid 2, besloten lag, is niet slechts wit bewijsrechrelijk oogpunt minder geluklig. er kleven ook materielle bezwaren aam. Niet zelden immers zal kemnis van een beding de wederpartij er niet waw weerhouden te contracteren, hetzij andat zij de juiste drasgiwijdte ervan niet begrijpt, hetrij omdat zij nier in staat is of meent te zijn zich tegen opmeming ervan in de overeenkomst te verzettent, hetzij oundat zij niet verwacht dat het tot een beroep op het beding zal komen. Het zou derhalve miel juist zijn de wederpartij de bescherming wan de onderhavige regeling te onthouden op de enkelle grond dat zij, bij kennis van het beding, het nietremin als deel van de overeenkomst zou hebben aanwaard. Dit neemt niet weg dat deze kennis een omstandighteid is waarmee de rechter bij de becordeting van het bezwarende karakter wan het beding in het kader wan arrikel 6.233 sub a BW rekening kan houden.

Een derde voordeel dat de in het wetsontwerp gekozen benadering biedt boven artikel 6.5.1.3, lid 2, is dat de maatstaf of een beding anredelijk bezwarend is, niet slechts bruikbaar is in verband met de vernierigbaarheid wan bedingen in gesloten contracten (artikel 6:233 sub a BW, witgewerkt in de artikelen 6:236 en $6.237 \mathrm{BW}$ ), doch ook in verband met de verbodsactie vart de artikelen 6:240 w. Het spreelt vanzelf dat een zodhuig op eien algemene norm opgebouwd stelsel wit een oogpunt van wetssystematiek en economische begripsworming aantrekkelijk is; de matstaf wan artikel 6.5 .1 .3$, bit 2, zou daarwoor niet bruikbaar zijn geweest." "190

193 (...vervolg) respectievelijk pag. 171, 165 en 169. Voor diepgaande beschouwing over (de wenselijkheid) van vage "open" normen en scherpe normen zij verwezen naar de dissertatie vain Barendrecht.

194 Zie hiervoor, paragraaf 4.4 .

195 VV, Parlementaire Geschiedenis, Inv. 3, 5 en 6, pag. 1583.

196. MvA, Parlementaire Geschiedenis, Inv. 3, 5 en 6, pag. 1585-1586. 
In de oorspronkelijke versies van artikel 6:233 sub a BW - eerst artikel $6.5,2 A .2$, lid 2 , sub a ontwerp NBW en vervolgens, na de tweede Nota van Wijziging, artikel 6.5.2A.2a sub a ontwerp NBW - was een beding in algemene voorwaarden dat deel uit maakte van een overeenkomst vernietigbaar:

windien diandoar word afgeweken van de mechisgevolgen die de overeenkonst zonder dat beding zou hebben gehad, op een wije die, gelet op de aard an de overige inhoud wan de overeenkomist, de

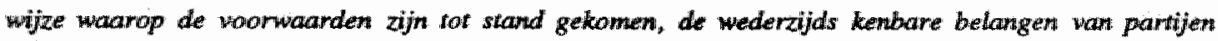
en de overige omstandigheden van het geval, onredelijk becwarend is woor de wedenparij. wit7

Doordat de Tweede Kamer het amendement van het Kamerlid Korthals overnam, ontstond de huidige versie van artikel 6:233 sub a BW. ${ }^{198}$ De oorspronkelijke tekst blijft echter zijn betekenis behouden. Het amendement Korthals was immers niet op een verandering van de daarin opgesloten toetsnorm gericht doch slechts op de creatie van de mogelijkheid dat ook bedingen die in overeenstemming zijn met bepalingen van dwingend of van regelend recht, vernietigd kunnen worden op grond van het bepaalde in artikel 6:233 sub a BW. ${ }^{199}$ Ook voor het huidige artikel 6:233 sub a BW geldt derhalve dat vernietigbaar zijn:

"... bedingen die, kort gezegd, op voor de wederpartij anredelijk bezwarende wijze affwijken wan hetgeen anders - namelijk indiew het beding er miet zou zijim-krachrens de owereenkomst zou hebben gegoldert. 2000

De uitgangspunten van de vernietigbaarheid van artikel 6:233 sub a BW worden verder als volgt (door mij aan de huidige situatie aangepast voor wat betreft de artikelnummering) toegelicht:

"De vemietigbatarheid betreft bedingen waardoor wordit afgeweken van de rechisgevolgen die de overeenkomst zonder die bedingen zou hebben gehad. Met deze formulering wordi gerefereerd aan arikel 6:248, lid $1 \mathrm{BW}$ (inhowdelijk overeenstemmende met artikel 1375 OBW), bepalende dat een overeenkoms niet alleen de door partijen overeengekomen rechisgevalgen theeft, matar ook die welke, mas de aard wan de overeenkomst, wit de wet, de gewoonte of de eisen wan redelijkheid en billikhetd woortwheten. Van vernietigbaarheid kan derhalve geen sprake zijn, indien het beding overechustemi met hergeen wit het woor de onderhavige overeankomst geldende weatelijke recht of gewoonterecht, of bij gebreke wan dien wit de redelijhheid en billijkheid zou voortwloeien. Levert het

197 OvW, Parlementaire Geschiedenis, Inv. 3, 5 en 6, pag. 1579. De zinsnede "de wijze warop de voorwaarden zijn tot stand gekomen," is bij de twcede Nota wan Wijziging ingevoegd. NwW, Parlementaire Geschiedenis, Inv. 3, 5 en 6, pag. 1597-1598.

198 Tweede Kamer, wergaderjaar 1984-1985, 16 983, nr. 30; Parlementaire Gegehiedenis, Inv. 3, 5 en 6, pag. 1598; Handelingen Tweede Kamer, vergaderjaar 1984-1985, pag. 4825; Parlementajre Geschiedenis, Inv. 3, 5 en 6, pag. 1599.

199 Tweede Kamer, vergadlerjaar 1984-1985, 16983 , nu. 30, Parlementaire Geschiedenis, Inv. 3, 5 en 6, pag. 1598-1599; MWA I, Parlementaire Geschiedenis, Inv. 3, 5 en 6, pag. 1622.

$200 \mathrm{MvT}_{\text {, }}$ Parlementaine Geschiedenis, Inv. 3, 5 en 6, pag. 1579. 
beding wel een afwijking op, dan kan het vemietigboar ajin, mits aok acon de hilema te besprehem veretsten - met name het wereiste dat de afiwijking onnedelijk bezwarend woor de wederpartij is - it woldown. Opmerking vendient hierbij dat, woor zover het beding in strijd is wer dwingend rech, deze nadere vereisten uiteraard geen aftrewt doen aan eventwelle gronden woor nietigheid of vermiethig-

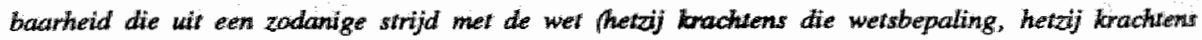
artiket 3:40 BW) woiorthomen."

(...) "Het spreekt vanzelf dat niet elke afwijking van het regelend recht of wan hetgeen krachiens redelijheid en billijkheid zou hebben gegolden, tot vemierigbaarheid mag leiden. Een zodange opwoting, die zou neerkomen op een verbod wan algemene voorwarden als middel om aw contractuele verhoudingen vorm te geven, is niet in overeenstemming met de nutrige functie wan algemene voorwairden." (...) "Echter kan ook niet elke gfwijking toegelaten worden geoondeeld, gelet op enerzijds het gemak waarmee deze voorwarden met het oog op de behoefte wan de gebrwikers daarvan aan de wederparij kunnew worden opgedrongen, en anderzijs de functie wan het regelend recht woarin watk naar het woord van P. Scholten (Algemeen Deel, P. 22) "het strewen naar gerechrigheid domineent bowen dat maar rechtszekerheid". Deze afweging heeft geleut tot de maatstaf dat de bestreden bedingen nies onredelijk bezwarend mogen zijn voor die wederpamij. warbij mol worden gelet op de aard en de overige inhowd van die overeenkomst, de wederajids kenbare belangen van partijen en de overige omstandighuden wan het geval" "

Expliciet uitgangspunt van de inhoudstoets van bedingen aan de open norm zijn derhalve de rechtsgevolgen die de overeenkomst op grond van de partijafspraak zonder de betreffende bedingen zou hebben gehad. De rechtstoestand zoals die voortvloeit uit de door partijen overeengekomen rechtsgevolgen en artikel 6:248 lid $1 \mathrm{BW}$.

De vraag die zich dan onmiddellijk opdringt is, wat bedoeld wordt met "overeenkomst". Is dit de "romp"-overeenkomst bestaande uit de essentialia of is dit de "romp"'- overeenkomst samen met de algemene voorwaarden. De parlementaire geschiedenis is daar niet echt duidelijk over. Het ligt echter voor de hand dat de "romp"-overeenkomst samen met de algemene voorwaarden wordt bedoeld. De open norm toets richt zich immers in beginsel op slechts eén beding, dat mede beoordeeld moeten worden aan de hand van de aard en de overige inhoud van de overeenkomst. De aard van de overeenkomst ligt besloten in de "romp" -overeenkomst. De overige inhoud van de overeenkomst duidt daarbij op alle - dus ook algemene - contractvoorwaarden, behalve het aan de toetsing onderworpen beding. Het ter beoordeling staande beding moet dan ook in onderling verband met de rest van de (ook algemene) contractvoorwaarden worden beoordeeld. Het uitgangspunt van de inhoudstoetsing is derhalve de rechtstoestand zoals die zou zijn zonder het bestreden beding, maar met in beginsel alle overige algemene voorwaarden. In beginsel, omdat daarbij dient te worden aangetekend dat wel rekening moet worden gehouden met het feit dat die andere bedingen een zelfde inhoud kunnen hebben als het bestreden beding. Uiteraard dient dan getoetst te worden aan de rechtsgevolgen die de "overeenkomst" ook zonder deze identieke bedingen heeft. Bij voorbeeld: Indien in twee bedingen de aansprakelijkheid van de gebruiker voor eigen schuld wordt 
uitgesloten en de overige bedingen de aansprakelijkheid niet regarderen, is het uitgangspunt van de toetsing de rechtstoestand die zou gelden zonder beide bedingen. Een andere opvatting zou tot de conclusie leiden dat voor de inhoudstoetsing van de beide afzonderlijke bedingen geen plaats is omdat zij, afzonderlijk bezien, geen andere rechtsgevolgen bewerkstelligen dan die welke zonder hen zouden hebben gegolden.

Ter beoordeling van de rechter staat dus op de eerste plaats de vraag of een algemene voorwaarde een rechtstoestand in het leven roept die afwijkt van de rechtstoestand zonder dat beding. Indien deze vraag ontkennend wordt beantwoord kan de rechter enkel concluderen dat het betreffende beding dus niet onredelijk bezwarend is. Pas indien de rechter tot de conclusie komt dat een beding rechtsgevolgen in het leven roept die afwijken van de rechtsgevolgen die zouden gelden zonder dat beding komt hij toe aan de vraag of de afwijking en dus de inhoud van het beding onredelijk bezwarend is voor de wederpartij.

\section{Algemene voorwaarden die overeenstemmen met een wettelijke bepaling}

Zoals reeds eerder werd opgemerkt, maakt de huidige versie van de open norm van artikel 6:233 sub a BW geen uitzondering voor bedingen die in overeenstemming zijn met bepalingen van regelend of dwingend recht. Doorgaans zullen bedingen die in overeenstemming zijn met wetsbepalingen niet onredelijk bezwarend zijn, om de eenvoudige reden dat zij geen ander rechtsgevolg bewerkstelligen dan zonder dit beding ook zou zijn bewerkstelligd. In een concreet geval is het echter zeer wel mogelijk dat een beding dat een bepaling van regelend of dwingend recht bevat, zelfs indien deze bepaling letterlijk is overgenomen, onredelijk bezwarend is jegens de wederpartij en daardoor dus vernietigbaar op grond van het bepaalde in artikel 6:233 sub a BW. ${ }^{201}$

In het stelsel van het oorspronkelijk ontwerp zou, volgens de parlementaire geschiedenis, in zulk een geval een beroep moeten worden gedaan op artikel 6:248 lid 2 BW. De gedachte daarbij was de volgende:

"lemand kan zich soms in verband met de goede troww of de redelijkheid en billijkhieid niet beroepen op en wettelijke bepaling en dus ook niet op een beding dat in overeenstemming is met die wertelijke bepaling. "2002

20ll MvA I, Parlementaire Geschiedenis, Inv, 3, 5 en 6, pag. 1622; UCV II, Parlementaire Geschiedenis, Inv. 3, 5 en 6, pag. 1598-1599.

202 UCV II, Parlementaire Geschiedenis, Inv, 3, 5 en 6, pag. 1599. 
De wederpartij zou moeten terugvallen op artikel 6:248 lid $2 \mathrm{BW}$ omdat in het oorspronkelijke ontwerp een beding immers eerst vernietigbaar was indien daardoor wordt afgeweken van de rechtsgevolgen die de overeenkomst zonder dat beding zou hebben gehad ${ }^{203}$.

Deze zinsnede is echter, als gevolg van overname door de Tweede Kamer van het amendement van het kamerlid Korthals ${ }^{204}$, samen met de zinsnede, "op een wijze die" vervangen door "het". Daardoor staat vast dat artikel 6:233 sub a $\mathrm{BW}$ in zijn huidige vorm mede ziet op een mogelijke vernietiging van bedingen die overeenstemmen met bepalingen van dwingend of regelend recht. $^{205}$

Het verschil tussen het stelsel van het oorspronkelijk ontwerp en het huidige is voornamelijk rechtstheoretisch van aard. Een beroep op artikel 6:248 lid 2 BW kan leiden tot het rechtsgevolg dat een beding in de concrete omstandigheden van het geval niet van toepassing is, terwijl een beroep op artikel 6:233 sub a $\mathrm{BW}$ daarentegen mogelijk leidt tot een vernietiging van het betreffende beding omdat het onredelijk bezwarend is voor de wederpartij. In beide gevallen is het gevolg uiteindelijk hetzelfde: het beding bindt de wederpartij in het concrete geval niet. Het verschil heeft voor wat betreft de rechtsgevolgen dan ook nauwelijks praktische waarde. ${ }^{206}$ Vandaar ook dat raadadviseur Hartkamp en de Minister tot de conclusie kwamen:

"Tegen de wijziging bestaat geen bezwaar, zij is alleen niet echt nodig. "207

Het komt mij echter voor dat slechts zeer zelden een beding dat in overeenstemming is met een wettelijke bepaling onredelijk bezwarend zal zijn. Men mag toch gevoeglijk aannemen dat een beding dat in overeenstemming is met een wettelijke bepaling slechts bij hoge uitzondering, in een zeer concreet geval en onder de specifieke omstandigheden van dat geval, onredelijk zal uitpakken voor de wederpartij. In het algemeen, en daar zien algemene voorwaarden naar

203 OvW, Parlementaire Geschiedenis, Inv, 3,5 cn 6, pag. 1579.

204 Twede Kamer, vengaderjaar 1984-1985, 16983 , nr. 30; Parlementaire Geschiedenis, Inv. 3, 5 en 6, pag. 1598; Handelingen Tweede Kamer, vergaderjanr 1984-1985, pag. 4825; Parlementaire Gesehiedenis, Inv. 3,5 en 6, pag. 1599.

205 Natr mijn mening bevatte de oorspronkelijke bepaling deze mogelijkheid ook reeds. De omstandigheden voor of bij het shiten van de overeenkomst kunnen zeer well tot reehtsgevolg. hebber dat wettelijke bepalingen die niet zijn opgenomen in de partijafspraken, op grond van de redelijkheid of billijkheid buiten toepassing dienen te blijwen. In die zin was een afwijkend mechtsgevolg als vereist in de compronkelijke versie zeker mogelijk. De wijziging wss mijns inziens dan ook overbodig.

206 Verhoeven $^{*}$ pag. 56.

207 UCV II, Parlementaire Geschiedenis, Inv. 3, 5 en 6, pag. 1599; MvA I, Parlernentain Geschiedienis, , Inv, 3, 5 en 6, pag. 1622, 
hun aard op, zal zulk een beding de toets van artikel 6:233 sub a BW gemakkelijk kunnen doorstaan en dus niet onredelijk bezwarend zijn.

Uitgaande van deze algemene werking, waar naar hun aard zowel algemene voorwaarden als wettelijke regelingen op zien, lijkt mij een contractuele regel die een weergave is van een dwingende wettelijke bepaling per definitie niet onredelijk bezwarend. Aan het buiten toepassing laten van een dwingende wetsbepaling is dan enkel behoefte in uitzonderingsgevallen. Daartoe is de toets aan de redelijkheid en billijkheid zoals neergelegd in artikel 6:248 lid 2 BW een geschikter instrument dan de toets van de open norm van artikel 6:233 sub a BW.

Het past naar mijn mening ook veel logischer in het systeem van afdeling 6.5.3 BW om bedingen die dwingende wetsbepalingen bevatten te toetsen aan artikel 6:248 lid 2 BW. Een beding in algemene voorwaarden kan immers alleen onredelijk bezwarend zijn, indien het afwijkt van de rechtsgevolgen die de overeenkomst zonder dat beding zou hebben gehad. Een beding dat een wetsbepaling van dwingend recht bevat zal echter welhaast nooit bewerkstelligen dat daardoor rechtsgevolgen ontstaan die afwijken van de rechtsgevolgen die de overeenkomst zonder dat beding zou hebben gehad. Dit om de simpele reden dat de wettelijke bepaling als contractregel (artikel 6:248 lid 1 BW) in de plaats komt van de identieke partijafspraak, indien deze laatste wordt weggedacht. Als het beding er niet zou zijn (overigens ook indien dat wel het geval is) geldt de identieke wettelijke bepaling. Slechts in concrete uitzonderingsgevallen is het mogelijk dat de beperkende werking van de redelijkheid en billijkheid (6:248 lid 2 BW) meebrengt dat een dwingende wetsbepaling buiten toepassing dient te blijven. ${ }^{208}$ Alleen in die uitzonderlijke gevallen bewerkstelligt een beding, dat een dwingende wetsbepaling weergeeft, een afwijking van de rechtsgevolgen van die welke zonder het beding zouden hebben gegolden.

De mogelijkheid bestaat dus dat een beding dat een dwingende wetsbepaling weergeeft, vanwege de afwijking in de rechtsgevolgen ten opzichte van wat zonder het beding gegolden zou hebben, onredelijk bezwarend is. Indien de rechter echter in het gegeven geval geconstateerd heeft dat de wettelijke bepaling, gemeten naar maatstaven van redelijkheid en billijkheid, buiten toepassing dient te blijven, staat daarmee tegelijkertijd vast, dat ook het beding dat een weergave is van die bepaling buiten toepassing dient te blijven op grond van die zelfde redelijkheid en billijkheid. In dat licht is het vanuit praktisch oogpunt bezien overbodig om het beding daarna nog eens aan artikel 6:233 sub a BW te toetsen op zijn onredelijk bezwarendheid. Wetssystematisch moet dit echter wel. Artikel 6:233 sub a BW is voor het door haar bestreken gebied immers een lex

208. Bijl hoge uitzondering kan ook de gewoonte afbreuk doen man een dwingende wetsbepaling. HR 3 mairt 1972, NJ 1973, 339, m.nt. H.B. (La Confiance/Maring). 
specialis ten opzichte van artikel 6:248 lid 2 BW. ${ }^{209}$ Een beding in algemene voorwaarden dat een letterlijke weergave is van een (dwingende) wettelijke bepaling die de toets aan artikel 6:248 lid 2 BW niet kan doorstaan is derhalve onredelijk bezwarend op grond van artikel 6:233 sub a BW en daarmee vernietigbaar.

Ook bij een beding dat een weergave is van een regelende wetsbepaling dient allereerst te worden nagegaan of het beding andere rechtsgevolgen doet ontstaan dan zonder dat beding zouden hebben gegolden. Het karakter van het dispositieve recht is echter vrijblijvender dan dat van het dwingende recht. In tegenstelling tot het regelend recht stoelt dwingend recht, zoals Paul Scholten het verwoordde, op

"(...) een watrdering en een op grond dier waardering stewnende gezagsuitoefening. In het awanvullende recht zijn beide er ook, doch zij verschillen: de watardering is zwakker, de gezagswitoefening van andere aurd dam bij het dwingende. Ook de wetgever (...) achr de toeshand die bij zulk een regeling onistwat, in het algemeen te verkiezen. Hij is zich echter bewust, diat de omstandigheden van die aard kunnen zijn, dat zijn oordeel miet meer juist is, hij laat daarom afwijking toe. m210

Een beding dat een regel van regelend recht weergeeft zal naar mijn mening desalniettemin slechts zelden bewerkstelligen dat er een wijziging in de rechtsgevolgen ontstaat ten opzichte van de situatie zonder het beding. Algemene voorwaarden zien naar hun aard immers, net als deze wettelijke bepalingen, op de "doorsnee" wederpartijen en de "doorsnee" omstandigheden bij een bepaald soort overeenkomsten. Zij zijn niet gericht op én individuele wederpartij maar gericht op de kring van gerechtigden waarvan de wederpartij deel uitmaakt. ${ }^{211}$ Een wetsbepaling van regelend recht geeft vaak een wettelijke voorkeur aan voor deze "doorsnee" situatie en zou bij gebreke van het betreffende beding, daarvoor in de plaats komen. In die gevallen ontstaan door het beding geen andere rechtsgevolgen dan mét het beding. Slechts indien de gewoonte of de redelijkheid en billijkheid derogeren aan de wetsbepaling van regelend recht, is het mogelijk dat het beding dat een weergave is van deze wetsbepaling andere rechtsgevolgen in het leven roept dan zonder dat beding zouden hebben gegolden. Het is derhalve niet uitgesloten dat een beding dat een weergave is van een regelende wetsbepaling onredelijk bezwarend is.

Daarbij dient te worden aangetekend dat regelende wetsbepalingen een verschillend karakter kunnen hebben. Er kan een onderscheid worden gemaakt

209 Zie over de verhouding tussen de open nom vam artikel 6.233 sub a BW en de beperkende werking van artikel 6:248 lid 2 BW hiema onder het kopje Lex specialis ten opaichte van antkel 6:248 II 2 BW. Zie ook: Rijken, Redelijkheid en billijkheid, pag. 60-63.

210 Asser-Scholten, 1974 , pag, 21 .

211 Jongeneel, diss, pag. 188. 
tussen enerzijds regels die naar hun aard slechts een ordeningsdoel hebben en anderzijds regels met een meer normerend karakter. ${ }^{212}$ De eerste regels zijn gebaseerd op zuiver pragmatische overwegingen en de laatste regels geven een op rechtvaardigheidsoverwegingen gebaseerde wettelijke voorkeur. Als vuistregel kan gehanteerd worden, hoe meer een dispositiewe wetsbepaling een ordeningsfunktie heeft, hoe groter de kans dat de gewoonte of de redelijkheid en billikheid daaraan derogeren.

In de zeldzame gevallen dat de rechter op grond van artikell 6:248 BW well tot de conclusie komt dat de gewoonte of de redelijkheid en billijkheid een ander rechtsgevolg meebrengt dan de wetsbepaling van regelend recht en dus ook het beding dat een identieke inhoud heeft, is het, zoals reeds eerder gezegd, ailt praktisch oogpunt vervolgens overbodig om nog eens de onredelijk bezwarendheid van dit beding te toetsen aan de open norm. Deze staat dan immers vast. Artikel 6:233 sub a $\mathrm{BW}$ is immers een specialis van artikel $6: 248$ lid 2 BW.

Zowel bij bedingen die een wetsbepaling van dwingend recht weergeven als bij bedingen die een wetsbepaling van regelend recht weergeven is, mijns inziens, de toets aan de open norm van artikel 6:233 sub a $\mathrm{BW}$ overbodig. De rechter moet bij de inhoudstoets van dergelijke bedingen immers altijd eerst vaststellen of de wettelijke regeling waarvan het beding een weergave is, in de gegeven omstandigheden op grond van artikel 6:248 BW buiten toepassing dient te blijwen. Praktisch gezien is de uit wetssystematisch oogpunt vereiste extra stap naar een vernietigbaarheid op grond van artikel 6:233 sub a BW echter niet al te bezwaarlijk. Voor de wederpartij zal het niet uitmaken of het beding vernietigd wordt of buiten toepassing wordt verklaard. Er kleven slechts twee nadelen aan deze extra stap. Ten eerste, dat er qua toepasselijke wettelijke bepaling onderscheid wordt gemaakt tussen gebruikers die wél en die niet een dusdanig beding hebben opgenomen in hun overeenkomst terwijl het resultaat hetzelfde is. Ten tweede, dat de beperkende werking van de redelijkheid en billijkheid van artikel $6: 248$ lid $2 \mathrm{BW}$ in beginsel ambtshalve dient te worden toegepast door de rechter $^{213}$, hetgeen hij bij de toepassing van artikel $6: 233$ sub a $\mathrm{BW}$ niet doet. Artikel 6:233 sub a betreft immers een vernietigbaarheid. Dit laatste verschil maakt dat, vanuit het perspectief van de wederpartij, toepasselijkheid van artikel $6: 248$ lid $2 \mathrm{BW}$ in plaats van artikel $6: 233$ sub a dus gunstiger zou zijn.

212 Asser-Scholten, 1974, pag. 21; Hondius, preadviea NJV, pag. 164; Jongeneel, diss. "pag. 190. 213 Rijken, Redlelijkheid en billijkheid, pag. 47-48. 
De formulering van de maatstaf van artikel $6: 233$ sub a BW moet duidelihk maken dat het een concrete inhoudstoets betreft, dit in afwijking van de toetsing door de bijzondere rechter in de ge- en verbodsprocedure van artikel 6:240 BW e.v.. De toetsnorm van artikel 6:233 sub a BW is concreet omdat deze allijid gericht is op bedingen in concrete contracturele relaties. Op bedingen dus die werkelijk zijn opgenomen in een concrete overeenkomst. Dit in tegenstelling tot de abstracte toets van artikel $6: 240 \mathrm{BW}$ waarbij wordt getoetst onafhankelijk vain de vraag of het beding reeds is opgenomen in een concrete overeenkomst en met het oog op het gebruik van het beding in het algemeen.

Het concrete karakter van de toetsnorm van artikel 6:233 sub a BW brengt met zich dat de rechter op zoek naar een antwoord op de vraag of een beding onredelijk bezwarend is, in zijn afweging moet betrekken de aard en de overige inhoud van de concrete overeenkomst, de belangen van partijen voorzover deze wederzijds voor hen kenbaar zijn en de andere omstandigheden van het geval. ${ }^{214}$ De rechter moet dus een antwoord vinden op de vraag of in het concrete geval de afwijking in rechtsgevolgen van die welke zouden gelden indien het: beding niet zou zijn opgenomen, voor de wederpartij onredelijk bezwarend is en daarmee vernietigbaar.

\section{Lex specialis ten opzichte van artikel 6:248 lid $2 \mathrm{BW}$}

De toetsnorm van artikel 6:233 sub a BW moet voor het door haar bestreken gebied worden gezien als een specialis van de redelijkheid en billijkheid van de artikellen 6:2 BW en 6:248 BW. ${ }^{215}$ Op het door haar bestreken gebied derogeert artikel 6:233 sub a BW daarom aan de redelijkheid en billijkheid van artikel $6: 248 \mathrm{BW}{ }^{216}$ Wat betreft de inhoud van de toetsnorm is er geen verschil tussen artikel 6:233 sub a BW en artikel 6:248 lid 2 BW. De open norm is derhalve niet repressiever dan de artikelen $6: 2$ lid 2 en 6:248 lid 2 BW. ${ }^{217}$

De open norm heeft in tegenstelling tot de algemene norm van artikel 6:248 lid 2 echter een andere structuur omdat deze voorziet in een bijzonder rechtsge-

214 MvT, Parlementaire Gesehiedenis, Inv. 3,5 en 6, pag. 1580.

$215 \mathrm{Zie}$ verder ower de verhouding tussen de open norm en de redelijkkheid en billijkheid vast de artikelen 6:2 lid 2 en 6:248 lid 2 BW (onder andere): Wessels en Jongeneell, 1992, pag. 53-56; Verhoeven, pag. 64:68; Jongeneel, diss., pag. 147-148, 164-166 en 180-184; Asser-Hartikamp I, 1993, nr. 358; Rijken, KwNBW 1988, pag. 60; Rijken, Redelijkheid en billijklheid, pag. 6063.

$216 \mathrm{NEV}$, Parlementaire Gesehiedenis, Inv, 3, 5 en 6, pag. 1596.

217 Mva I, Parlementaine Geschiedenis, Inw. 3, 5 en 6, pag. 1620-1621. 
volg, namelijk vernietigbaarheid en bovendien meer is toegespitst op een zuivere inhoudstoetsing. ${ }^{218}$

Het feit dat de open norm een lex specialis is ten opzichte van de artikel 6:248 lid 2 BW sluit echter niet uit, dat buiten het door artikel 6:233 sub a BW bestreken terrein toetsing kan plaats vinden van algemene voorwaarden aan artikel 6:248 lid $2 \mathrm{BW}:{ }^{219}$ Enerzijds is daarbij te denken aan:

- algemene voorwaarden die de wederpartij niet kan laten toetsen aan de open norm van artikel 6:233 sub a BW omdat zij behoort tot de wederpartijen die op grond van artikel 6:235 BW geen beroep op open norm toekomt ${ }^{230}$;

- algemene voorwaarden waarop afdeling 6.5.3 niet van toepassing is omdat zij deel uitmaken van een (collectieve) arbeidsovereenkomsten (6:245 BW) of een internationale handelsovereenkomst;

- aan algemene voorwaarden waartegen de gebruiker zelf wil opkomen ${ }^{221}$.

Anderzijds valt daarbij te denken aan het gegeven dat aan de inhoudstoets van artikel 6:233 sub a BW een vernietigbaarheid is verbonden. Omdat het in casu een vernietigbaarheid betreft komen bij de toets aan de open norm in beginsel slechts die omstandigheden in aanmerking van vór of bij het sluiten van de overeenkomst. Omstandigheden die betrekking hebben op de uitvoering van de overeenkomst worden bij deze toets niet meegenomen en kunnen slechts worden meegenomen in de toets aan de redelijkheid en billijkheid van artikel 6:248 lid 2 BW. In dat licht is de zinsnede "en de overige omstandigheden van het geval" in artikel 6:233 sub a BW nogal misleidend. Immers niet alle "overige omstandigheden" spelen een rol bij de toets aan de open norm.

Bedingen die op grond van de omstandigheden van voór of bij de aanvaarding van de gelding van de betreffende algemene voorwaarden de toets aan de open norm doorstaan, kunnen op grond van omstandigheden die zich eerst hebben voorgedaan bij de uitvoering van de overeenkomst getoetst worden aan artikel 6:248 lid 2 BW. Deze toetsing brengt dan mogelijk met zich dat het beding buiten toepassing blijft. Daarbij moet echter alleen worden gedacht aan rechtsverwerking of onvoorziene omstandigheden. ${ }^{222}$

Allén rechtsverwerking en gewijzigde omstandigheden omdat uitdrukkelijk moet worden aangetekend dat de inhoudstoets van artikel 6:233 sub a BW wel

218 NEV, Parlementaire Geschiedenis, Inv. 3, 5 en 6, pag. 1595-1596.

219 Zie voor een overzicht: Rijken, Redelijkheid en billijkheid, pag. 61-62.

220 MvA 1, Parlementaire Geschiedenis, Inv. 3, 5 en 6, pag. 1621. Tot deze groep behoren volgens de memorie wan antwoond eveneens kembedingen en mondelinge bedingen die meerdere malen gebruikt worden. Zie: MvA, Parlementaire Geschiedenis, Inw, 3, 5 en 6, pag. 1621. Dit is echter onjuist, deze bedingen zijin immers geen algemeno yoorwaarden en daarom is de open norm daarop dus niet van toepassing. De toetsing van deze bedingen arn artikel 6:248 lid $2 \mathrm{BW}$ betreft dan ook niet de toetsing van algemene voorwasirden.

221 Rijken, Redelijkheid en billijkheid, pag. 61.

222 MvA I, Parlementaire Geschiedenis, Inv. 3, 5 en 6, pag. 1621-1622. 
degelijk ook betrekking heeft op rechtsgevolgen - niet te verwarren met omstandigheden - die in de overeenkomst worden verbonden aan gebeurtenissen die zich pas na het sluiten van de overeenkomst voordoen. Dit is bij algemene voorwaarden immers meestal het geval. ${ }^{23}$ Deze, eventueel onredelijk bezwarende, gevolgen worden immers reeds vooraf in de algemene voorwaarden geregeld en treden pas in op grond van omstandigheden die zich eerst na het sluiten van de overeenkomst manifesteren. De inhoud van bedingen ziet expliciet op deze rechtsgevolgen én deze omstandigheden. In die zin is de inhoud van een beding altijd een omstandigheid van vớr het sluiten van de overeenkomst die zich echter richt op de situatie ná het sluiten van de overeenkomst. Tijdens de behandeling in de Eerste Kamer werd dit als volgt verwoord (door mij aangepast aan de huidige artikelnummering):

"Dat deze gedraging of andere gebeurtenis na het sluiten wan de owereenkomst plaats grijpt" neemst immers niet weg dat de overeenkomst daaromirent bedingen bevat die op hum redelijkheid kunnem worden getoetst. De artikelen 6:248 lid 2 en 6.258 komen dus pas in het spel wanneer het gaal am de wrag welke invloed het door partijen overeengekomene ondervindt van nadien plactsvindende gebeurtemissen die niet in de overeenkomst zijn geregeld of verdisconteerd. "224

Een voorbeeld van zulk een toetsing van de inhoud van een beding aan de rechtsgevolgen die zijn verbonden aan gebeurtenissen die zich voor doen ná het sluiten van de overeenkomst, is te vinden in het arrest van de Hoge Raad van 23 maart 1990. ${ }^{225}$ Daarin overwoog de Hoge Raad immers dat de verbindendheid van een beding niet dient te worden beoordeeld aan de hand van de nadelen die zich daadwerkelijk hebben verwezenlijkt bij de uitvoering van de overeenkomst, maar aan de hand van de eventueel onredelijk bezwarende gevolgen waaraan het beding, bij gebondenheid daaraan, de wederpartij van meet af aan blootstelde. Daaronder worden ook begrepen de nadelen waarvan de verwezenlijking bij handhaving van het beding slechts "mogelijk" was. ${ }^{226}$

Voor de inhoudstoets van algemene voorwaarden op grond van artikel 6:233 sub a BW brengt een en ander met zich dat alle mogelijke omstandigheden bij de uitvoering van de overeenkomst waaraan het beding rechtsgevolgen verbindt - met andere woorden alle mogelijke omstandigheden waarin een beroep op het beding kan worden gedaan - meewegen bij de beoordeling van het betreffende beding. ${ }^{227}$ Of deze omstandigheden zich bij de uitvoering van de overeenkomst

223 MvA I, Parlementaïre Geschiedenis, Inv, 3, 5 en 6, pag. 1622.

224 MvA I, Parlementaire Geschiedenis, inw. 3, 5 en 6, pag. 1622.

225 HR 23 maart 1990, NJ 1991, 214, m.nt. H.J.S. (Botman/Van Hagster). Geannoteerd door W.J.G. Oosterveen en E.H. Hondius in respectievelijh Bb 1990, pag. 113-115 en KwNBW 1990 , pag. 130.132.

226 Zie r.o. 3.4, wan het betreffende arrest.

227 Asser-Hartkamp 11, 1993, nr. 358; Rijken, Redelijkheid en billijkheid, pag. 62-63. 
vervolgens werkelijk hebben voorgedaan of dat er tijdens de uitvoering van de overeenkomst door de gebruiker een beroep op het beding wordt gedaan is niet relevant voor deze toets.

Omdat alle omstandigheden bij de uitvoering van de overeenkomst waarop het bestreden beding ziet, mee worden gewogen in de open norm van artikel 6:233 sub a BW is de rol van artikel 6:248 lid 2 BW beperkt tot de omstandigheden die zich voordoen na het sluiten van de overeenkomst én waaraan het betreffende beding geen rechtsgevolgen verbindt. ${ }^{23}$ Met andere woorden in geval van algemene voorwaarden die onder de toetsing van artikel 6:233 sub a BW vallen, is de toetsing aan de redelijkheid en billijkheid van artikel 6:248 lid 2 BW beperkt tot gevallen van rechtsverwerking en onvoorziene omstandigheden. ${ }^{220}$

Een algemene voorwaarde is op grond van de open norm vernietigbaar indien het beding op een onredelijk bezwarende wijze afwijkt van de rechtsgevolgen die de overeenkomst zonder dat beding zou hebben gehad. Uitgangspunt daarbij is dat in beginsel partijen alles kunnen overeenkomen, mits zij daarbij maar blijven binnen de grenzen die de wet stelt.

Indien daarbij wordt afgeweken van een dwingende wetsbepaling komt men in beginsel niet toe aan de toets van artikel 6:233 sub a BW. ${ }^{230}$ Het beding is immers in strijd met de wet en nietig of vernietigbaar op grond van het bepaalde in artikel 3:40 lid $2 \mathrm{BW}$. Volgens de MvT doen de nadere vereisten van artikel $6: 233$ sub a BW dan ook

*... geen afbrewk acu eventuele gronden voor nietigheid of vernietigbatarheid" die uit een zodanige strijid met de wet (hetzij krachtens die wetsbepaling, hetzij krachens artikel 3.2.7) voortkowern. 231

228 Asser-Hartkamp II, 1993, nr. 358; Rijken, Redelijkheid en billijkheid, pag. 62.

229 Asser-Hartkamp 11, 1993, nr. 358; Rijken, Redellijkheid en billijkheid, pag. 62. Anders: Wessels en Jongeneel, 1992, pag. 55; Jongeneel, dist., pag. $164-166$ en 180-184 die in hun twee-fasen-toetsing meer ruimte zien voor een toetsing an de redeljikheid on billijkheid van artikkel 6:248 lid 2 BW. Pertinent onjuist is mijns inziens de opvatting van Heisterikamp dat men is wangewezen op artikel 6:248 lid 2 BW indien men zich (mede) will beroepen op omstandigheden die ziveh eerst voordoen na het slutiten van de overeenkomst of de omstandighedlen waronder het beding in concrelto wordt ingeroepen zoals de zwaarte van de schuld (zie: Heisterkamp, pag. 167). Indien een beroep op een beding bij bepaalde vormen van schuld immers is toegelaten dan ziet dit beding van meet af aan ook op die worm van schuid en verbindt daar ook rechtsgevolgen aan. Dit is dan ook een omstandigheid die zich weliswar eerst conereet voondoet bij de uitvoering van de overesenkomst maar welke wel verdisconteend is in het beding. Deze omstandigheid dient dan ook te worden meegewogen in de open norm toets van artikel $6: 233$ sub a BW.

230 Zive voor voorbeelden van algemene voorwaarden die in strijd zijn met dwingend recht: Jongeneel, diss., pag. 147.

231 MvT, Parlementaüre Geschiedenis, Inw, 3, 5 en 6, pag. 1579-1580. 
Bepalingen van dwingend recht prevaleren in die zin boven afdeling 6.5.3 $\mathrm{BW}$; dat de toetsing an de normen van die afdeling niet meer aan de orde komt ${ }^{232}$. Hetzelfde geldt indien de inhoud van een beding nietig is wegens strijd met de goede zeden of de openbare orde (artikel 3:40 lid $1 \mathrm{BW}$ ) of indien de nietigheid of vernietigbaarheid voortvloeit uit andere dwingende wetsbepalingen zoals die van artikel 3:39 BW (rechtshandeling die afwijkt van de wettelijk voorgeschreven vorm) of de willsgebreken van de artikelen 3:44 BW (bedreiging, bedrog en misbruik van omstandigheden) en 6:228 BW (dwaling). ${ }^{233}$ Let wel! De hiervoor genoemde wetsbepalingen inzake de totstandkoming zijn, net als de artikelen 6:248 en 6:258 BW van dwingend recht. ${ }^{234}$ Indien in algemene voorwaarden wordt afgeweken van deze wetsbepalingen, bij voorbeeld een beding dat een beroep op dwaling uitsluit, zijn deze uiteraard nietig op grond van artikel 3:40 lid 2 BW.

Afwijking van het regelende recht is in beginsel toegestaan. Contractsvrijheid staat voorop. Een andere opvatting zou het gebruik van algemene voorwaarden praktisch onmogelijk maken. Contractsvrijheid is immers het primaire vereiste voor de existentie van algemene voorwaarden. Hiermee wordt tevens een nadere begrenzing gegeven van de toets aan de open norm. De toets van artikel 6:233 sub a BW ziet naar haar aard slechts op die gebieden waar contractsvrijheid heerst. Dat betekent dat slechts bedingen die qua inhoud afwijken van het regelend recht, onderwerp kunnen zijn van de inhoudstoets op grond van artikel 6:233 sub a BW. Bij bedingen met een inhoud in strijd met dwingende rechtsregels, de openbare orde of de goede zeden derogeert artikel 3:40 BW immers aan artikel 6:233 sub a BW.

Aan de contractsvrijheid van partijen zijn echter grenzen gesteld. Niet elke afwijking van het regelende recht is toelaatbaar. Voor wat betreft algemene voorwaarden zijn slechts afwijkingen toegestaan die niet onredelijk bezwarend zijn voor de wederpartij. De aard van dispositieve bepaling waarvan wordt afgeweken speelt bij de beoordeling van die onredelijk bezwarendheid jegens de wederpartij een duidelijke rol en is "... een nuttige hulpmaatstaf bij de beoordeling van algemene voorwaarden". ${ }^{235}$ Daarbij dient een onderscheid te worden gemaakt tussen enerzijds regels die naar hun aard slechts een ordeningsdoel hebben en anderzijds regels met een meer normerend karakter. Bij orderegels kiest de overheid voor een pragmatische oplossing die niet is ingegeven door enige rechtvaardigheidsoverweging. Voorbeelden van zulke orderegels zijn de

232 MvA, Perlementaire Geschiedenis, Inv, 3, 5 en 6, pag. 1462.

233 MvA, Parlementaine Geschiedenis, Inv. 3, 5 en 6, 6 , 1620. Zie meer uitgebreid: Jongeneel, diss. , pag. 146-150.

234 Asser-Hartkamp II, 1993 , nr. 246.

235 Hondius, preadvies NJV, pag. 164. Zie ook: Jongeneel, diss., pag. 189-191. 
artikelen 6:41 en 6:116 BW. ${ }^{236}$ Daar tegenover staan dispositieve wetsbepalingen waaruit een duidelijke waardering van de wetgever spreekt over hetgeen vanuit rechtvaardigheidsoogpunt de voorkeur verdient. Bij voorbeeld de regel van artikel 6:74 BW waaruit een duidelijke rechtvaardigheidsoverweging biijkt. ${ }^{237}$ Vanuit dit onderscheid bezien, herbergt ons regelend recht een groot scala aan mogelijkheden. Het bevat strikte ordeningsregels, duidelijke normeringsregels en alles wat daar tussenin zit. Een duidelijke afbakening is niet te maken. Per wetsbepaling zal bekeken moeten worden welk karakter deze heeft. Uitgangspunt bij de inhoudstoets dient daarbij te zijn dat afwijking van orderegels minder snel onredelijk bezwarend zal zijn dan afwijking van normeringsregells. Of, zoals Jongeneel het verwoordt:

"Hoe meer een regel een "orderegel' is, hoe minder afwijking daanan in algemene voorwaarden becwarar ontmoet". 238

Zoals reeds gezegd, is een beding pas vernietigbaar indien het niet alleen de wederpartij in een nadeliger positie brengt dan zonder dat beding, het moet tevens op een onredelijke wijze benadelen. Daarbij is niet vereist dat het nadeel van de wederpartij van financiële aard is. De aard van het geleden nadeel speelt, net als in het leerstuk inzake misbruik van omstandigheden geen rol ${ }^{239} \mathrm{Zo}$ kan het nadeel evenzeer een immaterieel karakter hebben of gelegen zijn in de ongebruikelijkheid of verrassendheid van de inhoud van het betreffende beding. ${ }^{240}$

\section{De relevante omstandigheden}

Of uiteindelijk in de concrete omstandigheden van het geval sprake is van een beding dat inhoudelijk niet alleen bezwarend is voor de wederpartij, maar tevens ook onredielijk bezwarend, is overgelaten aan het oordeel van de rechter. ${ }^{241}$ Het concrete karakter van de toets brengt met zich dat de rechter in zijn afweging moet betrekken:

- de aard en de overige inhoud van de concrete overeenkomst;

236 Zie ook: Jongeneel, diss., pag. 190, noot 45.

237 Jongeneel geeft, abusievelijk narar ik aanmeen, als voorbeeid van een regeling met een tamelijk sterk gerechtigheidsaspect artikel 3:44 BW. Zie: Jongeneel, dis8., pag. 190-191, noot 45. Toegegeven moet wonden dat dit artikel een sterk normerend karakter heeft. Het is desalniettemin als voorbeld ongelukkig gekozen omdat het een dwingendrechtelijke wetsbepaling is.

Zie: Asser-Hartkamp II, 1993, nr. 246.

238 Jongeneel, diss., pag. 190.

239 MvT, Parlementaire Geschiedenis, Inv. 3, 5 en 6, pag. 1580.

240 Verthoven, pag. 55 . Verhoeven noemt in dit kader als voorbeeld bezwarende huurbedingen.

241 MvT, Parlementaire Geschiedenis, Inv. 3, 5 en 6, pag. 1580. 
- de belangen van partijen voorzover deze wederzijds voor hen kenbaar zijn;

- alle andere omstandigheden van het geval. Aldus de in de oorspronkelijk voorziene tekst van artikel 6:233 sub a BW genoemde omstandigheden. ${ }^{242}$

Op aandringen van de vaste Commissie voor Justitie ${ }^{243}$ werd daar in de tweede Nota van wijziging aan toegevoegd "de wijze waarop de voorwaarden tot stand zijn gekomen".

Op welke wijze de aard van de overeenkomst een rol speelt wordt in de parlementaire geschiedenis niet nader toegelicht. Bij de aard van de overeenkomst moet echter vooral gedacht worden aan vragen als:

- is het een benoemde of onbenoemde overeenkomst?

- in welke branche wordt de overeenkomst gehanteerd?

- wat is het onderwerp van de overeenkomst?

- wat is aard van de verplichtingen over en weer?

- brengt de overeenkomst inspannings- of resultaatsverplichtingen met zich?

- betreft het een duurovereenkomst of niet?

- heeft de overeenkomst betrekking op goederen of diensten die tot het primaire levensonderhoud behoren?

- in hoeverre is er sprake van vrije concurrentie? ${ }^{245}$

Bij de vraag naar de aard van de overeenkomst gaat het mijns inziens om de aard van de "romp"-overeenkomst. Algemene voorwaarden spelen bij de toetsing aan deze omstandigheid geen rol.

In tegenstelling tot het toetsingscriterium de aard van de overeenkomst ziet de overige inhoud van de overeenkomst zowel op de "romp"-overeenkomst als de daarop toepasselijke algemene voorwaarden. In de parlementaire behandeling wordt dit criterium immers als volgt toegelicht:

"... zo zal onder omstandigheden de hoogte van de prijs of een voor de wederpanij uitgesproken en ongewoon gunstig beding. met name indien dit verband houdt met het bekritiseerde beding. het onredelijk bezwarend karakter wan dit laatste kunnen wegnemen. 246

Het tegenovergestelde kan mijns inziens echter ook het geval zijn. Onder omstandigheden zal de hoogte van de prijs of een voor de wederpartij ongunstig beding, met name indien dit verband houdt met het bekritiseerde beding, het

242 Antikel 6.5.2A.2 lid 2 sub a OwW, Parlementaire Geschiedenis, Inw. 3, 5 en 6, pag. 1578.

243 EV, Parlementaire Geschiedenis, Inv. 3, 5 en 6, pag. 1591.

244 NvW II, Parlementaire Geschiedenis, Inw. 3, 5 en 6, pag. 1597-1598.

245 Zie ook: Jongeneel, diss., pag. 201-202, Vertoeven, pag. 58; Wessels en Jongeneel, 1992, pag. 51

246 MvT, Parlementaire Geschiedenis, Inv. 3, 5 en 6, pag. 1580 en 1625-1626. 
niet-onredelijk bezwarend karakter van dit laatste kunnen wegnemen. Om met Jongeneel te spreken: "Als een beding nog net toelaatbaar is, kan een ander beding het ten val brengen. ${ }^{247}$

De derde uitdrukkelijk in de wet genoemde toetsingsfactor van de inhoud van algemene voorwaarden is de wijze waarop de bedingen zijn tot stand gekomen. Oorspronkelijk was deze omstandigheid niet uitdrukkelijk in de wet opgenomen maar werd zij wel, in navolging van de rechtspraak gewezen onder het oude recht, genoemd als "overige omstandigheid van het geval". ${ }^{248}$ Op aandringen van de vaste Commissie voor Justitie ${ }^{249}$ ging de Minister "gaarne akkoord" 250 met het alsnog uitdrukkelijk vermelden van deze toetsingsmaatstaf in de wet ${ }^{251}$.

De toetsingsfactor betreft de vraag door wie de algemene voorwaarden zijn opgesteld. Relevant is daarbij of de ter toetsing voorliggende algemene voorwaarden eenzijdig door de gebruiker of diens belangenorganisatie zijn opgesteld of het resultaat zijn van overleg tussen aanbiedersorganisaties en organisaties van potentiële wederpartijen. Hoe meer collectieve consensus bestaat over de toelaatbaarheid van algemene voorwaarden, hoe eerder aangenomen mag worden dat een beding niet onredelijk bezwarend is. De invloed die de overheid bij de totstandkoming van die algemene voorwaarden heeft gehad, kan daarbij ook een rol spelen. ${ }^{252}$ In deze toetsingsmaatstaf komt duidelijk naar voren dat de overheid belang hecht aan zelfregulering tussen marktpartijen.

Bij deze toetsingsfactor kunnen verder relevant zijn de omstandigheid dat in casu sprake is van nulzijdige algemene voorwaarden opgesteld door een derde en dat de algemene voorwaarden zijn goedgekeurd door de overheid of een onafhankelijke instantie of dat zij gebaseerd zijn op uitdrukkelijke richtlijnen van de overheid.

Jongeneel wijst er op dat bij tweezijdig vastgestelde algemene voorwaarden de collectieve consensus meestal ziet op de gehele set algemene voorwaarden in hun onderling verband. "De organisaties van gebruikers zijn het immers over het geheel eens geworden" en daarom mag men in geval van tweezijdige voorwaarden "eerder aannemen dat een nadeel in het ene beding wordt gecompenseerd door een ander beding". ${ }^{253}$ Dit brengt volgens hem mee dat de rechter terughoudender dient te toetsen indien hem bedingen uit zulke tweezijdig

247 Jongeneel, diss., pag, 202.

248 MvT, Parlementaire Geschiedenis, Inv. 3, 5 en 6, pag. 1519-1520.

$249 \mathrm{EV}$, Parlementaire Geschiedenis, Inv. 3, 5 en 6, pag. 1591.

$250 \mathrm{NEV}$, Parlementaire Geschiedeniss, Inv. 3, 5 en 6, pag. 1596.

$251 \mathrm{NwW}$ II, Parlementaire Geachiedenis, Inv. 3, 5 en 6, pag. 1597-1598.

252 Verhoeven, pag. 58.

253 Jongeneel, disa., pag. 203. 
vastgestelde algemene voorwaarden worden voorgelegd. Het beding moet worden bezien in het geheel van de regeling en in het verband met de andere bepalingen van die regeling. ${ }^{2.54}$

Ik kan deze visie slechts ten dele onderschrijven. Uiteraard kan ik mij vinden in het gegeven dat de consensus van de organisaties ziet op de gehele set algemene voorwaarden en het uitgangspunt dat bij toetsing van zulk een beding gekeken dient te worden naar mogelijk compenserend voordeel in andere bedingen. Dit laatste volgt echter niet uit het feit dat het tweezijdig vastgestelde algemene voorwaarden betreft; het volgt gewoon uit de wettelijke regeling. Artikel 6:233 sub a BW bepaalt immers uitdrukkelijk dat bij de inhoudelijke toetsing gekeken moet worden naar "de overige inhoud" van de overeenkomst. Ook bedingen in een- of nulzijdig vastgestelde algemene voorwaarden moeten derhalve worden getoetst in hun onderling verband.

Mijn bezwaren zijn echter vooral gericht tegen de conclusie van Jongeneel dat de rechter zich terughoudender dient op te stellen bij de toetsing van tweezijdig vastgestelde algemene voorwaarden aan artikel 6:233 sub a BW en eerder dient aan te memen dat een nadeel in een beding is gecompenseerd door een ander beding. Het feit dat sprake is van een beding in tweezijdig vastgestelde algemene voorwaarden maakt weliswaar de kans groter dat er compenserend voordeel schuilt in de andere voorwaarden, dit hoeft feitelijk echter allerminst het geval te zijn. Of er werkelijk sprake is van zulk een voordeel in het licht van de gehele overeenkomst zal de rechter derhalve feitelijk moeten vaststellen. Het compenserend voordeel is er of het is er niet, daarop heeft de herkomst van de betreffende algemene voorwaarden geen enkele invloed. In die zin kan de rechter dus niet terughoudender toetsen bij tweezijdig vastgestelde algemene voorwaarden dan bij eenzijdig vastgestelde algemene voorwaarden. Dat is mijns inziens ook niet de bedoeling van de inhoudstoets van artikel 6:233 sub a BW en er is ook geen reden voor. Ook in tweezijdig vastgestelde algemene voorwaarden kunnen zich immers, evenals in algemene voorwaarden gehanteerd door de overheid, net zo goed bedingen bevinden die onredelijk bezwarend zijn voor de wederpartij. ${ }^{2 s s}$ De aanwezigheid van deze bedingen is afhankelijk van factoren als (on)deskundigheid, onwil, onderhandelingspositie en -doel, representativiteit en gewijzigde opvattingen met betrekking tot de onredelijkheid wan een beding bij de partijen bij de onderhandelingen betrokken. Voor de toetsing van deze tweezijdig vastgestelde bedingen geldt derhalve dezelfde objectieve toetsnorm als voor alle andere algemene voorwaarden. Een andere opvatting zou leiden tot rechtsongelijkheid en de rechtszekerheid zeker niet ten goede komen.

254 Jongeneel, diss., pag. 203.

255 Zie ook: Jongeneel, diss., pag. 203; MvT, Parlementaire Geschiedenis, Inv, 3, 5 en 6, pag. 1519. 
Er is mijns inziens voor de rechter dan ook geen enkele reden om voor tweezijdig vastgestelde algemene voorwaarden een ander (terughoudender) regime te hanteren.

De herkomst van algemene voorwaarden speelt mijns inziens hoogstens een rol bij twijfell van de rechter omtrent het onredelijk bezwarende karakter van een bepaald beding. De afkomst van het beding kon dan well eens nét die factor zijn die voor de rechter de doorslag geeft. De goedkeuring van het gebruik van een beding door een representatieve organisatie van wederpartijen doet immers vermoeden dat een beding voor die wederpartijen niet op al te grote bezwaren stuit. Het blijft echter een vermoeden, de rechter zal steeds moeten nagaan of het beding ook werkelijk qua inhoud onredelijk bezwarend is voor deze wederpartij of niet. Ook bij tweezijdig vastgestelde algemene voorwaarden geldt immers dat de wederpartij zelf geen directe invloed heeft op de inhoud van die yoorwaarden en ook dat hij slechts de keuze heeft tussen het contracteren mét die algemene voorwaarden of niet. De wederpartij bij tweezijdig vastgestelde algemene voorwaarden heeft dus dezelfde beschermingsbehoefte als de wederpartij bij éen- of nulzijdig vastgestelde algemene voorwaarden. Het feit dat het beding (mede) is vastgesteld door een consumentenorganisatie of door de overheid ontslaat de rechter derhalve niet van zijn verplichting de inhoud van dat beding integraal te toetsen aan artikel 6:233 sub a BW. Niet voor niets vallen ook algemene voorwaarden gehanteerd door de overheid, waarvan men toch mag verwachten dat deze de wet volgt, onder het bereik van afdeling 6.5 .3 $\mathrm{BW}{ }^{256}$

Mede omdat de toets van artikel 6:233 sub a BW ziet op de inhoud van een beding en niet op de totstandkoming daarvan, is naar mijn mening de wijze waarop de algemene voorwaarden tot stand zijn gekomen, een omstandigheid die, ondanks het feit dat zij nadrukkelijk in de wettekst wordt genoemd, nagenoeg geen importantie heeft voor de vraag of een beding onredelijk bezwarend is. In mijn ogen volstond de oorspronkelijk voorziene wettekst en is de wijziging volstrekt overbodig en zelfs ongewenst. Ongewenst, omdat in de huidige wettekst zonder grond gesuggereerd wordt dat de afkomst van een beding invloed heeft op de onredelijk bezwarendheid daarvan en daardoor wellicht een te groot gewicht aan deze omstandigheid wordt gehecht.

Het vierde uitdrukkelijk in de wet genoemde toetscriterium is de wederzijds kenbare belangen van partijen. In de kamerstukken wordt dit criterium als volgt toegelicht:

256 Zie hierover uitgebreid: F.J. wan Ommeren, Rechterlijke toetsing van algemene voorwa:arden van de overtheid, NJB 1990, pag. 132-137. 
"Woons moet hij (de rechter, toevoeging LJHM) de betangen wan partijen in zijn afweging betrekbets, allhans woor zower deze wederzijds voor hen kenbaar zijm. $Z$ o zal bijw. een bepenking wan die bevoegutheid op de voet van artikel 6.1.10.4 (6:127 BW, toevoeging LJHM) te verrekenen medt: moeten worden bezien in het licht wan de noodzank voor de gebruiker van de algemene voorwanden om een rationele administratie te voeren, maar zal anderzijds geen rekening mogem worden gehouden met niet acan de andere partij kenbare belangen als biju de ecomomische positie of de afhankelijhheid wan voorschakels van een ondermemer, dan wel de draagkrachi of gezinsomstiandigheden was een particulier. ${ }^{257}$

Voor het meewegen van het partijbelang is dus duidelijk vereist dat dit kenbaar is voor de wederpartij. In een aantal gevallen is voldoende dat het belang in het algemeen bekend is. ${ }^{25 x}$ Zo gaat de Memorie van Antwoord er zonder meer van uit, dat het belang dat de verkoper van nieuwe auto's heeft bij een beding dat hem de mogelijkheid verschaft een auto te leveren die afwijkt van hetgeen in de reclamefolder daarover wordt medegedeeld, bij de wederpartij bekend is, althans behoort te zijn. De afhankelijkheid van de verkoper van de fabrikant en het feit dat de constructie van auto's door fabrikanten kan worden aangepast, zijn immers "van algemene bekendheid".259

Uiteraard geldt ook hier dat de vernietigbaarheid van artikel 6:233 sub a BW met zich brengt dat de wederzijds kenbare belangen van partijen slechts een rol kunnen spelen bij de toetsing van algemene voorwaarden indien zij vór de aanvaarding van de gelding kenbaar zijn voor partijen.

Mijns inziens dient bij dit en het navolgende criterium te worden opgemerkt dat het "concrete" karakter van de inhoudstoets aan de open norm enigszins gerelativeerd dient te worden. Algemene voorwaarden zijn van tevoren opgesteld en naar hun aard niet gericht op én individuele wederpartij maar op de gehele kring van potentiële wederpartijen. ${ }^{260}$ Ook bij de vraag in hoeverre kenbare partijbelangen en met name die van de wederpartij een rol spelen bij het oordeel over de onredelijk bezwarendheid van een beding dient met deze algemene werking van algemene voorwaarden rekening te worden gehouden. Daarom zijn in beginsel niet alle belangen van de individuele wederpartij relevant. Men moet immers niet uit het oog verliezen dat het hier een toets van de inhoud van algemene voorwaarden betreft. Algemene voorwaarden zijn naar hun aard van te voren geconcipieerde bedingen, bedoeld te worden gebruikt in meerdere overeenkomsten. Zij dragen zoals de naam reeds zegt een algemeen karakter. De opsteller dient bij de vaststelling van de inhoud van algemene

257 MvT, Parlementaire Geschiedenis, Irv. 3, 5 en 6, pag. 1580.

258 Verhoeven, pag. 59.

$259 \mathrm{MWA}$, Parlementaire Geschiedenis, Inv. 3, 5 en 6, pag. 1728-1729; NEV, Parlementaire Geschiedenis, Inv. 3, 5 en 6, pag. 19.

260 Zie ook: NEV, Parlementaire Geschiedenis, Inv, 3, 5 en 6, pag. 1540. 
woorwaarden rekening te houden met de gerechtvaardigde belangen van de wederpartij. Van wege dit algemene karakter van algemene voorwaarden hoeft hij echter geen rekening te houden met de belangen van de individuele wederpartij maar met die van de gemiddelde wederpartij, zoals deze zich normaal gesproken bij dit soort overeenkomsten, betreffende dit soort goederen of onderwerpen voordoen. Het zou in strijd zijn met de aard van algemene voorwaarden indien de gebruiker daarin rekening zou moeten houden met uitzonderlijke belangen van elke concrete wederpartij afzonderlijk. Dit zou niet alleen grote rechtsonzekerheid met zich brengen over de onredelijk bezwarendheid van een beding ( $\mathrm{er}$ is altijd wel een uitzonderingsgeval te bedenken waarin het beding onredelijk voor de concrete individuele wederpartij uitpakt); het zou tevens verder gaan dan de redelijkheid en billijkheid van de gebruiker verlangt. Hij hoeft immers slechts rekening te houden met de kenbare belangen van de wederpartij. Hij moet zijn gedrag mede laten bepalen door de gerechtvaardigde belangen van de wederpartij. ${ }_{2}^{201}$ Bij het opstellen van de algemene voorwaarden is de individuele wederpartij echter niet bekend. Well de doorsnee wederpartij. De individuele wederpartij wordt pas bekend bij het sluiten van de overeenkomst. Met uitzonderlijke individuele belangen van concrete wederpartijen kan in deze vooraf opgestelde algemene voorwaarden in beginsel derhalve geen rekening worden gehouden.

Voor zover deze concrete individuele belangen van de wederpartij afwijken van hetgeen normaal te verwachten is, kan en hoeft de gebruiker daar dus geen rekening mee te houden. Hij kan er geen rekening mee houden omdat hij én de individuele wederpartij niet kent én algemene voorwaarden die met alle mogelijk denkbare uitzonderingen rekening houden, zo deze al te maken zijn, complex en onleesbaar zouden worden. Hij hoeft er mijns inziens bovendien geen rekening mee te houden, omdat de redelijkheid en billijkheid zoals gexegd, "slechts" vereist dat hij als opsteller van de algemene voorwaarden met de redelijkerwijs te voorziene belangen van de kring van de wederpartijen op een faire wijze rekening houdt.

Naar mijn mening dient de rechter dient derhalve bij de vraag of een beding inhoudelijk onredelijk bezwarend is op grond van artikel $6: 233$ sub a $B W$, in eerste instantie uit te gaan van de omstandigheden zoals die gelden voor de "doorsnee" wederpartij. Hij dient te abstraheren van de uitzonderlijke omstandigheden van het concrete individuele geval. Het beding is immers niet gemaakt met het oog op dit uitzonderlijke individuele geval maar op het doorsnee geval.

Wat echter indien de uitzonderlijke omstandigheden en de belangen van de wederpartij in het concrete geval, zoals deze bekend zijn bij de aanvaarding van

261 HR 15 november 1957, NJ 1958, 67, m.nt. L.E.H.R., AA. 1957, pag. 103, m.nt. G. (Baris/ Riezenkamp). 
de gelding van de algemene voorwaarden, afwijken van hetgeen de gebruiker normaal gesproken redelijkerwijs had kunnen voorzien én deze omstandigheden er bovendien toe leiden, dat een beroep van de gebruiker op het normaal gesproken niet onredelijk bezwarende beding zou resulteren in een onbillijke benadeling van deze concrete wederpartij? Maakt een dergelijk beroep op een normaal gesproken toelaatbaar beding, zulk een beding in dat geval onredelijk. bezwarend?

Vooropgesteld zij dat de hiervoor gestelde vraag slechts speelt indien de gebruiker ook daadwerkelijk een beroep doet op een dergelijk beding. Het is zeer wel mogelijk dat de gebruiker in het beschreven geval, juist vanwege het feit dat het beding voor deze uitzonderlijke wederpartij onredellijk bezwarend uitpakt, gewoon geen beroep doet op het beding en tot een billijke oplossing komt met deze wederpartij. De vraag speelt pas indien de gebruiker ook daadwerkelijk een beroep doet op een beding dat eigenlijk niet is opgesteld met het oog op die uitzonderlijke wederpartij. Twee oplossingen zijn hier denkbaar.

In de eerste, naar mij voorkomt dogmatisch de meest aangewezene, kan de rechter zich op het standpunt stellen dat de gebruiker in beginsel geen beroep op het beding toekomt. Het beding voorziet immers niet in een regeling voor de voorliggende situatie en mist dus toepassing. Algemene voorwaarden, de naam zegt het al, zijn naar hun aard slechts bedoeld om een algemene regeling te geven voor de gebruikelijke wederpartij. Aan een inhoudelijke toets van het beding aan artikel 6:233 sub a BW komt de rechter dan niet toe. De vraag dient in deze oplossing ontkennend te worden beantwoord.

De tweede mogelijkheid is, dat de rechter aan het beroep van de gebruiker op het beding in de uitzonderlijke situatie waarvoor het eigenlijk niet is bedoeld, de consequentie c.q. fictie verbindt dat de gebruiker het beding van meet af aan dus ook bedoeld heeft voor deze uitzonderlijke situatie. Anders zou de gebruiker daar immers geen beroep op (kunnen) doen. In dat geval dient de rechter vervolgens bij de inhoudstoets aan artikel 6:233 sub a BW ook rekening te houden met de uitzonderlijke omstandigheden van dit concrete geval en deze concrete wederpartij. In dat geval kan de gestelde vraag bevestigend worden beantwoord en gaat het er om of sprake is van een onredelijk bezwarend beding.

De omgekeerde vraag kan zich echter ook voordoen. Wat indien de buitengewone omstandigheden en de belangen van de wederpartij in het concrete geval, zoals deze bekend zijn bij de anvaarding van de gelding van de algemene voorwaarden, afwijken van hetgeen de gebruiker normaal gesproken redelijkerwijs had kunnen verwachten én juist deze uitzonderlijke omstandigheden en belangen er tevens toe leiden, dat een beroep van de gebruiker op het, normaal gesproken onredelijk bezwarende, beding resulteert in een niet onredelijk 
bezwarende oplossing voor deze concrete wederpartij? Maken de buitengewone belangen en omstandigheden van juist deze concrete wederpartij dat een normaal gesproken ontoelaatbaar beding, in dat geval niet onredelijk bezwarend is? Ook hier geldt mijns inziens dat de gebruiker een beroep op het beding in die uitzonderlijke situatie niet toekomt, omdat het beding niet op die uitzonderlijke situatie ziet. Aan een inhoudstoetsing op grond van artikel $6: 233$ sub a BW komt de rechter dan niet toe.

De rechter heeft echter eveneens de, mijns inziens dogmatisch minder fraaie, mogelijkheid aan het beroep van de gebruiker het gevolg te verbinden dat het beding dus van meet af aan ook op deze uitzonderlijke omstandigheden toepasselijk was en deze omstandigheden vervolgens meewegen in zijn oordeel over de onredelijk bezwarendheid van het beding. Doet de rechter er echter verstandig aan een beding toelaatbaar te achten dat normaal gesproken met het oog op de kring der wederpartijen onredelijk bezwarend zou zijn, maar dat in het uitzonderlijke concrete geval niet is? Mij dunkt van niet. Men bedenke dat de gebruiker (te kwader trouw) aan de rechterlijke uitspraak onterechte argumenten zou kunnen ontlenen naar de normale kring der wederpartijen toe, jegens wie een beroep op het beding net wel onredelijk bezwarend zou uitpakken. Het beding is immers voorzien van een "goedkeuring" door de rechter, weliswaar niet voor het doorsneegeval, maar dat weet de wederpartij niet. Om deze ongewenste precedentwerking tegen te gaan dient de rechter, als hij het beding al toetst, een dergelijk beding derhalve onredelijk bezwarend te verklaren ook voor deze uitzonderlijke wederpartij. Dit komt de rechtszekerheid ten aanzien van de geoorloofdheid van algemene voorwaarden zeker ten goede.

Gezien het voorgaande kan geconcludeerd worden dat de uitzonderlijke belangen van de geïndividualiseerde wederpartij in de inhoudstoets van algemene voorwaarden pas een rol spelen als de gebruiker een beroep doet op het beding in die uitzonderlijke situatie waarvoor het beding eigenlijk niet is bedoeld. Daarbij moet worden vooropgesteld dat het dogmatisch juister is de gebruiker het beroep op het beding te ontzeggen omdat het beding niet op de uitzonderlijke situatie ziet. Indien de rechter oordeelt dat het beding toch ook op de uitzonderlijke belangen en omstandigheden ziet, biedt artikel 6:233 sub a BW hem de mogelijkheid dat hij vervolgens ook kan toetsen aan alle uitzonderlijke omstandigheden van het concrete geval die vóor de aanvaarding van de gelding van die voorwaarden bekend waren bij de gebruiker.

De rechter hoeft in het "normale" geval, bij de beoordeling van de onredelijk bezwarendheid van een beding in beginsel dan ook geen rekening te houden met de kenbare belangen van de individuele wederpartij maar met de kenbare belangen van "de kring van wederpartijen waarvan de wederpartij deel uit- 
maakt" "262 De belangen en omstandigheden van de "normale" wederpartij komen immers overeen met die van de kring van wederpartijen waartoe zij] behoort. De persoon van de individuelle wederpartij dient derhalve bij de toetsing aan artikel 6:233 sub a BW in beginsel buiten beschouwing te worden gelaten. ${ }^{260}$ Ook de omstandigheden die in de parlementaire geschiedenis als voorbeeld worden aangehaald geven steun aan deze opvatting. $\mathrm{Zij}$ hebben steeds een algemeen karakter.

Bij de inhoudstoets van artikel 6:233 BW dient de rechter verder rekening te houden "met de overige omstandigheden van het geval". De parlementaire geschiedenis is slechts zeer summier in de toelichting van dit criterium.

\footnotetext{
"Ten slotte zijn ook de andere amstandigheden van het geval wan belang. Zo zall de redelijkheid wan een aansprakelijkheidsbeperking mede afhankelijk kunnem zijn wan de wraag of her risico had kannem worden verzekerd, op wiens weg dit had gelegen, of een redelijk aanbod daarioe van de hand is gewezen, elc. ${ }^{264}$
}

In de literatuur wordt voor de rellevante omstandigheden doorgaans verwezen naar de HBU-criteria en de, voortbouwend op dit arrest, in de jurisprudentie genoemde omstandigheden. ${ }^{265}$ Als relevante omstandigheden worden genoemd:

- de maatschappelijke positie van partijen;

- de deskundigheid van partijen;

- de onderlinge verhouding van partijen;

- de zwakke of sterke sociaal-economische positie van partijen;

- de strekking van het beding en de mate waarin de wederpartij zich de strekking van het beding bewust is geweest;

- misbruik van machtspositie;

- de zwaarte van de schuld en de ernst van de wanprestatie;

- de technische geschiktheid tot kennisneming van de voorwaarde (lay-out, omvang, redactie, formulering);

- de aanwezigheid c.q. mogelijkheid van verzekering en de vraag op wiens weg het sluiten van een verzekering ligt; ${ }^{260}$

- de verhouding tussen de waarde van het artikel en de mogelijke schade die een mogelijk defect aan dit artikel kan veroorzaken;

262 Zie in dezelfde zin: Jongeneel, diss., pag. 188, 199 en 203.

263 Zie ook: Jongeneel, diss., pag. 188 en 223.

264 Mv'T, Parlementaire Geschiedemis, Inv. 3, 5 en 6, pag. 1580.

265 Rijken, diss., pag. 225; Wessels en Jongeneel, 1992, pag. 52-53; Jongeneel, diss., pag. 204 e.v"; Verhoeven, pag, 59; Asser-Hartkamp II, 1993, nr. 357.

266 HR 5 januani 1968, NJ 1968, 102, m.nt. G.J.S., AA 1969, pag. 429, m.nt. H.K.K. (Fokker/Zentveld); Rijken, diss. , pag. 145 . 
- de omstandigheid dat de gebruiker de wederpartij uitdrukkelijk op het beding en de gevolgen daarvan heeft gewezen.

Niet al deze omstandigheden zijn echter relevant bij de inhoudstoetsing op grond van artikel 6:233 sub a BW. Rijken komt tot de conclusie dat slechts de billijkheidsomstandigheden een rol kunnen spelen bij de inhoudstoets aan de open norm en dat het merendeel van de HBU-omstandigheden pas aan de orde komt bij een toets aan de redelijkheid en billijkheid van artikel 6:248 BW. ${ }^{267} \mathrm{De}$ verklaring ligt voor de hand. De HBU-toets op grond van artikel 1374 lid $3 \mathrm{BW}$ omvatte niet alleen de inhoudstoets, maar tevens de aanvaardings- en informatietoets. Naar huidig BW zijn deze toetsen voor wat betreft algemene voorwaarden strikt gescheiden. Bij de inhoudstoets aan de open norm spelen HBU-omstandigheden die zien op de aanvaarding, de informatieplicht van de gebruiker en de kenbaarheid van de inhoud van algemene voorwaarden voor de wederpartij derhalve in beginsel geen enkele rol.

Bovendien ziet de HBU-toets op alle omstandigheden van het geval. De omstandigheden dus van zowel vóror, bij als na het sluiten van de overeenkomst. De aard van de inhoudstoets aan de open norm brengt echter met zich dat daarbij alleen omstandigheden van voór of bij het sluiten van de overeenkomst een rol kunnen spelen en dat bovendien in beginsel alleen die omstandigheden relevant zijn die typisch zijn voor de kring der wederpartijen waarvan de wederpartij deel uitmaakt. Uitzonderlijke omstandigheden die de persoon van de concrete individuele wederpartij betreffen dienen naar mijn mening ook hier in beginsel buiten beschouwing te worden gelaten voor zover zij niet in overeenstemming zijn met de omstandigheden van de kring van wederpartijen waartoe deze individuele wederpartij behoort. ${ }^{208}$

Het zal duidelijk zijn dat ik een groot aantal van de in de literatuur opgesomde "relevante" HBU-omstandigheden bij de inhoudstoets aan de open norm helemaal niet zo relevant acht. $\mathrm{Zij}$ zijn door het huidige stelsel van afdeling 6.5.3 BW grotendeels achterhaald. Dit geldt te meer als het gaat om de beoordeling van algemene voorwaarden gehanteerd jegens consumenten.

Bij de toetsing aan de open norm gaat het immers om de inhoud van een beding. De vraag of deze inhoud, gezien de omstandigheden die partijen bekend (of bekend behoren te) zijn vór of bij het sluiten van de overeenkomst, van meet af aan onredelijk bezwarend is voor de kring van wederpartijen waarvan de wederpartij deel uit maakt, met het oog op de mogelijke risico"s waaraan dit

267 Rijjken, disws., pag, 224-225.

268 Anders Jongeneel, diss., pag. 205. 
beding haar van meet af aan blootstelt. De vraag of deze risico's zich werkelijk zullen verwezenlijken is daarbij niet van belang.

Gezien het feit dat het om de toetsing van een algemene voorwaarde gaat moet de rechter er bij consumententransacties in het algemeen reeds bij voorbaat van een aantal van de hiervoor genoemde omstandigheden uitgaan. Deze volgen uit de aard van de inhoudstoets op grond van artikel 6:233 sub a BW. Zo zal hij er van uil dienen te gaan dat de wederpartij, ook als zij meer deskundig is, de voorwaarden ongelezen aanvaardt en pas kennis neemt van die algemene voorwaarden op het moment dat er problemen zijn bij de uitvoering van de overeenkomst. De vraag naar de mate waarin de wederpartij zich de strekking van het beding (vooraf) bewust is geweest is daardoor gemakkelijk te beantwoorden. Er moet van worden uitgegaan dat de consument zich in beginsel niet van de strekking van een beding bewust is.

Bovendien moet de rechter er bij consumententransacties van uitgaan dat sprake is van een "take it or leave it"-situatie die gebaseerd is op een sociaaleconomisch overwicht van de gebruiker. Algemene voorwaarden zijn naar hun aard immers bedoeld om zonder wijzigingsmogelijkheid ongelezen te worden aanvaard. De sociaal-economische ongelijkheid en de beperking van de individuele invloed op algemene voorwaarden zijn ook geen bezwaar mits de inhoud van die voorwaarden maar niet onredelijk bezwarend is. Dat is ook het uitgangspunt van het stelsel van afdeling 6.5.3 $\mathrm{BW}$. HBU-omstandigheden die uitgaan van een mogelijke onderhandelingspositie of invloed van de consument op de inhoud van de hem voorgelegde algemene voorwaarden, zijn voor consumententransacties dan ook irrelevant. Deze omstandigheden zien meer op het gebruik van algemene voorwaarden tussen ondernemers onderling, waar het (soms) wel mogelijk is dat over de inhoud of toepasselijkheid van algemene voorwaarden wordt onderhandeld.

Omdat algemene voorwaarden van te voren zijn opgesteld met het oog op de kenbare belangen van de kring der wederpartijen en niet met het oog op de concrete individuele wederpartij dienen verder bijzondere omstandigheden die betrekking hebben op de persoon van de individuele wederpartij bij de inhoudstoets in beginsel buiten beschouwing te worden gelaten.

Bij consumententransacties moet daarbij tevens er van uit worden gegaan dat de gebruiker de deskundige, de professional is en de consument-wederpartij de ondeskundige leek met bijzonder weinig rechtskennis. Bij consumententransacties is de wederpartij immers per definitie een natuurlijk persoon niet handelend in de uitoefening van een beroep of bedrijf. 


\section{Vernietigbaarheid}

Een beding in algemene voorwaarden dat onredelijk bezwarend is voor de wederpartij is vernietigbaar, aldus artikel 6:233 sub a BW. Op deze vernietigbaarheid, alsmede die van de artikelen 6:233 sub b, 6:234 lid 2 en 6:243 BW, zijin de algemene regels van de artikelen 3:49 e.v. BW en 3:41 en 3:42 BW van toepassing. ${ }^{269}$ Op aandringen van de vaste Commissie voor Justitie ${ }^{200}$ is in artikel 6:246 $\mathrm{BW}$ bovendien uitdrukkelijk vastgelegd, dat de bevoegdheid om een beding op grond van artikel 6:233 sub a BW door een buitengerechtelijk verklaring te vernietigen niet kan worden uitgesloten. ${ }^{2 \pi}$

Doorgaans zal de wederpartij pas een beroep doen op de vernietigbaarheid van een beding nadat de gebruiker een beroep op het beding heeft gedaan. Een beroep op de vernietigbaarheid veronderstelt dat de wederpartij bekend is met de mogelijkheden die afdeling 6.5.3 $\mathrm{BW}$ haar biedt. Vooralsnog mag volgens mij echter worden aangenomen dat het de doorsnee consument aan deze kennis ontbreekt. Indien het toch tot een beroep op de vernietigingsgronden van artikel 6:233 BW komt staan de wederpartij daartoe op grond van artikel 3:49 BW in beginsel twee wegen ter beschikking. De buitengerechtelijke verklaring of de rechterlijke uitspraak.

\section{Vernietiging door middel van een buitengerechtelijke verklaring}

De buitengerechtelijke verklaring dient zich op grond van artikel 3:50 BW te richten tot hen die partij bij de rechtshandeling zijnn. ${ }^{27} \mathrm{Bij}$ consumententransacties zal dit doorgaans de gebruiker zijn. Het is echter niet uitgesioten dat ook derden partij zijn bij de overeenkomst. In dat geval dient de buitengerechtelijke verklaring eveneens gericht te zijn tot deze derden. Aan de buitengerechtelijke verklaring zijn in beginsel geen nadere eisen verbonden, zij is dus vormvrij en kan in beginsel ook mondeling geschieden. ${ }^{27}$ Alleen in het gevall de vernietiging een rechtshandeling betreft met betrekking tot een registergoed die heeft geleid tot een inschrijving in de openbare registers, wordt een uitzondering gemaakt. Op grond van artikel 3:50 lid $2 \mathrm{BW}$ wordt de rechtshandeling in dat geval pas door de buitengerechtelijke verklaring vernietigd, indien alle partijen in de vernietiging berusten.

269 MvT, Parlementaire Geschiedenis, Inw. 3, 5 en 6, pag. 1459 en 1582; MvA, Parlementaire Geschiedenis, lnv. 3, 5 en 6, pag. 1587-1588.

270 VV, Parllementaire Geschiedenis, Inv, 3, 5 en 6, pag. 1806.

271 MvA, Parlementaire Geschiedenis, Inv. 3, 5 en 6, pag. 1806.

272 Asser-Hartkamp II, 1993, nr. 471.

273 Asser-Hartkamp II, 1993, nr. 469. 
De buitengerechtelijke vernietiging van een beding sluit niet uit dat deze wordt gevolgd door een gerechtelijke procedure. Dit kan het geval zijn als de vernietigingsgrond door de gebruiker wordt betwist, indien de gebruiker gewoonweg geen gevollg geeft aan de vernietiging of als de gebruiker een gerechtelijke procedure jegens de wederpartij begint. In dat laatste geval kan op de vernietiging een beroep worden gedaan bij wege van verweer. Het uitbrengen van een buitengerechtelijke verklaring tot vernietiging bewerkstelligt dan dat, indien de wederpartij in de gerechtelijke procedure in het gelijk wordt gesteld, de rechterlijke uitspraak een declaratoire werking heeft. ${ }^{274}$

\section{Vernietiging bij wege van rechterlijke wüspraak}

De tweede mogelijkheid om een beding te vernietigen is bij wege van rechterlijke uitspraak. Voor wat betreft algemene voorwaarden, bepaalt artikel 3:51 BW dat indien de rechter een beroep in rechte op de vernietigingsgrond aanvaardt, de rechterlijke uitspraak het betreffende beding vernietigt. Het beroep in rechte kan ook hier weer plaats vinden bij wege van verweer. ${ }^{275}$ Als een beroep op een vernietigingsgrond eerst in rechte wordt gedaan, dan heeft de rechterlijke uitspraak die dit beroep honoreert een constitutief karakter. Niet het beroep doch de uitspraak vernietigt het beding. ${ }^{276}$

In beginsel is de wederpartij vrij in de keuze of zij buitengerechtelijk dan wel in rechte, door middel van een rechterlijke uitspraak, wil vernietigen. In de praktijk ligt het echter voor de hand dat de wederpartij, als zij tenminste op de hoogte is van haar wettelijke bevoegdheden, meestal zal kiezen voor vernietiging door middel van een buitengerechtelijke verklaring.

Het is zeker niet uitgesloten dat de wederpartij niet in de gelegenheid is geweest een buitengerechtelijk beroep op de vernietigingsgronden van artikel 6:233 $\mathrm{BW}$ of eerst in de processuele fase tot het inzicht kwam dat zij een beroep op deze vernietigingsgronden kon doen. In die gevallen is de wederpartij aangewezen op een vernietiging door middel van een rechterlijke verklaring. Doorgaans is dit echter niet het geval en is de wederpartij zeer goed in staat een buitengerechtelijke vernietiging te bewerkstelligen. De wederpartij zal de gebruiker meestal reeds in het préprocessuele stadium mededelen dat zij vindt dat het beding waar hij een beroep op doet onredelijk bezwarend is en daarmee dus vernietigbaar. Indien dit redelijkerwijs mogelijk is wordt dit mijns inziens ook door de redelijkheid en billijkheid geëist. Ook indien de wederpartij bij het

274 Asser-Hartkamp II, 1993, nr. 471.

275 Asser-Hartkamp II, 1993, nr. 472.

276 Asser-Hartkamp III, 1993, nr, 472. 
beroep op de onredelijk bezwarendheid van een beding niet expliciet een beroep doet op de vernietigbaarheid of uitdrukkelijk meedeelt dat hij de rechter om vernietiging zal vragen, kan zulk een mededeling door de gebruiker niet anders worden begrepen dan als een beroep op de vernietigingsgrond.

Er is nog een tweede reden die de wederpartij reeds in de preprocessuele fase gebiedt het beroep op de vernietigingsgrond aan de gebruiker mee te delen. Artikel 56 lid $1 \mathrm{Rv}$ bepaalt immers dat de rechter de proceskosten die nodeloos werden aangewend of veroorzaakt, voor rekening van degene zal laten die ze nodeloos heeft aangewend of veroorzaakt. Indien de wederpartij als eiser optreedt kan het feit dat hij niet reeds buitengerechtelijk een beroep op de vernietigbaarheid heeft gedaan, onder omstandigheden met zich brengen dat hij, ondanks het feit dat zijn eis tot vernietiging wordt toegewezen, wordt veroordeeld in de proceskosten. Ik doel hier op de rechtsfiguur van de rauwelijkse dagvaarding. Het is vaste rechtspraak dat degene die een andere partij rauwelijks dagvaart, dat wil zeggen zonder deze in de gelegenheid te stellen buitengerechtelijk aan de eis toe te geven of een schikking te treffen, wordt veroordeeld in de proceskosten indien de gedaagde in de procedure zonder meer aan de eis tegemoet komt.

\section{Partiële nietigheid}

Vernietiging van een beding leidt niet altijd tot vernietiging van de hele overeenkomst. Integendeel, artikel 3:41 BW bepaalt immers:

"Betreft een grond wan nietigheid slechts een deel wan de rechtshandeling" dan blijft deze poor het owerige in stand, woor zover dit, gelet op inhoud en strekking van de handeling, niet in onverbrekeHijk verband met het nietige deel stat. ${ }^{227}$

Voor algemene voorwaarden leidt de regel echter onvermijdelijk tot het resultaat dat de rechtshandeling in de meeste gevallen voor het overige in stand blijft. Algemene voorwaarden zijn immers per definitie geen kernbedingen en dus geen essentialia zonder welke de overeenkomst niet bepaalbaar zou zijn. Zij zijn meestal niet onverbrekelijk verbonden met de rest van de overeenkomst. ${ }^{278}$ Bovendien speelt bij de vraag of de nietigheid van een beding uit een overeenkomst, partiële dan wel algehele nietigheid van de overeenkomst met zich brengt, de strekking van de overtreden wetsbepaling die tot nietigheid of vernietiging van dat beding leidt een duidelijke rol. ${ }^{279}$ Indien de overtreden

277 Zie meer uitgebreid over partiële nietigheid: Van Schaick, diss., pag. 269 e.w.

278 Hijma, diss. pag. 280-282; Jongeneel, diss, pag. 171-172; Wessels en Jongeneel, 1992, pag. 20. Zie vender over over partiële nietigheid: Van Schaick, diss., pag. 269-276.

279 Asser-Hartkamp II, 1993, nr. 491; Verthoeven, pag. 60 
norm strekt ter bescherming van een van de contractanten, hetgeen bij een beroep van de wederpartij op artikel 6:233 sub a BW uitdrukkelijk het geval is, zal er rekening mee moeten worden gehouden dat het aannemen van een algehele nietigheid de beschermde partij ook van de voordelen van de overeenkomst zou beroven en zelfs onder omstandigheden zou beletten dat zij de prestatie zonder de voor haar bezwarende contractsbedingen kan verkrijgen. ${ }^{280}$

Net zo als de overeenkomst partieel nietig kan zijn, kan ook een beding partieel nietig zijn. Voorwaarde is wel dat het beding "splitsbaar" moet zijn. Het te vernietigen gedeelte moet "isoleerbaar" zijm. Dat will zeggen dat hetgeen na partiële vernietiging van een beding overblijft als een afzonderlijk begrijpelijk en redelijk beding kan voortbestaan. ${ }^{28 \pi}$

\section{Conversie}

Op de vernietigbaarheden van artikel 6:233 $\mathrm{BW}$ is, net als op alle andere vernietigingsgronden, in beginsel ook artikel 3:42 BW (conversie) van toepas$\operatorname{sing} 282$

"Beantwoordt de strekking van een nietige rechtshandeling in een zodanige mate aan die van een andere, als geldig aan te merken rechtshandeling, dat acangenomen moet worden dat die andere rechtshandeling zou zijn verricht, indien van de eerst genoende wegens haar ongeldigheid was afgezien, dan komi haar de werking van die andere rechtshandeling toe, tenzij dit onvedelijk zou zijm jegens en belanghebbende die niet vot de rechtshandeling als partij heeft medegewerkt."

De rechtsgrond van conversie is de redelijkheid en billijkheid. Conversie vindt van rechtswege plaats en dient door de rechter ambtshalve te worden geconstateerd. ${ }^{283}$ Er vindt geen conversie plaats indien dit onredelijk zou zijn jegens een belanghebbende die geen partij is bij de nietige rechtshandeling. ${ }^{284}$ In het geval van vernietiging van algemene voorwaarden dient conversie echter met de nodige voorzichtigheid te worden toegepast. ${ }^{285}$ De toelichting in de Memorie van antwoord, door mij aangepast aan de huidige artikelnummering, is wat dit betreft duidelijk genoeg:

280 Asser-Hartkamp II, 1993, 491; Verhoewen, pag. 60; Van Schaick, diss., pag. 307.

281 Hijma, diss., prg. 259-261; Jongeneel, diss., pag "254, Wessels en Jongeneel, 1992, pag. 20.

282 MvA, Parlementaine Geschiedenis, Inv. 3, 5 en 6, pag. 1587. Zie verder over conversie: Van Schaick, diss., pag. 262-269.

283 Asser-Hartkamp II, 1993, nr. 496.

284 Asser-Hartkamp II, 1993, nr. 499.

285 Zie meer uitgebreid: Hijma, diss. , pag. 313 e.v.* Asser-Hlartkamp II, 1993, nr. 499; Jongeneel, diss., pag. 169-171; Wessels en Jongeneel, 1992, pag. 20-21; Verhoeven, pag. 60-61, Van Schailick, diss. , pag. $262-269$. 
Maj) concluderent dat de conversie, howel niet uitgesloten, in de onderhavige materie met woorzichtigheid moer worden toegepast, en dat woor toeposselijikheid in elk geval geen ruimue is in gerallen waarin acmnemelijk is dat de gebrwiker min of meer bewnst onredilijke bedingen hanteert, a.4. de onredelijkheid fop grond van de lijst wan anikel 6:236 BW] boven twijfel verheven is, respectieveliji op grond van de lijst wan artikel 6:237 mag wonden woorondersteld. Er bestacat echter geen bezwaar tegen conversie indien gerede twijfel mogelijk was over de wraag of de rechter een beding onredelijk bezwarend zal oordelen, en conwersie, indien de rechiter inderdand tor dit oordeel konst, een redelijke oplossing is gelet op de belangen wan beide partijen.

Ook het volgende argument verzet zich tegen het snel aannemen van conversie. Door het al te snel aannemen van conversie zou de gebruiker zonder risico onredelijk bezwarende bedingen kunnen opnemen, in de veronderstelling dat indien dat beding wordt vernietigd, de rechter dit automatisch terugbrengt tot het wettelijk toelaatbare. De gebruiker zou door de toepassing van conversie als het ware beloond worden voor laakbaar gedrag. Jegens de wederpartij zou dit onredelijk zijn. Dit kan zowel gebaseerd worden op de slotzin van artikel 3:42 BW als op de strekking van de overtreden beschermingsnorm. ${ }^{287}$ In het geval van vernietigbaarheid op grond van het bepaalde in artikel 233 sub b j ${ }^{\circ} 234 \mathrm{BW}$ brengt de strekking van de overtreden beschermingsnorm mijns inziens zelfs mee dat conversie helemaal uit den boze is. De regel van artikel 6:233 sub b jo 234 BW zou anders illusoir zijn.

\subsubsection{De lijsten van de artikelen 6:236 en 6:237 BW}

Op de zojuist besproken open norm is een tweede toetsingsinstrument gebaseerd, namelijk de lijsten van de artikelen 6:236 en 6:237 BW. Mede ter bevordering van de rechtszekerheid wordt in deze lijsten, die elk veertien bedingen bevatten, een uitwerking gegeven van de open norm van artikel 6:233 sub a BW voor transacties met consumenten. $\mathrm{Zij}$ beogen mede aan te geven hoe de wetgever de open norm toets graag ziet ingevuld. In de Memorie van Toelichting, door mij aangepast aan de huidige nummering, wordt dit als volgt toegelicht:

"Zoals in deze memorie bij de artikelen 6:236-237 BW (...) nader zal worden witeengezet, wormen witwerkingen wan artikel $6: 233$ sub a BW, die zowel de rechiszekerheid beogren te dienien, als een

28.6 MvA, Parlementaire Geschiedenis, Inv. 3,5 en 6, pag. 1588. Rujken wijst in dit werband op een convensiebeding (bedingen dat bepaalt dat vemietigbare of nietige bedingen worden tenuggebracht tot het rechtens toelaatbare) in de algemene voorwaarden van de vereniging wan exploitanten van parkeergarages (VEXPAN). Een beding dat hij op zichzelf reeds onredelijk bezwarend acht op grond van het bepaslde in artikel $6: 233$ aub a BW. Zie: Rijken, NJB 1994, pag. 644 en noot 7 .

287 MvA, Parlementaire Geschiedenis, Inv. 3, 5 en 6, pag, IS88; zie ook: Asser-Hartkamp II, 1993 , nr. 499. 
voorbeeldfunctie wernullem voor de loepassing wan artikel 6.233 sub a BW, in werhoudingen wararop de artikelen $6: 236$ en 6.237 BW niet van toepassing zijn, hetgeen, kort gezegd het geval is warneer

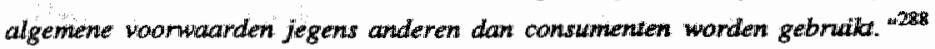

\section{De zwarte lijist}

De zogenaamde "zwarte lijst" van artikel 6:236 BW bevat bedingen die in transacties met consumenten als onredelijk bezwarend jegens de wederpartij worden aangemerkt, dat wil zeggen steeds vernietigbaar zijn. ${ }^{289}$ Het opnemen van de zwarte lijst van artikel 6:236 $\mathrm{BW}$ is vooral ingegeven door de behoefte aan rechtszekerheid bij de invulling van een open norm en

\footnotetext{
"het jwist bij een massaal werschijnsel als het gebruik van algemene voorwarden, waken woar een onevenredig groot beslag op de rechterlijke macht." (...) "Het is derhalve wit een oogpunit want doelmatigheid en wan rechtvaardigheid dringend gewenst om zoveel mogelijk rechtszekerheid te scheppen over de vraag wanneer bedingen anredelijk bezwarend zijn ${ }^{\prime}$ opdat individuele procedures daarover waar mogelijk worden vermeden. 2090
}

De lijst geeft daartoe een veertiental bedingen waarvan vaststaat dat zij alltijid onredelijk bezwarend zijn omdat $\mathrm{zij}$ "... - uiteraard mede gelet op de voormelde wijze waarop de wederpartij daaraan wordt gebonden - hoogst onbillijk kwnnen worden geacht, doorgaans omdat zij het evenwicht tussen de uit een wederkerige overeenkomst voortvloeiende rechten en verplichtingen op fundamentele wijze ten nadele van de wederpartij verstoren". ${ }^{291}$

De bedingen genoemd op de zwarte \ijst zijn onredelijk bezwarend ongeacht de overige feiten en omstandigheden van het geval die bij de toetsing aan de open norm van belang zijn. ${ }^{202}$ Er wordt ook geen uitzondering gemaakt voor bedingen waaromtrent tussen partijen werkelijk overeenstemming bestaat en tevens compenserend voordeel in de overeenkomst is opgenomen.

"Een witzondering als bedoeld zou - gezien de onwarschijilijkheid dat de consument in her volle besef wan hes bezwarende karakter wan het beding zal noustemmen in ongewijzigde opmeming - woor

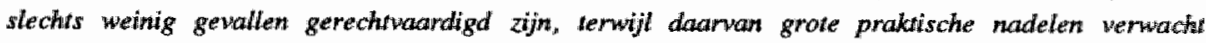
kunnew worden." (...) "Een wilzondering (...) zou een bron wan movilijkheden voor de praktijk

288 MvT, Peurlementaine Geschiedenis, Inv. 3, 5 en 6, pag. 1581.

289 MvT, Peurlementaire Geschiedenis, Inv. 3, 5 en 6, pag. 1649.

290 MvT, Parlementaire Geschiedenis, Inv. 3, 5 en 6, pag. 1649.

291 MvT, Parlementaire Geschiedenis, Inv, 3, 5 en 6, pag. 1649-1650.

292 MvT, Parlementaire Geschiedenis, Inv. 3, 5 en 6, pag. 1649. 
laumen worden en zo de functie wan het artikel - her dienen van de rechiszekerheid - andergntawern: 2093

In een dergelijk geval kan de rechter, rekening houdend met de concrete omstandigheden, eventueel wel de gevolgen van de nietigheid mitigeren. ${ }^{294} \mathrm{Bij}$ deze mitigering van de nulliteit moet gedacht worden aan de mogelijkheden en bevoegdheden die de wet en de jurisprudentie de rechter verschaffen op grond wan de artikelen $3: 41,3: 42,3: 53,6: 162,6: 248,6: 258$ en 6:278 BW. ${ }^{295}$

Bij de zwarte lijst heeft de Nederlandse wetgever gekozen voor een vernietigbaarheid te entameren door de (consument-)wederpartij en niet voor een nietigheid van rechtswege. De keuze is wellicht ingegeven door het feit dat de zwarte lijst slechts én der partijen bescherming biedt en artikel 3:40 lid 2 BW daaraan normaliter een vernietigbaarheid ten behoeve van de beschermde partij verbindt. Vanuit artikel 3:40 lid 2 BW bezien is dit weliswaar een logische keuze, in de systematiek van afdeling 6.5.3 BW is het mijns inziens echter geen gelukkige keuze. Gezien de aangevoerde argumenten voor een zwarte lijst is het immers vreemd dat de Nederlandse wetgever heeft gekozen voor een vaststaande vernietigbaarheid in plaats van een nietigheid van rechtswege. Een nietigheid van rechtswege verschaft namelijk optimale rechtszekerheid. De rechter moet een nietigheid van rechtswege immers ambtshalve toepassen en dit zal zeker bijdragen aan het uitbannen van de bedingen op de zwarte lijst. Het is bovendien vreemd dat wetgever die er bij de totstandkoming van afdeling 6.5.3 $\mathrm{BW}$ van uitging dat de gemiddelde consument nauwelijks weet heeft van de wettelijke bescherming en, zo hij daar al weet van heeft, nauwelijks in staat is deze wettelijke bescherming te effectueren, van diezelfde consument verlangt dat hij zelf het initiatief neemt tot vernietiging van een beding waarvan onomstotelijk vaststaat dat het onredelijk bezwarend is. Een nietigheid van rechtswege is in het geval van de zwarte lijst dan ook bepaald niet misplaatst.

\section{De grijze lijst}

De grijze lijst van artikel 6:237 bevat eveneens veertien bedingen. In tegenstelling tot de bedingen op de zwarte lijst, bevat de grijze lijst

293 MvA, Parlementaire Geschiedenis, Inv. 3, 5 en 6, pag. 1529; NEV, Parlementaire Geschiedenis, Inv, 3, 5 en 6, pag. 1541; MvA I, Partementaire Geschiedenis, Irv, 3, 5 en 6, prag. 15641.565 .

294 VV I, Parlementaire Gesehiedenis, Inv. 3, 5 en 6, pag. 1562; MvA. I, Parlementaire Gessehiedenis, luw. 3, 5 en 6, pag. 1565.

295 Zie meer uithgebreid: Jongencel, dïs., pag. 227-228. 


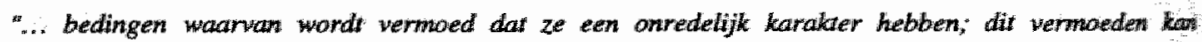
door de gebruiker wan de algemene voorwarden worden weerlegd. Bij het oorded over ds onredelijkheid van het beding kunnen alle (...) feiten en omstandigheden van belang zijn. "z206

\section{Een minder streng regime dan de zwarte lijst omdat het bedingen betreft}

"... warvan niet op voorhand' gezegd kan worden dat zij steeds anredelijk bezwarend wow de wederpartij zijn, maar die a priori - wederom mede gelat op de wijze waarop de wederpartij wanis wordt gebonden - zo bezwarend schijnen dat het gerechtwardigd is de bewijslasit wan her tegendied te leggem op degene die de algemene voorwaarden gebruild: 297

In tegenstelling tot de zwarte lijst bevat de grijze lijst enerzijds bedingen die de vraag of zij onredelijk bezwarend zijn laat afhangen van rekbare begrippen als bij voorbeeld "ongebruikelijk", "onvoldoende" en "wezenlijk" en anderzijds bedingen die weliswaar wel exact geformuleerd kunnen worden, maar niet per definitie als onredelijk bezwarend te beschouwen zijn. ${ }^{298}$ Het stelsel van de grijze lijst gaat daarom ook uit van een weerlegbaar vermoeden. De gebruiker mag bewijzen dat het beding in de concrete omstandigheden van het geval de toets van artikel 6:233 sub a BW kan doorstaan. Indien de gebruiker niet slaagt in dit bewijs of daarvan afziet, moet de rechter uitgaan van een niet weerlegd wettelijk vermoeden, met de slotsom dat het beding onredelijk bezwarend is. In dat geval heeft de rechter, net als bij bedingen op de zwarte lijst, geen beoordelingsvrijheid.

De lijsten van de artikelen 6:236 en 6:237 BW zijn uitwerkingen van de algemene norm van artikel 6:233 sub a BW. Als zodanig dienen zij limitatief te worden opgevat: slechts de bedingen bedoeld in artikel 6:236 worden steeds als onredelijk bezwarend aangemerkt en slechts bij de bedingen bedoeld in artikel 6:237 BW rust de bewijslast van het tegendeel steeds op de gebruiker Daarmee wordt volgens de Memorie van Toelichting, door mij aangepast aan de huidige artikelnummering, het volgende bedoeld:

"Uit het feit dat en beding niet op de lijsten wan de artikelen 6:236 BW en 6:237 BW woorkovu" mag wimmer en argwment worden ontleend ten betoge dat het wiet anredelijk bezwarend in de zin vant araikel 6.233 sub a BW zow zijn, ook niet wanneer het vlak nactst een wal opgenomen beding zoun liggen; dit laatste kan zich bijwoonbeeld woomdoen wanneer een bepaalde termijn is vermeld. Ment denke ool aan hel geval dat een bepaling in de artikelen 6:236 BW en 6:237 BW aen witzondering bewat; voldoet een beding aan die witzondering, dan staat daardoor slechts vast dat het miet ondur

296 MvT, Parlementaïre Geschiedenis, lnv. 3, 5 en 6, pag. 1649.

297 MVT, Parlementaíre Geschiedenis, Inv, 3, 5 en 6, pag. 1650.

298 Mv', Parlementaire Geschiedenis, Inv. 3, 5 en 6, pag. 1650.

299 MvT, Parlementaine Geschiedenis, Inv, 3, 5 en 6, pag. 1652. 
antikel 6:236 BW of arrikel 6:237 BW walt, doch geenszins das het miet acon de toetsing krachtens antikel 6:233 swb a BW zou kunnen worden anderworpen, warbì het bewijs dan nommal door de whederpartij moet worden gelewerd. Elk argwment a contrario, elke refleswerking dient hier te wonden wermedev. Bif het opstellen vaw de lijsten is grote voorzichtigheid betracht, ton einde het te regelen gebtied steeds tot het - naar wij thans menen - voordienbare te beperken. Bifj twiffel is het

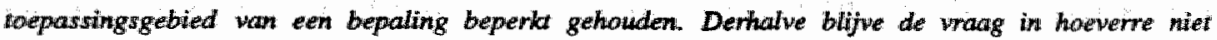
onder de artikelen $6: 236 \mathrm{BW}$ en $6.237 \mathrm{BW}$ vallende bedingen onredelijk bezwarend zijn, c.q. in hoeverre thet redelijk is de bewijslast daabij om te keren, steeds in volle wrijheid aan de rechter ter beoondeling owergelaten. "300

Daarmee is het argument dat een beding niet onredelijk bezwarend is omdat het niet op de lijsten voorkomt, voor eens en voor altijd van tafel geveegd. Het tegendeel is eerder het geval. De lijsten vervullen een duidelijke voorbeeldfunctie en geven een idee over de invulling van de open norm zoals de wetgever dat graag ziet. Let wel! De lijsten voorzien niet in een zelfstandige vernietigingsgrond. Voor vernietiging zal steeds moeten worden teruggegrepen op artikel 6:233 sub a BW. De bepalingen van de lijsten leggen immers slechts vast of een beding onredelijk bezwarend is of niet, of dat het behept is met een weerlegbaar vermoeden daarvan.

De lijsten geven eveneens een vrij gedetailleerd beeld over hetgeen de overheid ten aanzien van de rechten en plichten bij consumentenovereenkomsten ziet als een soort contractuele "grondrechten" van de consument. Zo staan in de lijsten van de artikelen 6:236 BW en 6:237 BW duidelijk voorop:

- het recht van de consument op nakoming wan de prestatie zoals deze is toegezegd;

- zijn bevoegdheid om te ontbinden, op te schorten en schadevergoeding te vorderen indien de gebruiker tekortschiet in de door hem toegezegde prestatie;

- dat hij in beginsel tot niet meer gehouden is dan waartoe hij zich uitdrukkelijk verbond.

In die zin hebben de lijsten een expliciet zo bedoelde reflexwerking en geven zij een helder zicht op hetgeen volgens de wetgever bij consumententransacties geboden is. Bedingen die niet onder het (soms beperkte) toepassingsgebied van een bepaling van de lijsten vallen, maar een soortgelijke werking hebben, zijn derhalve reeds besmet met het vermoeden dat zij de consument wel eens onredelijk bezwarend zouden kunnen benadelen. Wellicht een reden voor de rechter het bewijs van het feit dat een beding niet onredelijk bezwarend is op te dragen aan de gebruiker. ${ }^{301}$ Overigens werkt deze reflexwerking niet alleen naar consumenten. $\mathrm{Zij}$ werkt ook door naar degenen die geen beroep kunnen

300 MvT, Parlementaire Geschiedenis, Inv, 3, 5 en 6, pag. 1652.

301 Zie in dezelfide zin: Jongeneel, dis:s, pag 227. 
doen op de lijsten of omdat zij geen consument zijn of omdat zij in het geheel geen beroep kunnen doen op afdeling 6.5.3 BW. Ook voor hen geven de lijsten aan wat onder "normale" omstandigheden geboden is. ${ }^{302}$

Vraag blijft echter wanneer een beding in consumententransacties valt onder het toepassingsgebied van de lijsten. Soms valt een beding immers niet onder de letter van een onderdeel van de lijsten te vangen, maar is het effect nagenoeg hetzelfde. Een voorbeeld hiervan is het, ook tijdens de parlementaire behandeling ter sprake gekomen ${ }^{303}$, beding dat de wederpartij reeds bij het sluiten van de overeenkomst verplicht tot een $100 \%$ vooruitbetaling voor een prestatie van de gebruiker die eerst later hoeft plaats te vinden. Van een letterlijke uitsluiting of beperking van de wettelijke bevoegdheid van de consument tot opschorting van de nakoming is geen sprake. Het beding regelt immers alleen de volgorde waarin de prestaties van partijen dienen te worden verricht. Het beding heeft echter wel hetzelfde effect als een beding dat de opschortingsbevoegdheid uitsluit. Er valt immers niets meer op te schorten. Valt een dergelijk beding nu well of niet onder de werking van artikel 6:236 sub c BW? In het geval van het hiervoor bedoelde beding is de Memorie van Toelichting, door mij aangepast aan de huidige artikelnummering, zeer resoluut:

"Er zij op gewezen dat de regel onder a geen betrekking heeft op de wraag of bij algemene voorwacarden bepalingen kunnen worden opgenomen over de volgorde waarin de prestaties moesen worden verricht; men denke in het bijzonder aan eest beding dat de consument tot voonuitbetaling verplicht, hetgeen uiterasard tot verlies van het opschortingsrecht leidt. " (...) "Dit neemt uiteraard niet weg dat zij wel aan artikel 6:233 sub a BW kunnen worden getoetst. ${ }^{\text {"304 }}$

Ook in het algemeen is de teneur in de parlementaire geschiedenis dat de bepalingen van de lijsten strikt moeten worden uitgelegd en dat niet de feitelijke werking van een beding relevant is maar de vraag of het beding naar de letter onder het werkingsgebied van de betreffende regeling in de lijsten valt. Voor het werkingsgebied van de bepalingen van de lijsten kan men echter niet alleen afgaan op de letterlijke wettekst. Zo is de werking van artikel 6:236 sub j BW uitgesloten voor huur-, pacht- en verzekeringsovereenkomsten. Men zal daarom steeds de toelichtende stukken uit de parlementaire geschiedenis moeten raadplegen om het werkingsgebied te achterhalen. Slechts in eén geval wordt bepaald dat de strekking ook relevant is. Namelijk bij artikel 6:236 sub $\mathrm{f}$ waarin bepaald wordt dat een beding dat tot bepaalde gevolgen strekt onredelijk bezwarend is. Een en ander noopt tot de conclusie dat bedingen die niet letterlijk onder én

302 Zie ower deze laatste reflexwerking: Wessels en Jongeneel, 1992, pag. 79-81; Verhoeven, pag. 108-111; Jongeneel, diss., pag. 271 e.v.

303 Parlementaire Gesshiedenis, Inv. 3, 5 en 6, pag. 1692-1694.

304 MvT, Parlementsire Geschiedenis, Inv. 3, 5 en 6, pag. 1693. 
van de onderdelen van de zwarte en grijze lijst vallen, moeten worden beoordeeld volgens de open norm. ${ }^{305}$ Uiteraard zullen bedingen die dezelfde strekking hebben als bedingen die op de lijsten staan, in het algemeen ook nêt zo onredelijk bezwarend zijn.

Bij het voorgaande dient well aangetekend te worden dat de letterlijke tekst van een beding in algemene voorwaarden niet doorslaggevend is voor de betekenis van zulk een beding. Volgens vaste jurisprudentie dient een beding immers uitgelegd te worden overeenkomstig "de zin die partijen in de gegeven omstandigheden over en weer redelijkerwijs aan deze bepalingen mochten toekennen" ${ }^{306}$ Dit kan betekenen dat een beding dat, om bij het eerdere voorbeeld te blijven, letterlijk slechts een vooruitbetaling regelt, in de gegeven omstandigheden uitgelegd moet worden als een uitsluiting of beperking van de opschortingsbevoegdheid. Alsdan valt zulk een beding uiteraard wél onder het werkingsgebied van de lijsten, in dit geval artikel 6:236 sub c BW.

Over de inhoud van de lijsten van de artikelen 6:236 en 6:237 BW zal ik kort zijn. Van een gedetailleerde bespreking van de inhoud van de beide lijsten moet ik in dit bestek afzien, daarvoor zij verwezen maar de uitvoerige toelichtingen in de parlementaire geschiedenis ${ }^{307}$ en de commentaren op de artikelen van Wessels en Jongeneel ${ }^{308}$ en van Verhoeven ${ }^{309}$. Ik wil daarom volstaan met een enkele algemene opmerking over de opbouw van de lijsten.

De zwarte en de grijze lijst zijn volgens hetzelfde principe opgebouwd. ${ }^{310}$ $Z i j$ beginnen met bedingen die ten opzichte van wat zonder die bedingen gegolden zou hebben, de rechten van de wederpartij of de verplichtingen van de gebruiker beperken. Voor de zwarte lijst zijn dit de bedingen sub a-g en voor de grijze lijst de bedingen sub a-h. Vervolgens bedingen waarin de verplichtingen van de wederpartij of de rechten van de gebruiker worden uitgebreid, respectievelijk de artikel 6:236 sub h-j BW en 6:237 sub $\mathrm{i}-\mathrm{j}$ BW. Sluitstuk vormen tenslotte de bedingen van andere aard, de bedingen sub $k$ tot en met $\mathrm{m}$. De opbouw is overigens niet strikt, de overgangen zijn somtijds vloeiend en er zijn ook overlappingen. ${ }^{311}$ De bepalingen op de grijze lijst kunnen op grond van het bepaalde in artikel 6:239 BW, nadat de Minister de naar zijn oordeel representatieve gebruikers- en consumentenorganisaties heeft gehoord, bij

305 Jongeneel, dilss., pag. 227.

306 HR 13 maart 1981, NJ 1981, 635, m.rnt. C.J.H.B., AA 1981, pag. 355, m.nt. Van Schilfgaarde (Haviltex).

307 Parlementaine Geschiedenis, Inv. 3, 5 en 6, pag. 1686-1749.

308 Wessels en Jongeneel, 1992, pag. 87-164.

309 Verhoeven, pag. 82-108.

310 MVT, Parlementaine Geschiedenis, Inw. 3, 5 en 6, pag. 1685.

311 MvT, Parlementaire Geschiedenis, Inv. 3, 5 en 6, pag. 1685; Asser-Hartkamp II, 1993, nr. 362; Wessels en Jongeneell, 1992, pag. 83. 
algemene maatregel van bestuur worden gewijzigd en kan hun toepassingsgebied worden beperkt.

\subsubsection{De Haagse lijst, artikel $6: 243 \mathrm{BW}$}

Naast de twee lijsten van de artikelen 6:236 en 6:237 BW zal er een derde lijst ontstaan van bedingen die altijd vernietigbaar zijn. ${ }^{312}$ Het betreft de bedingen die door een uitspraak van het Haagse Hof in een procedure ex artikel 6:240 BW zijn getroffen met een verbod van gebruik als bedoeld in artikel $6: 241$ lid 3 $\mathrm{BW}{ }^{313}$ Artikel 6:243 BW bepaalt dat deze bedingen vernietigbaar zijn.

\section{Artikel 6:243 BW}

Een beding in algememe voorwaarden dat door degene jegens wie een verbod tot gebruik enwan is uitgesproken, in strijd met het verbod in een overeenkomst wordt opgenomen, is vernietigbaar. Artikel 235 is wan overeenkomstige toepassing.

Daarmee geeft artikel 6:243 $\mathrm{BW}$ aan de wederpartij een zelfstandige vernietigingsgrond naast die van de artikelen 6:233 en 6:234 BW. De wederpartij hoeft in dat geval geen beroep te doen op de open norm. De rechter heeft, net alls bij bedingen die bestreken worden door de bepalingen van de zwarte lijst, geen discretionaire bevoegdheid. Indien een door een Haags verbod getroffen beding in strijd met dit verbod door de gebruiker in zijn overeenkomst wordt opgenomen, is dit beding zonder meer vernietigbaar. ${ }^{314}$ De uitspraken van het Haagse Hof gaan mijn inziens fungeren als een soort zwarte lijst. Deze lijst onderscheidt zich van de zwarte en grijze lijst doordat deze "Haagse" lijst niet alleen op consumenten maar eveneens op andere wederpartijen betrekking kan hebben. Verbodsvorderingen kunnen immers ook worden ingediend door organisaties van professionele wederpartijen. ${ }^{31 s}$

Hoe komt de (consument-)wederpartij er echter achter dat het beding waarmee zij geconfronteerd wordt mogelijk getroffen is door een verbod van gebruik? In deze wordt mijns inziens node een deugdelijk en eenvoudig toegankelijk register van uitspraken van het Haagse Hof gemist. De vaste Commissie voor Justitie heeft tijdens de parlementaire behandeling herhaaldelijk aangedrongen op de realisatie van een goed toegankelijke registratie van op basis van afdeling 6.5 .3

312 VV I, Parlementaire Geschiedenis, Inw, 3, 5 en 6, pag. 1777; MvA I, Parlementaire Geschiedenis, Inv. 3, 5 en 6, pag. 1779.

313 Zie ook: Verhoeven, pag. 129-130.

314 Parlementaire Geschiedenis, Inv, 3, 5 en 6, pag. 1791-1794.

315 Zie artikel 6:240 lid 3 BW. 
BW aanhangig gemaakte procedures en gegeven rechterlijke uitspraken. ${ }^{316}$ Met het kostenargument voorop en voorts argumenten die zich slechts richten tegen een centrale registratie van algemene voorwaarden, werd de centrale registratie van aanhangig gemaakte procedures bij en uitspraken van het Haagse Hof, eigenlijk zonder enige motivering zijdens de Minister, afgewezen. ${ }^{317}$ Het is mijns inziens, mede met het oog op de rechtszekerheid en een efficiènte rechtspleging, een ernstig manco dat de Kamer in deze niet vasthoudender is geweest.

\subsubsection{Verjaring en verval}

Een rechtsvordering tot vernietiging verjaart, op grond van artikel 3:52 lid 1 sub d BW, in beginsel drie jaren nadat de bewoegdheid om de vernietigingsgrond in te roepen aan degene aan wie deze bevoegdheid toekomt, ten dienste is komen te staan. Op grond van het bepaalde in artikel 6:235 lid 4 BW begint deze termijn van drie jaar voor wat betreft de vernietiging van algemene voorwaarden op grond van de artikelen 6:233, 6:234 en 6:243 BW, te lopen op de dag volgende op die waarop door de gebruiker een beroep op het beding is gedaan. ${ }^{318}$ Zoals reeds eerder vermeld, gaat de bepaling er van uit dat de wederpartij pas kennis neemt van de inhoud of het bestaan van algemene voorwaarden op het moment dat de gebruiker er een beroep op doet. ${ }^{319}$ Dit betekent tevens dat de gebruiker van het vernietigbare beding vanaf dat moment pas een beroep kan doen op artikel 3:55 lid 2 BW. Artikel 3:55 lid 2 BW geeft de gebruiker de mogelijkheid de wederpartij een redelijke termijn te stellen waarbinnen deze, op straffe van verval van zijn vernietigingsbevoegdheid, een keuze moet doen tussen bevestiging (3:55 lid $1 \mathrm{BW})$ en vernietiging. ${ }^{320}$

Artikel 3:52 lid 2 BW brengt met zich dat na de verjaring van de vernietiging van de rechtshandeling, deze niet meer op dezelfde vernietigingsgrond door een buitengerechtelijke verklaring kan worden vernietigd. Dit moet worden gezien als een verval van de vernietigingsbevoegdheid. ${ }^{321}$ Op grond van het bepaalde in artikel 3:51 lid $3 \mathrm{BW}$ staat het verstrijken van de termijn van drie

316 VV, Parlementaire Geschiedenis, Inv, 3, 5 en 6, pag. 1785; EV, Parliementaire Geschiedenis, Inv. 3, 5 en 6, pag. 1592 .

317 MVT, Parlementaire Geschiedenis, Inv. 3, 5 en 6, pag. 1582; MvA, Parlementaire Gessehiedenis, Inv. 3, 5 en 6, pag. 1585; NEV, Parlementaire Geschiedenis, Inv. 3, 5 en 6, pag. 1597.

318 Mv.A, Perlementaire Geschiedenis, Inw. 3, 5 en 6, pag. 1628-1629.

319 MvA, Parlementaine Gesehiedenis, Inv. 3, 5 en 6, pag. 1629.

$320 \mathrm{UCV}$ II, Handelingen Tweede Krmer, vergaderjaar 1984-1985, pag. 40-21 e.v.; Zie ook: Asser-Hartkamp II, 1989, pag. 331 .

321 Asser-Hartkamp II, 1993 , nr. 474. 
jaar echter niet in de weg aan een beroep op de vernietigingsgronden vam afdeling $6.5 .3 \mathrm{BW}$ bij wege van verweer in rechte. ${ }^{322}$

Behalve door tijdsverloop, kan de bevoegdheid zich buitengerechtelijk of in rechte op een vernietigingsgrond van afdeling 6.5.3 BW te beroepen, ook vervallen door bevestiging (3:55 lid $1 \mathrm{BW}$ ) of, zoals hiervoor reeds opgemerkt, doordat de wederpartij een door de gebruiker gestelde termijn als bedoeld in artikel 3:55 lid 2 BW laat verstrijken zonder een keuze te doen.

\subsubsection{Internationale aspecten}

De toepasselijkheid van afdeling 6.5.3 BW op overeenkomsten met internationale aspecten wordt nader geregeld in artikel 6:247 BW..$^{323}$

\section{Arrikel 6:247}

1. Op overecnkonsten tussen partijen die handeler in de witoefening van een beroep of bedriff en

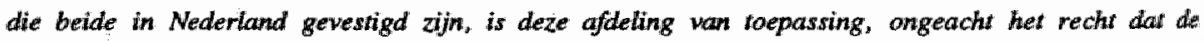
avereenkomst beheerst.

2. Op averenkomsten tussen partijen die havdehen in de witafening van een beroep of bedriff ent die niet beide in Nederland gevestigd zijn, is deze afdeling niet wa taepassing, ongeach het rech dat de overeenkomst beheerst.

3. Eien partij is in de an wan de Leden I en 2 in Nederland gevestigd "indien haar hoofdwestiging, of, zo de prestatie walgens de overeenkomst door een andere vestiging dan de hoofdvestiging moet worden verrichit, deze andere vestiging zich in Nederland bevindt.

4. Op overeenkomsten tussen een gebruiker en een wederpartij, natuurlijk persoon, die miet handeli in de witoefening wan een beroep of bedrijf, is, indisen de wederpartij hatar gewone verbliffplouts in: Nederland heeft, deze afdeling van toepassing, ongeach het recht dat de overeenkomst beheerst.

Het artikel is gebaseerd op enerzijds de gedachte dat behoefte bestaat aan rechtszekerheid omtrent de internationale werking van afdeling 6.5.3 $\mathrm{BW}^{324}$ en anderzijds de gedachte dat voorkomen moet worden dat de internationale handel door de afdeling wordt belemmerd. ${ }^{325}$

In artikel 6:247 BW is aansluiting gezocht bij het Verdrag van Rome van 19 juni 1980 inzake het recht dat van toepassing is op verbintenissen uit overeenkomst (EEG-verbintenissenverdrag). ${ }^{326}$

322 Asser-Hartkamp II, 1993, nr. 474.

323 Parlementaire Geschiedenis, Inw. 3, 5 en 6, pag. 1806-1817. Zie vender: Wessels en Jongeneel, 1992, pag. 207-213; Verhoeven, pag. 140-144; Asser-Hartkamp II, 1993, nr. 375; Westenberg; pag. $461-466$.

324 MvT, Parlementaüre Geschiedenis, Inv. 3, 5 en 6, pag. 1807; MvA, Parlementaine Geschiedenis, Inv, 3, 5 en 6 , pag. 1810.

325 MvT, Parlementaire Geschiedenis, Inv. 3, 5 en 6, pag. 1807.

326 Trb. 1980. 156. 
Uitgangspunt van het EEG-verbintenissenverdrag (EEV) is de rechtskeuze van partijen (artikel 3 leden 1 en 2 EEV). Indien echter, op het tijdstip van de rechtskeuze voor een buitenlands recht, alle overige elementen van het geval met een enkel land zijn verbonden, laat deze rechtskeuze de dwingende wetsbepalingen van dat land onverlet (artikel 3 lid 3 EEV).

Indien partijen geen rechtskeuze hebben gemaakt, wordt de overeenkomst beheerst door het recht van het land waarmee zij het nauwst is verbonden (artikel 4 lid 1 EEV). In de meeste gevallen is dit het land waar de partij die de kenmerkende prestatie moet verrichten, ten tijde van het sluiten van die overeenkomst, haar woon- of vestigingsplaats heeft (artikel 4 lid 2. EEV). ${ }^{327}$

Voor consumentenovereenkomsten die betrekking hebben op de levering van roerende lichamelijke zaken of de verstrekking van diensten voor niet-professioneel gebruik ${ }^{328}$, alsmede de overeenkomsten ter financiering van een dergelijke levering of verstrekking, voorziet artikel $5 \mathrm{EEV}$ in een uitzonderingsregime. Indien partijen een rechtskeuze hebben gemaakt, geniet de consument in een aantal gevallen toch altijd de bescherming van de dwingende wetsbepalingen van het land waar hij zijn gewone verblijfplaats heeft (artikel 5 lid 2 EEV). Indien bij de bedoelde consumentenovereenkomst echter geen rechtskeuze is gemaakt, wordt in deze gevallen de overeenkomst beheerst door het recht van het land waar de consument zijn gewone verblijfplaats heeft (artikel 5 lid 3 EEV).

Artikel $7 \mathrm{EEV}$ voorziet eveneens in een uitzonderingsregime, maar dan voor consumentenovereenkomsten die niet onder artikel $5 \mathrm{EEV}$ vallen en voor nietconsumentenovereenkomsten. ${ }^{329}$ Op grond van artikel 7 lid 1 EEV kan de rechter indien hij op grond van het EEG-verbintenissenverdrag het recht van een bepaald land toepast, tevens gevolgen toekennen aan de dwingende wetsbepalingen van een ander land die naar het recht van dat andere land toepasselijk zijn ongeacht het recht dat de overeenkomst beheerst, indien het betreffende geval naw is verbonden met dat andere land. De rechter wordt daarin echter vrij gelaten. Hij kan ook besluiten de dwingende wetsbepalingen van dat andere land niet toe te passen. Bovendien is artikel 7 lid 1 EEV niet van toepassing in de landen die weliswaar partij zijn bij het verdrag, maar tevens gebruik hebben

327 De uttzondleringen worden genoend in artikel 4 lid 5 EEV.

328 Uitgezonderd de vervoenowereenkomst en overeenkomsten tot verstrekking van diensten die uitisluitend worden versitrekt in cen ander land dan war de consument zijn gewone verbliffplaats heeft (artikel 5 lid 4 EEV).

329 De aunvullendie werking van artikel 7 EEV voor overeenkomsten die niet onder het bereik wan artikel 5 EEV vallen is in de literathur nogal omatreden. Zie: Rammeloo, diss., pag. 341 e.w. 
gemaakt van de mogelijkheid van artikel 22 lid 1 EEV om een voorbehoud te maken ten aanzien van de toepassing van artikel 7 lid $1 \mathrm{EEV} .{ }^{330}$

Artikel 7 lid 2 EEV bepaalt voorts, dat het EEG-verbintenissenverdrag de toepassing van de bepalingen van het recht van het land van de rechter onverlat laat, indien deze wetsbepalingen op grond van diens nationale recht dwingend: zijn ongeacht het recht dat de overeenkomst beheerst.

Partij bij het EEG-verbintenissenverdrag zijn: België, Denemarken, de Bondsrepubliek Duitsland, Frankrijk, Griekenland, Ierland, Italië, Luxemburg, Nederland en het Verenigd Koninkrijk. Het verdrag is voor Nederland op 1 september 1991 in werking getreden, hetgeen impliceert dat de Nederlandse rechter het verdrag toepast op alle overeenkomsten die na 1 september 1991 zijin gesloten. ${ }^{331}$

Artikel 6:247 BW geeft aan van welke regels van afdeling 6.5.3 BW volgens Nederlands recht niet mag worden afgeweken ongeacht het recht dat de overeenkomst beheerst. Regels dus als bedoeld in de artikellen 3,5 en 7 van hel EEG-verbintenissenverdrag.

\subsubsection{Handelstransacties}

De internationale werking van afdeling $6.5 .3 \mathrm{BW}$ is voor wat betreft de transacties tussen ondernemers onderling, geregeld in de leden een tot en met drie van artikel 6:247 BW.

Uit lid 1 van dit artikel vloeit voort dat woor de Nederlandse rechter, afdeling 6.5.3 BW steeds van toepassing is indien de partijen beide in Nederland gevestigd zijn, ongeacht het recht dat de overeenkomst beheerst. ${ }^{332} \mathrm{Bij}$ de bepaling van lid 1 staat, naast de behoefte aan rechtszekerheid, de beschermingsfunctie voorop. Afdeling 6.5.3 BW is op grond van artikel 6:246 $\mathrm{BW}$ immers ook van toepassing op partijen die handelen in de uitoefening van hun beroep of bedrijf en biedt ook deze partijen bescherming. Bij een overeenkomst die, blijkens het feit dat beide partijen in Nederland gevestigd zijn, op duidelijke wijze met de Nederlandse rechtsorde is verbonden, dient afdeling 6.5.3 BW van toepassing te zijn, ongeacht het recht dat deze overeenkomst beheerst. ${ }^{333}$

De bepaling van artikel 6:247 lid $1 \mathrm{BW}$ bewerkstelligt vanuit IPR-perspectief twee dingen. Allereerst dat de Nederlandse rechter altijd afdeling 6.5.3 BW dient toe te passen indien de betrokken partijen ondernemer zijn en in Nederland

330 De Bondsrepubliek Duitsland, Luxemburg en het Verenigde Koninkrijk hebben van dexe mogelijkheid gebruik gemaakt. Zie: Wessels en Jongeneel, 1992, prg. 209.

331 Wessels en Jongeneel, 1992 , pag. 208.

332 Niet relevant is of het vreemde recht door partijafspraak of door IPR-conflietregel van toepasising is op de overeenkomst. Zie ook: Verhoeven, pag. 141.

333 MvA, Parlementaire Geschiedenis, Inv, 3, 5 en 6, pag. 1811 . 
zijn gevestigd..334 Voorts, dat indien in Nederland gevestigde partijen hun conflict ter beoordeling voorleggen aan een buitenlandse rechter, deze gevolg kan toekennen aan de regels van afdeling 6.5.3 BW op grond van de in zijn land toepasselijke IPR-conflictregels. ${ }^{335}$

Lid 2 van artikel 6:247 BW wil vooral tegengaan dat afdeling 6.5 .3 belemmerend werkt voor de internationale handel tussen ondernemingen. Het bepaalt derhalve dat afdeling 6.5.3 BW in beginsel nimmer van toepassing is indien eén wan de partijen buiten Nederland is gevestigd, ook niet indien de overeenkomst voor het overige door Nederlands recht wordt beheerst. ${ }^{330}$ De strekking van de regel van artikel 6:247 lid 2 BW verzet zich echter niet tegen toepasselijkheid van afdeling 6.5.3 BW, "indien deze toepasselijkheid in het kader van een rechtskeuzeclausule uitdrukkelijk wordt overeengekomen ". ${ }^{337}$

Artikel 6:247 lid 3 BW legt naar het voorbeeld van het artikel 4 lid 2 EEV vast, wat dient te worden verstaan onder de vestigingsplaats van de in de leden 1 en 2 bedoelde ondernemingen. ${ }^{338}$

\subsubsection{Consumententransacties}

Ook bij artikel 6:247 lid $4 \mathrm{BW}$ staat de beschermingsfunctie voorop. ${ }^{339}$ Artikel 6:247 lid 4 BW bepaalt dat afdeling 6.5.3 BW van toepassing is op alle transacties waarbij de wederpartij een consument is die zijn gewone verblijfplaats in Nederland heeft. De regel sluit aan bij artikel 5 van het EEG-verbintenissenverdrag maar heeft een verdergaande strekking. De toepasselijkheid van dwingende wetsbepalingen van het land van de consument wordt door artikel 5 EEV immers enerzijds beperkt tot een aantal met name genoemde overeenkomsten (artikel 5 leden 1, 4 en 5 EEV) en anderzijds afhankelijk gemaakt van de voorwaarden genoemd in artikel 5 lid 2 EEV. Artikel 6:247 lid 4 BW kent deze beperkingen echter niet. ${ }^{340}$ Een in Nederland wonende consument kan zich altijd op de dwingendrechtelijke bescherming van afdeling 6.5.3 BW beroepen. De Nederlandse rechter zal afdeling 6.5.3 BW derhalve steeds moeten toepassen op internationale transacties waarbij de wederpartij een in Nederland woonachtig

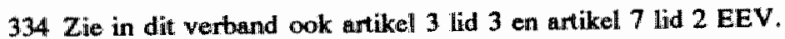

$335 \mathrm{Zie}$ in dit verband artikel 7 lid $1 \mathrm{EEV}$ en voorts: EV, Parlementaire Geschiedenis, InN. 3, 5 en 6. pag. 1812; NEV, Parlementaire Geschiedenis, Inw. 3, 5 en 6, pag. 1812.

336 MvA, Parlementaire Geschiedenis, Inv, 3,5 en 6, pag. 1811 .

337 MvA 1, Parlementaine Geschiedenis, Inv. 3, 5 en 6, pag. 1816.

$338 \mathrm{VV}$, Parlementaire Geschiedenis, lnv. 3, 5 en 6, pag. 1808; MwA, Parlementaire Geschiedenis, Inv. 3, 5 en 6, pag. 1810.

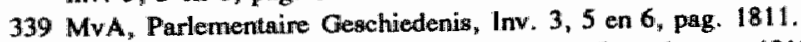

340 MvA, Parlementaire Geschiedenis, Inw. 3, 5 en 6, pag. 1810. Zie ook: Wessels en Jongencel, 1992, pag. 211-212; Verthoeven, pag. 143-144. 
consument is. ${ }^{341}$ De buitenlandse rechter zall, indien volgens de in zijn land geldende IPR-conflictregels ander dan Nederlands recht op de overeenkomst van toepassing is, gevolg kunnen toekennen aan de regels van afdeling 6.5.3 $\mathrm{BW}$ op grond van de in zijn land toepasselijke IPR-conflictregels. ${ }^{342}$

Voor de toepassing van artikel 6:247 lid 4 BW wordt geen onderscheid gemaakt tussen professionele gebruikers van algemene voorwaarden en consumenten die algemene woorwaarden gebruiken in hun overeenkomsten met andere consumenten. ${ }^{343}$ Beslissend is slechts de vraag of de wederpartij zijn gewone verblijfplaats heeft in Nederland. De hoedanigheid van de gebruiker is irrelevant.

Artikel 6:247 lid 4 BW geeft geen antwoord op de vraag welk recht van toepassing is op in Nederland gesloten overeenkomsten tussen in Nederland gevestigde gebruikers van algemene voorwaarden en buitenlandse consumenten als wederpartij. In dat geval dienen de oplossingen gezocht te worden in de toepasselijk IPR-conflictregells. Tijdens het mondelinge overleg in de Eerste Kamer, tussen de Minister van Justitie en de B̈̈jzondere Commissie voor de herziening van het Burgerlijk Wetboek, werd hierover het volgende opgemerkt:

"Op een overeenkomst tussen een buitenkandse toerist en een Nederlandse gebruiker van algemene voarwaarden is krachtens algemene regels wan internationaal privaatrecht het Nederlandse recht in beginsel wan toepassing omdat de Nederlandse contractspartif, dus de verkoper, de verhuurder efc." de karakteristieke prestatie verricht. Dan is dus ook afdeling 6.5.2A wan toepassing.

Naar mijn mening ligt de zaak niet zo eenvoudig. Allereerst dient men zich namelijk af te vragen welke rechter door de buitenlandse consument wordt geadieerd. Is dit de Nederlandse rechter of een buitenlandse collega? In thet eerste geval ligt de zaak eenvoudig. Op grond van artikel 7 lid $2 \mathrm{EEV}$ dient de Nederlandse rechter de bepalingen van afdeling $6.5 .3 \mathrm{BW}$ toe te passen ongeacht het recht dat de overeenkomst beheerst. ${ }^{345}$ Het wordt aanzienlijk gecompliceerder indien de buitenlandse consument zijn conflict voorlegt aan een buitenlandse rechter. Deze dient voor de oplossing van de vraag welk recht op deze overeenkomst van toepassing is, te rade te gaan bij de in zijn land geldende IPR-conflictregels. Daaruit kan zeer goed voortvloeien dat een ander recht van

341 MvA, Parlementaire Gesehiedenis, Inv, 3, 5 en 6, pag. 1811. Zie in dit werband ook artikel 7 lid 2 EEV.

342 MvA, Parlementaire Geschiedenis, Inv. 3,5 en 6, pag. 1811. Zie in dit werband ook artikel 7 lid 1 EEV.

343 Zie hilerwoor paragraaf 1.5.4.

$344 \mathrm{MO}$, Parliementaire Geschiedenis, Inw, 3, 5 en 6, pag. 1816.

345 Zie noot 299. 
toepassing is dan het Nederlandse. ${ }^{346}$ Ook indien de buitenlandse consument zijn klacht voorlegt aan een rechter van een land dat partij is bij het EEGverbintenissenverdrag, staat gezien het bepaalde in met name de artikelen 5 en 7 EEV, allerminst vast dat afdeling 6.5.3 BW toegepast zal worden door die rechter. $^{347}$

\subsubsection{Forumkeuze}

Bij internationale transacties waarbij algemene voorwaarden worden gebruikt is niet alleen interessant de vraag welk recht op de overeenkomst van toepassing is, maar tevens de vraag bij welke rechter de wederpartij terecht kan. Is de Nederlandse rechter bevoegd of een buitenlandse? Voor iedere rechter gelden zijn eigen nationale bevoegdheidregels. Het is derhalve zeer wel mogelijk dat in bepaalde geschillen zowel de buitenlandse als de Nederlandse rechter bevoegd is. ${ }^{348} \mathrm{Bij}$ de vraag welke rechter in geschillen betreffende internationale overeenkomsten bevoegd is, zijn voor de Nederlandse rechter twee situaties te onderscheiden:

a. Nederlandse wetsbepalingen of een in Nederland geldend verdrag geven een expliciete regel betreffende de internationale rechtsmacht;

b. Een expliciete regel ontbreekt.

Voor wat betreft algemene voorwaarden zijn de belangrijkste in ons land geldende regelingen van internationale rechtsmacht het EEG-executieverdrag (hierna EEX) $)^{349}$ en het Verdrag van Lugano ${ }^{350}$. Hoofdregel van beide verdragen is, dat de gedaagde die woonplaats heeft op het grondgebied van een verdragsluitende staat, ongeacht zijn nationaliteit, wordt gedagvaard voor de

346 Zie in dit verband met name: LG Köln 22 januari 1992, Nr. 260 142/91, VSV-Info 1992/3, pag. 1 , m.nt. Bultmann (VSV/Center Parcs), waarin ten aanzien van algemene voorwanden van een Nederlandse gebniker de Duitse rechter zich bevoegd verklande en daarop hat Duitse recht toepeuste. Zie ook: KG Berlin 22 juini 1994, Nr. U 939/94, VSV-Info 1994/3, pag. 1, m.nit. Bullimann (VSV/Novasiol); LG Berlin, 15 november 1993, VuR 1994, pag. IB4.

347 Danarbij komt dat artikel 7 lid 1 EEV in de Bondsrepubliek Duitsland, Luxemburg en het Verenigd Koninkrijk buiten toepassing blijft. Zie hiervoor paragraaf 5.2.7.1.

348 Hugenholtz/Heenmikerk, pag ", 21.

349 Verdrag wan Brussel van 27 september 1968 , betreffende de rechterlijke bevoegdheid en de temuitvoerlegging wan beslissingen in burgerlijke en handelszaken, (Trb. 1969, 101) laatstelijk gewijzigd bij Verdrag van Donastia-San Sebastian van 26 meil 1989 (Trb. 1989, 142). Hett wangepaste EEX-verdrag van Donastia-San Sebagtian is in Nederland in werking getreden op 1 februari 1991. Zile ook: Wessels en Jongeneel, 1992, pag. 213.

350 Verdiag van Lugano betneffende de rechterlijke bewoegdheid en de tenuitvoerlegging in burgerlijke en handelszaken (Trb. 1989, 58). Het vendrag regelt, overeenkomatig het EEX, de internationale rechtsmacht tussen de landen van de Europese Gemeenschap en de zes landen van de Europese Vrijhandels Associatie (EVA) Finland, Dostenrijk, Noorwegen, IJsland, Zweden en Zwitserland. Voor Nederland is het Verdrag van Lugano in werking getreden op 1 januari 1992. Zie: Wessels en Jongeneel, 1992, pag. 213m214. 
rechter van die staat (artikel 2 lid $1 \mathrm{EEX})^{351}$. Uitzonderingen op deze hoofdre gel zijn slechts toegellaten krachtens de bepalingen van het verdrag (artikelen 5 18 EEX). Een wereldomvattende jurisdictieverdeling is niet voorhanden ${ }^{35}$ ? Indien een expliciete wets- of verdragsregel ontbreekt geldt naar vaste Nederlandse jurisprudentie ${ }^{333}$ de regel, dat de Nederlandse rechter bevoegd is indien naar de in Nederland geldende regels van de relatieve competentie een bepaalde Nederlandse rechter bevoegd is.

Voor wat betreft consumenten kunnen in deze materie doorgaans ${ }^{354}$ twee situaties worden onderscheiden:

1. Een Nederlandse consument sluit een overeenkomst met een buitenlandse gebruiker van algemene voorwaarden;

2. Een buitenlandse consument sluit een overeenkomst met een Nederlandse gebruiker van algemene voorwaarden.

ad 1.

In het geval dat een Nederlandse consument een overeenkomst sluit met een buitenlandse gebruiker van algemene voorwaarden zijn bij toepasselijkheid van het EEG-executieverdrag (of het nagenoeg identieke Verdrag van Lugano) met name de op consumenten gerichte artikelen 13-15 EEX van belang. Deze artikelen zien op enerzijds koopovereenkomsten betreffende roerende goederen en kredietovereenkomsten ter financiering daarvan (artikel 13 sub 1 en 2 EEX) en anderzijds alle andere overeenkomsten die betrekking hebben op de verstrekking van diensten of de levering van onroerende goederen mits deze zijn voorafgegaan door aanbiedings- of aanvaardingshandelingen in het land van de consument (artikel 13 sub 3 EEX). Indien sprake is van een in artikel 13 EEX genoemde overeenkomst heeft de Nederlandse consument, op grond van artikel 14 EEX, de keuze tussen de Nederlandse rechter en de rechter van het land waar de gebruiker is gevestigd. De rechtsvordering tegen de Nederlandse consument kan in die gevallen slechts in Nederland worden ingesteld.

In geval van overeenkomsten die buiten de werkingssfeer van artikel 13 EEX vallen, geldt de algemene regel van artikel 3 EEX dat de (buitenlandse) rechter van de woonplaats van de gebruiker bevoegd is, tenzij dit anders is

351 Vanwege de verregaande gelijkenis met het EEG-executieverdrag en de analoge werking, worden de bepalingen van het Verdrag wan Lugano niet afzonderlijk genoemd.

352 Hugenholtz/Heemskerk, pag. 21.

353 Hugenholtz/Heernskerk, pag. 22, noot 15.

354 Uiteraard is het ook mogelijk dat een Nederlandse consument contracteert met een buitenlandse consument die algemene voorwaanden hanteert. Omgekeend kan ook de Nederlandse consument gebruiker zijn. Deze gevallen zullen zich in de praktijk echter niet vaak voordoen. Ik heb dan ook afgezien van afzonderlijke bespreking van deze casuspositic. 
bepaald in de afdelingen $2,3,5$ en 6 EEX. Voor Nederlandse consumenten zijn met name van belang:

- artikel 5 lid 1 EEX, dat bepaalt dat de gebruiker voor de Nederlandse rechter kan worden opgeroepen bij verbintenissen die zijn of moeten worden uitgevoerd in Nederland;

- artikel 8 lid 2 EEX, dat bepaalt dat de Nederlandse rechter bevoegd is indien de verzekerde bij een verzekeringsovereenkomst in Nederland zijn woonplaats heeft;

- artikel 9 EEX, dat bepaalt dat de verzekeraar in geval van een aansprakelijkheidsverzekering of een verzekering met betrekking tot onroerende goederen, voor de Nederlandse rechter kan worden opgeroepen indien de schadetoebrengende gebeurtenis in Nederland heeft plaatsgevonden;

- artikel 16 lid 1 sub a EEX, dat bepaalt dat de Nederlandse rechter bevoegd is indien het betreft algemene voorwaarden met betrekking tot onroerende goederen in Nederland gelegen;

- artikel 17 EEX, dat de mogelijkheid schept dat partijen de Nederlandse rechter als bevoegd aanwijzen;

- artikel 18 EEX, dat de Nederlandse rechter in beginsel bevoegd verklaart indien de buitenlandse gebruiker voor hem verschijnt.

Indien het EEG-executieverdrag of het Verdrag van Lugano niet van toepassing is, is de Nederlandse rechter bevoegd indien partijen dat zo hebben bepaald door een jurisdictie- of forumkeuze beding. ${ }^{355}$ Indien dat niet het geval is, heeft de Nederlandse rechter slechts rechtsmacht indien hij dat volgens de regels van de relatieve competentie ook zou hebben.

Voor wat betreft kantongerechtsprocedures moet daarvoor gekeken worden naar artikel $98 \mathrm{Rv}$ en voor rechtbankprocedures artikel $126 \mathrm{Rv}$. Zo geldt voor (voor algemene voorwaarden weinig relevante) kantongerechtszaken met betrekking tot arbeids- of agentuurovereenkomsten dat de Nederlandse kantonrechter bevoegd is indien de arbeid gewoonlijk binnen Nederland wordt verricht (artikel 98 lid $2 \mathrm{Rv}$ ). In geval van algemene voorwaarden met betrekking tot pacht of huur van onroerende zaken is de Nederlandse kantonrechter in beginsel slechts bevoegd indien het onroerende goed binnen Nederland is gelegen (artikel 98 lid $1 \mathrm{Rv}$ ). In zaken betreffende algemene voorwaarden bij andere overeenkomsten is de Nederlandse kantonrechter bevoegd op grond van artikel 98 lid 3 Rv. 
ad 2 .

Indien het EEG-executieverdrag of het Verdrag van Lugano van toepassing is op een buitenlandse consument die een overeenkomst sluit met een Nederlandse gebruiker van algemene voorwaarden, geniet deze buitenlandse consument dezelfde bescherming als de Nederlandse consument. Deze buitenlandse consument kan, afhankelijk van de soort overeenkomst en de omstandigheden, immers op dezelfde bepalingen een beroep doen. Als echter geen explieliete regeling met betrekking tot de internationale rechtsmacht voorhanden is, is de Nederlandse rechter slechts bevoegd indien hij dat naar regels van relatieve competentie ook zou zijn. Dat betekent dat de Nederlandse rechter bevoegd is in alle gevallen waarin deze regels voorzien in of de bevoegdheid van de rechter van de woonplaats van de Nederlandse gebruiker (bij voorbeeld artikel 126 lid 1 Rv) of de bevoegdheil van een andere Nederlandse rechter (bij voorbeeld. artikel 98 lid 1 of lid 3 Rv).

\subsection{Collectieve actie en procesrechtelijke bepalingen}

Een bijzonder aspect van de regeling van afdeling 6.5.3 BW is ongetwijfeld dat de inhoudstoetsing van artikel 6:233 sub a BW niet alleen geëntameerd kan worden door individuele wederpartijen bij de gewone rechter, maar ook door branche- en consumentenorganisaties bij een bijzondere rechter. Branche- en consumentenorganisaties hebben daarbij de mogelijkheid een collectief van gebruikers te dagvaarden. Daartoe zijn in afdeling 6.5.3 BW de artikelen 6:240 tot en met 6:243 BW opgenomen en zijn de artikelen 4 sub 13, 9 lid 3,67 en 1003 tot en met 1006 aan het Wetboek van Burgerlijke Rechtsvordering toegevoegd. ${ }^{356}$ Met de regeling van de collectieve actie is het Advies van de Commissie voor Consumentenaangelegenheden van de SER, waarin wordt aangedrongen op een preventief collectief controle mechanisme $e^{357}$, gevolgd. ${ }^{358} \mathrm{De}$ collectieve actie

"... beoogt, mede door de prikkel tot onderhandelen die zij vorm, een "collectief" controlemechanisme te bieden regen het in wezen collectiewe werschijinsel der algemene voorwararden. "359

Het vorderingsrecht van artikel 6:240 lid $1 \mathrm{BW}$ - en de daaraan verbonden nevenvorderingen - is aan consumentenorganisaties vooral toegekend in de

356 Parlementaire Geschiedenis, Inv, 3,5 en 6, pag. 1761-1794. Zie hierover ook: Wessels ent Jongeneel, 1992, pag. 165-200; Vertoeven, pag. 113-132; Asser-Hartkamp II, 1993, nr. 369. 371; Rijken, KwINBW 1984, pag. 126-128.

357 CCA-advies, pag. 19-39.

358 MvT, Parlementaire Geschiedenis, Inv. 3, 5 en 6, pag. 1457 en 1762.

359 MvT, Parlementaire Geschiedenis, Inv. 3, 5 en 6, pag. 1762. 
verwachting dat alleen al de dreiging van een verbodsprocedure de gebruikers van algemene voorwaarden en hun branche-organisatie aan de onderhandelingstafel zal brengen en dat op die wijze algemene voorwaarden tot stand komen die op evenwichtige wijze rekening houden met de wederzijdse belangen. ${ }^{360} \mathrm{De}$ collectieve actie van artikel 6:240 e.v. BW beoogt daarmee niet alleen een drukmiddel te zijn om de gebruikers en hun organisaties aan de tafel te krijgen maar tevens een drukmiddel om binnen bekwame tijd tot een resultaat te geraken. ${ }^{361}$ Het belang dat de wetgever aan deze onderhandelingen hecht wordt verder ondersteund door de "overlegverplichting" van artikel 6:240 lid 4 BW en de instemmingsregeling van artikel 6:240 lid 5 BW.

Daarnaast wil de collectieve actie een oplossing bieden voor een aantal bezwaren die kleven aan de individuele rechterlijke controle. Op de eerste plaats valt daarbij te denken aan het feit dat de individuele rechterlijke controle in beginsel slechts repressief is en, afgezien van de precedentwerking, geen preventieve waarde heeft. ${ }^{362}$ Ter toetsing kunnen immers slechts algemene voorwaarden in reeds gesloten overeenkomsten worden voorgelegd. Hernieuwd gebruik van een onredelijk bezwarend verklaard beding in een volgende overeenkomst kan dan slechts worden tegengegaan door middel van een nieuwe procedure. De collectieve actie werkt daarentegen naar de toekomst en heeft daardoor een preventief karakter. Getoetst wordt immers met het oog op bedingen in algemene voorwaarden die gebruikt zullen worden in nog te sluiten overeenkomsten. ${ }^{363}$ In geval van toetsing van een aanbeveling tot gebruik van bepaalde algemene voorwaarden (artikel 6:241 lid 3 sub b BW) kan deze toetsing zelfs plaatsvinden voordat de aanbevolen algemene voorwaarden feitelijk zijn gebruikt in een overeenkomst. Verder valt te denken aan het gegeven dat de rechterlijke uitspraak in de individuele procedure slechts een beperkte reikwijdte heeft omdat de uitspraak slechts werking heeft tussen de partijen betrokken in die procedure, hetgeen met name bij een collectief verschijnsel als algemene voorwaarden weinig effectief is ${ }^{364}$ Op de derde plaats dient gedacht te worden aan de "ontoegankelijkheid" van de burgerlijke rechter voor de individuele consument. ${ }^{365}$

360 MvT, Parlementaire Geschiedenis, Inv. 3, 5 en 6, pag. 1455 en 1764-1765; MvA, Parlementajre Geschiedenis, Inv, 3, 5 en 6, pag. 1515.

361 MVA 1, Parlementaire Geschiedienis, Inv. 3, 5 en 6, pag. 1780.

362 VV, Parlementaire Geschiedenis, Inv. 3, 5 en 6, pag. 1460 en 1766, MvA, Parlementaine Geschiedenis, Inv. 3,5 en 6 , pag. 1461 en 1769. Zie ook hiervoor paragraf 3.5.3.

$363 \mathrm{VV}$, Parlementaire Geschiedenis, Inv. 3,5 en 6, pag. 1.460-1461 en 1766.

364 Zie hierwoor paragraaf 3.5.2.

$365 \mathrm{VV}$, Parlementaire Geschiedenis, Inv. 3, 5 en 6, pag $1460^{\circ}$, Zie hiervoor paragraaf 3.5.1.1. 


\subsubsection{De hoofdvordering}

De basis van de collectieve actiebevoegdheid (ius agendi) op het terrein van de algemene voorwaarden is gelegen in het eerste lid van artikel 6:240 lid $1 \mathrm{BW}$.

\section{Artikel 6:240 lid' I BW}

Op vordering wan een rechtspersoon als bedoeld in lid 3 kwnen bepacilde bedingen in bupande algemene yoonwaarden onredelijk bezwarend worden verklacard; de artikelen 233 onder 0,236 . 237 zijm van overeenkomstige toepassing. Voor de toepassing van de vorige zin wordr een bieding th algemene voonvaarden dat in strijd is met een dwingende wetsbepaling, als onredelijk bezwarend aangemerhs:

Lid 1 geeft de bijzondere rechter de mogelijkheid om door middel van een verklaring van recht bedingen in algemene voorwaarden onredelijk bezwarend te verklaren.

Uit de bepaling vloeit uitdrukkelijk voort dat de rechtsvordering steeds bepaalde bedingen moet betreffen. De set algemene voorwaarden kan als zodanig dan ook geen onderwerp zijn van de collectieve inhoudstoets door de rechter. Het declaratoir en de eventueel toegekende nevenvorderingen van artikel 6:241 lid $3 \mathrm{BW}$ kunnen derhalve ook slechts betrekking hebben op bepaalde algemene voorwaarden..$^{366}$ Uiteraard is daarbij niet uitgesloten dat de gevraagde verklaring voor recht betrekking heeft op alle bedingen van een set algemene voorwaarden. De rechter kan echter niet de set als zodanig onredelijk bezwarend verklaren.

Het gevraagde declaratoir moet voorts betrekking hebben op een bepaalde (set) algemene voorwaarden. De bepaling is van belang indien een ondernemer voor verschillende soorten transacties verschillende (setjes) algemene voorwaarden hanteert, waarin echter well weer identieke bedingen voorkomen. De overeenkomstige toepassing van de artikelen 6:233 sub a, 236 en 237 BW (zie hierna paragraaf 5.3.2) brengt immers met zich dat de rechter bij de beoordeling of een beding onredelijk bezwarend is, de overige inhoud van de overeenkomst en dus ook de set algemene voorwaarden, mede in ogenschouw moet nemen. De werking van het declaratoir en de toegewezen nevenvorderingen aangaande een specifiek beding is derhalve beperkt tot dat bepaalde stel algemene voorwaarden waarin dat beding voorkomt. ${ }^{367}$ In de Memorie van Toelichting wordt hierbij uitdrukkelijk opgemerkt

"... dat de term "bepaalde algemene voonuaarden" miet tot de gevolgtrekking mag leiden dai algemene voonwaanden ophouden de "beparalde algemene voorwaarden" te zijn waarop een uilspreath

366 MvT, Parlementaire Geschiedenis, Inv. 3, 5 en 6, pag. 1762-176..

367 MvT, Parlementaire Geschiedenis. Inv. 3, 5 en 6, pag. 1763.. 
betrellking had, op de enkele grond dat de gebraiker daarin ma de ütsprouk wijzigingen acnbrentgr. wh:

Let wel! De memorie van toelichting heeft in deze slechts betrekking op "bepaalde algemene voorwaarden. Op de vraag of de zinsnede "bepaalde bedingen in bepaalde algemene voorwaarden" tot de gevolgtrekking kan leiden dat bedingen in algemene voorwaarden ophouden de "bepaalde bedingen" te zijn waarop een uitspraak betrekking had, op de enkele grond dat de gebruiker in het beding na de uitspraak wijzigingen aanbrengt, wordt in de Parlementaire Geschiedenis geen antwoord gegeven. Naar het mij voorkomt is er echter geen enkele reden deze vraag bevestigend te beantwoorden. Het zou in strijd zijn met de ratio van de collectieve actie en de beschermingsfunctie van afdeling 6.5.3 BW, indien gebruikers of aanbevelers zich aan de werking van een uitspraak van de bijzondere rechter zouden kunnen onttrekken, enkel en alleen omdat zij een beding tekstueel hebben veranderd zonder aan de strekking en werking van het beding iets wezenlijks te veranderen.

Het feit dat het gevraagde declaratoir betrekking moet hebben op bepaalde bedingen in bepaalde algemene voorwaarden, sluit niet uit dat de rechtsvordering van een eisendle organisatie zich beperkt tot het gebruik van het beding in bepaalde specifieke situaties of ten aanzien van bepaalde produkten uit het assortiment van de gebruiker. Tijdens het mondeling overleg in de Eerste Kamer werd dit, weliswaar aan de hand van het rechterlijk verbod, geillustreerd:

"... dar de rechter zich bij zijn oordeel krachtens artikel 6:240 lid 1 BW-wanneer het gaat om wredelijk bezwarend-verklaring, of bij artikel $6: 241$ als het goat om eem verbod - zal richten op de grote meerderheid van de gewallen, maar daarbij ook zal kijken voor welk soor overeenkomsten de algemene voomwararden bestemd zijn en welke groep vas personen daabij als partij oprreedi. Op basis dacanon kom hij tot eem verbod. Als dat zo is, dan geldt het verbod dus woor elk gebrulk wan dite wortwarden binnen de door de wispraak getrokken grenzen. En die grenzent zullen witeraard worden afgebakend in de procedure, enerajds door de stellingen van partijen ep uiteindelijk in de

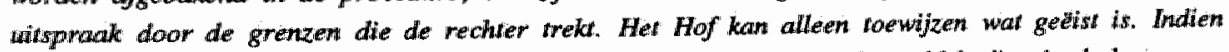
een algemeen wenbod wordt geeturt bij voorbeeld tem aanzien wan een bepald beding in de koopovereevkomst wan een warenhwis, dan kan het Hof niet eigener bewegring zeggen dat het beding wèl aniredelijk bezwarend is in koopovereenkomsten betreffende fwishoudelijke artikelen, marr niet in hoogowereenkomsten betreffende speelgoed.

Het is derhalve niet uitgesloten dat eisende organisaties in plaats van een declaratoir met "algemene" werking, een op bepaalde diensten of produkten 
gericht toegespitst declaratoir vragen. Zo kunnen consumentenorganisaties, on bij het hiervoor geschetste voorbeeld te blijven, hun verbodsvordering jegens het warenhuis beperken tot het gebruik in koopovereenkomsten betreffende huishoudelijke artikelen.

De eisende organisatie zal doorgaans aan het gevorderde declaratoir een verbod van (verder) gebruik of van (verdere) aanbeveling van het gewraakte beding koppelen. Als de bijzondere rechter het gevraagde declaratoir toewijst zal een toekenning van het gevraagde verbod praktisch steeds op zijn plaats zijn. Vooral omdat de op hergebruik van een onredelijk bezwarend verklaard beding rustende sanctie van vernietigbaarheid is gekoppeld aan het verbod van artikel 6:241 lid $3 \mathrm{BW}{ }^{370}$ Het is echter niet uitgesloten dat de rechter slechts het gevraagde declaratoir toewijst en afziet van het leggen van een verbod tot hergebruik op de gebruikers. De declaratoire uitspraak zelf heeft echter ook zonder dat daar een verbod aan is gekoppeld, feitelijke werking voor ondernemers die het door het declaratoir getroffen beding in hun algemene voorwaarden blijven gebruiken. De rechter in de individuele procedure is in beginsel weliswaar niet gebonden aan het declaratoir van de bijzondere rechter, hij zal daar, als feitelijk gegeven, wel rekening mee kunnen houden bij de toetsing aan de open norm. Zo zal de gewone rechter een beding eerder onredelijk bezwarend achten als de bijzondere rechter dat ook reeds heeft geconstateerd. ${ }^{371}$

Het gevraagde declaratoir zal - indien toegewezen - evenals een aan de gebruiker of aanbeveler opgelegd verbod, slechts werking hebben voor de toekomst. Het declaratoir ziet derhalve niet op het gebruik van het beding in overeenkomsten die zijn gesloten vór de datum waarop de uitspraak in werking is getreden. De werking van de uitspraak inzake het gevraagde declaratoir wordt voor de individuele procedure ex artikel 6:233 sub a BW als volgt uitgelegd:

"( $(.$.

- Heeft en bepaald beding in algemene voonwaarden de voutsing door de bijzondere rechter doorstaan, dan kan ditzelfde beding nog invegraal door de gewone rechter getoetst warden; de uitspraak wan de bijzondere rechter bindt de gewone rechter niet doch is voor hem slechts est feitelijk gegevert.

- Ook de declaratoire uitspraak wan de bijzondere' rechrer inhoudende dat een bepaald beding onredetijk bezwarend is, is woor de gewone rechter slecths een feitelijk gegeven. ${ }^{3372}$

Bij de beoordeling van zulk een beding door de rechter in de individuele procedure geldt ook hier dat de gewone rechter het declaratoir van de bijzonde-

370 Zie hierna paragranf 5.3.8.1.

371 MvT, Parlementaire Geschiedenis, Inv. 3, 5 en 6, pag. 1792.

372 VV, Parlementaire Geschiedenis, Inv. 3, 5 en 6, pag. 1792. 
re rechter als feitelijk gegeven kan meewegen in zijn oordeel, maar dat hij daar dus ook van mag afwijken. ${ }^{373}$. Het ligt echter voor de hand dat de gewone rechter in de praktijk niet licht zal afwijken van het declaratoir van de bijzondere rechter. Een beding dat voor de gehele kring van wederpartijen onredelijk bezwarend is, is per definitie immers ook onredelijk bezwarend voor het individu dat deel uitmaakt van deze kring.

\subsubsection{De toetsnorm}

Zoals reeds eerder opgemerkt, is één van de in de kamerstukken genoemde voordelen van de open norm van artikel 6:233 sub a BW ten opzichte van de toetsnorm van artikel 6:248 lid $2 \mathrm{BW}$, dat "de maatstaf of een beding onredelijk bezwarend is, niet slechts bruikbaar is in verband met de vernietigbaarheid van bedingen in gesloten contracten (...), doch ook in verband met de verbodsactie wan de artikelen 6:240 e.v."." Artikel 6:240 lid 1 BW verklaart derhalve de open norm van artikel 6:233 sub a BW en de lijsten van de artikelen 6:236 en $6: 237 \mathrm{BW}$ van overeenkomstige toepassing.

\section{Artikel $6: 240$ lid $1 \mathrm{BW}$}

Op vordering wan eev rechtspersoon als bedoeld in lid 3 kumen bepaalde bedingen in bepactde algemene voorwaarden onredijik bezwarend worden verklaard; de artikelen 233 onder a, 236 en 23.7 zijn van overeenkomstige toepassing. Voor de toepassing wan de varige zin wordt een beding in algemene woorwaarden dat in strijd is met cen dwingende wetsbepaling, als onredielijk bezwarend aangemerkt.

\subsubsection{Abstracte inhoudstoets}

De overeenkomstige toepassing van de artikelen 6:233 sub $a$, 6:236 en 6:237 BW betekent voor consumentenovereenkomsten dat op de eerste plaats van belang is of het ter toetsing voorgelegde beding voorkomt op de zwarte of grijze lijist. Ook in de abstracte toetsing geldt dat indien een beding in algemene voorwaarden, dat wordt gehanteerd jegens consumenten, voorkomt op de zwarte lijst van artikel $6: 236 \mathrm{BW}$, dit beding zonder meer onredelijk bezwarend is. De bijzondere rechter heeft dan net als bij de individuele inhoudstoetsing geen beoordelingsvrijheid en moet het gevraagde declaratoir toekennen. Evenzeer als bij de individuele actie op grond van de open norm geldt het wettelijk vermoeden van onredelijk bezwarendheid ten aanzien van bedingen in consumentenovereenkomsten die voorkomen op de grijze lijst van artikel 6:237 BW. Ook bij de abstracte inhoudstoets moet de gebruiker of de aanbeveler in dat geval 
bewijzen dat het betreffende beding niet onredelijk bezwarend is. Toetsnorm bij bedingen die voorkomen op de grijze lijst, bedingen die niet voorkomen op de lijsten van de artikelen 6:236 en 6:237 $\mathrm{BW}$ en bedingen gehanteerd jegens ondernemers, is de maatstaf van artikel 6:233 sub a BW. ${ }^{375}$

De maatstaf van artikel 6:233 sub a BW wordt bij de collectieve actie van artikel 6:240 BW e.v. evenwel niet op geheel dezelfde wijze gehanteerd als in de individuele procedure van artikel 6:240 BW. Bij de collectieve toetsing is sprake van een meer "abstracte" wijze van toetsing. In de Memorie van toelichting wordt dit als volgt, door mij aangepast aan de huidige artikelnummering, verwoord:

"Deze bepaling kan evenwel niet rechtstreeks van toepassing zijn, daar zij is bestemd woar "concrete", contractuele, relaties war op alle omstandigheden van hel geval, waaronder de card en inhoud van de overeenkomst en de kenbare belangen van partijen, dient te worden gelet. Daarentegen heeft artikel 6.240 BW betrekking op een meer "abstracte" toersing; bezien wordt hier immers of" het aangevochten beding onredelijk bezwarend is met het oog op zijn gebraik in overeenkomsten in het algemeen, ongeacht de persoon van de wederpartij en ongeacht de omstandigheden wan het geval, bijv. de gedragingen wan twee partijen bij en na het siuiten wan de overeenkomst. Er zij overigens op gewezen dat het onderscheid gradueel is. Ook de toetsing in de onderhavige procedure kan meer of minder abstract zijn, al naar gelang de inhowd van de rechtsvordering. Deze zal bijw. waak beperkt zijn tor thet gebruik wan het beding in een bepaalde soort overeenkomsten c.q. int overeenkomsten met een bepacald object, en tot overeenkomsten met eer bepaalde soort wederpartijen (consumenten, een bepalde soort ondernemers), etc.

Op deze grond zal shechts wam een overeenkomstige roepassing van artikel 6:233 sub a BW sprake kunnen zijn. Vitgaande van de formulering wan de eis zal gelet moeten worden op o. m. de aard en inhoud van de overeenkomsten waanvoor de algemene voonvaarden zijn bestemd, en op de personen met wie deze overeenkomsten plegen te worden gesloten en hun "typische" eigenschappen en belangen. Wat die, eveneens in artikel $6: 233$ sub a BW vermelde, belangen van de gebruiker betreft geldt m.m. hetzelfde: relevant is miet slechts welke belangen de gebruiker - of, bij een vardering regen een branchevereniging, de daarbij aangesloven gebrwikers - bij het gebruik van de algemene noorwaarden heeft c.q. pleegt te hebben, maar ook in hoeverre deze belangen kenbaar plegen te zijw voor hun wederpartijen. De bijzondere rechter dient derhalve, uirgaande wan de norm wan artikel 6:233 sub a BW, de daarin genoemde maatstaven zo te generaliseren als met het oag op de van hem krachtens artikel 6:240 BW gevraagde beslissing nodig is. 1376

375 MvT, Parlementaire Geschiedenis, Inv. 3,5 en 6, pag. 1763.

376 MvT, Parlementaire Geschiedlenis, Inv. 3, 5 en 6, pag. 1763-1764. Zie in dezelfde zin: MvA $\mathbb{I}_{\text {, }}$ Parlementaire Geschiedenis, Inv. 3, 5 en 6, pag. 1778. De opmerking in de MvT dat bij de abstracte toets, in tegenstelling tot de individuele toets, de gedragingen van partijen ma het sluiten vam de overeenkomst geen rol spelen, is een misvatting. Bij de toetsing asn de open norm spelen omstandigheden wan ná het shiten van de overeenkomst waaraan het bestreden beding geen rechtsgevolgen vertindt, immers ook geen rol. In die zin onderseheidt de abstracte inhoudstoets zich niet van de individuele inhoudstoets. 
Dat de rechter zich doorgaans zal richten op de grote meerderheid van de gevallen waarin de desbetreffende voorwaarden worden gebruikt en aldus moet abstraheren van concrete individuele omstandigheden ligt voor de hand. Het vorderingsrecht van artikel 6:240 BW berust immers op de gedachte dat het gebruik van algemene voorwaarden een collectief verschijnsel is dat derhalve in vele vergelijkbare situaties plaatsvindt. Bovendien kan de collectieve actie ook "preventief" worden ingesteld ter zake van nog niet of niet frequent gebruikte bedingen. Daarbij valt te denken aan het geval dat een ondernemer, een ondernemersvereniging of een overheidslichaam aankondigt (nieuwe) algemene voorwaarden te gaan gebruiken. In dergelijke gevallen zijn concrete omstandigheden (nog) niet voorhanden en kan de rechter enkel afgaan "op zijn verwachting omtrent de aard der overeenkomsten waarvoor de voorwaarden zijn bestemd" ". ${ }^{37}$ Ook het feit dat de abstracte inhoudstoets slechts werking heeft voor nadien gesloten overeenkomsten brengt met zich, dat de rechter noodzakelijkerwijs een bepaalde mate van abstrahering moet betrachten ten opzichte van de concrete omstandigheden van de individuele wederpartijen bij die later te sluiten overeenkomsten.

Naar de aard van de toets is het onvermijdbaar dat de rechter bij de collectieve inhoudstoets tot op zekere hoogte moet abstraheren. Aan dit abstraheren worden in de parlementaire geschiedenis echter uitdrukkelijk duidelijke grenzen gesteld. De bijzondere rechter dient immers, uitgaande van de norm van artikel 6:233 sub a BW, de daarin genoemde maatstaven slechts zo te generaliseren als met het oog op de van hem krachtens artikel 6:240 BW gevraagde beslissing nodig is. De abstracte inhoudstoets moet zo concreet mogelijk zijn. ${ }^{378}$

Omdat de open norm van artikel 6:233 sub a BW van overeenkomstige toepassing is, moet er van uit worden gegaan dat bij de abstracte inhoudstoets in beginsel dezelfde omstandigheden een rol kunnen spelen als bij de individuele toets. ${ }^{379}$ Dit betekent in eerste instantie dat ook in de abstracte toets slechts rekening kan worden gehouden met omstandigheden van vớr of bij het sluiten van de overeenkomst. ${ }^{300}$ Daarbij is het interessant om na te gaan in hoeverre

377 MvA I, Parlementaire Geschiedenis, Inv, 3, 5 en 6, pag. 1778.

378 VV, Parlementaire Geschiedenis, Inw. 3, 5 en 6, pag. 1767.

379 Zie hiervoor paragraf 5.2.5.2 onder het kopje "De relevante omstandigheden".

380 In gewal van cen toetsing van een aanbeveling tot gebriik van bepaalde algemene voorwaarden kan het zo zijn dat de algemene voorwaarden nog niet daadwerkelijk zijn gebruikt in een overeenkomst. Uiteraard gaat het dan om de omstandigheden van vór of bij de te sluiten overeenkomst. 
de toepassing van de toetscriteria van de open norm verschilt van de toepassing daarvan bij de abstracte toets van artikel 6:240 BW. ${ }^{381}$

Volgens de Memorie van toelichting is het onderscheid tussen de concrete individuele toets van artikel 6:233 sub a en de abstracte collectieve toets slechts gradueel en vooral afhankelijk van de inhoud van de collectieve rechtsvordering.

De inhoud van de rechtsvordering zal echter altijd vrij concreet zijn. De leden 1 en $3^{382}$ van artikel 6:240 BW vereisen immers dat de rechtsvordering altijd betrekking heeft op specifieke bedingen in bepaalde algemene voorwaarden, gehanteerd jegens bepaalde wederpartijen waarvan de belangen door de eisende organisatie worden behartigd. ${ }^{383}$ Voor wat bij voorbeeld betreft rechtsvorderingen van consumentenorganisaties op grond van artikel 6:240 lid 1 BW staat altijd vast, dat het gaat om specifieke bedingen in een bepaalde set algemene voorwaarden die worden gehanteerd door bepaalde gebruikers in een bepaalde soort overeenkomsten met wederpartijen die niet handelen in de uitoefening van een beroep of bedrijf. In dat licht is de opmerking in de Memorie van Toelichting, dat de inhoud van de rechtsvordering in de abstracte toetsing "vaak" - dus niet altijd- beperkt zal zijn "tot het gebruik van het beding in een bepaalde soort overeenkomsten c.q. in overeenkomsten met een bepaald object. en tot overeenkomsten met een bepaalde soort wederpartijen (consumenten, een bepaalde soort ondernemers), etc. ${ }^{m 84}$ enigszins misplaatst. Bij de vergelijking van de toepassing van de toetscriteria van de open norm moet er derhalve van uit worden gegaan dat de inhoud van de rechtswordering in de abstracte procedure altijd vrij concreet is.

Het eerste toetsingscriterium dat zich voor vergelijking aandient, is de aard van de overeenkomst. Bij dit toetsingscriterium lopen de concrete en abstracte toetsing nagenoeg parallel. ${ }^{385}$ Het feit dat de inhoudstoets betrekking heeft op bij voorbeeld algemene voorwaarden gehanteerd in koopovereenkomsten met betrekking tot tweedehands auto's is bij de concrete en abstracte toets van gelijke importantie. ${ }^{386}$ De toets loopt nagenoeg parallel, omdat er toch een klein verschil is. De concrete individuele procedure heeft betrekking op de aard van de concrete overeenkomst gesloten met de betreffende wederpartij, terwij] in de abstracte procedure de inhoudstoets zeer wel betrekking kan hebben op verschillende overeenkomsten met ook een verschillende aard. Ter illustratie (inhakend op een voorbeeld van Jongeneel): in de concrete procedure kan de

381 Zie ook Jongeneel, disa., pag. 223-224.

382 Zie hierna paragraaf 5.3.3.

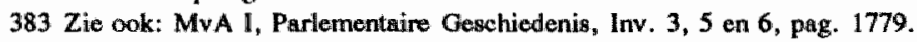

384 MvT, Parlementaire Geschiedenis, lnv. 3, 5 en 6, pag. 1763.

385 Zie ook Jongeneel, dists., pag. 223.

386 Voorbeeld ontleend aan Jongeneel, diss., pag. 223. 
toets een beding betreffen in algemene voorwaarden gehanteerd in een koopovereenkomst met betrekking tot een tweedehands auto, terwijl het in de abstracte procedure gevraagde declaratoir met betrekking tot hetzelfde beding niet alleen op de koop van tweedehands auto's kan zien maar tevens op de koop van nieuwe auto's en de koop van aanhangwagens.

Voor wat betreft het toetscriterium de overige inhoud van de overeenkomst dient te worden onderscheiden tussen de kernbedingen en de overige algemene voorwaarden.

Het belang van de inhoud van de andere algemene voorwaarden dan het ter toetsing voorliggende beding, zal in de individuele procedure niet anders zijn dan in de abstracte procedure. Voor beide procedures geldt dat de inhoud van deze andere voorwaarden identiek is. De betreffende algemene voorwaarden worden immers gehanteerd jegens de gehele kring van wederpartijen.

Anders ligt het ten aanzien van kernbedingen, zoals de prijs en de daar tegenover staande prestatie. Deze zijn niet voor de gehele kring der wederpartijen identiek. In een concrete procedure staan deze kernbedingen vast terwijl dit bij de abstracte toets geenszins het geval is. De concrete toets betreft, om bij het zojuist genoemde voorbeeld te blijven, een algemene voorwaarde in een koopovereenkomst met betrekking tot een auto van een specifiek merk en type, die tegen een vaststaande prijs is verkocht. De abstracte toets van hetzelfde beding ziet daarentegen op alle koopovereenkomsten die de autoverkoper sluit, ongeacht het merk, type en prijs. Tijdens de parlementaire behandeling wordt hierover het volgende opgemerkt:

"... hetgeen ten gevolge heeft dat bij de toetsing een meer abstracte toetsingsmaastaf geldt waarbij miel kannen meewegen de inhoud wan de te stuiten overeenkomsten en met name niet de prijs, hetgeen tevens ten gevolge heeft dat de rechter en verbod kan opleggen om bepaalde bedingen in de woekomst is: owereenkomsten te gebruiken welke de inhowd wan die overeenkomsten ook zal $2 i j n .387$

Wordt hiermee bedoeld dat de bijzondere rechter bij de abstracte inhoudstoets de kernbedingen absoluut niet mag laten meewegen in zijn oordeel? Mijns inziens niet. Bedoeld is hier viteraard, dat de bijzondere rechter in zijn oordeel niet de concrete prijs en inhoud van elke concrete overeenkomst kan meewegen, hetgeen hij in beginsel wél kan in de concrete procedure van artikel 6:233 sub a BW. Ook de bijzondere rechter zal echter in zijn afweging zijn verwachting omtrent de "doorsnee" kernbedingen, waarop het ter toetsing voorgelegde beding toepasselijk is, moeten meewegen. Zo zal de bijzondere rechter heel

387 VV, Parlementaire Genchiedenis, Inw. 3, 5 en 6, pag. 1766-1767 en 1789. 
goed kunnen overwegen dat de algemene voorwaarden zien op overeenkomsten met betrekking tot de verkoop van een bepaald merk auto's uit een duurdere prijsklasse met bepaalde uit reclamepublicaties bekende prijzen of dat de voorwaarden alleen betrekking hebben op produkten met een uitzonderlijk lage prijs. Dit zal zeker zo zijn indien de prijs is gestandaardiseerd. ${ }^{388}$

Een verschill tussen de abstracte en de individuele toets kan zich derhalve pas voordoen indien er in de individuele toets sprake is van uitzonderlijke kernbedingen die afwijken van hetgeen de rechter in het allgemeen, abstract gezien, bij het betreffende soort overeenkomsten had mogen verwachten. Of er vervolgens met betrekking tot de waardering van de kernbedingen werkelijk een verschil is tussen de abstracte en de individuele inhoudstoets hangt af van de opstelling van de rechter ten aanzien van de individuele toets en de uitleg van het betreffende beding. Indien de rechter er in de individuele procedure van uitgaat dat het beding vanwege zijn algemene werking niet ziet op dit bijzondere gevall, komt hij aan een inhoudstoetsing niet toe omdat de gebruiker zich dan niet op het beding kan beroepen. ${ }^{389}$ In dat geval is er ten aanzien van de waardering van kernbedingen geen verschil tussen de individuele en abstracte inhoudstoets. Gaat de rechter er echter in de individuele procedure, mede doordat de gebruiker een beroep doet op het beding, van uit dat het beding ook ziet op deze uitzonderlijke kernbedingen, dan dient hij deze uitzonderlijke kernbedingen mee te wegen in zijn oordeel. Slechts in het geval de rechter voor de laatste, mijns inziens dogmatisch minder fraaie, oplossing kiest is er ten aanzien van de waardering van kernbedingen een verschil tussen de abstracte en concrete inhoudstoets.

Het derde toetscriterium is de wijze waarop de voorwaarden tot stand zijn gekomen. Het ziet op de afkomst van algemene voorwaarden, op de vraag of de algemene voorwaarden nul-, een- of meerzijdig zijn tot stand gekomen, op de mate van representativiteit van de instemmende organisatie van wederpartijen en de eventuele betrokkenheid van de overheid. Het belang van dit toetscriterium zal in de abstracte toets hetzelfde zijn als bij de individuele toets. Bij concrete bedingen in bepaalde algemene voorwaarden is de afkomst immers in beide gevallen altijd identiek.

Zoals hiervoor reeds aangegeven in paragraaf 5.2.5.2, heeft deze toetsingsfactor naar mijn mening nagenoeg geen importantie voor de concrete inhoudstoets. Ook in de abstracte inhoudstoets zal zij slechts een zeer summiere rol spelen. Slechts indien de bijzondere rechter twijfelt over het onredelijk bezwa-

388 EV, Parlementaine Geschiedenis, Imv, 3, 5 en 6, pag. 1790; NEV, Parlementaire Geschiedenis, Inv. 3,5 en 6, pag. 1791 .

389 Zie hiervoor paragraaf 5.2.5.2. onder het kopje "De relevante amstandigheder". 
rende karakter van een beding kan de afkomst van het beding nét de doorslaggevende factor zijn.

Het vierde relevante toetseriterium wordt gevonden in de wederajids kenbare belangen van partijen. Uiteraard kan de rechter in de abstracte inhoudstoets van artikel 6:240 BW geen rekening houden met concrete individuele belangen. $\mathrm{Hij}$ zal moeten uitgaan van de typische belangen van de gehele kring van wederpartijen. Doorgaans zijn de typische belangen van de kring van wederpartijen dezelfde als die van de doorsnee wederpartij. In die zin is het toetscriterium hetzelfde voor zowel de individuele als de collectieve inhoudstoets.

Slechts incidenteel zijn de (vooraf) kenbare belangen van de individuele wederpartij zo uitzonderlijk, dat zij afwijken van de belangen van de kring der wederpartijen. Net als bij de waardering van de invloed van kernbedingen op het onredelijk bezwarende karakter van algemene voorwaarden, kan een verschil tussen de abstracte en de individuele toets zich dan pas voordoen, indien er in de individuele toets sprake is van uitzonderlijke belangen die afwijken van hetgeen de rechter in het algemeen, abstract gezien, bij het betreffende soort overeenkomsten had mogen verwachten. Of er vervolgens met betrekking tot de waardering van die belangen, werkelijk een verschil is tussen de abstracte en de individuele inhoudstoets hangt wederom af van de opstelling van de rechter ten aanzien van de individuele toets en de uitleg van het betreffende beding.

Indien de rechter in de individuele procedure de, door mij geprefereerde, weg van uitlegging volgt en er van uitgaat dat het beding vanwege zijn algemene werking niet ziet op dit bijzondere geval, komt hij niet aan een inhoudstoetsing daarvan toe omdat de gebruiker zich dan niet op het beding kan beroepen. ${ }^{300}$ In dat geval is er ten aanzien van de waardering van de kenbare belangen van de wederpartij geen verschil tussen de individuele en abstracte inhoudstoets. Gaat de rechter er echter in de individuele procedure, mede doordat de gebruiker een beroep doet op het beding, wan uit dat het beding ook ziet op deze uitzonderlijke belangen van de wederpartij, dan dient hij deze uitzonderlijke belangen mee te wegen in zijn oordeel. Slechts in het geval de rechter voor de laatste oplossing kiest, is er ten aanzien van de waardering van belangen van de wederpartij een verschil tussen de abstracte en concrete inhoudstoets.

Voor wat betreft de belangen van de gebruiker(s) zal de rechter moeten uitgaan van de belangen zoals deze in het algemeen kenbaar zijn voor de kring. van wederpartijen. Dit is voor wat betreft consumententransacties niet anders dan bij de individuelle inhoudstoets.

390 Zie hiervoor paragraaf 5.2.5.2. onder het kopje "De relevante omstandigheden". 
Het laatste toetscriterium betreft de overige omstandigheden wan het geval. Het zal aanstonds duidelijk zijn dat bij de abstracte toetsing slechts van een analoge toepassing van dit criterium sprake kan zijn. Strikt genomen is er in de abstracte toets immers geen sprake van een (concreet) geval. De abstracte toets ziet voor wat betreft dit criterium derhalve op de typische omstandigheden zoals deze zich, vóor of bij het sluiten van de overeenkomst, voordoen bij de kring van wederpartijen bij de betreffende overeenkomsten. Voor het verschil in waardering van dit toetscriterium tussen de abstracte en de concrete toets, geldt ook hiler uiteraard hetzelfde als bij de toetscriteria de overige inhoud van de overeenkomst en de wederzijds kenbare belangen. Slechts in geval van uitzonderlijke individuele omstandigheden van de wederpartij kan er een verschil zijn tussen de abstracte en concrete inhoudstoets. Maar alleen indien de rechter in de individuele procedure kiest voor de weg van de inhoudstoetsing op grond van de open norm.

Het voorgaande overziend, kom ik tot de conclusie dat de waardering van de relevante omstandigheden bij de abstracte collectieve toets doorgaans niet hoeft te verschillen van de waardering van die omstandigheden bij de concrete individuele toets. De "normale" omstandigheden (de omstandigheden waarin de doorsnee-wederpartij zich bevindt) waaraan doorgaans getoetst wordt in de individuelle procedure van artikel 6:233 sub a BW worden immers ook altijd meegewogen in de abstracte toets. Deze laatste gaat immers uit van de doorsnee-wederpartij. Uitgangspunt daarbij is dat de meeste individuele procedures gevoerd zullen worden door doorsnee wederpartijen.

Slechts in uitzonderlijke concrete gevallen, met het oog waarop algemene voorwaarden niet zijn opgesteld, kan er een verschil zijn tussen de relevante omstandigheden en de waardering van die omstandigheden. Deze uitzonderlijke omstandigheden kan de bijzondere rechter naar hun aard immers niet meewegen in de abstracte inhoudstoets van artikel 6:240 BW. Naar mijn mening komt de "gewone" rechter aan een weging van deze bijzondere omstandigheden in de individuele inhoudstoets niet toe, zodat ook in die gevallen geen onderscheid ontstaat tussen de abstracte en concrete toets. Algemene voorwaarden zien immers niet op deze uitzonderlijke omstandigheden en missen derhalve toepassing in zulke gevallen. Voor het geval de "gewone" rechter echter van oordeel is dat een objectieve uitleg van het beding met zich brengt, dat het ook van toepassing is op de uitzonderlijke situatie, kan hij overgaan tot de individuele inhoudstoets van artikel 6:233 sub a BW en kan hij de uitzonderlijke omstandigheden mee laten wegen in zijn beslissing. In die gevallen is er een verschil tussen de abstracte en concrete inhoudstoets. Men bedenke daarbij echter dat indien een objectieve uitleg van het beding in het individuele geval met zich brengt dat het ook ziet op de uitzonderlijke omstandigheden, dezelfde objectieve 
uitleg met zich zal brengen dat het beding ook in de abstracte procedure mede op deze uitzonderlijke omstandigheden ziet. Hetgeen dan weer betekent dat ook de bijzondere rechter bij de abstracte inhoudstoets rekening dient te houden met deze bijzondere uitzonderlijke omstandigheden.

\subsubsection{Strijd met een dwingende wetsbepaling}

Op grond van artikel 6:240 lid 1 BW kan het door belangenorganisaties gevraagde declaratoir eveneens betrekking hebben op bedingen die in strijd zijn met de wet. De laatste zin van lid 1 bepaalt immers dat in een procedure voor de bijzondere rechter een beding in algemene voorwaarden dat in strijd is met een dwingende wetsbepaling als onredelijk bezwarend wordt aangemerkt.

In het oorspronkelijk ontwerp ontbrak deze bepaling. Zij is pas bij de eerste nota van wijziging voorgesteld. ${ }^{391}$ Uitgaande van de constatering dat bij een beding dat in strijd is met een dwingende wetsbepaling de open norm toets van artikel 6:233 sub a BW niet meer aan de orde is, wordt de wenselijkheid van de toevoeging als volgt, door mij aangepast aan de huidige artikelnummering, toegelicht in de kamerstukken:

"Dit neemt averigens niet weg, dat indien bedingen, die in strijd zijn met een bepaling van dwingend rechi, in algemene woonwaarden worden gebrwikt, een rechiswordering als bedoeld in artikel 6:240 BW tegen degene die de algemene wormaarden gebruiks of het gebruik erwan bevorden, naar onze mening magelijk moet zijn. Een dergelijke rechtsvordering kan bij voombeeld gewenst zijn indien niet op woorhand duidelijk is of het beding onder de verbadsbepaling valt. Een witspraak van het Gerechishof te Den Haag is dan een geschikte weg om duidelijkheid hierover te verknigen. Tevens biedt zij het yoordeel dat acin deze waststelling de weroondelingen als bedoeld in artikel 6:241 leden 3 en $5 \mathrm{BW}$, kunnen worden verbonden. Ten einde deze magelijkheid buiten twijfel te stellen is artikel 6.240 lid I BW, acangevuld met een bepaling inhoudende dat een beding in algemene voonwaarden, dat in srrijd is met een bepaling van dwingend rechr, als onredelijk bezwarend wordt acangemewkt. Dok artikel 6:242 lid $4 \mathrm{BW}$ is in verband hiermee acungepast." 392

De voordelen van het toekennen van het collectief actierecht van artikel 6:240 BW voor bedingen die in strijd zijn met dwingende wetsbepalingen is mijns inziens echter nauwelijks gelegen in de voordelen die de nevenvorderingen van artikel 6:241 BW opleveren maar veeleer in de voordelen die de toepasselijkheid van de artikelen 1003 tot en met $1006 \mathrm{Rv}$ op de collectieve actie van artikel 6:240 BW met zich brengt. Het is zelfs de vraag of de eventuele nevenveroordelingen ex artikel 6:241 BW zoveel voordeel opleveren voor een eisende organisatie.

391 NwW 1, Parlementaire Geschiedenis, Inv. 3, 5 en 6, pag. 1771.

392 MwA, Parlementaine Geschiedenis, Inv. 3, 5 en 6, pag. 1462 en 1769. 
De nevenvorderingen bedoeld in artikel 6:241 BW kunnen immers net zo goed worden gevorderd in een collectieve actie op grond van artikel 3:305a $j^{\circ} 3: 40 j^{\circ}$ 6:162 BW. ${ }^{393}$ Artikel 3:305a BW makt het uitdrukkelijk mogelijk dat belangenorganisaties op grond van artikel 3:40 en 6:162 BW bij de rechter een verklaring voor recht dat een beding in strijd is met een dwingende wetsbepaling, een verbod of gebod, een veroordeling tot openbaarmaking van de uitspraak en een dwangsom kunnen vorderen jegens de gebruiker of aanbeveler van algemene voorwaarden die in strijd zijn met de wet. Evenals afdeling 6.5.3 BW voor de collectieve actie op het terrein van de algemene voorwaarden voorziet artikel 3:305a lid $2 \mathrm{BW}$ voor de algemene collectieve actie in een overlegverplichting voor vorderende organisaties. In artikel 3:305a BW worden slechts (minieme) eisen gesteld ten aanzien van representativiteit en feitelijke werkzaamheden van de vorderende belangenorganisatie ${ }^{344}$, hetgeen afdeling 6.5.3 BW niet doet. Dit zal voor de organisaties die bevoegd zijn om op te treden in het kader van artikel 6:240 BW echter nauwelijks een belemmering zijn om gebruik te maken van het algemene collectieve actierecht. Tegenover deze minimale eisen ten aanzien van representativiteit en feitelijke werkzaamheid van de eisende organisatie, staat echter als voordeel van de algemene collectieve actie dat ook andere rechters dan het Haagse hof competent zijn. Bovendien zijn de vorderingen op grond van artikel 3:305a $\mathrm{j}^{\circ} 3: 40 \mathrm{j}^{\circ} 162 \mathrm{BW}$, in tegenstelling tot de collectieve vorderingen van afdelingen $6.5 .3 \mathrm{BW}$, ook mogelijk bij wege van een kort geding. Het argument dat de mogelijkheid van een collectieve actie ex artikel 6:240 BW ten aanzien van bedingen die in strijd zijn met een dwingende wetsbepaling, tevens het voordeel biedt dat aan deze vaststelling de veroordelingen als bedoeld in artikel 6:241 leden 3 en 5 BW, kunnen worden verbonden, is in mijn ogen weinig overtuigend nu belangenorganisaties deze mogelijkheid ten aanzien van het gebruik van bedingen in algemene voorwaarden die in strijd zijn met een wettelijke bepaling toch al hadden. Het voordeel van het toekennen van deze vorderingen is mijns inziens dan ook enkel gelegen in het feit dat ter verkrijging van dit oordeel niet nog eens een extra procedure bij een andere rechter hoeft te worden gestart.

Hetzelfde geldt voor het argument dat een dergelijke rechtsvordering bij voorbeeld gewenst kan zijn indien niet op voorhand duidelijk is of het beding onder de verbodsbepaling valt en dat een uitspraak van het Gerechtshof te

393 Ook vóor 1 juli 1994 (de datum van inwerkingtreding van de artikelen 3:305a en 3:305b BW) werd in de rechtspraak collectieve acties op grond van artikel 1402 BW(oud) en naderhand artikel 6:162 BW toegestaan. Zie voor een overzicht van de rechtspraak de memorie van toelichting bij het Wetsontwerp vonderingsnecht belangenorganisaties, Tweede Kamer, vergaderjaar 1991-1992, 22486 , nr. 3, pag. 3-7.

394 MvT, Tweede Kamer, vergaderjarar 1991-1992, 22 486, nr. 3, pag. 20. Zie ook: Rodrigues, SR 1992, pag. 109; Rozemond, pag. 14. 
's-Gravenhage een geschikte weg is om duidelijkheid hierover te verkrijgen. Het verschaffen van duidelijkheid omtrent de vraag of een beding in strijd is met een dwingende wetsbepaling is immers niet alleen voorbehouden aan het Haagse hof. Ook bij andere rechters kan hetzelfde gevorderd worden op grond van artikel 3:305a $j^{\circ}$ 3:40 BW. Dit kan bij deze rechters zelfs in kort geding. Ook in dit verband is het voordeel van de mogelijkheid de bijzondere rechter te vragen ook zijn oordeel te geven over de vraag of bepaalde bedingen in strijd zijn met een dwingende wetsbepaling, enkel gelegen in het feit dat belangenorganisaties ter verkrijging van dit oordeel niet nog eens een extra procedure hoeven te starten bij een andere rechter.

Het belang van de mogelijkheid om ook bedingen die in strijd zijn met een dwingende wetsbepaling onredelijk bezwarend te laten verklaren door de bijzondere rechter, is mijns inziens echter vooral gelegen op een ander vlak dat echter in de kamerstukken niet wordt genoemd. Op de collectieve actie inzake algemene voorwaarden zijn namelijk de bepalingen van de artikelen 1003 tot en met $1006 \mathrm{Rv}$ over de rechtspleging in zaken betreffende onredelijk bezwarende bedingen in algemene voorwaarden van toepassing. Deze bepalingen verschaffen de eisende belangenorganisatie immers de mogelijkheid om gezamenlijk met de aanbevelende branche-organisatie ook de leden van deze organisatie collectief te dagvaarden, zonder vermelding in de dagvaarding van de namen of woonplaatsen van deze gebruikers. Op die manier kunnen de vorderingen van de artikelen 6:240 lid 1 BW en 6:241 leden 3 en 5 BW een aanzienlijke breedtewerking en dus een grotere effectiviteit krijgen. Zo zal, bij voorbeeld, een door de bijzondere rechter opgelegde dwangsom ten aanzien van een beding dat onredelijk bezwarend is wegens strijd met een dwingende wetsbepaling, geëffectueerd kunnen worden jegens elk lid van het gehele collectief van gebruikers. Een dergelijke breedtewerking zou met een collectieve vordering ex artikel 3:305a $\mathrm{j}^{\circ} 3: 40 \mathrm{j}^{\circ} 6: 162 \mathrm{BW}$ niet mogelijk zijn. De mogelijkheid van collectieve dagvaarding van gebruikers zonder hun naam of woonplaats te noemen, bestaat immers alleen voor vorderingen als bedoeld in de artikelen 6:240 en 6:242 BW. De uitbreiding van de abstracte inhoudstoets tot algemene voorwaarden die in strijd zijn met een dwingende wetsbepaling is mijns inziens derhalve vooral van grote waarde voor belangenorganisaties omdat zij daardoor de mogelijkheid van collectieve dagvaarding krijgen met betrekking tot algemene voorwaarden die in strijd zijn met een dwingende wetsbepaling.

Opmerkelijk is dat de collectieve actie kan bewerkstelligen dat een beding dat in strijd is met dwingend recht, op de Haagse lijst komt te staan. Indien het betreffende beding dan wordt gebruikt door de gebruikers jegens wie het verbod geldt, is het altijd vernietigbaar. Dit laatste ondanks het feit dat zulk een beding 
op grond van artikel 3:40 leden 2 en $3 \mathrm{BW}$ helemaal niet behept is met de sanctie vernietigbaarheid, maar met nietigheid van rechtswege of soms zelf instandhouding van het beding.

Ten aanzien van de nietigheid van rechtswege is dit aspect ook aan de orde gekomen tijdens de parlementaire behandeling. ${ }^{395}$ Daaruit komt naar voren dat, indien een beding van rechtswege nietig is, het stelsel van de artt. 6:240 tot en met 6:243 BW aan dit rechtsgevolg niet afdoet. Aan een vernietiging op grond van artikel 6:233 sub a $\mathrm{j}^{\circ} 6: 243 \mathrm{BW}$ komt men in individuele procedures daarom niet toe. De mogelijkheid van een rechtsvordering ex artikel 6:240 en een verbod behoudt daarnaast toch haar zin, met het oog op de sancties van artikel 6:241 BW. ${ }^{390}$

In de toelichtende kamerstukken wordt echter geen aandacht geschonken atan het feit dat artikel 3:40 leden 2 en 3 BW niet uitsluit dat de strijdigheid van een beding met een dwingende wetsbepaling helemaal niet leidt tot een nietigheid of vernietigbaarheid, maar tot instandhouding van het beding omdat de overtreden bepaling niet strekt tot een nietigheid of vernietigbaarheid. De tekst van artikel 6:240 lid $1 \mathrm{BW}$ is nogal resoluut: een beding dat in strijd is met een dwingende wetsbepaling wordt altijd als onredelijk bezwarend aangemerkt. Dit lijkt mij echter niet de bedoeling van de bepaling in de laatste volzin van artikel 6:240 lid $1 \mathrm{BW}$ en bovendien wetssystematisch ongewenst. In dat licht verdient het de voorkeur dat de bijzondere rechter de onredelijk bezwarend verklaring van bedingen die in strijd zijn met een dwingende wetsbepaling, beperkt tot die bedingen die op grond van artikel 3:40 lid 2 en $3 \mathrm{BW}$ behept zijn met de sanctie van nietigheid of vernietigbaarheid.

\subsubsection{De bevoegde organisaties}

In artikel $6: 240$ lid $3 \mathrm{BW}$ is vastgelegd aan welke organisaties een rechtsvordering als bedoeld in artikel 6:240 lid $1 \mathrm{BW}$, all dan niet geflankeerd met een nevenvordering als bedoeld in artikel 6:241 leden 3 en $5 \mathrm{BW}$, toekomt.

6:240 lid 3 BW"

De wondering kom toe an rechispersonen met wolledige rechisbevoegdheid die ten doel hebben det behartiging van belangen van personen die een beroep of bedriff witoefenen of was eindgebruikers:

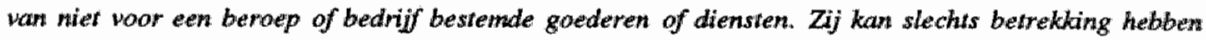
op algemene voorwaarden die worder gebruiks of bestemd zijn te worden gebruikt in overemkomstem met persomen wier belangen door de rechispersoon worden behartigd.

395 EV, Parlementaire Geschiedenis, Inv. 3, 5 en 6, pag. 1771; NEV, Parlementaire Geschiedenis, Inv. 3, 5 en 6, pag. 1772 .

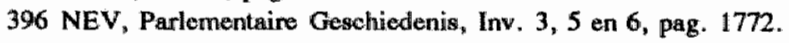


De formulering van artikel 6:240 lid $3 \mathrm{BW}$ is afgestemd op artikel 6:196 lid 2 sub a BW (misleidende reclame). ${ }^{397}$

De eisende partij moet een rechtspersoon zijn met volledige rechtsbevoegdheid die tot doel heef de belangen te behartigen van ondernemers, beroepsbeoefenaren of consumenten. In overeenstemming met het CCA-advies, ${ }^{398}$ vereist de omschrijving van artikel 6:240 lid 3 BW echter niet dat de daar genoemde rechtspersonen de behartiging van consumenten- of ondernemersbelangen als uitsluitend doel hebben. ${ }^{399}$ Andersom is eveneens niet vereist, dat deze rechtspersonen andere activiteiten ontplooien dan alleen het waken voor de belangen van consumenten of ondernemers. 400

De organisaties kunnen slechts optreden ter behartiging van de belangen die zij zich statutair hebben aangetrokken. De vordering van artikel 6:240 lid 1 en de nevenvorderingen van artikel $6: 241$ lid 3 BW kunnen derhalve slechts betrekking hebben op algemene voorwaarden die gebruikt worden of bestemd zijn te worden gebruikt tegenover de personen wier belangen door de rechtspersoon worden behartigd. Dit betekent dat een consumentenorganisatie die een vordering instelt met betrekking tot bedingen die slechts gebruikt worden tussen ondernemers onderling, niet ontvankelijk is. Heeft de vordering betrekking op bedingen die zowel jegens ondernemers als consumenten worden gebruikt, dan is de vordering slechts ontwankelijk voor zover een uitspraak ten aanzien van het gebruik in overeenkomsten met consumenten wordt gevorderd. Hetzelfde geldt uiteraard voor rechtsvorderingen ingesteld door ondernemersorganisaties. ${ }^{401}$ Derhalve kunnen ondernemersorganisaties miet door middel van de collectieve actie optreden tegen een gebruiker die slechts algemene voorwarden hanteert jegens consumenten. Ook niet indien deze gebruiker zich door het gebruik van die algemene voorwaarden een voorsprong op hen verschaft of hun goede naam op het spel zet. Afdeling 6.5.3 BW beoogt voor zover het consumenten betreft, immers slechts bescherming te bieden tegen het gebruik door een ondernemer van onreoielijk bezwarende voorwaarden jegens consumenten. ${ }^{402}$

397 MWT Parlementäre Geschiedenis, Inw. 3, 5 en 6, pag. 1764.

398 CCA-rudvies, pag. 27.28.

$399 \mathrm{MVT}$, Parlementaire Geschiedenis, Inw. 3, 5 en 6, pag. 1764.

400 Wessels en Jongeneel, 1992 , pag. 176.

401 MVT, Parlementaire Geschiedenie, Inv. 3, 5 en 6, pag. 1765.

402 MvT, Parlementaire Geschiedenis, Inv, 3, 5 en 6, pag. 1765 . 
Naast het vereiste van volledige rechtsbevoegdheid ${ }^{403}$, stelt artikel $6: 240$ lid 3 BW als voorwaarde dat de eisende rechtspersoon de belangen behartigt van de wederpartijen die betrokken zijn bij de litigieuze algemene voorwaarden. Daartoe is voldoende dat de eisende organisatie statutair heeft vastgelegd dat zij zich deze belangenbehartiging mede aantrekt. Verdere representativiteitseisen worden niet gesteld. ${ }^{\text {sot }}$ Een bepaalde vorm van erkenning of aanwijzing door een bepaald orgaan is niet vereist. ${ }^{405}$ Afgezien van de overlegverplichting in artikel 6:240 لlid $4 \mathrm{BW},{ }^{406}$ is ook niet vereist dat de eisende organisatie reeds feitelijke werkzaamheden op het terrein van de bedoelde belangenbehartiging heeft ontplooid. Het is derhalve mogelijk dat een organisatie ad hoc wordt opgericht met het oog op een enkele procedure. De mate van representativiteit speelt daarom geen rol bij de vraag of een rechtspersoon bevoegd is te ageren op grond van artikel 6:240 BW. ${ }^{407}$ In de literatuur wordt er op gewezen dat de mate van representativiteit feitelijk wél een rol zal spelen bij de collectieve inhoudstoets van een beding. Opgemerkt wordt:

"... dat het eerder waarschijnlijk is dat een representatieve organisatie met succes vraagt een beding onvedelijk bezwarend te verklaren, dat voorkomt in de algemene voorwacarden, watromtrent met een niet-representatieve arganisatie overeenstemming is bereikt, dan dat, amgekeerd, een niet represenvatiewe organisatie er in zou slagen een beding onredelijk bezwarend verklaard te krijgen, welk beding voorkomt in algemene woonwarden waarover met een representatieve arganisatie overeenstemming is bereikt". 408

In dezelfde zin ook de memorie van antwoord bij artikel 6:231 BW:

"Dè vraag wan de commissie, of bij meerzijdig tot stand gekomen algemene voorwarden de mate van representativiteit van de organisatie, die bij het opstellen of goedkeuren van de voonwaarden

403 Het Wetswoorstel ter regeling van de bevoegdheid yan bepaalde rechtspersionen orn ter bescherming van de belangen van andere personen een rechtsvordering in to stellen (Tweedle Kamer, vergaderjaar 199॥-1992, 22 486, nrs. 1-2), voorzag in artikell IIII ondermeer in wijzjging van artikel $6: 240$ lid $3 \mathrm{BW}$ in die zin, dat het vereiste van volledige rechtsbevoegdheid zou komen te vervallen oindat dit in het ontwerp artikel 3:305a BW ook niet werd gesteld. Biji amendement is het vereiste van volledige rechtsbevoegdheid toch opgenomen in artikel 305. BW (Tweede Kamer, vergaderjaar 1993-1994, 22 486, nr. 14; Handelingen Tweede Kamer, 2 november 1993, pag. 19-350).

404 In het stelsell van afdeling 6.5.3 BW speelt de mate van representativiteit slechts aen rol bij artikel 6:239 lid $2 \mathrm{BW}$. In het kader van een wijziging bij AMvB van de bepalingen van de grijze lijst dient de Minister van Justitie immers de naar zijn oordeel representatieve organissaties te horen.

405 Wessels en Jongeneell, 1992, pag. 176.

406 Zie hiema paragmaf 5.3.3.

407 VV I, Parlementaire Geschiedenis, Inv. 3, 5 en 6, pag. 1777; MvA I, Parlementaire Geschicdenis, Inv. 3, 5 en 6, pag. 1779.

408. Wessels en Jongeneel, 1992, pag. 176 en 171-172. Zie ook: W.J. Slagter, Aspecten vara algemene voorwaanden, in: Contracten in de Praktijk, Zwolle 1985, pag. 93. 
bernolken was, een rol kan spelen bij de toetsing, beaniwoorden wij bewestigend. Hoe breder de instewmaing - hetzj waw de betrokken wederpartijen, hettij wan hen vertegenwoondigendle organisafies

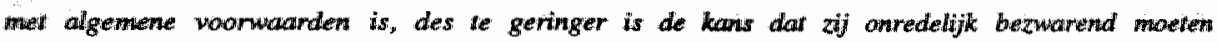
whorden geachs: 409

Dat er een grotere kans is dat de algemene voorwaarden die zijn opgesteld in overleg met representatieve vertegenwoordigende organisaties niet onredelijk bezwarend zijn, wil ik gaarne onderschrijven. Verder dan een kansindicatie zou ik echter niet willen gaan. De mate van representativiteit van de organisatie dient geen rol te spelen in de inhoudstoets zelf. De afkomst van algemene voorwaarden geeft weliswaar een indicatie voor de mogelijke bezwarendheid van bedingen, maar zegt niets over de feitelijke inhoud van een beding. De kansindicatie ontslaat de rechter derhalve niet van zijn taak de inhoud van het beding te toetsen. Ook in algemene voorwaarden die zijn vastgesteld in overleg met een in hoge mate representatieve organisatie kunnen immers algemene voorwaarden voorkomen die onredelijk bezwarend zijn voor (de kring van) wederpartijen. Onderhandelingsresultaten zijn vaak een compromis en worden beïnvloed door allerlei factoren als onderhandelingspositie en -doel, deskundigheid, onwil, gewijzigde opvattingen, etc. Voor deze voorwaarden geldt dan ook dezelfde objectieve toetsnorm als voor alle andere algemene voorwaarden. Voor de suggestie dat mér representatieve organisaties een beter onderhandelingsresultaat zouden bereiken dan minder representatieve, is voorshands in de praktijk nog geen grondslag te vinden. Er is mijns inziens dan ook weinig reden om bij de inhoudstoets een uitzondering te maken voor algemene voorwaarden die zijn vastgesteld in overleg met meer of minder representatieve organisaties van wederpartijen. ${ }^{410}$

In afwijking van het $\mathrm{CCA}$-advies ${ }^{41}$, zijn individuele ondernemers en consumenten van de procesbevoegdheid als bedoeld in artikel 6:240 BW uitgesloten. ${ }^{412}$ De uitsluiting van de collectieve actiebevoegdheid wordt als volgt, door mij aangepast aan de huidige artikelnummering, gemotiveerd:

De ratio wan deze beperking is gelegen in de strekling van de regeling die er immers in belangrijke mate op is gerich dat er onderhandelingen op gang komen over als onredelijk bezwarend beschouwde algemene woonwaanden; men vergelijke lid 4 van het onderhavige artikel. Her daar bedolde owerleg kan - alhwans aan de zijde van de personen jegens wie de algemene voorwarden worden gebraikt - slechts tussien organisaties zinwol plaatsvinden. Indien een ondememer fof een in een organisatie verenigde groep ondermemers) na onderhandelingen met de representatiene organisaties

$409 \mathrm{MvA}$, Parlementaire Geschiedenis, linw. 3, 5 en 6, pag. 1528.

410 Zie ook hierwoor paragraf 5.2.5.2 onder het kopje "De relevante omstandigheden".

411 CCA-Adwies, pag. 29-30.

412 MvT, Parlementaire Geschiedenis, Inv. 3,5 en 6, pag. 1764. 
van die personen met wie hij pleegt te contracteren tot een accoord over zijn algemene voomwairden is gekomen, dien hij er in beginsel van op acan te llownen dat hij zijn verdere bedrijfswoering op dut akkoord kan afstemumen. Het ware onwenselijk indien hif spoedig weer met een verbodsactie of ext bedreiging daurmee zou kunnen worden gestoord. Oak tid 5 is op deze gedachte gebaseerd. ${ }^{415}$

De argumenten die worden aangehaald om de collectieve procesbevoegdheid voor individuele consumenten en ondernemers af te wijzen, zijn mijns inziens echter niet overtuigend. Zeker niet als men deze afzet tegen de, mijns inziens zeer valabele, argumenten die in het CCA-advies naar voren werden gebracht ten faveure van de toegang van individuele eisers tot de bijzondere rechter. ${ }^{414}$

In het $\mathrm{CCA}$-advies wordt er van uit gegaan dat een individuele consument die met een onereus beding wordt geconfronteerd, zich doorgaans met een consumentenorganisatie in verbinding zal stellen, die dan, met het oog op de bescherming van de collectiviteit van consumenten, een eventueel verbod van het betreffende beding bij de bijzondere rechter kan uitlokken. Verder wordt terecht geconstateerd dat een individuele consument die wordt toegelaten tot de collectieve actie, slechts een verbod voor de toekomst kan vragen en dus geen wijziging kan brengen in een mogelijk tussen hem en de ondernemer in kwestie bestaande rechtsverhouding. Voor dit laatste moet de consument zich immers tot de gewone rechter wenden met een beroep op artikel 6:233 sub a BW. Bovendien wordt er van uitgegaan dat de procedure voor de bijzondere rechter ingewikkeld en daardoor vrij langdurig en kostbaar zal zijn, zodat de individuele consument weinig gebaat lijkt bij toegang tot de bijzondere rechter en daar ook slechts zelden gebruik van zal maken. Desalniettemin pleit het CCA er voor om ook de individuele consument de mogelijkheid te geven zich tot de bijzondere rechter te wenden, omdat zij van mening is

"... dat die consument zelf wel degelijk bij die uitspraak belang kan hebben, nl. als het gaal ant transacties die hij in de soekomst nog frequent zal stuiten. (...)

Men kan trauwens nilet op woorhand stellen dat een individuele consumemt niet bereid zal zijn terwille wan de consumeni in het algemeen stappen te ondememen am meer structurele veranderim gen te bewerkstelligen."

Bovendien zou, in de visie van het CCA, het toekennen van de toegang tot de bijzondere rechter aan de individuele consument er mede toe kunnen leiden

"... dat de consumentenorganisaties op dit gebied' geactiveerd worden, wat positief beoordleeld moet worden. Immers zal in het door de commissie acmbevolen systeem de totstandkoming wan eew meer

413 MvT, Parlementaire Geschiedenis, Inv. 3, 5 en 6, pag. 1764-1765.

414 CCA-advies, pag. 29-30. 
evemwichutig rechtshestel op thet stukt van de standaardwoonwraarden woorat afhankelijik zijm van de actinutiten die de conswmentenorganisaties ter zake oniplaaien. "415.

De bezwaren die de wetgever daar tegenover stelt steunen op het argument dat het toekennen van een collectieve actiebevoegdheid aan individuele consumenten en ondernemers, het onderhandelingsproces zou doorkruisen dat afdeling 6.5.3 BW juist probeert te stimuleren. Enerzijds omdat de individuele consument geen geschikte onderhandelingspartner is en anderzijds omdat ondernemers die een onderhandelingsresultaat hebben bereikt met consumentenorganisaties gevrijwaard moeten zijn van een collectieve actie jegens hen.

Het laatste argument is niet erg steekhoudend indien men bedenkt dat de instemming van een consumentenorganisatie met het gebruik van een bepaald beding, de gebruiker niet vrijwaart van een collectieve actie jegens hem, omdat slechts de instemmende organisatie haar actierecht verliest. Voor organisaties die niet in het overleg zijn betrokken of die hebben afgezien van instemming, staat de weg naar de bijzondere rechter nog steeds open.

Het is wellicht waar dat de individuele consument doorgaans minder geschikt is als onderhandelingspartner van gebruikers of branche-organisaties. Dit doet echter niet af aan het eventueel onredelijk bezwarend karakter van het ter discussie staande beding in algemene voorwaarden. Een beding is onredelijk bezwarend of niet; een tussenweg is er niet. Voor de objectieve inhoudstoets van artikel 6:240 BW is de hoedanigheid van degene die de collectieve vordering instelt ook niet relevant. Het actierecht van artikel 6:240 $\mathrm{BW}$ is immers gericht op een algemeen belang. ${ }^{416}$ Of, zoals het tijdens de mondelinge behandeling van het wetsontwerp werd uitgedrukt,

"In de letterlijke zin des woards is eigenlijk geen sprake van een groepsactie, maar van een actile wan een rechispersoon die een bepaald belang wertegenwoordigt. "4417

En dit bepaalde belang blijft steeds hetzelfde, namelijk het "abstracte" belang van de kring der potentiële wederpartijen jegens wie de in het geding zijnde algemene voorwaarden worden gebruikt. Dit belang staat in die zin los van de hoedanigheid van de eiser in de procedure. Voor de uitkomst van de inhoudstoets door de bijzondere rechter is derhalve irrelevant of een individu of een belangenorganisatie als eiser optreedt.

De individuele consument en de consumentenorganisatie bewerkstelligen dus voor de kring van de desbetreffende wederpartijen, exact dezelfde bescherming

415 CCA-advies, pag. 29.

416 MVA, Parlementaire Geschiedenus, Inv. 3, 5 en 6, pag. 1770; UCV II, Parlementaire Geschiedenis, Inw. 3, 5 en 6, pag. 1774 .

417 UCV II, Parlementaire Gieschiedenis, Inv. 3, 5 en 6, pag. 1775. 
tegen het gebruik van jegens hen onredelijk bezwarende algemene voorwaarden. Deze bescherming van wederpartijen tegen het gebruik jegens hen van onredelijk bezwarende algemene voorwaarden is het doel van afdeling $6.5 .3 \mathrm{BW}$. De strekking van afdeling 6.5.3 BW mag dan wel mede gericht zijn op het op gang brengen van onderhandelingen tussen branche- en consumentenorganisaties; het uiteindelijke doel van afdeling 6.5.3 $\mathrm{BW}$ is gelegen in het effectief tegengaan van het gebruik van onredelijk bezwarende algemene voorwaarden. Onderhandelingen kunnen daartoe zeker een belangrijk hulpmiddel zijn; zij zijn echter geen doel op zich. Een individuele collectieve actie zou voor het bereiken van de in afdeling 6.5.3 $\mathrm{BW}$ beoogde bescherming dan ook net zo effectief kunnen zijn als de collectieve actie door een belangenorganisatie. Beide acties dienen hetzelfde algemene belang. Collectieve acties door individuele consumenten zouden consumentenorganisaties van een deel van hun taak op dit terrein ontlasten en zijn in die zin alleen maar toe te juichen.

Ook een individuele consument zou de gebruiker of aanbeveler de gelegenheid moeten geven om in onderling overleg de bezwaren die de consument tegen het beding heeft weg te nemen (artikel 6:240 lid $4 \mathrm{BW}$ ). Zoals hiervoor reeds vermeld doet het er voor het onredelijk bezwarend karakter van het beding niet toe, wie zich met de bezwaren tegen het betreffende beding tot de gebruiker of diens branche-organisatie wendt. De gebruiker of diens organisatie heeft dan in beginsel de mogelijkheid te kiezen tussen ontkenning of bevestiging van het onredelijk bezwarend karakter van het betreffende beding. De gebruiker of diens organisatie die de bezwaren van de consument erkent, zal - er van uitgaande dat zij het recht en de belangen van hun wederpartijen serieus nemen - de betreffende algemene voorwaarden op eigen initiatief dusdanig wijzigen dat de bezwaren zijn weggenomen. Onderhandelingen tussen de gebruiker of diens organisatie met consumentenorganisaties zijn dan overbodig. Om de geuite bezwaren weg te nemen heeft de gebruiker of de branche-organisatie vervolgens 6 maanden de tijd (artikel 6:240 lid $4 \mathrm{BW}$ ). Niets let de gebruiker of branche-organisaties om in die tussentijd ook onderhandelingen te starten met consumentenorganisaties teneinde een bredere instemming te bereiken voor de beoogde wijziging van het onredelijk bezwarend geachte beding. Het initiatief tot het voeren van overleg hoeft immers niet uit te gaan van consumentenorganisaties. Het kan net zo goed uitgaan van een branche-organisatie naar aanleiding van een individuele collectieve actie. In die zin zal het toekennen van een actierecht aan individuele consumenten het overleg tussen gebruikers of hun organisaties enerzijds en consumentenorganisaties anderzijds dus ook stimuleren.

Mocht het toch tot een procedure komen, dan zouden consumentenorganisaties zich nog altijd kunnen voegen in de procedure die de individuele consument 
heeft aangespannen (6:241 lid $2 \mathrm{BW}) .^{418} \mathrm{Zij}$ zouden echter ook het resultaat kunnen afwachten van de toetsing door de bijzondere rechter om deze vervolgens in een eventueel overleg mee te nemen. In dit kader dient opgemerkt te worden dat de collectieve actie van artikel 6:240 BW net zo goed gericht kan zijin tegen eén enkele gebruiker. Ook dan is de procedure van artikel 6:240 BW niet direct gericht op het totstandkomen van onderhandelingen tussen brancheen consumentenorganisaties, maar kan de branche-organisatie door voeging tussenkomen.

Een laatste voordeel van het toekennen van de collectieve actie aan individuele consumenten zou zijn, dat consumenten de onderhandelingsresultaten van consumentenorganisaties zouden kunnen voorleggen aan de rechter en zodoende ook direct invloed kunnen uitoefenen op die onderhandelingsresultaten. Het is immers niet uitgesloten dat ook in algemene voorwaarden die het resultaat zijn van overleg tussen branche- en consumentenorganisaties bedingen voorkomen die onredelijk bezwarend zijn. Consumenten zouden via de bijzondere rechter consumentenorganisaties terug kunnen fluiten indien het onderhandelingsresultaat om welke reden dan ook onredelijk bezwarend voor hen uitpakt.

Kortom de door de wetgever aangehaalde argumenten om de toegang tot de bijzondere rechter aan individuele consumenten en ondernemers te ontzeggen zijn verre van overtuigend. Gezien de voordelen die de individuele collectieve actie zou bieden, is het jammer dat de wetgever in deze het advies van het CCA niet heeft gevolgd.

In Nederland zijn verschillende organisaties aan te wijzen die voldoen aan de vereisten gesteld in artikel 6:240 lid $3 \mathrm{BW}$. Ze kunnen grofweg ingedeeld worden in algemene en categoriale consumentenorganisaties. Het verschil tussen beide categorieën ligt in de doelstelling van de verschillende consumentenorganisaties en het vertegenwoordigde consumentenbelang. ${ }^{419}$ Waar de algemene consumentenorganisaties, met als belangrijkste exponenten de Consumentenbond en het Konsumenten Kontakt ${ }^{420}$, zich richten op de behartiging van consumentenbelangen in het algemeen, beperken categoriale consumentenorganisaties zich tot de behartiging van belangen van een specifieke groep consumenten. Tot de laatste categorie kunnen niet alleen organisaties als de ANWB, Vereniging Eigen Huis, Landelijk Patiëntenplatform en de Algemene Nederlandse Bond van Ouderen gerekend worden, maar ook bij voorbeeld de Moto Guzzi Club

418 Zie ook: CCA-gdvies, pag. 30. Zie voor artikel 6:241 lid 2 BW, hierna paragraf 5.3.10.5.

419 Zive hiervoor paragrasif 1.5.3.

420 Het Konsumenten Kontakt heeft met ingang van 1 juni 1994 zijn activiteiten als consumentenorganisatie beëindigd. Zie: TrC 1994, pag 334. 
Nederland als organisatie van eindgebruikers van een specifiek Italiaans merk motorrijwielen.

Voor de actiebevoegdheid is het genoemde onderscheid zonder belang. Het geeft echter wel duidelijk aan dat in Nederland tal van verschillende organisaties van eindgebruikers bevoegd zijn om gebruik te maken van het actierecht als bedoeld in artikel 6:240 $\mathrm{BW}$.

Een vraag die in de wet en tijdens de parlementaire behandeling van het wetsontwerp niet aan de orde is gekomen, is of ook buitenlandse consumentenorganisaties bevoegd zijn om op te treden voor de bijzondere rechter in 's-Gravenhage.

Artikel 6:240 lid 3 BW stelt niet als voorwaarde dat de eisende organisatie een Nederlandse organisatie moet zijn, dat de eisende organisatie in Nederland gevestigd is, noch dat de eisende organisatie een rechtspersoon naar Nederlands recht is. Naar mijn mening staat de rechtsgang voor de bijzondere rechter in "sGravenhage derhalve in beginsel ook open voor buitenlandse consumentenorganisaties. Uiteraard moeten ook buitenlandse consumentenorganisaties voldoen aan de eisen die artikel 6:240 lid $3 \mathrm{BW}$ stelt. Zij moeten volledige rechtsbevoegdheid bezitten en ten doel hebben de belangen te behartigen van consumenten. De vordering van de buitenlandse consumentenorganisatie kan ook slechts betrekking hebben op algemene voorwaarden die worden gebruikt of bestemd zijn te worden gebruikt in overeenkomsten met personen wier belangen door de rechtspersoon worden behartigd. In dat kader is het, bij voorbeeld, zeer wel mogelijk dat een Duitse consumentenorganisatie optreedt tegen een Nederlandse hotelier die onredelijk bezwarende algemene voorwaarden hanteert jegens zijn Duitse gasten. Ook voor de buitenlandse consumentenorganisatie geldt dan de overlegverplichting van artikel 6:240 lid $4 \mathrm{BW}$.

\subsubsection{Instemming van belangenorganisaties met het gebruik van bedingen in algemene voorwaarden}

Van de procesbevoegdheid als bedoeld in artikel 6:240 lid $1 \mathrm{BW}$ zijn uitgesloten de belangenorganisaties die met het gebruik van bepaalde algemene voorwaarden hebben ingestemd.

\section{Artikel $6: 240$ lid $5 \mathrm{BW}$}

Voov zover en rechispersoow met het gebruik wan bedingen in algemene woomwarden heef ingestemd, komt hem geen wordering als bedoeld in lid 1 toe.

Aan de bepaling ligt de gedachte ten grondslag dat de gebruiker "veilig dient te zijn tegen een rechtsvordering van de wederpartij met wie hij tot overeenstem- 
ming is gekomen". ${ }^{421}$ In het oorspronkelijke ontwerp lag het zelfs in de bedoeling dat de instemming van daartoe bij AMvB aangewezen belangenorganisaties met het gebruik van bepaalde bedingen, met zich zou brengen dat voor die bedingen de zwarte en grijze lijst niet zouden gelden in de individuele procedures ex artikel 6:233 sub a BW. ${ }^{422}$

De bepaling is net als die van artikel 6:240 lid $3 \mathrm{BW}$ bedoeld als stimulans voor zelfregulering. $\mathrm{Zij}$ beloont de gebruiker of de aanbevelende branche-organisatie voor met succes gevoerd overleg. De belangenorganisatie, die heeft ingestemd met het gebruik van bepaalde bedingen, verliest ten aanzien van die bedingen haar bevoegdheid een vordering als bedoeld in artikel 6:240 lid $1 \mathrm{BW}$ in te stellen. Haar vorderingsrecht is dus vervallen. Het gevolg is dat de rechter in dat geval een eisende organisatie niet-ontvankelijk dient te verklaren. ${ }^{423} \mathrm{De}$ eis wordt immers niet afgewezen omdat de vordering ongegrond of onbewezen is, maar om een reden die buiten de zaak zelf is gelegen. ${ }^{424}$ In de Memorie van Toelichting wordt terecht opgemerkt dat de "bepaling in de pas loopt met" artikel 3:303 BW. ${ }^{425}$

In de kamerstukken wordt een aantal situaties genoemd waaruit een instemming van belangenorganisaties van wederpartijen zou kunnen voortkomen. Daarbij wordt onderscheiden tussen enerzijds het verplichte overleg, bedoeld in artikel 6:240 lid $3 \mathrm{BW}$ en anderzijds, overleg dat anderszins is gevoerd. Van dit laatste overleg worden twee voorbeelden genoemd:

- algemene voorwaarden die in overleg tussen organisaties zijn opgesteld.

Gedoeld wordt daarmee op zelfregulering zoals deze onder andere plaatsvindt onder auspiciën van de CCA;

- overleg nadat een uitspraak als bedoeld in artikel 6:240 BW is gedaan, doch de gewijzigde omstandigheden een herroeping daarvan rechtvaardigen. ${ }^{426}$

In de kamerstukken wordt de nadruk gelegd op instemming als resultaat van overleg. Het is echter niet uitgesloten dat consumentenorganisaties ook zonder overleg instemmen met het gebruik van bepaalde algemene voorwaarden. Zo is niet alleen denkbaar dat consumentenorganisaties eenzijdig instemmen met bepaalde algemene voorwaarden als een waardering voor het consumentvriende-

421 MvT, Parlementaire Geschiedenis, Inv. 3, 5 en 6, pag. 1765.

422 MWT, Parlementaire Geschiedenis, Inw. 3, 5 en 6, pag. 1757.

423 Andens: Wessels en Jongeneel, 1992, pag. 179 en 182 . Zij verbinden aan de instemming het gevolg dat de eisende organisatie de vordering wordt ontzegd.

424 Hugenhollz/Heernskerk, pag. 104.

425 MwT, Parlementaire Geschiedenis, Inv. 3, 5 en 6, pag. 1765. De vaste Commissie voor Justitie tekende echter uitdruktkelijk aan "dat zij dasarlaat of artikel $3.303 \mathrm{BW}$ hier wel in het spel is". Zie: EV, Parlementaire Gesehiedenis, Inv, 3, 5 en 6, pag. 1772. Een antwoord op de vrag of artikel 3:303 BW van toepassing is acht de Minister vervolgens zonder belang. Zie: NEV, Parlementaine Geachiedenis, Inv. 3, 5 en 6, pag. 1773.

426 MvT, Parlementaire Geschiedenis, Inv. 3, 5 en 6, pag. 1765. 
lijke karakter van de algemene voorwaarden van bepaalde gebruikers of aanbevelers, ${ }^{427}$ maar ook dat een consumentenorganisatie zelf algemene voorwaarden opstelt die vervolgens worden gebruikt door ondernemers. Voor de toepassing van artikel 6:240 lid $5 \mathrm{BW}$ makt het dan ook niet uit hoe de instemming tot stand is gekomen. Zoals Wessels en Jongeneel terecht opmerken, is de instemming bedoeld in artikel 6:240 lid 5 BW niet onderworpen aan een vormvoorschrift en kan zij, op grond van artikel 3:37 $\mathrm{BW}$, besloten liggen in een of meer gedragingen van de eisende organisatie. ${ }^{428}$ Zo mag bij voorbeeld de gebruiker er van uitgaan dat een belangenorganisatie heeft ingestemd met het gebruik van door haarzelf opgestelde algemene voorwaarden.

De instemming kan geclausuleerd worden gegeven. ${ }^{429}$ Dit vloeit voort uit de woorden "Voor zover" in de aanhef van artikel 6:240 lid 5 BW. De instemmende rechtspersoon is bevoegd aan te geven in hoeverre hij instemt met het gebruik van het betreffende beding. Hij kan zijn instemming beperken tot overeenkomsten van een bepaalde soort of met betrekking tot bepaalde goederen. De instemming kan ook worden gegeven onder een of meerdere voorwaarden of voor een bepaalde tijd. ${ }^{430}$ De instemming kan behalve op de set algemene voorwaarden als geheel, ook betrekking hebben op afzonderlijke bedingen daaruit. ${ }^{431}$ Indien de instemming is gegeven voor een bepaalde tijd betekent dit dat de bevoegdheid van een instemmende organisatie om een vordering ex artikel 6:240 lid $1 \mathrm{BW}$ in te stellen weer herleeft op het moment dat de periode waarover de toestemming is gegeven, is verstreken.

De stelling dat de eisende organisatie heeft ingestemd met het gebruik van bepaalde bedingen in bepaalde algemene voorwaarden, zal in een procedure - in geval van betwisting - moeten worden bewezen door de gedaagde gebruiker of aanbeveler.

\subsubsection{Overlegverplichting}

Het vierde lid van artikel 6:240 $\mathrm{BW}$ onderstreept, net als het vijfde lid van artikel 6:240 $\mathrm{BW}$, het belang dat de wetgever hecht aan onderhandelingen tussen (organisaties van) gebruikers en organisaties van wederpartijen, ten einde 427 Te denken valt dan bijyoorbeeld aran cen kwaliteitskeurmerk. Zie ook: Rijken, inaug. rede, pag.
31 .

428 Wessels en Jongeneel, 1992, pag. 182.

429 MvA, Parlementaire Gessehiedenis, Inv. 3, 5 en 6, pag. 1770. Zive voor een praktijkwoorbeeld van een geclausuleende instemining: Verhoeven, pag. 123.

430 MvT, Parlementaire Gaschiedenis, Inv, 3, 5 en 6, pag. 1765 en 1757.

431 Mva I, Parlementaire Geschiedenis, Inv, 3, 5 en 6, pag. 1781. 
op die wijze te komen tot algemene voorwaarden die op evenwichtige wijze rekening houden met de wederzijdse belangen. 02

\section{Amikel 6:240 lid 4}

De eiser is miet ontwankelijk indien niet blijk dat hij, alworths de vordering in te stellen, de gebruiker of, in het geval bediold in arrikel 1003 van het Wetboek wan Burgerlijke Rechtsvordering. de aldaar bedoelde vereniging, de gelegenheid heeft geboden om in onderling owerleg de algemene waonwaarden zodanig te wijzigen dat de bezwaren die gromd voor de wordering zouden opleveren, zijn weggenomen. Een termijn yan zes maanden na schriftelijke kennisgeving van de bezwaren is dowartoe in elk geval voldoende.

Het artikellid is geënt op artikel $2: 349$ BW inzake het recht van enquête bij rechtspersonen als bedoeld in artikel 2:344 BW. ${ }^{433}$ De bepaling verplicht belangenorganisaties, op straffe van niet-ontvankelijkheid, de gebruiker of de aanbeveller de gelegenheid te bieden om in overleg met de gebruiker of de aanbevelende organisatie de gerezen bezwaren tegen het betreffende beding weg te nemen, alvorens zij een vordering als bedoeld in artikel 6:240 BW kunnen instellen.

Om niet-ontvankelijkheid op grond van artikel $6: 240$ lid $4 \mathrm{BW}$ te vermijden, is de eisende organisatie op de eerste plaats verplicht aan de gebruiker of aanbeveler kenbaar te maken welke de bezwaren zijn, die hebben geleid tot haar oordeel dat de betreffende bedingen onredelijk bezwarend zijn.

De wijze waarop deze bezwaren kenbaar worden gemaakt aan de gebruiker of de aanbeveler is niet vastgelegd in de wet. Het staat de eisende organisatie in beginsel dus vrij haar bezwaren mondeling, schriftelijk of op andere wijze aan de gebruiker of aanbeveler kenbaar te maken. ${ }^{434}$ In verband met het bepaalde in de laatste volzin van artikel 6:240 lid $4 \mathrm{BW}$, doet de eisende organisatie er echter verstandig aan de bezwaren schriftelijk kenbaar te maken aan de gebruiker of aanbeveler.

In de kennisgeving aan de gebruiker of aanbeveler moeten in de eerste plaats "de bezwaren die grond voor de vordering zouden opleveren" worden vermeld. De gebruiker of aanbeveler moet immers in de gelegenheid worden gestelld aan die bezwaren tegemoet te komen. De eisende organisatie moet dus kenbaar maken waarom het beding volgens haar onredelijk bezwarend is. In het geval van een beding dat wordt gehanteerd jegens consumenten én tevens voorkomt op de lijsten van de artikelen 6:236 en 6:237 $\mathrm{BW}$, zijn de bezwaren mijns 
inziens voldoende kenbaar gemaakt indien wordt gewezen op het feit dat het betreffende beding voorkomt op de zwarte of grijze lijst.

Artikel 6:240 lid $4 \mathrm{BW}$ vereist overigens niet dat de eisende organisatie in haar kennisgeving naar de gebruiker of aanbeveler wijzigingsvoorstellen doet of verlangens kenbaar maakt ten aanzien van het aangevallen beding. ${ }^{435}$ De tekst van het artikellid is daar vrij duidelijk over. Het is aan de gebruiker of diens organisatie om maatregelen te nemen teneinde aan de bezwaren van de eisende organisatie tegemoet te komen. Een andere uitleg zou betekenen dat consumentenorganisaties die van mening zijn dat een bepaald beding onredelijk bezwarend is en motiveren waarom dat volgens hen zo is, vervolgens ook nog herformuleringen, wijzigingen of alternatieven voor dat beding moeten aandragen. Dit lijkt mij niet de bedoeling van de wetgever. Gebruikers en aanbevelers van algemene voorwaarden dienen er immers op de eerste plaats zelf voor te zorgen, dat hun algemene voorwaarden voldoen aan de daaraan door afdeling 6.5.3 $\mathrm{BW}$ dwingendrechtelijk gestelde eisen. Het opnieuw concipiëren van bedingen die vanwege hun onredelijk bezwarend karakter niet meer gehanteerd kunnen worden, is, mede gezien het feit dat consumentenorganisaties op de eerste plaats worden verondersteld het consumentenbelang te behartigen en niet dat van gebruikers of aanbevelers, een taak van de gebruiker of diens organisatie. ${ }^{436}$ Uiteraard sluit dit niet uit dat de eisende organisatie in haar kennisgeving of in een mogelijk overleg kan aangeven hoe het nieuw te concipiëren beding volgens haar dient uit te zien.

In de tweede plaats dient de eisende organisatie in de kennisgeving aan de gebruiker of aanbeveler aan te geven dat zij bereid is om met deze, indien hij dat wenst, te overleggen over een dusdanige wijziging van de aangevallen bedingen dat de gerezen bezwaren zijn weggenomen. De eisende organisatie hoeft de gebruiker niet uit te nodigen voor overleg, zij hoeft daartoe slechts de gelegenheid te bieden. ${ }^{437}$ Het is vervolgens aan de gebruiker of aanbeveler om van de bereidheid van de eisende organisatie om te overleggen gebruik te maken of niet.

Naar haar aard is de kennisgeving van de eisende organisatie er in eerste instantie op gericht dat de gebruiker of aanbeveler het aangevallen beding voortaan niet meer hanteert jegens consumenten. De kennisgeving moet doorgaans echter tevens worden gezien als een inleiding voor de collectieve actie van artikel 6:240 lid 1 BW met als doel het gebrilik van het betreffende beding te verbieden (6:241 lid 3 sub a BW).

435 Anders: Wessels en Jongeneel, 1992, pag. 178.

436 Mölenberg en Rijken, pag. 65.

437 Anders: Wessels en Jongeneel, 1992, pag. 178; Verhoeven, pag. 124. 
Artikel 6:240 lid $4 \mathrm{BW}$ legt op de eisende organisatie de verplichting om in onderling overleg te treden met de gebruiker of aanbeveler over een eventuele wijziging van de aangevallen bedingen, indien deze dat wenst. Het overleg dient er op gericht te zijn de algemene voorwaarden zodanig te wijzigen dat de bezwaren die grond voor de vordering zouden opleveren, zijn weggenomen'. De consumentenorganisaties worden als het ware verplicht de gebruikers of aanbevelers te helpen bij het zodanig wijzilgen van hun algemene voorwaarden dat deze miet langer onredelijk bezwarend zijn. Uiteraard ligt het in de bedoeling dat de gebruiker of aanbeveler deze nieuwe, niet langer onredlelijk bezwarende, algemene voorwaarden voortaan gaat gebruiken in plaats van de aangevallen bedingen. Hoever dient de hulp van consumentenorganisaties in deze te gaan?

In de eerste plaats is er in de wet een duidelijke beperking in tijd gesteld aan de overlegverplichting van de eisende organisatie. Teneinde zoveel mogelijk rechtszekerheid te scheppen en nodeloos tijdverlies door de overlegverplichting te vermijden, is in de laatste volzin van artikel 6:240 lid $4 \mathrm{BW}$ immers uitdrukkelijk bepaald dat een termijn van zes maanden in elk geval voldoende is om het risico van niet-ontvankelijkheid te vermijden. ${ }^{438}$ De termijin wordt tijdens de parlementaire behandeling als volgt, door mij aangepast aan de huidige artikelnummering, nader toegelicht:

"Mer artikel $6: 240$ lid $4 \mathrm{BW}$ is bedold dat de eisende organisatie ontwankelijk is indien zes maanden na haar schriftelijke kennisgeving het overleg niet tot resullatem heeft geleid. De commissile achute the temijn kont, maar het altematief voor het stellen van een waste termijn is afwel dat de gebruiker (of diens organisatie) de eisende arganisatie eindeloos aan het lijntje kan houden, ofwel dat de beslissing of "het overteg retel is en woortdurt" acon de bijzondere rechter is, hetgeen rot veel anzekerheid en tot allerlei onverhoedse onderhamdelingsmanaeures nog tijidens de procedure kan Leider. In dit verband zij er ook aan herinnerd dal het in de onderhavige procedure niet mogetijk is. een woozieming in kort geding te vragen (...). Eir moet dus na een redelijke en vaste termijn eevi! procedure geopend kunnen worden. De termijm wan zes maanden lijk ons hiertoe ook bij nadere owernweging a anvaardbach.

De overlegverplichting van de eisende organisatie houdt dus in "elk geval" op zes maanden na schriftelijke kennisgeving van de bezwaren tegen een bepaald beding. Uiteraard staat het de eisende organisatie vrij om ook ná die periode van zes maanden overleg te voeren over wijzigingsvoorstellen. Het staat haar echter vrij de rechter een verbod te vragen van het gebruik wan het aangevallen beding als aan haar verlangens niet is tegemoetgekomen.

De zinsnede "in elk geval" in de laatste volzin van artikel $6: 240$ lid $4 \mathrm{BW}$ duidt er op, dat de termijn van zes maanden een maximum termijn is. Het lijkt

438 MVT, Parlementaire Geschiedenis, Inv, 3, 5 en 6, pag. 1765.

439 MvA I, Parlementaire Geschiedenis, Inv. 3, 5 en 6, pag. 1780. 
voldoende dat consumentenorganisaties de gebruiker of aanbeveler een redelijke termijn stellen ter aanpassing van de gewraakte bedingen. De zinsnede "in elk geval" geeft het Haagse hof de vrijheid om, onder omstandigheden, ontvankelijkheid van een consumentenorganisatie aan te nemen voór het verstrijken van zes maanden na schriftelijke kennisgeving van de bezwaren. ${ }^{40}$ Dit zal met name het geval zijn indien de gebruiker of aanbeveler reeds vorr het verstrijken van de termijn van zes maanden uitdrukkelijk te kennen heeft gegeven dat hij het beding niet onredelijk bezwarend acht en bovendien niet bereid is daarover te onderhandelen.

De overlegverplichting is verder beperkt omdat, zoals reeds eerder aangegeven, het mijns inziens niet op de weg ligt van de eisende organisatie om wijzigingsvoorstellen te doen ten aanzien van bedingen die als onredelijk bezwarend worden beschouwd. Dit ligt, gezien het dwingendrechtelijk karakter van afdeling 6.5.3 $\mathrm{BW}$, meer op de weg van de gebruiker of aanbeveler van algemene voorwaarden. Het lijkt mij derhalve voor de hand te liggen dat de overlegverplichting van de consumentenorganisaties zich kan beperken tot het geven van commentaar ten aanzien van de onredelijk bezwarendheid van de bedingen die het resultaat zijn van de door de gebruiker of aanbeveler gedane wijzigingsvoorstellen. Uiteraard staat het de consumentenorganisaties vrij om ook zelf wijzigingsvoorstellen te doen, zeker indien zij daarmee kunnen bereiken dat er evenwichtige algemene voorwaarden tot stand komen; zij zijn er echter niet toe verplicht.

De gebruiker of aanbeveler die een gewijzigd beding voorlegt aan de eisende organisatie mag van deze laatste verwachten dat zij haar oordeel geeft over het onredelijk bezwarend karakter van het gewijzigde beding. De consumentenorganisatie hoeft echter niet in te stemmen met het gebruik van het gewijzigde beding als bedoeld in artikel 6:240 lid $5 \mathrm{BW}$. Van een onderhandelingsverplichting is geen sprake. Dit komt ook tot uiting in de toelichtende kamerstukken waarin wordt aangegeven dat artikel 6:240 lid 4 BW een "prikkel" tot onderhandelen vormt $\mathrm{t}^{\text {t41 }}$ en voorts tot "onderhandelingen tussen de organisaties van betrokkenen over de voorwaarden zal kunnen leiden" ${ }^{\text {442 }}$ (cursivering LJHM). Uiteraard staat het de eisende organisatie vrij om, indien zij bij voorbeeld zeer tevreden is met de aangebrachte wijziging, in te stemmen met het gebruik van bepaalde bedingen; zij is daartoe echter niet verplicht.

440 Mölenberg en Rijken, pag. 65-66.

441 MvT, Parlementaire Geschiedenis, Inv. 3, 5 en 6, pag. 1762.

442 MvT, Parlementaire Geschiedenis, Inv. 3, 5 en 6, pag. 1764. 
Voor de ontvankelijkheid van de eisende organisatie is niet vereist dat er ook daadwerkelijk overleg is gevoerd. Vereist is slechts dat de eisende organisatie de gelegenheid biedt tot overleg over wijzigingsvoorstellen van de gebruiker of aanbeveler. Indien de gebruiker of aanbeveler van deze geboden gelegenheid geen gebruik maakt, staat dat niet in de weg aan ontvankelijkheid van de eisende organisatie. Het is vanzelfsprekend dat de eisende organisatie daadwerkelijk overleg moet voeren als de gebruiker of aanbeveler wêl gebruik maakt van de geboden gelegenheid.

Het overleg als bedoeld in artikel 6:240 lid 4 BW dient gericht te zijn op het wegnemen, door de gebruiker of aanbeveler, van de bezwaren die de eisende organisatie grond opleveren voor een vordering als bedoeld in artikel 6:240 BW. Strikt genomen is er echter maar én wijze waarmee de gebruiker of aanbeveler aan de bezwaren die grond opleveren voor de vordering zonder meer tegemoet komt: het omstreden beding in de aangevallen redactie en met de aangevallen strekking niet meer gebruiken. Het beding is naar het oordeel van de eisende organisatie immers onredelijk bezwarend. Niet voor niets is de collectieve actie van artikel 6:240 BW vooral gericht op het verbod van het gebruik van onredelijk bezwarende algemene voorwaarden.

Overleg tussen enerzijds de gebruiker of aanbeveler en anderzijds de consumentenorganisatie over een vervangend beding doet aan het onredelijk bezwarend karakter van het aangevallen beding niet af. Het omstreden beding is en blijft, ook tijdens het overleg over vervangende bedingen, onredelijk bezwarend. Het is ook niet uitgesloten dat de gebruiker of de aanbeveler reeds voorafgaand aan het overleg, te kennen heeft gegeven dat ook deze het beding onredelijk bezwarend acht. Dit zal zeker het geval zijn indien het een beding betreft dat voorkomt op de zwarte lijst of dat in strijd is met een dwingende wetsbepaling. Ook het feit dat de gebruiker in overleg treedt met de consumentenorganisatie over een wijziging van het omstreden beding, impliceert dat de gebruiker of aanbeveler de bezwaren van de eisende organisatie tegen het aangevallen beding geheel of gedeeltelijk gegrond bevindt. Indien de gebruiker of de aanbeveler de bezwaren van de consumentenorganisatie ongegrond vindt, is er immers geen reden voor deze om het omstreden beding te wijzigen.

Het overleg tussen enerzijds de gebruiker of aanbeveler en anderzijds de eisende organisatie is in eerste instantie dan ook niet gericht op het aangevallen (onredelijk bezwarende) beding zelf, maar op het vinden van niet-onredelijk bezwarende vervangers voor het gewraakte beding. 
Met het opleggen van de overlegverplichting kiest de Nederlandse wetgever op het collectieve vlak voor een twee-fasen systeem. Het gebruik van een onredelijk bezwarend beding kan niet direct worden verboden door de bijzondere rechter. In de eerste fase krijgt de gebruiker of aanbeveler zes maanden de tijd vrijwillig aan de bezwaren van de eisende organisatie tegemoet te komen door met deze te overleggen over een dusdanige wijziging van de algemene voorwaarden dat de bezwaren zijn weggenomen. De overlegverplichting van artikel 6:240 lid $4 \mathrm{BW}$ beoogt in eerste instantie onredelijk bezwarende bedingen uit de markt te lichten door deze in onderling overleg te vervangen door niet-onredelijk bezwarende algemene voorwaarden. Pas als deze vervanging niet lukt staat in de tweede fase de gang naar de bijzondere rechter open om middels een rechterlijk verbod of gebod het gebruik of de aanbeveling van onredelijk bezwarende bedingen tegen te gaan.

De eerste fase is in tijd begrenst om deze niet ongewenst lang te laten duren. Het is immers de bedoeling dat binnen een termijn van zes maanden het overleg over de wijziging van het aangevallen beding niet alleen opgang komt doch ook met resultaat wordt afgerond. Resultaat wil zeggen dat de bezwaren van de eisende organisatie zijn weggenomen doordat het aangevallen beding is vervangen door een, naar het oordeel van de eisende organisatie, niet-onredelijk bezwarend beding of dat de gebruiker heeft verklaard af te zien van verder gebruik of aanbeveling van het bestreden beding. Op die manier is het aangevallen beding na hoogstens zes maanden uit de markt genomen en bestaat er voor de eisende organisatie geen reden tot een collectieve actie voor de bijzondere rechter.

Het ontbreken, na ommekomst van de genoemde termijn van zes maanden, van een overlegresultaat waar de eisende organisatie tevreden mee is, maakt de eisende organisatie ten aanzien van het gewraakte beding ontvankelijk in haar vorderingen voor de bijzondere rechter. In die zin beoogt artikel 6:240 BW een drukmiddel te zijn om binnen die zes maanden tot het beoogde resultaat te komen. ${ }^{443}$ In dit verband wordt in de kamerstukken gewezen op de moeizaamheid van de onderhandelingen in CCA-verband ${ }^{44}$ welke moeizaamheid naar het oordeel van de Minister juist mede moet worden verklaard uit het ontbreken van een drukmiddel als artikel 6:240 BW.445

443 MvA I, Parlementaine Geschiedenis, lnv. 3, 5 en 6, pag. 1780.

444 Zie voor de moeizaamheid van de onderhandelingen omtrent de ANVR-voorwarden: Mölenberg en van der Sluijjs, pag. 267-268.

445 MvA I, Parlementaine Geschiedenis, Inv, 3, 5 en 6, pag, 1780. 
De eisende organisatie is derhalve na ommekomst van de genoemde zes maanden zonder meer ontvankelijk voor de bijzondere rechter. Een reeds aangevangen overleg stuit deze termijn niet. In de toelichtende kamerstukken wordt hierover uitdrukkelijk opgemerkt, dat de stelling, dat zolang het overleg reëel is en voortduurt, op straffe van niet ontvankelijkheid niet geprocedeerd kan worden, onjuist is. ${ }^{46}$ Ook indien na ommekomst van de zes maanden nog steeds reëel overleg plaats vind zal de rechter de eisende organisatie ontvankelijk moeten verklaren in haar rechtsvordering.

Wessels en Jongeneel sluiten niet uit dat in het geval dat het overleg nog reëel voortduurt, de bijzondere rechter derhalve kan oordelen dat de eiser door het instellen van een rechtsvordering ex artikel 6:240 BW misbruik maakt van zijn bevoegdheid (artikel 3:13 BW).447 Dit lijkt mij niet juist. Uiteraard is het mogelijk dat een eisende organisatie haar vordering wordt ontzegd omdat zij misbruik maakt van haar bevoegdheid tot het instellen van die vordering. Dit misbruik kan echter niet gelegen zijn in het feit dat nog steeds reëel overleg over wijziging van het angevallen beding gaande is. Dit overleg doet immers aan het onredelijk bezwarende karakter van het betreffende beding niet af. Zolang het overleg nog niet tot een voor de eisende organisatie bevredigend resultaat heeft geleid, staat het de gebruiker of aanbeveler in beginsel echter vrij het aangevallen beding te blijven gebruiken. Het is natuurlijk ook mogelijk dat de gebruiker of aanbeveler zich jegens de eisende organisatie verplicht om het aangevallen beding niet meer te gebruiken. Aan een procedure ex artikel 6:240 BW komt men dan niet toe, omdat in dat geval de eisende organisatie, wegens het ontbreken van het gevaar van hernieuwd gebruik van het aangevallen beding, onvoldoende belang heeft bij haar vordering (artikell 3:303 BW). ${ }^{448}$ Het is echter niet uitgesloten dat de gebruiker of aanbeveler het aangevallen beding blijft gebruiken. De eisende organisatie mist de eerste zes maanden immers de bevoegdheid collectief op te treden middels een gebods- of verbodsactie. Gebruikers lopen bij het gecontinueerd gebruik van een dergelijk onredelijk bezwarend beding, in die periode geen groter risico dan dat de individuele wederpartij een dergelijk beding vernietigt met een beroep op artikel 6:233 sub a BW, al dan niet in verbinding met de lijsten van de artikelen 6:236 en 6:237 BW. Van een effectieve bescherming van de individuele consument is dan echter geen sprake, deze zal zich immers veelal niet bewust zijn van de bescherming die afdeling $6.5 .3 \mathrm{BW}$ hem biedt. ${ }^{49}$

446 VV I, Parlementaire Geschiedenis, Inv. 3, 5 en 6, pag. 1778; MvA 1, Parlementaire Geschiedenis, Inv. 3,5 en 6 , pag. 1780 .

447 Wessels en Jongeneel, 1992 , pag. 180.

$448 \mathrm{Z}$ ie hierma paragranf 5.3.6.

449 Rijken, inaug. rede, pag. 25 en 30 . 
Consumentenorganisaties hebben er dus belang bij dat het onredelijk bezwarende beding zo snel mogelijk van de markt verdwijnt. Ofwel door vervanging of door verbod. Op het moment dat de bijzondere rechter te beoordelen heeft of er, gezien het feit dat nog sprake is van reëel overleg, mogelijk sprake is van misbruik van bevoegdheid van de eisende organisatie, zijn reeds minstens zes maanden verstreken na het uitbrengen van de kennisgeving aan de gebruiker of aanbeveler dat een beding in zijn algemene voorwaarden onredelijk bezwarend is. ${ }^{450}$ Van een, naar het oordeel van de eisende organisatie, tevredenstellende vervanging van het onredelijk bezwarende beding is dan nog geen sprake en de gebruiker of aanbeveler heeft eveneens nagelaten zich te verplichten om het aangevallen beding niet meer te gebruiken of aan te bevelen. Onder die omstandigheden is het weinig reëel een eisende organisatie tegen te werpen dat zij misbruik maakt van procesbevoegdheid omdat zij het (gevaar van) gebruik van een onredelijk bezwarend beding nu eindelijk effectief en afdwingbaar wil tegengaan. Daarbij komt dat een rechterlijk verbod van gebruik of aanbeveling of een rechterlijk gebod tot herroeping van een onredelijk bezwarend beding niet in de weg staat aan overleg over een vervanger van dit beding.

Of de bezwaren tegen het aangevallen beding zijn weggenomen is ter beoordeling van de eisende organisatie. De bijzondere rechter mag ná het verstrijken van de termijn van zes maanden derhalve niet in zijn overwegingen betrekken of reëel overleg is gevoerd. ${ }^{451}$ De rechter hoeft slechts in zijn oordeel te betrekken of de eisende partij de gebruiker of anbeveler de gelegenheid heeft geboden aan de bezwaren tegemoet te komen en, indien de gebruiker of aanbeveler de wens tot overleg te kennen heeft gegeven, of er overleg is gevoerd.

"Slaagt het overleg niet, dan is het miet de taak van de bijzondere rechter om de gang wan zaken tijdens dat overleg te beoordelen, maar om over het al dan niet onredelijk bezwarende karakter wari het aangevallen beding te beslissen. "452

De procedure voor de bijzondere rechter is de tweede fase. In deze fase is de collectieve actie in beginsel niet meer gericht op het wegnemen van de bezwaren van de eisende organisatie door middel van een wijziging of vervanging van het als onredelijk bezwarend beschouwde beding. De inhoudstoets van artikel 6:240 lid 1 BW is direct gericht op het onredelijk bezwarende karakter van het

450 Zes maanden van verplicht overleg (artikel 6:240 lid $4 \mathrm{BW}$ ) en cén maand voor de dagvardingstermijn indien collectief wordt gedagvaand (artikel 9 lid $3 \mathrm{Rw}$ ) of acht dagen indien niet collectief wordt gedagvaand (artikel 7 Rv).

45I. MvA I, Parlementaire Geschiedenis, Inv. 3, 5 en 6, pag. 1780.

452 MvA I, Parlementaire Geschiedenis, Inv. 3, 5 en 6, pag. 1781. 
gewraakte beding zelf. De bijzondere rechter dient te beoordelen of het betwiste beding onredelijk bezwarend is en eventueel verboden dient te worden. Het uit de markt nemen van onredelijk bezwarende bedingen wordt in deze fase primair middels de weg van het rechterlijk ge- en verbod bereikt. Het onredelijk bezwarende karakter van het beding wordt in deze fase niet tegengegaan door wijziging van het beding maar door uitbanning ervan.

Primair, omdat de wetgever ook in de tweede fase nadrukkelijk ruimte laat voor gebruikers of aanbevelers om hun algemene voorwaarden, al dan niet in overleg, dusdanig te wijzigen dat de bezwaren die de eisende organisatie grond opleverden voor hun vordering, zijn weggenomen. Zo zal er bij voorbeeld geen reden zijn voor de bijzondere rechter om een verbod als bedoeld in artikel 6:241 lid 3 sub a BW op te leggen, indien de gebruiker voor of tijdens de procedure te kennen heeft gegeven dat hij van verder gebruik van het beding zal afzien indien de rechter dit beding onredelijk bezwarend verklaart. ${ }^{453}$ De nadruk die de wetgever legt op bestrijding van onredelijk bezwarende algemene voorwaarden door middel van wijziging daarvan komt ook tot uiting in artikel 6:241 lid 4 BW waarin de bijzondere rechter de mogelijkheid wordt geboden om in zijn uitspraak aan te geven, op welke wijze het onredelijk bezwarende karakter van de bedingen waarop de uitspraak betrekking heeft kan worden weggenomen..$^{454}$

In het licht van het gegeven, dat het de gebruiker tijdens het overleg als bedoeld in artikel 6:240 lid $4 \mathrm{BW}$ in beginsel vrij staat de aangevallen bedingen te blijven gebruiken, doet de keuze van de wetgever voor een overlegverplichting van maximaal een half jaar alvorens de eisende organisatie ontvankelijk is om een verbod van het gebruik van een beding dat naar haar mening onredelijk bezwarend is te kunnen vorderen, enigszins vreemd en onterecht aan. Te meer nu afdeling 6.5.3 BW vooral tot doel heeft het gebruik van onredelijk bezwarende bedingen op een efficiënte wijze terug te dringen. De meest efficiënte wijze is ongetwijfeld het verbod van het gebruik van het onredelijk bezwarende beding. Consumentenorganisaties moeten echter eerst een half jaar met een gebruiker of aanbeveler over de wijziging van een onredelijk bezwarend beding in een niet onredelijk bezwarend, alvorens zij een rechtsvordering kunnen instellen die het gebruik van het onredelijk bezwarende beding ook daadwerkelijk verbiedt. Dit brengt met zich dat gebruikers in die tussentijd ook niet door middel van een collectieve actie gedwongen kunnen worden het gebruik van het omstreden beding te staken. Voor gebruikers en aanbevelers heeft dit stelsel als voordeel dat zij in beginsel de mogelijkheid hebben nog gedurende minimaal zes maanden hun oude, onredelijk bezwarende algemene voorwaarden,

453 MVA, Parlementaire Geschiedenis, Inv. 3, 5 en 6, pag. 1793.

454 Zie hiema paragraaf 5.3.10.7. 
te blijven gebruiken. Voor consumentenorganisaties is dit ongetwijfeld een weinig bevredigende situatie. Zeker indien de aangevallen bedingen onredelijt: bezwarend zijn omdat zij op de zwarte lijst staan of in strijd zijn met een dwingende wetsbepaling. In dat geval staat immers ook voor de gebruiker of aanbeveler onomstotelijk vast dat het betreffende beding onredelijk bezwarend is. Een voorziening in kort geding is echter uitgesloten. ${ }^{455}$ Bij onwil van de gebruiker of aanbeveler om het gebruik van het aangevallen beding te staken, is derhalve een efficiënte en effectieve bescherming van consumenten tegen het gebruik van onredelijk bezwarende bedingen in beginsel pas mogelijk zes maanden na kennisgeving van de bezwaren.

Een oplossing voor dit probleem is mogelijk te vinden in het gegeven dat de termijn van zes maanden na kennisgeving van de bezwaren tegen het beding een maximum-termijn is. De rechter heeft onder omstandigheden de mogelijkheid om dus ook reeds ontvankelijkheid van de eisende organisatie aan te nemen op een eerder moment. Dit doet zich volgens mij voor indien vast staat dat de gebruiker of aanbeveler, na door de eisende organisatie verzocht te zijn zich te verplichten om terstond van het gebruik van een evident onredelijk bezwarende beding af te zien, geen gehoor heeft gegeven aan dit verzoek. Alsdan staat mijns inziens ook vast dat hij niet bereid is de bezwaren van de eisende organisatie die grond op leveren voor de vordering weg te nemen. Daar doet niet aan af dat ondertussen overleg wordt gevoerd over een mogelijke vervanging van het aangevallen beding.

Een andere oplossing van het probleem zou gezocht kunnen worden in artikel 3:13 BW. De bijzondere rechter kan onder omstandigheden oordelen dat het beroep van de gebruiker of aanbeveler op de niet-ontvankelijkheid van de eisende organisatie ex artikel 6:240 lid 4 BW, misbruik van bevoegdheid oplevert (artikel 3:13 BW) en dat de gebruiker zich dus niet op artikel 6:240 lid $4 \mathrm{BW}$ kan beroepen.

\subsubsection{Algemene ontvankelijkheidsvereisten}

De algemene ontvankelijkheidseisen volgen uit artikel 3:303 BW:

"Zonder valdoende belang kom niemand een rechisvordering toe."

De bepaling van artikel 3:303 BW ziet enerzijds op het vereiste van een processueel belang en anderzijds op het vereiste van voldoende materieel belang. ${ }^{456}$ 
Zoals reeds eerder vermeld ziet het vereiste van een processueel belang zoals dat tot uiting komt in het adagium "point d'interat, point d'action" oftewel "geen (processueel) belang, geen actie" op de vraag of de eiser enig belang heeft bij toewijzing van het door haar gevorderde. De vraag dus of met de vordering eisers recht en belang is te verwezenlijken. ${ }^{457} \mathrm{Zo}$ zal, bij voorbeeld, een processueel belang ontbreken indien eisers nakoming van een onmogelijke prestatie vordert of indien een reeds toegewezen vordering nogmaals wordt ingesteld. Het vereiste geeft uitdrukking aan de gedachte dat men de rechter en de tegenpartij niet onnodig lastig moet vallen.

Het vereiste van voldoende materieel belang ziet op de eerste plaats op de vraag of de eiser enig eigen materieel belang heeft bij de vordering en vervolgens op de vraag of dit belang van voldoende importantie is om de rechter daarover een uitspraak te laten doen. ${ }^{458}$

Het vereiste dat men enig eigen materieel belang moet hebben is een uitwerking van de procesrechtelijke beginselen dat een eiser in een civiele procedure slechts voor zijn eigen belangen kan opkomen en dat niemand tegen zijn wil kan worden gedwongen zijn persoonlijke belangen in een civiele procedure te behartigen. Artikel 6:240 lid $3 \mathrm{BW}$ legt in dit verband wettelijk vast dat de daar genoemde organisaties materieel belang hebben bij een vordering als bedoeld in artikel 6:240 BW, althans voor zover het betreft een vordering met betrekking tot algemene voorwaarden gebruikt jegens wederpartijen wier belangenbehartiging de eisende organisaties zich statutair heeft aangetrokken. Een consumentenorganisatie heeft geen belang bij een vordering met betrekking tot algemene voorwaarden die enkel worden gehanteerd jegens professionele wederpartijen.

Over de ard van het belang van consumentenorganisaties wordt in de kamerstukken het volgende opgemerkt:

"De consumentenorganisaties oefenen (...) een taak wit in het algemeen conswmentenbelang, whantor kun elgen middelen weelal niet toereikend zijm. "4s9

Daarmee wordt aangegeven dat het belang dat consumentenorganisaties in de collectieve actie van artikel 6:240 BW vertegenwoordigen een algemeen belang is. Namelijk het algemene belang dat is gelegen in de bescherming van consumenten. ${ }^{400}$ Een belang dat volgens de klassieke staatsopvatting behartigd dient te worden door de overheid, maar waarvan de behartiging in afdeling 6.5.3 BW

457 Zie meer uitgebneid: Frenk, dis: , pag. 27-32.

458 Zie witgebreid: Frenk, diss., pag. 32 env.

459 MVA. Parlementaine Geschiedenis, Inv. 3, 5 en 6, pag. 1770.

460 UCV II, Parlementaire Geschiedenis, Inv. 3, 5 en 6, pag. 1774. 
uitdrukkelijk ook in handen van consumentenorganisaties is gelegd. Van daar ook, dat de wetgever het op zijn weg vindt liggen een deel van de activiteiten van consumentenorganisaties op dit terrein te subsidiëren. ${ }^{461}$ In die zin is de collectieve actie van consumentenorganisaties op grond van artikel 6:240 $\mathrm{BW}$ dan ook geen groepsactie, maar een actie van een rechtspersoon die een algemeen belang vertegenwoordigt. ${ }^{462}$ Hierop sluit ook de volgende, tijdens de mondelinge behandeling in de Tweede Kamer gemaakte, opmerking aan:

"Wij openen hier de mogelijkheid" voor consumentenorganisaties om actie te ondernemen zonder dat er een materieel belang, maar wel een idezel belang voor die organisaties aan de orde is, een belang dat statutair is omschreven. ${ }^{463}$

Ongetwijfeld is hiermee bedoeld dat aan consumentenorganisaties het actierecht wordt gegeven ondanks het feit dat deze strikt genomen geen eigen materieel belang bij collectieve actie hebben. De collectieve actie betreft immers in wezen belangen van anderen dan de eisende organisatie, namelijk consumenten. Strikt genomen treedt een organisatie in de collectieve actie van artikel 6:240 BW dus steeds op ter behartiging van belangen van anderen dan haarzelf. Op grond van artikel 6:240 lid $3 \mathrm{BW}$ echter, moeten belangenorganisaties die zich de behartiging van belangen van wederpartijen hebben aangetrokken in beginsel geacht worden een eigen belang te hebben bij de vorderingen van de artikelen 6:240 en 6:241 BW.

Artikel 3:303 BW vereist niet alleen dat er een materieel belang is maar ook dat dit materiële belang voldoende is om de rechter te raadplegen. De eis van voldoende belang berust op de gedachte dat men de rechter niet voor elke futiliteit of in triviale kwesties kan adiëren. Zo zal bij voorbeeld niemand een vordering toekomen als het belang beperkt is tot de enkele afgifte van een geldbedrag ter hoogte van een dubbeltje, hoe gegrond deze vordering ook mag zijn.

Het ontbreken van een processueel belang of voldoende materieel belang als bedoeld in artikel 3:303 BW leidt tot niet-ontvankelijkheid van de eiser.

In de kamerstukken wordt, overigens in verband met het verjaringsvraagstuk, gewezen op de mogelijkheid van niet-ontvankelijkheid van de eisende organisatie.

461 Zie hiema paragraaf 5.3.11.

462 UCV II, Parlementaire Geschiedenis, linv. 3, 5 en 6, pag. 1775.

463 UCV II, Parlementaire Geschiedenis, Inv. 3, 5 en 6, pag. 1774. 
Het Higt voor de hand dat de vordering alleen kan worden ingesteld ter zathe vam bedingen in: algemene voomaarden die recentelijik nog werden gebruik en waarvan niet uitgesioten is dat dij gebruik wordt voortgezer, ondat anders voldoende belang ontbreekt (artikel $3: 303 \mathrm{BW}$ ). 4 .464

Consumentenorganisaties moeten dus kunnen aantonen dat niet is uitgesloten, dat het beding dat zij aan de bijzondere rechter ter toetsing voorleggen, nog eens zal worden gebruikt. Zij moeten dus een herhalingsgevaar aannemelijk kunnen maken. Kunnen zij dit niet dan is de eisende organisatie niet-ontvankelijk. Dit zal bij voorbeeld het geval zijn indien de gebruiker of aanbeveler van het aangevallen beding zich uitdrukkelijk jegens de eisende organisatie heeft verplicht het aangevallen beding voortaan niet meer te gebruiken.

Zoals reeds eerder opgemerkt is in de collectieve actie met betrekking tot bepaalde bedingen in bepaalde algemene voorwaarden het door consumentenorganisaties vertegenwoordigde belang steeds hetzelfde. Het betreft immers altijd het belang van de kring van (consumenten)wederpartijen bij deze specifieke bedingen. In beginsel maakt het derhalve niets uit welke belangenorganisatie voor de bijzondere rechter optreedt ter behartiging van dit belang. De uitkomst van de inhoudstoets van artikel 6:240 BW is immers niet afhankelijk van de vraag wie als eisende organisatie ageert.

Het voorgaande betekent echter ook dat indien de bijzondere rechter reeds door een consumentenorganisatie is gevraagd om een uitspraak te doen of indien de bijzondere rechter reeds een uitspraak over de onredelijk bezwarendheid van een specifiek beding in algemene voorwaarden heeft gedaan, een tweede organisatie die eenzelfde uitspraak wil uitlokken over hetzelfde beding, in beginsel niet-ontvankelijk is. De laatste organisatie heeft immers geen processueel belang. $\mathrm{Zij}$ vraagt de rechter immers hetzelfde oordeel te geven in het belang van dezelfde wederpartijen en dus (nog eens) dezelfde uitspraak te doen. ${ }^{465}$

Aan het declaratoir van artikel 6:240 lid $1 \mathrm{BW}$ kunnen de nevenvorderingen van artikel 6:241 leden 3 en 5 BW worden gekoppeld. Deze nevenvorderingen kunnen door de rechter slechts tegelijkertijd met toekenning van het declaratoir worden toegekend. Indien reeds een eerdere abstracte procedure is gevoerd,

464 MvT, Parlementaire Gesschiedenis, Inv. 3, 5 en 6, pag. 1765-1766.

$465 \mathrm{Van}$ dexe situatie dient te wonden onderscheiden het gevall dat een eisende organisatie goede gronden meent te hebben een reeds eerder gedane uitsprab van de bijzondere reehter te kunnen wijzigen. Bij voorbeeld in het (hypothetische) geval dat cen eisende organisattie aan hear vordering om een beding onmedelijk bezwarend te verklaren, slechts cen beroep op de omstan" digheden als bedoeld in de open norm open norm ten grondslag legt en daarbij over het hoofd ziet dat het beding in strijd is met dwingend recht. Dit lamatste stelt zij dain ook niet. Indien het Hof dat dan ook niet ziet is thet niet onmogelijk dat de vordering, gestoeld op de omstandigheden als bedoeld in artikel $6: 233$ sub a BW, wondt afgewexen. In zulk een geval theeft een andere eisende organisatie well belang bij cen (eigen) vordering. 
staat daarmee in ieder geval vast, dat ook reeds eerder het declaratoir van. artikel 6:240 lid $1 \mathrm{BW}$ is gevorderd. In beginsel is een tweede organisatie die hetzelfde declaratoir vraagt derhalve niet-ontvankelijk. Het is echter mogelijk dat de eerste vordering zich heeft beperkt tot dit declaratoir en dat er verder geen nevenvordering als bedoeld in artikel $6: 241$ leden 3 en 5 is ingesteld. Het is in dat geval niet uitgesloten dat een organisatie die eerst later de gang naar de bijzondere rechter maakt, naast het declaratoir ook nog een of meer van de nevenvorderingen instelt. In dat geval vordert de eisende organisatie welliswaar hetzelfde declaratoir, maar haar vordering verschilt, vanwege de uitbreiding van de eis, echter wezenlijk van de vordering van de eerste organisatie. Omdat zij] slechts gedeeltelijk hetzelfde vordert als de eerdere eiser, heeft zij een eigen processueel belang en is zij dus in beginsell ontvankelijk.

Hetzelfde doet zich voor indien in een eerdere abstracte procedure ten aanzien van hetzelfde beding, een dwangsom is opgelegd. Een dwangsom kan immers slechts worden verbeurd aan de eisende organisatie die partij was bij de procedure waarin deze dwangsom is opgelegd. ${ }^{40 k}$ in dat geval heeft een organisatie die eerst Jater de gang naar de bijzondere rechter maakt in beginsel een eigen processueel belang bij de vordering tot het opleggen van een dwangsom ten behoeve van haarzelf.

Voor wat betreft de nevenvorderingen van artikel 6:241 lid $3 \mathrm{BW}$ geldt mijns inziens altijd dat een herhaalde vordering hiervan altijd moet leiden tot niet-ontvankelijkheid van de dan eisende organisatie. Een organisatie heeft immers nooit een eigen processueel belang bij toekenning van deze nevenvorderingen.

De stelling dat een organisatie die een reeds door een andere organisatie ingestelde vordering ten aanzien van een bepaald beding, nogmaals instelt, nietontvankelijk is, lijdt uiteraard uitzondering, indien er sprake is van dusdanig gewijzigde omstandigheden en opvattingen dat de eerdere uitspraak van de bijzondere rechter als achterhaald kan worden beschouwd. In dat geval staat een eerdere uitspraak van de bijzondere rechter niet in de weg aan ontvankelijkheid van de dan eisende organisatie.

Het feit dat een organisatie in een later aangespannen procedure mogelijk nietontvankelijk is, staat niet in de weg aan de mogelijkheid van consumentenorganisaties om zich te voegen in de eerste collectieve procedure die met betrekking tot het gewraakte beding wordt gevoerd (artikel 6:241 lid $2 \mathrm{BW}^{467}$ ). Deze mogelijkheid van voeging is vooral van belang met betrekking tot een mogelijke

466 Zie hiema paragraf 5.3.8.4.

467 Zie hiema paragraf 5.3.10.5. 
dwangsom die de bijzondere rechter kan opleggen op herhaald gebruik van een verboden beding. Dwangsommen kunnen immers slechts verbeurd worden aan procespartijen.

\subsubsection{De geadresseerden van de vorderingen}

Degenen tegen wie de vorderingen als bedoeld in de artikelen 6:240 en 6:241 BW kunnen worden gericht staan vermeld in artikel 6:240 lid 2 BW.

\section{Artikel 6:240 lid 2 BW}

De wordering kan worden ingesteld tegen de gebraiker, alsmede tegen een rechtspersoom mer wolledige rechisbevoegdheid die ten doel heeft de behartiging war belangen van personen die een beroep of bedriff witoefenen, indien hij het gebruik wan de algemene voorwarden door die personen bevoritent.

De vordering richt zich in de eerste plaats tegen de gebruiker van algemene voorwaarden als bedoeld in artikel 6:231 sub b BW. Niet vereist is dat deze de betreffende algemene voorwaarden reeds heeft gebruikt in zijn overeenkomsten. De vorderingen als bedoeld in de artikelen 6:240 en 6:241 BW kunnen eveneens worden ingesteld tegen de gebruiker die het gebruik van bepaalde algemene voorwaarden aankondigt.

"Mier wan belang is of het gebruik in een bepaald of onbepaald aamtal gevallen plaatsvindt of zal placassinden; het artikel (6:231 sub a BW; toevoeging LJHM) vereist slechts dat de voorwaarden "geregeld" (zullen) worden gebezigd.

Artikel 6:231 sub b BW ziet niet op de gevolmachtigde. In het geval dat een gevolmachtigde algemene voorwaarden gebruikt is de volmachtgever immers de gebruiker ${ }^{409}$ Toch kan de vordering van artikel 6:240 BW ook worden ingesteld tegen de gevolmachtigde die op naam van de volmachtgevers algemene voorwaarden gebruikt.

"Immers, zulks maakt een effectiewe bestrijding van onerewze algewnene voorwadrden mogelijk acangezien owertreding van het tegen een gevolmachigde als gebruiker witgesproken wenbod om een bepaald beding in naam van een toekomstige opdrachgewevs te hanteren, vernietigbactheid van het beding ten gevolge heeft. "A70

468 MvT, Parlementaire Geschiedenis, Inv. 3, 5 en 6, pag. 1520.

469 Wessels en Jongeneel, 1992 , pag. 38-39.

$470 \mathrm{VW}$, Parlementaire Geschiedenis, Imv. 3, 5 en 6, pag. 1768. Zie ook: NEV, Parlementaire Geschiedenis, Inv, 3, 5 en 6, pag. 1540. 
Hierbij moet vooral gedacht worden aan de gevolmachtigde die optreedt namens telkens andere volmachtgevers en daarbij zijn eigen onredelijk bezwarende algemene voorwaarden hanteert. Een verbod om die onredelijk bezwarende bedingen te gebruiken dient op de eerste plaats de gevolmachtigde te treffen en niet de toevallige volmachtgever. ${ }^{471}$

Met degene die het gebruik van algemene voorwaarden bevordert wordt uitsluitend gedoeld op branche-organisaties die ten behoeve van de bij hen aangesloten ondernemers algemene voorwaarden opstellen of doen opstellen. Daarbij is niet van belang of deze branche-organisaties het gebruik van die voorwaarden verplicht stellen of aanbevelen dan wel slechts ter beschikking stellen. 42

De mogelijkheid dat belangenorganisaties van wederpartijen ook een vordering kunnen instellen tegen de aanbeveler, wordt vooral gewenst geacht:

"in het belang wan en effectieve bestrijding van onereuze algemene voorwaarden die collectief worden gebriikt, mede omdat zij tor onderhandelingen tussen de organisaties vam betrokkemen over de voorwaarden zal kiminen leiden. "47s

Hierin komt uitdrukkelijk de "countervailing-power" gedachte tot uitdrukking. ${ }^{474}$

Oorspronkelijk werd het ook mogelijk geacht anderen dan branche-organisaties, zoals notarissen, advocaten, redacties of uitgevers van modellenboeken etc., als aanbeveler te beschouwen en met een rechtsvordering als bedoeld in artikel 6:240 BW aan te spreken. ${ }^{475}$ Op aandringen van de vaste Commissie voor Justitie $e^{476}$, die niet kon instemmen met deze brede werking van de collectieve actie, werd het instellen van een rechtsvordering tegen degene die het gebruik bevordert, uitdrukkelijk beperkt tot het voor de praktijk belangrijkste geval van "de brancheorganisatie die ten behoeve van de bij haar aangesloten ondernemers algemene voorwaarden opstelt of doet opstellen".477

De vorderingen van artikel 6:240 en 6:241 BW kunnen enkel worden gericht tegen aanbevelers die de belangen behartigen van personen die een beroep of bedrijf uitoefenen. Andere aanbevelers van algemene voorwaarden zoals bij

471 Wesselis en Jongeneel, 1992, pag. 39.

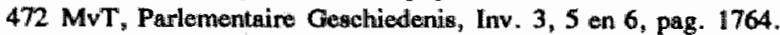

473 MvT, Parlementaire Geschiedenis, Inv. 3, 5 en 6, pag. 1764.

474 Zie onder andere: MvA 1, Parlementaire Geschiedenis, Inw. 3, 5 en 6, pag. 1780.

475 Het oorspnonkelijk ontwerp richtte de vordering mede tegen degene "die het gebruik daarvan bevondert." OwW, Parlementaire Geschiedenis, Inv. 3, 5 en 6, pag. 1762; MvT, Parlementaire Geschiedenis, Inv. 3, 5 en 6, pag. 1764.

476 VV, Parlementaire Geschiedenis, Inv. 3, 5 en 6, pag. 1768.

477 Mv.A, Parlementaire Geschiedenis, Inv. 3, 5 en 6, pag. 1770. 
voorbeeld de Vereniging van Nederlandse Gemeenten (als behartiger van de belangen van bepaalde openbare lichamen) of werknemersorganisaties kunnen in beginsel dus niet worden gedagvaard. ${ }^{478}$

De opvatting dat de collectieve actie van artikel 6:240 e.v. BW zich niet kan richten tot aanbevelers als de Vereniging van Nederlandse Gemeenten (VNG) wordt bestreden door Rijken ${ }^{479}$, die dit, mijns inziens terecht, in strijd acht met de ratio van de verbodsactie. Mede gezien het feit dat collectieve actie jegens de overheid als gebruiker wel is toegestaan, lijkt er ook geen reden verenigingen van overheidslichamen - deel uitmakend van het overheids"bedrijf" - uit te sluiten als gedaagden bij de collectieve actie. De uitspraak van de Minister dat de collectieve actie zich niet kan richten tegen deze verenigingen lijkt derhalve eerder ingegeven door de wens de tekst van artikel 6:240 lid 2 niet te veranderen dan door rationele argumenten.

Een vraag waar wet en de toelichtende kamerstukken geen antwoord op geven is, in hoeverre de vorderingen als bedoeld in artikel 6:240 en 6:241 BW door consumentenorganisaties kunnen worden ingesteld tegen buitenlandse gebruikers of aanbevelers van algemene voorwaarden.

Vooropgesteld zij, dat de vraag alleen speelt indien buitenlandse gebruikers algemene voorwaarden hanteren jegens in Nederland wonende consumenten. Op grond van artikel 6:247 lid $4 \mathrm{BW}$ is in dat geval immers afdeling 6.5.3 BW van toepassing ongeacht het recht dat de overeenkomst beheerst. De bijzondere rechter in 's-Gravenhage moet dit dwingende recht dan toepassen ongeacht het recht dat de overeenkomst beheerst (artikel 7 lid 2 EEV).

Op grond van hetzelfde artikel 6:247 lid $4 \mathrm{BW}$ zal een rechtsvordering tegen een buitenlandse aanbeveler van algemene voorwaarden doorgaans niet mogelijk zijn. Dit vanwege het feit dat zijn aanbeveling in beginsel niet wordt beheerst door Nederlands recht. Afdeling 6.5.3 BW is op deze aanbeveling dan ook niet van toepassing. Daaraan doet niet af dat de aanbevolen algemene voorwaarden mogelijk worden gebruikt jegens in Nederland wonende consumenten. Dit is mogelijk anders indien de buitenlandse aanbeveler zich bij het bevorderen van het gebruik van bepaalde algemene voorwaarden (ook) richt tot Nederlandse gebruikers. Het aanbevelen kan dan zoveel raakvlakken hebben met de Nederlandse rechtssfeer dat Nederlands recht op deze aanbeveling van toepassing moet worden geacht.

478 UCV II, Parlementaire Geschiedenis, Inw. 3, 5 en 6, pag. 1776; NEV, Parlementaire Geschiedenis, Inv. 3, 5 en 6, pag. 1803.

479 Rijken, KwNBW 1988, pag. 61. 
De (competentie)vraag of een buitenlandse gebruiker die onredelijk bezwarende algemene voorwaarden hanteert jegens in Nederland wonende consumenten in een collectieve actie voor het Haagse hof gedagvaard kan worden, is uiteindelijk te beantwoorden door het Haagse hof zelf. Bij die beantwoording zal het hof er van uitgaan dat afdeling 6.5.3 BW van toepassing is ongeacht het recht dat de overeenkomst beheerst.

Indien de overeenkomst tussen de buitenlandse gebruiker en de Nederlandse wederpartij onder de werking van het EEG-executieverdrag of het Verdrag van Lugano valt is de hoofdregel dat de gebruiker die gevestigd is in een staat die partij is bij het verdrag, slechts gedagvaard kan worden voor de rechter van zijn eigen staat (artikel 2 en 3 EEX).

Indien de buitenlandse gebruiker niet gevestigd is op het grondgebied van een van de staten die partij zijn bij het verdrag, wordt de bevoegdheid geregeld door de Nederlandse wetgeving (artikel 4 EEX) ${ }^{4}$ Aangezien de Nederlandse wet niet voorziet in een specifieke internationale jurisdictieregeling voor deze gevallen, is de regell van toepassing, dat de Nederlandse rechter bevoegd is indien naar de in Nederland geldende regels van de relatieve competentie een Nederlandse rechter rechtsmacht heeft. In de genoemde gevallen is dat het gerechtshof in 's-Gravenhage. Buitenlandse gebruikers die niet zijn gevestigd in een bij het EEG-executieverdrag aangesloten staat, kunnen dus gedagvaard worden voor het Haagse hof. Uiteraard gelden ook in die procedure de voorwaarden gesteld in artikel 6:240 BW ten aanzien van de overlegverplichting en de bevoegdheid van de eisende organisatie.

Indien de buitenlandse gebruiker is gevestigd in een land dat partij is bij het EEG-executieverdrag of het Verdrag van Lugano, kan deze in beginsel niet worden gedagvaard voor de Nederlandse rechter. Uitzonderingen op deze hoofdregel zijn slechts toegelaten indien de artikelen 5 tot en met 18 EEX dit uitdrukkelijk toelaten. In casu zijn met name van belang:

- artikel 5 lid 1 EEX, dat bepaalt dat de gebruiker voor het Haagse hof kan worden opgeroepen bij verbintenissen die zijn of moeten worden uitgevoerd in Nederland;

- artikel 5 lid 5 EEX, dat bepaalt dat de gebruiker voor de rechter van de vestigingsplaats van zijn filiaal kan worden opgeroepen;

- artikel 8 lid 2 EEX dat bepaalt dat de Nederlandse (bijzondere) rechter bevoegd is indien de verzekerde bij een verzekeringsovereenkomst in Nederland zijn woonplaats heeft;

480 Dit lijdt slechts uitzondering indien artikel $16 \mathrm{EEX}$ van toepassing is. Dit artikel regelt in de lidstaten bij het verdrag namelijk een exclusieve bevoegdheid ongeacht de vrarg waar de verweender zijn woonplaats heeft. 
- artikel 9 EEX, dat bepaalt dat de verzekeraar in geval van een aansprakelijkheidsverzekering of een verzekering met betrekking tot onroerende goederen, voor het Haagse hof kan worden opgeroepen indien de schadetoebrengende gebeurtenis in Nederland heeft plaatsgevonden;

- artikel 16 lid 1 sub a EEX, dat bepaalt dat de Nederlandse (bijzondere) rechter bevoegd is indien het betreft algemene voorwaarden met betrekking tot onroerende goederen in Nederland gelegen;

- artikel 17 EEX, dat de mogelijkheild schept dat partijen de Nederlandse rechter als bevoegd aanwijzen;

- artikel $18 \mathrm{EEX}$, dat het Haagse hof in beginsel bevoegd verklaart indien de buitenlandse gebruiker voor haar verschijnt.

Indien het EEG-executieverdrag of het Verdrag van Lugano niet van toepassing zijn, is de Nederlandse rechter bevoegd indien partijen dat zo hebben bepaald door een jurisdictie- of forumkeuze beding. ${ }^{481}$ Indien dat niet het geval is, heeft de Nederlandse rechter slechts rechtsmacht indien hij dat volgens de regels van de relatieve competentie ook zou hebben. Voor wat betreft de collectieve actie als bedoeld in artikel 6:240 e.v. BW is het Hagse hof op grond van artikel 6:241 lid 1 BW dan bij uitsluiting bevoegd.

\subsubsection{De nevenvorderingen}

De hoofdvordering van artikel 6:240 lid $1 \mathrm{BW}$ kan, op vordering van de eiser, worden vergezeld van de nevenvorderingen zoals deze zijn neergelegd in de leden 3 en 5 van artikel 6:241 BW. Aan het declaratoir dat een beding in algemene voorwaarden onredelijk bezwarend is, kan worden verbonden: een verbod van gebruik, een gebod om een aanbeveling tot gebruik te herroepen, een veroordeling tot openbaar maken van de uitspraak en een dwangsom.

Artikel 6:24l leden 3 en $5 \mathrm{BW}$

3. Op vordering van de eiser kan aan de wisprack wordien verbonden:

$a_{n}$ een verbod wan het gebruik van de door de uitsprack getroffen bedingen of wan hel bevarderem daconvan,"

b. een gebod om een aambeveling tot het gebruik van deze bedingen te herroepen;

c. een weroordeling tot het openbaar maken van de witspraak, zulks op door de rechter te bepalen wijze en op kosten van de door de rechter aan te geven partij of partijen.

5. Geschillen terzake van de tenuitvoerlegging van de in lid 3 bedoelde veroordelingen, alsmede wan die weroordeling tot betaling van een dwangsom, zo deze is opgelegd, worden bij uitsluiting door het Gerechtshof te "s Gravenhage bestist.

481 Hugenholtz/Heemsikerk, pag. 22. 
Volgens de toelichtende kamerstukken is de opsomming van artikel 6:241 lid 3 BW limitatief, met dien verstande echter dat uit artikel 6:241 lid $5 \mathrm{BW}$ volgt dat ook een dwangsom kan worden opgelegd. Geheel limitatief is de opsomming van de vorderingen in artikel 6:241 leden 3 en 5 BW echter niet. Er is immers geen enkele reden om aan te nemen dat een vordering ex artikel 56 e.v. Rv om de partij die in het ongelijk wordt gesteld in de kosten van de procedure te veroordelen is uitgesloten. ${ }^{483}$ Zulk een veroordeling in de proceskosten wordt ook in de toelichtende kamerstukken voor mogelijk gehouden. ${ }^{484}$

De vorderingen van artikel 6:241 lid 3 komen uitdrukkelijk slechts toe aar de eisende organisatie. Zo zal een gedaagde gebruiker niet kumnen vorderen dat een voor hem gunstig oordeell wordt gepubliceerd. ${ }^{435}$

Het zal duidelijk zijn dat de bijzondere rechter alleen dan een verbod, een gebod of het opleggen van de plicht tot publikatie aan zijn uitspraak kan verbinden, indien hij tevens de betreffende algemene voorwaarden onredelijk bezwarend verklaart.

\subsubsection{Verbod van gebruik of aanbevelling}

De meest belangrijke nevenveroordeling in het systeem van de collectieve actie is ongetwijfeld het rechterlijk verbod van het gebruik of het bevorderen van algemene voorwaarden die getroffen zijn door de uitspraak dat zij onredelijk bezwarend zijn. Onder gebruiken van een beding in algemene voorwaarden moet in dit kader "worden verstaan het opnemen daarvan in overeenkomsten". 40 Het verbod ziet daarmee dus niet op een eventueel beroep van de gebruiker op het gewraakte beding maar op het opnemen van een dergelijk beding in de overeenkomst, ongeacht of het tot een beroep daarop komt of niet. Ofschoon dat nergens in de toelichtende stukken wordt vermeld, ziet mijns inzilens het verbod van artikel $6: 241$ lid 3 sub a BW naar zijn aard eveneens op het opnemen van het verboden beding in aanbiedingen, ook als deze aanbiedingen nilet tot een overeenkomst leiden.

Het verbod ziet niet alleen op de letterlijke tekst van de door de uitspraak getroffen bedingen maar tevens op de bedingen "die daaraan nagenoeg gelik $z i j{ }^{*}$ Gebruikers of aanbevelers kunnen zich daardoor niet aan de werking van het verbod onttrekken door een minimale wijziging van de tekst of de strekking van het getroffen beding.

482 MvA, Parlementaine Geschiedenis; Inv. 3, 5 en 6, pag. 1785.

483 Zie ook Slagter, aangehaald door Verhoevem op pag. 126 en de daarin opgenomen moot 39.

484 MvT, Parlementsine Gegchiedlenis, Inv, 3, 5 en 6, pag. 1764.

485 Dit staat miet in de weg an de mogelikheid om de uitspraak woor eigen rekening te publiceren.

486 MwT, Parlementaine Geschiedenis, Inv. 3, 5 en 6, pag. 1783.

487 MwT, Parlementaire Geschiedienis, Inv, 3, 5 en 6, pag. 1783. 
Het verbod van artikell 6:241 lid 3 sub a $\mathrm{BW}$ zal praktisch steeds op zijn plaats zijin naast het declaratoir van artikel 6:240 lid $1 \mathrm{BW}$. Tijdens de parlementaire behandeling van het wetsontwerp werd, door de vaste Commissie voor Justitie, dan ook aangedrongen op een duidelijke bepaling in de wet, die de bijzondere rechter ambtshalve zou verplichten een verbod van gebruik te verbinden aan de declaratoire uitspraak, indien deze wordt gedaan tegen een of meer gebruikers. De bijzondere rechter heeft echter een discretionaire bevoegdheid in deze. Hij hoeft niet ambtshalve aan een declaratoire uitspraak tevens een verbod van gebruik of aanbeveling te verbinden. ${ }^{400}$ Het is derhalve niet uitgesloten dat de bijzondere rechter alleen het gevraagde declaratoir toekent aan de eisende organisatie, zonder dat hij tegelijkertijd een verbod legt op de gedaagde gebruiker of aanbeveller. Deze discretionaire bevoegdheid wordt als volgt gemotiveerd:

"Blijkens de memorie van toelichting houdt de bepaling die de beslissing om eem verbod uit te spreken acan het inzicht van de rechter overlaat vooral verband met de speelruimte die eigen is aant het criterium "bevorderen van gebruik". De enige reden is dir echter niet. Het is niet uitgesloten, bij woonbeeld indien redelijke twijfel bestaat over de ongeoarloofdheid wan een beding, dat partijen de beslissing van de rechter wagen, terwijl de gebruiker tegen wie de vordering wordt ingesteld, voor of rijdens de procedure verklaart dat hij wan verder gebruik van het beding zal afien indiew de rechter dit beding onredelijk bezwarend verklaart. In zo'n geval behoeft er voor een verbod' geen reden te zijm, zoals de rechler ook, indien wel een werbod wordi witgesproken, kan afzien van het opleggen var een dwangsom. Wij menen dat het aan de bijzondere rechter kan worden overgelaten hiler wan geval tot geval te bezien was de meest passende beslissing is.

Hoewel de bijzondere rechter dus niet verplicht is een gevraagd verbod toe te kennen, zal hij dit in beginsel wel dienen te doen. Met name indien de vorderimg gericht is tegen gebruikers van algemene voorwaarden. De sanctie van vernietigbaarheid bij hernieuwd gebruik van een onredelijk bezwarend beding is, op grond van het bepaalde in artikel 6:243 BW, immers niet verbonden aan het declaratoir maar aan het verbod. De bijzondere rechter zal in verband hiermee, een gevraagd verbod slechts kunnen weigeren, indien hij mag verwachten dat de gedaagde gebruikers of aanbevelers ook zonder een verbod, van verder gebruik van de onredelijk bezwarend verklaarde bedingen zullen afzien. ${ }^{492}$

488 MwT, Parllementaire Geachiedenis, Inv " 3, 5 en 6, pag. 1783.

489 VW, Parlementaire Geschiedenis, Inv. 3, 5 en 6, pag. 1793.

490 MvA, Parlementailre Gesehiedenis, Inv. 3, 5 en 6, pag. 1793.

491 MwT, Parlementaire Geschiedenis, Inv. 3, 5 en 6, pag. 1792; MvA, Parlementaire Geschiedenis, Inv. 3, 5 en 6, pag. 1793.

492 Assser-Hartkamp II, 1993 , nr. 370. 
Het verbod strekt zich slechts uit tot degenen die partij waren bij de procedure. ${ }^{493}$ Indien een branche-organisatie tezamen met haar leden wordt gedagvaard, strekt het verbod zich in beginsel uit over al de gedagvaarde leden. In beginsel, want de bijzondere rechter kan, op grond van het bepaalde in artikel 6:241 lid $3 \mathrm{BW}$, ook slechts aan een deel der gedaagde gebruikers het verbod opleggen ${ }^{494}$ of beperken tot het gebruik in bepaalde overeenkomsten. ${ }^{495}$

Het opgelegde verbod van gebruik blijft zijn werking behouden ook indien de eisende of gedaagde belangenorganisatie na de uitspraak is ontbonden. Een aan een aanbeveler of een lid daarvan opgelegd verbod wordt niet krachteloos door het enkele feit dat de branche-organisatie wordt ontbonden. Zo zal een gebruiker die als lid van een branche-organisatie is gedagvaard en op wie een verbod van verder gebruik van een bepaald beding is opgelegd, zich ook niet aan de werking van dit verbod kunnen onttrekken door ná de uitspraak zijn lidmaatschap van de branche-organisatie op te zeggen. Omdat hij partij was bij de uitspraak blijft het verbod zijn werking behouden ook na het lidmaatschap.

De wet geeft geen antwoord op de vraag welk tijdstip bepalend is voor de vraag op welke leden/gebruikers het verbod ziet bij een collectieve dagvaarding. De vraag dus, welke gebruikers partij zijn in de collectieve procedure. In de toelichtende stukken wordt hierover het volgende opgemerkt:

"De kring wan de leden der wereniging geeft de reikwijhe en dus tevens de begrenzing acon wan de woorgestelde regeling: ondememers die de litigieuze bedingen gebruiken maar geen deel witmaken: wan de gedagwaarde collectiviteit en evenmin apart gedagvaard worden, blijwen buiten schot. De verbodsuitspraak bindt hen derhaitue niet, al zal witeraard well van de uitspraak een preventilef effect kannen uitgaars." 497

Wessels en Jongeneel achten daarvoor het moment van betekening van de dagvaarding doorslaggevend.

"Indien op dat moment waststaar dat betrokkene geen lid (meer) is van bedoelde veremiging don kan de collecrieve dagwaarding dit ex-lid niet betreffen.

Voor zover het betreft gebruikers die op het tijdstip van betekening van de collectieve dagvaarding ex-lid waren kan ik mij in dit uitgangspunt vinden.

493 UCV II, Parlementaire Geschiedenis, Inv. 3, 5 en 6, pag. 1787.

494 "... men bedenke worts dat artikel 6:241 lid 3 hem toestadt sommige gedaagden wel, anderent geen verbod op te leggen." MvT, Parlementaire Geschiedenis, Inv. 3, 5 en 6, pag. 1764.

495 MO I, Parlementaire Gesehiedenis, Inv. 3, 5 en 6, pag. 1781.

496 MvA, Parlementaine Geschiedenis, Inv. 3,5 en 6, pag. 1789-1790. Zie ook antike1 6:242 lid 2 BW en de bespreking daarvan in paragraaf 5.3 .10 .7 .4 .

497 MvT, Tweede Kamer, zitting 1981, 16983 , nrs. 1-3, pag. 68.

498 Wessels en Jongeneel, 1992 , pag. 198. 
Naar mijn mening ligt dit echter enigszins anders ten aanzien van gebruikers die pas na het tijdstip van betekening van de collectieve dagvaarding lid worden van de gedagvaarde vereniging. Strikt genomen is het uiteraard juist dat slechts die gebruikers gedagvaard zijn, die op het moment van betekening van de dagvaarding lid zijn en dat gebruikers die eerst na de betekening lid worden, daar niet bij horen. In beginsel ziet het verbod dus ook niet op latere leden. De uitspraak van de bijzondere rechter bindt het nieuwe lid dus niet. De werking van de verbodsuitspraak wordt in de toelichtende kamerstukken immers als volgt toegelicht:

"De commissie kon zich geheel vinden in het voorgestelde systeem wavin emerzijis slechts de getaagde( $n$ ) gebonden is (zij) aan de witspraak van de rechter aan wie de preventieve toetsing is opgedragen, en warim anderzijds ook een collectiviteit wan gebnaikers gedagwaard kan worden. Hierdoor wardi immers enerzijds gehandhagfd het beginsel dat niet gebonden kavmen zijhu diegenen die niet de gelegentheid hebben gekregen zich te venweren, en wordt andertijls beveikt dat er een zekere "erga omnes"-werking aan de rechterlijke witsprack verborden is hetgeer ean meer effectieve en efficiente bestrijding wan onereuze algemene yoonwarden mogetijk maakt. "499

Dit levert een vreemde en mijns inziens weinig bevredigende situatie op. Het ene deel van de vereniging valt wel onder de rechtstreekse werking van het verbod en het andere deel niet, terwijl het voor beiden om hetzelfde "verboden" beding gaat.

Voor de individuele wederpartij die geconfronteerd wordt met het gebruik van een "verboden" beding zal het in de praktijk overigens niet veel uitmaken dat de gebruiker eerst na het tijdstip van de betekening van de dagvaarding lid is geworden van de veroordeelde vereniging. Het verbod van de bijzondere rechter is voor de gewone rechter in dat geval slechts een feitelijk gegeven en strikt genomen heeft de gewone rechter in deze gevallen daarom de vrijheid een verboden beding niet onredelijk bezwarend te verklaren. Het ligt echter voor de hand dat de gewone rechter daar niet snel aanleiding toe zal vinden.

Hetgeen voor de branche-organisatie en de wél door het verbod getroffen branchegenoten geldt, zal naar alle waarschijnlijkheid immers ook voor het latere lid gelden. De "erga omnes"-werking van het verbod van de bijzondere rechter dat gericht is op een meer effectieve en efficiënte bestrijding van onredelijk bezwarende algemene voorwaarden, zou voor een deel worden uitgehold indien de gewone rechter het latere lid zou toestaan het gewraakte beding te gebruiken. ${ }^{500}$ Voor een afwijking van het verbod van de bijzondere

499 VV, Parlementaire Geschiedenis, Inv. 3, 5 en 6, pag. 1768.

500 De vereniging die lijdelijk toexiet dat haur nieuwe leden gebruilk maken van het verboden beding handelk mijns inziens anzorgvildig tegenover de organisatie die dit verbod heeft weten te bewerkstelligen. Er is dan alle reden om de aan het verbod gekoppelde dwangsom door de (wordt vervolgd....) 
rechter zal naar mijn mening derhalve slechts plaats zijn, als de feitelijke omstandigheden dusdanig zijn gewijzigd dat het verbod niet langer gerechtvaardigd zou zijn als bedoeld in artikel 6:242 lid $1 \mathrm{BW}$. Ook dan echter zal de gewone rechter zich mijns inziens uiterst terughoudend dienen op te stellen ten anzien van de mogelijkheid om in de individuele procedure af te wijken van het verbod van de bijzondere rechter. De hereiking van een eerder gegeven verbod, als bedoeld in artikel 6:242 $\mathrm{BW}$ is immers uitdrukkelijk voorbehouden aan het Haagse hof. ${ }^{501}$ Bovendien treedt het nieuwe lid vrijwillig toe bij een organisatie die, tezamen met haar leden, getroffen is door het verbod. Daarmee wordt het nieuwe lid "deelgenoot" van alle rechten en plichten die het lidmaatschap met zich brengt. Mijns inziens treedt het latere lid derhalve mede in het op de vereniging rustende verbod.

Naar het mij voorkomt is er dan ook weinig reden voor de gewone rechter, om in zulk een geval aan het verbod van de bijzondere rechter voorbij te gaan. Het feit dat de vernietigbaarheid van het gebruik van het betreffende beding door gebruikers die eerst na het in werking treden van de uitspraak lid zijn geworden van de door het verbod getroffen vereniging, gebaseerd is op artikel 6:233 sub a BW en niet rechtstreeks op artikel 6:243 BW, zal voor de wederpartij weinig relevant zijn; de sanctie is immers dezelfde. Het geval dat de wederpartij een rechtstreeks beroep doet op artikel 6:243 BW en tijdens de procedure mocht blijken dat de gedaagde gebruiker op het tijdstip van dagvaarding voor de bijzondere rechter nog geen lid was van de branche-organisatie, hoeft ook geen probleem te zijn. De gewone rechter is op grond van artikel 48 Rv immers ambtshalve verplicht de rechtsgrond in die zin aan te vullen, dat hij het beroep op de vernietigbaarheid toekent op grond van artikel 6:233 sub a BW. Voor het gebruik van de betreffende bedingen door een gebruiker die eerst na de betekening van de dagvaarding aan de branche-organisatie en haar leden, lid is geworden van die organisatie, dient de Hagse lijst in de inhoudstoets aan de open norm van artikel 6:233 sub a BW derhalve in beginsel te fungeren als een zwarte lijst.

De vraag of het door de bijzondere rechter uitgesproken verbod eveneens rust op de gebruiker die eerst na de betekening van de dagvaarding lid is geworden van de veroordeelde vereniging, is alleen van belang vanuit collectief oogpunt. Aan het verbod kan namelijk een dwangsom zijn gekoppeld ter ondersteuning van dat verbod. Indien het verbod niet ook rust op de eerst later toegetreden

\footnotetext{
500(... vervolg)

veneniging te laten verbeuren. De veneniging kan aan de inbreuk op het verbod dan een eirnd maken door het lid te dwingen het gebruik van het verboden beding te stoppen en royement van het lid indien het an deze oproep geen gehoor geeft (artikel 2:35 BW).

S01 MwA I, Parlementaire Geschiedenis, Inv. 3, 5 en 6, pag. 1780.
} 
leden, kan men jegens hen geen dwangsom effectueren. Vooropgesteld zij, dat een later toegetreden lid doorgaans zal afzien van het gebruik van het verboden beding omdat hij dezelfde bedingen zal gebruiken als zijn collega's die wel onder het verbod vallen en omdat de branchevereniging hem op de hoogte zal hebben gebracht van het rechterlijk verbod of de daartoe dienende procedure.

Voor de beantwoording van de vraag of het verbod eveneens ziet op de eerst na de dagvaarding lid geworden gebruikers, dient mijns inziens te worden onderscheiden tussen enerzijds de gebruikers die na de betekening van de dagvaarding doch vóor het tijdstip waarop het verbod door de bijzondere rechter is uitgesproken lid zijn geworden en de gebruikers die eerst lid zijn geworden nadat de verbodsuitspraak is gewezen. Een van de redenen waarom het verbod zich slechts dient uit te strekken tot de gedagvaarde leden is immers gelegen in het argument dat slechts deze leden de gelegenheid hebben gehad zich te verweren in de procedure voor de bijzondere rechter. ${ }^{502}$ Mijns inziens hebben de gebruikers die na de betekening doch voor de dag van de uitspraak lid zijn geworden, echter eveneens de mogelijkheid om zich te verweren, zodat dit argument jegens hen niet op gaat en er dus geen reden is het verbod en de daaraan gekoppelde dwangsom niet ook op deze gebruikers te laten rusten. Tot deze categorie van gebruikers die duidelijk wél in de gelegenheid zijn zich in de procedure te verweren kunnen mijns inziens op de eerste plaats worden gerekend, de gebruikers die hinnen eén maand na betekening van de collectieve dagvaarding lid zijn geworden van de gedaagde vereniging. De collectieve dagvaardingstermijn bedraagt immers minstens een maand (artikel 9 lid 3 Rv). Er van uitgaande dat de branchevereniging aspirant-leden op de hoogte stelt van de dagvaarding, zijn deze gebruikers duidelijk in de gelegenheid zich in de procedure te verweren. Eveneens in de gelegenheid om zich te verweren in de collectieve procedure zijn de gebruikers die weliswaar eerst na het verstrijken van de dagvaardingstermijn lid zijn geworden doch vó́r het tijdstip waarop zij zich nog kunnen voegen in de collectieve procedure. Volgens artikel $286 \mathrm{Rv}$ kunnen partijen zich voegen tot op de terechtzitting waarop de laatste conclusie in het aanhangige rechtsgeding wordt genomen. Daarom is er mijns inziens geen enkele reden om het verbod, en daarmee dus ook de daaraan gekoppelde dwangsom, niet ook te laten gelden voor de latere leden die lid zijn geworden van de veroordeelde vereniging voordat de bijzondere rechter het verbod uitsprak.

Bij gebruikers die eerst ná de verbodsuitspraak lid zijn geworden gaat dit argument natuurlijk niet op. Zij hebben immers niet de kans gehad zich te verweren in de procedure. Betekent dit dan ook dat een verbod jegens hen geen

502 VV, Parlementaire Geschiedenis, Inv. 3,5 en 6, pag. 1768. 
directe werking heeft en dat de door de bijzondere rechter aan de andere leden opgelegde dwangsom jegens deze leden niet geëffectueerd kan worden?

Voorop staat uiteraard dat de betreffende branche-organisatie aan haar nieuwe leden het gebruik van de gewraakte bedingen niet mag aanbevelen indien het verbod door de bijzondere rechter is uitgesproken. De vereniging zou in dat geval in strijd handelen met het haar opgelegde verbod en daarmee een eventueel opgelegde dwangsom kunnen verbeuren. Een branche-organisatie heeft er mijns inziens echter ook vanuit een ander oogpunt alle belang bij dat nieuwe leden de gewraakte bedingen niet gebruiken. Gebruik van een verboden beding door een nieuw lid leidt immers gemakkelijk tot het (overigens weerlegbare) vermoeden, dat de aanbeveler in strijd met een opgelegd verbod de gewraakte bedingen toch heeft aanbevolen. Een en ander sluit echter niet uit dat een nieuw toegetreden lid het gewraakte beding toch gebruikt.

Ofschoon voor deze latere leden het argument dat zij zich hebben kunnen verweren niet opgaat, zijn er mijns inziens wel andere argumenten aan te voeren waarom het verbod en de daaraan gekoppelde dwangsom ook zouden moeten gelden voor de leden die eerst ná de uitspraak lid worden. De argumenten zijn overigens ook onverkort van toepassing op de leden die ná de dagtekening van de dagvaarding maar vór de datum van de verbodsuitspraak lid zijn geworden. In de eerste plaats is er een proceseconomisch argument. Het zou zeer vreemd zijn indien de eisende organisatie de latere leden nog eens apart zou moeten dagvaarden om ook aan hen een verbod op te leggen. Het is zelfs de vraag of deze collectief kunnen worden gedagvaard. In de tweede plaats is er het feit dat een gebruiker vrijwillig toetreedt tot een vereniging waarvan hij weet of behoort te weten dat deze ofwel in een procedure is betrokken waarin haar een verbod boven het hoofd hangt ofwel geconfronteerd is met een opgelegd verbod. Door lid te worden treedt hij in de rechten en plichten van de vereniging. Hij treedt daarmee dus ook in het opgelegde verbod. Dit is immers opgelegd aan de vereniging en al haar leden. Het is in dat licht ongerijmd dat een verbod dat is opgelegd aan een vereniging en al haar leden niet zou gelden voor haar toekomstige leden.

Voor gebruikers die eerst na de betekening van de dagvaarding lid van de gedaagde vereniging zijn geworden, zou ik derhalve als vuistregel willen stellen dat zij zijn gebonden aan het rechterlijk verbod en de daaraan gekoppelde dwangsom dus kunnen verbeuren indien zij ná de betekening van de uitspraak het "verboden" beding gebruiken.

Net als het declaratoir van artikel 6:240 lid $1 \mathrm{BW}$, heeft het verbod krachtens artikel 6:241 lid 3 sub a BW slechts werking voor de toekomst. Het verbod leidt slechts tot vernietigbaarheid van bedingen die worden gebruikt, dat wil zeggen worden opgenomen in overeenkomsten, nadat het verbod in werking is getre- 
den. De geldigheid van een beding dat is opgenomen in een overeenkomst die is gesloten vớr de datum van inwerkingtreding van het verbod, wordt derhalve door het verbod in beginsel niet aangetast. ${ }^{50}$ In beginsel, omdat ook hier geldt dat de toetsing aan de open norm van artikel 6:233 sub a BW gewoon mogelijk blijft en dat de uitspraak van de bijzondere rechter daarbij een (feitelijke) factor van belang zal zijn. ${ }^{504}$

Gebruik van een beding - of een nagenoeg gelijk beding - in algemene voorwaarden door degene jegens wie een verbod tot gebruik ervan is uitgesproken, leidt in de individuele procedure ex artikel 6:233 sub a BW altijd tot vernietigbaarheid van dat beding.

\section{Arrikel 6:243 BW:}

Een beding in algemene voonwarden dat door degene jegens wie een verbod tot gebrik ervan is wilgesproken, in strijd met het werbod in een overcenkomst wordt opgenownen, is vernietigbaar. Arikell 235 is van overeenkomstige toepassing.

De sanctie van vernietigbaarheid van een beding dat na de uitspraak opnieuw wordt gebruikt is daarmee uitdrukkelijk gekoppeld aan de verbodsuitspraak. Indien een verbod is uitgesproken door de bijzondere rechter dan heeft de rechter in de individuele procedure geen beoordelingsvrijheid. Aan een toetsing van het beding an artikel 6:233 sub a BW komt hij dan niet toe. ${ }^{505} \mathrm{Hij}$ dient de vordering tot vernietiging of het beroep op een buitengerechtelijke vernietiging zonder meer toe te wijzen. Ook indien de wederpartij geen beroep doet op de verbodsuitspraak maar de vernietigbaarheid stoelt op een andere rechtsgrond (bij voorbeeld de open norm) dient de rechter ambtshalve (artikel $48 \mathrm{Rv}$ ) de rechtsgronden aan te vullen met die van artikel 6:243 BW.

\subsubsection{Gebod tot herroeping van de aanbeveling}

De tweede nevenvordering die in artikel 6:241 BW lid $3 \mathrm{BW}$ wordt genoemd is een gebod om een aanbeveling tot het gebruik van onredelijk bezwarende bedingen te herroepen. De toelichting in de kamerstukken, aangepast aan de huidige artikelnummering, is kort:

"In de tweede plaats kan de bijzondere rechter bevelen een gedame aambeveling tot gebraik te" herroepen. Dat het bevorderen van het gebruik a.m. in aambevelen kam bestaan werd reeds vermeld' in deze memorie bij arrikel 6:240 BW. De henroping zal moeten worden gedara aan allen die de 
aambeveling hebben ontwangen. Dit middel om bekemalheid te geven de witspraak is a.m. belang indien het de eiser miet mogelijk is alle gebruikers van de algemene voorwarden te zamen met de branchevereniging in rechte te betrekken, bij voorbeeld omdar ook niet-leden wan die vereniging de voonwaarden gebruiken; men vergelijhe het voorgestelde artikel $1003 \mathrm{Rv}$.

Uit de toelichting blijkt dat de vordering enkel ziet op het "aanbevelen" van algemene voorwaarden. Aanbevelen wordt daarbij uitdrukkelijk gezien als $\epsilon_{n}$ van de vormen van het overkoepelende begrip "bevorderen van het gebruik". Daarmee lijkt de vordering in beginsel beperkt tot deze vorm van bevorderen en niet toegelaten voor de andere vormen van het bevorderen van gebruik zoals het dwingend voorschrijven aan branche-leden of het ter beschikking stellen van algemene voorwaarden. .07

Ook in het geval van het dwingend voorschrijven of ter beschikking stellen van onredelijk bezwarende algemene voorwaarden, kan er mijns inziens echter behoefte bestaan aan herroeping van dat dwingende voorschrift of een uitdrukkelijke mededeling dat het gebruik van de ter beschikking gestelde algemene voorwaarden dient te worden ontraden vanwege het feit dat deze onredelijk bezwarend zijn. Men denke bij voorbeeld aan een stichting die het gebruik van algemene voorwaarden dwingend voorschrijft aan "deelnemende" gebruikers. In dat geval kunnen de gebruikers niet gezamenlijk met de aanbeveler worden gedagvaard. De collectieve dagvaarding is in beginsel immers beperkt tot verenigingen met hun leden. ${ }^{508}$ Ook dan is het voor de eisende organisatie van belang, dat de aanbeveler verplicht wordt de gebruikers bij wie hij het gebruik van de gewraakte algemene voorwaarden heeft bevorderd, uitdrukkelijk op de hoogte te stellen van het feit dat hij de gewraakte algemene voorwaarden (op bevel van de bijzondere rechter) voortaan niet meer bevordert.

In het licht van deze behoefte aan een herroeping van ook de andere vormen van het bevorderen van gebruik en mede omdat de grens tussen aanbevelen en de andere vormen van bevorderen vaak niet duidelijk is te trekken, is het wellicht wenselijk dat de bijzondere rechter het begrip aanbevelen ruim uitlegt en waar nodig eveneens de andere vormen van het bevorderen van gebruik onder dit begrip brengt.

Indien de vordering tot herroeping van de aanbeveling wordt toegewezen, zal de herroeping moeten worden gedaan aan allen die de aanbeveling hebben ontvangen. Met allen die de aanbeveling hebben ontvangen worden naar mijn mening slechts diegenen bedoeld die de aanbeveling hebben ontvangen van of door toedoen van de aanbeveler. De herroeping hoeft zich daarom niet te richten tot 
de gebruikers die de aanbeveling hebben overgenomen zonder dat deze tot hen was gericht.

De wet geeft geen regeling voor de wijze en het tijdstip waarop de herroeping dient te geschieden. Doorgaans zal voor de herroeping voldoende zijn dat de aanbeveler de herroeping op dezelfde wijze doet als de aanbeveling. Immers dan staat vast dat men dezelfde kring van gebruikers bereikt. Uiteraard staat het de aanbeveler ook vrij om op andere wijze de herroeping te bewerkstelligen, mits degenen worden bereikt die de aanbeveling hebben ontvangen.

De aard van de veroordeling brengt met zich dat de herroeping van de aambeveling zo snel als voor de aanbeveler redelijkerwijs mogelijk is, dient plaats te vinden na betekening van de uitspraak indien deze uitvoerbaar bij woorraad verklaard is of nadat de uitspraak kracht van gewijsde heeft verkregen. Van wege het feit dat de wet in deze zwijgt en om zoveel mogelijk geschillen terzake van de tenuitvoerlegging van de veroordeling tot het herroepen van de aanbeveling te vermijden, lijkt het wenselijk dat de bijzondere rechter in zijn uitspraak tevens aangeeft op welke wijze en op wellk tijdstip de herroeping uiterlijk dient te geschieden.

\subsubsection{Publikatie van de uitspraak}

De laatste nevenvordering die artikel 6:241 lid $3 \mathrm{BW}$ noemt is een veroordeling tot het openbaar maken of laten openbaar maken van de uitspraak. De vordering sub c wordt uiterst summier toegelicht in de kamerstukken:

"ren derde kan de rechter een veroordeling tor publikatie van de witspraak gelasten. Zo'n publikatie kaw ook naast een bevel tor herroeping zinvol zijn ten einde degenen jegens wie de voorwacurden worden gebruilat op de hoogte te brengen. De rechter bepaalt de wijze woarop de publikatie moet geschieden en wor rekening wan welke partij de kosten komen; hij kan deze kosten ook over beide pantijen weidellen. 509

Net als alle andere vorderingen van artikel 6:241 lid $3 \mathrm{BW}$ komt deze vordering sllechts toe aan de eisende organisatie. Gedaagde gebruikers of aanbevelers kunnen de bijzondere rechter daarom niet vragen de eisende organisatie te veroordelen in publikatie van een voor hen gunstige uitspraak. De ratio van het toekennen van deze vordering is daarmee gericht op het belang van wederpartijen (degenen jegens wie de voorwaarden worden gebruikt) om kennis te kunnen nemen van het feit dat bepaalde jegens hen gehanteerde of te hanteren algemene voorwaarden onredelijk bezwarend zijn en getroffen zijn met een rechterlijk verbod. Een bevel tot publikatie is derhalve niet alleen zinvol naast een bevel tot

509 MvT, Parlementaire Geschiedenis, Inv, 3, 5 en 6, pag. 1784. 
herroeping van een aanbeveling, maar tevens naast een toegekend declaratoir en een opgelegd verbod of gebod.

Het zal duidelijk zijn dat een eisende organisatie alleen dan belang heeft bij toekenning van een vordering tot publikatie, indien het gevraagde declaratoir en de daaraan verbonden nevenvorderingen ook daadwerkelijk worden toegekend door de bijzondere rechter. De vordering van een eisende organisatie zal in de praktijk altijd gericht zijn op het opleggen van een publicatieplicht aan de gedaagde voor rekening van deze gedaagde en beperkt zijn tot de publikatie van uitspraken waarin het gevraagde declaratoir en het daaraan gekoppelde ver- of gebod is toegewezen. De eisende organisatie heeft immers geen (processueel) belang bij publikatie van een uitspraak waarin haar vordering wordt afgewezen en evenmin bij het opleggen van een publicatieplicht op haarzelf, zeker niet als zij de kosten van publikatie geheel of gedeeltelijk zelf zal moeten dragen.

In dat licht doet de bepaling in artikel 6:241 lid 3 sub $\mathrm{c}$ BW volgens welke de rechter (discretionair) kan bepalen voor rekening van welke partij de kosten komen en dat hij deze kosten ook over beide partijen kan verdelen, enigszins vreemd aan. De eisende partij loopt namelijk altijd het, mijns inziens onterechte, risico dat zij de door haarzelf gevorderde publikatie van de uitspraak geheel of gedeeltelijk zelf zal moeten betalen, terwijl de gevorderde publikatie een uitspraak betreft waarin de bijzondere rechter heeft vastgesteld dat er sprake is van gebruik of aanbeveling van een onredelijk bezwarend beding. Dit risico kan eisende organisaties er mogelijk van weerhouden een vordering tot publikatie van de uitspraak in te stellen. Het gebruik of de aanbeveling van een onredelijk bezwarend beding kan de eisende organisatie echter niet worden angerekend; het valt geheel in de risicosfeer van de gebruiker of aanbeveler. Het ligt dan ook zeer voor de hand dat de bijzondere rechter, aangenomen dat hij publikatie van de uitspraak oplegt aan de gedaagde, ook de kosten daarvan door deze gedaagde laat dragen. Een andere opvatting zou mee brengen dat consumentenorganisaties thet risico lopen dat zij financieel zouden moeten opdraaien voor het corrigeren van de tekortkomingen van de gedaagden. Daarom zou het mijns inziens Jogischer zijn geweest, als de wetgever de rechter in deze geen discretionaire bevoegdheid had toegekend maar ondubbelzinnig had vastgelegd dat de kosten van publikatie voor rekening van de in het ongelijk gestelde gedaagde komen. De discretionaire bevoegdheid met betrekking tot de kosten van publikatie hoeft echter allerminst een probleem te zijn. Diezelfde discretionaire bevoegdheid laat het immers toe dat het Haagse hof in zijn uitspraken ondubbelzinnig vastlegt dat het zijn vaste beleid is dat de kosten van publikatie van een uitspraak waarin wordt vastgesteld dat sprake is van een onredelijk bezwarende voorwaarde altijd ten laste komen van de gedaagde gebruiker of aanbeveler.

Voor het geval dat meerdere gebruikers zijn gedagvaard, laat de bepaling van artikel 6:241 lid 3 BW de rechter de vrijheid om te kiezen wie van deze 
gedaagden en voor welk deel in de kosten van publikatie zal worden veroordeeld.

\subsubsection{Dwangsom}

Aan de vorderingen van artikel 6:24l lid $3 \mathrm{BW}$ kan blijkens lid 5 van datzelfde artikel een dwangsom worden gekoppeld. Aan het declaratoir van artikel $6: 240$ lid $1 \mathrm{BW}$ kan geen dwangsom worden gekoppeld. De dwangsom kan dus enkel worden opgelegd ter nakoming van een verbod van gebruik of aanbeveling, een gebod tot herroeping van een aanbeveling en een gebod tot publikatie van de uitspraak.

Op de dwangsom in de collectieve procedure van artikel 6:240 e.v. BW is de algemene regeling van de artikelen 611 a tot en met $611 \mathrm{i} \mathrm{Rv}$ van toepassing.

Op grond van het bepaalde in artikel 611a leden 1 en 2 kan de dwangsom niet ambtshalve worden uitgesproken, maar alleen op vordering van een partij. De eisende partij hoeft in haar vordering echter niet het bedrag van de dwangsom of de modaliteiten in haar vordering op te nemen. ${ }^{510}$

In de procedure van artikel 6:240 BW kan doorgaans alleen de eisende organisatie als bedoeld in artikel 6:240 lid $3 \mathrm{BW}$ een dwangsom vorderen. In die procedure kan de gedaagde gebruiker immers alleen vorderen dat de eiser wordt veroordeeld in de proceskosten en alleen aan deze vordering kan hij een vordering tot het opleggen van een dwangsom koppelen. Het vorderen van een dwangsom door de gedaagde(n) zal daardoor niet vaak plaatsvinden in de procedure van artikel $6: 240 \mathrm{BW} .{ }^{511}$

Volgens artikel $611 \mathrm{~b}$ Rv kan de bijzondere rechter de dwangsom vaststellen hetzij op een bedrag ineens, hetzij op een bedrag per tijdseenheid of per avertreding. De rechter is vrij om de gevorderde dwangsom al dan niet toe te wijzen en is eveneens vrij in de vaststelling van de hoogte van de dwangsom. Bij de vaststelling van de hoogte van de dwangsom zal de rechter zich moeten leiden door de vraag of zij voldoende effectief is om de nakoming van de veroordeling te verzekeren. ${ }^{512} \mathrm{Hij}$ zal dus een zodanig bedrag moeten vaststellen dat dit een afdoende prikkel vormt om de hoofdveroordeling na te komen. Indien de rechter de dwangsom vaststelt op een bedrag per tijdseenheid of per

510 Hugentholtz/Heemskerk, pag. 332.

511 Een gebniker of aambeveler die getroffen is door een rechterlijk ver- of gebod kan op grond wan artikell 6:242 lid $3 \mathrm{BW}$ wél cen wordering tot het opleggen van een dwangsom koppelen aan de vordering tot het doen van een declaratoir als bedoeld in artilkel 6:241 lid $4 \mathrm{BW}$. Zie hiema paragrafif 5.3.10.7.

512 Hugenholtz/Heemskerk, pag. 329. 
overtreding, kan hij tevens een maximum bedrag aangeven waarboven geen dwangsom meer kan worden verbeurd.

Indien de dwangsom wordt gekoppeld aan een verbod van gebruik of aanbeveling, ligt het voor de hand dat de bijzondere rechter kiest voor een bedrag per overtreding. Dit ligt met name voor de hand indien sprake is van een uitspraak waarin een verbod van gebruik is opgelegd aan een collectief van gebruikers. Indien de bijzondere rechter daarbij tevens een bedrag bepaalt waarboven geen dwangsom meer kan worden verbeurd, dient hij eveneens aan te geven of dit: maximum bedrag geldt voor ellke veroordeelde gebruiker of aanbeveler afzonderlijk of voor het gehele collectief gezamenlijk. Indien de rechter daarower niets vermeldt, dient er mijns inziens van uit te worden gegaan dat het genoemde maximum geldt voor elke afzonderlijke gedaagde. Het verbod geldt immers ook voor elke afzonderlijke gedaagde.

Wordt de dwangsom daarentegen verbonden aan een gebod tot herroeping. van een aanbevelling of een gebod tot publikatie van de uitspraak, dan ligt het meer voor de hand dat de bijzondere rechter de dwangsom vaststelt op een bedrag ineens of wellicht een bedrag per tijdseenheid waarin de veroordeelde. partij heeft nagelaten het haar opgelegde gebod uit te voeren.

Het verbeuren van dwangsommen is het verschuldigd worden daarvan ten gevolge van het niet nakomen van de door de bijzondere rechter opgelegde hoofdverplichting. Een opgelegde dwangsom kan echter pas worden verbeurd $\mathrm{n}$ a de betekening, door de eisende organisatie, aan de gedaagde gebruiker of aambeveler van de uitspraak waarin zij is vastgesteld (artikel $611 \mathrm{a}$ lid $3 \mathrm{Rv}$ ). De rechter kan echter bepalen dat de veroordeelde gebruiker of aanbeveler de dwangsom pas na verloop van een zekere termijn zal kunnen verbeuren (artikel 611 a lid 4 Rv). Naar mijn mening is deze laatste mogelijkheid in de procedure van artikel 6:240 $\mathrm{BW}$ met name van belang, indien de bijzondere rechter de dwangsom koppelt aan een verbod tot gebruik van bepaalde onredelijk bezwarende algemene voorwaarden. Gebruikers dienen immers een redelijke mogelijkheid te hebben aan het verbod tot gebruik te voldoen. Met name indien het verbod gebruikers betreft met een complexe en wijdvertakte verkooporganisatie zal de instructie van personeel en het omschakelen op een niet-gebruik van de betreffende bedingen enige tijd vergen. Het is in die gevallen alleszins redelijk dat de gebruiker daarvoor een redelijke termijn wordt gegeven waarbinnen hij ook indien het gewraakte beding onverhoopt toch mocht wordlen gebruikt, geen dwangsom verbeurt. In het vaststellen van een dergelijke termijn zal de bijzondere rechter er mijns inziens wél rekening mee dienen te houden dat de gebruiker of aanbeveler hangende de procedure reeds de nodige voorbereidende maatregelen had kunnen nemen voor het niet ondenkbeeldige geval dat hem een verbod wordt opgelegd. Daarbij kan voor de vaststelling van deze termijn de 
mate van onredelijk bezwarendheid van het bestreden beding mede bepalend zijn. Het ligt voor de hand dat de rechter een korte of zelfs geen termijn aan de gebruiker zal toekennen indien het bestreden beding onredelijk bezwarend is op grond van de zwarte lijst of omdat het in strijd is met een dwingende wetsbepaling en dus, ook voor de gebruiker, kenbaar onredelijk bezwarend is.

Voor het verbeuren van een dwangsom en de tenuitvoerlegging daarvan, is niet vereist dat de uitspraak waarin zij is opgelegd, in kracht van gewijsde is gegaan. ${ }^{513}$ Indien de uitspraak bij verstek is gewezen brengt artikel $80 \mathrm{Rv}$ mee, dat de uitspraak, en dus ook de dwangsom, niet eerder ten uitwoer kan worden gelegd dan na verloop van acht dagen na betekening van de uitspraak aan de gedaagde.

Of een uitspraak uitvoerbaar bij voorraad is verklaard of niet, is in beginsel niet relevant voor het verbeuren en effectueren van de dwangsom. Het wordt pas relevant indien de gedaagde rechtsmiddelen instelt tegen de uitspraak. Rechtsmiddelen schorsen immers alleen de executie van niet bij voorraad uitvoerbare uitspraken en de daarin uitgesproken dwangsom. ${ }^{514}$ Gedurende de schorsing kan geen dwangsom worden verbeurd en kunnen vór de periode van schorsing reeds verbeurde dwangsommen niet op het vermogen van de veroordeelde aanbeveler of gebruiker worden verhaald. ${ }^{515}$

Indien de uitspraak waarin de dwangsom wordt opgelegd na het aanwenden van een rechtsmiddel daartegen wordt vernietigd, vervalt met terugwerkende kracht de in artikel $611 \mathrm{c}$ Rv bedoelde titel. Executie van nog niet verbeurde dwangsommen is dan niet meer mogelijk en reeds geëffectueerde dwangsommen kunnen als onverschuldigd betaald worden teruggevorderd. ${ }^{516}$

Onder gebruiken van een beding in algemene voorwaarden moet worden verstaan het opnemen daarvan in overeenkomsten. ${ }^{517}$ Voor het verbeuren van de opgelegde dwangsom is derhalve niet vereist dat de veroordeelde gebruiker daadwerkelijk een beroep doet op het door het verbod getroffen beding. Het volstaat als hij het gewraakte beding, na betekening van de uitspraak of het verstrijken van een daarin opgenomen termijn als bedoeld in artikel $611 \mathrm{a}$ lid 4 $\mathbf{R} v$, in zijn overeenkomsten heeft opgenomen. Onder gebruik van algemene voorwaarden dient, naar mijn mening, eveneens verstaan te worden het gebruik van die bedingen in aanbiedingen, ook al leiden die aanbiedingen (nog) niet tot een concrete overeenkomst. In dat licht kan een gebruiker die het verboden is

5 il3 Hugenholtz/Heemskerk, pag. 333.

514 Hugenholtz/Heemskerk, pag. 333.

515 Hugenholta/Heemskerk, pag. 333.

516 Hugenholtz/Heemskerk, pag. 333. Zie in dit verband: Benelux-Gerechtshof 14 april 1983, NJ 1983, 615, m.nt. W.H.H.

517 Zie hiervoor paragrafif 5.3.8.1. 
bepaalde bedingen te gebruiken, de opgelegde dwangsom ook reeds verbeuren indien hij de gewraakte bedingen opneemt in zijn aanbiedingen.

Het feit dat het verbod van artikel 6:241 lid 3 sub a $\mathrm{BW}$ niet alleen ziet op de letterlijke tekst van de door de uitspraak getroffen bedingen maar tevens op de bedingen die daaraan nagenoeg gelijk zijn, ${ }^{518}$ brengt naar mijn mening met zich, dat de dwangsom eveneens verbeurd kan worden bij gebruik van bedingen die tekstueel of qua werking slechts in geringe mate afwijken van het door het verbod getroffen beding.

Reeds eerder is de problematiek aangestipt van het gebruik van verboden bedingen door gebruikers die eerst ná de betekening van een collectieve dagvaarding als bedoeld in artikel $1003 \mathrm{Rv}$, lid zijn geworden van de gedaagde vereniging. ${ }^{519}$ Aldaar werd door mij geconstateerd dat het feit dat het gebruik van het onredelijk bezwarende beding plaatsvindt door gebruikers die eerst na de betekening van de uitspraak lid zijn geworden van de door het verbod getroffen vereniging, weinig problemen zal oplleveren voor de individuele wederpartij. Voor de eisendle organisatie in de collectieve procedure is dit echter wel een probleem. De dwangsom kan in beginsel immers alleen verbeurd worden door gebruikers die partij waren bij de collectieve procedure. Tegenover latere leden van een veroordeelde vereniging missen zij dus in beginsel dit dwangmiddel. ${ }^{520}$ Voor een effectieve rechtspleging zou het mijns inziens wenselijk zijn dat consumentenorganisaties een opgelegde dwangsom eveneens kunnen effectueren tegen deze gebruikers. Ofschoon ik van mening ben dat nieuwe leden die toetreden tot een vereniging die tezamen met haar leden, onder oplegging van een dwangsom, een verbod tot gebruik van bepaalde bedingen opgelegd heeft gekregen, eveneens toetreden tot dit verbod en de daaraan gekoppelde dwangsom en ik het dus wel mogelijk acht dat ook deze latere leden een dwangsom verbeuren, is het wellicht wenselijk dat de wetgever zich hierover nader uitspreekt.

Wat, volgens mij, wel vaststaat is dat indien een nieuw lid van een collectief gedagvaarde vereniging de gewraakte bedingen gebruikt in zijn overeenkomsten, dit een (weerlegbaar) vermoeden oplevert dat de aanbeveler in strijd met een

518 Zie hiervoor paragrat 5.3 .8 .1 .

519 Zie hiervoor paragraaf 5.3 .8 .1$.

$520 \mathrm{De}$ veneniging die lijdelijk toeziet dat haar nieuwe leden gebruik maken wan het vertodien beding haudelt mujns inziens onzorgvuldig tegenover de organisatie die dit verbod heeft weten te bewerkstelligen. Er is dan alle reden om de an het verbod gekoppelde dwangsom door de vereniging te laten verbeuren. De wereniging kan aan de inbreuk op het verbod dan een eind maken door het lid te dwingen het gebruik van het verboden beding te stoppen en royement wan het lid indien het aan deze oproep geen gehoor geeft (artikell 2:35 BW). 
opgelegd verbod die bedingen toch heeft aanbevolen en daarmee mogelijk een opgelegde dwangsom verbeurt.

Indien de gebruiker de dwangsom heeft verbeurd komt deze krachtens artikel 611c Rv ten volle toe aan de partij die de veroordeling heeft gekregen. Deze kan de dwangsom dan ten uitvoer leggen krachtens de titel waarbij zij is vastgesteld. In beginsel dient de partij ten wiens behoeve de dwangsom is opgelegd deze te effectueren binnen zes maanden na de dag waarop zij is verbeurd. Op die dag verjaart in beginsel immers de dwangsom (artikel $611 \mathrm{~g}$ lid 1 Rv). De verjaringstermijn wordt echter geschorst zolang degene die de veroordeling verkreeg met het verbeuren van de dwangsom redelijkerwijs niet bekend kon zijn (artikel $611 \mathrm{~g}$ lid $3 \mathrm{Rv}$ ).

Het bepaalde in artikel $611 \mathrm{c}$ Rv brengt tevens mee dat de dwangsom niet kan worden opgelegd ten gunste van een derde die niet partij is in het geding, maar slechts ten gunste van de partij die haar heeft gevorderd. ${ }^{521}$ Dit betekent voor de procedure ex artikel 6:240 e.v. BW dat in beginsel slechts de eisende organisaties die de dwangsom heeft gevorderd de dwangsom toekomt. De individuele wederpartij die geconfronteerd wordt met een door de bijzondere rechter verboden beding kan de dwangsom niet effectueren. Het is echter niet uitgesloten dat zich tijdens de procedure tevens een andere organisatie aan de zijde van de eisende organisatie voegt (artikel $285 \mathrm{Rv}$ ) of dat een andere organisatie gebruik maakt van de mogelijkheid van derdenverzet (artikel 376 Rv)..$^{52}$ Ook deze organisaties kunnen ten eigen behoeve de dwangsom vorderen en toegewezen krijgen. In het geval de dwangsom ten behoeve van meerdere eisende organisaties is toegekend, lijkt het mij redelijk dat de dwangsom per overtreding van het verbod slechts aan én van deze organisaties (de meest gerede) kan worden verbeurd en dat de door deze organisatie geëffectueerde dwangsom voor gelijke delen toekomt aan alle organisaties waaraan de gevorderde dwangsom is toegekend.

\subsubsection{Verjaring}

De wetgever heeft het niet nodig geacht ten aanzien van de rechtsvorderingen als bedoeld in de artikelen 6:240 en 6:242 $\mathrm{BW}$ een regeling inzake de verjaring op te nemen. 
"Het ligt woor de hand dat de vordering alleen kan worden ingesteld ver zake van bedingen in

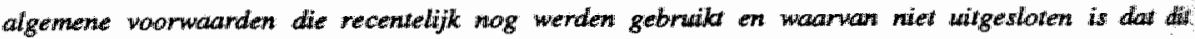
gebruik wordt voorigezet, omdat anders voldoende belang antbreekt fartikel $3.303 \mathrm{BW}$. w52

Met het ontbreken van een specifieke verjaringstermijn geldt voor de vorderingen bedoeld in de artikelen 6:240 en 6:241 BW in beginsel de algemene verjaringstermijn van twintig jaar (artikel 3:306 BW). De motivering van het ontbreken van een verjaringstermijn steunt op de gedachte dat een specifieke regeling niet vereist is omdat het belangvereiste van artikel 3:303 BW een afdoende regel geeft voor de vraag tot welk tijdstip een rechtsvordering kan worden ingesteld. Zollang de vordering wordt ingediend binnen twintig jaar nadat de vordering aan de eiser ten dienste is komen te staan, wordt de "verjaring" dan ook bepaald aan de hand van de vraag of eiser op het tijdstip waarop hij zijn vordering instelt voldoende belang heeft bij toewijzing van zijn vordering.

In de memorie van toelichting wordt het belangvereiste van artikel 3:303 BW voor de collectieve actie van artikel 6:240 BW nader ingevuld. Opvallend is echter dat deze invulling van het belangvereiste slechts gericht is op het gebruik van bedingen in algemene voorwaarden en niet op het aanbevelen daarvan.

Met betrekking tot het belangvereiste bij het gebruik - lees: het opnemen in overeenkomsten - van onredelijk bezwarende algemene voorwaarden worden in de memorie van toelichting twee eisen gesteld aan de eisende organisatie. De vordering moet op de eerste plaats bedingen betreffen die recentelijk nog werden gebruikt en op de tweede plaats moet het niet uitgesloten zijn dat dit gebruik wordt voortgezet.

Voor een collectieve (verbods)actie tegen een gebruiker van algemene voorwaarden is het vereiste van een reëel herhalingsgevaar logisch, als men bedenkt dat de collectieve actie van artikel 6:240 e.v. BW alleen werking heeft naar de toekomst en niet ziet op reeds bestaande contractuele relaties. De eis dat de vordering slechts kan worden ingesteld ten aanzien van bedingen in algemene voorwaarden die recentelijk nog werden gebruikt lijkt mij voor wat betreft een vordering gericht tegen gebruikers op het eerste gezicht eveneens gerechtvaardigd. Een absoluut vereiste voor ontvankelijkheid in de verbodsvordering kan het mijns inziens echter niet zijn. De vordering tegen een gebruiker is immers gericht op een verbod van het gebruik van onredelijk bezwarende bedingen in de toekomst. Het verbod ziet niet op het gebruik van de betreffende bedingen in reeds bestaande overeenkomsten, ook niet op recentelijk gesloten overeenkomsten. Voor ontvankelijkheid in de verbodsvordering is derhalve niet vereist dat 
de gebruiker het aangevallen beding recent heeft gebruikt doch slechts dat vaststaat dat er een reale kans is dat het betreffende (onredelijk bezwarende) beding door de gebruiker zall worden opgenomen in zijn overeenkomsten. Niet voor niets werd, tijdens de parlementaire behandeling, de vordering van artikel 6:240 e.v. BW uitdrukkelijk ook opengesteld tegen gebruikers die het gebruik van bepaalde algemene voorwaarden hebben aangekondigd maar deze noch niet hebben gebruikt. ${ }^{524}$

Voor een collectieve actie tegen een branche-arganisatie die het gebruik bewordert is, naar mijn mening, echter niet altijd vereist dat er een concreet gevaar bestaat dat de aanbeveler dit bevorderen voortzet. De actie tegen een aanbeveler is naast een verbod van verdere aanbeveling (6:241 lid 3 sub a BW), dat wel een concreet herhalingsgevaar vereist, vaak immers mede gericht zijn op een herroeping van een reeds eerder gedane aanbeveling (6:241 lid 3 sub b BW). De vordering tot herroeping van de aanbeveling van onredelijk bezwarende bedingen beoogt daarmee weliswaar het gebruik van onredelijk bezwarende bedingen in de toekomst tegen te gaan, maar doet dit door een correctie van een handeling van de aanbeveler die reeds eerder heeft plaatsgevonden. Voor deze vordering is daarom geen concreet herhalingsgevaar vereist. Eveneens is niet vereist, dat de aanbeveler eerst recentelijk heeft aanbevolen of recentelijk op andere wijze het gebruik heeft bevorderd. Los van de vraag wat recentelijk in dit verband inhoudt, kan een aanbeveling in tijd immers lang doorwerken. Wel is vereist dat de eisende organisatie voldoende belang theeft bij haar gebodsvordering tegen de aanbeveler. Voor de beoordeling van dit belang is mogelijk relevant of de aanbeveling recentelijk of in een verder verleden heeft plaatsgevonden. Een aanbeveling die langer geleden is gedaan is mogelijk reeds "uitgewerkt", waardoor het belang van de eisende organisatie bij een herroeping ontbreekt.

\subsubsection{De rechtsgang}

De collectieve actie van artikel 6:240 e.v. BW voorziet in een aparte procedure voor het gerechtshof te 's-Gravenhage. Op deze procedure bij het Haagse hof zijn de algemene bepalingen van de artikelen 1 tot en met 96 van de eerste titel en de artikelen 126 tot en met 288 van de derde titel van het eerste boek van het Wetboek van Burgerlijke Rechtsvordering van toepassing. Het bijzondere karakter van de collectieve actie en de wens deze een zo breed mogelijke werking te verschaffen via de mogelijkheid van een collectieve dagvaarding zonder afbreuk te doen aan de waarborgen waarmee de civiele procedure is 
omgeven, maakten enige nieuwe voorzieningen in de regels inzake het burgerlijk procesrecht noodzakelijk. ${ }^{525} \mathrm{Zo}$ is naast de vaststelling van de regeling van afdeling 6.5.3 BW tevens voorzien in enerzijds een uitbreiding van het Wetboek van Burgerlijke Rechtsvordering met een geheel nieuwe twaalfde titel (artikelen 1003-1004) inzake de rechtspleging in zaken betreffende onredelijk bezwarende bedingen in algemene voorwaarden en de artikelen 4 onder $13^{\circ}$ en 9 lid 3 en anderzijds de toevoeging van artikell 67 aan de Wet op de Rechterlijke Organisatie. In de volgende subparagrafen komt de bijzondere rechtspleging inzake de collectieve actie op het terrein van de algemene voorwaarden aan de orde.

\subsubsection{De bevoegde rechter}

In navolging van het CCA-advies ${ }^{520}$ is de collectieve preventieve inhoudstoetsing van artikel 6:240 e.v. BW geconcentreerd bij het gerechtshof te 's-Gravenhage.

Artikel 6:24I leden 1 en 2 BW

1. Het Gerechsshof te 's-Gravenhage is bij witsluiting bevoegd' tot kennisneming van vorderingen als in het vorige artikel bedoeld.

Bellangrijkste motief voor het concentreren van de collectieve actie op het terrein van de algemene voorwaarden bij slechts een der gerechtshoven is, dat "ook in de eerste instantie reeds eenheid wan rechtspraak wordt gewaarborgd". 527 De afwijking van de normale competentieregells en het streven naar rechtseenheid worden verder gerechtvaardigd vanuit de brede, algemene werking van de collectieve actie:

"Hierbij moet worden bedacht dat het volgens de voargestelde artikelen 4 onder $13^{\circ}$ en 1003 ev. Rv. mogetijk zal zijn on en branchewereniging te zamen met al haar leden te daguaarden, in wath geval de witsprack al deze personew zal binden. Voorts zal de witspraak gevolgen kamnert hebben

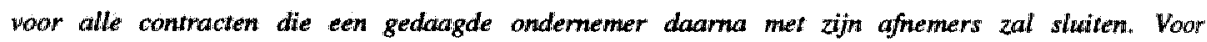
witspraken way deze aand, wanvan de gevolgen zich voor wele personen overal in het land kanmen Latem gewolen (...). Wijkt het gerechtwaardigd wan de normale competentieregels, verwat in de Wier op de rechteritijke organisisatie, af ie wijkerw. "s28

Deze keuze voor het hof te "s-Gravenhage is vooral ingegeven door het gegeven dat de procedure van artikel 6:240 e.v. BW vaak van beide zijden gevoerd zal worden tussen belangenorganisaties, waarvan vele in "s-Gravenhage gevestigd

525 MVT, Tweede Kamer, zitting 1981, 16983 , nrs, 1-3, pag. 67-68.

526 CCA-advies, pag. 20-21.

527 MvT, Parlementaire Geschiedenis, Inv. 3, 5 en 6, pag. 1782.

528 MvT, Parlementaire Geschiedenis, Inv. 3, 5 en 6, pag. 1782. 
zijn. ${ }^{529}$ Verdere voordelen van concentratie van de collectieve actie bij eên gerechtshof kunnen zijn:

- de gespecialiseerde rechter kan snel de nodige ervaringen opdoen met een complexe materie;

- dat mag worden verwacht dat centralisatie bij én bijzondere rechter ook tot specialisatie bij de advocatuur zal leiden, hetgeen, gelet op de ingewikkelde aard van de problematiek, stellig nuttig zal zijn;

- de uitspraken zijn op een centraal punt te vinden, waardoor kennisneming daarvan voor belanghebbenden zeer wordt vergemakkelijkt. ${ }^{530}$

In afwijking van het CCA-advies ${ }^{531}$ heeft de wetgever afgezien van het instellen van een bijzondere kamer bij het hof te 's-Gravenhage. Een regeling in de trant van de artikelen 72 en 73 RO inzake de ondernemingskamer bij het hof Amsterdam, werd niet nodig geoordeeld.

"Het komut ons woor dat de onderhavige zaken zich ertae lenen door een normale civiele kamer wan her Hof (artikel 70 Wet R. O.) berecht te worden. "532.

De bezetting van het hof te 's-Gravenhage zal, indien de noodzaak daartoe blijkt, ter vervulling van deze bijzondere taak worden uitgebreid. ${ }^{533}$

Vanuit de gedachte dat de Wet op de Rechterlijke Organisatie een volledig overzicht dient te geven van de taken der gerechten is de bijzondere bevoegdheid van het Haagse hof uitdrukkelijk in deze wet vastgelegd. ${ }^{534}$

529 De vaste Commissic voor Justitie leek aanvankelijk de voorikeur te geven aan het hof te Ansterdam omdat daar reeds een economische specialisatie (Ondernemingskamer) aanwezig is. Dat de algemene consumentenorganisaties in Den Haag gevestigd zijn vond de commissie geen doonslaggewend argument. Zie: VV, Parlementaine Geschiederis, Inv. 3, 5 en 6, pag. 1784 en woorts het de beradalaging rond het (niet aangenomen) amendement van het Kamerlid Salomons "Parlementaire Geschiedenis, Inv. 3, 5 en 6, pag. 1787-1788.

530 CCA-advies, pag. 20.

531 CCA-advies, pag, 20.

532 MvT, Parlementaire Geschiedenis, Inv, 3, 5 en 6, pag. 1782. Dessgevrangd deelde de president van het Gerechtshof te 's-Gravenhage, mr. M.J. Heikens, mij medio november 1994 mee: "Besloten is een vaste kamer - bestaande uit leden van de diverse civiele kamers - in te stellen, die alle genoemde vonderingen zal behandelen, zulks in verband met de rechtseenheid. Aanwijzing van leden van deze kamer heeft nog niet plaatsgevonden, nu zich nog geen vonderingen hebben voorgedas".

533 EV, Parlementaine Geschiedenis, Inv. 3, 5 en 6, pag. 1785; NEV, Parlementaire Geschiedenis, Inv. 3,5 en 6 , pag. 1786 .

534 MvT, Tweede Kamer, zitting 1981, 16983, nirs. 1-3, pag. 68. 
Het Gerechtshof te "s-Gravenhage neems in eerste aanleg en in het hoogste ressont behoudenss dte voorziening in cassatie, kennis wan de worderingen bedoeld in de ant. 240 en 242 van Boek 6 wan het Burgerlijk Wetboek.

Artikel 6:241 lid $1 \mathrm{BW}$ refereert aan artikel $67 \mathrm{RO}$. Door de woorden "bij uitsluiting" wordt voorts aangegeven dat voor de vorderingen als bedoeld in de artikelen 6:240 en 6:242 BW geen voorziening in kort geding (artikelen 289-297 Rv) openstaat. 535

Artikel 6:241 lid 5 BW concentreert alle geschillen die kunnen rijzen ter zake van de tenuitwoerlegging van de in artikel $6: 241$ leden 3 en $5 \mathrm{BW}$ bedoelde (neven-)veroordelingen eveneens bij het hof te 's-Gravenhage.

\section{Artikel 6:241 lid $5 \mathrm{BW}$}

Geschillen terzake wan de tenuitvoerlegging van de in tid 3 bedoelde veroordelingen, alsmede van de veroordeling tot betaling van een dwangsom zoals deze is opgelegd, worden bij wirsluating door het Gerechtshof' te 's-Gravenhage beslist.

De concentratie van deze geschillen bij het Haagse hof wordt vooral ingegeven door het logische gegeven dat het hof zelf het beste zal kunnen beoordelen of zijn uitspraken zijn overtreden, terwijl de afwijking van de normale competentieregels geen ernstig bezwaar mag heten in de vele gevallen dat deze nevenveroordelingen zijn opgelegd aan een rechtspersoon of een grote(re) onderneming. ${ }^{536}$

Artikel 6:241 lid $5 \mathrm{BW}$ beperkt zich tot de veroordelingen waarvan de oorspronkelijke eiser (in de collectieve procedure) de nakoming kan afdwingen. In procedures waarin een individuele wederpartij een verboden beding op grond van artikel 6:243 BW wil vernietigen of waarin deze zich beroept op een buitengerechtelijke vernietiging van zulk een beding is daarom de gewone rechter bevoegd. ${ }^{537}$

\subsubsection{De "gewone" dagvaarding}

De eerste stap op weg naar een eventuele gerechtelijke procedure als bedoeld in artikel 6:240 BW wordt gezet door de kennisgeving aan gebruiker van de bezwaren welke de eisende organisatie grond oplevert voor een vordering als bedoeld in artikel 6:240 lid 1 BW. ${ }^{538}$ Indien deze kennisgeving echter niet

535 Zie hiema paragraaf $5.3,10.6$.

536 MvT, Parlementaire Geschiedenis, Inv, 3, 5 en 6, pag. 1784.

537 MvT, Parlementaire Geachiedenis, Inv. 3, 5 en 6, pag. 1784.

538 Zie hiervoor paragraf 5.3 .5 . 
leidt tot een buitengerechtelijke oplossing vangt de gerechtelijke procedure in eerste aanleg als bedoeld in artikel 6:240 BW aan met een dagvaarding (artikel 1 lid $1 \mathrm{Rv}$ ). In de procedure van artikel 6:240 BW zijn twee vormen van dagvaarding mogelijk:

- de "gewone" dagvaarding van gebruikers of aanbevelers als bedoeld in de artikelen 1 tot en met $17 \mathbf{R v}$;

- de collectieve dagvaarding van de vereniging tezamen met haar leden als bedoeld in artikel $1003 \mathrm{Rv}$.

Als de eisende organisatie in de procedure van artikel 6:240 BW geen gebruik maakt van de collectieve dagvaardingsprocedure als bedoeld in artikel $1003 \mathrm{Rv}$ maar van de wat ik in deze ter onderscheid van de collectieve dagvaarding noem de "gewone" dagvaarding, zijn op het uitbrengen van deze "gewone" dagvaarding de algemene regels van de artikelen 1 tot en met $17 \mathrm{Rv}$ van toepassing.

$\mathrm{Zo}$ is allereerst vereist dat de "gewone" dagvaarding bij deurwaardersexploot wordt betekend aan de gedaagde gebruiker of aanbeveler (artikel $\mathbb{1} \mathrm{Rv}$ ). Het staat de eisende organisatie vrij in een procedure meerdere gebruikers al of niet tezamen met de eventuele aanbeveler "gewoon" te dagvaarden. Aan elk der gedaagde gebruikers moet in dat geval het deurwaardersexploit worden betekend of zoals artikel $3 \mathrm{Rv}$ het verwoordt: "Aan elk der gedaagden moet een afschrift van het dagvaardingsexploit gelaten worden".

Indien de gedaagde gebruiker een natuurlijk persoon is en woonplaats heeft in Nederland kan het exploit op drie wijzen worden betekend:

- aan de persoon van de gedaagde (artikel 1 lid $1 \mathrm{Rv}$ );

- aan de woonplaats van de gedaagde (artikel 1 lid $1 \mathrm{Rv}$ ), het afschrift van het exploit wordt dan uitgereikt aan een (mondige) huisgenoot van de gedaagde;

- door het achterlaten van een afschrift van het exploit in een gesloten envelop aan de woonplaats van de gedaagde, indien de deurwaarder noch aan de gedaagde in persoon noch aan een huisgenoot afschrift kan laten (artikel 2 Rv).

Als de gedaagde een rechtspersoon is kan het exploit van dagvaarding worden betekend aan de persoon of de woonplaats van een der bestuurders (artikel 4 sub $3^{\circ} \mathrm{Rv}$ ). Ten aanzien van vennootschappen onder firma en commanditaire vennootschappen wordt het exploit betekend aan een de persoon of de woonplaats van een van de beherende vennoten (artikel 4 sub $^{\circ} \mathrm{Rv}$ ).

Het exploit van dagvaarding zal op straffe van nietigheid de inhoud moeten bevatten die in artikel $5 \mathrm{Rv}$ is voorgeschreven:

- de dagtekening van het exploit (artikel 5 lid 1 sub $1^{\circ} \mathrm{Rv}$ );

- voornamen, naam en woonplaats van de eiser of de naam en plaats van de eisende rechtspersoon of vennootschap (artikel 5 lid 1 sub $1^{\circ}$ Rv); 
- opgave van een gekozen domicilie in de gemeente waar de rechter zitting houdt (artikel 5 lid 1 sub $1^{\circ} \mathrm{Rv}$ );

- voornamen, naam en woonplaats van de deurwaarder (artikel 5 lid 1 sub $2^{\circ}$ Rv);

- naam en woonplaats van de gedaagde of de naam en plaats van vestiging van de gedaagde rechtspersoon of vennootschap (artikel 5 lid 1 sub $2^{\circ} \mathrm{Rv}$ );

- vermelding van de persoon aan wie een afschrift van het dagvaardingsexploit is gelaten (artikel 5 lid 1 sub $2^{\circ} \mathrm{Rv}$ );

- aanwijzing van de rechter die van de zaak zal kennis nemen (artikel 5 lid 1 sub $4^{\circ}$ Rv);

- dag en uur waarop de gedaagde voor de rechter dient te verschijnen (artikel 5 lid 1 sub $\left.5^{\circ} \mathrm{Rv}\right)$;

- de handtekening van de deurwaarder (artikel 5 lid 2 Rv);

- de middelen (de motivering van hetgeen de eiser vordert) en het onderwerp van de eis (artikel 5 lid 1 sub $3^{\circ} \mathrm{Rv}$ );

- en een duidelijke en bepaalde conclusie (artikel 5 lid 1 sub $3^{\circ}$ Rv)..$^{539}$

Op grond van artikel $133 \mathrm{Rv}$ dient het exploit van dagvaarding tevens, op straffe van nietigheid, procureurstelling te bevatten.

De termijn van de dagvaarding is de periode gelegen tussen de dag van betekening en de dag van verschijning voor de rechter. De dag van betekening en de dag van verschijning worden niet meegeteld in de berekening van deze termijn (artikel $8 \mathrm{Rv}$ ). Volgens artikel 7 lid $1 \mathrm{Rv}$ is de termijn van de "gewone" dagvaarding (de niet-collectiewe dagvaarding) voor een procedure bij het Haagse hof en bij de Hoge Raad in cassatie, ten minste acht dagen. In spoedeisende zaken kan de president van het Haagse hof of de Hoge Raad op mondeling of schriftelijk verzoek van de eiser de dagvaardingstermijn verkorten (artikel 7 lid 2 Rv). De (positieve) beschikking van de president dient dan aan het hoofd van het dagvaardingsexploit te worden vermeld..$^{50}$ Teneinde niet-ontvankelijkheid met zekerheid te vermijden, dient de eisende organisatie bij de collectieve actie van artikel 6:240 BW er op te letten dat de overlegtermijn bedoeld in artikel $6: 240$ lid $4 \mathrm{BW}$ verstreken is op de dag van verschijning.

\subsubsection{De collectieve dagvaarding}

Artikell 4 sub $13^{\circ}, 9$ lid 3 en 1003-1006 Rv zijn aan het Wetboek van Burgerlijke rechtsvordering toegevoegd om de collectieve actie van afdeling $6.5 .3 \mathrm{BW}$

539 Zie meer uitgebreid: Hugenholtz/Heemskerk, pag. 60-63.

540 Zie meer uitgebreid: Hugenholtz/Heemskerk, pag. 58-60. 
een maximale effectiviteit te verschaffen. ${ }^{541}$ In artikel $1003 \mathrm{Rv}$ wordt voor eisende organisaties de mogelijkheid geopend om zowell een branchevereniging alsook haar leden die de algemene voorwaarden gebruiken, tegelijkertijd voor de bijzondere rechter te dagen.

Antikel 1003 sub $I^{\circ} R w^{\prime}$

Bij wonderingen als bedoeld in de artikelen 240 en 242 was Boek 6 wan het Burgerlijk Wetboek kan als wolgt worden afgeweken van het bepoalde in artikel 5 , eerste lid"

1. Een exploit dar bestend' is zowel voor een vereniging die ten doel heeft die behartiging wan belangen wan personen die een beroep of bedriff witoefenen, alsook woor de leden van dieze wereniging, alsmede een exploit dat bestema is woor de gewezen leden wan cen in eerstie aanleg mede-gedagnaarde, doch inmiddels onbonden werentiging als hienwor bedoeld, behoeft de nacam en de woonplats van deze leden of gewezen leden niet afzonderlijk te vermulden.

$2^{3}$ Eem exploit dat wordt witgebracht zowel ten verzoeke van een vereniging die ten doel heeft die behartiging van belangen wan personen die een beroep of bedirif witoefenen, alsook ten werzoke wan de ledem wan deze vereniging; alsmede een exploit dat wordi witgebracht ven verzoeke wan de gewezen leden van een in eerste aanleg mede-gedaguaarde, doch inmiddels ontbonden vereniging als hienvor bedoeld, behoef de wormaam, de nacm en de woonplaars van deze leden of gewezen leden miet afzonderlijk te vermelden.

De eisende organisatie heeft in geval van een collectieve dagvaarding dus twee partijen gedagvaard: enerzijds de vereniging en anderzijds het collectief "de leden van de vereniging".

Aldus wordt ook in het burgerlijk procesrecht het collectieve karakter van het gebruik van algemene voorwaarden tot uitdrukking gebracht. ${ }^{542} \mathrm{De}$ voorzieningen die de mogelijkheid verschaffen om collectief te dagvaarden worden in de memorie van toelichting, door mij aangepast aan de huidige artikelnummering, als volgt gemotiveerd:

"Die voorzieningen zijn met name nodig woor gevallen dat algenene voorwaarden door een groep ondememers worden gebruikt. Alsdan is het wenselijk dat zoveel mogelijk ondememers bij de anderhavige procedure worden betrokken; dararwan hangt immers (...) het directe effect van de werbodsuitsprack wan het Hof of: Dat directe affect reiks niet verder dan tot dit ondenthemers ten acanzien van wie de witspratak werd gedaan, d.w.z. tor de ondernemers die als partij bij het geding waren betrokken.

De moetlijkheid hienbij is dai men van de aanlegger bezwaarijk kan vemwachen dar deze alle ondememers die de gewraakte bedingen hanteren of wan plan zijn te hanteren opspoort en bij name in de dagwarding opsom, iets wat trowwens wak praktisch onmogelijk zal zijn. "s43

Artikel $1003 \mathrm{Rv}$ is afgestemd op het geval dat een groep ondernemers algemene voorwaarden gebruikt die zijn opgesteld door de organisatie waarbij zij als leden

541 MwT, Parlementaire Geschiedenis, Inv. 3, 5 en 6, pag. 1764.

542 MwT, Tweede Kamer, zitting 1981, 16983 , nrs. 1-3, pag. 67.

543 MwT. Tweede Kamer, zitting 1981, 16983 , nrs. 1-3, pag. 67. 
zijn aangesloten. De eisende organisatie die deze groep van gebruikers will aanspreken hoeft hen nilet afzonderlijk te dagvaarden, mits zij tevens de ondernemersvereniging die het gebruik van de algemene voorwaarden bevordert en waarvan de gebruikers lid zijn, in het geding betrekt. De aangesloten leden worden in dat geval als collectiviteit, als niet-geïndividualiseerde leden van de ondernemersvereniging, gedagvaard. ${ }^{544}$ Voornaam $^{545}$, nalam en woonpllaats van de gedagvaarde leden hoeven daarom niet te worden vermeld (artikell 1003 sub $1^{\circ}$ Rv). Daar staat tegenover dat ook het gedagvaarde collectief in de explloiten aan de eisende organisatie deze gegevens niet hoeft te vermelden (artikel 1003 sub $2^{\circ} \mathrm{Rv}$ ).

De regeling is eveneens van toepassing wanneer de in eerste aanleg mede gedagvaarde vereniging inmiddels is ontbonden. Ook in exploiten tegen de in dat geval gewezen verenigingsleden hoeven deze niet geïndividualiseerd te worden. Deze laatste voorziening is vooral van belang indien de eisende organisatie haar vordering afgewezen ziet en in cassatie wil gaan, maar de eerder gedagvaarde branchevereniging inmiddels ontbonden is. Het stelsel is gebaseerd op de gedachte

"dat men de collectieve dagwaarding alleen mag kiezen indien de vereniging mede wordt gedagwaand of in een eerder stadium mede was gedagvaard, maar inmiddels is onvbonden." 540

De eiser is overigens niet verplicht om de leden van de vereniging collectief te dagvaarden.

"Indien hij zulks verkiest, mag hij ook alle ledent of zoveel leden als hij in rechte wenst te betrekken, bij name dagwaarden. Naturulijk riskeert hij dan dat hij leden over het hoofd ziet en bovendien is een dagvaarding van vele gedaagdien kostbaar. Derhalve zal in het algemeen een voorkeur bestoun voor de thans voorgestelde collectieve dagvaarding. ${ }^{547}$

De toelichtende stukken bij artikel $1003 \mathrm{RV}$ hebben vooral het oog op het dagvaardingsexploit. De regeling van artikel 1003 sub $1^{\circ} \mathrm{Rv}$ is mijns inziens echter niet beperkt tot het dagvaardingsexploit. Niet voor niets hanteert de wetgever in artikel 1003 sub $1^{\circ} \mathrm{Rv}$ het algemene begrip exploit. De regeling ziet daarmee eveneens op andere exploiten die in de procedure in eerste aanleg of in cassatie aan het gedlagvaarde collectief moeten worden gedaan, zoals bij

$544 \mathrm{MvT}$, Tweede Kamer, zitting 1981, 16983 , nrs. 1-3, pag. 67.

545 In tegenstelling tot artikel 5 lid 1 onder $2^{\circ} \mathrm{Rv}$ wordt in antikel 1003 sub $1^{\circ} \mathrm{Rv}$ de voomsam weliswaar niet genoemd. Het ligt echter voor de hand dat met het laten vervallen van het vereiste van het noemen van de naam tevens het vereiste van het noemen van de voomaam is: vervallen.

546 MvT, Tweede Kamer, zitting 1981,16983 , nrs. 1-3, pag. 69.

547 MvT, Tweede Kamer, zitting 1981,16983 , nrs. 1-3, pag. 69. 
voorbeeld de betekening van de uitspraak. Hoewel over het uitbrengen van deze andere exploiten niets naders geregeld is, mag worden aangenomen dat dergelijke exploiten op dezelfde wijze moeten worden uitgebracht als het collectieve dagvaardingsexploit. Dat houdt in dat de regeling van artikel 4 onder $13^{\circ}$ analoog van toepassing is op deze andere exploiten.

Het feit dat de gedagvaarde leden niet zijn geïndividualiseerd wordt door de wetgever geenszins als een probleem ervaren. Bij de collectieve dagvaarding wordt er van uitgegaan dat een ondernemersvereniging bereid en in staat is al haar leden tijdig op de hoogte te stellen van de dagvaarding, zodat ook de individuele leden, indien zij dat wensen, hun maatregelen kunnen nemen. $\mathrm{Zij}_{\mathrm{ij}}$ kunnen het verweer overlaten aan hun branchevereniging, zij kunnen echter ook zelf - gezamenlijk (als "de leden") of individueel, verweer voeren. ${ }^{548}$ Indien zij als collectief verweer voeren of indien de vereniging namens hen verweer voert, is artikel 1003 sub $2 \mathrm{Rv}$ van toepassing. Dit verklaart tevens waarom de mogelijkheid van de collectieve dagvaarding is begrensd tot de kring van de leden van de ondernemersvereniging. Ondernemers die dezelfde bedingen gebruiken in hun algemene voorwaarden maar geen lid zijn van de gedaagde ondernemersvereniging, moeten derhalve apart worden gedagvaard. Indien de niet-leden niet apart worden gedagvaard bindt de verbodsuitspraak van de bijzondere rechter hen derhalve niet. De uitspraak tegen de leden van de branchevereniging heeft in dat geval hoogstens preventieve werking. De verbodsuitspraak kan tevens in de individuele procedure als bedoeld in artikell 6:233 sub a $\mathrm{BW}$, als feitelijk gegeven, worden meegewogen door de gewone rechter.

Om de ondernemersvereniging in staat te stellen haar leden tijdig op de hoogte te stellen is van de normale dagvaardingstermijn van tenminste 8 dagen (artikel 7 lid $1 \mathrm{Rv}$ ) afgeweken.

Artikel 9 lid 3 Rv

In het geval in artikel 4 ander $13^{\circ}$ witgedrukt, zal de termijn van de dagvaarding zijnt tenminste een maxind.

Teneinde zoveel mogelijk te waarborgen dat de leden van de ondernemersvereniging op de hoogte zijn van de tegen hen uitgebrachte dagvaarding, bepaalt artikel 4 sub $13^{\circ} \mathrm{Rv}$ tevens dat een uittreksel van het dagvaardingsexploit wordt gepubliceerd in een landelijk dagblad onder verwijzing naar de plaats waar, indien gewenst, een afschrift van de dagvaarding kan worden verkregen. 
Artikel 4 sub $13^{\circ}$ Rv

De dagvaarding alle andere exploiten zullen gedacon worden op de wijze als volgt:"

$13^{\circ}$. Ten aanzien van hen die algemene voorwararden gebruiken waarin onredelijk bezwarende bedingen voorkomen, indien ingevalge her bepaalde in artikel 1003 onder $1^{\circ}$ hun notam en wowplaats miet aftonderlijk in het exploit worden vermeld, acan de persoan of in het parket van de procurewr-generaal bij het gerecht woar de zaak acanhangig wordt gemaaks, is of lacustelijk was, terwijl een uittreksel wan het exploit ten spoedigste zal worden bekend gemarakt in een landelijk dagblad onder vermelding wan de nam en het adres wan de deurwaarder of wan de advocalat wan wite afschrift wan het exploit verkregen kan warden.

In afwijking van de normale regels inzake betekening, dient het dagvaardingsexploit gericht tegen het collectief van niet-geïndividualiseerde gebruikers ("de leden") te worden betekend aan de persoon of het parket van de procureurgeneraal bij het hof te "s-Gravenhage of, in cassatie, bij de procureur-generaal van de Hoge Raad. Het dagvaardingsexploit tegen de geîndividualiseerde leden en de ondernemersvereniging zelf - alsmede de medegedagvaarde niet-leden die hetzelfde beding gebruiken -, dient echter op de normale wijze betekend te worden aan de persoon of de woonplaats van deze gedaagden. ${ }^{549}$

Hoewel dit niet uitdrukkelijk is bepaald, volgt uit artikel 4 sub $13^{\circ}$ eveneens dat, in afwijking van artikel $3 \mathrm{Rv}$, niet aan elke gedlagde een afschrift van het exploit gelaten hoeft te worden. Aan de niet-geïndividualiseerde gedaagde hoeft slechts een afschrift van het exploit te worden verstrekt indien hij de deurwaarder of de advocaat van wie afschrift van het exploit verkregen kan worden, daarom verzoekt. Aan de persoon of het parket van de procureur-generaal hoeft daarom slechts esen afschrift te worden gelaten van het dagvaardingsexploit.

De collectieve dagvaardingsmogelijkheid van artikel $1003 \mathrm{Rv}$ is uitdrukkelijk afgestemd op het geval dat een groep ondernemers algemene voorwaarden gebruikt die zijn opgesteld door de vereniging waarbij zij als leden zijn aangesloten. Dit betekent dat de collectieve dagvaarding van artikel $1003 \mathrm{Rv}$ niet ziet op branche-organisaties (en de daar bij aangeslotenen) die hebben gekozen voor een andere rechtsvorm, zoals bij voorbeeld de stïchting. In dat geval zijn er immers geen leden die tezamen met hun vereniging kunnen worden gedagvaard.

In de praktijk komt het voor, dat niet alleen verenigingen maar ook stichtingen zich ten doel hebben gesteld de belangen te behartigen van personen die een bepaald beroep of bedrijf uitoefenen en dat ook deze laatsten dit mede doen door het bevorderen van het uniforme gebruik bij de aangeslotenen of deelnemers van door hen ontworpen algemene voorwaarden. Deze stichtingen hebben daarbij vaak een structuur die nauwelijks van die van een vereniging te onder-

549 Indien de gedargde een rechtspersoon of een vennootschap onder finma of en commandite kan ook an de persoon of de woonplaats wan respectievelijk een van de bestuurders of beherend vennoten. Zie de vorige paragraf. 
scheiden is. Volgens de letter van de wet vallen deze collectieven echter niet onder het bereik van de artikel $1003 \mathrm{Rv}$. Waarschijnlijk heeft de wetgever niet aan deze mogelijkheid gedacht. Dit betekent dat consumentenorganisaties stichtingen en de daarbij aangeslotenen, niet collectief kunnen dagvaarden, niettegenstaande het feit dat de argumenten die de wetgever hebben doen kiezen voor de collectieve dagvaarding bij verenigingen, ook hier onverkort opgaan.

Wessels en Jongeneel houden in deze een slag om de arm. Zij stellen dat de regeling van artikel $1003 \mathrm{Rv}$ "niet eenvoudig" kan worden toegepast "indien algemene voorwaarden worden opgesteld en aanbevolen door een stichting, al dan niet speciaal daartoe door een branche-vereniging opgericht. " 550 Onder omstandigheden achten zij een collectieve dagvaarding jegens een stichting en de daarbij aangeslotenen, zij het niet eenvoudig, mogelijk. Het is jammer dat zij niet aangeven onder welke omstandigheden. Desalniettemin wil ik hun standpunt dat een collectieve dagvaarding jegens stichtingen ook mogelijk moet zijn, gaarne onderschrijven, echter met een restrictie. Wessels en Jongeneel noemen mede als voorbeeld de stichting die door een branchevereniging speciaal is opgericht met het doel algemene voorwaarden op te stellen en aan te bevelen. In dat geval is mijns inziens sprake van een doen aanbevelen door de vereniging aan de leden. Er is dan geen bezwaar tegen het collectief dagvaarden van de vereniging en haar leden. Aan de materiële vereisten van artikel $1003 \mathrm{Rv}$ is door het doen aanbevelen door de vereniging immers voldaan.

Dat stichtingen en de daarbij aangeslotenen eveneens collectief gedagvaard kunnen worden past ook in de opzet van afdeling 6.5.3 BW. Het verdraagt zich immers niet met de ratio van afdeling 6.5.3 $\mathrm{BW}$, die mede gericht is op een zo breed mogelijk werking van het rechterlijk verbod, dat stichtingen die op een nagenoeg gelijke wijze als verenigingen dat jegens hun leden doen, het gebruik van onredelijk bezwarende bedingen bevorderen bij de deelnemers aan die stichtingen, niet collectief gedagvaard kunnen worden. Ik zou daarom willen pleiten voor een niet al te strikte toepassing van artikel $1003 \mathrm{Rv}$ in die zin dat de bijzondere rechter aan het begrip "vereniging en haar leden" een ruime uitleg geeft en daar ook onder begrijpt de "verenigingen" die gebruik maken van een stichting ter behartiging van commerciële doeleinden. Dit voorkomt dat brancheverenigingen enkel met het oog op het verijdelen van een collectieve dagvaardingsmogelijkheid kiezen voor een andere rechtsvorm. De mogelijkheid van een dergelijke vlucht in een andere rechtsvorm zou de effectiviteit van afdeling 6.5.3 BW aanzienlijk verminderen. In dat licht is het wellicht wenselijk dat de wetgever uitdrukkelijk in artikel $1003 \mathrm{Rv}$ vastlegt dat ook branche-organisaties 
dile een andere rechtsvorm hebben als de vereniging gezamenlijk met hun "leden" kunnen worden gedagvaard.

\subsubsection{Verstek en verzet}

In de procedure van artikel 6:240 e.v.. BW mogen partijen niet zelf in het proces werschijnen. $\mathrm{Zij}$ moeten zich daartoe doen vertegenwoordigen door een procureur (artikel 133 en $136 \mathrm{Rv}$ ) en in cassatie door een advocaat bij de Hoge Raad (artikel 407 en $409 \mathrm{Rv}$ ).

Indien de procureur van gedaagde op de in de dagvaarding genoemde verschijndag niet verschijnt en de eisende organisatie wel, ${ }^{551}$ zal de eisende organisatie de bijzondere rechter verzoeken om verstek te verlenen tegen de niet verschenen gedaagde (artikel $138 \mathrm{Rv}$ ) en een verstekvonnis uit te spreken. Als de eisende organisatie de voorgeschreven termijnen en formaliteiten in acht heeft genomen zal de rechter het verstek verlenen en de vordering bij verstekvonnis toewijzen, tenzij de rechter de eis onrechtmatig of ongegrond voorkomt (artikel 76 lid $1 \mathrm{Rv}$ ).

In plaats van vonnis te wijzen kan de bijzondere rechter de zaak ook voor een bepaalde termijn aanhouden. ${ }^{552}$ De gedaagde tegen wie verstek is verleend kan zich in dat geval op de dienende dag alsnog doen vertegenwoordigen door een procureur en daardoor het verstek zuiveren. Het verstek vervalt dan. De kosten van het verstek blijven echter voor rekening van de defaillant (artikel $89 \mathrm{a}$ Rv).

Indien de bijzondere rechter vonnis heeft gewezen en de niet-verschenen gedaagde heeft veroordeeld kan deze daartegen slechts opkomen door het doen van verzet (artikel $81 \mathrm{Rv}$ ). De defaillant kan geen beroep in cassatie instellen tegen een verstekvonnis (artikel $401 \mathrm{~b}$ lid $1 \mathrm{Rv}$ ). Verzet is mogelijk tegen elk verstekvonnis waarin de vordering van de eisende organisatie geheel of gedeeltelijk is toegewezen, dus ook tegen een zuiver declaratoir verstekvonnis als bedoeld in artikel 6:240 lid $\mathbb{B}$ BW. Het verzet dient te worden gedaan binnen een termijn van 14 dagen (artikel $81 \cdot \mathrm{Rv}$ ). De verzettermijn kan op grond van artikel 81 Rv op twee manieren aanvangen:

551I Indien de elisende organisatie ook niet werschünt, wordt de zaak ambtshalve van de rol gevoend zonder versitekverlening (artikel 42 Reglement I).

552 Indien de gedaggde in persoon versehijnt zonder procureur wordt tegen hem verstek verleend (artikel $138 \mathrm{Rv}$ ). Gewoonlijk houdt de molrechter de zaak dan een periode an om de gedaigde de gelegenheid te geven het verstek te zuiveren. Zie: Hugenholtz/Heemskerk; pag. 67. 
1. door betekening van de uitspraak, of van enige uit kracht daarvan opgemaakte of ter uitvoering daarvan strekkende akte, aan de persoon van de veroordeelde $\mathrm{e}^{533}$; of

2. doordat de veroordeelde enige daad pleegt, waaruit noodzakelijkerwijs voortvloeit, dat het verstekvonnis of de aangevangen tenuitvoerlegging hem bekend is. ${ }^{5.54}$

Wanneer de verzettermijn niet is aangevangen omdat of eiser er niet in slaagt aan de gedaagde in persoon te betekenen of omdat de veroordeelde niet door enige daad laat blijken daarvan op de hoogte te zijn, staat dit niet in de weg aan executie van het verstekvonnis. De organisatie die haar vorderingen bij verstekvonnis toegewezen heeft gekregen, kan, tenzij voorlopige tenuitvoerlegging is toegestaan, de uitspraak echter niet eerder tenuitvoerleggen dan na verloop van acht dagen na de betekening van het verstekvonnis aan de persoon of de woonplaats van de gedaagde (artikel $80 \mathrm{Rv}$ ). Indien de uitspraak geheel ten uitvoer is gelegd of indien de defaillant in de uitspraak heeft berust, is deze niet meer ontvankelijk in zijn verzet (artikel 81 leden 2 en 3 Rv).

Het zal vaak voorkomen dat de eisende organisatie in een procedure ex artikel 6:240 BW die wordt ingeleid met een "gewone" dagvaarding, al dan niet naast de aanbeveler, meerdere gebruikers dagvaart. Het is dan niet uitgesloten dat sommige (procureurs van) gedaagden verschijnen en és of meer anderen niet. In dat geval wordt op grond van artikel 79 lid $1 \mathrm{Rv}$ tegen de niet-verschenen gedaagden verstek verleend en wordt de zaak ten opzichte van de wel verschenen gedaagden aangehouden. ${ }^{555}$ Ieder van de bij procureur verschenen partijen, doorgaans de eiser, heeft vervolgens het recht om de verstekverlening aan de niet-verschenen partijen te betekenen en deze partijen, met inachtneming van de normale dagvaardingstermijn, op te roepen tegen een nieuwe verschijningsdag (artikel 79 lid $1 \mathrm{Rv}$ ). Op de nieuwe verschijningsdag wordt de procedure met de (bij procureur) verschenen gedaagden voortgezet en wordt voor alle partijen, ook de niet-verschenen, eến vonnis gewezen. Dit vonnis wordt gezien als een op tegenspraak gewezen vonnis, waartegen voor de niet verschenen partijen geen verzet mogelijk is (artikel 79 lid $3 \mathrm{Rv}$ ). De ten tweede male niet verschenen partijen kunnen wel cassatie instellen tegen deze uitspraak van de bijzondere rechter. Tevens wordt het mogelijk geacht dat de ten tweede male

553 Uitdrukkelijk wordt betekening aan de persoon wan de veroordeelde verlangd. Betekening aan de woonplaats van de weroordeclde of een andere wijze van betekening doet de verzettlermäjn dan ook niet arnvangen.

554. Zie meer uitgebreid over de aanvang van de verzettermijn: Hugenholtz/Heernskerk, pag. 190. 192.

555 MvT, Tweede Kamer, zitting 1981, 16983 , nrs. $1-3$, pag. 70. 
niet verschenen gedaagde het verstek zuivert zolang de bijzondere rechter nog geen uitspraak heeft gedaan (artikel 89a Rv).

Artikell 79 lid $1 \mathrm{Rv}$ is mijns inziens eveneens van toepassing indien van meerdere gedaagden geen enkele ter zitting verschijnt. Artikel 79 lid 1 Rv stelt immers als vereiste dat ến of meer van de gedaagden niet verschijnen. Tegen alle niet verschenen gedaagden wordt in dat geval verstek verleend. De zaak wordt dan niet aangehouden omdat artikel 79 lid $1 \mathrm{Rv}$ vereist dat minstens eén gedaagde is verschenen. De rechter kan de zaak wél aanhouden op grond van artikel $77 \mathrm{Rv}$. In dat geval hebben defaillanten op grond van artikel 89a Rv de mogelijkheid het verstek te zuiveren tot de dienende dag waarop de bijzondere rechter het verstekvonnis wijst. Indien de bijzondere rechter, al dan niet na aanhouding op grond van artikel $77 \mathrm{Rv}$, vonnis wijst, is artikel 79 lid $3 \mathrm{Rv}$ niet van toepassing. Het vonnis is dan een verstekvonnis, waartegen normaal verzet mogelijk is.

In het geval dat de procedure ex artikel 6:240 $\mathrm{BW}$ wordt ingeleid met een collectieve dagvaarding als bedoeld in artikel $1003 \mathrm{Rv}$, is op grond van artikel 1005 sub $1^{\circ} \mathrm{Rv}$ het bepaalde in artikel 79 lid $1 \mathrm{Rv}$ niet van toepassing indien de vereniging of tenminste éen van haar leden, dan wel tenminste eén van de gewezen leden van de ontbonden vereniging, ter zitting verschijnt.

Arrikel I005 sub $1^{\circ} \mathrm{R} v$

In geval van een vordering als bedoeld in antkel 240 van Boek 6 van het Burgerlijk Wetboek gelden, indien de in arrikel 1003 onder $1^{\circ}$ bedoelde gegevens niet in het exploit worden vermeld, naxast het bepaalde in artikel 4 onder $13^{\circ}$ en artikel 9 , derde lid, de navolgende bijzondere voorzieningen."

$1^{\circ}$ Indien de vereniging of tenminste een wan haar leden, dan wel tenminste een der gewezen leden van de ontbonden wereniging verschijnt, is artikel 79 , eerste lid, miet van toepassing.

Aan het buiten werking stellen van artikel $79 \mathrm{Rv}$ bij de collectieve dagvaarding ligt de gedachte ten grondslag dat bij de dagvaarding van een collectiviteit als hier bedoeld geen behoefte bestaat aan deze omslachtige en tijdrovende procedure

"... omdat men ervan mag witgaan dat men niet alleen formeel maar ook materieel met een homogene belangengroep ile maken heef, waarwan de leden met elkar in contact staan en in hel algemeen in de onderhavige zaken ein lijw zullen volgen. "s56.

556 MvT, Tweede Kamer, zitting 1981, 16983 , nrs. 1-3, pag. 70. 
Tegen de niet verschenen leden van de vereniging moet bij een collectieve dagvaarding wel verstek worden verleend. ${ }^{557}$ Daarbij kunnen zich twee situaties voordoen:

1. de leden van de vereniging zijn als collectief niet verschenen en er zijn tevens geen leden individueel verschenen;

2. de leden van de vereniging zijn als collectief niet verschenen maar er zijn wel individuele leden (bij procureur) verschenen.

In het eerste geval moet verstek worden verleend tegen de leden van de vereniging als collectief. In het tweede geval moet verstek worden verleend tegen de "overige" leden van de vereniging als collectief. In het laatste geval kan de bijzondere rechter dat doen door aan te geven welke leden wel zijn verschenen en dus niet zijn begrepen in het verstekvonnis.

Ook voor de niet-verschenenen bij een collectieve dagvaarding vangt de verzettermijn van veertien dagen in beginsel aan als bepaald in artikel 81 Rv: door betekening van de uitspraak aan de veroordeelde in persoon of doordat de veroordeelde enige daad pleegt, waaruit noodzakelijkerwijs voortvloeit, dat het verstekvonnis of de aangevangen tenuitvoerlegging hem bekend is. De betekening van de uitspraak aan de persoon van de veroordeelde is echter in het geval van een collectieve dagvaarding nogal bezwaarlijk als de gebruiker niet is geïndividualiseerd. Zijn woonplaats is immers niet bekend. Een specifieke wettelijke regeling ontbreekt. Mijns inziens dient de betekening van deze collectieve uitspraak dan op dezelfde wijze te geschieden als de betekening van de dagvaarding. Dit betekent dat artikel 4 sub $13^{\circ} \mathrm{Rv}$ analoog van toepassing is. De verzettermijn vangt dan jegens deze collectief gedagvaarde en bij verstek veroordeelde gebruikers an op het moment van betekening van het (collectieve) verstekvonnis aan de veroordeelde vereniging en de procureur-generaal van het hof te 's-Gravenhage of, in geval van cassatie, van de Hoge Raad. ${ }^{558}$

Artikel 1005 sub $1^{\circ} \mathrm{Rv}$ stelt de aanhoudingsregeling van artikel 79 lid $1 \mathrm{Rv}$ uitdrukkelijk slechts buiten werking indien of de vereniging of een van haar leden ter zitting verschijnt. Er is niet voorzien in een uitsluiting van artikel 79 lid $1 \mathrm{Rv}$ voor het geval zowel de vereniging als haar leden niet verschijnen. Het geval dus dat niemand der collectief gedaagden ter zitting verschijnt. In dat geval geldt voor de collectieve dagvaarding mutatis mutandis hetzelfde als bij de gewone dagvaarding. Indien van meerdere gedaagden geen enkele verschijnt wordt de zaak niet aangehouden, wordt tegen allen verstek verleend (artikel 79 lid $1 \mathrm{Rv}$ ) en kan de bijzondere rechter in beginsel tegen allen een verstekvonnis wijzen, waartegen dezen op dezelfde wijze in verzet kunnen komen.

557 MvT, Tweede Kamer, zitting 1981, 16983 , nns. 1-3, pag. 70.

$558 \mathrm{Zie}$ voor de betekening van het "collectieve" wonnis, hiema paragraaf 5.3.10.7. 
In het geval gedaagde verschijnt maar de eisende organisatie niet, wordt verstek verleend tegen de eisende organisatie, wordt gedaagde van de instantie ontslagen en wordt de eisende organisatie in de kosten veroordeeld (artikel $75 \mathrm{Rv}$ ). De eisende organisatie zal, indien zij de procedure wil voortzetten, de gedaagde andermaal moeten dagvaarden. Alvorens opnieuw te beginnen zal de eiser echter de kosten van het verstek aan de gedaagde moeten betalen (artikel $75 \mathrm{Rv}$ ).

\subsubsection{Voeging, tussenkomst en derdenverzet}

Indien op grond van artikel 6:240 BW een procedure wordt aangespannen tegen een of meer gebruikers van de door de branche-organisatie aanbevolen algemene voorwaarden, zijn de in artikel 6:240 leden 2 en 3 genoemde organisaties enerzijds bevoegd om zich te voegen in een procedure als bedoeld in artikel 6:240 BW of daarin tussen te komen (artikel 6:285 Rv) en anderzijds om als derde in verzet te komen tegen een door de bijzondere rechter gewezen vonnis (artikel 376 e.v. Rv). Artikel 6:241 lid 2 BW stelt dit buiten twijfel.

\section{6:241 lid 2}

De in het vorige artikel genoemde rechtspersonen hebben de bewoegdheden, geregeld in de artikelen 285 en 376 wan het Wetboek wan Burgerlijke Rechtsvordering; artikel 379 wan das Wetboek is wilut van roepassing.

De genoemde organisaties hebben dezelfde bevoegdheden eveneens voor de herzieningsprocedure als bedoeld in artikel 6:242 lid 1 BW. Artikel 6:242 lid 3 BW bepaalt immers dat artikel 6:241 lid 2 BW op deze procedure van overeenkomstige toepassing is.

De organisatie die zich voegt in de procedure van artikel 6:240 lid $1 \mathrm{BW}$ doet dit om een der partijen te steunen. De organisatie die tussenkomt in een abstracte procedure stelt zich zowel op tegen de eiser als tegen de gedaagde. In dat geval wordt de tussenkomende organisatie beschouwd als eiser en nemen zowel de oorspronkelijk gedaagde als de oorspronkelijk eiser tegenover deze tussenkomende organisatie de positie van gedaagden in. ${ }^{559}$

Voor wat betreft de voeging van branche-organisaties, is het artikellid opgenomen in afdeling 6.5.3 BW "... ten einde te waarborgen dat de litigieuze bedingen op zo adequaat mogelijke wijze kunnen worden verdedigd" ${ }^{560}$ In die zin is de voeging van branche-organisaties in een procedure op grond van artikel 
6:240 BW bedoeld als ondersteuning van de gedaagde gebruiker. In een procedure als bedoeld in artikel 6:242 BW voegt de branche-organisatie zich met hetzelfde doel aan de zijde van de eisende gebruiker.

Andersom bestaat ook voor consumentenorganisaties de mogelijkheid om zich te voegen in een procedure voor de bijzondere rechter. In de procedure van artikel 6:240 BW is dat uiteraard aan de zijde van een andere eisende consumentenorganisatie ${ }^{561}$ en met het doel de betreffende bedingen zo adequaat mogelijk aan te vallen. In geval van de procedure van artikel 6:242 BW voegt een consumentenorganisatie zich aan de zijde van de gedaagde consumentenorganisatie met het doel de gevraagde wijziging of opheffing van een onredelijk bezwarend verklaring van specifieke bedingen tegen te gaan.

De organisaties die zich willen voegen, dienen aan te tonen dat zij daarbij een aantoonbaar belang hebben. Zo zal een consumentenorganisatie in beginsel niet ontvankelijk zijn (en zich dus niet kunnen voegen) in een procedure als bedoeld in artikel 6:240 BW die is aangespannen door een branche-organisatie. ${ }^{562}$ Andersom geldt hetzelfde voor een branche-organisatie die zich aan de zijde van een eisende consumentenorganisatie wil voegen in de procedure van artikel 6:240 BW. Dit vloeit voort uit de strekking van de laatste volzin van artikel 6:240 lid 3 BW. Uiteraard kan een consumentenorganisatie zich wél voegen (aan de zijde van de gedaagde consumentenorganisatie) indien een brancheorganisatie als eiser een procedure als bedoeld in artikel 6:242 BW aanspant.

Ook indien de voegende organisatie voldoet aan het bepaalde in de laatste volzin van artikel 6:240 lid $3 \mathrm{BW}$ moet deze een aantoonbaar belang bij de voeging hebben. Artikel 6:241 lid 2 BW strekt er uitdrukkelijk toe, dat dit belang niet kan worden ontkend op de enkele grond dat degene die zich wil voegen een rechtspersoon is. ${ }^{563}$

De organisatie die zich wil voegen in de procedure van artikel 6:240 $\mathrm{BW}$ of van artikel 6:242 BW moet door middel van een procureur een incidentele conclusie ter terechtzitting nemen en wel ten dienenden dag vór of op die, waarop de laatste conclusie in het aanhangige rechtsgeding wordt genomen (artikelen 286 en $287 \mathrm{Rv}$ ). De gedaagde en de eiser in het aanhangige rechtsgeding kunnen daarop antwoorden, waarna de bijzondere rechter in het incident dient te beslissen of hij voeging al dan niet toestaat. ${ }^{564}$

561 MwT, Parlementaire Geschiedenis, Inv. 3, 5 en 6, pag. 1783.

562 MvT, Parlementaire Geschiedenis, Inv, 3, 5 en 6, pag. 1783. De toelichtende stukken wermelden weliswaar dat een consumentenorganisatie niet "tussenbeide kan komen", bedoeld is, volgens mij, echter dat cen consumentenorganisatie zich niet kan voegen.

563 MvT, Parlementaire Geschiedenis, Inw. 3, 5 en 6, pag. 1783.

564 Hugenholtz/Heemakerk, pag. 166. 
Op grond van het bepaalde in artikel $6: 241$ lid $2 \mathrm{BW} \mathrm{j}^{\circ}$ artikel $285 \mathrm{Rv}$ kunnen de in artikel 6:240 leden 2 en $3 \mathrm{BW}$ genoemde organisaties ook tussenkomen in de procedures als bedoeld in de artikelen 6:240 en 6:242 BW. Het karakter van tussenkomst brengt echter met zich dat de organisatie die tussenkomt in een abstracte procedure zich zowel opstelt tegen de eiser als tegen de gedaagde. Het komt mij voor dat in dit licht zowel consumenten- als branche-organisaties geen belang hebben bij een tussenkomst als bedoeld in artikel $285 \mathrm{Rv}$. De figuur tussenkomst heeft voor de procedures van de artikelen 6:240 en 6:242 BW dan ook geen praktische betekenis.

Naast de bevoegdheden van artikel $285 \mathrm{Rv}$, wordt de in artikel 6:240 leden 2 en 3 BW genoemde rechtspersonen de mogelijkheid gegeven van derdenverzet zoals geregeld in de artikelen 376 tot en met $380 \mathrm{Rv}$, echter met uitzondering van de mogelijkheid van artikel $379 \mathrm{Rv}$.

Consumenten- en branche-organisaties krijgen daardoor de mogelijkheid zich te verzetten tegen uitspraken van de bijzondere rechter in procedures waarin zij geen partij noch gevoegde of tussenkomende partij zijn geweest, indien zij van mening zijn dat deze uitspraken hen in hun rechten of belangen benadelen. (artikel $376 \mathrm{Rv}$ ). Ten aanzien van het derdenverzet is de rechter bevoegd die de uitspraak heeft gedaan (artikel $377 \mathrm{Rv}$ ). Voor een uitspraak in de procedures van artikel $6: 240$ en $6: 242 \mathrm{BW}$ is dat dus de bijzondere rechter in 's-Gravenhage. Derdenverzet wordt ingesteld door een dagvaarding gericht tegen allen die partij in het gedling zijn geweest. De procedure vindt op dezelfde wijze plaats als de procedure in eerste aanleg. ${ }^{.65}$

Ten aanzien van het derdenverzet van zowel de in artikel 6:240 leden 2 en 3 genoemde organisaties tegen een uitspraak in de abstracte procedures van artikel 6:240 en 6:242 BW is uitdrukkelijk bepaald dat dit verzet geen schorsende werking heeft. ${ }^{566}$ Artikel $379 \mathrm{Rv}$, dat de rechter toestaat de uitvoering van de aangevallen uitspraak te schorsen totdat het verzet zal zijn uitgewezen, is in artikel 6:241 lid 2 BW immers uitdrukkelijk buiten toepassing verklaard. De reden hiervoor is dat een zodanige schorsing, bij voorbeeld in verband met artikel $6: 243 \mathrm{BW}$, tót grote verwarring zou kunnen leiden. ${ }^{567}$

Indien het derdenverzet gegrond wordt bevonden kan de bijzondere rechter de bestreden uitsprak verbeteren voor zover het de rechten van die derde belangenorganisatie heeft benadeeld, tenzij de onsplitsbaarheid van de uitspraak vernietiging van de gehele uitspraak nodig maakt. ${ }^{568}$

565 Hugenholtz/Heemblkerk, pag. 234.

566 MvT, Partementaire Geschiedenis, Inv. 3, 5 en 6, pag. 1783.

567 MvT, Parlementaire Geschiedenis, Inv. 3, 5 en 6, pag. 1783.

568 Hugenholtz/Heennskerk, pag. 235. 
In de wet wordt geen specifieke termijn gesteld voor het doen van derdenverzet. De algemene verjaringstermijnen zijn derhalve van toepassing. Het middel kan daarom ook worden ingesteld tegen uitspraken die reeds in kracht van gewijsde zijn gegaan. ${ }^{\text {sos }}$

\subsubsection{Voorlopige voorziening}

Volgens artikel $67 \mathrm{RO}$ neemt het gerechtshof te 's-Gravenhage in eerste aanleg en in hoogste ressort, behoudens voorziening in cassatie, kennis van de vorderingen als bedoeld in artikel 6:240 en 6:242 BW. Artikel 6:241 lid 1 BW refereert aan artikel $67 \mathrm{RO}$. De woorden "bij uitsluiting" in artikel 6:240 lid 1 BW geven daarbij uitdrukkelijk aan dat een voorziening in kort geding, als bedoeld in artikel 289 e.v. Rv, in de procedures op grond van respectievelijk de artikelen 6:240 en 6:242 $\mathrm{BW}$, niet mogelijk is. ${ }^{577}$ De uitsluiting van de mogelijkheid van een kort geding wordt als volgt gemotiveerd:

"Naar ons oordeel lenem de hier bedoelde zaken met hun sterk juridisch-techmische karakter zich er" minder goed toe om in kort geding le worden beslist, terwijl er ook zelden wam een grote spoedeisendheid sprake zal zijn. Om deze reden zal ook voor een procedure op verkorte termijn, hoewel mogelijk (artikelen 7 en 145 Rv), hier geen ruim emplooi zijn. ${ }^{.571}$

De enige mogelijkheden die de eisende organisaties open lijken te staan voor het verkrijgen van een snel resultaat, zijn dus de verkorte dagvaardingstermijn van artikel 7 lid $2 \mathrm{Rv}$ en een procedure op verkorte termijn waarin het nemen van conclusies van re- en dupliek niet is toegestaan als bedoeld in artikel $145 \mathrm{Rv}$.

De argumentatie die de wetgever bezigt voor het uitsluiten van het kort geding is ondertussen niet erg overtuigend. Het zal inderdaad zo zijn dat de procedure van artikel 6:240 BW vaak ingewikkelde civielrechtelijke zaken betreft met een sterk juridisch-technisch karakter, waarin uiteenlopende, wellicht grote, belangen moeten worden afgewogen. Dit is echter ook vaak het geval in procedures die wel in kort geding worden beslecht. De rechter in kort geding heeft mijns inziens afdoende bewezen ook in complexe juridische zaken in staat te zijn een verantwoorde beslissing te nemen over het al dan niet toekennen van een voorlopige voorziening. ${ }^{572}$ Bovendien zijn niet alle procedures ex artikel 6:240 BW complex, men denke daarbij met name aan de toetsing van bedingen die voorkomen op de zwarte lijst of die in strijd zijn met dwingend recht. De complexiteit en het sterk juridisch-technische karakter lijken in dat licht nauwe-

569 Hugenholtz/Heemskerk, pag. 234.

570 MvT, Parlementaire Gesehiedenis, Imv. 3, 5 en 6, pag. 1782-1783.

571 MvT, Parlementaire Gesehiedenis, Inv. 3, 5 en 6, pag. 1783.

572 Zie ook" Rijken, SR 1987, pag. 255 
lijks een argument, zeker niet als men bedenkt dat de gewone rechter in de individuele procedure op grond van artikel 6:233 sub a BW in feite dezelfue toets moet uitvoeren als de bijzondere rechter, en dat voor deze individuele procedure in beginsel well de mogelijkheid van een kort geding open staat. Met Snijders bestrijd ik daarnaast de mening dat er zelden sprake zal zijn van spoedeisendheid. ${ }^{57}$ Met name in het geval dat op grote schaal gebruik dreigt te worden gemaakt van evident onredelijk bezwarende algemene voorwaarden kan, ter bescherming van wederpartijen, behoefte bestaan aan een voorlopig verbod in afwachting van een definitieve voorziening. De weg naar het kort geding is in deze echter afgesloten.. ${ }^{574}$

Consumentenorganisaties staat, naast de mogelijkheid van een verkorte dagvaarding en verkorte procedure, echter toch een uitdrukkelijke mogelijkheid open om ook in de procedure ex artikel 6:240 BW een voorlopige voorziening te verkrijgen. Merkwaardigerwijs wordt deze mogelijkheid tijdens de parlementaire behandeling wel genoemd voor de procedure ex artikel 6:242 BW maar niet voor die van artikel 6:240 BW. Ik doel hier op de mogelijkheid van een provisionelle eis als bedoeld in artikel $51 \mathrm{Rv}$. Ten aanzien van de procedure wan artikel 6:242 $\mathrm{BW}$ wordt, nadat is geconstateerd dat ook in deze procedure de mogelijkheid van een kort geding is uitgesloten, hierover het volgende, door mij aangepast aan de huidige artikelnummering, vermeld:

\footnotetext{
"Maar dit latat onverlet dat de gebrutker in de geschetste situatie een voorlopige voorziening kan wragen, en wel aan het Hof te Den Haag, waanvoor slechts de voorwatardie geldt dat hij de in artikel 6:242 BW bedoelde vordering heeft ingesteld; men zie art. SI Rv. Naar de modeme schrijvers levert (men zie de schrijvers genoemd in Losbladige Rechtswordering, ad art. 51, noot 3 bij aant. 2, alsmede Hugenholrz-Heemskerk nr. 82 en A-G Ten Kate in zijn conclusie voor HR 28 sept. 1984, NI $1985,83 \mathrm{~m} . \mathrm{a}$. W.H.H.), kan de eiser in dit incident bij wege van woorlopige voorziening ook geheel of gedeelselijk hetzelfde vorderen als in de zaak ten principale. Het komt ons voor dat art. 51 Rw. een afdoende mogelijkheid aan de gebruiker bied" om zich, zo daartoe grond bestaat, op konte termijn uit een knelsinuatie te bewrijden. "575
}

Niet is in te zien waarom dezelfde voorziening niet zou open staan voor consumentenorganisaties in de procedure ex artikel 6:240 $\mathrm{BW}$. Dit betekent dat consumentenorganisaties in spoedeisende kwesties bij wege van een provisionele eis een voorlopige voorziening kunnen vragen bij de bijzondere rechter aan het hof te 's-Gravenhage. De enige voorwaarde is dat zij de in artikel 6:240 BW

573 Snijders, inaug. rede, pag. 35.

574 Rijken ziet in verband met de procedure wan artïkel 6:240 BW wél een duidelijke rol weggellegd voar het kort geding ter effectuering van buitengerechtelijke afspraken tussen comsumentenorgamisaties enerzijjds en gebruilkers en ambevelers anderzijds die zijn gemaakt ter vermijding van een procedure als bedoeld in artikel $6: 240 \mathrm{BW}$. Zie: Rijken, SR 1987, pag. 255.

575 MvA I, Parlementaire Gesiehiedenis, Inv, 3, 5 en 6, pag. 1780. 
bedoelde vordering hebben ingesteld. In dit incident kan de eisende consumentenorganisatie dan door middel van een provisionele eis, hetzelfde vorderen als in de zaak ten principale. Dit betekent dat ook de nevenvorderingen bedoeld in artikel 6:241 lid 3 en 5 BW bij wege van voorlopige voorziening gevorderd kunnen worden.

Op de procedure die volgt na een provisionele eis zijn de artikelen 247 tot en met $249 \mathrm{Rv}$ van toepassing. De provisionele vorderingen worden gedaan hetzij meteen in de dagvaarding, hetzij bij incidentele conclusie. Indien mogelijk wordt op de provisionele eis afzonderlijk en voordat de zaak ten principale dient, beslist (artikel $249 \mathrm{Rv}$ ). Ook bij een provisionele eis kan, indien daarbij een dringend belang bestaat, de rechter gevraagd worden deze (bij toewijzing) uitvoerbaar bij voorraad te verklaren (artikel $53 \mathrm{Rv}$ ). ${ }^{576}$ De werking van de provisionele voorziening is beperkt tot de duur van de procedure in de hoofdzaak, dat wil zeggen totdat de laatste uitspraak in die procedure kracht van gewijsde heeft verkregen. Ofschoon een toegekende voorlopige voorziening ook werkt tijdens het geding ten principale en in cassatie, is de bijzondere rechter bij zijn beslissing ten principale of de Hoge Raad in cassatie niet gebonden aan de provisionele uitspraak..$^{5 n}$

\subsubsection{De uitspraak}

In de procedure ex artikel 6:240 BW kunnen verschillende soorten uitspraken worden onderscheiden. In het algemeen is het onderscheid vooral van belang voor het instellen van hoger beroep en beroep in cassatie. ${ }^{578}$ Wegens thet ontbreken van de mogelijkheid van hoger beroep is voor de procedure ex artikel 6:240 BW het onderscheid enkel het beroep in cassatie van belang. ${ }^{579}$

In de eerste plaats kan, afhankelijk van de vraag of de gedaagde in het geding is verschenen, onderscheid worden gemaakt tussen een vonnis op tegenspraak gewezen (contradictoir vonnis) en een verstekvonnis. Voor het geval dat de procedure als bedoeld in artikel 6:240 BW is gericht tegen meerdere gedaagden is het zeer wel mogelijk dat de bijzondere rechter deels contradictoir vonnis wijst en deels bij verstek. Tussen partijen wordt echter uitspraak gedaan bij een en hetzelfde vonnis dat als contradictoir wordt beschouwd (artikel 79 lid $3 \mathrm{Rv}$ ).

In de tweede plaats wordt onderscheiden tussen declaratoire, constitutieve en condemnatoire vonnissen. In het declaratoire vonnis wordt door de rechter een 
rechtstoestand of rechtsverhouding vastgesteld. In de procedure ex artikel 6:240 BW valt daarbij vooral te denken aan de vaststelling dat een bepaald beding onredelijk bezwarend is als bedoeld in artikel 6:240 lid $1 \mathrm{BW}$. Een vonnis is constitutief, indien daarbij een bepaalde rechtstoestand wordt gewijzigd of opgeheven of een nieuwe in het leven wordt geroepen. In de procedure ex artikel 6:240 BW moet daarbij vooral gedacht worden aan de uitspraken waarin een verbod, een gebod of een dwangsom wordt opgelegd als bedoeld in artikel 6:241 leden 3 en $5 \mathrm{BW}$. Het condemnatoir vonnis is een veroordelend vonnis, een vonnis dus waarbij de gedaagde wordt veroordeeld om iets te doen of te laten. In het kader van de procedure ex artikel 6:240 BW valt hierbij wederom te denken aan de uitspraken met betrekking tot de vorderingen als bedoeld in artikel 6:241 leden 3 en $5 \mathrm{BW}$ maar ook aan de veroordeling in de kosten van de procedure. De uitspraken waarin een verbod, gebod of een dwangsom worden opgelegd zijn derhalve niet alleen condemnatoir maar tevens constitutief.

In de derde plaats kunnen vonnissen worden onderscheiden in eindvonnissen en tussenvomnissen. ${ }^{580} \mathrm{De}$ tussenvonnissen kunnen weer nader worden onderverdeeld in preparatoire, interlocutoire, provisionele en incidentele vonnissen. Preparatoire vonnissen zijn de tussenvonnissen die worden gewezen tot instructie van de zaak en die strekken om het proces in staat van wijzen te brengen, zonder dat zulks op de beslissing in de zaak ten principale van invloed kan zijn (artikel 46 lid $3 \mathrm{Rv}$ ). In het kader van de procedure ex artikel 6:240 BW dient daarbij vooral gedacht te worden aan de uitspraken met betrekking tot de aanhouding van de zaak bij verstek als de gedaagden "gewoon" zijn gedagvaard. Interlocutoir zijn de tussenvonnissen waarbij de rechter, alvorens recht te doen, een bewijs, een onderzoek of een instructie beveelt, waarvan de beslissing in de zaak zelf afhankelijk kan zijn (artikel 46 lid $4 \mathrm{Rv}$ ). In de procedure van artikel 6:240 BW valt daarbij vooral te denken aan uitspraken met betrekking tot bewijsopdrachten, de inlichtingencomparitie en het deskundigenbericht. Het provisionele vonnis is het tussenvonnis waarin de rechter beslist over een gevraagde voorlopige voorziening die bij provisionele eis als bedoeld in artikel $51 \mathrm{Rv}$ is gedaan. Bij gebreke van de mogelijkheid van een voorziening in kort geding in de procedure van artikel $6: 240 \mathrm{BW}$, is het provisionele vonnis de enige mogelijkheid voor een eisende organisatie om een voorlopige voorziening te verkrijgen. Incidentele vonnissen zijn de tussenvonnissen die niet zijn preparatoir, interlocutoir of provisioneel. Ten opzichte van het eindwonnis in de hoofdzaak is het incidentele vonnis een tussenvonnis. Het is echter een eindvonnis voor wat betreft de incidentele vordering. ${ }^{581}$ In het kader van de procedure

580 Hugenholle/Heemskerk, pagg. 93 .

581 Hugenholu/Heemskerk, pag. 99. 
ex artikel 6:240 BW kan daarbij vooral worden gedacht aan uitspraken naar aanleiding van een vordering tot het stellen van zekerheid als bedoeld in artikel $152 \mathrm{Rv}$ en 1006 sub $2^{\circ} \mathrm{Rv}$ en een vordering tot voeging als bodoeld in artikel $285 \mathrm{Rv}$.

Zoals reeds vermeld is het onderscheid tussen de verschillende soorten uitspraken vooral van belang voor het instellen van beroep in cassatie, waarop nader wordt ingegaan in paragraaf 5.3.10.8. Van belang voor de procedure van artikel 6:240 BW zijn vooral de eindvonnissen gewezen door de bijzondere rechter in eerste instantie en de eindvonnissen in cassatie. In de navolgende subparagrafen is het begrip uitspraak derhalve beperkt tot het eindvonnis in de hoofdzaak.

\section{De inhoud wan de uitspraak}

Net als elk ander vonnis dienen de arresten van de bijzondere rechter en de Hoge Raad in de procedure ex artikel 6:240 $\mathrm{BW}$ gemotiveerd te zijn (artikelen 121 Grondwet en $20 \mathrm{RO}$ ) en te voldoen aan het bepaalde in artikel $59 \mathrm{Rv}$. De uitspraak moet derhalve in beginsel behelzen:

- de namen en de woonplaats van de partijen en de namen van de procureurs;

- de gronden waarop de uitspraak berust, afzonderlijk zowel betreffende de feiten als betreffende het recht;

- de namen van de rechters die het arrest hebben gewezen.

Strikt genomen brengt artikel $59 \mathrm{Rv}$ mee, dat de bijzondere rechter en de Hoge Raad de namen en woonplaatsen van alle partijen bij de procedure, in de uitspraak moeten vermelden. Dit zal geen probleem opleveren indien sprake is van een procedure die is ingelleid met een "gewone" dagvaarding. De voornamen, namen en woonplaatsen van alle partijen zijn dan immers bekend.. Betreft het echter een procedure die is ingeleid met een collectieve dagvaarding als bedoeld in artikel $1003 \mathrm{Rv}$ dan zijn de namen en woonplaatsen van de als collectief gedagvaarde leden van de vereniging niet bekend bij de bijzondere rechter of de Hoge Raad. Ofschoon er geen specifieke regeling is voorzien ten aanzien van de uitspraak bij een collectieve dagvaarding, mag er mijns inziens van uit worden gegaan, dat artikel 1003 sub $1^{\circ}$ Rv hier analoog toegepast kan worden. Dit betekent dat de rechter bij een collectieve dagvalarding slechts die gebruikers met naam en woonplaats in de uitspraak vermeldt welke zijn geïndividualiseerd en dat hij ten aanzien van de niet-geïndividualiseerde gebruikers net als in de dagvaarding kan volstaan met de aanduiding "de (overige) leden van de gedaagde vereniging". De geïndividualiseerde gebruikers zijn niet alleen de gebruikers die met voornaam, naam en woonplaats in de dagvaarding zijn vermeld maar ook de collectief gedaagde gebruikers die als partij op de terecht- 
zitting zijn verschenen. Partijen, ook de niet-geïndividualiseerde leden van de vereniging, kunnen kosteloos een afschrift of grosse van de hen betreffende uitspraak ontvangen en op grond van artikel $64 \mathrm{Rv}$ kunnen zij van de griffiers een expeditie van de uiltspraak verlangen. ${ }^{52}$ Voor het verkrijgen van de grosse of expeditie door de niet-geïndividualiseerde gedaagden zal voldoende zijn dat zij aantonen lid te zijn van de veroordeelde vereniging of, in geval van tussentijdse ontbinding van de gedagvaarde vereniging, dat zij gewezen lid zijn van de inmiddels ontbonden vereniging.

\section{De bevoegdheid van artikel 6:241 lid $4 \mathrm{BW}$}

Een bijzonder aspect van de uitspraak in de procedure ex artikel 6:240 BW is, dat de bijzondere rechter bevoegd is om daarin aan te geven op welke wijze het bezwarende karakter van een onredelijk bezwarend beding kan worden weggenomen.

\section{Artikel 6.241 lid $4 \mathrm{BW}$}

De rechter kan in ziji uinspraak aangeven op welke wijze het onredelijk bezwarend karakier van de bedingen watarop de uitspraak betrekking heeft, kan worden weggenomen.

Blijkens de memorie van toelichting kan de rechter dit "eventueel ambtshalve" doen. ${ }^{583}$ In de visie van de wetgever is het dus mogelijk dat de bijzondere rechter niet alleen ambtshalve doch eveneens op vordering van een van de partijen - voor de hand ligt dat de gedaagde dit doet - aangeeft hoe het onredelijk bezwarend karakter van bedingen kan worden weggenomen. Het woord "kan" in artikel 6:241 lid 4 BW duidt er mijns inziens op dat het een discretionaire bevoegdheid van de bijzondere rechter betreft. Ook indien een van de partijen de bedoelde voorziening uitdrukkelijk vordert, hoeft de bijzondere rechter haar niet te geven.

Het nut van deze voorziening ligt volgens de memorie van toelichting in het feit dat zij "de kans op executiegeschillen kan reduceren". Of en in hoeverre de bijzondere rechter van deze mogelijkheid echter gebruik zal maken zal er mede van afhangen of de tussen partijen tijdens het proces gevoerde discussie hem daartoe de benodigde informatie verschaft. ${ }^{584}$

Mijns inziens dient de rechter uiterst terughoudend van de mogelijkheid van artikel 6:241 lid 4 BW gebruik te maken. In de eerste plaats is het niet an de rechter om nieuwe bedingen ten behoeve van gebruikers te concipiëren. Bovendien verdraagt de mogelijkheid om an te geven hoe een beding niet langer

582 Artikel 5 Wet tarieven in burgerlijke zaken.

583 MvT, Parlementaine Geschiedenis, Inv, 3, 5 en 6, pag. 1784.

584 MvT, Parlementaire Geschiedenis, Inv, 3,5 en 6, pag. 1784. 
onredelijk bezwarend is zich niet met het gegeven dat de collectieve actie van artikel 6:240 BW vooral gericht is op het op gang brengen van onderhandelingen tussen marktpartijen om zodoende te komen tot evenwichtige algemene voorwaarden. Als de rechter in zijn uitspraak aangeeft hoe het onredelijk bezwarend karakter van bepaalde bedingen kan worden weggenomen, legt hij in feite het onderhandelingsresultaat ten aanzien van die bedingen vast en zijn onderhandelingen over dit beding feitelijk overbodig of reeds bij voorbaat gefrustreerd. Bovendien ontneemt de bijzondere rechter in dat geval de consumentenorganisaties het drukmiddel dat artikel 6:240 BW voor deze onderhandelingen beoogt te zijn. Aanbevelers en gebruikers zullen immers niet snel bereid zijn het betreffende beding consumentvriendelijker te maken dan de bijzondere rechter heeft aangegeven. Dat de bijzondere rechter zich bemoeit met de onderhandelingsresultaten of daar een oordeel over velt, is echter uitdrukkelijk niet de bedoeling van de collectieve inhoudstoets. ${ }^{595}$ Een derde argument voor een uiterst terughoudende opstelling van de bijzondere rechter ten aanzien van het geven van deze voorziening, is gelegen in het feit dat niet direct duidelijk is hoe en hoe lang deze voorziening zal doorwerken in de individuele procedure op grond van artikel 6:233 sub a BW. Kan de gewone rechter in de individuele procedure bij de toetsing van het conform de uitspraak van de bijzondere rechter gewijzigde beding voorbijgaan aan de uitspraak van de bijzondere rechter? Gaan de uitspraken ex artikel 6:241 lid $4 \mathrm{BW}$ werken als een lijst van goedgekeurde en daarmee onaantastbare bedingen? Rechtens hoeft de gewone rechter zich mijns inziens niet aan de uitspraak van de bijzondere rechter te houden, hij dient immers te oordelen in het concrete geval. Feitelijk zal hij doorgaans echter wél de uitspraak in de abstracte procedure volgen, zeker als de omstandigheden van de individuele wederpartij in het individuele geval overeenkomen met die van de kring der wederpartijen die uitgangspunt zijn bij de abstracte toets, hetgeen doorgaans het geval is. De uitspraak van de bijzondere rechter zal dan ook al snel een eigen leven gaan leiden ook in die gevallen waarin in de concrete omstandigheden van de individuele procedure het advies van de bijzondere rechter onredelijk bezwarend uitpakt voor de wederpartij. De bijzondere rechter heeft immers geoordeeld dat het betreffende beding niet onredelijk bezwarend is. Een vierde argument voor een terughoudende opstelling van de bijzondere rechter is gelegen in de toetsnorm van artikel 6:240 $\mathrm{BW}$. De bijzondere rechter moet toetsen of een beding onredelijk bezwarend is en vervolgens aangeven hoe een beding niet langer onredelijk bezwarend is. Dat betekent dat de rechter slechts hoeft aan te geven hoe het beding veranderd moet worden om het nét niet onredelijk bezwarend te doen zijn. Voor de rechter is het wettelijke vereiste 
dus de minimum maar tegelijkertijd ook de maximum standaard. Tussen net niet onredelijk bezwarend, evenwichtig en consumentvriendelijk ligt echter vaak een wereld van verschil. Voor een consument is een net niet onredelijk bezwarend beding meer bezwarend dan een consumentvriendelijk beding. Een consumentvriendelijk beding daarentegen is voor de gebruiker weer meer bezwarend dan een net niet bezwarend beding. Op wiens belangen dient de bijzondere rechter het accent te leggen? Mijns inziens is het niet aan de rechter om daar een keuze in te doen. Een laatste argument ten slotte, is gelegen in het feit dat de bijzondere rechter ten dele abstract toetst. De bijzondere rechter kan slechts aangeven op welke wijze het beding niet onredelijk bezwarend is voor de kring van wederpartijen jegens wie het beding wordt gebruikt. In dat licht is het bijzonder moeilijk voor hem, zo niet onmogelijk, om voor alle uitzonderlijke gevallen waarin het beding ook wordt gebruikt aan te geven wanneer het beding niet onredelijk bezwarend is. Het betekent dat de bijzondere rechter zijn eigen beslissing in deze steeds moet toetsen aan de open norm. Het zal volgens mij al ras blijken dat het eenvoudiger is een beding onredelijk bezwarend te oordelen dan andersom, een beding te bedenken dat de toets aan de open norm in alle concrete gevallen kan doorstaan.

\section{De werking van de uitspraak}

Ons wetboek van burgerlijke rechtsvordering gaat ervan uit dat vonnissen in beginsel van rechtswege werken. Dit brengt met zich dat de uit het vonnis voortvloeiende verplichtingen in beginsel ingaan op het moment waarop het vonnis wordt uitgesproken. De rechter kan in zijn vonnis echter ook aangeven dat de verplichtingen van partijen voortvloeiend uit het vonnis eerst ingaan op een later tijdstip. ${ }^{586}$

Omdat een vonnis in beginsel van rechtswege werkt is het niet alleen van meet af aan bindend voor partijen, het heeft ook dadelijk na de uitspraak executoriale kracht. Wil een partij echter gebruik maken van de executoriale kracht van een vonnis, dan zal zij het vonnis eerst moeten betekenen aan de wederpartij (artikel 430 lid $3 \mathrm{Rv}$ ). ${ }^{587}$ Een partij die het vonnis ten uitvoer wil leggen hoeft niet te wachten tot het vonnis kracht van gewijsde heeft verkregen. De hoofdregel is dat een vonnis dadelijk na betekening aan de andere partij ten uitvoer kan worden gelegd. Een uitzondering op de hoofdregel wordt gemaakt ten aanzien van het verstekvonnis. Een verstekvonnis kan, tenzij eerdere tenuitvoerlegging door de rechter is toegestaan, eerst acht dagen na betekening aan de wederpartij worden geëxecuteerd (artikel $80 \mathrm{Rv}$ ).

586 Hugenholtz/Heemskerk, pag. 106.

587 Dit geldt in beginsel niet voor preparatoire en interlocutoire vonnissen. Artilkel $66 \mathrm{RV}$.

322 
Een vonnis verkrijgt kracht van gewijsde op het moment dat tegen het vonnis geen van de gewone rechtsmiddelen (verzet, hoger beroep, cassatie en revisie) meer openstaat, zodat het vonnis niet meer kan worden aangetast door een van deze rechtsmiddelen. ${ }^{588}$ Indien echter tijdig een van de gewone rechtsmiddelen tegen het vonnis wordt ingesteld, wordt de tenuitwoerlegging van het vonnis geschorst. Een nog niet aangevangen executie kan dan niet worden begonnen en een reeds aangevangen executie kan niet worden voortgezet. De gewone rechtsmiddelen hebben geen schorsende werking in het geval de rechter het vonnis uitvoerbaar bij voorraad heeft verklaard (artikel $52 \mathrm{Rv}$ ). Het vonnis kan worden geëxecuteerd ondanks het feit dat een rechtsmiddel is ingesteld, de tenuitvoerlegging komt echter voor risico van de executant indien het bij voorraad uitvoerbaar verklaarde vonnis door het instellen van het rechtsmiddel wordt vernietigd.

Genoemde regels gelden in beginsel ook voor de uitspraken van de bijzondere rechter in de procedure ex artikel 6:240 BW. Het hof kan zijn uitspraak uitvoerbaar bij voorraad verklaren. ${ }^{599}$ Dit kan met name van belang zijn voor consumentenorganisaties die de handhaving van een verbodsuitspraak, bij voorbeeld door het effectueren van opgelegde dwangsommen, onverwijld ter hand willen nemen. Van belang ook, omdat de gerechtelijke procedure, die op zichzelf al de nodige tijd vergt, vooraf wordt gegaan door de verplichte overlegperiode van maximaal een half jaar.

Voor het antwoord op de vraag welke betekenis aan de executieregels toekomt bij uitspraken gewezen door de bijzondere rechter dient te worden onderscheiden tussen enerzijds de werking van de verbodsuitspraak in de individuele procedure ex artikel 6:243 $\mathrm{BW}$ en anderzijds de executie van de uitspraak tussen de (collectieve) procespartijen bij de abstracte inhoudstoets.

De betekenis van de algemene executieregels is voor de werking van de verbodsuitspraak in de individuele procedure op grond van artikel 6:243 BW slechts beperkt en niet alle executieregels zijn relevant. De "erga omnes"werking van de verbodsuitspraak wordt immers rechtstreeks geregeld in artikel 6:243 BW. De zinsnede "jegens wie een verbod tot gebruik ervan is uitgesproken" in dit artikel, impliceert dat het verbod door de wederpartij kan worden ingeroepen, of zo men wil kan worden geëxecuteerd, vanaf het moment dat de verbodsuitspraak is gedaan. De wederpartij kan een beding dat jegens haar wordt gebruikt in een overeenkomst gesloten nadat de verbodsuitspraak is gedaan, derhalve zonder meer (buitengerechtelijk) vernietigen. Enige betekening of andere handeling van procespartijen is daartoe niet vereist. De "bindende"

588 Hugenholtz/Heemskerk, pag. 106.

589 MvT, Parlementaine Geschiedenis, Inw , 3, 5 en 6, pag . 1783. 
werking van de verbodsuitspraak van de bijzondere rechter in de individuele procedure voor de gewone rechter wordt tijdens de parlementaire behandeling immers als volgt uitgelegd:

"... Heeft de bijzondere rechter acan de declaratoire witspracak het verbod tot verder gebruil van eent bepaald beding in bepaalde algemene voorwaciden verbonden, daw geldt het volgende:

Dit verbod is voor de gewone rechter slechts een jeitelijk gegeven in het geval dat degene aan wie een verbod tot verder gebruik is opgelegd, het bewuste beding reeds woil het werbod in (duur) overeenkonusten is overeengekomen;

Dit verbad "bindt" de gewonte rechter in het geval dat degeme aan wie een verbod tot verder gebruik is opgelegd, het bewuste beding madien in een overeenkomst opmeemt; de gewone rechis dient wit te gaan wan de vemietigboarheid' ex artikel 6:243 BW. "390

Wat echter indien een van de in de collectieve actie mogelijke gewone rechtsmiddelen (verzet en cassatie) wordt ingesteld tegen de verbodsuitspraak van de bijzondere rechter? Heeft dit dan ook schorsende werking ten aanzien van het opgelegde verbod en welke gevolgen heeft dit voor het beroep op artikel 6:243 $\mathrm{BW}$ in de individuele procedure?

Indien de bijzondere rechter de verbodsuitspraak uitvoerbaar bij voorraad heeft verklaard, heeft het instellen van een gewoon rechtsmiddel geen schorsende werking. In dat geval brengt artikel 6:243 $\mathrm{BW}$ mijns inziens mee dat de gewone rechter in beginsel verplicht is het verbod van de bijzondere rechter in de individuele procedure te volgen. De werking van de verbodsuitspraak is immers niet opgeschort. Probleem daarbij is echter dat achteraf kan blijken dat de bij voorraad uitvoerbare verbodsuitspraak vernietigd is. De rechtsgrond van de vernietiging in de individuele procedure ex artikel 6:243 $\mathrm{BW}$ (de verbodsuitspraak) is dan immers met terugwerkende kracht vervallen. Moeten dan ook de gevolgen van de vernietiging in de individuele procedure ex artikel 6:243 BW ongedaan worden gemaakt en draagt de individuele consument die is overgegaan tot "executie" van de bij voorraad uitvoerbare verbodsuitspraak daarvan het risico?

Mij lijkt van niet als de uitspraak van de gewone rechter kracht van gewijsde heeft verkregen. Deze uitspraak is immers onaantastbaar. Een andere opvatting zou er toe leiden dat de "erga omnes"-werking wan artikel 6:243 BW veel rechtsonzekerheid met zich zou brengen. Indien de uitspraak van de gewone rechter echter nog geen kracht van gewijsde heeft verkregen staat voor de gebruiker wiens beding door de gewone rechter is vernietigd, well de mogelijkheid van het instellen van een rechtsmiddlell ter beschikking. In dat geval is het zeer waarschijnlijk dat de uitspraak van de gewone rechter in de individuele procedure in verzet, hoger beroep of cassatie niet in stand blijft.

590 VV, Parlementaïre Geschiedenis, lnv. 3, 5 en 6, pag. 1792-1793. 
Voor wie in dat geval de kosten van de ongedaanmaking van de vernietiging zijn, is ter beoordeling van de rechter. Hij dient daarbij mijns inziens wél rekening te houden met het feit dat de rechter in de individuele procedure ambtshalve rekening moet houden met een verbodsuitspraak ook als de wederpartij zich daar niet op beroept ${ }^{591}$ en het de wederpartij dus niet te verwijten valt dat op grond van de verbodsuitspraak wordt vernietigd. Ook als dit laatste niet het geval is lijkt het mij redelijk dat de rechter er niet te snel toe over gaat de kosten van ongedaanmaking op de individuele wederpartij te leggen.

Als de verbodsuitspraak niet uitvoerbaar bij voorraad is verklaard, hebben ingestelde rechtsmiddelen schorsende werking voor de verbodsuitspraak. Mijns inziens is er geen reden waarom deze schorsende werking niet ook zou gelden in de individuele procedure. De schorsende werking van het instellen van verzet of beroep in cassatie tegen de verbodsuitspraak van de bijzondere rechter, brengt dan met zich dat de opgeschorte uitspraak voor de gewone rechter slechts een feitelijk gegeven is, waarmee hij rekening kan houden bij de individuele inhoudstoets aan de open norm. Een beroep op artikel 6:243 BW komt de individuele wederpartij dan niet toe. Het staat de gewone rechter bij de toets aan artikel 6:233 sub a BW vrij om van de opgeschorte uitspraak van de bijzondere rechter af te wijken. Uiteraard dient de gewone rechter bij de beoordeling van het betreffende beding rekening te houden met het feit dat tegen deze uitspraak verzet of beroep in cassatie is ingesteld.

Voor consumentenorganisaties zijn in het kader van de collectieve actie op grond van artikel 6:240 BW de algemene executieregels enkel van belang, voor de effectuering van een dwangsom die is gekoppeld aan een gebod of verbod als bedoeld in artikel 6:241 lid $3 \mathrm{BW}$ of de ten uitvoerlegging van een veroordeling in de kosten. Indien de bijzondere rechter in zijn uitspraak de gebruiker of aanbeveler niet veroordeelt in de kosten van de procedure of een dwangsom oplegt, valt er voor de in het gelijk gestelde organisatie immers niets te executeren.

In de eerste plaats moet de consumentenorganisatie die tot executie wil overgaan; de uitspraak betekenen aan de wederpartij(en). Betreft het wederpartijen die "gewoon", dat will zeggen niet middels de collectieve dagvaarding ex artikel $1003 \mathrm{Rv}$, zijn gedagvaard, dan dient de betekening op de normale manier te gebeuren aan de persoon of de woonplaats van de wederpartij. Na de betekening kan de dwangsom en de veroordeling in de kosten terstond worden geëxecuteerd, tenzij sprake is van een verstekvonnis. In dat geval kan eerst 
worden geëxecuteerd acht dagen na de betekening, tenzij de voorlopige tenuitvoerlegging van het verstekvonnis is toegestaan (artikel $80 \mathrm{Rv}$ ).

De betekening van het arrest dat is gewezen tegen gebruikers die samen met hun branchevereniging collectief zijn gedagvaard, schept echter meer problemen. Met name voor wat betreft de betekening aan de niet-geïndividualiseerde gebruikers. De betekening van de uitspraak aan de gedaagde vereniging kan immers op de normale wijze plaatsvinden. Dit ligt echter anders voor de collectief gedaagde leden van de vereniging die als collectief in het geheel niet zijn verschenen of waarvan slechts enkele leden in de procedure zijn verschenen. Artikel $1003 \mathrm{Rv}$ bepaalt weliswaar dat het exploit waarin de uitspraak aan de niet-geïndividualiseerde gebruiker wordt betekend, de naam en de woonplaats van deze gebruikers niet afzonderlijk hoeft te vermelden, maar geeft geen regeling voor de vraag aan wie de uitspraak moet worden betekend. Mijns inziens ligt het voor de hand dat de betekening van de uitspraak op dezelfde wijze dient te geschieden als bij de dagvaarding. Artikel 4 sub $13^{\circ} \mathrm{Rv}$ is daarom van overeenkomstige toepassing. Dat houdt in dat de uitspraak jegens het collectief of indien enige leden zijn verschenen de "overige" leden van de vereniging als collectief wordt betekend door middel van een exploit dat wordt uitgebracht aan de persoon of het kabinet van de procureur-generaal van of het hof in 's-Gravenhage of de Hoge Raad. Tevens moet een uittreksel van het betekenings-exploit ten spoedigste bekend worden gemaakt in een landelijk dagblad onder vermelding van de naam en het adres van de deurwaarder of advocaat van wie afschrift van thet exploit kan worden verkregen. Indien vervolgens bij een niet-geïndividualiseerde gebruiker een overtreding van het verbod wordt geconstateerd en deze gebruiker tegelijkertijd ook bekend wordt bij de eisende organisatie kan vervolgens terstond tot executie worden overgegaan zonder dat aan deze inmiddels bekende gebruiker wordt betekend.

Jegens het collectief of, indien een aantal leden wél verschenen is, de "overige" leden van de vereniging als collectief zal de verbodsuitspraak een verstekvonnis zijn. In dat geval kan jegens het collectief niet eerder geẻxecuteerd worden dan na acht dagen na betekening van de uitspraak aan de persoon of het parket van de procureur-generaal. In het geval dat de vereniging inmiddels ontbonden is, alleen aan de procureur-generaal. De vereniging heeft daardoor acht dagen de tijd om haar niet-geïndividualiseerde leden op de hoogte te stellen van de betekening van de uitspraak.

In de tweede plaats zijn de executieregels van belang voor het geval dat verzet of beroep in cassatie wordt ingesteld tegen het opleggen van de dwangsom en de veroordeling in de kosten. Indien de uitspraak niet bij voorraad uitvoerbaar is, heeft verzet of cassatie immers schorsende werking voor de uitspraak. Gedurende de schorsing kan geen dwangsom worden verbeurd en kunnen vóor de periode van schorsing verbeurde dwangsommen alsmede de nog 
niet geïnde proceskosten niet op de veroordeelde aanbeveler of gebruiker worden verhaald. Indien de uitspraak waarin de dwangsom of de veroordeling in de proceskosten wordt opgelegd, na het aanwenden van verzet of beroep in cassatie wordt vernietigd, vervalt met terugwerkende kracht de executoriale titel. Executie van nog niet verbeurde dwangsommen en nog niet verhaalde proceskosten is dan niet meer mogelijk en reeds geëfectueerde dwangsommen of proceskosten kunnen als onverschuldigd betaald worden teruggevorderd.

\section{Registratie van de uitspraak}

De wettelijke regeling voorziet niet in een bijzondere registratie van arresten gewezen door de bijzondere rechter. Zoals reeds eerder aangegeven, voorziet de regeling van afdeling 6.5.3 $\mathrm{BW}$ en de daarbij behorende procesrechtelijke bepalingen, ondanks herhaald aandringen van de vaste Commissie voor Justitie, niet in een eenvoudig toegankelijke registratie van op basis van afdeling 6.5.3 BW aanhangig gemaakte procedures en gegeven rechterlijke uitspraken. ${ }^{592}$ Voor wat betreft de uitspraken in de individuele procedures voor de gewone rechter valt daar wel mee te leven. Voor de uitspraken van de bijzondere rechter en de Hoge Raad in de procedure ex artikel 6:240 BW is het ontbreken van een eenvoudig toegankelijke registratie mijns inziens echter een ernstig gemis. Voor deze stelling is een aantal argumenten aan te voeren.

Zoals reeds eerder aangegeven zal een deugdelijke en eenvoudig toegankelijke registratie aan wederpartijen de mogelijkheid verschaffen zich, al dan niet via een rechtshulpverlener, op de hoogte te stellen van het feit dat een beding waarmee zij worden geconfronteerd door de bijzondere rechter verboden is. Voorts geeft een dergelijk registratiesysteem een makkelijke toegang tot de uitspraken van de bijzondere rechter aan rechtshulpverleners. Dit stelt dezen in staat om bij het opstellen en beoordelen van (nieuwe) algemene voorwaarden rekening te houden met de visie van de bijzondere rechter omtrent het (onredelijk bezwarende) karakter van bepaalde bedingen en met name de Haagse verbodslijst. Dit zal vooral ook een buitenprocessuele oplossing van conflicten bevorderen. Hoe duidelijker immers vaststaat hoe de bijzondere rechter over bepaalde bedingen denkt, des te eerder zullen partijen in een conflict omtrent de toelaatbaarheid van algemene voorwaarden daarmee rekening houden. Dit voorkomt onnodige procedures. Verder zal een dergelijke registratie ook voordelen meebrengen voor de gewone rechter in de individuele procedure ex artikel 6:233 sub a BW. De uitspraken van de bijzondere rechter bieden de gewone, niet gespecialiseerde rechter, niet alleen een duidelijk richtsnoer en 
houvast, het bevordert tevens eenheid van rechtspraak. Als laatste argument kan worden aangevoerd dat de uitspraken van de bijzondere rechter een duidelijk richtsnoer kunnen zijn voor onderhandelingen tussen branche-organisaties en consumentenorganisaties over de te hanteren algemene voorwaarden, hetgeen met name de snelheid van deze onderhandelingen ten goede zal komen.

Kortom, het zou de rechtszekerheid omtrent de (on)toelaatbaarheid van algemene voorwaarden en een efficiënte rechtspleging op dit terrein zeker ten goede komen, indien de uitspraken inzake de collectieve actie van artikel 6:240 BW niet alleen integraal en eenvoudig toegankelijk zouden worden geregistreerd, maar ook, liefst voorzien van annotaties door deskundigen op dit terrein, zouden worden gepubliceerd.

Integrale registratie van de aanhangige procedures en de uitspraken in de collectieve actie ex artikel 6:240 BW, in een voor ieder toegankelijk informatiesysteem hoeft naar mijn idee, gezien de huidige stand van de techniek op het terrein van de gedigitaliseerde informatietechnologie, de geautomatiseerde wijze waarop de verwerking van uitspraken bij de rechterlijke colleges reeds plaatsvindt en het feit dat alle procedures zijn geconcentreerd bij eén college, technisch en financieel geen al te groot probleem te zijn. De kosten zullen daarbij deels of geheel gecompenseerd worden door het feit dat enerzijds de gewone rechter in de individuele procedure bij de beoordeling van algemene voorwaarden door het geboden houvast sneller tot een beslissing zal komen en daarmee dus tijdwinst boekt en anderzijds omdat de gecreëerde rechtszekerheid procedures voorkomt.

Dat de wettelijke regeling niet in een dergelijk registratiesysteem voorziet staat overigens het inrichten van een dergelijk systeem niet in de weg. Vanwege de continuïteit dient een dergelijk systeem bij voorkeur onder verantwoordelijkheid van de centrale overheid te worden ingericht.

\section{Herziening van de uitspraak op vordering van de gebruiker of aanbeveler}

Als de bijzondere rechter een beding onredelijk bezwarend heeft verklaard en het gebruik of de aanbeveling ervan verboden heeft, kunnen de door de uitspraak gebonden gebruikers dit beding in beginsel niet meer opnemen in hun overeenkomsten. Opvartingen omtrent hetgeen onredelijk bezwarend is, zijn echter afhankelijk van de tijd en de op dat moment geldende omstandigheden. Een uitgesproken verbod kan door de tijd en een wijzigingen in de omstandigheden achterhaald zijn. Artikel 6:242 BW schept daarom voor de veroordeelde aanbeveler of gebruiker de mogelijkheid om een jegens hen uitgesproken declaratoir als bedoeld in artikel 6:240 lid $1 \mathrm{BW}$ (en de daaraan verbonden 
nevenveroordelingen) te wijzigen of op te heffen indien die uitspraak door een wijziging van omstandigheden niet langer gerechtvaardigd is. 590

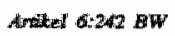

1. Op wordering wan een of meer wan degementegen wie de in artikel 240 lid 1 bedoelde uitspraak is gedaan, kan de rechter die taitspraak wijzigen of opheffen op grand dat zij tengevolge wan een wijtiging in de omstandighedien niet langer gerechnaandigd is. De vordering wordit ingesteld tegen die rechtspersoon op wiens wordering de uitspurack was gedacw.

2 Indiem de rechtspersoon op wiens vordering de witspratak was gedacon is onwbonden, wordl de zaak met een werzoekschrifi ingeleid. Voor de voepassing wan artikel 429 flid 1 wan het We boek wan Burgerlijke Rechtswordering worden rechtspersomen als bedoeld in artikel 240 liot 3 als belkangheb. berten aangemerks.

3. Artikel 241 leden $1,2,3$ onder $c$ en 5 is van overeenkomstige loepassing.

4. De worige leden zijn wiet wan toepassing voor zover de witspraak betrekking had op een beding das door de wet als onredelyjk bezwarend wordit angemerk.

Gevorderd kan worden dat een eerder gegeven declaratoir wordt gewijzigd of opgeheven. De bepaling van het artikel richt zich in eerste instantie slechts op de uitspraak dat een beding onredelijk bezwarend is. Logischerwijs heeft een opheffing of wijziging van het declaratoir echter ook gevolgen voor een daaraan gekoppeld verbod als bedoeld in artikell 6:241 lid 3 sub a BW. Het aan het oorspronkelijk declaratoir verbonden verbod verliest

zijn werking bij opheffing van het declaratoir, terwijl het bij wijziging daarvan op overeenkomstige wijze wordt beperkt. ${ }^{\text {s94 }}$

De overeenkomstige toepassing van artikel 6:241 lid $1 \mathrm{BW}$ brengt met zich, dat het hof te 's-Gravenhage bij uitsluiting bevoegd is om kennis te nemen van de wijzigingsvordering. Dit is ook zo als de uitspraak waarvan wijziging wordt gevraagd in cassatie tot stand is gekomen (als de Hoge Raad de uitspraak van het Haagse hof heeft gecasseerd en de zaak zelf heeft afgedaan). ${ }^{59 s}$ De woorden "bij uitsluiting" bewerkstelligen ook hier, dat geen voorziening in kort geding open staat in de procedure ex artikel 6:242 BW. Dit laat echter onverlet dat de gebruiker een voorlopige voorziening kan vragen ex artikel $51 \mathrm{Rv}$. Daarvoor gelld slechts de voorwaarde dat hij de in artikel $6: 242 \mathrm{BW}$ bedoelde vordering heeft ingesteld. De eiser in dit incident kan dan bij wege van voorlopige voorziening geheel of gedeeltelijk hetzelfde vorderen als in de zaak ten principale. Dit biedt de gebruiker een afdoende mogelijkheid om zich, zo daartoe grond bestaat, op korte termijn uit een knelsituatie te bevrijden. ${ }^{506}$

593 MvT, Parlementaine Geschiedenis, Inv. 3, 5 en 6, pag. 1788.

594 MvT, Parlementaine Gesehiedenis, Inv. 3, 5 en 6, pag. 1789.

595 VV, Parlementaire Geachiedenis, Inv. 3, 5 en 6, pag. 1789; MvA, Parlementaire Geachiedenis * Inv. 3, 5 en 6, pag. 1789.

596 MWA I, Parlementaire Geschiedenis, Inv, 3, 5 en 6, pag. 1780. 
Net als bij de vordering ex artikel 6:240 BW bepaalt artikel 67 RO dat het Haagse hof in eerste aanleg en in hoogste ressort, behoudens voorziening in cassatie, kennis neemt van de vordering.

De vordering tot wijziging van een eerder gegeven declaratoir komt toe aan een of meer van degenen tegen wie het declaratoir is gewezen. Dit betekent dat slechts eén van de veroordeelde gebruikers, het collectief van de leden van de vereniging of de veroordeelde aanbeveler de vordering hoeft in te stellen, om een uitspraak voor al degenen te verkrijgen die door het oorspronkelijke declaratoir werden getroffen. De vordering is immers gericht op wijziging op opheffing van het declaratoir en dit declaratoir werkt in de procedure van artikel 6:240 BW jegens iedere veroordeelde partij. Ook indien aanbeveler en gebruiker collectief zijn gedagvaard en veroordeeld, is derhalve voldoende dat of de aanbevelende vereniging óf éen van de veroordeelde leden een vordering tot herziening van het declaratoir als bedoeld in artikel 6:242 $\mathrm{BW}$ instelt. ${ }^{597} \mathrm{De}$ uitspraak geldt immers jegens al degenen tegen wie de oorspronkelijke uitspraak is gedaan.

De vordering dient te worden ingesteld tegen de rechtspersoon op wiens vordering de uitspraak was gedaan. Deze dient daartoe te worden gedagvaard voor de bijzondere rechter in "s-Gravenhage. Indien de rechtspersoon op wiens vordering het bestreden declaratoir is gewezen is ontbonden, wordt de procedure ingeleid door een verzoekschrift.

De vordering van artikel 6:242 $\mathrm{BW}$ richt zich derhalve in beginsel tegen de eisende organisatie in de procedure waarin het declaratoir is uitgesproken. De toepasselijkheid van artikel 6:241 lid 2 BW maakt dat de daarin genoemde organisaties zich kunnen voegen in de procedure.

In het geval de procedure met een verzoekschrift wordt ingeleid, stelt de laatste volzin van artikel 6:242 lid $2 \mathrm{BW}$ buiten twijfel dat de bijzondere rechter rechtspersonen als bedoeld in artikel 6:240 lid $3 \mathrm{BW}$ op grond van artikel $429 \mathrm{f}$ $R v$ als belanghebbenden kan oproepen.

De beoordeling van de vraag of van een dusdanige wijziging in de omstandigheden sprake is dat een wijziging of opheffing van een eerder uitgesproken declaratoir aan de orde is, is bij uitsluiting overgelaten aan het Haagse hof. Aan een andere rechter dan het hof komt de beslissing omtrent de gegrondheid van een beroep op gewijzigde omstandigheden bij een door een Haags verbod

597 Anders: Verhoeven, pag. 128. "De wet voorziet niet in een speciale regeling dat deze partijen als én eisende partij kunmen optreden. Het is aan het initiatief van belanghebbenden om gezamenlijk en met een zo groot mogelijk aantal eisers tot actie te komen." 
getroffen beding, uitdrukkelijk niet toe. ${ }^{59}$ Daaruit vloeit voort dat de gebruiker een door een uitspraak als bedoeld in artikel 6:240 BW - eventueel versterkt door een verbod krachtens artikel 6:241 BW - getroffen beding in beginsel niet meer mag gebruiken totdat hij een uitspraak als bedoeld in artikel 6:242 BW heeft verkregen.

Bij de beoordeling van de vraag of het eerder gegeven declaratoir gezien de wijziging in de omstandigheden nog steeds gerechtvaardigd is, heeft de bijzondere rechter een vergaande discretionaire bevoegdheid. De toelichtende stukken zijn hierover vrij duidelijk:

\begin{abstract}
Men denke bij voabeeld an wijziging warn de verzekerbarheid wan bepaalde risico's in verband met een door een witspraak getroffen exomeraviebeding, aan een werswijziging die van invloed is op de convractuele rechtspositie wan de gebrwiker van algememe voorwaarden, of aan wijzigingen in de madschappelijke opwatringen omtrent wat behoorlijk is en dus voor degenen die de algemene woomwarden alanwarden, bezwarend genoemd kan worden. (..) Het spreekt vanzelf dat de wijziging in de omstandigheden van betekenis moet zijn om wijziging of opheffing van de uitspraak te rechinaardigen. Voorts zal za wijziging wan omstandigheden in de regel onafhankelijk zijn wan de will want degene die zich daarop beroept. Zo zal bijwoorbeeld een wijziging wan de algemene woorwatarden op andere punten of een wijziging van de prijs waanvoor de gebruiker het goed of de dienst ter beschikking stelt, slechts bij hoge uifzondering een grond woor wijziging of opheffing van de witspraak opleveren. Het trekken wan de jwiste grenzen kam hier intussem ann de rechter worden overgelaten.
\end{abstract}

Op de procedure van artikel 6:242 BW zijn de leden 3 sub c en 5 van artikel 6:241 BW van overeenkomstige toepassing. Dit betekent dat de eiser in de herzieningsprocedure van artikel 6:242 BW kan vorderen dat de gedaagde organisatie, eventueel op straffe van een dwangsom, wordt veroordeeld tot het openbaar maken van de uitspraak van de bijzondere rechter in deze herzieningsprocedure. De bijzondere rechter dient dan tevens aan te geven op kosten van welke partij de publikatie dient plaats te vinden. In beginsel kan de rechter dus niet alleen de gedaagde organisatie veroordelen tot publikatie van zijn uitspraak maar eveneens in de kosten van deze publikatie. Net als een veroordeling van de gedaagde organisatie in de kosten van de procedure ex artikel 6:242 BW lijkt mij een veroordeling van de gedaagde organisatie tot publikatie van de uitspraak op kosten van de gedaagde organisatie echter principieel onjuist. Tussen de gedaagde organisatie en de eisende organisatie of gebruiker in de procedure ex artikel 6:242 BW hoeft immers geen sprake van een geschil. ${ }^{600}$ De wet dwingt de eiser in de procedure ex artikel 6:242 BW tot het dagvaarden van de organisatie die het bestreden declaratoir heeft gevorderd. Werkelijk

598. MvA 1, Parlementaire Geschiedenis, Inv. 3, 5 en 6, prg. 1780.

599 MVT, Parlementaine Geschiedenis, Inv. 3, 5 en 6, pag. 1788.

600 Zie ook: VV, Parlementaire Geschiedenis, Inv. 3, 5 en 6, pag. 1789. 
nodig is dit echter niet. Het declaratoir kan immers ook worden gewijzigd. indien deze organisatie reeds is ontbonden (zie artikel 6:242 lid 2). Bovendien is er geen sprake van enig "verwijtbaar" handelen van de gedaagde organisatie dat de eisende organisatie noopt tot de procedure en het maken van de daarmee gepaard gaande kosten. De procedure ex artikel 6:242 BW wordt immers ingegeven door een wijziging van omstandigheden en staat dus geheel los van handelingen van de gedaagde organisatie. De gedaagde organisatie treft geen enkel verwijt dat zij toentertijd het toegewezen declaratoir heeft gevorderd. Mede omdat de vordering ex artikel 6:242 BW geheel in het belang van de eiser(s) in deze procedure is, gaat het mijns inziens dan ook niet aan om de gedaagde organisatie te veroordelen in of de kosten van de procedure of publikatie van de uitspraak op haar kosten, ook niet als zij verweer heeft gevoerd met het doel de gevraagde wijziging van het declaratoir tegen te gaan.

De procedure van artikel 6:242 BW is in lid 4 van dit artikel uitdrukkelijk uitgesloten voor bedingen die onredelijk bezwarend zijn verklaard omdat zij door de wet als onredelijk bezwarend worden aangemerkt. Door de wet als onredelijk bezwarend aangemerkt zijn de bedingen die voorkomen op de zwarte lijst, de bedingen in strijd met de wet als bedoeld in de laatste volzin van artikel 6:240 lid $1 \mathrm{BW}$ en bedingen waarvan een andere regeling dan afdeling 6.5.3 BW bepaalt dat zij onredelijk bezwarend zijn (zie bij voorbeeld artikel 7:6 lid 2 BW). ${ }^{601}$ Declaratoiren met betrekking tot zulke bedingen komen niet voor wijziging of opheffing in aanmerking.

Alhoewel dit niet uitdrukkelijk is bepaald, lijkt mij de procedure van artikel 6:242 BW eveneens uitgesloten, als tegen de uitspraak van de bijzondere rechter waarvan wijziging of opheffing wordt gevraagd, beroep in cassatie nog open staat. In dat geval lijkt mij de eisende aanbeveler of gebruiker, wegens het ontbreken van voldoende belang niet ontvankelijk in zijn vordering ex artikel $6: 242 \mathrm{BW}$.

\subsubsection{Hoger beroep en cassatie}

Hoger beroep tegen de uitspraak van de bijzondere rechter bij het hof te 's-Gravenhage is niet mogelijk. Wél is uitdrukkelijk de voorziening in cassatie toegestaan. Artikel 67 RO bepaalt immers dat het Gerechtshof te 's-Gravenhage in eerste aanleg en in het hoogste ressort, behoudens de voorziening in cassatie, kennis neemt van de vorderingen bedoeld in de artikelen 6:240 en 6:242 BW. 
Het hof te "s-Gravenhage is voor de collectieve actie van artikel 6:240 BW en de actie van artikell 6:242 BW derhalve de enige feitelijke instantie. In dat verband bepaalt artikel 1005 sub $2^{\circ} \mathrm{Rv}$ dat het beroep in cassatie slechts kan worden ingesteld door degenen die in eerste aanleg verschenen zijn.

Artikel 1005 sub $2^{\circ} R v$

In geval van eent pordering als bedoeld in artikel 240 van Boek 6 wan het Burgentijk Wetboek gelden, indien de in arrikel 1003 onder $1^{\circ}$ bedoelde gegevens miet in het exploit worden vermeld, naast het bepacalde in artikel 4 onder $13^{\circ}$ en artikel 9 , derde lid, de navolgende bijzondere voorzieningen:

$(\ldots .$.

$2^{\circ}$ Her beroep in cassatie kan slechts wonden ingesteld door degenen die in eerste aumleg verschenen zijn.

De regel van artikel 1005 sub $2^{\circ} \mathrm{Rv}$ is zo geformuleerd dat de uitsluiting van het beroep in cassatie slechts van toepassing is op overeenkomstig artikel 1003 Rv collectief gedagvaarde leden of gewezen leden die niet zijn verschenen. ${ }^{\infty}$ Het artikel ziet dus niet op de gebruikers of aanbevelers die "gewoon" zijn gedagvaard en bij verstek zijn veroordeeld. Op deze laatsten ziet het algemene artikel $401 \mathrm{~b} \mathrm{Rv}$ dat eveneens bepaalt dat degene die bij verstek veroordeeld is tegen het verstekvonnis niet in cassatie kan gaan. In dat licht bezien, bepaalt de bijzondere bepaling van artikel 1005 sub $2^{\circ} \mathrm{Rv}$ niets anders en is zij dus volstrekt overbodig.

In cassatie is slechts ontvankelijk de aanbeveler of de gebruiker die in eerste instantie (al dan niet nadat tegen deze aanvankelijk verstek is verleend) verschenen is. ${ }^{603}$ Voor de procedure ex artikel 6:240 BW betekent dit dat de gebruikers die samen met hun vereniging collectief zijn gedagvaard, niet in cassatie kunnen komen indien zij in eerste aanleg niet als collectief of als individueel lid zijn verschenen. Dit is ook geen bezwaar omdat vernietiging van de uitspraak in cassatie op vordering van één van de wél-verschenen gedaagdlen eveneens werking heeft voor deze niet verschenen gedaagden. Artikel 1003 sub $2^{\circ} \mathrm{Rv}$ ziet immers ook op de situatie dat de gedagvaarde vereniging én het gedagvaarde collectief (de leden van de vereniging) gezamenlijk in cassatie gaan. Degene die beroep in cassatie kunnen aantekenen, kunnen dit dus ook namens het collectief doen. ${ }^{604}$ Bovendien kunnen ook de bij verstek veroordeelde gedaagden een procedure als bedoeld in artikel 6:242 BW starten om zodoende tot wijziging of herziening van de bij verstek gewezen uitspraak te geraken.

602 MvT, Tweede Kamer, zitting 1981, 16983 , nns. I-3, pag. 69.

603 Het is niet uitgesloten dat het rechterlijk verbod slechts op een deel van het gedagvaarde collectief wordt opgelegd. Uiteraand kunnen slechts die gebnikers in cassatie konuen jegens wie cen verbod is uitgesproken; slechts zij hebben belang bij cassatie.

604 MvT, Tweede Kumer, zilting 1981, 16983, nurs, 1-3, pag. 70. 
Zoals gezegd staat voor de defaillant geen beroep in cassatie open tegen een verstekvonnis (artikel 401b lid $1 \mathrm{Rv}$ ). Voor de eisende organisatie staat echter wel cassatie open tegen het verstekvonnis (artikel $67 \mathrm{RO} \mathrm{j}^{\circ}$ artikel $398{\text { sub } \mathrm{1}^{\circ}}^{\circ}$ Rv). De samenloop tussen de cassatiebevoegdheid van de eisende organisatie en de bevoegdheid in verzet te komen tegen het verstekvonnis wordt in de artikelen $401 \mathrm{~b}$ lid 2 en $401 \mathrm{c} \mathrm{Rv}$ duidelijk geregeld. Indien de eisende organisatie cassatie instelt tegen het verstekvonnis, kan de defaillant in cassatie verweer voeren en eventueel incidenteel beroep instellen (artikel $401 \mathrm{~b}$ lid $2 \mathrm{Rv}$ ). Indien de defailllant van deze mogelijkheid gebruik maakt kan hij geen gebruik meer maken van de mogelijkheid om in verzet te gaan (artikel $401 \mathrm{c}$ lid $1 \mathrm{Rv}$ ). Gaat de defaillant in verzet in plaats van gebruik te maken van de mogelijkheid verweer te voeren als bedoeld in artikel $401 \mathrm{~b}$ lid $2 \mathrm{Rv}$, dan vervalt het geding bij de Hoge Raad en wordt eerst de verzetprocedure behandeld, waarna cassatie, voor beide partijen weer open staat (artikell $401 \mathrm{c}$ lid $2 \mathrm{Rv}$ ). Indien de defaillant geen verweer heeft gevoerd in cassatie, kan het theoretisch zelfs zo zijn, dat verzet tegen het verstekvonnis in eerste aanleg kan worden gedaan nadat het arrest van de Hoge raad is gewezen maar de verzettermijn nog niet is verstreken (artikel $401 \mathrm{c}$ lid 3 Rv).

Ook in cassatie kan het arrest bij verstek worden gewezen indien de gedaagde niet verschijnt. De defaillant heeft in dat geval eveneens gedurende 14 dagen na betekening van het arrest aan zijn persoon of nadat hij door enige daad te kennen heeft gegeven dat het arrest hem bekend is, de mogelijkheid om daartegen in verzet te komen, echter alleen op de gronden vermeld in artikel $425 \mathrm{Rv}$.

Het beroep in cassatie dient te worden ingesteld binnen drie maanden, te rekenen vanaf de dag van de uitspraak van de bijzondere rechter (artikel 402 Rv). De dagvaarding dient aan dezelfde vereisten te voldoen als bij de procedure in eerste aanleg. Voor de collectieve dagvaarding in cassatie zijn de artikelen 4 sub $13^{\circ}$ (betekening), 9 lid 3 (termijn) en $1003 \mathrm{Rv}$ (niet geïndividualiseerd) derhalve onverkort van toepassing.

\subsubsection{De kosten van de procedure}

Indien de procedure als bedoeld in artikel 6:240 $\mathrm{BW}$ wordt ingeleid met een "gewone" dagvaarding, zijn voor wat betreft de kosten van de procedure in eerste aanleg de algemene regels van de artikelen $56-58 \mathrm{Rv}$ van toepassing. Dit betekent dat de in het ongelijk gestelde partij wordt veroordeeld in de proceskosten. Het is vast gebruik dat partijen over en weer elkaars veroordeling in de proceskosten vragen. Wanneer partijen dit niet uitdrukkelijk vorderen zal de 
rechter ambtshalve een uitspraak over de proceskosten moeten doen ${ }^{605}$ In cassatie zijn de artikelen 56-58 Rv niet van toepassing. De Hoge Raad is op grond van artikel 419 lid $4 \mathrm{Rv}$ volledige vrij om naar eigen inzicht over de veroordeling van de proceskosten te oordelen.

Voor de procedure van artikel 6:240 BW betekent dit in beginsel dat de in het ongelijk gestelde partij in de proceskosten van de winnende partij wordt veroordeeld. De in het ongelijk gestelde partij is of de eisende organisatie die het door haar gevraagde declaratoir ziet afgewezen of de gedaagde partij tegen wie het gevorderde declaratoir is toegewezen. De in het ongelijk gestelde partij is echter niet altijd de partij die de procedure verliest. Het is niet uitgesloten dat de hoofdvordering aan eiser wordt toegewezen en deze het proces wint, maar hij toch in de kosten van de andere partij wordt veroordeeld omdat zijn nevenvorderingen worden afgewezen. In de procedure ex artikel 6:240 BW zal er mijns inziens echter niet snell reden zijn de verliezende partij niet in de proceskosten van de andere partij te veroordelen. Dit omdat de procedure van artikel 6:240 BW altijd is vooraf gegaan door een overlegperiode, zodat de verliezende partij genoeg tijd heeft gehad zich over het karakter van het bestreden beding te beraden. Een veroordeling in de proceskosten zal in dat licht vooral op zijn plaats zijn indien de procedure bedingen betreft die op de zwarte lijst staan, in strijd zijn met de wet of in andere wettelijke bepalingen dan afdeling 6.5.3 BW onredelijk bezwarend worden verklaard. In die gevallen is er mijns inziens zelfs reden om de veroordeelde gebruiker of aanbeveler te veroordelen in alle door de eisende organisatie gemaakte proceskosten en dus niet slechts in de zogenaamde " te liquideren kosten". ${ }^{600}$ Hij hoorde of behoorde immers te weten dat hij de procedure zondermeer zou verliezen. Wie desondanks de andere partij tot een procedure dwingt, handelt jegens deze onzorgvuldig en behoort de kosten van deze nodeloze procedure te dragen.

De bijzondere rechter mag in de gevallen genoemd in artikel 56 lid $1 \mathrm{Rv}$ de kosten ook geheel of ten dele compenseren. Dit houdt in dat hij bepaalt dat of iedere partij haar eigen kosten draagt of dat een partij slechts een gedeelte van de kosten van de andere partij hoeft te vergoeden. ${ }^{607}$ Voor de procedure ex artikel 6:240 BW valt daarbij vooral te denken aan het geval dat "partijen over en weder op eenige punten in het ongelijk zijn gesteld". Dit zal met name het geval zijn indien de collectieve actie betrekking heeft op meerdere bedingen. Het is dan niet uitgesloten dat het gevorderde declaratoir voor het ene beding

605 Hugenholtz/Heemskerk, pag. 113.

606 In de praktijk blijken de rechtbanken en gerechtshoven het procureursalaris vast te stellen op het, niet bindende, usantieel tarief dat is vastgesteld door Nederlandse orde van advocatien." Deze zogenaamde "te liquideren kosten" liggen echter altijd onder het door de advocaat in werkelijkheid in rekening gebrachte tarief. Zix: Hugenhaltz/Heemskerk, pag "116.

607 Hugenholtz/Heemskerk, pag. 114. 
wel en het andere nilet wordt toegewezen. Een compensatie van de kosten ligt dan voor de hand.

Artikel $1006 \mathrm{Rv}$ geeft een nadere regeling ten aanzien van de proceskosten bij een collectieve dagvaarding.

\section{Artikel 1006 Rv}

Bovendien gelden in geval wan een vordering of verzoek als bedoeld in de artikelen 240 en 242 Boek 6 wan hat Burgerlijk Wetboek, indien de in de artikelen 1003 en 1004 bedoelde gegevens miet in het exploit of in het verzoelsschrift werden vermeld, de nawolgende bijzondere voorzieningen:

$I^{\circ}$ De artikelen 56 en 57, alsmede artikel 42\%, tweede Ld, laatste wolzin, worden toegepast als wormden de hiervoor bedoelde vereniging en haar leden, onderscheidenlijk de gewezen leden van een antbonden vereniging, tezamen éen partij. Niet verschenen leden of gewezen leden worden niet in de kosten wan het geding venwezen.

$2^{\circ}$ Op vordering anderscheidenlijk yerzoek van ieder des partijen kan de rechter, indient gerede twijfel bestaat of de wederpartij voor de proceskosten voldoende verhaal zal bieden, in elk stadium van de procedure bevelen dat terzake van de betaling der procestosten zekerheid wordt gesteld.

De voorziening sub $1^{\circ}$ sluit aan bij de erkenning van de ondernemersvereniging en haar leden als een voor het procesrecht relevante colllectiviteit, dus als een eenheid. De collectiviteit (vereniging én leden) wordt voor de berekening van de proceskosten daarom als éen partij beschouwd. ${ }^{608}$ Dit betekent mijns inziens dat in dat geval het gedaagde collectief als ware het eén partij gebruik zal moeten maken van de diensten van advocaten en procureurs. Het is in dat licht weliswaar niet uitgesloten dat elk der collectief gedaagden zich laat bijstaan door een eigen procureur, de rechter zal op grond van artikel 1006 sub $1^{\circ} \mathrm{Rv} \mathrm{j}^{\circ}$ artikel 56 lid $1 \mathrm{Rv}$ echter slechts rekening kunnen houden met de kosten van rechtshulpverlening van één van de gedaagden (vereniging óf het collectief van leden of het individueel verschenen lid). Er van uitgaande dat de collectief gedaagden kunnen optreden als sen partij (de leden kunnen de procesvoering immers overlaten aan hun vereniging) zijn de kosten van de overige gedaagden immers onnodig.

De regeling van artikel $1006 \mathrm{Rv}$ is uitdrukkelijk beperkt tot de collectief gedagvaarde partijen. De regeling geldt dus niet wanneer de leden van de vereniging niet als collectiviteit worden gedagvaard. De eisende organisatie heeft in dat opzicht de omvang van een veroordeling in de kosten der wederpartij in geval wan verlies dus grotendeels zelf in de hand. ${ }^{609}$ Hoe meer gebruikers zij op de "gewone" wijze dagvaart des te groter is haar procesrisico bij verlies. Uit de formulering van artikel $1006 \mathrm{Rv}$ kan worden opgemaakt dat de regeling ook geldt indien naast het collectief ook niet-lleden worden gedagvaard.

608 MvT, Tweede Kamer, zitting 1981, 16983 , nrs. 1-3, pag. 71.

609 Mv' , Tweede Kamer, zitting 1981, 16983 , nrs. 1-3, pag. 71. 
Het collectief en de daarvan verschenen leden gelden dan voor wat betreft de kosten als éen partij naast de andere, niet collectief, gedaagde partijen.

Artikel 1006 sub $1^{\circ}$ Rv bepaalt voorts dat de niet-verschenen leden of gewezen leden niet in de kosten van de procedure worden verwezen. Bij verlies komen de kosten dus ten laste van de vereniging en de verschenen leden. ${ }^{610}$ Indien alleen de gedaagde vereniging in de procedure verschijnt, draagt zij bij verlies de kosten alleen. Wel wordt het mogelijk geacht dat de vereniging of de verschenen leden die zijn veroordeeld in de kosten van de eisende organisatie, regres nemen op de niet verschenen of gewezen leden. Op niet verschenen of gewezen leden zal de vereniging en de wel verschenen leden echter slechts regres hebben indien dat uit de onderlinge verbouding voortvloeit. Zo kan een regresverplichting van de leden voortvloeien uit de statuten of uit een overeenkomst die met het oog op de te voeren procedure is gesloten tussen de vereniging en haar leden. ${ }^{611}$

\title{
5.3.11 Overheidssubsidie
}

Tijdens de parlementaire behandeling is herhaaldelijk aangedrongen op een regeling ter financiering van de activiteiten van consumentenorganisaties als bedoeld in artikel 6:240 BW.

In de memorie van toelichting wordt hierover het volgende vermeld:

\begin{abstract}
"In het CCA-advies (pag. 39) wordt door een deel wan de commissie gesteld dat indien aan consumentenorgcmisaties de bevoegdheid wordt toegekend om cen vordering woar de bijzondere rechter in te stellen de kosten volledig of grotendeels door de overheid moeten worden vergoed, daar anders te wrezen valt dat en feftectieve contmale nier te realiseren is. Inderdaad zijn wij in beginsel wan. aordeel dat de hier acm de consumentenorganisaties toegekende taak door de regering gehoel of ten dele behoort te worden geswbsidieerd, evenzo als dit bij de nieume regeling inzake misleidende reclame (...) het geval is. (...) over de omvang wan de subsidie en over de vragg of ook andere tot procederen bevoegde organisaties acaspraak op subsidie moeten kunnen maken, zall to zijner tijd na overleg met de arganisaties en in het licht wan de dan bestacande fincanciele situatie wordien. bestist. 612
\end{abstract}

Ofschoon de vaste Commissie voor Justitie van oordeel was dat niet alleen de consumentenorganisaties doch alle organisaties aan wie het ius agendi is

610 MvT, Tweede Kamer, zitting 1981, 16983 , nrs. 1-3, pag. 71.

611 MvA I, Tweede Kamer, zitting 1981, 16 983, nrs. 1m3, pag. 20.

612 MVT, Parlementaire Geschiedenis, Inv. 3, 5 en 6, pag- 1457. 
toegekend, gesubsidieerd dienen te worden ${ }^{613}$ werd de voorgenomen subsidieregeling uitdrukkelijk beperkt tot consumentenorganisaties:

"De consumentenorganisaties aefenen (...) een taak wit in het algemeen consumentenbelang: waanvow hun eigen middelen veelal niet toereikend zijn. (...)) Ondat de belangen die de ondermemersorganisaties in dit kader behartigen vooral van bedrijfseconomische aand zijn, achten wij het niet op onze weg liggen de ondememersarganisaties ter zake een subsidie te verlenen. "w614

Het streven van de wetgever was, op uitdrukkelijke wens van de Tweede Kamer erop gericht dat de basisstructuur, de criteria en de wijze van controle van de subsidieregeling gereed zouden zijin voror de openbare behandeling van het wetsontwerp door de Tweede Kamer. Hoewel het belang van een goede subsidieregeling door de wetgever werd onderschreven kon de wetgever, ondanks hernieuwd aandringen van de Tweede Kamer op een subsidieregeling, ${ }^{615}$ bij de eindstemming in de Tweede Kamer nog geen subsidieregeling voorleggen. Als reden daarvoor werd aangegeven "dat nog te veel praktische onzekerheden bestaan omtrent het effect wan de wet". ${ }^{616}$ Ten einde de Kamer toch in de gelegenheid te stellen na te gaan of er ten tijde van inwerkingtreding sprake zal zijn van een goede subsildieregeling beloofdle de Minister de Tweede Kamer dat ruim vór de inwerkingtreding van de wet de beslissingen met betrekking tot subsidiëring aan de Kamer zouden worden gezonden. ${ }^{617}$

Ook de Eerste Kamer hechtte bijzonder aan de toezegging van de Minister dat ruim vóór de inwerkingstelling van de afdeling 6.5.3 BW de subsidiëring van consumentemorganisaties geregeld zou zijn, ${ }^{618}$ waarvan "goede nota" werd genomen door de Minister. ${ }^{619}$

Blijkens de toelichtende kamerstukken staat de wetgever bij de invulling van een dergelijke subsidieregeling niet een volledige subsidiëring voor ogen maar een zodanige financiële handreiking dat het de consumentenorganisaties mogelijk wordt, de hun toebedachte talak in het belang van de bescherming van consu-

$613 \mathrm{VV}$, Parlementaire Geschiedenis, Inv, 3, 5 en 6, pag. 1768.

614 MvA, Pälementaire Geschiedenis, Inv. 3,5 en 6, pag. 1770. Zie ook: EV, Parlementaire Geschiedenils, Imw, 3, 5 en 6, pag. 1771.

615 De vaste Commissie voor Justitie wees er madrukkelijk op dat de subsidieregeling "... nok dardwerkelijk bekend moet zijn vóor de openbare behandeling ( ...) opdat nagegaan kan wonden of voldaun an de door haar gestelde voorwaarde dat een goede subsidieregeling bij de annvaarding van het onderhavige wetsontwerp verzekerd moet zijn". EV, Parlementhaire Geschiedenis, Inw. 3,5 en 6, pag. 1771.

616 NEV, Parlementaire Geschiedenis, Inv. 3, 5 en 6, pag. 1772.

617 NEV, Parlementaire Gegchiedenis, Inv. 3, 5 en 6, pag. 1772.

618 VV I, Parlennentaire Geschiedenis; Inv, 3, 5 en 6, pag. 1777.

619 Mva 1, Parlementaire Geschiedenis, Inv. 3, 5 en 6, pag. 1779. 
menten goed te vervullen. ${ }^{620}$ Naar aanleiding van de vraag of iedere rechtspersoon met een statutaire doelomschrijving die past in artikel 6:240 lid $3 \mathrm{BW}$, voor subsidie in aanmerking komt, antwoordde de Minister dat ten aanzien van aspecten als representativiteit en het ontwikkelen van materiële activiteiten "wellicht criteria moeten worden ontwikkeld voor subsidiering, maar daarbij kan de problematiek - anders dan bij in de wet neer te leggen criteria - zo nodig van geval tot geval in het licht van de dan bestaande praktijk en van de financiele mogelijkheden worden bezien. ${ }^{\text {w1 }}$

Tot op heden, en dus ook op het tijdstip van inwerkingtreding van afdeling 6.5.3 BW, heeft de wetgever echter nog niet voorzien in de bedoelde subsidieregeling. Daarmee staat vast dat de regering de uitdrukkelijke belofte aan de beide Kamers, dat voor de inwerkingtreding van afdeling 6.5.3 $\mathrm{BW}$ een subsildieregeling klaar zou liggen, niet is nagekomen. Het valt mijns inziens te vrezen dat als gevolg daarvan, gepaard aan een gebrek aan eigen middelen bij de consumentenorganisaties, een effectieve controle van algemene voorwaarden niet te realiseren is. ${ }^{622}$

\subsubsection{De verhouding tussen artikel 6:240 BW en artikel 3:305a BW}

In het op 1 juli 1994 in werking getreden artikel 3:305a BW hebben belangenorganisaties een algemeen vorderingsrecht gekregen dat zich niet alleen beperkt tot collectieve acties uit onrechtmatige daad maar zich uitstrekt tot alle vorderingen $^{623}$ met uitzondering van de vordering tot schadevergoeding in geld. Daarmee is voor belangenorganisaties wettelijk vastgelegd, in de

620 UCV II, Parlementaire Geschiedenis, Inv. 3, 5 en 6 , pag. 1773.

621 MvA 1, Parlementaire Geschiedenis, Im, 3, 5 en 6, pag. 1779.

622 Desgevrangd deelde de directiesecretaris wan de Consumentenibond (mr. L.P. Willigenburg) mij medio december 1994 mede dat er geen sprake is van een afzonderlijke algemene subsidieregelling. Met collectieve acties is wel rekening gehouden in de door het Ministerie van Esonomische Zaken met de consumentenorganisaties gemaakte algemene afspraken over subsidiëring via de Stichting Samenwerking Consumentenbond/Konsumenten Kontakt. In het werkprogramma wan de Stichting (kortweg Stisam genoemd) is in het cluster "Marktwerking" een project "Juridische positie consument" opgenomen " waronder zowel de activiteiten van de genoemde consumentenorganisaties in het voorwardenoverleg als het voeren van (eventuele) collectieve acties zijn vermeld. In 1994 was woor dit project in zijn geheel een bedrag van nuim $f 450,000,=$ beschilkbaar, zonder specifieke "earmarking" voor collectieve actics. Nian werwachting van Dhr. Willigenburg zal dit bedrag woor 1995 "belangrijk lager komen te liggen".

623 MvT, Tweede Kamer, vergaderjaar 1991-1992, 22 486, nr. 3, pag. 24.

624 Uitigebreid zie: Frenk, diss., pag. 145-162. 
rechtspraak was dit immers reeds aanvaard, ${ }^{625}$ dat zij gelijksoortige belangen van anderen, die zij zich statutair hebben aangetrokken, ook collectief mogen behartigen op het gebied van het contractenrecht en dus ook op het terrein van de algemene voorwaarden. ${ }^{626}$

De verhouding tussen de specifieke collectieve actie van artikel 6:240 BW en de algemene collectieve actie van artikel 3:305a BW komt in de kamerstukken met betrekking tot de totstandkoming van artikel 3:305a $\mathrm{BW}$, herhaaldelijk aan de orde. Zo acht de Minister in de memorie van toelichting bij het ontwerp van artikel 3:305a BW een collectieve actie op grond van dit artikel ook uitdrukkelijk mogelijk op het terrein van de algemene voorwaarden. Bij de opsomming van een aantal op grond van artikel 3:305a BW mogelijke vorderingen die tot een constitutief vonnis kunnen leiden noemt hij uitdrukkelijk de mogelijkheid van een collectieve vernietiging van een beding in algemene voorwaarden:

"Voorts kan worden gedacht atan vernieviging wan een beding in algemene voonwatarden op grond van de artikelen 6:233 en 243 of 7:862 nieww BW. 627

Vervolgens komt de verhouding aan de orde bij de beantwoording van de vraag of er naast de algemene regeling van het vorderingsrecht voor belangenorganisaties van artikel 3:305a BW nog wel behoefte is aan de bijzondere regeling van het collectieve actierecht op het terrein van de algemene voorwaarden. Nadat de Minister geconstateerd heeft dat met het tot wet verheffen van de algemene regeling van het collectief actierecht, de bijzondere regelingen ${ }^{628}$ overbodig worden, makt hij een uitzondering voor de bijzondere regeling van artikel 6:240 BW:

"Het enige duidelijke geval wavin behoefie aan een bijzondere regeling blijft bestaan, betreft dte collectieve actit die tot doel heef, algemene voorwaarden onredelijk bezwarend te laten verklaren door het Haagse Gerechshof (artikel 6:240 an volgende nieuw BW). Dit is een zeer specifieke regeling. Verwezen moge worden nacir paragraaf 3 van het algemeen deel wan deze memarie. Het is acanstonds duidelijk dat deze regeling in haar geheel gehandhagfid dient te blijuen. Het gaat hier miet om een $<<$ gewore $>>$ collectieve actie. Het bijzondere schuilt wooral hierin, dat het gaat om

625 HR 30 november 1990, NJ 1991,492 , m.nt. M.S. (Vereniging assistent-geneeskundigen/gemeente 's-Gravenhage); HR $\mathbb{1}$ julli 1992 , NJ 1993, 450, m.nt. H.S. (Abva-Kabo/Staat der Nederlanden); HR 1 juli 1993, NJ 1994, 461, m.nt. H.J.S. (De drie HLO's Westland/gemeente 's-Oravenhage). Orilangs nog: HR 2 september 1994, RvdW 1994, 165C, TvC 1994, pag. 369, m.nt. L. Domumering-van Rongen ${ }_{i}$ NJB 1994, pag. 431-432 (Consumentenbond/Nuts-verzekeringen):

626 Frenk, diss., pag. 159-162; Mölenberg, pag. 284-287.

627 MvT, Tweede Kamer, vergaderjaar 1991-1992, 22 486, nr. 3, pag. 25.

628 Zie hilervoor paragmaf 4.6.3. 
declamatoire uitspraken met algemene werkimg. Extra beperkingen en waiaborgen zijn daanom in de megeling opgenomen. Die lowmen geen wan alle worden gemulst.

De fracties van het CDA en de VVD vroegen daarop een nadere toelichting van de Minister over de verhouding tussen artikel 3:305a BW en artikel 6:240 e.v. BW omdat zij signaleerden dat de Minister niet alleen aangeeft dat artikel 6:240 BW op het terrein van de algemene voorwaarden wordt gezien als lex specialis van artikel 3:305 BW maar tevens dat artikel 3:305a BW toestaat dat bedingen in algemene voorwaarden collectief worden vernietigd. 630 De Minister geeft hierop het volgende antwoord:

${ }^{4} \mathrm{De}$ leden wan de fracties van $C D A$ en WW hebben nige vragen gesteld aver de relatie tussem artikel 305 a en de artikelen 6:240-241 BW. Meer in het bijzonder vroegen zij zich of of als gevolg van dit wetswoorstel het de bedoeling is dat ook de vemieriging van onredielijk bezwarende bedingen door een belangenorganisatie kam worden gevorderd.

Zaals in de memorie wan toelichving op p. 25 staat aangegeven, is dit inderdoad miet uitgesloten, al zal dit weinig voorkomen, reeds omdat in het sinds 1 janwari 1992 geldende recht de wernietiging in de regel door een buitengerechtelijke verklaring zal plactsvinden. In het oog dient te movden gehouden dat het hier uitsluitend zal kunnen gaan om algemene woorwarden die wan toepassing zijn in reeds gesloten overeenkomsten. Deze figuur werschilt derhalve principieel van de figuwr van het verbod tot (toekomstig) gebruilk van anredelijk bezwarende bedingen in de artiketen $6: 240-241$ BW.

In de praktijk zal behoefte aan vemietiging door de rechter wit hoofde wan een collectievie actie kwnen bestaan bij grote groepen lang lopende gelijkwomige overeenkomsten op basis wan gelijke algemene voorwaarden. Men denke aan een hutundersweremiging die wit het oogpunt van rechtszekerheid woor een grote groep huurders buj een verhuurder in rechte de wernietiging van een wermeend anredelijk bezwarend beding in reeds lopende overeenkomsten vordert. Men denke voorts aan een collectieve vondering tot vernietiging in de zin van artikel $6.243 \mathrm{BW}$. Een dergelijke toetsing zal owerigens placats moeten vinden door de rechter die daartoe volgens de gewone regels bevoegd is. Anders dan bij de preventieve toetsing wordt hier de necherlijke toetsing niet bij het Gerechtshof te 's-Gravenhage geconcentreerd. Het verschil met de actie van artikel 6:240 BW is immers dat de wernietigingsantie betrekking moet hebben op cancrete zich voorgedaan hebbende gevallen wan hantering wan bitigieuze voonwadrden. 601

Daarmee is duidelijk dat de preventieve collectieve actie van de artikelen $6: 240$ en 6:241 BW met betrekking tot het gebruik van algemene voorwaarden in toekomstige overeenkomsten lex specialis is van het algemene actierecht van artikel 3:305a BW. De specifieke voorwaarden en gevolgen die aan de preventieve collectieve actie op het terrein van de algemene voorwaarden zijn verbonden, maken dat de regeling van de artikellen 6:240 en 6:241 BW derogeert aan

629 MvT, Tweede Kamer, vergaderjaar 1991-1992, 22 486, nr. 3, pag. 35.

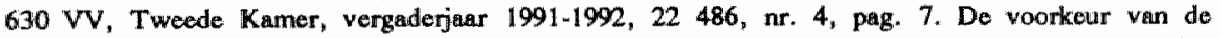
CDA-fractive lijkt daarbij uit te gaan naar een exclusieve rol woor antikel 6:240 e v. BW op het terrein van de algemene voorwarden.

631 MvA, Tweede Kamer, vergaderjaur $1992-1993,22486$, ar. 5, pag. 10. 
die van art. 3:305a BW. Met betrekking tot algemene voorwaarden heeft artikel 3:305a BW alleen nog relevantie voor het collectief vernietigen van algemene voorwaarden in reeds bestaande overeenkomsten. De collectieve actie van de artikel 6:240 en 6:241 heeft immers alleen gevolgen voor de toekomst en geen, althans geen rechtstreeks, gevolg voor reeds bestaande overeenkomsten of reeds afgewikkelde overeenkomsten. ${ }^{632}$

Volgens de Minister zal een actie tot collectieve vernietiging van algemene voorwaarden niet snel voorkomen. Daarmee onderschat hij volgens mij de mogelijkheden die het algemeen vorderingsrecht van artikel 3:305a BW aan belangenorganisaties - ook preventief - biedt op het terrein van de algemene voorwaarden. Artikel 3:305 a BW biedt namelijk een aantal mogelijkheden die het actierecht van de artikelen 6:240 en 6:241 BW niet biedt.

Ten eerste kunnen consumentenorganisaties in én procedure, op welke grond dan ook, vernietiging vragen van onredelijk bezwarende bedingen in massaal met consumenten gesloten overeenkomsten. Dat een collectieve actie zich bij uitstek leent voor de vernietiging van onredelijk bezwarende algemene voorwaarden die reeds in, al dan niet afgewikkelde, overeenkomsten met consumenten zijn opgenomen hoeft nauwelijks betoog. In de woorden van Frenk:

"Algemene voonwaarden zijn immers schriftelijke bedingen die zijn opgenomen ten cinde in een aantal overeenkomsten te worden opgenomen (art. 6:231 onder a). Toch is hiermee niet gezegd dat een beding onredelijk bezwarend kan zijn voar leder van de wederpartijen van de gebruiker van algemene worwaanden. Artikel 6:233 onder a BW somt immers een aantal soms slechts individweel in te vwlen onsitandigheden op waaronder een beding als onredelijk bezwarend kam worden aangemerkt. Desondanks kan in weel gevallem wel een eenduidig antwoord worden gegewen op de maag of eem in algemene voorwwarden opgenomen bedimg onredelijk bezwarend is. Het meest duidelijk is deze vraag the beanwwoonden ten acanzien van bedingen die in de zwarte hjst zijn opgenomen (ant. 6:236). Deze worden immers zonder meer als onredelijk bezwarend aangemerks. Ook bedingen watrwan het verdere gebruik op vordering van een rechrspersoom als bedoeld in artikel 6.240 lid $3 \mathrm{BW}$ is verboden, zijn na abstrakte toetsing door de rechter als onredeitik bezwarend acongemerkt. Voor zover deze bedingen reeds in overeenkomsten zijin opgenomen, lenen deze zich ook zonder meer voor een kallektieve vemietiging. Maar ook buiten deze twe gevallem is goed denkbaar dat de rechier zonder in te gaan op de omstandigheden van konkrete gevallen - dus wa en meer abstrakte toetsing - tot het oordeel kan comen dat een reeds in overeenkomsten opgenomen beding onredelijk bezwarend is. Met mame bij bedingen die op de grijze lijst woorkoment kan naar mijin mening de rechter snel tot deze konklusie komen. Bij deze bedingen wordt immers de onvedelijk bezwardheid" daarvan reeds bij voonbacat vernoed (art. 6:237 BW). "033.

632 Zie hierwoor paragraaf 5.3.8.1.

633 Frenk, diss., pag. 161 . 
Zo zouden consumentenorganisaties door middel van eển procedure gericht tegen alle Nederlandse gebruikers van bepaalde onredelijk bezwarende bedingen, in én klap deze bedingen in alle overeenkomsten met consumenten kunnen vernietigen en zo uit de markt kunnen lichten. Dit heeft tot voordeel dat de individuele consument, die meestal niet op de hoogte is van de inhoud van het betreffende beding en het feit dat hij een beroep kan doen op een vernietigingsgrond omdat het beding onredelijk bezwarend is, niet telkens een buitengerechtelijk een beroep hoeft te doen op de vernietigbaarheid om vernietiging ook daadwerkelijk te bewerkstelligen. ${ }^{634}$ Daarbij biedt artikel 3:305a BW niet alleen mogelijkheden als sprake is van een vernietigbaarheid op grond van de artikelen 6:233 sub a BW en 6:243 BW, maar onder andere ook in geval van nietigheid of vernietigbaarheid wegens strijd met een dwingende wetsbepaling, de openbare orde of de goede zeden $(3: 40 \mathrm{BW})$ of wegens het (massaal) schenden van de infoplicht (6:233 sub b $\mathrm{j}^{\circ}$ 6:234 BW).

Ten tweede heeft een dergelijke actie of de dreiging daarvan ongetwijfeld ook preventieve werking voor nog te sluiten overeenkomsten en zal zij ook zeker een voor consumentenorganisaties positieve invloed hebben op zelfreguleringsprocessen. Daarmee bewerkstelligt een dergelijke actie deels dezelfde effecten als de preventieve collectieve actie van de artikelen 6:240 en 6:241 BW.

Ten derde gelden voor een collectieve actie op basis van artikel 3:305a BW de algemene competentieregels. De regel van artikel 6:241 lid $1 \mathrm{BW}$, waarin het Haagse hof bij uitsluiting bevoegd wordt verklaard, geldt in dat geval niet. Daardoor kan de gewone rechter gevraagd worden een collectief oordeel te vellen over het onredelijk bezwarende karakter van bepaalde algemene voorwaarden $^{635}$ Dit kan onder omstandigheden een (processueel) voordeel opleveren mede omdat het kort geding in de procedure van artikel 3:305a BW niet is uitgesloten. Het is de echter de vraag of het vanuit het oogpunt van rechtszekerheid wenselijk is dat de gewone rechter zijn oordeel gaat vellen over de onredelijk bezwarendheid van collectief gehanteerde algemene voorwaarden terwijl daar nou juist een bijzondere rechter voor is aangewezen. Concentratie van de rechtspraak bij een bijzondere rechter die daardoor ook bijzondere deskundigheid zal verwerven (waardoor ook de procedure doelmatiger en dus sneller zal verlopen) heeft mijn voorkeur omdat dit mijns inzien meer rechtseenheid en zekerheid biedt. Daar staat echter tegenover dat in een procedure op grond van artikel 3:305a BW het doorgaans zo zal zijn dat zowel hoger beroep als beroep in cassatie open staat, zodat ook hier de Hoge Raad met betrekking tot de rechtseenheid een oogje in het zeil kan houden. 


\section{Het "Gesetz zur Regelung des Rechts der allgemeinen Geschäftsbedingungen"}

\subsection{Inleiding}

Bij de totstandkoming van afdeling 6.5.3 BW heeft, naast Oostenrijkse', Fran$\mathrm{se}^{2}$, Engelse ${ }^{3}$ en Europese ${ }^{4}$ (ontwerpen van) regelgeving, ${ }^{5}$ met name het Duitse Gesetz zur Regelung des Rechts der Allgemeinen Geschäftsbedingungen ${ }^{6}$ (AGB-Gesetz/AGBG) model gestaan. ${ }^{7}$ Het AGB-Gesetz, dat op 1 april 1977 in werking is getreden, kan, in tegenstelling tot de Wet algemene voorwaarden, inmiddels terugzien op een relatief korte doch rijke historie die een schat aan literatuur en rechtspraak op het terrein van de algemene voorwaarden heeft voortgebracht. Net als de Wet algemene voorwaarden voorziet het AGB-Gesetz in een collectief actierecht voor consumentenorganisaties. Met dit collectief actierecht is in Duitsland inmiddels meer dan 15 jaar ervaring opgedaan. Reden te meer om in dit hoofdstuk het AGB-Gesetz en met name de procesrechtelijke bepalingen inzake het collectief actierecht nader te beschouwen. ${ }^{\mathrm{g}}$

Daartoe worden allereerst kort de ontstaansgeschiedenis van de wet, de doelstelling en verwachtingen van de wet, de plaats en indeling van de wettelijke regeling en de materieelrechtelijke hoofdlijnen van het AGB-Gesetz nader

1 Bundesgesetz vom 8. Märx 1979, Init dem Bestimmungen zum Schutz der Verbraucher getrofien wenden (Konsumentenschutzgesetz - KSchO), BGBL. 1979, nr. 140.

2 Loi no. $78-23$ du 10 janvier 1978 sur ls protection et l'information desi consommateurs de produits et de services, Joumal Officiel 1978, 301; Déret no. $78-464$ du 24 mars 1978 portant application du chapitre IV (De la protection des consommateurs contre les clauses abusives), Joumal Officiel $1978,1412$.

3 Unfair Contract Terms Act 1977, Elizabuth Ill 1977, Chapter 50.

4 Resolution 1976 nr. 47 (16 november 1976), Unfair Terms in Consumer Contracts and an Appropriate Method of Control.

5 Zive voor een overzicht van deze regelingen Hondius, preadvies, pag. $126-140$.

6 Gesetz zur Regelung des rechts der Allgemeinen Geschäftsbedingungen vom 9. Dezember 1976, BCB1. I pag. 3317 .

7 MwT Inv., Psurlementajine Geschiedenis, Inv. 3, 5 en 6, pag. 1554-1455; Asser-Hartkamp II, pag. 317; Wessels en Jongeneel, pag. 5; Mölenberg en Rijken, pag. I; Jongencel, diss., pag. 2 en 4; Verhoeven, pag. 5.

8 Zie voor een uitgebreide vergelijking vain het materieelnechtelijke gedeelte van het AGB-Gesetz met de Wet algemene voorwaarden de dissertatie van Jongeneel. 
bekeken. Vervolgens wordt in het laatste deel van dit hoofdstuk uitgebreid ingegaan op de procesrechtelijke bepalingen van het AGB-Gesetz.

\subsubsection{Ontstaansgeschiedenis}

Net als in Nederland spelen in Duitsland algemene voorwaarden een belangrijke rol in het economisch en juridisch verkeer. In praktisch alle takken van produktie, handel en dienstverlening hebben standaardvoorwaarden en standaardcontracten de plaats ingenomen van op basis van onderhandelingen tussen beide contractspartijen tot stand gekomen overeenkomsten.

Over het aantal in omloop zijnde (sets) algemene voorwaarden zijn geen exacte cijfers bekend. Bij de totstandkoming van het AGB-Gesetz schatte de Duitse wetgever dit aantal op enkele honderdduizenden stuks. ${ }^{9}$ Het beroeps- en bedrijfsleven ging op dat moment uit van 20.000 tot 30.000 in omloop zijnde (sets) algemene voorwaarden. ${ }^{10}$ In de literatuur wordt er, overigens zonder exacte cijfers te noemen, van uitgegaan dat dit aantal, mede als gevolg van een toenemende tendens tot uniformering binnen de verschillende branches, aanzienlijk geringer is geworden. ${ }^{\text {" }}$ Voor wat betreft het gebruik in de verschillende branches dient gewezen te worden op de schattingen van Rehbinder. ${ }^{12}$ Deze gaat er van uit dat het gebruik van algemene voorwaarden een spreiding heeft van $100 \%$ in de verzekeringsbranche, de bank- en kredietbranche, het toeristisch verkeer, autobranche, handelskoop en het schriftelijk onderwijs; $90 \%$ in de bouwbranche, de makelaardij, de meubelbranche en de woningverhuur en van $50 \%$ in de autoreparatie en onderhoudsbranche, chemische reiniging en de reparatie van huishoudelijke artikelen.

Vanuit de optiek van de ondernemer zijn algemene voorwaarden en de uniforme toepassing daarvan vooral van belang voor de rationalisering van zijn onderneming. ${ }^{13}$ Ook in Duitsland had en heeft het gebruik van algemene voorwaarden echter de bekende schaduwzijden:

9 Begründung, BT Drucksache 7/3919, pag. 10.

10 Ulmer, AGE-Kommentar, Einl. Rndnr. 5.

11 Bunte, BB 1980, pag. 326; Bunte, Handbuch, pag. 2; Gerlach, Münchener Kommentar, Vor 13 AGBG Rndnr. 24. De lastste auteur gaat er echter van uit dat niet in alle branches een unificatie is opgetreden en dat veel gebruikers in de praktijk van alledag geen standaard sets gebruiken, maar door hun zelf geconcipieerde algemene voorwaarden. Vanuit dat standpunt bezien acht hij "die geschabzte Zahl won 20.000 bis 30.000 AGB bestimmi erheblich zu niedrig angesetz".

12 Rehbinder, pag. 11-12.

13 Vergelïk onder meer: Kötz, Münchener Kommentar, Einl. AGBG Rndnr. 1. 1616; Hefermehl, Handkommentar zum BGB, Vor 1 AGBG Rndnr. 1; Heinrichs, BGB (Palandt), Einf. v. AGBG 1, Nr. 1; Ulmer, AGB-Kommentar, Einl. Rndnr. 3; Wolf, AGBG Kommentar, Einl. Rndnr. 1. 
- in praktisch alle standaardvoorwaarden wordt de rechtspositie van de ondernemer versterkt en worden de rechten van de consument (vaak ontoelaatbaar) beperkt. ${ }^{14}$ De risico's worden door ondernemers vaak afgewenteld op de consument. ${ }^{15}$

- de consument heeft nauwelijks invloed op de contractsinhoud. ${ }^{16}$

- algemene voorwaarden zijn voor de gemiddelde consument onbegrijpelijk. 17

Vanwege het ontbreken van een expliciete wettelijke regeling vór de totstandkoming van het AGB-Gesetz, waren het vooral de rechterlijke instanties die de criteria ontwikkellen om de consument te beschermen tegen al te rigoureus misbruik van algemene voorwaarden door de gebruikers hiervan. De bescherming die het Reichsgericht en naderhand het Bundesgerichtshof (BGH) aan wederpartijen te bieden hadden, richtte zich vooral op drie deelgebieden van de algemene voorwaarden-problematiek ${ }^{18}$ :

1. De wijze waarop algemene voorwaarden contractsinhoud worden. Algemene voorwaarden werden geacht geen deel uit te maken van de contractsinhoud indien de wederpartij niet uitdrukkelijk of stilzwijgend heeft ingestemd met de toepasselijkheid van die algemene voorwaarden op de overeenkomst. ${ }^{19}$ Bedingen waarmee de wederpartij redelijkerwijs geen rekening had behoeven te houden bij het instemmen met de toepasselijkheid van een set algemene voorwaarden werden eveneens geacht geen contractsinhoud te worden ${ }^{20}$ Hetzelfde lot was bedingen beschoren die vanwege hun inhoud te verrassend waren voor de wederpartij. ${ }^{21}$

2. De uitleg van algemene voorwaarden. Volgens vaste rechtspraak dienden exoneratie- en vrijwaringsclausules in twijfelgevallen dusdanig uitgelegd te worden dat hun (voor de wederpartij nadelige) werking zo beperkt mogelijk bleef. ${ }^{22}$ Op niet-eenduidige algemene voorwaarden werd de contra proferen-

14 Heinrichs, BGB (Palandt), Einf. v. AGBG 1, Nr. 1; Wolf, AGBG Kommentar, Einll, Rndnr. 3.

15 Kötz, Mänchener Kommentar, Einl. AGBO Rndnr. 2; Hensen, JA 1981, pag " 133; Ulmer, AGB-Gesetz, Einl. Rndnu.. 4.

16 Hefermeh1, Haudkommentar zum BGB, Vor 1 AGBG Radnr. 2; Wolf, AGBG Kommentar, Einl. Rndinr, 3.

17 Hefermehl, Handkommentar zum BGB, Vor 1 AGBG Rndnr. 2; Wolf, AGBG Kommentar, Einl. Rndinr. 3.

18 Koch en Stübing, pag. 42 - 55; Kötz, Münchener Kommentar, Einl. AGBG Rndrur. 5-6; Hefermehl, Handkommentar zum BGB, Vor \& 1 AGBG Rndnr. 3i-5; Ulmer, AGBi-Gesetz, Einl. Rndar. 8.

19 BGHZ 3, 200, 203, NJW 1951, pag. 957; BGHZ 9, 1, 3, NJW 1953, pag.541; BGHZ 33. 216,219 , NJW 1961, pag. 212; BGHZ 38, 183, 185, NJW 1963, pag. 99.

20 BGHZ 17, 1, 3, NJW 1955, pag. 1145; BGHZ 33, 216, 219, NJW 1961, pag. 212.

$21 \mathrm{BGH}$, NJW 1973, pag. 1194.

22 BGHZ 54, 299, NJW 1970, pag. 2208; BGH, BB 1974, pag. 1368. Zie ook. Wolf, AGBG Kommentar, Einl. Rndinr. 5 . 
tem-regel toegepast. Onduidelijke algemene voorwaarden moesten in het voordeel van de wederpartij van de gebruiker van die voorwaarden worden uitgelegd. ${ }^{23}$ Verder werden algemene voorwaarden die niet in overeenstemming waren met uitdrukkelijk tussen partijen gemaakte afspraken of met stilzwijgende afspraken die voortvloeiden uit de omstandigheden van het specifieke geval, als vervallen beschouwd. ${ }^{24}$

3 De inhoudscontrole van algemene voorwaarden. Aanvankelijk baseerde het Reichsgericht en naderhand ook het BGH de inhoudscontrole voornamelijk op $\S 138$ BGB (goede zeden en misbruik van omstandigheden). ${ }^{25}$ Sinds zijn arrest van 29 oktober $1956^{26}$ is het BGH echter in toenemende mate de goede trouw (Treu und Glauben, $\$ 242$ BGB) als toetsingsmaatstaf gaan hanteren. ${ }^{27}$ Soms werd ook een oplossing gezocht in $\$ 315$ BGB (vaststelling van de inhoud van de verbintenis door én van de partijen "nach billigem Ermessen "). ${ }^{28}$ De goede trouw brengt met zich dat de gebruiker van algemene voorwaarden, mede gezien het feit dat hij deze in de regel eenzijdig vaststelt, bij het opstellen van deze voorwaarden rekening dient te houden met de gerechtvaardigde belangen van de wederpartij. In dat licht zijn die bedingen ontoelaatbaar, en dus in strijd met $\S 242$ BGB, die gezien de belangen van beide partijen onbillijk zijn. Dit was zeker het geval indien door algemene voorwaarden (aanvullende) wettelijke regelingen opzij werden gezet die niet alleen tot stand zijn gekomen op grond van doelmatigheidsoverwegingen maar tevens op grond van rechtvaardigheidsoverwegingen..$^{29}$

Ondanks het feit dat deze criteria in de rechtspraak en literatuur algemeen erkenning vonden, werd de roep naar een specifieke wettelijke regeling op het terrein van de algemene voorwaarden in het begin van de jaren zeventig steeds luider. Het idee was niet nieuw en voert in feite terug tot het, in 1935 verschenen, onderzoek van Ludwig Raiser over "Das Recht der Allgemeinen Geschäftsbedingungen". ${ }^{30}$ Onder invloed van een opkomend consumentisme, een groeiende tendens naar betere consumentenbescherming en een politiek klimaat dat

BGHZ 5, 111, 115 .

24 BGHZ 50, 200, 206f. NJW 1968, pag. 1622; BGH, LM 355 HGB Nr. 3.

25 Wolf, AGBG Kormmentar, Einl. Rndinr. 6; Ulmer, AGB-Gesetz, Einl. Rndnr. 8.

26. BGHZ 22, 90, 97ff (1956).

27 Koeh en Stübing, pag. 48-51; Kötz, Münchener Kommentar, Einl. AGBG Rndnr. 6; Hefermehl, Handkommentar zum BGB, Vor 1 AGBG Rndnr. 4; Wolf, AGBG Kommentar, Einl. Rndnr. 6; Ulmer, AGB-Gesetz, Einl. Rndir. 8.

$28 \mathrm{BGHZ} 41,151,154$.

29 Hefermehl, Handkommentar zum BGB, Vor 1 AGBG Rndnr. 4.

30 Raiser L., Das Recht der Allgemeinen Geschäftsbedingungen, 1935. 
daar gevoelig voor was, werd in de jaren zeventig aan deze roep naar een wettelijke regeling gehoor gegeven. ${ }^{31}$

Voorstanders van een wettelijke regeling hanteerden vooral de volgende argumenten:

- De ütspraken van de hoogste rechterlijke instantie (BGH) werken onvoldoende door in de lagere rechtspraak. De rechterlijke controle heeft immers alleen betrekking op individuele gevallen en daardoor ontbreekt de breedtewerking.

- De criteria die in de rechtspraak zijn ontwikkeld met betrekking tot de wijze waarop algemene voorwaarden contractsinhoud worden, zijn onduidelijk en dienen aangescherpt te worden. Met name het feit dat het BGH een stilzwijgende acceptatie (stillschweigende Unterwerfung) voldoende achtte voor de toepasselijkheid van algemene voorwaarden, stuitte op hevige kritiek.

- De gerechtelijke inhoudscontrole is grotendeels beperkt tot overeenkomsten tussen professionele contractanten. De individuele consument heeft immers slechts zeer zelden voldoende juridische kennis en doorzettingsvermogen om de zijns inziens onredelijke bedingen met succes te bestrijden. Daarbij komt nog het feit dat consumenten, vanwege het geringe belang en het hoge procesrisico, doorgaans weinig animo hebben gerechtelijke procedures te voeren. ${ }^{32}$

De geschiedenis van het AGB-Gesetz begint op 18 oktober 1971 met een nota van de Duitse regering inzake het consumentenbeleid. In deze nota werd uitdrukkelijk gewezen op de noodzaak van bescherming van de consument tegen onredelijk bezwarende algemene voorwaarden en werd een ambtelijk onderzoek naar een oplossing van de problematiek aangekondigd. ${ }^{33}$

Nadat de Bundesrat begin 1972 zijn visie over de nota had gegeven ${ }^{34}$, werd in december 1972 door de toenmalige Minister van Justitie (Bundesjustizminister) een werkgroep (Arbeitsgruppe) in het leven geroepen, bestaande uit vertegenwoordigers van de juridische wetenschap, de rechterlijke macht, ondernemersorganisaties, consumentenorganisaties en regering, die ten doel had de mogelijkheden van wetgeving te onderzoeken. Deze werkgroep begon haar werkzaamheden in februari 1973 en bracht in maart 1974 een eerste deelrapport (Erster Teilbericht) uit met voorstellen voor een materieelrechtelijke regeling ter

31 Hefermehl, Handkonmentar zum BGB, Vor 1 AGBG Rndnr. 6; Dietlein en Rebmann, pag. 26.

32 Koch en Stübing, pag. 55; Heinrichs, BGB (Palandt), Einf. v. AGBG I Nr. 1; Kötz, Münchener Kommentar, Einl. AGBG Rndnr. $7_{;}$Bunte, Handbuch, pag. 25; Woll, AGBG Kommentar, Einl. Rndnr. 7.

33 BT Drucksache VI/2724, pag. 8.

34 BR Drucksache 568/71. 
bescherming van consumenten tegen algemene voorwaarden. ${ }^{35}$ Dit rapport werd overgenomen in een voorontwerp (Referentenentwurf) dat diende als basis voor overleg met organisaties van consumenten en ondernemers. ${ }^{36}$ In gewijzigde vorm werd dit voorontwerp als regeringsontwerp (Regierungsentwurf) gepresenteerd aan de Bundesrat. ${ }^{37}$ In maart 1975 bracht de werkgroep een tweede deelrapport uit met uitsluitend procesrechtelijke voorstellen. ${ }^{38}$ Daarin werd een procesrechtelijke regeling voorgesteld die gebaseerd was op drie peilers: een abstracte rechterlijke inhoudstoets met een brede werking, het oprichten van een overheidsorgaan voor consumentenbescherming (Bundesbehörde für Verbraucherschutz) en een procedure woor het opstellen van modelvoorwaarden (Muster-AGB). ${ }^{9}$ Ondertussen, op 31 januari 1975, had ook de CDU/CSU-fractie een eligen wetsontwerp ingediend, dat niet alleen voorzag in een materieelrechtelijke regeling maar ook in een regeling die het gebruik van algemene voorwaarden slechts mogelijk maakte indien dezen vooraf waren goedgekeurd door een op te richten Bundesanstalt fur Verbraucherschutz. ${ }^{40}$

In zijn commentaar op het regeringsontwerp maakte de Bundesrat zich, in navolging van de aanbevelingen genomen op de 50 . Deutschen Juristentag ${ }^{4}$, sterk voor het opnemen van een procesrechtelijke voorziening in de voorgestelde wettelijke regeling, omdat gevreesd werd dat zonder een specialle procesrechtelijke regeling de effectiviteit van het materieelrechtelijk deel te gering zou zijn. $^{42}$ De Bundesrat stelde een eigen procesrechtelijke regeling voor die voorzag in enerzijds een collectieve verbodsactie voor consumenten- en ondernemersorganisaties en anderzijds een bevoegdheid voor deze organisaties om op basis van procesvolmacht op te treden namens haar leden. ${ }^{43}$

Het regeringsontwerp - dat enkel materieelrechtelijke voorschriften bevatte werd, vergezell van het commentaar en de voorstellen van de Bundesrat, op 6 augustus 1975 als wetsontwerp voorgelegd aan het Duitse parlement (Bundestag). 4

35 BJM Arbitsgruppe, Erster Teilbericht, Vorschläge zur Verbesserung des Schutzes der Verbraucher gegenüber AGB, Reform I, 1974.

36 DB 1974, Beilage 18.

37 BT Drucksache 7/3919.

38 BMJ Arbeitsgruppe, Zweiter Teilbericht, Vorschläge zur Verbesserung des Schutzes der Verbraucher gegenüber AGB, Reform II, 1975.

39 Hensen, AGB-Gesetz, Vor 13 Rndnr. 10.

40 BT Drucksache 7/3200. De procesrechtelijke regeling was in dit ontwerp voorzien in de $\$ 26$ e.v.

41 Deutseher Juristentag, Beschlüsse 11 en 13.

42 BRat Drucksache 360/75; BT Drucksache 7/3919, pag. 47 e.v.

43 Stellungnahane des Bundesrates, \$\& 14 en 15, BT Drucksache 7/3919, pag; 52.

44 Gesetzentwurf der Bundesregienung, Entwurf eines Gesetzes zur Regelung des Rechts der Allgemeinen Geschäftsbedingungen, BT Drucksache 7/3919. 
De Bundestag vroeg daarop advies aan de Rechtsausschuß en de Ausschuß fur Wirtschaft (commissies te vergelijken met onze kamercommissies) omtrent de voorgestelde regelingen. De RechtsausschuB adviseerde de Bundestag om het regeringsontwerp, aangevuld met een door de RechtsausschuB zelf, in spoedprocedure opgestelde, procesrechtelijke regeling over te nemen. $\mathrm{De}$ door de Rechtsausschuß geconcipieerde procesrechtelijke regeling voorzag in een preventieve abstracte inhoudstoets van algemene voorwaarden op vordering van consumenten- of ondernemersorganisaties, zoals deze in de uiteindelijke wet is neergelegd.

Het advies van de Rechtsausschuß werd door de Bundestag, op 24 juni 1976 , in tweede en derde lezing, met instemming van alle fracties overgenomen. ${ }^{46}$ Nadat daarin nog enige kleine wijzigingen waren aangebrach ${ }^{47}$, werd het wetsontwerp door de Bundestag goedgekeurd op 10 november 1976 en door de Bundesrat op 12 november 1976. De wet werd op 9 december 1976 in het Bundesgesetzblatt gepubliceerd ${ }^{48}$ en trad op 1 april 1977 in werking ( $\$ 30$ AGBG). ${ }^{49}$

Tot op heden is het AGB-Gesetz een aantal keren gewijzigd. De bepaling in $\S 16 \mathrm{Nr}$. 1 AGBG werd in 1983 dusdanig angepast dat zij zich niet meer richtte op het "Bundesaufsichtsamt für das Versicherungswesen" en het "Gesetz über die Beaufsichtigung der privaten Versicherungsunternehmungen" maar op de "zuständige Aufsichtsbehörde" en het "Versicherungsaufsichtsgesetz" . ${ }^{\text {so }}$ § $10 \mathrm{Nr}$. 8 AGBG werd per 1 september 1986, de datum waarop het "Gesetz zur Neuregelung des IPR ${ }^{\prime \prime}$ in werking trad, opgeheven. ${ }^{51}$

45 BT Drucksmehe $7 / 5412,7 / 5422$.

46. BRat Drucksache 443/76.

47 BRat Drucksache 443/1/76; BT Drucksache 7/5636; BT Drucksache 7/5617. Voor het procesrechtelijk deel betroffen deze wijzigingen het aanwijzen van het Landgericht (LG) als competente instantie in eerste arnleg in plaats van het Oberlandesgericht (OL) in 14 Abs. 1 AGBG en het toevoegen van een nieuw viende lid aan \$13 AGBG waarin cen verjaringsregeling wast voorzien.

48 BGBl 1, 3317.

49 Uitgezonderd \$ 14 Abs. 2, 27 en 27 AGBG. Deze traden in werking op 10 december 1976 (8. 30 AGBG).

50 Gesetz vom 29.3.1983, BGBI. I, pag. 377. Müt de inwerkingtreding en implementatie van de derde verzekeringarichtlijn van de EG op uiterlijk 1 julli 1994 zal $\$ 16 \mathrm{Nr}$. 1 AGBG waansehijnlijk zijn betekenis verliezen. Vanaf juli 1994 mogen verzekeringsbedingen namelijk niet meer onderworpen zijn aan voorafgaande goedkeuring door een overhieidsorgaan van de lidstaat van het land warar zij worden gebruikt. Derde richtijin schadeverzekering (RU. 92/49, PbEG 1992, nr. L 228/1) en derde richtlijn directe levensverzekeringen (RI. 92/96, PbEG 1992, nr. L $360 / 1)$.

51 Gesetz vom 25.7.1986, BGBI. I pag. 1142. 
Met de inwerkingtreding van het Einigungswertrag ${ }^{52}$ op 3 oktober 1990 is het AGB-Gesetz eveneens in werking getreden in de deelstaten die tot de voormalige DDR behoorden.

Het ziet er momenteel naar uit (eind 1994, LJHM) dat het AGB-Gesetz binnenkort voor een derde keer wordt gewijzigd om te voldoen aan de EEGrichtlijn betreffende oneerlijke bedingen. Momenteel ligt er enerzijds een voorstel om $\& 12$ AGBG aan te passen aan het EEG-verbintenissenverdrag ${ }^{53}$ en anderzijds een voorstel om door middel van toevoeging van een nieuwe 23 AGBG (de huidige \& 23 AGBG wordt \& 23a AGBG) en een wijziging van \$24 $A G B G$ te voldoen aan de eis van de richtlijn dat de bescherming die deze richtlijn biedt eveneens van toepassing dient te zijn op bedingen die slechts voor eenmalig gebruik zijn bestemd als de wederpartij geen invloed heeft gehad op de inhoud van deze bedingen ${ }^{54}$. Op het collectieve actierecht hebben deze wijzigingen echter geen betrekking. ${ }^{53}$

52 Vertrag zwischen der Bundesrepublik Deutschland und der Deutschen Demokratischen Republik über die Herstellung der Einheit Deutschlands wom 31. August 1990, BT Drucksache 11/7817.

53 Artikel 1: 1 Referentenentwurf 2411-1a:

12 wird wie folgt gefagt:

* 12 Intemationaler Geliungsbereich

Unterliegt ein Verrag auslindischem Recht, so sind die Varschinftien dieses Gesetzes gleichwohl anzuwenden, wenn

1. der Vertrag auf Grund eines offentlichen Angebots, einer Offentichen Werbung ader einer Whilichen geschafflichen Tatigkeit zustande kommt, die der Verwender in einem Mitgliedstaat der Europdischen Union ader in einem anderen Vertragsstaat des Abkommens uber den Europisischen Wirsichafisraum entfaltet hat, und

2. der andere Vertragsteil bei Abgabe seiner auf den Vertragsschlü gerichteten Erklamung seinen Wohnsitz oder seinen gewohnlichen Aufenthait in einem Mitgliedstaat der Europalischen Union oder in einem anderen Vertragsstaat des Abkommens aber den Europaischen Wirischafisraum."

Zie hilenover: Eokert, pag. 1989.

54 Artilsel 1.2 Refementenentwurf $2411-1 \sim \mathrm{a}:$

23 wird wie folgt gefaßt:

" 23 Erweitering des sachlichew Anwendungsbereichs

Die 5,6 und 8 bis 12 sind auf vorformulievte Vertragsbedingungen awch dann anzunemdet. werw diese nur zur einmaligen Verwendung bestimmt sind und soweit die andere Vertragspartei, der die Vertragsbedingungen gestellt werden, aufgrund der Vorformulierung auf ihnen Inhalt Keinten Einflup mehmen konnte."

Tegellijkertijd is: voorzien in een nieuwe titel woor $823 a$ n.l. "Einschränkang des sachlichen Anwendungsbereich" en een wijziging van 24 AGBG als volgt:

"Die Vorschirfien der \$8 2,10,11, 12 und 23 finden keine Anwendung auf Gerchaffisbedingumgen,

1. dite gegenaber einem Kaufmann verwendel werden; wenn der Vertrag zam Betriebe seimes Handalsgewerbes gehon;

2. die gegenuber einer juristischen Person des offentichen Rechts oder einem offent-rechuli.. chen Sondenuermögen verwinudet werden."

Zie hienver: Eckent, pag, 1986-1988.

55 Eckert, pqg. 1987. 


\subsubsection{De doelstelling en verwachtingen van de wet}

Omtrent de invulling van het procesrechtelijk gedeelte is veel discussie gevoerd. De voorstellen voor de invulling van dit gedeelte varieerden van een algemene verplichting om voor het gebruik van algemene voorwaarden vooraf toestemming te vragen aan een federaal orgaan voor consumentenbescherming ${ }^{56}$, een registratieplicht ${ }^{57}$, registers en modelvoorwaarden ${ }^{58}$ tot een algemeen klachtrecht voor consumenten-, ondernemers- en branche-organisaties. Het Duitse parlement koos uiteindelijk voor een abstracte inhoudscontrole door middel van een klachtrecht voor consurmenten-, ondernemers- en branche-organisaties. ${ }^{59}$

Volgens de toelichting op het wetsontwerp is het doel van het AGB-Gesetz de - als gevolg van een ongeremde contractsvrijheid, de machtspositie van gebruikers en het ongebreideld gebruik van algemene voorwaarden - scheefgegroeide verhouding tussen gebruikers van algemene voorwaarden en consumenten door middel van consumentenbeschermende regels weer in evenwicht te brengen.

"Das vorrangige rechuspolitische Ziel dieses Gesetzentwurfs liegt darin, bei der Venwendung won AGB im rechtsgeschafflichen Wirtschafisverkehr dem Prinzip des angemessenen Ausgleichs der beiderseitigen Iruteressen Geltwng zu verschaffen, das nach den Grwndworstellungen des Bürgerlichen Geselzbuches die Vertragsfreiheit legitimien; denn deren Funltion besteht darin, durch freies Aushandeln won Ventragen znvischen freien und zur rechisgeschaftlichen Selbstbestimnung fahigen Partmem Vertragsgerechigkeit zu schaffen. Der Gesetzentwurf beabsichtigt demzufolge nichts anderes als die durch eine ungehemume Entwickling im Bereich der AGB gestärte Funktion des prituaten Vermagsrechts widerherzustelien.

Die auf dieses rechtspolinische Ziel ausgerichteten Regelungsworschlage des Gesetzentwurfs gehen won der Vberlegung aus, daß derjenige Vertragsteil, der seine eigenen $A G B$ in dow einzelne Rechrsgeschaft einbringt, gegenibber dem anderen Vertragsteil stets einen organisatorischen Worsprung hat insofen, als das eingebrachte Klauselwerk das in sich abgeschlossene Ergebnis einer sorgfarigen Analyse der wirtschaftichen Gesichuftsrimiken ist, deren mögliche rechuliche Konsequenzen dwrch die in den AGB getroffenew Bestimunungen bereils am voraus juristisch bewaligt whd soweit nachteilig - in aller Regel von dem Verwender abgewender werden. Schon alkein dieser organisatarischer Vorsprung der vorgefertigten Vertragsgestallumg, deren rechulthe Tragweit der

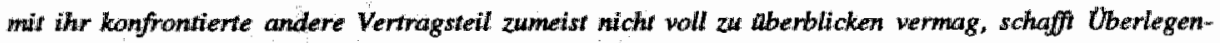
heit; nicht selven wird sie aber noch dadurch werstlinkt, dab der Vertragspartner, der sich den AGB whiternerfen soll, wirtschafilich schwdicher oder intellekwel witerlegen ist.

56. ASI-Sindbayem, ZRP 1972, pag. 148.

57 ASI Hessen, ZRP 1970, pag. 190.

58. Zweiter Teilbericht, Reform II/1975, pag. 62.

59 Kötz, Münchener Kommentar, Einl. AGBG Rndnr. 9; Hefermehl, Handkommentar zum BGB, Vor \& AGBG Rndmr. 6; Heinrichs, BGB (Palandt), Eimf. v. AGBG I Nr. 2; Dietlein en Rebmann, pag. 26-27. 
Aufgabe eines Gesetzes zur Regeling des Rechts der AGB mup es daher sein, dit der Vertragsgestaltung vorgegebene aberlegenheit des AGB-Venwenders durch Schuzzworschriften zugunsten des AGBUnterworfenen sachgerecht und vemulanfig auszugleichen, ohne die Privatautonomie mehr als zu Erreichung dieses Zieles enforderlich einzwengen. "60

Voor het materieelrechtelijk deel van het AGB-Gesetz was het uitgangspunt dan ook het in het Bürgerliches Gesetzbuch (BGB) neergelegde principe van contractsvrijheid. Contractsvrijheid wordt namelijk gelegitimeerd door de onderliggende gedachte dat contractspartijen die in vrijheid en op basis van gelijkheid handelen, zelf het beste kunnen opkomen voor hun eigen belangen en door onderhandelen aldus komen tot een evenwichtige overeenkomst die recht doet aan hun wederzijdse belangen. Deze privaatrechtelijke functie van de contractsvrijheid werd echter door ongebreidelde ontwikkelingen op het gebied van algemene voorwaarden danig verstoord. Doel van het materieelrechtelijk gedeelte van het AGB-Gesetz is deze verstoorde functie te herstellen zonder daarbij de contractsvrijheid al te zeer te beperken.

Om dit doel te bereiken omvatte het materieelrechtelijke gedeelte enerzijds regels met betrekking tot de toepasselijkheid van algemene voorwaarden en de wijze waarop zij contractsbestanddeel worden en anderzijds normen waaraan de inhoud van algemene voorwaarden getoetst dient te worden.

Het zwaartepunt van het AGB-Gesetz ligt ongetwijfeld bij de open norm (Generalklausel) van $\& 9$ AGBG die als maatstaf gehanteerd dient te worden voor de inhoudelijke toetsing van algemene voorwaarden. De open norm wordt aangevuld door de lijsten van $\S 10$ en $\S 11$ AGBG die bedingen bevatten die als ontoelaatbaar worden beschouwd. Met deze lijsten wordt enerzijds beoogd rechtszekerheid te scheppen en anderzijds de markt te zuiveren van die (onredelijk bezwarende) bedingen die, zoals de praktijk heeft uitgewezen, het meest inbreuk maken op de grondbeginselen van het overeenkomstenrecht. ${ }^{61}$ Met deze lijsten zouden grove uitwassen op het gebied van standaardvoorwaarden reeds in de préprocessuele fase bestreden kunnen worden en gerechtelijke procedures vermeden kunnen worden.

"Deshalb wind die Generalklausel durch die beiden Kataloge unzulassiger Einzelklauseln erganzt, in denen die erfahrungsgemafs fitr unangemessene AGB typischen Eimbruchstellen des bügerlichen Vertragsrecths abgedichtet werden sollen. Sie sollen durch klare und konkrete Verbote Rechtssicherheit fiur die AGB-Praxis schaffen, grobe Auswilchse schon im Vorfeld gerichticher Verfahrent bekampfen und Prozessen worbeugen; sie sollen seriotse Gewerbetreibenden dazu veramkassen, die weitere Verwendung anstbjiger Klausein als riskant und sinmlos aufzugeben; dem Kunden sollen sie schlieflich Rechtsklarheit geben, wenn er vor Gericht zieht oder gezogen wird. ${ }^{62}$

60 Begründung, BT Drucksache 7/3919, pag. 13.

61 Begründung, BT Drucksache 7/3919, pag. 14.

62 Begründung, BT Drucksache 7/3919, pag. 14. 
De Duitse wetgever ging er van uit dat zichzelf respecterende organisaties en ondernemingen hun algemene voorwaarden zouden aanpassen aan de wettelijke vereisten en dat malafide ondernemers gedwongen zouden zijn het verdere gebruik van evident onredelijk bezwarende algemene voorwaarden te staken, omdat deze voor hen zinloos of zelfs (financieel) te riskant zouden zijn. De materieelrechtelijke voorschriften beoogden op zichzelf dus al effectief te zijn en een aanzienlijke bijdrage te leveren aan het "zuiveren" van algemene voorwaarden in het rechtsverkeer. ${ }^{63}$

Voor wat het procesrechtelijk gedeelte van het AGB-Gesetz betreft, was men unaniem van mening dat de invoering van specifieke procesrechtelijke voorschriften noodzakelijk was om een efficiëntere werking te geven aan het materieelrechtelijk gedeelte van de wet. $^{.4}$ Noodzakelijk omdat enerzijds de individuele consument vanwege het ontbreken van rechtskennis en een hoge procesdrempel nauwelijks in staat is zijn belangen in en buiten rechte te behartigen en anderzijds een vonnis in een individuele procedure nawwelijks precedenten breedtewerking heeft. ${ }^{6 s}$ De verbodsactie (Unterlassungsanspruch) tegen het gebruik van ongeldige algemene voorwaarden, uit te voeren door consumenten-, producenten- en branche-organisaties, werd daarbij als geëigend middel gezien om het materieelrechtelijk gedeelte van de wet de beoogde preventieve breedtewerking te verschaffen. ${ }^{6}$

De wetgever was zich bewust van het feit dat de nieuwe wet in een aanzienlijk aantal gevallen ondernemers zou noodzaken tot een toetsing van tot dan toe gehanteerde algemene voorwaarden aan de nieuwe voorschriften en deze eventueel aan te passen aan deze voorschriften. De gebruikers van algemene voorwaarden werd daartoe een in de opvatting van de Duitse wetgever redelijke termijn van bijna 4 maanden geboden; de wet werd weliswaar op 9 december 1976 gepubliceerd maar trad pas in werking op 1 april 1977. De Duitse wetgever verwachtte van de bedrijven en ondernemingen dat zij in de tussenliggende periode hun algemene voorwaarden aan de nieuwe wet zouden aanpassen. $^{67}$ Daartegen steekt de in Nederland gehanteerde "aanpassings"-termijn schril af. In Nederland werd de tekst van afdeling 6.5.3 NBW op 14 juli 1987 gepubliceerd, trad de wet in werking op 1 januari 1992 en werd ondernemers voor wat betreft door hen reeds vó́r 1 januari 1992 gehanteerde algemene voorwaarden, een overgangstermijn van één jaar gegund, waarin deze niet aan

63 Begrindung, BT Drucksache 7/3919, pag. 15.

64 Begründung, BT Drucksache 7/3919, pag. 15.

65 Lindacher, AGBG Kommentar, Vor \& 13 Rndnr. 3-4.

66 BT Drucksache 7/3919, pag. 54.

67 Bunte, AcP 1982, pag. 32-33. 
afdeling 6.5.3 BW aangepaste voorwaarden nog konden worden gebruikt, zelfs indien in deze voorwaarden ná 1 januari 1992 nog wijzigingen werden aangebracht.

\subsubsection{Plaats en indeling van de wet}

Het AGB-Gesetz is niet geĩntegreerd in het Bürgerliches Gesetzbuch (BGB) maar als aparte wet opgenomen in het Duitse vermogensrecht.

Inhoudelijk liggen de zwaartepunten van de wet bij de regels omtrent de toepasselijkheid van algemene voorwaarden ( $8 \& 2$ en 3), de materieelrechtelijke regels met betrekking tot de inhoudscontrole (\$\$ 9-11) en de abstracte inhoudstoets van $\$ 13$ e.v. AGBG.

Het AGB-Gesetz (AGBG) is opgebouwd uit 5 afdelingen (Abschnitte). In de eerste afdeling ( $\$ 1$ tot en met 11 AGBG) vinden we de materieelrechtelijke voorschriften die weer zijn onder te verdelen in twee onderafdelingen; de eerste onderafdeling ( $\$ \S 1$ tot en met 7 AGBG) met algemene regels en de tweede onderafdeling ( $\$ \$ 8$ tot en met 11 AGBG) die de criteria bevat voor ongeldigheid c.q. nietigheid (Unwirksamkeit) van algemene voorwaarden.

De tweede afdeling van het AGB-Gesetz bestaat uit eén paragraaf ( $\$ 12$ AGBG) waarin de internationale werkingssfeer van de wet wordt geregeld.

De derde afdeling van het AGB-Gesetz bevat in de paragrafen 13 tot en met 22 AGBG de procesrechtelijke voorschriften van de wet. Kort belicht - in de volgende paragrafen wordt uitgebreider op deze materie ingegaan - bevat deze afdeling de volgende voorschriften. Op grond van \$13 AGBG kunnen consumenten-, branche-, bedrijfs- en beroepsorganisaties een verbodsactie (Anspruch auf Unterlassung) instellen tegen de gebruiker van onredelijk bezwarende algemene voorwaarden of degene die het gebruik van onredelijk bezwarende algemene voorwaarden stimuleert, adviseert of propageert (aanbeveler). $\S 13$ AGBG geeft bovengenoemde organisaties tevens een gebodsactie om de aanbeveling tot het gebruik van onredelijk bezwarende algemene voorwaarden te herroepen (Anspruch auf Widerruf) tegen degene die het gebruik van bepaalde algemene voorwaarden stimuleert, adviseert of propageert.

In de paragrafen 14 tot en met 21 AGBG worden de rechterlijke competentie, de procedure, de inhoud van het vonnis, publikatie, registratie en de juridische werking van het vonnis geregeld. § 22 AGBG fixeert de Streitwert ${ }^{\text {s }}$ (in Duitsland de factor die ondermeer bepalend is voor de hoogte van de procesen advocaatkosten) op maximaal 500.000 DM. 
De vierde afdeling ( $\$ 23$ en 24 AGBG) beschrijft (als aanvulling op $\S 1$ ) het zakelijke- en persoonlijke toepassingsgebied van deze wet. Zo zijin bij voorbeeld de paragrafen $2,10,11$ en een gedeelte van 12 AGBG alleen van toepassing op overeenkomsten met consumenten ( $\$ 24$ AGBG).

De vijfde afdeling ( $\$ 25$ tot en met $30 \mathrm{AGBG}$ ) bevat wijzigingen van andere wetten ( $\$$ 25-26 AGBG), de bevoegdheid van de Minister voor economische zaken (Bundesminister für Wirtschaft) een "soort" standaardregeling vast te stellen voor nutsbedrijven ( $\$ 27$ AGBG), overgangsrecht ( $\$ 28$ AGBG), de (inmiddels achterhaalde) "Berlin Klausel" die de wet ook in werking doet treden in de deelstaat (West) Berlijn ( $\$ 29$ AGBG) en de datum van inwerkingtreding (\$30 AGBG).

\subsection{Materieelrechtelijke bepalingen}

De algemene materieelrechtelijke bepalingen van het AGB-Gesetz zijn neergelegd in de paragrafen 1 tot en met 12 van het AGB-Gesetz. Het materieelrechtelijke bereik van de wet wordt echter geregeld in een aparte afdeling in de paragrafen 34 en 24 . Te beginnen met het bereik van het AGB-Gesetz komen in de volgende subparagrafen algemene bepalingen met betrekking tot de definitie van algemene voorwaarden, de toepasselijkheid van algemene voorwaarden, uitleg van onduidelijke bedingen en de normen voor de inhoudscontrole aan de orde.

\subsubsection{Bereik van de wet}

Net als de Wet algemene voorwaarden wordt het AGB-Gesetz op tweërlei wijze beperkt. Enerzijds beperkingen ten aanzien van het materiële bereik en anderzijds beperkingen ten aanzien van het personele bereik. Het materiële bereik wordt aan de ene kant begrensd door de definitie van het begrip algemene voorwaarden in $\$ 1 \mathrm{AGBG}$ en an de andere kant door de bepalingen van $\$ 8$ en $\$ 23 \mathrm{AGBG}^{6}$. Het personele bereik wordt beperkt in $\$ 24 \mathrm{AGBG}$.

\subsubsection{Het materiële bereik}

In $\S 1$ AGBG wordt een definitie gegeven van het begrip "algemene voorwaarden" en deze paragraaf is daarom de centrale norm, die (naast $\$ 8$ en 23 AGBG) het materiële toepassingsgebied van het AGB-Gesetz begrenst.

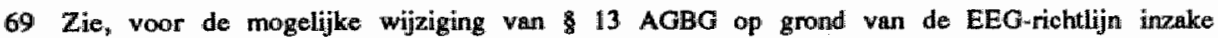
oneerlijke bedingen in consumentenovereenkomsten, hiervoor paragraaf 6.1.1. 


\section{\$ 1 Begriffshestimmung}

(1) Allgemeine Geschafisbedingungen sind alle fïr eine Vielzahl von Verträgen vorformulienten Virtragsbedingungen, die eine Vertragspartei (Verwender) der anderen Vertragspartei bei Abschlugh: eines Vertrages stellt. Gleichgultig ist, ab die Bestimmwngen einen dupberlich gesanderten Bestandteil des Vertrages bilden oder in die Vertragsurkunde selbst aufgenommen werden, welchen Umfang sie haben, in welcher Schrifian sie verfabit sind wnd welche Form der Vertrag hat.

(2) Allgemeine Geschafisbedingungen liegen nicht vor, soweit die Vertragsbedingungen zwischem dem Vertragsparteien in einzelinen ausgehandelt sind.

Materieel gezien is het toepassingsbereik van het AGB-Gesetz beperkt tot algemene voorwaarden in obligatoire overeenkomsten en andere tweezijdige rechtshandelingen. ${ }^{\infty}$ De aard en de inhoud van de overeenkomst waarin de bedingen zijn opgenomen, zijn voor de vraag of sprake is van algemene voorwalarden irrelevant. Vereist is slechts dat het gat om bedingen in overeenkomsten. Van algemene voorwaarden in de zin van $\$ 1$ AGBG kan derhalve sprake zijn in praktisch alle verbintenisrechtelijke, goederenrechtelijke en procesrechtelijke obligatoire overeenkomsten. ${ }^{71}$ Het AGB-Gesetz is op grond van 23 Abs. 1 AGBG echter niet van toepassing op overeenkomsten op het terrein van het arbeids-, erf-, familie- en rechtspersonenrecht. ${ }^{72}$ Ofschoon de personenassociaties niet gerekend worden tot het rechtspersonenrecht (Gesellschaftsrecht) is de algemene opvatting dat het AGB-Gesetz eveneens niet van toepassing is op statuten van verenigingen, coöperaties en coöperatieve verenigingen. ${ }^{7}$

Op de eerste plaats zijn algemene voorwaarden dus eén of meer contractsbedingen (Vertragsbedingungen). ${ }^{74}$ Het AGB-Gesetz ziet daarom in eerste instantie op allgemene voorwaarden bij tweezijdige rechtshandelingen. Strikt genomen vallen voorwaarden in eenzijdige rechtshandelingen zoals, onder andere, de volmacht ( $\$ 167 \mathrm{BGB}$ ) en het aanbod ( $\$ 145 \mathrm{BGB}$ ), dus niet onder de definitie van $\$ 1$ Abs. 1 AGBG. Indien deze voorwaarden echter dienen om de contractuele verhouding inhoudelijk vorm te geven en zij tevens eenzijdig worden vastgesteld, is het AGB-Gesetz onverkort van toepassing. Een analoge toepassing van $\$ 1$ Abs. 1 AGBG maakt dat deze voorwaarden worden be-

70 Wolf, AGBG Kommentar, 1 Rndnr. 6; Ulmer, AGB-Gesetz, \& 1 Rndnr. 9.

71 Stein, BGB, pag. 10-11; Ulmer, AGB Gesetz, \&1 Rndnr. 15; Wolf, AGBG Kommentar, 1 Rndnr. 8.

72 Zie uitvoerig: Hom, AGBG Kommentar, 23 Rndnr. 30-91; Ulmer, AGB-Gesetz, \& 23 Rndnr. 2-30.

73 Wolf, AGBG Kommentar, \& 1 Rndnr. 9 en $\$ 23$ Rndnr. 77; Ulmer, AGB-Gesetz, \$23 Rndinr. 22.

74 Wolf, AGBG Kommentar, \$1 Rndnr. 6. 
schouwd als algemene voorwaarden waarop het AGB-Gesetz van toepassing is. ${ }^{\text {.s }}$

Het feit dat het begrip algemene voorwaarden ziet op bedingen van contractuele aard, maakt dat tussen partijen geldende regels met een rechtsnormkarakter, dat will zeggen regels die niet op grond van de partijwil maar op grond van de wet, verordening, statuut, handelsgebruik of de aanvullende werking van $\$ 242$ (Treu und Glauben) deel uitmaken van de rechtsbetrekking tussen partijen, niet vallen onder het begrip algemene voorwaarden als bedoeld in $\S 1$ Abs. 1 AGBG. ${ }^{76}$ Zo vallen onder andere niet onder het bereik van de definitie van $\& 1$ AGBG de voorwaarden gehanteerd door overheidsinstanties en openbare inrichtingen indien deze van rechtswege gelden. Hierbij moet vooral ook gedacht worden aan de wettelijk vastgelegde algemene voorwaarden van nutsbedrijven en het openbaar vervoer. ${ }^{n}$

Indien echter de wettelijk, bij verordening of bij statuut voorgeschreven voorwaarden pas deel uit gaan maken van de rechtsbetrekking tussen partijen door overeenkomst en niet van rechtswege, is het AGB-Gesetz onverkort van toepassing. Voor het begrip algemene voorwaarden is het derhalve irrelevant of deze voorwaarden wel of niet inhoudelijk overeenstemmen met een wettelijke regeling $^{78}$ of dat zij door een overheidsinstantie zijn goedgekeurd ${ }^{79}$.

Het AGB-Gesetz maakt geen uitzonderingen voor algemene voorwaarden die op grond van een overeenkomst deel uitmaken van rechtsbetrekkingen met de overheid en is daar onverkort op van toepassing. Indien deze rechtsverhouding een privaatrechtelijk karakter draagt en de overheid de voorwaarden gebruikt als private gebruiker, is het AGB-Gesetz rechtstreeks van toepassing. Op de toetsing van voorwaarden in een rechtsbetrekking met een publiekrechtelijke karakter zijn de $\$ \S 54-61$ Verwaltungsverfahrensgesetz (VwVfG) van toepassing en mist het AGB-Gesetz in beginsel directe werking. $\S 62$ VwVfG bepaalt echter dat bij de toetsing van dergelijke bedingen ook de bepalingen van het BGB en dus ook het AGB-Gesetz toegepast kunnen worden, zodat het AGBGesetz, zij het indirect en naast de bepalingen van het Verwaltungsverfahrensgesetz, van toepassing is op deze overheidsvoorwaarden. ${ }^{80}$

Stein, BGB "pag. 8; Schlünder, pag. 3; Wolf, AGBG Kommentar, 1 Rndnr. 10; Ulmer, AGB-Gesetz, 1 Rndnr. 16.

76 Stein, BGB, pag. 9; Wolf, AGBG Kommentar, $\$ 1$ Rndnr. 7; Ulmer, AGB-Gesetz, $\$ 1$ Rndnr. 9.

77 Stein, BGB, pag. 9; Wolf, AGBG Kommentar, \&1 Rndnr. 7.

78 Wolf, AGBG Kommentar, 1 Rndinr. 8.

79 Ulmer, AGB-Gesetz, 1 Rndnr. 71-72; Wolf, AGBG Kommentar, 1 Rndnr. 8; Stein, BGB. pag. 9.

80 Wolf, Einl. Rndnr. 20; Ulmer, AGB-Gesetz, I Rndnr. 14 en 1 Rndnr. 73. 
Van algemene voorwaarden is pas sprake indien het gaat om bedingen die van tevoren zijn opgesteld (vorformulierten Vertragsbedingungen) voor gebruik in een aantal overeenkomsten. Het vereiste ziet op de eenzijdige vaststelling van de inhoud van de bedingen door de gebruiker, eén van de legitimatiegronden van wettelijk ingrijpen. Indien bedingen van te voren zijn opgesteld om in een aantal overeenkomsten te worden gebruikt staat deze eenzijdige vaststelling van de inhoud vast. ${ }^{81}$

Het bestemmingscriterium is doorslaggevend. Niet vereist is derhalve dat deze van tevoren opgestelde bedingen ook reeds daadwerkelijk in een of meer overeenkomst(e) zijn opgenomen. Voldoende is dat zij zijn bestemd om te worden opgenomen in een antal overeenkomsten. ${ }^{82}$

Ter onderscheiding van individuele afspraken is vereist dat de algemene voorwaarden moeten zijn opgesteld ten einde te worden opgenomen in een aantal overeenkomsten (eine Vielzahl von Verträgen). ${ }^{83}$ In beginsel hoeft van een daadwerkelijk gebruik in een aantal overeenkomsten geen sprake te zijn. De bestemming is voldoende. In beginsel is daarom reeds sprake van algemene voorwaarden bij het eerste gebruik van bedingen die bestemd zijn om in meerdere overeenkomsten te worden gebruikt. Bij twijfel is het gebruik van dezelfde bedingen in drie tot vijf overeenkomsten een afdoende indicatie om aan te nemen dat sprake is van een beding dat is opgesteld om meermalen te worden gebruikt. ${ }^{84}$ Daarbij is niet vereist dat het beding herhaaldelijk wordt gebruikt tegenover verschillende wederpartijen. Van algemene voorwaarden is ook sprake indien bedingen zijn opgesteld teneinde deze meerdere malen jegens dezelfde wederpartij te gebruiken. ${ }^{85}$

Voor het antwoord op de vraag of sprake is van meermaals gebruik, zijn bedingen die een aantal keren zijn gebruikt en qua strekking identiek doch qua redactie verschillend zijn, te beschouwen als dezelfde algemene voorwaarden. ${ }^{86}$ Ook herhaaldelijk gebruik van bedingen die slechts gering verschillen in strekking, leidt tot de conclusie dat sprake is van algemene voorwaarden. ${ }^{87}$

Bij de beoordeling of sprake is van algemene voorwaarden is niet relevant in welke vorm of lettertype deze van te voren zijn opgesteld. Zowel mondelinge

81 Wolf, AGBG Kommentar, \& 1 Rndnr. 12; Ulmer, AGB-Gesetz, 20 Rndrur. 20-21.

82 Wolf, AGBG Kommentar $\$ 1$ Rndnr. 13; Stein, BGB, pag. 11; Ulmer, AGB-Gesetz, 1 Rndinr. 13.

83 Zie, voor de mogelijke wijziging van dit vereiste op grond van de EEG-richtlijn inzake onerlijke bedingen in consumentenowereenkomsten, hiervoor paragraf 6.1 .1 .

84 BGH, NJW 1981, pag, 2343-2444, WM, pag. 944-946; Wolf, AGBG Kommentar, 1 Rndrur. 13-14; Stein, BGB, pag. 9-10; UIner, AGB-Gesetz, \& Rndnr. 24-25.

85 Wolf, AGBG Kommentar, \& Rndinr. 14; Stein, BGB, pag. 9-10.

86 BOH, NIW 1979, pag. 2387-2388; Wolf, AGBG Kommentar, \& 1 Rndrur. 15.

87 Wolf, AGBG Kommentar, \& $\|$ Rndnr. 15. 
als schriftelijke bedingen vallen onder de definitie van $\& \| A G B G{ }^{88}$ Het maakt niet uit of deze voorwaarden schriftelijk zijn opgesteld, als tekstblokken zijn neergelegd in een tekstverwerkingsprogramma, notarieel zijn vastgelegd, in het geheugen van de gebruiker vastliggen ${ }^{85}$, dat zij niet in hetzelfde contractsdocument staan als de romp-overeenkomst of de overige voorwaarden, etc. Doorslaggevend is slechts dat zij van tevoren zijn opgesteld..$^{\infty 0}$

Uit de tekst van de wet volgt strikt genomen, dat pas van algemene voorwaarden sprake is als de gebruiker deze voorwaarden aan de wederpartij voorlegt ("stellt"). Het begrip algemene voorwaarden vereist echter niet dat sprake is van een daadwerkelijk voorleggen van bedingen aan de wederpartij. Het is voldoende dat de bedingen door de gebruiker of aanbeveler bedoeld zijn om te worden voorgelegd aan meerdere wederpartijen. ${ }^{.1}$

De term "stellt" vereist niet dat de gebruiker de algemene voorwaarden eenzijdig oplegt aan de wederpartij zonder dat deze laatste de mogelijkheid heeft om deze te wijzigen of de toepasselijkheid geheel af te wijzen. Voldoende is dat de gebruiker op enigerlei wijze aan de wederpartij het aanbod doet om bepaalde bedingen contractsinhoud te laten worden. ${ }^{92}$ Het begrip "stellen" heeft ook voornamelijk de functie om vast te stellen welke contractspartij de gebruiker is van de algemene voorwaarden en welke partij de wederpartij. De partij die het voorstel doet om, de vooraf geformuleerde, algemene voorwaarden op te nemen in de overeenkomst is de gebruiker. ${ }^{93}$ Van het voorleggen van algemene voorwaarden is geen sprake indien een derde, bij voorbeeld een notaris of makelaar, op eigen initiatief algemene voorwaarden in een contract ten behoeve van contractspartijen opneemt of indien beide partijen kiezen voor dezelfde algemene voorwaarden die zijn opgesteld door een derde. Indien de opdracht naar die derde echter uitgaat van één der partijen en deze derde geacht wordt de belangen van slechts deze partij te vertegenwoordigen is wel sprake van het. voorleggen (via de derde), aan de andere partij. In dat geval moet degene wiens belangen door de derde worden behartigd gezien worden als degene die het initiatief heeft genomen tot het opnemen van algemene voorwaarden in de overeenkomst en dus als gebruiker. ${ }^{94}$

88 Wolf, AGBG Kommentar, 1 Rndnr. 12; Stein, BGB, pag. 11; Ulmer, AGB-Gesetz, 1 Rndnr. 20.

89 BGH, NJW 1988, pag. 410.

90 Ulmer, AGB-Gesetz, 1 Rndnr. 33-38; Wolf, AGBG Kommentar, \& 1 Rndnr. 17-22.

91 Wolf, AGBG Kommentar, I Rndnr. 16; Ulmer, AGB-Gesetz, I Rndnr. 26-27; Stein, BGB, pag. 12.

92 Wolf, AGBG Kommentar, 1 Rndnr. 27; Ulmer, AGB-Gesetz, 1 Rndnr. 26.

93 Wolf, AGBG Kommentar, 1 Rndnr. 27; Ulmer, AGB-Gesetz, I Rndnr. 27.

94 Wolf, AGBG Kommeritar, I Rndnr. 28; Ulmer, AGB-Gesetz, \& Rndnr. 31. 
\$ 1 AGBG bepaalt dat van algemene voorwaarden sprake is als ze door de gebruiker aan de wederpartij worden voorgelegd bij het sluiten van de (romp-) overeenkomst. Strikt genomen zouden algemene voorwaarden die pas na het sluiten van de overeenkomst contractsinhoud worden derhalve niet onder de definitie van $\$ 1$ AGBG vallen. Indien algemene voorwaarden echter eerst later deel zijn geworden van de overeenkomst, veronderstelt dit een aanbod tot wijziging van de oorspronkelijke overeenkomst en acceptatie daarvan. In dat geval is bepalend het tijdstip waarop de gewijzigde overeenkomst tot stand komt. Ook algemene voorwaarden die eerst ná het sluiten van de romp-overeenkomst contractsinhoud worden, vallen daarmee onder de definitie van $\S \mathbb{1}$ AGBG. ${ }^{95}$

De hoofdregel van $\$ 1$ Abs. 1 AGBG is dat slechts bedingen die voor gebruik in meerdere overeenkomsten zijn opgesteld algemene voorwaarden zijn en dat bedingen die vooraf zijn opgesteld om te worden gebruikt in slechts é́n overeenkomst (Einzelfall- of Individualvereinbarungen) niet onder het begrip algemene voorwaarden vallen en dus ook niet onder het bereik van het AGBGesetz. Voor de vraag of sprake is van algemene voorwaarden is in dat licht irrelevant of over deze algemene voorwaarden is onderhandeld tussen contractspartijen. Beslissende factor is slechts de bestemming. Zijn de bedingen opgesteld met de bestemming van eenmalig gebruik dan zijn het geen algemene voorwaarden.

Toch kunnen ook bedingen die op grond van hun bestemming eigenlijk gekwalificeerd moeten worden als algemene voorwaarden, door contractspartijen worden bestempeld als individueel overeengekomen bedingen. Deze mogelijkheid staat voor partijen open op grond van de bepaling van $\S 1$ Abs. 2 AGBG.

A Ugemeine Geschaffibedingungen liegen nucht vor, soweir die Vertragsbedingungen zwischen den Vertragsparteien int einzelnen ausgehandeh sind.

$\$ 1$ Abs. 2 AGBG veronderstelt dat sprake is van algemene voorwaarden als bedoeld in $\$ 1$ Abs. 1 AGBG, maar dat partijen daarover onderhandeld hebben en uitdrukkelijk over het gebruik van (hetzelfde) beding overeenstemming hebben bereikt (Aushandlungsvereinbarung). $\S 1$ Abs. 2 AGBG is dan ook uitdrukkelijk bedoeld als uitzondering op de algemene bepaling van $\S 1$ Abs. 1 AGBG. ${ }^{* 6}$

95 Wolf, AGBG Kommentar, \$ 1 Rndinr. 31; Ulmer, AGB-Gesetz, 1 Rndmr. 28 .

96 Wolf, AGBG Kommentar, 1 Rndnr. 32; Ulmer, AGB-Gesetz, 1 Rndinr. 39. 
Bedingen die door onderhandelingen tussen de contractspartijen uiteindelijk zijn gewijzigd, zijn daardoor in beginsel een eenmalige afspraak geworden en vallen niet onder het begrip algemene voorwaarden als bedoeld in $\$ 1$ Abs. 1 AGBG. ${ }^{97}$ Op deze eenmalige afspraken ziet $\& 1$ Abs. 2 niet. Toch maakt het enkele feit dat een beding is gewijzigd nog niet dat het beding daardoor een individuele afspraak wordt. De toelichting op het wetsontwerp vermeldt hierover het volgende:

Zahlreiche Einfingungen ader Änderwngen in einem vorformulierten Text Köwien im Einzelfall den Bewheis erleichterm, däB das ganze Klawselwenk ausgehandels ist. Andererseits ist eine Andenwng des wom KLauselvenwender urspringlich vorgeschlagenen Workauts der Vertragsbestimmungen heineswegs Voraussetzung for die Annahme einer Individualvereinbanang. Der Rechtsprechung nus es iberlassen bleiben, im Zweifelfall zu entscheiden, ob und inwieweit der andere Vertragsteil trotz Verwendung eines Musiters so viel Eimfußj auf die Abmachungen genommen hat, daß diese als individuelle Abrede angesehen werden können. $\$ 98$

Voor de toepassing van $\S 1$ Abs. 2 AGBG is vereist dat sprake is van een reële onderhandelingsmogelijkheid, wijzigingsbereidheid van de gebruiker en wijzigingsbevoegdheid van de wederpartij. Zo maken voorgeformuleerde keuzemogelijkheden voor de wederpartij en voorgeformuleerde verklaringen waarin of de gebruiker verklaart dat hij bereid is te onderhandelen over zijn algemene voorwaarden en bereid is deze te wijzigen of de wederpartij verklaart dat de bedingen na onderhandelingen en uitdrukkelijke toestemming contractsinhoud zijn geworden, een algemene voorwaarde nog niet tot een individuele afspraak. ${ }^{99}$

$\S 1$ Abs. 2 AGBG vereist dat sprake is van onderhandelingen tussen de contractspartijen. Het feit dat over algemene voorwaarden collectieve overeenstemming is bereikt tussen organisaties van aanbieders en afnemers, heeft derhalve geen enkele betekenis voor de toepassing van de uitzondering van $\S 1$ Abs. 2 AGBG. ${ }^{100}$

Het bewijs van het feit dat sprake is van algemene voorwaarden moet in beginsel worden geleverd door degene die zich op de bescherming van het AGB-Gesetz beroept; dus de wederpartij in de individuele procedure en de consumenten- en branche-organisaties in de collectieve procedure. Dezen zullen eveneens moeten aantonen dat de andere partij de gebruiker is, dat wil zeggen dat de andere partij het initiatief heeft genomen om de algemene voorwaarden in

97 Wolf, AGBG Kommentar, \& 1 Rndnr. 32; Ulmer, AGB-Gegetz, \& 1 Rndnr. 41.

98 Begündung, BT Drucksache $7 / 3919$, pag. 17.

99 Zie meer uitgebreid onder andere: Wolf, AGBO Kommentar, \& 1 Rndnr. 33-41; Ulmer, AGBGesetz, \& 1 Rndnr. 40-59. Zie ook: Jongeneel, diss.", pag. 55-57.

100 Wolf, AGBG Kommentar, 1 Rndnr. 40; Ulmer, AGB-Gesetz, \& 1 Rndnr. 59. 
de overeenkomst op te nemen. De gebruiker die zich aan de inhoudstoets van het AGB-Gesetz wil onttrekken zal vervolgens moeten aantonen dat sprake is van of een eenmalige afspraak (Individualvereinbarung) of dat sprake is van en beding dat door partijafspraak (Aushandlungsvereinbarung) is bestempeld als indivildueel overeengekomen. ${ }^{101}$

Naast de definitie van het begrip algemene voorwaarden en de begrenzing van $823 \mathrm{Abs}$. $1 \mathrm{AGBG}$, is een verdere materiële beperking van het AGB-Gesetz te vinden in de bepaling van $\$ 8$ AGBG.

\section{8 Schranken der Inhaliskontrolle}

Die $\$ 9$ bis 11 gelten nur fur Bestimumungen in Allgemeinen Geschatsbedingungen, durch die von Rechtsvorschriftem abweichende oder diese erganzende Regelungen vereinbart werdem.

\$ 8 AGBG geeft de grenzen aan van de inhoudscontrole van de paragrafen 9 tot en met 11 AGBG. Op grond van deze bepaling geldt de inhoudscontrole enkel voor die bedingen die of in een van de wet of het geldende recht afwijkende regeling voorzien of die een wettelijke regel of rechtsregel aanvullen. In tegenstelling tot $\$ 1$ AGBG waarin de definitie van algemene voorwaarden afhankelijk wordt gemaakt van uiterlijke factoren die los van de inhoud staan, knoopt $\$ 8$ AGBG aan bij de inhoud van bedingen die ter beoordeling staan. ${ }^{102} \& 8$ AGBG brengt twee gedachten tot uitdrukking.

Op de eerste plaats de gedachte dat de inhoudstoets niet dient ter controle of modificatie van wettelijke regelingen en dat specifieke wettelijke regelingen voorrang dienen te hebben op het AGB-Gesetz. ${ }^{100}$ Algemene voorwaarden die in overeenstemming zijn met op de overeenkomst toepasselijke ${ }^{104}$ Rechtsworschriften (Deklaratorische Klauseln) zijn daarom uitgesloten van de inhoudscontrole van het AGB-Gesetz. ${ }^{105}$ Een andere opvatting zou betekenen dat de rechter door middel van de inhoudstoetsing controle zou uitoefenen op rechtsregels. Onder de term Rechtsvorschriften vallen echter niet alleen alle wetten in materiële zin, ongeacht of deze dwingend of regelend van aard zijn, maar ook het ongeschreven recht en de rechten en plichten die voortvloeien uit de aard van de overeenkomst of de aanvullende werking van de paragrafen 157 en 242

101 Zie meer uitgebreid over het bewijis inzake 1 AGBG, onder andere: Wolf, AGBG Kommentar, 1 Rndnr; 63-64; Ulmer, AGB-Gesetz, \$ 1 Rndnr. 62-65.

102 Wolf, AGBG Kommentar, \$ Rndnr. 1 .

103 Begründung, BT dnucksache 7/3919, pag. 22.

104 Bedingen die weliswaar in oveneenstemming zijn met een wettelijke regel of een rechtsregel maar worden gebruikt voor overeenkomsten war zij niet op zien zijn wél asn de inhoudscontrolle anderworpen.

105 Zie meer uitgebreid onder meer: Wolf, AGBG Kommentar, 8 Rndnr. 19-24; Ulmer, AGB. Gesetz, 8 Rndir. 23-26; Niebling, pag. 1713-1718. 
BGB. ${ }^{106}$ Van een afwijking of vervanging van wets- en rechtsregels is sprake indien het schrappen van het betreffende beding uit de overeenkomst andere rechten en plichten voor partijen met zich zou brengen dan met het beding ${ }^{107}$

De tweede gedachte die aan $\& \&$ AGBG ten grondslag ligt is dat de rechter niet dient te treden in de beoordeling van de kernbedingen (Leistingsbeschreibungen und Preisvereinbarungen). Dit omdat enerzijds een wettelijke maatstaf ontbreekt en anderzijds de regulering van deze kernbedingen wordt overgelaten aan het (vrije) marktmechanisme. ${ }^{108}$

De laatste beperkingen van het materiële bereik van het AGB-Gesetz zijn te vinden in de leden 2 en 3 van $\$ 23$ AGBG. $\$ 23$ Abs. 2 AGBG bepaalt dat bepaalde onderdelen van het AGB-gesetz niet van toepassing zijn op bepaalde overeenkomsten. Zo is onder andere $\$ 2$ AGBG en $\$ 11 \mathrm{Nr}$. 7 en 8 AGBG niet van toepassing op de algemene voorwaarden voor het openbaar vervoer en $\$ 10$ en $\$ 11$ AGBG niet van toepassing op de algemene voorwaarden van nutsbedrijven die niet ten nadele van de wederpartij afwijken van de door de overheid vastgestelde leveringsvoorwaarden voor nutsbedrijven. ${ }^{100} \S 23$ Abs. 3 AGBG bepaalt dat de, door de overheid goedgekeurde, algemene voorwaarden van bouwspaarfondsen, verzekerings-, beleggings- en investeringsmaatschappijen ook van toepassing zijn op overeenkomsten met wederpartijen als niet aan de voorwaarden van $\S 2$ Abs. $1 \mathrm{Nr} .1$ en 2 AGBG is voldaan. ${ }^{110}$

In het kader van de bespreking van het materiële bereik van de wet dient eveneens gewezen te worden op $\$ 7$ AGBG.

\section{\$ 7 Ungehungsverbot}

Dieses Gesetz finder auch Anwendwng, wenn seine Vorschriften durch anderweitige Gestaltungen unngangen werden.

Volgens deze bepaling is het AGB-Gesetz eveneens van toepassing als de regels van deze wet door een andere redactie of vormgeving van de overeenkomst of door andere kunstgrepen ontdoken worden. ${ }^{11}$ In de praktijk heeft deze bepa-

106 BGH, NJW 1993, pag. 721. Zie meer uitgebreid onder meer: Wolf, AGBG Konumentar, 8 Rndnr. 5.

107 Ulmer, AGB-Giesietz, 88 Rndnr. 23.

108 Wolf, AGBG Kommentar, 8 Rndnr. 1; Ulmer; AGB-Geselz, \& 8 Rndnr, 1; Niebling, pag. 1713-1718; BGH, NJW 1985, pag. 3013. Zie ook: Jongeneel, diss., pag. 45-48.

109 Zie uitwoerig: Hom, AGBG Kommentar, \& 23 Rndnr. 100-361; Ulmer, AGB-Gesetz, 23 Rndinr. $31-51$.

110. Zie meer uitgebreid: Hom, AGBG Kommentar, 23 Rndnr: 400-603; Ulmer, AGB-GeBetz, 23 Rndnr. 52-55.

111 BT Drucksache 7/3919, pag. 48-49; Lindacher, AGBG Kommentar, \& 7 Rndnr. 1-7; Ulmer; AGB-Gesetz, \& 7 Rndir. 1-15. 
ling, die een concretisering is van het ongeschreven algemene beginsel dat: wetsontduiking niet kan worden toegestaan, echter weinig betekenis. ${ }^{112}$

\subsubsection{Het personele bereik}

Het personele toepassingsbereik van het AGB-Gesetz wordt geregeld in de bepaling van $\$ 24 \mathrm{AGBG}$.

\section{Persöndicher Anwendungshereich}

Die Vorschvifien der $\$ 2,10,11$ und 12 finden keine Anwendung auf Allgemeine Geschaffisbedimgungen,

1. die gegenubber einem Kaufinamn venwendet werden, wenn der Vertrag zum Betriebe seines Handelsgewerbes gehort;

2. die gegenuber einer juristischen Person des offentlichen Rechts ader einem offentlicth-rechtlichew Sondervermögen verwendet werden.

9 ist in den Fallem des Satzes 1 auch insoweit anzuwenden, als dies zur Unwirksamkeit von in den \$8 10 und 11 genannten Vertragsbestimmungen filhrt; auf die im Handelsverkehr geliendem Gewohnheiten und Gebraluche ist angemessen Racksicht zu nehmen.

$\$ 24$ AGBG is een uitzondering op het beginsel dat het AGB-Gesetz ziet op alle algemene voorwaarden als bedoeld in $\$ 1$ AGBG ongeacht de status of persoon van de wederpartij. De voorschriften van de paragrafen 2, 10, 11 en 12 AGBG zijn niet van toepassing op algemene voorwaarden die worden gehanteerd tegenover een wederpartij die handelt in de uitoefening van zijn beroep of bedrijf of worden gehanteerd tegenover een publiekrechtelijke rechtspersoon of een "Offentlich-rechtlichen Sondervermögen ${ }^{1133}$.

De ratio van de bepaling is vooral gelegen in de gedachte dat in beginsel elke wederpartij ongeacht of deze wel of niet handelt in de uitoefening van zijn beroep of bedrijf, de bescherming van het AGB-gesetz verdient - $\$ 9$ AGBG is derhalve van toepassing op alle wederpartijen - maar dat de in $\$ 24$ AGBG genoemde wederpartijen minder bescherming behoeven en derhalve de werking van de paragrafen 2, 10, 11 en 12 AGBG jegens hen is uitgesloten. ${ }^{114}$ Verder in de gedachte dat een dwingende toepassing van de lijsten van de paragrafen 10 en 11 AGBG de noodzakelijke flexibilliteit van overeenkomsten in het handelsverkeer te zeer zou beperken. ${ }^{115}$

De laatste volzin van $\$ 24$ AGBG bepaalt uitdrukkelijk dat uit het feit dat de lijsten van $\S 10$ en $\S 11$ AGBG niet van toepassing zijn jegens professionele

112 Ulmer, AGB-Gesetz, $\$ 7$ Rndar. 1 .

113 Een Nedertands equivalent van de term is niet te geven. Voor zichzelf sprekende voorbeelden van öffentlich-rechtliche Sondervermögen zijn de Deutsche Bundesbahn en de Bundespost.

114 Hom, AGBG Kommentar, \& 24 Rndnr. 1-4; Brandner, AGB-Gesetz, \& 24 Rndinr. 1-2.

115 Brandner, AGB-Gesetz, 24 Rndnr. 2. 
wederpartijen, publiekrechtelijke rechtspersonen en bepaalde "staatsbedrijven" niet mag worden afgeleid dat bedingen die overeenstemmen met de bedingen opgenomen in de lijsten van $\$ 10$ en $\$ 11$ AGBG niet onredelijk bezwarend zijn of dat de inhoudstoets van $\$ 9$ AGBG niet van toepassing zou zijn op deze bedingen. ${ }^{16}$

\subsubsection{Het toepasselijkheidsvraagstuk}

De bepaling van $\$ 2$ AGBG geeft de voorwaarden die, op straffe van niettoepasselijkheid van de desbetreffende algemene voorwaarden, in acht moeten worden genomen om te bewerkstelligen dat algemene voorwaarden contractsinhoud worden.

\section{$\$ 2$ Einbeziehung in den Vertrag}

(I) Allgemeine Geschaftsbedingungen werden nur dann Bestandteil eines Vertrages, wenn der Verwender bei Vertragsabschlü

1. die andere Vertragspartei ausdricklich oder, wenn eim ausdricklicher Hinweis wegen der Ant des Vertragsabschlusses nur unter unverhalmismajigen Schwiengkeiren möglich ist, durch deurlich sichtbaren Aushang am Ort des Vertragsabschlusses auf sie hinweist und

2. der anderen Vertragspartei die Moglichkeit verschaff, in zumutbarer Weise von ihrem Imhalt Kennmis zu mehmen.

und wem die andere Vertragspartei mit ihrer Geltung einverstanden ist.

(2) Die Vertragsparteien konnen für eine bestimmte Ar von Rechrsgeschidften die Geltung bestimmuter Allgemeiner Geschaftsbedimgungen urter Beachung der in Absatz 1 bezeichneten Erfordemisse im voraus vereinbarem.

De ratio van $\$ 2$ AGBG is gelegen in het scheppen van voorwaarden die het mogelijk maken dat de wederpartij zich bewust is van het feit dat zij contracteert onder algemene voorwaarden. Tijdens de parlementaire behandeling wordt dit als volgt toegelicht:

"Soll sich die Venwendung von AGB' ouf dem Boden des Vertragsrechtes vollziehen und demgemajß wernigstens dem Grundsatz mach an dem Evfordemis einer Willensabereinstimunung beider Vertragsparteien festgehalten werden, so ist es notwendig, daß der Verwender seine Bedingungen offenlegt und seimen Vertragspartiver auf die beabsichtigte Einbeziehung hinweist. Nur so kann dieser die Tragweive seiner eigenem Erklarung ermessem und sich gegebenenfalls gegen unerwilnschte oder sogar unbillige Bedingungen zu wehren versuchen. ${ }^{1117}$

Daar staat tegenover dat het niet in de bedoeling van de Duitse wetgever lag om de rationaliseringsfunctie van algemene voorwaarden te zeer te beperken en het

116 Horn, AGBG Kommentar, \$24 Rndnr. 1; Brandmer, AGB-Gegetz, \& 24 Rndnr. 1.

117 Begründung, BT Druckaache 7/3919, pag. 17. 
rechtsverkeer met onnodige formaliteiten te belasten. ${ }^{118}$ De regeling van 2 AGBG is derhalve een compromis tussen enerzijds het belang van de wederpartij op redelijkerwijs van de gebruiker vergbare informatie en anderzijds op het algemene belang van een doelmatig functioneren van het rechtsverkeer. ${ }^{119}$

De regeling van $\S 2$ AGBG beklemtoont het contractuele karakter van algemene voorwaarden en sluit aan bij de algemene regeling van het $B G B$ inzake de totstandkoming van overeenkomsten zoals neergelegd in de $\$ \S 104-115$ BGB (handelingsbekwaamheid), de $\$ \S 116-144$ BGB (wilsverklaringen) en de $\$ \S 145$ 157 BGB (overeenkomsten). Op een aantal punten wijkt de regeling van \& 2 AGBG echter af van de algemene regels van het BGB. Voor algemene voorwaarden als bedoeld in $\$ 1$ AGBG is de regeling van $\S 2$ AGBG dan ook een lex specialis die op het door haar bestreken gebied derogeert aan de generale regels van het BGB. Buiten het door $\S 2$ AGBG bestreken gebied gelden onverkort de algemene regels van het BGB. ${ }^{120}$

De regeling van $\$ 2$ AGBG wijkt op twee punten af van de algemene regels. De eerste afwijking volgt uit de voorwaarde van $\S 2$ Abs. 1 Nr. 1 AGBG. Het vereiste dat de gebruiker de wederpartij uitdrukkelijk dient te wijzen op de toepasselijkheid van algemene voorwaarden, sluit uit dat deze verwijzing bij wege van uitleg kan worden afgeleid uit het aanbod van de wederpartij indien deze verwijzing niet uitdrukkelijk is geschied. ${ }^{121}$ Daardoor is de toepassing van de $\S \S 133$ en 157 BGB uitgesloten. ${ }^{122}$ De tweede afwijking volgt uit $\$ 2$ Abs. 1 Nr. 2 AGBG. Uit de verplichting van de gebruiker om de wederpartij een redelijke mogelijkheid te bieden van de inhoud van de algemene voorwaarden kennis te nemen, vloeit voort dat de wederpartij geen eigen onderzoeksplicht heeft naar de inhoud van die algemene voorwaarden. De uit de algemene regels voortvloeiende vraag of de wederpartij de mogelijkheid had om zich op eigen initiatief op de hoogte te stellen van de inhoud van de toepasselijk verklaarde algemene voorwaarden is daarom niet relevant. ${ }^{123}$ Ondanks het feit dat de wederpartij de gelding van de algemene voorwaarden kan aanvaarden zonder van de inhoud daarvan kennis te nemen, heeft de gebruiker de plicht de wederpartij de redelijke mogelijkheid tot kennisname te verschaffen.

Een laatste afwijking ten opzichte van de algemene regels van het BGB is tenslotte te vinden in $\$ 6$ AGBG. Deze regeling geeft enerzijds een van $\$ 139$

118 Begründung, BT Drucksache 7/3919, pag. 13 en 17.

119 Wolf, AGBG Kommentar 2 Rndnr. 1; Ulmer, AGB-Gesetz, 2 Rndnr. 2.

120 Wolf, AGBG Kommentar, 2 Rndnr. 4; Ulmer, AGB-Gesetz, 2 Rndnr. 18-22.

$121 \mathrm{BGH}$, NJW-RR 1987, pag. 112-113.

122 Wolf, AGBG Kommentar, \& 2 Rndnr. 5; Ulmer, AGB-Gesetz, \$2 Rndni. 19.

123 Wolf, AGBG Kommentar, \& 2 Rindnr. 5; Ulmer, AGB-Gesetz, \& 2 Rndnr, 20. 
BGB afwijkende regeling voor de partiële nietigheid van overeenkomsten en zet anderzijds de werking van de $\$ \$ 154$ en 155 BGB opzij. ${ }^{124}$

De regeling van $\$ 2$ AGBG is van toepassing op alle algemene voorwaarden ongeacht of deze schriftelijk, mondeling of stilzwijgend deel zijn gaan uitmaken van de overeenkomst. ${ }^{125}$ Op grond van $\$ 24$ AGBG geldt de regeling van $\$ 2$ AGBG echter niet voor de inlassing van algemene voorwaarden in overeenkomsten met professionele wederpartijen en publiekrechtelijke rechtspersonen. Voor de inlassing van deze voorwaarden gelden de algemene toepasselijkheidsregels van het BGB onverkort. ${ }^{126} \S 23$ Abs. 2 Nr. 1 AGBG sluit de toepasselijkheid van de regeling eveneens uit voor de wettelijk geregelde algemene voorwaarden voor het openbaar vervoer. Verder is op grond van het bepaalde in $\S 13$ Abs. 3 AGBG, de werking van $\$ 2$ Abs. 1 Nr: 1 en 2 AGBG uitgesloten voor door de overheid goedgekeurde algemene voorwaarden van bouwspaarfondsen, verzekeringsmaatschappijen en beleggings- of investeringsmaatschappijen.

De bepaling van $\$ 2$ AGBG voorziet niet in een regeling voor het probleem van de battle-of-forms; het geval dat beide contractspartijen verwijzen naar de toepasselijkheid van hun eigen, onderling verschillende, algemene voorwaarden (kollidierende AGB). De problematiek wordt opgelost met behulp van de algemene regels van het $\mathrm{BGB}$ met betrekking tot de totstandkoming van overeenkomsten en met name de $\S \S 150$ Abs. $2^{127}, 151$ en 154 BGB. ${ }^{128}$

\subsubsection{Verwijzing naar de toepasselijke algemene voorwaarden}

$\$ 2$ AGBG stelt een aantal bijzondere vereisten voor de toepasselijkheid van algemene voorwaarden als bedoeld in $\$ 1$ AGBG. Op de eerste plaats legt $\$ 2$ Abs. 1 Nr. 1 AGBG op de gebruiker de plicht om uitdrukkelijk (mondeling of schriftelijk) te verwijzen naar de toepasselijke algemene voorwaarden. Van een uitdrukkelijke verwijzing is slechts sprake als de gebruiker bij het sluiten van de overeenkomst op ondubbelzinnige en voor de wederpartij duidelijke wijze

124 Wolf, AGBG Kommentar, 2 Rndnr. 5 ; Ulmer, AGB-Gesetz, 2 Rndnr. 21.

125 Begründung, BT Drucksache 7/3919, pag. 17.

126 Zie uitvoerig: Wolf, AGBG Kommentar, 2 Rndnr. 57-85; Ulmer, AGB-Gesetz, 2 Rndnr. 79-106.

127 Vergelijkbaar met artikel 6:225 lid $1 \mathrm{BW}$.

128 Uitvoerig: Wolf, AGBG Kommentar, 2 Rndnr. 73-80; Ulmer, AGB-Gegetz, \& 7 Rndnr. 92106. Zie ook: Jongeneel, diss., pag. $130-13 \|$. 
verklaart dat hij zijn algemene voorwaarden van toepassing wil doen zijn op de te sluiten overeenkomst. ${ }^{129}$

De aanhef van lid 1 van $\$ 2$ AGBG bepaalt dat de verwijzing dient plaats te vinden bij het sluiten van de overeenkomst (bei Vertragsabschluß). Dat wil zeggen dat de verwijzing dient plaats te vinden op een dusdanig tijdstip dat de wederpartij de mogelijkheid heeft de toepasselijkheid van de betreffende algemene voorwaarden af te wijzen. ${ }^{130}$ In beginsel dient dus voór het moment waarop de (romp-) overeenkomst wordt gesloten, verwezen te zijn naar de toepasselijke algemene voorwaarden. De enkele verwijzing van de gebruiker ná het sluiten van de (romp-) overeenkomst heeft daarom niet tot gevolg dat de betreffende allgemene voorwaarden contractsinhoud worden. ${ }^{131}$ Uiteraard is het niet uitgesloten dat gebruiker en wederpartij ná het sluiten van de romp-overeenkomst alsnog overeenstemming bereiken over de toepasselijkheid van bepaalde algemene voorwaarden (Abänderungsvertrag). In dat geval moet aan de vereisten van $\$ 2$ Abs. 1 AGBG worden voldaan vóor het tijdstip van de totstandkoming van deze nadere wijzigingsovereenkomst. ${ }^{132}$

Indien een uitdrukkelijke mondelinge of schriftelijke verwijzing wegens de aard van de overeenkomst redelijkerwijs niet mogelijk is, kan de gebruiker volstaan met een duidelijk zichtbare mededeling op de plaats waar de overeenkomst wordt gesloten. De mogelijkheid is vooral bedoeld voor overeenkomsten die worden gesloten zonder dat sprake is van persoonlijk contact met de wederpartij, zoals overeenkomsten via een automaat, of voor massaal gesloten dagelijkse overeenkomsten waarbij strikt genomen uitdrukkelijke verwijzing wel mogelijk is maar op relatief grote moeilijkheden zou stuiten. ${ }^{133}$

De regel is een uitzondering op de hoofdregel dat de verwijzing uitdrukkelijk dient te geschieden en geldt ook slechts voor het geval dat uitdrukkelijke mededeling praktisch of economisch gezien redelijkerwijs niet mogelijk is. Treffend is in dit verband de volgende opmerking tijdens de parlementaire behandeling:

$129 \mathrm{BOH}$, NJW-RR 1987, pag. $112-114$. Bij een combinatie van (setjes) algemene woorwatrden is een uitdrukkelijke verwijzing in de eerate set naar toepasselijkheid van een tweedle set voldoende voor de toepasselijkheid wan de tweede set. Zie: BGH, NJW 1990, 3197. Zie uitvoerig over de vereisten die worden gesteld aan een uitdrulkkelijke verwijzing: Wolf, AGBG Kommentar, \$ 2 Rndnr. \& 17; Ulmer, AGB-Gesetz, \& 2 Rndnr. 23-35a; Jongeneel, diss., pag. 99.101.

130 BGH, NJW 1990, pag. 715-716.

131 BGH, NJW-RR 1987 , pag. 112-114; Wolf, AGBG Kommentar, \& 2 Rndnr. 36; Ulmer, AGBGesetz; \& 2 Rndnr. 55; Jongeneel, dïss., pag. 101.

132 BGH, NJW 1983, pag. 816-817; BGH, NJW 1984, pag. 1112; BGH, NJW-RR 1987, pag. 112-114; Wolf, AGBG Kommentar, \$2 Rndnr. 37; Ulmer, AGB-Gesetz, 2 Rndnr. 57.

133 Begründing, BT Drucksache, pag. 18; Wolf; AGBG Kommentar, \& 2 Rndnr. 18-21; UMmer, AGB-Gesetz, 2 Rndnr. 26-44; Jongeneel, diss., pag. 101-102. 
"Von solchen Ausnahmefalle abgesehen soll aber stets ein ausdrizckicher Hinweis erfolgen;" denn eime allgemeine Pflicht, beï Abschluß eines jedweden Vertrags etwa die Wünde am Ort des Vertragsabschlusses nach ausgehängten AGB abzusuchen, bestehi nicht. "1.134

Het is voldoende dat de gebruiker verwijst naar de toepasselijke set algemene voorwaarden. Hij hoeft niet apart te verwijzen naar de toepasselijkheid van elk beding dat deel uitmaakt van de set. ${ }^{135}$ Verwijst de gebruiker echter slechts naar een deel van de algemene voorwaarden dan is ook slechts dat deel van toepassing op de overeenkomst. ${ }^{136}$ De verwijzing hoeft bovendien niet de tekst van de toepasselijke algemene voorwaarden te bevatten. ${ }^{137}$

\subsubsection{Informatieplicht van de gebruiker ten aanzien van de inhoud}

Op de inhoud van de toepasselijk verklaarde algemene voorwaarden ziet de voorwaarde gesteld in $\S 2$ Abs. $1 \mathrm{Nr}$. 2 AGBG. De gebruiker moet de wederpartij vóór de aanvaarding van de gelding van de algemene voorwaarden een redelijke mogelijkheid bieden om van de inhoud daarvan kennis te nemen. Daarvoor zal in het algemeen van de gebruiker worden vereist dat hij de wederpartij de mogelijkheid verschaft om van de tekst van de algemene voorwaarden kennis te nemen. Dit dient te geschieden voor de aanvaarding van de gelding daarvan. Het voorlezen van de algemene voorwaarden of het overhandigen of toezenden daarvan vór de aanvaarding is in elk geval voldoende. Het volstaat echter ook indien de gebruiker de wederpartij er op wijst dat op diens verzoek de algemene voorwaarden overhandigd worden. Dit laatste echter alleen indien de algemene voorwaarden ook daadwerkelijk beschikbaar zijn, de wederpartij geen extra handelingen hoeft te verrichten (bij voorbeeld een schriftelijke aanvraag) of extra kosten moet maken en het redelijkerwijs van de wederpartij te verlangen is dat deze zelf naar de algemene voorwaarden vraagt. ${ }^{138}$

Het bieden van een redelijke mogelijkheid om kennis te nemen van de algemene voorwaarden ziet eveneens op de leesbaarheid en begrijpelijkheid van de toepasselijk verklaarde algemene voorwaarden.

134 Begründung, BT Drucksache 7/3919, pag. 18.

135 Wolf, AGBG Kommentar, 2 Rndinr. 9; Ulmer, AGB-Gesetz, \& 2 Rndnr. 25.

136 LG Frankfurt, NJW 1984, pag. 1626; BGH, NJW 1987, pag. 2431-2432; Wolf, AGBG Kommentar, 2 Rndnr. 9; Ulmer, AGB-Gesetz, \& 2 Rndnr. 25.

137 Ulmer, AGB-Gesetz, 82 Rndnr. 25.

138 Wolf, AGBG Kommentar, 2 Rndnr. 23-26; Ulmer, AGB-Gesetz, 2 Rndnr. 45-49a; Jongeneel, pag. 117-119. 
"Zur Mòglichkeit, in zumwbarer Weise wom Inhalt der AGB Kennmis zu nehmen, gehön es im: abrigen auch, daj diese mohelos Lesbar sind. "wli39

De bepaling van $\& 2$ Abs. 1 Nr. 2 AGBG legt op de gebruiker dus eveneens de plicht om heldere en begrijpelijke algemene voorwaarden te hanteren (Transparenzgebot). ${ }^{140}$ Bedingen die onleesbaar of onbegrijpelijk zijn worden geen contractsinhoud ondat de wederpartij geen redelijke mogelijkheid heeft gehad van deze voorwaarden kennis te nemen. ${ }^{141}$ Doorslaggevend voor de leesbaarheid en begrijpelijkheid van bedingen is niet de individuele wederpartij maar de doorsnee wederpartij bij de betreffende overeenkomsten: doorgaans is dat der rechtsunkundige Durchschnittskunde. ${ }^{142}$ Het gebod om moeiteloos leesbare algemene voorwaarden te hanteren zoals dat is neergelegd in $\S 2$ Abs. 1 Nr. 2 AGBG dient goed te worden onderscheiden wan de contra-proferentem-regel van $\S 5$ AGBG.

\section{Unklarheitenregel}

Zweifel bet der Auslegung Allgemeiner Geschafisbedingungen gehen zu Lasten des Verwenders.

Bedingen in algemene voorwaarden die onleesbaar of onbegrijpelijk zijn worden geen contractsinhoud op grond van het bepaalde in $\$ 2$ Abs. 1 Nr. 2 AGBG. Bedingen die deze toets hebben doorstaan en in beginsel weliswaar begrijpelijk zijn doch op verschillende manieren kunnen worden uitgelegd, vallen onder de werking van $\$ 5$ AGBG. ${ }^{143}$

\subsubsection{Aanvaarding van de gelding}

Als laatste vereiste voor toepasselijkheid vereist $\& 2$ AGBG dat de wederpartij heeft ingestemd met de toepasselijkheid van de algemene voorwaarden op de te sluiten overeenkomst. De aanvaarding is als wilsverklaring onderworpen aan de algemene regels van het BGB. De aanvaardingsverklaring kan derhalve besloten liggen in elke gedraging en dus ook een stilzwijgen. De gebruiker die aan de voorwaarden van $\$ 2$ Abs. 1 Nr. 1 en 2 AGBG heeft voldaan, mag er van uitgaan dat zijn wederpartij de gelding van de algemene voorwaarden stilzwij-

139 Begruindung, BT Drucksache 7/3919, pag. 18.

140 Wolf, AGBO Kommentar, 2 Rndnr. 27-28; Ulmer, AGB-Gesetz, 2 Rndmr. 50-54; Jongenel, diss., pag, 136-138.

141 Het Tranzparenzgebot komt eveneens tot uiting in de rechtspraak van het BGH naar aanleiding van de inhoudstoets van \& 9 AGBG en komt er kort gezegd op neer dat de imhoudelijke onduidelijkheid van een beding een reden kan zijn zulk cen beding onredelijk bezwarend te achten. Zie nader paragraaf 6.2.3.2 onder het kopje De relevante omstandigheden.

142 Wolf, AGBG Kommentar, \& 2 Rndnr. 27; Ulmer, AGB-Gesetz, 2 Rridnr. 51.

143 Zie hiema paragraaf 6.2.3.1. 
gend heeft aanvaard indien deze wederpartij de overeengekomen prestatie in ontvangst heeft genomen en niet tevens uitdrukkelijk de gelding van de desbetreffende algemene voorwaarden heeft afgewezen. ${ }^{144}$

Voldoende is dat de wederpartij de gelding van de set heeft aanvaard. In beginsel is de wederpartij derhalve gebonden aan alle algemene voorwaarden die deel uitmaken van de set die zij heeft aanvaard. ${ }^{145}$ In beginsel, omdat $\$ 3$ AGBG bepaalt dat bedingen die, gezien de omstandigheden van het geval, te verrassend zijn voor de wederpartij, geen deel uitmaken van de overeenkomst.

\section{3 Überraschendie Klauseln}

Bestimwumgen in Allgemeinen Geschafisbedingungen, die nach den Umstönden, insbesondere nach dem auberen Erscheinungsbild des Ventrags, so ungewohulich sind, daj der Vertragspartmer des Verwenders mit ihnen nicht zu rechnen braucht, werden nicht Vertragsbestandieil.

Aan de bepaling van $\$ 3$ AGBG ligt de gedachte ten grondslag dat de wederpartij doorgaans niet of slechts beperkt kennis neemt van de inhoud van de algemene voorwaarden waarvan zij de gelding heeft aanvaard. Deze beperkte interesse in de inhoud van deze voorwaarden kan haar ook niet verweten worden. De wederpartij handelt objectief gezien zelfs verstandig als hij van de kennisname van de inhoud van de door haar aanvaarde algemene voorwaarden afziet. Lindacher verwoordt dit als volgt:

"Vor allem aber handelt der Kunde in aller Regel durchaus objektiv veminfig, wern er wan der wheren inhallichen Kenntnissname absieh. Einmual, weil er bei - in Konsumentengeschafisbereich so gur wie stets, im beidseits kaufmalnnischen Verkehr jedenfalls weithin gegebener - wirtschafflicher Unterlegenheit realistischenveise ohnehin kaum darauf hoffen darf, daß sich der Klauselverwender in Konditionembereich verhaudlungsbereit geben wïrde. Vor allem aber, weil es für den Kunden; unabhangig won der Frage der mareriellen Vertragsparizat, gemeimhin (...) skonomisch einfach micht sinnwoll ist, das Klauselwerk in toto sinnerfassend zur Kennmis zu mehmen und gegebenfalls Zeit und Geld in den - mach den vorab Konstatiemen zudem zumeist untauglichen - Versuch einer fur ihn gillnstigeren Konditionengestaliung zu investierem. " 146

Vanuit dit oogpunt bezien is het doel van de bepaling van $\$ 3$ AGBG de wederpartij te beschermen tegen overrompelende algemene voorwaarden. De wederpartij moet er op kunnen vertrouwen dat de inhoud van de door haar aanvaarde algemene voorwaarden blijft binnen de grenzen die zij op grond van de omstandigheden bij de totstandkoming wan de overeenkomst had kunnen verwachten. ${ }^{147}$ Bedingen die de wederpartij, gezien de omstandigheden van het

144 Wolf, AGBG Kommentar, 82 Rndnr. 43; Ulmer, AGB-Gesetz, 2 Rndmr. 61 .

145 Wolf, AGBG Kommentar, \& 2 Rndnr. 42; Jongeneel, pag. 102.

146 Lindacher, AGBG Kommentar; 3 Rndnr. 1.

147 Begnündung, BT Drucksache 7/3919, pag. 19. 
geval en met name de uiterlijke verschijningsvorm van de betreffende overeenkomst en de presentatie van die bedingen, niet had hoeven te verwachten in de set algemene voorwaarden waarvan hij de gelding heeft aanvaard, worden, ongeacht of aan de voorwaarden van $\$ 2$ AGBG is voldaan, geen contractsinhoud. ${ }^{148}$

In verband met de aanvaarding van de gelding van algemene voorwaarden dient eveneens \& 4 AGBG genoemd te worden, waarin wordt bepaald dat individuele afspraken, ongeacht of deze schriftelijk dan wel mondeling zijn, voorrang hebben boven daarmee strijdige algemene voorwaarden die, door de aanvaarding van de gelding van de gehele set, eveneens contractsinhoud zijn.

\section{$\$ 4$ Vorrang der Individualabrede}

Individuelle Vertragsabreden haben vorrang vor Allgemeinen Geschaftsbedingungen.

De regeling van $\S 4$ AGBG gaat uit van de opvatting dat algemene voorwaarden naar hun aard bedoeld zijn om individuele afspraken tussen partijen aan te vullen en niet om deze opzij te zetten. De bepaling legt daarom onomstotelijk vast dat bij inhoudelijke diversiteit tussen individuele afspraak en een beding in de algemene voorwaarden, het laatste altijd buiten toepassing blijft. ${ }^{149}$

\subsubsection{De gevolgen van niet-toepasselijkheid}

Algemene voorwaarden zijn pas toepasselijk indien aan alle eisen van $\$ 2$ Abs. 1 AGBG is voldaan. Indien slechts ten aanzien van een gedeelte van de algemene voorwaarden is voldaan aan de vereisten van $\S 2$ Abs. 1 AGBG, zijn slechts die algemene voorwaarden contractsinhoud geworden ten aanzien waarvan wél aan alle drie de gestelde eisen is voldaan. Partijen hebben op grond van het bepaalde in $\$ 2$ Abs. 2 AGBG echter de mogelijkheid overeen te komen dat bepaalde algemene voorwaarden zullen gelden voor een bepaald of onbepaald aantal tussen partijen te sluiten overeenkomsten van een bepaalde soort. Uiteraard geldt ook voor deze overeenkomst dat voldaan moet zijn aan de vereisten van $\$ 2$ Abs. 1 AGBG. ${ }^{150}$

Indien de voorwaarden van $\$ 2$ AGBG niet zijn vervuld en de betreffende algemene voorwaarden derhalve geen deel zijn gaan uitmaken van de overeen-

148 Zie unitwoerig: Begrindung, BT Drucksache 7/3919, pag. 19.20; Lindacher, AGBG Kommentar, 83; Ulmer, AGB-Gesetz, \$ 3. Zie ook: Jongeneel, diss., pag. 217.222.

149 Zie uitvoerig: Begründung, BT Drucksache 7/3919, pag. 20; Lindscher, AGBG Kommentar, 8; Ulmer, AGB-Gesetz; 4.

150 Zie uitwoerig: Begründung, BT Drueksache 7/3919, pag. 18; Wolf, AGBG Kommentar, 82 Rndni. 51 56; Ulmer, AGB-Gesetz, \& 2 Rndnr. 70-78. 
komst, of indien bepaalde bedingen op grond van $\$ 3$ AGBG niet toepasselijk zijn, regelt \& 6 AGBG de rechtsgevolgen daarvan.

\section{\$ 6 Rechtsfolgen bei Nichteinbexiehung und Unwirksamkeit}

(1) Sind Allgemeine Geschdfisbedingumgen ganz ader teilweise nicht Vertragsbestanditeil geworden oder unwirksam, sa bleibt der Vertrag im abrigen mirksam.

2) Soweit die Bestimmungen nicht Vermagsbestandieil gewarden oxler wnwinkam sind", nichtet sich der Inhalt des Vertrages nach den gesetzlichen Vorschriften.

3) Der Verrag ist unwinksam, wenn das Festhalten an Dhm auch unter Berücksichtigung der nach Absatz 2 worgesehemen, Anderung eine unzumutbarte Harte fiur eine Vertragspartei darstellen wille.

Uitgangspunt is dat de overeenkomst ook zonder de betreffende algemene voorwaarden in stand blijft (Abs. 1) en dat de door het wegvallen van deze bedingen ontstane hiaten in de overeenkomst worden ingevuld door het regelende recht (Abs. 2). De hoofdregel dat de overeenkomst voor het overige in stand blijft geeft uiting aan de gedachte dat in algemene voorwaarden slechts de modaliteiten van de overeenkomst worden geregeld en niet de essentialia. In het algemeen zal er geen bezwaar bestaan tegen het voortbestaan van de rompovereenkomst zonder de niet-toepasselijke voorwaarden. De overeenkomst is immers voldoende bepaalbaar. Daarbij zijn algemene voorwaarden regelcomplexen die de plaats hebben ingenomen van de in beginsel rechtvaardige rechtsregels die zonder die bedingen voor deze overeenkomst zouden gelden. Dat deze in beginsel evenwichtige regels weer herleven voor de overeenkomst is doorgaans dan ook geen probleem.

Voor zover de door het wegvallen van onredelijk bezwarende bedingen ontstane hiaten in de overeenkomst niet kunnen worden aangevuld door bepalingen van regelend recht, worden deze door aanvullende uitleg (ergänzende Vertragsauslegung), overeenkomstig de hypothetische wil van partijen, nader aangevuld. ${ }^{15 n}$

De Duitse wetgever achtte het niet uitgesloten, dat het niet toepasselijk zijn van de betreffende algemene voorwaarden éen der partijen bijzonder tot nadeel kan strekken. $\$ 6$ Abs. 3 AGBG bepaalt daarom dat de overeenkomst geheel vervalt indien de toepassing van $\S 6$ Abs. 1 en 2 AGBG leidt tot onaanvaardbare gevolgen voor één der partijen. ${ }^{152}$

151 Te vergelijken met de aanvullende werking van de redelijkheid en billijkheid van artikel 6:248 lid II BW. Zie hierover: Rijken, Redelijkheid en billijkheid, pag. 7-8.

152 Zie uitvoerig: Begründung "BT Druckssche 7/3919, pag. 20-22; Lindacher, AGBG Kommentar, 8; Ulmer, AGB-Gesetz, \& 6. Zie ook: Jongeneel, disa., pag. 174. 


\subsubsection{De inhoudstoetsing}

De kern van de Duitse regeling inzake algemene voorwaarden is ongetwijfeld de inhoudstoets zoals deze is neergelegd in de 889,10 en 11 van AGB-Gesetz. Aan de ene kant de open norm van $\$ 9$ AGBG en aan de andere kant een concrete uitwerking van die norm in twee lijsten van bedingen die geacht worden nietig te zijn als zij gebruikt worden in overeenkomsten met consumenten. Naar haar aard gaat aan de inhoudstoetsing van algemene voorwaarden de vaststelling van de inhoud van die voorwaarden vooraf. Alvorens op de inhoudstoets in te gaan bespreek ik eerst kort de Duitse rechtsregels met betrekking tot de uitleg van algemene voorwaarden.

\subsubsection{Uitlegregels voor algemene voorwaarden}

De uitleg van een beding in algemene voorwaarden bepaalt het object van de inhoudstoets van de \$\$ 9-11 AGBG. ${ }^{153}$ In beginsel zijn op de uitleg van algemene voorwaarden de algemene regels die voortvloeien uit de $\$ \S 133$ en 157 BGB van toepassing. Net als bij de uitleg van andere contractuele bedingen geldt voor de uitleg van algemene voorwarden in beginsel dat niet de woordelijke betekenis van een beding doorslaggevend is, maar de betekenis die partijen aan het beding hechten. Indien de uitleg van partijen overeenstemt is deze maatgevend ondanks een andersluidende objectieve uitleg. ${ }^{154}$

In de Duitse rechtspraak en literatuur is uit de algemene regels een aantal specifiek voor algemene voorwaarden geldende uitlegregels ontwikkeld ${ }^{155}$ :

- De regel dat algemene voorwaarden naar hun aard (genereller Maßstab) objectief en uniform dienen te worden uitgelegd. Dat wil zeggen dat bijzondere omstandigheden van het concrete individuele geval in beginsel buiten beschouwing dienen te blijven en dat slechts de typische omstandigheden zoals die gelden voor de kring van de wederpartijen maatgevend zijn voor de uitleg. ${ }^{156}$ Dit betekent dat bij de uitleg dient te worden nagegaan welke, uitgaande van de woordelijke tekst, de systematische plaats van het beding en de typische belangen van partijen bij het gegeven soort overeenkomsten, de economische betekenis en het doel van de betreffende voorwaarde is. ${ }^{157}$ Daarbij dient te worden uitgegaan van het begrijpvaardigheidsniveau van de doorsnee wederpartij bij dit soort overeenkomsten. Met uitzonderlijke

153 Lindacher, AGBG Kommentar, \& 5 Rndnr. 2.

154 BGH, NJW 1983, 2638; Lindacher, AGBG Kommentar, \& 5 Rndnr. 4; Ulmer, AGB-Gesetz, $\$ 5$ Rndnr. 24.

155 Zie ook: Jongeneel, dissi „pag. 156-161.

156 Lindacher, AGBG Kommentar, \$ 5 Rndnr. 5-16; Ulmer, AGB-Gesetz, \& 5 Rmdnr. 13-21.

157 BGH, NJW 1988, 12611-1262. 
begrijpvaardigheidsvermogens van wederpartijen mag pas rekening worden gehouden als dit uitzonderlijke begrijpvaardigheidsniveau typisch is voor de gehele kring van wederpartijen. ${ }^{158}$ Voor consumenten brengt dit doorgaans mee dat van hen geen bijzondere vak- of rechtskennis te verwachten is. Uitgangspunt is immers de rechtsonkundige doorsnee-consument die vaktechnische een leek is, ${ }^{159}$ in Duitsland wel eens aangeduid als "Otto Normalverbraucher". ${ }^{100}$ Als gevolg van de objectieve uitleg naar maatstaven van het typische begrijpvaardigheidsniveau van de kring van wederpartijen, zijn de ontstaansgeschiedenis van het beding en de wijze waarop het tot stand is gekomen in beginsel niet relevant voor de uitleg van het beding. $\mathrm{Zij}$ zijn in het algemeen immers niet bekend bij de wederpartij. ${ }^{161}$

- de regel dat voor de wederpartijen bezwarende clausules, zoals bij voorbeeld exoneratieclausules, naar reikwijdte zo beperkt mogelijk dienen te worden uitgelegd (Restriktionsprinzip). De ratio achter deze uitlegregel is dat men wederpartijen bij wege van uitleg beschermt tegen al te rigoureuze toepassing van bepaalde bedingen. In wezen was deze uitlegregel een verkapte inhoudstoets. Alhoewel deze regel ook in de rechtspraak van ná de inwerkingtreding van het AGB-Gesetz werd gehanteerd is men in de literatuur gaandeweg tot de opvatting gekomen dat er in het stelsel van het AGBGesetz met zijn strikte scheiding tussen uitleg en inhoudscontrole, nauwelijks nog ruimte is voor deze regel. ${ }^{162}$

- de contra proferentem-regel, inhoudende dat bij onduidelijkheden de algemene voorwaarden in het nadeel van de gebruiker moeten worden uitgelegd. Deze regel steunt op de gedachte dat diegene die eenzijdig de algemene voorwaarden opstelt er voor dient te zorgen dat deze begrijpelijk en eenduidig zijn. Indien de door hem opgestelde bedingen op meerdere wijzen zijn uit te leggen dient de opsteller het risico van deze door hemzelf gecreëerde onduidelijkheid te dragen. ${ }^{163}$

Alleen de laatste uitlegregel is uitdrukkelijk opgenomen in het AGB-Gesetz. $\$ 5$ AGBG bevat de zogenaamde Unklarheitenregel, dat wil zeggen dat indien algemene voorwaarden onduidelijk of op verschillende wijzen te interpreteren

158 Lindacher, AGBG Kommentar, \& 5 Rndnr. 12-13; Ulmer, AGB-Gesetz, \$ 5 Rndnr. 23.

159 Lindacher, AGBG Kommentar, \& 5 Rndnr. 12-13; Ulmer, AGB-Gesetz, \& 5 Rndnr. 23.

160 In żjn college op de studiedag over algemene voorwaarden in het grensovenschrijdende verkeer, georganiseerd door de Belgiseh.Duitse Juristenvereniging in 1991 te Aken, stelde F. Graf von Westphalen dat de doorsnee consument op grond van de rechtspraak getypeend kan worden als "der durehschnittliche Verbraucher mit unterdurchsehnittliche Kenntnisse".

161 Lindacher, AGBG Kommentar, 5 Rndmr. 15; Ulmer, AGB-Gesetz, 5 Rndnr. 22.

162 Ulmer, AGB-Gesetz, 5 Rndrur. 7 en 40-41. Anders: Lindacher, AGBG Kommentar, 5 Rndnr. 37-39.

163 Lindacher, AGBG Kommentar, \& 5 Rndnr. 24; Ulmer, AGB-Gesetz, \& 5 Rndur. 1. 
zijn, gekozen dient te worden voor de voor de wederpartij voordeligste uitleg. ${ }^{104}$

\section{Unklarheitenregel}

Zweiffl bei der Auslegung Algemeiner Geschaffsbedingungen gehen zu Lasten des Verwenders.

De regel veronderstelt de mogelijkheid van een meerduidige uitleg van een op zich begrijpelijk beding. Indien een beding niet begrijpelijk is, wordt het op grond van het bepaalde in $\$ 2$ AGBG immers niet tot contractsinhoud en komt men aan de toepassing van regell van $\$ 5$ AGBG niet toe. Aan de regel komt slechts geringe betekenis toe. $\$ 5$ AGBG heeft enkel betekenis indien na toepassing van de algemene uitlegregels een meerduidige betekenis van het beding resulteert. ${ }^{105}$

De regel ziet niet alleen op het gebruik van door de gebruiker zelf opgestelde algemene voorwaarden maar ook op het gebruik van door derden, al dan niet in overleg, opgestelde algemene voorwaarden. Voor de toepassing van de regel is de herkomst van het betreffende beding of een eventuele overheidsgoedkenring zonder betekenis. Een meerduidig beding wordt ongeacht de afkomst of overheidsgoedkeuring altijd ten gunste van de wederpartij uitgelegd. ${ }^{166} \mathrm{De}$ enige uitzondering op deze regel doet zich voor als de gebruiker bedingen hanteert die een letterlijke weergave zijn van wettelijke regels en deze wettelijke regels op zich een meerduidige uitleg toelaten. In dat geval rust het risico van de meerduidige uitleg niet op de gebruiker en dient het beding te worden uitgelegd conform de regels voor de uitleg van wettelijke bepalingen. ${ }^{167}$

De algemene uitlegregels van het BGB en de uitlegregel van $§ 5$ AGBG gelden in beginsel zowel in de individuele als abstracte procedure. Toch is er een duidelijk onderscheid tussen de toepassing van de regel van $\$ 5$ AGBG in de individuele procedure en de toepassing daarvan in de collectieve procedure. In tegenstelling tot de individuele procedure waarin bij niet-eenduidigheid van een beding wordt uitgegaan van de meest consumentvriendelijke uitleg, wordt naar algemene opvatting in literatuur en rechtspraak in de abstracte procedure van

164 BT Drucksache $7 / 3919$, pag. 47.

165 BGH, NJW 1979, pag. 2148; OLG Dügseldorf, NJW.RR 1990 , pag. 821; Lindacher, AGBG Kommentar, \$ 5 Rndnr. 28; Uliner, AGB-Gesetz; \& Rndnr. 25-27.

166 Lindacher, AGBG Kommentar, \$ 5 Rndnr. 25-26.

167 Lindacher, AGBG Kommentar, 5 Rndnr. 27. 
$\$ 13$ AGBG in het belang van een efficiènte en effectieve rechtspleging uitgegaan van de meest consumentonvriendelijke uitleg van het beding. ${ }^{\text {to }}$ gedachte achter deze opvatting is, dat het mogelijk moet zijn om een beding dat zowel een onredelijk bezwarende als een niet-onredelijk bezwarende betekenis in zich bergt door middel van een collectieve actie te lijf te gaan.

\subsubsection{De open norm van $\$ 9$ AGBG}

\$ 9-I AGBG bevat de zogenaamde "open norm" (Generalklausel) waarin bepaald wordt dat algemene voorwaarden nietig (unwirksam) zijn als zij de wederpartij van de gebruiker van algemene voorwaarden in strijd met de goede trouw onevenredig benadelen.

\section{$\$ 9$ Generalklausel}

(1) Bestümmungen in Allgemeinen Geschaftsbedingungen sind unwirksam, wenn sie den Verthagspartner des Venwenders enrgegen den Geboten won Treu und Glawben unangemessen benachreilfgent.

(2) Einve unangemessene Benachteiligung ist im Zweifel anzunehmen, wemin eine Bestimmung 1. Wit wesentichen Grundgedanken der gesetzlichen Regelang, won der abgewichen wird, nichi zi werieinbaren ist, ader.

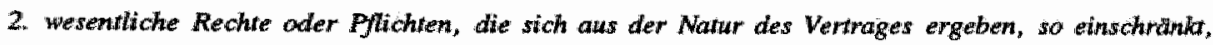
daff die Erreichung des Vertragszwecks gefahrdet ist.

In \$ 9-II AGBG wordt deze norm nader gespecificeerd. In twijfelgevallen dient er van uit te worden gegaan dat een beding unangemessen benachteiligend (verder te noemen: onredelijk bezwarend) is, indien de inhoud hiervan in strijd is met essentiële principes van de wettelijke regeling waarvan wordt afgeweken of indien de inhoud van het beding rechten en plichten die noodzakelijkerwijs uit de aard van de overeenkomst voortvloeien, op een zodanige manier opzij zet, dat het doel van de overeenkomst in gevaar komt.

\section{Uitgangspunten}

Belangrijkste uitgangspunt van de inhoudelijke toets van de $\$ 9$ AGBG is dat de algemene grenzen van de contractsvrijheid op het terrein van de algemene voorwaarden tekortschieten omdat de gebruiker van vooraf geformuleerde contractsbedingen de contractsvrijheid voor zich alleen opeist en de contractsvrijheid van de wederpartij beperkt tot het al dan niet contracteren. Daar de medewerking van de wederpartij aan de totstandkoming van algemene voor-

$168 \mathrm{BGH}$, ZIP 1984, pag. 1485-1486; BGH, NJW 1984, pag. 2161-2162; BGHZ 91, 55,61; BGH, NJW 1985, pag. 320-323; BGH, NJW 1988, 1726-1727; BGH, NJW-RR 1989, pag. 625-626; BGH, NJW 1991, pag. 1887; Lindacher, AGBG Kommenter, 5 Rndnr. 41-42; Ulmer, AGBGesetz. 5 Rndmr. 33-36. 
waarden ontbreekt kan deze zijn belangen niet behartigen. De inhoud van deze voorwaarden dient derhalve te worden onderworpen aan een verscherpte rechterlijke controle. ${ }^{169}$ Degene die de in beginsel voor beide partijen evenwichtige bepalingen van het regelende recht voor zijn overeenkomsten algemeen buiten werking stelt of die eenzijdig algemene regels opstelt voor die contractuele gebieden waarvoor geen wettelijke regels voorhanden zijn, is verplicht om daarbij naar maatstaven van redelijkheid en billijkheid (Treu und Glauben, $\S 242$ BGB) op een passende wijze rekening te houden met de belangen van de partijen bij die overeenkomst. ${ }^{170}$ Het AGB-Gesetz heeft dan ook vooral als doel een positieve bijdrage te leveren aan het totstandkomen van algemene voorwaarden die op een behoorlijke wijze rekening houden met de belangen van de wederpartij (Grundsatz des angemessenen Interessenausgleichs).

Dit doel tracht het AGB-Gesetz op de eerste plaats te bereiken door bepaalde typische clausules die worden gebruikt jegens consumenten zonder meer onredelijk bezwarend en nietig te verklaren in de $\$ \S 10$ en 11 AGBG. De casuistische regelingen van de $\$ \S 10$ en 11 AGBG hebben naar hun aard echter slechts een beperkte werking en kunnen nooit het hele terrein van de algemene voorwaarden bestrijken. Er zullen in een dynamische maatschappij altijd onredelijk bezwarende bedingen voorkomen die niet onder de lijsten van de \$\& 10 en 11 AGBG te vangen zijn. Derhalve worden de op specifieke bedingen gerichte verbodslijsten (Verbotskatalogen) van de $\$ \S 10$ en 11 AGBG geflankeerd door de algemene norm van \&9 AGBG, waarin de algemene beginselen van de inhoudstoets (Angemessenheitskontrole) van algemene voorwaarden zijn neergelegd. ${ }^{171}$ Een algemene (open) norm omdat de vraag of een beding in algemene voorwaarden onredelijk bezwarend is vaak afhangt van de aard van de concrete overeenkomst, de kenbare belangen van contractspartijen en de overige inhoud van de overeenkomst. De open norm van $\S 9$ AGBG is dan ook bedoeld als een vangnet voor de inhoudelijke toetsing van al die algemene voorwarden die niet onder het bereik van de lijsten van de $\$ \S 10$ en 11 AGBG vallen. ${ }^{12}$

De algemene toetsingsmaatstaf voor het al dan niet onredelijk bezwarende karakter van algemene voorwaarden is de redelijkheid en billijkheid van $\$ 242$ BGB. Daarmee wordt voortgebouwd op de rechtspraak die reeds vớr de totstandkoming van het AGBG-Gesetz is ontwikkeld. Het BGH baseerde de inhoudstoets van algemene voorwaarden immers reeds vanaf 1956 voornamelijk op de redelijkheid en billijkheid van $\$ 242$ BGB. Voor het door haar bestreken

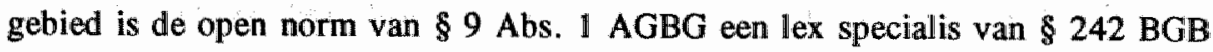

169 Begründung, BT Drucksache 7/3919, pag. 22; Wolf, \& 9 Rndnr. 1; Ulmer, AGB-Gesetz, \& 9 Rndinr. 1.

170 Begründung, BT Drucksache 7/3919, pag. 22.

171 Begrindung, BT Drucksache 7/3919, pag. 22.

172 Begründung, BT Druckasche 7/3919, pag. 22; Brandner, AGB-Gesetz, 89 Rndnir. 8. 
en derogeert de Generalklausel dus aan de redelijkheid en billijkheid. Bij de inhoudscontrole van algemene voorwaarden blijft $\$ 242$ BGB derhalve buiten toepassing. Wél kan een beroep worden gedaan op $\$ 242$ BGB in die gevallen die niet onder het bereik van de inhoudscontrole vallen of bij misbruik van recht van een op zich niet-onredelijk bezwarend beding. ${ }^{174}$

Naar maatstaven van redelijkheid en billijkheid is echter niet elk beding dat voor de wederpartij bepaalde ongemakken of nadelen met zich brengt ook tevens onredelijk bezwarend. Voor de kwalificatie onredelijk bezwarend is veeleer een nadeel of ongemak van enig gewicht vereist. ${ }^{175}$ De redelijkheid en billijkheid is dan weer de maatstaf voor de vaststelling van het onredelijkheidsgehalte van te beoordelen bedingen. ${ }^{176}$

De in $\$ 9$ Abs. 1 AGBG neergelegde toetsmaatstaf brengt met zich dat de inhoudscontrole van $\$ 9$ AGBG zich niet dient te beperken tot het enkele tegengaan van eenzijdig misbruik van algemene voorwaarden. De inhoudscontrole dient zich naar haar aard verdergaand te richten op het positieve gebod dat algemene voorwaarden inhoudelijk op evenwichtige wijze rekening dienen te houden met de belangen van beide partijen (Gebot des angemessenen Interessenausgleichs). ${ }^{17}$ Dit verdergaande doel van de inhoudstoets van $\$ 9$ AGBG wordt als volgt gemotiveerd:

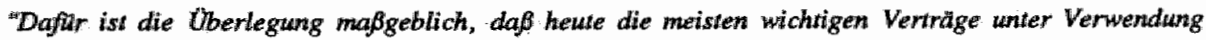
von AGB abgewickelt werden, es dem im Grundgesetz verankerten Prinzip des Sozialstavats jedoch werig entsprechen wirde, wenn die Masse dieser Rechtsgeschafte mit Hilfe won AGB - gegebenenfrils bis zur Mißbrauchsgrenze - einseitig zum Nachteil des AOB-Unterworfenten gestaliet werden dinfite. 2178

In de rechtspraak is dit verdergaande streven inmiddels nader begrensd. De inhoudscontrole is niet gericht op het, vanuit het perspectief van de wederpartij, bewerkstelligen van de meest optimale contractsinvulling, doch op het tegengaan van onredelijke benadeling van de wederpartij. ${ }^{179}$

Zoals reeds eerder gemeld is de inhoudstoets van de $\$ \$ 9$ tot en met 11 AGBG op grond van de bepaling in $\$ 8 \mathrm{AGBG}$ beperkt tot bedingen die of in een van de wet of het geldende recht afwijkende regeling voorzien of die een wettelijke

173 Wolf, AGBG Kommentar, 9 Rndnr. 25 .

174 Wolf, AGBG Kommentar, \& 9 Rndnr. 24, Brandner, AGB-Gesetz, 9 Rndnr. 36.

175 Begründung, BT Drucksache 7/3919, pag. 23; BT Drucksache 7/5422, pag. 6; Wolf, AGBO Kommentar, \&9 Rndnr. 100.

176 Wolf, AGBG Kommentar, 9 Rndnr. 114.

177 Begründung, BT Drucksache 7/3919, pag. 22.

178 Begründung, BT Drucksache 7/3919, pag. 22.

179 BGH, NJW 1986, pag. 2369; Wolf, AGBG Kommentar, \& 9 Rndnr. 2. 
regel of rechtsregel aanvullen. ${ }^{100}$ Bedingen die in strijd zijn met een dwingendrechtelijke wetsbepaling zijn echter nietig op grond van het bepaalde in

$\$ 134$ BGB of nietig op grond van een direct op die dwingende regeling gerichte wettelijke bepaling. Bedingen die in strijd zijn met een dwingendrechtelijke wetsbepaling kunnen echter ook bij wege van een beroep op $\& 9$ AGBG worden vernietigd. ${ }^{181}$ De toetsen van $\$ 134 \mathrm{BGB}$ en $\$ 9$ AGBG sluiten elkaar niet uit. Dit is vooral van belang voor de collectieve actie van $\$ 13$ AGBG. Een beding dat in strijd is met de wet zou anders niet te bestrijden zijn met de collectieve actie als bedoeld in $\$ 13$ AGBG. ${ }^{182}$

Indien in algemene voorwaarden geen acht wordt geslagen op essentiële principes van een wettelijke regeling of essentiële rechten en plichten op een dusdanige wijze worden beperkt of uitgebreid dat het contractuele doel in gevaar komt, doet dit vermoeden dat een behoorlijke belangenafweging niet heeft plaatsgevonden en de betreffende bedingen voor de wederpartij onredelijk bezwarend zijn. Dit uitgangspunt is neergelegd in Absatz 2 van $\$ 9$ AGBG. ${ }^{13}$ De bepaling van $\$ 9$ Abs. 2 AGBG heeft ten doel de inhoudscontrole van algemene voorwaarden te vereenvoudigen door het verschaffen van twee criteria die een indicatie geven van het ontbreken van een behoorlijke belangenafweging. Indien een van de in lid 2 van $\S$ AGBG genoemde situaties zich voordoet, wordt het betreffende beding vermoed onredelijk bezwarend te zijn en kan het betreffende beding slechts onder bijzondere, door de gebruiker aan te tonen, omstandigheden rechtens in stand blijven. ${ }^{184}$

Het criterium in $\S 9$ Abs. $2 \mathrm{Nr}$. 1 AGBG sluit aan bij de in de rechtspraak ontwikkelde grondbeginselen omtrent de voorbeeldfunctie van de geschreven en ongeschreven normen van het regelende recht (die Leitbildfunktion des dispositieven Rechts). ${ }^{185}$ Tot het dispositieve recht worden gerekend: de wet (dus ook de algemene bepalingen van het AGB-Gesetz), het ongeschreven recht maar ook de voor bepaalde overeenkomsten typische rechtsbeginselen. ${ }^{186}$ Hoewel de regeling van $\$ 9$ Abs. $2 \mathrm{Nr}$. 1 AGBG niet ziet op dwingendrechtelijke wetsbepalingen, bedingen die in strijd zijn met dwingendrechtelijke wetsbepalingen zijn immers nietig op grond van het bepaalde in $\$ 134$ BGB of nietig op grond van

$180 \mathrm{Zie}$ hiervoor paragraf 6.2.1.1.

181 BGH, BB 1983, pag. 524-527.

182. Wolf, AGBG Kommentar, 9 Rndnr. 10.

183 Begründung, BT Drucksache 7/3919, pag. 22.

184 Begruindung, BT Drucksache 7/3919, pag. 22; Wolf, AGBG Kommentar, \& 9 Rndnr. 57-58;

Brandner, AGB-Gesetz, \& 9 Rndnr. 121.

185 Begrindung, BT Drucksache 7/3919, pag. 23; Brandner, AGB-Gesetz, \$ 9 Rndnr. 124.

186 Brandner, AGB-Gesetz, \$ 9 Rndnr. 124-128. 
een direct op die dwingende regeling gerichte wettelijke bepaling, kunnen deze dwingendrechtelijke wetsbepalingen wel een voorbeeldfunctie hebben bij de uitleg van andere normen. ${ }^{187}$

Niet elke afwijking van thet regelende recht met daarmee gepaard gaand verlies van rechten voor de wederpartij dient echter te leiden tot de nietigheid van de betreffende algemene voorwaarde. Een beding is slechts nietig indien het in strijd is met wezenlijke grondbeginselen van de wettelijke regeling waarvan wordt afgeweken. ${ }^{188}$ Aangezien de bepaling van $\$ 9$ Abs. 2 Nr. 1 AGBG een uitwerking is van de algemene norm van $\S 9$ Abs. 1 AGBG treedt het wettelijk vermoeden van nietigheid enkel in als wordt afgeweken van wezenlijke grondgedachten van een wettelijke regeling die zien op de bescherming van de belangen van de wederpartij. ${ }^{129}$ In de rechtspraak is met betrekking tot de voorbeeldfunctie van het regelend recht wel eens het onderscheid gemaakt tussen enerzijds regels met een ordenend karakter en anderzijds regels met een normerend karakter. ${ }^{190}$ Gedachte achter dit onderscheid is dat afwijking van regels met een ordenend karakter eerder is toegestaan dan afwijking van regels met een normerend karakter. In de literatuur wordt dit onderscheid echter algemeen als weinig relevant beschouwd. ${ }^{191}$

Het in $\$ 9$ Abs. 2 Nr. 2 AGBG neergelegde criterium sluit eveneens aan bij een in de rechtspraak ontwikkeld beginsel. De regel dat bedingen, die wezenlijke plichten of rechten die uit de overeenkomst zonder het beding zouden voortvloeien, op een dusdanige wijze beperken dat daardoor het bereiken van het contractsdoel in gevaar komt, slechts onder bijzondere, door de gebruiker aan te voeren, omstandigheden rechtens in stand kunnen blijven. ${ }^{192}$

$\$ 9$ Abs. 2 Nr. 2 AGBG is in beginsel geschreven voor die gevallen waarin een wettelijke regeling, die als richtsnoer kan dienen, ontbreekt. ${ }^{193}$ Sommige schrijvers menen dat door de vangnetwerking van $\$ 157$ BGB in combinatie met $\$ 242$ BGB (te vergelijken met de aanvullende werking van de redelijkheid en billijkheid in Nederland) in principe elke contractuele mogelijkheid wettelijk geregeld is en $\$ 9$ Abs. 2 nr. 2 AGBG derhalve geen zelfstandige betekenis toekomt naast $\$ 9$ Abs. $2 \mathrm{Nr}$. 1 AGBG. ${ }^{194}$ Een zuivere begrenzing tussen de

187 BGHZ 87, 17; BGH, NJW 1983, 1322; Wolf, AGBG Kommentar, 9 Rndnr. 68.

188 Begründung, BT Drucksache, pag. 23.

189 Wolf, AGBG Kommentar, 9 Rndnr. 70; Brandner, AGB-Gesetz, 9 Rndrur. 124.

190 BOH, NJW 1984, pag. $1182 ;$ BGH, NJW 1985, parg. 57.

191. Wolf, AGBG Kommentar, 9 Rndnr. 71; Brandner, AGB-Gesetz, 9 Rndnr. 124. Zie ook: Jongeneel, disis., pag. 186-187.

192 Begründung, BT Drucksache 7/3919, pag. 23.

193 Wolf, AGBG Kommentar, 9 Rndnr. 82; Brandner, AGB-Gesetz, \& Rndnr. 130.

194 Brandner, AGB-Gesetz, 9 Rndmr. 130; Kötz, Münchener Kommentar $\$ 9$ AGBG Rndnr. 15. 
bepaling van $\mathrm{Nr} .1$ en $\mathrm{Nr} .2$ van lid 2 van 9 AGBG is derhalve niet altijd duidelijk te trekken.

De wezenlijke rechten en plichten (Kardinalrechte und Kardinalpflichten) vloeien voornamelijk voort uit de aard van de gesloten overeenkomst (die Natur des Vertrages). ${ }^{195}$ De wezenlijke rechten en plichten die wit de aard van de overeenkomst voortwloeien zijn die rechten en plichten die op grond van de redelijkheid en billijkheid en de verkeersopvattingen typisch zijn voor dat soort overeenkomsten en die de betrokken kring van contractanten redelijkerwijs had mogen verwachten. Tot de wezenlijke rechten en plichten die uit een overeenkomst voortvloeien behoren niet alleen de hoofdverplichtingen in een wederkerige overeenkomst maar ook de nevenverplichtingen die voor de wederpartij van wezenlijk belang züjn voor het bereiken van het contractsdoel. ${ }^{197}$ Voor de toepassing van $\$ 9$ Abs. $2 \mathrm{Nr} .2 \mathrm{AGBG}$ is niet vereist dat het contractsdoel daadwerkelijk niet wordt bereikt. Voldoende is de mogelijkheid dat het contractsdoel geheel of gedeeltelijk niet wordt bereikt. ${ }^{198}$

Tenslotte brengt de toepasselijkheid van de maatstaven van redelijkheid en billijkheid voor de inhoudstoets van $\$ 9$ AGBG tevens met zich, dat de gebruiker zelf geen beroep kan doen op de nietigheid van zijn eigen algemene voorwaarden omdat zij voor hemzelf onredelijk bezwarend zouden zijn. ${ }^{\text {घ99 }}$

\section{Algenene inhoudstoets}

De in $\$ 9$ AGBG vastgelegde norm is een algemene, op de redelijkheid en billijkheild geënte toetsnorm (Genereller Prüfungsmaßstab) voor algemene voorwaarden. In de literatuur en rechtspraak is men algemeen van opvatting dat, net als bij de uitleg van algemene voorwaarden, deze toets zich op grond van het algemene karakter van algemene voorwaarden niet richt op de individuele belangen en omstandigheden van elke wederpartij afzonderlijk, maar op de typische belangen en omstandigheden van de kring der wederpartijen jegens wie de betreffende algemene voorwaarden worden gehanteerd (uberindividuell-generalisierende Betrachtungsweise). ${ }^{200}$

195 Wolf, AGBG Kommentar, \& 9 Rndnr. 83; Brandner, AGB-Gesetz, 9 Rndar. 131 .

196 Woll, AGBG Kommentar, $\$ 9$ Rndinr. 84-88; Brandner, AGB Gesetz, 9 Rndnr. 131-133. Zie ook: Jongeneel, disis., pag. 187.

197 Wolf, AGBG Kommentar; 89 Rndmr. 89; Brandner, AGB-Gesetz, 8 Rndnr. 132. 437-438.

198 Heinrichs, BGB (Pelandt), AGBG 9 Nr. 4; Wolf, AGBG Kommentar, 9 Rndnr. 92; Brandner, AGB-Gesetz, \& 9 Rndur. 133.

199 Begründung, BT Drucksache 7/3919, pag. 23.

200 BGH, NJW 1982, pag. 765; BGH, NJW 1982, pag. 1391.1392; BGH, NJW 1987, pag. 4874818; BGH, NJW 1993, pag. 2369-2371; Wolf, AGBG Kommentar, 9 Rndrur. 51; Brandiner, AGB-Gesetz, 9 Rndnr. 75-76. Zie ook: Jongeneel, diss., pag. 188. 
De inhoudstoets van $\S 9$ AGBG geeft derhalve antwoord op de vraag of een bepaald beding in algemene voorwaarden onredelijk bezwarend is voor de kring van wederpartijen en niet of het beding onredelijk bezwarend is voor de concrete individuele wederpartij. Dit betekent enerzijds dat een beding dat onredelijk bezwarend is voor de kring der wederpartijen maar in de concrete omstandigheden van het individuele geval niet onredelijk bezwarend uitpakt toch nietig is op grond van het bepaalde in $\$ 9 \mathrm{AGBG}^{201}$ en anderzijds dat een beding dat in het concrete individuele geval onredelijk bezwarend uitpakt voor die ene wederpartij maar algemeen gezien, met het oog op de belangen van de kring der wederpartijen, niet onredelijk bezwarend is, ook niet getroffen wordt door de nietigheid van $\S 9$ AGBG. ${ }^{202}$ Wel is het onder omstandigheden mogelijk dat de gebruiker het beroep op het beding dat algemeen gezien niet onredelijk bezwarend is maar in het specifieke individuele geval juist wel, wordt ontzegd op grond van de redelijkheid en billijkheid van $\S 242$ BGB (misbruik van recht/Unzulässige Rechtsausübung). ${ }^{203}$

De inhoudstoets in de abstracte procedure van $\$ 13$ AGBG is naar haar aard gericht op de typische belangen en omstandigheden zoals die gelden voor de kring der wederpartijen jegens wie de in het geding zijnde clausule wordt gehanteerd. ${ }^{204}$ In die zin is er geen verschil tussen de inhoudstoets in de individuele procedure en de inhoudstoets in de collectieve procedure van $\S 13$ AGBG. ${ }^{205}$ In Duitsland kan het onderscheid tussen abstracte en concrete inhoudstoets derhalve niet worden gehanteerd ter onderscheiding van de individuele en de collectieve inhoudstoets. Beide inhoudstoetsen zijn immers nagenoeg even abstract of, zo men wil, even concreet.

Nagenoeg, omdat de individuele inhoudstoets zich in én opzicht wel onderscheidt van de collectieve inhoudstoets. De inhoudstoets in de individuele procedure richt zich op en is beperkt tot de typische belangen en omstandigheden van de kring der wederpartijen bij én concrete overeenkomst met een specifiek onderwerp. In de individuele procedure staat immers het daadwerkelijk gebruik van een (bepaald) beding in algemene voorwaarden in een concrete rechtsrelatie ter discussie. Daarentegen is het onderwerp van de inhoudstoets bij de collectieve procedure noodzakelijkerwijs het beding op zichzelf, los van concrete omstandigheden. In de collectieve procedure hoeft zelfs geen sprake te zijn van een concreet gebruik van algemene voorwaarden..$^{206}$ Concrete omstan-

201 BGH, NJW 1986, pag. 842.

202 BGH, NJW 1982, pag. 644-646; Wolf, AGBG Kommentar, \& 9 Rndnr. 140.

203. Wolf, AGBG Kommentar, 9 Rndnr. 26-27 en 51; Brandner, AGB-Gesetz, 89 Rndnr. 78.

204 Wolf, AGBG Kommentar, 9 Rndnr. 51; Brandner, AGB-Gesetz, 9 Rndnr. 76.

205 BGH, NJW 1983, pag. 1603-1604; OLG Köln, NJW 1983, pag. 1002-1003; BGH, NJW 1982, pag. 765; Wolf, AGBG Kommentar, 9 Rndnr. 51.

206 Wolf, AGBG Kommentar, 9 Rndnr. 54. 
digheden kunnen in de collectieve procedure derhalve niet mee worden gewogen.

\section{De relewante omstandigheden}

Het belangrijkste criterium voor de toetsing van algemene voorwaarden is de redelijkheid en billijkheid van $\$ 242$ BGB. Door het toepasselijk verklaren van de redelijkheid en billijkheid geeft $\$ 9$ AGBG een open norm voor de inhoudstoetsing van algemene voorwaarden.

In $\$ 9$ AGBG worden geen bijzondere omstandigheden aangegeven die relevant zijn voor de inhoudelijke beoordeling van een beding. In beginsel zijn alle typische omstandigheden van het geval relevant voor de inhoudstoets. Tijdens de parlementaire behandeling worden echter uitdrukkelijk reeds een aantal relevante omstandigheden genoemd:

"Bei Beurteilung eüner bestimmsten Einzellklausel wird haufig eine wertende Borücksichtigung anderer Vertragsbestimmungen notwendig sein. Femer gebieten Trew und Giauben Räkssichmahme auf die Eigenanen der Geschafisbetiehwngen, auf den beteiligten Verkehrskreisen verankerten Anschausongew von Recht und Gerechtigkeit oder awch auf den Lebensbereich, in dem die Vertragspartner witig werden.

De rechtspraak en literatuur hebben zich hierbij aangesloten. De volgende omstandigheden worden met name van belang geacht voor de inhoudstoets:

- de aard van de overeenkomst;

- de hoedanigheid van de bij de overeenkomst betrokken partijen;

- de wederzijds kenbare belangen;

- de overige inhoud van de overeenkomst;

- de wijze van totstandkoming;

- de verkeersopvattingen en gewoonte;

- de verzekerbaarheid van het risico;

- de bepaabaarheid en duidelijkheid van het beding;

- algemene belangen.

De aard wan de overeenkomst is een van de bepalende factoren bij de inhoudstoetsing van algemene voorwaarden. Met de aard van de overeenkomst wordt gedoeld op de specifieke eigemaardigheden en kenmerken van het soort overeen-

207 BGH, NJW 1991, pag. 36; BGH, NJW 1992, pag. 179-180; BGH, NJW 1992, pag. 503.

208 Begründung, BT Drucksache 7/3919, pag. 22-23.

209 Heinrichs, BGB (Palandt), AGBG 9 Nr. 2; Wolf, AGBG Kommentar, 9 Rndnr. 118-139; Brandner, AGB-Gesetz, \$ Rndnr. 79-120. 
komst, het onderwerp van de overeenkomst en de belangen die daarmee zijn gemoeid. ${ }^{210} \mathrm{Zo}$ zal bij voorbeeld de risicoverdeling tussen partijen ten aanzien van gebreken aan het verkochte bij de koop van nieuwe auto's aanmerkelijk anders liggen dan bij de verkoop van tweede-hands auto' ${ }^{211}$, zullen exoneratieclausules in de ene branche wél en in de andere niet zijn toegelaten ${ }^{212}$ en zal bij overeenkomsten met betrekking tot de levering van stroom rekening moeten worden gehouden met de belangen van het collectief van afnemers. ${ }^{213}$

De hoedanigheid van de bij de overeenkomst betrokken partijen is eveneens een omstandigheid die mede bepalend is voor de inhoudstoets van $\$$ AGBG. Ofschoon de inhoudstoets van $\S 9$ AGBG geen rekening houdt met specifieke individuele omstandigheden richt hij zich wel op de typische belangen en beschermingsbehoefte van de bij de overeenkomst betrokken (kringen van) partijen. ${ }^{214}$ Daarbij is met name van belang of de wederpartij handelt in de uitoefening van zijn beroep of bedrijf of dat het een consument betreft. De beschermingsbehoefte van degene die beroeps- of bedrijfsmatig handelt, zal in het algemeen minder zijn dan die van consumenten. ${ }^{215}$

Uit de redelijkheid en billijkheid vloeit voor contractspartijen de verplichting voort om op gepaste wijze rekening te houden met de wederzijds kenbare belangen. Voor algemene voorwaarden betekent dit dat moet worden nagegaan of de gebruiker in voldoende mate rekening heeft gehouden met de belangen van de wederpartij. Daarom dient de inhoudstoets van $\$ 9$ AGBG zich te richten op een objectieve afweging van de wederzijdse belangen van partijen bij de betreffende overeenkomst. ${ }^{216}$ Niet elk beding dat gezien de belangen van de wederpartij voor deze bezwarend is, is daarmee ook onredelijk bezwarend. Een beding is pas onredelijk bezwarend als de gebruiker enkel oog heeft voor zijn eigen belangen en in onvoldoende mate rekening houdt met de belangen van zijn wederpartij. ${ }^{217} \mathrm{Bij}$ de beantwoording van de vraag of de gebruiker voldoende rekening heeft gehouden met de belangen van zijn wederpartij wordt het belang van de (kring van) wederpartij(en) afgezet tegen het belang dat de gebruiker

210 BGH, NJW 1986, pag. 2102; Heinrichs, BGB (Palandt), AGBG 9, Nr. 2; Wolf, AGBG Kommentar, 9 Rndnr. 119; Brandner, AGB-Gesetz, 9 Rndnr. 79; Jongeneel, diss., parg. 193.

211 BGHZ 74, 383, NJW 1979, pag. 1886.

212 BGH, NJW 1988, pag. 1785.

213 BGHZ 64, 355; Brandner, AGB-Gesetz, 9 Rndnr. 79.

214 BGilZ 22, 90, 96; Wolf, AGBG Kommentar, 9 Rndnr. 120-128; Ulmer, AGB-Gesetz, 9 Rndnr. 115-116.

215 Wolf, AGBG Kommentar, 9 Rndnr. 121-128; Brandner, AGB-Gesetz, \& 9 Rndhr. 115.

$216 \mathrm{BGH}_{\text {。 }}$ ZIP 1987, pag. 1457, NJW 1988, pag. 258-259; BGH, ZIP 1987, pag. 1582-1583.

217 BGHZ 74, 383, 390; BGH, NJW 1981, pag. 117-118; BGH, NJW 1982, pag. 178. 
heeft bij de rationalisering van de contractuele verhouding. ${ }^{218}$ Voor dit laatste belang hoeven echter niet alle belangen van de wederpartij te wijken, of, zoals Wolf het uitdrukt:

"Das Ravionalisterimgsimueresse kam sich nur instoweit durchsetzen, als es die Interessen der anderen Vertragspartei angemessen beracksichtigt. Bedarfinisse der anderen Vertragspartei, die wertwoller sind als das Rationalisierwangsinteresse, mossen auch in $A G B$ bericksichtigt werdem. 219

Van een onvoldoende rekening houden met de belangen van de wederpartij is sprake als de gebruiker geen rekening heeft gehouden met belangen van de wederpartij die van meer importantie zijn als zijn belang bij rationalïsering. ${ }^{220}$

Het toetscriterium de overige inhoud van de overeenkomst ziet op het feit dat een ter beoordeling staande clausule deel uitmaakt van een regelcomplex. De inhoud, de strekking en het onredelijk bezwarend karakter van het betreffende beding dienen te worden beoordeeld vanuit de samenhang van het beding met de rest van de overeenkomst. ${ }^{221}$ Een op het eerste gezicht onredelijk bezwarend beding kan vanwege de samenhang met een compenserend voordeel in een ander beding haar onredelijk bezwarend karakter verliezen en andersom kan een beding dat op zichzelf beschouwd niet onredelijk bezwarend is door zijn samenhang met een ander bezwarend beding onredelijk bezwarend zijn. ${ }^{222}$

Als criterium dat eveneens van belang is voor de inhoudstoets van algemene voorwaarden wordt de wijze van totstandkoming genoemd. ${ }^{223}$ Daarbij is vooral bepalend of de ter toetsing voorliggende algemene voorwaarden zijn tot stand gekomen in onderling overleg tussen marktpartijen die betrokken zijn bij de overeenkomst waarop die yoorwaarden zien. Met de tweezijdigheid van zulke algemene voorwaarden dient in die zin rekening te worden gehouden dat individuele bedingen die deel uitmaken van een tweezijdig vastgesteld regelcomplex moeten worden beoordeeld in het licht van het gehele regelcomplex (Gesamtwürdigung). ${ }^{224}$ De overeenstemming tussen marktpartijen is immers

218 Begrindung, BT Drucksache 7/3919, pag. 9; BGH, NJW 1981, pag. 117-118; Wolf, AGBG Kommentar, 9 Rndnr. 55; Brandner, AGB-Gesetz, 9 Rndinr. 110.

219 Wolf, AGBG Kommentar, \$ 9 Rndnr. 55.

220 Wolf, AGBG Kommentar, \& 9 Rndnr. 114. Zie voor een overzicht van jurisprudentie: Jongeneel, diss., pag. 193-194.

221 Wolf, AGBG Kommentar, \& 9 Rndinr. 132; Branener, AGB-Gesetz, \& 9 Rndnr. 81-82.

222 Wolf, AGBG Kommentar, 9 Rndmr. 133-134; Brandner, AGB-Gesetz, 9 Rndinr. 81-82. Zie ook: Jongeneel, disss, pag. 193-194.

223 Wolf, AGBG Kommentar, 9 Rndnr. 125-127; Heinrichs, BGB (Palandt), AGBG 9 Nr. 2. 224 BGH, NJW 1982 , pag. 1820. 
grericht op het gehele regelcomplex en het daarin bereikte evenwicht tussen de belangen van gebruikers en wederpartijen. Er dient dan ook voor te worden gewaakt dat een geissoleerde beoordeling van een beding het bereikte evenwicht in het complex van regels niet onnodig verstoort. ${ }^{205}$

Het feit dat sprake is van tweezijdig tot stand gekomen algemene voorwaarden heeft overigens geen enkele invloed op het toetscriterium van de $\$ \$ 9$ tot en met 11 AGBG, dit blijft hetzelfde. ${ }^{22 *}$ De medewerking van marktpartijen kan immers geen legitimatie zijn voor het gebruik van onredelijk bezwarende algemene voorwarden. 227

De regel dat rekening moet worden gehouden met de wijze waarop de betreffende voorwaarden zijn tot stand gekomen is in dat licht slechts een uitwerking van het toetscriterium dat dient te worden gelet op de overige inhoud van de overeenkomst. Bij twijfel van de rechter zall het feit dat de betreffende bedingen tweezijdig tot stand zijn gekomen echter invloed hebben op zijn beslissing. Tweezijdig vastgestelde algemene voorwaarden doorstaan in dat geval eerder de inhoudstoets dan eenzijdig vastgestelde voorwaarden of voorwaarden die slechts door een deel der betrokken marktpartijen zijn opgesteld. 228

Voor algemene voorwaarden in het handelsverkeer heeft het feit dat deze de vrucht zijn van overleg tussen marktpartijen tot gevolg dat deze eerder contractsinhoud worden op grond van gebruik of gewoonte dan algemene voorwaarden die eenzijdig zijn opgesteld. ${ }^{220}$

De verkeersopvattingen en gewoonte spelen vooral een rol bij de inhoudstoetsing van algemene voorwaarden die worden gehanteerd in het handelsverkeer. $\$ 24$ AGBG bepaalt immers uitdrukkelijk dat in zulk geval mede acht moet worden geslagen op de in het handelsverkeer geldende gewoonten en gebruiken. Ook bij de inhoudstoetsing van algemene voorwaarden die worden gehanteerd in het rechtsverkeer met consumenten spelen de verkeersopvattingen en gewoonte een rol. 230

225 BGH, NJW 1983, pag. 816-818; BGH, NJW 1988, pag. 55; BGH, NJW-RR 1991, pag. 570 572.

226 Wolf, AGBG Kommentar, 9 Rndinr. 129.

227 Wolf, AGBG Kommentar, 9 Rndnr. 129.

$228 \mathrm{BGH}$ ZIP 1987, pag. 989-991; BGH, NJW 1988, pag. 55-56; Wolf, AGBG Kommentar, 9 Rndnr. 129. Zie ook: Jongeneel, pag. 194-195.

229 Wolf, AGBG Kommentar, 9 Rndnr. 129.

230 Brandner, AGB-Gesetz, 8 Rndnr. 111-112. 
De rol van verkeersopvattingen en gewoonte bij de inhoudstoets wordt echter beperkt door de grenzen die de redelijkheid en billijkheid aangeven. ${ }^{231}$ Het feit dat een bepaald beding algemeen of in een bepaalde branche gebruikelijk is, sluit de inhoudstoets van 9 AGBG niet uit en is eveneens geen doorslaggevende factor bij de inhoudstoets van $\$ 9$ AGBG. ${ }^{232}$ Het gebruik kan echter wel een indicatie zijn dat het beding door de betrokken marktpartijen als doelmatig en niet-onredelijk bezwarend wordt gezien; aan het gebruik of de verkeersopvattingen die leven bij de betrokken marktpartijen mag bij de inhoudstoets daarom niet zonder meer voorbij worden gegaan. ${ }^{233}$ Met gebruik en verkeersopvattingen wordt overigens slechts rekening gehouden bij de inhoudstoets, indien zij door alle betrokken marktpartijen bekend en erkend zijn. ${ }^{234}$

Met name bij de toetsing van exoneratieclausules speelt ook de verzekerbaarheid van het risico een duidelijke rol. Een afgewogen verdeling van het schaderisico wordt immers allereerst beïnvloed door de vraag of een bepaald risico te verzekeren is en vervolgens de vraag op wiens weg het ligt de verzekering af te sluiten, de premie te betalen en de schadeafwikkeling op zich te nemen. ${ }^{235}$

Voor een aantal beroeps- en bedrijfsgroepen is het wettelijk verplicht zich voor wettelijke aansprakelijkheid te verzekeren. Ook branche- en beroepsorganisaties gaan er steeds meer toe over hun leden een WA-verzekeringsplicht op te leggen en in steeds meer bedrijfstakken is het gebruik dat men zich verzekert voor de beroeps- of bedrijfsaansprakelijkheid. In die gevallen is het principieel uitgesloten dat een gebruiker ter afwering van de onredelijk bezwarendheid van een beding, aanvoert dat het op de weg van de wederpartij ligt zich tegen dit risico te verzekeren. ${ }^{236}$

Een verder toetscriterium is de bepaalbaarheid en duidelijkheid van het beding (Transparenzgebot). Het Transparenzgebot, dat in het AGB-Gesetz een promi-

231 BGH, NJW 1973, pag. 991; BGH, NJW 1982, pag. 644-645; BGH, NJW 1989, pag, 592; BGH, NJW 1991, pag. 1677; BGH, NJW 1991, pag. 2414; Wolf, AGBG Kommentar, o 9 Rndnr. 131; Brandner, AGB-Gesetz, pag. 426.

232 BGH, NJW 1984, pag. 2160; BGH, NJW 1985, pag. 3016-3017, BB 1984, pag. 939; BGH, NJW 1991, pag. 1677; BGH, NJW 1991, pag. 2414-2416; Wolf, AGBG Kommentar, 9 Rndnr. 131; Brandner, AGB-Gesetz, 9 Rndnr. 111.

233 BGH, NJW 1982, pag. 1820; BGH, NJW 1985, pag. 3016; BGH, NJW 1986, pag. 1434-1435; BGH, NJW 1987, pag. 1931; Wolf, AGBG Kommentar, 9 Rndnr. 131; Brandner, AGBGesetz, \$9 Rndnr. 111 .

234 Wolf, AGBG Kommentar, 9 Rndnr. 131.

235 BGH, JZ 1979, pag. 346; Brandner, AGB-Geset, \& 9 Rndnr. 107-108.

236 OLG Stuttgart, NNW 1979, pag. 2355; Brandner, AGB-Gesetz, \$9 Rndnr. 109. 
nente plaats inneemt ${ }^{237}$ en dat de laatste jaren in de rechtspraak op het terrein van de algemene voorwaarden steeds meer aanhang vind ${ }^{238}$, vereist dat algemene voorwaarden qua vormgeving en formulering dusdanig zijn opgesteld dat de wederpartij op een heldere, juiste, eenduidige, overzienbare, volledige en eenvoudige wijze wordt geïnformeerd over de rechten en plichten die voor haar uit de betreffende bedingen voortvloeien. ${ }^{20}$ Niet elke "ondoorzichtigheid" voert echter tot de kwalificatie onredelijk bezwarend. Een niet transparant beding is pas onredelijk bezwarend indien deze ondoorzichtigheid leidt tot een onredelijke benadeling van de wederpartij. ${ }^{240}$

Ook algemene belangen kunnen, zowel aan de zijde van de gebruiker als de wederpartij, een rol spelen bij de inhoudstoets van $\$ 9$ AGBG. Tot de algemene belangen waarmee rekening dient te worden gehouden behoren onder andere de (grondwettelijke) belangen van vrije nieuwsgaring, persvrijheid, vrijheid van meningsuiting en gelijke behandeling en het recht op privacy. ${ }^{241}$

De prijs die voor de prestatie moet worden betaald is geen argument dat meetelt bij de inhoudstoetsing op grond van $\$ 9$ AGBG. Voor de wederpartij nadelige exoneratieclausules kunnen niet worden gecompenseerd door een lage prijs. Hoewel economisch gezien tussen de prijs en de omvang van het door de gebruiker te dragen aansprakelijkheidsrisico wel degelijk verband kan bestaan telt het prijsargument in beginsel niet bij de inhoudstoets van $\$ 9$ AGBG. $^{242}$ Dit omdat de rechter niet kan vaststellen wat een redelijke prijs voor de overeengekomen prestatie is en hij derhalve ook nooit kan constateren of inderdaad sprake is van een compenserend prijsvoordeel. ${ }^{243}$

Op het beginsel dat de prijs die voor de overeengekomen prestatie moet worden betaald geen invloed heeft op het onredelijk karakter van een beding wordt slechts een uitzondering gemaakt in het geval dat de wederpartij de keuze heeft tussen in hoogte verschillende tarieven met daaraan gekoppeld verschillende aansprakelijkheidsregimes. Onder omstandigheden kan het feit dat de

237 Zie: 2 Abs. 1 Nr. $2,3,85,86,89,10 \mathrm{Nr} .1$ em $2,810 \mathrm{Nr} .3,811 \mathrm{Nr} .10 \mathrm{~b}, \$ 11 \mathrm{Nr}$. $13 \mathrm{a}$ en $\$ 11 \mathrm{Nr}$. 14a AGBG. Zie: Wolf, AGBG Kommentar, 9 Rndnr. 143-144; Brandner, AGB-Gesetz, 9 Rndir. 84.

238 Brandner, AGB-Gesetz, 9 Rndar. 83.

239 BGH, NJW 1988, pag. 1726, WM 1988, pag. 1780; BGH, WM 1989, pag. 126; BGH, NJW 1990, pag. 2383; BGH, NJW 1992, pag. 3158; Wolf, AGBG Kommentar, \& 9 Rndnr. 143-145; Brandner, AGB-Giesetz, 9 Rndnr. 83.

240 Wolf, AGBG Kommentar, 9 Rndnr. 146; Brandner, AGB-Gesetz, 9 Rndur. 85.

241 Wolf, AGBG Kommentar, 9 Rndnr. 141.

242 BGHZ 22, 90, 98; BGHZ 77, 126, 131, NJW 1980, pag. 1953; BGH, NJW 1993, pag. 2442. 2444; OLG München, NJW-RR 1993, pag. 736.

243 Heinrichs, BGB (Palandt), AGBG 9 Nr. 2; Brandner, AGB-Gesetz, 9 Rndnr. 102-103. 
wederpartij een, duidelijk aan haar kenbaar gemaakte, vrije keuzemogelijkheid heeft tussen aanvaarding van een voor haar ongunstig beding (bij voorbeeld exoneratie) met een lage prijs of een gunstig beding (volledige garantie) tegen een hogere prijs, meebrengen dat door deze keuzemogelijkheid het onredelijk bezwarend karakter van het eerstgenoemde beding wordt weggenomen. ${ }^{244}$

\section{Unwirksam / nietigheid}

Indien een beding in algemene voorwaarden onredelijk bezwarend is op grond van de inhoudstoets van $\$ 9$ AGBG of indien het voorkomt op de lijsten van de $\$ 810$ en 11 AGBG, is het unwirksam, dat wil zeggen met terugwerkende kracht van rechtswege nietig (Nichtigkeit von Anfang an). De rechter dient derhalve, zowel in de individuele als de collectieve procedure, de eventuele nietigheid van algemene voorwaarden op grond van het bepaalde in de \$\$ 9-11 AGBG ambtshalve te onderzoeken. Het is niet vereist dat daaraan een eis, beroep of verweer van partijen is voorafgegaan. ${ }^{24}$ De ambtshalve inhoudstoetsing door de rechter verplicht deze echter niet om in de individuele procedure acht te slaan op het feit dat het gebruik van het betroffen beding in een collectieve procedure is verboden ( $\$ 13$ Abs. $1 \mathrm{AGBG}$ ). Op grond van $\$ 21 \mathrm{AGBG}$ verklaart de rechter een door een rechterlijk verbod getroffen beding immers alleen nietig indien de wederpartij zich op het verbodsvonnis beroept. ${ }^{246} \mathrm{De}$ collectieve procedure onderscheidt zich van de individuele procedure doordat de ambtshalve toetsing in de collectieve procedure zich op grond van het bepaalde in $\S 308 \mathrm{ZPO}$ beperkt tot de door de eisende organisatie voorgelegde bedingen in de door eiser aangegeven overeenkomsten. ${ }^{247}$ In de praktijk van de collectieve procedure is volgens Reich van een ambtshalve toetsing dan ook geen sprake. ${ }^{248}$

De nietigheid is in beginsel beperkt tot de aangevallen regeling. Een beding kan dus in beginsel partieel nietig zijn indien het taalkundig en inhoudelijk gezien een aantal regelingen bevat en dus splitsbaar is. ${ }^{249}$ De resterende regelingen blijven gewoon contractsinhoud. Dit echter alleen indien het resterende deel van het beding taalkundig en inhoudelijk een zinvolle, gepaste en op zichzelf begrijpelijk regeling vormt. Bovendien moet het overgebleven deel van het beding het zelfde bereik hebben als de oorspronkelijke regeling en mag zij

244 Heinrichs, BGB (Palandt), AGBG 9 Nr. 2; Wolf, AGBG Kommentar \& 9 Rndnr. 138 ; Braniner, AGB Gesetz, 9 Rndnr. 104.

245 Wolf, AGBG Kommentar, 9 Rndnr. 159-161; Brandner, AGB-Gesetz, \& 9 Rndnr. 53.

246 Wilf, AOBG Kommentar, 9 Rndnr. 160 .

247 Brandner, AGB-Gesetz, 9 Rndnr. 53.

248 N. Reich, tijdens de op 6 en 7 januari 1994 te Maastricht gehouden studiedagen "Europees Consumentennecht" voor het landelijk netwerk voor AIO/OIO/RAIO "s Europees Privaatrecht.

249 Jongeneel, disis, pag. 174-175. 
in vergelijking met de oorspronkelijke regeling niet een volledig afwijkende en nieuwe regeling vormen. ${ }^{250}$ Op het resterende deel van de aangevallen regeling wordt geen conversie (Umdeutung, $\$ 140 \mathrm{BGB}$ ) of aanvulling toegepast. De rechter zal het resterende deel dus niet mogen veranderen om het zodoende toelaatbaar te maken. ${ }^{251}$ Het overblijvende deel moet op zichzelf toelaatbaar zijn. Indien een beding niet splitsbaar is en tevens onredelijk bezwarend, is thet hele beding dus nietig. ${ }^{252}$

Indien een beding eenmaal onredelijk bezwarend is wordt een conversie (Uindeutung, $\$ 140$ BGB) tot het wettelijk toelaatbare deel (geltungserhaltende Reduktion) in de rechtspraak en literatuur principieel en unaniem afgewezen. $^{253}$ Een beding bij voorbeeld, dat elke vorm van aansprakelijkheid uitsluit zal door de rechter niet mogen worden omgezet in een beding dat slechts de aansprakelijkheid uitsluit waar dat rechtens wel zou zijn toegelaten. Ratio achter het verbod van conversie is enerzijds de gedachte dat het AGB-Gesetz wil bewerkstelligen dat gebruikers algemene voorwaarden hanteren die van meet af aan niet-onredelijk bezwarend zijn en dat de gebruikers het risico van algehelle nietigheid van onredelijk bezwarende bedingen dienen te dragen (Risikogedanke) en anderzijds de gedachte dat algemene voorwaarden de wederpartij op een heldere en eenduidige wijze moeten informeren over zijn rechten en plichten (Transparenzgebot). Het zou in strijd zijn met de doelstelling van het AGBGesetz indien door het toelaten van een conversie tot het (maximal) wettelijk toelaatbare, het risico van algehele nietigheid zou vervallen en daardoor de gebruiker de prikkel zou worden ontnomen om zelf te zorgen voor de door het AGB-Gesetz voorziene reiniging van de markt van onredelijk bezwarende bedingen, ${ }^{254}$ of zoals Lindacher het uitdrukt:

Der Verwuender sei zu einer ACB-Gestaliung anzwhatten, die so, wie sich ihrem textlichen Sinn mach ausnimmt, auch Biestand habe. Dem Schurzweck des Gesetzes widerspreche es, wenn es dem Verweruder woglich bleibe, seine AGB einseitig in seinem Sinne auszugestalien, wm es dasn der

250 BGH, NJW 1982, pag. 178-181; BGH, NJW 1984, pag. 2816-2817; BGH, NJW 1984, pag. 2687-2688; BGH, NJW 1985, pag. 623; BGH, ZIP 1988, pag. 360-362; BGH, NNW 1989, pag. 831-833; BGH, NJW 1992, pag. 2759; Wolf, AGBG Kommentar, 9 Rndnr. 157; Brandner, AGB-Gesetz, 9 Rndnr. 50.

$251 \mathrm{BGH}, \mathrm{NJW} 1982$, pag. 2311.

252 BGH, NJW 1984, 2404; BGH, NJW 1984, pag. 2817; BGH, NJW 1985, pag. 320-325; BGH, WM 1989, pag. 1028-1032; BGH, NJW 1991, pag. 1750; Wolf, AGBO Kommentar, 8 Rndnr. 35; Schmidt, AGB-Gesetz, 6 Rndnr. 12; Jongeneel, diss., pag. 174-175.

253 BGH, NJW 1982, 2309; BGH, NJW 1983, pag. 2309; BGH, NJW 1984, pag. 1177; BGH, NJW 1986, pag. 1610; BGH, NJW 1989; pag. 1796-1798, WM 1989, pag 1028-1031. Lindacher, AGBG Kommentar, \& 6 Rndnr. 28; Schmidt, AGB-Gesetz, 6 Rndnr. 15; Jongeneel, diss, pag. 172-173.

254 BGH, NJW 1983, pag. 2309; BGH, NJW 1984, pag. 48-49; Lindacher, AGBO Kommentar,

6 Rndnr. 28; Schmidt, AGB-Gesetz, 6 Rndnr. 14. 
Innitiative zeines Vertragspartmers und den Gerichten zu aberlassen, dafi derarige Klausein auf das noch zultissige Maß zuriackgefulhirt werden. ${ }^{25 s}$

Bedingen die onredelijk bezwarend zijn worden daarom niet teruggebracht tot het wettelijk toelaatbare maar zijn in het geheel nietig (Verbot der geltungserhaltende Reduktion).

Indien een beding op grond van de inhoudstoets nietig is, worden de gevolgen daarvan geregeld door $\$ 6$ AGBG. Net als bij niet-gebondenheid ${ }^{256}$ is het uitgangspunt dat de overeenkomst ook zonder de betreffende algemene voorwaarden in stand blijft ( 86 Abs. 1 AGBG) en dat de door het wegvallen van deze bedingen ontstane hiaten in de overeenkomst worden aangevuld door het regelende recht ( $\$ 6 \mathrm{Abs}$. 2 AGBG). Voorzover in de door het wegvallen van onredelijk bezwarende bedingen ontstane hiaten in de overeenkomst niet kan worden voorzien door bepalingen van regelend recht, worden deze door aanvullende uitleg (ergänzende Vertragsauslegung) nader aangevuld. § 6 Abs. 3 AGBG bepaalt dat de overeenkomst geheel vervalt indien de toepassing van $\$ 6$ Abs. 1 en 2 AGBG leidt tot onaanvaardbare gevolgen voor én der partijen. ${ }^{257}$

\subsubsection{De lijsten van $\& 10$ en 11 AGBG}

Naast de Generalklausel van $\$ 9$ AGBG bevat het AGB-Gesetz in de $\$ \S 10$ en 11 AGBG twee lijsten van bedingen die geacht worden onredelijk bezwarend te zijn indien ze gehanteerd worden tegenover consumenten. De lijsten zijn een concretisering van de algemene norm van $\$ 9$ AGBG en zijn in het AGB-Gesetz opgenomen om, met name in de buitengerechtelijke fase, rechtszekerheid en duidelijkheid over de toelaatbaarheid van algemene voorwaarden te bieden aan de consument. De bepalingen van de $\$ \$ 10$ en 11 AGBG worden door de Duitse wetgever, door mij aangepast aan de huidige nummering van het AGB-Gesetz, als volgt gemotiveerd:

"Im Hinblick auf die Vielfalt yon $A G B$ und der durch sie geregelten Sachverhalte sind Generalklawseln wie in den 88 2,3 und 9 zwar unverzichbares Instrument der Einbeziehungs- und Angemessen. heitskontrolle. Der damit erreichten Flexibilitis stehen jedoch auch Nachteile gegenuber. Weiter Wertungsspielraum und die Möglichkeit verschiedener Interpretation unbestimmuer Rechtsbegriffe sichwinken den praktischen Nutzen solcher Generalklauseln wor allem im aubergerichticher Anwendungsbereich ein. Namenulich den Belangen des Letzuerbrawchers, der den Weg vor die Gerichre aus vielerlei Grinden scheut, wird mit der eindeutigen Regelumg wichuger Eingelfragen

255 Lindacher, AGBG Kommentar, 8 Rndnr. 28.

256 Zie hiervoor paragraaf 6.2.2.4.

257 Zie uitvoerig: Begründung, BT Drucksache 7/3919, pag. 20-22; Lindacher, AGBO Kommentar, $\$ 6$; Schmidt, AGB-Gesetz, \$ 6. 
Whaffig besser gedient sein als mit einer Generalklausel. Der Entwunf greift deshalb im Interesse der Rechtssicherheit wnd Rechtsklarheit in den 8810 und 11 komkreter bestimmse Klawsiln wnd fornularmajige Gestalnungen auf, die fur den AGB-untenworfenen Ventragsteil eine besondere Gefaht darstellen, weil sie ihn wherraschen oder unangemessen benachteiligen. Die Awswahl der einzelmen Klauseln ist von der praktischen Bedeutung und der Klarungsbediaffigkeit fitr den Rechtswerkehr mit Letzherbrauchem bestimmi, wobei die Aufzahlung wegen der Vielfialt der AGB naturgemaj nur exemplarisch sein kann. "258

In tegenstelling tot de Wet algemene voorwaarden, waarin de lijsten van de artikel 6:236 en 6:237 BW slechts hun werking hebben via de weg van artikel 6:233 sub a BW, bevatten de lijsten van de $\$ \S 10$ en 11 AGBG een zelfstandige nietigheidsgrond. De lijsten hebben, niettegenstaande het feit dat zij een concretisering van de open norm van $\$ 9$ AGBG zijn, een zelfstandige betekenis. Zij bewerkstelligen de nietigheid ook dan als van een nietigheid op grond van de open norm geen sprake is. ${ }^{259}$ Andersom kan ook steeds een beroep op de

$\S \S 10$ en 11 AGBG worden gedaan indien de nietigheid van een beding eveneens gegrond kan worden op de algemene norm van $\$ 9$ AGBG.

Op grond van het bepaalde in $\S 24$ AGBG kan op de lijsten van de $\$ \S 10$ en 11 AGBG geen beroep worden gedaan door professionele wederpartijen. Dit sluit echter niet uit dat bedingen die voorkomen op de lijsten van de $\$ \$ 10$ en 11 AGBG jegens professionele wederpartijen onredelijk bezwarend zijn op grond van de open norm van $\$ 9$ AGBG. De laatste volzin van $\$ 24$ AGBG bepaalt dit uitdrukkelijk. ${ }^{200}$ Hoewel omstreden, wordt in de rechtspraak aangenomen dat de lijsten van de $\S \S 10$ en 11 een zekere reflexwerking (Indizwirkung) hebben op het handelsverkeer. ${ }^{261}$ Niet elke bepaling van de lijsten heeft echter een even sterke reflexwerking. ${ }^{262}$ Richtinggevend voor de reflexwerking is de uitspraak van het $\mathrm{BGH}$ van 8 maart $1984 .{ }^{263}$ In deze uitspraak stelt het BGH, dat het feit dat een beding dat wordt gebruikt jegens een professionele wederpartij valt onder de bepalingen van de lijsten van de $\$ \S 10$ en 11 AGBG, een aanwijzing is dat het beding ook jegens professionele wederpartijen onredelijk bezwarend is, tenzij de bijzondere belangen en eisen van het handelsverkeer met zich brengen dat dit niet het geval is. ${ }^{264}$

258 Begründung, BT Drucksache 7/3919, pag. 23.

259 BayOLG, BB 1980, pag. 283-285; Wolf, AGBG Kommentar, Vor \$8 10, 11 Rndnr. 9.

260 " $\$ 9$ ist in den Fällen des Satzes 1 auch insoweit anxuwenden, als dies zur Unwirksamkeit von in den $\$ \$ 10$ und 11 genannten Vertragsbestimmungen führt $(. .)^{\prime \prime}$.

261 BGH, NJW 1984, pag. 1750; BGH, ZIP 1986, pag. 653-656; BGH, NJW 1988, pag. 1785. Wolf, AGBG Kommentar, Vor \$10,11 Rndnr. 14; Brandner, AGB-Gesetz, \& 9 Rndnr. 1314 en $\$ 24$ Rndnr. 19.

262 BGH, NJW 1985, pag. 2328.

$263 \mathrm{BGH}, \mathrm{NJW} 1984$, pag. 1750 .

264 Brandner, AGB-Gesetz, 24 Rndnr. 18-19; Jongeneel, diss., pag. 281. 
Het wezenlijke verschil tussen de lijsten van de $\$ \$ 10$ en 11 AGBG is het verschil in gehanteerde rechtsbegrippen. In de regeling van $\$ 10 \mathrm{AGBG}$ wordt steeds een flexibele en onbepaalde rechtsnorm (unbestimmte Rechtsbegriffe) gehanteerd, zoals angemessen (Nr. 5a), unangemessen (Nr. 1, 2, 7a en 7b), sachlich gerechufertigt (Nr. 3), zumutbar (Nr. 4), besondere Bedeutung (Nr.6) of anerkennenswertes Interesse (de inmiddels vervallen regeling wan $\mathrm{Nr}$. 8). De regelingen van $\$ 10$ AGBG geven slechts algemene regels en normen, met als gevolg dat enkel de rechter beslist of in het concrete geval al dan niet sprake is van een onredelijk bezwarende algemene voorwaarde (Klauselverbote mit Wertungsmöglichkeit).

"Bei der Anwendung diester Vorschriften mus also stets unter Bericksichrigung der Umstande des Einzelfalls abgewogen werden, ob die fragliche Vertragsklausel als unangemessen angeseher werden kann ader micht. wos

De beoordelingsruimte die de rechter heeft dient te worden ingevuld naar de maatstaven van redelijk en billijkheid. De lijst van $\$ 10$ AGBG is immers een concretisering van $\$ 9$ AGBG, hetgeen ook blijkt uit de aanhef van de bepaling "In Allgemeinen Geschaftsbedingungen ist insbesondere unwirksam" "266

De bedingen genoemd op de lijst van $\$ 10 \mathrm{AGBG}$ zijn alle typische voorbeelden van bedingen die ontegenzeglijk het gevaar in zich bergen dat zij onvoldoende rekening houden met de belangen van de niet professionele wederpartij. Daarom is een nadere inhoudelijke toets van juist deze bedingen geboden. In de toelichting op het wetsontwerp wordt dit, door mij aangepast aan de huidige nummering, als volgt verwoord:

"Die in \$ 10 zuscommengefajon Klauseln mit Wertungstpielraum sind Arwwendungsfalle fur typische gejahrliche Einzelklatuseln, bei denen die Gefahr eines gestorten Interessenausgleichs besonders naheliegt und eine Angemessenheitsprifung geboten ist. ${ }^{-267}$

In $\$ 11$ AGBG zijn de gehanteerde rechtsbegrippen daarentegen concreet en zien op specifieke situaties zodat ook zonder rechterlijke tussenkomst altijd vaststaat dat een beding voorkomend op deze lijst onder alle omstandigheden onredelijk bezwarend is (Klauselverbote ohne Wertungsmöglichkeit). De rechter heeft derhalve geen beoordelingsruimte bij de toetsing van de inhoud van deze bedingen. Zij zijn altijd nietig omdat de wet dit bepaalt.

265 Begnindung, BT Drucksache 7/3919, pag. 24.

266 Wolf, AGBG Kommentar, Vor $\$ \$ 10,11$ Rndnr. 7; Brandner, AGB-Gesetz, 9 Rndnr. 10; Jongeneel, diss, pag. 229.

267 Begründung, BT Drucksache 7/3919, pag. 24. 
"Diemgegenuber sind die in 11 zusammengefaßten Einzelvenbote strikter Natur, weil hier die Unangemessenheix kraft geserzgeberischer Wertung generell anzunthmen ist, so dap sich im Einzelfall jede weitere inhaltliche Praffung enibrigt. "268

De bedingen op de lijst van $\$ 11$ AGBG zijn een concretisering van het bepaalde in $\$ 9$ Abs. 2 AGBG. Het zijn typische voorbeelden van bedingen die indien zij worden gehanteerd tegenover een consument altijd onredlelijk bezwarend zijn omdat zij op een ongeoorloofde wijze afwijken van het regelend recht $(\$ 9$ Abs. $2 \mathrm{Nr} .1 \mathrm{AGBG}$ ) of wezenlijke contractuele rechten en plichten ten nadele van de wederpartij uithollen ( $\$ 9$ Abs. 2 Nr. 2 AGBG). ${ }^{269}$ Met de zinsnede "sind stets unwirksam" wordt tot uitdrukking gebracht dat deze bedingen op geen enkele wijze contractsinhoud kunnen worden. ${ }^{200}$

\subsubsection{Internationale aspecten}

De internationale werking van het AGB-Gesetz is in beginsel neergelegd in $\$ 12$ AGBG. ${ }^{271}$

\section{\$12 Zwischenstaatlicher Geltungshereich}

Unserliegt ein Vertrag auslandischem Recht oder dem recht der Deutschen Demokratischen Republik, so sind die Vorschriften dieses Gesetzes gleichwohl zu berïcksichnigen, wenn

1. der Ventrag aufgrund eines offentlichen Angebots, einer öffentlichen Werbung oder eine Whylichen in Geltungsbereich dieses Gesetzes entfalteten geschdfflichen Tatigheit des Verwenders zustande kommut und

2. der andere Vertragsteil bei Abgabe seiner auf den Vertragsschluß gerichteten Erkldrung seinen Wohnsitz oder gewohnlichen Aufenthalt im Geliungsbereich dieses Gesetzes hat und seine Willenserklärung im Geltungsbereich dieses Gesetzes abgibr.

Op grond van het bepaalde in $₹ 24$ AGBG is de bepaling van $₹ 12$ AGBG slechts van toepassing op algemene voòrwaarden gehanteerd tegenover consumenten. Het doel van de regeling is derhalve de in Duitsland wonende consument de bescherming van het AGB-Gesetz ook dan te bieden, als deze overeenkomsten sluit die, om wat voor reden dan ook, beheerst worden door ander dan Duits recht en deze overeenkomsten in een bepaalde mate zijn verbonden aan Duitsland..$^{272}$ Als op de overeenkomst waarvan de betreffende algemene voorwaarden deel uit maken, Duits recht van toepassing is zijn de bepalingen van

268 Begrïndung, BT Drucksache 7/3919, pag. 24.

269 Begrindung, BT Drucksache 7/3919, pag. 24.

270 Begründung, BT Drucksache 7/3919, pag. 24.

271 Zie, voor de mogelijke wijziging van 12 AGBG op grond van de EEG-richtlijn inzake oncerlijke bedingen in consumentenovereenkomsten, hiervoor paragraaf 6.1.1.

272 Begründung, BT Drucksache 7/3919, pag. 40-41; Lindacher, AGBG Kommentar, s 12 Rnillir. 1: Schmidt, AGB-Gesetz, Vor 12 Rndnr. 1. 
Mede omdat artikel 27 Abs. 3 EGBGB (identiek aan artikel 3 lid 3 EEV) bepaalt, dat de keuze voor buitenlands recht de bepalingen waarvan volgens het recht van een ander land niet bij overeenkomst mag worden afgeweken, onverlet laat wanneer alle overige elementen van het geval op het tijdstip van deze keuze met dit andere land zijn verbonden, heeft $\$ 12$ AGBG in de praktijk alleen nog maar betekenis voor die consumentenovereenkomsten waarop buitenlands rechts van toepassing is en die tevens niet onder het bereik van artikel 29 EGBGB vallen. ${ }^{281}$ In het algemeen zullen derhalve IPR vraagstukken met betrekking tot algemene voorwaarden gehanteerd in consumentenovereenkomsten worden opgelost conform de regels van het EEG-verbintenissenverdrag die voor Duitsland zijn neergelegd in het EGBGB. Daarbij dient te worden aangetekend dat de regel van artikel 7 lid $1 \mathrm{EEV}$ in Duitsland geen toepassing vindt. ${ }^{202}$

Als voorbeelden van consumentenovereenkomsten die niet onder het bereik van artikel 29 EGBGB vallen doch slechts onder het bereik van $\$ 12$ AGBG, worden genoemd de overeenkomsten gesloten vóor 1 september 1986 waarop op grond van de overgangsbepaling van artikel 220 EGBGB het oude recht van toepassing is, overeenkomsten gesloten door niet-professionele wederpartijen voor beroeps- of bedrijfsmatige doelen ${ }^{23}$ én overeenkomsten die op grond van artikel 29 Abs. 4 EGBGB zijn uitgesloten van de werking van artikel 29 EGBGB. ${ }^{284}$

\subsection{Procesrechtelijke bepalingen}

De hiervoor beschreven materieelrechtelijke voorschriften van het AGB-Gesetz zijn grotendeels een codificatie van de reeds in de rechtspraak ontwikkelde regels ten aanzien van de gebondenheid aan en de inhoudelijke toelaatbaarheid van algemene voorwaarden. De procesrechtelijke bepalingen, met daarin opgenomen een collectief actierecht voor consumenten- en ondernemersorganisaties dat ook zijn werking heeft buiten de kring der procespartijen, zijn daarentegen een substantiële vernieuwing ten opzichte van de mogelijkheden die de rechtspraak op dit terrein bood.

Het procesrechtelijk gedeelte van het AGB-Gesetz is gebaseerd op de alom heersende mening dat de invoering van specifieke procesrechtelijke voorschriften noodzakelijk is om een efficiëntere werking te geven aan het materieel-

281 Lindacher, AGBG Kommentar, \&12 Rndnr. 3-5; Schmidt, AGB-Gesetz, Vor \& 12 Rndnr. 1 en 12 Rndnr. $2-3$.

282 Zie hiervoor paragraf 5.2.7.1.

283 Als voorbeeld van deze categorie worden genoemd overeenkomsten gesiloten door vrijeberoepsuitoefenaren ("Vertrige von Freiberuflem $\mathbf{n u}$ beruflichen Zweeken"). Zie: Lindacher, AGBG Kommentar, 12 Rndnr, 5; Schmidt, AGB-Gesetz, \& 12 Rndnr. 3.

284 Lindacher, AGBG Kommentar, 12 Rndnr" 5; Schmidt, AGB-Gesetz, \$12 Rndnr. 3. 
rechtelijk gedeelte van de wet. ${ }^{285}$ Het uitgangspunt van het AGB-Gesetz is, dat de aan het beginsel van contractsvrijheid ten grondslag liggende individuele belangenbehartiging, op het terrein van de algemene voorwaarden niet of ontoereikend functioneert en onvoldoende bescherming biedt aan wederpartijen. Het AGB-Gesetz stelt in het materieelrechtelijk gedeelte derhalve duidelijke grenzen aan de contractsvrijheid op het terrein van de algemene voorwaarden. ${ }^{236}$ Het stellen van duidelijke wettelijke grenzen aan de contractsvrijheid op het terrein van de algemene voorwaarden werd echter niet voldoende geacht voor de bescherming van wederpartijen. Enerzijds omdat de individuele consument vanwege het ontbreken van rechtskennis en een hoge procesdrempel nauwelijks in staat is zijn belangen in en buiten rechte te behartigen en anderzijds omdat een vonnis in een individuele procedure nauwelijks precedent- en breedtewerking heeft. ${ }^{287}$ Het tekortschieten van de rechterlijke inhoudscontrole van algemene voorwaarden, vór de totstandkoming van het AGB-Gesetz, werd dan ook vooral geweten aan deze twee factoren. In het zeldzame geval dat de rechter tot het oordeel kwam dat een beding ontoelaatbaar was, gold dit enkel voor het concrete geval. Dit schiep de mogelijkheid voor gebruikers van algemene voorwaarden de ontoelaatbare bedingen tegenover andere consumenten ongewijzigd en ongestraft te blijven hanteren. Van het enkele toekennen van een individuele actie op het terrein van de algemene voorwaarden werd derhalve weinig breedtewerking verwacht.

"Solange eine Inhaltskontrolle nur auf klage- oder verteidigungsweise Geltendmachwng der Klauselumwirksamkeit im IndividualprozeB enfolgt, befinder sich der AGB-Venwender, der seine unbilligen AGB erst eimmal in den Vertrag eingefahnt huat, schon allein deshalb in der Vorhand" weil in eben dieser Situation erfahrungsgemïß auch unwirksame Klauseln aus Rechtsunkennmis sowie Prozepscheu kaufig, wenn nicht gar in der Regel, durchaus hingenommen werden, zumindest aber einen idealen Ausgangspunkt far "Kulanzverhandlungen" darsiellen. Setzt aber ein Kunde im Einzelfall gleichwohl sein Recht durch, aupert das Urteil, weent uberhaupt, nur als faktisches Prajwuliz Wirkung aber den konkreten Rechisstreit hinaus: der AGB definitionsgemafo eigemen Sireuwirkung korrespondiert keine oder nur eine unvollkommene Breitenwirkung des Regelbehilfs Individualklage. ${ }^{2088}$

Teneinde de gewenste breedtewerking te realiseren en de markt te bevrijden van onredelijke algemene voorwaarden is in het AGB-Gesetz, naar het voorbeeld van reeds bestaande wettelijke regelingen ${ }^{289}$, in de $\$ \$ 13$ tot en met 22 AGBG

285 Begruindung, BT Drucksache 7/3919, pag. 15; Stellungnahme des Bundesrates, BT Drucksache $7 / 3919$, pag. 54 .

286 Lindacher, AGBG Kommentar, Vor \& 13 Rndnr. $3-4$.

287 Lindacher, AGBG Kommentar, Vor 13 Rndnr. 4.

28. Lindacher, AGBG Kommentar, Vor \& 13 Rndnr. 4.

289 \& 13 Abs. 1 en 1a UWG, 35 Abs. 2 GWB, \& 12 Abs. I Rabattgesetz; 2 Abs. I Zugabeverondnung. Zie: BT Drucksache 7/3919, pag. 54. 
een procesrechtelijk deel aan het materieelrechtelijk deel toegevoegd. ${ }^{20}$ In dit procesrechtelijk deel werd gekozen voor een repressieve abstracte gerechtelijke inhoudscontrole, uit te voeren door consumenten-, branche-, beroeps- en industriële organisaties, waarbij een eventueel verbodsvonnis niet alleen werking tussen de procespartijen heeft maar tewens preventief werkt naar individuele wederpartijen.

De wetgever stond daarbij voor ogen dat de gewenste breedtewerking op de eerste plaats wordt gerealiseerd doordat aan consumenten- en ondernemersorganisaties de mogelijkheid wordt geboden om zich door middel van een collectieve actie een executoriale verbods- of gebodstitel te verschaffen ( $\$ 13 \mathrm{AGBG}$ ). Het rechterlijk verbod geeft dan immers duidelijkheid en daarmee rechtszekerheid over de toelaatbaarheid van de ter toetsing voorliggende bedingen. Deze duidelijkheid en de dreiging van executiemaatregelen door de eisende organisaties moet gebruikers en aanbevelers vervolgens weerhouden van een hergebruik of opnieuw aanbevelen van de gewraakte bedingen. Verder heeft de publiciteit rondom een gebods- of verbodsvonnis doorgaans een gewisse precedentwerking, waarmee meer in het algemeen wordt bewerkstelligd dat gebruikers bij het opstellen van hun algemene voorwaarden minder snel verboden bedingen zullien opnemen. De benodigde publiciteit wordt in het AGB-Gesetz op twee manieren gerealiseerd: door de registratie van het vonnis in een openbaar register $(\$ 20$ AGBG) en de bevoegdheid van eisende organisaties een verbods- of gebodsvonnis te publiceren ( $\$ 18$ AGBG). De breedtewerking wordt gecompleteerd doordat individuele wederpartijen de mogelijkheid hebben om zich op het verbodsvonnis in de collectieve procedure te beroepen ( $\$ 21 \mathrm{AGBG})$.

Het collectieve actierecht voor consumenten-en ondernemersorganisaties zoals neergelegd in de $\$ \$ 13$ tot en met 23 AGBG heeft een drieledige functie.

Op de eerste plaats wordt door het uitdrukkelijk toekennen van een actierecht aan consumenten- en branche-organisaties de behartiging van het algemeen (consumenten) belang met betrekking tot algemene voorwaarden overgelaten aan het initiatief en de mogelijkheden van particuliere organisaties. Het actierecht wordt deze organisaties gegeven ter behartiging van het algemeen bellang en niet ter behartiging van een eigen belang. Doel van het collectieve actierecht is immers een effectieve inhoudscontrole van algemene voorwaarden te creëren die los staat van individuele rechtsbetrekkingen om zodoende het privaatrechtelijk rechtsverkeer ook bij onvoldoende individueel initiatief te zuiveren van onredelijk bezwarende algemene voorwaarden..$^{29} \& 13$ AGBG brengt derhalve expli-

290 BT Drucksache 7/3919, pag. 54; Lindacher, AGBG Kommentar, Vor $\$ 13$ Rndnr. 5-6; Hensem, AOB-Gesetza, Vor $\$ 13$ Rndnr. 7-12.

291 Lindacher, AGBG Kommentar, Vor \$13 Rndnr. 7.

402 
ciet tot uiting dat consumenten- en ondernemersorganisaties op het terrein van de algemene voorwaarden in rechte kunnen optreden zonder dat zij daarbij een eigen belang hebben. ${ }^{202}$ Het feit dat de eisende organisaties in de collectieve procedure het algemeen belang behartigen, legitimeert vervolgens dat de werking van het zo verkregen verbodsvonnis niet beperkt is tot procespartijen maar tegenover de gebruiker een algemene werking heeft voor alle wederpartijen jegens wie de gebruiker het verboden beding gebruikt. ${ }^{203}$

De tweede functie van het collectieve actierecht is gelegen in de bescherming van het systeem van de vrije markt-economie dat gebaseerd is op contractsvrijheid (privaatautonomie), privé-eigendom en concurrentie. Het collectief actierecht is derhalve niet alleen een concretisering van de gedachte dat het recht sociaal en economisch zwakkeren dient te beschermen (collectieve actie ter bescherming van consumenten) maar tevens een legitimatie van het instituut van de contractsvrijheid. De wetgever benut het belang dat de in $\S 13$ Abs. 2 AGBG genoemde organisaties hebben om door middel van de uitoefening van het collectief actierecht de markt te bevrijden van eenzijdige en onredelijk bezwarende bedingen, immers om institutioneel misbruik van de contractsvrijheid tegen te gaan en er zodoende voor te zorgen dat de bestaande privaatrechtsorde naar behoren blijft functioneren. ${ }^{204}$

De derde functie is gelegen in de preventieve rechtsbescherming die het collectieve actierecht biedt. De bevoegdheid van consumenten- en ondernemersorganisaties om jegens gebruikers of aanbevelers zowel buiten als in rechte een verbod van gebruik of aanbeveling of een gebod tot herroeping van een aanbeveling te vorderen heeft tot doel het feitelijk gebruik van onredelijk bezwarende algemene voorwaarden voor de toekomst te verhinderen. De collectieve actie van $\S 13$ AGBG is dan ook in beginsel uitsluitend gericht op preventieve rechtsbescherming. ${ }^{205}$

\subsubsection{De vorderingen}

De vorderingen die consumenten- en branche-organisaties in de collectieve procedure van $\S 13$ AGBG kunnen indienen zijn nader te verdelen in enerzijds de hoofdvorderingen zoals deze zijn neergelegd in $\& 13$ Abs. 1 AGBG en anderzijds de nevenvorderingen die volgen uit $\S 18$ AGBG en de algemene bepalingen van het Duitse civiele procesrecht.

292 Reinel, pag. 126 e.v.; Gerlach, Münchener Kommentar, 13 AGBG Rndnr. 3-5; Lindacher, AGBG Kommentar, Vor \$13 Rndnir. 7.

293 Gerlach, Münchener Kornmentar, \$13 AGBG Rndnr. 3.

294 Lindacher, AGBG Kommentar, Vor 13 Rndnr. 8.

295 Lindacher, AGBG Kommentar, Vor 813 Rndnr. 9. 


\subsubsection{De hoofdvorderingen}

De hoofdvorderingen In de collectieve actie zijn meergelegd in $\$ 13$ Abs. 1 AGBG.

\section{Unterlassungs- und Widerrufsanspruch}

(1) Wer in Allgemeinem Geschaffisbedingungen Bestimunungen, die nach 889 bis 11 dieses Gesetzes unwirksam sind', verwendet ader fur den rechtsgeschafflichen Verkehr empfiehit, kamn auf Unterlassung und im Fall des Empfehlens auch auf Widerruf in Ansprwch genommen werden.

Door het gebruik of de aanbeveling van onredelijk bezwarende algemene voorwaarden ontstaat een rechtsverhouding tussen enerzijds de gebruiker of aanbeveler van die voorwaarden en anderzijds de in $\$ 13$ Abs. 2 AGBG genoemde organisaties die op grond van de wet de bevoegdheid hebben om toezicht te houden op het gebruik van algemene voorwaarden. Daardoor kunnen de actiebevoegde organisaties in een collectieve procedure een verbod (Unterlassung) van gebruik of aanbeveling van onredelijk bezwarende bedingen vorderen of een gebod tot herroeping (Widerruf) van een gedane aanbeveling van onredelijk bezwarende bedingen vorderen. Dit collectieve vorderingsrecht kan door de gebruiker of aanbeveler op geen enkele wijze rechtsgeldig worden uitgesloten of aan een derde worden overgedragen.. ${ }^{207}$

\section{De verbodswordering}

De vordering tot het verbod van gebruik (Unterlassungsklage) kan zich zowel richten tegen het hergebruik van onredelijk bezwarende algemene voorwaarden als tegen het eerste gebruik van onredelijk bezwarende algemene voorwaarden waarvan is aangekondigd dat deze zullen worden gebruikt.

Een ongeschreven vereiste voor de verbodsactie met betrekking tot bedingen die reeds eerder werden gebruikt is het herhalingsgevaar. Zonder het gevaar van herhaald gebruik heeft de eisende organisatie geen belang bij haar vordering en is een verbodsactie overbodig. ${ }^{203}$ Het enkele gebruik van algemene voorwaarden in een overeenkomst doet echter reeds vermoeden dat er sprake is van een herhalingsgevaar. Algemene voorwaarden zijn naar hun aard immers bestemd

296 Hensien, AGB-Gesetz, 13 Rndnr. 26 .

297 Gerlach, Münchener Kommentar, \$13 AGBG Rndnr. 59.

$298 \mathrm{BGHZ} 79,117, \mathrm{NJW} 1981$, pag, 867, BGHZ 81, 222, NJW 1981, pag. 2412; BGH, NJW 1983, pag. 2026; BGH, NJW 1984, pag. 2161, Reinel, pag. 35; Lindacher, AGBG Kormentar, I3 Rndnr. 51-53; Hensen, AGB-Gesetz, 813 Rndnr. 29-30; Bunte, DB 1980, pag. 484. 
om meermalen te worden gebruikt. ${ }^{299}$ Slechts in uitzonderingsgevallen worden algemene voorwaarden in de zin van $\$ 1$ AGBG eenmalig gebruikt. ${ }^{300} \mathrm{De}$ gebruiker dient derhalve aan te tonen en zonodig te bewijzen dat slechts sprake is van een eenmalig gebruik of dat het herhalingsgevaar niet (meer) bestaat. ${ }^{301}$ Het feit dat de gebruiker de toelaatbaarheid van een beding in een procedure verdedigt is eveneens voldoende om aan te nemen dat sprake is van een herhalingsgevaar. ${ }^{300}$

In de literatuur en rechtspraak wordt niet spoedig aangenomen dat het herhalingsgevaar is geweken. ${ }^{300}$ De enkelle bewering van de gebruiker dat hij de in het geding zijnde bedingen niet meer zal gebruiken en er ook niet meer naar zal verwijzen op contractsbescheiden of dat de betreffende bedingen door hem zijn veranderd is in het algemeen niet voldoende om het herhalingsgevaar te elimineren. ${ }^{304}$ Ook de enkele vernietiging van de aangevallen contractsformulieren is niet altijd voldoende om het herhalingsgevaar te doen wijken. ${ }^{305}$ In beginsel is voor het uitsluiten van het herhalingsgevaar - en daarmee de actiebevoegdheid van consumentenorganisaties - vereist dat de gebruiker zich contractueel verplicht, op straffe van een boete, de in het geding zijnde algemene voorwaarde( $\mathrm{n}$ ) niet meer te gebruiken (strafbewehrte Unterlassungserklärung), ${ }^{306}$ In uitzonderingsgevallen kan ook aangenomen worden dat het herhalingsgevaar is geweken zonder een strafbewehrte Unterlassungserklärung. Dit echter alleen indien het gedrag van de gebruiker voldoende garantie biedt en hij ook anderszins al het mogelijke doet om te bewerkstelligen dat de ontoelaatbare bedingen

299 OLG Koblenz, WM 1983, pag. 1272-1273; OLG Saarbrücken, BB 1979, pag. 705; BGH, NJW-RR 1990, pag. 1141-1142; BGH, NJW 1992, pag. 3158-3161; Lindacher, AGBG Kommentar, 13 Rndnr. 51; Hensen, AGB-Gesetz, 13 Rndnr. 29.

$300 \mathrm{Bjj}$ voorbeeld indien voor een eenmalige rechtsbetrekking gebruik wordt gemaakt van cen standaandovereenkomgt zoals die in een boekhandel te verkrijgen is. In dat geval kan zulk een beding enkell door middel van een individuele procedure ex \$\$ 9-11 AGBG aangetast worden. Zie ondermeer: Lindacher; AGBG Kommentar; 13 Rndnr, 52-53; Hensen, AGB-Gesetz, \$13 Rindiner. 31 .

301. Lindacher, AGBG Kommentar, 13 Rndmr. 51 .

302 BGH, NJW 1984, pag, 2161.

303 Bunte, Handbuch, pag. 27; Bunte, DB 1980, pag. 484; Lindacher, AGBG Kommentar, 13 Rndnr. 52; Löwe, Großkommentar zaim AGB-Gesetz; 813 Rndnr. 10; Hensen, AGB-Giesetz, \& 13 Rndur. 30.

304 OLG München, BB 1979, pag 805; BGHZ 79, 117, NJW 1981, pag. 867; BGH, NJW 1983, pag: 2026; BGH, NJW 1992 , pag. $1108-1109$.

305 OLG SaArbrücken, BB 1979, pag. 705; BGHZ 81, 222; AGBE II \& 13 Nr. 3, NJW 1981, pag. 2412, BB 1981, pag. 1791, ZIP 1:981, pag. 989, Löwe, Grolkommentar zum A,GB-Gesetz, 13 Rndar, 10; Lindacher, AGBG Kommentar, 8 13 Rundnr. 53.

$306 \mathrm{BGH}, \mathrm{AGBE}$ I \& $13 \mathrm{Nr} .2$, BB 1981, pag. 389, NJW 1981, pag. 867; BGH, NJW 1981, pag. 1511 ; OLG Koblenz, WM 1983, pag. 1272; BGH, AGBE II \& $13 \mathrm{Nr} .3$, NJW 1981, pag. 2412, ZIP 1981, pag. 989; BGH, NJW 1982, pag. 2311, BB 1982, pag. 1750; Lindacher, AGBG Kommentar, 13 Rndnr. 52 en 87-103; Hensen, AGB-Geselz, \& 13 Rndnr. 30 en 49 . 60; Löwe, Großkommentar zum AGB Gesetz; 13 Rindnr. I1. Zie voor een voorbeeld van een "strafbewehrte Unterlassungsentänung": Mölenberg en Rijken, pag. 84-85, 
niet meer gehanteerd zullen worden. Dit is bij voorbeell het geval indien de gebruiker van meet af aan erkent dat zijn algemene voorwaarden onredelijk bezwarend zijn, de tot dan toe gebruikte contractsformulieren vernietigt, enkel nog toellaatbare bedingen hanteert in zijn nieuwe contractsformulieren en zijn (reeds bestaande) wederpartijen uitdrukkelijk meedeelt dat hij geen rechten zal ontlenen aan de tot dan toe gebruikte, onredelijk bezwarende algemene voorwaarden. 307

Onder gebruiken van een (verboden) beding moet in het kader van de verbodsactie worden verstaan het gebruiken van algemene voorwaarden in de contractuele sfeer in ruime zin, ook al leidt dit gebruik niet tot een overeenkomst of het opnemen daarvan in overeenkomsten of tot een beroep van de gebruiker op het gewrakkte beding. Een toegekend verbod ziet daarmee tevens op het gebruik van een beding in aanbiedingen. ${ }^{308}$ Het ziet bovendien niet alleen op de letterlijke tekst van de door de verbodsuitspraak getroffen bedingen maar ook op het hergebruik van bedingen die in wezen dezelfde strekking hebben als het verboden beding. ${ }^{309}$ Omdat het verbod onmiddellijk na de uitspraak ingaat wordt de gebruiker geen termijn gelaten waarbinnen hij de gewraakte bedingen, bij voorbeeld in het geval ze zijn opgenomen in een catalogus die in grote oplage is gedrukt, nog mag gebruiken (Aufbrauchfrist) of een termijn waarin hij de gelegenheid krijgt de gewraakte bedingen te herzien (Umstellungsfrist). ${ }^{310}$ Integendeel, van het gebruik van een verboden beding is niet alleen sprake als de gebruiker het beding opneemt in overeenkomsten die pas worden gesloten ná dat het verbodsvonnis is gewezen, van (verboden) gebruik is ook sprake als de

307 BGHZ 81, 222, AGBE II \& 13 Nr. 3, NJW 1981, pag. 2412; BB 1981, pag. 1791, ZIP 1981, pag. 989; DB 1981, pag. 2118; Axmann, pag. 97; Lindacher, AGBG Kommentar, \& 13 Rndnr. 52-53; Hensen, AGB-Gesetz, \& 13 Rndnr. 30; Löwe, Grofkommentar zum AGB-Gesetz, \$13 Rndnr, 11: Kritisch ten amzien van de aangehaalde uitspraak van het BGH: Bultmann, BB 1982, pag. 703, die betoogt dat het $\mathbf{B G H}$, duidelijker had moeten aangeven dat zijn beslissing het karakter van een uitzonderingsregel had.

308 RechisausschuB, BT Drucksache 7/5422, pag. 10; BGH, NJW 1981, pag. 979; BGHZ 101, 271, NJW 1987, pag. 2867; Lindacher, AGBO Kommentar, 13 Rndnr. 47; Löwe, GroBkommentar zum AOB-Gesetz, 13 Rndnr. 5; Reinel, pag. 28-29; Hensen, AGB-Gesetz, \$13 Rndinr. 13.

309 Lindacher, AGBG Kommentar, 13 Rndar. 97; Geflach, Münchener Kommentar," 15 AGBG Rndnr. 20. De opvatting vloeit voont uit het, in het executierecht algemeen anwaarde, rechtsbeginsel dat is neergelegd in de zogenaande Kemmeorie. Volgens dit beginsel omvat het verbod niet alleen de letterlijk verboden handeling maar tovens alle handelingen die in wezen hetzelfde inhouden als de verboden handeling en tevens vaststaat diat de nechter die het vorbod heeft opgelegd ook deze handeling zou verbiedien.

$310 \mathrm{BOH}$, NJW 1980, 2518; BGH, NJW 1982, pag. 2311-2312, BB 1982, pag. 1752, WM 1982, pag. 869; BGHZ 86, 284, NJW 1983, pag. 1322; BGHZ 86, 299, NJW 1983, pag. 1326; Gerlach, Münchener Kommentar, 15 AGBG Rndar. 23; Lindacher, AGBG Kommentair, $\$ 13$ Rudnr. 63; Heinrichs, BGB (Palandt), AGBG 13 Nr. 2; Lowe, Großkommentar zum AGB;Gesetz, 17 Rndimr. 45; Hensen, AGB-Gesetz, 17 Rndinr. 16. 
gebruiker zich ná dat het verbodsvonnis is uitgesproken bij de uitvoering van reeds voordien gesloten overeenkomsten op het verboden beding beroept. ${ }^{311}$

De verbodsvordering kan ook gericht zijn tegen het aanbevelen van onredelijk bezwarende algemene voorwaarden. Letterlijk wordt onder aanbeveling een verklaring verstaan waardoor iemand een ander iets presenteert, aanraadt of voorstelt als zijnde goed of voordelig voor die ander, met de bedoeling de wil van die ander te beïnvloeden. De aanbeveling als bedoeld in \$ 13 AGBG is echter beperkt tot algemene verklaringen gericht tot een bepaalde kring van minstens twee personen en derhalve met een zekere breedtewerking. ${ }^{312}$ Typische vormen van aanbeveling zijn in die optiek:

- algemene voorwaarden die beroeps- of ondernemersorganisaties niet-bindend voorleggen aan of propageren bij hun leden (Konditionenempfehlungen ${ }^{313}$ );

- boeken met modellen van algemene voorwaarden ${ }^{314}$;

- standaardcontracten voor individueel gebruik (bij voorbeeld huurcontracten en koopcontracten die in de boekhandel verkrijgbaar zijn). ${ }^{315}$

Onder aanbeveling van algemene voorwaarden wordt echter niet het aanbevelen bij wege van individuele advisering begrepen. ${ }^{316} \mathrm{Zo}$ wordt de advocaat of notaris die voor zijn cliënt algemene voorwaarden opstelt niet gezien als

311 BGH, NJW 1981, pag. 1511-1512; BGH, NJW 1982, pag. 1511-1512; LG Berlin, ZIP 1988, pag. 1311; Lōwe, Großkommentar zum AGB-Gesetz, 21 Rndnr. 20-21; Lindacher, AGBG Kommentar, 21 Rndnr. 4-5; Hensen, AGB-Gesetz, 821 Rndnr. 5 .

312 Lindacher, AGBG Kommentar, 13 Rndnr. 56; Gerlach, Münchener Kommentar $\$ 13$ AGBG Rndnr. 43; Löwe, Grobkommentar zum AGB-Gesetz, 13 Rndnr. 6.

313 Kondituonenempfehlungen van beroeps- of ondememersorganisaties mogen op grond wan het Gesetz gegen Wettbewerbsbeschränkungen (GWB) niet bindend worden voorgeschreven anin de aangeslotenen en moten op grond van 38 Abs. 2 Nr. 3 GWB worden aangemeld bij het Bundeskartellamt (BKA). Indien zij niet wondt aangemeld is de aanbeveling in strijd met het GWB en kan de anbeweler op grond van $83 \mathrm{Abs}$. $1 \mathrm{Nr}$. $11 \mathrm{GWB}$ vervolgd worden. Het BKA is bevoegd de aangemelde Konditionenempfehlungen te toetsen aan de voorschriften van het BGB en het AGB-Gesetz. De toetsing door het BKA is echter zeer marginal. Het BKA voorziet de, op grond van 10 Absi 1 GWB verplichte, publikatie van de Konditionenempfehlungen in de Bundesanzeiger dan ook standaard wan de mededeling, dat de publikatie geen enkele indicatie is voor de verenighamirheid van de betreffende bedingen met het AGB-Giestetz. Zie: Hensen, AGB-Gesetz, \& 13 Rndnr. 16-17; Lindacher, AGBG Kommentar, \& 13 Rndnr. 57.

314 Aanbeveler is dan de auteur of de uitgever van het betreffende modellenboek. Zic: Hensen, AGB-Gesetz, pag. 996-997; Lindacher, AGBG Kommentar, \& 13 Rndnr. 57-58; Löwe, GroBkommentar zum AGB-Gesetz, \& 13 Rndnr. 7; Gerlach, Münchener Kommentar, 13 AGBGi Rndnr. 46.

315 Zie uitwoeriger onder andere: Lindacher, AGBG Kommentar, \& 13 Rndnr. 57; Gerlach, Münchener Kommentar, 13 AGBG Rndnr. 44-45; Hensen, AGB-Gesetz, \& 13 Rndnr. 15-22.

316 Lindacher, AGBG Kommentar, 13 Rndnr. 56; Gerlach, Münchener Kommentar, \&13 AGBG Rndnr. 44; Löwe, GroBkommentar zum AGB-Gesetz, 13 Rndnr. 8. 
aanbeveler ${ }^{317}$ Dit wordt echter anders indien de advocaat of notaris hetzelfde regelcomplex aanbeveelt aan meerdere cliënten. ${ }^{318}$ Wetenschappelijke meningsuitingen over algemene voorwaarden en het enkele ontwerpen van algemene voorwaarden worden eveneens niet gezien als aanbevelingen in de zin van $\$ 13$ AGBG. $^{319}$

De verbodsvordering tegen de aanbeveler kan net als de vordering tegen de gebruiker worden ingesteld zowel ter voorkoming van herhaalde aanbeveling als ook ter voorkoming van een eerste aanbeveling indien de potentiële aanbeveler te kennen heeft gegeven dat hij voornemens is het gebruik van onredelijk bezwarende bedingen te propageren. ${ }^{320}$ Net als bij de verbodsvordering tegen het gebruik van onredelijk bezwarende algemene voorwaarden geldt ook voor de vordering tot verbod van verdere aanbeveling dat sprake moet zijn van herhalingsgevaar. Dit wordt echter reeds vermoed aanwezig te zijn als sprake is van een daadwerkelijke aanbeveling. In dat geval dient de aanbeveler aan te tonen dat zijn aanbeveling slechts eenmalig was. ${ }^{321}$

\section{De gebodsvordering}

Om het effect van een eenmaal gedane aanbeveling tot gebruik van onredelijk bezwarende algemene voorwaarden te niet te doen kunnen de op grond van $\$ 13$ Abs. 2 AGBG bevoegde organisaties eveneens een gebod tot herroeping van een aanbeveling vorderen (Widerrufsklage). ${ }^{322}$ De gebodsvordering is slechts mogelijk zolang de aanbeveling nog haar werking heeft in het rechtsverkeer en de inbreuk die het aanbevelen van onredelijk bezwarende bedingen hierop maakt, voortduurt. ${ }^{323}$

Indien de gebodsvordering wordt toegewezen, wordt de wijze waarop de aanbeveler de onredelijk bezwarende voorwaarden dient te herroepen door de rechter aangegeven in het vonnis ( $\$ 17 \mathrm{Nr} .4$ AGBG). In beginsel dient de herroeping pllaats te vinden door mededeling van het rechterlijk vonnis jegens dezelfde kring van personen en op dezelfde wijze als de aanbeveling bekend is

317 Löwe, Grolkkommentar zam AGB-Gesetz, \& 13 Rndnr. 8; Hensen, AGB-Gesetz, \& 13 Rndnr.

22; Lindacher; AGBG Kommentar, 13 Rndnr. 56.

318 LG Konstunz, BB 1981, pag. 1420; OLG Karlsruhe, BB 1983, pag. 725; Lindacher, AGBG Kommentar, 13 Rndnr. 56-57; Löwe, GroBkommentar zum AGB-Gesetz, 13 Rndnr. 6; Reinel, pag. 31; Gerlach, Münchener Kornmentar, 13 AGBG Rndnr. 44; Hensen, AGBGesetz, \& 13 Rndnr. 21.

319 Hensen, AGB-Gesetz, 13 Rndnr. 22; Löwe, GiroBkommentar zum AGB-Gesetz, \&13 Rndirr. 7; Lindacher, AGBG Kommentar, 13 Rndnr. 56-57.

320 Lindacher, AGBG Kommentar, \& 13 Rndnr. 60.

321 Lindacher, AGBG Kommentar, 13 Rndnr. 60.

322 Lindacher, AGBG Kommentar, \$13 Rndnr. 56; Hensen, AGB-Gesetz, \$13 Rndnr. 32.

323 Löwe, Großkommentar zum AGB-Gesetz, \&13 Rndnr. 46; Gerlach, Münchener Kommentar, 8. 13 AGBG Rndnr. 49: 
gemaakt. ${ }^{334}$ In het geval van zogenaamde Konditionenempfehlungen, die op grond van $\$ 10 \mathrm{Abs} .1 \mathrm{Nr} .3 \mathrm{GWB}$ door het BKA in de Bundesanzeiger worden gepubliceerd, dient de aanbeveler eveneens zorg te dragen voor een herroeping in de Bundesanzeiger. ${ }^{325}$ Indien de herroeping naar haar aard niet op dezelfde wijze als de aanbeveling kan plaatsvinden, dient de herroeping zo adequaat als mogelijk te zijn om de inbreuk die het aanbevelen van onredelijk bezwarende bedingen op het rechtsverkeer heeft gemaakt, te corrigeren. ${ }^{326}$ Voor het geval de aanbeveling heeft plaatsgevonden in boeken of andere uitgaven die zich nog in de handel bevinden, dient de herroeping te geschieden door hiervan mededeling te doen in een daartoe geschikt medium aan de kring van personen die deze boeken of uitgaven gebruiken (vaktijdschrift of verenigingsorgaan). ${ }^{327}$ Een aantal auteurs is van mening dat in het geval van aanbevelingen in modellenboeken of andere uitgaven, de herroeping slechts of mede het uit de handel nemen van deze werken omvat. ${ }^{328}$ Gerlach wijst er, mijns inziens terecht, op dat het uit de handel terugnemen van modellenboeken en andere uitgaven volgt uit het verbodsvonnis dat de aanbeveler verbiedt om nog langer aan te bevelen en niet uit het gebodsvonnis dat de aanbeveler verplicht zijn aanbeveling te herroepen. ${ }^{329}$

\subsubsection{De nevenvorderingen}

Aan de vordering tot verbod van gebruik of aanbeveling of tot een gebod tot herroeping van een aanbeveling tot gebruik van onredelijk bezwarende bedingen als bedoeld in $\$ 13$ Abs. 1 AGBG, kunnen een tweetal nevenvorderingen worden verbonden. De vordering tot publikatie van het vonnis en de dwangsom.

De bevoegdheid om een vordering tot publikatie van het vonnis in te dienen, is vastgelegd in $\$ 18$ AGBG.

324 Löwe, Großkommentar zwim AGB-Gesetz, 13 Rndnr. $49-52$ en \$17 Rndnr. 25; Heinrichs, BGB (Palandi), AGBG $13 \mathrm{Nr}$. 3; Gerlach, Mïnchener Kommentar, \& 17 AGBG Rndrir. 6; Wemer, Handkommentar zum BGB, 13 AGBG Rndnr. 34; Lindacher, AGBG Kommentar, 17 Rndar. 8 .

325 OLG Köln, BB 1982, pag. 638, WRP 1981, pag. 663; Gerlach, Münehener Kommentar, 17 Rndni. 6; Löwe, Grobkommentar zum AGB-Gesetz, 17 Rndnr 26.

326 Lündacher, AGBG Kommentar, 17 Rndnr. 10; Löwe, GroBkommentar zum AGB-Gesetz, 8. 17 Rndnr. 27.

327 Lindacher, AGBG Kommentar, \$17 Rndnr. 10; Gerlach, Münchener Kommentar, 17 AGBG Rndinr. 6.

328 Zie bij voorbeeld: Lowe, Grofkommentar zum AGB-Gesetz, 813 Rndinr. 50; Hensen, AGBGeselz, 17 Rndir. 9-10.

329 Gerlach; Großkommentar zum AGB-Gesetz, \& 17 Rndnir. 6. 
Wird der Klage stangegeben, so kann dem Klager auf Antrag die Befugris zugesprochen werden, din Uneilsformel mit der Bezeichnung des verurteilien Venwenders ader Emplehlers auf Kosten Las Beklagten im Bundesanzeiger, im abrigen auf eigene Kosten bekanntzumachen. Das Gericht kann the Befugris zeitlich begrenzert.

Op grond van deze bepaling kan de rechter de eiser, op diens vordering, toestaan het vonnis en gedaagdes naam of de naam waaronder deze opereert te publiceren in de Bundesanzeiger en wel op kosten van gedaagde. Verder kan het eiser - wederom op diens vordering - worden toegestaan het vonnis voor eigen rekening te publiceren in andere bladen of periodieken. De rechter kan deze bevoegdheid beperken tot een door hem vast te stellen periode. ${ }^{330}$

De vordering kan enkel worden ingediend door de eisende organisatie en veronderstelt dat de verbods- of gebodsvordering geheel of gedeeltelijk is toegewezen. De vordering dient aard en omvang van de gewenste publikatie te bevatten. ${ }^{331}$ Indien sprake is van een gedeeltelijke toewijzing van de verbodsof gebodsvordering ziet de publikatiebevoegdheid slechts op het deel van het vonnis warin de vordering (gedeeltelijk) wordt toegewezen. ${ }^{332}$ of een publikatie als bedoeld in $\$ 18$ AGBG ook gevorderd kan worden in kort geding is in de literatuur omstreden, het merendeel van de auteurs acht toepassing van $\S 18$ AGBG echter ook in een procedure in kort geding mogelijk..$^{333}$

De rechter zal bij zijn beslissing omtrent het al dan niet toestaan van publikatie van het vonnis een belangenafweging dienen te maken. $\& 18$ AGBG bepaalt immers dat de rechter op vordering van de eiser een publikatiebevoegdheid kan toekennen. ${ }^{334}$ Publikatie van een vonnis is vooral op haar plaats als het gebruikers met een uitgebreide klantenkring en veelvuldig gebruikte bedingen betreft. ${ }^{335}$

De bekendmaking of publikatie van rechterlijke beslissingen inzake algemene voorwaarden werd door de wetgever gezien als eén van de belangrijkste middelen in de bestrijding van het gebruik van onredelijk bezwarende algemene voorwalarden. Met de publikatie beoogt de wetgever breedtewerking te verschaf-

330 Hensen; AGB-Gesetz, 18 Rndnr. 6.

331 Lindacher, AGBG Kommentar, \$18 Rndnr. 5; Hensen, AGB-Gesetz, \$18 Rndnr. 4.

332 Lindacher, AGBG Kommentar, \& 18 Rndnr. 9.

333 Vór onder meer: Lindacher, AGBG Kommentar, 18 Rndinr. 4; Gerlach, Münchener Kommentar, 18 AGBG Rndinr. 2; Wemer, Handkommentar zum BGB, 18 Rndnr. 1; Löwe, Grobkommentar zum AGB-Gesetz, 18 Rndnr. 4. Tegen: Heinrichs, BGB (Paiandt), AGBG 18 Rndnr. 1; Hensen, AGB-Gesetz, \& 18 Rndnr. 3.

334 Löwe, Grodkommentar zum AGB-Gesetz, 18 Rndnr. 7; Hensen, AGB-Gesetz, \& 18 Rndnr. 5; Werner, Handkommentar zum BGB, 818 Rndnr. 2. Anders: Lindacher, AGBG Kommentar. 18 Rndinr. 6.

335 Bunte, Handbuch, pag. 29; Gerlach, Münchener Kommentar, \& 18 AGBG Rndnr. 2; Heinrichs, BGB (Palandt), AGBG $18 \mathrm{Nr} .1$. 
fen aan rechterlijke vonnissen. Door de bekendmaking wordt het geïnteresseerde publiek de mogelijkheid gegeven om kennis te nemen van de vonnissen in de abstracte procedure. ${ }^{336}$ Het doel van publikatie van het verbods- of gebodsvonnis is tweeledig. Aan de ene kant is de publikatie gericht op de vrijwaring van het rechtsverkeer van hergebruik en herhaalde aanbeveling van door de rechter verboden bedingen en het corrigeren van een reeds gedane aanbeveling van zulke bedingen. Aan de andere kant is de publikatie gericht op het versterken van de precedentwerking van het vonnis voor vergelijkbare gevallen. ${ }^{337}$

Of deze doelen met de bepalingen van $\$ 18 \mathrm{AGBG}$ worden bereikt wordt in de literatuur ernstig betwijfeld. De Bundesanzeiger is immers niet bepaald een blad dat door een breed publiek wordt gelezen en aan de bevoegdheid om tot publikatie over te gaan in andere media als kranten en tijdschriften, waarvan een grotere breedte- en precedentwerking is te verwachten, kleeft het ernstige nadeel dat de eisende organisatie deze zelf moet bekostigen. ${ }^{338}$ In de praktijk heeft de bepaling van $\S 18$ AGBG daarom weinig betekenis. ${ }^{339}$

De bevoegdheid om naast een verbod of gebod een dwangsom te vorderen is niet uitdrukkelijk geregeld in het AGB-Gesetz. De bevoegdheid volgt indirect uit $\$ 15$ Abs. 1 AGBG waarin is bepaald dat, voor zover uit de bepalingen van het AGB-Gesetz niet anders voortvloeit, op de procedure van $\$ 13$ AGBG de voorschriften van de Zivilprozeßordnung (ZPO) van toepassing zijn.

Voor de dwangsom gekoppeld aan een verbodsvordering is met name $\$ 890$ ZPO van belang dat ziet op de executie van de verplichting om iets te laten of te dulden. ${ }^{340}$ Op grond van deze bepaling kunnen de eisende organisaties verlangen dat aan het verbodsvonnis een dwangsom (Ordnungsgeld) van maximaal 500.000 DM per overtreding wordt verbonden voor het geval de veroordeelde gebruiker of aanbeveler geen uitvoering wil geven aan het verbodsvonnis. ${ }^{341}$ Bij een verbodsvonnis is het niet onredelijk dat de hoogte van de dwangsom wordt vastgesteld op $5.000 \mathrm{DM}$ per geval en per clausule. ${ }^{342}$ Voor het geval dat de dwangsom niet verhaald kan worden, kan degene op wie het verbod rust,

336 Rechtsausschuß, BT Drucksache 7/5422, pag. 12.

337 Lindacher, AGBG Kommentar, \& 18 Rndnr. 1 en 6; Hensen, AGB-Gesetz, 18 Rndnr. 1; Gertlach, Münchener Kommentar, \& 18 Rndinr. 1 .

338 Gerlach, Münchener Kommentar, \$18 Rndrur. 1; Heïrichs, BGB (Palandt), AGBG 18 Nr. 1; Löwe, Großkommentar zum AGB-Gestetz, \$18 Rndnr: 1 .

339 Hensen, AGB-Gesetz, 18 Rndnr. 1.

$340 \& 890$ ZPO Erzwingung von Unterlassungen und Duldungen:

341 Gerlach, Münchener Kommentar, 15 Rndnr. 18; Lindacher, AGBG Komumentar, 13 Rndnr. 115; Löwe, GroBkommentar zum AGB-Gesetz, 17 Rndur. 29.

342 LG Konstanz, AGBE Band II $11 \mathrm{Nr}$. 5b, Nr. 59; Gerlmch, Münchener Kommentar, 15 Rndnr. 18. 
op vordering van eiser, tevens worden veroordeeld tot vervangende hechtenis (Ersatzordnungshaft). ${ }^{343}$

De dwangsom en eventuele lijfsdwang gekoppeld aan een veroordeling tot herroeping van een eerder gedane aambeveling vindt haar regeling in $\$ 888$ $\mathrm{ZPO}$. Op grond van deze regeling kan de eisende organisatie een dwangsom (Zwangsgeld) wan maximaal 50.000 DM per geval vorderen. ${ }^{344}$ Voor het geval dat de dwangsom niet verhaald kan worden, kan degene op wie het gebod rust, op vordering van eiser, tevens worden veroordeeld tot vervangende hechtenis (Ersatzzwangshaft). ${ }^{345}$ In tegenstelling tot Nederland kan de dwangsom niet worden verbeurd aan de eisende organisatie maar wordt zij verbeurd aan de staat.

\subsubsection{De toetsnorm}

Volgens de wettekst is er enkel plaats voor een verbods- of gebodsvordering indien de ongeldigheid van bedingen voortvloeit uit de $\$ \$ 9$ tot en met 11 AGBG. De centrale toetsnorm in de collectieve actie is derhalve voor handelstransacties $\$ 9$ AGBG en voor consumententransacties de $\$ \$ 9$ tot en met 11 AGBG. Dit heeft ondermeer tot gevolg dat de collectieve actie hetzelfde materiële en personele bereik heeft als de individuele actie. De $\$ \$ 8,23$ en 24 AGBG zijn daarom van overeenkomstige toepassing. ${ }^{346}$

\subsubsection{De uitleg van algemene voorwaarden in de abstracte procedure}

Net als in de individuele procedure begint de inhoudelijke toetsing van een beding in de collectieve procedure logischerwijs met de vaststelling van de inhoud van het beding. De algemene regels met betrekking tot de uitleg van overeenkomsten gelden in beginsel ook voor de uitleg van algemene voorwaarden in de collectieve procedure.

343 In theorie is het zelfs mogelijk dat de rechter de gebnuker of aanbeveler op wie een verbod van verder gebnulk of anbeveling rust, op vordering van de eiser; in plasts van cen dwangsom, lijfsdwang (Ordnungshaft) tot een maximum van zes maanden per geval oplegt. Een praktijkge val is mij echter niet bekend.

344 Gerlach, Müncheiner Kommentar, \& 15 Rndnr. 24; Lindacher, AGBG Kommentar, $\$ 13$ Rmdnr. 116; Lowwe, Grollkommentar zum AGB-Gesetz, \$17 Rndinr. 39.

345 In theorie is het eveneens mogelijk dat de rechter de aanbeveler op wie cen gebod tot herroeping rust, in pilats van een dwangsom, liffodwang ( $Z$ wangahaft) to cen maximum van zes maanden per geval oplegt. Zie; Gerlech, Münchener Kommentar, 8 is Rndnr. 24.

346 Heinrichs, BGB (Palandt), AGBG $13 \mathrm{Nr}$. 1-2; Lindacher, AGBG Kommentar, \& 13 Rndnr. 30; Hengen, AGB-Gesetz, \&13 Rndmir. 4; Gerlach, Münchener Kommentar, 13 AGBG Rndnr. 
Ook in de abstracte procedure staat in beginsel de objectieve uitleg van algemene voorwaarden voorop. ${ }^{347}$ Door het ontbreken van concrete individuele omstandigheden en interpretaties van de concrete contractspartijen zijn bij de vaststelling van de inhoud in de collectieve procedure per definitie alleen de typische omstandigheden en opvattingen van de bij dat soort overeenkomsten betrokken marktpartijen doorslaggevend.

Indien na objectieve uitleg van het beding geen eenduidige inhoud kan worden vastgesteld dient de rechter in de collectieve procedure in beginsel eveneens de bepaling van $\$ 5$ AGBG (Unklarheitenregel) toe te passen. Dit zou er eigenlijk toe leiden dat de rechter zou moeten kiezen voor de meest consumentvriendelijke uitleg van het beding. In literatuur en rechtspraak wordt een contra proferentem-uitleg voor de collectieve actie van $\$ 13$ AGBG echter nagenoeg unaniem afgewezen. In het belang van een efficiënte en effectieve rechtspleging wordt bij (objectieve) niet-eenduidigheid van bedingen, in de collectieve procedure van $\$ 13$ AGBG uitgegaan van de meest consumentonvriendelijkste uitleg van het beding. ${ }^{348}$ De ratio achter deze gedachte is dat het vanwege de beoogde breedtewerking van de collectieve actie mogelijk moet zijn een beding dat zowel een onredelijk bezwarende als een niet-onredelijk bezwarende betekenis in zich bergt, door middel van een collectieve actie te lijf te gaan. ${ }^{349}$ De gebruiker heeft bij niet-eenduidige clausules immers altijd de mogelijkheid zich op de voor de wederpartij meest ongunstige uitleg van het beding te beroepen.

"Tritt ein Verwender mit tatsachlich mehrdeutigen Klauselu awf, so liegt die Gefahr fur" den Kunden darin, daß dieser seine Rechte nicht wahmimm, weil eiste der Aluslegungen den Rechtsstandpunk des Vermenders stüt.

Indien een beding niet-eenduidig is uit te leggen én minstens één van de uitlegmogelijkheden inhoudelijk onredelijk bezwarend is, dient in de abstracte procedure derhalve te worden uitgegaan van de uitleg die voert tot nietigheid van het beding. ${ }^{351}$

347 BGH, NIW 1969, pag. 230-232; BGHZ 77, 116, 118f; BGH, NJW-RR 1990, pag. 1525-1526; Lindiacher, AGBG Kommentar, \$ 5 Rndnr. 5; Bastodow, pag. 354; Ulmer, AGB-Gesetz, \& 5 Rudini, 8.

348 BGH, NJW 1980, pag. 831-832; BGH, NJW 1983, pag. 1671-1672; BGH, ZIP 1984, pag. 1485-1486; BGH, NJW 1984, pag, 2161-2162; BGHZ 91,55, 61; BGH, NJW 1985, pag. 320323; BGH, NJW 1988, 1726-1727; BGH, NJW-RR 1989, pag. 625-626; BGH, NJW 1991 , pag. 1886-1887; BGH, MDR 1993, pag. 339-340; Lindacher, AGBG Kommentar, 8 Rndnr. 41-42; Ulmer, AGB-Gesetz, \$ 5 Rndnr. 33-36; Basedow, pag. 355.

349 Basedow, pag. 355.

350 Hensen, AGB-Gesetz, 813 Rndnr. 10.

$351 \mathrm{BGH}$, NJW 1983, pag. 1671; BGH, NJW 1985, 320; Lindacher, AGBG Kommentar, 5 Rndnr. 41; Bessedow, pag. 355; Hensen, AGB-Gesetz, 13 Rndnr. 10. 


\subsubsection{Abstracte inhoudstoets}

De overeenkomstige toepassing van de $\$ 9$ tot en 11 AGBG betekent voor consumentenovereenkomsten in de eerste plaats dat van belang is of het ter toetsing voorgelegde beding voorkomt op de lijst van $\$ 11 \mathrm{AGBG}$. Bedingen die worden gehanteerd tegenover consumenten en voorkomen op de lijst van $\$ 11$ AGBG zijn immers zonder meer onredelijk bezwarend. De wet laat in deze geen enkele beoordelingsvrijheid en de rechter dient bij zulke bedingen het gevorderde verbod of gebod toe te wijzen. ${ }^{352}$

Beoordelingsruimte heeft de rechter wel bij de collectieve inhoudstoetsing alan de open norm van $\$ 9$ AGBG en de lijst van $\$ 10$ AGBG. Naar haar aard is de collectieve inhoudstoets echter niet gericht op het gebruik van algemene voorwaarden in het concrete individuele geval maar op het gebruik in het algemeen.

"Anders als im Individualprozeß ist die bloße Existenz der Klausel - unabhingig davon, ob sie aberhaupt wirksam vereimbant worden ist ader werden kann - der Stäfakuor, der mit der Verbandlsklage beseivigt werden soll. "353

De maatstaf van $\$ 9$ AGBG, die evenzeer de maatstaf is bij de beoordelingsruimte die de rechter heeft bij de toetsing aan $\$ 10 \mathrm{AGBG}$, wordt in de collectieve procedure derhalve anders toegepast dan in de individuele procedure. $\mathrm{De}$ collectieve inhoudstoets is noodzakelijkerwijs een meer abstracte toets, met concrete individuele omstandigheden kan immers geen rekening worden gehouden. Naar algemene opvatting is een beding in de abstracte toets derhalve onredelijk bezwarend indien het beding bij objectieve beschouwing van de omstandigheden en partijbelangen naar maatstaven van redelijkheid en billijkheid onredelijk bezwarend uitpakt voor een niet geheel onbelangrijk toepassingsbereik van het beding. ${ }^{354}$

"Da 13 Abs. I vom Wesen der Ansprache und vom Verfahren her betrachter Rein Individualpro-

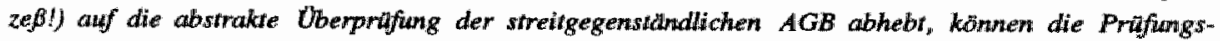
maßstabe der $\$ 89$ und 10 somit nur dawn zu einer abstrakten, von den Umstinden des jeweiligen konkreten Einzelfalles unabhangigem Verwerfung einer AGB.Klawsel fiwhen, werm die Klausel so gestaltet ist daß sie unabhängig von den Umstinden des Einzelfalles in einem nicht vollig wherheblichen Anwendungsbereich bei abjekwiver Awslegung (...) der Gründe (...) als wnangemessen i.s. des 89 anzusehen ist. 355

352 Löwe, Grobkommenttar zum AGB-Gesetz, \& 13 Rndnr. 25.

353 Henisen, AGB-Gesetz, \$ 13 Rndinr. 4.

354 Reinel, pag. 39.

355 Löwe, Großkommentar zum AGB-Gesetz, \& 13 Rndır. 25. 
De rechter moet bij de collectieve inhoudstoetsing, los van concrete individuele omstandigheden nagaan voor welke gevallen de betreffende clausule betekenis heeft en of het beding in die gevallen mogelijk onredelijk bezwarend is voor de wederpartijen die met het beding worden geconfronteerd. De rechter moet zich daarbij, aan de hand van de inhoud, de ard van de overeenkomst en de objectief kenbare belangen van partijen en omstandigheden bij dit soort overeenkomsten, een zo volledig mogelijke voorstelling maken van alle mogelijke feitenconstellaties waartoe de overeenkomst kan leiden en daarbij nagaan of het beroep op het beding in die feitenconstellaties leidt tot een onredelijk bezwarende benadeling van de wederpartij. ${ }^{3.66}$ Beslissend is daarbij enkel het mogelijke gebruik dat de gebruiker van het beding kan maken en dus de mogelijke risico's die de wederpartij daarbij kan lopen. Of de gebruiker zich daadwerkelijk op een dergelijke wijze op het beding zal beroepen of dat de risico's zich werkelijk zullen voordoen is daarbij niet relevant. ${ }^{357}$

Dat de rechter abstract toetst wil niet zeggen dat hij geen enkele omstandigheid meeneemt in zijn beslissing. Hij dient slechts te abstraheren van het individuele geval. De typische omstandigheden en partijbelangen die zich bij voorbeeld steeds voordoen bij een bepaalde soort en aard overeenkomst worden in de abstracte toets net zo goed meegenomen.

"Je eher sich also der konkrete Anwendungsbereich der zu prifenden AGB aberschauen, definieren und abgremzen Laßt, desto weniger Probleme wift die Herchuziehung der $\$ 9$ und 10 als Prifungsmabsuab im Rahmen einer abstraktem Bewrteilang auf." 358

De rechter heeft wat betreft die omstandigheden altijd houvast aan de dagvaarding (Klageantrag). De eisende organisaties moeten op grond van het bepaalde in $\$ 13$ Abs. 3 en $\$ 15$ Abs. 2 Nr. 2 AGBG in de dagvaarding immers de aard van de overeenkomst aangeven waarvoor het beding wordt gebruikt en de wederpartijen waarvoor zij optreden. Ook in de abstracte procedure staan derhalve typische omstandigheden en belangen concreet vast.

Omdat de open norm van $\$ 9$ AGBG van overeenkomstige toepassing is, zijn dezelfde omstandigheden relevant als bij de individuele inhoudstoets. Gezien het feit dat ook bij de individuele inhoudstoets wordt uitgegaan van een uberindividuell-generalisierende Betrachtungsweise ${ }^{360}$ moet derhalve geconstateerd worden dat de toetsnorm voor de abstracte en individuele inhoudstoets gelijk is en dat dezelfde geobjectiveerde omstandigheden daarbij een rol spelen.

356 BGH, NJW 1980, pag, 2518-2519; Bassedow, pag. 356; Jongeneel, disa., pag. 224.

357 OLG Köln, ZIP 1981, pag, 1101 1102; Basedow, pag. 356-357.

358 Lôwe, Großkommentar zum AGB-Gesetz, \& 13 Rndinr. 26.

359 Zie hiervoor paragraaf 6.2.3.2 onder het kopje "De relevante omatandigheden".

360 Zie hiervoor paragranf 6.2.3.2 onder het kopje "Algemene inhoudatoets". 


\subsubsection{Strijd met een dwingende wetsbepaling}

De toetsingsmaatstaf voor de inhoud van algemene voorwaarden is de oper norm van $\$ 9$ AGBG. Deze ziet in beginsel niet op de toetsing van bedingen aan dwingende wetgeving maar aan de maatstaven van redelijkheild en billijkheid. ( $\$ 242$ BGB). Bedingen in strijd met de wet zijn immers nietig op grond van 8134 BGB (Gesetzliches Verbot) of op grond van een direct op die wetsbepaling gerichte wettelijke regeling. Het staat de wederpartij in de individuele procedure echter eveneens wrij om de nietigheid van dergelijke bedingen te baseren op de open norm van $\$ 9$ AGBG of de lijsten van de $\$ \$ 10$ en 11 AGBG. ${ }^{361}$ Mede gezien het doel van de wet, namelijk het tegengaan van het gebruik van ongeldige bedingen, wordt in de rechtspraak en literatuur derhalve aangenomen dat een verbods- of gebodsvordering ook mogelijk is tegen bedingen in algemene voorwaarden die in strijd zijn met dwingende rechtsregels die beogen de wederpartij te beschermen $(134 \mathrm{BGB})$ of die in strijd zijn met de goede zeden $(\$ 138 \mathrm{BGB}) .^{362}$ In de visie van het Bundesgerichtshof leidt een inbreuk op dwingende wetgeving tegelijkertijd tot nietigheid van een dergelijk beding op grond van de $\$ \$ 9$ tot en met 11 AGBG. ${ }^{363}$

$\mathrm{Bij}$ dwingende rechtsregels dient onder andere te worden gedacht aan de bepalingen van $\$ 38$ ZPO (keuze van bevoegde rechter door contractspartijen) $^{364}$, de bepalingen van het huurrecht voor woonruimte van de $\$ \$ 550$ $554 \mathrm{a}^{365}, \S 225 \mathrm{BGB}$ (uitsluiten van verjaring of verlenging van verjaringstermijnen) ${ }^{366}$, \& $125 \mathrm{BGB}$ juncto $\$ 313 \mathrm{BGB}$ (vereiste van notariële akte bij onroerend goed-transacties), het Abzahlungsgesetz $(\mathrm{AbzG})^{367}$, de $\$ \$ 651$ a e.w. BGB (reisovereenkomst en pakketreisovereenkomst) ${ }^{368}$, het Versicherungsvertragsgesetz (VVG) ${ }^{369}$, het Handelsgesetzbuch ${ }^{300}$ en het Bundesdatenschutzgesert ${ }^{37}$.

361 Zle hiervoor paragraaf 6.2 .3 .2 onder het kopjo "Uitgangspunten".

362 OLG Stuttgart, NJW 1981, pag. 1105, ACBE I \& $13 \mathrm{Nr}, 28$; BCH, NJW 1983, pag. 13201322; BGH, NJW 1985, pag. 320-324; BOH, NJW 1989, pag. 1673; BGH, NJW 1992, pag. 1759. Begnindung, BT-Drucksache $7 / 5422$, pag. 10; Heinrichs, BGB (Palandt), AGBG $13 \mathrm{Nr}$. 2; Bunte, Handbuch, pag. 26; Löwe, Groglkommentar zum AGB-Gesetz, 13 Rndinr, 21-22; Hensen, AGB-Gesetz, \& 13 Rndnr 5\%; Lindacher, 13 Rndnr. 38; Reinel, pag. 44; Gerlach, Münchener Kommentar, 13 AGBG Rndnr, 26-27.

363 BGH, NJW 1987, pag. 2867; BGH, VenR 1988, 1281; BGH, NJW 1989, pag. 1673.

364 BGH, NJW 1983, pag. 1320-1322; BGH, NJW 1985, pag. 320; BGH, NJW 1987, pag. 2867.

365 BGH, NJW 1989, pag. 1673; BGH 1992, pag. 1759.

366 OLG Stuttgart, BB 1982, pag. 1753, WRP 1983, pag. 177-178.

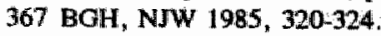

$368 \mathrm{BGH}$ NJW 1983, pag. 1612; OLO Frankfunt, NJW 1982, 2200.

$369 \mathrm{BGH}$, VersR 1988, pag. 1281.

370 BGH, NJW 1985, pag. 621.

$371 \mathrm{BOH}$, NJW 1986, pag. 46. 
Tot de regels van dwingend recht die beogen de wederpartij te beschermen, boren eveneens de bepalingen van het AGB-Gesetz die zien op de toepasselijkheid van algemene voorwaarden (\$\$ 2-4 AGBG) en de uitleg daarvan ( $\$ 5$ AGBG). De verbods- en gebodsactie van $\$ 13$ AGBG strekt zich derhalve eveneens uit tot bedingen die inbreuk maken op de wettelijke bescherming die de $\$ 2$ tot en met 5 AGBG bieden en daarom eveneens onredelijk bezwarend zijn op grond van $\$ 9$ AGBG. ${ }^{372}$

"Der Rechtswerkehr soll nimlich auch won Scheinbindungen freigehalten werdien, die jede rechtich unwirksame oder unerhebliche Klausel tarsachlich herzustellen vermag. ${ }^{373}$

Op de eerste plaats kunnen door middel van de verbods- of gebodsactie van $\$ 13$ AGBG derhalve bedingen onderuit gehaald worden die de gebruiker bevrijden van de toepasselijkheidswoorschriften van $\$ 2$ Abs. 1 AGBG en in strijd met dit artikel bepaalde bedingen toch tot contractsinhoud bestempelen. ${ }^{374} \mathrm{Zo}$ zijn op grond van \$ 13 AGBG onder andere bedingen verboden:

- die de wederpartij zonder meer binden aan andere (algemene) voorwaarden door enkel te bepalen dat deze toepasselijk zijn ${ }^{375}$;

- die de wederpartij binden aan algemene voorwaarden waarnaar eerst ná het sluiten van de overeenkomst is verwezen of waarvan de redelijke mogelijkheid tot kennisname eerst ná het sluiten van de overeenkomst is geboden, bij voorbeeld bedingen die op facturen of afleveringsbewijzen vermelde voorwaarden tot contractsinhoud bestempelen ${ }^{376}$;

- waarvan de wederpartij niet op een redelijke manier kennis heeft kunnen nemen omdat zij onduidelijk, versluierd of ondoorzichtig zijn $\mathrm{n}^{377}$.

Verrassende bedingen in de zin van $\$ 3$ AGBG zijn vaak tevens inhoudelijk ( $\$ 9$ - 11 AGBG) onredelijk bezwarend en derhalve via de weg van $\S 13$ AGBG eveneens aantastbaar. Onzeker is of bedingen die objectief gezien inhoudelijk weliswaar verrassend zijn maar niet tevens onredelijk bezwarend, door middel van een $\$ 13$ AGBG-actie kunnen worden aangetast. Tegen de

372. OLG Stuttgart, BB 1979, pag. 1468; BGH, NJW 1981 , pag. 979-980; BGH, NJW 1991, pag. 1750; Lindacher, AGBG Kommentar, 13 Rndnr. 39-42; Gerlach, Münchener Kommentar,

13 AGBG Rndnr. 17-20; Hensen, AGB-Kommentar, 13 Rndnr. 7-10.

373 BGHZ 100, 158, NJW 1987, pag. 1913.

374 Gerlach, Münchener Kommentar, 13 Rndnr. 19; Lindacher, AGBG Kommentar, 13 Rndnr. 40: Hensen, AGB-Gesetz, 13 Rndnr. 8.

375 OLG Düsseldorf, NJW-RR 1988, pag. 884-886; BGH, NJW 1991, pag. 1750. In casu betrof het een clausule in de algemene voonwaarden wan cen ziekenhuis warrin de huistegels van toepassing werden werklaard: "Die Benutzer sind an die Hausordnung gebunden".

376 Hensen, AGB-Gesetz, 13 Rndnr. 8.

377 OLG Stuttgart, NJW 1981, pag. 1106; BGH, NJW 1985, prag. 53; OLG Hamburg, NJW-RR 1986, pag. 1440. 
heersende mening in de literatuur ${ }^{378}$ en lagere rechtspraak ${ }^{379}$ dat de wederpartij eveneens collectief beschermo dient te worden bij clausules die in de individuele procedure vanwege hun verrassend karakter - ongeacht het bezwarende karakter van het beding - ongeldig zouden zijn, heeft het BGH deze vraag inmiddels ontkennend beantwoord. ${ }^{380}$

Ook bedingen die objectief gezien in strijd met $\$ 4$ AGBG zijn en uitdrukkelijk gemaakte mondelinge of schriftelijke afspraken ten aanzien van bij voorbeeld de prijs, de tijd van nakoming tussen partijen hun werking ontnemen, kunnen door middel van een verbodsactie ex $\S 13$ AGBG onderuit worden gehaald ${ }^{381}$ Zo zijn op grond van de inhoudstoets van 13 AGBG onder meer bedingen verboden verklaard die tot doel hebben (mondeling) overeengekomen levertijden $^{382}$ en toezeggingen ${ }^{383}$ van de gebruiker of diens hulppersonen, buiten werking te stellen.

Verder zijn door middel van de gebods- of verbodsactie van \$ 13 AGBG bedingen te attaqueren die de voor de wederpartij gunstige uitlegregel van $\S 5$ AGBG omdraaien in het voordeel van de gebruiker. $\mathrm{Zij}$ zijn immers zonder meer in strijd met een dwingende wettelijke regeling. ${ }^{384}$

\subsubsection{De bevoegde organisaties}

$\$ 13$ lid 1 AGBG bepaalt dat degene die algemene voorwaarden gebruikt of propageert die, op grond van de $\$ \S 9$ tot en met 11 AGBG, ongeldig zijn, veroordeeld kan worden tot een verbod deze algemene voorwaarden te hanteren of veroordeeld kan worden tot het herroepen van zijn advies de in het geding zijnde bedingen te gebruiken. Lid 2 van $\$ 13$ AGBG geeft aan welke organisaties bevoegd zijn een verbods- of gebodsvordering in te stellen.

\$ 13 Unterlassungs- und Widerrufsanspruch

(2) Die Anspritche auf Unterlassung und auf Widernuf können nur geltend gemacht werden

378 Lôwe, Großlkommentar zum AGB-Gesetz, 13 Rndnr. 23; Heinrichs, BGB (Palandt), AGBG 13 Nr. 2; Lindacher, AGBG Kommentar, \$13 Rndnr. 42; Hensen, AGB-Gesetz, 13 Rndnr. 8.

379 OLG-Hamm, NJW-RR 1986, pag. 927-930; OLG Karlanuhe, NJW-RR 1988, pag. 302-303.

380 BGH, MDR 1983, pag. 113; BGH, WM 1986, pag. 1253-1254; BGH, NJW 1987, pag. 1886; BGH, NJW 1990, pag. 2313-2314.

381 Löwe, Grobkommemtar zum AGB-Gesetz, \& 13 Rndinr. 23; Lindacher, AGBG Kommentar, 13 Rndinr. 40; Hensen, AGB-Gesetz, 13 Rndnr. 9.

382 BGHZ 92, 24. NJW 1984, pag. 2468. In casu ging het on het in een aannemingsovereenkomst opgenomen beding: "Der Liefertermin kann um sechs Wochen verschoben werden."

$383 \mathrm{BGH}$, NJW 1983, pag. 1853 (eenmansbedrijf); BGH, NJW 1985, pag. 320-322; BGHZ 86, 712 , NJW 1986, pag. 1809.

384 Hensen, AGB-Gesetz, \& 13 Rndnr. 7. 
I. won rechisfahigen Verbanden, zu deren satzungsgemaßen Aufgabien es gehtirt, die Interessen der Ventraucher durch Auflianung wnd Beratung wahrzunehmen, wenn sie in diesem Alufgaburbereich tatige Verbinde oder mundestens funfundsiebzig natarliche Personen als Mitglieder haben,

2. Wan rechrsfahigen Verbanden zur Fördenung gewerblicher Interessen oder

3. won den Industrie- und Hardelskammem oder den Handwerkskammen.

Het collectief actierecht inzake algemene voorwaarden wordt daarmee enkel toegekend aan privaatrechtelijke organisaties met volledige rechtsbevoegdheid die de belangenbehartiging van consumenten of ondernemers tot doel hebben en publiekrechtelijke branche-, beroeps- en bedrijfsorganisaties (Industrie-, Handels- und Handwerkskammern). De onder Nr. 3 genoemde publiekrechtelijke organisaties (öffentlich-rechtlichen berufsständischen Körperschaften) worden geacht ondernemers en beroepsbelangen te behartigen. In die zin is $\S 13$ Abs. 2 Nr. 3 AGBG een species van $\S 13$ Abs. 2 Nr. 2 AGBG welke tot doel heeft uitdrukkelijk vast te leggen dat de genoemde publiekrechtelijke organisaties bevoegd zijn om collectief op te treden. ${ }^{385}$ In afwijking van de voorstellen van de CDU/CSU-fractie ${ }^{386}$ en de Bundesrat ${ }^{387}$ kan de individuele wederpartij geen verbods- of gebodsvordering instellen tegen de gebruiker of wederpartij en kan deze enkel een beroep doen op de concrete inhoudscontrole van de $\$ \$ 9$ tot en met 11 AGBG. $^{338}$ Dat het ius agendi van $\$ 13$ AGBG wordt beperkt tot de in $\$ 13$ Abs. 2 AGBG genoemde organisaties vindt zijn verklaring in het belang dat de gerechtelijke instanties en de potentiële gedaagden hebben bij een concentratie van de actiebevoegdheid bij serieuze, ervaren en vooral deskundige eisers. ${ }^{389}$

Aan consumentenorganisaties (Verbraucherverbände) worden in Abs. $2 \mathrm{Nr} .1$ een aantal duidelijke vereisten gesteld waaraan zij moeten voldoen om actiebevoegd te zijn.

Op de eerste plaats moeten zij, net als ondernemersorganisaties, rechtsbevoegdheid bezitten. Dat wil zeggen dat zij moeten zijn ingeschreven in het verenigingsregister (Vereinsregister) als bedoeld in $\$ 21$ BGB.

Verder moeten de consumentenorganisaties zich statutair ten doel hebben gesteld de belangen van consumenten door middel van voorlichting en individuele advisering te behartigen. Het gegeven dat de wettelijke regel beoogt enkel ervaren en deskundige organisaties als eiser op te laten treden, brengt met zich

385 BT Drucksache 7/5422, pag. 11; BGHZ 81, 230; Gerlach, Münohener Kommentar, \& 13 AGBG Rndnr. 75; Lindacher, AGBG Kommentar, \& 13 Rndm. 12; Hensen, AGB-Gesetz, \& 13 Rudnr: $42-43$.

386 BT Drucksache 7/3200, 26.

387 BT Druckswache $7 / 3919,13$ Abs. 1, pag. 52.

388 Herusen, AGB-Gesetz, 13 Rndnr. 35.

389 Lindacher, AGBG Kommentar, Vor \$13 Rndmr. 7 en \&13 Rndnr. 5. 
dat de statutaire doelstelling ook daadwerkelijk in de praktijk moet worden of zijn gebracht. ${ }^{390}$ Deze daadwerkelijke activiteiten kunnen bij voorbeeld bestaan uit de verspreiding van geschriften, lezingen, congressen, vergaderingen of het opzetten en organiseren van voorlichtings- of adviesbureaus. ${ }^{391}$ Een daadwerkelijke behartiging van het consumentenbelang door middel van voorlichting en advies vereist in die zin eveneens dat aan bepaalde organisatorische en personele voorwaarden moet zijn voldaan, hetgeen de vorderende organisatie zonodig moet bewijzen. Aan consumentenorganisaties die het consumentenbelang enkel behartigen door middel van rechtsvervolging wordt het collectief actierecht als. bedoeld in \& 13 AGBG ontzegd. ${ }^{392}$ Het feit dat de behartiging van de belangen van consumenten door het geven van voorlichting en advies niet de enige of de belangrijkste statutaire doelstelling van de eisende organisatie is, vormt geen belemmering voor de actiebevoegdheid. Wel is vereist dat de belangenbehartiging door het geven van zowel voorlichting als advies aan consumenten, geen ondergeschikt belang van de eisende vereniging is. ${ }^{393}$ Op grond van de wettekst is het onvoldoende indien de eisende organisatie de belangen van consumenten behartigt door of alleen voorlichting of alleen advisering. Vereist is dat de eisende organisatie op beide terreinen actief is of is geweest. ${ }^{394}$

De wet verlangt niet dat de eisende organisatie opkomt voor alle consumentenbelangen of het algemeen consumentenbelang. Categoriale consumentenorganisaties die slechts bepaalde belangen van bepaalde consumenten statutair en daadwerkelijk behartigen - zoals bij voorbeeld huurdersverenigingen ${ }^{395}$ of de $\mathrm{ADAC}^{396}$ - hebben, indien zij aan de andere voorwaarden van $\$ 13$ Abs. 2 Nr. 1 AGBG voldoen, eveneens het ius agendi van $\$ 13$ Abs. 1 AGBG. ${ }^{397}$ Wel is vereist, dat de consumentenorganisaties niet alleen de belangen van

390. Rechtsausschu1, BT Drucksache 7/5422, pag, 11; BGH, NJW 1986, pag. 1613; Gerlach, Münchener Kommentar, 8 i AGBG Rndnr. 69; Löwe, Grolkommentar zum AGB-Gesetz,

\$13 Rudinr. 72, Lindacher, AGBO Kommentar, $\| 3$ Rndnr. 7, Hengen, AGB-Gesetz, 13 Rndinr. 37.

391 Rechtsawsischul, BT Druckswche 7/5422, pag. 11 .

392 Axmann, pag. 43 .

393 BGH, NJW 1986, pag. 1613; Gerlach, Minchener Kommentar, 13 AGBG Rndnr. 66w67" Reinel, pag. 48; Lindacher, AGBG Kommentar, 13 Rndnr, 7; Hensen, AGB Gesetz, 13 Rndnr. 37; Axmann, payg. 42.

394 Hensen, AGB-Gesetz, \& 13 Rndin. 37; Lindacher, AGBG Kommentar, 13 Rndnr. 7* Heinrichs, BGB (Palandt), ACBG $13 \mathrm{Nr}$. 4, Het geven van rechtskundige adviezen in in Duitsland op grond van het Rechtsberatungsgesetx voorbehouden aan slechts enkele beroweps. groepen. Daarbuiten is het geven van rechtskundige adviezen sllechts bij uitzondering toegellaten. In de literatuur wondt aangenomen dlat het consumentenorganisaties op grond van $\$ 7$ RBerG is toegestaran hun leden wan rechtskundige adviezen te voorzien. Zie: Urbanezyk, pag. 204; Lindacher, AGBG Kommentar; \& 13 Rndnr. 7.

395 BGH, NJW 1986, pag. 1613; BGH, NJW 1986, pag, 2247.

396 Allgemeiner Deutscher Automobil Club e. . (te vergelijken met de ANWB). BGH, MDR 1988, pag. 1027.

397 Lindacher, AGBG Kommentar, 13 Rndnr. 7; Hensen, AGB-Gesetz, \& 13 Rndar.. 39. 
aangesloten leden behartigen maar tevens die van niet-leden die tot de doelgroep behoren. ${ }^{398}$

Als laatste voorwaarde voor actiebevoegdheid stelt $\& 13 \mathrm{Abs} .2 \mathrm{Nr} .1$ dat de eisende consumentenorganisatie een ledenbestand heeft van minstens 75 naturlijke personen of indien een overkoepelende organisatie als eiser optreedt dat minstens 2 organisaties met genoemde doeistelling daarvan lid zijn. ${ }^{399}$

Of de eisende consumentenorganisaties aan de vereisten van $\$ 13$ Abs. $2 \mathrm{Nr}$. 1 AGBG voldoen, dient de rechter ambtshalve vast te stellen. Algemeen wordt echter aangenomen dat de algemene consumentenorganisaties zoals de Arbeitsgemeinschaft der Verbraucher e.V. (AGV) te Bonn, de Verbraucherschutzverein e.V. (VSV) te Berlijn en de Verbraucherzentralen van de diverse deelstaten in ieder geval aan de vereisten van \& $13 \mathrm{Abs}$. $2 \mathrm{Nr} .1 \mathrm{AGBG}$ voldoen.

In $\$ 13$ lid 3 AGBG wordt de bevoegdheid van consumentenorganisaties tot het instellen van een verbods- of gebodsvordering nader beperkt.

13 Unterkassungs- und Widerrufsanspruch

(3) Die in Absatz 2 Nr. 1 bezeichneten Verbande kinnen Anspriche auf Unterlassiung und auf Widemuf nicht geltend machen, wenn Allgemuine Geschafisbedingungen gegeriaber einem Kaufinann wenwendet werden und der Vertrag zum Betriebe seines Handelsgewenbes gehort ader wenn Allgemeine Geschäfisbedingungen zur ausschließlichen Verwendung zwischen Kaufleuten empfohlen werden.

Consumentenorganisaties hebben slechts actiebevoegdheid inzake algemene voorwaarden die gehanteerd worden in transacties met consumenten. Consumentenorganisaties hebben derhalve geen actiebevoegdheid ten opzichte van gebruikers van algemene voorwaarden die deze slechts hanteren tegenover nietconsumenten. Hieraan ligt de evidente gedachte ten grondslag dat consumentenbelangen in die gevallen niet in het geding zijn en consumentenorganisaties derhalve niet de aangewezen belangenbehartigers zijn. ${ }^{401}$ Als de gebruiker de betreffende algemene voorwaarden gebruikt (of aanbeveler deze propageert voor gebruik) jegens zowel consumenten als ondernemers, zijn consumentenorganisaties slechts bevoegd een vordering in te stellen voor zover het gebruik of de aanbeveling het rechtsverkeer met consumenten betreft. ${ }^{402}$

398 Axmann, pag. 42.

399 Lindacher, AGBG Kommentar, 13 Rndnr. 8; Hensen, AGB-Gesetz, 13 Rndnr. 37.

400 Reinel, pag. 58; Lindacher, AGBG Kommentar; 13 Rndar, 21-22; Hensen, AGB-Gesetz, 13 Rndnr. 40.

401 RechtsausschuB, BT Drueksache 7/5422, pag. 11, OLG Nümberg, BB 1978, pag. 1183.

402 Lindacher, AGBG Kommentar, 13 Rndnr. 14-15; Hensen, AGB-Gesetz; 13 Rndar. 45. 
Het is mogelijk dat met betrekking tot het gebruik of de aanbeveling van ten bepaalde onredelijk bezwarende voorwaarde aan meerdere consumentenorganisaties een verbods- of gebodsactie toekomt en dat de bevoegde organisaties hetzij tegelijkertijd, hetzij opeenvolgend, van hun bevoegdheid gebruik maken. In beginsel hebben de verschillende organisaties een onafhankelijk en zelfstandig actierecht. Dit omdat elke organisatie een eigen belang heeft bij het verkrijgen van een executoriale titel met betrekking tot het gevorderde verbod of gebod, zodat ook zij executoriale maatregelen, zoals bij voorbeeld een dwangsom, kan effectueren. Bovendien heeft de wetgever de bevoegdheid om in het algemeen belang op te treden, bewust bij meerdere, van elkaar onafhankelijke, organisaties gelegd. Een beschermingsmodel dat gebaseerd is op het particuliere initiatief en kiest voor een privaatrechtelijke en op het burgerlijk procesrecht gebaseerde handhaving, vereist immers een "concurrerende" bevoegdheid van meerdere organisaties om eventueel tekortschieten van individuele particuliere initiatieven van optredende organisaties te corrigeren. ${ }^{404}$

Een en ander brengt met zich dat het feit dat een andere procedure met betrekking tot hetzelfde beding aanhangig is of een vonnis is gewezen dat kracht van gewijsde heeft verkregen, niets afdoet aan de actiebevoegdheid van niet bij de procedure betrokken consumentenorganisaties. Consumentenorganisaties kunnen in beginsel ten aanzien van hetzelfde beding tegelijkertijd en los van elkaar een verbods- of gebodsvordering indienen..$^{405}$ Onder omstandigheden is het echter mogelijk dat een verbodsvonnis dat kracht van gewijsde heeft gekregen, andere eisende organisaties het belang bij nog eens dezelfde vordering ontneemt. ${ }^{4 a n}$ Indien aan het reeds uitgesproken verbod een dwangsom is gekoppeld en de gebruiker of aanbeveler zich aan het opgelegde verbod houdt, is er immers geen herhalingsgevaar en daarmee geen actiebevoegdheid. ${ }^{40 x}$

Indien verschillende bevoegde organisaties met betrekking tot een zelfde beding tegelijkertijd een yordering indienen bij hetzelfde rechtscollege is dit laatste, op grond van $\S 147$ ZPO bevoegd de verschillende partijen in een procedure te voegen.

Het AGB-Gesetz en de literatuur geven geen antwoord op de vraag of ook buitenlandse consumentenorganisaties bevoegd zijn een verbods- of gebodsvor-

403 Lindacher, AGBG Kommentar, \$13 Rndnr. 111-112.

404 Lindacher, AGBG Kommentar, 13 Rndnr. 111.

405 Heinrichs, BGB (Palandt), AGBG 13 Nr. 4; Lindacher, AGBG Kommentar, 13 Rndnr. 111; Gerlach, Münchener Kommentar, 13 AGBG Rndnr. 62.

$406 \mathrm{BGH}, \mathrm{NJW} 1983$, pag. 1060.

407 Lindacher, AGBG Kommentar, \& 13 Rndnr. 113; Gerlach, Münchener Kommentar, \& 13 AGBG Rndnr. 62.

408 Gerlach, Münehener Kommentar, 13 AGBG Rndnr. 63; Lündacher, AGBG Kommentar, \$13 Rndnr. 112; Hensen, AGB-Gesetz; 15 Rndur. 31. 
dering ex $\$ 13$ AGBG in te stellen tegen in Duitsland opererende gebruikers en aanbevelers. $\S 13$ Abs. 2 Nr. 1 AGBG stelt niet als voorwaarde dat de eisende organisatie een Duitse organisatie moet zijn, dat eisende organisatie in Duitsland is gevestigd, noch dat de eisende organisatie een rechtspersoon naar Duits recht is. Ik ben derhalve van mening dat ook niet-Duitse consumentenorganisaties in beginsel het Duitse ius agendi op het terrein van de algemene voorwaarden toekomt. Uiteraard moeten ook buitenlandse organisaties voldoen aan de eisen die $\$ 13$ Abs. $2 \mathrm{Nr}$. 1 AGBG stelt. Zij moeten rechtsbevoegdheid bezitten, zich statutair (mede) ten doel hebben gesteld de belangen van consumenten door voorlichting en advies te behartigen en ook daadwerkelijk op deze terreinen actief zijn of zijn geweest. Bovendien moeten zij minstens 75 natuurlijke personen of twee consumentenorganisaties als lid hebben. Daarbij kan ook de vordering van buitenlandse organisaties slechts betrekking hebben op algemene voorwaarden die worden gebruikt of bestemd zijn te worden gebruikt in overeenkomsten met personen wier belangen deze organisaties behartigen.

\subsubsection{De geadresseerden van de vorderingen}

De geadresseerden van de vorderingen ex $\S 13$ AGBG worden genoemd in het eerste lid van $\S 13$ AGBG.

\section{\$ 13 Unterlassungs- und Widerrufsanspruch}

(1) Wer in Allgemeinen Geschdfubedingumgen Bestimmungen, die mach $\$ 9$ bis 11 dieses Gesetzes unwirksam sind, verwerdet oder fur den rechtsgeschdfilichen Verkehr empfiehll, kann auf Unterlassuog whd im Fall des Empfehlens auch auf Widerruf in Anspruch genommen werdien.

De verbodsactie van $\S 13$ AGBG richt zich daarmee tegen de gebruiker van algemene voorwaarden en de aanbeveler daarvan.

Gebruiker in de zin van $\$ 13$ AGBG is niet alleen degene in wiens naam de door algemene voorwaarden bepaalde overeenkomst wordt afgesloten, maar eveneens degene die als tussenpersoon bewerkstelligt dat bepaalde algemene voorwaarden contractsinhoud worden en daar als tussenpersoon belang bij heeft. ${ }^{409}$ Algemene voorwaarden hoeven niet perse contractsinhoud te zijn om ze tot onderwerp te maken van een verbods- of gebodsvordering. Voldoende is dat algemene voorwaarden in het rechtsverkeer worden gehanteerd; bij voorbeeld bij het doen of accepteren van een aanbod of bij wijze van aambeveling

409 OLG Stuttgart, AGBE I $13 \mathrm{Nr} .21$, NJW 1980, pag. 1583; BHGZ 81, 229, $230 \mathrm{f}$, NJW 1981. pag. 2351; Heinrichs, BGB (Palandt), AGBG 13 Nr. 2; Gierlach, Münchener Kommentar, 13 AGBG Rndnr. 34-35; Lindacher, AGBG Kommentar, 13 Rndnr. 48-49; Hensen, AGB-Gesetz, 113 Rndnr. 14. 
door een branche-organisatie. ${ }^{410}$ Onder gebruiken van een beding moet derhalve in het kader van de verbodsactie worden verstaan, het gebruiken van algemene voorwaarden in de contractuele sfeer in ruime zin, ook al leidt dit gebraik niet tot een overeenkomst, het opnemen van het beding in een overeenkomst of een beroep van de gebruiker op het betreffende beding. ${ }^{411}$

Letterlijk is een aanbeveler degene die een verklaring afgeeft waarin hij een ander iets presenteert, aanraadt of voorstelt als zijnde goed of voordelig voor: die ander, met de bedoeling de wil van die ander te beînvloeden. De aanbeveling moet ook breedtewerking hebben. Aanbeveler als bedoeld in $\$ 13$ AGBG is derhalve degene die met betrekking tot algemene voorwaarden algemene verklaringen richt tot een bepaalde kring van minstens twee personen. ${ }^{412}$

In geval van algemene voorwaarden die worden gebruikt door een buitenlandse gebruiker, waarop op grond van $\$ 12$ AGBG en de artikelen 27 Abs. 3 en 29 EGBGB de bepalingen van het AGB-Gesetz van toepassing $\mathrm{zijn}^{413}$, kan de verbodsvordering van \& 13 AGBG eveneens gericht worden tegen deze buitenlandse gebruiker. Dit kan zelfs indien de overeenkomst, op grond van een rechtskeuzeclausule of op grond van het feit dat de overeenkomst overwegend verbonden is met een ander rechtsstelsel, in beginsel wordt beheerst door buitenlands recht. ${ }^{414}$

\subsubsection{Declaratoire uitspraak ten behoeve van de gebruiker of aanbeveler}

Op grond van \& 256 ZPO kunnen partijen, indien zij daar een gerechtvaardigd belang bij hebben, van de rechter een verklaring voor recht vorderen omtrent een bepaalde rechtssituatie of rechtsverhouding. In het kader van de collectieve actie van $\S 13$ AGBG is het aan eisende organisaties echter niet toegestaan van de rechter een declaratoir te vragen waarin deze vaststelt dat bepaalde algemene voorwaarden onredelijk bezwarend zijn. Dit vanwege het feit dat de eisende organisatie de mogelijkheid heeft een verbod of gebod te vorderen en de rechter daarbij noodzakelijkerwijs eveneens een uitspraak doet over de toelaatbaarheid van het beding, waardoor het vereiste belang bij een declaratoir voor de eisende organisatie ontbreekt. Bovendien is de collectieve actiebevoegdheid van eisende

410 Bunte, Handbuch, pag. 26.

411. Rechtsausschuß, BT Drucksache 7/5422, pag. 10; BGH, NJW 1981, pag. 979; BGHZ 101, 271. NJW 1987, pag. 2867; Löwe, GroBkommentar zum AGB-Gesetz, 13 Rndrur. S; Reinel, pag. 28-29; Hensen, AGB-Gesetz, \&13 Rndnr. 13; Lindacher, AGBG Kommentar, 13 $412 \mathrm{Zie}$ voor het begrip aanbeveler hiervoor paragraaf 6.3.1.1 onder het subkopje "De verbodsvor-
dering".

$413 \mathrm{Zie}$ hiervoor paragnaf 6.2.4.

414 Schmidt, AGB-Gesetz, \& 12 Rndnr. 14 
(consumenten)organisaties gericht op het bevrijden van de markt van onredelijk bezwarende bedingen. De vordering moet zich derhalve naar haar aard richten op een ver- of gebod. ${ }^{415}$

Daarentegen kunnen gebruikers of aanbevelers op grond van $\$ 256$ ZPO, indien zij daar een gerechtvaardigd belang bij hebben, een procedure beginnen tegen de bevoegde organisaties waarin zij van de rechter een verklaring voor recht vorderen dat bepaalde bedingen niet onredelijk bezwarend zijn (negative Feststellungsklage). Een gebruiker of aanbeveler heeft pas een gerechtvaardigd belang bij een dergelijk declaratoir als hij:

- een van de bevoegde organisaties, met de dreiging een procedure te starten, van hem heeft gevorderd het gebruik of de aanbeveling van bepaalde - naar de mening van de betreffende organisatie - onredelijk bezwarende algemene voorwaarden te staken;

- van zijn zijde gemotiveerd heeft aangevoerd waarom volgens hem het beding niet onredelijk bezwarend is;

- de eisende organisatie een redelijke termijn heeft gesteld waarbinnen deze moet verklaren van haar vordering af te zien en deze organisatie daar geen gehoor aan heeft gegeven;

en,

- de eisende organisatie niet inmiddels een gerechtelijke procedure is begonnen. ${ }^{416}$

De vordering is gericht tegen de organisatie die van de gebruiker of aanbeveler heeft verlangd het gebruik te staken en op de procedure zijn de $\$ \$ 14$ tot en met 22 AGBG, voor zover mogelijk, analloog toepasbaar. ${ }^{417}$

\subsubsection{Verjaring}

De verjaring van de vorderingen in de collectieve procedure is geregeld in $\S 13$ Abs. 4 AGBG.

13 Unterlassungs- und Widerruifsanspruch

(4) Die Anspriache nach Absatz I verjahren in zwei Jahren von dem Zeilpunka an, in welchem der Anspruchsbuerechtigte wov der Verwendwng oder Empfehung der unwirksamen Allgemeimen Geschaftsbedingungen Kennmis erlangt hat, ohne Racksicht auf diese Kenntnis in vier Jahren von der jumpeiligen Verwendung oder Empfehlung an.

415Hensen, AGB-Gesetz, 15 Rndnr. 25, Gerlach, Münehener Kommentar, 13 Rndnr. 9-10.

416 Lindacher, AGBG Kommentar, 13 Rndnr. 134-136; Hensen, AGB-Gesetz, 15 Rndnr. 2627; Löwe, Großkommentar zum AGB-Gesetz, 13 Rndnr. 60-61.

417 Lindacher, AGBG Kommentar, 13 Rndnr. 135; Hensen, AGB-Gesetz, 15 Rndnr. 27. 
Volgens deze bepaling verjaart de verbods- of gebodsvordering 2 jaar nadat de volgens $\S 13$ lid 2 AGBG bevoegde organisaties kennis hebben genomen van het: gebruik of de aanbeveling van onredelijk bezwarende algemene voorwaarden en in ieder geval 4 jaar nadat de desbetreffende algemene voorwaarden zijn gebruikt of aanbevolen.

Voor een verjaringstermijn van twee jaar na kennisname van het gebruik of: de aanbeveling is gekozen teneinde de (potentiële) eisende organisatie voldoende tijd te verschaffen zich te beraden over haar juridische positie en processuele maatregelen voor te bereiden. ${ }^{418}$ De regel brengt met zich dat de termijn van twee jaar telkens opnieuw begint te lopen als een beding opnieuw wordt gebruikt of aanbevolen. Maatgevend voor het tijdstip waarop de termijn ingaat is het tijdstip waarop het met de inhoudelijke controle van algemene voorwaarden belaste orgaan van de bevoegde organisatie kennis heeft gekregen van het gebruik of de aanbeveling. ${ }^{419}$

Voor zover de rechtsvorderingen nog niet zijn verjaard op grond van het feit dat reeds twee jaar zijn verstreken nadat de eisende organisatie kennis heeft genomen van het gebruik of de anbeveling, verjaren zij in ieder geval 4 jaar nadat de betreffende algemene voorwaarden zijn gebruikt of aanbevolen. Bij het gebruik van algemene voorwaarden is voor de aanvang van de verjaringstermijn van 4 jaar maatgevend het tijdstip waarop de toepasselijkheid van de algemene voorwaarden is overeengekomen of indien het niet tot een overeenkomst is gekomen, het tijdstip waarop de contractsonderhandelingen zijn afgebroken. ${ }^{420}$ Bij de aanbeveling vangt de verjaringstermijn aan op het tijdstip dat deze degenen aan wie zij gericht was heeft bereikt. ${ }^{421}$

\subsubsection{De rechtsgang}

De rechtsgang van de collectieve actie is voor een deel overgelaten aan de algemene regels van het Duitse burgerlijk procesrecht en voor een deel in de specifiek op de procedure van $\S 13$ AGBG gerichte bijzondere regels van de $\S 14$ tot en met 22 AGBG. $\$ 15$ AGBG regelt de wijze waarop het proces gevoerd dient te worden.

418 BT Drucksache 7/3919, pag. 56; BT Drucksache 7/5617, pag. 2; Lindacher, AGBG Kommentar, 13 Rndin. 71-73; Hensen AGB-Gesetz, \& 13 Rndnr. 46-48.

419 Lindacher, AGBG Kommentar, \$13 Rndnr. 60; Hensen, AGB-Gesetz, \$ 13 Rndnr. 48.

420 Lindacher, AGBG Kommentar, 13 Rndnr. 72 en 74-75; Hensen, AGB-Gesetz, 813 Rndnr. 48. Het BGH stelt zich op het standpunt dat op zijn lastst sprake is van gebruik als de gebruiker zich op het beding beroept (BOH, NJW 1981, pag. 1511).

421 Lindacher, AGBG Kommentar, 13 Rndnr. 72 en 75; Hensen, AGB-Gesetx, \$13 Rndnr. 46 en 48 . 


\section{Verfahren}

(1) Auf das Vexfahren sind die Vorschriften der Zivilprozefordinung anzuwenden, soweit sich aus diesem Geselz nicht etwas anderes ergibt.

(2) Der Klageanirag mup auch enthalten:

1. den Wortlaut der becinstandeten Bestimunungen in Algemeinen Geschuftsbedingungen;

2. die Bezeichnung der An der Rechtsgeschaffe, fur die Bestimuringen beanstandet werden.

Belangrijkste bepaling is dat de bepalingen van de ZPO (Zivilprozeßordnung) van toepassing zijn op de procesvoering, gebaseerd op $\$ 13$ AGBG. Het tweede lid van $\$ 15$ AGBG stelt daarbij nog nadere eisen aan de dagvaarding (Klageantrag). De dagvaarding moet onder meer de woordelijke inhoud van het in het geding zijnde beding bevatten en een omschrijving geven van de aard van de overeenkomst en de branche waarin het desbetreffende beding wordt gebruikt. ${ }^{422}$

De collectieve actie van $\$ 13$ AGBG neemt echter doorgaans reeds in een eerder stadium zijn aanvang met een buitengerechtelijke verklaring van de bevoegde organisatie gericht aan de gebruiker of aanbeveler, waarin die organisatie van de gebruiker of aanbeveler vordert dat deze het gebruik of aanbeveling van bepaalde algemene voorwaarden staakt (Abmahnung). De bespreking van de rechtsgang vangt derhalve aan met een nadere beschouwing van deze Abmahnung. ${ }^{423}$

\subsubsection{De Abmahnung}

De verbods- of gebodsvordering kan, volgens de wettekst, geëffectueerd worden zonder dat de gebruiker of degene die het gebruik van algemene voorwaarden propageert, vooraf op de hoogte wordt gesteld van de gerechtelijke stappen die tegen hem worden ondernomen. Toch is men in de literatuur eensluidend van mening dat de eisende partij in beginsel verplicht is een voorafgaande Abmahnung aan de tegenpartij te doen toekomen. ${ }^{424}$ De reden daarvoor is gelegen in het feit dat de proceskosten, volgens \& $93 \mathrm{ZPO}$, ten laste komen van de eisende partij indien de gedaagde partij ten processe zonder verder voorbehoud tegemoet komt aan eisers vorderingen (Anerkenntnisurteil). ${ }^{425}$

422 Zie uitvoerig: Lindacher, AGBG Kommentar, \& 15 Rndnr. 6-10; Hensen, AGB-Gesetz, \& 13 Rendnr. 3-6.

423 Zie woor een voorbeeld van een "Abmahnung"t: Mölenberg en Rijken, pag. 80-83.

424 OLG Frankfurt, AGBE I \& $13 \mathrm{Nr}$. 14, WRP 1980, pag. 84; Heinrichs, BGB (Palandt), AGBG 15 Nr. 3; Bunte, Handbuch, pag. 27; Gerlach, Münchener Kommentar, 15 AGBO Rndnr. 12; Wemer, Handkommentar zum BGB, 15 Rndnr. 7-8; Dietlein en Rebmann, pag. 171-172; Lindacher, AGBG Kommentar, 13 Rndnr. 79-82; Hensen, AGB-Gesetz, 13 Rndnr. 49-60.

425 Gerlach, Münchener Kommentar, 15 Rndnr. 12; Wemer, Handkommentar zum BGB, \& 15 AGBG Rndinr. 7; Dietlein en Rebmann, pag. 171-172; Lindacher, AGBG Kommentar, \& 13 Rndnr. 81; Hensen, AGB-Gesetz, \& 13 Rndnr. 49. 
De Abmahnung dient schriftelijk te geschieden en moet inhoudelijk aan verschillende eisen voldoen. ${ }^{* 20}$ De Abmahnung vangt meestal aan met een verklaring van de worderende organisatie waaruit blijkt dat zij op grond van het AGBgesetz bevoegd is tot de vorderingen van $\$ 13$ AGBG. ${ }^{427}$

De eiser moet in de Abmahnung exact aangeven welke bedingen, voorkomend in de algemene voorwaarden van de gebruiker of degene die deze propageert, volgens hem onredelijk bezwarend zijn. Verder moet de eiser de gronden aangeven waarop zijn eisen zijn gebaseerd. ${ }^{428}$ Deze motivering is met name vereist indien de ongeldigheid van bepaalde bedingen gebaseerd is op de $\$ \$ 9$ en 10 AGBG. In geval van bedingen die onredelijk bezwarend zijn op grond van

$\$ 11 \mathrm{AGBG}$ is het voldoende dat wordt verwezen naar de betreffende regeling van $\$ 11$ AGBG. In ieder geval moet de gebruiker of degene die het gebruik van algemene voorwaarden stimuleert de mogelijkheid hebben om aan de hand van de in de Abmahnung aangevoerde argumenten te beslissen of hij de in het geding zijnde standaardvoorwaarden al dan niet verder zal gebruiken of propageren. ${ }^{429}$

De Abmahnung dient verder de eis te bevatten het verdere gebruik of aanbeveling van de in de Abmahnung genoemde bedingen te beëindigen of te herroepen. ${ }^{430}$ De eisende partij kan van de gebruiker verlangen dat deze zich contractueel verplicht, op straffe van een boete, de in het geding zijnde - of inhoudelijk identieke - bedingen voortaan niet meer te gebruiken en zich ook bij de uitvoering van bestaande overeenkomsten niet meer op de betreffende bedingen te beroepen (strafbewehrte Unterlassungsverpflichtung). Van de aanbeveler kan worden verlangd dat hij zich, op straffe van een contractuele boete, verbindt het gebruik voortaan niet meer te propageren en de in het geding zijnde aanbeveling te herroepen. ${ }^{431}$

De contractuele boete dient om te verzekeren dat de gebruiker of aanbeveler zich houdt aan hetgeen waaraan hij zich in de Unterlassungserklärung heeft verbonden. In de overeenkomst wordt gemeenlijk vastgelegd dat de boete ten gunste van de eisende organisatie wordt verbeurd, zij kan echter ook worden

426 Lindacher, AGBG Kommentar, 13 Rndnr. 84-93; Hensen, AGB Gesetz, 13 Rndnr. 51 60; Löwe, GroBkommentar zum AGB-Gesetz, \& 15 Rndnr. 13.

427 Lindacher, AGBG Kornmentar, \$13 Rndar, 93.

428 Hensen, AGB-Gesetz, 13 Rndnr. 51; Löwe, Großkommentar zum AGB-Gesetz, \$15 Rudnr. 13. Anders: Lindacher, AGBG Kommentar, \&13 Rndnr. 85, die een opgave van de grondlen die tot de kwalificatie onnedeljik bezwarend hebben geleid, weliswar wenselijik en aan te bevellen achit, doch niet noodzakelijk. De gebriiker of anbeveller is immers verantwoondelijk woor de totstandkoming van algemene voorwaarden en bij hen ligt derhalve ook de plicht zich te informeren omtrent de toeliatbanarheid van een door hen gebruikt of annbevolen beding.

429 Hensen, AGB Gesetz, \$13 Rndinr. 51.

430 Lindacher, AGBG Kommentar, \$13 Rndnr. 87; Hensen, AGB-Gesetz, \$ 13 Rndnr. 52 .

431. Bunte, Handbuch, pag. 28; Löwe, Großkommentar zum AGB-Gesetz, \& 15 Rndnr. 11; Lindacher, AGBG Kommentar, \$13 Rndnr. 86-89; Hensen, AGB-Gessetz, 13 Rndnr. 52-58. 
bedongen ten gunste van een derde, bij voorbeeld een charitatieve instelling. ${ }^{432}$ Gezien de kosten die de Abmahnung met zich brengt en de beperkte funanciële middelen die consumentenorganisaties ter beschikking staan, lijkt het echter verstandig als consumentenorganisaties bedingen dat zij zelf de contractuele boete beuren.433 De hoogte van de contractuelle boete wordt meestall vastgesteld door de vorderende organisatie. In de praktijk wordt, afhankelijk van de aard van het betreffende beding en de rechtseconomische betekenis van het beding, een boete van 1000 tot 3000 DM per clausule en per overtreding als redelijk ervaren. ${ }^{434}$ Het spreekt vanzelf dat deze bedragen voor aanbevelers, vanwege de hogere spreidingsgraad, beduidend hoger kunnen liggen. ${ }^{435}$

Indien de vordering zich richt tegen meerdere bedingen in én set van algemene voorwaarden dient de vorderende organisatie tevens aan te geven dat de maximaal te verbeuren boete bij gebruik van de gehele set of meerdere bedingen aan een maximum is gebonden dat lager ligt dan de som van de boetes die per beding zijn te verbeuren. ${ }^{436}$ Zo achtte het Landgericht Frankfurt een Abmahnung gericht tegen 28 bedingen waarin per beding een contractuele boete van $1.000 \mathrm{DM}$ werd gevorderd vanwege de buitensporige gevolgen bij hergebruik van de gehele set (een boete van $28.000 \mathrm{DM}$ ) ongeldig. ${ }^{437}$ In de Unterlassungserklärung dient derhalve een maximale som per overtreding te worden vastgelegd, voor het geval dat verschillende of alle bedingen die voorwerp zijn van de Unterlassungserklärung hergebruikt worden. Dit bedrag dient lager te zijn dan de som van de boetes die op hergebruilk van de individuele bedingen staat. Bijvoorbeeld de bepaling: "abernimmt fur jeden Fall der Zuwiderhandlung eine vertragsstrafe von $1000,=D M$ pro Klausel, jedoch nicht mehr als $3500,=$ DM fur jeden Fall der Verwendung ${ }^{* 438}$

De Abmahnung dient verder een redelijke termijn te bevatten binnen welke de "abgemahnte" gebruiker of aanbeveler zich contractueel dient te verplichten het gebruik of de aanbeveling van de in het geding zijnde bedingen te beëindi-

432. Lindacher, AGBG Kommentar, 13 Rndnr. 88; Hensen, AGB-Gegetz, 8 13 Rndnr. 55 .

433 Hensen, AGB-Gesetz, 13 Rndnr. 55.

434 Bunte, Handbuch, pag. 27-28; Lindacher, AGBG Kommentar, 13 Rndnr. 88; Hensen, AGBGesseltz $z_{n} 13$ Rndnr. 56; Stilliner, pag. 145.

435 Vergelijk onder andene: Stillner, pag. 145; Löwe, Großkommenitar zum AGB-Gesetz, \$15 Rundnir. 13; Hensen, AGB-Gebet, 13 Rndnr. 56; Lindacher, AGBG Kommentar, 13 Rndnr. 88.

436 Löwe, GroBkommentar zum AGB-Gesek, \& 15 Rndnr. 13; Lindacher, AGBC Kommentar,

813 Rndnr. 88; Stillner; pag. 145. Anders: Herwen, AGB-Gegetz, 13 Rundnr, 56; Bohle en Micklitz, pag. 19, die een dergelijke quantumkorting in strijd achten met het doell van het $A G B-$ Gesetz.

437 LO Frankfurt, AGBE I 15 Nr. 8 .

438 Axmann, pag. 98-99. 
gen. Een kortere termijn dan 14 dagen wordt niet als redelijk beschouwd. De gestelde termijn dient de gebruiker of aanbeveler in ieder geval genoeg tj] te bieden om zich te beraden en eventueel juridisch advies in te winnen. Indien de gestelde termijn te krap bemeten is wordt zij van rechtswege verlengd tot een redelijke termijn. $4 \$ 0$ Voor het geval een op zichzelf genomen redelijke termijn door vertraging in de bezorging of toezending de gebruiker of aanbeveler nog slechts een korte tijdspanne laat, dient deze zelf bij de vorderende organisatie een verlenging van de oorspronkelijke termijn te verzoeken. ${ }^{4 / 1}$

Laatste bestanddeell van de Abmahnung is de dreiging met gerechtelijke stappen indien de gebruiker of de aanbeveler zich niet binnen de gestelde termijn contractueel verplicht het gebruik te beëindigen of de aanbeveling te herroepen. ${ }^{442}$

Indien aan de Abmahnung uitgevoerd door een van de in $\$ 13$ lid 2 AGBG genoemde organisaties geen gevolg wordt gegeven door de gebruiker, kan deze laatste in een eventuele gerechtelijke procedure, op grond van $\$ 91 \mathrm{ZPO}$, worden veroordeeld tot betaling van de kosten van deze Abmahnung. ${ }^{43}$ Over de vraag of de kosten van de Abmahnung eveneens verhaald kunnen worden op de gebruiker, indien deze wèl gehoor geeft aan de Abmahnung en de gevraagde strafbewehrte Unterlassungserklärung heeft afgegeven, en over de juridische grondslag van dit verhaalsrecht bestaat in de literatuur geen eenduidigheid. In navolging van de eenduidige rechtspraak op het gebied van het mededingingsrecht wordt echter aangenomen dat via de figuur van zaakwaarneming (Geschäftsführung ohne Auftrag) deze vraag bevestigend dient te worden beantwoord. ${ }^{45}$ In bepaalde gevallen - bij voorbeeld als een consumentenorganisatie niet de nodige juridische kennis in huis heeft - kunnen zelfs de kosten van juridisch advies en bijstand verhaald worden op de gebruiker of aanbeveler. ${ }^{.46}$

439 Lindacher, ACBG Kommentar, \& 13 Rudnr. 90-91; Hensen, AGB-Gesetz, \$13 Rndnr. 59; Stillner; pag. 144.

440 OLG Karlsruhe, BB 1980, pag. 599-600.

441 Lindacher, AGBG Kommentar, 13 Rndnr. 91.

442 Lindacher, AGBG Kommentar, \&13 Rndnr. 92; Hensen, AGB-Gesetz, \& 13 Rndnr. 60 .

443 Lindacher, AGBG Kommentar, 13 Rndnr. 104. Anders: Hensen, AGB-Gesetz, $\$ 13$ Rndar. 62-64.

444 Zie uitwoerig: Loewenheim, pag. 286-289; Borck, pag. 438-444.

445 OLG Nümberg, BB 1980, pag. 179, BGH, NJW 1984, pag. 2525; Lindacher, AGBG Kommentar; \& 13 Rndnr. 104; Löwe, Gmokkommentar zum AGB-Gesetz; \$ 15 Rudnr. 17; Bunte, DB 1980, pag. 482; Stillner, pag. 145; Loewentheim, pag. 289; Borck, pag. 442. Afwijzend onder andere: Hensen, AGB-Gesetz, \&13 Rndnr. 62; Wemer, Handkommentlar zum BGB, 15 AGBG Rndnr. 7; Reinel, pag. 140; Prelinger, pag. 533-535,

446 Bunte, Handbuch, pag. 28; Lindacher, AGBG Kommentar, \$13 Rndnr. 106. 
In uitzonderingsgevallen is een Abmahnung niet vereist omdat dit vanuit het perspectief van de eisende organisatie zinloos of redelijkerwijs niet te verlangen is. Dit is bij voorbeeld het geval als de gebruiker of aanbeveler uitdrukkelijk heeft aangegeven dat de door hem gebruikte of aanbevolen bedingen niet onredelijk bezwarend zijn of indien de gebruiker of aanbeveler all eens eerder zonder resultaat is "abgemahnt" of als de gebruiker klaarblijkelijk opzettelijk onredelijk bezwarende bedingen gebruikt. ${ }^{48}$.

\subsubsection{De bevoegde rechter}

De relatieve en absolute competentie inzake de procedure van $\& 13 \mathrm{AGBG}$ is geregeld in $\$ 14$ AGBG.

\section{$\$ 14$ Zuständigkeit}

(1) Fin Klagen nach 13 dieses Gesetzes ist das Landgericht ausschließlich zustindig, in dessen Beziok der Beklagie seine gewerbliche Niederlassung oder in Ermangelung eimer salchen seinem Wohnsiz hat. Hat der Bellagte im Inland weder eine gewerbliche Niederlassung noch einen Wothnsitz, so ist das Gericht des imldndischen Aufenthaltsorts zustandig. in Ermangelung eines solchen das Gericht, in dessen Bezirk die nach $\$ 9$ bis 11 dieses Gesetzes tunwirksamen Bestimmungen in Allgemeinen Geschäfisbedingungen verwendet wurden.

(2) Dïe Landesregienungent werden enmächtigt, zur sachdienlichen Förderung oder schnelleren Enledigung der Verfahren durch Rechtsverordnung einem Landgericht für die Bezirke mehrerer Laudgerichse Rechtsstreitigkeiten nach diesem Gesetz zuzuweisen. Die Landesregienungen können die Ermachtigung durch Rechtswerordhung auf die Landesjustizwerwaitungen abertragen.

(3) Die Parteien kännen sich wor den nach Absarz 2 bestimmien Gerichten auch durch Rechtsanwalte vertrelen lassen, die bei dem Gericht zugelassen sind, vor das der Rechtsstreit ohne die Regelung nach Absarz 2 gehören warde.

(4) Die Mehrkosten, die einer Partei dadurch enwachsen, daje sie sich nach Absatz 3 durch einen nicht beim Prozejgericht zugelassemen Rechtsanwalt vertreten $1 a \beta b$, sind micht za erstatten.

De regeling van $14 \mathrm{AGBG}$ is niet alleen van toepassing op de procedure van 8 13 AGBG maar eveneens op het daarop betrekking hebbende kort geding, de procedure van \$ $19 \mathrm{AGBG}$, procedures met betrekking tot de vergoeding van buitengerechtelijke "Abmahn"-kosten, de effectuering van contractuele boetes uit Unterlassungserklärungen en de zogenaamde negative Feststellungsklage. ${ }^{49}$ De regeling heeft vooral tot doel door concentratie van procedures bij de rechtbanken de deskundigheid van deze colleges te bevorderen en daardoor de

447 Gerlach, Mïnchener Kommentar, 15 AGBG Rndnt. 13; Löwe, Grobkommentar zum AGBGesetz, 15 Rndnr. 14\% Lindacher, AGBG Kommentar, 13 Rndnr. 82; Hengen, AGB-Gestiz, 13 Rndrur, 66; Bunte, DB 1980, pag. 481.

448 LG Stuttgrir, AGBE I $15 \mathrm{Nr}_{n}$ 10, KG Berlin, AGBE II 13 Nr. 17. WRP 1982, pag. 19; OLG DÜisseldorf, DB 1982, pag. 801 .

449 Lindacher, AGBG Kommentar, 14 Rndnr. 3; Hensen, AGB-Gesetz, 14 Rndnr. 9. 
randvoorwaarden te creëren voor een vlotte en efficiënte afhandeling van de collectieve actie van 13 AGBG. Het effect van concentratie wordt daarbij nog versterkt door de mogellijkheid van $\$ 14$ Abs. 2 AGBG. ${ }^{450}$

Volgens \$14 Abs. 1 AGBG is voor de hiervoor genoemde rechtsgedingen bij uitsluiting de rechtbank (Landgericht) bevoegd van het arrondissement (Bezirk) waar gedaagde zijn beroep of bedrijf uitoefent of bij het ontbreken daarvan het arrondissement waaronder gedaagdes woonplaats of vestigingsplaats (in het geval van een rechtspersoon) valt. Voor het geval de gedaagde zijn beroep of bedrijf niet uitoefent in Duitsland en er geen woon- of vestigingsplaats heeft, is in beginsel de rechtbank van het arrondissement van zijn verblijfplaats in Duitsland bevoegd. Bij gebreke van een verblijfplaats in Duitsland is de rechtbank bevoegd van het arrondissement waar de in het geding zijnde bedingen worden gehanteerd. ${ }^{451}$ Partijen kunnen bij overeenkomst niet van $\$ 14$ AGBG afwijken.

Indien de gedaagde geen woon- of vestigingsplaats binnen Duitsland heeft, is de laatste volzin van lid 1 van \& 14 AGBG slechts van toepassing voor zover het geval niet onder de werking van het EEG-executieverdrag valt. Indien de gedaagde zijn woonplaats heeft in een land dat partij is bij het EEG-executieverdrag kan deze in beginsel immers alleen voor het gerecht worden geroepen in het land van zijn woonplaats (artikel 2 en 3 EEX). Uitzonderingen op deze hoofdregel zijn slechts toegelaten indien de artikelen 5 tot en met $18 \mathrm{EEX}$ dit uitdrukkelijk toelaten (artikel $3 \mathrm{EEX)}{ }^{452}$ In de Duitse literatuur wordt daarbij met name gedacht aan artikel 5 lid 5 EEX (plaats waar het beroep of bedrijf wordt uitgeoefend) en artikel 5 lid 3 EEX. Volgens de opvatting in de Duitse literatuur is op grond van artikel 5 lid 3 EEX de rechter van de plaats waar het gebruik of de aanbeveling van de in het geding zijnde algemene voorwaarden heeft plaatsgevonden eveneens bevoegd. Het gebruik of de aanbeveling van inhoudelijk ontoelaatbare bedingen kan immers worden gezien als een met een onrechtmatige daad vergelijkbare handeling. ${ }^{453}$

Uit de jurisprudentie zijn mij slechts enkele gevallen bekend waarin een consumentenorganisatie een verbodsactie instelde tegen een buitenlandse gebruiker. Het betrof verbodsacties van de Verbraucherschutzverein e.V. (VSV) tegen een in Nederland gevestigde verhuurder van in Nederland gelegen

450 RechtsausschuA, BT Drucksache 7/5422, pag. 11; Lindacher, AGBG Konmentar, $\$ 14$ Rndnr. 2.

451 Bunte, Handbuch, pag. 28; Lifdacher, AGBG Kommentar, \$ 14 Rndnr. 6-10; Hensen, AGB Gesetz, 814 Rndnr. $4-5$.

452 Zie hiervoor 5.3 .7 .

453 Lindacher, AGBG Kommentar, 14 Rndnr. 12-16; Hensen, AGB-Gesetx, 14 Rndnr. 6; Löwe, Grobkommentar zum AOB-Gesetz, 14 Rndnr. 5. 
vakantieverblijven en een in Denemarken gevestigde verhuurder van Deense vakantieverblijven. ${ }^{454}$

De eerste vraag die het LG Köln had te beantwoorden, was of het Duitse recht van toepassing was. Op grond van de regels van het EEG-Verbintenissenverdrag kwam het LG Köln tot de conclusie dat de overeenkomsten werden beheerst door Duits recht. Redengevend voor deze conclusie waren de volgende omstandigheden:

- het ontbreken van een rechtskeuze in de overeenkomst (artikel 27 EGBGB $=$ artikel $3 \mathrm{EEV}$ );

- de overeenkomst betrof een recht tot gebruik van een onroerend goed in Nederland;

- de overeenkomst werd gesloten in een Duits filiaal van de gebruiker of op andere plaatsen in Duitsland;

- de orderbevestiging annex factuur gaat er van uit dat het Duitse filiaal de overeenkomst heeft gesloten;

- als bankrelatie is een Duitse bank aangewezen;

- de woonplaats van de wederpartijen is doorgaans gelegen in Duitsland;

- de overeenkomst en de algemene voorwaarden zijn opgesteld in de Duitse taal.

Ondanks het feit dat artikel 4 lid 3 EEV deed vermoeden dat de overeenkomst het nauwst verbonden was met Nederland, kwam het $L G$, onder toepassing van artikel 4 lid 5 EEV tot de conclusie dat de andere omstandigheden met zich brachten dat de overeenkomst nauwer was verbonden met Duitsland dan met Nederland.

De tweede vraag die het LG moest beantwoorden was de competentievraag. Op grond van het EEG-executieverdrag geldt in beginsel dat de gedaagde slechts voor de rechter van zijn eigen land gedagvaard kan worden (artikel 2 en 3 EEX) en is bovendien slechts de rechter bevoegd van het land waar het te verhuren onroerend goed is gelegen (artikel 16 lid $1 \mathrm{EEX}$ ). In navolging van het Bundesgerichtshof ${ }^{\text {s5s }}$ kwam het LG echter tot de conclusie dat het feit dat het een geschil betrof omtrent algemene voorwaarden gehanteerd door een filial van de gebruiker in Keulen en het feit dat artikel 16 EEX slechts ten doel heeft rekening te houden met voorschriften van de staat waarin het onroerend goed is

454 LG Köln 22 januari 1992, Nr. 26 0 142/91, VSV-Info 1992/3, pag. 1-10, m.nt. Bultmann (VSV/Center Parcs); KG Berlin 22 juni 1994, nr. U 939/94, pag. 1-7, m.nt. Bultinarn (VSV/Novasol); LG Berlin, 15 november 1993, VuR 1994, pag: 184. Zie in dit verband ook: BGH, NJW 1990, pag. 317, waarin de VSV optrad tegen een Duitse vertuurder van vakantieverblijven in Frankrijk en Spanje. In deze procedure achtte de Duitse rechter artikel 16 EEX niet van toepassing en zichzelf bevoegd.

455 BGH, NJW 1990, pag. 317. 
gelegen welke in deze echter niet in het geding waren, met zich brachten dat de Duitse rechter bevoegd was.

\$ 14 lid 2 AGBG geeft de deelstaatregeringen de mogelijkheid de rechtsgedingen gebaseerd op \&13 AGBG te concentreren bij én van de verschillende rechtbanken. Doel van deze concentratie is, zoals hiervoor reeds vermeld, een snellere afwikkeling, deskundigheidsbevordering en meer homogeniteit in de rechtspraak. Voor zover in de literatuur is na te gaan hebben tot nu toe de deelstaten Nordrhein-Westfalen, Hessen en Beieren van deze mogelijkheid gebruik gemaakt. ${ }^{457} \mathrm{Bij}$ de in deze deelstaten aangewezen rechtbanken maar ook bij andere bevoegde rechterlijke instanties zijn, voor rechtsgedingen op grond van \& 13 AGBG, veelal speciale kamers ingesteld, hetgeen de deskundigheid en daarmee een vlotte afhandeling bevordert. ${ }^{458}$

Vanwege deze concentratiebevoegdheid is in de leden 3 en 4 van 14 AGBG voorzien in een tweetal regelingen die tweeërlei moeten bewerkstelligen. Allereerst dat advocaten die bevoegd zouden zijn indien er geen gebruik was gemaakt van de concentratiebevoegdheid van \& 14 Abs. 2 AGBG, automatisch ook bevoegd zijn voor ie rechtbank waar de procedure is geconcentreerd $(814$ Abs. 3 AGBG). Op de tweede plaats dat de extra kosten die het optreden van een advocaat in een ander arrondissement dan dat waarin hij is toegelaten met zich brengen, echter niet voor vergoeding in aanmerking komen ( $\$ 14 \mathrm{Abs} .4$ AGBG) ${ }^{459}$

\subsubsection{Voorlopige voorziening}

De procesrechtelijke voorschriften van de $\$ \$ 13$ tot en met 22 AGBG bevatten geen uitdrukkelijke regeling die voorziet in een voorlopige rechterlijke voorziening (Einstweilige Verfügung), te vergelijken met het Nederlandse kort geding. Derhalve gelden de algemene regels van de $\$ \$ 935$ en 940 ZPO. Na een aanvankelijke aarzeling ${ }^{40}$ wordt echter algemeen aangenomen dat een voorlopige voorziening in de verbodsprocedure van \$13 AGBG is toegelaten. ${ }^{461}$

456 Bunte, Handbuch, pag. 28; Lindacher, AGBG Kommentar, 14 Rndnr. 18; Hensen, ACBiGesetz, \& 14 Rndnr. $10-11$.

457 Lindacher, AGBG Kommentar, \& 14 Rndnr. 18; Hensen, AGB-Gegetz, \$14 Rndnr. $\mathbb{1}$.

458 Bunte, Handbuch, pag. 28; Stillner, pag. 147; Hensen, AGB-Gesetz, \& 14 Rndnr. 12 .

459 Lündacher, AGBG Kommentar, 14 Rindinr. 10; Hensen, AGB-Gesetz, 514 Rndinr. 13-14.

460 OLO Düsseldorf, NJW 1978, pag. 2512.

$461 \mathrm{KG}, \mathrm{OLGZ} 80,400$, NJW 1981, pag. 2420, BB 1981, pag. 148; OLG Hambarg, NJW 1981, pag. 2420; OLO Düsseldorf, NIW 1989; pag. 1487; Stilliner, pag. 143; Reinel, pag. 77; Lindecher, AGBG Kommentar, 13 Rndinr. 117; Hensen, AGB-Gesetz, 15 Rndmr. 10-12. Zie ook: Begrindung zu \$ 15, BT Drucksache 75617 , pag. 4, waarin het volgende wordt opgenterkt: 
Een voorlopige voorziening in de rechtsgang van de gebodsvordering (Widerrufsanspruch) wordt naar haar aard niet mogelijk geacht, omdat zij niet voldoet aan de eisen gesteld in de $\$ \$ 935$ en 940 ZPO. Een toekenning van de eis in de voorlopige voorziening zou in de bodemprocedure immers irreparabel zijn. ${ }^{462}$

Daarentegen is een voorlopige voorziening in de rechtsgang van de verbodsactie (Unterlassungsanspruch) wél toegelaten. ${ }^{463}$ De voorlopige voorziening lijkt met name geïndiceerd voor:

- de verbodsactie tegen het gebruik van algemene voorwaarden waarvan het onredelijk bezwarend karakter onomstotelijk vaststaat;

- de verbodsactie die, met het oog op breedtewerking, gericht is tegen gebruikers van bedingen waarvan op grond van eerdere gerechtelijke verboden jegens gebruikers van inhoudelijk identieke bedingen vaststaat dat zij onredelijk bezwarend zijn. ${ }^{464}$

Voor een voorlopige voorziening is een Verfugungsanspruch (bevoegdheid) en een Verfugungsgrund (belang) vereist. De Verfügungsanspruch volgt uit $\& 13$ AGBG. Eiser hoeft slechts aan te tonen dat de gedaagde ongeldige algemene voorwaarden hanteert. De Verfügungsgrund is aanwezig als een voorlopige voorziening in de bestaande omstandigheden dringend noodzakelijk is ( $\$ 9935$ en $940 \mathrm{ZPO}$ ). In tegenstelling tot het Gesetz gegen unlauteren Wettbewerb (UWG) ontbeert het AGB-Gesetz een regeling op grond waarvan de spoedeisendheid vermoed wordt aanwezig te zijn. ${ }^{465}$ Dit brengt met zich dat eiser dient aan te tonen dat er sprake is van spoedeisendheid.

In de literatuur gaan stemmen op die menen dat de spoedeisendheid in het karakter van (onredelijk bezwarende) algemene voorwaarden ligt opgesloten en daarmee dus altijd vaststaat. Algernene voorwaarden zijn immers opgesteld met het oog op een bepaalde breedtewerking en hebben dus in beginsel een wezenlijke invloed op het rechtsverkeer. Ook indien de negatieve beïnvloeding van het rechtsverkeer voor het individuele geval slechts geringe gevolgen heeft, brengt de beoogde breedtewerking toch een aanzienlijke verstoring van het rechtsver-

46. 1 (....vervolg)

Insbesondere im gewerblichen Rechischutz spielt bekanulich das Verfahren der einstweiligen

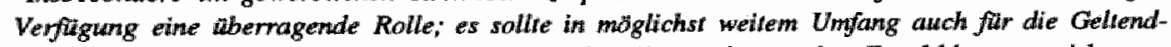
machuong des Anspruchs auf Unterlassung der Verwendung oder Empfehlung unwirksamer Bestimmungen in $A G B$ zur Verfitgung gestellt werden."

462 Heinrichs, BGB (Palandt), AGBG $15 \mathrm{Nr}$ 4; Lindacher, AGBG Kommentar, 13 Rndnr. 118; Hensen, AGB-Geselz, 15 Rndnr. 13.

$463 \mathrm{KG}_{3}$ OLGZ 80,400 , NJW 1981, pag. 2420, BB 1981, pag. 148; Lindacher, AGBG Kommentar, 13 Rndnr. 117; Hensen, AGB-Gesetz, \& 15 Rndnr. 10.

464 Lindacher, AGBG Kommentar, 13 Rndir. 100; Hensen, AGB-Gesetz, 15 Rndnr. 12.

465 Heinrichs, BGB (Pallandt), AGBG 15 $\mathrm{Nr}$. 4; Hensen, AGB-Gesetz, $15 \mathrm{Rndnr}$, 14; Bunte, Handbuch, pag. 29; Lindacher, AGBO Kommentar, 13 Rndnr. 119-122. 
keer mee. Het lijkt er echter op dat in de rechtspraak wordt vastgehouden aan de regel dat de eiser de spoedeisendheid moet aantonen. ${ }^{467}$

\subsubsection{Het horen van toezichthoudende instanties}

\$16 AGBG bepaalt dat de rechter, indilen de procedure volgens $\$ 13$ AGBG bedingen in verzekeringsovereenkomsten of kredietovereenkomsten betref, verplicht is het toezichtsorgaan (Aufsichtsbehörde) voor het verzekeringswezen respectievelijk het kredietwezen te horen, voordat hij zijn oordeel geef. Algemene voorwaarden die worden gehanteerd in verzekerings- of kredietovereenkomsten staan immers onder toezicht en moeten worden goedgekeurd door toezichtorganen. ${ }^{48}$ Daarmee heeft de Duitse wetgever enerzijds aangegeven dat ook door de overheid goedgekeurde algemene voorwaarden aan de inhoudstoets van \& 13 AGBG zijn onderworpen en anderzijds dat de bijzondere ervaring en kennis van deze organen nuttig kan zijn in de beoordeling van het geschil ex $\$ 113 \mathrm{AGBG} .{ }^{4}$ In aansluiting hierop heeft het Bundesgerichtshof uitdrukkelijk bepaald:

"Die gerichtliche Kontrolle von Algemeinen Geschaffisbedingungen wird micht dadurch beschraikls oder gar ausgeschlossen, daß die Genehmigung einer Venwaltungsbehorde vorgesehen ist. "wito

De opvatting dat door de overheid goedgekeurde algemene voorwaarden slechts marginaal getoetst dienen te worden is daarmee achterhaall. ${ }^{471}$

\subsubsection{De waarde van het geschil}

In $\$ 22$ AGBG wordt de waarde van het geschill (Streitwert), in het Duitse rechtssysteem de bepalende factor voor de hoogte van proces- en advocaatkosten, beperkt tot een maximum van 500.000 DM.

466 Lindacher, AGBG Kommentar, 13 Rndnr. 120-121; Hensen, AGB-Gesetz, $\$ 15$ Rndinr. 15 ; Löwe, GroBlkommentar zum AGB-Gesetz, \& is Rndnr. 21.

467 OLG Dïsseldorf, NJW 1989, pag, 1487; OLG Frankfurt, NJW 1989, pag. 1489. Anders: OLG Hamburg, WRP 1981, pag, 536/537.

468 Bundesaufsichtsaint für das Versichenumgsweasen en het Bundesaufsichtsamt für dasi Kreditowesen, allebei te Berlijn.

469 Lindacher, AGBG Kommentar, 16 Rndar. 2. Anders: Heinrichs, BGB (Palandt), AGBG 16 Nr. 1; Hensen, AGB-Gesetz, \& 16 Rndnr. 3. Deze auteurs zien als onderliggende gedachte dat. de betreffende "Aufsichtsbehönde" de gelegenheid dient to hebben haar goedkeuring wan het betreffende beding to verdedigien.

470 BGHZ 86, 284, NJW 1983, pag. 1322.

471 Lindacher, AGBG Kommentar, 16 Rndnr. 1; Hensem, AGB-Gegetz, \& 16 Rndnr. 2. 
Bei Rechtssitreitigikeiten auf Grund dieses Gesetzes daff der Streirwert micht wiber 500 000 Deutsche Mark angenomumen werden.

Een minimumgrens is niet voorzien. De ratio van deze bepaling is de bevoegde organisaties te beschermen tegen een te groot procesrisico door de waarde van het geschil, en daarmee van de proces- en advocaatkosten, te begrenzen. ${ }^{472}$

Tot aan het in de wet gestelde maximum is de rechter vrij in de vaststelling van de waarde van het geschil. Er zijn geen vaste regels, maar maatgevend voor de bepaling van de waarde van procedure is, in tegenstelling tot individuele procedures waarin het belang van de eiser de waarde van het geschil bepaalt, het algemeen belang gelegen in de onttrekking van de betreffende bedingen aan het rechtsverkeer. ${ }^{473}$

Uitgaande van de opvatting dat de maximale streitwert bedoeld is voor complete sets van algemene voorwaarden gehanteerd door bedrijven met een beduidende economische omvang en betekenis, komt men in de literatuur tot de volgende richtlijnen. ${ }^{474}$

Bij een verbodsactie gericht tegen het gebruik van onredelijk bezwarende bedingen is een Streitwert van 5.000 DM per clausule op zijn plaats indien de economische betekenis van een beding niet is in te schatten en de betreffende onderneming niet meer dan een gemiddelde omvang heeft. ${ }^{475}$ In de rechtspraak wordt in die gevallen meestal een bedrag van 2.000 of 3.000 DM gehanteerd. ${ }^{476}$ Indien de economische betekenis van een beding voor de gebruiker tamelijk gering is kan worden volstaan met een Streitwert van 2.000 DM per beding. Andersom kan bij grotere ondernemingen de Streitwert al snel oplopen tot 10.000 DM per clausule. ${ }^{47}$ Bij clausules die een grote economische betekenis hebben kan een nog hogere Streitwert gepast zijn. ${ }^{478}$

472 Bunte, Handbuch, pag. 30; Wemer, Handkommentiar zum BGB, 22 AGBG Rndnr. 1; Heinrichs, BGB (Paiandt), AGBG $22 \mathrm{Nr}$. 1; Lindacher, AGBG Kommentar, \&22 Rndmr. 1; Hensen, AGB-Gesetz, \&22 Rndnr. 1" Zie voor een indicatie van de kosten bij de maximale "Streitwert" hiema pangraaf 9.6.1.

473 Lindacher, 22 Rndnr. 6-8; Hensen, AGB-Gesetz, 22 Rndur. 3-5.

474 Hensen, AGB-Gesetz, 22 Rndrr. 4-13; Traub, pag. 557-560.

475 Hensen, AGB-Gesetz, \& 22 Rndnr. 6; Stillner, pag. 148; Lindacher, AGBG Kommentar $\$ 22$ Rndinr. 10.

476 OLG Karlsruhe, AGBE III $22 \mathrm{Nr}$. 1 en 2 (3.000 DM); OLG Karlsruhe, AGBE I $22 \mathrm{Nr}$. 8 (2.000 DM).

477 OLG Stuttgart, AGBE I \& 22 Nr. 7; BGHZ 100, 373, NJW 1987, pag. 2012.

478 BGHZ 74, 383, NJW 1979, pag. 1866 (20.000 DM voor een exoneratieclausulle in de handel in tweede-hands-auto's); OLG Frankfurt a.M., BB 1983, Beitage 11; pag. 7 (100.000 DM voor een prijswijzigingsclausule in de automobielbranche); OLG Hamburg, WM 1978 , pag. $1358 \mathrm{en}$ BGH, NJW 1986, pag. 325 (respectievelijk 300.000 en 200.000 DM voor enige clsusules met betrekking tot de berekening van de door de wederpartij te betalen sommen bij relatieberniddelingsbureau's); BGHZ 86, 284, NJW 1983, pag. 1322, BB 1983, pag. 527 (180.000 DM voor 
Voor een ge- en verbodsactie gericht tegen een aanbeveling gaat men vanwege de breedtewerking van een aanbeveling uit van een hoger bedrag dan bij een gebodsactie gericht tegen het gebruik van onredelijk bezwarende algemene voorwaarden. In de regel wordt ingestemd met een bedrag van minstens 10.000 DM per clausule. ${ }^{479}$

\subsubsection{Het vonnis}

Op het vonnis van de rechter zijn in beginsel de algemene procesrechtelijke regels ten aanzien van het vonnis ( $\$ 300-347 \mathrm{ZPO}$ ) van toepassing. In het AGB-Gesetz zijn in de $\$ \$ 17,19,20$ en 21 AGBG voor het vonnis in de collectieve procedure van $\$ 13$ AGBG een aantal bijzondere voorschriften voorzien.

\section{De inhoud van het vonnis}

$\$ 17$ AGBG bepaalt dat, indien de rechter de verbods- of gebodsvordering gegrond acht, de beslissing (Urteilsformel), het zogenaamde dictum (Tenor), inhoudelijk aan een aantall eisen dient te voldoen. ${ }^{400}$

\section{$\$ 17$ Urteilsformel}

Erachtet das Gericht die Klage far begrindet, so enthalt die Urteilsformel awch:

1. die beanstandeten Bestimmungen der Allgemeinen Geschafisbedingungen im Wortlawt;

2. dite Bezetchnung der Art Rechisgeschofie, fir die den Unterlassungscanspruch begrizhdenden Bestimmungen der Allgemeinen Geschaftsbedingungen nicht verwendet werden darfen,

3. das Gebor, die Venwendung inhaltsgleicher Bestimumungen in Allgemeinen Geschaftsbedingungen zan unterlassen;

4. fur den Fall der Verurteilung zum Widernuf das Gebat, das Vrteil in gleücher Weise bekanurzugeben, wie die Empfehlung verbreittet wurde.

In de bepaling die een aanvulling en concretisering van de algemene bepaling van $\$ 313$ Abs. $1 \mathrm{Nr}$. 4 ZPO is, komt het bijzondere karakter van een collectieve gebods- of verbodsactie tot uitdrukking. De beoogde breedtewerking van een collectief verbods- of gebodsvonnis, informatieve waarde van het register als bedoeld in $\$ 20$ AGBG en de openbaarmaking als bedoeld in $\$ 18$ AGBG en

$478(\ldots$ wervolg)

zes cllausules van de Lutharisa); BGH, NJW 1985, pag. 853 (50.000 DM voor een prijiswijzigingsclausule in de autogroothandel); BCH, NWW-RR 1991, pag. 1074 (50.000 DM woor een aflossingselausule van een bank).

479 Hensen, AGB-Gesetz, $\$ 22$ Rndnr. 8.

480 Zie uitvoeriger: Bunte, Handbuch, pag. 29; Wemer, Handkommentar zum BGB, \& 17 AGBG Rndinr. 1-6; Heinrichs, BGB (Pallandt); AGBG 17 Nr. 1-2, Lowe, Grobkommentar zum AGBGesetz, \$17 Rndnr. 1-51; Lindacher, AGBG Kommentar, \& 17 Rndnr. 1-12; Hensen, AGB-
Gesetz, \& 17 Rndnr. 1-16. 
derdenwerking van $\$ 21 \mathrm{AGBG}_{\text {, }}$ vereist een duidelijk en concreet dictum dat niet eerst behoeft te worden uitgelegd aan de hand van de motivering. ${ }^{481} \mathrm{De}$ bepaling is eveneens van toepassing op het dictum in kort geding en vonnissen waarin de rechter het gevorderde slechts gedeeltelijk toewijst. ${ }^{432}$

De bepaling onder 1 , dat het dictum de woordelijke inhoud van het verboden beding moet bevatten, sluit aan bij de bepaling van $\S 15 \mathrm{Abs}$. $2 \mathrm{Nr}$. 1 AGBG welke vereist dat de ter beoordeling voorgelegde clausule letterlijk moet worden opgenomen in de dagvaarding. Omdat de rechter op grond van $\$ 308$ $\mathrm{ZPO}^{43}$ gebonden is aan hetgeen partijen hebben gevorderd en dus niet ultra petita mag gaan, hoeft de rechter in het dictum ook niet aan te geven welke wijzigingen het verboden beding toelaatbaar zouden maken. ${ }^{484}$

De bepaling onder 2 , dat het dictum eveneens de aard van de overeenkomst en de branche in welke het desbetreffende beding niet meer gebruikt mag worden, moet noemen, sluit aan bij het bepaalde in $\$ 15$ Abs. $2 \mathrm{Nr} .2$ AGBG welke hetzelfde vereist voor de dagvaarding. Ofschoon de bepaling onder 2 en 3 letterlijk genomen alleen op een verbod van gebruik zien zijn zij eveneens van toepassing op de aanbeveling. ${ }^{485}$ Indien het gevorderde verbod slechts wordt toegekend voor een bepaalde soort en naar hun aard begrensde overeenkomsten, dient dit dienovereenkomstig tot uitdrukking te komen in het dictum. ${ }^{486}$ Voor de motivering van het ver- of gebod is in het dictum geen plaats, deze is immers af te leiden uit de in het vonnis vermelde overwegingen of gronden die tot de beslissing hebben geleid. Het dictum dient in beginsel derhalve slechts aan te geven of het beding nietig is of niet. ${ }^{477}$ Indien sprake is van een verstekvonnis (Versäumnisurteil) of een vonnis in een procedure waarin de gedaagde zondler meer heeft toegegeven aan de vordering van eiser (Anerkenntnisurteil) kunnen de gronden die tot het ver- of gebod hebben gevoerd echter niet uit het vonnis worden afgeleid. Ook in die gevallen hoeft het dictum niet nader aan te geven waarom de betreffende bedingen verboden zijn. De rechter hoeft immers niet aan te geven op welke wijze het verboden beding veranderd dient te worden om de nietigheid te ontgaan. ${ }^{488}$

481 Lindacher, AGBG Kommentar, \$ 17 Rndnr. 1.

482 Lindacher, AGBG Kommentar; 17 Rndnr. 2; Hensen, AGB-Gesetz, 17 Rndnr. 1.

483 In de Nederlandse wetgeving komt dit beginsel tot uitdrukking in artikel 382 sub 2 en 3 Rv.

484 BGH, NJW 1982, pag. 2311; BGHZ 104, 82, NJW 1988, pag. 1726; Hensen, AGB-Gesetz,

5 17 Rndnr. 3. Het is de rechter echter toegestaan om het wel te doen. Zo gaf het OLG Franlkfurt bij voorteeld in het dictum an dat een beding op grond van \& $11 \mathrm{Nr}$. I AGBG werboden was voorzover het niet tegelijkertijd tot uitdrukking bracht dat het slechts gold woor leveringstermijnen van meer dan vier maanden (NJW 1979, pag. 985).

485 Hensen, AGB-Gesetz, 17 Rndnr. 4-5.

486. BGH, NJW 1985, pag. 320-326; BGH, NJW 1986, pag. 4344; Lindacher, AGBG Kommentar, \$1 17 Rndnr. 5; Hensen, AGB-Gesetz, \& 17 Rndnr. 4.

487 BGH, NJW 1982, pag. 2311.

488i Hensen, AGB-Gesetz, 17 Rndmr. 3. 
De bepaling onder 3 dat in het dictum eveneens moet worden aangegeven da het ver- of gebod en de daaraan gekoppelde dwangsom zich eveneens uitstreht over inhoudelijk identieke bedingen als het verboden beding, is een codificatie van de Kerntheorie. ${ }^{489}$

Voor het geval de gedaagde veroordeeld wordt zijn anbeveling te herroepen, is onder 4 bepaald dat gedaagde het vonnis op dezelfde manier dient te publiceren als hij zijn aanbeveling heeft bekend gemaakt. ${ }^{400}$

Voor het geval aan de ver- of gebodsvordering een dwangsom of een bevoegdheid tot openbaarmaking van het vonnis is gekoppeld, dient het dictum eveneens de opgelegde dwangsom ( $\$ 890 \mathrm{ZPO}$ ) en de toekenning van de bevoegdheid tot openbaarmaking ( $\$ 18$ AGBG) te bevatten. Daarnaast dient het dictum aan te geven welke partij dient op te komen voor de proceskosten en of het vonnis uitvoerbaar is bij voorraad. ${ }^{491}$

\section{De werking van het verbodsvonnis}

De werking van het verbodsvonnis voor de eisende organisatie en de veroordeelde gebruiker is in beginsel geregeld in de algemene bepaling van $\$ 325$ ZPO. Op grond van die bepaling heeft het verbodsvonnis enkel werking voor de partijen in de abstracte procedure en hun rechtsopvolgers. In \$ 21 AGBG wordt de werking van het vonnis geregeld tussen de veroordeelde gebruiker en zijn contractuele wederpartij.

\section{\$21 Wirkungen des Urteils}

Handelt der verunteilte Venvender dem Unterlassungsgebot zunvider, so ist die Bestimmung din den Allgemeinen Geschafisbedingwngen als wmwinksam anzwsehen, soweit sich der betroffeme Ventragnteil auf die Wirkung des Unterlassingssurteils beruft. Er kann sich jedoch auf die Wirkong des Unier. lassungsurteil micht berufen, wenn der wenurteilte Verwender gegen das Urieil die Klage nach 19
erheben kdnwte.

Iedere wederpartij van de gebruiker - de wederpartij van de aanbeveler dus niet - van algemene voorwaarden kan zich in en buiten rechte beroepen op een vonnis waarin de gebruiker veroordeeld wordt een bepaald beding niet meer te gebruiken en op die wijze de nietigheid van het beding inroepen.

Voor het beroep in de individuele procedure als bedoeld in $\S 21$ AGBG is op de eerste plaats vereist dat er tegen de gebruiker een verbodsvonnis is

489 Zie hiervoor paragraf 6.3. 11 onder het subkopje "De verbodsvordering"
490 Zie witvoerig: Lindacher, AGBG Kommentar, 17 Rndnr. 8-10; Hensen, AGB-Gesetx, 17
Rndnr. 8-11. 491 Lindacher, AGBG Kommentar, 17 Rndmr. 12. 
uitgesproken dat in kracht van gewijsde (rechtskräftig) is gegaan. ${ }^{492} \S 21$ AGBG is op analoge wijze ook van toepassing indien een door de gebruiker gevraagd declaratoir behelzend dat het door hem gebruikte beding niet onredelijk bezwarend is (negative Feststellungsklage), door de rechter is afgewezen. ${ }^{493}$ Omdat bij een verbodsvonnis in kort geding een beslissing in de bodemprocedure nog open staat wordt in het algemeen aangenomen dat $\$ 21$ AGBG niet meebrengt dat de wederpartij zich in de individuele procedure kan beroepen op een verbodswonnis in kort geding.

Op de tweede plaats is vereist dat de veroordeelde gebruiker het verboden beding gebruikt. Daarvan is niet alleen sprake als hij het beding opneemt in overeenkomsten die pas worden gesloten nadat het verbodsvonnis is gewezen, daarvan is ook sprake als de gebruiker zich bij de uitvoering van reeds voordien gesloten overeenkomsten op het verboden beding beroept nadat het verbodsvonnis is gewezen. ${ }^{495}$

Op de derde plaats is vereist dat de wederpartij zich op het verbodsvonnis beroept. De rechter moet er dan zonder meer van uitgaan dat de desbetreffende clausule onredelijk bezwarend is. Het beroep op het verbodsvonnis kan worden gedaan tot op de laatste mondelinge behandeling. Theoretisch is het dus mogelijk, dat het Bundesgerichtshof gebonden is aan een in kracht van gewijsde gegaan verbodsvonnis van een Landgericht. ${ }^{496}$

De wederpartij kan zich echter niet op een verbodsvonnis beroepen als de gebruiker zich met succes zou kunnen beroepen op $\S 19$ AGBG. Daarvoor is niet vereist dat de gebruiker de procedure van $\$ 19$ AGBG daadwerkelijk heeft gevoerd. De rechter moet de hypothetische mogelijkheid onderzoeken van een succesvol beroep van de gebruiker op $\$ 19$ AGBG. De literatuur is verdeeld over de vraag of de rechter ambtshalve moet nagaan of de gebruiker met succes een beroep op $\S 19$ AGBG zou kunnen doen of dat de gebruiker op het verweermiddel van de laatste zin van $\$ 21$ AGBG daarop uitdrukkelijk een beroep moet doen. ${ }^{497}$

492 Heinrichs, BGB (Palandi), AGBG 21 Nr. 3; Basedow, pag. 350; Löwe, Großkommentar zum AGB-Gesetz, \&21 Rndnr. 19; Reinel, pag. 76; Lindacher, AGBG Kommentar, \& 21 Rndnr. 8; Hensen, AGB-Gesetz, \$21 Rndnr. 4.

493 Lindacher, AGBG Kommentar, 21 Rndnr. 9; Hensen, AGB-Gesetz, 21 Rndnr. 4. Afwijzend: Löwe, Grollkommentar zum AGB-Gesetz, 21 Rndnr. 7.

494 Lindacher, AGBG Kommentar, 21 Rndnr. 10; Hensen, AGB-Gesetz, 21 Rndnr. 4.

495 BGH, NJW 1982, pag. 1511-1512; LG Berlin, ZIP 1988, pag. 1311; Löwe, Großkommentar zum AGB-Gesetz, 21 Rndnr. 20-21; Lindacher, AGBG Kommentar, \$21 Rndnr. 4-6; Hensen, AGB-Gesetz, 21 Rndnr. 5; Kötz, BB 1982, pag. 645-646.

496 Hensen, AGB-Gesetz, 21 Rndnr. 7.

497 Voor ambtshslve toepassing onder andere: Hensen; AGB-Gesetz. \& 21 Rndnr. 13; Gerlach, Münchener Kommentar, 21 AGBG Rndmr. 16. Tegen onder andere: Lindacher, AGAG Kornmentar, 21 Rndnr. 14; Heinrichs, BGB (Palandt), AGBG 21 Nr. 3. 
De herziening van een aan de gebruiker opgelegd verbod van gebruik van bepaalde algemene voorwaarden, is geregeld in 19 AGBG.

\section{Einwiendung bei abweichender Entscheidung}

Der Verwender, dem die Verwendung einer Bestimumung untersagt worden ist, kanm im Wege der Klage nach 767 ZPO einwenden, dap nachtrdglich eine Entscheidung des Bundesgerichishofs adder dest Gemeinsamen Semats der Obersten Gerichushofe des Bundes ergangen ist, welche die Vemwents dung dieser Bestimmung for dieselbe An von Rechtsgeschafien nicht unversagt, und dap die Zwangsvollstreckurtg aus dem Urteil gegen ihn in unzumubarer Weise seinen Geschaffisbetrieb beeinuratchrigen willde.

$\$ 19$ AGBG geeft de gebruiker van algemene voorwaarden, die getroffen is door een verbodsvonnis, de mogelijkheid (op grond van $\$ 767$ ZPO) deze veroordeling - en daarmee de werking van $\$ 21$ AGBG - ongedaan te maken indien, nadat het vonnis gewezen is, de hoogste rechterlijke instantie, in een procedure als bedoeld in $\$ 13 \mathrm{AGBG}$, heeft beslist dat het in het geding zijnde beding voor soortgelijke overeenkomsten niet onredelijk bezwarend is en tevens: vaststaat dat de executie van het verbodsvonnis een onredelijke belasting zou zijn voor de beroeps- of bedrijfsuitoefening van de gebruiker. In de praktijk is de betekenis van $\$ 19$ AGBG zeer gering gebleken. ${ }^{498}$

\section{Regïtratie van het vonnis}

De registratie van vonnissen gewezen in de collectieve procedure van $\$ 13$ AGBG of de procedure van $\$ 19$ AGBG is in $\$ 20$ AGBG neergelegd.

\section{$\$ 20$ Register}

(1) Das Gericht teilt dem Butdeskartellamt van Amts wegen mit

1. Klagen, die mach 13 ader mach 819 anhangig werdien.

2. Unteile" die im Verfahren nach 13 ader mach 19 ergehen, sobald sile rechtikndfig sind,

3. die sonstige Erledigung der Klage.

(2) Das Bundeskartellanut fulht uber die nach Absatz I eingehenden Mitreilungen ein Register.

(3) Die Eintragung ist mach zwanzig Jahren seit dew Schlub des Jahres zu Loschen, in dew du Eintragung in das Register enfolgt ist. Die Loschung enfolgt durch Eimiragung eines LDschwongswermerks;" mit der Loschung der Eintragung einer Klage ist die Loschuong der Eintraguong Hurer sansrigen Erledigung (Absatz I Nr. 3) zu vertindten.

(4) Ober eine bestehende Eintragung ist jedermann auf Antrag Auskumf zu erteilen. Die Auskumf whilt folgende Angaben:

1. fir Klagen mach Absatz I Nr. I

498 Zie witvoeriger: Urbanczyk, pag. 220 e.v.; Lindacher, AGBG Kommentar, \$19 Rndnr. 1-25, Hensen, AGB-Gesetz, 19 Rndnr. 1-18. 
a) die beklaghe Partei,

b) das angerufene Gericht samt Geschaffisusummer,

c) den Klagecontrag;

2. far Urteile nach dbsatz $1 \mathrm{Nr}, 2$

a) die verurteille Partiei,

b) das entscheidende Gericht samt Geschafisnummer,

c) die Urteilsformel;

3. fur die sonstige Erledigung nach Absatz $1 \mathrm{Nr}, 3$ die Ant der Erledigung.

De bepaling heeft tot doel de rechterlijke macht en het geïnteresseerde publiek een betrouwbare informatiebron te bieden van in kracht van gewijsde gegane uitspraken in de procedure van $\S 13$ AGBG en (mede) zo deze uitspraken de beoogde breedtewerking te verschaffen. ${ }^{499}$

Op grond van $\$ 20$ AGBG worden alle verbods- en gebodsworderingen, alle verbods- en gebodsvonnissen en verdere afdoeningen van het klachtrecht volgens $\$ 13$ en $\$ 19$ AGBG geregistreerd bij het Bundeskartellamt (BKA) te Berlijn. De rechters moeten ambtshalve de benodigde informatie verstrekken aan het BKA.

De informatie uit het register van het Bundeskartellamt is, op aanvraag, voor een ieder toegankelijk. $\S 20$ lid 4 AGBG bepaalt welke inhoud deze informatie behelst. Het registratiesysteem bij het Bundeskartellamt is echter beperkt. De vonnissen gebaseerd op de concrete inhoudelijke toetsing van de $\$ \S 9$ tot en met 11 AGBG en buitengerechtelijke procedures (bijwoorbeeld het Abmahnverfahren) worden niet geregistreerd. Voorlopige voorzieningen vallen echter wel onder de mededelingsplicht van de rechter en worden dus wel geregistreerd. ${ }^{500}$ Dat het register in de praktijk echter weinig waarde heeft komt vooral door de beperkte informatie die het verschaft. Zo zijn de aard van de overeenkomst waarin het beding werd gebruikt, de branche, de waarde van de procedure en de gronden die tot de uitspraak hebben geleid, niet uit de registratie af te leiden. ${ }^{\text {sol }}$

\subsubsection{Hoger beroep, bezwaar, cassatie en verzet}

In het AGB-Gesetz zijn geen bijzondere regels opgenomen ten aanzien van de rechtsmiddelen die tegen het vonnis in eerste instantie open staan. Voor wat betreft de rechtsmiddelen gelden daarom de algemene regels van het derde boek van het ZPO en het Gerichtsverfassungsgesetz (GVG). Tegen het vonnis gewezen in eerste instantie staan derhalve de gebruikelijke rechtsmiddelen hoger

499 RechtsausschuB, BT Drucksache $7 / 5422$, pag. 12.

$500 \mathrm{KG} \mathrm{Berlin,} \mathrm{AGBE} \mathrm{I} 20 \mathrm{Nr}$. 1, BB 1981, pag. 148; Bunte, Handbuch, pag. 29; Lindacher, AGBG Kommentar, 20 Rndnr. 5 .

501 Creutzig, pag. 20-21; Hardieck, pag. 708; Stillner, pag. 148; Bunte, AcP 1981, pag. 57-58. 
beroep (Berufung), bezwaar (Beschwerde ${ }^{\text {sor }}$ ) en cassatie ${ }^{\mathrm{s} / 3}$ (Revision) open. Tegen een verstekvonnis (Versäumnisurteil) kan de niet-verschenen partij in verzet (Einspruch) komen ( $\$ 330-347 \mathrm{ZPO}$ ).

Omdat de eerste feitelijke instantie in de procedure van $\$ 13$ AGBG het Landgericht is, vindt op grond van \& 119 GVG het bezwaar en het hoger beroep plaats bij het Oberlandesgericht. Om toegelaten te worden in hoger beroep is vereist dat de waarde van de procedure in eerste aanleg minstens $1200 \mathrm{DM}$ bedraagt ( $8511 \mathrm{a} \mathrm{ZPO)}$. Degene tegen wie in eerste instantie een verstekvonnis is gewezen kan, vanwege de mogelijkheid van verzet, niet in hoger beroep. komen tegen die uitspraak ( $\$ 513 \mathrm{ZPO}$ ).

Tegen het vonnis van het Oberlandesgericht staat cassatie open bij het Bundesgerichtshof te Karlsruhe ( $8133 \mathrm{ZPO}$ ). Cassatie is echter alleen mogelijk indien de waarde van de procedure tenminste $60.000 \mathrm{DM}$ bedraagt of indien de beroepsinstantie Revision uitdrukkelijk toestaat vanwege het bijzondere juridische belang van de aan het geding ten grondslag liggende rechtsvraag of vanwege het feit dat de hoogste rechterlijke instantie in haar beslissingen van de rechtsvraag verschillende antwoorden heeft gegeven (\$546 ZPO). Het feit dat het gaat om een collectieve actie in het algemeen belang brengt niet zonder meer met zich dat daarmee het bijzondere juridische belang van de procedure is gegeven. ${ }^{504} \mathrm{Bij}$ een Streitwert van 2.000 tot $5.000 \mathrm{DM}$ per clausule betekent dit in de praktijk dat de meeste AGB-procedures vanwege een te geringe Streitwert in ten hoogste twee instanties worden gevoerd.

\subsubsection{De kosten van de procedure}

Zoals reeds eerder vermeld zijn de proces- en advocaatkosten afhankelijk van de waarde van de procedure. Buiten de regel van $\$ 22$ AGBG dat de Streitwert niet boven de $500.000 \mathrm{DM}$ kan worden vastgesteld bevat het AGB-Gesetz geen bijzondere regels voor de verdeling van de kosten van de procedure. De verde-

502 Het bezwamr, geregeld in de $\$ \$ 567-577$ ZPO, is het rechtsmiddel dat open stant tegen gerechtelijke beshisaingen die niet in de vorm wan een vonnis (Urteil) maar in de vorm van een beschikking (Besehlub) wonden gegeven. De beslissing op de vondering zelf wondt gegeven in de vorm vam een wonnis. In besluitvorm wonden al die beslissingen gewezen die niet zien op een beslissing ten aanzien van de vordering zelf mar op andere uit de procedure voortvloeiende beslissingen zoals bij voorbeeld ten aanzien van de waande van de procedure, het bewrija, voeging en tussenkomst.

503 Wellicht is het gezien de werachillen, die in het kader van deze verhandeling vender van weinig importantie zijn, tussen het Nederlandse beroep in cassatie en de Duitse Revision niet geheel zuiver de tem Revision met cassarie te vertalen. Toch heb ik voor deze term gekozen omdat van de in Nederland bestaande rechtsmiddelen de tern cassatie het dichtst die van Revision benademd.

504 Hensen, AGB-Gesetz, 21 Rndnr. 28. 
ling van de proceskosten is derhalve onderworpen aan de algemene regels van het ZPO zoals die zijn neergelegd in de \$\$ 91-107 ZPO.

In $\S 91$ ZPO is de hoofdregel ten aanzien van de omvang en de verdeling van de kosten neergelegd. Volgens deze regel dient de verliezende partij in beginsel de kosten van de procedure te dragen. Tot deze kosten horen in beginsel ook alle voor een doelmatige proceswoering noodzakelijke uitgaven die de wederpartij heeft moeten maken. Daaronder worden onder meer begrepen de noodzakelijke reiskosten en het honorarium van de advocaat. De regel van $\$ 91$ ZPO leidt er toe dat de winnende partij in beginsel al haar kosten vergoed krijgt.

Voor het geval dat beide partijen voor een deel in het gelijk en voor een deel in het ongelijk worden gesteld, geldt de regel van $\$ 92 \mathrm{ZPO}$. De kosten worden naar evenredigheid over partijen verdeeld of elk der partijen draagt zijn eigen kosten. In het laatste geval worden de gerechtskosten door ieder der partijen voor de helft gedragen. Indien één der partijen slechts voor een ondergeschikt deel van haar vordering in het ongelijk wordt gesteld kan de rechter op grond van lid 2 van $\$ 92$ ZPO de andere partij echter veroordelen tot betaling van alle proceskosten. 



\section{De wet algemene voorwaarden vergeleken met het AGB-Gesetz}

\subsection{Inleiding}

De gelijkenis tussen het AGB-Gesetz en de Wet algemene voorwaarden is onmiskenbaar. Beide regelingen voorzien immers in een dwingendrechtelijk regelcomplex dat voor het terrein van de algemene voorwaarden nadere bepalingen geeft ten aanzien van:

- het begrip algemene voorwaarden;

- de wijze waarop men daar aan gebonden raakt;

- de wijze waarop de gebruiker de wederpartij dient te informeren over zowel de toepasselijkheid als de inhoud van deze voorwaarden;

- de inhoudelijke toetsing van algemene voorwaarden.

Beide regelingen hanteren voor de inhoudstoets van algemene voorwaarden een van de redelijkheid en billijkheid afgeleide norm, die nader wordt uitgewerkt in twee lijsten van bedingen die ofwel altijd tot onredelijk bezwarendheid van een daardoor betroffen beding leiden ofwel een onredelijk bezwarendheid indiceren.

Ook op het procesrechtelijk vlak komen de beide regelingen in essentie grotendeels overeen. Zowel het AGB-Gesetz als de Wet algemene voorwaarden biedt immers niet alleen de individuele wederpartij de mogelijkheid om in een individuele procedure de bescherming die de wet biedt te effectueren, maar voorziet tevens in een procedure waarin belangenorganisaties ten behoeve van het algemeen belang de wettelijk bescherming collectief kunnen afdwingen en waarin belangenorganisaties een verbod van gebruik kunnen afdwingen dat ook buiten de collectieve procedure directe werking heeft.

Om te kunnen beoordelen welke betekenis de Duitse regeling en de ervaringen daarmee hebben voor de toepassing van de Nederlandse regeling en de verwachtingen omtrent de praktische werking van de Nederlandse regeling, zal allereerst bekeken moeten worden in hoeverre de beide regelingen overeenkomen en verschillen. In de navolgende paragrafen komt daartoe eerst een (korte) 
nadere vergelijking van deze materieelrechtelijke regels aan de orde ${ }^{1}$ en vervalgens een uitgebreide vergelijking van de regeling van het collectieve actierechit, waarbij uiteraard de nadruk komt te liggen op de consumentenrechtelijke aspecten van een en ander. Het hoofdstuk wordt afgesloten met een korte conclusie ten aanzien van de onderlinge conformiteit van beide regelingen.

\subsection{Materieelrechtelijke bepalingen}

In deze paragraaf worden de belangrijkste materieelrechtelijke bepalingen van het AGB-Gesetz en de Wet algemene voorwaarden nader met elkaar vergeleken. Achtereenvolgens komen aan de orde het toepassingsbereik van de wet en de definitie van het begrip algemene voorwaarden, de regels met betrekking tot de gebondenheid en de wijze waarop de gebruiker de wederpartij dient te informeren over zowel de toepasselijkheid als de inhoud van deze voorwaarden, verrassende bedingen, de leesbaarheid en duidelijkheid van bedingen, uitlegregels, de inhoudstoets en de toetsnorm, de lijsten, de gevolgen van onredelijk bezwarendheid, de rol van de rechter en de kosten van de procedure.

\subsubsection{Definitie van het begrip algemene voorwaarden en het toepassingsbereik van de wet}

De definitie van het begrip algemene voorwaarden en het toepassingsbereik van de wettelijke regeling worden in beide wetten verschillend geregeld maar ontlopen elkaar qua resultaat nauwelijks. Beide regelingen beginnen in de eerste bepaling met de definitie van het begrip algemene voorwaarden. In beide regelingen zijn algemene voorwaarden bedingen die zijn opgesteld teneinde te worden gebruikt in een aantal overeenkomsten. In de Wet algemene voorwaarden is het begrip beperkt tot schriftelijke bedingen. In het AGB-Gesetz vallen ook mondelinge bedingen onder de definitie. In zowel het AGB-Gesetz als de Wet algemene voorwaarden is de bestemming daarbij doorslaggevend.

In beide regelingen zijn algemene voorwaarden bedingen van contractuele aard, Regels die van rechtswege deel uit maken van de overeenkomst vallen niet onder het begrip algemene voorwaarden.

In de Nederlandse regeling vallen kernbedingen uitdrukkelijk buiten de definitie. In tegenstelling tot de Nederlandse regeling zijn in Duitsland onder de definitie van het begrip algemene voorwaarden ook standaard kernbedingen (essentialia en prijs) begrepen die door de gebruiker bedoeld zijn om ongewijzigd meerdere malen te worden gebruikt. Deze zijn echter op grond van $\$ 8$

1. Zie daartoe untwoeriger de dissertatie van Jongeneel. 
AGBG uitgesloten van de inhoudelijke toets van de $\$ \$ 9$ tot en met 11 AGBG. Het verschil met de Nederlandse regeling ten aanzien van kernbedingen is derhalve gelegen in het feit dat standaard kernbedingen in Duitsland onder de werking van het AGB-Gesetz vallen, zodat de regels omtrent de toepasselijkheid en de informatieplicht van de gebruiker onverkort van toepassing blijven. In Nederland is de Wet algemene voorwaarden in het geheel niet van toepassing op kernbedingen.

In beginsel omvatten beide definities van het begrip algemene voorwaarden ook bedingen die een letterlijke weergave zijn van wettelijke regelingen. In Duitsland zijn deze algemene voorwaarden in \& 8 AGBG uitdrukkelijk uitgesloten van de inhoudelijke toets. In Nederland is dat niet het geval. Omdat alleen bedingen die afwijken van hetgeen zonder hen gegolden zou hebben, inhoudelijk toetsbaar zijn, zullen bedingen die een wettelijke regeling weergeven echter vrijwel nooit onredelijk bezwarend zijn, zeker niet bij de abstracte toets. Praktisch gezien heeft dit verschil dat ook nauwelijks betekenis.

Beide regelingen gaan er van uit dat individueel overeengekomen bedingen in beginsel geen algemene voorwaarden zijn en dat deze bedingen voorrang hebben boven algemene voorwaarden. In Nederland is de laatste regel weliswaar niet gecodificeerd, maar wél algemeen aanvaard als uitleg-regel. In wezen is deze regel echter geen uitlegregel maar een voorrangsregel.

In het Duitse AGB-Gesetz vallen standaardbedingen waarover tussen partijen uitdrukkelijk is onderhandeld maar die desondanks niet zijn gewijzigd, niet onder het begrip algemene voorwaarden. Daarentegen blijven in de Nederlandse regeling standaardbedingen waarover is onderhandeld en die onveranderd zijn gebleven onder de definitie van algemene voorwaarden vallen en zijn deze dus toetsbaar.

Beide regelingen zien in beginsel zowel op het professionele rechtsverkeer als het rechtsverkeer met consumenten. In zowel het AGB-Gesetz als de Wet algemene voorwaarden is de (directe) werking van de lijsten met onredelijk bezwarende clausules echter beperkt tot transacties met consumenten. In Duitsland is daarenboven ook de werking van de toepasselijkheidsvoorschriften van $\$ 2$ AGBG beperkt tot consumententransacties. In tegenstelling tot Duitsland is in Nederland de bescherming van de regeling beperkt tot een bepaalde groep van wederpartijen. Grote wederpartijen als bedoeld in artikell 6:235 BW en wederpartijen die dezelfde algemene voorwaarden gebruiken kunnen immers geen beroep doen op de vernietigingsgronden van artikel 6:233 BW. In Duitsland richt de bescherming van de regeling zich daarentegen op alle wederpartijen.

Zowel de Nederlandse als de Duitse regelingen sluiten arbeidsovereenkomsten uit van het bereik van de wet. Daarnaast worden in Duitsland ook overeenkomsten op het terrein van het erf-, familie- en rechtspersonenrecht van de 
werking wan het AGB-Gesetz met zoveel woorden uitgesloten. Bovendien zijn bepaalde onderdelen van het AGB-Gesetz niet van toepassing op algemente voorwaarden in het openbaar vervoer en van nutsbedrijven en zijn sommige door de overheid goedgekeurde algemene voorwaarden van toepassing op overeenkomsten zonder dat aan de voorschriften van $\$ 2$ AGBG is voldaan.

\subsubsection{De gebondenheid en de informatieplicht}

Aan de gebondenheid worden in de Nederlandse regelling niet al te grote eisen gesteld. Het accent van de regeling ligt immers op de inhoudstoetsing. In Nederland is voor gebondenheid derhalve voldoende dat de wederpartij op de hoogte is van het feit dat de gebruiker zijn algemene voorwaarden tot contractsinhoud wil maken en hij tevens de gelling van deze algemene voorwaarden heeft aanvaard. In Duitsland is dat in beginsel niet anders. De wederpartij moet door de gebruiker op de hoogte worden gebracht van het feit dat deze algemene voorwaarden hanteert en de wederpartij moet de gelding van deze voorwaarden aanvaarden. Hoewel dat in Duitsland niet is gecodificeerd, geldt ook daar dat de wederpartij de gelding van algemene voorwaarden kan aanvaarden zonder dat hij van de inhoud daarvan op de hoogte is.

In het Duitse systeem is de verwijzing naar en de aanvaarding van de gelding van algemene voorwaarden echter nog niet voldoende om gebondenheid aan te nemen. De gebruiker moet de wederpartij bovendien een redelijke mogelijkheid hebben geboden om van de inhoud van de algemene voorwaarden kennis te nemen en de gebruikte bedingen mogen niet verrassend zijn voor de wederpartij. Daarbij omvat het bieden van een redelijke mogelijkheid aan de wederpartij om kennis te nemen van de betreffende voorwaarden tevens de verplichting dat de bedingen leesbaar en begrijpelijk moeten zijn. Indien aan deze gebondenheidswoorschriften niet is voldaan leidt dit in Duitsland ertoe dat de betreffende bedingen geen contractsinhoud worden en dat de overeenkomst voor het overige in stand blijft. Dit laatste lijdt slechts uitzondering indien het niet-toepasselijk zijn van de betreffende algemene voorwaarden leidt tot onaanvaardbare gevolgen voor én der partijen.

In het Nederlandse recht inzake algemene voorwaarden is de informatieplicht van de gebruiker losgekoppeld van het gebondenheidsvraagstuk en is bovendien geen regeling opgenomen ten aanzien van verrassende, onleesbare en onbegrijpelijke bedingen. De loskoppeling van de informatieplicht van het gebondenheidsvraagstuk heeft in Nederland geleid tot een andere sanctie. In plaats van niet-gebondenheid is voorzien in een vernietigbaarheid indien de gebruiker niet voldoet aan zijn informatieplicht. In de praktijk zal dit verschil echter weinig relevantie hebben. 
De informatieplicht is in Nederland, afgezien van het feit dat de Duitse informatieplicht mede het Transparenzgebot omvat, aanzienlijk strenger dan in Duitsland. In Duitsland is voldoende dat de gebruiker de voorwaarden ter inzage heeft en op verzoek een exemplaar verschaft. In Nederland is de hoofdregel daarentegen dat de gebruiker ongevraagd zijn voorwaarden aan de wederpartij ter hand moet stellen.

\subsubsection{Verrassende bedingen}

De Nederlandse wet voorziet niet in een regeling ten aanzien van verrassende bedingen zoals de Duitse $\$ 3$ AGBG. In de Nederlandse rechtspraak onder het oude Burgerlijk Wetboek is de regel van $\$ 3$ AGBG dat er zich onder de tussen gebruiker en wederpartij overeengekomen voorwaarden mogelijk bepalingen bevinden van een zodanige (verrassende) inhoud dat de toestemming van de wederpartij niet kan worden geacht op toepasselijkverklaring ook daarvan gericht te zijn geweest, echter diverse malen aanvaard. ${ }^{2}$ Of deze regel in het stelsel van afdeling 6.5.3 BW nog toepassing zal vinden is echter de vraag. Het stelsel legt immers de nadruk op een inhoudelijke toetsing en niet op een gebondenheidstoetsing. In dat stelsel zou de bescherming tegen verrassende bedingen enkel plaats moeten vinden door de inhoudstoetsing. ${ }^{3} \mathrm{De}$ inhoudstoetsing van verrassende bedingen, die in Duitsland naast de regel van $\$ 3$ AGBG eveneens wordt toegepast, biedt de wederpartij echter enkel soelaas indien het verrassende beding (daardoor) tevens onredelijk bezwarend is. Voor bedingen die weliswaar verrassend zijn maar niet onredelijk bezwarend biedt de inhoudstoetsing, in tegenstelling tot de Duitse regeling van $\$ 3$ AGBG die deze bedingen buiten de overeenkomst houdt, dan ook geen oplossing.

In beginsel is het mijns inziens nog steeds mogelijk dat de artikelen 3:33 en 3:35 BW met zich brengen dat de gebruiker er in beginsel weliswaar op mag vertrouwen dat de toestemming van de wederpartij ziet op de gehele set algemene voorwaarden ook indien deze de inhoud niet kent, maar dat artikel $35 \mathrm{BW}$ tevens met zich brengt dat de gebruiker er niet op mag vertrouwen dat de toestemming van de wederpartij ook gericht is op (bij de gebruiker bekende) verrassende bedingen die tevens (evident) bezwarend zijn voor de wederpartij. Daar doet de regel van artikel 6:232 BW niet aan af. De Holleman/De Klerk constructie heeft mijns inziens haar geldigheid derhalve niet geheel verloren. Geconstateerd moet echter worden dat zij ten opzichte van de inhoudstoets van

2 HR 20 november 1981, NJ 1982, 517, m.nt. C.J.H.B., AA 1982, pag. 247 m.nt. G. (Holleman/De Klerk); HR 1 juli 1993, NJ 1993, 688 (Bowma/Cavo). Zie in dit verband ook: HR 9 september 1994, RwdW 1994, nr, 169C. NJB 1994, pag. 445 (Trouwborst/Tollenatir en Wegener).

3 Jongeneel, diss * pag. 151 en 222 . 
artikel 6:233 sub a BW niets mér biedt. Ook in de Holleman/De Klerk-toets is immers vereist dat het verrassende beding (onredelijk) bezwarend is voor weder partij.

\subsubsection{Leesbaarheid en duidelijkheid}

Ten aanzien van de leesbaarheid en duidelijkheid van bedingen in algemene voorwaarden is in beide regelingen geen expliciete bepaling opgenomen. In Duitsland is het uitgangspunt dat de gebruiker die onleesbare of onbegrijpelijke voorwaarden hanteert de wederpartij geen redelijke mogelijkheid heeft geboden van die voorwaarden kennis te nemen. De onduidelijkheid van een beding kan echter ook leiden tot onredelijk bezwarendheid op grond van de open norm van $\$ 9$ AGBG. Voor Nederland zou aan beide opvattingen aangeknoopt kunnen worden. Een onbegrijpelijk of onleesbaar beding zou of een vernietigbaarheid opleveren omdat de gebruiker niet aan zijn informatieplicht heeft voldaan of een vernietigbaarheid omdat onleesbaarheid en onbegrijpelijkheid het beding onredelijk bezwarend maken. ${ }^{4}$ In die visie is er nauwelijks verschil tussen de Duitse en de Nederlandse regeling. In dit kader dient opgemerkt te worden, dat artikel 10 van de EEG-richtlijn van 5 april 1993 betreffende oneerlijke bedingen in consumentenovereenkomsten ${ }^{5}$ de Lidstaten verplicht om vór 1 januari 1995 (onder andere) de regel van artikel 5 van die richtlijn - dat algemene voorwaarden steeds duidelijk en begrijpelijk moeten zijn opgesteld - te implementeren in hun nationale wetgeving.

\section{2 .5 Uitlegregels}

Alleen het Duitse AGB-Gesetz bevat een regel met betrekking tot de uitleg van bedingen, namelijk de contra proferentem-regel van $\$ 5$ AGBG. De Wet algemene voorwaarden bevat een dergelijke regeling niet, ofschoon zij in de literatuur wordt bepleit. In de rechtspraak van de Hoge Raad wordt deze regel in zijn algemeenheid eveneens niet aanvaard. Artikel 10 van de EEG-richtlijn betreffende oneerlijke bedingen in consumentenovereenkomsten verplicht Nederland echter om vóor 1 januari 1995 de contra proferentem-regel van artikel 5 van die richtlijn te implementeren in de nationale wetgeving.

De hoofdregel dat algemene voorwaarden naar hun aard objectief uitgelegd dienen te worden, is in beide stelsels als ongeschreven rechtsregel aanvaard.

4 Zie ook: Jongeneel, diss., pag. 141.

5 EEG-Publikatieblad 21 april 1993, Nr. L 95/29. 


\subsubsection{Inhoudstoets en toetsinorm}

Voor beide wetten geldt dat de kern van de regeling is gelegen in de inhoudstoetsing van algemene voorwaarden. Zowel de Duitse als de Nederlandse regeling gaan bij de toetsing van de inhoud van algemene voorwaarden uit van een op de redelijkheid en billijkheid gebaseerde open norm die voor consumenten wordt uitgewerkt in een tweetal lijsten met ontoelaatbare bedingen. De open norm en de lijsten zijn in beide regelingen de grondslag voor zowel de individuele als de collectieve inhoudstoets.

In tegenstelling tot de Nederlandse regeling is de open norm in de Duitse regeling nog eens nader geconcretiseerd doordat uitdrukkelijk wordt bepaald dat in twijfelgevallen er van dient te worden uitgegaan dat een beding onredelijk bezwarend is, indien de inhoud hiervan in strijd is met wezenlijke grondgedachten van de wettelijke regeling waarvan wordt afgeweken of indien de inhoud van het beding rechten en plichten die noodzakellijkerwijs uit de aard van de overeenkomst voortvloeien op een zodanige manier opzij zet, dat het doel van de overeenkomst in gevaar komt. Tot praktische verschillen tussen de Nederlandse en de Duitse toetsnorm leidt dit mijns inziens echter niet. Aangenomen mag worden dat de nadere uitwerking die de Duitse wetgever van de open norm geeft, in beginsel ook voor de toepassing van de Nederlandse open norm geschikt is.

In beide regelingen kunnen slechts bedingen worden getoetst die afwijken van hetgeen zonder deze bedingen zou hebben gegolden. Voor Duitsland is dat uitdrukkelijk gecodificeerd in $\$ 8 \mathrm{AGBG}$. In de Nederland is (uiteindelijk) afgezien van codificatie van deze regel. Op grond van de totstandkomingsgeschiedenis van artikel 6:233 sub a BW en de toelichtende stukken daarop uit de parlementaire geschiedenis moet echter worden aangenomen dat de regel ook in Nederland geldt. ${ }^{6}$

Voor de toepassing van de open norm zijn in beide systemen dezelfde omstandigheden relevant. In Duitsland gaat men daarbij uit van een generaliserende benaderingswijze welke volgt uit het algemene karakter van algemene voorwaarden. Bij de individuele inhoudstoets van algemene voorwaarden wordt niet uitgegaan van de omstandigheden van de concrete wederpartij maar van de omstandigheden en belangen zoals die gelden voor de groep van wederpartijen waartoe de individuele wederpartij behoort. De Nederlandse regelling gaat er van uit dat in beginsel alle omstandigheden, ook de a-typische, relevant zijn voor de individuele inhoudstoets op grond van artikel 6:233 sub a BW. 
De Duitse generaliserende benaderingswijze zou mijns inziens ook moeten gelden voor de Nederlandse regeling. Algemene voorwaarden zien naar hun aard immers niet op individuele omstandigheden en belangen die a-typisch zijn voor de kring van wederpartijen en missen in deze omstandigheden toepassing. In dat soort omstandigheden komt de gebruiker een beroep op het beding derhalve niet toe. Aan de open norm toets komt de rechter dan niet toe. Daardoor zal de toets aan de open norm slechts toegepast worden bij wederpar: tijen die verkeren in de omstandigheden die typisch zijn voor de groep van wederpartijen waarvoor de betreffende algemene voorwaarden zijn bedoeld. Het lijkt mij dan ook logisch dat voor het oordeel dat een beding onredelijk bezwarend is of niet, slechts de omstandigheden relevant zijn zoals die gelden voor de groep van wederpartijen waartoe de individuele wederpartij behoort.

Jongeneel neemt in deze een ander standpunt in. ${ }^{7}$ Gezien de "individuele aanpak" in de Nederlandse rechtspraak is hij geen voorstander van de Duitse aanpak. Met alle individuele omstandigheden, zoals bijzondere deskundigheid en maatschappelijke of sociaal-economische positie, die in de relatie tussen gebruiker en wederpartij tot uiting zijn gekomen dient volgens hem rekening te worden gehouden bij de individuele inhoudstoets. Deze (a-typische) omstandigheden maken het de wederpartij in theorie immers mogelijk om in het concrete geval ongunstige voorwaarden te onderkennen en/of in geval een beding ongunstig is betere voorwaarden te bedingen. Daarmee geeft Jongeneel aan dat een beding mogelijk nilet-onredelijk bezwarend is in het a-typische geval waar het dat mogelijk wel zou zijn in het "normale" geval. Andersom kan natuurlijk ook. Jongeneel neemt echter tegelijkertijd weer gas terug door te stellen:

"Maar dat is meer theorie en minder praktijk naarmate het belang van een transactie geringer is. Als hel (financiele) belang wan de overeenkomst niet al te groot is hebben partijen wel wat beters te doen dan het mapluizen van de algemene voorwaarden; de voorwaarden worden zonder meer alanvaard.

Bij de beoordeling van een bezwarend beting moeten daanom naar mijn mening de praktische mogelijkheid wan de wederpartij om dit wit de weg te maimen lager worden ingeschat naarmate het belang wan de overeenkomst geringer is en moet ook "de deskundigheid en de maarschappelifike ent sociacal-economische positio van partijen' een geringere betekenis hebben."

Jongeneel licht zijn opvatting toe met alls voorbeeld een notaris:

"... een notaris die een rieuw bureaw koopt en daabij de werkoopwoorwatarden wan de mewbelhamdelaar acmwandt moet mi. precies hetzelfde worden behandeld als een juridisch ongeschoold persoon die hetzelfde doer. Pas als de notaris over de algemene voonwarden met de verkoper onderhandeft zou ik wat anders willen annemen. Als diezelfde notaris een auto koopt op de verkaopwoonwarden 
went de autodealer zou ik - gezien het belang van de transactie - Mijfelen. Koopt hij tenslotte een woonhuais cunnex bedrijfspand, dan zijn deskundigheid, zijn matschappelijke en sociaal-economische poritie natururlijk zeer relevant"."

In de visie van Jongeneel spelen concrete a-typische individuele omstandigheden derhalve pas een rol bij inhoudelijke toetsing aan de open norm, indien zij kenbaar zijn voor partijen en het belang van de transactie een bepaalde waarde ontstijgt. Ik deel zijn opvatting in deze niet. Dit omdat ook een deskundige of iemand die een dusdanige economische positie heeft dat hij een wijziging van de inhoud van de hem voorgelegde voorwaarden kan bewerkstelligen, er op moet kunnen vertrouwen dat de gebruiker hem hetzelfde behandelt als alle andere klanten en jegens hem dezelfde niet-onredelijk bezwarende bedingen gebruikt als hij tegenover al zijn klanten gebruikt. Een ieder die algemene voorwaarden krijgt voorgelegd die zijn geschreven voor een bepaalde kring van wederpartijen mag toch zonder meer verwachten dat de gebruiker zich bij het opstellen van die algemene voorwaarden heeft laten leiden door de maatstaven van redelijkheid en billijkheid. Dat zijn voorwaarden derhalve rekening houden met de gerechtwaardigde en kenbare belangen van deze kring en dat ook voor hém geldt dat hij deze voorwaarden, mede gezien de dwingendrechtelijke wettelijke bescherming, zonder risico ongelezen mag en kan aanvaarden. Daar doet de waarde van de transactie niet aan af. Zowel in transacties met een geringe waarde als in transacties met aanzienlijke waarde worden algemene voorwaarden immers opgesteld en gebruikt met het oog op een bepaalde kring van wederpartijen en hebben zij ten doel het rechtsverkeer vlot en adequaat te reguleren. Van deze voordelen moet ook de a-typische wederpartij kunnen profiteren. Ook hij moet ongelezen kunnen aanvaarden zonder het risico te lopen dat zijn a-typische omstandigheden hem naderhand worden tegengeworpen. Met andere woorden: algemene voorwaarden zijn niet gericht op de a-typische wederpartij, bij hun beoordeling dient met a-typische omstandigheden derhalve geen rekening te worden gehouden. Dat is ook niet nodig. Een beroep op een beding onder a-typische omstandigheden kan door de rechter zonder meer worden gepasseerd omdat het beding naar zijn aard niet op deze a-typische omstandigheden ziet. Naar mijn mening hoeft er betreffende de toepassing van de omstandigheden die bij de toetsing aan de open norm een rol spelen, dan ook geen verschil te zijn tussen de überindividuell-generalisierende Duitse aanpak en de Nederlandse aanpak. 


\subsubsection{De lijsten}

Zowel in het Nederlandse als het Duitse stelsel is de open norm nader uitgwerkt in een tweetal lijsten met bedingen die of altijd onredelijk bezwarend zijn of onredelijk bezwarendheid indiceren. Het verschil zit voornamelijk in de werking van de Nederlandse grijze lijst en de Duitse lijst van $\S 10 \mathrm{AGBG}$. De Nederlandse lijst gaat uit van een, door de gebruiker weerlegbaar, vermoeden van onredelijk bezwarendheid. De Duitse "grijze" lijst gaat uit van onredelijk bezwarendheid maar laat, door het hanteren van "open" normen, het oordeel over de onredelijk bezwarendheid in het concrete geval over aan de rechter. De lijsten vertonen eveneens grote gelijkenis voor wat betreft de specifieke clausules die geacht of vermoed worden onredelijk bezwarend te zijn en in beide stelsels is de (directe) werking van de lijsten beperkt tot transacties met consumenten.

Een verder verschil, van geringe praktische betekenis, tussen het Nederlandse en het Duitse systeem met betrekking tot de lijsten is dat de lijsten in het Nederlandse systeem slechts hun werking hebben via de weg van artikel 6:233 sub a $B W$, terwijl de Duitse lijsten een zelfstandige vernietigingsgrond bevatten die weliswaar en uitwerking is van de open norm, maar daar toch los van staat.

\subsubsection{Nietigheid versus vernietigbaarheid}

De sanctie die is verbonden aan het gebruik van een onredelijk bezwarend beding is in beide stelsels verschillend. In het Nederlandse stelsel is in een vernietigbaarheid voorzien en in het Duitse stelsel in een nietigheid van rechtswege. In beide stelsels kan de wederpartij zich zowel in als buiten rechte op de nietigheid respectievelijk vernietigbaarheid beroepen. In Duitsland omdat een nietigheid van rechtswege dat naar zijn aard meebrengt. In Nederland omdat dat uitdrukkelijk in de wettelijke regeling is vastgelegd. De vernietiging heeft tot gevolg dat het beding met terugwerkende kracht uit de overeenkomst wordt gelicht. In die zin zit er tussen de Duitse Unwirksamkeit en de Nederlandse vernietigbaarheid geen verschil in rechtsgevolg.

Het op het eerste gezicht geringe verschil tussen nietigheid van rechtswege en vernietigbaarheid heeft echter wél gevolgen voor de rol van de rechter in de verschillende rechtsstelsels. In het Duitse stelsel moet de rechter in beginsel ambtshalve een eventuele nietigheid van algemene voorwaarden op grond van het bepaalde in de $\$ \S 9-11$ AGBG onderzoeken, zonder dat daaraan een eis, beroep of verweer is voorafgegaan. Voor het Nederlandse stelsel zal vanwege de vernietigbaarheid er van uit moeten worden gegaan dat de rechter lijdelijk is en niet ambtshalve mag toetsen. De wederpartij zal zich dus, al dan niet bij 
wege van verweer, op de vernietigbaarheid van een onredelijk berwarend beding moeten beroepen.

In dit verband dient opgemerkt te worden dat aan dit verschil mogelijk een einde wordt gemaakt door de Europese richtlijn betreffende oneerlijke bedingen in consumentenovereenkomsten. Artikel 10 van de richtlijn verplicht Nederland immers om vóor 1 januari 1995 te voldoen aan artikel 6 lid 1 van die richtlijn.

\section{Anthel 6 ind 1}

"De Lid-Staten bepalen dat oneerlijke bedingen in overeemkomuten tussen een verkoper en een consument onder de in het mationale rech geldende woarwaarden de comsument niet binden en dat de overeenkomst woor de partijen bindend bliff indiem de overeenkomst zonder de oneerlijke bedingen kan roombestaan."

Aan het voorschrift dat "oneerlijke" bedingen de wederpartij niet binden kan in het Nederlandse rechtsstelsel naar mijn mening alleen maar worden voldaan door onredelijk bezwarende algemene voorwaarden van rechtswege nietig te verklaren. In die zin dient artikel 6:233 sub a $\mathrm{BW}$ vór 1 januari 1995 aangepast te worden aan de regels die de Europese richtlijn voorschrijft.

In het AGB-Gesetz zijn de gevolgen van de nietigheid van een beding nader geregeld in $\& 6 \mathrm{AGBG}$. Afdeling $6.5 .3 \mathrm{BW}$ bevat geen regeling dienaangaande en op de nietigheid van een beding zijn derhalve in beginsel de algemene bepalingen van toepassing. De Nederlandse en Duitse regeling ontlopen zich op dit terrein echter nauwelijks.

Net als in Nederland is in Duitsland de nietigheid van een beding in beginsel beperkt tot de aangevallen regeling. Een beding kan in beide systemen geheel of gedeeltelijk (ver)nietig(baar) zijn. In beginsel blijft in beide systemen het resterende deel van het beding en de overeenkomst onverkort gelden tussen partijen tenzij het resterende deel redelijkerwijs niet in stand kan blijven. Voor de leemte die door het wegvallen van een (ver)nietig(d)e clausule ontstaat, voorziet het Duitse systeem in een expliciete regel die bepaalt dat daarvoor het regelende recht in de plaats komt en dat bij gebreke daarvan de hiaten door aanvullende uitleg dienen te worden ingevuld. Alhoewel niet uitdrukkelijk gecodificeerd wijkt het Nederlandse systeem hier niet van af. ${ }^{10}$

Indien een beding onredelijk bezwarend is wordt in het Duitse systeem een conversie tot het toelaatbare deel unaniem afgewezen. Uit de parlementaire geschiedenis valt voor de Nederlandse regeling nagenoeg hetzelfde af te leiden. Ook in Nederland dient de conversie uiterst terughoudend te worden toegepast. 
Beide regelingen laten de verdeling van de kosten inzake procedures met betrekking tot algemene voorwaarden over aan de algemene regels van het burgerlijk procesrecht. In beide stelsels is het uitgangspunt dat de kosten van een individuele procedure in beginsel ten laste komen van de partij die in het ongelijk wordt gesteld en dat de in het ongelijk gestelde partij veroordeeld wordt in de proceskosten van haar wederpartij. In beide stelsels is het ook zo dat indien partijen slechts voor een deel in het gelijk worden gesteld zij ofwel hun eigen proceskosten moeten dragen en voor de helft van de gerechtelijke kosten moeten opdraaien offwel veroordeeld worden tot een deel van de proceskosten van de andere partij. In beide systemen loopt de wederpartij dus een procesrisico dat afhankelijk is van de winstkansen van een vordering. In Duitsland wordt deze risicoverdeling zeer consequent toegepast in die zin dat de winnende partij haar procedurekosten altijd geheel krijgt vergoed als de verliezende partij voldoende verhaal biedt. Dit komt voornamelijk omdat in Duitsland de kosten van de procedure en de tarieven van advocaten objectief berekend worden aan de hand van de door de rechter vast te stellen waarde van de procedure en de rechter in de toekenning van de kosten daar bij aansluit.

Ofschoon artikel $56 \mathrm{Rv}$ de beslissing over het bedrag van de kosten en de vaststelling van wat tot die kosten gerekend mag worden overlaat aan het oordeel van de rechter ${ }^{11}$ en het de Nederlandse rechter mijns inziens derhalve vrijstaat om de verliezende partij te veroordelen in de door de winnende partij werkelijk gemaakte kosten (de beslissing hoeft zelfs niet met redenen omkleed te worden), vindt dat in de praktijk niet of nauwelijks plaats. In het Nederlandse stelsel is het doorgaans zo dat al wordt een partij volledig in het gelijk gesteld, de ten behoeve van haar uitgesproken kostenveroordeling niet meer dan een gedeelte ornvat van de in werkelijkheid door haar gemaakte kosten. In Nederland geldt dan ook het aloude adagium "Wie pleit om een koe, legt er één op toe". Daardoor loopt de Nederlandse justitiabele bij zijn gang naar de rechter niet alleen een procesrisico dat afhankelijk is van de winstkansen maar wordt hij steevast geconfronteerd met het feit dat hij, ook indien zijn winstkansen bij voorbaat reeds voor $100 \%$ vaststonden, een deel van zijn eigen kosten zelf zal moeten dragen. Voor de Nederlandse consument betekent dit in principe dat hij zijn gelijk bij de rechter moet kopen. Zeker indien de procedure algemene voorwaarden betreft die op grond van de zwarte lijst of op grond van een uitspraak van de bijzondere rechter zonder meer onredelijk bezwarend zijn, een gegeven waarvan de gebruiker op de hoogte is of behoort te zijn, is er mijns

11 Hugenholtz/Heemskerk, pag, 113. 
inziens geen enkele reden om de werkellijke proceskosten die de wederpartij redelijkerwijs heeft moeten maken om bij de rechter zijn dwingendrechtelijke bescherming af te dwingen, niet geheel te vergoeden.

\subsection{Procesrechtelijke bepalingen}

Bij een vergelijking van het collectief actierecht voor consumentenorganisaties in het AGB-Gesetz met het collectief actierecht voor Nederlandse consumentenorganisaties in de Wet Algemene Voorwaarden springt direct in het oog dat beide regelingen eveneens grote gelijkenis met elkaar vertonen doch ook een aantal verschillen. Hieronder zullen deze overeenkomsten en verschillen de revue passeren. Aan de orde komen achtereenvolgens de bevoegde organisaties, de toetsnorm, de vorderingen, de geadresseerden van de vorderingen en de collectieve dagvaarding, de overlegverplichting en de "Abmahn-verplichting", de rechtsgang, de werking van het verbodsvonnis, de registratie van collectieve procedures en de kosten van de abstracte procedure.

\subsubsection{De bevoegde organisaties}

Beide regelingen gaan uit van organisaties met volledige rechtspersoonlijkheid die zich statutair ten doel hebben gesteld de belangen van consumenten te behartigen. In beide regelingen hebben zowel algemene als categoriale consumentenorganisaties het ius agendi op het terrein van de algemene voorwaarden.

In tegenstelling tot de Nederlandse regeling vereist de Duitse regeling tevens dat de belangenbehartiging van consumenten daadwerkelijk dient plaats te vinden door middel van voorlichting en advies en als zodanig als een nietbijkomstige statutaire doelstelling moet zijn vastgelegd. Bovendien vereist het AGB-Gesetz dat consumentenorganisaties minimaal 75 natuurlijke personen of twee consumentenorganisaties als leden hebben.

De bevoegdheid van consumentenorganisaties wordt in beide regelingen beperkt tot het actierecht inzake algemene voorwaarden die gehanteerd worden in transacties met consumenten wier belang door de eisende organisatie wordt behartigd.

\subsubsection{De toetsnorm}

Zowel afdeling 6.5.3 BW als het AGB-Gesetz gaat bij de toetsing in de collectieve procedure uit van de normen die in de individuele procedure gelden, zij het dat deze geabstraheerd van de omstandigheden van het individuele geval worden toegepast. 
Beide regelingen gaan bij de collectieve inhoudstoets dus uit van de open norm van artikel 6:233 sub a BW respectievelijk 8 Absatz 1 AGBG en de te concretisering van deze "open norm" en omwille van de rechtszekerhieid vastgestelde lijsten. Ondat in beide regelingen de open norm niet verschilt en de lijsten van artikel 6:236 en 6:237 BW nagenoeg dezelfde bedingen onredelijk bezwarend verklaren (of daar een vermoeden van uitspreken) als de lijsten van $\$ 10$ en 11 AGBG, is er qua toetsnorm geen verschil tussen de Nederlandse en de Duitse abstracte toetsnorm.

In zowel het AGB-Gesetz als de Wet algemene voorwaarden kan de collectieve vordering zich eveneens richten tegen bedingen in algemene voorwaarden die in strijd zijn met het dwingende recht.

\subsubsection{De vorderingen}

Uitgangspunt in afdeling 6.5.3 $\mathrm{BW}$ is de vordering specifieke bedingen in bepaalde algemene voorwaarden onredelijk bezwarend te doen verklaren met eventueel daaraan verbonden een aantal nevenvorderingen, namelijk een verbod van gebruik of aanbeveling, een gebod tot herroeping van een aanbeveling, publikatie van het vonnis en een dwangsom.

De vorderingen volgens het AGB-Gesetz gaan niet uit van een verklaring voor recht met nevenvorderingen doch van rechtstreekse vorderingen, namelijk een verbod van gebruik of aanbeveling, een gebod tot herroeping van een aanbeveling, publikatie van het vonnis en een dwangsom. Het verschil ligt hierin dat Nederlandse consumentenorganisaties hun vordering kunnen beperken tot een verklaring voor recht, hetgeen in Duitsland niet mogelijk is. Andersom is het zo dat in Duitsland de rechter een verbod moet uitspreken indien algemene voorwaarden onredelijk bezwarend zijn, terwijl de Nederlandse rechter in beginsel de vrijheid heeft een beding weliswaar onredelijk bezwarend te verklaren, maar de bijgaande nevenvordering gericht op een verbod van gebruik af te wijzen. Het praktische belang van dit verschil lijkt mij echter gering. Ook als het gevraagde verbod niet wordt toegewezen maar slechts het declaratoir wordt toegekend, zal dat immers tot gevolg hebben dat het betreffende beding vernietigbaar is in de individuele procedure. Weliswaar niet rechtstreeks op grond van artikel 6:243 BW maar op grond van artikel 6:233 sub a BW. Het beding is immers onredelijk bezwarend.

Een gering verschil bestaat ook ten aanzien van de regeling omtrent de publikatie van het vonnis. In Duitsland zijn de kosten van publikatie in de Bundesanzeiger voor rekening van de gebruiker of aanbeveler en de kosten van publikatie in een ander blad of periodiek voor rekening van de vorderende consumentenorganisatie. In Nederland wordt de rechter vrij gelaten de wijze van publikatie en de verdeling van de kosten hiervan te bepalen. 
In het Duitse systeem is het op grond van $\$ 256$ ZPO onder bepaalde omstandigheden mogelijk dat de gebruiker of aanbeveler aan de bijzondere rechter een declaratoire uitspraak vraagt dat de door hem gebruikte of aanbevolen bedingen miet onredelijk bezwarend zijn. Artikel 6:242 BW biedt deze mogelijkheid niet, althans niet als er geen sprake is van een uitspraak als bedoeld in artikel 240 lid $\mathbb{1}$ (onredelijk bezwarend verklaring). Niet is in te zien waarom een Nederlandse gebruiker of aanbeveler, die niet is getroffen door een declaratoir als bedoeld in artikel 6:240 lid BW, als hij daar belang bij heeft, niet eveneens aan de rechter een verklaring voor recht kan vragen dat zijn algemene voorwaarden niet onredelijk bezwarend zijn. In dat geval verdient het mijns inziens, gezien het abstracte karakter van een dergelijke vordering, well de voorkeur dat een dergelijke vordering bij uitsluiting wordt berecht door de bijzondere rechter te Den Haag.

\subsubsection{De geadresseerden van de vorderingen}

In beide regelingen kan de verbodsactie ingesteld worden tegen zowel de gebruiker van algemene voorwaarden als degene die het gebruik van algemene woorwaarden bevordert en kan de gebodsactie tot herroeping van de aanbeveling ingesteld worden tegen de aanbeveler.

Het meest in het oog springende verschil tussen de Duitse en de Nederlandse regeling is de mogelijkheid in Nederland van collectieve dagvaarding van een vereniging tezamen met haar leden zonder dat deze leden afzonderlijk hoeven te worden gedagvaard. Deze mogelijkheid bestaat in Duitsland niet. Elke gebruiker dient geïndividualiseerd te worden gedagvaard. Uiteraard kunnen ook in Duitsland meerdere gebruikers tegelijkertijd in eén procedure worden betrokken.

\subsubsection{Overlegverplichting versus Abmahnung}

Nederlandse consumentenorganisaties zijn niet ontvankelijk indien niet blijkt dat zij, alvorens een vordering in te stellen, de gebruiker of degene die het gebruik van bepaalde algemene voorwaarden bevordert de gelegenheid hebben geboden om in onderling overleg de algemene voorwaarden zodanig te wijzigen dat de bezwaren die grond opleveren voor de vordering zijn weggenomen. ${ }^{12}$ Een termijn van zes maanden na schriftelijke kennisgeving van de bezwaren is daartoe in $e l k$ geval voldoende (artikell 6:240 lid $4 \mathrm{BW}$ ). Met deze regel wordt het belang dat de Nederlandse wetgever aan onderhandelingen hecht, onderstreept. Ook de bepaling van artikel 6:240 lid $5 \mathrm{BW}$ dat het actierecht voor een

12 Consumentenorganisaties moeten in de dagvaarding dan ook stellen dat $x$ jij aan de overlegverplichting hebben voldasm. 
consumentenorganisatie vervalt indien deze instemt met het gebruik van bepaatde algemene voorwaarden moet in dat licht gezien worden. De wetgever will daarmee de bestaande zelfreguleringsactiviteiten tussen aanbiedersorganisaties en consumentenorganisaties stimuleren zoals deze, onder andere onder auspiciền van de CCA, reeds geruime tijd worden gevoerd.

Dergelijke bepalingen kent het AGB-Gesetz niet. Een zelfreguleringscultuur zoals die in Nederland bestaat, is in Duitsland ook nauwelijks voorhanden en onderhandelingen tussen consumentenorganisaties en aanbiedersorganisaties zijn een rariteit. Vanwege de financiële risico's "verplicht" \& 93 ZPO (te vergelijken met de figuur van rauwelijkse dagvaarding, art. 56 lid 1 Rv) consumentenotganisaties echter om een Abmahnung aan de tegenpartij te doen toekomen alvorens zij een vordering kunnen instellen. De Abmahnung heeft daarmee in principe hetzelfde praktische effect als de "overlegverplichting", namelijk de gebruiker of aanbeveler een redelijke mogelijkheid te bieden aan de bezwaren die grond opleveren voor de vordering tegemoet te komen of deze te weerleggen. Het verschil tussen de Abmahnung en de overlegverplichting is gelegen in het feit dat de Abmahnung in eerste instantie is gericht op een overeenkomst met de gebruiker waarin deze verklaart het aangevallen beding niet langer te gebruiken en bereid is een boete te betalen voor het geval hij dat wél doet, en de overlegverplichting in eerste instantie gericht is op vervanging van het aangevallen beding door een beding dat wel toelaatbaar is.

De sanctie op het niet uitbrengen van de Abmahnung of de "overlegverplichting" verschilt duidelijk. In Nederland leidt het niet nakomen van de overlegverplichting tot niet-ontvankelijkheid en in Duitsland leidt het afzien van de "Abmahn-verplichting" tot een verhoogd financieel procesrisico.

Ofschoon een uitdrukkelijke bepaling in het AGB-Gesetz hierover ontbreekt verwachten de twee op het terrein van $\$ 13$ AGBG meest actieve consumentenorganisaties (VSV te Berlijn en de Verbraucherzentrale Baden-Württemberg te Stuttgart) ${ }^{13}$ dat de Duitse rechter een eventuele instemming met het gebruik van een bepaald beding door de eisende consumentenorganisatie, in zijn beoordeling zwaar mee zal laten wegen of zelfs zou kunnen concluderen dat de grondslag van de vordering van de consumentenorganisatie met de gegeven toestemming vervalt. 


\subsubsection{De rechtsgang}

In de Nederlandse regeling is in tegenstelling tot de Duitse regelling niet voorzien in hoger beroep. Cassatie bij de Hoge Raad e.q. Revision bij het Bundesgerichtshof is in beide regelingen mogelijk.

Hoewel niet uitdrukkelijk voorzien in het AGB-Gesetz, wordt een kort geding (Einstweilige Verfügung) voor Duitse consumentenorganisaties voor mogelijk gehouden, terwijl in Nederland de mogelijkheid van een kort geding voor vorderingen op grond van artikel 6:240 BW uitdrukkelijk is uitgesloten. De Nederlandse wetgever sluit de mogelijkheid van een procedure op verkorte termijn van artikel $145 \mathrm{Rv}$ echter niet uit. In de plaats van een kort geding kunnen consumentenorganisaties echter wél gebruik maken van de figuur van de provisionele eis als neergelegd in artikel $51 \mathrm{Rv}$. Deze voorlopige voorziening van artikel $51 \mathrm{Rv}$ biedt aan consumentenorganisaties in beginsel dezelfde mogelijkheden als het kort geding van artikel 289 e.v. Rv, zodat dienaangaande de situatie in Duitsland niet noemenswaardig verschilt van de Nederlandse.

Doordat de Duitse regeling hoger beroep toelaat voorziet zij in twee feitelijke instanties. Voor de collectieve actie van $\$ 13$ AGBG is dat in eerste aanleg een Landgericht en in hoger beroep een Oberlandesgericht. In de Duitse regeling bestaat de mogelijkheid van "concentratie" van de rechtspraak in eerste instantie bij daartoe aangewezen rechtbanken. $\$ 14$ lid 2 AGBG geeft de deelstaatregeringen de mogelijkheid de rechtsgedingen gebaseerd op $\$ 13$ AGBG te concentreren bij eén van de verschillende rechtbanken. Doel van deze concentratie is een snellere afwikkeling, deskundigheidsbevordering en meer homogeniteit in de rechtspraak. In Nederland is het Haagse Gerechtshof bij uitsluiting bevoegd verklaard tot kennisneming van vorderingen gebaseerd op artikel 6:240 BW (artikel 6:241 lid $1 \mathrm{BW}$ ), zodat alle collectieve acties op het terrein van algemene voorwaarden door dit hof als enige feitelijke instantie worden berecht. Deze wettelijke concentratie zal naar verwachting eveneens leiden tot een snellere afwikkeling, deskundigheidsbevordering bij het Haagse Hof en homogeniteit in rechtspraak.

In tegenstelling tot het AGB-Gesetz is in de Nederlandse regeling uitdrukkelijk bepaald dat de rechter in zijn uitspraak kan aangeven op welke wijze het onredelijk bezwarend karakter van de bedingen waarop de uitspraak betrekking heeft kan worden weggenomen (artikel 6:241 lid 5 BW). In de Duitse rechtspraak en literatuur wordt algemeen aangenomen dat op dit terrein geen taak is weggelegd voor de rechter. Uitgangspunt is immers dat de gebruiker of aanbeveler er voor dient te zorgen dat zijn algemene voorwaarden in overeenstemming zijn met de wet. 
In Duitsland is de rechter voor sommige algemene voorwaarden verplicht om bij de beoordeling van de inhoud daarvan een op die voorwaarden toezicht houdende (overheids)instantie te horen. De Wet algemene voorwaarden kent een dergelijke verplichting niet, hetgeen overigens niet verhindert dat het Haagse hof zulks waar nuttig zal doen.

\subsubsection{De werking van het verbodswonnis}

Het verbodsvonnis heeft zowel in het Duitse als in het Nederlandse systeem zijn uitwerking naar wederpartijen die ná de verbodsuitspraak worden geconfronteerd met het gebruik jegens hen van het verboden beding door de veroordeelde gebruiker. In beide wetten is bepaald dat de wederpartij in die gevallen een direct beroep open staat op het verbodsvonnis en dat de rechter in beginsel gebonden is aan dat verbodsvonnis. In tegenstelling tot zijn Nederlandse collega dient de Duitse rechter bij een beroep van de wederpartij op een verbodswonnis echter tevens na te gaan of de gebruiker, vanwege het feit dat de hoogste rechterlijke instantie nadat het verbodsvonnis is gewezen, ten aanzien van eenzelfde beding een daarvan afwijkend vonnis heeft gewezen, een beroep toekomt op de regeling van $\$ 19$ AGBG. Indien dit beroep op $\$ 19$ AGBG hypothetisch gezien zou slagen kan de wederpartij geen beroep doen op het verbodsvonnis.

Beide regelingen voorzien in een mogelijkheid tot herziening van een collectief vonnis op vordering van de veroordeelde gebruiker. In de Duitse regeling is deze herziening beperkt tot het verbodsvonnis, staat deze mogelijkheid enkel open voor de gebruiker en alleen indien een latere uitspraak van de hoogste Duitse rechterlijke instanties van het verbodsvonnis afwijkt en het gezien deze afwijking niet langer redelijk zou zijn de gebruiker aan het hem opgelegde verbod te houden ( $\$ 19$ AGBG). In het Nederlandse systeem staat de herzieningsmogelijkheid zowel voor de gebruiker als de aanbeveler open voor alle collectieve vonnissen van de bijzondere rechter. In Nederland kan de bijzondere rechter een eerder opgelegd verbod wijzigen of opheffen indien de verbodsuitspraak tengevolge van een wijziging in de omstandigheden niet langer gerechtvaardigd is (artikel 6:242 BW).

\subsubsection{De registratie van collectieve procedures en vonnissen}

In het AGB-Gesetz is voorzien in een verplichte centrale registratie van alle procedures en vonnissen die op grond van \$ 13 AGBG zijn gevoerd respectievelijk zijn gewezen. In de Wet algemene voorwaarden is van een dergelijk registratiesysteem vanwege de kosten afgezien. 


\subsubsection{De kosten van de procedure}

Zowel de Duitse als de Nederlandse regeling bevatten eén nadere bepaling omtrent de kosten van de procedure. In het AGB-Gesetz is dat $\$ 22$ die de maximale waarde van de collectieve procedure vastlegt op een half miljoen Duitse Mark waardoor het procesrisico van een eisende organisatie een maximale grens niet te boven kan gaan. Voor de Nederlandse regeling is dat de bepaling van artikel $1006 \mathrm{Rv}$ waarin is vastgelegd dat een gedagvaarde collectiviteit (vereniging en haar leden) voor de berekening van de proceskosten wordt beschouwd als éen partij. Ook deze bepaling geeft de eisende organisatie de mogelijkheid het proceskostenrisico te verkleinen door in plaats van verschillende individuele dagvaardingen én collectieve dagvaarding uit te brengen.

Verder bevatten beide wetten geen nadere regels omtrent de kosten van de procedure. In beginsel zijn daar de algemene regels van de burgerlijke rechtsvordering c.q. de Zivilprozeßordnung op van toepassing. In beginsel gelden voor de verdeling van de proceskosten in de abstracte procedure dezelfde regels als in de individuele procedure. Ook hier onderscheidt het Duitse recht zich van het Nederlandse doordat de in het gelijk gestelde partij in beginsel al haar kosten vergoed krijgt, hetgeen in Nederland doorgaans niet het geval is.

\subsection{Conclusie}

Materieel gezien komt de Nederlandse Wet algemene voorwaarden qua systeem, opbouw, invulling en werking grotendeels overeen met het Duitse AGB-Gesetz. Slechts op enkele punten wijken de materieelrechtelijke regels van elkaar af. Zo is met name de informatieplicht in het Nederlandse systeem aanzienlijk strenger dan die in het AGB-Gesetz. Daar staat tegenover dat het AGB-Gesetz de helderheid en begrijpelijkheid van een beding meeneemt bij de informatieplicht waardoor de wederpartij niet is gebonden aan bedingen die niet helder of niet begrijpelijk zijn. Een gering verschil is ook te bespeuren ten aanzien van de reikwijdte van de twee wetten. De Wet algemene voorwaarden heeft een iets groter bereik dan het AGB-Gesetz.

Een aanmerkelijk materieel verschil tussen de Duitse en de Nederlandse regeling wordt echter veroorzaakt door het verschil in sanctie dat staat op het gebruik van onredelijk bezwarende algemene voorwaarden. De Duitse rechter toetst daardoor ambtshalve of een beding in algemene voorwaarden onredelijk bezwarend is. De Nederlandse rechter doet en mag dit vanwege de vernietigbaarheid niet. Het gebruik maken van een vernietigbaarheid is in het systeem van het Nederlandse burgerlijk wetboek immers een bevoegdheid van procespartijen. 
Voor wat betreft de collectieve actie op het terrein van de algemene voorwaarden ontlopen de regelingen zich qua opzet, invulling en werking eveneens nauwelijks. Het verschil zit grotendeels in de nadruk die de Nederlandse wetgever legt op zelfregulering van de marktpartijen, waardoor Nederlandse consumentenorganisaties zich in tegenstelling tot de Duitse consumentenorganisaties geplaatst zien voor een overlegverplichting. Daar staat weer tegenover dat de Nederlandse regeling - ten behoeve van de beoogde breedtewerking - de mogelijkheid schept om een branchevereniging tezamen met haar leden collectief te dagvaarden hetgeen in het Duitse systeem niet kan.

Een opmerkelijk verschil tussen beide regelingen is dat in Nederland de rechtspraak in eerste instantie op het gebied van de collectieve actie is geconcentreerd bij het Haagse hof. Duitsland kent een soortgelijke regeling als bevoegdheid op deelstaatniveau. Niet elke deelstaat heeft echter gebruik gemaakt van deze concentratiebevoegdheid. Concentratie van rechtspraak in eerste instantie bevordert de eenheid van rechtspraak en rechtszekerheid op het terrein van de algemene voorwaarden. In Nederland wordt het voordeel dat concentratie bij het Haagse hof biedt echter weer gedeeltelijk teniet gedaan. Artikel 3:305a BW kent deze concentratie van rechtspraak voor de collectieve vernietiging van onredelijk bezwarende algemene voorwaarden in bestaande overeenkomsten immers niet.

Een ander aanmerkelijk verschil tussen de Nederlandse regeling en de Duitse regeling vloeit, voor zowel de individuele als de collectieve procedure, voort uit de algemene regels ten aanzien van de verdeling van de kosten. In Nederland zal een procedure voor de wederpartij of de eisende organisatie welhaast altijd kosten met zich brengen, ook al wordt de procedure voor $100 \%$ gewonnen. In Duitsland daarentegen krijgt de in een individuele of collectieve procedure in het gelijk gestelde partij in beginsel al haar proceskosten vergoed door de in het ongelijk gestelde partij. 
III PRAKTISCHE ERVARINGEN VAN CONSUMENTENORGANISATIES MET HET COLLECTIEF ACTIERECHT ALS BEDOELD IN \& 13 AGB-GESETZ 



\section{De rol van de Duitse consumentenorganisa- ties in de praktijk van het AGB-Gesetz}

\subsection{Inleiding}

Zoals in paragraaf 6.3.3 reeds aangegeven, kunnen de vorderingen als bedoeld in $\$ 13$ AGBG slechts worden geëffectueerd door organisaties met rechtsbevoegdheid, die als statutaire doelstelling hebben de belangen van consumenten door middel van voorlichting en advies te behartigen, op dit terrein ook daadwerkelijk activiteiten ontplooien of ontplooid hebben èn minstens 75 natuurlijke personen of minstens 2 organisaties met genoemde doelstelling als leden hebben. Bovendien is vereist dat consumentenorganisaties de behartiging van consumentenbelangen door middel van voorlichting en advies als statutaire doelstelling moeten hebben en op dit gebied ook daadwerkelijk activiteiten ontplooien of ontplooid hebben.

In dit hoofdstuk komt aan de orde de rol die de Duitse consumentenorganisaties, die aan bovenstaande voorwaarden voldoen, in de praktijk van het AGB-Gesetz hebben gespeeld en spelen. Daartoe zullen, met name de meest actieve, Duitse consumentenorganisaties nader worden beschouwd en zal vervolgens worden beschreven welk aandeel zij in de collectieve rechtshandhaving op het terrein van de algemene voorwaarden hebben en hadden. De resultaten van dit hoofdstuk zijn voor een deel gebaseerd op onderzoek van Axmann ${ }^{1}$ en het door Rijken en schrijver dezes, in opdracht van SWOKA, uitgevoerde onderzoek naar de ervaringen van de Duitse consumentenorganisaties met het AGBGesetz $z^{2}$, en voor een deel op jaarverslagen van en eigen onderzoek bij de betroffen consumentenorganisaties en het Bundeskartellamt.

1 Axmann, Die praktische Bedeutung und Effizienz der Verbandsklage nach $\$ 13$ ff. AGBGesetz, Göttingen 1986.

2 Mölenberg en Rijken, De ervaringen van de Duitse consumentenorganisaties met het AGBGesetz, SWOKA-Onderzoeksrapporten 1991, nr. 115, Den Haag 1991. 


\subsection{Consumentenorganisaties in Duitsland}

In Duitsland zijn de consumentenorganisaties die aan bovengenoemde voorwaar den voldoen grotendeels georganiseerd in de Arbeitsgemeinschaft der Verbrawcher e.V. (AGV) te Bonn", een overkoepelende organisatie waarbij een dertigtal consumentenorganisaties is aangesloten. De AGV is in 1953 opgericht met als doelstelling de politieke belangenbehartiging van consumentenorganisaties. De overkoepelende consumentenorganisaties op deelstaatniveau (Verbraucherzentralen) zijn alle opgericht door de AGV en zijn daar tevens lid van.

Op initiatief wan de AGV en de gezamenlijke Verbraucherzentralen ${ }^{4}$ werd in 1966 in Berlijn de Verbraucherschutzverein e.V. (VSV) ${ }^{5}$ opgericht met het doel hilerin de processuele activiteiten van de Verbraucherzentralen onder te brengen. De Verbraucherzentralen zijn allemaal lid van de VSV. De VSV is lid van de AGV.

Oorspronkelijk werd de VSV door de AGV en de Verbraucherzentralen belast met de gerechtelijke handhaving van consumentenbelangen op het gebied van het mededingingsrecht. In augustus 1977 - enkele maanden na de inwerkingtreding van het AGB-Gesetz - werd de VSV tevens belast met de gerechte lijke handhaving van consumentenbellangen op het terrein van de algemene voorwaarden. Hiertoe werd de VSV toentertijd met twee formatieplaatsen uitgebreid. Na de hereniging van de beide Duitslanden is daar nog een derde formatieplaats aan toegevoegd.

Zoals hierna zal blijken, is niet alleen de VSV te Berlijn collectief actief geweest op het terrein van de algemene voorwaarden. Ook de Verbraucherzentrale Baden-Württemberg te Stuttgart is vanaf het prille begin van het $A G B$ Gesetz in 1977 (in haar eigen deelstaat) collectief actief geweest op het terrein van de algemene voorwaarden en aan het eind van de jaren tachtig zijn ook de Verbraucherzentralen van respectievelijk Nordrhein-Westfalen te Düsseldorf en van Hamburg in hun deelstaten gebruik gaan maken van het collectief actierecht van $\$ 13$ AGBG. Omdat $\mathrm{zij}$ vanuit consumentenperspectief de belangrijkste

3 Heilsbachstraße 20 , Bonn-Duisdorf.

4 De Verbraucherzentrallen van respectievelijk de deelstaten Baden-Württemberg (Pawlinenstralle 47. Stuttgart), Bayern (Mozartstraße 9, München), Bremen (ObernstraBe 38-42, Bremen') Hamburg (Grobe Bleichen 23, Hamburg), Hessen (Berliner Straße 27, Frankfurt), Niedersachsen (Herrenstraße 14, Hannover), Nordrhein-Westfalen (Mintropstraße 27, Düsseldori), Rheinland-Pfalz (Große Langgasse 16, Mainz), Saariand (Hohenzollemstraßje 11, Sasrbrückeni) en Schleswig Holntein (Bergstraße 24, Kiel).

5 Lützowstralle 33-36, 10785 Berlin.

6 In het Geselz gegen den unlawtenen Wettbewerb (UWG) werd in 1965 een collectief actïienecht toegekend aan consumentenorganisaties. Aan ondernemersorganisaties werd al in 1896 een collectief klachtrecht toegekend, eerst in \$ \& van thet Gesetz zur Bekampfung des unlautenen Wetbewerbs (1896) en later in het UWG van 1909. Zie: Urbanczyk, pag. 6-14; Von Falleken stein, pag. 19. 
actoren zijn op het terrein van de collectieve actie met betrekking tot algemene voorwaarden worden hieronder de structuur, organisatie en doelstelling van deze vier consumentenorganisaties nader belicht.

\subsubsection{Verbraucherschutzverein e.V.}

De op het terrein van de algemene voorwaarden meest actieve ${ }^{7}$ consumentenorganisatie is de Verbraucherschutzverein e.V.(VSV) te Berlijn.

\section{Structuur en organisatie}

Zoals reeds vermeld werd de VSV in 1966 opgericht door de AGV en de Verbraucherzentrallen van de deelstaten. De VSV is evenals de Verbraucherzentralen en de AGV een federatie van consumentenorganisaties. Het lidmaatschap staat open voor rechtspersonen die op grond van hun statutaire doelstelling en activiteiten kunnen bijdragen tot de doelstelling van de VSV. Op 31 december 1992 waren de volgende organisaties lid van de Verbraucherschutzverein ${ }^{8}$ :

- Arbeitsgemeinschaft der Verbraucher e.V.;

- Arbeitsgemeinschaft Hauswirtschaft e.V. (Bonn);

- Deutscher Hausfrauenbund e.V. (Bonn);

- Institut für angewandte Verbraucherforschung e.V. (Köln);

- Stiftung Verbraucherinstitut (Berlin);

- Stiftung Warentest (Berlin);

- Verbraucherzentrale Baden-Württemberg e.V. (Stuttgart);

- Verbraucherzentrale Bayern e.V. (München);

- Verbraucherzentrale Berlin e.V. (Berlin);

- Verbraucherzentrale Brandenburg e.V (Potsdam);

- Verbraucherzentrale des Landes Bremen e.V. (Bremen);

- Verbraucherzentrale Hamburg e.V. (Hamburg);

- Verbraucherzentrale Hessen e.V. (Frankfurt);

- Verbraucherzentrale Mecklenburg-Vorpommern e.V. (Rostock);

- Verbraucherzentrale Niedersachsen e.V. (Hannover);

- Verbraucherzentrale Nordrhein-Westfalen e.V. (Düsseldorf);

- Verbraucherzentrale Rheinland-Pfalz e.V. (Mainz);

- Verbraucherzentrale des Saarlandes e.V. (Saarbrücken);

- Verbraucherzentrale Sachsen-Anhalt e.V. (Halle);

- Verbraucherzentrale Schleswig-Holstein e.V. (Kiel);

- Verbraucherzentrale Thüringen e.V. (Erfurt).

7 Zie hiema paragraaf 8.3.

8 Verbrauchersehutzverein (VSV), Tätigkeitsbericht 1992. 
De leden zijn statutair verplïcht hun jaarlijkse bijdrage te betalen en de doelstelling van de VSV te ondersteunen.

Belangrijkste organen binnen de organisatiestructuur van de VSV zijn de ledenvergadering en het bestuur. Het bestuur bestaat uit een voorzitter, een vice voorzitter en drie overige leden (Beisitzer). Op 31 december 1992 waren nasi. een directeur (jurist), 7 juristen, 2 boekhoudsters en 5 secretaresses in vaste: dienst bij de VSV. Voor de hereniging waren dit 6 juristen, 1 boekhoudster en 4 secretaresses."

Sinds 1974 wordt de Verbraucherschutzverein nagenoeg volledig gesubsidieerd door het Bundesministerium fur Wirtschaft (BMWi). In 1992 had de VSV 1.688.500, = DM aan inkomsten, bestaande uit:

- Subsidie BMWi $\quad 1.657 .396,=$ DM

- Contributie leden $\quad 1.500,=D M$

- Overige inkomsten $\quad 30.000,=D M$

Daartegenover staan in 1992 aan uitgaven $1.688 .500,=\mathrm{DM}$, bestaande uit:

- Personeelskosten $1.138 .500,=\mathrm{DM}$

- Bureaukosten $\quad 510.900,=D M$

- Overige kosten $\quad 39.100,=\mathrm{DM}$

Tot de bureaukosten behoren eveneens de proceskosten op het terrein van het UWG $(108.000,=$ DM) en het AGB-Gesetz $(72.000,=$ DM). De post Prozeßkosten $A G B$-Bereich bestaat voornamelijk uit advocaat- en proceskosten. De proceskosten op het gebied van het AGB-Gesetz worden betaald uit een fonds c.q. reservering waarvoor oorspronkelijk - in 1978 - een bedrag van $100.000_{3}=$ DM ter beschikking stond. De omvang van dit fonds is in de loop der jaren echter geleidelijk teruggebracht tot $72.000,=D M$ omdat het fonds nog nooit volledig werd benut, hetgeen zijn oorzaak vindt in het feit dat circa $86 \%$ wan alle gerechtelijke procedures wordt gewonnen. ${ }^{10}$ Voor het geval de middelen uit het fonds ontoereikend zouden zijn, bestaat de mogelijkheid om achteraf een verhoging van dit fonds bij het Bundesministerium fïr Wirtschaft aan te vragen. Van deze mogelijkheid is echter nog nooit gebruik gemaakt.

9 Op 16 augustus 1990 wenden door het BMWi extra gelden ter besehikking gestell voor formatieplants met bijbehonende secretariële ondersteuning. Zie VSV-Tätigkeitsbericht 1990 , Sonderbeilage neue Bundesländer, pag. 1.

10 Zie hiema paragnaf 8.3 . 
Vanaf augustus 1977 krijgt de VSV van het Bundesministerium für Wirtschaft twee en sinds de eenwording van de beide Duitslanden drie formatieplaatsen gesubsidieerd. Sinds augustus 1977 ontplooit de VSV dan ook rechtshandhavingsactiviteiten op het gebied van de algemene voorwaarden.

Doelstelling van de VSV is om, zonder winstoogmerk, de belangen van consumenten door middel van voorlichting en advies te behartigen en te bevorderen. Daarbij stelt de VSV zich in het bijzonder ten doel ongeoorloofde mededinging te bestrijden die nadelen voor consumenten met zich brengt; alsmede op te treden tegen onredelijk bezwarende algemene voorwaarden die gehanteerd worden in overeenkomsten met consumenten. Zonodig dient dit te geschieden door het entameren van gerechtelijke procedures. In het kader van haar statutaire doelstelling geeft de VSV tevens consumenten advies over hun rechten en behandelt zij klachten die gebaseerd zijn op ongeoorloofde mededinging of onredelijk bezwarende algemene voorwaarden.

De werkzaamheden van de met de rechtshandhaving op het terrein van de algemene voorwaarden belaste juristen omvatten het controleren van contractsformulieren op de aanwezigheid van onredelijk bezwarende bedingen en het verzorgen van de eventuele Abmahnung indien onredelijk bezwarende bedingen worden aangetroffen. Indien de Abmahnung niet leidt tot een contractuele verplichting van de gebruiker om het desbetreffende beding - op straffe van een contractuele boete - niet meer te gebruiken of te propageren, wordt de zaak overgedragen aan een, bij het bevoegde Landgericht toegelaten, advocaat. De juristen in dienst van de VSV mogen - net als de juristen in dienst van de Nederlandse consumentenorganisaties - niet zelf als advocaat optreden omdat zij niet onafhankelijk zijn van de VSV.

De te controleren contractsformulieren met algemene voorwaarden zijn hoofdzakelijk bijeengebracht door de aangesloten Verbraucherzentralen van de deelstaten, die deze contractsformulieren ter controle aan de VSV voorleggen. De uitvoering van de eventueel daarop volgende (buiten)gerechtelijke procedures wordt daarbij geheel overgelaten aan de VSV.

Naast de controle van individuele contractsformulieren op onredelijk bezwarende algemene voorwaarden heeft de VSV haar activiteiten voor een substantieel deel gericht op een voortdurende inhoudscontrole van setjes van algemene voorwaarden waarvan het gebruik bevorderd wordt door branche-, beroeps- of ondernemersorganisaties (Konditionenempfehlungen).

Konditionenempfehlungen hebben op het gebied van algemene voorwaarden een bijzondere betekenis en breedtewerking omdat ze ontworpen worden met het oog op uniform gebruik door branche-, beroeps- of ondernemersorganisaties en 
doorgaans als voorbeeld dienen voor het midden- en kleinbedrijf. ${ }^{11}$ Ondat 2 if zijn opgesteld teneinde door een gehele branche-, beroeps- of bedrijfsorganisadie gebruikt te worden, moeten zij worden aangemeld bij het Bundeskartellamit op grond van $\$ 38$ Abs. 2 Nr. 3 GWB $^{12}$. Aanmelding bij het Bundeskartellart heeft tot gevolg dat de aangemelde Konditionenempfehlungen niet meer door hid BKA als Ordnungswidrigkeit vervolgd kunnen worden ( $\$ 38$ Abs. 1 Nr. II GWB). Het BKA toetst de aangemelde algemene voorwaarden slechts marginal met het oog op grove inbreuken op het BGB en het AGB-Gesetz. ${ }^{13}$

De bij het BKA aangemelde Konditionenempfehlungen worden in de reget door deze instantie voorgelegd aan de AGV zodat deze haar standpunten ten aanzien van deze Konditionenempfehlungen kenbaar kan maken. De AGV laid deze Konditionenempfehlungen vervolgens inhoudelijk toetsen door de VSV. Vervolgens maken zij gezamenlijk hun standpunten ten aanzien van de desbe treffende algemene voorwaarden kenbaar aan het Bundeskartellamt, waarbij zij uiteraard voornamelijk oog hebben voor het consumentenbelang.

De toetsing en gezamenlijke standpuntbepaling heeft ten doel de aanbeveling van onredelijk bezwarende algemene voorwaarden reeds in een vroeg stadium te verhinderen. Voor zover dan toch nog algemene voorwaarden aangemeld worden, die naar de opvatting van de VSV en AGV onvoldoende rekening houden met consumentenbelangen, worden door de VSV gerechtelijke stappen ondernomen. Het feit dat de Konditionenempfehlungen zijn aangemeld bij en getoetst worden door het BKA staat aan een inhoudstoetsing als bedoeld in $\$ 13$ AGBG niet in de weg. De verplichte publikatie van de aangemelde Konditionenempfehlungen in de Bundesanzeiger wordt derhalve meestal voorzien van de uitdrukkelijke clausule dat tegen bedingen voorkomend in deze Konditionenemp. fehlung, die in strijd zijn met het AGB-Gesetz, een vordering als bedoeld in $\$ 13$ AGBG mogelijk blijft. Het BKA wil hiermee vermijden dat de indruk ontstaat dat het de desbetreffende algemene voorwaarden heeft goedgekeurd.

Onderzoek van Axmann over de periode 1 april 1977 tot 1 april 1983 laat zien dat in die periode door de VSV 40 Konditionenempfehlungen zijn gecontro* leerd. In 15 gevallen leidde deze controle tot een Abmahnung en in 3 gevallen kwam het tot een gerechtelijke procedure. ${ }^{14}$ In de periode 1 april 1977 tot 31 december 1992 zijn door de VSV in totaal 81 Konditionenempfehlungen inhoudelijk getoetst. De inhoudelijke toetsing van deze Konditionenempfehlungen gaat volgens de VSV gepaard met een aanzienlijke tijdsinvestering en vereist specifieke deskundigheid omdat deze doorgaans zijn opgesteld door

\footnotetext{
Bunte, AcP 1982 , pag. 60.

Gesetz gegen Wettbewerbsbeschrankungen.

Zie hiervoor paragranaf 6.3.4.

Axmann, pag. 87.
} 
gespecialiseerde juristen die goed op de hoogte zijn van de heersende rechtsopvattingen betreffende de toelaatbaarheid van algemene voorwaarden. Bovendien zijn de Konditionenempfehlungen meestal ondoorzichtig en complex van aard.

\subsubsection{Verbraucherzentrale Baden-Wurttemberg e.V.}

Vanaf de inwerkingtreding van het AGB-Gesetz in 1977 is de Verbraucherzentrale Baden-Württemberg de op het terrein van $\$ 13$ AGBG meest actieve consumentenorganisatie op deelstaatniveau..$^{\text {is }}$

\section{Structuur en organisatie}

De Verbraucherzentrale Baden-Württemberg is gevestigd te Stuttgart. Net als alle andere Verbraucherzentralen is zij een federatie van consumentenorganisaties op deelstaatniveau en opgericht door de AGV. Het lidmaatschap staat open voor organisaties en verenigingen, op ideële basis, uit Baden-Württemberg die als (een van hun) doel(en) de handhaving van consumentenbelangen hebben.

Op 31 december 1992 waren 29 organisaties ${ }^{16}$ lid van de Verbraucherzentrale Baden-Württemberg en 965 natuurlijke personen (ondersteunende leden). Natuurlijke personen die de doelstelling van de Verbraucherzentrale BadenWürttemberg onderschrijven kunnen, tegen betalling van een door de ledenvergadering vastgestelde contributie, lid worden, mits zij met het lidmaatschap geen commerciële doelen nastreven.

Belangrijkste organen van de Verbraucherzentrale Baden-Württemberg zijn de ledenvergadering, het twaalfkoppig bestuur en een adviesraad (Beirat)

15 Zie hiema paragranaf 8.3 .

16 Aktion Bildungsinformation e.V.; Arbeiterwohlfahrt, Bezirkswertand Baden e. V.; Bund der Vertriebenen, LV Baden-Wüttemberg; Deutsche Angestellten-Gewerkschaft, LV BadenWürttemberg; Deutscher Evangelischer Frauenbund, LV Badien-Württemberg; Deutscher Familienverband e.V., LV Baden-Württemberg; Deutscher Frauenring, LV Baden; Deutscher Frauenring, LV Württemberg; Deutseher Gewerkschaftsbund, Landesbezirk Baden-Württemberg; Deutscher Hausfrauenbund, LV Baden e.V.; Deutseher Hausfrauenbund, LV Württemberg; Deutscher Mieterbund, LV Baden-Württemberg; Dewtscher Siedlerbund, LV BadenWürttemberg; Deutseher Vertand Berufstätiger Frauen e.V., Club Stuttgart; Die Grünen, LV Baden-Württemberg; Evangelisches Bauernwerk in Württemberg; Frauenarbeil der evangelischen Landeskirche in Würtemberg; Gewerkschaft der Polizei, Landesbezirk Baxden-Württemberg; Hausfrauenvereinigung des kath. Frauenbundes Diöz. Rottenburg-Stuttgart; Kath. Deutscher Frauenhund, Abt. Haugfrauenvereinigung, Diözesanverb. Freiburg; Landesgirokasse; Landesverband der CDU Baden-Württemberg; Landesverband der FDP Baden-Wïrttemberg; Landesverband der SPD Baden-Württemberg; Landfrawenverband Württemberg-Baden $e$. Werband der Kriegs- und Wehrdienstopfer, Behinderten und Sozialnentmer Deutschlands (VdK), LV Baden-Württemberg; Volkshochschulverband Badem-Württernberg e.V. 
bestaande uit 54 leden. ${ }^{17}$ De Verbraucherzentrale Baden-Württemberg heeft in 27 steden van de deelstaat adviesbureaus (Beratungsstellen) die, net als de Zentrale aan consumenten advies en bijstand verlenen.

Op 31 december 1992 waren bij de Verbraucherzentrale Baden-Württemberg werkzaam: 22 full-time arbeidskrachten (2 directeuren), 49 part-time arbeidskrachten en 53 vrijwilligers. Van deze medewerkers zijn 17 full-time arbeidskrachten, 14 part-time arbeidskrachten en 15 vrijwilligers werkzaam op de Zen: trale in Stuttgart.

Bij de Verbraucherzentrale Baden-Württemberg is niet, zoals dat bij de VSV het geval is, een (of meer) medewerker(s) uitsluitend belast met de inhoudelijke controle van algemene voorwaarden. De Verbraucherzentrale heeft daartoe een overeenkomst gesloten met een advocaat (W. Stillner) die, in overleg met de Verbraucherzentrale, de inhoudstoetsing en het aanspannen van eventuele (buiten)gerechtelijke procedures geheel voor zijn rekening neemt.

De Verbraucherzentrale Baden-Württemberg wordt voor het grootste gedeelte gesubsidieerd door de overheid. In 1992 had de Verbraucherzentrale DM $5.041 .343,10$ aan inkomsten, bestaande uit:

- Subsidie Bundeswirtschaftsminist.

$$
633.975,=\mathrm{DM}
$$

- Subsidie Bundesernährungsminist.

$472.048,=\mathrm{DM}$

- Subsidie Landeswirtschaftsminist. $2.600 .000,=\mathrm{DM}$

- Bijdragen andere deelstaatorganen $227.965,41 \mathrm{DM}$

- Steden 363.226,77 DM

- Eigen baten (o.a. contributie leden)

- Overige inkomsten $544.100,13 \mathrm{DM}$ $200.045,79 \mathrm{DM}$

Daartegenover staan in 1992 aan uitgaven 4.941.608,79 DM, bestaande uit:
- Personeelskosten
$3.154 .935,23 \mathrm{DM}$
- Bureaukosten
$1.786 .673,56 \mathrm{DM}$

Tot de bureaukosten behoort ook de post voor het honorarium van de advocaat. Tezamen met de kosten voor andere deskundigen bedraagt deze post in 1992 $115.484,85$ DM. Voor de proceskosten op het gebied van het AGB-Gesetz en de proceskosten op andere gebieden reserveert de deelstaat Baden-Württemberg elk jaar $10.000,=$ DM. De Verbraucherzentrale zelf had daarvoor op 31 
december 1992 een bedrag van 13.754,83 DM gereserveerd (Verbraucherschutzfonds)

\section{Doelstelling en activiteiten}

De Verbraucherzentrale Baden-Württemberg beschouwt zichzelf als een nietconfessionele, politiek onafhankelijke organisatie die op non-profitbasis de algemene belangen van consumenten wil behartigen. Voor de verwezenlijking van dit doel kunnen onder andere adviesbureaus en consumentenverenigingen worden opgericht en zonodig worden ondersteund. Voorlichting aan consumenten over en het steunen en bevorderen van gericht onderzoek naar consumentenpolitieke vraagstukken ziet de Verbraucherzentrale eveneens als haar taak.

In tegenstelling tot de VSV, die zich uitsluitend de rechtshandhaving op het gebied van het mededingingsrecht en de algemene voorwaarden ten doel stelt, is de Verbraucherzentrale Baden-Württemberg, net als alle andere Verbraucherzentralen werkzaam op tal van gebieden waar consumentenbelangen in het geding zijn. De belangrijkste werkzaamheden liggen op het gebied van de consumentenvoorlichting en advisering, zoals bijvoorbeeld voedingsvoorlichting, prijsvergelijking, produktinformatie, klachtenbegeleiding en advisering, energievoorlichting, etcetera. Daartoe worden onder meer spreekuren, cursussen, lezingen en tentoonstellingen gehouden.

De start van de eigen rechtshandhavingsactiviteiten op het gebied van het mededingingsrecht door de Verbraucherzentrale Baden-Württemberg ligt bij een proces in 1970, waarin de Verbraucherzentrale als gedaagde verloor. Omdat de Verbraucherzentrale Baden-Württemberg de gedaagde partij was en niet de eisende partij, nam de VSV het proces niet over. De Verbraucherzentrale besloot daarop op eigen naam te procederen. Dit (weliswaar verloren) proces en de initiatieven van de Stuttgarter advocaat Stillner hebben er vervolgens toe geleid dat de Verbraucherzentrale haar vorderingsrecht op het gebied van het mededingingsrecht zelf ging uitoefenen. $\mathrm{Na}$ het inwerkingtreden van het AGBGesetz begon de Verbraucherzentrale Baden-Württenberg tegen het einde van 1977, wederom op initiatief van Stillner, ook algemene voorwaarden inhoudelijk te toetsen en hanteerde zij van meet af aan het actierecht op het gebied van de algemene voorwaarden.

\subsubsection{Andere actieve consumentenorganisaties}

Van de overige consumentenorganisaties op deelstaatniveau zijn enkel de Verbraucherzentrale Nordrhein-Westfalen en de Verbraucherzentrale Hamburg zelf actief op het terrein van de collectieve actie op grond van $\$ 13$ AGBG. 
De Verbraucherzentrale Nordrhein-Westfalen e.V. is gevestigd te Düsseldorf en qua structuur, organisatie, doelstelling en activiteiten te vergelijken met de Verbraucherzentrale Baden-Württemberg. In 1988 heeft deze Verbraucherzentra le de beschikking gekregen over een derde full-time jurist en sindsdien heeft $x$ ij gebruik gemaakt van haar actiebevoegdheid op het terrein van de algemene voorwaarden. Vanaf 1989 tot 1 januari 1993 heeft de Verbraucherzentrale. Nordrhein-Westfalen ruïm 150 Abmahnungen naar gebruikers laten uitgaan en heeft zij naar aanleiding daarvan ongeveer 50 verbodsacties gestart. ${ }^{18}$ Voor het voeren van de gerechtelijke procedures worden advocaten in de arm genomen. Procedures betreffende algemene voorwaarden die qua betekenis over het deelstaatniveau heen gaan, zoals bijvoorbeeld tegen aanbevelers van algemene voorwaarden, worden doorgestuurd naar de VSV. Dit gebeurt volgens schattingen van de Verbraucherzentrale Nordrhein-Westfalen ongeveer 100 keer per jaar.

De Verbraucherzentrale te Düsseldorf kan slechts bescheiden middelen vrijmaken voor de collectieve rechtshandhaving op het terrein van de algemene voorwaarden. Jaarlijks staat de Verbraucherzentrale Nordrhein-Westfalen ongeveer $40.000,=\mathrm{DM}$ voor proceskosten ter beschikking. Indien dit budget is verbruikt, hetgeen in 1990 bij voorbeeld reeds in augustus het geval was, eindigen daarmee noodzakelijkerwijs voor dat jaar ook de rechtshandhavingsactiviteiten van de verbraucherzentrale Nordrhein-Westfalen op het terrein van de algemene voorwaarden. De Verbraucherzentrale stelt zich namelijk op het standpunt dat het geen zin heeft een Abmahnung te versturen als men bij een weigering van de desbetreffende gebruiker om een Unterlassungserklärung af te geven, wegens gebrek aan geld geen gerechtelijke procedure kan voeren.

De Verbraucherzentrale Hamburg is gevestigd te Hamburg en qua structuur; organisatie, doelstelling en activiteiten eveneens te vergelijken met de Verbraucherzentrale Baden-Württemberg. De actiebevoegdheid op het terrein van de algemene voorwaarden ligt bij de Verbraucherzentrale Hamburg voornamelijk in handen van de cheffin van de afdeling Rechtsberatung/Verbraucherschutz. Tot haar takenpakket behoort het beheer van de Prozeßabteilung, de afdeling die verantwoordelijk is voor de rechtshandhavingsactiviteiten op het gebied van de algemene voorwaarden en op het gebied van het mededingingsrecht. $\mathrm{Zij}$ werkt nauw samen met een aantal ervaren advocaten, die voor extra "manpower" zorgen. Vanaf 1988 is de Verbraucherzentrale op eigen naam collectieve acties als bedoeld in \$ 13 AGBG gaan voeren. Van 1 januari 1988 tot 1 januari 1990 heeft de Verbraucherzentrale Hamburg een kleine 40 Abmahnungen naar gebruikers laten uitgaan waarvan ongeveer én op de vijf heeft geleid tot een 
verbodsprocedure. Procedures betreffende algemene voorwaarden van gebruikers buiten de deelstaat Hamburg maar ook die betreffende algemene voorwaarden die qua betekenis over het deelstaatniveau heengaan, worden overgelaten aan de VSV te Berlijn. Volgens schatting van de Verbraucherzentrale Hamburg gaat het daarbij om ongeveer 30 setjes algemene voorwaarden per jaar.

In de jaren 1988 en 1989 is door de Verbraucherzentrale Hamburg in totaal 25.506,88 DM uitgegeven aan Rechtsberatung en Verbandsklagen. Daarvan $20.349,52 \mathrm{DM}$ in 1988 en $5.157,30 \mathrm{DM}$ in 1989 . In 1990 en 1991 werden respectievelijk 5.000 DM en $8.000 \mathrm{DM}$ aan proceskosten uitgegeven. In 1989 werd de Verbraucherzentrale met een nieuw probleem geconfronteerd. In een procedure als bedoeld in $\$ 13$ AGBG tegen een bank is, door toedoen van de bank, de Streitwert vastgesteld op $250.000,=$ DM. Indien de Verbraucherzentrale deze procedure zou verliezen, zouden de proceskosten voor de Verbraucherzentrale Hamburg zo hoog zijn dat daarmee de collectieve actiebevoegdheid van de Verbraucherzentrale - voor de daaropvolgende jaren - in gevaar zou komen. De middelen die de Verbraucherzentrale ten dienste staan zijn eigenlijk ontoereikend voor het voeren van procedures met een dergelijk procesrisico. Het liep echter goed af voor de Verbraucherzentrale Hamburg; de procedure werd gewonnen.

\subsection{De uitoefening van het klachtrecht als bedoeld in $\$ \$ 13$ e.v. AGBG door consumentenorganisaties}

Naar de uitoefening van het klachtrecht als bedoeld in $\$ \S 13$ e.v. AGBG in de eerste zes jaren van het AGB-Gesetz is onderzoek gedaan door Axmann. ${ }^{19}$ Dit onderzoek geeft een duidelijk beeld van de activiteiten op het terrein van het collectief actierecht met betrekking tot algemene voorwaarden over de periode 1 april 1977 tot en met 1 april 1983. In deze paragraaf wordt derhalve begonnen met een weergave van de uitkomsten van dit onderzoek. Het onderzoek van Axmann vond plaats aan de hand van het AGB-register bij het Bundeskartellamt te Berlijn. De laatste jaren wordt in dit register echter niet meer aangegeven wie als eisende partij in de procedure van $\$ 13$ AGBG optrad. Aan de hand van het register bij het BKA is wél een totaaloverzicht te geven van alle tot en met 1992 gevoerde collectieve procedures op het terrein van de algemene voorwaarden en is een nadere verdeling te geven naar processuele stap. De uitkomsten daarvan worden weergegeven in paragraaf 8.3.2.

Het aandeel van de verschillende consumentenorganisaties in de collectieve rechtshandhaving op het terrein van de algemene voorwaarden na 1 april 1983 is

19 J. Axmann "Die praktische Bedeutung und Effizienz der Verbandsklage nach $8 \$ 13$ ff. AGBGestzet, Göttingen 1986. 
aan de hand van het BKA-register niet meer te achterhalen. Bovendien geeft het BKA-register geen beeld over de buitengerechtelijke rechtshandhaving op het terrein van de algemene voorwaarden. Het aandeel van de vier meest actieve consumentenorganisaties over de periode 1977-1992 in de gerechtelijke en buitengerechtelijke rechtshandhaving op het terrein van de algemene voorwarden wordt in paragraaf 8.3.3 geschetst. Dit doe ik aan de hand van de jaarverslagen van die consumentenorganisaties, gevoerde interviews met de medewerkers daarvan en archiefonderzoek bij de VSV te Berlijn en de Verbraucherzentrale Baden-Württemberg.

\subsubsection{De beginjaren}

Zoals reeds vermeld is de uitoefening van het klachtrecht als bedoeld in $\$ 13$ AGBG in de beginjaren van het AGB-Gesetz onderzocht door Axmann aan de hand van het register van vonnissen en andere gerechtelijke afdoeningen op grond van $\S 13$ AGBG, bij het Bundeskartellamt (BKA). Aan dit onderzoek zij de volgende gegevens ontleend. ${ }^{20}$

In de procedure van $\$ 13$ AGBG worden bij het BKA de volgende "processuele stappen" (Verfahrensschritte) vastgelegd: de verbods- of gebodsvordering van de eisende organisatie, het verzoek voor een voorlopige voorziening, de toegekende voorlopige voorziening, het vonnis en de andere gerechtelijke afdoeningen.

In de periode van 1 april 1977 - de datum van inwerkingtreding van het AGBGesetz - tot 1 april 1983, werden bij het BKA 981 processuele stappen tegen onredelijk bezwarende algemene voorwaarden geregistreerd (afbeelding 1):

- 385 verbods- en gebodsvorderingen (39\%);

- 79 verzoeken voor een voorlopige voorziening $(8 \%)$;

- 66 voorlopige voorzieningen $(7 \%)$;

- 335 definitieve vonnissen $(34 \%)$;

- 113 andere afdoeningen (12\%);

- 3 doorgehaalde registraties (0\%).

20 Axmann, pag. 47 e.v. Zie voor cijfers ontleend aan het register van het BKA eveneens: Bunte, AcP 1981, pag. 55-56; Ulmer, BB 1982, pag. 588; Bohle en Micklitz, pag. 8-9. 
BKA-register, 1 april 1977 - 1 april 1983

geregistreerde processuele stappen naar soort

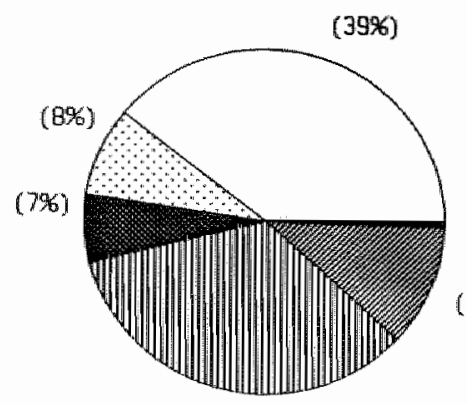

Legendia ver-en gebodsword. werz. woorl. voorz. woorl, woorz.

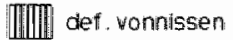

(0\%)

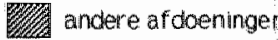
doorgen. registr. (1296)

(34\%)

Het zal duidelijk zijn dat het bovenstaande overzicht niet 981 verschillende procedures betreft. Bovenstaand overzicht is een typische uitwerking van de wijze van registratie bij het Bundeskartellamt. Het Bundeskartellamt registreert namelijk elke processuele stap afzonderlijk, hetgeen ertoe leidt dat én handhavingsprocedure een aantal keren wordt geregistreerd; van bijvoorbeeld twee registraties bij verbodsvordering en vonnis in eerste aanleg tot vijf registraties indien de procedure in een aantal instanties wordt beslist. ${ }^{21}$

De $385(100 \%)$ verbods- en gebodsacties betreffen 44 vorderingen van 25 verschillende branche-, beroeps- of ondernemersorganisaties $(11,4 \%)$ en 341 vorderingen geinitieerd door 9 verschillende consumentenorganisaties $(45 \%+$ $26 \%+18 \%=88,6 \%$ ). Zie afbeelding 2 .

21 Creutzig, pag, 21. 
BKA-register, 1 april 1977 - 1 april 1983

verbods-en gebodsacties naar (soort) organisatie

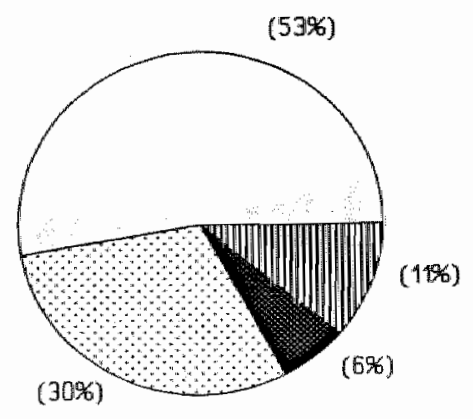

Legenda

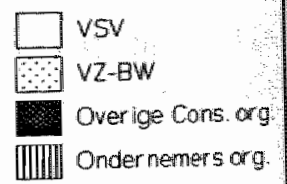

Van de $341(100 \%)$ verbods- en gebodsvorderingen ingesteld door consumenttenorganisaties werden er $203(59,5 \%)$ geïnitieerd door de VSV en $115(33,7 \%)$ door de Verbraucherzentrale Baden-Württemberg. De overige 7 consumentenorganisaties initieerden 23 vorderingen $(6,7 \%)$ waarbij de verdeling in aantallen als volgt is (afbeelding 3):

- Verbraucherzentrale Rheinland-Pfalz (Mainz) 1;

- Verbraucherzentrale Hamburg 2;

- Verbraucherzentrale Nordrhein-Westfalen (Düsseldorf) 1;

- Verein Konsumenten- und Verbraucherschutz (München) 16;

- Verbrauchergemeinschaft, Interessenverband und Selbsthilfeorganisation der Verbraucher (Bonn) 1;

- Verband zur Bekämpfung mißbräuchlicher Geschäftsbedingungen und unlauteren Wettbewerbs (Wuppertal) 2;

- Aktion Bildungsinformation (Stuttgart) 0 . 


\section{Afbeelding 3}

BKA-register, 1 april 1977 - 1 april $19 \mathrm{~B} 3$ verbods-en gebodsact les naar consumentenorganisatie

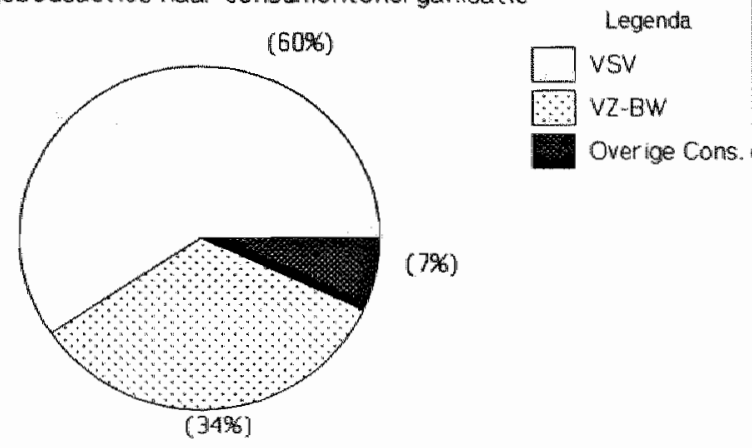

\section{Afbeelding 4}

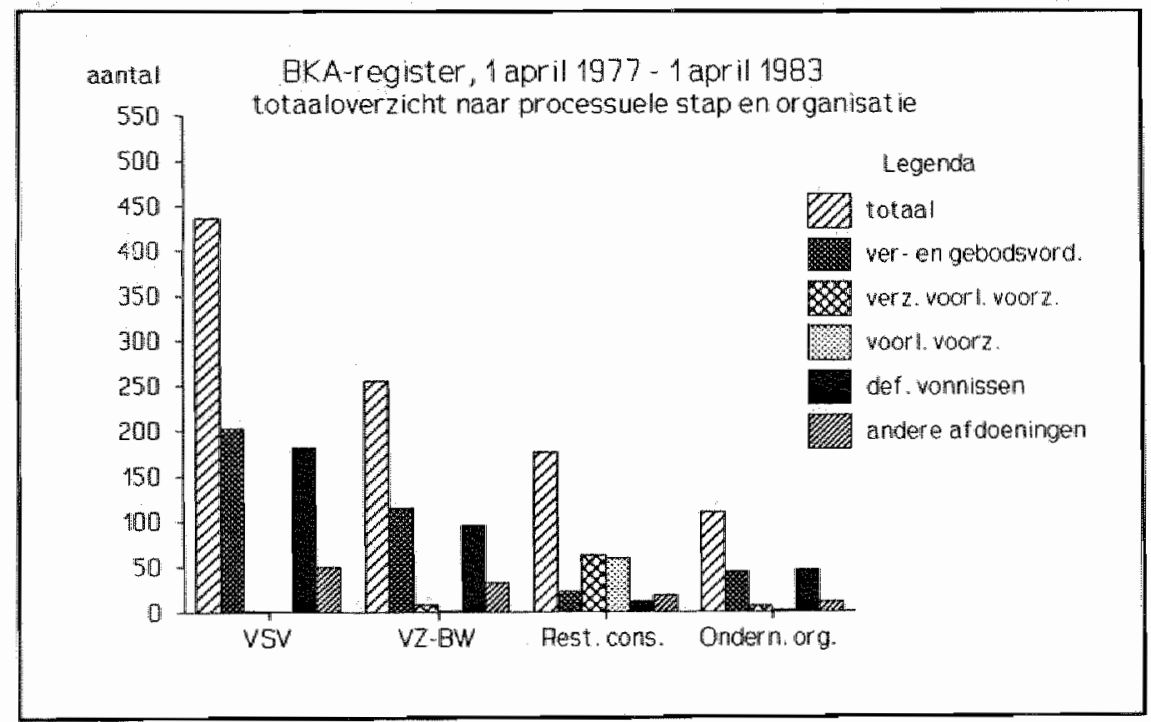


Aan de hand van de cijfers van Axmann kan het volgende totaal overzicht worden gemaakt van de verschillende processuele stappen onderverdeeld naar (soort) organisatie (afbeelding 4):

Van de overige consumentenorganisaties was de Verein Konsumenten- und Verbraucherschutz procentueel gezien (tussen de haakjes staan de aantallen vermeld) verantwoordelijk voor:

- 4,2\% (16) van alle verbods- en gebodsvorderingen;

- $73,4 \%$ (60) van alle verzoeken voor een voorlopige voorziening;

- $71,6 \%$ (58) van alle voorlopige voorzieningen;

- $1,8 \%$ (6) van de gewezen vonnissen;

- $15,9 \%(18)$ van alle andere afdoeningen.

Opvallend is dat van de eerste honderd registraties van $\S 13$ AGBG-procedures bij het BKA er 84 voor rekening komen van de Verein Konsumenten und Verbraucherschutz (VKV) uit München. De vereniging bestaat echter sinds 1980 niet meer. De VKV werd kort voor de inwerkingtreding van het AGB-Gesetz opgericht door een advocaat uit München en vertoonde van meet af aan een hoge "Abmahn"-activiteit. Tot midden juli 1977 werden circa 40 Abmahnungen gestuurd aan voornamelijk uitgeverijen, waarbij de Abmahnung steeds dezelfde 1 of 2 bedingen betrof. De Abmahnungen werden verzorgd door de procesgevolmachtigde en tevens oprichter van de vereniging. De bijbehorende Unterlassungserklärungen verplichtten de aangeschreven gebruikers de kosten van de Abmahnung te vergoeden, waarbij door de vereniging regelmatig de vastgestelde Streitwerte voor de desbetreffende clausules te hoog werden vastgesteld.

Nadat aanvankelijk de meeste verzoeken van deze vereniging voor een voorlopige voorziening door het Münchener Landgericht werden gehonoreerd, zijn zij in de daaropvolgende tijd weer allemaal opgeheven. Het Landgericht München kwam tot de conclusie dat de gerechtelijke rechtshandhaving als bedoeld in $\$ 13$ AGBG hoofddoel en taak van de VKV was en dat de voorlicho tingsactiviteiten naar consumenten toe (ến van de vereisten voor procesbevoegdheid als bedoeld in $\$ 13$ AGBG) slechts op papier werden uitgeoefend. Reden genoeg voor het Münchener Landgericht - en naderhand ook het Oberlandesgericht München - om de VKV de actiebevoegdheid als bedoeld in $\$ 13$ AGBG te ontzeggen, waarmee ook de door de VKV uitgebrachte Abmahnungen hun werking verloren. ${ }^{22}$ De VKV kan daardoor niet als serieuze consumentenorganisatie in de zin van $\S 13$ AGBG worden bestempeld omdat haar doelen uiteindelijk voornamelijk gelegen waren in het maken van winst en niet in 
daadwerkelijke handhaving van consumentenbelangen door middel van voorlichting en advies.

Omdat de verrichtingen van de VKV hun werking hebben verloren zijn in de navolgende overzichten de registraties ten aanzien van de VKV niet meegeteld.

Afbeelding 5 (afbeelding 4 minus registraties VKV)

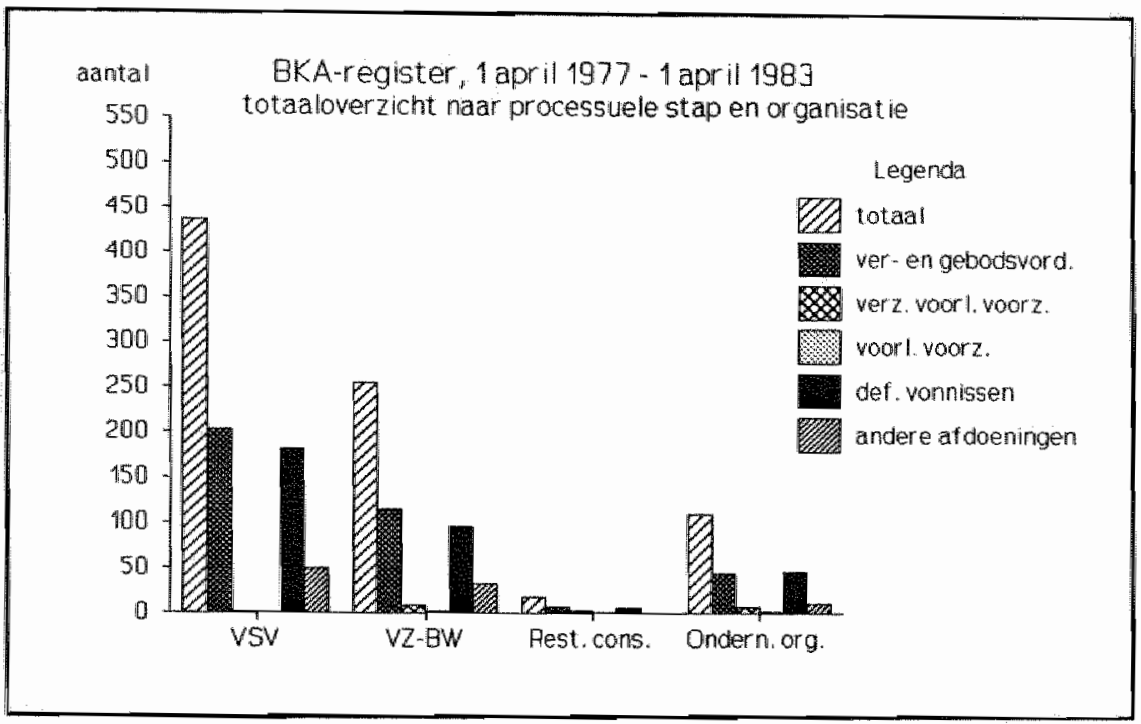

In de hierna volgende overzichten zijn deze totaalcijfers vertaald per (soort) actieve organisatie (afbeelding 6 tot en met 8 ).

Van de 33 actieve organisaties waren de acht genoemde consumentenorganisaties verantwoordelijk voor:

- $88,1 \%$ (325) van alle verbods- en gebodsvorderingen;

- $66,7 \%$ (14) van alle verzoeken voor een voorlopige voorziening;

- $66,7 \%$ (4) van alle voorlopige voorzieningen;

- $86 \%$ (283) van de gewezen vonnissen;

- $88,4 \%(84)$ van alle andere afdoeningen. 
Afbeelding 6

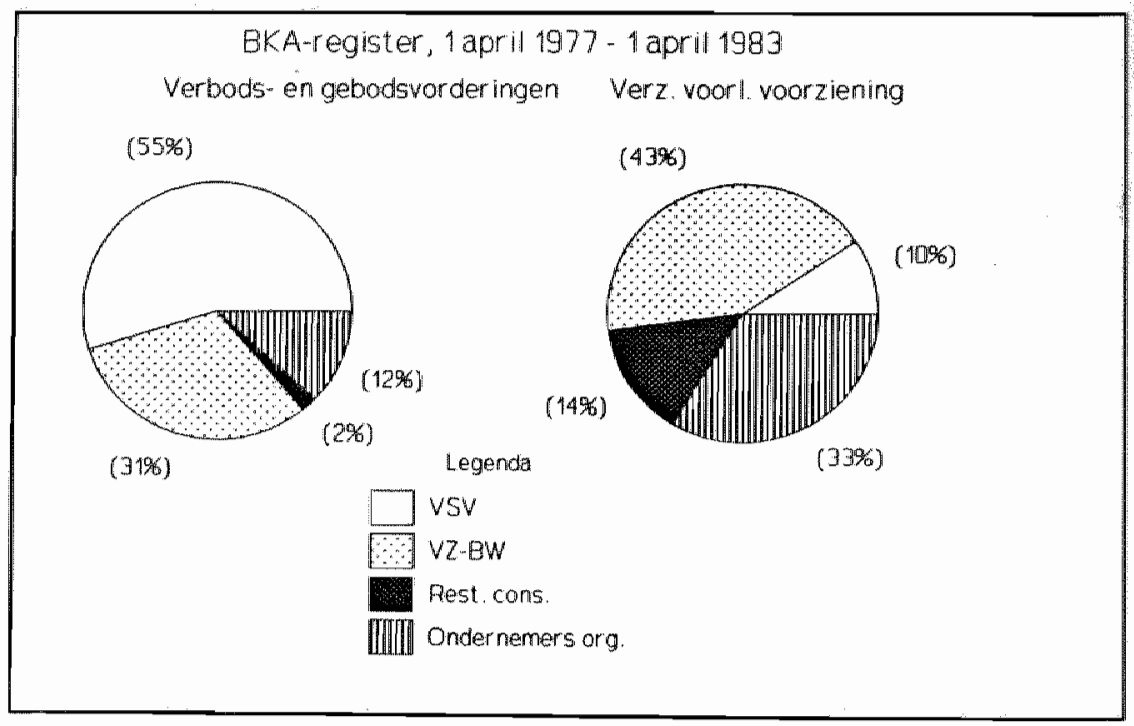

\section{Afbeelding 7}

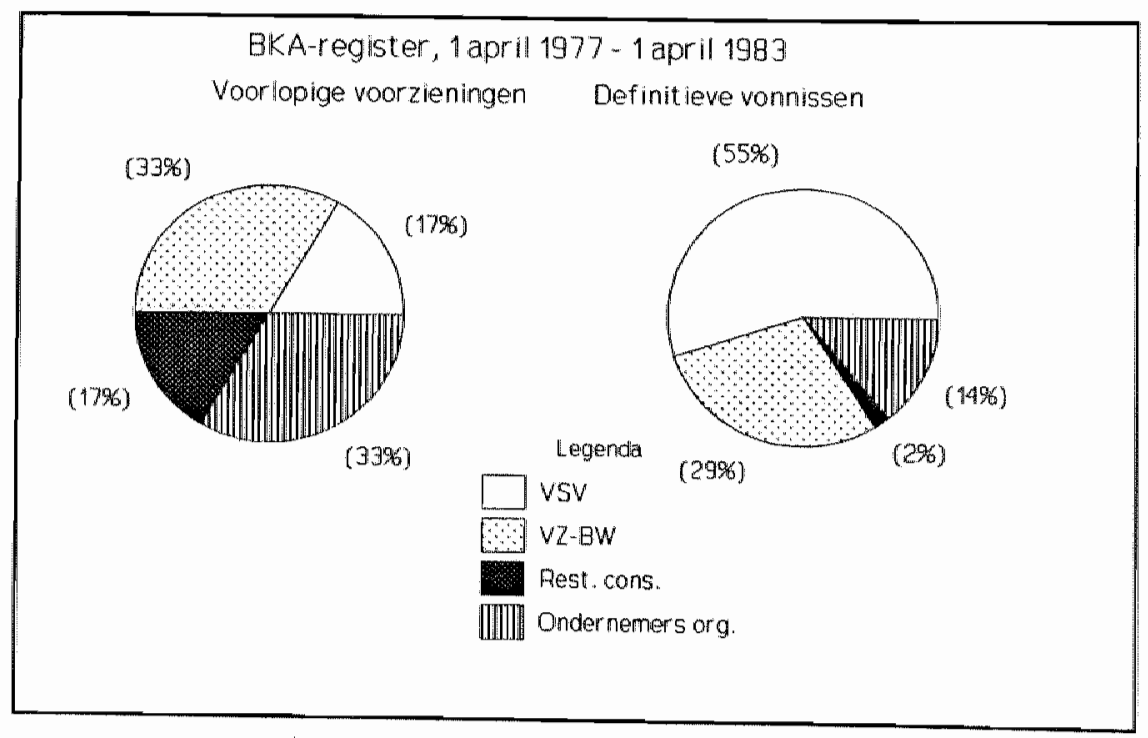


BKA-register, 1 april 1977 - 1 april 1983 Andere afdoening naar (soort) organisatie

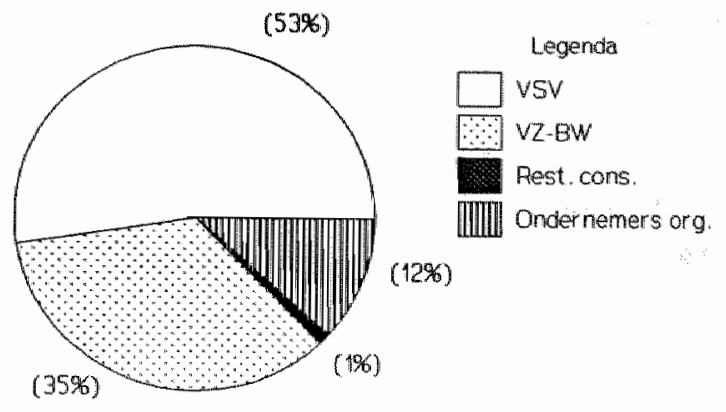

Voor rekening van de VSV kwamen:

- 55\% (203) van alle verbods- en gebodsvorderingen;

- $9,5 \%$ (2) van alle verzoeken voor een voorlopige voorziening;

- $16,7 \%$ (1) van alle voorlopige voorzieningen;

- $55 \%$ (181) van de gewezen vonnissen;

- $52,6 \%$ (50) van alle andere afdoeningen.

De Verbraucherzentrale Baden-Württemberg was verantwoordelijk voor:

- $31,2 \%$ (115) van alle verbods- en gebodsvorderingen;

- $42,9 \%$ (9) van alle verzoeken voor een voorlopige voorziening;

- $33,3 \%$ (2) van alle voorlopige voorzieningen;

- $29,2 \%$ (96) van de gewezen vonnissen;

- $34,7 \%$ (33) van alle andere afdoeningen.

De overige 6 consumentenorganisaties waren verantwoordelijk voor:

- $1,9 \%$ (7) van alle verbods- en gebodsworderingen;

- $\quad 14,3 \%$ (3) van alle verzoeken voor een voorlopige voorziening;

- $16,7 \%$ (1) van alle voorlopige voorzieningen;

- $1,8 \%$ (6) van de gewezen vonnissen;

- $1,1 \%$ (1) van alle andere afdoeningen. 
De 25 branche-, beroeps- en ondernemersorganisaties waren verantwoordelin voor:

- 11,9\% (44) van alle verbods- en gebodsvorderingen;

- $33,3 \%$ (7) van alle verzoeken voor een voorlopige voorziening;

- 33,3\% (2) van alle voorlopige voorzieningen;

- $14 \%$ (46) van de gewezen vonnissen;

- $11,6 \%$ (11) wan alle andere afdoeningen.

Van de tien bij de VSV alangesloten Verbraucherzentralen waren slechts vier actief in de door Axmann beschreven verslagperiode. Indien de Verbraucherzentrale Baden-Württemberg niet wordt meegeteld, zijn de andere negen Verbraucherzentralen verantwoordelijk voor:

- $1,1 \%$ (4) van alle verbods- en gebodsvorderingen;

- $9,5 \%$ (2) van alle verzoeken voor een voorlopige voorziening;

- $16,7 \%$ (1) van alle voorllopige voorzieningen;

- $1,2 \%$ (4) van de gewezen vonnissen;

- $0 \%(0)$ van alle andere afdoeningen.

Uit bovenstaande overzichten wordt duidelijk dat, in de eerste zes jaren waarin het AGB-Gesetz in werking was, de gerechtelijke handhaving van consumentenbelangen op het gebied van algemene voorwaarden voornamelijk steunde op de activiteiten van consumentenorganisaties en met name de VSV en de Verbraucherzentralle Baden-Württemberg.

\subsubsection{De gerechtelijke handhaving in de periode 1977-1992}

Op 31 december 1992 waren bij het BKA 2526 processuele stappen tegen onredelijk bezwarende algemene voorwaarden geregistreerd (afbeelding 9):

- 1068 verbods- en gebodsvorderingen (42\%);

- 86 verzoeken voor een voorlopige voorziening ( $3 \%)$;

- 73 voorllopige voorzieningen (3\%);

- 1054 definitieve vonnissen $(42 \%)$;

- 242 andere afdoeningen (10\%);

- 3 doorgehaallde registraties $(0 \%)$. 


\section{Afbeelding 9}

EKA-register, 1 april 1977 - 1 januari 1993 ger egistreer de processuele stappen naar soort

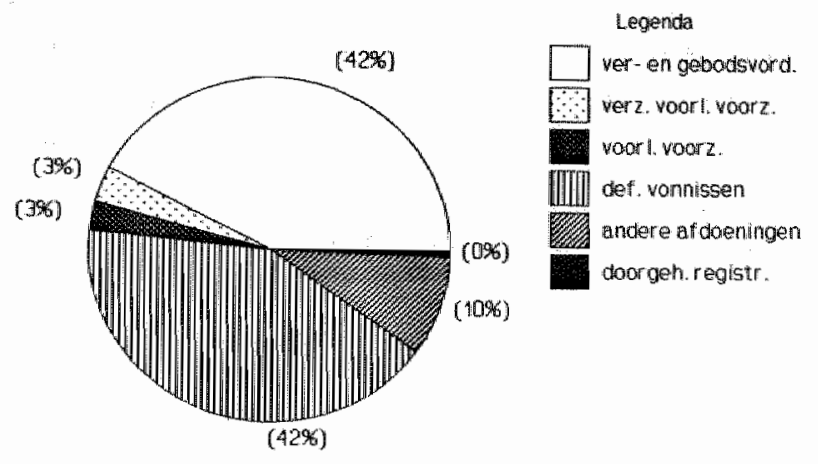

\section{Afbeelding 10}

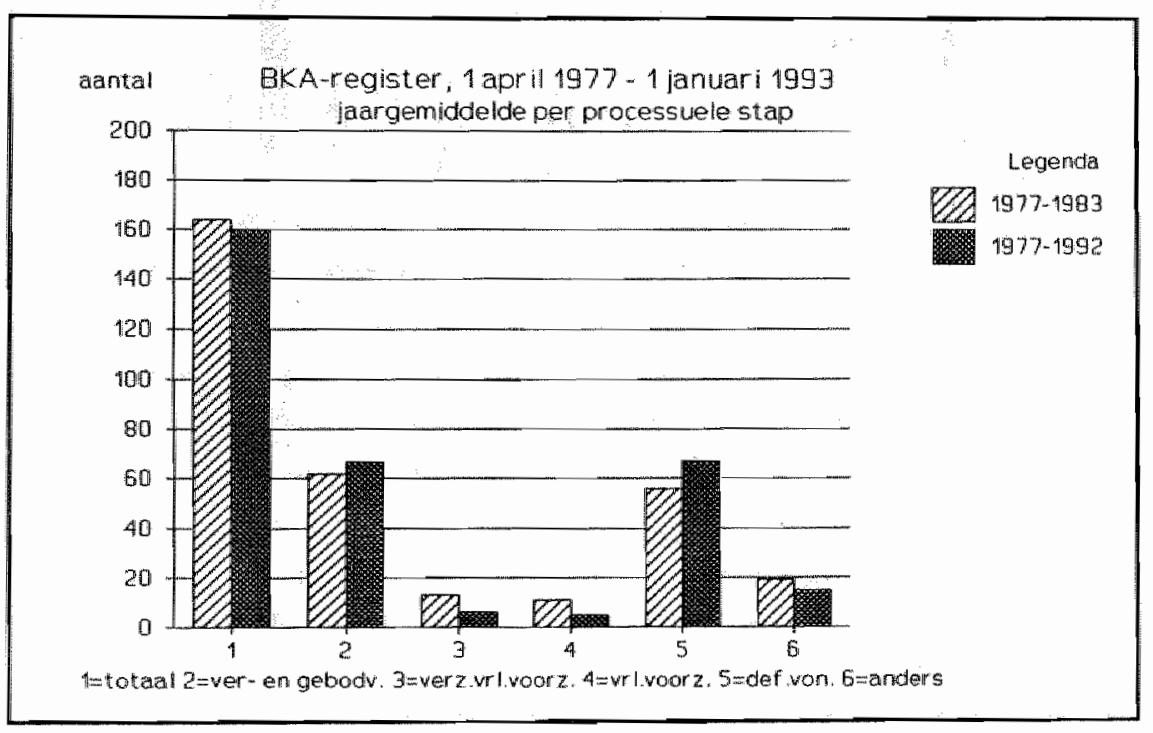


Indien we de jaargemiddelden per processuele stap van de eerste zes jaar dat ho AGB-Gesetz in werking was, vergelijken met de jaargemiddelden van 1 aprit. 1977 tot 1 januari 1993, zijn er geen al te grote verschuivingen te signaleren (afbeelding 10). Het gemiddelde aantal ver- en gebodsvorderingen alsmede hat aantal definitieve vonnissen per jaar is licht toegenomen. Het gemiddelde aantal verzoeken om een voorlopige voorziening en daarmee logischerwijs ook hes: aantall toegewezen voorlopige voorzieningen per jaar is afgenomen. Van 1 apri 1983 tot 1 januari 1993 zijn slechts 7 verzoeken om een voorlopige voorziening ingediend, waarvan de laatste twee in 1987 zijn toegewezen. Sinds die tijd wordt de collectieve actie op grond van $\$ 13$ AGBG derhalve niet meer gevoed door het vragen van een voorlopige voorziening.

Afbeelding 11

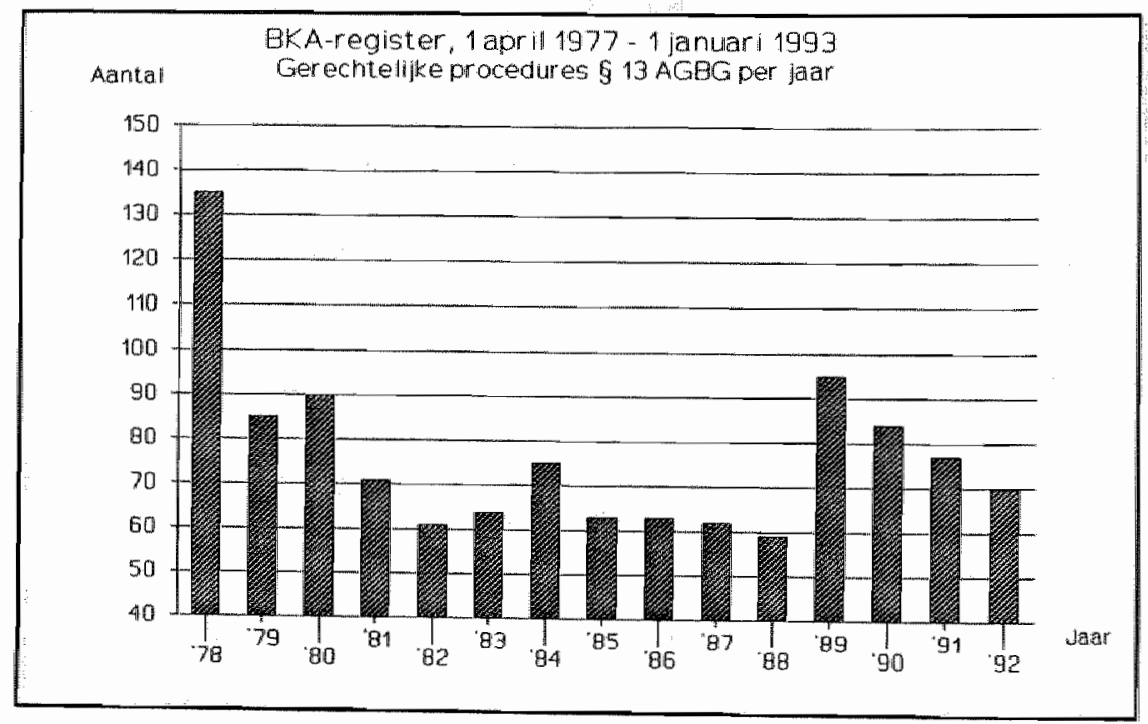

Net als bij het onderzoek van Axmann hebben de cijfers in afbeelding 9 en 10 slechts betrekking op de verschillende procedurele stappen (totaal 2526). ${ }^{23}$ Omdat het BKA elke processuele stap afzonderlijk registreert, kan én rechtsstrijd, indien gevoerd tot in hoogste instantie, tot vijf registraties leiden. Het BKA registreert echter ook het aantal gerechtelijke procedures (afbeelding 11). Op 31 december 1992 waren dat 1154 procedures, gemiddeld iets meer dan 73 procedures per jaar. 


\subsubsection{Het aandeel in de AGB-controle van de meest actieve consumentenorga- nisaties van 1977-1992}

Een schriftelijke enquête naar de rechtshandhavingsactiviteiten van de (toen nog) 9 overige Verbraucherzentralen ${ }^{24}$ in de jaren 1988 en 1989 geeft nagenoeg een zelfde beeld als dat in de eerste zes jaar van het AGB-Gesetz. ${ }^{25}$ De Verbraucherzentralen van Bremen, Rheinland-Pfalz, Berlin, Hessen, Bayern en het Saarland zijn alle in principe bevoegd om het klachtrecht als bedoeld in $\S 13$ AGBG uit te oefenen, maar doen dat tot op heden niet. In voorkomende gevallen wordt de uitoefening van het klachtrecht overgelaten aan de VSV. De Verbraucherzentrale Bremen was de enige van deze Verbraucherzentralen die aangaf er naar te streven om in de naaste toekomst het klachtrecht wél daadwerkelijk uit te oefenen. Op de enquete is geen antwoord ontvangen van de Verbraucherzentrale Niedersachsen. Volgens de VSV is in de opstelling van de genoemde Verbraucherzentralen in de jaren 1990-1992 geen verandering gekomen en volgen ook de Verbraucherzentralen in de voormalige DDR de strategie dat ze het collectieve klachtrecht op het terrein van de algemene voorwaarden overlaten aan de VSV.

Een uitzondering op het bovengeschetste beeld wordt gevormd door de Verbraucherzentrale Nordrhein-Westfalen te Düsseldorf en de Verbraucherzentrale Hamburg die op het eind van de jaren tachtig ook op eigen naam gebruik gingen maken van de hen in $\$ 13$ AGBG toegekende collectieve actiebevoegdheid op het terrein van de algemene voorwaarden.

\subsubsection{VSV Berlijn}

Aan de hand van de jaarverslagen van de VSV over de periode van 1 april 1977 tot en met 31 december 1992 zijn voor de VSV de volgende overzichten van rechtshandhavingsactiviteiten als bedoeld in $\S 13 \mathrm{AGBG}$ af te leiden (afbeelding 12-14).

In bovengenoemde periode verzorgde de VSV 2683 Abmahnungen. Dat betekent een gemiddelde van bijna 168 Abmahnungen per jaar (afbeelding 12). Van deze 2683 Abmahnungen waren er $2644(98,5 \%)$ gericht tegen gebruikers van

24 De consumentenorganisaties van de volgende deelgtaten werden aangeschreven: Bayem, Berlin, Hamburg, Hessen, Niedersachsen, Nordrthein-Westfalen, Rheinland-Pfalz, Schleswig-Holstein en Siarland.

25 Zie voor de vragenlijst: Mölenberg en Rijken, bijlage IV, pag. 7 . 
algemene woorwaarden en $39(1,5 \%)$ tegen branche-, beroeps- of bedrijfsorganisaties die het gebruik van bepaalde algemene voorwaarden bevorderen.

Afbeelding 12

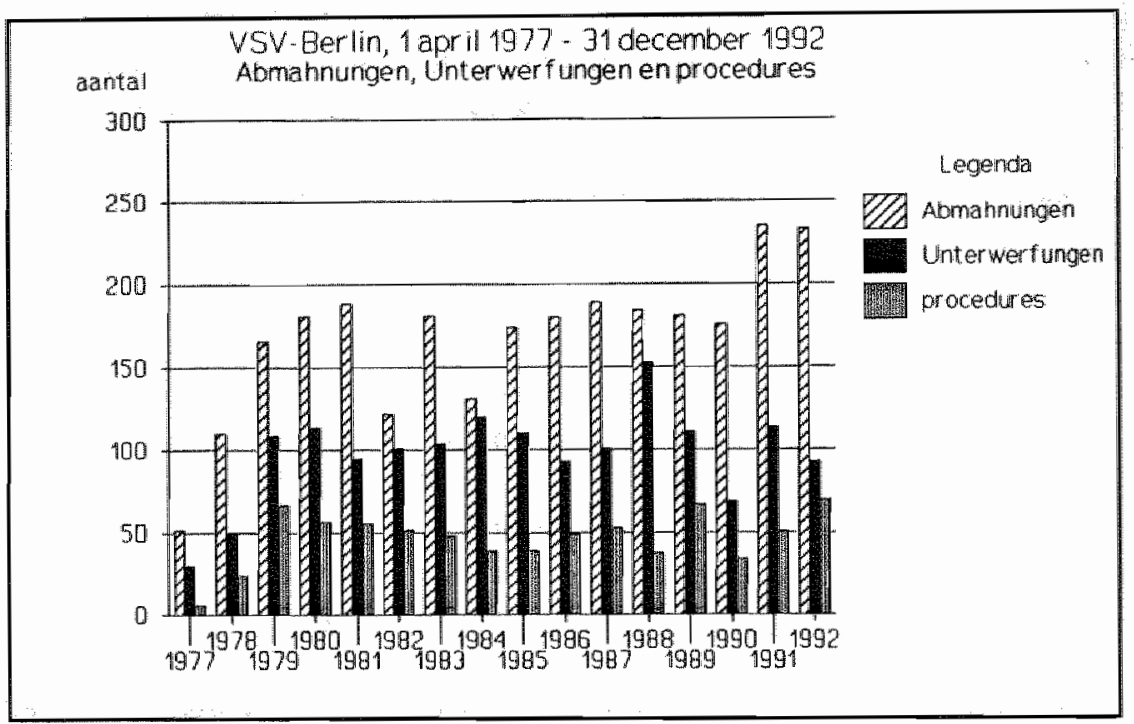

De 2683 Abmahnungen hebben uiteindelijk geleid tot $1567(58,4 \%)$ strafbewehrte Unterlassungserklärungen, welke nagenoeg alle afkomstig waren van gebruikers. Dat is een jaargemiddelde van iets minder dan 98 Unterlassungserklärungen. Op deze wijze wordt bijna tweederde van alle aangevangen zaken buitengerechtelijk opgelost (afbeelding 13). Bijna 42\% (1116) van alle Abmahnungen leidde niet tot een Unterwerfung. Dat is gemiddeld iets minder dan 70 maal per jaar. Tegen deze 1116 overblijvende Abmahnungen werden 690 gebods- of verbodsacties $(25,7 \%)$ en $18(0,7 \%)$ verzoeken om een voorlopige voorziening ingesteld. Gemiddeld iets meer dan 43 gebods- of verbodsvorderingen per jaar.

26 Van de 2683 "abgemahnte" gebnuikers waren or 44 tevens aanbeveler. Omdat zij in eerste instantie zijn aangeschreven in hun hoedanigheid als gebruiker zijn zij bij de aanbevelers niet meregeteld. 
VSV-Berlin, 1april 1977. - 1 december 1992

resultaten Abmahnungen

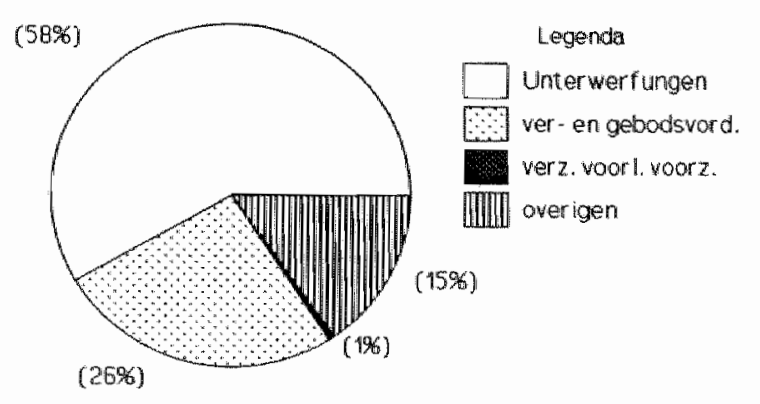

\section{Afbeelding 14}

VSV-Berlin, 1 april 1977 - 31 december 1992 resultaten gerechtelijke procedures

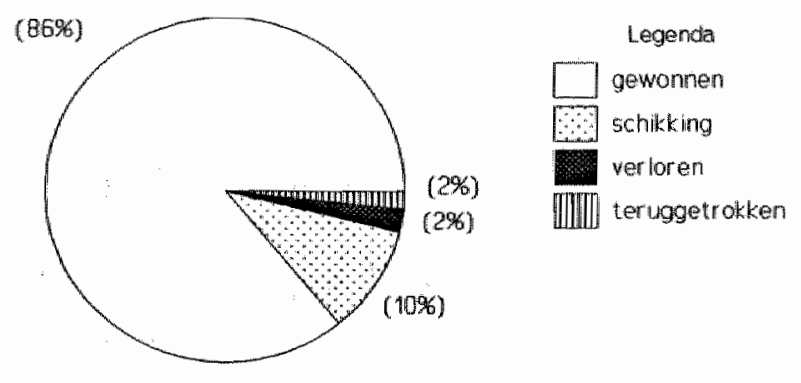


Van de 276 gerechtelijke procedures waarvan de uitkomst in de jaarverslager vermeld staat zijn er 237 gewonnen, hebben er 28 tot een schikking geleid, bat wil zeggen dat de gedaagde gebruiker tijdens de gerechtelijke procedure een Unterlassungserklärung heeft afgegeven, zijn er 6 verloren en heeft de VSV zich 5 keer uit de procedure teruggetrokken (afbeelding 14).

De resterende 408 Abmahnungen (gemiddeld 25,5 per jaar) hebben geleil tot het beëindigen van de handhavingsprocedure zonder dat een Unterlassungserklärung is verkregen.

Naast bovengenoemde procedures werden nog $38(1,4 \%)$ procedures gevoerd ter verkrijging van contractuele boetes naar aanleiding van overtredingen van de strafbewehrte Unterlassungserklärung en $9(0,3 \%)$ ter effectuering van een bij rechterlijk vonnis opgelegde dwangsom.

\subsubsection{Verbraucherzentrale Baden-Württemberg}

Aan de hand van de jaarverslagen van de Verbraucherzentrale Baden-Württemberg over de periode van 1 januari 1978 tot en met 31 december 1992 kan men voor deze Verbraucherzentrale de navolgende overzichten van rechtshandhavingsactiviteiten als bedoeld in $₹ 13$ AGBG opstellen.

\section{Afbeelding 15}

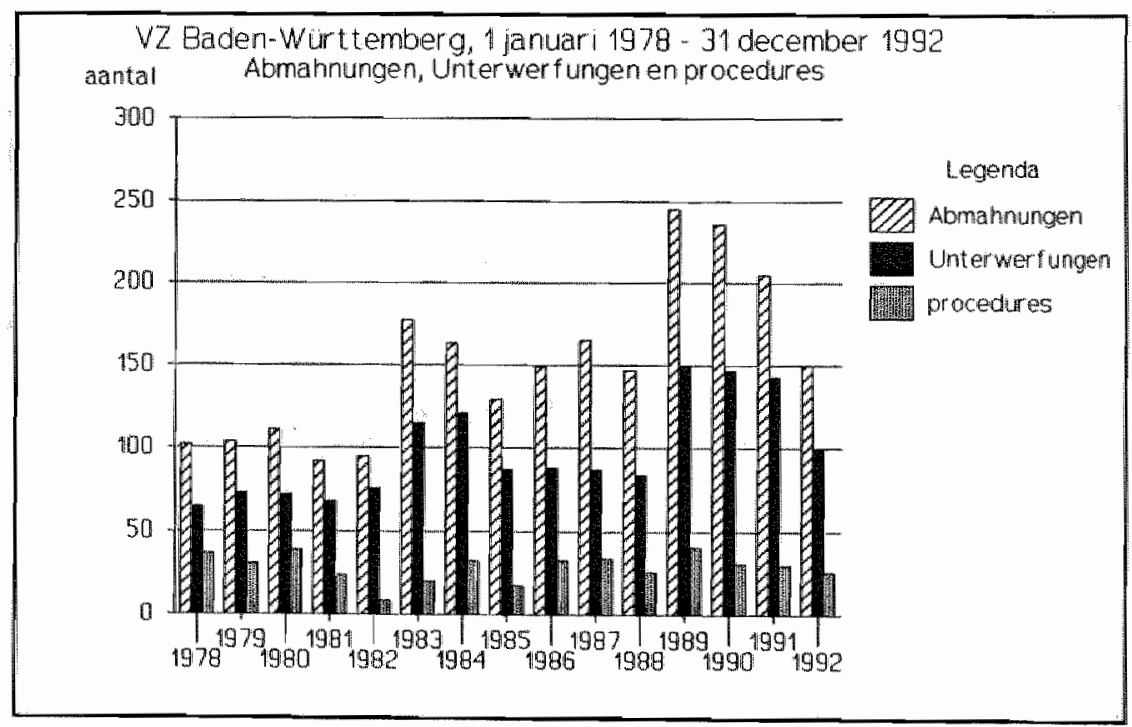


In bovengenoemde periode verzorgde de Verbraucherzentrale Baden-Württemberg 2270 Abmahnungen. Dat betekent een gemiddelde van ruim 151 Abmahnungen per jaar. Alle Abmahnungen waren gericht tegen gebruikers van algemene voorwaarden (afbeelding 15).

Afbeelding 16

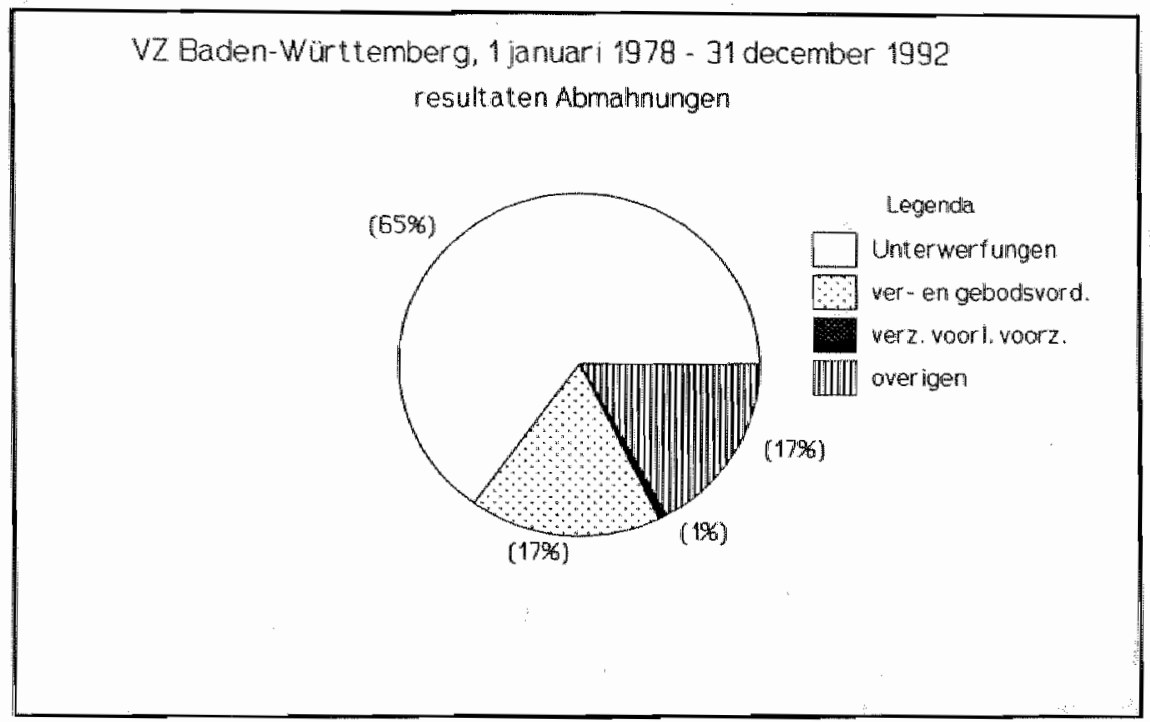

De 2270 Abmahnungen hebben uiteindelijk geleid tot 1475 (65\%) strafbewehrte Unterlassungserklärungen. Hetgeen een jaargemiddelde van iets meer dan 98 Unterlassungserklärungen oplevert. Op deze wijze wordt net als bij de VSV bijna tweederde van alle aangevangen zaken buitengerechtelijk opgelost (afbeelding 16). 35\% Procent (795) van alle Abmahnungen leidde niet tot een Unterwerfung. Dat is gemiddeld 53 maal per jaar. Tegen deze 795 overblijvende Abrnahnungen werden 392 verbodsacties $(17,3 \%)$ en $17(0,7 \%)$ verzoeken om een voorlopige voorziening ingesteld. Gemiddeld zijn dat iets meer dan 26 verbodsacties per jaar.

Van de 391 procedures waarvan de afloop in de jaarverslagen vermeld staat zijn er 356 gewonnen, 22 verloren, 10 door middel van een schikking beëindigd en heeft de Zentrale zich eén keer uit de procedure teruggetrokken (afbeelding 17). 


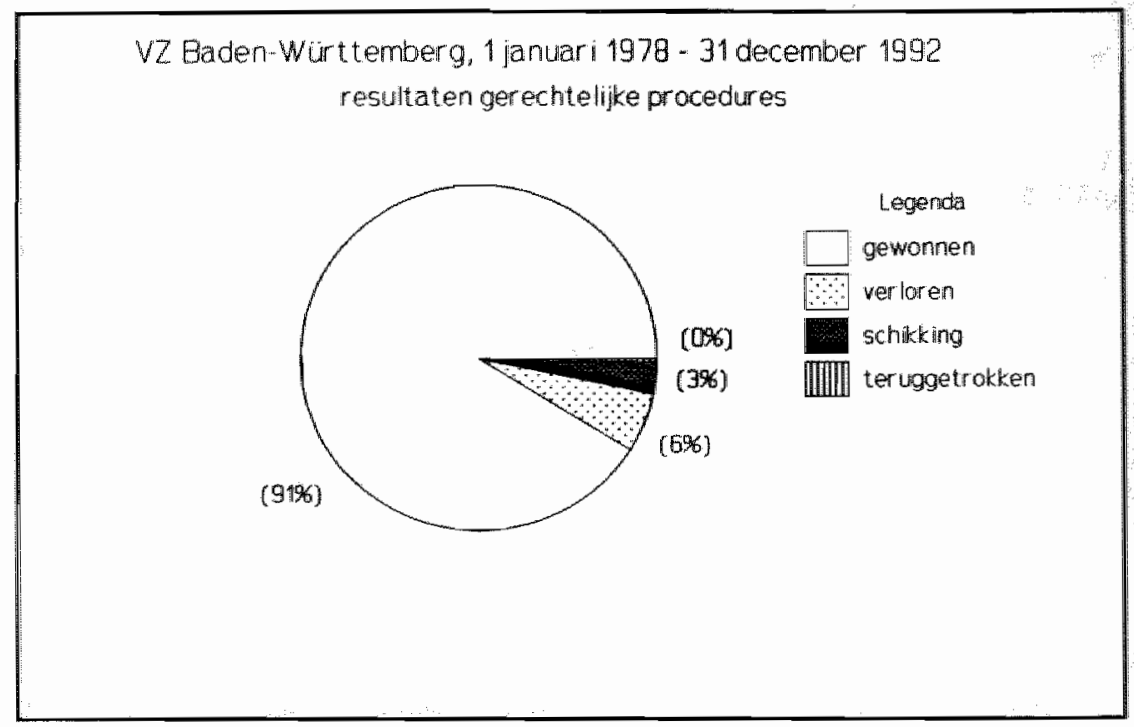

De resterende 386 Abmahnungen (gemiddeld bijna 26 per jaar) hebben geleid tot het beëindigen van de handhavingsprocedure zonder dat een Unterlassungserklärung is verkregen.

Naast bovengenoemde procedures werden nog $33(1,5 \%)$ procedures gevoerd ter verkrijging van contractuele boetes naar aanleiding van overtredingen van de strafbewehrte Unterlassungserklärung en ter effectuering van een bij rechterlijk vonnis opgelegde dwangsom.

\subsubsection{Andere actieve consumentenorganisaties}

Van de andere consumentenorganisaties verdienen enkel de Verbraucherzentralle Nordrhein-Westfalen en de Verbraucherzentrale Hamburg nadere aandacht. Van deze Verbraucherzentralen zijn de volgende gegevens bekend.

\section{Verbraucherzentrale Nordrhein-Westfalen}

Sinds 1988 maakt de Verbraucherzentrale Nordrhein-Westfalen structureel gebruik van haar actiebevoegdheid op het gebied van de algemene voorwaarden. In de daaraan voorafgaande periode maakte deze Verbraucherzentrale slechts 
incidenteel gebruik van het haar toegekende actierecht. Hoewel exacte cijfers ontbreken heeft de Verbraucherzentrale Nordrhein-Westfalen, volgens eigen opgave $^{27}$, in de periode 1989 tot 1 januari 1993, 45 Abmahnungen naar meubelondernemingen, 40 naar fitness-studio's en naar schatting lets meer dan 50 Abmahnungen naar bedrijven in andere branches doen uitgaan. In totaal dus ruim 150 stuks. Daarvan leverde meer dan $50 \%$ een Unterlassungserklärung op en werd in ongeveer 50 gevallen een gerechtelijke verbodsactie ingesteld. In dezelfde periode werd in 5 gevallen een procedure ter verkrijging van een contractuele boete tegen gebruikers ingesteld, bovendien werd nog eens minstens 15 keer een contractuele boete buiten rechte geëffectueerd. In 1991 werd zo een totaalbedrag van DM 15.500, = aan contractuele boetes geëffectueerd en in $1992 \mathrm{DM}$ 33.000, = . Daarmee is, sinds een aantal jaren, de rol van de Verbraucherzentralle Nordrhein-Westfalen in de rechtshandhaving op het gebied van de algemene voorwaarden, hoewel op iets bescheidener schaal, te vergelijken met die van de Verbraucherzentrale Baden-Württemberg.

\section{Verbraucherzentrale Hamburg}

De Verbraucherzentrale Hamburg is sinds 1988 eveneens haar actiebevoegdheid op het gebied van de algemene voorwaarden gaan uitoefenen. In hoeverre de verbraucherzentrale Hamburg het klachtrecht als bedoeld in $\S 13 \mathrm{AGBG}$ in de periode tussen 1 april 1983 en 1 januari 1988 heeft gehanteerd, is niet onderzocht. Hoewel exacte cijfers ontbreken, heeft de Verbraucherzentrale Hamburg in 1988, volgens eigen opgave $e^{28}, 23$ Abmahnungen naar verschillende gebruikers doen uitgaan. Daarvan leverde volgens een grove schatting ongeveer $80 \%$ een Unterlassungserklärung op en werd in ongeveer $20 \%$ van alle gevallen een gerechtelijke verbodsactie geïnitieerd. Het zwaartepunt lag bij algemene voorwaarden gehanteerd door banken. In 1988 werden in totaal 105 onredelijk bezwarende algemene voorwaarden "uit de markt gehaald".

In 1989 werden door de Verbraucherzentrale Hamburg 15 gebruikers "abgemahnt" en werd in én geval een contractuele boete geëffectueerd door middel van een Vertragsstrafeverfahren. Zwaartepunten lagen bij fitness-studio's en banken. Van deze 15 Abmahnungen leverde eveneens, weer volgens schatting van de Verbraucherzentrale Hamburg, eén op de vijf geen Unterlassungserklärung op en leidde tot een gerechtelijke procedure. In 1988 werden in totaal 88 onredelijk bezwarende algemene voorwaarden aan het rechtsverkeer onttrokken. 
In 1990 en 1991 werden respectievelijk 14 en 19 Abmahnungen naar gebruikers gestuurd. Deze hebben in respectievelijk 11 en 17 keer geleid tot een Unterlas: sungserklärung. Gedurende deze twee jaren werden 9 gerechtelijke verbodsac: ties gevoerd, welke op eén na werden gewonnen. In 1990 werd én procedure: gevoerd ter verkrijging van een contractuele boete.

In 1992 vertoonden de AGB-activiteiten van de Verbraucherzentrale Ham burg een opmerkelijke teruggang. In dat jaar werden slechts twee Abmahnungen uitgebracht, die allebei leidden tot een Unterlassungserklärung, en werd slechles. eén verbodsactie gevoerd die overigens werd gewonnen. Deze terugval was te wijten aan een dreigend faillissement van de Verbraucherzentrale als gevolg van het stopzetten van de subsidie door de deelstaat Hamburg. De afwending van dit, overigens door de Zentrale zelf aangevraagde faillissement, eiste alle aandacht op van de Zentrale. Na de hervatting van de subsidie door de deelstaat Hamburg heeft de Zentrale haar activiteiten op het terrein van de algemene voorwaarden weer opgenomen. Wekelijks worden gemiddeld ongeveer 5 uur: besteed aan de rechtshandhaving op het terrein van de algemene voorwaarden. Dit heeft er toe geleid dat in 1993 naar schatting in totaal meer procedures werden gevoerd dan in 1990, 1991 en 1992 tezamen.

In de jaren 1990, 1991 en 1992 werden gemiddeld twee zaken met betrekking tot algemene voorwaarden doorgespeeld aan de VSV te Berlijn. 


\section{Handhavingsprocedure en strategie}

\subsection{Inleiding}

De consumentenbescherming die met het AGB-Gesetz wordt beoogd is niet alleen afhankelijk van de ontwikkeling van het materiële recht en de daarin tot uiting komende normen, maar tevens van de wijze waarop deze normen door consumentenorganisaties geëffectueerd kunnen worden. Zowel de Wet allgemene voorwaarden als het AGB-Gesetz steunen voor een groot gedeelte op de gedachte dat de beoogde consumentenbescherming en de breedtewerking van de materieelrechtelijke regels zijn beslag zal verkrijgen door een effectief optreden van consumentenorganisaties. De rechtshandhaving op het terrein van de algemene voorwaarden is daarmee voornamelijk in de handen van consumentenorganisaties gelegd.

Gezien het feit dat algemene voorwaarden in het rechtsverkeer met consumenten op grote schaal gehanteerd worden, zijn de snelheid, de praktische hanteerbaarheid en de werkelijke effectiviteit van de rechtshandhavingsprocedure de belangrijkste factoren voor een daadwerkelijke consumentenbescherming. Om inzicht te krijgen in de hanteerbaarheid en de effectiviteit van het collectieveactiemodel op het terrein van de algemene voorwaarden, wordt in volgende paragrafen allereerst begonnen met het in kaart brengen van de verschillende stappen van de rechtshandhavingsprocedure als bedoeld in $\$ 13$ AGBG, van de opsporing van onredelijk bezwarende bedingen tot de gerechtelijke procedures en de nacontrole. Vervolgens wordt de praktijk van dit actiemodel geschetst aan de hand van de invulling van de rechtshandhavingsprocedure door de twee actiefste consumentenorganisaties, de VSV en de Verbraucherzentrale BadenWürttemberg. Van belang hierbij zijn vooral de beslissingsprocessen en strategieën die de actieve consumentenorganisaties bij de opsporing en (buiten)gerechtelijke vervolging van onredelijk bezwarende algemene voorwaarden hanteren. 
De gegevens in dit hoofdstuk zijn hoofdzakelijk ontleend aan de antwoorden op de vragenlijsten ${ }^{1}$ die zijn voorgelegd aan en besproken met medewerkers van de twee meest actieve consumentenorganisaties, de VSV en de Verbraucherzentrale Baden-Württemberg, die verantwoordelijk zijn voor het grootste gedeelte van de gevoerde procedures.

\subsection{Het collectieve rechtshandhavingsmodel op het terrein van de algemene voorwaarden}

Het rechtshandhavingsmodel op het terrein van de algemene voorwaarden gaat er van uit dat consumentenorganisaties actief gebruik zullen maken van de hen toegekende bevoegdheden om zo te bewerkstelligen dat de (consumenten)markt wordt bevrijd van onredelijk bezwarende algemene voorwaarden. Dit vereist een actieve opstelling en inzet van consumentenorganisaties. Zonder een actieve opstelling van consumentenorganisaties zal de effectiviteit van de materieelrechtelijke regels slechts gering zijn. Zowel het Nederlandse als het Duitse stelsel gaat er immers van uit dat de individuele consument niet of nauwelijks in staat is zijn dwingendrechtelijke bescherming te effectueren. ${ }^{2}$ Bij de beschrijving van de stappen van het rechtshandhavingsmodel wordt er van uitgegaan dat consumentenorganisaties slechts beperkte middelen ter beschikking hebben om de hen toekomende taak uit te oefenen en dus steeds gedwongen zullen zijn om keuzes te maken teneinde hun schaarse middelen zo effectief mogelijk in te zetten.

De collectieve rechtshanidhaving op het terrein van de algemene voorwaarden begint natuurlijk met de opsporing van algemene voorwaarden door de consumentenorganisaties. Om te kunnen beoordelen of algemene voorwaarden de toets van de wet kunnen doorstaan dient men deze immers de letterlijke tekst te hebben. Deze opsporing kan actief en gericht zijn, maar ook passief bij voorbeeld indien de aanzetten tot een inhoudelijke beoordeling enkel voortkomen uit individuele consumentenklachten die bij de organisatie binnenkomen.

Nadat algemene voorwaarden zijn opgespoord komt de vraag aan de orde of deze ook inhoudelijk zullen worden beoordeeld. Het inhoudelijk toetsen van algemene voorwaarden is immers een tijdrovende bezigheid. Indien deze vraag bevestigend is beantwoord, vindt vervolgens een inhoudelijke beoordeling van de gevonden algemene voorwaarden plaats. De rechtshandhaving houdt op indien de beoordeelde algemene voorwaarden niet onredelijk bezwarend blijken te zijn. Indien de voorliggende bedingen naar het oordeel van de toetsende

1 Zie voor de voorgelegde vragenlijsten: Mölenberg en Rijken, Bijlage IV, pag. $1-6$.

2 Rijken, inaug. rede, pag. 25 en 30. 
organisatie echter wel onredelijk bezwarend zijn, dient te worden overwogen of er vervolgens gerichte stappen tegen de gebruiker of aanbeveler zullen worden genomen. Deze zullen in eerste instantie buitengerechtelijk zijn. Het feit dat een beding onredelijk bezwarend wordt beoordeeld kan daarbij tevens aanleiding zijn voor een (hernieuwde) gerichte opsporing van het betreffende beding.

De buitengerechtelijke stappen kunnen er toe leiden dat de gebruiker aan de bezwaren van de consumentenorganisatie tegemoet komt. Indien dit het geval is, vereist een effectieve rechtshandhaving dat de consumentenorganisatie geregeld controleert of de gebruiker of aanbeveler de gemaakte afspraken ook daadwerkelijk nakomt. Een effectieve rechtshandhaving vereist eveneens dat de consumentenorganisatie deze afspraken desnoods gerechtelijk afdwingt. De geloofwaardigheid van consumentenorganisaties komt immers in het geding wanneer zij niet zouden staan op nakoming van gemaakte afspraken.

Als de buitengerechtelijke stappen niet tot het gewenste resultaat leiden, zall de consumentenorganisatie moeten overwegen of zij al dan niet overgaat tot een gerechtelijke procedure tegen de betreffende gebruiker of aanbeveler. Indien het besluit is gevallen dat de rechter gevraagd zal worden een oordeel te vellen, dient vervolgens overwogen te worden of bij wege van kort geding geprocedeerd zal worden of niet. Nadat deze keuze is gemaakt volgt, indien er niet ondertussen een schikking is getroffen tussen partijen, een uitspraak van de rechter.

Indien de rechter van oordeel is dat het betreffende beding niet onredelijk bezwarend is, kan de eisende consumentenorganisatie vervolgens overwegen in hoger beroep te gaan en eventueel in cassatie. In geval van een voor de consumentenorganisatie ongunstige uitspraak in kort geding, kan worden overwogen een bodemprocedure te starten.

Als de rechter eveneens van mening is dat het voorgelegde beding onredelijk bezwarend is, komt hij tot een verbods- of gebodsvonnis met daaraan eventueel gekoppeld een toekenning aan de eisende organisatie van de bevoegdheid tot publikatie van het vonnis of de vaststelling van een dwangsom ten behoeve van de eisende organisatie. Voor de consumentenorganisatie rest dan nog slechts de taak te controleren of de veroordeelde gebruiker of aanbeveler zich aan het rechtelijk ver- of gebod houdt. Indien geconstateerd wordt dat de gebruiker of aanbeveler het verbods- of gebodsvonnis negeert, dient overwogen te worden of stappen worden ondernomen om het verbods- of gebodsvonnis, desnoods middels een hernieuwde gerechtelijke procedure bij voorbeeld door het executeren van een opgelegde dwangsom, te effectueren. 


\subsection{Opsporingsactiviteiten en strategie}

Zoals gezegd begint elke handhavingsactiviteit bij de opsporing van onredelijk bezwarende algemene voorwaarden. Interessant is hierbij op welke wijze en van wie de consumentenorganisaties kennis nemen van onredelijk bezwarende algemene voorwaarden, die later voorwerp zijn van (buiten)gerechtelijke procedures. Is er sprake van een systematische en gerichte opsporing van onredelijk bezwarende bedingen of komen de aanzetten tot de controle vaa algemene voorwaarden voort uit individuele consumentenklachten die bij de consumentenorganisaties binnenkomen? Daarbij is tevens de vraag interessant of bij de keuze van de op te sporen of te controleren algemene voorwaarden bepaalde criteria worden gehanteerd zoals bijvoorbeeld het marktaandeel van de desbetreffende gebruiker of branche. Indien algemene voorwaarden zijn gecontroleerd en onredelijk bezwarend zijn bevonden komt vervolgens de vraag aan de orde of tegen de betreffende gebruiker of aanbeveler stappen zullen worden ondernomen.

\subsubsection{De VSV}

In tegenstelling tot de Verbraucherzentralen, die zich beperken tot regionalle activiteiten, omvat het werkterrein van de VSV de gehele Bondsrepubliek. Het grootste gedeelte van de door de VSV gecontroleerde algemene voorwaarden is afkomstig van de Verbraucherzentralen op deelstaatniveau. Doorgaans betreft het algemene voorwaarden die op grond van individuele consumentenklachten ter kennis komen van deze Verbraucherzentralen. De Verbraucherzentrale Baden-Württemberg en de laatste jaren eveneens de Verbraucherzentralen van Hamburg en Nordrhein-Westfalen nemen het klachtrecht inzake onredelijk bezwarende algemene voorwaarden echter grotendeels zelf ter hand en sturen slechts die algemene voorwaarden door naar de VSV die qua spreiding en/of betekenis uitgaan boven het niveau van de desbetreffende deelstaten. Daarmee beperken de handhavingsactiviteiten van de VSV zich hoofdzakelijk tot enerzijds de waarneming van het actierecht als bedoeld in $\$ 13 \mathrm{AGBG}$ voor die organisaties die zelf geen actief gebruik maken van het collectief actierecht en anderzijds tot de handhavingsactiviteiten met een bovenregionale of principiële betekenis (Grundsatzverfahren).

Eien gering deel van de gecontroleerde algemene voorwaarden is afkomstig uit andere bronnen zoals van advocaten die in hun praktijk geconfronteerd worden met algemene voorwaarden of van universiteiten. Het komt sllechts zelden voor dat consumenten zich direct met algemene voorwaarden tot de VSV wenden, hetgeen zijn oorzaak waarschijnlijk vindt in het feit dat consumenten van deze mogelijkheid nauwelijks op de hoogte zijn. Daarmee wordt duidelijk 
dat de VSV zelf geen systematische en gerichte opsporingsactiviteiten ontplooit en de controleactiviteiten voornamelijk plaatsvinden naar aanleiding van concrete individuele consumentenklachten die bij de Verbraucherzentralen binnenkomen.

Door de VSV worden in beginsel alle binnenkomende algemene voorwaarden op dezelfde wijze gecontroleerd, zonder dat er een selectie plaatsvindt op grond van criteria als marktaandeel van de desbetreffende gebruiker of de spreidingsgraad van de desbetreffende voorwaarden. Gezien de beperkte financiële en personele middelen kan de VSV echter niet in alle zaken die zich voordoen op het terrein van het AGB-Gesetz overgaan tot het initiëren van de buitengerechtelijke of gerechtelijke handhavingsprocedure. Niet alle geconstateerde inbreuken op het AGB-Gesetz leiden derhalve tot een Abmahnung of het instellen van een gerechtelijke procedure.

Omdat de VSV niet elke zaak kan aanpakken, richt zij zich de laatste jaren in toenemende mate op bepaalde speerpunten (Schwerpunkte) die elk jaar worden vastgesteld. Zo werd in 1988 prioriteit gegeven aan de controle en eventuele Abmahnung van de algemene voorwaarden van de (spaar)banken en de algemene voorwaarden van reisorganisatoren. Voor het jaar 1989 lagen de prioriteiten bij de algemene voorwaarden in verzekeringsovereenkomsten en de algemene voorwaarden van reisorganisatoren. In 1990 bij algemene voorwarden van fitness-centra en liftcentrales, in 1991 bij algemene voorwaarden in verzekeringsovereenkomsten en in 1992 wederom bij algemene voorwaarden van fitness-centra.

In het kader van deze prioriteitstellingen worden vooral die branches of die algemene voorwaarden gecontroleerd en eventueel "abgemahnt" die naar hun inhoud of hun spreidingsgraad van bijzondere betekenis zijn voor het consumentenbelang, waarbij echter de omvang van de activiteiten van de VSV voornamelijk bepaald wordt door de personele mogelijkheden. Meestal gaat het daarbij om branches of algemene voorwaarden waarvan gesignaleerd werd dat deze, meer dan gemiddeld, voorwerp waren van consumentenklachten. Een toenemend aantal consumentenklachten in een bepaalde branche of naar aanleiding van bepaalde bedingen voerde meestal eveneens tot een toename van het aantal algemene voorwaarden die op het desbetreffende terrein ter controle aan de VSV werden voorgelegd. De aanleiding voor gericht optreden kan ook gelegen zijn in factoren als nieuwe produkten (bijvoorbeeld video en personal computers), nieuwe inzichten in de literatuur of nieuwe (consumenten)wetgeving. Gericht optreden vindt ook wel eens plaats wanneer de door een branche gebruikte algemene voorwaarden reeds verzameld aan de VSV worden aangeboden. Zo noemt Axmann als voorbeeld een honderdtal huurovereenkomsten betreffende personenauto's die door de Stiftung Warentest door middel van een enquête waren verzameld. Door het tijd- en geldrovend voorwerk van de 
Stiftung Warentest kon de VSV gelijk beginnen met de rechtshandhavingsprocedures. ${ }^{3}$ Buiten deze zwaartepunten wordt natuurlijk ook tot de handhavingsprocedure overgegaan bij die onredelijk bezwarende algemene voorwaarden die qua betekenis of spreiding van bijzonder belang zijn voor de handhaving van het consumentenbelang of de rechtsontwikkeling.

Naast deze twee factoren speelt de publicitaire waarde van de Abmahnung of de eventuele gerechtelijke procedure een grote rol bij de beslissing of wel of niet tot vervolging van specifieke algemene voorwaarden wordt overgegaan. Een procedure tegen bijvoorbeeld Daimler-Benz of de Lufthansa zal het publicitair beter doen, dan eenzelfde procedure tegen respectievelijk een plaatselijke autodealer of een klein boekingskantoor.

De enige echt systematische en gerichte controle-activiteit die plaatsvindt bij de VSV is die betreffende de Konditionenempfehlungen. Deze Konditionenempfehlungen behoeven echter niet opgespoord te worden door de VSV. Zij worden immers altijd door het Bundeskartellamt ter becommentariëring voorgelegd aan de VSV. De controle zelf legt, vanwege de complexiteit van de Konditionenempfehlungen, echter reeds beslag op een substantieel deel van de personele middelen die de VSV ter beschikking staan. Een aanzienlijk deel van de personele middelen wordt daarbij besteed aan de (achteraf)controle van de uiteindelijke Konditionenempfehlungen, waarbij wordt nagegaan in hoeverre met de opmerkingen van de VSV door de branche-organisaties (én het Bundeskartellamt) rekening wordt gehouden. Daarbij komt nog, dat steeds meer en steeds langer onderhandeld wordt tussen de VSV en de desbetreffende brancheorganisaties over de formulering van deze Konditionenempfehlungen, waarbij vaak eerst de uitkomst van procedures tegen individuele gebruikers van de desbetreffende algemene voorwaarden wordt afgewacht, alvorens tot een definitieve standpuntbepaling wordt overgegaan.

\subsubsection{Verbraucherzentrale Baden-Warttemberg}

Door de Verbraucherzentrale Baden-Württemberg wordt evenmin gericht onderzoek gedaan teneinde onredelijk bezwarende algemene voorwaarden op het spoor te komen. De aanzetten tot rechtshandhavingsactiviteiten komen voort uit de individuele consumentenklachten die, al dan niet via de regionale adviesbureaus (Verbraucherberatungsstellen), bij de Verbraucherzentrale binnenkomen. De regionale steunpunten sturen consumentenklachten waarbij (mogelijk) sprake is van door gebruikers gehanteerde onredelijk bezwarende algemene voorwaar- 
den door naar de Verbraucherzentrale in Stuttgart. De kosten van opsporing van onredelijk bezwarende algemene voorwaarden beperken zich dan ook doorgaans tot de kosten van het kopiëren van de desbetreffende algemene voorwaarden en de kosten van het verzenden van deze voorwaarden naar de Verbraucherzentrale Baden-Württemberg.

De Verbraucherzentrale Baden-Württemberg streeft er tevens naar om via de zogenaamde Öffentlichkeitsarbeit de consumenten in de deelstaat te activeren. Via de pers en eventueel andere media worden consumenten opgeroepen om na te gaan of in bepaalde branches bepaalde onredelijk bezwarende algemene voorwaarden gebruikt worden. ${ }^{4}$ De Verbraucherzentrale Baden-Württemberg heeft een goede relatie met de pers en biedt deze alle "succes-stories" aan. De publikatie van de gewonnen processen en verkregen Unterlassungserklärungen heeft meestal weer een stroom van consumentenklachten tot gevolg, omdat consumenten er achter komen dat zij geconfronteerd zijn of worden met bedingen waarvan vaststaat dat ze onredelijk bezwarend zijn. Het mediawerk en de daarvoor benodigde goede relatie met de pers wordt door de Verbraucherzentrale Baden-Württemberg derhalve als én van de meest essentiële werkzaamheden in de bestrijding van onredelijk bezwarende algemene voorwaarden gezien. De Verbraucherzentrale Baden-Württemberg komt daarbij tot de conclusie dat haar werkzaamheden op het terrein van het AGB-Gesetz door deze Öffentlichkeitsarbeit in eerste instantie echter eerder leiden tot een toename van het aantal consumentenklachten op het terrein van algemene voorwaarden dan tot een afname.

De opgespoorde algemene voorwaarden worden door één van de directeuren (mevr. M. Ketterer) aan een - voorlopige - inhoudstoetsing onderworpen. Evident onredelijk bezwarende bedingen en twijfelgevallen worden doorgestuurd naar de advocaat. Deze laatste beslist uiteindelijk of een Abmahnung wordt gestuurd en of, indien deze niet tot een Unterlassungserklärung leildt, een gerechtelijke procedure wordt aangespannen. Indien de vaste advocaat van de verbraucherzentrale de verzamelde algemene voorwaarden eveneens onredelijk bezwarend acht, wordt door middel van een Abmahnung met verzoek om afgifte van een strafbewehrte Unterlassungserklärung geageerd bij de desbetreffende gebruiker. Factoren als marktaandeel van de desbetreffende gebruiker of de spreiding van het desbetreffende beding spelen in de beslissing of vervolgd wordt of niet, geen rol. Doorslaggevend is enkel het al dan niet onredelijk bezwarende karakter van het desbetreffende beding. De Verbraucherzentrale

4 In het kader van deze Öffentlichkeitsarbeit reikt de Verbraucherzentrale Baden-Württemberg elk jaar "Die Goldene Nase" uit an de ondernemer die thet mar de mening van de Verbraucherxentrale in een bepaald jaar wel erg bont heeft gemaakt. Zie hierover: Rijken, inaug. rede, pag. 31 . 
Baden-Württemberg stelt zich op het principiële standpunt dat het AGB-Gesetz nagekomen dient te worden.

Indien de desbetreffende gebruiker zijn bedrijf niet uitoefent in Baden Württemberg maar in een andere deelstaat, wordt door de Verbraucherzentrals: eerst contact opgenomen met de Verbraucherzentrale van de desbetreffends deelstaat of de VSV teneinde het beleid van de Verbraucherzentrale van de desbetreffende deelstaat niet te doorkruisen. Indien de desbetreffende algemene voorwaarden qua betekenis en spreiding uitgaan boven het niveau van de deelstaat worden deze doorgegeven aan de VSV, die dan ook de rechtshandha ving voor deze voorwaarden ter hand neemt. Evenals de VSV werkt de Ver braucherzentrale Baden-Wïrttemberg met speerpunten. In 1989 bij voorbeeld lag de prioriteit bij algemene voorwaarden gehanteerd door fitness-studio's.

\subsection{Abmahnung}

De (buiten)gerechtelijke handhavingsprocedure start in de regel steeds met een Abmahnung. Dit is het schriftelijke verzoek aan de gebruiker van de desbe treffende algemene voorwaarden om zich schriftelijk, op straffe van een boete per overtreding, te verplichten het gebruik van de naar de opvatting van de consumentenorganisatie onredelijk bezwarende algemene voorwaarde(n) te beëindigen (strafbewehrte Unterlassungserklärung). ${ }^{5}$ Met de afgifte van een strafbewehrte Unterlassungserklärung door de gebruiker of aanbeveler aan de consumentenorganisatie vervalt het zogenaamde herhalingsgevaar dat voorwarde is voor de actiebevoegdheid als bedoeld in $\$ 13 \mathrm{AGBG}$.

Beide consumentenorganisaties nemen voorafgaand aan de Abmahnung doorgaans geen contact op met de betreffende gebruiker of aanbeveler. Aan de Abmahnung voorafgaande correspondentie met de gebruiker of aanbeveler vindt hoogstens plaats ter verificatie van de klacht van de individuele gebruiker en vindt meestal reeds plaats bij de Verbraucherberatungsstellen van de Verbraucherzentralen.

\subsubsection{De VSV}

De VSV stelt zich op het standpunt dat in beginsel elke geconstateerde inbreuk op het AGB-Gesetz dient te leiden tot een Abmahnung. De grenzen van de "Abmahn"-activiteiten worden voornamelijk bepaald door de personele en financiële mogelijkheden die de VSV ter beschikking staan. In de praktijk konit het er grotendeels op neer dat slechts in die gevallen de handhavingsprocedure 
wordt ingezet waarin sprake is van een evident onredelijk bezwarend beding. Echter, zelfs deze gevallen zijn al zo talrijk dat de VSV daar haar handen aan vol heeft.

De inhoud van de door de VSV gehanteerde Abmahnungen voldoet aan alle hierboven genoemde vereisten en de hoogte van de contractuele boete bedraagt per clausule $1000,=\mathrm{DM}$. Aanvankelijk werd de total te verbeuren boete bij hergebruik van de gehele set algemene voorwaarden samengesteld uit de optelsom van de boetes per individueel beding. Deze methode werd veranderd toen het Landgericht Frankfurt in een geval dat 28 verschillende bedingen betrof, oordeelde dat de totale contractuele boete van 28.000 , $=$ DM te hoog was. Het oordeel werd gemotiveerd met de stelling dat de verschillen in betekenis van de diverse bedingen en de verschillen in economische verhoudingen bij de gebruikers, met zich brengt dat geen uniforme contractuele boete verlangd kan worden. ${ }^{6}$ Vanwege deze te hoge contractuele (totaal)boete werd de Abmahnung haar werking ontzegd en werd de VSV, ondanks het feit dat het Landgericht van oordeel was dat alle 28 bedingen onredelijk bezwarend waren, veroordeeld in de kosten van de procedure. Vanaf dat moment vordert de VSV weliswaar nog steeds een boete van $1000,=D M$ per clausule, maar wordt de boete voor hergebruik van de totale set vastgesteld op de helft van de som van de boetes per individueel beding. Bij hergebruik van slechts een of enkele bedingen kan dan toch $1000,=$ DM per beding gevorderd worden.

De termijn die gehanteerd wordt voor de afgifte van de Unterlassungserklärung varieert, maar beslaat doorgaans drie weken. Een termijn korter dan twee weken wordt niet gehanteerd. In het algemeen worden deze termijnen niet al te strikt gehanteerd door de VSV. Verzoeken om verlenging van de termijn, nodig bijvoorbeeld om juridisch advies in te winnen, worden meestal zonder verdere problemen gehonoreerd.

Bij de Abmahnung doet zich het probleem voor dat gebruikers - in afwachting van de gewijzigde algemene voorwaarden - vaak een termijn verlangen, tijdens welke zij ongestraft de oude, onredelijk bezwarende bedingen bevattende, sets van algemene voorwaarden kunnen blijven gebruiken of opmaken (Umstellungsfrist of Aufbrauchfrist). Alhoewel het Bundesgerichtshof (BGH) inmiddels heeft bepaald dat een dergelijke termijn door de consumentenorganisaties niet behoeft te worden toegestaan, stelt de VSV zich op het standpunt dat, afhankelijk van de omstandigheden van het geval, een termijn van 2 tot 6 weken toegestaan kan worden. Deze termijn wordt echter alleen toegestaan nadat een strafbewehrte Unterlassungserklärung is verkregen en alleen in de buitengerechtelijke fase. 
Indien de gegunde Umstellungsfrist wordt overschreden door de betrokken ge bruiker wordt onmiddellijk overgegaan tot effectuering van de contractuele boete, desnoods door middel van een gerechtelijke vordering (Vertragsstrafever fahren). Het probleem doet zich bijvoorbeeld voor bij reisbrochures die meestal zijn gemaakt om het gehele jaar te gelden. Vanwege de hoge kosten die verandering of een herdruk van deze brochures met zich brengt, verlangt de VSV niet dat de reisorganisaties hun brochures opnieuw laten drukken. De VSV verlangt in gevallen waarin zij een dergelijk termijn toestaat echter well dat de betrokken reisorganisaties geen beroep meer doen op de "abgemahnte" bedingen en dit bijwoorbeeld kenbaar maken door een sticker op de desbetreffende brochures:

De VSV heeft de ervaring opgedaan dat een aantal gebruikers ermee dreigt dat ze geen strafbewehrte Unterlassungserklärung afgeven indien hen geen Umstellungsfrist wordt gegund. Het door gebruikers gehanteerde argument is: dan dat de VSV in een dergelijk geval naar de rechter moet en zodoende veel meer tijd moet besteden om de "abgemahnte" bedingen uit de wereld te helpen. Op dergelijke dreigementen gaat de VSV echter principieel niet in.

Bijna 60\% van alle Abmahnungen van de VSV hebben geleid tot een strafbewehrte Unterlassungserklärung, waarmee de buitengerechtelijke fase zeer effectief genoemd mag worden. De kosten van de Abmahnung worden door de VSV nooit in rekening gebracht bij de "abgemahnte" gebruiker of aanbeveler.

Door de VSV wordt niet gericht gecontroleerd of "abgemahnte" gebruikers zich aan de contractuele afspraken houden. Well wordt aan alle Verbraucherzentralen doorgegeven welke bedingen van welke gebruiker zijn "abgemahnt" en voor welke bedingen een strafbewehrte Unterlassungserklärung is verkregen. Indien deze Verbraucherzentralen constateren (in de regel naar aanleiding van individuele consumentenklachten) dat een "abgemahnt" beding of een beding van gelijke strekking toch wordt gehanteerd door de desbetreffende gebruiker, wordt de contractuele boete onmiddellijk (desnoods via de rechter) geëffectueerd. Gericht onderzoek naar hergebruik van algemene voorwaarden die voorwerp zijn van een strafbewehrte Unterlassungserklärung vindt echter niet plaats. De opsporing wordt geheel aan het toeval overgelaten.

De VSV onderhandelt niet met individuele gebruikers van algemene voorwaarden en geeft eveneens niet aan hoe deze gebruikers hun allgemene voorwaarden vorm en inhoud dienen te geven. De VSV mag deze activiteiten niet ontplooien op grond van het Rechtsberatungsgesetz. Deze wet bepaalt dat individuele Rechtsberatung slechts mag geschieden door de advocatuur. Bovendien stelt de VSV zich op het standpunt dat haar statutaire doelstelling zich richt op consumenten en niet op het bedrijfsleven. De VSV bekijkt op verzoek van individuele gebruikers hoogstens welke van de door deze gebruikers opgestelde 
algemene voorwaarden in de opvatting van de VSV onredelijk bezwarend zijn; de zogenaamde negative Feststellung.

De VSV onderhandelt wêl met branche-organisaties over door deze organisaties aan hun leden aanbevolen algemene voorwaarden (Konditionenempfehlungen). Hoewel ook deze onderhandelingen zich aan de zijde van de VSV beperken tot de zogenaamde negative Feststellung, vergen deze onderhandelingen meestal langere tijd, waarbij vaak de uitslag van procedures tegen individuele gebruikers wordt afgewacht alvorens men over en weer tot een definitieve standpuntbepaling komt. ${ }^{7}$ In tegenstelling tot afdeling 6.5.3 BW brengt het onderhandelen op het terrein van de algemene voorwaarden niet met zich dat de consumentenorganisaties daardoor hun klachtrecht kunnen verwerken. Dit komt mede ook doordat de VSV enkel aan negative Feststellung doet en dus ook geen instemming in de zin van artikel 6:240 lid 5 BW kenbaar maakt. Dat er geen verval van recht plaatsvindt indien de VSV onderhandelt als hierboven omschreven, is inmiddels bevestigd in de rechtspraak. Het onderhandelen door de VSV is dan ook geënt op het vaststellen van onredelijk bezwarende bedingen die zij eventueel kan onderuithalen met $\S 13$ AGBG. Door de VSV werd er op gewezen dat onderhandelen vooral voordelig kan zijn in die situaties waarin nog niet vaststaat hoe de rechter mogelijk zal beslissen. In tegenstelling tot afdeling 6.5.3 heeft het AGB-Gesetz niet als onderliggend doel de marktpartijen aan de onderhandelingstafel te brengen.

\subsubsection{De Verbraucherzentrale Baden-Warttemberg}

De Verbraucherzentrale Baden-Württemberg stelt zich, net als de VSV, op het standpunt dat het AGB-Gesetz nagekomen moet worden. De ernst van het vergrijp, de verspreidingsgraad van de in het geding zijnde algemene voorwaarden, de markteconomische omvang van de gebruiker van die algemene voorwaarden, etcetera, doen er niet toe. Indien geconstateerd wordt dat algemene voorwaarden in strijd zijn met het AGB-Gesetz wordt opgetreden.

"Abgemahnt" wordt in beginsel slechts in die gevallen waarbij vaststaat dat de desbetreffende bedingen evident in strijd zijn met het AGB-Gesetz. Deze gevallen zijn zo talrijk dat de capaciteit van de Verbraucherzentrale BadenWürttemberg daarmee nagenoeg volledig wordt benut. Bij grensgevallen, bedingen waarbij de organisatie twijfelt omtrent eventuele strijd met het AGBGesetz, hangt het al dan niet optreden door de Verbraucherzentrale Baden-

7 Zie voor een procedure waarin door de VSV uitvoerige ondertandlelingen zijn gevoerd met de Deutscher Reisebüro-Ventand e.V. over de Allgemeine Geschaffsbedingungen far Reisevertralge: Mölenberg en Rijken, pag. 87-90. 
Württemberg onder andere af van factoren als verspreidingsgraad, algemeen nut: voor de consument en proceskostenrisico.

Bij de Abmahnung wordt de gebruiker van algemene voorwaarden in beginsel een termijn van 14 dagen gegeven om de gevraagde strafbewehrte Unterlassungserklärung af te geven. In de praktijk wordt met deze termijn echter soepel omgesprongen. Deze soepelheid wordt door de Verbraucherzentrale BadenWürttemberg vooral ingegeven door de gedachte dat zij bij de gebruikers niet de indruk wil vestigen dat de Verbraucherzentrale Baden-Württemberg koste wat het kost wil procederen, hetgeen wederom de bereidheid tot medewerking bij de gebruiker positief kan beînvloeden.

De herformulering of wijziging van "abgemahnte" algemene voorwaarden wordt aan de desbetreffende gebruiker overgelaten. De Verbraucherzentrale BadenWürttemberg geeft geen adviezen over inhoud en redactie van te wijzigen bedingen. Dit zou Rechtsberatung zijn en dat is op grond van thet Rechtsberatungsgesetz verboden. Bovendien stelt de vaste advocaat die in deze aan de Verbraucherzentrale adviseert, zich op het standpunt dat hij niet tegelijkertijd kan werken voor zowel de Verbraucherzentrale Baden-Württemberg als de gebruikers van algemene voorwaarden.

Onderhandelingen tussen de Verbraucherzentrale Baden-Württemberg en branche-organisaties over de inhoud van de door de gebruikers(organisaties) tegenover consumenten te hanteren algemene voorwaarden vinden niet plaats. Zowel de Verbraucherzentrale als haar advocaat bestempelen dergelijke onderhandelingen als "Wahnsinn", omdat dit onderhandelen niet effectief zou zijn. Het onderhandelen brengt immers veel werk met zich en verlangt een gedegen expertise van consumentenorganisaties, het gevaar bestaat dat gebruikers de onderhandelingen onnodig rekken en onderhandelen kost enorm veel tijd en dus ook gell.

Wel worden herziene versies (zogenaamde Neufassungen) van "abgemahnte" algemene voorwaarden die door gebruikers ter beoordeling aan de Verbraucherzentrale Baden-Württemberg worden voorgelegd, beoordeeld in die zin dat (slechts) vastgesteld wordt of de desbetreffende bedingen volgens de Verbraucherzentrale al of niet in strijd zijn met het AGB-Gesetz (negative Feststelhung). Instemming zijdens de Verbraucherzentrale Baden-Württemberg met opnieuw geredigeerde algemene voorwaarden wordt slechts gegeven onder het voorbehoud dat de instemming berust op de dan heersende rechtsopvattingen en dat het andere consumentenorganisaties nog steeds vrijstaat om te procederen indien zij van mening mochten zijn dat het desbetreffende beding in strijd is met het AGBGesetz. Indien de Verbraucherzentrale Baden-Württemberg, nadat zij op een eerder tijdstip aan de gebruiker te kennen had gegeven dat zij bedingen niet in strijd achtte met het AGB-Gesetz, deze bedingen alsnog abmahnt, worden geen 
Abmahnkosten in rekening gebracht en wordt heel soepel omgesprongen met een verzoek zijdens de gebruiker om een Aufbrauch- of Umstellungsfrist. De Verbraucherzentrale Baden-Württemberg wordt verder door gebruikers en branche-organisaties niet betrokken bij het opstellen van algemene voorwaarden.

Ook bij de Verbraucherzentrale Baden-Württemberg vragen de gebruikers geregeld een Aufbrauch- of Umstellungsfrist. Ofschoon het Bundesgerichtshof (BGH) heeft beslist dat een dergelijke termijn door de consumentenorganisaties niet behoeft te worden toegestaan, bekijkt de Verbraucherzentrale BadenWürttemberg echter van geval tot geval of er een Aufbrauch- of Umstellungsfrist aan de gebruiker wordt verleend en wordt meestal een termijn van 1 à 2 maanden toegestaan. Deze termijn wordt echter eerst toegestaan nadat een strafbewehrte Unterlassungserklärung van de gebruiker verkregen is. De Verbraucherzentrale Baden-Württemberg geeft aan gebruikers vaak het advies om een stempel of sticker te laten maken - dit kan doorgaans binnen een week waarmee de gebruiker op vrij eenvoudige wijze aan de consument kenbaar kan maken dat de "abgemahnte" bedingen uit de algemene voorwaarden niet meer van toepassing zijn. De Verbraucherzentrale Baden-Württemberg stelt zich soepel op ten aanzien van een verzoek van een gebruiker voor een Aufbrauchof Umstellungsfrist omdat van deze soepelheid vaak de bereidheid van gebruikers om een strafbewehrte Unterlassungserklärung af te geven afhankelijk is. Ook de Verbraucherzentrale Baden-Württemberg heeft ervaren dat gebruikers er wel eens mee dreigen dat zij het op een proces laten aankomen (en dus tijdverlies, etcetera), indien de Verbraucherzentrale Baden-Württemberg niet een dergelijke termijn toestaat. Indien de toegestane termijn door de gebruiker wordt overschreden effectueert de Verbraucherzentrale Baden-Württemberg (desnoods bij de rechter) de contractuele boete uit de strafbewehrte Unterlassungserklärung.

De door de Verbraucherzentrale Baden-Württemberg gevorderde contractuele boete in strafbewehrte Unterlassungserklärungen bedraagt doorgaans 1000 , = DM per overtreding van én "abgemahnt" beding. Omdat de Verbraucherzentrale Baden-Württemberg wil vermijden dat gebruikers het idee krijgen dat het de Verbraucherzentrale Baden-Württemberg enkel om het geld te doen is, wordt bij Abmahnung van meer dan drie bedingen een maximum boete gehanteerd van $3500,=\mathrm{DM}$. Criterium bij het vaststellen van de hoogte van de contractuele boete is dat deze hoog genoeg moet zijn om de gebruiker van hergebruik te doen afzien (hinreichende Drohung).

65\% van alle Abmahnungen van de Verbraucherzentrale Baden-Württemberg hebben tot een strafbewehrte Unterlassungserklärung geleid, waarmee de buitengerechtelijke fase ongeveer eenzelfde effectiviteit vertoont als die bij de VSV. 
De kosten van de Abmahnung worden, in tegenstelling tot de VSV, in rekening gebracht bij de desbetreffende gebruiker op grond van Geschäftsführung ohne Auftrag (zaakwaarneming). De heer Stillner heeft een permanente adviesovereenkomst (Beratungsvertrag) met de Verbraucherzentrale Baden-Württemberg. $\mathrm{Hij}$ is daarnaast tevens belast met de Abmahnungen en brengt de kosten die hij in dat kader maakt in rekening bij de desbetreffende gebruiker. De kosten bedragen 150, = DM per Abmahnung. Indien de Verbraucherzentrale Baden-Württemberg geen gebruik zou maken van een advocaat, maar zelf de bevoegdheid om "abzumahnen" zou waarnemen, zou zij daarvoor een jurist en een secretaresse in dienst moeten nemen, een (extra) schrijfmachine of tekstverwerker moeten aanschaffen en dergelijke. Dit zou de Verbraucherzentrale Baden-Württemberg ongeveer $120,=\mathrm{DM}$ per Abmahnung kosten, een bedrag dat in de beginjaren van het AGB-Gesetz ( \pm 15 jaar geleden) in de rechtspraak als redelijk is bestempeld. In ansluiting hierop zijn de kosten van een Abmahnung vastgesteld op $150_{;}=$DM. Naast deze Abmahnkosten ontvangt de advocaat een vast maandelijks bedrag voor juridisch advies inzake consumentenklachten en de inhoudscontrole van algemene voorwaarden. Door deze constructie zijn de kosten van de rechtshandhaving op het gebied van de algemene voorwaarden voor de Verbraucherzentrale Baden-Württemberg aanzienlijk lager dan voor de VSV, waar een aantal juristen in vast dienstverband werkzaam zijn.

Door de Verbraucherzentrale Baden-Württemberg wordt niet gericht gecontroleerd of "abgemahnte" gebruikers zich aan de contractuele afspraken of rechterlijke uitspraken houden. Wél wordt aan alle medewerkers van de Verbraucherberatungsstellen wekelijks een lijst gezonden met "abgemahnte" gebruikers, veroordelingen van gebruikers, de desbetreffende bedingen en de eventueel verkregen strafbewehrte Unterlassungserklärungen. Indien dan naar aanleiding van individuele consumentenklachten wordt geconstateerd dat een beding of een beding van gelijke strekking in strijd met een strafbewehrte Unterlassungserklärung toch wordt gehanteerd door de desbetreffende gebruiker, wordt de contractuele boete (desnoods via de rechter door middel van het zogenaamde Vertragsstrafeverfahren of een schikking) geëffectueerd.

\subsection{Voorlopige voorziening}

Een voorlopige voorziening in de rechtsgang van de Unterlassungsanspruch (verbodsactie) wordt in de literatuur en rechtspraak algemeen voor mogelijk 
gehouden, met name bij verbodsacties tegen het gebruik van algemene voorwaarden waarvan het onredelijk bezwarend karakter onomstotelijk vaststaat. ${ }^{8}$

\subsubsection{De VSV}

Volgens de VSV werd vooral in de beginjaren van het AGB-Gesetz door de rechters in een aantal deelstaten, analoog aan het UWG, in de AGB-procedure een Antrag auf Erlab einer einstweiligen Verfügung (kort geding) toelaatbaar geacht. De spoedeisendheid werd zonder meer aangenomen indien er een herhalingsgevaar bestond, waarvoor weer voldoende was dat de gebruiker van algemene voorwaarden weigerde een strafbewehrte Unterlassungserklärung af te geven. Te constateren valt echter eveneens dat er in deze beginjaren een aantal Oberlandesgerichte (OLG $=$ de hoogste rechterlijke instantie op deelstaatniveau) de opvatting was toegedaan dat een voorlopige voorziening bij gebrek aan een uitdrukkelijke wettelijke regeling niet was toegelaten.

Volgens de VSV begint deze laatste opvatting de laatste jaren steeds meer terrein te winnen en wordt het in toenemende mate problematisch om een verzoek om een voorlopige voorziening gehonoreerd te krijgen, бók bij die Oberlandesgerichte die aanvankellijk de einstweilige Verfügung wél toestonden. De "Dringlichkeits"-eis is namelijk aangescherpt en de spoedeisendheid wordt niet zonder meer vermoed aanwezig te zijn. De stelling dat het karakter van algemene voorwaarden - algemene voorwaarden worden immers opgesteld teneinde een aantal malen te worden gebruikt - zonder meer met zich brengt dat er een herhalingsgevaar bestaat, wordt niet meer geaccepteerd door de meeste rechters. Consumentenorganisaties moeten aantonen dat er een concreet herhalingsgevaar bestaat. De oorzaak van deze veranderde opvatting moet volgens de VSV voornamelijk gezocht worden in een vrees voor overbelasting van de rechterlijke macht met einstweilige Verfügungen. De Antrag auf Erlaß einer eïnstweiligen Verfügung werd daarom slechts terughoudend en de laatste jaren helemaal niet meer gehanteerd door de VSV. In de onderzochte periode van 16 jaar werd het verzoek voor een voorlopige voorziening gemiddeld iets meer dan 1 maal per jaar gedaan.

\subsubsection{De Verbraucherzentrale Baden-Wurttemberg}

Evenals bij de VSV wordt een Antrag auf Erlaß einer einstweiligen Verfügung door de Verbraucherzentrale Baden-Württemberg in de praktijk niet meer gehanteerd. In de eerste drie jaar dat het AGB-Gesetz van kracht was, heeft de 
Verbraucherzentrale wel met succes gebruik gemaakt van de voorlopige voorziening (17 keer), totdat een verzoek om een voorlopige voorziening bij het Landgericht Heilbronn leidde tot een veroordeling in de kosten van dat geding. Kostenoverwegingen hebben er vervolgens toe geleid dat dit procesmiddel door de Verbraucherzentrale Baden-Württemberg niet meer wordt gehanteerd.

\subsection{Verbodsvordering}

Door de Verbraucherzentrale Baden-Württemberg en de VSV zijn van 1 april 1977 tot en met 31 december 1992 in totaal 1082 verbodsacties en 35 verbodsacties bij wege van een Antrag auf Erlaß einer einstweiligen Verfügung gevoerd. Problemen met de toepassing van de procesrechtelijke voorschriften deden zich daarbij niet in een noemenswaardige omvang voor.

\subsection{De VSV}

In ruim $63 \%$ (708) van alle gevallen (1116) waarin de Abmahnung niet leidde tot een strafbewehrte Unterlassungserklärung werd door de VSV overgegaan tot een verbodsactie. Ongeveer $86 \%$ van deze gerechtelijke procedures werd gewonnen en ongeveer 10\% leidde tot een schikking, hetgeen betekent dat tijdens de procedure alsnog een strafbewehrte Unterlassungserklärung werd afgegeven door de tegenpartij. Op andere voorstellen tot een schikking gaat de VSV principieel niet in, zelfs niet indien de rechter een schikkingscomparitie gelast."

Zoals reeds eerder vermeld, mogen de juristen in dienst van de VSV - net als in Nederland de juristen in dienst van de consumentenorganisaties - niet als advocaat optreden voor de VSV omdat ze niet onafhankelijk zijn van de VSV. Voor het optreden in rechte wordt derhalve gebruik gemaakt van onafhankelijke advocaten. De "eigen" juristen doen in beginsel alleen de "Abmahn"-fase. De in het (financieel) jaaroverzicht 1992 opgenomen kostenpost Prozeßkosten AGBBereich van $72.000,=$ DM bestaat daarom voornamelijk uit de advocaat- en proceskosten. Zoals reeds vermeld zijn deze advocaat- en proceskosten zijn in Duitsland afhankelijk van de hoogte van de Streitwert van de desbetreffende procedure. Bij de verbodsacties gevoerd door de VSV varieert deze Streitwert doorgaans van $2000,=$ tot $5000,=D M$ per beding. Bij procedures omtrent bedingen in algemene voorwaarden van enige economische betekenis kan de waarde van de procedure echter snel oplopen. Zo bijvoorbeeld in de procedure van de VSV betreffende een algehele exoneratieclausule in de tweedehands 
auto-branche $20.000=\mathrm{DM}^{10}$, de procedure tegen een Hamburgs huwelijksbemiddelingsbureau waarin het bestaan van dit bureau afhing van de uitkomst van de procedure $300.000,=D M^{11}$, de procedure tegen de "Lufthansa" betreffende 6 clausules $180.000,=D^{12}$ en de procedure tegen de automobielbranche betreffende een prijswijzigingsclausule en de op grond daarvan doorberekende BTW-verhoging $100.000=\mathrm{DM}^{13}$.

Ongeveer $86 \%$ van alle in rechte aangespannen zaken wordt echter gewonnen - hetgeen impliceert dat de tegenpartij de honoraria van de advocaten en de proceskosten dient te betalen - zodat het voor Prozeßkosten AGB-Bereich begrote bedrag (het zogenaamde Prozeßkostenfonds, in $199272.000,=\mathrm{DM}$ ) meestal niet ten volle wordt benut. In tegenstelling tot de Nederlandse situatie brengt het winnen van een proces in Duitsland met zich dat alle kosten (ook de honoraria van advocaten) betaald dienen te worden door de verliezende procespartij. Dit is alleen anders indien de verliezende partij geen verhaal biedt. Sinds kort is met het Bundeswirtschaftsministerium afgesproken dat de opbrengst van de door de VSV geëffectueerde contractuele boetes (op grond van de strafbewehrte Unterlassungserklärung) mogen worden bijgeboekt bij het Prozeßkostenfonds. Vór 1987 werd de opbrengst van deze contractuele boetes nog in mindering gebracht op de jaarlijks door het Bundeswirtschaftsministerium te verstrekken subsidie. Het Bundeswirtschaftsministerium heeft echter uitdrukkelijk bedongen dat de opbrengst van de geëffectueerde contractuele boetes niet mag worden benut voor andere zaken zoals bijvoorbeeld het in dienst nemen van meer personeel.

Het Prozeßkostenfonds wordt mede aangehouden voor het geval de VSV een procedure weliswaar wint, maar de tegenpartij in de tussentijd failliet is gegaan, daardoor geen verhaal biedt en de VSV zou moeten opkomen voor niet alleen haar eigen advocaatkosten maar ook de kosten van de gerechtelijke procedure.

In de literatuur is, naar de tarieven van 1983, berekend dat in een procedure met een maximale Streitwert van $500.000=0 \mathrm{DM}$ die wordt gevoerd tot in hoogste instantie, alleen al de advocaatkosten circa $80.000=0 \mathrm{DM}$ kunnen bedragen. ${ }^{14}$ Dit zou kunnen betekenen dat de bereidheid van consumentenorganisaties tot het voeren van procedures mede afhangt van het procesrisico dat zij daarbij lopen. Met name bij gecompliceerde, lees riskante, procedures tegen grote ondernemingen en marktleiders zouden deze overwegingen een rol kunnen spelen. Immers verlies van én van dergelijke procedures zou de proceskostenvoorziening voor meer dan een jaar kunnen opslokken. Een indicatie voor de

10 BGHZ 74, 383, NJW 1979, pag. 1886.

11. OLG Hamburg, 10 U 31/78, W/M 1978 , paig. 1358.

12 BGH, BB 1983, pag. 527.

13 OLG Frankfurt, 6 U 57/78, BB 1983, Beilage 11, pag. 7 .

14 Bohle en Micklitz, pag. 6; Axmann, pag. 108. 
stelling dat de VSV zich bij de keuze van de te voeren procedures mede laat: leiden door het te verwachten financiële risico, ligt besloten in het feit dat: slechts $2 \%$ ( $86 \%$ gewonnen, $10 \%$ schikking en $2 \%$ teruggetrokken gedurende de procedure) van alle gevoerde procedures wordt verloren en dat uiteindelijk $84 \%$ van alle Abmahnungen heeft geleid tot een, vanuit consumentenperspectief, positief resultaat.

\subsubsection{Verbraucherzentrale Baden-Wurttemberg}

Indien geen Unterlassungserklärung wordt verkregen van de desbetreffende gebruiker, wordt in ruim 51\% (409) van de gevallen (795) overgegaan tot de gerechtelijke fase door middel van het instellen van een Unterlassungsklage of een verzoek voor een voorlopige voorziening.

De deelstaat Baden-Württemberg heeft gebruik gemaakt van haar bevoegdheid om de abstracte procedure als bedoeld in $\$ 13$ AGBG te concentreren bij eén of meerdere Landgerichte ( $\$ 14$ lid 2 AGBG) ${ }^{15}$ Voor het gebied dat wordt bestreken door het Oberlandesgericht Stuttgart is het Landgericht Stuttgart bevoegd dat een speciale AGB-kamer heeft. Het Oberlandesgericht Stuttgart heeft geen speciale AGB-Kamer. AGB-procedures worden daar behandeld door de 6. Senat für Verbraucherfragen. ${ }^{16}$

Voor Hessen, het gebied dat bestreken wordt door het Oberlandesgericht Frankfurt is het Landgericht Frankfurt bevoegd dat eveneens een bijzondere AGB-kamer (20. Kammer) heeft. Bij het Oberlandesgericht Frankfurt worden AGB-procedures behandeld door de 2. Zivilsenat.

Voordeel van zo'n speciale kamer en van concentratie van alle procedures bij én Gericht is een grote mate van deskundigheid van de rechter(s), voorspelbaarheid van uitspraken van deze rechter(s) en het feit dat de Verbraucherzentrale Baden-Württemberg niet meer elk detail van het AGB-Gesetz hoeft uit te leggen aan de rechter (tijdwinst).

Voor het gebied dat bestreken wordt door het Oberlandesgericht NürnbergFürth is het Landgericht Nürnberg-Fürth bevoegd en voor het gebied dat bestreken wordt door het Oberlandesgericht München het Landgericht München. Niet bekend is of deze Gerichte een speciale AGB-kamer hebben. Wel wordt door de Verbraucherzentrale Baden-Württemberg aangegeven dat met name bij het Landgericht Karlsruhe de uitkomst van een procedure sterk afhangt van de Kammer die kennis neemt van de procedure.

15 Zie hiervoor paragranf 6.3.7.2.

16 Een soort wan "consumentenkamer". In Nederland wordt een dergeljike speciale kamer voorgegtaan door Boer, pag. 48 e.v. 
In de procedure als bedoeld in $\$ 13$ AGBG wordt slechts zelden overgegaan tot een schikking (Vergleich). Een schikking leidt immers tot deling van de gerechtskosten en dat is niet in het belang van de Verbraucherzentrale BadenWürttemberg. Indien de procedure wordt gewonnen wordt de tegenpartij immers veroordeeld tot betaling van zowel de gerechtskosten als de advocaatkosten. De Verbraucherzentrale Baden-Württemberg is derhalve in beginsel alleen bereid tot een schikking, indien de gerechts- en advocaatkosten gedragen worden door tegenpartij en deze tevens een strafbewehrte Unterlassungserklärung afgeeft.

In de regel betreft de gerechtelijke activiteit van de Verbraucherzentrale Baden-Württemberg een Unterlassungsklage en nooit een Widerrufsklage.

De lange duur van de gerechtelijke procedure als bedoeld in $\$ 13$ AGBG wordt door de Verbraucherzentrale Baden-Württemberg als een nadeel ervaren. Gemiddeld duurt het 6 maanden (nach Klageerhebung) alvorens het Landgericht tot een uitspraak komt. Een uitspraak in hoger beroep bij het Oberlandesgericht laat gemiddeld 6 tot 8 maanden op zich wachten. Een eventuele cassatieprocedure bij het BGH neemt gemiddeld 2 jaar in beslag. ${ }^{17}$ In gevallen waarin sprake is van evident onredelijk bezwarende algemene voorwaarden theeft de tegenpartij de mogelijkheid om dit te erkennen (anerkennen). Indien de tegenpartij van deze mogelijkheid gebruik maakt, volgt een versnelde procedure. Ongeveer de helft van alle Unterlassungsklagen worden in "Anerkenntniss" en dus versneld afgedaan.

De Verbraucherzentrale Baden-Württemberg merkt op dat de procedure in eerste aanleg bij het Landgericht Stuttgart gemiddeld ongeveer 4 maanden in beslag neemt. Dit is volgens de Verbraucherzentrale Baden-Württemberg enerzijds te danken aan het feit dat het Landgericht Stuttgart een speciale AGBKamer heeft en anderzijds omdat de procedures meestal evident onredelijk bezwarende algemene voorwaarden betreffen.

De Streitwert, dat is de factor die in Duitsland bepalend is voor de hoogte van de gerechts- en advocaatkosten, van Unterlassungsklagen varieert in de procedures gevoerd door de Verbraucherzentrale van $1000,=$ tot $5000,=\mathrm{DM}$ per beding. Dit leidde er toe dat de Streitwert van door de Verbraucherzentrale Baden-Württemberg gevoerde procedures varieerde van $5000,=$ tot $50.000=$ DM. De in $\& 22$ AGBG genoemde wettelijke maximum Streitwert van $500.000,=D M$ is in geen enkele procedure bereikt.

17 Met name in de feitelijke instanties krijgt men in Duitsland een uitspraak aanmerkelijk veel sneller dan in Nederland. Daar staat tegenower dat in ons systeem door én rechter (het Haagse Hof) in slechts éen feitelijke instantie ower deze collectieve acties wordt beslist. Dat bevordert een redelijik snelle procesgang. 
De gerechtskosten van een procedure als bedoeld in $\$ 13$ AGBG liggen volgens de Verbraucherzentrale tussen de $1500,=$ en $5000,=D M$. De proces- en advocaatkosten tezamen bedragen gemiddeld $5000=\mathrm{DM}$. Volgens \& $91 \mathrm{ZPO}$ worden de proces- en advocaatkosten gedragen door de verliezende partij. De Verbraucherzentrale Baden-Württemberg beschikt niet over een speciaal proceskostenfonds of een expliciete begrotingspost voor AGB-proceskosten. Toch worden uit de algemene middelen $12.000,=\mathrm{a} 13.000,=\mathrm{DM}$ gereserveerd voor procedures van bijzonder belang voor de ontwikkeling van het consumentenrecht. De resterende procedures worden betaald uit de algemene begroting. Mef tegenvorderingen van gebruikers van algemene voorwaarden is de Verbraucherzentrale Baden-Württemberg tot nu toe niet geconfronteerd.

Opmerkelijk is dat van de door de Verbraucherzentrale Baden-Württemberg gevoerde procedures ongeveer $91 \%$ wordt gewonnen en $3 \%$ leidt tot een schikking. Daarmee leidt $82 \%$ van alle Abmahnungen uiteindelijk tot een, vanuit consumentenperspectief, positief resultaat. Net als bij de VSV lijkt dit hoge winstpercentage een indicatie voor de conclusie dat de keuze van te voeren procedures, als gevolg van de financiële mogelijkheden, mede bepaald wordt door de winstkansen.

\subsection{Gebodsvordering}

De Widerrufsklage, de gebodsactie tegen de aanbeveler van algemene voorwaarden om zijn aanbevelingen te herroepen wordt in Duitsland, vanwege de Überregionale Bedeutung enkel ingesteld door de VSV.

Volgens de jaarverslagen heeft de VSV van 1 april 1977 tot en met $3 !$ december 1992 tien procedures tegen aanbevelers (Empfehler) gevoerd.

\subsection{Vertragsstrafeklage}

Zowel door de VSV als de Verbraucherzentrale Baden-Württemberg wordt njet gericht gecontroleerd of "abgemahnte" gebruikers zich aan de contractuele afspraken houden. Wêl wordt aan alle Verbraucherzentralen respectievelijk Verbraucherberatungsstellen doorgegeven welke bedingen van welke gebruiker zijn "abgemahnt" en voor welke bedingen een strafbewehrte Unterlassungserklärung is verkregen. Indien deze Verbraucherzentralen respectievelijk Verbraucherberatungsstellen constateren (in de regel naar aanleiding van individuele consumentenklachten) dat een "abgemahnt" beding of een beding van gelijke strekking toch wordt gehanteerd door de desbetreffende gebruiker, wordt de contractuele boete onmiddellijk (desnoods via de rechter) geëffectueerd. Gericht onderzoek naar hergebruik van algemene voorwaarden die 
onderwerp zijn van een strafbewehrte Unterlassungserklärung vindt echter niet plarats.

Tot 1 januari 1993 werden door de VSV 38 en door de Verbraucherzentrale Baden-Würtemberg 24 gerechtelijke procedures ter verkrijging van een contractuele boete (Vertragsstrafeklage) gevoerd.

\subsection{Ordnungsgeldverfahren}

Door de beide consumentenorganisaties wordt evenmin gericht gecontroleerd of gebruikers zich wel houden aan rechterlijke uitspraken waarin hen, op straffe van een dwangsom (Ordnungsgeld), verboden wordt bepaalde algemene voorwaarden te gebruiken. Overtredingen komt men ook hier doorgaans op het spoor naar aanleiding van individuele consumentenklachten. In de periode tot $\mathbb{1}$ januari 1993 zijn door zowel de VSV als de Verbraucherzentrale Baden-Württemberg negen gerechtelijke procedures gevoerd waarin de veroordeling tot betaling van een dwangsom (Ordnungsgeldverfahren) gevorderd werd.

\subsection{Registratie als bedoeld in $\$ 20$ AGBG}

Op grond van $\$ 20$ AGBG worden alle aanhangige procedures als bedoeld in \$ 13 AGBG en de rechterlijke uiltspraken daarin geregistreerd bij het Bundeskartellamt (BKA). Ratio van deze registratie is een snelle en volledige informatie over de actuele stand van de rechtspraak voor het geïnteresseerde publiek, de rechterlijke macht, de overheid en de actiegerechtigde organisaties. Tegelijkertijd zou deze registratie de collectieve actie een grotere breedtewerking verschaffen.

In de praktijk wordt echter slechts spaarzaam gebruilk gemaakt van de diensten van het BKA op dit gebied. Zo blijkt uit onderzoek van Axmann ${ }^{18}$ dat medio 1986 slechts een groep van 20 "vaste" abonnees regelmatig de registraties van het BKA ontvangt. Deze groep bestond uit zeven federale branche-organisaties, drie universiteiten, zeven advocatenkantoren, én uitgever, de Landeskartellbehörde Berlin, het Landgericht Berlin en de VSV. Navraag door mij bij het BKA $^{19}$ leerde dat medio juli 1993 nog maar een groep van 15 vaste abonnees regelmatig de registraties van het BKA ontving. Daarvan kregen zeven abonnees alle registraties en acht abonnees slechts de registraties met betrekking

18. Axmann, pag. 109 en 148.

19 In het kader van dit onderzoek heb ik het BKA te Berligin op 1 en 2 juli 1993 bezocht en mader onderzoek gedean met betrekking tot de registraties. Nadere informatie over het AGB-register werd mij wan de zijde van het BKA verstrekt door Mevr. Topel en Dhr. Wagemann. 
tot bepaalde branches. Deze geringe interesse is waarschijnlijk te wijten aan de ontoereikende inhoud van de registraties. ${ }^{20}$

Het register wordt gemiddeld ongeveer 30 keer per jaar geraadpleegd, meestal door advocaten. Voor de schriftelijke informatie in de vorm van fotokopieën van de desbetreffende registraties brengt het BKA voor de eerste 50 kopieën $1,=D M$ per kopie in rekening en voor alle kopieën daarboven 0,30 DM per kopie. Indien consumenten ("Privatpersonen") informatie wensen ziji de eerste 10 tot 12 kopieën gratis. Omdat het BKA ook mondeling informatie verstrekt krijgt het BKA ook geregeld telefonische verzoeken om informatie, meestal van advocaten die informatie wensen voor concrete gevallen op hat gebied van algemene voorwaarden waarmee zij in hun praktijk te maken hebben. Beide consumentenorganisaties geven aan dat zij slechts sporadisch gebruik maken van het BKA-register. 


\section{Toepassingsgebieden en spreiding van de AGB-rechtshandhaving}

\subsection{Inleiding}

Kwantitatieve aspecten laten slechts een deel zien van de werking van het collectief vorderingsrecht ex $\$ 13$ AGBG zoals dat door Duitse consumentenorganisaties wordt gehanteerd. Een nader beeld van de uitoefening van het collectief actierecht door consumentenorganisaties op het terrein van de algemene voorwaarden verkrijgt men door te kijken naar de verschillende branches die betrokken zijn bij de verschillende procedures, de soorten bedingen die onderwerp zijn van de procedures en de regionale spreiding van de rechtshandhaving. De navolgende gegevens zijn ontleend aan onderzoek van $A x m a n n^{1}$, eigen onderzoek bij het BKA, de Verbraucherzentrale Baden-Württemberg en de VSV, en uit de jaarverslagen van de VSV. Op de regionale spreiding van de rechtshandhaving in Duitsland zal slechts zeer beknopt worden ingegaan omdat deze voor de Nederlandse situatie slechts van ondergeschikt belang is.

\subsection{Regionale spreiding}

Door de verschillende bij het Bundeskartellamt in de periode van 1 april 1977 tot 1 april 1983 geregistreerde uitspraken in te delen naar deelstaat en daarna te onderzoeken welke van de actieve consumentenorganisaties als eiser in die deelstaat bij welke "rechtbank" optraden, komt Axmann tot de conclusie dat de meeste initiatieven die tot deze uitspraken hebben geleid, zijn uitgegaan van de Verbraucherzentrale Baden-Württemberg en dat deze consumentenorganisatie de rechtshandhaving op het gebied van de algemene voorwaarden in de eigen deelstaat grotendeels zelf ter hand neemt en deze niet overdraagt aan de VSV'. Slechts in twee gevallen was de VSV actief in Baden-Württemberg. Voorzover de VZ Baden-Württemberg optrad buiten haar eigen deelstaat was dit omdat de gedaagde zijn woonplaats had in die andere deelstaat, maar zijn algemene 
voorwaarden gebruikte in Baden-Württemberg. De activiteiten van de WSV waren in tegenstelling tot de VZ Baden-Württemberg verspreid over de gehele. Bondsrepubliek, waarmee de functie van de VSV als uitvoerend orgaan van de Verbraucherzentralen nog eens wordt onderstreept. Statutair doel van de VSV is immers de uitwoering van de door de Verbraucherzentrallen, voor de handhaving van het consumentenbelang, noodzakelijk geachte gerechtelijke procedures. De zwaartepunten van de activiteiten van de VSV lagen in Berlijn en de deelstaten Bayern, Hessen en Nordrhein-Westfalen.

In een aantal deelstaten is de VSV nauwelijks actief geweest. Omdat volgens de VSV toentertijd $80 \%$ van alle gecontroleerde (sets van) algemene voorwaarden afkomstig waren van de Verbraucherzentralen geeft de spreiding van de activiteiten van de VSV naar deelstaat een beeld van de opsporingsactiviteiten van de Verbraucherzentrale in die deelstaat en daarmee ook van de rechtshandhaving op het gebied van de algemene voorwaarden in die deelstaat. Axmann komt tot de conclusie dat van een systematische en evenwichtig over de verschillende deelstaten verspreide inhoudelijke controle van algemene voorwaarden in de Bondsrepubliek geen sprake is.

\subsection{Branchegewijze spreiding}

De reikwijdte van de rechtshandhavingsactiviteiten wordt nader geconcretiseerd door te onderzoeken in welke branches het gebruik van bepaalde algemene voorwaarden is "abgemahnt" of is opgetreden door middel van een procedure als bedoeld in $\$ 13$ AGBG.

Eerder onderzoek van Axmann toont aan dat de branchegewijze spreiding van de rechtshandhaving bij de Abmahnungen en procedures van de VSV representatief is voor rechtshandhavingsactiviteiten van de andere consumentenorganisaties in de gehele Bondsrepubliek. De onderstaande gegevens zijn daarom gebaseerd op de door de VSV in de periode van 1 april 1977 tot 1 januari 1993 uitgevoerde 2683 Abrnahnungen (afbeelding 1) en 708 procedures ex \&13 AGBG (afbeelding 2). De verschillende Abmahnungen en procedures zijn daarbij onderverdeeld in de volgende 24 branches:

1. Auto's en motoren

2. Banken en Bausparkassen

3. Bouw en renovatie

4. Computer

5. Dienstverlening

6. Partnerbemiddeling

7. Huishoudel. apparatuur/elektronica

8. Sport/fitness/vrije tijd/gezondheid
13. Kredietbemiddeling

14. Levensmiddelen

15. Meubelen

16. Reizen

17. Verkoop- en demonstratiereizen

18. Mode/boutiques/textiel

19. Uitgeverijen/tijdschriften

20. Verhuur en lease 
9. Foto

10. Onroerend goed

11. Warenhuizen

12. Kosmetica
21. Postorderbedrijven

22. Verzekeringen

23. Radio/TV/video

24. Overige

De cijfers in de grafieken corresponderen met de hierboven genoemde branches.

De overzichten laten zien dat de meeste Abmahnungen van de VSV zijn uitgegaan naar de volgende 5 branches:

1. Dienstverlening, 295 Abmahnungen;

2. Huishoudelijke apparatuur en elektronica, 285 Abmahnungen;

3. Reizen, 278 Abmahnungen;

4. Meubelen, 278 Abmahnungen;

5. Huizenbouw en renovatie, 265 Abmahnungen.

Dezelfde branches zijn eveneens koploper voor wat betreft het aantal door de VSV gevoerde procedures. De onderlinge posities zijn echter verschoven, hetgeen mogelijk een indicatie is voor de procesbereidheid in de verschillende branches.

1. Dienstverlening, 90 procedures;

2. Huizenbouw en renovatie, 86 procedures;

3. Huishoudelijke apparatuur en elektronica, 58 procedures;

3. Meubelen, 53 procedures;

5. Reizen, 42 procedures.

Omdat doorgaans een individuele consumentenklacht aan de Abmahnung ten grondslag ligt, geeft de onderverdeling naar branches enerzijds aan in welke branches consumenten geconfronteerd worden met onredelijk bezwarende algemene voorwaarden en anderzijds een indicatie voor de mate waarin de consument in de verschillende branches geconfronteerd wordt met onredelijk bezwarende algemene voorwaarden. De onderverdeling maakt in ieder geval duidelijk dat consumenten in bijna elke branche geconfronteerd worden met onredelijk bezwarende algemene voorwaarden.

Van alle Abmahnungen (2683) heeft 26,4\% (708) geleid tot een procedure. $26,4 \%$ is dan de gemiddelde procesbereidheid van de "abgemahnte" gebruikers. Het percentage Abmahnungen dat in een bepaalde branche tot procedures leidt, geeft vervolgens een indicatie over de procesbereidheid in een bepaalde branche. 


\section{Afbeelding 1}

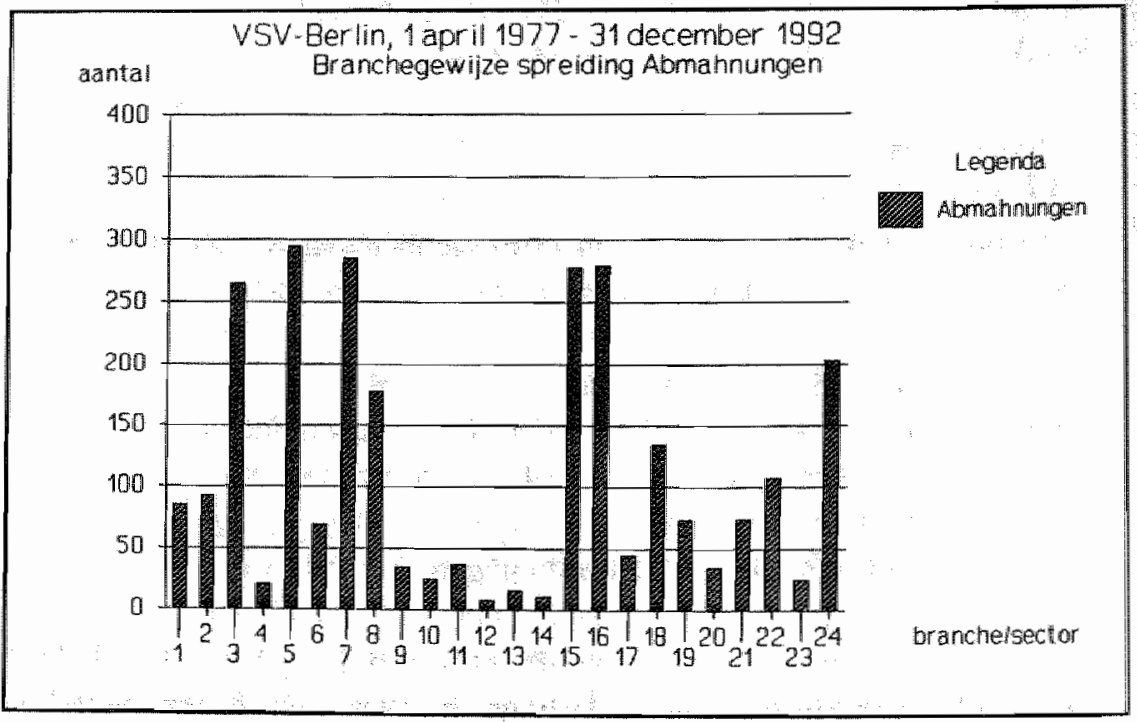

\section{Afbeelding 2}

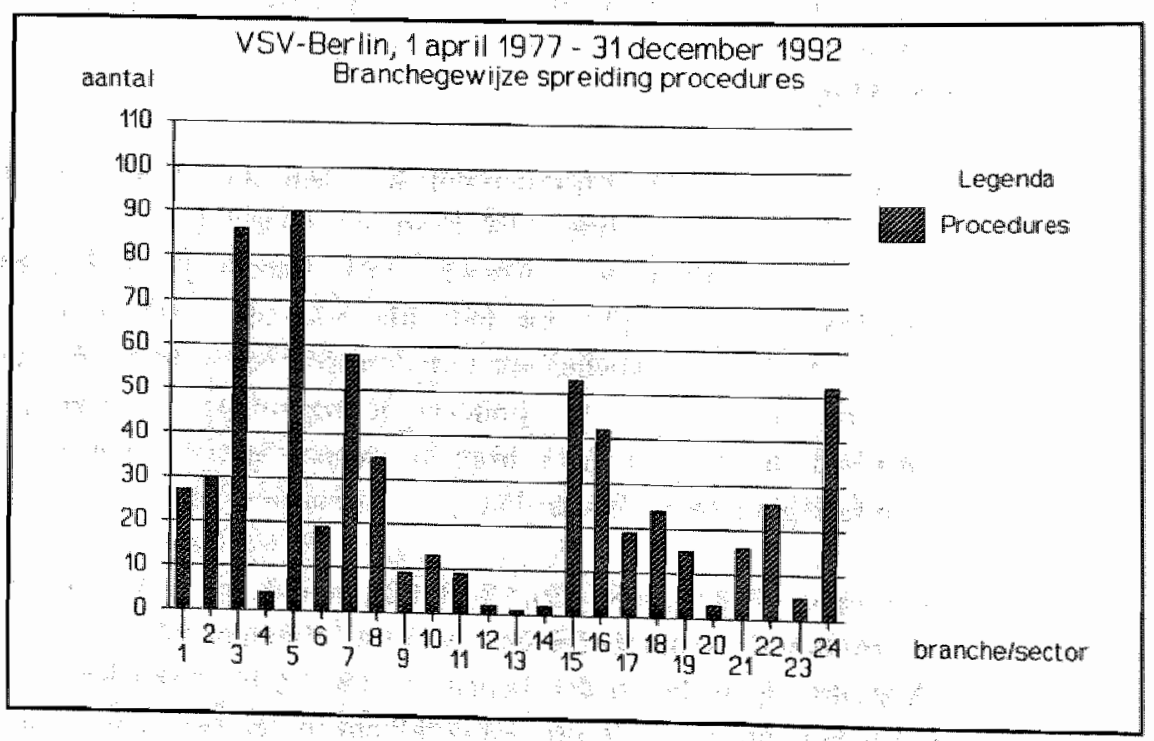


Het onderstaande overzicht (afbeelding 3) geeft een indicatie van de procesbereidheid in de verschillende branches, uitgedrukt in percentages gevoerde procedures.

\section{Afbeelding 3}

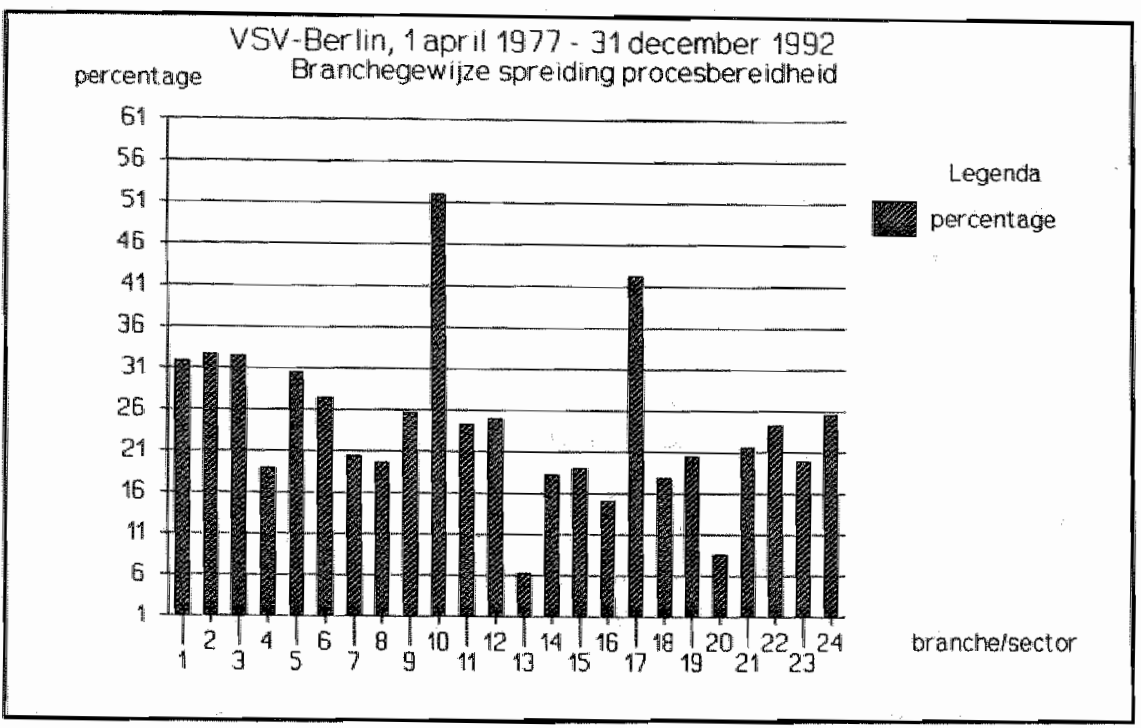

De top vijf in deze categorie wordt gevormd door de volgende branches:

1. Onroerend goed, $52 \%$;

2. Verkoops- en demonstratiereizen, $42,2 \%$;

3. Banken en Bausparkassen, $32,6 \%$;

4. Huizenbouw en renovatie, $32,5 \%$;

5. Auto's en motoren, $31,8 \%$.

\subsection{Spreiding naar soort onredelijk bezwarend beding}

Om een overzicht te krijgen van de inhoud van de verschillende bedingen die voorwerp waren van de verschillende $\$ 13$ AGBG-procedures, heeft Axmann de wan 1 april 1977 tot 1 april 1983 bij het Bundeskartellamt (BKA) geregistreerde uitspraken onderzocht naar branche en - aan de hand van de lijsten van $\$ \S 10$ en 11 en de open norm van $\$ 9$ van het AGB-Gesetz - naar soort wetsinbreuk 
(Gesetzesverstoß). ${ }^{3}$ De resultaten van dit onderzoek worden hierna onder 10.4 .1 weergegeven. Axmann's onderzoek werd in 1983 afgesloten. Meer recente cijfers over de spreiding naar soort onredelijk beding worden, aan de hand wan het BKA-register op 1 juli 1993, 150 Abmahnungen van de Verbraucherzentrale Baden-Württemberg uit de jaren 1989-1991 en 75 Abmahnungen van de VSV uit 1991 en 1992, in paragraaf 10.4.2 weergegeven.

\subsubsection{De beginjaren 1977-1983}

Tot 1 april 1983 werden bij het BKA 335 uitspraken op grond van een procedure als bedoeld in $\$ 13$ AGBG geregistreerd. 289 van deze uitspraken betroffen procedures aangespannen door consumentenorganisaties en 26 uitspraken betroffen procedures gevoerd door branche-organisaties. ${ }^{4}$ Deze 335 uitspraken betreffen voor een deel "Anerkenntnis"- en verstekuitspraken waarbij de rechterlijke inhoudstoetsing geen rol speelt én meervoudige registraties in procedures over een aantal verschillende instanties waarbij echter steeds dezelfde bedingen onderwerp van de procedure waren.

Indien de "Anerkenntnis"- en verstekuitspraken buiten beschouwing worden gelaten en de meervoudlige registraties tot eén uitspraak worden teruggebracht, resteren 135 uitspraken die procedures betreffen waarin bedingen in algemene voorwaarden, nadat beide procespartijen gehoord waren, op grond wan een rechterlijke inhoudstoetsing onredelijk bezwarend werden verklaard..$^{s}$

\section{Bedingen in strijd met \$ 11 AGB-Gesetz}

\$11 AGBG geeft een duidelijke lijst van bedingen in algemene voorwaarden die, indien ze gehanteerd worden in overeenkomsten met consumenten, zonder meer onredelijk bezwarend zijn. Het is daarom enigszins verrassend dat het merendeel van de bedingen in de door het BKA geregistreerde en door Axmann onderzochte 135 uitspraken, bedingen betreft die onredelijk bezwarend zijn op grond van \& 11 AGBG. In totaal vond Axmann 254 bedingen die door de rechter onredelijk bezwarend werden bevonden op grond van \$11 AGBG. ${ }^{.}$

Naar branche onderverdeeld komen de bedingen die op grond van het bepaalde in \$ 11 AGBG onredelijk bezwarend zijn bevonden het meest frequent voor in de volgende bedrijfstakken: 
1. Meubelen

2. Bouw/nieuwbouw

3. Bouwmaterialen

4. Reparatie

5. Personenauto's

Elektronische apparatuur

7. Reisorganisatoren Postorderbedrijven

9. Overige
$92 \mathrm{x}$

$31 x$

$25 x$

$18 \mathrm{x}$

$16 \mathrm{x}$

$16 \mathrm{x}$

$10 x$

$10 \mathrm{x}$

$36 x$
$36,2 \%$

$12,2 \%$

$9,8 \%$

$7,1 \%$

$6,3 \%$

$6,3 \%$

$3,9 \%$

$3,9 \%$

$14,2 \%$

Van de lijst van onredelijk bezwarende bedingen in algemene voorwaarden genoemd in $\$ 11$ AGBG waren de volgende bedingen het meest frequent onderwerp van een verbodsuitspraak:

1. Beschränkung der Gewährleistung

$\begin{array}{rrr}\text { Nr. } & 10 a & 12 x \\ \text { Nr. } & 10 b & 20 x \\ \text { Nr. } & 10 c & 3 x \\ \text { Nr. } & 10 d & 4 x \\ \text { Nr. } & 10 \mathrm{e} & 17 x \\ \text { Nr. } & 10 \mathrm{f} & 5 \mathrm{x} \\ \text { Nr. } & 5 \mathrm{a} & 12 \mathrm{x} \\ \text { Nr. } & 5 \mathrm{~b} & 37 \mathrm{x} \\ \text { Nr. } & 7 & 34 \mathrm{x} \\ \text { Nr. } & 8 \mathrm{a} & 11 \mathrm{x} \\ \text { Nr. } & 8 \mathrm{~b} & 10 \mathrm{x} \\ \text { Nr. } & 15 \mathrm{a} & 3 \mathrm{x} \\ \text { Nr. } & 15 \mathrm{~b} & 16 \mathrm{x}\end{array}$

6. Freistellung von Mahnung und Fristsetzung

7. Kurzfristige Preiserhöhungen

8. Overige

$\begin{array}{lll}\text { Nr. } & 4 & 17 \mathrm{x} \\ \text { Nr. } & 1 & 14 \mathrm{x} \\ & & 41 \mathrm{x}\end{array}$

\section{ad 1. Beschränkungen der Gewährleistung}

$\$ 11 \mathrm{Nr} .10$ AGBG heeft betrekking op bedingen in algemene voorwaarden die de garantieverplichtingen van de gebruiker beperken of uitsluiten in die $\operatorname{zin}_{\mathrm{x}}$ dat zij het recht van de wederpartij op herstel (Nachbesserung) en vervanging (Ersatzlieferung) van het geleverde beperken of uitsluiten of de wederpartij geheel of gedeeltelijk belasten met de kosten van herstel of vervanging. Dit soort bedingen kwam het meest frequent voor in de onderzochte uitspraken. 
Van de 254 bedingen die onredelijk bezwarend werden bevonden op grond van $\S 11$ AGBG betroffen in totaal 61 bedingen (24\%) een uitsluiting of beperking van de garantieverplichtingen van de gebruiker.

De bedingen die, in strijd met het bepaalde in $\$ 11 \mathrm{Nr}$. 10 sub b AGBG, de rechten van de wederpartij beperkten tot of herstel of vervanging werden hiverbij het meest aangetroffen ( 20 keer). Bedingen die, in strijd met het bepaalde in $\$ 11 \mathrm{Nr} .10$ sub e AGBG, de tijd waarbinnen de wederpartij klachten omtrent niet direct kenbare gebreken aan de wederpartij dient mede te delen beperkt, werden 17 keer aangetroffen. Bedingen die, in strijd met het bepaalde in $\$ 11$ Nr. 10 sub a AGBG, de garantieverplichtingen van de gebruiker geheel of gedeeltelijk uitsluiten, de garantieverplichting van de gebruiker doen overgaan op een derde of de garantieverplichting van de gebruiker afhankelijk maken van een voorafgaande gerechtelijke procedure waarin een derde aansprakelijk gesteld wordt, werden 12 keer aangetroffen.

Bedingen in strijd met $\$ 11 \mathrm{Nr}$. 10 AGBG werden het meest frequent (27 keer) aangetroffen in de meubelbranche.

\section{ad 2. Pauschalierter Schadensersatz}

$\$ 11 \mathrm{Nr} .5$ AGBG ziet op bedingen in algemene voorwaarden die de wederpartij verplichten een van te voren vastgestelde som geld te betalen voor het geval de gebruiker schade lijdt èn deze vastgestelde som hoger ligt dan de doorgaans te verwachten schade (Nr. 5 sub a) of de wederpartij beperkt in haar bewijs dat de schade in het geheel niet of slechts gedeeltelijk is geleden (Nr. 5 sub b).

Van de 254 bedingen die onredelijk bezwarend werden bevonden op grond van $\$ 11$ AGBG betroffen in totaal 49 bedingen $(19,3 \%)$ zulk een regeling. Het meest frequent $(24 \mathrm{keer})$ werden dergelijke bedingen waargenomen in de meubelbranche.

\section{ad 3. Haftungsfreizeichntingen}

$\$ 11 \mathrm{Nr} .7$ AGBG gaat over bedingen die de aansprakelijkheid van de gebruiker voor schade als gevolg van wanprestatie veroorzaakt door grove schuld (grob fahrlässige Vertragsverletzung) van de gebruiker of opzet (vorsätzliche Vertragsverletzung) of grove schuld van diens vertegenwoordiger of ondergeschikten, uitsluiten of beperken.

Van de 254 bedingen die onredelijk bezwarend werden bevonden op grond van $\$ 11$ AGBG betroffen in totaal 34 bedingen $(13,4 \%)$ zulk een exoneratieclausule. Het meest frequent (telkens 9 keer) werden dergelijke bedingen gevonden in de (nieuw)bouw- en de meubelbranche. 


\section{ad 4. Ausschlü der Rechte bei Verzug oder Unmöglichkeit}

811 Nr. 8 AGBG heeft betrekking op bedingen die, in geval van vertraging in de nakoming of niet-nakoming door de gebruiker, of het recht van de wederpartij om de overeenkomst te ontbinden beperken of uitsluiten ( $\mathrm{Nr} .8$ sub a) of het recht van de wederpartij op schadevergoeding beperken of uitsluiten ( $\mathrm{Nr}$. 8 sub b).

Van de 254 bedingen die onredelijk bezwarend werden bevonden op grond van $\$ 11$ AGBG betroffen in totaal 21 bedingen $(8,3 \%$ ) zulk een regeling. Het meest frequent ( 12 keer) werden dergelijke bedingen gevonden in de meubelbranche.

\section{ad 5. Umkehr der Beweislast}

$\$ 11 \mathrm{Nr}$. 15 AGBG ziet op bedingen die de bewijslast in het nadeel van de wederpartij wijzigen in die zin dat of de wederpartij belast wordt met het bewijs van omstandigheden die onder de verantwoording van de gebruiker vallen

(Nr. 15 sub a) of de wederpartij bepaalde omstandigheden (bij voorbaat) bevestigt (Nr. 15 sub b).

Van de 254 bedingen die onredelijk bezwarend werden bevonden op grond van $\$ 11$ AGBG betroffen in totaal 19 bedingen $(7,5 \%)$ zulk een bewijsregeling. Het meest frequent ( 5 keer) werden dergelijke bedingen gevonden in de (nieuw)bouwbranche.

\section{ad 6. Freistellung won Mahnung und Fristsetzung}

$\S 11 \mathrm{Nr}$. 4 AGBG heeft betrekking op bedingen die de gebruiker bevrijden van zijn plicht de wederpartij aan te manen of in gebreke te stellen.

Van de 254 bedingen die onredelijk bezwarend werden bevonden op grond van $\$ 11$ AGBG betroffen in total 17 bedingen $(6,7 \%)$ zulk een clausule. Het meest frequent werden dergelijke bedingen aangetroffen in de meubel- $(7$ keer) en in de (nieuw)bouwbranche (4 keer).

\section{ad 7. Kurzfristige Preiserhöhungen}

$\S 11 \mathrm{Nr} .1$ AGBG ziet op bedingen die de gebruiker het recht geven om binnen 4 maanden na het sluiten van de overeenkomst de prijs te verhogen.

Van de 254 bedingen die onredelijk bezwarend werden bevonden op grond van $\$ 11$ AGBG betroffen in totaal 14 bedingen $(5,5 \%)$ zulk een prijsverhogingsclausule. Het meest frequent (telkens 3 keer) werden dergelijke bedingen aangetroffen in de personenauto-, de bouwmaterialen-, de reis- en de meubelbranche. 


\section{ad 8. Overige bedingen}

Bij de overige bedingen (41) komen het meest frequent voor de bedingen die hat opschortingsrecht van de wederpartij beperken of uitsluiten als bedoeld in $\$ 11$ Nr. 2 AGBG (11 keer) en bedingen als bedoeld in $\$ 11 \mathrm{Nr} .16$ AGBG die voorschriften geven voor de vorm waarin de wederpartij haar klachten of mededelingen dient te verrichten. Beide bedingen kwamen niet in een verhoogde frequentie bij een bepaalde branche voor.

\section{Bedingen in strijd met $\& 10 \mathrm{AGB}-$ Gesetz}

De door Axmann onderzochte 135 uitspraken betroffen in totaal 85 keer een beding in algemene voorwaarden dat door de rechter onredelijk bezwarend werd verklaard op grond van het bepaalde in \$10 AGBG.?

Naar branche onderverdeeld komen de bedingen die op grond van het bepaalde in $\S 10$ AGBG onredelijk bezwarend zijn bevonden het meest frequent voor in de volgende bedrijfstakken:

1. Meubelen

2. Reisorganisatoren

Bouwmaterialen

Bouw/nieuwbouw

5. Textiel

6. Chemisch reinigen

7. Elektronische apparatuur

8. Overige
$18 \times$

$12 \times$

$12 \times$

$12 x$

$7 \mathrm{x}$

$4 x$

$4 \mathrm{x}$

$16 x$
$21,2 \%$

$14,1 \%$

$14,1 \%$

$14,1 \%$

$8,2 \%$

$4,7 \%$

$4,7 \%$

$18,8 \%$

Van de lijst van onredelijk bezwarende bedingen in algemene voorwaarden genoemd in $\$ 10$ AGBG waren de volgende bedingen het meest frequent voorwerp van een verbodsuitspraak:

1. Annahme und Leistungsfrist

$\begin{array}{rr}\text { Nr. } 1 & 30 x \\ \text { Nr. } 4 & 18 x \\ \text { Nr. } 3 & 16 x \\ \text { Nr. 2 } & 15 x \\ & 6 x\end{array}$




\section{ad 1. Annahme und Leistungsfrist}

\& $10 \mathrm{Nr}$. 1 AGBG heeft betrekking op bedingen die de gebruiker een onredelijk lange of onvoldoende bepaalde termijn geven om na te komen of om op een aanbod of een andere verklaring van de wederpartij te reageren.

Van de 85 bedingen die onredelijk bezwarend werden bevonden op grond van $\$ 10$ AGBG betroffen in totaal 30 bedingen $(35,3 \%)$ zulk een regeling. Het meest frequent werden dergelijke bedingen gevonden in de bouwmaterialenbranche ( 8 keer) en (nieuw)bouwbranche (6 keer).

\section{ad 2. Änderungsvorbehalt}

$\$ 10 \mathrm{Nr} .4$ AGBG ziet op bedingen die de gebruiker het recht geven om van de overeengekomen prestatie af te wijken op een wijze die, voor de wederpartij, onredelijk bezwarend is.

Van de 85 bedingen die onredelijk bezwarend werden bevonden op grond van $\$ 10$ AGBG betroffen in totaal 18 bedingen $(21,2 \%)$ zulk een regeling. Het meest frequent werden dergelijke bedingen aangetroffen in de reisbranche (6 keer).

\section{ad 3. Rücktrittsvorbehalt}

\$10 Nr. 3 AGBG heeft betrekking op bedingen die de gebruiker de bevoegdheid geven zich van zijn gebondenheid aan de overeenkomst te bevrijden anders dan op redelijke, in de overeenkomst vermelde, gronden.

Van de 85 bedingen die onredelijk bezwarend werden bevonden op grond van $\$ 10$ AGBG betroffen in totaal 16 bedingen $(18,8 \%)$ zulk een regeling. Het meest frequent werden dergelijke bedingen aangetroffen in de meubelbranche (6 keer), de reisbranche ( 3 keer) en (nieuw)bouwbranche ( 3 keer).

\section{ad 4. Nachfrist}

Om te ontbinden of om "Schadensersatz wegen Nichterfüllung" te kunnen vorderen is in beginsel vereist - $\$ 326$ Abs, 1 BGB - dat de schuldeiser de schuldenaar een redelijke termijn stelt waarbinnen de schuldenaar alsnog kan nakomen (Nachfrist) met de mededeling dat na afloop van die termijn nakoming door de schuldenaar niet meer geaccepteerd wordt door de schuldeiser (Ablehnungsandrohung). $\& 10 \mathrm{Nr}$. 2 AGBG heeft betrekking op bedingen die de redelijke termijn (Nachfrist), die de wederpartij op grond van $\S 326$ Abs. 1 BGB aan de gebruiker moet verlenen om alsnog na te komen, onredelijk verlengen of in onvoldoende mate bepalen.

Van de 85 bedingen die onredelijk bezwarend werden bevonden op grond van $\$ 10$ AGBG betroffen in totaal 15 bedingen $(17,6 \%)$ zulk een regeling. Het meest frequent werden dergelijke bedingen gevonden in de meubelbranche ( 6 keer), de reisbranche ( 3 keer) en (nieuw)bouwbranche ( 3 keer). 


\section{ad 5 . Overige bedingen}

De overige bedingen als bedoeld in $\$ 10 \mathrm{Nr}$. 5 tot en met 7 AGBG kwamen niet in een opvallende frequentie voor (in totaal $6 \mathrm{keer}$ ).

\section{Bedingen in strijd met 9 AGB-Gesetz}

De bepalingen van $\& 9$ AGBG worden toegepast als enerzijds een algemene norm naast de specifieke normen van de lijsten van $\$ 10$ en $\$ 11 \mathrm{AGBG}$ en anderzijds, op grond van 9 Abs. II Nr. 1 AGBG, in verbinding met de bepalingen uit het Bürgerliches. Gesetzbuch of andere wettelijke regelingen als bijvoorbeeld het Abzahlungsgesetz of het Reisevertragsgesetz. Ondanks het feit dat door dit gegeven bepaalde zwaartepunten in de bedingen die op grond van $\$ 9$ AGBG door de rechter onredelijk bezwarend verklaard werden slechts moeilijk te ontdekken waren, komen vollgens Axmann de volgende (onredelijk bezwarende) bedingen in een verhoogde frequentie voor ${ }^{8}$ :

\section{Gerichtsstandsklauseln}

Bedingen die voorzien in beslechting door een andere rechter dan de rechter die op grond van de wet bevoegd zou zijn werden 21 keer aangetroffen;

2. Schriftformklauseln

Bedingen op grond warvan mondelinge afspraken ongeldig zijn werden 18 keer aangetroffen;

3. Abweichungen vom Schuldrecht

Bedingen die voorzien in een regeling die afwijkt van (dwingende) bepalingen van het algemene of bijzondere verbintenissenrecht, zoals bijwoorbeeld de bepalingen omtrent schadevergoeding en de bepalingen in de huurwetgeving, werden 14 keer aangetroffen;

4. Vertragszweckgefährdung

Bedingen die het met de uitvoering van de overeenkomst beoogde economische doel van de overeenkomst wezenlijk beperken of door een afwenteling van contractsrisico's in gevaar brengen werden 12 keer aangetroffen;

5. Etgentumsvorbehaltsklauseln

Bedingen die de gebruiker een onredelijke uitbreiding van het eigendoms: voorbehoud verstrekken werden 8 keer aangetroffen;

6. Ubensichering und Lohnabtretung

Bedingen op grond waarvan de wederpartij haar loon- of inkomensvorderingen aan de gebruiker cedeert of die de wederpartij anderszins verplichten in 
een onredelijk bezwarende omvang zekerheid te bieden, werden 8 keer aangetroffen.

\subsubsection{Recentere cijfers over de spreiding naar soort onredelijk bezwarend beding}

De cijfers van Axmann geven slechts een beperkt beeld van de spreiding naar soort onredelijk bezwarend beding. De cijfers hebben enerzijds slechts betrekking op zes jaar AGB-Gesetz terwijl dit al meer dan 15 jaar in werking is getreden en anderzijds slechts op de spreiding in gerechtelijke procedures. Dit laatste gegeven brengt met zich dat de spreiding in de buitengerechtelijke fase, waarin de rechtshandhaving juist voor het grootste gedeelte plaats vindt, buiten beeld blijft. Om een recenter beeld te krijgen van de spreiding naar soort onredelijk bezwarend beding, in welk beeld mogelijk verschuivingen zijn te constateren ten opzichte van de uitkomsten in de beginjaren van het AGBGesetz, heb ik de registraties met betrekking tot vorderingen en vonnissen in het AGB-register tot 1 juli 1993 geraadpleegd. Een beeld van de spreiding in de buitengerechtelijke fase wordt verschaft aan de hand van een door mij genomen steekproef uit recente Abmahnungen van de Verbraucherzentrale Baden-Württemberg en de VSV.

\section{Het BKA-register per 1 juli 1993}

In het AGB-register is onder meer vastgelegd op welke artikelen uit het AGBGesetz de geregistreerde vorderingen van de eisende organisaties en de geregistreerde vonnissen zijn gebaseerd.

In alle vorderingen van de eisende organisaties in de periode 1 april 1977 tot 1 juli 1993 werd in totaal 1110 maal $(31 \%)$ een beding (mede) onredelijk bezwarend geacht op grond van de open norm van $\$ 9$ AGBG, 503 (14\%) maal op grond wan $\$ 10$ AGBG en 2023 maal $(56 \%$ ) op grond van $\$ 11$ AGBG (afbeelding 4).

In de in dezelfde periode gewezen vonnissen werden de bedingen in algemene voorwaarden uiteindelijk 664 maal (37\%) (mede) onredelijk bezwarend geacht op grond van $\$ 9$ AGBG, 246 maal (14\%) op grond van $\$ 10$ AGBG en 899 maal (50\%) op grond van $\$ 11$ AGBG (afbeelding 5). 


\section{Afbeelding 4}

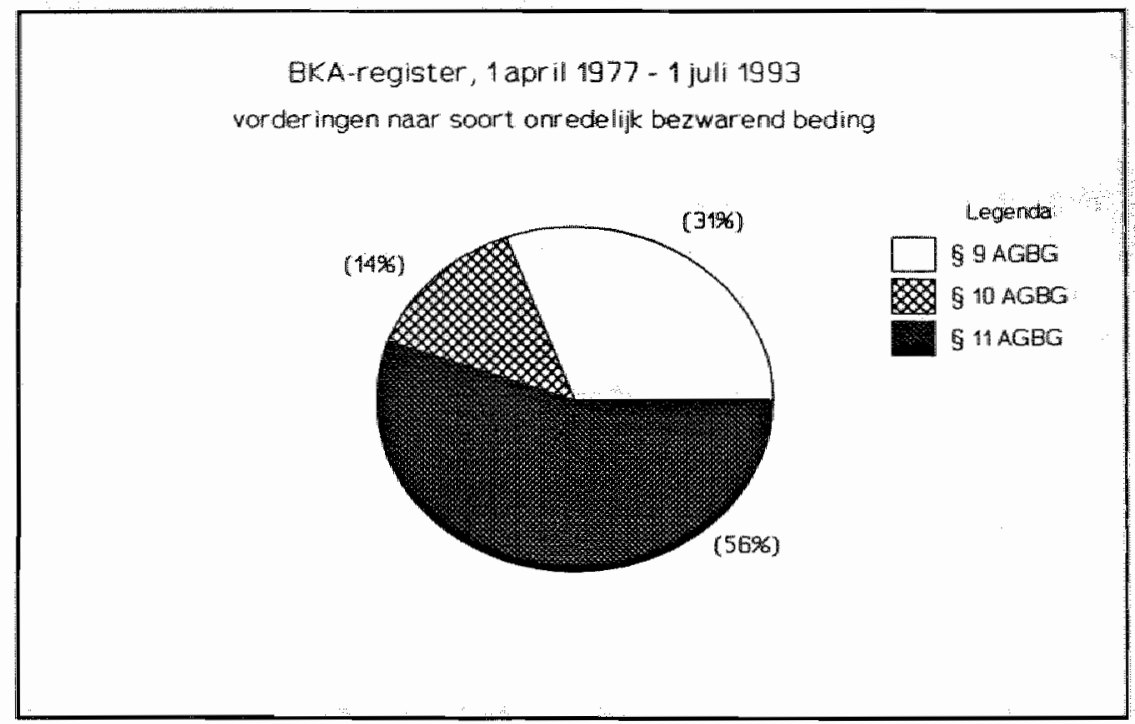

\section{Afbeelding 5}

BKA-register, 1 april 1977 - 1 juli 1993

vonnissen naar soort anredelijk bezwarend beding

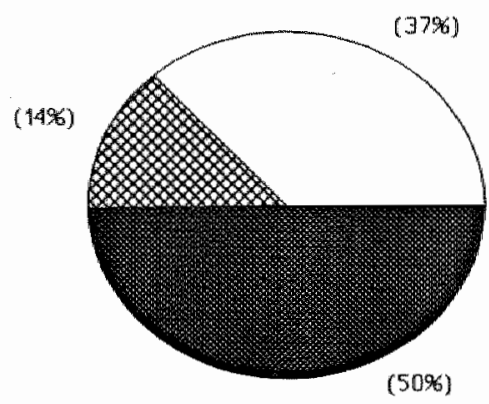

Legrenda ริ 9 AGEG

\& 10 AGBG

51 11 AGBG 
Dok in deze cijfers, die elkaar niet veel ontlopen, valt op dat in de procedure wan $\$ 13$ AGBG verhoudingsgewijs vaak een beroep op de lijst van $\$ 11$ AGBG en dat de rechter de onredelijk bezwarendheid van bedingen verhoudingsgewijs net zo vaak baseert op de bepalingen van deze lijst.

Van de lijst van onredelijk bezwarende bedingen in algemene voorwaarden genoemd in $\S 11$ AGBG waren de volgende bedingen het meest frequent onderwerp van een verbodsuitspraak:

1. Beschränkung der Gewährleistung

$\begin{array}{lll}\text { Nr. 10a } & 45 x \\ \text { Nr. 10b } & 51 \times \\ \text { Nr. 10c } & 13 \mathrm{x} \\ \text { Nr. 10d } & 10 \mathrm{x} \\ \text { Nr. 10e } & 61 \mathrm{x} \\ \text { Nr. 10f } & 22 \mathrm{x} \\ \text { Nr. 5a } & 63 \mathrm{x} \\ \text { Nr. 5b } & 79 \mathrm{x} \\ \text { Nr. 7 } & 97 \mathrm{x} \\ \text { Nr. 15a } & 19 \mathrm{x} \\ \text { Nr. 15b } & 72 \mathrm{x} \\ \text { Nr. 8a } & 42 \mathrm{x} \\ \text { Nr. 8b } & 37 \mathrm{x} \\ \text { Nr. 2a } & 48 \mathrm{x} \\ \text { Nr. 2b } & 23 \mathrm{x} \\ & \\ \text { Nr. } 4 & 62 \mathrm{x} \\ \text { Nr. 1 } & 44 \mathrm{x} \\ & 111 \mathrm{x}\end{array}$

2. Pauschalierter Schadensersatz

3. Haftungsfreizeichnungen

4. Umkehr der Beweislast

5. Ausschluß der Rechte bei Verzug oder Unmöglichkeit

6. Beschränkung der Leistungsverweigerung"

7. Freistellung von Mahnung und Fristsetzung

8. Kurzfristige Preiserhöhungen

9. Overige

Van de lijst van onredelijk bezwarende bedingen in algemene voorwaarden genoemd in \$ 10 AGBG waren de volgende bedingen het meest frequent voorwerp van een verbodsuitspraak:

$911 \mathrm{Nr}$. 2a AGBG heeft betrekking op bedingen die de opschortingsbevoegdheid van de wederpartij uitsluitem of beperken. \& $11 \mathrm{Nr}$. $2 \mathrm{~b}$ ziet op cen beperking of uitsluiting van een retentienecht dat aan de wederpartij toekomt. 
1. Annahme und Leistungsfrist

2. Änderungsvorbehalt

3. Rücktrittsvorbehalt

4. Nachfrist

5. Overige
Nr. 1

Nr. 4

Nr. 3

Nr. 2
$72 \times$ $53 \mathrm{x}$ $48 \times$ $25 x$ $48 \times$

De cijfers tot 1 juli 1993 met betrekking tot de verdeling van de bedingen genoemd in $\$ 10$ en $\$ 11$ AGBG geven daarmee nagenoeg een zelfde beeld als de cijfers over de eerste zes jaar dat het AGB-Gesetz in werking was zoals die blijken uit het onderzoek van Axmann. ${ }^{10}$

\section{Afbeelding 6}

VZ Baden Wurttemberg, 1989 - 1991

Abmahnungen naar soort onredelijk bezwarend beding

(11\%)

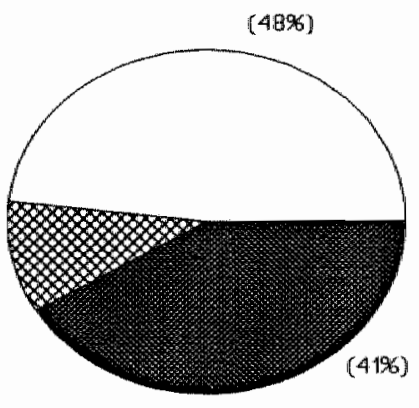

\section{Abmahnungen van de Verbraucherzentrale Baden-Württemberg.}

De gegevens met betrekking tot de spreiding naar soort onredelijk bezwarend beding in de buitengerechtelijke fase zijn voor de Verbraucherzentrale BadenWürttemberg ontleend aan een door mij uitgevoerde steekproef van $150 \mathrm{Abmah}$ - 
numgen van de Verbraucherzentrale uit de jaren 1989 tot en met $1991 .{ }^{\text {"I }}$ In de onderzochte 150 Abmahnungen werd 327 maal (48\%) een beding (mede) onredelijk bezwarend geacht op grond van de open norm van $\$$ AGBG, 72 (11\%) maal op grond van $\$ 10$ AGBG en 281 maal (41\%) op grond van $\$ 11$ AGBG (afbeelding 6).

Uit deze cijfers blijkt dat de Verbraucherzentrale Baden-Württemberg haar Abmahnungen nagenoeg net zo vaak baseert op de open norm van $\$ 9$ AGBG $(48 \%)$ als op de lijsten van \$10 AGBG (11\%) en \$11 AGBG (41\%). Daarmee wijkt de (meer recente) verdelling in de buitengerechtelijke fase van de Verbraucherzentrale Baden-Württemberg af van de verdeling in de gerechtelijke fase zoals gevonden in het BKA-register. In de Abmahnungen van de Verbraucherzentrale Baden-Württemberg wordt verhoudingsgewijs vaker een beroep gedaan op de open norm dan in de vonnissen uit het AGB-register.

Indien men de spreiding naar soort onredelijk beding per jaar bekijkt valt op dat de verhouding tussen de grondslag waarop de bedingen (mede) onredelijk bezwarend worden geacht per jaar sterk wisselt (afbeelding 7).

\section{Afbeelding 7}

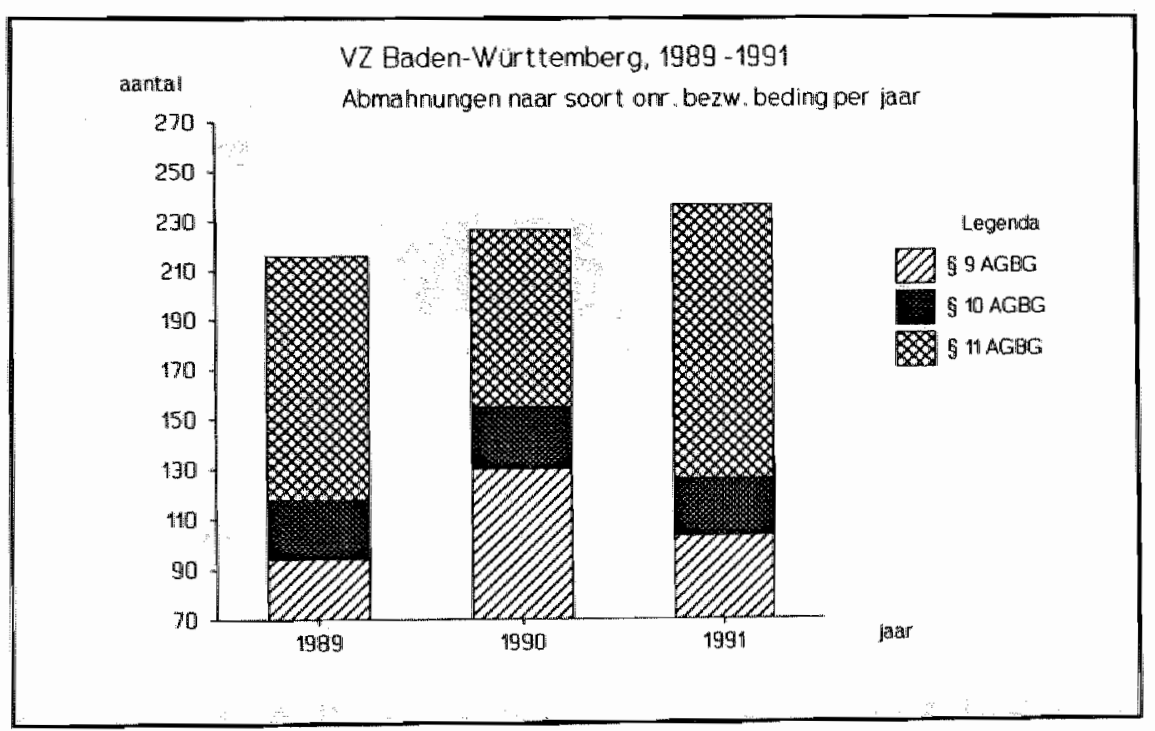

11. Telkens de eerate 50 Abmahnungen van het betreffende jaar. 
In 1989 werden de door de Verbraucherzentrale "Abgemahnte" bedingen nagenoeg net zo vaak onredelijk bezwarend geacht op grond van de open norm van $\$ 9$ AGBG als op grond van de lijst van \$11 AGBG. In 1990 werden die bedingen echter voor het merendeel onredelijk bezwarend geacht op grond van $\$ 9$ AGBG. 1991 geeft een omgekeerd beeld. In dat jaar heeft de lijst van \& II duidelijk de overhand. Opvallend is dat het aantal keren dat een "Abgemahnt" beding onredelijk bezwarend wordt geacht op grond van de lijst van $\$ 10$ AGBG in alle drie de jaren nagenoeg gelijk is.

24 van de onderzochte 150 Abmahnungen van de Verbraucherzentrale hebben geleid tot een verbodsvordering op grond van \$ 13 AGBG. In deze verbodsworderingen werd 50 maal $(58,1 \%)$ een beroep gedaan op $\& 9$ AGBG, 9 maal $(10,5 \%)$ op $\$ 10$ AGBG en 27 maal $(31,4 \%)$ op $\$ 11$ AGBG (afbeelding 8 ).

\section{Afbeelding 8}

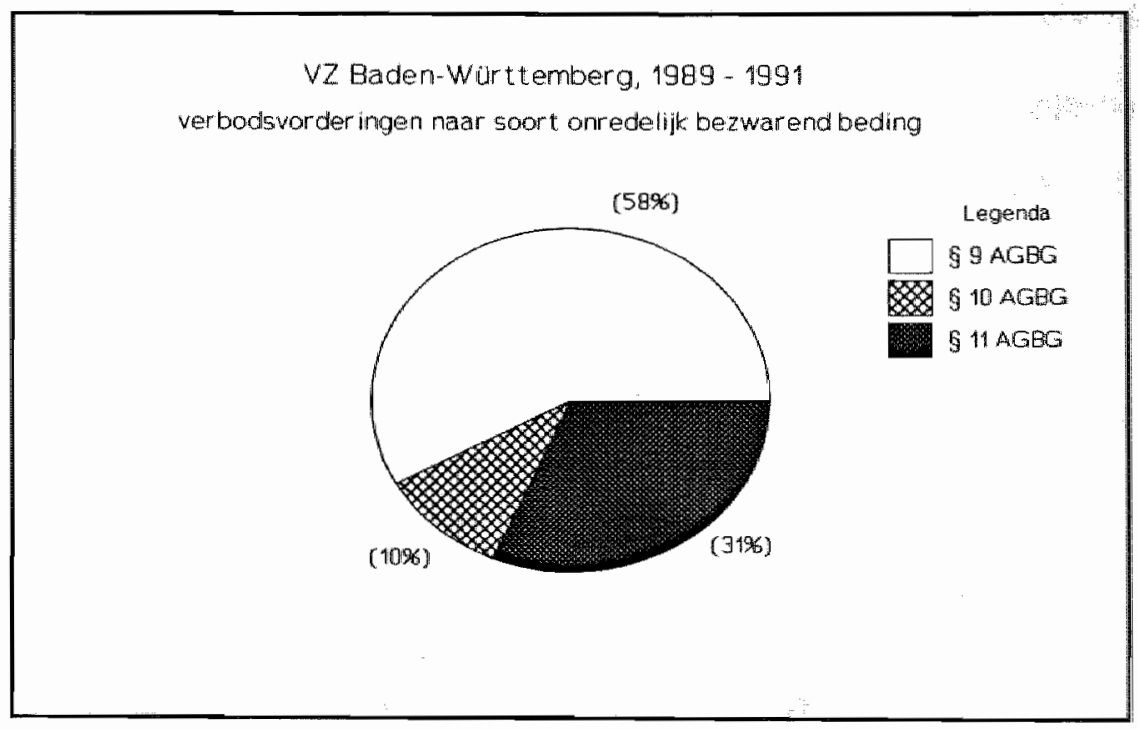

Daarmee wijkt ook de verdeling in gerechtelijke fase van de Verbraucherzentrale Baden-Württemberg af van de gemiddelde verdeling in de gerechtelijke fase zoals gevonden in het BKA-register. In de verbodsvorderingen van de Verbratcherzentrale Baden-Württemberg wordt verhoudingsgewijs vaker een beroep gedaan op de open norm dan in de vonnissen uit het AGB-register. 
Van de lijst van onredelijk bezwarende bedingen in algemene voorwaarden genoemd in $\$ 11$ AGBG waren bij de Verbraucherzentrale Baden-Württemberg de volgende bedingen het meest frequent onderwerp van een Abmahnung:

1. Beschränkung der Gewährleistung

$\begin{array}{ll}\text { Nr. } 10 & 82 \times \\ \text { Nr. } 7 & 64 \times \\ \text { Nr. } 1 & 22 \times \\ \text { Nr. } 5 & 22 \times \\ \text { Nr. } 15 & 20 \times\end{array}$

2. Haftungsfreizeichnungen

3. Kurzfristige Preiserhöhungen

3. Pauschalierter Schadensersatz

5. Umkehr der Beweislast

6. Freistellung von Mahnung und Fristsetzung

7. Ausschluß der Rechte bei Verzug oder Unmöglichkeit

Nr. $4 \quad 17 x$

Nr. $8 \quad 15 x$

7. Beschränkung der Leistungsverweigerung

9. Overige

Nr. $212 x$

$27 x$

Van de lijst van onredelijk bezwarende bedingen in algemene voorwaarden genoemd in $\$ 10$ AGBG waren bij de Verbraucherzentrale de volgende bedingen het meest frequent voorwerp van een verbodsuitspraak:

1. Änderungsvorbehalt

$\begin{array}{rr}\text { Nr. 4 } & 34 x \\ \text { Nr. 3 } & 18 \times \\ \text { Nr. 2 } & 13 \times \\ \text { Nr. 1 } & 6 x \\ & 1 \times\end{array}$

2. Rücktrittsvorbehalt

3. Nachfrist

4. Annahme und Leistungsfrist

5. Overige

$1 \mathrm{x}$

Alhoewel er enige accentverschillen zijn te signaleren valt op dat de cijfers met betrekking tot de verdeling van de bedingen genoemd in $\$ 10$ en $\$ 11$ AGBG in de buitengerechtelijke fase bij de Verbraucherzentrale nagenoeg een zelfde beeld geven als de cijfers met betrekking tot de verbodsprocedures zoals die blijken wit het BKA-register.

\section{Abmahnungen van de VSV}

De spreidingsgegevens naar soort onredelijk bezwarend beding in de buitengerechtelijke fase zijn voor de VSV ontleend aan een door mij uitgevoerde steekproef van 75 Abmahnungen van de VSV uit de jaren 1991 en $1992 .{ }^{12}$ 
VSV-Berlin, 1991 - 1992

Abmahnungen naar soort onredelijk bezwarend beding

(996)

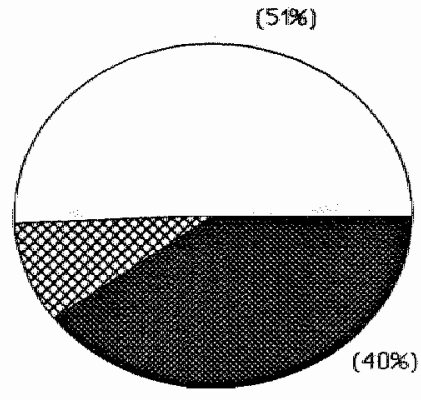

Legenda

59 AGBG

S 10 AGBG

S11 AGBG

\section{Afbeelding 10}

\section{VSV-Berlin, 1991 - 1992}

verbodsworder ingen naar soort onredelijk bezwarend beding

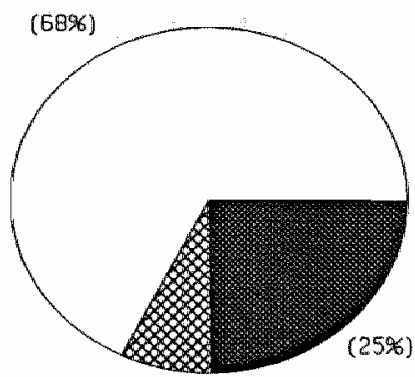

Legendata

(7\%) 
In de onderzochte 75 Abmahnungen werd 298 maal (51\%) een beding (mede) onredelijk bezwarend geacht op grond van de open norm van $\$ 9$ AGBG, 55 (9\%) maal op grond van $\$ 10$ AGBG en 234 maal (40\%) op grond van $\$ 11$ AGBG (afbeelding 9).

Uit deze cijfers blijkt dat de VSV haar Abmahnungen nagenoeg net zo vaak baseert op de open norm van $\$ 9$ AGBG $(51 \%)$ als op de lijsten van $\$ 10$ AGBG $(9 \%)$ en $\& 11$ AGBG (40\%). Daarmee is de verdeling in de buitengerechtelijke fase van de VSV nagenoeg gelijk aan die van de Verbraucherzentrale Baden-Württemberg. Ook hier geldt dat de spreiding in de buitengerechtelijke fase van de VSV afwijkt van de verdeling in de gerechtelijke fase zoals gevonden in het BKA-register. In de (meer recente) Abmahnungen van de VSV wordt verhoudingsgewijs vaker een beroep gedaan op de open norm dan in de vonnissen uit het AGB-register.

17 van de onderzochte 75 Abmahnungen van de VSV hebben geleid tot een verbodsvordering op grond van $\$ 13 \mathrm{AGBG}$. In deze verbodsvorderingen werd 55 maal $(68 \%)$ een beroep gedaan op $\$ 9$ AGBG, 6 maal $(7 \%)$ op $\$ 10$ AGBG en 20 maal (25\%) op $\S 11$ AGBG (afbeelding 10). Daarmee wijkt ook de verdeling in gerechtelijke fase van de VSV af van de gemiddelde verdeling in de gerechtelijke fase zoals gevonden in het BKA-register. In de verbodsvorderingen van de VSV wordt verhoudingsgewijs vaker een beroep gedaan op de open norm dan in de vonnissen uit het AGB-register.

Van de lijst van onredelijk bezwarende bedingen in algemene voorwaarden genoemd in $\$ 11$ AGBG waren bij de VSV de volgende bedingen het meest frequent onderwerp van een Abmahnung:

1. Beschränkung der Gewährleistung

$\begin{array}{ll}\text { Nr. } 10 & 71 x \\ \text { Nr. } 7 & 40 x \\ \text { Nr. } 15 & 30 x \\ \text { Nr. 1 } & 24 x\end{array}$

2. Haftungsfreizeichnungen

3. Umkehr der Beweislast

4. Kurzfristige Preiserhöhungen

5. Ausschluß der Rechte bei Verzug oder Unmöglichkeit

Nr. $819 x$

6. Pauschalierter Schadensersatz

Nr. $5 \quad 15 x$

7. Beschrånkung der Leistungsverweigerung

9. Overige

Nr. $210 \times$

$24 \times$

Van de lijst van onredelijk bezwarende bedingen in algemene voorwaarden genoemd in \& 10 AGBG waren bij de VSV de volgende bedingen het meest frequent voorwerp van een verbodsuitspraak: 
1. Annahme und Leistungsfrist

Nr. 1

$20 \mathrm{x}$

2. Änderungsvorbehallt

Nr. 4

$12 x$

3. Rücktrittsvorbehalt

Nr. 3

$11 \mathrm{x}$

4. Nachfrist

Nr. 2

$6 \times$

5. Overige

$6 x$

Alhoewel er enige accentverschillen zijn te signaleren valt op dat de cijfers met betrekking tot de verdeling van de bedingen genoemd in $\S 10$ en $\S 11 \mathrm{AGBG}$ in de buitengerechtelijke fase bij de VSV nagenoeg een zelfde beeld geven als de cijfers met betrekking tot de verbodsprocedures zoals die blijken uit het BKAregister.

\subsection{Conclusies}

\section{Regionale spreiding}

Uit bovenstaande overzichten is af te leiden dat Duitse consumenten voor wat betreft de rechtshandhaving op het gebied van de algemene voorwaarden voor een deel afhankelijk zijn van de activiteiten van de regionale Verbraucherzentralen. De Verbraucherzentralen van sommige deelstaten zijn niet of nauwelijks zelf actief op het terrein van de rechtshandhaving inzake algemene voorwaarden en sturen ook niet of nauwelijks algemene voorwaarden ter controle naar de VSV. Andere daarentegen zijn duidelijk actiever zoals bijvoorbeeld de Verbraucherzentralen van Baden-Württemberg, Nordrhein-Westfalen en Hamburg waardoor de rechtshandhavingsactiviteiten per regio sterk kunnen verschillen. In Nederland zal zich dit verschijnsel waarschijnlijk niet voordoen omdat, mede door de beperkte geografische omvang van ons land, regionale consumentenorganisaties niet bestaan.

\section{Branchegewijze spreiding}

De meeste Abmahnungen van de VSV zijn uitgegaan naar de dienstverleningsbranche, de huishoudelijke apparatuur en electro-branche, de reis-branche, de meubel-branche, en de bouw en renovatie-branche. Bij de gevoerde procedures zijn het eveneens deze branches, weliswaar in een gewijzigde volgorde, die de toon aangeven. De gewijzigde volgorde duidt op een verschil in procesbereidheid bij deze branches.

Opvallend is dat de procesbereidheid in deze branches nogal verschilt. $\mathrm{Z}_{0}$ zitten de meubel-branche, de branche voor huishoudelijke apparatuur en electro en de reisbranche met respectievelijk $19,1 \%, 20,4 \%$ en $15,1 \%$ ver beneden de gemiddelde procesbereidheid gemeten over alle branches van $26,4 \%$. De dienstverleningsbranche en de bouw en renovatie-branche zitten met respectievelijk $30,5 \%$ en $32,5 \%$ weer ruim boven de gemiddelde procesbereidheid. Voor 
wat betreft de procesbereidheid moeten zij echter de onroerend goed-branche (52\%) en de branche voor verkoops- en demonstratiereizen $(42,2 \%)$ voor laten gaan. Deze laatste branches zaten voor wat betreft het aantal tegen hen gerichte Abmahnungen en procedures ver beneden het gemiddelde.

\section{Spreiding naar soort beding}

Belangrijkste conclusie is wel dat uit het BKA-register blijkt dat het aantal gevoerde procedures gemiddeld voor het grootste deel bedingen betrof die woorkomen op de lijst van $\$ 11$ AGBG. Dit is gezien de geringe bereidheid van consumentenorganisaties om al te grote procesrisico's te lopen wellicht niet eens zo vreemd. Indien een beding immers valt onder de formulering van één van de "verboden" clausules van $\$ 11$ AGBG, staat daarmee onomstotelijk vast dat het beding onredelijk bezwarend is en brengt een procedure tegen de gebruiker of aambeveler van zulk een beding nauwelijks tot geen procesrisico's met zich. Anders ligt dit bij de vraag of een beding onredelijk bezwarend is op grond van $\$ 9$ of 10 AGBG. Het antwoord op deze vraag is immers sterk afhankelijk van de interpretatie van de omstandigheden van het geval en de invulling die de rechter aan minder concrete verbodsnormen van $\$ 9$ en $\$ 10$ AGBG geeft.

Als we echter kijken naar meer recente verbodsvorderingen van zowell de VSV als de Verbraucherzentrale Baden-Württemberg zien we een andere tendens. Steeds meer worden verbodsvorderingen gebaseerd op de open norm van $\$ 9$ AGBG. Er valt in de gerechtelijke procedure een verschuiving te constateren van de lijsten van $\$ 10$ en 11 AGBG (en met name de lijst van $\$ 11$ AGBG) als basis van onredelijk bezwarendheid naar \& 9 AGBG. Ondanks deze verschuiving vormen de vorderingen op basis van de lijsten overigens nog steeds een substantieel deel van alle vorderingen. Dat is zeker zo als we kijken naar de buitengerechtelijke fase. Ongeveer 50\% van alle Abmahnungen is gebaseerd op één van de lijsten van $\$ 10$ of $\$ 11$ AGBG. De lijsten van $\$ 10$ en $\$ 11$ AGBG spelen derhalve nog steeds een belangrijke rol in de buitengerechtelijke en gerechtelijke rechtshandhaving op het terrein van de allgemene voorwaarden. De stelling dat de lijsten ongeveer vijf jaar na inwerkingtreding van het AGB-Gesetz in de collectieve acties geen rol meer zouden spelen $^{13}$ heeft zich dan ook niet bewaarheid ${ }^{14}$.

Omdat Abmahnungen nog steeds voor ongeveer $50 \%$ gegrond zijn op de lijsten van $\$ 10$ en $\$ 11$ AGBG staat vast dat "verboden" bedingen nog steeds op grote schaal gebruikt worden. Daarmee staat tevens vast dat de lijsten op

13 Jongeneel haalt in zijn dissertatie (pag. 24, noot 100) een medewerker van de VSV aan die op de Maastrichtse onderzoeksdag consumentenrecht van 10 mei 1990 heeft gesteld dat de lijaten na vujf jaar waren "uitgewwerkt" en nauwelijks nog een rol spelen in collectieve acties.

14. In dezelfide zim: Rjjken, NTBR 1993, pag. 65. 
zichzelf beschouwd nauwelijks enige preventieve werking hebben. ${ }^{15}$ Ondernemers gaan kennelijk niet vrijwillig over tot het aanpassen van hun algemene voorwaarden aan de lijsten van $\$ 10$ en $\S 11$ AGBG. Zonder daadwerkelijke dreiging van een procedure, waarmee dan meestal een buitengerechtelijke oplossing wordt bereikt, zijn veel ondernemers niet bereid hun algemene voorwaarden aan te passen. ${ }^{16}$

15 Zie ook: Jongeneel, diss., pag. 24; Mölenberg en Rijken, pag. 78; Rijken, NTBR 1993, paga. 65.

16 In dezelfde zin: Rijken, inaug. rede, pag. 24; Rijken, NTBR 1993, pag. 65. 


\section{Knelpunten in de collectieve AGB-rechts- handhaving door consumentenorganisaties}

\section{II Inleiding}

Het AGB-Gesetz heeft een ongekende uitwerking gehad in de Duitse rechtspraktijk. Zo ging de invoering van de wet reeds gepaard met een enorme golf aan publiciteit en nog geen vier maanden na inwerkingtreding waren reeds 10 specifiek op het AGB-Gesetz gerichte handboeken (Kommentare) gepubliceerd en elk zichzelf respecterend juridisch tijdschrift besteedde in die tijd in minstens én inleidend artikel aandacht aan de nieuwe wet. ${ }^{1}$ De publiciteit rondom het AGB-Gesetz is in de afgelopen jaren weliswaar iets afgenomen, maar nog steeds vindt men in praktisch elke uitgave van de gezaghebbende (privaatrechtelijke) periodieken uitspraken en artikelen met betrekking tot het AGB-Gesetz, hetgeen mede zijn oorzaak vindt in de niet aflatende stroom van (gepubliceerde) rechterlijke uitspraken op het terrein van de algemene voorwaarden. Zo maakt Schlosser gewag van meer dan 2000 gepubliceerde rechterlijke uitspraken in de periode van 1 april 1977 tot begin $1985^{2}$, zijn in Bunte's Entscheidungssammlung zum AGB-Gesetz over de periode 1977-1985 1190 rechterlijke uitspraken (meestal van hogere instanties) opgenomen ${ }^{3}$, constateren Heinrichs, Löwe en Ulmer dat gedurende de eerste 10 jaar dat het AGB-Gesetz in werking was, meer dan 2500 gepubliceerde rechterlijke uitspraken, enige honderden opstellen of artikelen en een groot aantal handboeken en monografieën het licht zagen ${ }^{4}$ en tellt Jongeneel 832 uitspraken van het BGH in het vindplaatsenregister van BGHuitspraken over 1977-1988 van Ulmer, Brandner en Hensen. ${ }^{5}$

1 Zie woor een overzicht: Bunte AcP, pag. 33, noten 8 en 9.

2 Schlosiser, ZIP 1985, pag. 450.

3 Bunte, AGBE I-VI.

4 H. Heinrichs, W. Löwe en P. Ulmer; Vorwort, Zehn Ilahre AGB-Gesetz, pag. VI. In zijn bujdrage verwijst Ulmer naar een uitspraak van Stumpf, volgens wie de literatuur over het AGB-Gesetz zich in 1986 reeds uitstrekte over meer dan twee meter boekenplank, RWS-Forum 2, Zehuri Jahre AGB-Gesetz, pag. 3.

5 Jongeneel, diss, pag. 21, noot 75. Zie cok: Ulmer, Brandner, Hensen en Siehmidt, AGBGesetz, pag. 1135-1167. 
Niet voor niets wordt het AGB-Gesetz voor het terrein van het verbintenissenrecht dan ook gezien als de belangrijkste novelle sinds de totstandkoming van het $\mathrm{B} G B$ die het

"(..) Zivilrecht im letzten Quartal des 20. Jahrhunderts ganz entscheidend mitgepragt hat und weiler beeinflussen wird ${ }^{\text {s }}$

Ulmer ziet het AGB-Gesetz als een soort modern algemeen deel voor massaal gesloten overeenkomsten ${ }^{7}$ warvan hij de betekenis als volgt aangeeft:

"Anßer dem BGB gibt es kein anderes Gesetz, das bei Streitigkeiten im Rahmen wom Schuldwertragen so hauffig herangezogen wurde und so deutliche Spuren hinterlassen hat wie das AGB-Gesetz. ${ }^{\text {sil }}$

\subsection{De ervaringen met het AGB-Gesetz}

Duitse auteurs hebben geregeld de balans opgemaakt van het AGB-Gesetz zoals dat in de praktijk werkt." Buiten enige zogenaamde Revisionisten, vooral uit hel. kamp van het bedrijfsleven, die vinden dat de wet storend werkt op het handelsverkeer ${ }^{10}$, is de overgrote meerderheid het er over eens dat het AGBGesetz rechtstheoretisch en qua opbouw lof verdient en dat de uitwerking en toepassing daarvan in de rechtspraak, in wezen aan de gestelde verwachtingen en eisen voldoen. " In de praktijk is gebleken dat het AGB-Gestz zowel materieel- als procesrechtelijk voldoende houvast geeft aan rechtsbeoefenaren. In

6 Bunte, NJW 1987, pag. 921.

7 "(...) eimer Art modemen AMgemeänen Teils für Miassenvertrïge", Ulmer, Zehn Jahre AGBGesetz - Rückblick und Ausblick, Zehn Jahre AGB-Gesetz, pag. 10.

8 Uliner, AGP Geselz, Einl. Rndnr; 64.

9 Zie onder meer: Hardieck, Die gerichtliche Entseheidungspraxis in Verfahren nach 13 AGBG; Bunte, Zur Kontrolle Algemeiner Geschätsbedingungen und Konditionenermpfahlungen; BB 1980; Bunte. Erfahrungen müt dem AGB-Gesetz * Eine Zwischenbilanz nach 4 Jahren; Acp 1981; Ulmer, Erfahrungen mït dem AGB-Gesetz, Zwischenbilanz nach fünfjihriger Gieltuang: BB 1982; Bunte, Entwicklungen im Recht der Allgemeimen Geschäftsbedingungen "Eï Erfahrungsbericht nach 5 Jahnen AGB-Gesetz, DB 1982; Bohle en Mickliz, Erfahnungen müt dem AGB-Gesek im michtkeufmännischen Beneich, Eine Zwischenbilanz nach sechs Jahren, BB 1983; Schlosser, Entwicklungstendenzen im Recht der Allgemeinen Geschäftsbedingungen, Zip 1985; Von Hippel, Zur Kontrolle Allgemeiner Geschäftsbedingungen, BB 1985; Bunle, Zelinn Jahre AGB-Gesetz - Rückblick und Ausblick, NJW 1987; Ulmer, Zehn Jahre AGB-Gesetz Rürkblick und Ausblick, Zehn Jahre AGB-Gesetz 1987; Löwe, Instrumente der abstrakten Konttrolle, Zehn Jahre AGB-Gesetz 1987; Sehlosiser, 10 Jahre AGB-Gesetz, JR 1988; Bunte, 10 Jahre AGB-Gesetz - ein Gewinn an Rechtssicherheit?, JA 1988; Ulmer, Bilanz nach zwöllyäh. riger Gelung des AGBG, AGB-Gesetz, pag. 44-52, 1990.

10 Stumpf, paig. 963* Rabe, pag. 1978 e.w.

11 Heinrichs, Löwe en Ulmer, Vorwort, Zehn Jahre AGB-Gesetz, pag, V; Ulmer, Zehn Jahre AGB-Gesetz - Rückblick und Ausblick, Zehn Jahre AGB-Gesetz, pag. 5 en 17; Bunte, NN/ 1987, pag. 222 . 
rechtspraak en literatuur zijn enkele vragen weliswaar nog open gebleven, maar in grote lijnen heeft de enorme vloed aan rechterlijke uitspraken de grenzen van de toelaatbaarheid van algemene voorwaarden, met name indien deze worden gehanteerd jegens consumenten, voor tal van overeenkomsten verscherpt en duidelijk weten aan te geven. Een verscherping en duidelijkheid die zonder het AGB-Gesetz niet bereikt zou zijn. ${ }^{12}$ Zowel materieelrechtelijk als procesrechtelijk doen zich in de praktijk van het AGB-Gesetz voor wat betreft de voorschriften met betrekking tot de toepasselijkheid van algemene voorwaarden als met betrekking tot de toelaatbaarheid van de inhoud daarvan daarom ook nauwelijks problemen voor. De ervaringen ten aanzien van de verschillende onderdelen van het AGB-Gesetz komen in de volgende paragrafen aan de orde.

\subsubsection{De algemene regels van de $\$ \$ 1$ tot en met 7 AGBG}

De ten opzichte van de ontwikkelingen in de rechtspraak vór de inwerkingtreding van het AGB-Gesetz ruim gekozen begripsomschrijving van $\& 1$ Abs. 1 AGBG en het daarmee gepaard gaande ruime bereik van de wet blijkt in de praktijk een goed keuze te zijn. Pogingen van gebruikers om onder het bereik van de wet uit te komen door het hanteren van pseudo-individuele overeenkomsten of door te kiezen voor een onder de uitzonderingen van $\$ 23$ AGBG vallende vormgeving van de overeenkomst, zijn in de rechtspraak snel onderkend en adequaat verhinderd. ${ }^{13}$ Bovendien is ook gebruikers al snel gebleken dat dergelijke kunstgrepen zich moeilijk laten verenigen met de rationaliseringsfunctie van algemene voorwaarden. ${ }^{14}$

Op de toepasselijkheidsregels van $\S 2$ Abs. 1 AGBG is in de praktijk slechts beperkt beroep gedaan. Zo signaleert Ulmer dat in de Entscheidungssammlung zum AGB-Gesetz van Bunte voor het jaar 1984 (Band V) slechts acht van de 198 uitspraken betrekking hebben op $\$ 2$ AGBG. ${ }^{15}$ Er zijn maar weinig uitspraken bekend waarin de toepasselijkheid van algemene voorwaarden werd ontkend op grond van het niet voldoen aan de voorschriften van $\$ 2$ AGBG. ${ }^{16}$ Niet bekend is of deze geringe aandacht voor $\$ 2$ AGBG voortkomt uit het feit dat gebruikers zich in het algemeen aan de voorschriften van dit artikel houden of uit het feit dat partijen doorgaans niet op de hoogte zijn van het bestaan van deze voorschriften. Hoe het ook moge zijn, de beschermingsfunctie van de

12 Bunte, NIW 1987, pag. 922; Bunte, JA 1988, pag. 313.

13 Dunte, AcP 1981 , pag. 37; Wolf, AGBG Kommentar, Einl Rndnr. 30; Ulmer, AGB-Gesetz, Einl. Rndinr. 46.

14 Ulmer, AGB-Gesetz, Ein1. Rndnr. 46.

15 Ulmer, AGB-Gesetz, Eiml. Rndnr. 47, nool 72.

16 Sehlosser, ZIP 1985, pag. 456; Wolf, AGBG Kommentar, Einl Rndnr. 31; Ulmer, AGBGesetz, Einl. Rndinr. 47. 
voorschriften van 2 Abs. 1 AGBG wordt niet al te hoog ingeschat. ${ }^{17}$ De regel van 2 Abs. 2 AGBG blijkt in de praktijk van geringe betekenis te zijn. ${ }^{18}$

Van grotere praktische betekenis voor de toepasselijkheid van algemene voorwaarden dan de hoofdregels van \& $2 \mathrm{AGBG}$ is de regel van $\& 3 \mathrm{AGBG}$, op grond waarvan verrassende bedingen geen contractsinhoud worden ${ }^{19} \mathrm{Zo}$ hadden bij voorbeeld 93 van de 1190 in Bunte's Entscheidungssammlung zum AGB-Gesetz over de jaren 1977-1985 opgenomen uitspraken, betrekking op $\$ 3$ AGBG. ${ }^{20}$

De praktische betekenis van \& 4 AGBG (Vorrang der Individualabrede) is, gemeten aan het aantal uitspraken dat daarop betrekking heeft, daarentegen weer vrij gering. $\$ 4$ AGBG heeft enkel praktische relevantie in samenhang met de zogenaamde Schriffformklausel. In de rechtspraak is met betrekking tot deze bedingen een middenweg gevolgd. Individuele afspraken gaan weliswaar in beginsel voor algemene voorwaarden, maar tegelijkertijd wordt ook erkend dat de gebruiker er belang bij heeft dat hij niet wordt gebonden aan niet te controleren toezeggingen van hulppersonen die hun bevoegdheden voor de wederpartij kenbaar overschrijden. ${ }^{21}$

De contra proferentem regel van $\S 5$ AGBG is een voor de uitleg van algemene voorwaarden belangrijke regel. In de praktijk wordt er echter weinig gebruik van gemaakt omdat bedingen die meerduidig zijn uit te leggen kennelijk niet zo vaak voorkomen. Voor de collectieve actie is de voor de individuele procedure ontwikkelde regel zonder enige problemen verder ontwikkeld in die zin, dat een verbod of gebod ook op zijn plaats is, als slechts de voor de wederpartij meest ongunstige uitleg van een meerduidig beding leidt tot de kwalificatie onredelijk bezwarend op grond van $\$$ 9-11 AGBG. ${ }^{22}$

De regel van $\$ 6$ AGBG waarin de gevolgen van de nietigheid of niet gebondenheid aan algemene voorwaarden zijn opgenomen, heeft intussen geleid tot algemene erkenning van de regel dat "geltungserhaltende Reduktion" voor nietige algemene voorwaarden dient te worden afgewezen. De overeenkomst blijft in stand zonder het onredelijk bezwarend beding. Zodoende wordt de gebruiker bij het opstellen van zijn algemene voorwaarden min of meer gedwongen om acht te slaan op de bepalingen van de wet. ${ }^{23}$ De regel van $\$ 6$ AGBG

17 Ulmer, ACBB-Gesetz, Einl. Rndnr. 47.

18 Wolf, AGBG Kommentar, Einl Rudnr. 31.

19 Wolf, AGBG Kommentar, Einl Rudnr. 32; Ulmer, AGB-Geselz, Einl. Rndnr. 47.

20 Bunte, AGBE, Band I-VI; Ulmer, AGB-Gesetz, Einl. Rndnr. 47, noot 73.

21 Wolf, AGBG Kommentar, Einl Rndnr. 33; Ulmer, AGB-Gesetz, Einl. Rndnr. 48.

22 Schlosser, ZIP 1985, pag. 457, Löwe, Instrumente der abstrakten Kontrolle, Zehn Jahne AGBGesetz, pag. 110; Wolf, AGBG Kommentar, Einl Rndnr. 34; Ulmer, AGB-Gesetz; Einl. Rndnr. 48.

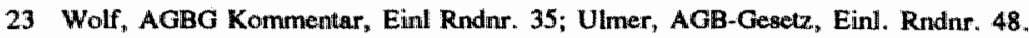


heeft er eveneens voor gezorgd dat de aanvulling van de overeenkomst op grond wan de redelijkheid en billijkheid voor de gevallen waarin het regelend recht niet voorziet in aanvulling van een door het wegvallen van een nietig beding ontstaan hiaat in de overeenkomst, niet alleen vaste voet aan de grond heeft gekregen in de Duitse rechtspraak maar eveneens in een omvang wordt gehanteerd die men voór de inwerkingtreding van de wet niet voor mogelijk had gehouden. ${ }^{24}$

De regel van $\$ 7$ AGBG (Umgehungsverbot) heeft in de praktijk geen noemenswaardige betekenis gehad. ${ }^{25}$

\subsubsection{De inhoudscontrole van de $\$ \$ 9$ tot en met 11 AGBG}

In de praktijk heeft de wet vooral belang gehad voor de inhoudelijke toetsing van algemene voorwaarden. Het merendeel van het grote aantal rechterlijke uitspraken heeft betrekking op de inhoudstoets op grond van de $\$$ 9-11 AGBG.

Algemeen wordt aanvaard dat de rechtsgrond voor de inhoudscontrole van algemene voorwaarden is gelegen in de voor algemene voorwaarden typische

"(...) einserige Inanspruchnahme des Rechts, den Inhalt der Vertrage zu gestallsen" "26.

Ondat dit reeds voortvloeit uit de aard van algemene voorwaarden speelt het (eventuele) economische of intellectuele overwicht van de gebruiker op de wederpartij en bijzondere beschermingsbehoefte van wederpartijen uitdrukkelijk geen rol. ${ }^{27}$

\$ 8 AGBG dat het toepassingsbereik van de inhoudscontrole beperkt tot nietkernbedingen is in de rechtspraak niet extensief uitgelegd en heeft daarom niet geleid tot een beperking van het toepassingsbereik van de inhoudscontrole. In tegendeel: in de rechtspraak is eerder een tendens waar te nemen dat de regel van $\$ 8$ AGBG restrictief dient te worden uitgelegd ten aanzien van algemene voorwaarden waarin de prijs of de te leveren prestatie nader wordt omschreven (Preis- und Leistungsbeschreibungsabreden) en zodoende alle (algemene) voorwaarden aan de inhoudscontrole te onderwerpen die niet direkt zijn voortgekomen uit het overeenkomen van de kern van de prestatie. ${ }^{28}$ Algemeen aan-

Woif, AGBG Kommentar, Einl Rndmr. 35.

Wolf, AGBG Kormmentar, Einl Rndnr. 36: Ulmer, AGB-Gesetz, Einl. Rndinr. 48.

BCH, NJW 1976, pag. 2346, WM 1976, pag. 960; BGH, NJW 1987, pag. 837. WM 1987, perg. 214.

7 BGH, NIW 1976, pag. 2346, WM 1976, pag. 960. Bunte, NJW 1987, pag. 923. Zo wordt bij de toepassing van het Transparenzebot uitgegaan van de Durchschnittskunde.

Schlosser, ZIP 1985, pag. 453; Wolf, AGBG Kommentar, Einl Rndnr. 37; Ulmer; AGBGesetz, Einl. Rnding. 49. 
vaard is eveneens; dat wettelijke bepalingen die het gebruik van bepaalde bedingen uitdrukkelijk toelaten er niet aan in de weg staan deze bedingen aan de inhoudscontrole van de $\$ \$$ 9-11 AGBG te onderwerpen. ${ }^{29}$

Gezien het grote aantal uitspraken waarin de inhoud van algemene voorwaarden is getoetst is het niet verwonderlijk dat de grenzen van de toelaatbaarheid van algemene voorwaarden voor een groot aantal soorten overeenkomsten en voor verschillende takken van (detail)handel tamelijk nauwkeurig zijn vastgelegd. Elk gezaghebbend handboek op het terrein van algemene voorwaarden bevat dan ook een uitgebreide, naar soort overeenkomst gerubriceerde, bijlage met de gevolgen van de rechterlijke uitspraken voor de verschillende soorten overeenkomsten. ${ }^{30}$

In vergelijking mét de inhoudstoets op grond van de lijsten van de $\$ 10$ en 11 was het merendeel van de rechterlijke uitspraken met betrekking tot de inhoudstoetsing gebaseerd op de open norm van $\$ 9$ AGBG. ${ }^{31}$ In de praktijk is de Generalklausel van $\& 9$ Abs. 1 AGBG, een flexibele norm gebleken, die mede door de nadere uitwerking in de $\$ \S 9$ Abs. 2, 10 en 11 AGBG voldoende houvast bood en, in vergelijking met de rechtspraak van vóor de inwerkingtreding van het AGB-Gesetz, een duidelijk strengere inhoudstoetsing heeft bewerkstelligd. ${ }^{32}$

Het feit dat de open norm beduidend vaker ten grondslag ligt aan de rechterlijke toetsing dan de lijsten van de $\S \S 10$ en 11 AGBG, vindt aan de ene kant zijn oorzaak in het feit dat de lijsten van de $\$ \$ 10$ en 11 AGBG niet van toepassing zijn op het rechtsverkeer tussen ondernemers onderling en anderzijds omdat de lijsten een eigen preventieve werking hebben en de grenzen van de lijsten met het toenemen van het aantal rechterlijke uitspraken duidelijk zijn komen vast te liggen. ${ }^{33}$ Verder is het grote aandeel van de open norm bij de inhoudstoets het gevolg van het feit dat de lijsten van de $\$ \S 10$ en 11 AGBG nog veel gebieden ongeregeld laten en daardoor beschouwd worden als tuckenhaft. ${ }^{34}$ Dit geldt met name voor exoneratieclausules die buiten het bereik van

29 Wolf, AGBG Kornmentar, Einl Rndnr. 37.

30 Zie bij voorbeeld: Wolf, AGBG Kommentar, \& 9 VIII. Einzelne Klauselh und Vertragsitypen alphabetischer Reiheryfolge, pag. 405-989, van Abonnementwertrag tot Zuständigkeitsvereinthnungen; Ulmer, Brandner, Hensen en Schunidt, Anhang zu \$8 9-11, Einzelne Klawsel- whel vertragstypen, pag. 665.945 , van AbtretungsausschluB tot Zufallshaftung.

31 Bunte, NJW 1987, pag. 923; Wolf, AGBG Kommentar, Einl Rndnr. 38.

32. Wolf, AGBG Kommentar, Einl Rndnr. 38; Bunte, NJW 1987, pag. 922; Bunte, JA 1988, pag. 313; Ulmer, AGB-Gesetz, Einil. Rndnr. 50;. Heinrichs, Mallstäbe und Anwendumgsbenejich doet Inhaliskontrolle, in: Zehn Jahre AGB-Gesetz, Verlag Kommunikationsforum Recht Wirtschaif Streuem, Köln 1987, pag. 23 en 36.

33 Wolf, AGBG Kommentar, Einl Rndnr. 38.

34 Wolf, AGBG Kommentar, Einl Rndnr. 38; Ulmer, AGB-Gesetz, Einl, Rndinr. 50. 
$\$ 11$ Nr. 7,8 en 10 vallen en prijsverhogingsbedingen bij levertijden van meer dan 4 maanden. ${ }^{35}$

Indien de inhoudstoets wél plaats vindt aan de hand van de lijsten van de $\$ 10$ en 11 AGBG, valt op dat vooral de $\$ 10 \mathrm{Nr}$. 1 (te lange of onbepaalde levertijd), 2 (verlengde levertermijn), 3 (eenzijdig opzeggingsrecht voor gebruiker), 4 (eenzijdig wijzigingsrecht voor gebruiker) en 7 (vergoeding bij opzegging overeenkomst door partijen) AGBG en $\$ 11 \mathrm{Nr}$. 1 (prijsverhoging), 3 (verrekening), 4 (ingebrekestelling), 5 (vooraf vastleggen van schadevergoeding), 7 (aansprakelijkheid bij grove schuld), 8 (uitsluiting van ontbinding of schadevergoeding bij vertraging of onmogelijkheid van nakoming) en 10 (garantie) AGBG een rol spelen. ${ }^{36}$

\subsubsection{De procesrechtelijke voorschriften van de $\$ 13$ tot en met 22 AGBG}

In de vormgeving van het collectief actierecht en de daarvoor geldende procesrechtelijke voorschriften zijn tot nu toe geen zwaarwegende gebreken te herkennen. De praktijk richtte zich naar het voorbeeld van het collectief actierecht op het terrein van het mededingingsrecht waar reeds geruime tijd zowel door de rechterlijke macht als de consumentenorganisaties ervaringen mee waren opgedaan. Consumentenorganisaties ondervinden derhalve weinig problemen met de regeling van en de uitoefening van het collectief actierecht als bedoeld in $\$ 13$ e.v. AGBG. De extra eisen die $\$ 13$ Abs. 2 Nr. 1 AGBG aan consumentenorganisaties stelt bleken in de praktijk geen onoverkomelijke hindernis te zijn voor serieuze consumentenorganisaties. ${ }^{37}$

Enige kritiek wordt in de literatuur geuit ten aanzien van het ontbreken van een regeling die uitdrukkelijk voorziet in een voorlopige voorziening voor het collectief actierecht op het terrein van de algemene voorwaarden. ${ }^{38}$ Alhoewel algemeen wordt aanvaard dat de Einstweilige Verfügung ook zonder een uitdrukkelijke regeling in de collectieve procedure mogelijk is, blijkt deze in de praktijk door consumentenorganisaties met uiterste terughoudendheid te worden toegepast. ${ }^{39}$

Eenstemmig is men in literatuur en rechtspraak over de omkering van de regel van $\$ 5$ AGBG voor de collectieve actie. Voor de collectieve actie is de

Wolf, AGBG Kommentar, Einl Rndnr. 39; Axmann, pag. 123-135; zie cok hiervoor paragraaf 10.4 .

37 Wolf, AGBG Kommentar, Einl Rndnr. 40; Axmann, pag. 77; Ulmer, AGB-Gesetz, Einl. Rindnr. 52.

38 Woif, AGBG Kommentar, Einl Rndinr. 40.

39 Axmann, pag. 104-106; Ulmer, AGB-Gesetz, Einl. Rndnr. 51. Zie ook hiervoor paragranf 8.3 e.w. 
voor de individuele procedure ontwikkelde regel zonder enige problemen verdet ontwikkeld in die zin, dat een verbod of gebod ook op zijn plaats is, als slechits de voor de wederpartij meest ongunstige uitleg van een meerduidig beding leidt: tot de kwalificatie onredelijk bezwarend op grond van \$ 9-11 AGBG.

De preventieve werking van de collectieve verbodsactie heeft door de uitspraak van het BGH van 11 februari 1981 ook een terugwerkend en daarmee repressief karakter verkregen. ${ }^{41}$ Het collectieve verbod ziet immers niet alleen op ná het verbod gesloten overeenkomsten maar eveneens op bedingen in reeds vóor het verbod gesloten overeenkomsten die eerst ná het verbod worden uitgevoerd. ${ }^{42}$ Deze uitspraak heeft een verdergaand effect dan de in de ogen van dogmatici omstreden regeling van $\$ 21$ AGBG. $\$ 21$ AGBG alsmede $\$ 19$ AGBG hebben in de praktijk derhalve nauwelijks betekenis. ${ }^{43}$ Zo vermeldt Löwe dienaangaande:

"Mir persönlich ist ZB. Kein einziger praktische Fall bekcannt, in dem ein Gericht wrwer" Hinweis cay? 2. AGBG eine Bindung an eine vorherige Unterlassungsvenurteilung angenowmen whd eime AGE allein deshalb verworfen hat. Diese Norm wie auch die des 19 AGBG gehär daher wohl mit allow thren Streiffragen allenfalls noch in Ubungsveranstaltungen, hat aber praktisch keine Bedetw fwng. 14

Enige kritiek ondervindt ook de regeling van de Streitwert van $\S 22$ AGBG. De kritiek richt zich met name op het te hoge maximum van $500.000 \mathrm{DM}$, een maximum dat overigens in de praktijk nog nooit is bereikt. Procedures met een tegen het maximum aan liggende Streitwert brengen immers grotere kostenrisico's met zich ${ }^{45}$ en zouden het vooral kleinere consumentenorganisaties onmogelijk maken om te procederen omdat bij verlies het voortbestaan van deze organisaties op het spel staat. ${ }^{46}$

Ook met het register van het Bundeskartellamt van aanhangige procedures en uitspraken op het terrein van de collectieve actie zoals bedoeld in 20 AGBG is niet iedereen onverdeeld gelukkig. Met name de ontoereikende inhoud van de registraties wordt daarbij als voornaamste probleem gezien. ${ }^{47}$ Sommige

40 Ulmer, AGB-Gegetz, Einl. Rndnr. 48.

41 BGH, NJW 1981 , pag. 1511.

42 Löwe, Instrumente der abstrakten Kontrolle, Zehu Jahre AGB-Gesetz, pag. 110-111.

43 Bohle en Mielditz, pag. 6; Axmann, pag. 147.

44 Lôwe, Instrumente der abstrakten Kontrolle, Zehn Jahre AGB-Gesetz, pag. 111.

45 Volgens de vaste advocaat van de Verbrawcherzentralle Baden-Wünttemberg (Stillner) wamen do proceskosten van proeedures die tot in hoogste instantie (BGH) werden gevoend medio 1991 bij een "Streitwert" van 50.000 DM ongeveer 40.000 DM en bij een "Streitwert" van 300.000 DMU ongeveer $60.000 \mathrm{DM}$.

46 Damm, pag. 170; Bunte, AcP 1981, pag. 59; Axmann, pag. 107.

47 Creutzig, pag. 20; Hardieck, pag. 708; Stiliner, pag. 148; Axmann "pag; 148; Ulmer, AGBGesetz, Einl. Rndnr. 52. 
auteurs vinden het bovendien wenselijk dat ook de uitspraken in individuele procedures worden geregistreerd ${ }^{48}$, hetgeen door anderen vanwege de praktische onmogelijkheid wordt afgewezen ${ }^{49}$.

\subsection{De zuiverende werking van het AGB-Gesetz}

De effectiviteit van het AGB-Gesetz is vooral te meten aan de mate waarin in de praktijk algemene voorwaarden zijn aangepast aan de vereisten van de wet; de mate dus waarin de markt is bevrijd van onredelijk bezwarende bedingen.

Bij de totstandkoming van de wet ging de Duitse wetgever ervan uit dat het enkele bestaan van alleen al het materieelrechtelijke gedeelte van het AGBGesetz tot gevolg zou hebben dat serieuze organisaties en ondernemers hun algemene voorwaarden van onredelijk bezwarende bedingen zouden ontdoen en zodoende reeds een deel van de markt verlost zou worden van onredelijk bezwarende bedingen. De juistheid van deze verwachting is door verschillende Duitse schrijvers echter in twijfel getrokken.

Buiten een enkele optimist als Schlosser, die van mening is dat het AGBGesetz heeft geleid tot een verregaande bevrijding van de markt van onredelijk bezwarende algemene voorwaarden ${ }^{50}$, komt de meerderheid tot de conclusie, dat het AGB-Gesetz weliswaar een zuiverende werking heeft gehad die zonder de wet niet zou zijn opgetreden doch dat de zuiverende werking van het AGBGesetz nog lang niet optimaal is. ${ }^{51}$

Aan de ene kant is op een aantal terreinen duidelijk vooruitgang geboekt. Met name in belangrijke branches als de automobielbranche, de reisbranche, de banken, spaarinstellingen en ziekenhuizen zijn de algemene voorwaarden, vaak meerdere malen en mede gedwongen door collectieve acties, aangepast aan de eisen van het AGB-Gesetz. ${ }^{52}$ De invoering van het AGB-Gesetz heeft dan ook geleid tot een aanmerkelijke toename van het aantal bij het BKA aangemelde Konditionenempfehlungen. ${ }^{53}$ Zo werden de 18 reeds bestaande aanmeldingen van 1 april 1977 tot eind 1986, aangevuld met 179 nieuwe Konditionenemp-

48 Gerlach, Münchener Kommentar, Vor \$ 13 AGBG Rndnr. 17; Bunte, AcP 1981, pag. 57.

49 Axmann, pag. 148; Ulmer, AGB-Gesetz, Einl. Rndnr. 52.

SO Schlosser, ZIP, pag. 449.

51 Ulmer, BB 1982, pag. 587; Ulmer, AGB-Gesetz, Einl. Rndnr. 58-59; Bunte, DB 1982, pag. 11 ; Bohle en Micklitz, pag. 2 en 22; Von Hippel, BB 1985, pag. 1629; Axmarn, pag. 146; Bunte, NJW 1987, pag. 922; Bunte, JA 1988, pag. 313, Löwe, Grokkommentar zum AOBGesetz, Vorbemerkungen zu den \$ 13-22 Rudnr. 24-25; Lôwe, Instrumente der abotrakten Kontrolle, Zehn Jahre AGB-Gesetz, pag. 118-120; Gerlach, Münchener Kommentar, Vor 13 AGBG Rndnr. 29-3-; Wolf, AGBG Kommentiar, Einll Rndnr. 24-26.

52 Bunte, NJW 1987, pag. 922.

53 Zie voor cen owerzicht van alle tot jamuari 1989 bij het BKA en de Landegkartellbehörden anigernelde Konditionenempfehlungen: Schmidt, AGB-Gesetz, Anh. 88 9-11, pag. 945-967, Tätigkeitshericht des Bundeskartellamts 1987/1988, BT Drucksache 11, pag. 4611. 
fehlungen en werden 10 Konditionenempfehlungen gewijzigd. Van deze Konditionenempfehlungen waren er 55 bedoeld om uitsluitend of mede te worden gebruikt in overeenkomsten met consumenten. ${ }^{44}$ Op 30 juni 1992 waren in totaal 274 Konditionenempfehlungen aangemeld. ${ }^{55}$ Daaronder bevinden zich belangrijke aanbevelingen voor de algemene voorwaarden van onder andere de automobielbranche, automobielreparatiebranche, parkeergarages, meubelbranche, textielbranche reisbranche ete. ${ }^{56}$ Consumentenorganisaties, doorgaans de VSV en de AGV, kunnen niet alleen invloed op de inhoud van deze Konditionenempfehlungen uitoefenen doordat zij door het BKA gehoord worden maar tevens, indien dit niet het gewenste effect heeft, door het voorleggen van de betreffende Empfehlungen aan de rechter. De countervailing power van consumentenorganisaties is wat dat betreft aanzienlijk toegenomen. De markt is juist voor een aanzienlijk deel bevrijd van onredelijk bezwarende algemene voorwaarden door de aanpassing van voor de consument belangrijke Konditionenempfehlungen. ${ }^{57}$ Bunte meent dat deze vooral uniform worden overgenomen door het midden- en kleinbedrijf zonder eigen juridische dienst. ${ }^{58}$ Met name op het terrein van de Koditionenempfehlungen zijn aanmerkelijke verbeteringen in de positie van de consument bewerkstelligd.

Andere auteurs zijn een stuk minder optimistisch wat betreft de uniforme werking van deze Konditionenempfehlungen. Hun pessimisme is daarbij vooral gebaseerd op het gegeven dat Konditionenempfehlungen niet dwingend mogen worden voorgeschreven en volkomen onduidelijk is in hoeverre door brancheorganisaties aanbevolen algemene voorwaarden in de praktijk ongewijzigd: worden gebruikt. Het staat elke gebruiker immers vrij van deze Konditionen empfehlungen af te wijken, hetgeen in de praktijk ook veelvuldig gebeurt. ${ }^{59}$

Vooral met betrekking tot de zuiverende werking van de wet in het professionele handelsverkeer en in het rechtsverkeer tussen consumenten en het klein- en middenbedrijf, worden in de literatuur grote twijfels geuit. Afgezet tegen de 20.000 tot 30.000 sets van algemene voorwaarden welke naar schatting in omloop zijn is het aantal tot nu toe gevoerde procedures (op 31 december 1992

54 Bunte, AcP, 1981, pag. 60; Löwe, Instrumente der abstrakten Kontrolle, Zehn Jahre AGEGesetz, pag. 103.

55 Woif, AGBG Kommentar, Einl Rndnr. 28.

56 Löwe, Instrumente der abstrakten Kontrolle, Zehn Jahre AGB-Gesetz, pag. 103.

57 Bunte, DB 1980, pag. 329; Bunte, AcP 1981, pag. 60; Ulmer, BB 1982, pag. 587; Axmiana, pag. 56 e.v.; Löwe, Instrumente der abstrakten Kontrolle, Zehn Jahre AGB-Gesetz, pag. 103.

58 Bunte, AcP 1981, pag. 61.

59 Löwe, Instrumente der abstrakten Kontrolle, Zehn Jahre AGB-Gesetz, pag, 104 en 113. 
waren bij het BKA 1054 in kracht van gewijsde gegane vonnissen geregistreerd) toch tamelijk gering. ${ }^{60}$

Voor wat betreft het nagenoeg ontbreken van een zuiverende werking in het professionele handelsverkeer is deze grotendeels te wijten aan het feit dat branche-organisaties nauwelijks gebruik hebben gemaakt van de hen toekomende actiebewoegdheid van \& 13 AGBG. .1 $^{\prime}$

Voor wat betreft de geringe doorwerking van het AGB-Gesetz in overeenkomsten met consumenten in met name het midden- en kleinbedrijf, wordt deze vooral geweten aan het geringe eigen initiatief of onwetendheid van de gebruikers aan de ene kant en een in omvang tekortschietende controleactiviteit van de consumentenorganisaties aan de andere kant. ${ }^{62}$ Voor het terrein van de algemene voorwaarden gehanteerd jegens consumenten valt op dat branche-organisaties, zo zij al gebruik maakten van het collectief actierecht als bedoeld in $\$ 13$ AGBG, dit enkel deden tegenover gebruikers in hun voorschakels en ten behoeve van hun eigen leden. Het oogmerk van deze acties was niet gelegen in een aanpassing van de algemene voorwaarden gebruikt jegens consumenten. ${ }^{63}$

Opvallend veel algemene voorwaarden die de toets van het AGB-Gesetz niet kunnen doorstaan zijn en worden nog steeds gebruikt in de meubelbranche, door sportscholen, fitness-studio's en door huwelijks- en relatiebemiddelingsbureau"s. ${ }^{6}$ Volgens Bunte zijn er nog (te) veel branches waarin onredelijk bezwarende algemene voorwaarden worden gebruikt:

Dies deckt sich mit meinen Untersuchumgen, nach deren sich die Praxis der Untermehmen nur sehr showher auf das Gesetz einstellen kann, wonach zwar ganz bedeuternde Branchen, wie etwo dep Rraffahrzeuthaudel, das Krafffahrzeughandwerk, die Banken und viele andere Bereiche die dort besitehenden Konditionemempfehtungen an das AGB-Gesetz angepast haben, daß es aber immer noch Branchen gibs, in denen won den Majsiäben des AGB-Gesetzes noch nich viel in die eigenen Bedingungen abernommen wurde. "65

Sterker nog drukt Löwe het uit:

60 Axmann, pag. 146; Heinriehs, Maßistäbe und Anwendungsbereich der Inhaltakontrolle, Zehn Jahre AGB-Gesetz, pag. 37; Bunte, NJW 1987, pug. 921 en 923; Bunte, JA 1988, pag. 313; Löwe, Instrumente der abstrakten Kontrolle, Zehn Jahure AGB-Gesetz, pag. 104-105 en 1.12 113.

61 Bunte, BB 1980, pgg. 327; Bohle en Micklitz, pag. 7; Axmann, pag. 138; Wolf, AGBG Kommentar, Einl Rndnr. 25; Ulmer, AGB-Geselz, Einl. Rndnr. 60. Zie ook hiervoor paragragef : 3.

62. Axmann, pag. 138; Wolf, AGBO Kommentar, Einl Rndnir. 25-26; Löwe, Instrumente der abstrakten Kontrolle, Zehn Jahre AGB-Gesetz, peg. 111-114; Ulmer, AGB-Gesetz, Einl. Rndnr. 60-61.

63 Ulmer, AGB-Gesetz, Einl. Rndnr. 60.

64 Bunte, NJW 1987, pag. 922.

65 Bunte, JA 1988, pag. 313. 
"Wie vielfach schon belklagt worden ist, gibt es auch Jahre nach dem Inikaffitreten des AGB-Gesenes noch eine Masse won Klauselwerken, in denen sich wonwirksame AGB befinden, welche Birmats. mavn auch immer stichprobenartig therprafen mag. Weder die Verbote aus den Klauselleatalogem. noch sonst zwingendes Recht (Z.B. Reiserecht, Gerichtsstandswereinbunongen, Abzahlungsgeneid) werden durchgehend beachtet. Nach meiner eigenen Erfahinung sind AGB, welche keine umwirksumen Klauseln enthatien, noch immer leider eher die Ausnahme. "66

\subsection{Effectiviteit van het collectieve actierecht als middel ter compensatie van de ongelijkheid van partijen}

Op zichzelf gezien heeft het collectief actierecht niet tot al te grote problemen geleid. De regels zijn duidelijk en (vooral) consumentenorganisaties maken veelvuldig gebruik van het collectief actierecht. De hoge succesquota van de consumentenorganisaties maken duidelijk dat zij weinig problemen ondervinden met de toepassing van het collectief actierecht.

Het AGB-Gesetz is ook veelvuldig toegepast in individuele procedures. Alhoewel over het aantal van deze procedures weinig bekend is, geldt ook voor sommige van deze procedures dat zij, mits voorzien van de nodige publiciteit, eenzelfde duidelijke precedent- en daarmee breedtewerking hebben gehad als uitspraken in collectieve procedures.

Zoals gezegd zijn het echter vooral de consumentenorganisaties die gebriik maken van het collectieve actierecht. De op 31 december 1992 geregistreerde 1054 vonnissen zijn voor meer dan $90 \%$ toe te schrijven aan de activiteiten van consumentenorganisaties. De nadere verscherping en de duidelijkheid ten aanzien van de toelaatbaarheid van algemene voorwaarden, alsmede de toch aanmerkelijke bevrijding van de markt van onredelijk bezwarende algemene voorwaarden die zowel buiten als in rechte wel heeft plaatsgevonden, is daarom voornamelijk te danken aan het, meestal succesvolle, collectieve optreden van consumentenorganisaties. In tegenstelling tot het rechtsverkeer tussen ondernemers onderling heeft de collectieve actie op het consumententerrein dus duidelijk haar sporen verdiend als een effectief middel ter bescherming van consumentenbelangen op het terrein van de algemene voorwaarden. Consumentenorganisaties geven dan ook aan dat het collectief actierecht in beginsel een effectief middel is ter compensatie van individuele ongelijkheid.

Tegelijkertijd wordt echter eveneens gesignaleerd dat de gewenste breedtewerking van het AGB-Gesetz (nog steeds) niet is gerealiseerd en dat dit met name ligt aan het feit dat de handhavingsactiviteiten van de actiebevoegde organisaties in omvang te gering zijn, zij hun aandacht vooral richten op die gevallen waarin 
een klinkend resultaat te behalen is (dus voornamelijk op de evident onredelijk bezwarende bedingen), om een daadwerkelijke zuivering van de markt van onredelijk bezwarende algemene voorwaarden te bewerkstelligen en dat dit woornamelijk te wijten is aan het gebrek aan financiële middelen. ${ }^{67}$

Dit alles doet op zijn minst genomen ernstige twijfel rijzen omtrent de vraag of de in het AGB-Gesetz verankerde consumentenbescherming wel voldoende gerealiseerd wordt. De effectiviteit van een wettelijke regeling a la het AGBGesetz lijkt immers grotendeels afhankelijk van het systematisch optreden van consumentenorganisaties en daarmee van de financiële middelen die de agerende consumentenorganisaties ten dienste worden gesteld. Vooral dit gebrek aan fimanciële middelen leidt tot een aantal knelpunten in de toepassing van een, volgens de consumentenorganisaties op zichzelf gezien effectief actiemiddel.

\section{Te weinig menskracht}

In de gehele Bondsrepubliek waren ten tijde van het afsluiten van dit onderzoek (zomer 1994) bij de consumentenorganisaties slechts zeven personen actief bezig met de inhoudelijke controle van algemene voorwaarden. Aangezien brancheorganisaties in beduidend mindere mate dan de consumentenorganisaties op het terrein van het AGB-Gesetz actief zijn, rust de collectieve handhaving van het (algemene) consumentenbelang op het terrein van de algemene voorwaarden derhalve voornamelijk op de schouders van deze zeven personen. De actieve consumentenorganisaties geven aan dat dit te weinig is. In de wandelgangen spreekt men van een benodigd team van circa 30 medewerkers.

Gedwongen door een tekort aan menskracht, blijft het optreden van de consumentenorganisaties veelal beperkt tot de evidente inbreuken op het AGBGesetz. Met dit beperkte optreden is de grens van de personele capaciteit all bereikt. Dit blijkt ook uit een vergelijking van het aantal in omloop zijnde algemene voorwaarden met het aantal Abmahnungen. Het aantal in omloop zijnde algemene voorwaarden wordt geschat op 20.000 tot 30.000 stuks, terwijl het aantal Abmahnungen in de periode 1977-1992 door mij wordt geschat op ruim 5200 (VSV 2683, VZ Baden-Württemberg 2270 en de Verbraucherzentralen Hamburg en Nordrhein-Westfalen samen ruim 250); vergelijk paragraaf 8.3.3. Gegeven de beperkte personele middelen kunnen de consumentenorganisaties slechts een beperkt deel van de in omloop zijnde algemene voorwaarden aan de AGB-controle onderwerpen.

67 Axmann, pag. 152; Wolf, AGBG Kommentar, Einl Rndrr. 26; Löwe, Ingtrumente der abstralkten Kontrolle, Zehn Jahre AGB-Gesetz, pag. 115; Ulmer, AGB-Gesedz, Einl. Rndnr. 62. 


\section{Nauwelijks gerichte opsporing}

Van een gerichte opsporingsactiviteit zou slechts in zoverre kunnen worden gesproken, dat de VSV de Konditionenempfehlungen aan een inhoudscontrole onderwerpt, alsmede in zoverre dat "zwaartepunten" worden gesteld. Vergeling paragraaf 9.3. Voor het overige is van een gerichte opsporingsactiviteit geen sprake: de controle van algemene voorwaarden door de consumentenorganisaties vindt derhalve voornamelijk plaats naar aanleiding van individuele consumen: tenklachten. Daarbij kan de Offentlichkeitsarbeit zoals deze gehanteerd wordi door de Verbraucherzentralle Baden-Württemberg (zie paragraaf 9.3.2) etn nuttige functie vervullen.

Aan de hoeveelheid algemene voorwaarden die zich langs deze wegen ter controle aandienen, hebben de consumentenorganisaties hun handen vol. Reeds het enkele feit dat men moet overgaan tot het stellen van "zwaartepunten" vornts een genoegzame indicatie dat voor een gerichte opsporing - en systematische controle van de inhoud van de aldus gevonden algemene voorwaarden - de menskracht ontbreekt.

\section{Doorgaans geen risicovolle zaken}

Het verliezen van een procedure is veelal een kostbare zaak. De VSV heeft van de 276 gevoerde gerechtelijke procedures waarvan de uitkomst in de jaarverslagen staat vermeld er 237 gewonnen, 28 leidden tot een schikking, terwijl er 6 zijn verloren en de VSV zich 5 keer uit de procedure heeft teruggetrokken; zie paragraaf 8.3.3.1. De Verbraucherzentrale Baden-Württemberg heeft van de 391 procedures, waarvan de afloop in de jaarverslagen was vermeld, 356 zaken gewonnen, 22 verloren, 10 geschikt en heeft zij zich één keer teruggetrokken uit de procedure; zie paragraaf 8.3.3.2. De geringe financiële middelen die voor de procedures ter beschikking staan - vergelijk paragraaf 9.6 - belemmeren het starten van risicovolle procedures, ook al zijn juist die zo interessant voor de verdere ontwikkeling van het consumentenrecht op het gebied van de algemene voorwaarden. Dit beeld stemt overeen met de constatering bij knelpunt 1 dat als gevolg van een tekort aan menskracht het optreden van de consumentenorganisaties veelal beperkt blijft tot de evidente inbreuken op het AGB-Gesetz. Een indicatie hiervoor ligt eveneens besloten in het feit dat de door consumentenorganisaties gevoerde procedures een groot aantal "zwarte" bedingen tot voorwerp hadden en nog steeds hebben; vergelijk paragraaf 10.4 .

\section{Geen gerichte na-controle}

De consumentenorganisaties controleren niet gericht of gebruikers en aanbevelers zich wel houden aan de afgegeven strafbewehrte Unterlassungserklärungen of verbodsuitspraken, alhoewel een financieel belang voor een dergelijke activiteit gegeven lijkt. Ook het nalaten van deze na-controle wordt verklaard 
met een beroep op het ontbreken van voldoende personele middelen. Het ontbreken van deze na-controle is mogelijk een (extra) reden voor organisaties en ondernemers om onredelijk bezwarende algemene voorwaarden ten aanzien waarvan een strafbewehrte Unterlassungserklärung is afgegeven dan wel ten aanzien waarvan op straffe van een dwangsom een rechterlijk verbod van gebruik is uitgesproken, desondanks te blijven gebruiken. De "pakkans" is in deze situatie immers vrij gering.

\section{Geen voorlopige voorziening}

Met name de VSV verklaart als knelpunt te ervaren dat het in de praktijk steeds moeilijker wordt om evidente overtredingen van het AGB-Gesetz te bestrijden door middel van een einstweilige Verfügung. Daarom kan niet of nauwelijks van deze snelle manier om de markt te bevrijden van onredelijk bezwarende voorwaarden gebruik worden gemaakt. Zie hierover paragraaf 9.5 .

Afgezien van de feitelijke onmogelijkheid van de voorlopige voorziening in de procedure van $\$ 13$ AGBG, loop als een rode draad door de bovengenoemde knelpunten het gemis aan voldoende financiële middelen bij consumentenorganisaties. Voor een overzicht van de inkomsten en uitgaven van de VSV respectievelijk de Verbraucherzentrale Baden-Württemberg zie hierboven paragraaf 8.2. Dit knelpunt behoeft geen nadere toelichting: de omvang van de uitoefening van het collectieve actierecht op het terrein van de algemene voorwaarden is Duitsland in sterke mate afhankelijk van het ter beschikking stellen van voldoende financiële middelen aan consumentenorganisaties door de Duitse overheid. In de Duitse literatuur is men magenoeg eensluidend van mening dat het collectief actierecht op zichzelf gezien voldoende potentie heeft om de ongelijkheid van partijen op het terrein van de algemene voorwaarden te compenseren. In die zin behoeft het AGB-Gesetz geen wijzigingen. De beoogde breedtewerking en bevrijding van de markt van onredelijk bezwarende algemene voorwaarden en daarmee dus de effectiviteit van het AGB-Gesetz kan echter aanmerkelijk worden verbeterd, als de overheid bereid is aan consumentenorganisaties meer financiële middelen te bieden dan tot nu toe het gevall is. Daardoor zou het voor consumentenorganisaties mogelijk worden om ook daadwerkelijk een volledig rechtshandhavingsmodel te kunnen hanteren met gerichte opsporing en nacontrole, om zodoende niet alleen het aantal optredende consumentenorganisaties uit te breiden maar ook het aantal in en buiten rechte te entameren procedures op te voeren. ${ }^{68}$

68 Zie colk: Axmann, pag. 152-153; Löwe, Instrumente der abstrakten Kontrolle, Zehn Jahre AGB-Gesetz, pag. 115-116; Ulmer, AGB-Gesetz, Einl. Rndnr. 62. 
IV NIEUWE WEGEN 


\section{De Duitse ervaringen vertaald naar de Nederlandse situatie}

\subsection{Inleiding}

Zoals reeds besproken in hoofdstuk 7 komt het Duitse AGB-Gesetz materieel gezien voor wat betreft systeem, opbouw, invulling en werking grotendeels overeen met de Nederlandse Wet algemene voorwaarden. Slechts op enkele punten wijken de materieelrechtelijke regels van elkaar af. Zo is met name de informatieplicht in het Nederlandse systeem aanzienlijk strenger dan die in het AGB-Gesetz. Daar staat tegenover dat het AGB-Gesetz de helderheid en begrijpelijkheid van een beding meeneemt bij de informatieplicht waardoor de wederpartij niet is gebonden aan bedingen die niet helder of niet begrijpelijk zijn. Een gering verschil is ook te bespeuren ten aanzien van de reikwijdte van de twee wetten. De Wet algemene voorwaarden heeft een iets groter bereik dan het AGB-Gesetz.

Een aanzienlijk materieel verschil tussen de Duitse en de Nederlandse regeling wordt veroorzaakt door het verschil in sanctie dat staat op het gebruik wan onredelijk bezwarende algemene voorwaarden. De Duitse rechter toetst daardoor ambtshalve of een beding in algemene voorwaarden onredelijk bezwarend is. De Nederlandse rechter mag dit niet en stelt zich lijdelijk op.

Voor wat betreft de collectieve actie op het terrein van de algemene voorwalarden ontlopen de regellingen elkaar in opzet, invulling en werking eveneens nanwelijks. Een duidelijk verschil is dat de Duitse regeling in twee feitelijke instanties voorziet en de Nederlandse regeling slechts in een feitelijke instantie. Bovendien is in Nederland de rechtspraak in eerste instantie geconcentreerd bij een gerechtshof. In Duitsland is slechts in een beperkt aantal deelstaten sprake van concentratie. Het verschil zit grotendeels in de nadruk die de Nederlandse wetgever legt op zelfregulering van de marktpartijen, waardoor Nederlandse consumentenorganisaties zich in tegenstelling tot de Duitse consumentenorganiSaties geplaatst zien voor een overlegverplichting. Daar staat weer tegenover dat de Nederlandse regeling - ten behoeve van de beoogde breedtewerking - de mogelijkheid schept om een branchevereniging tezamen met haar leden collectief te dagvaarden hetgeen in het Duitse systeem niet kan. 
Een aanmerkelijk verschil tussen de Nederlandse regeling en de Duitse regeling: vloeit, zowel bij de individuele als bij de collectieve procedure, voort uit de algemene regels ten aanzien van de verdeling van de kosten. In Nederland zal een procedure voor de wederpartij of de eisende organisatie welhaast altijd. kosten met zich brengen, ook al wordt de procedure voor $100 \%$ gewonnen. In Duitsland daarentegen krijgt de in een individuele of collectieve procedure in hat gelijk gestelde partij in beginsel al haar proceskosten vergoed door de in het ongelijk gestelde partij.

In dit hoofdstuk zal ik de Duitse ervaringen met het AGB-Gesetz vertalen naar de Nederlandse wet algemene voorwaarden om zodoende een prognose te geven van de effectiviteit van de Wet algemene voorwaarden in het algemeen en het collectief actierecht als middel ter compensatie van ongelijkheid op het terrein van algemene voorwaarden in het bijzonder. Daarbij richt zich de aandacht uiteraard enkel op het consumentenperspectief in deze.

\subsection{Te verwachten effectiviteit van de Wet algemene voorwaarden}

Net als in Duitsland, zij het in iets bescheidener mate, is de invoering van de nieuwe regelgeving op het terrein van de algemene voorwaarden gepaard gegaan met een naar Nederlandse begrippen ruime belangstelling in de juridische literatuur' en zijn her en der in den lande cursussen, symposia en voorlichtingsbijeenkomsten gehouden die de nieuwe wet en de gevolgen daarvan voor de praktijk tot onderwerp hadden of hebben. Of deze aandacht voor de wet ook tot uitdrukking komt in de praktijk, dat wil zeggen onredelijk bezwarende algemene voorwaarden van de markt zal doen verdwijnen, is bijna twee jaar na inwerkingtreding van de wet nog onzeker. Rijken is daarover begin 1994, én jaar nadat de Wet algemene voorwaarden volledig operationeel is geworden, niet al te optimistisch. $^{2}$

De Nederlandse wet heeft net als het Duitse AGB-Gesetz (mede) ten doel het rechtsverkeer tussen consumenten en professionele aanbieders te zuiveren vail onredelijk bezwarende algemene voorwaarden. Daarenboven beoogt de Wet algemene voorwaarden een impuls te bieden voor tweezijdig overleg tussén

1 In de serie Praktijkhandleidingen verscheen reeds in 1987 het Nederlandse "stiandaardwerk" op het terrein wan de algemene voorwarden van Wessels en Jongeneel (Algemene voorwararden) en is in juni 1992 een tweede druk verschenen in de serie Studiepockets privatrecht, Verdut onder meer: Verhoeven, Algemene voorwaarden getoetst (1989); Asser-Hartkarnp II, 1968, Hoofdstuk 17, pag. 314-346; Rijken, Mölenterg en Verstappen, Algemene voorwaanden in this toeristisch-recreatieve verkeer (1990); Jongeneel. De Wet algemene voorwanden en het AGBGesetz (1991). Zie voor de grote hoveelheid artikelen de lijst van verkort aangehaalde werken.

2 Rijken, NJB 1994, pag. 645. 
marktpartijen over de door aanbiedersorganisaties te hanteren algemene voorwaarden. Met dit overleg wordt op een surplus, een verder liggend doel dan het enkele uit de weg ruimen van onredelijk bezwarende algemene voorwaarden gemikt, namelijk het doel om te komen tot voorwaarden die op een evenwichtige wijze rekening houden met de belangen van beide contractspartijen. ${ }^{3}$ Tussen (net) niet-onredelijk bezwarend en evenwichtig bestaat zowel vanuit consumenten- als ondernemersperspectief immers een evident verschil.

Gezien de met de Wet algemene voorwaarden beoogde doelen dient de effectiviteit hiervan primair gemeten te worden aan de mate waarin ondernemers hun voorwaarden hebben aangepast aan de nieuwe wet en de mate waarin de markt wordt bevrijd van onredelijk bezwarende algemene voorwaarden en secundair of de wet voldoende impuls geeft aan de voorziene zelfreguleringsactiviteiten van marktpartijen en zodoende wordt bereikt dat onderhandelingen leiden tot het surplus voor de consument dat de wet zelf niet geeft.

Bij de prognose van de effectiviteit zal eerst worden bekeken in hoeverre de nieuwe wet direct aan individuele consumenten bescherming geeft en de mate waarin het enkele bestaan van de wet reeds heeft geleid tot een aanpassing van gebruikers van bun algemene voorwaarden aan de eisen die de nieuwe wet stelt. Vervolgens komt de rol van het collectief actierecht aan de orde. Daarvoor wordt nagegaan in hoeverre dit actierecht kansen biedt om het rechtsverkeer met consumenten te bevrijden van onredelijk bezwarende algemene voorwaarden. Tevens wordt bekeken in hoeverre het collectief actierecht kansen biedt voor het bereiken van de secundaire wettelijke doelstelling, namelijk niet alleen nietonredelijk bezwarende algemene voorwaarden maar algemene voorwaarden die getuigen van een evenwichtige waardering van de belangen van beide partijen.

\subsubsection{De verwachte directe individuele bescherming van de Wet algemene voorwaarden}

De Nederlandse regeling vertoont qua opbouw en invulling grote gelijkenis met het Duitse AGB-Gesetz. Zoals is gebleken uit de Duitse ervaringen heeft het AGB-gesetz als wettelijke regeling de rechtspraktijk niet voor onoverkomelijke juridische problemen gesteld. De Duitse rechters hebben mede door het grote aantal uitspraken dat zij hebben gedaan voldoende rechtszekerheid weten te creëren over de grenzen van toelaatbaarheid van algemene voorwaarden en laten zien dat het AGB-Gesetz in de praktijk zeer goed te hanteren is. Gezien de grote gelijkenis van de Nederlandse met de Duitse regeling is te verwachten dat ook 
de Nederlandse regeling de rechter en rechtsbeoefenaren technisch gezien niet al te grote problemen zal opleveren.

De duidelijkheid en rechtszekerheid op het terrein van de algemene voorwaarden die de Duitse regeling heeft bewerkstelligd is voor Nederland echter nog niet ingetreden. De wet staat nog in de kinderschoenen en zoals elke nieuwe regelgeving bevat zij nog een aantal onduidelijkheden en interpretatiemogelijkheden. Over de wijze waarop de Nederlandse rechter de speelruimte van de open norm en de grijze lijst gaat invullen is op dit moment nog weinig te zeggen. Wellicht dat de Nederlandse rechter voor een deel gaat putten uit de ervaringen van zijn Duitse collega's. Het is immers weinig efficiënt het wiel andermaal te willen uitvinden.

Eerste aanzetten voor de invulling van de inhoudstoetsing zijn reeds gegeven doordat de Nederlandse rechter voor gevallen gewezen onder toepassing van het oude recht reeds anticipeert op de inhoudstoetsing zoals voorzien in het huidig. BW. Tot op heden zijn er echter nauwelijks individuele uitspraken en geen enkele collectieve rechterlijke uitspraak die in deze duidelijk richting geven.

Afgaande op de Duitse ervaringen heeft de Nederlandse wetgever terecht besloten tot een collectieve actiebevoegdheid voor consumentenorganisaties er van uitgaande dat de individuele consument de weg naar het recht en de rechter doorgaans niet zal vinden. De consument is zich als individu immers enerzijds nauwelijks bewust van de wettelijke bescherming en zo hij zich daar al van bewust is, valt te verwachten dat de drempels voor hem te hoog zijn en hij dus nauwelijks gebruik zal of kan maken van de overigens verregaande bescherming die de wet hem biedt. ${ }^{4}$

Ook de Duitse wetgever ging van dit standpunt uit en de praktijk gaf hem gelijk. De Duitse ervaring leert dat weliswaar een aanzienlijk aantal individuele procedures is gevoerd waarin het AGB-Gesetz werd toegepast en dat ook een aanzienlijk deel van deze procedures betrekking heeft op consumententransacties, de bereikte zuiverende werking van het AGB-Gesetz blijkt toch vooral te zijn terug te voeren op de initiatieven van consumentenorganisaties. Van de uitspraken die betrekking hebben op het gebruik van algemene voorwaarden in consumententransacties is bovendien een aanzienlijk deel niet geïnitieerd door consumenten maar door gebruikers. De toepassing van de inhoudstoets als bedoeld in het AGB-Gesetz is in dergelijke procedures voornamelijk het gevolg van het feit dat de Duitse rechter de inhoudstoets van de \$\$ 9-11 AGBG ambtshalve dient toe te passen en geen verdienste van individuele consumenten.

4 Zie ook: Rijken, inaug. rede, pag. 25-26; Rijken, NJB 1994, pag. 645. 
Van ambtshalve toepassing van de inhoudstoets zal in Nederland geen sprake zijn. Dit betekent dat in Nederland de rechtsontwikkeling op het terrein van de algemene voorwaarden in consumententransacties voor wat betreft de individuele procedures geheel afhankelijk is van de initiatieven van de consument. Deze zal immers eerst een beroep moeten doen op de vernietigingsgronden alvorens de rechter ingrijpt. Het valt niet te verwachten dat gebruikers, bij voorbeeld in procedures waarin de wederpartij verstek laat gaan, de rechter zullen wijzen op de onverenigbaarheid van de bedingen waar zij een beroep op doen met de Wet algemene voorwaarden of het dwingende consumentenkooprecht.

Van de Nederlandse consument valt in deze echter weinig te verwachten. Zoals reeds eerder werd geconstateerd zal de gemiddelde Nederlandse consument, net als de gemiddelde Duitse consument, niet op de hoogte zijn van de wettelijke bescherming die hem wordt geboden. Bovendien weet hij de gang naar de rechter slechts moeilijk te vinden en als hij daar al terecht komt, is dat meestal als gedaagde die vaak verstek laat gaan. Buiten het gegeven dat de Nederlandse justitiabele ongetwijfeld ietwat minder "prozeBfreudig" is dan de Duitse, zullen aan een individueel optreden in rechte van Nederlandse consumenten met name de kosten van een gerechtelijke procedure in de weg staan. De Duitse consument heeft het in dat opzicht ietwat gemakkelijker. Indien hij in de procedure zijn gelijk behaalt, krijgt hij immers alle proceskosten vergoed die hij heeft moeten maken om zijn dwingendrechtelijke bescherming te effectueren. Bovendien hoeft hij niet in rechte te verschijnen om de dwingendrechtelijke bescherming deelachtig te worden; de Duitse rechter past deze immers ambtshalve toe.

Gezien de lijdelijkheid van de Nederlandse rechter op het terrein van de algemene voorwaarden gehanteerd jegens consumenten, de hoge kosten van gerechtelijke procedures en de rechtsonzekerheid die wordt veroorzaakt door het feit dat de grenzen van de inhoudelijk toets nog lang niet zijn uitgekristalliseerd in de rechtspraak, valt mijns inziens te verwachten dat de doorwerking van de Wet algemene voorwaarden in individuele procedures aanzienlijk geringer zal zijn dan in Duitsland, hetgeen betekent dat het zuiverende effect van afdeling 6.5.3 BW voor wat betreft consumententransacties voornamelijk afhankelijk is van de handhavingsactiviteiten van Nederlandse consumentenorganisaties.

Vanuit consumentenperspectief is het jammer te moeten constateren dat de Nederlandse wetgever weliswaar een prachtig materieelrechtelijk regelcomplex heeft geschapen dat de consument bescherming biedt tegen het gebruik van onredelijk bezwarende algemene voorwaarden, maar dat hij nalaat iets te doen aan de kenbare ontoegankelijkheid van deze wettelijke regels en de overheidsrechter voor de individuele consument. De minimale vereenvoudiging van de kantongerechtsprocedure zoals deze onlangs heeft plaatsgevonden moet uit het 
oogpunt van verbetering van de toegang voor de consument tot de overheilsrechter, als een ernstige misslag worden beoordeeld.

Ook aan de bewustwording van de consument inzake de wettelijke beschermingsmogelijkheden wordt slechts mondjesmaat iets gedaan. Zo is bij voorbeeld aan de ene kant bepaald dat een verbodsvonnis directe werking heeft voor de individuele consument en dat een eisende organisatie publicatie van het vomis kan vorderen, doch in een eenvoudig toegankelijk register dat de consument effectief informeert over de uitgesproken verboden is niet voorzien. Bovendien zal ook met betrekking tot de doorwerking van het verbodsvonnis naar individuele procedures gelden dat de overheidsrechtspraak nauwelijks toegankeljik is voor consumenten. Voor wat betreft de voorlichting die de Nederlandse overheid geeft aan haar burgers kan ik net zo kort zijn als de voorlichting zelf. Dere is volstrekt ontoereikend. De nieuwe wettelijke bescherming die het nieuwe Burgerlijk Wetboek de consument biedt, is mijns inziens onvoldoende doorgedrongen tot niet alleen de doorsnee consument maar ook de doorsnee gebruiker. Het mediale voorlichtingsinstituut $\mathrm{COMAC}^{5}$ is in het kader van bezuinigingen met ingang van het seizoen 1991-1992 opgeheven ${ }^{6}$ en de voorlichting aan en educatie van consumenten wordt, gering gesubsidieerd, overgelaten aan consumentenorganisaties. ${ }^{7}$ Een verbetering valt mijns inziens op korte termijn niet te verwachten.

Toch is te verwachten dat ook door individuele consumenten geprocedeerd zal worden op basis van afdeling 6.5.3 BW. Naar de ervaring in Duitsland leert zal de toepassing van de wet in de individuele procedure voor de Nederlandse rechter waarschijnlijk weinig problemen opleveren en zullen de wettelijke regells hem voldoende houvast bieden. Net als voor de consument doet zich voor de rechter in de individuele procedure het probleem voor, dat hij niet eenvoudig te rade kan gaan bij een register waarin eerdere uitspraken van de bijzondere rechter op een eenvoudig toegankelijke wijze zijn opgenomen. De toegankelijkheid van deze uitspraken is echter ook van belang voor, de doorgaans niet gespecialiseerde, rechter omdat zij hem richting geven bij zijn beslissing.

Net als in Duitsland zal ook voor Nederland blijken dat rechterlijke vonnissen in individuele procedures met betrekking tot algemene voorwaarden juilst door het algemene karakter van die voorwaarden en mits voorzien van de nodige publicitaire aandacht, precedent- en breedtewerking kunnen hebben. Rechters dienen er zich dan ook bewust van te zijn dat hun uitspraken, gezien

5 Coöndinatiepunt Massamediale Consumentenwoworlichting, een in nowember 1985 opigerichtiv stichting onder bestuur van Consumentenbond, Konsumenten Kontakt en de Stichting Ombusds. main. Zie: Koopman, pag. 41.

6 Koopman, pag. 62-63.

7 Koopman, pag. 49, 55 en 69-70. 
de aard van het getoetste, een grotere werking hebben dan enkel tussen partijen. Een heldere (transparante) motivering van de beslissing zal zeker bijdragen tot een grotere rechtszekerheid omtrent de toelaatbaarheid van bepaalde algemene voorwaarden, mede gezien het feit dat de mate waarin de nieuwe wet met zijn open normen rechtszekerheid verschaft, voornamelijk afhankelijk is van de mate waarin de rechterlijke macht helderheid kan verschaffen over de wijze waarop zij met name de open norm en de grijze lijst invult.

In Duitsland wordt in de individuele procedures grotendeels de inhoud van algemene voorwaarden getoetst en wordt nauwelijks getoetst aan de toepasselijkheidsvereisten die het AGB-Gesetz stelt. Of dit in Nederland ook zo zal zijn is moeilijk te voorzien. De Nederlandse regeling stelt immers aanzienlijk strengere eisen aan de informatieplicht van gebruikers dan de Duitse en plaatst de gebruikers van algemene voorwaarden voor vooral bewijsrechtelijke problemen. Voorshands is onduidelijk hoe de Nederlandse rechter met de informatieplicht van gebruikers zal omgaan. Indien de letter van de artikelen $6: 233$ sub $b \mathrm{j}^{\circ}$ 6:234 BW door de rechter wordt gevolgd, is het niet te gewaagd om te voorspellen dat, vooral vanwege de door de bewijsnood van de gebruiker veroorzaakte grote kans op succes, een beroep op het schenden van de informatieplicht (ook tegen de gebruiker die zich daar wel aan heeft gehouden maar dit niet kan bewijzen) in Nederland waarschijnlijk in grotere mate zal worden gedaan dan in Duitsland.

\subsubsection{De aanpassing door gebruikers en aanbevelers van hun algemene voor- waarden aan de nieuwe wetgeving}

Het nieuwe Burgerlijk Wetboek met zijn dwingende consumentenwetgeving noopt ondernemers als het ware hun algemene voorwaarden aan te passen aan nieuwe criteria. Een aanpassing die welhaast in alle gevallen waarin algemene voorwaarden werden gehanteerd op zijn plaats is. De nieuwe wetgeving is immers een duidelijk wettelijk antwoord op het in de praktijk van het rechtsverkeer met consumenten jarenlange institutionele misbruik dat gebruikers van algemene voorwaarden van de in de wet verankerde contractsvrijheid maakten.

Bij dit aanpassingsproces dient door gebruikers en aanbevelers niet alleen rekening te worden gehouden met de nieuwe dwingende regels van de Wet algemene voorwaarden maar tevens met nieuwe dwingende wetgeving voor onder andere de consumentenkoop, het consumentenkrediet, de pakketreisovereenkomst en het terrein van de produktaansprakelijkheid.

Net als in Duitsland valt te constateren dat van gebruikerskant met name branche-organisaties hebben gereageerd op de invoering van de nieuwe wet. Het overleg tussen aanbiedersorganisaties en consumentenorganisaties over in 
consumententransacties te hanteren voorwaarden onder auspiciën van het $\mathrm{CCA}$ heeft met de invoering van de nieuwe wetgeving een forse impuls gehad. Het overleg in CCA-verband heeft niet alleen een aanmerkelijke uitbreiding ondergaan voor wat betreft het aantal nieuwe branches, tevens zijn met het oog op aanpassing aan de nieuwe regels ook onderhandelingen heropend en deels reads afgesioten met branche-organisaties waar in het verleden reeds een akkoord mee was bereikt. ${ }^{8}$ In die zin heeft de wet reeds een duidelijk effect gehad, het neerleggen van duidelijke regels in met name de lijsten van de artikelen 6:236 en 6:237 BW alsmede het toekennen van actiebevoegdheid in deze aan consimentenorganisaties is kennelijk een duidelijke impuls geweest voor ondernemersorganisaties om in overleg te treden met consumentenorganisaties.

Zoals de ervaringen in Duitsland leren wordt vooral aan een uniforme werking van aan de nieuwe wetgeving aangepaste branchevoorwaarden - die dan echter ook onveranderd door de brancheleden moeten worden gehanteerd - een voor de consument gunstige zuiverende werking toegekend. De toegenomen belangstelling van ondernemersorganisaties voor het overleg in CCA-verband kan mijns inziens dan ook een belangrijke rol spelen in het bereiken van de doelstelling van de wet, vooral als de tweezijdig tot stand gekomen voorwaarden uniform en ongewijzigd door de bij de branche aangesloten ondernemers worden gehanteerd.

Ook op het overleg in CCA-verband zelf heeft de nieuwe wettelijke regeling een directe invloed gehad. De dwingende consumentenwetgeving geeft consumentenorganisaties duidelijke, desnoods voor de rechter afdwingbare argumenten en dient als basis voor het overleg. ${ }^{9}$ Met name de dreigende collectieve gerechtelijke actie maakt het overleg voor branche-organisaties minder vrijblijvend dan het voor de invoering van het huidige Burgerlijk wetboek was. Het overleg is in een duidelijk juridisch kader gekomen, hetgeen er toe heeft geleid dat ook in voor de consument belangrijke branches de algemene voorwaarden aanmerkelijk zijn verbeterd of op korte termijn verbeterd zullen worden. De Duitse ervaringen met branchevoorwaarden leren echter ook dat de zuiverende werking van branchevoorwaarden met enige scepsis moet worden bezien. Ook voor Nederland is het immers de vraag in hoeverre deze branchevoorwaarden onverkort en ongewijzigd door de bij de branche-organisatie aangesloten ondernemers worden gehanteerd. Zo schrijft niet elke branche-organisatie het gebruik van de overeengekomen algemene voorwaarden dwingend voor aan haar leden en valt bij voorbeeld herhaaldelijk te constateren dat reisorganisatoren

8 Zie onder meer: CCA, Van consument en consumptie, pag. 56-59 en Jaarverslagen SGC 1990 en 1991 .

9 A.H.J. Kolnaar (dagvoorzitter), H. Franken (voorzitter verschillende CCA-overleggroepen) en J.H.W. Anderson (Consumentenbond) in hun redes op het CCA-Symposium naar aanleiding van 10 jaar CCA-voonwaardenoverleg, Den Haag 21 oktober 1993. 

hanteren.

Tegelijkertijd valt echter ook op dat partijen aan het CCA-overleg duîdelijk aan de nieuwe wetgeving en de juridisering van het overleg moeten wennen ${ }^{10}$, dat met name branche-organisaties duidelijk moeite hebben met de verregaande bescherming die de Wet algemene voorwaarden biedt en dat partijen in het overleg vaak lijnrecht tegenover elkaar staan voor wat betreft de betekenis van de wet. Zo meldt Franken op het CCA-symposium naar aanleiding van 10 jaar CCAvoorwaardenoverleg, dat in het overleg nog veel onzekerheid heerst over de strekking en het bereik van de bepalingen van de zwarte en de grijze lijst en de invulling van de open norm en dat dit het overleg aanzienlijk bemoeilijkt. Een onzekerheid die mijns inziens mede wordt gevoed door het ontbreken van richtinggevende rechterlijke uitspraken.

Dat partijen nog moeten wennen aan de wettelijke regels blijkt ook uit het feit dat het CCA-overleg soms resulteert in een overeenstemming over het gebruik van bedingen die voor de consument onredelijk bezwarend zijn op grond van de wet algemene voorwaarden of in strijd zijn met bij voorbeeld het dwingende kooprecht. ${ }^{11}$ Vermoedelijk is dit onder het wettelijke basisbeschermingsniveau duiken een gevolg van een aantal factoren.

In de eerste plaats de beweerde onduidelijkheid in de wet. Mijns inziens echter een minder valide argument: de wettelijke regeling met zijn zwarte en grijze lijst alsmede de goed toegankelijke toelichtende parlementaire stukken geven voldoende duidelijk de bedoelingen weer van de wetgever omtrent de invulling van onredelijk bezwarendheid op het terrein van algemene voorwaarden gehanteerd tegenover consumenten. Ik heb daarom de stellige indruk, mede uit de werkzaamheden die ik als medewerker van het aan de Maastrichtse rechtenfaculteit verbonden Iens Verburgh Instituut voor Consumentenrecht in het kader van het zelfreguleringsoverleg heb mogen verrichten, dat deze beweerde onduidelijkheid in de wet door branche-organisaties voornamelijk wordt aangegrepen om onder de werking van de wet uit te komen. De meeste branche-organisaties in het CCA-overleg blijken immers aan de ene kant bereid te zijn om evidente zwarte bedingen en bedingen die duidelijk in strijd zijn met het

10 Zo werzuchtte L.P. de Vries, die als vertegenwoordiger van de nutsorganimaties deelneemt aun het CCA-overleg over de nutswoorwaanden, in zijn rede op het genoemde CCA-symposium, natar anleiding van deze juridisering, dat het overleg wor de inwerkingtreding van de dwingende consumentenwetgeving veel "gezelliger" en "gemoedielijker" was.

11 Tekenend is in deze ook de opmerking van Franken tijden voomoemd symposium dat hij alls woorzitter vain verschillende CCA-overlegnondes cerst ingrijpt en het licht op rood zet als do onderhandelingen tot het resultast zouden leiden dat een beding ewident zwart of donkergrijs is, maar dat "lichtgrijze" bedingen onder de eigen verantwoondelijkheid van de onderhandelende partijer viallen. 
dwingende consumentenrecht op het terrein van bij voorbeeld de koop of de reisovereenkomst te herzien, maar aan de andere kant zijn zij minder snel bereid of staan zij zelfs afwijzend tegenover veranderingen in voorwaarden waarbij de rechter bij de inhoudelijke beoordeling enige speelruimte heeft, zoals bedingen die voorkomen op de grijze lijst of bedingen die onredelijk bezwarend zouden zijn op grond van de open norm. Het lijkt er dan ook op dat branche-organisaties deze beoordelingsruimte voorall aangrijpen ten betoge dat hun algemene voorwaarden dus niet onredelijk bezwarend zijn.

In de tweede plaats is het duiken onder het wettelijke minimum het gevolg van het feit dat het ook voor consumentenorganisaties wennen is aan de nieuwe positie en rol in het overleg waarin de nieuwe wetgeving hen heeft geplaatst, hetgeen begrijpelijk maakt dat zij de mogelijkheden die het collectief actierecht hen op dit terrein biedt nog niet ten volle weten te benutten. Een logisch gevolg ook van het feit dat consumentenorganisaties in het CCA-overleg doorgaans het voortouw nemen en zij in feite de eersten zijn die de nieuwe wettelijke (open) normen invullen. De ervaring in Duitsland leert dat consumentenorganisaties, mede gesteund door rechterlijke uitspraken, op dit terrein snel leren en door ervaring de nodige deskundigheid zullen verwerven (Repeat Player).

In de derde plaats is het inleveren van dwingendrechtelijke bescherming het typische gevolg van onderhandelen. Onderhandelen is immers een proces van geven en nemen waarin van beide partijen verwacht wordt dat zij van tijd tot tijd in meer of mindere mate water bij de wijn doen. Dit zal zeker het geval zijn als aan het slagen van het voorwaardenoverleg de instandhouding van een branchegeschillencommissie is gekoppeld. Om het ene doel, voor de consument toegankelijke geschillenbeslechting, te bereiken, wordt ten aanzien van een ander doel, het uitbannen van onredelijk bezwarende voorwaarden, ietwat toegegeven. De belangrijkste consumentenorganisatie in het CCA-overleg overweegt in deze echter een koerswijziging. Volgens Anderson van de Consumentenbond is het wellicht gewenst het voorwaardenoverleg los te koppelen van het overleg over branchegeschillencommisies en dat de Consumentenbond zich in het overleg op het standpunt stelt dat in het overleg niet meer gemarchandeerd gaat worden met de dwingendrechtelijke wettelijke bescherming en dat dus de dwingendrechtelijke bescherming van de wet het absolute minimum is. ${ }^{12}$

Dit laatste lijkt mij een juiste opstelling. Consumentenorganisaties moeten er mijns inziens voor waken dat zij in het CCA-overleg stelselmatig onder het beschermingsniveau van de Wet algemene voorwaarden of andere dwingende wetgeving gaan zitten. Het overleg in CCA-verband alsook ander zelfreguleringsoverleg heeft immers ten doel een surplus te leveren ten opzichte van de 
wettelijke basisbescherming die de Wet algemene voorwaarden reeds biedt. Voor de handhaving van de wettelijke minimumbescherming is het CCA-overleg niet bedoeld en ook zinloos. Ondernemers moeten immers uit zichzelf voldoen aan de dwingende regels van de Wet algemene voorwaarden en het overige dwingende consumentenrecht. Daar valt in beginsel niet over te onderhandelen, de wet zet een duidelijke norm. Het overleg als bedoeld in artikel 6:240 lid 3 BW heeft primair tot doel de wettelijke norm te handhaven en heeft daarom ook een geheel ander karakter dan het overleg zoals dat dient plaats te vinden binnen het CCA-verband.

Het overleg in artikel 6:240 is in eerste instantie immers niet gericht op een surplus, hetgeen overigens niet uitsluit dat het daar well toe kan leiden, maar op de vervanging (binnen zes maanden) van een naar de mening van de optredende consumentenorganisatie onredelijk bezwarend beding door een niet-onredelijk bezwarend beding. Indien deze vervanging niet binnen zes maanden plaatsvindt heeft de optredende consumentenorganisatie het recht de rechter te vragen een verbod van gebruik van het betreffende beding op te leggen. Opvallend en tekenend voor het verschillende karakter van het CCA-overleg is dat dit overleg in de regel langer dan een half jaar in beslag neemt en dat gebruikers en aanbevelers gedurende het overleg hun algemene voorwaarden ongewijzigd blijven gebruiken, ook indien het evident onredelijk bezwarende bedingen betreft en ook als van de zijde van consumentenorganisatie op wijziging van bepaalde bedingen wordt aangedrongen omdat deze naar hun opvatting onredelijk bezwarend zijn. Consumentenorganisaties moeten er daarom ook voor waken dat branche-organisaties het CCA-overleg niet aangrijpen om onder het basisbeschermingsniveau van de Wet algemene voorwaarden uit te komen of om het gebruik van voor de consument onredelijk bezwarende algemene voorwarden zolang als mogelijk te rekken.

Buiten de verhevigde belangstelling van branche-organisaties voor het zelfreguleringsoverleg in CCA-verband en de ongetwijfeld positieve effecten die dit heeft op de aldus vastgestelde branchevoorwaarden, is van een doorwerking van de nieuwe wettelijke regeling in algemene voorwaarden die worden gehanteerd jegens consumenten in andere branches nog niet veel te merken. Wie om zich heen kijkt zal bemerken dat de nieuwe wettelijke regels nog niet veel gebruikers hebben aangezet tot het herzien van hun algemene voorwaarden ${ }^{13}$, dat nagenoeg geen enkele (ook niet de in CCA-verband vastgestelde) set algemene voorwaarden vrij is van onredelijke bezwarende bedingen of bedingen die in strijd zijn met dwingende consumentenwetgeving. Een goede indicatie voor het 
niet aanpassen is vaak te vinden in de datum waarop de algemene voorwaarden zijn opgesteld of gedeponeerd. Indien deze datum vóor 1 januari 1992 ligt, kan men er in het algemeen van uitgaan dat de betreffende algemene voorwaarden niet zijn aangepast aan de nieuwe wetgeving.

Een van de redenen waarom gebruikers hun algemene voorwaarden niet hebben aangepast is ongetwijfeld gelegen in onbekendheid met de nieuwe wettelijke regeling. Gebruikers, met name in het midden- en kleinbedrijf, die niet zijn georganiseerd in branche-organisaties, zijn over het algemeen niet op de hoogte van de vereisten die de nieuwe wettelijke regelingen aan het gebriilk van algemene voorwaarden stellen. De Duitse ervaring laat zien dat zelfs een tiental jaren na de inwerkingtreding van specifieke wettelijke regels niet is uitgesloten dat gebruikers niet op de hoogte zijn van de dwingende wetgeving op het terrein van de algemene voorwaarden en daar door consumentenorganisaties op moeten worden gewezen. Een andere reden is echter ongetwijfeld ook gelegen in onwil van gebruikers om afscheid te nemen van voor hen profijtelijke doch voor de consument onredelijk bezwarende bedingen. Deze onwil zal in een aantal gevallen ongetwijfeld worden verstrekt door de wetenschap dat de individuele consument toch niet op de hoogte is van de wettelijke bescherming die hem ten deel valt, deze wettelijke bescherming zo die al bekend is veelal niet kan effectueren en dat een eventueel optreden van consumentenorganisatie nog steeds zes maanden respijt geeft.

De conclusie moet dan ook zijn dat, net als in Duitsland, een vrijwillige aanpassing van gebruikers van hun algemene voorwaarden door het enkele bestaan van de wet nagenoeg niet, althans in onvoldoende mate, heeft plaatsgevonden. ${ }^{14}$

\subsubsection{Te verwachten effectiviteit van het collectieve actierecht}

Zoals hiervoor gezien en ook de Duitse ervaringen uitwijzen zal de zuiverende werking van de Wet algemene voorwaarden op het terrein van de algemene voorwaarden gehanteerd tegenover consumenten vooral bewerkstelligd moeten worden door de activiteiten van consumentenorganisaties. Van branche-organisaties valt in Nederland voor wat betreft de collectieve actie ten behoeve van consumenten niets te verwachten. In tegenstelling tot Duitsland mogen Nederlandse organisaties die de belangen van ondernemers behartigen immers miet optreden tegen voorwaarden die worden gehanteerd tegenover consumenten (artikel 6:240 lid $3 \mathrm{BW}$ ). Niet dat dit veel uitmaakt, want de Duitse ervaringen 
wijzen uit dat branche-organisaties nauwelijks gebruik hebben gemaakt van het hen toegekende actierecht.

De Duitse ervaringen leren dat het collectief actierecht in de handen van consumentenorganisaties een uiterst effectief middel kan zijn ter bestrijding van onredelijk bezwarende algemene voorwaarden. Opvallend is daarbij het grote succes dat de (actieve) Duitse consumentenorganisaties boeken in de buitengerechtelijke fase. Dit succes kan zondermeer voor een groot deel worden toegeschreven aan het feit dat hen een actierecht is toegekend en zij duidelijk hebben gemaakt aan gebruikers dat zij van dit actierecht ook daadwerkelijk gebruik maken. Voor een niet onaanzienlijk deel is dit succes ook toe te schrijven aan de rechterlijke macht, die duidelijk oog heeft gehad voor de ongelijkheidscompenserende functie van het collectief actierecht op het terrein van de algemene voorwaarden en aanmerkelijk scherpere grenzen heeft gesteld aan de toelaatbaarheid van algemene voorwaarden dan zonder het AGB-Gesetz en met name het collectief actierecht voor consumentenorganisaties voor mogelijk wordt gehouden.

Duitse consumentenorganisaties kiezen bij de handhaving van de dwingendrechtelijke norm zonder meer voor een conflict-model en niet voor een onderhandelingsmodel. Indien een beding naar het oordeel van de eisende consumentenorganisatie onredelijk bezwarend is, kan de gebruiker in Duitsland kiezen tussen of een onverwijlde stopzetting van het gebruik van het betreffende beding onder het afgeven van de nodige garanties of een gerechtelijke procedure die hij meestal verliest omdat de actieve consumentenorganisaties in Duitsland inmiddels door te procederen zoveel ervaring hebben opgedaan met het AGB-Gesetz dat zij vrij exact de wettelijke grenzen van toelaatbaarheid van algemene voorwaarden weten aan te geven.

Een zelfreguleringscultuur als in Nederland is in Duitsland niet voorhanden en wordt in Duitsland ook niet in die mate door de centrale overheid gestimuleerd als dat in Nederland het geval is. Het AGB-Gesetz heeft ook geenszins tot doel overleg tussen consumenten- en aanbiedersorganisaties te bevorderen. Naar het oordeel van Duitse consumentenorganisaties heeft onderhandelen met branche-organisaties of gebruikers over door hen jegens consumenten te gebruiken algemene voorwaarden weinig zin omdat de onderhandelingen te veel tijd, menskracht en dus geld kosten afgezet tegen het povere resultaat. Consumentenorganisaties hebben de stellige indruk dat onderhandelende gebruikers in de onderhandelingen toch niet verder willen gaan dan het wettelijk verplichte minimum, lees nét niet onredelijk bezwarend. Zij zijn daarom de opvatting toegedaan dat dit resultaat op een aanmerkelijk eenvoudigere, effectievere en 
goedkopere weg kan worden bereikt via het door hen gehanteerde Abmahnungsen procesmodel.

De Nederlandse wetgever opteert echter niet alleen voor de collectieve actie als middel om de in de Wet algemene voorwaarden neergelegde basisbescherming van de consument te realiseren. Hij kiest uitdrukkelijk ook voor zelfregulering als middel om deze in de wet verankerde basisbescherming - en mogelijk zelfs meer - te verwezenlijken. De overlegverplichting zoals neergelegd in artikel 6:240 lid $4 \mathrm{BW}$ en de bonus voor gebruikers van artikel 6:240 lid 5 BW beogen dit zelfreguleringsoverleg, dat ten doel heeft te komen tot een verdere bescherming van de consument dan de dwingende wetgeving (surplus), een eerste aanzet te geven. Het is echter niet meer dan een prikkel tot dergelijke (surplus)onderhandelingen. Het verplicht consumentenorganisaties niet tot dergelijke onderhandelingen. Allereerst rust er immers op gebruikers de "plicht" om hun algemene voorwaarden in overeenstemming te brengen met de wettelijke bepalingen. Gezien de regeling van artikel 6:240 lid 4 BW rust op de gebruikers of aanbevelers de verplichting om, uiterlijk 6 maanden nadat zij door consumentenorganisaties zijn gewezen op het onredelijk bezwarende karakter van hun algemene voorwaarden, van het gebruik van deze onredelijk bezwarende bedingen af te zien of deze zodanig te wijzigen dat zij naar het oordeel van de consumentenorganisaties niet (langer) onredelijk bezwarend zijn. De in artikel 6:240 lid 4 BW neergelegde overlegverplichting verplicht consumentenorganisaties niet verder dan tot het bieden van deze aanpassingstermijn van zes maanden alvorens zij overgaan tot dagvaarding en heeft in die zin dezelfde functie als de Abmahnung voor Duitse consumentenorganisaties. Dat het aldus gestarte overleg mogelijk ook leidt tot onderhandelingen over algemene voorwaarden die moeten leiden tot een surplus voor de consument ten opzichte van de dwingendrechtelijk minimumbescherming die de wet algemene voorwaarden biedt, is daarbij meegenomen. In die zin staan Nederlandse consumentenorganisaties twee modellen ter beschikking. Enerzijds het onderhandelingsmodel waarmee met het bereiken van het surplus logischerwijs ook de in de wet neergelegde basisbescherming verwezenlijkt wordt en anderzijds het conflictmodel dat enkel gericht is op handhaving van de wettelijke basisbescherming door middel van (de dreiging van) een verbods- of gebodsactie zoals dat door de Duitse consumentenorganisaties wordt gehanteerd en feitelijk ook is neergelegd in de regeling van artikel $6: 240$ lid $4 \mathrm{BW}$.

\section{Conflictmodel of onderhandelingsmodel?}

Een effectief omgaan met schaarse middelen zal consumentenorganisaties naar verwachting vanzelf $d$ wingen tot het kiezen van de voor het bereiken van hun 
doel meest effectieve strategie. Welke zijn de voor- en nadelen van beide modellen?

De ervaringen in de Duitse praktijk doen sterk vermoeden dat voor de handhaving van de wettelijke basisbescherming het conflictmodel een meer effectieve, dat wil zeggen snellere en financieel meer voordelige wijze van handhaving is dan onderhandelen. Een eenvoudige kosten-baten analyse laat zien dat onderhandelen vanwege de meerkosten pas aantrekkelijk wordt voor consumentenorganisaties indien deze onderhandelingen ten opzichte van de goedkopere handhaving van de wettelijke basisbescherming via het conflictmodel, een duidelijk voordeel bieden. Dit voordeel zal dan, uiteraard ter beoordeling van consumentenorganisaties, op moeten wegen tegen de extra inspanningen die onderhandelingen nu eenmaal met zich brengen.

\section{Het conflictmodel}

Het conflictmodel is het aangewezen handhavingsmodel als de inspanningen van consumentenorganisaties primair slechts gericht zijn op (snelle) handhaving van de basisbescherming zoals deze in de wet ligt verankerd. Bij voorbeeld het snel uit de markt halen van evident onredelijk bezwarende bedingen. Omdat deze inspanningen niet gericht zijn op een "surplus" ligt het voor de hand dat consumentenorganisaties kiezen voor het goedkope en, zoals de Duitse ervaringen aantonen, zeer effectieve conflictmodel. Uiteindelijk is dat ook goedkoper voor de gebruikers. Onderhandelingen vergen ook van hen immers aanzienlijk meer inspanningen dan het conflictmodel dat doorgaans leidt tot een buitengerechtelijke oplossing. Het conflictmodel heeft daarbij als voordeel dat het leidt tot een beslissing van de bijzondere rechter indien met de gebruiker of aanbeveler niet buitengerechtelijk een oplossing wordt bereikt. Deze beslissingen geven houvast omtrent het onredelijk bezwarend karakter van de bestreden bedingen hetgeen de rechtszekerheid ten goede zal komen.

\section{Het onderhandelingsmodel}

Het onderhandelingsmodel is het aangewezen handhavingsmodel als de inspanningen van de consumentenorganisaties gericht zijn op een "surplus". Ik ga er van uit dat consumentenorganisaties zich primair ten doel stellen de wettelijke basisbescherming te handhaven en dat zij geen genoegen nemen met minder, ook niet in het onderhandelingsmodel. Met dit uitgangspunt voor ogen biedt het onderhandelingsmodel voordelen ten opzichte van het conflictmodel indien consumentenorganisaties door onderhandelen mér kunnen bereiken dan de wettelijke basisbescherming. Dat is bij voorbeeld het gevall indien men overeen- 
stemming kan bereiken over bedingen die niet alleen niet onredelijk bezwarend zijn, maar zelfs consumentvriendelijk omdat zij de consument meer rechten verschaffen dan hij zonder deze bedingen zou hebben gehad. Het "surplus" kan ook zijn gelegen in overeenstemming over het oprichten of instandhouden van (branche-)geschillencommissies die geschillen beslechten op basis van tweezijdig vastgestelde algemene voorwaarden.

Onderhandelingen vergen ook van gebruikers en aanbevelers meer inspanningen dan het conflictmodel en dienen dus ook voor hen een meerwaarde te hebben. Ook daar dienen consumentenorganisaties oog voor te hebben als zij de onderhandelingen aangaan met branche-organisaties of gebruikers over algemene voorwaarden die een surplus moeten opleveren. Een ijzeren wet van onderhandelen is immers: Voor wat, hoort war! Onderhandelingen over een surplus hebben daarom doorgaans pas kans van slagen indien consumentenorganisaties ook een surplus kunnen bieden aan hun onderhandelingspartner. Het valt immers niet te verwachten dat ondernemers het beoogde surplus aan consumentenzijde zonder tegenprestatie zullen inleveren.

Voor wat betreft de tegenprestatie die consumentenorganisaties in Nederland aan de ondernemerszijde kunnen bieden zie ik in Nederland meer mogelijkheden dan in Duitsland. Voorop staat dat voor ondernemers het surplus altijd zal zijn gelegen in een verdere maximalisatie of consolidatie van hun bedrijfswinst, met andere woorden het surplus moet voor de ondernemer of de branche-organisatie financieel aantrekkelijk zijn. Voor ondernemers ligt een surplus dus enkel in een consolidatie of stijging van de omzet. In tegenstelling tot Duitsland kenmerken de Nederlandse algemene en categoriale consumentenorganisaties zich door een groot ledenaantal en daardoor een, vrij gezaghebbende, toegang tot brede lagen van de bevolking. Een beetje reclame, een kwaliteitskeurmerk, het predikaat consumentvriendelijk, "goodwill" en branche-geschillenbeslechting bij voorbeeld kunnen in dit verband voor de ondernemer aantrekkelijke ruilobjecten zijn omdat zij het bestedingsgedrag van deze leden mogelijk voor hem in positieve zin beïnvloeden.

Gezien de grote overeenkomsten tussen de Nederlandse collectieve actie en de Duitse, zal de hantering van het collectief actierecht in het conflictmodel de Nederlandse organisaties niet voor al te grote juridische problemen stellen.

Uiteraard geldt ook hier dat een nadere verduidelijking van met name de grenzen van de open norm en de grijze lijst in de rechtspraak tot grotere rechtszekerheid zal leiden. Het scheppen van deze duidelijkheid zal echter vooral afhankelijk zijn van juist het in rechte optreden van consumentenorganisaties. In die zin hebben consumentenorganisaties belang bij het entameren van zoveel mogelijk procedures voor de bijzondere rechter. De Duitse ervaringen leren dat de rechtszekerheid omtrent de toelaatbaarheid van algemene voorwaarden in de 
verschillende soorten overeenkomsten vooral wordt veroorzaakt door een grote hoeveelheid rechterlijke uitspraken.

Het bereiken van deze rechtszekerheid is dus vooral afhankelijk van het voeren van voldoende gerechtelijke procedures die de rechter in staat stellen om de grenzen aan te geven van de toelaatbaarheid van algemene voorwaarden voor de verschillende soorten overeenkomsten waarmee de doorsnee consument wordt geconfronteerd. Net deze rechtszekerheid geeft consumentenorganisaties immers niet alleen houvast in hun optreden in en buiten rechte ten behoeve van de handhaving van de wettelijke basisbescherming maar tevens een duidelijk startpunt en toetsmaatstaf voor het te bereiken resultaat bij de surplus-onderhandelingen.

Voorlopig is van deze rechtszekerheid in Nederland nog geen sprake. Een eerste procedure voor de bijzondere rechter te 's-Gravenhage liet op 18 november 1994 immers nog steeds op zich wachten. ${ }^{15}$ Mede gezien het gestegen aantal onderhandelingsronden in CCA-verband, ziet het er voorshands naar uit dat consumentenorganisaties in Nederland hebben gekozen voor het onderhandelingsmodel en daar eerst nadere ervaringen mee op willen doen. Dat is jammer, gezien het voorgaande zal duidelijk zijn dat ik de mening ben toegedaan dat een keuze voor het gelijktijdig hanteren van beide modellen vanuit het oogpunt van effectiviteit en efficiency een betere is.

De Duitse ervaring laat zien dat tweezijdig vastgestelde algemene voorwaarden vaak slechts een beperkt zuiverende werking hebben. Dit omdat een groot deel van de in het rechtsverkeer vigerende algemene voorwaarden wordt gehanteerd door individuele ondernemers, vaak in het midden- en kleinbedrijf die niet zijn georganiseerd in branche-organisaties of die de door hun branche-organisaties aanbevolen voorwaarden niet hanteren en er, vaak niet belemmerd door enige relevante wetskennis, hun eigen voorwaarden op na houden. Met name op deze algemene voorwaarden is het grootste deel van de activiteiten van consumentenorganisaties gericht en ook op dit terrein is in Duitsland gebleken dat de collectieve actie een effectief middel is, waarvan alleen de dreiging al meestal leidt tot een snelle buitengerechtelijke oplossing. Ook voor Nederland zal gelden dat een groot deel van de (onredelijk bezwarende) algemene voorwaarden slechts wordt gehanteerd door individuele ondernemers en dat onderhandelingen in dat opzicht meestal niet lonen gezien hun beperkte bereik. Een surplus kan dan niet worden bereikt en handhaving van de basisbescherming van afdeling 6.5.3 $\mathrm{BW}$ is het hoogst haalbare. In die gevallen verdient het relatief goedkope conflictmodel veruit de voorkeur boven het onderhandelingsmodel. 
Ofschoon in Duitsland algemeen wordt erkend dat het collectief actierecht voor consumentenorganisaties voor de overheid waarschijnlijk de goedkoopste manier van rechtshandhaving is op het terrein van de algemene voorwaarden, wordt algemeen ook gesignaleerd dat de omvang waarin het collectief actierecht door consumentenorganisaties in en buiten rechte wordt gehanteerd aanmerkelijk te kort schiet om de markt daadwerkelijk te bevrijden van onredelijk bezwarende algemene voorwaarden. Met name vanwege het ontbreken van voldoende, door de overheid te verschaffen, financiële middelen. Inderdaad valt te constateren dat consumentenorganisaties hun schaarse middelen slechts kunnen inzetten tegen wat zij beschouwen als de ergste misstanden en evidente inbreuken. $\mathrm{Zij}$ zouden met gemak, indien de financiële middelen dat zouden toelaten, bun activiteiten kunnen uitbreiden. Door bij voorbeeld meer aandacht te besteden aan een systematische opsporing en nacontrole zouden zij hun handhavingsactiviteiten kunnen optimaliseren en ongetwijfeld een grotere breedtewerking van de wettelijke normen kunnen bewerkstelligen.

Omdat de actieve Duitse consumentenorganisaties volledig door de overheid worden gefinancierd is de uitoefening van het collectief actierecht en de daarmee gepaard gaande breedtewerking in Duitsland voornamelijk afhankelijk van de middelen die de Duitse staat daarvoor ter beschikking stelt. Een mogelijk bredere werking van het AGB-Gesetz wordt dan ook voornamelijk tegengehouden door de Duitse overheid, die kennelijk aan een verdere zuivering van het rechtsverkeer met consumenten van onredelijk bezwarende algemene voorwaarden niet zoveel belang hecht dat hij daar verdere financiële middelen voor ter beschikking stelt.

Ook voor Nederland geldt dat de handhaving van de in de wet neergelegde basisbescherming voornamelijk uit zal moeten gaan van consumentenorganisaties en dat de door hen te verrichten handhavingsactiviteiten slechts efficiënt verricht kunnen worden indien daarvoor voldoende financiele middelen ter beschikking staan. De Nederlandse wetgever heeft zich in deze duidelijk uitgesproken en zich op het standpunt gesteld dat deze activiteiten, omdat zij in het algemeen belang zijn, geheel of ten dele gefinancierd dienen te worden door de Nederlandse overheid. $\mathrm{Er}$ is derhalve beloofd te voorzien in een subsidieregeling die moet waarborgen dat het de consumentenorganisaties mogelijk wordt de hun toebedachte taak in het belang van de bescherming van consumenten goed te vervullen. ${ }^{16}$ Een dergelijke subsidieregeling is er nog niet. Wél is voorzien in een meerjarenprogramma waarmee een subsidiebedrag van maximaal $f 6$ miljoen is gemoeid voor de in het voorjaar 1992 door Consumentenbond en 
Konsumenten Kontakt opgerichte Stichting Samenwerking ConsumentenbondKonsumenten Kontakt (Stisam) waarin beide consumentenorganisaties in beginsel alle projecten die zij of hun instituten met subsidie van EZ uitvoeren hebben ondergebracht. ${ }^{17}$ Het programma omvat, naast ondersteuning en coordinatie, zeven terreinen van activiteiten, te weten: de normalisatiewerkzaamheden van Consunorm (CB), het voorwaardenoverleg (CB/KK), de quasicollectieve sector $(\mathrm{KK})$, voeding en milieu $(\mathrm{KK})$, juridische en economische positie van de consument (CB/KK), gezondheidszorg en overige onderwerpen. Binnen dit meerjarenprogramma zij ook, weliswaar indirect, gelden gereserveerd voor het voeren, in en buiten rechte, van de collectieve actie als voorzien in artikel 6:240 BW. Binnen het cluster "Marktwerking" is onder de naam "Juridische positie consument" een project opgenomen waaronder zowel de activiteiten van de Consumentenbond in het voorwaardenoverleg als het voeren van (eventuele) collectieve acties zijn vermeld. In 1994 was voor dit project in zijn geheel een bedrag van ruim $f 450.000,=$ beschikbaar, zonder specifieke reservering van een deel van dit bedrag voor collectieve acties. Eind 1994 was de verwachting van de Consumentenbond dat dit bedrag voor 1995 aanmerkelijk lager zal komen te liggen. ${ }^{\text {is }}$

Gezien de onzekerheid bij consumentenorganisaties over de (hoogte van) financiering van de collectieve handhavingsactiviteiten op het terrein van de algemene voorwaarden is het wellicht niet verwonderlijk dat de Nederlandse consumentenorganisaties de stap naar de bijzondere rechter, die met name in de beginfase waarin nog geen richtinggevende rechterlijke uitspraken voorhanden zijn een groot processueel risico met zich brengt, tot nu toe nog niet hebben genomen. De door de wetgever beoogde zuivering van de markt van onredelijk bezwarende algemene voorwaarden door consumentenorganisaties wordt voor een deel dan ook tegengehouden doordat diezelfde wetgever onvoldoende garanties biedt voor de subsidiêring van de beoogde activiteiten van consumentenorganisaties. Voor een deel, omdat het procesrisico nauwelijks een rol speelt bij algemene voorwaarden die in strijd zijn met dwingende wetsbepalingen of die voorkomen op de zwarte lijst.

In tegenstelling tot Duitse consumentenorganisaties zullen Nederlandse consumentenorganisaties bij hun collectieve optreden ook nog een hoger kostenrisico lopen omdat in Nederland de winnaar van een procedure niet automatisch al zijn kosten krijgt vergoed. Ook is niet duidelijk in hoeverre consumentenorganisaties

17 Mer de opheffing van Konsumenten Kontalkt in 1994, wagrwan een deel trouwens wondt ondergebracht bij de Consumentenbond, zal het meejiarenprogramma waarschijnlijk door de Consumentenbond alleen worden voortgezet. Informatie van mr. L.P. Willigenburg, Directie-secretaris van de Consumentenbond. 
in Nederland de kosten die zij hebben moeten maken om de gebruiker buitengerechtelijk te bewegen niet langer onredelijk bezwarende algemene voorwaarden te gebruiken, voor vergoeding in aanmerking komen indien het niet tot een procedure komt. De Duitse oplossing van zaakwaarneming zal in Nederland waarschijnlijk op hevige weerstand stuiten. Tegenover deze, in vergelijking met Duitsland minder gunstige, kostenaspecten staat echter dat de verbodsactie in Nederland, althans indien zij gericht is tegen een branche-organisatie en haar leden, gezien de mogelijkheid van een collectieve dagvaarding een veel bredere werking zal hebben dan in Duitsland, slechts eén feitelijke instantie telt. Dit werkt, mede gezien de regel van artikel 1006 sub $1 \mathrm{Rv}$, kostenbesparend.

Ofschoon dat in de Wet algemene voorwaarden niet uitdrukkelijk is geregeld, staat voor Nederlandse consumentenorganisaties net als hun Duitse zusterorganisaties een voorlopige voorziening ter beschikking. Of consumentenorganisaties daar in Nederland gebruik van zullen maken is voornamelijk afhankelijk van de opstelling van de bijzondere rechter te 's-Gravenhage. Met name de mate waarin deze een dergelijke voorziening voor de collectieve actie als bedoeld in artikel 6:240 BW noodzakelijk acht en de mate waarin hij de spoedeisendheid van een dergelijke actie onderkent, zullen bepalend zijn voor het gebruik van de voorlopige voorziening. Indien de Nederlandse rechter net zulke zware eisen gaat stellen als zijn Duitse collega is te verwachten dat ook Nederlandse consumentenorganisaties nauwelijks van de voorlopige voorziening als bedoeld in artikel $51 \mathrm{Rv}$ gebruik zullen maken.

Ten aanzien van de mogelijke effectiviteit en de breedtewerking van het collectieve optreden van Nederlandse organisaties valt nog het volgende te zeggen. Het in vergelijking met Duitse consumentenorganisaties grote ledenpotentieel maakt dat Nederlandse consumentenorganisaties naar mijn mening beter in staat zullen zijn in hun handhavingsmodel een systematische opsporing en nacontrole op te nemen. In tegenstelling tot hun Duitse zusterorganisaties kunnen zij daarvoor immers hun, alleen al bij de Consumentenbond meer dan 600.000 , leden inschakelen, hetgeen een behoorlijk opsporings- en nacontrolepotentieel oplevert. De pakkans kan daardoor in Nederland met vrij bescheiden middelen aanzienlijk groter worden dan in Duitsland en de dreiging van contractuele boetes of dwangsommen kan voor gebruikers afdoende zijn om te bewerkstelligen dat gemaakte afspraken en gewezen vonnissen ook daadwerkelijk worden nagekomen.

Evenals in Duitsland heeft een verbodsvonnis van de bijzondere rechter directe werking voor individuele procedures. In Duitsland is door individuele consumenten echter nauwelijks een beroep op deze werking van een verbodsvonnis 
gedaan. ${ }^{19}$ Het is de vraag of individuele consumenten in Nederland, als zij al op de hoogte zijn van het uitgesproken verbod, daar in rechte veel gebruik van zullen maken. Daarvoor is de Nederlandse overheidsrechter gewoonweg te duur. Zelfs bij de effectuering van een verbodsvonnis valt, indien de huidige praktijk van kostenveroordeling ongewijzigd wordt voortgezet, te verwachten dat de rechter geen gehoor zal geven van een veroordeling van de evident ongelijk hebbende gebruiker in alle kosten die de consument heeft moeten maken om zijn evidente gelijk te behalen. In deze lijkt mij derhalve meer te verwachten van een effectieve nacontrole door consumentenorganisaties van met ondernemers gemaakte afspraken en tegen hen gewezen verbodsuitspraken en het daadwerkelijk innen van contractuele boetes en dwangsommen indien wordt geconstateerd dat ondernemers zich niet aan de gemaakte afspraken of tegen hen gewezen verbodsvonnissen houden.

19 Hensem AGB-Gesetz, 21 Rndnr. 15. 


\section{Slotbeschouwing en suggesties}

Het Duitse AGB-Gesetz heeft in de meer dan 15 jaar dat het in de praktijk functioneert, bewezen een uitstekend hanteerbare regeling voor de toepasselijkheid en inhoudelijke toetsing van algemene voorwaarden te zijn.

Een regeling kan technisch echter nog zo goed zijn, haar functioneren kan uiteindelijk slechts beoordeeld worden naar de mate waarin de gestelde doelen in de praktijk worden gerealiseerd. De ervaring in Duitsland leert wat dat betreft, dat na 15 jaar AGB-Gesetz weliswaar een scherp omlijnde norm is ontstaan die duidelijk maakt op welke minimale wettelijke bescherming de consument, alsook vanwege de reflexwerking de niet-consument, zich kan beroepen, maar dat tegelijkertijd geconstateerd moet worden dat de breedtewerking en de doorwerking daarvan in de praktijk vooral steunt op éen poot: de toekenning van het collectief actierecht aan consumentenorganisaties en de handhavingsactiviteiten van deze consumentenorganisaties.

Het AGB-Gesetz en met name de activiteiten van consumentenorganisaties hebben er voor gezorgd dat in een groot aantal branches de tegenover consumenten gehanteerde algemene voorwaarden en daarmee de contractuele positie van de consument, aanmerkelijk zijn verbeterd. Van een ongelijkheidscompensatie is dus duidelijk sprake en dat is een verdienste van het AGB-Gesetz en het collectieve actierecht.

Na 15 jaar AGB-Gesetz valt echter tevens te constateren dat van een algehele bevrijding van de markt van onredelijk bezwarende algemene voorwaarden geen sprake is. Consumentenorganisaties hebben nog steeds hun handen vol met het in en buiten rechte bestrijden van in het rechtsverkeer met consumenten gehanteerde ontoelaatbare algemene voorwaarden. Gezien de permanente toestroom van nieuwe produkten en diensten en daarmee, juridisch vaak nauwelijks onderlegde, nieuwe ondernemers, valt voorlopig niet te verwachten dat hun handhavingsactiviteiten overbodig zullen worden. Het oorspronkelijk "tijdelijke baantje" van consumentenorganisaties is een "vaste aanstell ling" geworden.

Dat onredelijk bezwarende bedingen geheel van de markt zouden verdwijnen, zal ook niemand in Duitsland echt verwacht hebben. Ondanks dat wordt 
echter door een aantal gezaghebbende Duitse rechtsgeleerden hardop uitgesproken dat de potentiële zuiverende en daarmee ongelijkheidscompenserende werking van met name het collectief actierecht nog niet ten volle wordt benut en in het rechtsverkeer nog te veel onredelijk bezwarende algemene voorwaarden worden gehanteerd. De oplossing wordt vooral gezocht in een intensivering van de rechtshandhavingsactiviteiten van consumentenorganisaties.

Gezien de grote overeenkomst tussen de Duitse en de Nederlandse regeling inzake algemene voorwaarden valt te verwachten dat ook de Nederlandse regeling, met het toenemen van de jurisprudentie, een helder en goed hanteerbaar instrumentarium zal bieden voor het vastleggen van de grenzen van de toelaatbaarheid van de inhoud van algemene voorwaarden en de regels omtrent de toepasselijkheid. Ook voor Nederland geldt dat de maatstaf voor effectiviteit van de wet vooral is gelegen in de mate waarin de markt wordt bevrijd van onredelijk bezwarende bedingen; in de breedtewerking dus.

De Duitse ervaringen laten zien dat de breedtewerking van de wet vooral zal afhangen van de activiteiten van consumentenorganisaties. Voor de rechtshandhaving op het terrein van de algemene voorwaarden hebben de gerechtelijke en buitengerechtelijke activiteiten van consumentenorganisaties immers het hoogste rendement.

Het ligt dan ook voor de hand dat met name het bevorderen van de activiteiten van de diverse algemene en categoriale consumentenorganisaties op dit terrein het meeste zall opleveren. In dat verband heeft de Nederlandse overheid een duidelijke kans laten liggen. Niettegenstaande het feit dat door de wetgever is onderkend is dat de rechtshandhaving op het terrein van de algemene voorwaarden een algemeen belang is, dat de basisbescherming voor de consument zoals die in de Wet algemene voorwaarden is neergelegd de primaire verantwoordelijkheid is van de centrale overheid en dat door diezelfde overheid beloofd is dat vór de inwerkingtreding van de wet een subsidieregeling ter beoordeling zou worden voorgelegd aan de Tweede Kamer om zeker te stellen dat consumentenorganisaties de hun toebedachte rechtshandhavingstaak in het (algemene) belang van de bescherming van consumenten goed kunnen vervullen, is van een subsidieregeling thans, ongeveer twee jaar na inwerkingtreding van de wet, absoluut geen sprake.

De gemiste kans kan echter eenvoudig worden recht gezet. Gezien het rendement van subsidies voor rechtshandhavingsactiviteiten van consumentenorganisaties lijkt het miet onverstandig dat de Nederlandse overheid alsnog ten spoedigste komt met een subsidieregeling waarin de overheid de kosten van de rechtshandhavingsactiviteiten van consumentenorganisaties op het terrein van de algemene voorwaarden geheel of gedeeltelijk voor haar rekening neemt. Indien 
de regering niet uit zichzelf met een dergelijk voorstel komt is het wellicht gewenst dat vanuit de Tweede Kamer enige drang op de verantwoordelijke mimister wordt uitgeoefend, zodat deze de beloften van zijn ambtswoorganger waarmaakt. Ik ben mij ervan bewust dat de overheid slechts beperkt middelen voor een subsidieregeling ter beschikking staan en dat zij weloverwogen met deze middelen dient om te gaan. Desalniettemin wil ik pleiten voor een subsidieregeling die het zowell algemene als categoriale consumentenorganisaties mogelijk maakt effectief op te treden tegen het gebruik of de aanbeveling van onredelijk bezwarende algemene voorwaarden. Daar gaat immers de meeste breedtewerking van uit.

Dat een dergelijke subsidieregeling aan consumentenorganisaties voorwaarden stelt teneinde te waarborgen dat deze organisaties de toegekende subsidie efficiënt en effectief gebruiken, spreekt voor zich "Wellicht valt vamuit kostenoogpunt op dit terrein een bundeling van de rechtshandhavingsactiviteiten van de diwerse consumentenorganisaties naar Duits model te overwegen."

Een dergelijke subsidieregeling dient in beginsel onathankelijk te zijn van de vraag of consumentenorganisaties met gebruikers of aanbevelers onderhandelen over te hanteren algemene voorwaarden, maar dient mijns inziens wél rekening te houden met eventuele subsidies op het terrein van de zelfregulering en het voorwaardenoverleg zoals dat in CCA-verband wordt gevoerd. De rechtshandhaving van de wettelijke minimumnorm zoals deze in de Wet algemene voorwaarden is neergelegd en het voorwaardenoverleg overlappen elkaar immers woor een groot gedeelte. Daarmee wil niet gezegd zijn dat voorshands een keuze dient te worden gemaakt tussen subsidiëring van het voorwaardenoverleg en subsidiëring van de rechtshandhavingsactiviteiten als bedoeld in afdeling 6:5.3 BW, Zoals de Duitse ervaring leert, gaat een aanzienlijke zuiverende werking van de markt immers uit van aan de wet aangepaste branchevoorwaarden. Bovendien zijn vanuit consumentenperspectief de onderhandellingen over algemene voorwaarden naar hun aard gericht op mér dan de wettelijke minimumbescherming, namelijk op evenwichtige of zelfs consumentvriendelijke algemene voorwaarden. Het voorwaardenoverleg dient dan ook duidelijk haar kans te krijgen. Het zal mij echter niet verbazen indien over enige tijd blijkt dat het conflictmodel in veel gevallen een hoger rendement heeft dan het overlegmodel.

De kosten van de rechtshandhaving en dus ook een eventuele subsidieregeling zullen voor een deel afhankelijk zijn van het procesrisico dat consumentenorganisaties lopen. De ervaringen in Duitsland leren dat consumentenorganisaties, 
mits zij daartoe de nodige middelen hebben, een dermate deskundigheid kunnen genereren dat zij de door hen gevoerde procedures nagenoeg allemaal winnen. Ten opzichte van Duitsland doet zich voor Nederland daarbij een kostenverhogend effect voor. In Nederland is het immers nagenoeg vaste praktijk dat de winnende partij met een deel van de door haar voor de procedure gemaakte kosten blijft zitten. Dit euvel zou eenvoudig kunnen worden verholpen indien de rechterlijk macht er vaker dan tot nu toe het geval is, toe zou overgaan de verliezende partij in de werkelijke kosten van de winnende partij te veroordelen. De rechter heeft deze vrijheid ${ }^{2}$ en is in beginsel niet gebonden aan bij voorbeeld het "Tarief voor te liquideren kosten" zoals dat is vastgesteld door de Nederlandse orde van advocaten. Een veroordeling in de werkelijke rechtshandhavingskosten van de winnende consumentenorganisatie doet zich dan met name voor indien sprake is van een evident en dus ook voor de gebruiker of aanbeveler kenbaar, onredelijk bezwarend beding, zoals bij voorbeeld bedingen in strijd met dwingend recht, bedingen die op de zwarte lijst voorkomen en bedingen die worden gebruikt in strijd met een rechterlijk verbod. Mijns inziens is er dan ook geen enkele reden waarom een partij die door de andere partij wordt gedwongen haar evidente dwingendrechtelijke gelijk via de rechter te effectueren en daarvoor kosten moet maken, niet geheel schadeloos zou worden gesteld. Een factor die mijns inziens eveneens vớr een dergelijke algehele vergoeding spreekt is het feit dat op de gebruiker of aanbeveler de "rechtsplicht" (Obliegenheit) rust slechts bedingen te gebruiken die niet onredelijk bezwarend zijn en dat de kosten van het wegnemen van een inbreuk op die rechtsplicht, net als bij een onrechtmatige daad voor rekening dienen te komen van diegene die inbreuk maakt op deze Obliegenheit. In Duitsland wordt het hanteren van onredelijk bezwarende voorwaarden niet voor niets gezien als een quasi-delict. In het geval van een handelen in strijd met een rechterlijk verbod als bedoeld in artikel 6:240 lid 3 BW lijken mij de parallellen met een handelen "in strijd met des daders rechtsplicht" evident.

Een andere opstelling van de rechterlijke macht inzake de kostenveroordeling zou ook op het vlak van de individuele procedures mogelijk een bijdrage kunnen leveren aan een frequenter beroep van de consument op de rechter en zodoende aan de breedtewerking van de dwingendrechtelijke bescherming die deze consument ten deel valt. Naar alle waarschijnlijkheid zijn het immers met name de kosten die de consument die zich bewust is van zijn rechten moet maken om zijn dwingendrechtelijk gelijk te halen, die, omdat hij deze niet vergoed krijgt, hem er van weerhouden naar de rechter te stappen. Een dergelijke opstelling

2 Zie hiervoor paragraaf 7.2.9. 
wan de rechterlijke macht zou het gebruikers een stuk moeilijker maken een beroep te doen op onredelijk bezwarende algemene voorwaarden. Een beroep dat vanwege de bij gebruikers bekende ontoegankelijkheid van de burgerlijk rechter voor individuele consumenten, in de praktijk helaas maar al te makkelijk wordt gedaan in het vertrouwen dat de consument toch niet naar de rechter stapt. Het is mijns inziens te betreuren dat de hedendaagse praktijk uitwijst dat de consument zijn dwingendrechtelijke gelijk als het ware moet kopen bij de overheidsrechter. Het is terecht dat hij dat meestal (afhankelijk van belang en de an- of afwezigheid van een rechtsbijstandverzekering) te duur vindt. Een ontwikkeling die mijns inziens kordaat een halt moet worden toegeroepen. Het falen van de overheidsrechtspraak komt wat dit betreft ook tot uiting in de hoge wlucht die de goedkopere particuliere geschillencommissies hebben genomen. Het succes van de geschillencommissies in deze doet er mijns inziens echter niet aan af dat de consument niet alleen op papier maar ook feitelijk in staat moet zijn om zijn kenbare dwingendrechtelijk gelijk ook voor de overheidsrechter af te dwingen.

Het feit dat de consument zijn juridisch gelijk moet kopen bij de rechter zou ook op het terrein van de verbodsuitspraak wel eens ongewenste effecten kunnen hebben. Ook voor het afdwingen van een verbodsuitspraak kan het immers nodig zijn dat de consument een beroep moet doen op de rechter omdat de veroordeelde gebruiker niet bereid is om vrijwillig van een beroep op een dergelijk verboden beding af te zien. Met name bij consumententransacties met een geringe waarde, kan het wel eens aantrekkelijk zijn voor gebruikers om een dergelijke beding toch te gebruiken.

Uiteraard hangt de mate waarin gebruikers door het Haagse hof verboden bedingen zullen hergebruiken uiteraard ook af van hun inschatting van de kans dat zij door consumentenorganisaties worden betrapt op het gebruik van een verboden beding en de kans dat zij daardoor de aan het verbod gekoppelde dwangsom verbeuren. Het ligt voor de hand dat consumentenorganisaties bij de controle van de naleving van verbodsuitspraken hun leden inschakelen en dat de effectiviteit van de controle voor een deel zal afhangen van de mate waarin consumentenorganisaties er in slagen hun achterban bij de opsporing en controle te betrekken. In dit verband zouden consumentenorganisaties kunnen overwegen hun leden te activeren door een financiële prikkel, bijvoorbeeld door een deel van de te innen dwangsom of de contractuele boete in het vooruitzicht te stellen. Mijns inziens zou zulk een maatregel de belangstelling van de consument voor algemene voorwaarden en het recht daaromtrent aanzienlijk doen toenemen en kunnen zorgen voor een enorme spreiding van de minimum bescherming die de wet beoogt te bieden. 
Met de prikkel die daarvan uitgaat naar de individuele consument en de mijns inziens positieve invloed op niet alleen het rechtsbewustzijn van de consument maar ook de beoogde zuivering van de markt van onredelik bezwarende bedingen die een dergelijke beloning voor de consument waarschijnlijk heef, zou bij de herziening van de wet, die zich aandient op grond van de EG-richtlijn van 5 april 1993 betreffende oneerlijke bedingen (Publikatieblad EG 21 april 1193, Nr. L 95/29) en die uiterlijk 31 december 1994 zou moeten hebben pllaatsgevonden (artikel 10 lid $\mathbb{1}$ van de richtlijn), rekening kunnen worden gehouden. Wellicht zou overwogen kunnen worden of het niet wenselijk is in de Wet algemene voorwaarden te voorzien in de mogelijkheid dat ook de indivduele consument de in een collectieve actie opgelegde dwangsom of een deel daarvan kan effectueren indien het verboden beding jegens hem in strijd met een opgelegd verbod wordt gebruikt. In dat kader kan ook worden gedacht aan de mogelijkheid om aan het gebruik van evident onredelijk bezwarende bedingen, zoals die bijvoorbeeld zijn opgenomen op de zwarte lijst, een privaatrechtelijke, aan de wederpartij die met het gebruik van dergelijke bedingen wordt geconfronteerd, te verbeuren boete wordt gekoppeld naar het voorbeeld van de "punitive damage" zoals die in de Verenigde Staten wordt gehanteerd.

De door de wetgever beoogde brede werking van de Wet algemene voorwarden, uniforme toepassing van de wettelijke regels en rechtszekerheid omtrent de inhoudelijke toelaatbaarheid van algemene voorwaarden en de toepasselijkheid daarvan, zou zeker ook ten goede worden beïnvloed door een openbaar register dat voor iedereen op een eenvoudige manier toegang geeft tot de vonnissen, van met name de bijzondere rechter en informatie verschaft over het beding dat ter discussie stond, de toelaatbaarheid daarvan, de gebruiker daarvan en de gronden die hebben geleid tot de beslissing. Met de moderne automatiserings- en communicatietechnieken moet een dergelijk informatiesysteem niet al te moeilijk tegen een consumentvriendelijke prijs te realiseren zijn.

De ervaring in Duitsland leert dat in een groot aantal individuele procedures de rechter het AGB-Gesetz ambtshalve toepast. Dit heeft in Duitsland zeker bijgedragen aan een brede verspreiding van de normen van het AGB-Gesetz. In Nederland zal de rechter de dwingendrechtelijke bescherming van de Wet algemene voorwaarden niet ambtshalve kunnen toepassen. Dit is te wijten aan de sanctie die op het gebruik van onredelijk bezwarende voorwaarden staat: vernietigbaarheid, een vernietiging dus op instigatie van de consument. Dit komt een brede werking van de wettelijke regels inzake algemene voorwaarden niet ten goede. Een directere betrokkenheid van de burgerlijke rechter door een verplichte ambtshalve inhoudstoetsing indien een partij een beroep doet op een algemene voorwaarde, zou een "doorwerking" van de Wet algemene voorwaar- 
den en daarmee de consumentenbescherming zeker ten goede komen. Dit omdat zo ook in procedures waarin de consument geen verweer voert (bij voorbeeld verstekzaken) of in procedures waarin de consument niet tot vernietiging overgaat omdat hij het recht inzake algemene voorwaarden niet kent, de Wet algemene voorwaarden wordt toegepast en aldus de dwingendrechtelijke minimumbescherming van de consument is gewaarborgd. Een minder lijdelijke opstelling van de rechter lijkt mij in deze gewenst. Er valt immers niet in te zien waarom een gebruiker door het niet in rechte verschijnen van zijn wederpartij of het ontbreken van een op artikel 6:233 sub a BW gericht verweer, "beloond" zou worden in die zin dat hij zich dan niet aan de o6k voor hem geldende dwingendrechtelijke regels inzake algemene voorwaarden hoeft te houden. Omdat dit ongetwijfeld de bescherming van de consument en een brede werking van de wettelijke basisbescherming ten goede komt, is het wellicht ook het overwegen waard, om naar Duits voorbeeld de sanctie van vernietigbaarheid, wellicht enkel voor consumententransacties, te wijzigen in een nietigheid van rechtswege. Een wijziging die de Nederlandse wetgever op grond van artikelen 10 lid 1 en 6 lid 1 van de EEG-richtlijn betreffende oneerlijke bedingen in consumentenovereenkomsten toch al verplicht is vóór 1 januari 1995 te implementeren in onze wetgeving. 



\section{Samenvatting}

Op 1 januari 1992 is de Wet algemene voorwaarden (afdeling 6.5.3 BW) in werking getreden. Daarmee heeft de Nederlandse wetgever de problematiek van de gestandaardiseerde contractsbepalingen wettelijk geregeld. Opvallend in de regeling is dat er naast materieelrechtelijke bepalingen geënt op het individuele actierecht van wederpartijen tevens procesrechtelijke bepalingen zijn opgenomen die voorzien in een actiebevoegdheid op het terrein van de algemene voorwaarden voor onder meer consumentenorganisaties.

Dit boek heeft tot doel dit collectief actierecht voor consumentenorganisatie binnen het systeem van afdeling 6.5.3 BW nader te onderzoeken. Vanwege de grote inhoudelijke en systematische gelijkenis tussen beide regelingen wordt de Nederlandse Wet algemene voorwaarden vergeleken met het Duitse AGBGesetz. De Duitse regeling geldt immers reeds sinds 1 april 1977 en heeft sindsdien een grote hoeveelheid literatuur en rechtspraak heeft voortgebracht. Verder wordt in dit boek onderzocht welke de praktische ervaringen van de Duitse consumentenorganisaties zijn met het collectief actierecht op het terrein van de algemene voorwaarden. Aan de hand van de verkregen uitkomsten wordt een prognose gegeven van de in Nederland te verwachten effectiviteit van het collectief actierecht op het terrein van de algemene voorwaarden en wordt aangegeven welke factoren van invloed zijn op deze effectiviteit. In hoofdstuk 1 wordt deze doelstelling, de onderzoeksmethode, de opzet van het onderzoek en de daarbij gehanteerde terminologie uiteengezet.

In hoofdistuk 2 staan het verschijnsel algemene voorwaarden en de procesrechtelijke positie van de consument op dit terrein centraal. Kenmerkend voor algemene voorwaarden is het feit dat hun inhoud van te voren is vastgesteld, dat de wederpartij op deze inhoud geen (althans geen directe) invloed heeft, dat zij zijn bestemd om zonder onderhandelingen in meerdere overeenkomsten te worden opgenomen en dat de wederpartij hun gelding doorgaans aanvaardt zonder van de inhoud kennis te nemen.

Het gebruik van algemene voorwaarden heeft sinds de industriële revolutie een grote vlucht genomen en zij zijn niet meer weg te denken uit ons gecollecti- 
veerde economisch verkeer. Het contractenrecht wordt grotendeels beheerst door algemene voorwaarden.

Algemene voorwaarden hebben zowel voor gebruikers als wederpartijen voor- en nadelen. Het voordeel van algemene voorwaarden is vooral gelegen in het feit dat zij het contracteren vereenvoudigen en bijdragen tot een rationalisatie van de onderneming van de gebruiker. Het nadeel van het gebruik van algemene voorwaarden is voor de wederpartij vooral gelegen in hun inhoud. Deze is vanwege de sociale ongelijkheid van partijen (de wederpartij staat meestal tegenover een organisatie) en het feit dat de wederpartij geen invloed heeft op de inhoud van algemene voorwaarden, doorgaans enkel gericht op de belangen van de gebruiker en daardoor vaak (onredelijk) bezwarend voor de wederpartij. Bovendien is het voor de wederpartij vaak moeilijk om achter de inhoud van de toepasselijke algemene voorwaarden te komen. Het verschijnsel algemene voorwaarden is dan ook moeilijk in overeenstemming te brengen met de " $\mathrm{klas}$ sieke" beginselen van ons contractenrecht: contractswrijheid, consensualisme en de daarop gebaseerde verbindende kracht van overeenkomsten. Het klassieke contractsmodel gaat immers uit van gelijkwaardige partijen die in vrijheid bepalen waar zij zich aan wensen te binden en zodoende komen tot een evenwichtige overeenkomst die op billijke wijze tegemoet komt aan beider belangen. Van contractsvrijheid en gelijkheid van partijen is op het terrein van de algemene voorwaarden echter geen sprake.

Ook op het procesrechtelijk vlak komt de ongelijkheid tussen gebruilkers en consumenten duidelijk naar voren. De sociaal-economische ongelijkheid van partijen, het feit dat gebruikers Repeat Players zijn en in een gerechtelijke procedure staan tegenover een consument die doorgaans One Shotter is, het gegeven dat vanuit het standpunt van de gebruiker sprake is van een niet-unieke contractuele relatie terwijl dat voor de wederpartij juist wel een unieke relatie is, de rechtsonkunde van de doorsnee consument, de sociale afstand en de hoogte van de kosten van gerechtelijke procedures, bewerkstelligen dat de individuele consument nauwelijks in staat is zijn rechten op het terrein van de algemene voorwaarden te handhaven.

Gezien het maatschappelijk nut en de voordelen die het gebruik van (niet onredelijk bezwarende) algemene voorwaarden voor zowel gebruiker als wederpartij heeft is een snelle gebondenheid aan algemene voorwaarden gewenst, ook als de wederpartij de inhoud van die algemene voorwaarden niet kent. In die zin behoeft de consument geen bescherming. De consument heeft vooral behoefte aan rechtsbescherming tegen inhoudelijk onredelijke algemene voorwaarden, aan een eenvoudige mogelijkheid van kennisneming van de inhoud van algemene voorwaarden op het moment dat hij dat wil en aan toegang tot het recht en de rechter. 
In hoofdstuk 3 komt de wijze waarop in de Nederlandse rechtspraak van vór de inwerkingtreding van afdeling 6.5.3 BW invulling werd gegeven aan de beschermingsbehoefte van de consument op het terrein van de algemene voorwaarden, aan de orde. In de Nederlandse rechtspraak worden aan het bedingen van toepasselijkheid van algemene voorwaarden geen andere eisen gesteld dan aan het totstandkomen van een overeenkomst. De wederpartij moet de gelding van algemene voorwaarden aanvaarden. De onbekendheid van de wederpartij met de inhoud van de aanvaarde algemene voorwaarden staat in beginsel aan de gebondenheid van de wederpartij niet in de weg. Volgens vaste rechtspraak is voor de uitleg van contractsbepalingen niet de letterlijke tekst en een zuiver taalkundige uitleg bepalend, maar de zin die partijen in de gegeven omstandigheden over en weer redelijkerwijs aan deze bepalingen mochten toekennen. De inhoud van de algemene voorwaarden werd in de Nederlandse rechtspraak getoetst aan de wet, openbare orde en goede zeden en met name de redelijk en billijkheid. De ongebruikelijke of verrassende inhoud van een beding kon echter ook bewerkstelligen dat de wederpartij die de gelding van de hele set heeft aanvaard niet geacht kan worden ook voor die bedingen toestemming te hebben gegeven.

Ondanks deze mogelijkheden kleefden aan de rechterlijke controle op algemene voorwaarden een aantal nadelen. Consumenten alsmede hun organisaties hadden nauwelijks toegang tot de rechter. De uitspraken van de overheidsrechter hadden weliswaar precedentwerking maar als gevolg van het feit dat het gezag van gewijsde van rechterlijke uitspraken slechts werking heeft ten aanzien wan procespartijen slechts een beperkte reikwijdte. Omdat de rechterlijke controle naar haar aard repressief is, hadden deze uitspraken bovendien slechts een beperkte preventieve werking.

Vanwege de hoge drempels in de toegang tot de rechter hebben consumenten in toenemende mate een beroep gedaan op particuliere geschillenbeslechting. Consumenten hebben met name een goed alternatief gevonden bij de branchegeschillencommissies aangesloten bij de Stichting Geschillencommissies voor Consumentenzaken, die "rechtspreken" op basis van algemene voorwaarden wastgesteld in onderling overleg tussen branche- en consumentenorganisaties.

In hoofdstuk 4 wordt het beleid van de Nederlandse overheid op het terrein van de algemene voorwaarden geïnventariseerd. De Nederlandse wetgever onderkent dat algemene voorwaarden een nuttige en onmisbare rol in het rechtsverkeer kunnen spelen maar dat tegelijkertijd de rechtspositie van consumenten vaak op versluierde wijze ontoelaatbaar wordt verzwakt in die algemene voorwaarden en dat overheidsingrijpen noodzakelijk is om te bewerkstelligen dat algemene voorwaarden op een evenwichtige wijze inhoudelijk recht doen aan de weder- 
zijdse belangen van beide partijen. Daartoe is tevens een versterking van de rechterlijke controle op de inhoud van algemene voorwaarden vereist.

Voor dit ingrijpen heeft de overheid de keuze uit wetgeving, subsidiëring, het optreden als moderator, voorlichting en zelfregulering. Met name het laatste beleidsinstrument krijgt sinds de jaren tachtig een steeds prominentere rol in het consumentenbeleid van de Nederlandse overheid. Op het terrein van de algemene voorwaarden wordt de door de Nederlandse wetgever beoogde basisbescherming van de consument gerealiseerd door enerzijds de beleidsinstrumenten wetgeving (afdeling 6.5.3 BW, titel 7.1 BW, artikel 6:214 BW en artikel 6:225 lid $3 \mathrm{BW}$ ), subsidie en voorlichting en anderzijds door het beleidsinstrument zelfregulering en wel in de vorm van overleg en overeenstemming tussen consumentenorganisaties en branche-organisaties over te hanteren algemene voorwaarden in transacties met consumenten. De gekozen beleidsinstrumenten bestrijken met name de volgende knelpunten in de algemene voorwaardenproblematiek: de toepasselijkheid, de versluiering van de contractsinhoud, de (vaak) onereuze inhoud, de ontoegankelijkheid van de overheidsrechter voor individuele consumenten en de weinig effectieve werking van het rechterlijk vonnis inzake algemene voorwaarden. De knelpunten onduidelijk taalgebruik, ondoorzichtigheid van bedingen in algemene voorwaarden en de uitleg van contractsbedingen worden niet bestreken door de gekozen beleidsinstrumenten. Het is echter niet uitgesloten dat de EEG-richtlijn betreffende oneerlijke bedingen in consumentenovereenkomsten daarin verandering zal brengen. De knelpunten inzake het gebruik van algemene voorwaarden vinden hun oorzaak voornamelijk in de ongelijke positie waarin gebruikers van algemene voorwaarden en consumenten-wederpartijen zich ten opzichte van elkaar bevinden bij de vaststelling van de inhoud van algemene voorwaarden en de toegankelijkheid van het recht en de rechter. In het gekozen beleidsinstrumentarium is met name de toekenning van het collectief actierecht op het terrein van de algemene voorwaarden aan consumentenorganisaties bedoeld om deze ongelijkheid te compenseren.

In hoofdstuk 5 komt de Wet algemene voorwaarden en met name de regeling van het collectief actierecht uitgebreid aan de orde. Allereerst worden de materieelrechtelijke bepalingen zoals vervat in de artikelen 6:231 tot en met 6:239 BW en de artikelen 6:243 tot en met 6:247 BW behandeld en vervolgens de collectieve actie en de procesrechtelijke bepalingen vervat in de artikelen 6:240 tot en met 6:243 BW en de artikelen 4 sub 13, 9 lid 3, 67 en 1003 tot en met $1006 \mathrm{Rv}$. Het stelsel van afdeling 6.5.3 BW is enerzijds gebaseerd op het uitgangspunt dat gezien de voordelen die het hanteren van algemene voorwaarden voor beide partijen heeft niet al te strenge eisen moeten worden gesteld aan de inlassing van die algemene voorwaarden in de overeenkomst en anderzijds 
het uitgangspunt dat de nadelen van dit gebruik voor de wederpartij (versluiering en onereuze inhoud) op een doeltreffende wijze moeten worden bestreden.

Materieel is het bereik van afdeling 6.5 .3 beperkt tot bedingen in algemene voorwaarden in obligatoire overeenkomsten en andere meerzijdige vermogensrechtelijke rechtshandelingen. Afdeling 6.5.3 BW is niet van toepassing op arbeidsovereenkomsten (artikel 6:245 BW) en op overeenkomsten gesloten tussen buitenlandse professionele partijen (artikel 6:247 BW). Algemene voorwaarden zijn in de wettelijke definitie een of meer schriftelijke bedingen die zijn opgesteld teneinde in een aantal overeenkomsten te worden opgenomen, met uitzondering van bedingen die de kern van de prestatie aangeven. Daarmee ziet afdeling 6.5.3 $\mathrm{BW}$ zowel op algemene voorwaarden bij consumententransacties als transacties tussen professionele contractanten, maar niet op mondelinge bedingen, niet op individuele bedingen en niet op kernbedingen. Voor de vraag of sprake is van algemene voorwaarden is zonder belang de vorm waarin de overeenkomst is gegoten en evenmin de herkomst (nul-, een- of tweezijdig vastgesteld of wettelijke regel) van de algemene voorwaarden.

Personeel is het bereik van afdeling 6.5 .3 in beginsel beperkt tot "kleine" wederpartijen. Op grond van artikel 6:235 lid $1 \mathrm{BW}$ zijn rechtspersonen die meer dan 50 personen in dienst hebben of rechtspersonen die hun jaarrekening openbaar hebben gemaakt alsmede partijen die identieke voorwaarden hanteren als die welke zij willen vernietigen, uitgesloten van een beroep op de artikelen 6:233 en 6:234 BW. Afdeling 6.5.3 BW is van dwingend recht.

In het belang van de rechtszekerheid wordt uitgegaan van gebondenheid aan algemene voorwaarden als de wederpartij de gelding daarvan heeft aanvaard (artikel 6:231 sub c BW). Daarvoor is, in het belang van de rechtszekerheid en het rechtsverkeer, niet vereist dat de wederpartij de inhoud van de aanvaarde bedingen kent (artikel 6:232 BW). Of de wederpartij de gelding heeft aanvaard moet worden beoordeeld aan de hand van de algemene regels van afdeling 6.5.2 BW en de artikelen 3:33 en 3:35 BW. Voor gebondenheid is dan vereist dat de gebruiker voror, bij of na het sluiten van de "romp"'-overeenkomst kenbaar maakt dat hij algemene voorwaarden hanteert en dat de wederpartij daarmee akkoord is gegaan of althans bij de gebruiker het gerechtvaardigde vertrouwen daarvan heeft gewekt.

Op grond van artikel 6:233 sub b BW rust op de gebruiker op straffe van vernietigbaarheid de "Obliegenheit" de wederpartij een redelijke mogelijkheid te bieden om van de algemene voorwaarden kennis te nemen. Indien terhandstelling of toezending vór de aanvaarding van de gelding van de algemene voorwaarden redelijkerwijs mogelijk is, is dit de enige wijze waarop aan de informatieverplichting kan worden voldaan (artikel 6:234 lid 1 sub a BW). Indien terhandstelling of toezending vooraf redelijkerwijs niet mogelijk is, kan de gebruiker volstaan met de mededeling dat de voorwaarden bij hem of bij een 
Kamer van Koophandel en Fabrieken of een griffie van een gerecht ter inzage liggen, en dat zij op verzoek kosteloos zullen worden toegezonden (artikel 6:234 lid 1 sub $\mathrm{b}$ BW). De algemene voorwaarden moeten in ieder geval bij de gebruiker zelf ter inzage liggen. Indien de wederpartij daarom vraagt moeten, zij op straffe van vernietigbaarheid, kosteloos worden toegezonden (artikel 6:234 lid 2), voor zover toezending redelijkerwijs gevergd kan worden (artikel 6:234 lid 3 BW). Ik beginsel zal de bewijslast van het feit dat aan de informatieverplichting is voldaan op de gebruiker rusten. Deze bewijslast maakt echter dat het uitgangspunt dat "men misstanden waartoe het gebruik van algemene voorwaarden soms leidt, niet moet willen bestrijden door strenge eisen te stellen voor de inlassing daarvan in de overeenkomst" op losse schroeven komt te staan. De inlassingseisen zijn weliswaar niet streng, de bewijseisen met betrekking tot artikel 6:233 sub b j ${ }^{\circ}$ 6:234 BW daarentegen wel. Daarmee wordt een deel van de voordelen die algemene voorwaarden bieden, namelijk het eenvoudig contracteren zonder dat veel aandacht hoeft te worden besteed aan die algemene voorwaarden, teniet gedaan. De uitwerking van de informatieplicht van de gebruiker zoals neergelegd in artikel 6:234 BW kan derhalve worden bestempeld als onredelijk bezwarend voor de gebruiker.

Afdeling 6.5.3 BW mist regels met betrekking tot de uitleg van algemene voorwaarden. De algemene in de rechtspraak ontwikkelde regels zijn hierop van toepassing. Dat is uit het oogpunt van rechtszekerheid jammer. Het is echter niet uitgesloten dat de EEG-richtlijn betreffende oneerlijke bedingen in consumentenovereenkomsten bewerkstelligt dat de contra proferentem regel alsnog wordt opgenomen in afdeling 6.5.3.

Zwaartepunt van de regeling van afdeling 6.5.3 BW is de inhoudstoetsing van artikel 6:233 sub a BW. Vernietigbaar zijn algemene voorwaarden die, alle omstandigheden in aanmerking genomen, naar hun inhoud onredelijk bezwarend zijn. Deze "open norm" is van toepassing op algemene voorwaarden gehanteerd jegens consumenten en ondernemers. De open norm is voor het door haar bestreken gebied lex specialis ten opzichte van artikel 6:248 lid $2 \mathrm{BW}$. Dit heeft tot gevolg dat bij algemene voorwaarden een beroep op de beperkende werking van de redelijkheid en billijkheid van artikel 6:248 lid 2 BW is beperkt tot gevallen van rechtsverwerking en gewijzigde omstandigheden.

Voor consumententransacties is de open norm nader uitgewerkt in de lijsten van de artikelen 6:236 en 6:237 BW. Bedingen opgenomen in de "zwarte" lijst van artikel 6:236 $\mathrm{BW}$ zijn altijd vernietigbaar. Bedingen opgenomen in de "grijze" lijst van artikel 6:237 BW worden vermoed onredelijk bezwarend te zijn. Op deze wijze wordt een bewijslastomkering ten gunste van de consument bewerkstelligt; de gebruiker moet bewijzen dat het "grijze" beding niet onredelijk bezwarend is voor de wederpartij. Aangenomen wordt dat de lijsten ook 
buiten het terrein van consumententransacties een zogenoemde reflexwerking zullen hebben.

Uitgangspunt van de inhoudstoets van bedingen aan de open norm zijn de rechtsgevolgen die de overeenkomst op grond van de partijafspraak zonder de betreffende bedingen zou hebben gehad. Ter beoordeling van de rechter staat dus op de eerste plaats de vraag of een algemene voorwaarde een rechtstoestand in het leven roept die afwijkt van de rechtstoestand zonder dat beding. Indien deze vraag ontkennend wordt beantwoord kan de rechter enkel concluderen dat het betreffende beding dus niet onredelijk bezwarend is. Pas indien de rechter tot de conclusie komt dat een beding rechtsgevolgen in het leven roept die afwijken van de rechtsgevolgen die zouden gelden zonder dat beding komt hij toe aan de vraag of de afwijking en dus de inhoud van het beding onredelijk bezwarend is voor de wederpartij.

De formulering van de maatstaf van artikel 6:233 sub a $\mathrm{BW}$ moet duidelijk maken dat het een concrete inhoudstoets betreft, dit in afwijking van de toetsing door de bijzondere rechter in de ge- en verbodsprocedure van artikel 6:240 BW e. $v_{m}$. De toetsnorm van artikel 6:233 sub a $B W$ is concreet omdat deze altijd grericht is op bedingen in concrete contractuele relaties. Dit in tegenstelling tot de abstracte toets van artikel $6: 240 \mathrm{BW}$ waarbij wordt getoetst onafhankelijk van de vraag of het beding reeds is opgenomen in een concrete overeenkomst en met het oog op het gebruik van het beding in het algemeen. Het concrete karakter wan de toets brengt met zich dat de rechter in zijn afweging in beginsel alle omstandigheden moet betrekken en volgens de wettekst met name de aard en de overige inhoud van de concrete overeenkomst, de belangen van partijen voor zover deze wederzijds voor hen kenbaar zijn, wijze waarop de voorwaarden tot stand zijn gekomen. De wijze waarop de voorwaarden tot stand zijn gekomen lijkt echter een weinig relevante omstandigheid bij de inhoudelijke toetsing van algemene voorwaarden. Het "concrete" karakter van de inhoudstoets aan de open norm is slechts relatief. Algemene voorwaarden zijn immers van tevoren opgesteld en naar hun aard niet gericht op een individuele wederpartij maar op de gehele kring van potentiële wederpartijen. $\mathrm{Zij}$ zien dan ook niet op atypische omstandigheden en dienen in die gevallen buiten beschouwing gelaten te worden omdat zij toepassing missen.

Een beding in algemene voorwaarden dat onredelijk bezwarend is voor de wederpartij is zowel in als buiten rechte vernietigbaar. In artikel 6:246 BW is bovendien uitdrukkelijk vastgelegd, dat de bevoegdheid om een beding op grond van artikel 6:233 sub a BW door een buitengerechtelijk verklaring te vernietigen niet kan worden uitgesloten. Gezien de vernietigbaarheid zijn bij de inhoudstoets aan de open norm slechts omstandigheden van vóor of bij het sluiten van de overeenkomst relevant. Omstandigheden die zich voordoen ná het sluiten van de overeenkomst waaraan het te toetsen beding vooraf reeds rechtsgevolgen 
verbindt worden echter eveneens bij de inhoudstoets meegewogen. Vernietiging van een beding zal doorgaans niet leiden tot vernietiging van de hele overeenkomst. Partiële nietigheid zall doorgaans het geval zijn. Conversie van een nietig beding wordt niet uitgesloten maar dient met uiterste voorzichtigheid te worden toegepast.

Naast de twee lijsten van de artikelen 6:236 en 6:237 BW zal er een derde lijst ontstaan van bedingen die altijd vernietigbaar zijn omdat zij door het Haagse Hof in een procedure ex artikel 6:240 BW zijn getroffen met een verbod van gebruik als bedoeld in artikel 6:241 lid 3 BW. Op grond van artikel 6:243 BW zijn deze bedingen vernietigbaar door de wederpartij.

Een rechtsvordering tot vernietiging verjaart in beginsel drie jaren nadat de bevoegdheid om de vernietigingsgrond in te roepen aan degene aan wie deze bevoegdheid toekomt, ten dienste is komen te staan (artikel 3:52 lid 2 BW). Deze begint voor wat betreft de vernietiging van algemene voorwaarden op grond van de artikelen 6:233, 6:234 en 6:243 BW, te lopen op de dag volgende op die waarop door de gebruiker een beroep op het beding is gedaan. De wederpartij neemt doorgaans immers pas kennis van het bestaan van het beding op het moment dat de gebruiker er een beroep op doet.

De toepasselijkheid van afdeling 6.5.3 BW op overeenkomsten met internationale aspecten wordt nader geregeld in artikel 6:247 BW. In dit artikel is aansluiting gezocht bij het EEG-verbintenissenverdrag. Voor consumententransacties gaat de regeling echter verder dan dit verdrag. Afdeling 6.5.3 $\mathrm{BW}$ is van toepassing als de consument zijn gewone verblijfplaats in Nederland heeft. De Nederlandse rechter is aan deze regel gebonden. In hoeverre de buitenlandse rechter echter aan deze regel gebonden is, is afhankelijk van de in zijn land toepasselijke IPR-conflictregels. Voor het geval dat Nederlandse gebruikers overeenkomsten sluiten met buitenlandse consumenten dient de oplossing gezocht te worden in het EEG-verbintenissenverdrag voor EU-burgers of andere IPR-conflictregels indien het een burger van buiten de Europese Unie betreft. De vraag welke rechter bij overeenkomsten met internationale aspecten bevoegd is dient voor Europese burgers te worden beantwoord aan de hand van het EEGexecutieverdrag en het Verdrag van Lugano.

Een bijzonder aspect van de regeling van afdeling 6.5.3 $\mathrm{BW}$ is ongetwijfeld de procesrechtelijke regeling waarin geregeld is dat de inhoudstoetsing van artikel 6:233 sub a BW niet alleen geëntameerd kan worden door individuele wederpartijen bij de gewone rechter, maar ook door branche- en consumentenorganisaties bij een bijzondere rechter. Branche- en consumentenorganisaties hebben daarbij de mogelijkheid een collectief van gebruikers te dagvaarden. De collectieve actie beoogt, mede door de prikkel tot onderhandelen die zij vormt, een "collectief" controlemechanisme te bieden tegen het in wezen collectieve verschijnsel der 
algemene voorwaarden. Het vorderingsrecht van artikel 6:240 lid 1 BW - en de daaraan verbonden nevenvorderingen - is aan consumentenorganisaties vooral toegekend in de verwachting dat alleen al de dreiging van een verbodsprocedure de gebruikers van algemene voorwaarden en hun branche-organisatie aan de onderhandelingstafel zal brengen en dat op die wijze algemene voorwaarden tot stand komen die op evenwichtige wijze rekening houden met de wederzijdse belangen. De collectieve actie van artikel 6:240 e.v. BW beoogt daarmee niet alleen een drukmiddel te zijn om de gebruikers en hun organisaties aan de tafel te krijgen maar tevens een drukmiddel om binnen bekwame tijd tot een resultaat te geraken. Het belang dat de wetgever aan deze onderhandelingen hecht wordt verder ondersteund door de "overlegverplichting" van artikel 6:240 lid 4 BW en de instemmingsregeling van artikel 6:240 lid $5 \mathrm{BW}$. Daarnaast wil de collectieve actie een oplossing bieden voor een aantal bezwaren die kleven aan de individuele rechterlijke controle.

Consumentenorganisaties en branche-organisaties kunnen op grond van artikel 6:240 lid $1 \mathrm{BW}$ de rechter vragen een bepaald beding in algemene voorwaarden onredelijk bezwarend te verklaren. De rechtsvordering moet steeds bepaalde bedingen in bepaalde algemene voorwaarden betreffen. Consumentenorganisaties kunnen slechts optreden tegen algemene voorwaarden gehanteerd jegens consumenten. De verklaring voor recht heeft slechts werking voor de toekomst. De artikelen 6:233 sub a, 6:236 en 6:237 BW zijn van overeenkomstige toepassing in de collectieve procedure. Ook in de abstracte procedure geldt dat een beding in algemene voorwaarden gehanteerd jegens consumenten dat voorkomt op de lijst van artikel 6:236 BW zondermeer onredelijk bezwarend is en geldt de omkering van de bewijslast indien deze bedingen op de grijze lijst van artikel 6:237 voorkomen.

Bij de collectieve toetsing is sprake van een meer "abstracte" wijze van toetsing. Naar de aard van de toets is het onvermijdbaar dat de rechter bij de collectieve inhoudstoets tot op zekere hoogte moet abstraheren. Het abstraheren is echter begrenst. De bijzondere rechter dient, uitgaande van de norm van artikel 6:233 sub a BW, de daarin genoemde maatstaven slechts zo te generaliseren als met het oog op de van hem krachtens artikel 6:240 BW gevraagde beslissing nodig is. De abstracte inhoudstoets moet zo concreet mogelijk zijn. De waardering van de relevante omstandigheden bij de abstracte collectieve toets zal doorgaans niet verschillen van de waardering van die omstandigheden bij de concrete individuele toets. De "normale" omstandigheden (de omstandigheden waarin de doorsnee-wederpartij zich bevindt) waaraan getoetst wordt in de "normale" individuele procedure van artikel 6:233 sub a BW worden immers ook altijd meegewogen in de abstracte toets. Deze laatste gaat immers uit van de doorsnee-wederpartij. Uitgangspunt daarbij is dat de meeste individuele procedures doorsnee wederpartijen betreffen. Slechts in uitzonderlijke gevallen heeft 
de individuele procedure betrekking op atypische omstandigheden. Dexe uitzonderlijke omstandigheden kan de bijzondere rechter niet meewegen in de abstracte inhoudstoets van artikel 6:240 BW. Naar mijn mening komt de rechter aan een weging van deze bijzondere omstandigheden in de individuele inhoudstoets ook niet toe, zodat ook in die gevallen geen onderscheid ontstaat tussen de abstracte en concrete toets. Algemene voorwaarden zien immers niet op deze uitzonderlijke omstandigheden en missen derhalve toepassing in zulke gevallen.

Omdat de open norm van artikel 6:233 sub a BW van overeenkomstige toepassing is, moet er van uit worden gegaan dat bij de abstracte inhoudstoets in beginsel dezelfde omstandigheden een rol kunnen spelen als bij de individuele toets. Dit betekent dat ook in de abstracte toets slechts rekening kan worden gehouden met omstandigheden van vo6r of bij het sluiten van de overeenkomst.

Het door belangenorganisaties gevraagde declaratoir kan ook betrekking hebben op bedingen die in strijd zijn met de wet. In een procedure voor de bijzondere rechter wordt een beding in algemene voorwaarden dat in strijd is met een dwingende wetsbepaling als onredelijk bezwarend aangemerkt (artikel 6:240 lid $1 \mathrm{BW}$ ). Het voordeel van de actiebevoegdheid op grond van artikel 6:240 BW ten opzichte van de allgemene actiebevoegdheid van artikel 3:305a BW is vooral gelegen in de mogelijkheid van collectieve dagvaarding als bedoeld in de artikelen 1003-1006 Rv.

De eisende organisatie moet een rechtspersoon zijn met volledige rechtsbevoegdheid die tot doel heeft de belangen te behartigen van ondernemers, beroepsbeoefenaren of consumenten. Niet vereist is dat de daar genoemde techtspersonen de behartiging van consumenten- of ondernemersbelangen als witsluitend doel hebben. Andersom is niet vereist, dat deze rechtspersonen andere activiteiten ontplooien dan alleen het waken voor de belangen van consumenten of ondernemers. De organisaties kunnen slechts optreden ter behartiging van de belangen die zij zich statutair hebben aangetrokken. De vordering van artikel 6:240 lid $1 \mathrm{BW}$ en de nevenvorderingen van artikel 6:241 lid 3 BW kunnen derhalve slechts betrekking hebben op algemene voorwaarden die gebruikt worden of bestemd zijn te worden gebruikt tegenover de personen wier belangen door de rechtspersoon worden behartigd. Artikel 6:240 lid 3 BW stelt niet als voorwaarde dat de eisende organisatie een Nederlandse organisatie moet zijn, dat de eisende organisatie in Nederland gevestigd is, noch dat de eisende organisatie een rechtspersoon naar Nederlands recht is. De rechtsgang voor de bijzondere rechter in 's-Gravenhage staat derhalve in beginsel ook open voor buitenlandse consumentenorganisaties. Ofschoon er argumenten zijn aan te dragen die pleiten voor een toekenning van het collectief actierecht aan individuele consumenten, zijn deze uitgesloten van het collectief actierecht. Van de procesbevoegdheid als bedoeld in artikel 6:240 lid $1 \mathrm{BW}$ zijn uitgesloten de belangenorganisaties die met het gebruik van bepaalde allgemene voorwaarden 
hebben ingestemd (artikel 6:240 lid 5). Eisende belangenorganisaties zijn bovendien, op straffe van niet-ontvankelijkheid, verplicht om de gebruiker of de aanbeveler de gelegenheid te bieden om in overleg met de gebruiker of de aanbevelende organisatie de gerezen bezwaren tegen het betreffende beding weg te nemen, alvorens zij een vordering als bedoeld in artikel 6:240 BW kunnen instellen (artikel 6:240 lid 4 BW). Beide artikelleden geven uiting aan het belang dat de wetgever aan zelfregulering hecht. Om niet-ontvankelijkheid op grond van artikel 6:240 lid $4 \mathrm{BW}$ te vermijden, is de eisende organisatie verplicht aan de gebruiker of aanbeveler kenbaar te maken welke de bezwaren zijn, die hebben geleid tot haar oordeel dat de betreffende bedingen onredelijk bezwarend zijn en dient de eisende organisatie in de kennisgeving aan de gebruiker of aanbeveler aan te geven dat zij bereid is om met deze, indien hij dat wenst, te overleggen over een dusdanige wijziging van de aangevallen bedingen dat de gerezen bezwaren zijn weggenomen. Aan de overlegverplichting is een duidelijke beperking in tijd gesteld. Een termijn van zes maanden is in elk geval voldoende om het risico van niet-ontvankelijkheid te vermijden (artikel 6:240 lid $4 \mathrm{BW}$ ). De eisende organisatie is niet verplicht om wijzigingsvoorstellen te doen ten aanzien van bedingen die door haar als onredelijk bezwarend worden beschouwd. Dit ligt, gezien het dwingendrechtelijk karakter van afdeling 6.5.3 BW, meer op de weg van de gebruiker of aanbeveler van algemene voorwaarden. Consumentenorganisaties kunnen zich derhalve beperken tot het geven van commentaar ten aanzien van de onredelijk bezwarendheid van bedingen.

Met de overlegverplichting kiest de Nederlandse wetgever op het collectieve vlak voor een twee-fasen-systeem. Het gebruik van een onredelijk bezwarend beding kan niet direct worden verboden door de bijzondere rechter. In de eerste fase krijgt de gebruiker of aanbeveler zes maanden de tijd vrijwillig aan de bezwaren van de eisende organisatie tegemoet te komen door met deze te overleggen over een dusdanige wijziging van de algemene voorwaarden dat de bezwaren zijn weggenomen. De overlegverplichting van artikel 6:240 lid 4 BW beoogt in eerste instantie onredelijk bezwarende bedingen uit de markt te lichten door deze in onderling overleg te vervangen door niet-onredelijk bezwarende algemene voorwaarden. Pas als deze vervanging niet lukt staat in de tweede fase de gang naar de bijzondere rechter open om middels een rechterlijk verbod of gebod het gebruik of de aanbeveling van onredelijk bezwarende bedingen tegen te gaan. Of de bezwaren tegen het aangevallen beding zijn weggenomen is ter beoordeling van de eisende organisatie. De bijzondere rechter mag ná het verstrijken van de termijn van zes maanden derhalve niet in zijn overwegingen betrekken of reëel overleg is gevoerd.

Consumentenorganisaties moeten om ontvankelijk te zijn een processueel belang en voldoende materieel belang hebben. Zo zullen consumentenorganisaties ondermeer moeten aantonen dat de aangevallen bedingen recentelijk nog 
werden gebruikt en dat het gebruik in de toekomst zal worden voortgezet. Een organisatie die hetzelfde declaratoir vordert als een eerdere organisatie zal nietontvankelijk worden verklaard. Voor de uitkomst van de inhoudstoets in de abstracte procedure is immers niet van belang wie de vordering instelt.

De vorderingen als bedoeld in de artikelen 6:240 en 6:241 BW kunnen worden gericht tegen gebruikers en aanbevelers van algemene voorwaarden. Ook buitenlandse gebruikers die algemene voorwaarden hanteren jegens in Nederland wonende consumenten zijn onderworpen aan de regels van afdeling 6.5.3 BW. Of zij ook gedagvaard kunnen worden aan het Haagse hof is afhankelijk van de toepasselijke executieverdragen.

Aan het declaratoir dat een beding in algemene voorwaarden onredelijk bezwarend is, kan worden verbonden: een verbod van gebruik of aanbeveling, een gebod om een aanbeveling tot gebruik te herroepen, een veroordeling tot openbaar maken van de uitspraak en een dwangsom (artikel 6:241 leden 3 en 5 BW). De belangrijkste nevenvordering is het rechterlijk verbod van gebruik of aanbeveling. Onder gebruiken van een beding in algemene voorwaarden moet in dit kader worden verstaan het opnemen daarvan in overeenkomsten. Het verbod ziet niet alleen op de letterlijke tekst van de door de uitspraak getroffen bedingen maar tevens op de bedingen die daaraan nagenoeg gelijk zijn. Het verbod strekt zich uit tot degenen die partij waren in de procedure en heeft, net als het declaratoir van artikel 6:240 lid $1 \mathrm{BW}$, slechts werking voor de toekomst. Het verbod leidt slechts tot vernietigbaarheid van bedingen die worden opgenomen in overeenkomsten, nadat het verbod in werking is getreden. De geldigheid van een beding dat is opgenomen in een overeenkomst die is gesloten vór de datum van inwerkingtreding van het verbod, wordt derhalve door het verbod in beginsel niet aangetast. De tweede mogelijke nevenvordering is het gebod om een aanbeveling tot het gebruik van onredelijk bezwarende algemene voorwaarden te herroepen. Indien de vordering wordt toegewezen, moet de herroeping zo snel als mogelijk worden gedaan aan allen die de aanbeveling hebben ontvangen. De derde nevenvordering is de veroordeling tot het openbaar maken of laten maken van de uitspraak. Een eisende organisatie heeft alleen belang bij toekenning van een vordering tot publikatie, indien het gevraagde declaratoir en eventuele nevenvorderingen worden toegekend door de bijzondere rechter. Het ligt voor de hand dat de bijzondere rechter, aangenomen dat hij publikatie van de uitspraak oplegt aan de gedaagde, ook de kosten daarvan door deze gedaagde laat dragen. Voor het geval dat meerdere gebruikers zijn gedagvaard, laat de bepaling van artikel 6:241 lid 3 BW de rechter de vrijheid om te kiezen wie van deze gedaagden en voor welk deel in de kosten van publikatie zal worden veroordeeld. Aan de verbods- en gebodsworderingen kan eveneens een dwangsom worden gekoppeld. Verbeurde dwangsommen komen ten volle toe aan de partij die de veroordeling heeft verkregen. 
Van een verjaringsregeling voor de collectieve actie is afgezien. Het belangvereiste van artikel 3:303 BW geeft een afdoende regel voor de vraag tot welk tijdstip een collectieve rechtsvordering kan worden ingesteld.

De collectieve actie van artikel 6:240 e.v. BW is geconcentreerd bij het gerechtshof te 's-Gravenhage om ook in eerste instantie reeds eenheid van rechtspraak te waarborgen. De procedure kan worden aangevangen met een "gewone" dagvaarding als bedoeld in de artikelen 1 tot en met $17 \mathrm{Rv}$, een collectieve dagvaarding van de branchevereniging tezamen met haar leden als bedoeld in artikel $1003 \mathrm{Rv}$ of een combinatie daarvan. De collectieve dagvaarding heeft vooral tot doel om de collectieve actie van afdeling 6.5.3 een maximale effectiviteit te verschaffen. In geval van een collectieve dagvaarding is de normale dagvaardingstermijn van tenminste 8 dagen verlengd tot tenminste een maand en is bepaald dat een uittreksel van het dagvaardingsexploit wordt gepubliceerd in een landelijk dagblad onder verwijzing naar de plaats waar, indien gewenst, een afschrift van de dagvaarding kan worden verkregen. Het dagvaardingsexploit gericht tegen het collectief van niet-geïndividualiseerde gebruikers ("de leden") moet worden betekend aan de persoon of het parket van de procureur-generaal bij het hof te 's-Gravenhage of, in cassatie, bij de procureur-generaal van de Hoge Raad. Het dagvaardingsexploit tegen de geindividualiseerde leden en de ondernemersvereniging zelf - alsmede de medegedagvaarde niet-leden die hetzelfde beding gebruiken -, dient op de normale wijze betekend te worden aan de persoon of de woonplaats van deze gedaagden.

Voor de collectieve actie gelden in beginsel de algemene regels van verstek, verzet, voeging, tussenkomst en derden-verzet. In een procedure die wordt ingeleid met een collectieve dagvaarding is het bepaalde in artikel 79 lid $1 \mathrm{Rv}$ niet van toepassing indien de vereniging of tenminste eén van haar leden ter zitting verschijnt. Aan de niet verschenen leden of vereniging wordt dan wel verstek verleent maar de zaak wordt niet aangehouden.

Een voorziening in kort geding als bedoeld in artikel 289 e.v. Rv is in de procedures op grond van de artikelen 6:240 en 6:242 BW niet mogelijk. Voor consumentenorganisaties staat wel de mogelijkheid open van een verkorte dagvaardingstermijn (artikel 7 lid $2 \mathrm{Rv}$ ), een procedure op korte termijn als bedoeld in artikel $145 \mathrm{Rv}$ en een voorlopige voorziening bij de bijzondere rechter bij wege van een provisionele eis als bedoeld in artikel $51 \mathrm{Rv}$.

In zijn uitspraak kan de bijzondere rechter aangeven op welke wijze het bezwarende karakter van een onredelijk bezwarend beding kan worden weggenomen $(6: 241$ lid $4 \mathrm{BW})$. De rechter dient hier echter uiterst terughoudend gebruik van te maken. De wettelijke regeling voorziet niet in een voor ieder toegankelijke registratie van de uitspraken van de bijzonder rechter. Een verbodsuitspraak van de bijzondere rechter kan op vordering van de door de uitspraak gebonden gebruikers of aanbevelers worden gewijzigd of opgeheven 
indien een wijziging in de omstandigheden dit rechtvaardigt. Tegen de uitspraken van de bijzondere rechter staat cassatie open bij de Hoge Raad. Voor de procedure die wordt ingeleid met een collectieve dagvaarding geldt de bijzondere regel dat het beroep in cassatie slechts kan worden ingesteld door degenen die in eerste aanleg verschenen zijn.

Indien de procedure als bedoeld in artikel 6:240 BW wordt ingeleid met een "gewone" dagvaarding, zijn voor wat betreft de kosten van de procedure in eerste aanleg de algemene regels van de artikelen 56-58 Rv van toepassing. Voor de proceskosten bij een collectieve dagvaarding geldt echter dat de collectiviteit (vereniging ên leden) voor de berekening van de proceskosten als én partij wordt beschouwd (artikel $1006 \mathrm{Rv}$ ).

De door de overheid aangekondigde wettelijke regeling voor de subsidiëring van de activiteiten van consumentenorganisaties met betrekking tot het collectief actierecht van artikel 6:240 BW ontbreekt tot op heden. Naast de collectieve actie van artikel 6:240 e.v. BW kunnen consumentenorganisaties sinds 1 juli 1994 ook gebruik maken van het algemene vorderingsrecht voor belangenorganisaties als bedoeld in artikel 3:305a BW. Daarbij kan met name worden gedacht aan collectieve vernietiging van bedingen in algemene voorwaarden op grond van de artikelen 6:233 en 6:243 BW.

In hoofdstuk 6 komen de ontstaansgeschiedenis en de materieel- en procesrechtelijke bepalingen van het AGB-Gesetz aan de orde. In hoofdstuk 7 wordt het AGB-Gesetz vergeleken met de Wet algemene voorwaarden. De gellikenis tussen het AGB-Gesetz en de Wet algemene voorwaarden is onmiskenbaar. Beide regelingen bevatten een dwingendrechtelijk regelcomplex dat nadere bepalingen geeft ten aanzien van het begrip algemene voorwaarden, de gebondenheid daaraan, de wijze waarop de gebruiker de wederpartij dient te informeren over de toepasselijkheid en de inhoud van deze voorwaarden en de inhoudstoets. In beide regelingen is de inhoudstoets gebaseerd op een van de redelijkheid en billijkheid afgeleide norm, die voor consumententransacties nader wordt uitgewerkt in twee lijsten van bedingen die ofwel altijd tot onredelijk bezwarendheid van een daardoor betroffen beding leiden ofwel een onredelijk bezwarendheid indiceren. Ook op het procesrechtelijk vlak komen de beide regelingen in essentie overeen. Beide regelingen bieden immers een individuele procedure met daarnaast een procedure waarin belangenorganisaties ten behoeve van het algemeen belang de wettelijk bescherming collectief kunnen afdwingen en waarin belangenorganisaties een verbod van gebruik kunnen afdwingen dat ook buiten de collectieve procedure directe werking heeft.

Materieel gezien komen beide regelingen qua systeem, opbouw, invulling en werking grotendeels overeen. Slechts op enkele punten wijken zij van elkaar af. De informatieplicht in het Nederlandse systeem is strenger dan die in het AGB- 
Gesetz. Daar staat tegenover dat het AGB-Gesetz de helderheid en begrijpelijkheid van een beding meeneemt bij de informatieplicht waardoor de wederparty niet is gebonden aan bedingen die niet helder of niet begrijpelijk zijn. De Wet algemene voorwaarden heeft een iets groter bereik dan het AGB-Gesetz. Een aanmerkelijk materieel verschil tussen de Duitse en de Nederlandse regeling wordt echter veroorzaakt door het verschil in sanctie dat staat op het gebruik van onredelijk bezwarende algemene voorwaarden. De Duitse rechter toetst vanwege de nietigheid van rechtswege ambtshalve of een beding onredelijk bezwarend is. De Nederlandse rechter doet en mag dit vanwege de vernietigbaarheid niet.

De collectieve actie op het terrein van de algemene voorwaarden is qua opbouw, invulling en werking eveneens nauwelijks verschillend. Het verschill zit voornamelijk in de nadruk die de Nederlandse wetgever legt op zelfregulering van de marktpartijen, waardoor Nederlandse consumentenorganisaties zich in tegenstelling tot de Duitse consumentenorganisaties geplaatst zien voor een overlegverplichting. Daar staat tegenover dat de Nederlandse regeling de mogelijkheid schept om een branchevereniging tezamen met haar leden collectief te dagvaarden, hetgeen in het Duitse systeem niet kan. Een verder verschil tussen beide regelingen is dat in Nederland de rechtspraak in eerste instantie op het gebied van de collectieve actie is geconcentreerd bij het Haagse hof. Duitsland kent een soortgelijke regeling als bevoegdheid op deelstaatniveau.

Een ander verschil tussen beide regelingen vloeit, voor zowel de individuele als de collectieve procedure, voort uit de toepassing van de algemene regels ten aanzien van de verdeling van de proceskosten. In Nederland zal een procedure voor de wederpartij of de eisende organisatie welhaast altijd kosten met zich brengen, ook al wordt de procedure voor $100 \%$ gewonnen. In Duitsland daarentegen krijgt de in een individuele of collectieve procedure in het gelijk gestelde partij in beginsel al haar proceskosten vergoed door de in het ongelijk gestelde partij.

In hoofdstuk 8 komt de rol aan de orde die de Duitse consumentenorganisaties in de praktijk van het AGB-Gesetz hebben gespeeld en spelen. De meest actieve consumentenorganisaties zijn de Verbraucherschutzverein te Berlijn (VSV) en de Verbraucherzentrale Baden-Württemberg te Stuttgart. Zij zijn vanaf het begin wan het AGB-Gesetz in 1977 actief geweest op het terrein van de algemene woorwaarden. Eind jaren tachtig zijn ook de Verbraucherzentralen van respectievelijk Nordrhein-Westfalen te Düsseldorf en van Hamburg in hun deelstaten gebruik gaan maken van het collectief actierecht, zij het in bescheidener omvang. De structuur, organisatie, doelstelling en activiteiten op het terrein van de collectieve rechtshandhaving inzake algemene voorwaarden van deze vier consumentenorganisaties worden nader belicht. Gebleken is dat de gerechtelijke 
handhaving van consumentenbelangen op het gebied van algemene voorwaarden voornamelijk steunt op de activiteiten van consumentenorganisaties en met name de VSV en de Verbraucherzentrale Baden-Württemberg. In de periode 1 april 1977 tot 1 januari 1993 verzorgden deze twee consumentenorganisaties respectievelijk 2683 en 2270 Abmahnungen, welke hebben geleid tot $1567(58,4 \%)$ en $1475(65 \%)$ strafbewehrte Unterlassungserklärungen. De VSV en de Verbraucherzentrale Baden-Württemberg hebben in die periode respectievelijk 690 en 392 verbods- en gebodsacties en 18 en 17 verzoeken om een voorlopige voorzieningen ingesteld. Van de gerechtelijke procedures waarvan de uitkomst te achterhalen was werden respectievelijk $86 \%$ en $91 \%$ gewonnen.

De handhavingsprocedure en de strategie van de twee meest actieve consumentenorganisaties wordt in hoofdstuk 9 in kaart gebracht. De collectieve rechtshandhavingsprocedure van $\$ 13$ AGBG kent de volgende stappen: opsporing, inhoudelijke beoordeling, Abmahnung, gerechtelijke procedure, nacontrole en effectuering van contractuele boetes en dwangsommen. Beide consumentenorganisaties volgen in beginsel dit model. De buitengerechtelijke fase wordt door beide organisaties zelf verzorgd. De gerechtelijke fase wordt noodgedwongen aan advocaten overgelaten. Beide organisaties hebben slechts beperkte financiële middelen ter beschikking. Daardoor is van een gerichte opsporing en nacontrole nauwelijks sprake en wordt van de voorlopige voorziening geen gebruik meer gemaakt. Beide organisaties staan aan "abgemahnte" gebruikers slechts beperkt een Umstellungs- of Aufbrauchfrist toe. Beide organisaties onderhandelen niet met gebruikers en aanbevelers over de te hanteren algemene voorwaarden omdat onderhandelingen in hun ogen niet effectief zijn. Zij geven, indien gevraagd, wel aan of een beding naar hun oordeel onredelijk bezwarend is of niet. Van het BKA-register van rechterlijke uitspraken in $\$ 13$ AGBG-procedures wordt slechts sporadisch gebruik gemaakt.

Hoofdstuk 10 geeft een beeld van de spreiding en toepassingsgebieden van de AGB-rechtshandhaving. Het blijkt dat in een groot land als Duitsland de rechtshandhavingsactiviteiten per regio sterk kunnen verschillen omdat deze grotendeels afhankelijk zijn van de activiteiten van de regionale Verbraucherzentralen. Beziet men de spreiding naar branche dan valt op dat de meeste Abmahnungen zijn uitgegaan naar de volgende branches: dienstverlening, huishoudelijke apparatuur en electro, reizen, meubelen en bouw/renovatie. De gevoerde procedures betroffen voor het grootste deel bedingen die voorkomen op de lijst van $\$ 11$ AGBG. Een mogelijke oorzaak ligt in het geringe procesrisico bij deze bedingen. De meer recente verbodsvorderingen van zowel de VSV als de Verbraucherzentrale Baden-Württemberg laten echter een verschuiving zien van de lijsten van $\$ 10$ en 11 AGBG (en met name de lijst van $\$ 11$ AGBG) naar de 
open norm van \& 9 AGBG. Ondanks deze verschuiving vormen de vorderingen op basis van de lijsten overigens mog steeds een substantieel deel van alle vorderingen. Dat is zeker zo in de buitengerechtelijke fase. Ongeveer $50 \%$ van alle Abmahnungen is gebaseerd op eén van de lijsten van $\$ 10$ of $\$ 11 \mathrm{AGBG}$.

In hoofdstuk 11 worden de knelpunten in de collectieve AGB-rechtshandhaving door consumentenorganisaties geïnventariseerd. Algemeen wordt het AGBGesetz voor het terrein van het verbintenissenrecht gezien als de belangrijkste novelle sinds de totstandkoming van het BGB. De omvangrijke stroom van rechtspraak en literatuur hebben de grenzen van de toelaatbaarheid van algememe voorwaarden aanzienlijk verduidelijkt en aangescherpt. De bepalingen van het AGB-Gesetz, met name die met betrekking tot de inhoudstoets, blijken goed hanteerbaar en hebben nauwelijks tot problemen geleid. Dit geldt ook voor procesrechtelijke bepalingen. De regels zijn duidelijk en consumentenorganisaties maken veelvuldig en met succes gebruik van het collectief actierecht. De collectieve actie is een effectief middel ter bescherming van consumentenbelangen op het terrein van de algemene voorwaarden. Consumentenorganisaties geven dan ook aan dat het collectief actierecht in beginsel een effectief middel is ter compensatie van individuele ongelijkheid. De gewenste breedtewerking van het AGB-Gesetz is echter niet gerealiseerd. De handhavingsactiviteiten van de actiebevoegde organisaties zijn in omvang te gering om een daadwerkelijke zuivering van de markt van onredelijk bezwarende allgemene voorwaarden te bewerkstelligen. De belangrijkste oorzaak is een gebrek aan financiële middelen. Vooral dit gebrek aan financiële middelen leidt tot een aantall knelpunten in de toepassing van een op zichzelf gezien effectief actiemiddel: te weinig menskracht, nauwelijks gerichte opsporing, doorgaans geen risicovolle zaken, geen gerichte na-controle en geen voorlopige voorziening.

In hoofdstuk 12 worden de Duitse ervaringen vertaald naar de Nederlandse situatie. Afgaande op de Duitse ervaringen heeft de Nederlandse wetgever terecht besloten tot een collectieve actiebevoegdheid voor consumentenorganisaties. De Duitse ervaring leert dat weliswaar een aanzienlijk aantal individuele procedures is gevoerd waarin het AGB-Gesetz werd toegepast en dat ook een aanzienlijk deel van deze procedures betrekking heeft op consumententransacties, de bereikte zuiverende werking van het AGB-Gesetz blijkt toch vooral terug te voeren op de initiatieven van consumentenorganisaties. Gezien de ontoegankelijkheid van het recht en de rechter is te verwachten dat de Nederlandse consument de weg naar de rechter minder snel zal vinden dan de Duitse. Als zij dit doen zullen de materieelrechtelijke regels hen waarschijnlijk weinig problemen opleveren. Net als in Duitsland valt te constateren dat van gebruilkerskant met name branche-organisaties hebben gereageerd op de invoering van 
de nieuwe wet. Het overleg tussen aanbiedersorganisaties en consumentenorganisaties over in consumententransacties te hanteren voorwaarden heeft door de nieuwe wetgeving een forse impuls gehad. In die zin heeft de wet reeds een duidelijk effect gehad. De ervaringen in Duitsland leren dat een uniforme werking van aan de nieuwe wetgeving aangepaste branchevoorwaarden een voor de consument gunstige zuiverende werking heeft. De dreigende collectieve gerechtelijke actie maakt het overleg voor branche-organisaties minder vrijblijvend dan het voor de invoering van het huidige Burgerlijk wetboek was. Het overleg is in een duidelijk juridisch kader gekomen, hetgeen er toe heeft geleid dat in voor de consument belangrijke branches de algemene voorwaarden aanmerkelijk zijn verbeterd of op korte termijn verbeterd zullen worden. Buiten deze branche-voorwaarden heeft een vrijwillige aanpassing van gebruikers van hun algemene voorwaarden aan de nieuwe wet in onvoldoende mate plaatsgevonden. De zuiverende werking van de Wet algemene voorwaarden op het terrein van de algemene voorwaarden gehanteerd tegenover consumenten zal vooral bewerkstelligd moeten worden door de activiteiten van consumentenorganisaties. In Duitsland blijkt het collectief actierecht voor consumentenorganisaties een uiterst effectief middel te zijn bij de bestrijding van onredelijk bezwarende algemene voorwaarden. Het maakt met name buitengerechtelijk acties zeer succesvol.

Duitse consumentenorganisaties kiezen bij de handhaving van de dwingendrechtelijke norm voor een conflict-model en niet voor een onderhandelingsmodel. Een zelfreguleringscultuur als in Nederland is in Duitsland niet voorhanden. Naar het oordeel van Duitse consumentenorganisaties heeft onderhandelen met branche-organisaties of gebruikers over algemene voorwaarden weinig zin omdat deze te veel tijd, menskracht en dus geld kosten met als resultaat dat gebruikers in de onderhandelingen toch niet verder willen gaan dan het wettelijk verplichte minimum, lees nét niet onredelijk bezwarend. Dit resultaat kan volgens hen eenvoudiger, effectiever en goedkoper worden bereikt met het Abmahnungs- en procesmodel. De Nederlandse wetgever hecht echter bijzonder aan het onderhandelingsmodel. Nederlandse consumentenorganisaties hebben de keuze tussen het onderhandelings- en conflictmodel. Het conflictmodel is het aangewezen handhavingsmodel voor (snelle) handhaving van de basisbescherming zoals deze in de wet ligt verankerd. Het onderhandelingsmodel als de inspanningen van de consumentenorganisaties gericht zijn op een "surplus". Het onderhandelingsmodel biedt voordelen ten opzichte van het conflictmodel indien consumentenorganisaties door onderhandelen mér kunnen bereiken dan de wettelijke basisbescherming.

De Duitse ervaringen laten zien dat de uitoefening van het collectief actierecht door middel van het conflictmodel de Nederlandse organisaties niet voor al te grote juridische problemen zal stellen. Een nadere verduidelijking van met 
mame de grenzen van de open norm en de grijze lijst in de rechtspraak zal tot grotere rechtszekerheid leiden. Het scheppen van deze duidelijkheid is vooral afhankelijk van het in rechte optreden van consumentenorganisaties. In die zin hebben consumentenorganisaties belang bij het entameren van zoveel mogelijk procedures voor de bijzondere rechter. Een eerste procedure voor de bijzondere rechter laat eind 1994 echter nog steeds op zich wachten. Het ziet er naar uit dat consumentenorganisaties in Nederland hebben gekozen voor het onderhandelingsmodel en daar eerst nadere ervaringen mee op willen doen. Dat is jammer, een keuze voor het gelijktijdig hanteren van beide modellen is vanuit het oogpunt van effectiviteit en efficiency een betere.

Ondanks de effectiviteit van het collectief actierecht voor consumentenorgamisaties blijkt de omvang waarin het collectief actierecht door consumentenorganisaties in Duitsland in en buiten rechte wordt gehanteerd, onvoldoende om de markt daadwerkelijk te bevrijden van onredelijk bezwarende algemene voorwaarden. Het ontbreken van voldoende, door de overheid te verschaffen, financiële middelen is de oorzaak. In Nederland heerst voorlopig nog onduidelijkheid over de overheidsfinanciering van collectieve acties op het terrein van de algemene voorwaarden. Gezien deze onzekerheid over de (hoogte van) financiering van de collectieve handhavingsactiviteiten is het niet verwonderlijk dat de Nederlandse consumentenorganisaties de stap naar de bijzondere rechter, die met name in de beginfase waarin nog geen richtinggevende rechterlijke uitspraken voorhanden zijn een groot processueel risico met zich brengt, tot mu toe nog niet hebben genomen. Daarbij komt nog dat Nederlandse consumentenorganisaties een groter kostenrisico lopen dan de Duitse consumentenorganisaties. De door de wetgever beoogde zuivering van de markt van onredelijk bezwarende algemene voorwaarden door consumentenorganisaties wordt deels tegengehouden doordat diezelfde wetgever onvoldoende garanties biedt voor de subsidiëring van de beoogde activiteiten van consumentenorganisaties. Daar staat tegenover dat het ledenpotentieel van Nederlandse consumentenorganisaties betere opsporings- en nacontrolemogelijkheid biedt dan in Duitsland.

Individuele consumenten zullen in Nederland naar verwachting nauwelijks in rechte een beroep doen op een verbodsvonnis. Daarvoor is de Nederlandse overheidsrechter te duur. Een effectieve nacontrole door consumentenorganisaties van met ondernemers gemaakte afspraken en tegen hen gewezen verbodsuitspraken en het daadwerkelijk innen van contractuele boetes en dwangsommen indien wordt geconstateerd dat ondernemers zich niet aan de gemaakte afspraken of tegen hen gewezen verbodswonnissen houden, lijkt daarom meer perspectief te bieden.

Hoofdstuk 13 bevat een slotbeschouwing en enkele suggesties ter verbetering van de effectiviteit van de Wet algemene voorwaarden en het daarin opgenomen 
collectief actierecht. Gezien de grote overeenkomst tussen de Duitse en de Nederlandse regeling inzake algemene voorwaarden valt te verwachten dat ook de Nederlandse regeling, met het toenemen van de jurisprudentie, een helder en goed hanteerbaar instrumentarium zal bieden voor het vastleggen van de grenzen van de toelaatbaarheid van de inhoud van algemene voorwaarden en de regels omtrent de toepasselijkheid. Ook voor Nederland geldt dat de maatstaf voor: effectiviteit van de wet vooral is gelegen in de mate waarin de markt wordt bevrijd van onredelijk bezwarende bedingen; in de breedtewerking dus. De Duitse ervaringen laten zien dat de breedtewerking van de wet vooral zal afhangen van de activiteiten van consumentenorganisaties. Voor de rechtshandhaving op het terrein van de algemene voorwaarden hebben de gerechtelijke en buitengerechtelijke activiteiten van consumentenorganisaties immers het hoogste rendement. Het bevorderen van de activiteiten van de diverse algemene en categoriale consumentenorganisaties zal het meeste rendement opleveren. In dat licht lijkt het niet onverstandig dat de Nederlandse overheid, die de primair verantwoordelijke is voor de basisbescherming van de consument op het terrein van de algemene voorwaarden, alsnog een subsidieregeling vaststelt waarin de overheid de kosten van de rechtshandhavingsactiviteiten van consumentenorganisaties op het terrein van de algemene voorwaarden geheel of gedeeltelijk voor haar rekening neemt.

De kosten van de rechtshandhaving en dus ook een eventuele subsidieregeling zullen voor een deel afhankelijk zijn van het procesrisico dat consumentenorganisaties lopen. De ervaringen in Duitsland leren dat consumentenorganisaties, mits zij daartoe de nodige middelen hebben, een dermate deskundigheid kunnen genereren dat zij de door hen gevoerde procedures nagenoeg allemaal winnen. Ten opzichte van Duitsland doet zich voor Nederland daarbij een kostenverhogend effect voor. In Nederland is het immers nagenoeg vaste praktijk dat de winnende partij met een deel van de door haar voor de procedure gemaakte kosten blijft zitten. Dit euvel zou eenvoudig kunnen worden verholpen indien de rechterlijk macht er vaker dan tot nu toe het geval is, toe zou overgaan de verliezende partij in de werkelijke kosten van de winnende partij te veroordelen. Een andere opstelling van de rechterlijke macht inzake de kostenveroordeling zou ook op het vlak van de individuele procedures een bijdrage kunnen leveren aan een frequenter beroep van de consument op de rechter en zodoende aan de breedtewerking van de dwingendrechtelijke bescherming die deze consument ten deel valt. Het zijn immers met name de kosten die de consument er van weerhouden om bij de rechter zijn dwingendrechtelijk gelijk te halen. Een dergelijke opstelling van de rechterlijke macht zou het gebruikers een stuk moeilijker maken een beroep te doen op onredelijk bezwarende algemene voorwaarden. 
De mate waarin gebruikers door het Haagse hof verboden bedingen zullen hergebruiken hangt deels af van hun inschatting van de kans dat zij door consumentenorganisaties worden betrapt op het gebruik van een verboden beding en de kans dat zij daardoor de aan het verbod gekoppelde dwangsom verbeuren. Het ligt voor de hand dat consumentenorganisaties bij de controle van de naleving van verbodsuitspraken hun leden inschakelen. De effectiviteit yan de controle zal deels afhangen van de mate waarin consumentenorganisaties er in slagen hun achterban bij de opsporing en controle te betrekken. In dit werband zouden consumentenorganisaties kunnen overwegen hun leden te activeren door een financiële prikkel, bijvoorbeeld door een deel van de te innen dwangsom of de contractuele boete in het vooruitzicht te stellen. Zulk een maatregel zou de belangstelling van de consument voor algemene voorwaarden en het recht daaromtrent aanzienilik doen toenemen en zorgen voor een enorme spreiding van de minimum bescherming die de wet beoogt te bieden. In dat verband zou overwogen kunnen worden om in de Wet algemene voorwaarden te voorzien in de mogelijkheid dat de individuele consument de in een collectieve actie opgelegde dwangsom of een deel daarvan kan effectueren indien het verboden beding jegens hem wordt gebruikt.

Een eenvoudig toegankelijk register van uitspraken van de bijzondere rechter zal eveneens bijdragen aan de beoogde brede werking van de Wet algemene voorwaarden. Met de moderne automatiserings- en communicatietechnieken moet het realiseren van een dergelijk informatiesysteem niet al te moeilijk zijn.

De ervaring in Duitsland leert dat de Duitse rechter het AGB-Gesetz ambtshalve toepast in individuele procedures. Dit heeft in Duitsland zeker bijgedragen aan een brede verspreiding van de normen van het AGB-Gesetz. In Nederland zal de rechter de dwingendrechtelijke bescherming van de Wet algemene voorwaarden niet ambtshalve kunnen toepassen. Een directere betrokkenheid van de burgerlijke rechter door een verplichte ambtshalve inhoudstoetsing indien een partij een beroep doet op een algemene voorwaarde, zou een "doorwerking" van de Wet algemene voorwaarden en daarmee de consumentenbescherming zeker ten goede komen. In dat licht is te overwegen om, naar Duits voorbeeld, de sanctie van vernietigbaarheid, wellicht enkel voor consumententransacties, te wijzigen in een nietigheid van rechtswege. 


\section{Zusammenfassung}

Am 1. Januar 1992 ist das niederländische Gesetz zur Regelung der allgemeinen Geschäftsbedingungen (Wet algemene voorwaarden, Abschmitt 6.5.3 BW) in Kraft getreten. Damit hat der niederländische Gesetzgeber die Problematik der standardisierten Vertragsbedingungen gesetzlich geregelt. Was auffällt ist, daß diese Regelung neben materiellrechtlichen auch prozeßrechtliche Bestimmungen enthält. Letztere enthalten eine Klagebefugnis auf dem Gebiet der allgemeinen Geschäftsbedingungen für u.a. Verbraucherschutzorganisationen.

Diese Arbeit bezweckt die Verbandsklage für Verbraucherschutzorganisationen im System des Abschnitts 6.5.3 BW näher zu untersuchen. Wegen der weitgehenden inhaltlichen und systematischen Übereinstimmung mit den deutschen Regelungen, wird das niederländische Gesetz zur Regelung der allgemeinen Geschäftsbedingungen verglichen mit dem deutschen AGB-Gesetz. Die deutsche Regelung ist bereits am 1. April 1977 in Kraft getreten. Seitdem hat sie eine Flut an Literatur und Jurisprudenz hervorgebracht. In dieser Arbeit werden ebenfalls die praktischen Erfahrungen der deutschen Verbraucherverbände mit der Verbandsklage auf dem Gebiet der allgemeinen Geschäftsbedingungen erforscht. Anhand der erworbenen Ergebnisse wird eine Prognose erstellt über die in den Niederlanden zu erwartende Effektivität der AGBVerbandsklage und wird beschrieben, welche Faktoren diese Effektivität beeinflussen. Im ersten Kapitel wird sich mit dieser Zielsetzung, der Untersuchungsmethode, der Struktur der Untersuchung, und den dabei verwendeten Begriffen auseinandergesetzt.

Im zweiten Kapitel stehen das Phänomen der allgemeinen Geschäftsbedingungen und die prozeßrechtliche Position des Verbrauchers auf diesem Gebiet im Mittelpunkt. Charakteristisch für die allgemeinen Geschäftsbedingungen ist, daß der Inhalt vorformuliert ist, daß die andere Vertragspartei auf diesen Inhalt keinen (jedenfalls keinen unmittelbaren) Einfluß hat, daß sie ohne Aushandlungsmöglichkeit für Mehrfachverwendung bestimmt sind und daß die andere Vertragspartei mit ihrer Geltung ohne Kenntnis des Inhalts einverstanden ist. 
Die Verwendung allgemeiner Geschäftsbedingungen hat seit der industriellen Revolution einen mächtigen Aufschwung genommen und der moderne Massenverkehr ist ohne sie undenkbar. Der Geschäftsverkehr wird größtenteils bestimmt durch allgemeine Geschäftsbedingungen.

Allgemeine Geschäftsbedingungen haben sowohl für den Verwender als auch für den Kunden Vor- und Nachteile. Der Vorteil liegt vor allem in der Vereinfachung der Vertragsgestaltung und der Rationalisierung des Unternehmens des Verwenders. Der Nachteil von allgemeinen Geschäftsbedingungen ergibt sich für den Kunden vor allem aus ihrem Inhalt. Wegen der sozialen und wirtschaftlichen Überlegenheit des Verwenders (der Kunde steht meistens gegenüber einer wirtschaftlichen Organisation) und aufgrund des fehlenden Einflusses des Kunden auf den Inhalt allgemeiner Geschäftsbedingungen, sind sie meistens so gestaltet, daß sie nur einseitig die Interessen des Verwenders wahren und dadurch den Kunden (unangemessen) benachteiligen. Außerdem ist es für den Kunden oft schwierig, den Inhalt der verwendeten Geschäftsbedingungen herauszufinden. Deshalb ist das Phänomen der allgemeinen Geschäftsbedingungen nur schwer in Einklang zu bringen mit den "klassischen" Grundsätzen des Vertragsrechts: Vertragsfreiheit, Konsensualismus und die darauf beruhende vertragliche Verbindlichkeit. Das klassische Vertragsmodell beruht ja auf dem Gedanken, daß gleichwertige Parteien in Freiheit bestimmen, woran sie sich vertraglich binden, und auf diese Weise zu einem ausgewogenen Vertrag kommen, der beide Interessen angemessen berücksichtigt. Von Vertragsfreiheit und Gleichwertigkeit der Vertragsparteien kann bei allgemeinen Geschäftsbedingungen jedoch keine Rede sein.

Die Ungleichheit zwischen Verwender und Verbraucher zeigt sich auch auf prozeßrechtlicher Ebene. Die soziale und wirtschaftliche Ungleichheit, die Tatsache, daß der Verwender meistens "Repeat Player" ist und der Verbraucher "One Shotter" ist, der Umstand, daß aus der Sicht des Verwenders der Vertrag nicht einmalig aus Sicht des Verbrauchers jedoch ein einmaliges Geschäft ist, die mangelnde Rechtskunde des Durchschnittskunden, die soziale Distanz und die Höhe der gerichtlichen Verfahrenskosten führen dazu, daß der individuelle Verbraucher kaum imstande ist, seine Rechte auf dem Gebiet der allgemeinen Geschäftsbedingungen wahrzunehmen.

In Anbetracht des gesellschaftlichen Nutzens und der Vorteile, die die Verwendung von (angemessenen) allgemeinen Geschäftsbedingungen für beide Vertragsparteien haben, ist es wünschenswert, daß allgemeine Geschäftsbedingungen auf einfache Weise in den Vertrag einbezogen werden können, auch wenn die andere Vertragspartei den Inhalt dieser Bedingungen nicht kennt. In diesem Sinne bedarf der Verbraucher keinen Schutz. Der Kunde benötigt vor allem Rechtsschutz gegen inhaltlich unangemessene allgemeine Geschäftsbedingungen, eine einfache Möglichkeit zur Kenntnisnahme des Inhalts der allgemei- 
nen Geschäftsbedingungen in einem vom Kunden gewünschten Zeitpunkt und Zugang zum Recht und Richter.

In dritten Kapitel wird die Art und Weise beschrieben, in der die niederländische Rechtsprechung vor dem Inkraftreten des Abschnitts 6.5.3 BW den Schutzbedarf des Verbrauchers im AGB-Bereich gestaltet hat. Die niederlăndische Rechtsprechung hat bezüglich der Einbeziehung von allgemeinen Geschäftsbedingungen in den Vertrag keine weiteren Erfordernisse gestellt als die generell für das Zustandekommen eines Vertrags notwendigen. Die andere Vertragspartei muß mit der Geltung der allgemeinen Geschäftsbedingungen einverstanden sein. Die Unkenntnis der anderen Vertragspartei vom Inhalt der allgemeinen Geschäftsbedingungen steht dem Einverständnis und der Einbeziehung grundsätzlich nicht im Wege. Nach ständiger Auffassung in der Rechtsprechung ist bei der Auslegung allgemeiner Geschäftsbedingungen nicht der buchstäbliche Text oder eine sprachwissenschaftliche Auslegung maßgebend, sondern die Bedeutung die Vertragsparteien den konkreten Umständen gemäß berechtigterweise den Bedingungen beimessen dürfen. Die niederländische Rechtsprechung bediente sich bei der offenen Inhaltskontrolle allgemeiner Geschäftsbedingungen des zwingenden Rechts und der Generalklauseln der guten Sitten, des ordre public und vor allem von Treu und Glauben. Weiter konnte der unübliche oder überraschende Inhalt dazu führen, daß das Einverständnis der anderen Vertragspartei sich nicht erstreckte auf diese Bedingungen, so daß angenommen wird, daß diese Klauseln kein Vertragsbestandteil sind.

Trotz dieser Möglichkeiten hatte die bisherige AGB-Rechtsprechung einige Nachteile. Verbraucher sowie ihre Verbände fanden kaum Zugang zum Richter. Die gerichtlichen Urteile im Individualprozeß hatten zwar eine gewisse Präzedenzwirkung infolge der Tatsache, daß das Urteil ausschließlich die Prozeßparteien bindet, jedoch kaum Breitenwirkung. Wegen der repressiven Natur der richterlichen Kontrolle haben diese Urteile außerdem nur eine beschränkte Präventivwirkung.

Die Schranken im Zugang zum Richter haben dazu gefuihrt, daß Verbraucher zunehmend private Schlichtungsstellen in Anspruch genommen haben. Aus Verbrauchersicht haben sich vor allem die Branchenschlichtungsstellen der "Stichting Geschillencommissies voor Consumentenzaken" als Alternative für den Richter bewährt. Die "Rechtsprechung" dieser Schlichtungsstellen beruht auf kollektiv ausgehandelten Konditionenempfehlungen.

Im vierten Kapitel wird die Politik des niederländischen Gesetzgebers im AGBBereich inventarisiert. Der niederländische Gesetzgeber erkennt, daf allgemeine Geschäftsbedingungen eine nützliche und unentbehrliche Funktion im Rechtsverkehr haben, aber zugleich, daß allgemeine Geschäftsbedingungen die Rechte der 
Verbraucher oft in verschleierter Art und Weise derart beschränken, daff staatliches Eingreifen notwendig ist, um zu erreichen, daß allgemeine Geschăftsbedingungen inhaltlich ausgeglichen die Interessen von beiden Vertragsparteien wahren. Dazu bedarf es eine Verstärkung der gerichtlichen Inhaltskontrolle im AGB-Bereich.

Für dieses Eingreifen hat der Staat verschiedene Möglichkeiten wie die Gesetzgebung, Subventionierung; das Auftreten als Moderator, Aufklärung und Selbstregulierung. Gerade das politische Instrument Selbstregulierung hat seit den achtziger Jahren in der Verbraucherpolitik des niederländischen Staats erheblich an Bedeutung gewonnen. Im AGB-Bereich wird der vom niederländischen Gesetzgeber bezweckte Mindestschutz realisiert durch einerseits Gesetzgebung (Abschnitt 6.5.3 BW, Titel 7.1 BW, Artikel 6:214 BW und Artikel 6:225 Absatz $3 \mathrm{BW}$ ), Subvention und Aufklärung und andererseits durch Selbstregulierung in Form von Verhandlungen zwischen Verbraucher- und Unternehmerverbänden, die im gegenseitigen Einvernehmen Konditionenempfehlungen festlegen. Die gewählten politischen Instrumente regulieren vor allem die folgenden Engpässe im AGB-Bereich: Die Einbeziehung in dem Vertrag, die Verschleierung des Vertragsinhalts, der (oft) unangemessene Inhalt, der für individuelle Verbraucher unzugăngige Richter und die fehlende Breitenwirkung von Urteilen im AGB-Bereich. Engpässe wie unklarer Wortlaut, fehlende Transparenz und Auslegung der allgemeinen Geschäftsbedingungen werden nicht ausdrücklich reguliert. Es ist aber nicht auszuschließen, daß die EWG-Richtlinie über mißbräuchliche Klauseln in Verbraucherverträgen den niederländischen Gesetzgeber zu einer nachträglichen Regulierung dieser Engpässe zwingt. Die Probleme im AGB-Bereich werden hauptsächlich verursacht durch die wirtschaftliche Überlegenheit des Verwenders über dea Verbraucher in der Vertragsgestaltung und im Zugang zum Recht und Richter. Die Verbandsklage bezweckt diese Unausgewogenheit zu kompensieren.

Im fünften Kapitel wird der Regelungsinhalt des Abschnitts 6.5.3 BW und vor allem die Verbandsklage ausführlich beschrieben. Zuerst werden die materiellrechtlichen Bestimmungen der Artikel 6:231 bis 6:239 BW und 6:243 bis 6:247 BW beschrieben. Danach folgt eine Beschreibung der Verbandsklage und der verfahrensrechtlichen Vorschriften der Artikel 6:240 bis 6:243 BW und der Artikel 4 sub 13, 9 Absatz 3, 67 und 1003 bis 1006 Rv (niederländische ZPO). Das System des Abschnitts 6.5.3 BW beruht einerseits auf dem Gedanken, dals zur Einbeziehung allgemeiner Geschäftsbedingungen in dem Vertrag aufgrund ihres Nutzens für beide Vertragsparteien keine allzu große Erfordernisse gestellt werden müssen und andererseits darauf, daß man den Nachteilen der allgemeinen Geschäftsbedingungen für den Verbraucher (Verschleierung und unbilliger Inhalt) wirkungswoll entgegentreten muß. 
Der materielle Anwendungsbereich des Abschnitts 6.5.3 ist beschränkt auf allgemeine Geschäftsbedingungen in Schuldverträgen und in sonstigen mehrseitigen, vermögensrechtlichen Rechtsgeschäften. Ausgenommen vom Geltungsbereich des Abschnitts 6.5.3 BW sind die Vertragsbedingungen arbeitsrechtlicher Verträge (Artikel 6:245 BW) und Vertragsbedingungen in Verträgen awischen ausländischen Kaufleuten (Artikel 6:247 BW). Nach der gesetzlichen Definition sind allgemeine Geschäftsbedingungen "eine oder mehrere schriftliche Bedingungen die dazu bestimmt sind, in einer Vielzahl von Vertragen aufgenommen zu werden, ausschließlich der Hauptleistungsvereinbarungen ". Damit erfaßt Abschnitt 6.5.3 BW sowohl Verbrauchervertrăge als auch Verträge im geschäftlichen Verkehr. Ausgeschlossen vom Anwendungsbereich sind jedoch mündliche Vereinbarungen, Individual- und Hauptleistungsvereinbarungen. Unbeachtlich für die Frage, ob man zu tun hat mit allgemeinen Geschäftsbedingungen, ist ihre Herkunft, also ob sie von keinem der Vertragsparteien, einoder mehrseitig aufgestellt sind oder gesetzlich vorgeschrieben sind.

In personeller Hinsicht ist der Anwendungsbereich des Abschnitts 6.5.3 BW grundsätzlich beschränkt auf "kleine" Vertragsparteien des Verwenders. Die Klagen nach den Artikeln 6:233 und 6:234 BW stehen nicht offen für Gesellschaften des bürgerlichen Rechts, die mehr als 50 Arbeitnehmer beschäftigen oder eine Jahresabschluß veröffentlicht haben und für Parteien, die selber identische Klauseln verwenden wie die Beanstandeten. Abschnitt 6.5.3 enthält nur zwingendes Recht.

Der Rechtssicherheit wegen wird davon ausgegangen, daß allgemeine Geschäftsbedingungen Vertragsinhalt werden, wenn die andere Vertragspartei mit ihrer Geltung einverstanden ist (Artikel 6:231 sub c BW). Dabei ist unbeachtlich, ob die andere Vertragspartei den Inhalt der akzeptierten Bedingungen kennt (Artikel 6:232 BW). Beurteilungsmaßstab für die Frage, ob die andere Vertragspartei der Geltung zugestimmt hat, sind die allgemeinen Regelungen des Abschnitts 6.5.2 BW und der Artikel 3:33 und 3:35 BW. Voraussetzung für die Einbeziehung ist, daß der Verwender vor, bei oder nach dem Zeitpunkt, in dem die Hauptleistungen vereinbart werden, der anderen Vertragspartei bekannt gibt, daß er allgemeine Geschäftsbedingungen verwendet und daß die andere Vertragspartei zustimmt oder davon beim Verwender der gerechtfertigte Eindruck entsteht.

Gemäß Artikel 6:233 sub b BW hat der Verwender die Obliegenheit, der anderen Vertragspartei eine zumutbare Möglichkeit der Kenntnisnahme des Inhalts der allgemeinen Geschäftsbedingungen zu schaffen. Wenn Aushändigung oder Zusendung der allgemeinen Geschäftsbedingungen dem Verwender zugemutet werden kann, ist das die einzige Möglichkeit des Verwenders seine Informationspflicht zu erfüllen (Artikel 6:234 Absatz 1 sub a BW). Im Falle der Unzumutbarkeit der Aushändigung oder Zusendung genügt es, wenn der Ver- 
wender mitteilt, daß die allgemeinen Geschäftsbedingungen in seinem Geschäft oder bei einer "Kamer van Koophandel en Fabrieken" (Kommerz- und Handelskammer) oder bei einem Gericht deponiert sind, und außerdern mitteilt, daß das Klauselwerk auf Anfrage gebührenfrei zugeschickt wird (Artikel 6:234 Absatz I sub b BW). Grundsätzlich muß der Verwender der anderen Vertragspartei in seinem Geschäft Einsicht in die allgemeinen Geschäftsbedingungen gewähren. Soweit die Zusendung für den Verwender zumutbar ist (Artikel 6:234 lid 3 $B W)$, muß er die allgemeinen Geschäftsbedingungen gebührenfrei zusenden. Verletzt der Verwender diese Obliegenheit, dann ist das Klauselwerk auf Antrag der anderen Vertragspartei anfechtbar. Grundsätzlich trägt der Verwender die Beweislast dafür, daß er seiner Informationspflicht nachgekommen ist. Diese Beweislast bewirkt aber, daß der gesetzliche Ausgangspunkt (Mißbrauch bei der Verwendung allgemeiner Geschäftsbedingungen nicht durch erhöhte Anforderungen an der Einbeziehung zu verhindern) verlassen wird. Die Einbeziehungsvorschriften sind zwar nicht streng, um so schwerer sind hingegen die Beweisanforderungen. Das führt dazu, daß ein Teil der Vorteile von allgemeinen Geschäftsbedingungen, namentlich, daß Parteien sich beim Zustandekommen des Vertrags beschränken können auf die Hauptleistungsvereinbarungen, zunichte gemacht wird. Die Gestaltung der Informationspflicht des Verwenders in Artikel 6:234 BW kann dadureh bezeichnet werden als unangemessen benachteiligend für den Verwender.

Abschnitt 6.5.3 BW enthält keine Auslegungsregel für allgemeine Geschäftsbedingungen. Die in der Rechtsprechung entwickelten Auslegungsgrundsätze finden Anwendung. Das ist im Hinblick auf die Rechtssicherheit bedauernswert. Es ist aber nicht ausgeschlossen, daß die EWG-Richtlinie über mißbräuchliche Klauseln in Verbraucherverträgen bewirkt, daß die Unklarheitenregel des Artikels 5 der EWG-Richtlinie nachträglich in Abschnitt 6.5.3 BW aufgenommen wird.

Schwerpunkt der Regelung des Abschnitts 6.5.3 BW ist die Inhaltsprüfung nach Artikel 6:233 sub a BW. Anfechtbar sind allgemeine Geschäftsbedingungen, die, allen Umständen des Falles gemäß̊, ihrem Inhalt nach unangemessen benachteiligend sind. Diese Generalklausel findet Anwendung auf allgemeine Geschäftsbedingungen, verwendet in Verbraucherverträgen und im Geschäftsverkehr. Diese Generalklausel gilt in ihrem Anwendungsbereich als lex specialis gegenüber der Artikel 6:248 Absatz $2 \mathrm{BW}$ (Treu und Glauben). Folglich ist eine Klage nach Artikel 6:248 Absatz 2 BW im AGB-Bereich beschränkt auf den Einwand der unzulässigen Rechtsausübung und den Einwand des Wegfalls der Geschäftsgrundlage.

Die Klauselkataloge der Artikel 6:236 und 6:237 BW sind für Verbraucherverträge eine Konkretisierung der Generalklausel des Artikels 6:233 sub a BW. Der sogenannte "schwarze" Katalog des Artikels 6:236 BW enthält Klauseln, 
die ohne Wertungsmöglichkeit anfechtbar sind. Der sogenannte "graue" Katalog des Artikels 6:237 BW enthält Klauseln, bei denen gesetzlich vermutet wird, dab sie unangemessen benachteiligend sind. Artikel 6:237 BW bewirkt eine Umkehrung der Beweislast der Unangemessenheit zu Lasten des Verwenders. Der Verwender muß beweisen, daß die "graue" Klausel die andere Vertragspartei nicht unangemessen benachteiligt. Nach herrschender Meinung wird angenommen, daß die Klauselkataloge auch im Geschäftsverkehr eine Indizwirkung ausüben.

Ausgangspunkt der Inhaltsprüfung von aligemeinen Geschäftsbedingungen aufgrund der Generalklausel des Artikels 6:233 sub a BW sind die Rechtsfolgen, die der Vertrag aufgrund der Parteivereinbarung ohne die beanstandete(n) Klausel(n) gehabt hätte. Der Richter muB deshalb zuerst der Frage nachgehen, ab die beanstandete Klausel eine Rechtslage gestaltet, die von der Rechtslage abne diese Klausel abweicht. Eine negative Antwort auf diese Frage muß für den Richter Anlaß sein die Unangemessenheit der Klausel zu verneinen. Erst wenn der Richter zu der Schlußfolgerung gelangt, daß die Klausel zu einer abweichenden Rechtslage führt, kann er prüfen, ob diese abweichende Rechtslage und damit der Klauselinhalt für die andere Vertragspartei unangemessen benachteiligend ist.

Der Text des Artikels 6:233 sub a BW soll klarstellen, daß es sich, im Gegensatz zu der Inhaltsprüfung der Verbandsklage gemäß Artikel 6:240 ff BW, um eine konkrete Inhaltsprüfung handeit. Konkret, weil der Prüfungsmaßstab des Artikels 6:233 sub a BW immer allgemeine Geschäftsbedingungen in konkreten Vertragsverhältnissen betrifft. Dies steht im Gegensatz zu dem abstrakten Verfahren nach Artikel 6:240 BW, in dem die Inhaltsprüfung unabhängig von der Frage ob die beanstandete Klausel bereits in einem konkreten Vertrag aufgenommen ist und in Anbetracht der allgemeinen Verwendung der Klausel, stattfindet. Die konkrete Natur der Inhaltsprüfung im Individualfall ergibt, daß der Richter in seiner Abwägung alle Umstände des Falles einbeziehen, und laut Gesetzestext insbesondere "die Art und den übrigen Inhalt des Vertragsverhältnisses, die beiderseitig erkennbaren Interessen der Vertragsparteien und die Art und Weise in der die Bedingungen zustandegekommen sind" berücksichtigen muß. Bei der Inhaltsprüfung allgemeiner Geschäftsbedingungen scheint der letzte Umstand jedoch nur geringe Relevanz zu haben. $\mathrm{Da}$ allgemeine Geschäftsbedingungen ihrer Art nach nicht auf einen bestimmten Kunden abzielen, sondern vorformuliert sind im Hinblick auf Verwendung gegenüber sämtlichen potentiellen Kunden, ist aber die konkrete Natur der Inhaltsprüfung bezüglich der Generalklausel des Artikels 6:233 sub a BW nur relativ. Angesichts der Tatsache, daß allgemeine Geschäftsbedingungen nicht auf atypische Umstände abzielen, finden sie hierauf keine Anwendung und sind daher unbeachtlich (überindividuelle Betrachtungsweise). 
Eine unangemessen benachteiligende AGB-Klausel ist auf Antrag der anderen Vertragspartei sowohl gerichtlich als auch außergerichtlich anfechtbar. Aufgrund des Artikels 6:246 BW darf der anderen Vertragspartei die außergerichtliche Anfechtungsbefugnis nicht vertraglich genommen werden. Der ex tunc Wirkung der Unwirksamkeit aufgrund eines Anfechtbarkeitsantrags wegen sind bei der Inhaltsprüfung aufgrund der Generalklausel nur die Umstände im Zeitraum vor oder während des Vertragsabschlusses beachtlich. Relevant für die Inhaltsprüfung sind aber auch Umstände im Zeitraum nach VertragsschluB, an denen die beanstandete Klausel von vornherein Rechtsfolgen verbindet. Unwirksamkeit einer AGB-Klausel aufgrund eines Anfechtbarkeitsantrags bewirkt meistens nicht die Unwirksamkeit des gesamten Vertrags. Eine teilweise Unwirksamkeit, die sich beschränkt auf die beanstandete Klausel (geltungserhaltende Reduktion) ist meistens angebracht. Umdeutung einer nichtigen AGBKlausel ist nicht ausgeschlossen, soll aber grundsätzlich nur mit äuBerster Zurückhaltung angewandt werden.

Neben den zwei Klauselkatalogen der Artikel 6:236 und 6:237 BW wird ein dritter Katalog unwirksamer Klauseln entstehen, der Klauseln enthält, die in Verbandsklageverfahren nach Artikel 6:240 BW aufgrund Verbotsurteile des Gerichtshofs in Den Haag nach Artikel 6:241 Absatz $3 \mathrm{BW}$ für unwirksam erklärt worden sind. Nach Artikel 6:243 BW sind diese Klauseln (ohne Wertungsmöglichkeit) unangemessen benachteiligend und auf Antrag der anderen Vertragspartei anfechtbar.

Der Anfechtungsanspruch verjährt grundsätzlich in drei Jahren von dem Zeitpunkt an, in welchem der Anspruch für den Anspruchsberechtigten entstanden ist (Artikel 3:52 Absatz $2 \mathrm{BW}$ ). Für die Anfechtungsansprüche im AGB-Bereich nach den Artikeln 6:233, 6:234 und 6:243 BW fängt der Verjährungstermin an am Tage folgend auf dem Tag, an dem der Verwender sich auf die Klausel beruft. Die andere Vertragspartei erlangt ja meistens erst Kenntnis von der Existenz der Klausel zu dem Zeitpunkt, in dem der Verwender sich auf die Klausel beruft.

Artikel 6:247 BW regeit den internationalen Geltungsbereich des Abschnitts 6.5.3 BW. Der Artikel folgt größtenteils dem europäischen Übereinkommen über das auf vertragliche Schuldverhältnisse anzuwendende Recht. Für Verbraucherverträge gibt Artikel 6:247 BW jedoch eine erweiterte Regelung. Abschnitt 6.5.3 BW findet immer Anwendung, wenn der Verbraucher seinen gewöhnlichen Aufenthalt in den Niederlanden hat. Der niederländische Richter darf von dieser Regel nicht abweichen. Inwieweit Artikel 6:247 BW den ausländischen Richter bindet, ist abhängig von dem in seinem Land geltenden Kollisionsrecht. Für Verträge zwischen niederländischen Verwendern und ausländischen Verbrauchern gilt für Verbraucher aus der europäischen Union das europäische Übereinkommen über das auf vertragliche Schuldverhältnisse anzuwendende 
Recht und für sonstige Verbraucher die dafür geltenden Kollisionsregel. Der Gerichtsstand wird in Verträgen mit Auslandsbezug, sofern es europäische Verbraucher betrifft, geregelt im europäischen Übereinkommen über die gerichtliche Zuständigkeit und die Vollstreckung gerichtlicher Entscheidungen in Zivil- und Handelssachen und im Lugano Übereinkommen.

Ein besonderer Aspekt der Regelung des Abschnitts 6.5.3 BW ist zweifelsohne die prozeßrechtliche Regelung, die es ermöglicht, daß neben der individuellen Klageerhebung beim üblichen Gericht auch Klage erhoben werden kann bei einem Sondergericht durch Verbände zur Förderung gewerblicher Interessen oder Verbraucherverbände. Dabei haben die gewerblichen Verbānde und die Verbraucherverbände die Möglichkeit der kollektiven Ladung sämtlïcher Mitglieder gewerblicher Verbände. Die Verbandsklage bezweckt auch dadurch, daß sie einen Anreiz für Verhandlungen gibt, einen "kollektiven" Kontrollmechanismus für das kollektive Phänomen der allgemeinen Geschäftsbedingungen zu bieten. Die Klagebefugnis des Artikels 6:240 Absatz $1 \mathrm{BW}$ - und die daran verbundenen Nebenansprïche - ist Verbraucherverbänden vor allem in der Erwartung gegeben, daff die Drohung einer Unterlassungsklage die Verwender allgemeiner Geschäftsbedingungen und ihre Interessenverbändle an den Unterhandlungstisch führen wird und daß auf diese Weise allgemeine Geschäftsbedingungen zustandekommen, die zu einer ausgeglichenen Interessenwahrung beider Marktseiten führen. Die Verbandsklage nach Artikel 6:240 ff BW soll dabei nicht nur ein Druckmittel sein, das zu Verhandlungen führt, sondern auch ein Druckmittel, um in diesen Verhandlungen binnen gehöriger Zeit zu einem Ergebnis zu gelangen. Das Interesse des niederländischen Gesetzgebers an Selbstregulierung wird weiter unterstrichen durch die "Unterhandlungsverpflichtung" des Artikels 6:240 Absatz 4 BW und die Zustimmungsregelung des Artikels 6:240 Absatz 5 BW. Weiter soll die Verbandsklage eine Lösung bieten für die Nachteile der richterlichen Inhaltskontrolle im Individualfall.

Verbraucherverbände und Verbände zur Förderung gewerblicher Interessen können beim Richter eine Erklärung, daß die beanstandete Klausel unangemessen benachteiligend ist, beantragen. Der Klage müssen immer bestimmte allgemeine Geschäftsbedingungen in bestimmten Klauselwerken zugrundeliegen. Verbraucherverbände können ihren KIagen nur allgemeine Geschäftsbedingungen, verwendet gegenüber Verbrauchern, zugrundelegen. Die richterliche Erklärung, daß eine Klausel unangemessen benachteiligend ist, hat nur Wirkung für die Zukunft (ex nunc). Im Verbandsklageverfahren finden die Artikel 6:233 sub a, 6:236 und 6:237 BW entsprechende Anwendung. Auch in diesem Verfahren gilt demnach die Beweislastumkehrung zu Lasten des Verwenders im Falle von Bedingungen des Klauselkatalogs des Artikels 6:237 BW und, daf 
Bedingungen des Klauselkatalogs des Artikels 6:236 BW ohne weiteres unangemessen benachteiligend sind.

Die Inhaltsprüfung im Verbandsklageverfahren liegt keinem Individualvertrag zugrunde. Daher ist unvermeidlich, dab der Richter bei der Inhaltsprüfung im Verbandsklageverfahren abstrahiert von konkreten Fallgestaltungen. Diesem Abstrahieren sind jedoch Grenzen gesetzt. Der Richter im Verbandsklageverfahren soll, auf der Grundlage des Prüfungsmaßstabs des Artikels 6:233 sub a BW, nur soweit abstrahieren als notwendig ist für sein Urteil. Die abstrakte Inhaltsprüfung soll so konkret wie möglich sein. Die Wertung der relevanten Umstände im Verbandsklageverfahren wird sich meistens nicht unterscheiden von der Wertung im konkreten individuellen Verfahren. Die "normalen" Umstănde (die Umstände in der sich der Durchschnittskunde befindet), die die Grundlage sind für die Inhaltsprüfung im "normalen" Individualverfahren, bilden auch die Grundlage für die abstrakte Inhaltskontrolle. Die abstrakte Inhaltskontrolle geht ja aus vom Durchschnittskunden. Ausgangspunkt dabei ist, daß die meisten individuellen Verfahren Durchschnittskunden betreffen. Nur in Ausnahmefällen wird im Individualverfahren die Rede sein von atypischen Umständen. Diese atypischen Umstände kann der Richter im Verbandsklageverfahren nicht mitwerten. Meines Erachtens wird der Richter im Individualverfahren auch nicht zu einer Wertung dieser atypischen Umstände kommen, so daß auch in diesem Bereich kein Unterschied entsteht zwischen der abstrakten und konkreten Inhaltsprüfung. Allgemeine Geschäftsbedingungen zielen ja nicht ab auf atypische Umstände und können deshalb keine Anwendung finden auf diese Umstände. Daher sind sie in atypischen Fallgestaltungen unbeachtlich.

Wegen der entsprechenden Anwendung des Prüfungsmaßstabs der Generalklausel im Verbandsklageverfahren muß davon ausgegangen werden, daß grundsätzlich dieselben Umstände $\mathrm{zu}$ beachten sind wie bei der individuellen Inhaltsprüfung. Demzufolge können im Verbandsklageverfahren auch nur Umstände im Zeitraum vor oder während des Vertragsabschlusses Beachtung finden.

Gesetzeswidrige Klauseln können ebenfalls Gegenstand des deklaratorischen Urteils im Verbandsklageverfahren sein. Eine gesetzeswidrige Klausel wird im Verbandsklageverfahren als unangemessen benachteiligend angesehen (Artikel 6:240 Absatz $1 \mathrm{BW}$ ). Diesbezïglich hat die Klagebefugnis nach Artikel 6:240 BW im Vergleich zu der allgemeinen Klagebefugnis nach Artikel 3:305a BW vor allem den Vorteil der kollektiven Ladung gemäß der Artikel 1003-1006 Rv.

Der klageerhebende Verband muß eine rechtsfähige juristische Person sein, die sich satzungsgemäß die Interessenwahrnehmung von Unternehmern, Freiberuflern oder Verbrauchern zum Ziel gesetzt hat. Nicht erforderlich ist, dab der klagende Verband ausschließlich die Interessenwahrnehmung von Unternehmern 
oder Verbrauchern zum Ziel hat. Andersherum ist nicht erforderlich, daß diese Verbände neben der Interessenwahrnehmung andere Tătigkeiten entfalten. Die Verbände können nur auftreten zur Förderung der Interessen, die sie sich satzungsgemäB zum Ziel gesetzt haben. Der Anspruch des Artikels 6:240 Absatz $1 \mathrm{BW}$ und die Nebenansprüche des Artikels 6:241 Absatz $3 \mathrm{BW}$, umfassen nur allgemeine Geschäftsbedingungen, die verwendet oder empfohlen werden gegenüber dem Kreis der Personen, deren Interessen durch den klagenden Verband satzungsgemäß herangezogen worden sind. Artikel 6:240 Absatz 3 BW erfordert nicht, daß der klageerhebende Verband seinen Sitz in den Niederlanden hat oder eine juristische Person nach niederländischem Recht ist. Deshalb steht das Verfahren beim Sonderrichter in Den Haag grundsătzlich auch offen für ausländische Verbraucherverbände. Obwohl eine Anerkennung der Kollektivinteressenwahrnehmung nach Artikel 6:240 ff BW durch individuelle Verbraucher im AGB-Bereich durchaus vertretbar wäre, steht dieser Rechtsgang für sie nicht offen. Von der Klagebefugnis nach Artikel 6:240 Absatz 1 BW sind ebenfalls die Interessenverbände ausgeschlossen, die die Verwendung der beanstandeten Klausel zugestimmt haben (Artikel 6:240 Absatz 5 BW). Die Klage einer niederiändischen Verbraucherschutzorganisation wird außerdem als unzulässig abgewiesen, falls sie diese Klage erhoben hat, ohne dem Verwender oder Empfehler bestimmter Geschäftsbedingungen die Möglichkeit geboten zu haben, entsprechend der Kritik Änderungen durchzufihren (Artikel 6:240 Absatz 4 BW). Diese Regelungen unterstreichen das Interesse des niederländischen Gesetzgebers an Selbstregulierung der Marktparteien. Zur Vermeidung der Unzulässigkeit der Klage gemäß Artikel 6:240 Absatz 4 BW muß der klagende Verband der Verwender oder Empfehler die Gründe mitteilen, die zu der Auffassung geführt haben, daß die beanstandete Klausel unangemessen benachteiligend ist. Ferner muß der klagende Verband sich bereit erklären zur Rücksprache über eine Änderung der beanstandeten Klausel, die die Beschwerden gegen diese Klausel behebt. Diese Rückspracheverpflichtung ist zeitlich begrenzt. Eine Frist von sechs Monaten ist nach Artikel 6:240 Absatz 4 BW jedenfalls ausreichend zur Vermeidung der Unzulässigkeit. Der klagende Verband ist nicht verpflichtet Abänderungsvorschläge in Bezug auf die beanstandeten Klauseln zu machen. Aufgrund der zwingend-rechtlichen Natur des Abschnitts 6.5.3 BW ist die Abänderung der beanstandeten Klausel eine Aufgabe des Verwenders oder Empfehlers. Der klagende Verband kann sich beschränken auf Anmerkungen hinsichtlich der Unangemessenheit der beanstandeten Klauseln.

Mit der Rückspracheverpflichtung entscheidet sich der niederländische Gesetzgeber sich entschieden für ein Zweiphasensystem. Die Verwendung einer unangemessen benachteiligenden Klausel kann nicht unmittelbar durch den Sonderrichter verboten werden. In der ersten Phase wird dem Verwender eine 
sechsmonatige Frist gegönnt, in der er freiwillig durch Änderung der beanstandeten Klausel die Beschwerden des klagenden Verbands gegen diese Klausel beheben kann. Die Rückspracheverpflichtung bezweckt an erster Stelle eine Reinigung des Marktes durch Ersetzung der unangemessen benachteiligenden Klauseln durch angemessene Klauseln. Erst wenn diese Ersetzung scheitert, steht in der zweiten Phase der Gang zum Sonderrichter offen, in der die unangemessen benachteiligenden Klauseln mittels richterlichen Verbots oder Gebots, bekämpft werden können. Ob die Bedenken gegen die beanstandete Klausel beseitigt sind, steht ausschließlich im Beurteilungsspielraum des klagenden Verbands. Der Sonderrichter darf deshalb nach Ablauf der sechsmonatigen Frist nicht in seine Erwägungen einbeziehen, ob reelle Verhandlungen stattgefunden haben oder nicht.

Um zur Klage beim Gericht zugelassen zu werden, müssen Verbraucherverbände einen prozessualen Belang und ausreichenden materiellen Belang haben. Verbraucherverbände müssen u.a. nachweisen, daß die beanstandeten Klauseln vor kurzem noch verwendet wurden und daß die Verwendung künftig fortgeführt wird. Ein Verband der ein deklaratorisches Urteil verlangt, das identisch ist mit einem früheren Urteil, wird nicht zugelassen zur Klage. Denn für das Ergebnis im abstrakten Verfahren ist irrelevant, wer die Kllage erhebt.

Die Ansprüche gemäß der Artikel 6:240 und 6:241 BW richten sich gegen Verwender und Empfehler von allgemeinen Geschäftsbedingungen. Die Regelungen des Abschnitts 6.5.3 BW gelten ebenfalls für ausländische Verwender die allgemeine Geschäftsbedingungen gegenüber in den Niederlanden wohnhaften Verbrauchern verwenden. $\mathrm{Ob}$ diese Verwender zum Gerichtshof in Den Haag geladen werden können, ist vom anwendbaren Kollisionsrecht abhängig.

Mit dem Antrag auf ein deklaratorisches Urteil können als Nebenanspruch verbunden werden ein Verbot der Verwendung oder Empfehlung, ein Gebot der Widerrufung einer Empfehlung, eine Verurteilung zur Veröffentlichung des Urteils und ein Ordnungsgeld (Artikel 6:241 Absatz 3 und 5 BW). Der wichtigste Nebenanspruch ist das richterliche Verbot der Verwendung oder Empfehlung. Unter Verwendung allgemeiner Geschäftsbedingungen muß in diesem Rahmen das Aufnehmen der Bedingungen im Vertrag verstanden werden. Das Verbot betrifft nicht nur den buchstäblichen Text der beanstandeten Klauseln sondern auch inhaltsgleiche Klauseln. Es erstreckt sich nur auf Verwender, die Partei im Verfahren waren und es hat, genau wie das deklaratorische Urteil, nur Wirkung für die Zukunft. Das Verbot bewirkt nur die Anfechtbarkeit allgemeiner Geschäftsbedingungen, die nach dem Zeitpunkt verwendet wurden, als das Verbotsurteil Rechtskraft erlangt hat. Es erstreckt sich grundsätzlich nicht auf allgemeine Geschäftsbedingungen in Verträgen, die vor dem Zeitpunkt geschlossen wurden, als das Verbotsurteil Rechtskraft erlangt hat. Der zweite Nebenanspruch ist das Gebot des Widerrufs der Empfehlung unangemessen benach- 
teiligender Klauseln. Falls dem Widerrufsantrag stattgegeben wird, mul\} der Widerruf so schnell wie möglich und an alle an die die Empfehlung weitergegeben wurde, bekanntgegeben werden. Der Antrag auf Verurteilung zur Veröffentlichung des Urteils ist der dritte Nebenanspruch. Die Verurteilung zur Veröffentlichung hat für den klagenden Verband nur dann Bedeutung, wenn der Sonderrichter dem beantragten deklaratorischen Urteil und etwaigen Nebenansprüchen, stattgibt. Es ist naheliegend, daB der Sonderrichter im Falle der Verurteilung des Geladenen die Veröffentlichung des Urteils und die Kosten der Veröffentlichung dem Gelladenen auferlegt. Falls mehrere Verwender geladen sind, läßt Artikel 6:241 Absatz 3 BW dem Richter die Freiheit zu entscheiden, welchem Verwender für welchen Teil die Kosten auferlegt werden. An die Verbots- oder Gebotsansprüchen kann auch ein Ordnungsgeld geknüpft werden. Verwirkte Ordnungsgelder stehen gänzlich der klagenden Partei zu.

Der niederländische Gesetzgeber hat auf eine Verjährungsregelung der Ansprüche im Verbandsklageverfahren verzichtet. Die Voraussetzung des materiellen Belangs des Artikels 3:303 BW gibt eine probate Regelung für die Frage, bis zu welchem Zeitpunkt eine Verbandsklage zulässig ist. Die Verbandsklage gemäß Artikel 6:240 ff BW findet nur statt beim Gerichtshof in Den Haag um bereits in erster Instanz eine einheitliche Rechtsprechung zu gewähren. Das Verfahren wird entweder eingeleitet mit einer üblichen Ladung gemäß der Artikel 1 bis $17 \mathrm{Rv}$ oder mit einer kollektiven Ladung des Branchenverbands samt ihren Mitgliedern gemäß der Artikel 1003-1006 Rv oder einer Kombination davon. Die kollektive Ladung bezweckt vor allem eine maximale Breitenwirkung der Verbandskiage im AGB-Bereich. Im Falle einer kollektiven Ladung ist die übliche Ladungsfrist von mindestens acht Tagen auf mindestens einen Monat verlängert und die Veröffentlichung der Vorladung in einer überregionalen Tageszeitung mit Vermerk des Orts in dem, auf Wunsch, eine Abschrift der Vorladung angefordert werden kann, wird vorgeschrieben. Die Vorladung des Kollektivs der nicht-individualisierten Verwender ("die Mitglieder") muß der Person oder dem Amtsraum des Generalstaatsanwaltes am Gerichtshof in Den Haag oder, im Falle der Revision ("cassatie"), der Person oder dem Amtsraum des Generalstaatsanwaltes am Hoge Raad (höchste richterliche Instanz in den Niederlanden) zugestellt werden. Die Vorladung der individualisierten Mitglieder und des Branchenverbands - wie auch die Geladenen, die kein Mitglied sind, aber dieselbe beanstandete Klausel verwenden - muß wie üblich zugestellt werden an die Person oder den Wohnsitz dieser Geladenen.

Für die Verbandsklage gelten grundsătzlich die generellen Regelungen in Bezug auf Versäumnis, Einspruch, Nebenintervention, Hauptintervention und "derden-verzet" (Einspruch Dritter gegen eine rechtskräftige Entscheidung). Im Verfahren, das anfängt mit einer kollektiven Ladung, ist die Regelung des Artikels 79 Absatz 1 Rv (Vertagung der Verhandlung) nicht anzuwenden, wenn 
der Branchenverband oder mindestens ein Mitglied nicht zum Termin erscheint. Gegen die nicht erschienenen Mitglieder oder den Branchenverband wird ein Versăumnisurteil erlassen. Das Verfahren wird nicht vertagt. In dem Verfahren gemäß den Artikel 6:240 und 6:242 ist ein Antrag auf Erlaß einer einstweiligen Verfügung gemäB Artikel 289 ff Rv nicht gestattet. Im Verbandsklageverfahren wird dagegen eine verkürzte Ladungsfrist (Artikel 7 Absatz 2 Rv), ein beschleunigtes Verfahren gemäß Artikel $145 \mathrm{Rv}$ und eine einstweilige Verfügung gemäß Artikel 51 Rv nicht verboten.

In seinem Urteil kann der Sonderrichter angeben, in welcher Weise die Unangemessenheit einer Klausel erhoben werden kann (6:241 Absatz 4 BW). Diese Möglichkeit soll durch den Sonderrichter aber nur mit äußerster Zurückhaltung angewandt werden. Ein für jeden zugängliches Register der Urteile im Verbandsklageverfahren ist im Abschnitt 6.5.3 BW nicht vorgesehen. Ein Verbotsurteil des Sonderrichters kann auf Antrag der betroffenen Verwender oder Empfehler geändert oder aufgehoben werden, wenn eine Änderung der Umstände das rechtfertigt. Gegen das Urteil des Sonderrichters ist die Revision zum Hoge Raad zugelassen. Im Verfahren, welches anfängt mit einer kollektiven Ladung, ist die Revision jedoch nur zugelassen für diejenigen, die in erster Instanz erschienen sind.

Hinsichtlich der Kosten im Verfahren, das eingeleitet wird durch eine "normale" Ladung, gelten die allgemeinen Regelungen der Artikel 56 bis 58 Rv. Hinsichtlich der Berechnung der Prozeßkosten im Falle einer kollektiven Ladung wird das Kollektiv (Branchenverband samt Mitglieder) jedoch betrachtet als eine einzige Partei (Artikel $1006 \mathrm{Rv}$ ).

Die vom niederländischen Gesetzgeber angekündigte gesetzliche Subventionsregelung für die Aktivitäten der Verbraucherverbände im Verbandsklageverfahren läßt bis auf den heutigen Tage auf sich warten. Neben der Klagebefugnis des Artikels 6:240 ff BW steht den Verbraucherverbänden seit dem in Kraft treten des Artikels 3:305a am 1. Juli 1994 ebenfalls eine allgemeine Klagebefugnis zu. Dabei kann im AGB-Bereich vor allem gedacht werden an eine kollektive Durchsetzung eines Anfechtungsanspruchs gemäß der Artikel 6:233 und 6:243 BW.

Im sechsten Kapitel werden die Entstehungsgeschichte sowie die materiell- und verfahrensrechtlichen Bestimmungen des AGB-Gesetzes beschrieben. Im siebenten Kapitel wird das deutsche AGB-Gesetz verglichen mit dem niederländischen "Wet algemene voorwaarden". Die Ähnlichkeit beider Gesetze ist unverkennbar. Beide Gesetze enthalten einen zwingend-rechtlichen Regelkomplex der nähere Bestimmungen gibt für den Begriff allgemeine Geschäftsbedingungen, deren Einbeziehung in dem Vertrag, die Art und Weise, in der der Verwender die andere Vertragspartei informieren muß, über die Anwendbarkeit 
und den Inhalt der allgemeinen Geschäftsbedingungen und die Inhaltsprüfung. In beiden Regelungen stützt sich die Inhaltsprüfung auf eine von Treu und Glauben abgeleitete Norm, die im Verbraucherbereich in zwei Katalogen von Klauseln näher konkretisiert wird. Einer der Kataloge enthält Bestimmungen, die ohne Wertungsmöglichkeit unangemessen benachteiligend sind. Der andere Katalog enthält Bestimmungen, deren Unangemessenheit indiziert ist. Auch auf verfahrensrechtlicher Ebene sind beide Gesetze im Wesen gleich. Beide Regelungen bieten neben der individuellen Klagebefugnis ein Verfahren, in dem Interessenverbände im allgemeinen Interesse den gesetzlichen Schutz und ein Verbot mit Breitenwirkung außerhalb des Verbandsverfahrens erzwingen können.

Im materiellen Bereich sind beide Regelungen, was die Systematik; den Aufbau, die Gestaltung und Wirkung betriff, nahezu gleich. Sie unterscheiden sich nur in wenigen Punkten. Die Informationspflicht des Verwenders ist in den Niederlanden wesentlich strenger als in Deutschland. Demgegenüber steht, daß im AGB-Gesetz die Transparenz und die Verständlichkeit allgemeiner Geschäftsbedingungen mit maßgebend sind für die Informationspflicht. Das führt dazu, daß undurchsichtige oder unverständliche Bedingungen unwirksam sind. Der Geltungsbereich des niederländischen Gesetzes ist etwas größer als der Geltungsbereich des deutschen Gesetzes. Ein erheblicher Unterschied zwischen der deutschen und niederländischen Regelung findet seine Ursache in der Verschiedenheit der Sanktionierung bei der Verwendung unangemessen benachteiligender Klauseln. Der deutsche Richter prüft wegen der Unwirksamkeit von Amts wegen. Der niederländische Richter tut und darf das aufgrund der Anfechtbarkeit nicht.

Die Verbandsklage im AGB-Bereich ist, was die Systematik, die Gestaltung und Wirkung betrifft, ebenfalls nahezu gleich. Der Unterschied ergibt sich vor allem aus dem Interesse des niederländischen Gesetzgebers an der Selbstregulierung der Marktparteien. Im Gegensatz zu deutschen Verbraucherverbänden haben niederländische eine Rückspracheverpflichtung. Demgegenüber steht, daß die niederländische Regelung es möglich macht einen Branchenverband samt ihrer Mitglieder kollektiv zu Laden. Eine derartige Regelung kennt das deutsche AGB-Gesetz nicht. Ein weiterer Unterschied zwischen beiden Regelungen ist, das in den Niederlanden im Gegensatz zu Deutschland die erstinstanzliche Rechtsprechung im Verbandsklageverfahren konzentriert ist, nämlich beim Gerichtshof in Den Haag. Das AGB-Gesetz kennt auf Landesebene eine vergleichbare Regelung in der Konzentrationsermächtigung der Landesregierungen.

Ein weiterer Unterschied zwischen beiden Regelungen folgt, sowohl für die Individualklage als auch fuir die Verbandsklage, aus der Anwendung der allgemeinen Bestimmungen hinsichtlich der Verteilung der Prozeßkosten. In den Niederlanden wird ein Verfahren für den Kläger nahezu immer Kosten mit sich bringen, auch wenn er das Verfahren hundertprozentig gewinnt. In Deutschland 
werden die Kosten der obsiegenden Partei grundsätzlich ganz durch die unterliegende Partei getragen.

Im achten Kapitel wird ein Einblick in die Rolle gegeben, die deutsche Verbraucherschutzverbände in der Praxis des AGB-Gesetzes vermitteln. Die im AGBBereich meist aktiven Verbraucherverbände sind der Verbraucherschutzverein in Berlin (VSV) und die Verbraucherzentrale Baden-Württemberg in Stuttgart. Sie sind seit dem Inkrafttreten des AGB-Gesetzes im Jahre 1977 im AGB-Bereich tätig gewesen. Seit dem Ende der achtziger Jahre haben auch, sei es in bescheidenerem Umfang, die Verbraucherzentralen in Düsseldorf und Hamburg ihre Klagebefugnis im AGB-Bereich ausgeübt. Die Struktur, Organisation, Zielsetzung und Tätigkeit im AGB-Bereich dieser vier Verbraucherschutzverbände wird năher beleuchtet. Dabei kommt heraus, daß die gerichtliche Handhabung der Verbraucherinteressen im AGB-Bereich sich hauptsächlich stützt auf die Tätigkeiten der Verbraucherverbände und insbesondere auf die Tätigkeiten der VSV und der Verbraucherzentrale Baden-Württemberg. In dem Zeitraum vom 1. April 1977 bis 1. Januar 1993 erfolgten durch diese zwei Verbraucherverbände jeweils 26830 und 2270 Abmahnungen, die zu $1567(58,4 \%)$ und 1475 (65\%) strafbewehrten Unterlassungserklärungen führten. Der VSV und die Verbraucherzentrale Baden-Württemberg haben in diesem Zeitraum jeweils 690 und 392 Unterlassungs- oder Widerrufsklagen erhoben und jeweils 18 und 17 Anträge auf eine einstweilige Verfügung eingereicht. Von den gerichtlichen Verfahren deren Ergebnisse aufspürbar waren, wurden jeweils $86 \%$ und $91 \%$ gewonnen.

Die Kontrolltătigkeit und die von den zwei meist aktiven Verbraucherverbănden verfolgte Strategie wird im neunten Kapitel beschrieben. Das abstrakte Verfahrensmodell gemäß $\S 13$ AGBG besteht aus den Verfahrensschritten Ermittlung, Inhaltsprüfung, Abmahnung, richterliches Verfahren, Nachkontrolle und Effektuierung von Vertragsstrafen und Ordnungsgeldern. Beide Verbraucherverbände folgen im Prinzip diesem Modell. Den außergerichtlichen Teil dieses Modells versorgen die beiden genannten Verbände selber. Der gerichtliche Teil des Modells wird gezwungenermaßen Anwälten überlassen. Die finanziellen Mittel, die den Verbänden zur Verfügung stehen, sind beschränkt. Von einer gezielten Ermittlung und Nachkontrolle ist daher kaum die Rede und Anträge auf einstweilige Verfügungen werden kaum noch eingereicht. Beide Verbănde erlauben den abgemahnten Verwendern mur beschränkt eine Umstellungs- oder Aufbrauchfrist. Sie verhandeln auch nicht mit Branchenverbänden über Konditionenempfehlungen. Beide Verbände bezeichnen derartigen Verhandlungen als unzureichend effektiv. Sie begutachten jedoch auf Anfrage, ob die verwendeten 
allgemeinen Geschäftsbedingungen unangemessen benachteiligend sind. Das AGB-Register beim BKA wird kaum genutzt.

Kapitel zehn gibt einen Einblick in die geographische Verteilung und den Anwendungsbereiche der Kontrolltätigkeit der Verbände. Es zeigt sich, daß in einem großen Land wie Deutschland die regionale Kontrolltätigkeit stark abhängig ist von den Aktivitäten der regionalen Verbraucherzentralen und daß nicht alle Verbraucherzentralen im selben Maße die Klagebefugnis gemäß $\S 13$ ff AGBG ausüben. Bezieht man die Verteilung nach Branchensorte dann fällt auf, daß die meisten Abmahnungen gerichtet waren an die branchen Dienstleistung, Haushaltsgeräte und Elektro, Reiseveranstalter, Möbel und Bau und Renovierung. Die durchgeführten Klagen richteten sich größtenteils gegen die in $\$ 11$ AGBG aufgelisteten unzulässigen Geschäftsbedingungen. Der Grund hierfür ist vermutlich das hiermit verbundene geringe Prozeßrisiko. In letzter Zeit zeigt sich jedoch, daß sich sowohl die Klagen des VSV als auch die der Verbraucherzentrale Baden-Württemberg von den Klauselkatalogen der $\$ \S 10$ und 11 AGBG (und vor allem der Klauselkatalog des $\$ 11$ AGBG) auf die Generalklausel des $\S$ 9 AGBG verschieben. Trotz dieser Verschiebung machen diese Klagen immer noch einen erheblichen Teil aller Klagen aus. Das gilt umsomehr für die auBergerichtliche Phase. Circa 50\% aller Abmahnungen richten sich auf die in den $\$ \$ 10$ und 11 AGBG aufgelisteten unzulässigen Geschäftsbedingungen.

Im elften Kapitel werden die Problemgebiete des deutschen Kontrollsystems aufgezeigt. Nach herrschender Meinung wird das AGB-Gesetz im Bereich des Schuldrechts als die wichtigste Novelle seit dem Zustandekommen des BGB bezeichnet. Die Flut an Rechtsprechung und Literatur; die das AGB-Gesetz hervorgebracht hat, hat die Grenzen der Zulässigkeit allgemeiner Geschäftsbedingungen erheblich verdeutlicht und verschärft. Die Bestimmungen des AGBGesetzes an sich und besonders die in Bezug auf die Inhaltsprüfung haben sich als gut handhabbar erwiesen und nur unerhebliche Problembereiche aufgezeigt. Dasselbe trifft zu für die verfahrensrechtlichen Bestimmungen. Die Regeln sind klar und Verbraucherverbände wenden häufig und mit Erfolg die Verbandsklage an. Die Verbandsklage hat sich erwiesen als ein probates Instrument zur Wahrung der Verbraucherinteressen im AGB-Bereich. Verbraucherverbände sind deshalb auch der Meinung, daß die kollektive Klagebefugnis ein geeignetes Instrument ist zum Ausgleich der individuellen Ungleichheit im AGB-Bereich. Zugleich wird aber auch erkannt, daß die gewünschte Breitenwirkung des AGBGesetzes nicht realisiert worden ist. Die Kontrolltätigkeiten der klagebefugten Verbände sind im Umfang zu gering um den Markt flächendeckend von unangemessen benachteiligenden allgemeinen Geschäftsbedingungen $\mathrm{zu}$ befreien. Hauptursache dafür ist das Fehlen genügender finanzieller Mittel. Dies ist vor 
allem der Grund für Engpässen in die Anwendung eines an sich probaten Instruments, Personalmangel, kaum gezielte Ermittlungen, häufiger Verzicht aut Risikofalle, keine gezielten Nachkontrollen und keine einstweiligen Verfügungen.

Im zwölften Kapitel werden die deutschen Erfahrungen ubertragen auf die Situation in den Niederlanden. Nach den deutschen Erfahrungen hat der niederländische Gesetzgeber sich zurecht für die Anerkeninung der Verbandsklagebefugnis im AGB-Bereich entschieden. Die deutschen Erfahrungen zeigen zwar, daß im AGB-Bereïch in großer Zahl Individualverfahren durchgeführt wurden und daß auch ein erheblicher Teil dieser Verfahren Bezug hatte auf Verbraucherverträge. Jedoch ist die erzielte reinigende Wirkung des AGB-Gesetzes vor allem zurückzuführen auf die Initiativen der Verbraucherschutzverbände. Aufgrund der Unzugänglichkeit zum Recht und Richter ist zu erwarten, daß für den niederländischen Verbraucher der Weg zum Richter schwerer ist als für den deutschen Verbraucher. Wenn sie den Weg aber finden, werden die materiellrechtlichen Bestimmungen ihnen kaum Schwierigkeiten bereiten. Genau wie in Deutschland ist zu beobachten, daß von Seiten der Verwender vor allem die niederländischen Branchenverbände reagiert haben auf die Einführung des neuen Gesetzes. Die Verhandlungen zwischen Anbieterorganisationen und Verbraucherverbänden über Konditionenempfehlungen haben durch die Einführung des Gesetzes einen erheblichen Impuls bekommen. In dem Sinne hat das Gesetz schon eine deutliche Wirkung gehabt. Die Erfahrungen in Deutschland zeigen, daß gerade die einheitlliche Wirkung der an dem neuen Gesetz angepaßten Konditionenempfehlungen eine für den Verbraucher günstige reinigende Wirkung auf den Markt hat. Die Drohung mit der Verbandsklage macht die Verhandlungen für Branchenverbände erheblich weniger freibleibend als dies der Fall war vor Inkrafttreten des neuen Gesetzes. Die Verhandlungen finden jetzt statt in einem deutlichen juristischen Rahmen. Das hat dazu gefuihrt, dafl die allgemeinen Geschäftsbedingungen in für den Verbraucher wilchtigen Marktsegmenten erheblich verbessert wurden oder demnächst verbessert werden. Außerhalb des Bereichs der Konditionenempfehlungen erfolgte freiwillig nur eine ungenügende Anpassung ihrer allgemeinen Geschäftsbedingungen an das neue Gesetz. Die reinigende Wirkung des niederländischen AGB-Gesetzes im Verbraucherbereich wird daher vor allem herbeigeführt werden müssen durch die Tätigkeiten der Verbraucherverbände. Die Verbandsklage hat sich in Deutschland als ein besonders wirksames Instrument in der Bekämpfung von unangemessen benachteiligenden allgemeinen Geschäftsbedingungen herausgestellt. Sie macht vor allem die außergerichtlichen Tätigkeiten der Verbraucherverbände besonders erfolgreich. 
Deutsche Verbraucherverbände haben sich bei der Wahrung des gesetzlichen Mindestschutzes für ein Konfliktmodell und nicht für ein Verhandlungsmodell entschieden. Eine Selbstregulierungskultur wie in den Niederlanden ist in Deutschland nicht vorhanden. Nach Auffassung der deutschen Verbraucherverbände haben Verhandlungen mit Branchenverbänden nur einen geringen Nutzen weil sie zu viel Zeit und Personal, also zu viel Geld kosten. Außerdem waren Verwender in diesen Verhandlungen nie bereit über den gesetzlichen Mindeststandart (gerade nicht unangemessen benachteilligend) hinaus zu kommen. Dieses Ergebnis kann nach Auffassung der deutschen Verbraucherverbände erheblich einfacher, effektiver und billiger durch Anwendung des Abmahnungs- und ProzeBmodells erreicht werden. Der niederländische Gesetzgeber legt aber besonderen Wert auf das Verhandlungsmodell. Niederländische Verbraucherverbände haben die Wahl zwischen dem Verhandlungs- und Konfliktmodell. Das Konfliktmodell ist das am meisten in Betracht kommende Modell für die (schnelle) Wahrung des gesetzlichen Mindeststandarts, während das Verhandlungsmodell mehr in Betracht kommt, wenn die Anstrengungen der Verbraucherverbände sich richten auf einem "Surplus". Das Verhandlungsmodell bietet mehr Vorteile als das Konfliktmodell, wenn Verbraucherverbände durch Verhandlungen mehr erreichen können als den gesetzlichen Mindestschutz.

Die deutschen Erfahrungen zeigen, daß die Ausübung der Klagebefugnis auf dem Wege des Konfliktmodells die niederländischen Verbraucherverbände vor keine allzu großen juristischen Probleme stellt. Eine nähere Verdeutlichung der Grenzen der Generalklausel und des Klauselkatalogs des Artikels 6:237 BW in der Rechtsprechung wird zu mehr Rechtssicherheit führen. Die Klarstellung dieser Grenzen ist vor allem abhängig von den Klagetätigkeiten der Verbraucherverbände. Aus dieser Sicht haben Verbraucherverbände ein Interesse daran, daß sie so viel wie möglich Verbandsklageverfahren beim Sonderrichter führen. Ein erstes Verbandsklageverfahren vor dem Sonderrichter läßt Ende 1994 aber noch immer auf sich warten. Es sieht so aus, als hätten die niederländischen Verbraucherverbände sich dazu entschieden vorläufig erstmal Erfahrungen zu machen mit dem Verhandlungsmodell. Das ist bedauerlich. Eine gleichzeitige Ausübung beider Modelle wäre aus dem Gesichtspunkt der Effektivität und der Effizienz zu bevorzugen.

Trotz der Effektivität der Klagebefugnis der Verbraucherverbände hat sich erwiesen, daß die außergerichtlichen und gerichtlichen Kontrolltätigkeiten der klagebefugten Verbände im Umfang zu gering sind um den Markt flächendeckend von unangemessen benachteiligenden allgemeinen Geschäftsbedingungen zu befreien. Hauptursache dafür ist, daß der Staat nur ungenügende finanzielle Mittel zur Verfügung stellt. In den Niederlanden herrscht zeitweilig noch Unklarheit in Bezug zur Staatssubventionierung der Verbandsklagetätigkeit 
im AGB-Bereich. Angesichts dieser Unsicherheit im Bezug zu der (Höhe der) Subvention der prozessualen und vorprozessualen Klagetătigkeiten der Verbraucherverbände ist es nicht verwunderlich, dab die niederländischen Verbraucherverbände den ersten Schritt zum Sonderrichter, der vor allem in der Anfangszeit, in der noch keine richtungsgebenden Urteile vorhanden sind, ein großes Prozeßrisiko mit sich bringt, bis jetzt noch nicht gewagt haben. Dazu kommt noch, daß̉ die niederländischen Verbraucherverbände ein größeres Kostenrisiko laufen als die deutschen Verbraucherverbände. Die vom Gesetzgeber bezweckte Reinigung des Marktes von unangemessen benachteiligenden allgemeinen Geschäftsbedingungen wird zum Teil verhindert, weil derselbe Gesetzgeber nicht bereit ist, die Subvention der bezweckten Verbandstätigkeiten zu garantieren. Demgegenüber steht, daß das Mitgliederpotential der niederländischen Verbraucherverbände bessere Ermittlungs- und Nachkontrollmöglichkeiten verspricht als die in Deutschland.

Es sieht so aus als würden individuelle Verbraucher in den Niederlanden kaum den Richter anrufen um sich auf ein Verbotsurteil des Sonderrichters zu berufen. Dafür ist der niederländische Richter einfach zu teuer. Daher verspricht eine effektive Nachkontrolle der Abkommen mit den Verwendern oder der gegen ihnen ergangenen Verbotsurteile und die Effektuierung der Vertragsstrafen und Ordnungsgelder durch die Verbraucherverbände viel mehr falls der Verwender sich nicht an das Abkommen oder das Urteil hält.

Kapitel dreizehn enthält eine Schlußbetrachtung und einige Vorschläge zur Verbesserung der Effektivität des niederländischen AGB-Gesetzes und der Verbandsklagebefugnis in diesem Gesetz. Angesichts der großen Ähnlichkeit der deutschen und niederländischen Regelung ist zu erwarten, daß auch das niederländische AGB-Gesetz mit einer Zunahme der Jurisprudenz im AGB-Bereich ein klares und handhabbares Instrument für die nähere Abgrenzung der inhaltlichen Zulässigkeit allgemeiner Geschäftsbedingungen und den Kriterien für die Einbeziehung davon in dem Vertrag bieten wird. Auch für die Niederlanden gilt, daß der Maßstab für die Effektivität des Gesetzes vor allem zu suchen ist in dem Ausmaß, in dem der Markt von unangemessen benachteiligenden allgemeinen Geschäftsbedingungen befreit wird, also in der Breitenwirkung. Die deutschen Erfahrungen zeigen, daß die Breitenwirkung größtenteils abhängig ist von den Tätigkeiten der Verbraucherverbände. Für die Interessenwahrung im AGB-Bereich haben die gerichtlichen und außergerichtlichen Tätigkeiten der Verbraucherverbände ja den höchstens Wirkungsgrad. Die Förderung der Tätigkeit der Verbraucherverbände im AGB-Bereich wird sich am meisten rentieren. Aus dieser Sicht erscheint es nicht unlogisch, daß der niederländische Staat, als Erstverantwortlicher für den gesetzlichen Mindestschutz der Verbraucher im AGB-Bereich, nachträglich eine Subventionsregelung beschließt, in der 
der niederländische Staat sich bereit erklärt, die Kosten der Kontrolltätigkeiten der Verbraucherverbände im AGB-Bereich ganz oder teilweise zu tragen.

Die Kosten der Kontrolltätigkeiten und damit auch die Kosten einer eventuellen Subventionsregelung werden zum Teil abhăngig sein von dem Prozeßrisiko, das die Verbraucherverbände laufen. Die Erfahrungen in Deutschland erweisen, daß Verbraucherverbände, vorausgesetzt sie haben dazu genügende finanziellen Mittel, einen dermaßen großen Sachverstand generieren werden, daß sie imstande sind in fast allen Verfahren zu obsiegen. Im Gegensatz zu Deutschland ereignet sich dabei in den Niederlanden ein kostenerhöhende Umstand. In den Niederlanden ist es ja nahezu ständige Praxis, daß die obsiegende Partei einen Teil ihrer Prozeßkosten selbst tragen muß. Dieses Übel würde verhinderd, wenn die Judikative öfter als bisher üblich sich dazu entschließt, der unterliegenden Partei sämtliche Kosten der obsiegenden Partei aufzuerlegen. Eine geänderte Haltung der Judikative hinsichtlich der Prozeßkostenverteilung könnte auf der Ebene der Individualverfahren ebenfalls einen Beitrag liefern zu einer besseren Frequentierung der Gerichte durch den individuellen Verbraucher und damit zu einer größeren Breitenwirkung des zwingend-rechtlichen Mindestschutzes des Verbrauchers. Es sind ja hauptsächlich die Kosten, die den Verbraucher davon abhalten seinen gesetzlichen Mindestschutz beim Richter zu erkämpfen. Eine derartig geänderte Haltung der Judikative würde es Verwendern erheblich schwieriger machen sich auf unangemessen benachteiligenden Klauseln zu berufen.

Das Ausmaß in dem die Verwender die von dem Gerichtshof in Den Haag verbotenen Klauseln weiterverwenden werden, hängt zum Teil davon $a b$, wie hoch die Verwender das Risiko einschätzen, daß sie bei der Weiterverwendung erwischt werden und auf Zahlung der festgestellten Ordnungsgelder angesprochen werden. Es ist naheliegend, daß die Verbraucherverbände in der Kontrolle der Befolgung der Verbotsurteile ihre Mitglieder einschalten. Die Effektivität der Nachkontrolle wird zum Teil davon abhängen, in wie weit die Verbraucherverbände imstande sind, ihre Mitglieder in die Ermittlung und in die Nachkontrolle einzubeziehen. Hierbei sollten die Verbraucherverbände vielleicht erwägen, ihre Mitglieder durch einen finanziellen Anreiz zu aktivieren. Dies könnte durch die Weitergabe von Teilen der Ordnungsgelder oder der Vertragsstrafen erreicht werden. Eine derartige Maßnahme würde das Interesse der Verbraucher an allgemeinen Geschäftsbedingungen und dem hierfür geltenden Recht erheblich steigern und damit für eine enorme Ausbreitung des bezweckten gesetzlichen Mindestschutzes sorgen. Außerdem wäre noch zu erwägen eine Änderung im Gesetz durchzuführen, die es dem individuellen Verbraucher möglich macht, daß im Verbandsklageverfahren auferlegte Ordnungsgeld ganz oder teilweise selber einzutreiben, wenn die verbotene Klausel ihm gegenüber verwendet wird. 
Ein leicht zugängliches Register von Urteilen des Sonderrichters würde ebenfalls zur bezweckten Breitenwirkung des niederländischen AGB-Gesetzes beitragen. In Anbetracht der modernen Automatisierungs- und Kommunikationstechnik dürfte dies nicht allzu schwierig sein.

Die deutschen Erfahrungen zeigen, daß der deutsche Richter das AGBGesetz im Individualverfahren von Amts wegen anwendet. Das hat in Deutschland sicherlich zur Breitenwirkung der Normen des AGB-Gesetzes beigetragen. In den Niederlanden darf der Richter den zwingend-rechtlichen Mindestschutz nicht von Amts wegen anwenden. Ein direkteres Engagement der Judikative mittels einer verpflichtenden Inhaltsprüfung von Amts wegen, falls eine Partei sich auf allgemeine Geschäftsbedingungen beruft, würde die Breitenwirkung des niederländischen AGB-Gesetzes und damit den Verbraucherschutz im AGB-Bereich erheblich unterstützen. Aus dieser Sicht wäre zu erwägen, nach dem deutschen Beispiel die Sanktion der Anfechtbarkeit vielleicht nur für Verbraucherverträge in eine Unwirksamkeit von Rechts wegen, zu ändern. 


\section{Wet algemene voorwaarden}

Art. 231. In deze afdeling wordt verstaan onder:

a. algemene voorwaarden: een of meer schriftelijke bedingen die zijn opgesteld teneinde in een aantal overeenkomsten te worden opgenomen, met uitzondering van bedingen die de kern van de prestaties aangeven;

b. gebruiker: degene die algemene voorwaarden in een overeenkomst gebruikt;

c. wederpartij: degene die door ondertekening van een geschrift of op andere wijze de gelding van algemene voorwaarden heeft aanvaard.

Art. 232. Een wederpartij is ook dan aan de algemene voorwaarden gebonden als bij het sluiten van de overeenkomst de gebruiker begreep of moest begrijpen dat zij de inhoud daarvan niet kende.

Art. 233. Een beding in algemene voorwaarden is vernietigbaar

$a$. indien het, gelet op de aard en de overige inhoud van de overeenkomst, de wijze waarop de voorwaarden zijn tot stand gekomen, de wederzijds kenbare belangen van partijen en de overige omstandigheden van het geval, onredelijk bezwarend is voor de wederpartij; of

$b$. indien de gebruiker aan de wederpartij niet een redelijke mogelijkheid heeft geboden om van de algemene voorwaarden kennis te nemen.

Art. 234. - 1. De gebruiker heeft aan de wederpartij de in artikel 233 onder $b$ bedoelde mogelijkheid geboden, indien hij

a. hetzij de algemene voorwaarden voor of bij het sluiten van de overeenkomst aan de wederpartij ter hand heeft gesteld,

$b$. hetzij, indien dit redelijkerwijs niet mogelijk is, voor de totstandkoming van de overeenkomst aan de wederpartij heeft bekend gemaakt dat de voorwaarden bij hem ter inzage liggen of bij een door hem opgegeven Kamer van Koophandel en Fabrieken of een griffie van een gerecht zijn gedeponeerd, alsmede dat zij op verzoek zullen worden toegezonden. 
- 2. Indien de voorwaarden niet voor of bij het sluiten van de overeenkomst aan de wederpartij zijn ter hand gesteld, zijn de bedingen tevens vernietigbaar indien de gebruiker de voorwaarden niet op verzoek van de wederpartij onverwijld op zijn kosten aan haar toezendt.

- 3. Het in de leden 1 onder $b$ en 2 omtrent de verplichting tot toezending bepaalde is niet van toepassing, voor zover deze toezending redelijkerwijze niet van de gebruiker kan worden gevergd.

Art. 235. - 1. Op de vernietigingsgronden bedoeld in de artikelen 233 en 234, kan geen beroep worden gedaan door

a. een rechtspersoon bedoeid in artikel 360 van Boek 2, die ten tijde van het sluiten van de overeenkomst laatstelijk haar jaarrekening openbaar heeft gemaakt, of ten aanzien waarvan op dat tijdstip laatstelijk artikel 403 lid 1 van Boek 2 is toegepast;

$b$. een partij op wie het onder a bepaalde niet van toepassing is, indien op voormeld tijdstip bij haar vijftig of meer personen werkzaam zijn of op dat tijdstip uit een opgave op grond van artikel $17 a$ van de Handelsregisterwet volgt dat bij haar vijftig of meer personen werkzaam zijn.

- 2. Op de vernietigingsgrond bedoeld in artikel 233 onder $a$, kan mede een beroep worden gedaan door een partij voor wie de algemene voorwaarden door een gevolmachtigde zijn gebruikt, mits de wederpartij meermalen overeenkomsten sluit waarop dezelfde of nagenoeg dezelfde algemene voorwaarden van toepassing zijn.

- 3. Op de vernietigingsgronden bedoeld in de artikelen 233 en 234, kan geen beroep worden gedaan door een partij die meermalen dezelfde of nagenoeg dezelfde algemene voorwaarden in haar overeenkomsten gebruikt.

- 4. De termijn bedoeld in artikel 52 lid 1 onder $d$ van Boek 3, begint met de aanvang van de dag, volgende op die waarop een beroep op het beding is gedaan.

Art. 236. Bij een overeenkomst tussen een gebruiker en een wederpartij, natuurlijk persoon, die niet handelt in de uitoefening van een beroep of bedrijf, wordt als onredelijk bezwarend aangemerkt een in de algemene voorwaarden voorkomend beding

$a$. dat de wederpartij geheel en onvoorwaardelijk het recht ontneemt de door de gebruiker toegezegde prestatie op te eisen;

$b$. dat de aan de wederpartij toekomende bevoegdheid tot ontbinding, zoals deze in afdeling 5 van titel 5 is geregeld, uitsluit of beperkt;

c. dat een de wederpartij volgens de wet toekomende bevoegdheid tot opschorting van de nakoming uitsluit of beperkt of de gebruiker een verdergaande bevoegdheid tot opschorting verleent dan hem volgens de wet toekomt; 
d. dat de beoordeling van de vraag of de gebruiker in de nakoming van een of meer van zijn verbintenissen is te kort geschoten aan hem zelf overlaat, of dat de uitoefening van de rechten die de wederpartij ter zake van een zodanige tekortkoming volgens de wet toekomen, afhankelijk stelt van de voorwaarde dat deze eerst een derde in rechte heeft aangesproken;

$e$. krachtens hetwelk de wederpartij aan de gebruiker bij voorbaat toestemming verleent zijn uit de overeenkomst voortvloeiende verplichtingen op een der in afdeling 3 van titel 2 bedoelde wijzen op een derde te doen overgaan, tenzij de wederpartij te allen tijde de bevoegdheid heeft de overeenkomst te ontbinden, of de gebruiker jegens de wederpartij aansprakelijk is voor de nakoming door de derde, of de overgang plaatsvindt in verband met de overdracht van een onderneming waartoe zowel die verplichtingen als de daartegenover bedongen rechten behoren;

$f$. dat voor het geval uit de overeenkomst voor de gebruiker voortvloeiende rechten op een derde overgaan, ertoe strekt bevoegdheden of verweermiddelen die de wederpartij volgens de wet jegens die derde zou kunnen doen gelden; uit te sluiten of te beperken;

g. dat een wettelijke verjarings- of vervaltermijn waarbinnen de wederpartij enig recht moet geldend maken, tot een verjarings- onderscheidenlijk vervaltermijn van minder dan een jaar verkort;

$h$. dat voor het geval bij de uitvoering van de overeenkomst schade aan een derde wordt toegebracht door de gebruiker of door een persoon of zaak waarvoor deze aansprakelijk is, de wederpartij verplicht deze schade hetzij aan de derde te vergoeden, hetzij in haar verhouding tot de gebruiker voor een groter deel te dragen dan waartoe zij volgens de wet verplicht zou zijn;

$i$. dat de gebruiker de bevoegdheid geeft de door hem bedongen prijs binnen drie maanden na het sluiten van de overeenkomst te verhogen, tenzij de wederpartij bevoegd is in dat geval de overeenkomst te ontbinden;

$j$. dat in geval van een overeenkomst tot het geregeld afleveren van zaken, elektriciteit daaronder begrepen, of tot het geregeld doen van verrichtingen, leidt tot stilzwijgende verlenging of vernieuwing van meer dan een jaar;

$k$. dat de bevoegdheid van de wederpartij om bewijs te leveren uitsluit of beperkt, of dat de uit de wet voortvloeiende verdeling van de bewijslast ten nadele van de wederpartii wijzigt, hetzij doordat het een verklaring van haar bevat omtrent de deugdelijkheid van de haar verschuldigde prestatie, hetzij doordat het haar belast met het bewijs dat een tekortkoming van de gebruiker aan hem kan worden toegerekend;

l. dat ten nadele van de wederpartij afwijkt van artikel 37 van Boek 3, tenzij het betrekking heeft op de vorm van door de wederpartij af te leggen verklaringen of bepaalt dat de gebruiker het hem door de wederpartij opgegeven adres als zodanig mag blijven beschouwen totdat hem een nieuw adres is meegedeeld; 
m. waarbij een wederpartij die bij het aangaan van de overeenkomst werkelijke woonplaats in een gemeente in Nederland heeft, woonplaats kiest anders dan voor het geval zij te eniger tijd geen bekende werkelijke woonplaats in die gemeente zal hebben, tenzij de overeenkomst betrekking heeft op een registergoed en woonplaats ten kantore van een notaris wordt gekozen;

n. dat voorziet in de beslechting van een geschil door een ander dan hetzij de rechter die volgens de wet bevoegd zou zijn, hetzij een of meer arbiters, tenzij het de wederpartij een termijn gunt van tenminste een maand nadat de gebruiker zich schriftelijk jegens haar op het beding heeft beroepen, om voor beslechting van het geschil door de volgens de wet bevoegde rechter te kiezen.

Art. 237. Bij een overeenkomst tussen een gebruiker en een wederpartij, natuurlijk persoon, die niet handelt in de uitoefening van een beroep of bedrijf, wordt vermoed onredelijk bezwarend te zijn een in de algemene voorwaarden voorkomend beding

a. dat de gebruiker een, gelet op de omstandigheden van het geval, ongebruikelijk lange of onvoldoende bepaalde termijn geeft om op een aanbod of een andere verklaring van de wedlerpartij te reageren;

b. dat de inhoud van de verplichtingen van de gebruiker ezenlijk beperkt ten opzichte van hetgeen de wederpartij, mede gelet op de wettelijke regels die op de overeenkomst betrekking hebben, zonder dat beding redelijkerwijs mocht verwachten;

c. dat de gebruiker de bevoegdheid verleent een prestatie te verschaffen die wezenlijk van de toegezegde prestatie afwijkt, tenzij de wederpartij bevoegd is in dat gevall de overeenkomst te ontbinden;

d. dat de gebruiker van zijn gebondenheid aan de overeenkomst bevrijdt of hem de bevoegdheid daartoe geeft anders dan op in de overeenkomst vermelde gronden welke van dien aard zijn dat deze gebondenheid niet meer van hem kan worden gevergd;

e. dat de gebruiker een ongebruikelijk lange of onvoldoende bepaalde termijn voor de nakoming geeft;

$f$. dat de gebruiker of een derde geheel of ten dele bevrijdt van een wettelijke verplichting tot schadevergoeding;

g. dat een de wederpartij volgens de wet toekomende bevoegdheid tot verrekening uitsluit of beperkt of de gebruiker een verdergaande bevoegdheid tot verrekening verleent dan hem volgens de wet toekomt;

$h$. dat als sanctie op bepaalde gedragingen van de wederpartij, nalaten daaronder begrepen, vervall stelt van haar toekomende rechten of van de bevoegdheid bepaalde verweren te voeren, behoudens voor zover deze gedragingen het verval van die rechten of verweren rechtvaardigen; 
$i$. dat voor het geval de overeenkomst wordt beëindigd anders dan op grond van het feit dat de wederpartij in de nakoming van haar verbintenis is tekort geschoten, de wederpartij verplicht een geldsom te betalen, behoudens voor zover het betreft een redelijke vergoeding voor door de gebruiker geleden verlies of gederfde winst;

$j$. dat de wederpartij verplicht tot het sluiten van een overeenkomst met de gebruiker of met een derde, tenzij dit, mede gelet op het verband van die overeenkomst met de in dit artikel bedoelde overeenkomst, redelijkerwijze van de wederpartij kan worden gevergd;

$k$. dat voor een overeenkomst als bedoeld in artikel 236 onder $j$ een duur bepaalt van meer dan een jaar, tenzij de wederpartij de bevoegdheid heeft de overeenkomst telkens na een jaar op te zeggen;

l. dat de wederpartij aan een opzegtermijn bindt die langer is dan drie maanden of langer dan de termijn waarop de gebruiker de overeenkomst kan opzeggen;

$m$. dat voor de geldigheid van een door de wederpartij te verrichten verklaring een strengere vorm dan het vereiste van een onderhandse akte stelt;

$n$. dat bepaalt dat een door de wederpartij verleende volmacht onherroepelijk is of niet eindigt door haar dood of ondercuratelestelling, tenzij de volmacht strekt tot levering van een registergoed.

Art. 238. Bij een overeenkomst als bedoeld in de artikelen 236 en 237, kan jegens de wederpartij geen beroep worden gedaan

$a$. op het feit dat de overeenkomst in naam van een derde is gesloten, indien dit beroep berust op het enkele feit dat een beding van deze strekking in de algemene voorwaarden voorkomt;

$b$. op het feit dat de algemene voorwaarden beperkingen bevatten van de bevoegdheid van een gevolmachtigde van de gebruiker, die zo ongebruikelijk zijn dat de wederpartij ze zonder het beding niet behoefde te verwachten, tenzij zij ze kende.

Art. 239. - 1. Bij algemene maatregel van bestuur kunnen de onderdelen $a-n$ van artikel 237 worden gewijzigd en kan hun toepassingsgebied worden beperkt.

- 2. Alvorens een voordracht tot vaststelling, wijziging of intrekking van een matregel als bedoeld in het eerste lid te doen, hoort Onze Minister van Justitie de naar zijn oordeel representatieve organisaties van hen die bij het sluiten van de overeenkomsten waarop de maatregel betrekking heeft, algemene voorwaarden plegen te gebruiken en van hen die bij die overeenkomsten als hun wederpartij plegen op te treden.

- 3. Een besluit als in het eerste lid bedoeld wordt zodra het is vastgesteld toegezonden aan de voorzitters van de beide Kamers van de Staten-Generaal. 
Een dergelijk besluit treedt niet in werking dan nadat twee maanden zijn verstreken sinds de datum van uitgifte van het Staatsblad waarin het is geplaatst.

Art. 240. - 1. Op vordering van een rechtspersoon als bedoeld in lid 3 kunnen bepaalde bedingen in bepaalde algemene voorwaarden onredelijk bezwarend worden verklaard: de artikelen 233 onder $a, 236$ en 237 zijn van overeenkomstige toepassing. Voor de toepassing van de vorige zin wordt een beding in algemene voorwaarden dat in strijd is met een dwingende wetsbepaling, als onredelijk bezwarend aangemerkt.

-2. De vordering kan worden ingesteld tegen de gebruiker, alsmede tegen een rechtspersoon met volledige rechtsbevoegdheid die ten doel heeft de behartiging van belangen van personen die een beroep of bedrijf uitoefenen, indien hij het gebruik van de algemene voorwaarden door die personen bevordert.

-3. De vordering komt toe aan rechtspersonen met volledige rechtsbevoegdheid die ten doel hebben de behartiging van belangen van personen die een beroep of bedrijf uitoefenen of van eindgebruikers van niet voor een beroep of bedrijf bestemde goederen of diensten. $Z$ ij kan slechts betrekking hebben op algemene voorwaarden die worden gebruikt of bestemd zijn te worden gebruikt in overeenkomsten met personen wier belangen door de rechtspersoon worden behartigd.

- 4. De eiser is niet ontvankelijk indien niet blijkt dat hij, alvorens de vordering in te stellen, de gebruiker of, in het geval bedoeld in artikel 1003 van het Wetboek van Burgerlijke Rechtsvordering, de aldaar bedoelde vereniging, de gelegenheid heeft geboden om in onderling overleg de algemene voorwaarden zodanig te wijzigen dat de bezwaren die grond voor de vordering zouden opleveren, zijn weggenomen. Een termijn van zes maanden na schriftelijke kennisgeving van de bezwaren is daartoe in elk geval voldoende.

- 5. Voor zover een rechtspersoon met het gebruik van bedingen in algemene voorwaarden heeft ingestemd, komt hem geen vordering als bedoeld in lid 1 toe.

Art. 241. - 1. Het Gerechtshof te 's-Gravenhage is bij uitsluiting bevoegd tot kennisneming van vorderingen als in het vorige artikel bedoeld.

- 2. De in het vorige artikel bedoelde rechtspersonen hebben de bevoegdheden, geregeld in de artikelen 285 en 376 van het Wetboek van Burgerlijke Rechtsvordering; artikel 379 van dat wetboek is niet van toepassing.

- 3. Op vordering van de eiser kan aan de uitspraak worden verbonden

$a$. een verbod van het gebruik van de door de uitspraak getroffen bedingen of van het bevorderen daarvan;

$b$. een gebod om een aanbeveling tot het gebruik van deze bedingen te herroepen; 
c. een veroordeling tot het openbaar maken of laten openbaar maken van de unitspraak, zulks op door de rechter te bepalen wijze en op kosten van de door de rechter aan te geven partij of partijen.

- 4. De rechter kan in zijn uitspraak aangeven op welke wijze het onredelijk bezwarend karakter van de bedingen warop de uitspraak betrekking heeft, kan worden weggenomen.

- 5. Geschillen terzake van de tenuitvoerlegging van de in lid 3 bedoelde veroordelingen, alsmede van de veroordeling tot betaling van een dwangsom, zo deze is opgelegd, worden bij uitsluiting door het Gerechtshof te 's-Gravenhage beslist.

Art. 242. - 1. Op vordering van een of meer van degenen tegen wie de in artikel 240 lid 1 bedoelde uitspraak is gedaan, kan de rechter die uitspraak wijzigen of opheffen op grond dat zij tengevolge van een wijziging in de omstandigheden niet langer gerechtvaardigd is. De vordering wordt ingesteld tegen de rechtspersoon op wiens vordering de uitspraak was gedaan.

- 2. Indien de rechtspersoon op wiens vordering de uitspraak was gedaan, is ontbonden wordt de zaak met een verzoekschrift ingeleid. Voor de toepassing van artikel $429 f 1$ id 1 van het Wetboek van Burgerlijke Rectsvordering worden rechtspersonen als bedoeld in artikel 240 lid 3 als belanghebbenden aangemerkt.

- 3. Artikel 241 leden $1,2,3$ onder $c$ en 5 is van overeenkomstige toepassing.

- 4. De vorige leden zijn niet van toepassing voor zover de uitspraak betrekking had op een beding dat door de wet als onredelijk bezwarend wordt aangemerkt.

Art. 243. Een beding in algemene voorwaarden dat door degene jegens wie een verbod tot gebruik ervan is uitgesproken, in strijd met het verbod in een overeenkomst wordt opgenomen, is vernietigbaar. Artikel 235 is van overeenkomstige toepassing.

Art. 244. - 1. Een persoon die handelt in de uitoefening van een beroep of bedrijf, kan geen beroep doen op een beding in een overeenkomst met een partij die terzake van de goederen of diensten waarop die overeenkomst betrekking heeft, met gebruikmaking van algemene voorwaarden overeenkomsten met haar afnemers heeft gesloten, voor zover een beroep op dat beding onredelijk zou zijn wegens zijn nauwe samenhang met een in de algemene voorwaarden voorkomend beding dat krachtens deze afdeling is vernietigd of door een uitspraak als bedoeld in artikel 240 lid 1 is getroffen.

- 2. Is tegen de gebruiker een vordering als bedoeld in artikel 240 lid 1 ingesteld, dan is hij bevoegd die persoon in het geding te roepen teneinde voor recht te horen verklaren dat een beroep als bedoeld in het vorige lid onredelijk zou zijn. Artikel 241 leden 2,3 onder $c, 4$ en 5 alsmede de artikellen 68,69 en 73 
van het Wetboek van Burgerlijke Rechtsvordering zijn van overeenkomstige toepassing.

-3. Op de uitspraak is artikel 242 van overeenkomstige toepassing.

- 4. Op eerdere overeenkomsten met betrekking tot de voormelde goederen en diensten zljn de leden 1-3 van overeenkomstige toepassing.

Art. 245. Dexe afdeling is noch van toepassing op arbeidsovereenkomsten, noch op collectieve arbeidsovereenkomsten.

Art. 246. Noch van de artikelen 231-244, noch van de bepalingen van de in artikel 239 lid 1 bedoelde algemene maatregelen van bestuur kan worden afgeweken. De bevoegdheid om een beding krachtens deze afdeling door een buitengerechtelijke verklaring te vernietigen, kan niet worden uitgesloten.

Art. 247. - 1. Op overeenkomsten tussen partijen die handelen in de uitoefening van een beroep of bedrijf en die beide in Nederland gevestigd zijn, is deze afdeling van toepassing, ongeacht het recht dat de overeenkomst beheerst.

- 2. Op overeenkomsten tussen partijen die handelen in de uitoefening van een beroep of bedrijf en die niet beide in Nederland gevestigd zijn, is deze afdeling niet van toepassing, ongeacht het recht dat de overeenkomst beheerst.

- 3. Een partij is in de zin van de leden 1 en 2 in Nederland gevestigd, indien haar hoofdvestiging, of, zo de prestatie volgens de overeenkomst door een andere vestiging dan de hoofdvestiging moet worden verricht, deze andere vestiging zich in Nederland bevindt.

- 4. Op overeenkomsten tussen een gebruiker en een wederpartij, natuurlijk persoon, die niet handelt in de uitoefening van een beroep of bedrijf, is, indien de wederpartij haar gewone verblijfplaats in Nederland heeft, deze afdeling van toepassing, ongeacht het recht dat de overeenkomst beheerst.

\section{Wetboek van burgerlijke rechtsvordering}

Art, 4. $-13^{\circ}$. Ten aanzien van hen die algemene voorwaarden gebruiken waarin onredelijk bezwarende bedingen voorkomen, indien ingevolge het bepaalde in artikel 1003 onder $\mathbb{1}^{\circ}$ hun naam en woonplaats niet afzonderlijk in het exploit worden vermeld, aan de persoon of in het parket van de procureur-generaal bij het gerecht wwar de zaak aanhangig wordt gemaakt, is of laatstelijk was, terwijl een uittreksel van het exploit ten spoedigste zal worden bekend gemaakt in een landelijk dagblad onder vermelding van de naam en het adres van de deurwaarder of van de advocaat van wie afschrift van het exploit verkregen kan worden. 
Art. 9. - 3. In het geval in artikel 4 onder $13^{\circ}$ uitgedrukt, zal de termijn van de dagvaarding zijn tenminste een maand.

Art. 1003. Bij vorderingen als bedoeld in de artikelen 240 en 242 van Boek 6 van het Burgerlijk Wetboek kan als volgt worden afgeweken van het bepaalde in artikel 5, eerste lid:

$1^{\circ}$ Een exploit dat bestemd is zowel voor een vereniging die ten doel heeft de behartiging van belangen van personen die een beroep of bedrijf uitoefenen, alsook voor de leden van deze vereniging, alsmede een exploit dat bestemd is voor de gewezen leden van een in eerste aanleg mede-gedagvaarde, doch inmiddels ontbonden vereniging als hiervoor bedoeld, behoeft de naam en de woonplaats van deze leden of gewezen leden niet afzonderlijk te vermelden.

$2^{\circ}$ Een exploit dat wordt uitgebracht zowel ten verzoeke van een vereniging die ten doel heeft de behartiging van belangen van personen die een beroep of bedrijf uitoefenen, alsook ten verzoeke van de leden van deze vereniging, alsmede een exploit dat wordt uitgebracht ten verzoeke van de gewezen leden van een in eerste aanleg mede-gedagvaarde, doch inmiddels ontbonden vereniging als hiervoor bedoeld, behoeft de voornaam, de naam en de woonplaats van deze leden of gewezen leden niet afzonderlijk te vermelden.

Art. 1004. Een verzoekschrift als bedoeld in artikel 242, tweede lid, van Boek 6 van het Burgerlijk Wetboek, dat wordt ingediend namens of mede namens de leden van een vereniging die ten doel heeft de behartiging van belangen van personen die een beroep of bedrijf uitoefenen, dan wel namens of mede namens de gewezen leden van een in eerste aanleg mede-gedagvaarde, doch inmiddels ontbonden vereniging als hiervoor bedoeld, behoeft, in afwijking van het bepaalde in artikel $429 d$, de voornamen, de naam en de woonplaats of het werkelijke verblijf van deze verzoekers niet afzonderlijk te vermelden.

Art. 1005. In geval van een vordering als bedoeld in artikel 240 van Boek 6 van het Burgerlijk Wetboek gelden, indien de in artikel 1003 onder $1^{\circ}$ bedoelde gegevens niet in het exploit worden vermeld, naast het bepaalde in artikel 4 onder $13^{\circ}$ en artikel 9 , derde lid, de navolgende bijzondere voorzieningen:

$1^{\circ}$ Indien de vereniging of tenminste een van haar leden, dan wel tenminste een der gewezen leden van de ontbonden vereniging verschijnt, is artikel 79, eerste lid, niet van toepassing.

$2^{\circ}$ Het beroep in cassatie kan slechts worden ingesteld door degenen die in eerste aanleg verschenen zijn.

Art. 1006. Bovendien gelden ingeval van een vordering of verzoek als bedoeld in de artikelen 240 en 242 van Boek 6 van het Burgerlijk Wetboek, indien de in 
de artikelen 1003 en 1004 bedoelde gegevens niet in het exploit of in het verzoekschrift werden vermeld, de navolgende bijzondere voorzieningen:

$1^{\circ}$ De artikelen 56 en 57 , alsmede artikel $429 k$, tweede lid, laatste volzin, worden toegepast als vormden de hiervoor bedoelde vereniging en haar leden, onderscheidenlijk de gewezen leden van een ontbonden vereniging, tezamen én partij. Niet verschenen leden of gewezen leden worden niet in de kosten van het geding verwezen.

$2^{\circ}$ Op vordering onderscheidenlijk verzoek van ieder der partijen kan de rechter, indien gerede twijfel bestaat of de wederpartij voor de proceskosten voldoende verhaal zal bieden, in elk stadium van de procedure bevelen dat terzake van de betaling der proceskosten zekerheid wordt gesteld.

\section{Overgangswet NBW}

Art. 191. - 1. Afdeling 3 van titel 5 van Boek 6 is op algemene voorwaarden die op het tijdstip van het inwerkingtreden van deze wet reeds door een partij in haar overeenkomsten worden gebruikt, van toepassing nadat een jaar na dit tijdstip is verstreken. Gedurende die termijn is de wet evenmin van toepassing op wijzigingen in die voorwaarden na het in werking treden van de wet.

- 2. In afwijking van artikel $79 \mathrm{kan}$ een beding in algemene voorwaarden deel uitmakend van een overeenkomst, na het verstrijken van het in lid 1 bedoelde tijdvak overeenkomstig afdeling 3 van titel 5 van Boek 6 worden vernietigd; deze vernietiging heeft evenwel geen werking over het tijdvak voordat die afdeling van toepassing is geworden, tenzij het beding toen reeds vernietigbaar of nietig was. 


\title{
Gesetz zur Regelung des Rechts der Allge- meinen Geschäftsbedingungen (AGB-Ge- setz) vom 9. 12. 1976 (BGBl. I 3317)
}

\author{
Erster Abschnitt. Sachlich-rechtliche Vorschriften
}

\section{Unterabschnitt. Allgemeine Vorschriften}

\section{Begriffsbestimmung}

(1) Allgemeine Geschäftsbedingungen sind alle für eine Vielzahl von Verträgen vorformulierten Vertragsbedingungen, die eine Vertragspartei (Verwender) der anderen Vertragspartei bei Abschluß eines Vertrages stellt. Gleichgültig ist, ob die Bestimmungen einen äußerlich gesonderten Bestandteil des Vertrages bilden oder in die Vertragsurkunde selbst aufgenommen werden, welchen Umfang sie haben, in welcher Schriftart sie verfaßt sind und welche Form der Vertrag hat.

(2) Allgemeine Geschäftsbedingungen liegen nicht vor, soweit die Vertragsbedingungen zwischen den Vertragsparteien im einzelnen ausgehandelt sind.

\section{\$2. Einbeziehung in den Vertrag}

(1) Allgemeine Geschäftsbedingungen werden nur dann Bestandteil eines Vertrages, wenn der Verwender bei Vertragsabschluß

1. die andere Vertragspartei ausdrücklich oder, wenn ein ausdrücklicher Hinweis wegen der Art des Vertragsabschlusses nur unter unverhältnismäßigen Schwierigkeiten möglich ist, durch deutlich sichtbaren Aushang am Ort des Vertragsabschlusses auf sie hinweist und

2. der anderen Vertragspartei die Möglichkeit verschafft, in zumutbarer Weise von ihrem Inhalt Kenntnis zu nehmen, und wenn die andere Vertragspartei mit ihrer Geltung einverstanden ist.

(2) Die Vertragsparteien können für eine bestimmte Art von Rechtsgeschäften die Geltung bestimmter Allgemeiner Geschäftsbedingungen unter Beachtung der in Absatz I bezeichneten Erfordernisse im voraus vereinbaren. 


\section{3. Überraschende Klauseln}

Bestimmungen in Allgemeinen Geschäftsbedingungen, die nach den Umständen, insbesondere nach dem äußeren Erscheinungsbild des Vertrags, so ungewöhnlich sind, daß der Vertragspartner des Verwenders mit ihnen nicht zu rechnen braucht, werden nicht Vertragsbestandteil.

\section{Vorrang der Individualabrede}

Individuelle Vertragsabreden haben Vorrang vor Allgemeinen Geschäftsbedingungen.

\section{\&. Unklarheitenregel}

Zweifel bei der Auslegung Allgemeiner Geschäftsbedingungen gehen zu Lasten des Verwenders.

\section{Rechtsfolgen bei Nichteinbexiehung und Unwirksamkeit}

(1) Sind Allgemeine Geschäftsbedingungen ganz oder teilweise nicht Vertragsbestandteil geworden oder unwirksam, so bleibt der Vertrag im übrigen wirksam.

(2) Soweit die Bestimmungen nicht Vertragsbestandteil geworden oder unwirksam sind, richtet sich der Inhalt des Vertrages nach den gesetzlichen Vorschriften.

(3) Der Vertrag ist unwirksam, wenn das Festhalten an ihm auch unter Berücksichtigung der nach Absatz 2 vorgesehenen Änderung eine unzumutbare Härte für eine Vertragspartei darstellen würde.

\section{Umgehungsverbot}

Dieses Gesetz findet auch Anwendung, wenn seine Vorschriften durch anderweitige Gestaltungen umgangen werden.

\section{Unterahschnitt. Unwirksame Klauseln}

\section{8. Schranken der Inhaltskontrolle}

Die $\$ \S 9$ bis 11 gelten nur für Bestimmungen in Allgemeinen Geschäftsbedingungen, durch die von Rechtsvorschriften abweichende oder diese ergänzende Regelungen vereinbart werden.

\section{Generalklausel}

(1) Bestimmungen in Allgemeinen Geschäftsbedingungen sind unwirksam, wenn sie den Vertragspartner des Verwenders entgegen den Geboten von Treu und Glauben unangemessen benachteiligen. 
(2) Eine unangemessene Benachteiligung ist im Zweifel anzunehmen, wenn eine Bestimmung

1. mit wesentlichen Grundgedanken der gesetzlichen Regelung, von der abgewichen wird, nicht zu vereinbaren ist, oder

2. wesentliche Rechte oder Pflichten, die sich aus der Natur des Vertrages ergeben, so einschränkt, daß die Erreichung des Vertragszwecks gefährdet ist.

\section{\$10. Klauselverbote mit Wertungsmöglichkeit}

In Allgemeinen Geschăftsbedingungen ist insbesondere unwirksam

1. (Annahme- und Leistungsfrist)

eine Bestimmung, durch die sich der Verwender unangemessen lange oder nicht hinreichend bestimmte Fristen für die Annahme oder Ablehnung eines Angebots oder die Erbringung einer Leistung vorbehält;

\section{2. (Nachfrist)}

eine Bestimmung, durch die sich der Verwender für die von ihm zu bewirkende Leistung entgegen $\$ 326$ Abs. 1 des Bürgerlichen Gesetzbuchs eine unangemessen lange oder nicht hinreichend bestimmte Nachfrist vorbehält;

\section{3. (Rücktrittsvorbehalt)}

die Vereinbarung eines Rechts des Verwenders, sich ohne sachlich gerechtfertigten und im Vertrag angegebenen Grund von seiner Leistungspflicht zu lösen; dies gilt nicht für Dauerschuldverhältnisse;

\section{4. (Änderungsvorbehalt)}

die Vereinbarung eines Rechts des Verwenders, die versprochene Leistung zu ändern oder von ihr abzuweichen, wenn nicht die Vereinbarung der Änderung oder Abweichung unter Berücksichtigung der Interessen des Verwenders für den anderen Vertragsteil zumutbar ist;

\section{5. (Fingierte Erklärungen)}

eine Bestimmung, wonach eine Erklärung des Vertragspartners des Verwenders bei Vornahme oder Unterlassung einer bestimmten Handlung als von ihm abgegeben oder nicht abgegeben gilt, es sei denn, daß

a) dem Vertragspartner eine angemessene Frist zur Abgabe einer ausdrücklichen Erklärung eingeräumt ist und

b) der Verwender sich verpflichtet, den Vertragspartner bei Beginn der Frist auf die vorgesehene Bedeutung seines Verhaltens besonders hinzuweisen 


\section{6. (Fiktion des Zugangs)}

eine Bestimmung, die vorsieht, daß eine Erklärung des Verwenders von besonderer Bedeutung dem anderen Vertragsteil als zugegangen gilt;

\section{7. (Abwicklung von Verträgen)}

eine Bestimmung, nach der der Verwender für den Fall, daß eine Vertragspartei vom Vertrage zurücktritt oder den Vertrag kündigt,

a) eine unangemessen hohe Vergütung für die Nutzung oder den Gebrauch einer Sache oder eines Rechts oder für erbrachte Leistungen oder

b) einen unangemessen hohen Ersatz von Aufwendungen verlangen kann;

\section{8 (Rechtswahl)}

die Vereinbarung der Geltung auslandischen Rechts oder des Rechts der Deutschen Demokratischen Republik in Fallen, in denen hierfur kein anerkennenswertes Interesse besteht. (Aufgehoben)

\section{Klauselverbote ohne Wertungsmöglichkeit}

In Allgemeinen Geschäftsbedingungen ist unwirksam

\section{1. (Kurzfristige Preiserhöhungen)}

eine Bestimmung, welche die Erhöhung des Entgelts für Waren oder Leistungen vorsieht, die innerhalb von vier Monaten nach Vertragsabschluß geliefert oder erbracht werden sollen; dies gilt nicht bei Waren oder Leistungen, die im Rahmen von Dauerschuldverhältnissen geliefert oder erbracht werden;

\section{2. (Leistungsverweigerungsrechte)}

eine Bestimmung, durch die

a) das Leistungsverweigerungsrecht, das dem Vertragspartner des Verwenders nach $\$ 320$ des Bürgerlichen Gesetzbuchs zusteht, ausgeschlossen oder eingeschränkt wird, oder

b) ein dem Vertragspartner des Verwenders zustehendes Zurückbehaltungsrecht, soweit es auf demselben Vertragsverhältnis beruht, ausgeschlossen oder eingeschränkt, insbesondere von der Anerkennung von Mängeln durch den Verwender abhängig gemacht wird;

\section{3. (Aufrechnungsverbot)}

eine Bestimmung, durch die dem Vertragspartner des Verwenders die Befugnis genommen wird, mit einer unbestrittenen oder rechtskrăftig festgesteliten Forderung aufzurechnen; 


\section{4. (Mahnung, Fristsetzung)}

eine Bestimmung, durch die der Verwender von der gesetzlichen Obliegenheit freigestellt wird, den anderen Vertragsteil zu mahnen oder ihm eine Nachfrist zu setzen;

\section{5. (Pauschalierung von Schadensersatzansprüchen)}

die Vereinbarung eines pauschalierten Anspruchs des Verwenders auf Schadensersatz oder Ersatz einer Wertminderung, wenn

a) die Pauschale den in den geregelten Fällen nach dem gewöhnlichen Lauf der Dinge zu erwartenden Schaden oder die gewöhnlich eintretende Wertminderung übersteigt, oder

b) dem anderen Vertragsteil der Nachweis abgeschnitten wird, ein Schaden oder eine Wertminderung sei überhaupt nicht entstanden oder wesentlich niedriger als die Pauschale;

\section{6. (Vertragsstrafe)}

eine Bestimmung, durch die dem Verwender für den Fall der Nichtabnahme oder verspäteten Abnahme der Leistung, des Zahllungsverzugs oder für den Fall, daß der andere Vertragsteil sich vom Vertrag löst, Zahlung einer Vertragsstrafe versprochen wird;

\section{7. (Haftung bei grobem Verschulden)}

ein Ausschluß oder eine Begrenzung der Haftung für einen Schaden, der auf einer grob fahrlässigen Vertragsverletzung des Verwenders oder auf einer vorsätzlichen oder grob fahrlässigen Vertragsverletzung eines gesetzlichen Vertreters oder Erfüllungsgehilfen des Verwenders beruht; dies gilt auch für Schäden aus der Verletzung von Pflichten bei den Vertragsverhandlungen;

\section{8. (Verzug, Unmöglichkeit)}

eine Bestimmung, durch die für den Fall des Leistungsverzugs des Verwenders oder der von ihm zu vertretenden Unmöglichkeit der Leistung

a) das Recht des anderen Vertragsteils, sich vom Vertrag zu lösen, ausgeschlossen oder eingeschränkt oder

b) das Recht des anderen Vertragsteils, Schadensersatz zu verlangen, ausgeschlossen oder entgegen Nummer 7 eingeschränkt wird;

\section{9. (Teilverzug, Teilunmöglichkeit)}

eine Bestimmung, die für den Fall des teilweisen Leistungsverzugs des Verwenders oder bei von ihm zu vertretender teilweiser Unmöglichkeit der Leistung das Recht der anderen Vertragspartei ausschließt, Schadensersatz wegen Nichterfüllung der ganzen Verbindlichkeit zu verlangen oder von dem ganzen Vertrag 
zurückzutreten, wenn die teilweise Erfüllung des Vertrages für ihn kein Interesse hat;

\section{0. (Gewährieistung)}

eine Bestimmung, durch die bei Verträgen über Lieferungen neu hergestellter Sachen und Leistungen

a) (Ausschluh und Verweisung auf Dritte)

die Gewährleistungsansprüche gegen den Verwender einschließlich etwaiger Nachbesserungs- und Ersatzlieferungsansprüche insgesamt oder bezüglich einzelner Telle ausgeschlossen, auf die Einrăumung von Ansprüchen gegen Dritte beschränkt oder von der vorherigen gerichtlichen Inanspruchnahme Dritter abhängig gemacht werden;

b) (Beschränkung auf Nachbesserung)

die Gewährleistungsansprüche gegen den Verwender insgesamt oder bezüglich einzelner Teile auf ein Recht auf Nachbesserung oder Ersatzlieferung beschränkt werden, sofern dem anderen Vertragsteil nicht ausdrücklich das Recht vorbehalten wird, bei Fehlschlagen der Nachbesserung oder Ersatzlieferung Herabsetzung der Vergütung oder, wenn nicht eine Bauleistung Gegenstand der Gewăhrleistung ist, nach seiner Wahl Rückgängigmachung des Vertrages zu verlangen;

c) (Aufwendungen bei Nachbesserung)

die Verpflichtung des gewährleistungspflichtigen Verwenders ausgeschlossen oder beschränkt wird, die Aufwendungen zu tragen, die zum Zweck der Nachbesserung erforderlich werden, insbesondere Transport-, Wege-, Arbeits-und Materialkosten:

d) (Vorenthalten der Mängelbeseitigung)

der Verwender die Beseitigung eines Mangels oder die Ersatzlieferung einer mangelfreien Sache von der vorherigen Zahlung des vollstandigen Entgelts oder eines unter Berūcksichtigung des Mangels unverhältnismäBig hohen Teils des Entgelts abhängig macht;

e) (Ausschlußfrist für Măngelanzeige)

der Verwender dem anderen Vertragsteil für die Anzeige nicht offensichtlicher Mängel eine Ausschlußfrist setzt, die kürzer ist als die Verjährungsfrist für den gesetzlichen Gewährleistungsanspruch;

f) (Verkürzung von Gewährleistungsfristen)

die gesetzlichen Gewährleistungsfristen verkürzt werden;

\section{1. (Haftung für zugesicherte Eigenschaften)}

eine Bestimmung, durch die bei einem Kauf- Werk- oder Werklieferungsvertrag Schadensersatzansprüche gegen den Verwender nach den $\$ \$ 463,480$ Abs. $2, \$$ 
635 des Bürgerlichen Gesetzbuchs wegen Fehlens zugesicherter Eigenschaften ausgeschlossen oder eingeschränkt werden;

12. (Laufzeit bei Dauerschuldverhältnissen)

bei einem Vertragsverhältnis, das die regelmäßige Lieferung von Waren oder die regelmäßige Erbringung von Dienst- oder Werkleistungen durch den Verwender zum Gegenstand hat,

a) eine den anderen Vertragsteil länger als zwei Jahre bindende Laufzeit des Vertrags,

b) eine den anderen Vertragsteil bindende stillschweigende Verlängerung des Vertragsverhältnisses um jeweils mehr als ein Jahr oder

c) zu Lasten des anderen Vertragsteils eine längere Kündigungsfrist als drei Monate vor Ablauf der zunächst vorgesehenen oder stillschweigend verlängerten Vertragsdauer;

\section{3. (Wechsel des Vertragspartners)}

eine Bestimmung, wonach bei Kauf-, Dienst- oder Werkverträgen ein Dritter an Stelle des Verwenders in die sich aus dem Vertrag ergebenden Rechte und Pflichten eintritt oder eintreten kann, es sei denn, in der Bestimmung wird

a) der Dritte namentlich bezeichnet, oder

b) dem anderen Vertragsteil das Recht eingeräumt, sich vom Vertrag zu lösen;

14. (Haftung des Abschlußvertreters)

eine Bestimmung, durch die der Verwender einem Vertreter, der den Vertrag für den anderen Vertragsteil abschließt,

a) ohne hierauf gerichtete ausdrückliche und gesonderte Erklärung eine eigene Haftung oder Einstandspflicht oder

b) im Falle vollmachtsloser Vertretung eine über $\$ 179$ des Bürgerlichen Gesetzbuchs hinausgehende Haftung

auferlegt;

\section{5. (Beweislast)}

eine Bestimmung, durch die der Verwender die Beweislast zum Nachteil des anderen Vertragsteils ändert, insbesondere indem er

a) diesem die Beweislast für Umstände auferlegt, die im Verantwortungsbereich des Verwenders liegen;

b) den anderen Vertragsteil bestimmte Tatsachen bestätigen läßt.

Buchstabe $b$ gilt nicht für gesondert unterschriebene Empfangsbekenntnisse; 
16. (Form von Anzeigen und Erklärungen)

eine Bestimmung, durch die Anzeigen oder Erklärungen, die dem Verwender oder einem Dritten gegenüber abzugeben sind, an eine strengere Form als die Schriftform oder an besondere Zugangserfordernisse gebunden werden.

\section{Zweiter Abschnitt. Kollisionsrecht}

\section{12. Zwischenstaatlicher Geltungsbereich}

Unterliegt ein Vertrag ausländischem Recht oder dem Recht der Deutschen Demokratischen Republik, so sind die Vorschriften dieses Gesetzes gleichwohl zu berücksichtigen, wenn

1. der Vertrag auf Grund eines öffentlichen Angebots, einer öffentlichen Werbung oder einer ähnlichen im Geltungsbereich dieses Gesetzes entfalteten geschäftlichen Tătigkeit des Verwenders zustande kommt und

2. der andere Vertragsteil bei Abgabe seiner auf den Vertragsschluß gerichteten Erklärung seinen Wohnsitz oder gewöhnlichen Aufenthalt im Geltungsbereich dieses Gesetzes hat und seine Willenserklärung im Geltungsbereich dieses Gesetzes abgibt.

\section{Dritter Abschnitt. Verfahren}

\section{\& 13. Unterlassungs- und Widerrufsanspruch}

(1) Wer in Allgemeinen Geschäftsbedingungen Bestimmungen, die nach $\$ \$ 9$ bis 11 dieses Gesetzes unwirksam sind, verwendet oder für den rechtsgeschäftlichen Verkehr empfiehlt, kann auf Unterlassung und im Fall des Empfehlens auch auf Widerruf in Anspruch genommen werden.

(2) Die Ansprüche auf Unterlassung und auf Widerruf können nur geltend gemacht werden

1. von rechtsfähigen Verbänden, zu deren satzungsgemäßen Aufgaben es gehört, die Interessen der Verbraucher durch Aufklärung und Beratung wahrzunehmen, wenn sie in diesem Aufgabenbereich tatige Verbände oder mindestens fünfundsiebzig natürliche Personen als Mitglieder haben,

2. von rechtsfähigen Verbänden zur Förderung gewerblicher Interessen oder

3. von den Industrie- und Handelskammern oder den Handwerkskammern.

(3) Die in Absatz $2 \mathrm{Nr} .1$ bezeichneten Verbände können Ansprüche auf Unterlassung und auf Widerruf nicht geltend machen, wenn Allgemeine Geschäftsbedingungen gegenüber einem Kaufmann verwendet werden und der Vertrag zum Betriebe seines Handelsgewerbes gehört oder wenn Allgemeine 
Geschäftsbedingungen zur ausschließlichen Verwendung zwischen Kaufleuten empfohlen werden.

(4) Die Ansprüche nach Abs. 1 verjähren in zwei Jahren von dem Zeitpunkt an, in welchem der Anspruchsberechtigte von der Verwendung oder Empfehlung der unwirksamen Allgemeinen Geschäftsbedingungen Kenntnis erlangt hat, ohne Rücksicht auf diese Kenntnis in vier Jahren von der jeweiligen Verwendung oder Empfehlung an.

\section{Zuständigkeit}

(1) Für Klagen nach $\$ 13$ dieses Gesetzes ist das Landgericht ausschließlich zuständig, in dessen Bezirk der Beklagte seine gewerbliche Niederlassung oder in Ermangelung einer solchen seinen Wohnsitz hat. Hat der BekJagte im Inland weder eine gewerbliche Niederlassung noch einen Wohnsitz, so ist das Gericht des inlandischen Aufenthaltsorts zuständig, in Ermangelung eines solchen das Gericht, in dessen Bezirk die nach $\$ \S 9$ bis 11 dieses Gesetzes unwirksamen Bestimmungen in Allgemeinen Geschäftsbedingungen verwendet wurden.

(2) Die Landesregierungen werden ermächtigt, zur sachdienlichen Förderung oder schnelleren Erledigung der Verfahren durch Rechtsverordnung einem Landgericht für die Bezirke mehrerer Landgerichte Rechtsstreitigkeiten nach diesem Gesetz zuzuweisen. Die Landesregierungen können die Ermächtigung durch Rechtsverordnung auf die Landesjustizverwaltungen übertragen.

(3) Die Parteien können sich vor den nach Absatz 2 bestimmten Gerichten auch durch Rechtsanwälte vertreten lassen, die bei dem Gericht zugelassen sind, vor das der Rechtsstreit ohne die Regelung nach Absatz 2 gehören würde.

(4) Die Mehrkosten die einer Partei dadurch erwachsen, daß sie sich nach Absatz 3 durch einen nicht beim Prozeßgericht zugelassenen Rechtsanwalt vertreten läßt, sind nicht zu erstatten.

\section{\$15. Verfahren}

(1) Auf das Verfahren sind die Vorschriften der Zivilprozeßordnung anzuwenden, soweit sich aus diesem Gesetz nicht etwas anderes ergibt.

(2) Der Klageantrag muß auch enthalten:

1. den Wortlaut der beanstandeten Bestimmungen in Allgemeinen Geschäftsbedingungen;

2. die Bezeichnung der Art der Rechtsgeschäfte, für die die Bestimmungen beanstandet werden.

\section{\$16. Anhörung}

Das Gericht hat vor der Entscheidung über eine Klage nach $\$ 13 \mathrm{zu}$ hören

1. die zuständige Aufsichtsbehörde für das Versicherungswesen, wenn Gegenstand der Klage Bestimmungen in Allgemeinen Geschäftsbedingungen sind, 
die von ihr nach Maßgabe des Versicherungsaufsichtsgesetzes zu genehmigen sind, oder

2. das Bundesaufsichtsamt für das Kreditwesen, wenn Gegenstand der Klage Bestimmungen in Allgemeinen Geschäftsbedingungen sind, die das Bundesaufsichtsamt für das Kreditwesen nach Maßgabe des Gesetzes über Bausparkassen, des Gesetzes über Kapitalanlagegesellschaften, des Hypothekenbankgesetzes oder des Gesetzes über Schiffspfandbriefbanken zu genehmigen hat.

\section{17. Urteilsformel}

Erachtet das Gericht die Klage für begründet so enthält die Urteilsformel auch:

1. die beanstandeten Bestimmungen der Allgemeinen Geschäftsbedingungen im Wortlaut;

2. die Bezeichnung der Art der Rechtsgeschäfte, für die die den Unterlassungsanspruch begründenden Bestimmungen der Allgemeinen Geschäftsbedingungen nicht verwendet werden dürfen;

3. das Gebot, die Verwendung inhaltsgleicher Bestimmungen in Allgemeinen Geschäftsbedingungen zu unterlassen;

4. für den Fall der Verurteilung zum Widerruf das Gebot, das Urteil in gleicher Weise bekanntzugeben, wie die Empfehlung verbreitet wurde.

\section{\$18. Veröffentlichungsbefugnis}

Wird der Klage stattgegeben, so kann dem Kläger auf Antrag die Befugnis zugesprochen werden, die Urteilsformel mit der Bezeichnung des verurteilten Verwenders oder Empfehlers auf Kosten des Beklagten im Bundesanzeiger, im übrigen auf eigene Kosten bekanntzumachen. Das Gericht kann die Befugnis zeitlich begrenzen.

\section{Einwendung bei abweichender Entscheidung}

Der Verwender, dem die Verwendung einer Bestimmung untersagt worden ist, kann im Wege der Klage nach $\$ 767$ ZPO einwenden, daß nachträglich eine Entscheidung des Bundesgerichtshofs oder des Gemeinsamen Senats der Obersten Gerichtshöfe des Bundes ergangen ist, welche die Verwendung dieser Bestimmung für dieselbe Art von Rechtsgeschäften nicht untersagt, und daß die Zwangsvollstreckung aus dem Urteil gegen ihn in unzumutbarer Weise seinen Geschäftsbetrieb beeinträchtigen würde.

\section{\$20. Register}

(1) Das Gericht teilt dem Bundeskartellamt von Amts wegen mit

1. Klagen, die nach $\S 13$ oder $\$ 19$ anhängig werden,

2. Urteile, die im Verfahren nach $\$ 13$ oder nach $\S 19$ ergehen, sobald sie rechtskraftig sind, 
3. die sonstige Erledigung der Klage.

(2) Das Bundeskartellamt führt uber die nach Absatz 1 eingehenden Mitteilungen ein Register.

(3) Die Eintragung ist nach zwanzig Jahren seit dem Schluß des Jahres zu löschen, in dem die Eintragung in das Register erfolgt ist. Die Löschung erfolgt durch Eintragung eines Löschungsvermerks; mit der Löschung der Eintragung einer Klage ist die Löschung der Eintragung ihrer sonstigen Erledigung (Absatz $1 \mathrm{Nr}$. 3) zu verbinden.

(4) Öber eine bestehende Eintragung ist jedermann auf Antrag Auskunft zu erteilen. Die Auskunft enthält folgende Angaben:

1. für Klagen nach Absatz 1 Nr. 1

a) die beklagte Partei,

b) das angerufene Gericht samt Geschäftsnummer,

c) den Klageantrag;

2. für Urteile nach Absatz $\mathbb{N r} .2$

a) die verurteilte Partei,

b) das entscheidende Gericht samt Geschäftsnummer,

c) die Urteilsformel;

3. für die sonstige Erledigung nach Absatz 1 Nr. 3 die Art der Erledigung.

\section{\$21. Wirkungen des Urteils}

Handelt der verurteilte Verwender dem Unterlassungsgebot zuwider, so ist die Bestimmung in den Allgemeinen Geschäftsbedingungen als unwirksam anzusehen, soweit sich der betroffene Vertragsteil auf die Wirkung des Unterlassungsurteils beruft. Er kann sich jedoch auf die Wirkung des Unterlassungsurteils nicht berufen, wenn der verurteilte Verwender gegen das Urteil die Klage nach $\S 19$ erheben könnte.

\section{\$22. Streitwert}

Bei Rechtsstreitigkeiten auf Grund dieses Gesetzes darf der Streitwert nicht über 500000 Deutsche Mark angenommen werden.

\section{Vierter Abschnitt. Anwendungsbereich}

\section{Sachlicher Anwendungsbereich}

(1) Dieses Gesetz findet keine Anwendung bei Verträgen auf dem Gebiet des Arbeits-, Erb-, Familien- und Gesellschaftsrechts.

(2) Keine Anwendung finden ferner

1. $\$ 2$ für die mit Genehmigung der zuständigen Verkehrsbehörde oder aufgrund von internationalen Übereinkommen erlassenen Tarife und Ausführungsbestimmungen der Eisenbahnen und die nach Maßgabe des Personen- 
beförderungsgesetzes genehmigten Beförderungsbedingungen der Straßenbahnen, Obusse und Kraftfahrzeuge im Linienverkehr;

1a. \& 2 für die Geschäfttsbedingungen und Leistungsentgelte der Deutschen

Bundespost, sofern sie im Wortlaut amtlich veröffentlich worden sind und bei den Ämtern des Post- und Fernmeldewesens zur Einsichtnahme bereitgehalten werden;

2. die $\$ \$ 10$ und 11 für Verträge der Elektrizitäts- und der Gasversorgungsunternehmen über die Versorgung von Sonderabnehmern mit elektrischer Energie und mit Gas aus dem Versorgungsnetz, soweit die Versorgungsbedingungen nicht zum Nachteil der Abnehmer von den auf Grund des $\$ 7$ des Energiewirtschaftsgesetzes erlassenen Allgemeinen Bedingungen für die Versorgung mit elektrischer Arbeit aus dem Niederspannungsnetz der Elektrizitätsversorgungsunternehmen und Allgemeinen Bedingungen für die Versorgung mit Gas aus dem Versorgungsnetz der Gasversorgungsunternehmen abweichen;

3. $11 \mathrm{Nr} .7$ und 8 für die nach Maßgabe des Personenbeförderungsgesetzes genehmigten Beförderungsbedingungen und Tarifvorschriften der Straßenbahnen, Obusse und Kraftfahrzeuge im Linienverkehr, soweit sie nicht zum Nachteil des Fahrgastes von der Verordnung über die Allgemeinen Beförderungsbedingungen für den Straßenbahn- und Obusverkehr sowie den Linienverkehr mit Kraftfahrzeugen vom 27. Februar 1970 abweichen;

4. $\$ 11 \mathrm{Nr} .7$ für staatlich genehmigte Lotterieverträge oder Ausspielverträge;

5. $\$ 10 \mathrm{Nr} .5$ und $\$ 11 \mathrm{Nr}$. 10 Buchstabe f für Leistungen, für die die Verdingungsordnung für Bauleistungen (VOB) Vertragsgrundlage ist;

6. $\$ 11 \mathrm{Nr}, 12$ für Verträge über die Lieferung als zusammengehörig verkaufter Sachen, für Versicherungsverträge sowie für Verträge zwischen den Inhabern urheberrechtlicher Rechte und Ansprüche und Verwertungsgesellschaften im Sinne des Gesetzes über die Wahrnehmung von Urheberrechten und verwandten Schutzrechten;

(3) Ein Bausparvertrag, ein Versicherungsvertrag sowie das Rechtsverhältnis zwischen einer Kapitalanlagegesellschaft und einem Anteilinhaber unterliegen den von der zuständigen Behörde genehmigten Allgemeinen Geschäftsbedingungen der Bausparkasse, des Versicherers sowie der Kapitalanlagegesellschaft auch dann, wenn die in $\S 2$ Abs. $\mathbb{1} \mathrm{Nr}$. 1 und 2 bezeichneten Erfordernisse nicht eingehalten sind.

\section{Persönlicher Anwendungsbereich}

Die Vorschriften der $\$ \S 2,10,11$ und 12 finden keine Anwendung auf Allgemeine Geschäftsbedingungen,

1. die gegenüber einem Kaufmann verwendet werden, wenn der Vertrag zum Betriebe seines Handelsgewerbes gehört; 
2. die gegenüber einer juristischen Person des öffentlichen Rechts oder einem öffentlich-rechtlichen Sondervermögen verwendet werden.

$\$ 9$ ist in den Fallen des Satzes 1 auch insoweit anzuwenden, als dies zur Unwirksamkeit von in den $\$ \$ 10$ und 11 genannten Vertragsbestimmungen führt; auf die im Handelsverkehr geltenden Gewohnheiten und Gebrãuche ist angemessen Rücksicht zu nehmen.

\section{Fünfter Abschnitt. Schluf- und Übergangsvorschriften}

\section{\$25. Änderung des Bürgerlichen Gesetzbuchs}

Das Bürgerliche Gesetzbuch wird wie folgt geändert:

1. Nach $\$ 476$ wird folgende Vorschrift eingefügt:

" $476 \mathrm{a}$

Ist an Stelle des Rechts des Käufers auf Wandlung oder Minderung ein Recht auf Nachbesserung vereinbart, so hat der zur Nachbesserung verpflichtete Verkäufer auch die zum Zwecke der Nachbesserung erforderlichen Aufwendungen, insbesondere Transport-, Wege-, Arbeits- und Materialkosten, zu tragen. Dies gilt nicht, soweit die Aufwendungen sich erhöhen, weil die gekaufte Sache nach der Lieferung an einen anderen Ort als den Wohnsitz oder die gewerbliche Niederlassung des Empfăngers verbracht worden ist, es sei denn, das Verbringen entspricht dem bestimmungsgemäßen Gebrauch der Sache."

2. In $\$ 633$ Abs. 2 wird folgender Satz 2 eingefügt:

"\$ 476a gilt entsprechend."

Der bisherige Satz 2 wird Satz 3.

\section{6. Änderung des Energiewirtschaftsgesetzes}

7 des Energiewirtschaftsgesetzes vom 13. Dezember 1935 (Reichsgesetzbl. I S. 1451), zuletzt geändert durch Artikel 18 des Zuständigkeitslockerungsgesetzes vom 10. März 1975 (Bundesgesetzbl. I S. 685), wird wie folgt geändert:

1. In Satz 1 werden die Worte "allgemeine Bedingungen und" gestrichen.

2. Die Sätze I und 2 werden Absatz 1.

3. Es wird folgender Absatz 2 angefügt:

(2) Der Bundesminister für Wirtschaft kann durch Rechtsverordnung mit Zustimmung des Bundesrates die allgemeinen Bedingungen der Energieversorgungsunternehmen ( $\$ 6$ Abs. 1) ausgewogen gestalten. Er kann dabei die Bestimmungen der Verträge einheitlich festsetzen und Regelungen über den Vertragsabschluß, den Gegenstand und die Beendigung der Vertrage treffen sowie die Rechte und Pflichten der Vertragspartner festlegen; hierbei sind die beiderseitigen Interessen angemessen zu berücksichtigen. Die Sätze 1 und 2 gelten entsprechend für Bedingungen öffentlich-rechtlich gestalteter 
Versorgungsverhăltnisse mit Ausnahme der Regelung des Verwaltungsverfahrens."

\section{27. Ermächtigung zum Erlaß von Rechtsverordnungen}

Der Bundesminister für Wirtschaft kann durch Rechtsverordnung mit Zustimmung des Bundesrates die allgemeinen Bedingungen für die Versorgung mit Wasser und Fernwärme ausgewogen gestalten. Er kann dabei die Bestimmungen der Verträge einheitlich festsetzen und Regelungen über den VertragsabschluB, den Gegenstand und die Beendigung der Verträge treffen sowie die Rechte und Pflichten der Vertragspartner festlegen; hierbei sind die beiderseitigen Interessen angemessen zu berücksichtigen. Die Såtze 1 und 2 gelten entsprechend für die Bedingungen öffentlich-rechtlich gestalteter Versorgungsverhältnisse mit Ausnahme der Regelung des Verwaltungsverfahrens.

\section{28. Übergangsvorschrift}

(1) Dieses Gesetz gilt vorbehaltlich des Absatzes 2 nicht für Verträge, die vor seinem Inkrafttreten geschlossen worden sind.

(2) $\$ 9$ gilt auch für vor Inkrafttreten dieses Gesetzes abgeschlossene Verträge über die regelmäßige Lieferung von Waren, die regelmäßige Erbringung von Dienst- oder Werkleistungen sowie die Gebrauchsüberlassung von Sachen, soweit diese Verträge noch nicht abgewickelt sind.

(3) Auf Verträge über die Versorgung mit Wasser und Fernwärme sind die Vorschriften dieses Gesetzes erst drei Jahre nach seinem Inkrafttreten anzuwenden.

\section{§ 29. Berlin-Klausel}

Dieses Gesetz gilt nach Maßgabe des $\S 13$ Abs. 1 des Dritten Überleitungsgesetzes vom 4. Januar 1952 (Bundesgesetzbl. I S. 1) auch im Land Berlin. Rechtsverordnungen die auf Grund dieses Gesetzes erlassen werden, gelten im Land Berlin nach \& 14 des Dritten Überleitungsgesetzes.

\section{\$ 30. Inkrafttreten}

Dieses Gesetz tritt vorbehaltlich des Satzes 2 am 1. April 1977 in Kraft. $\$ 14$ Abs. $2, \$ \$ 26$ und 27 treten am Tage nach der Verkundung in Kraft.

( $823 \mathrm{Nr}$. 1a eingefügt durch Art. 4 Poststrukturgesetz vom 8.6.1989, BGBl. I 1026) 


\section{Rechtspraakregister}

Verwezen wordt naar de paginanummers

\section{Nederland}

\section{Hoge Raad}

HR 26 maart 1920, NJ 1920, 476

HR 13 januari 1938, NJ 1938, 600

HR 3 juni 1938, NJ 1938, 920

HR 14 april 1950 , NJ 1951, 17

HR 11 mei 1951, NJ 1952, 127

HR 11 januari 1957, NJ 1957, 37

HR 15 november 1957, NJ 1958, 67

HR 19 mei 1967, NJ 1967, 261

$3,88,89,94,95$

HR 5 januari 1968, NJ 1968, 102

HR 3 maart 1972, NJ 1973, 339

HR 14 december 1973, NJ 1974, 127 88,95

HR 22 maart 1974, NJ 1974, 265

HR 20 februari 1976, NJ 1976, 486

HR 17 december 1976, NJ 1977, 241

HR 1 juli 1977, NJ 1978, 125

HR 9 december 1977, NJ 1978, 187

HR 13 maart 1981, NJ 1981, 635

HR 20 november 1981, NJ 1982, 517

HR 18 december 1981, NJ 1982, 71

HR 1 juli 1983, NJ 1984, 360

HR 18 november 1983, NJ 1984, 272

HR 20 januari 1984, NJ 1987, 295 
HR 28 sept. 1984, NJ 1985, 83

HR 25 januari 1985, NJ 1985, 559

HR 1 juli 1985, NJ 1986, 692

HR 18 oktober 1985, NJ 1987, 189

HR 25 april 1986, NJ 1986, 714

$3,88,95,96,98,100$

HR 27 juni 1986, NJ 1987, 743

HR 21 november 1986, NJ 1987, 946

$86,87,168$

HR 16 januari 1987, NJ 1987, 553

HR 11 december 1987, NJ 1990, 73 $3,88,95,96$

HR 11 november 1988, NJ 1990, 440 92,186

HR 28 april 1989 , NJ 1990, 583

HR 10 juli 1989 , NJ 1989,840 95,98

HR 3 november 1989, NJ 1991, 168 95,98

HR 23 maart 1990, NJ 1991, 214

HR 20 april 1990, NJ 1990, 676 , $95,96,198$

HR 20 april 1990, NJ 1990, 701 95,98

HR 30 november 1990, NJ 1991, 492 100,340

HR 4 januari 1991, NJ 1991, 254

HR 15 februari 1991, NJ 1991, 538

HR 8 maart 1991, NJ 1991, 396

HR 15 maart 1991, NJ 1991, 416

HR 7 juni 1991, NJ 1991, 525

HR 8 juli 1991, NJ 1991, 691

HR 5 juni 1992, NJ 1992, 565

HR 1 juli 1992, NJ 1993, 450 100,340

HR 9 oktober 1992, NJ 1994, 287

HR 18 december 1992, NJ 1994, 139

HR 1 juli 1993, NJ 1994, 461

HR 17 september 1993, RvdW 1993, 177 $100,340,451$

HR 24 september 1993, RvdW 1993, 186

HR 31 december 1993, RvdW 1994, 21

HR 10 juni 1994, NJ 1994, 611

HR 2 september 1994, TvC 1994, pag. 369

HR 9 september 1994, NJB 1994, pag. 445

\section{Gerechtshoven}

Hof Den Haag 13 april 1993, TvC 1993, pag. $355 \quad 101$

Hof Arnhem 19 oktober 1993, TvC 1994, pag. 27

Hof Arnhem 8 maart 1994, TvC 1994, pag. 128 


\section{Arrondissementsrechtbanken}

Rb. Den Haag 27 maart 1986, TvC 1986, pag. 371

Rb. Den Haag 15 februari 1989, TvC 1989, pag. 76

Pres. Rb. Den Haag 17 aprill 1991, TvC 1991, pag. 312

Pres. Rb. Rotterdam 24 april 1991, KG 1991, 179 


\section{Bundesgerichtshof}

BGHZ 3, 200, 203, NJW 1951, pag. 957

BGHZ 5, 11, 115

BGHZ 9, 1, 3, NJW 1953, pag. 541

BGHZ 17, 1, 3, NJW 1955, pag. 1145

BGHZ 22, 90, 96-98

$348,387,391$

BGHZ 33, 216, 219, NJW 1961, pag. 212

BGHZ 38, 183, 185, NJW 1963, pag. 99

BGHZ $41,151,154$

BGHZ 50, 200, 206f., NJW 1968, pag. 1622

BGH, NJW 1969, pag. 230-232 413

BGHZ 54, 299, NJW 1970, pag. 2208

BGH, NJW 1973, pag. $991 \quad 390$

BGH, NJW 1973, pag. $1194 \quad 347$

BGH, BB 1974, pag. $1368 \quad 347$

$\begin{array}{ll}\text { BGHZ 64, } 355 & 387\end{array}$

BGH, NJW 1976, pag. 2346, WM 1976, pag. 960

BGHZ 74, 383, NJW 1979, pag. 1886

$387,437,515$

BGHZ 74, 383, 390

387

BGH, JZ 1979, pag. 346

390

378

BGH, NJW 1979, pag. 2148

$\begin{array}{ll}\text { BGH, NJW 1979, pag. 2387-2388 } & 360 \\ \text { BGH, NJW 1980, pag. } 831-832 & 413\end{array}$

$\begin{array}{ll}\text { BGH, NJW 1980, pag. 831-832 } & 413 \\ \text { BGHZ 77, 116, 118f } & 413\end{array}$

BGHZ 77, 126, 131, NJW 1980, pag. 1953

BGH, NJW 1980, 2518

406,415

BGH, NJW 1981, pag. 117-118

BGHZ 79, 117, NJW 1981, pag. 867, BB 1981,

pag. 389 , AGBE I $\$ 13$ Nr. 2

404,405

BGH, NJW 1981, pag. 979-980

$406,417,424$

BGH, NJW 1981, pag. 1511-1512

$405,407,552$

BGHZ 81, 222, NJW 1981, pag. 2412, BB 1981,

pag. 1791, ZIP 1981, pag. 989

BGH, NJW 1981, pag. 2343-2344, WM, pag. 944-946

$404,405,406$

360

BGHZ 81, 229, 230f, NJW 1981, pag. 2351

419,423

BGH, NJW 1982, 178

BGH, NJW 1982, pag. 178-181 
BGH, NJW 1982, pag. 644-645

BGH, NJW 1982, pag. 644-646

385

BGH, NJW 1982, pag. 765

384,385

BGH, NJW 1982, pag. 1391-1392

384

BGH, NJW 1982, pag. 1511-1512

407,441

BGH, NJW 1982, pag. 1820

388,390

BGH, NJW 1982, pag. 2309

393

BGH, NJW 1982, pag. 2311-2312, BB 1982,

pag. 1750-1752, WM 1982 , pag. 869

BGH, MDR 1983, pag. 113

BGH, NJW 1983, pag. 816-817

BGH, NJW 1983, pag. 816-818

BGH, BB 1983, pag. 524-527

BGH, NJW 1983, pag. 1060

BGH, NJW 1983, pag. 1320-1322

BGHZ 86, 284, NJW 1983, pag. 1322, BB 1983, 527

BGHZ 86, 299, NJW 1983, pag. 1326

BGHZ 87, 17

$393,405,406,439$

418

370

389

382,515

422

383,416

$406,436,437$

406

383

BGH, NJW 1983, pag. 1603-1604

385

BGH, NJW 1983, pag. 1612

416

BGH, NJW 1983, pag. 1671-1672

413

BGH, NJW 1983, pag. 1853

418

BGH, NJW 1983, pag. 2026

404,405

393

376

BGH, NJW 1983, pag. 2638

393

BGH, NJW 1984, pag. 48-49

370

BGH, NJW 1984, pag. 1112

393

BGH, NJW 1984, pag. 1177

383

BGH, NJW 1984, pag. 1182

379,413

BGH, ZIP 1984, pag. 1485-1486

395

BGH, NJW 1984, pag. 1750

390

BGH, NJW 1984, pag. 2160

$379,404,405,413$
393

BGH, NJW 1984, pag. 2161-2162

BGH, NJW 1984, 2404

418

BGHZ 92, 24, NJW 1984, pag. 2468

430

BGH, NJW 1984, pag. 2525

393

BGH, NJW 1984, pag. 2687-2688

379,413

BGHZ 91, 55, 61

393

BGH, NJW 1984, pag. 2817

417

BGH, NJW 1985, pag. 53

383

BGH, NJW 1985, pag. 57 
BGH, NJW 1985, pag. 320-326

BGH, NJW 1985, pag. 621

BGH, NJW 1985, pag. 623

BGH, NJW 1985, pag. 853

BGH, NJW 1985, pag. 2328

BGH, NJW 1985, pag. 3013

BGH, NJW 1985, pag. 3016 390

BGH, NJW 1985, pag. 3016-3017, BB 1984, pag. 939

BGH, NJW 1986, pag. 43-44

439

BGH, NJW 1986, pag. 46

BGH, NJW 1986, pag. 325

437

BGH, ZIP 1986, pag. 653-656

395

BGH, NJW 1986, pag. 842

BGH, WM 1986, pag. 1253-1254

418

BGH, NJW 1986, pag. 1434-1435

390

BGH, NJW 1986, pag. 1610

393

BGH, NJW 1986, pag. 1613

420

BGHZ 86, 712, NJW 1986, pag. 1809

418

BGH, NJW 1986, pag. 2102

387

BGH, NJW 1986, pag. 2247

BGH, NJW 1986, pag. 2369

BGH, NJW-RR 1987, pag. 112-114

BGH, NJW 1987, pag. 487-488

BGH, NJW 1987, pag. 837, WM 1987, pag. 214

BGH, ZIP 1987, pag. 989-991

BGH, ZIP 1987, pag. 1457, NJW 1988, pag. 258-259

BGH, ZIP 1987, pag. 1582-1583

BGH, NJW 1987, pag. 1886

BGHZ 100, 158, NJW 1987, pag. 1913

417

BGH, NJW 1987, pag. 1931

BGHZ 100, 373, NJW 1987, pag. 2012

BGH, NJW 1987, pag. 2431-2432

371

BGHZ 101, 271, NJW 1987, pag. 2867

BGH, NJW 1988, pag. 55

BGH, NJW 1988, pag. 55-56

BGH, ZIP 1988, pag. 360-362

BGH, NJW 1988, pag. 410

BGH, MDR 1988, pag. 1027

BGH, NJW 1988, 1261-1262

BGH, NJW 1988, pag. 1726, WM 1988, pag. 1780

BGH, VersR 1988, pag. 1281 
BGHZ 104, 82, NJW 1988, pag. 1726-1727

BGH, NJW 1988, pag. 1785

$379,413,439$

BGH, WM 1989, pag. 126

387,395

BGH, NJW 1989, pag. 592

BGH, NJW-RR 1989, pag. 625-626

379,413

BGH, NJW 1989, pag. 831-833

393

BGH, WM 1989, pag. 1028-1032

393

BGH, NJW 1989, pag. 1673

416

BGH, NJW 1989, pag. 1796-1798, WM 1989, pag. 1028-1031

393

BGH, NJW 1990, pag. 317

433

BGH, NJW 1990, pag. 715-716

371

BGH, NJW-RR 1990, pag. 1141-1142

405

BGH, NJW-RR 1990, pag. 1525-1526

413

BGH, NJW 1990, pag. 2313-2314

418

BGH, NJW 1990, pag. 2383

391

BGH, NJW 1990, pag. 3197

370

BGH, NJW 1991, pag. 36

386

BGH, NJW-RR 1991, pag. 570-572

389

BGH, NJW-RR 1991, pag. 1074

438

BGH, NJW 1991, pag. 1677

390

BGH, NJW 1991, pag. 1750

393,417

BGH, NJW 1991, pag. 1886-1887

379,413

BGH, NJW 1991, pag. 2414-2416

390

BGH, NJW 1992, pag. 179-180

386

BGH, NJW 1992, pag. 503

386

BGH, NJW 1992, pag. 1108-1109

405

BGH, NJW 1992, pag. 1759

416

BGH, NJW 1992, pag. 2759

393

BGH, NJW 1992, pag. 3158-3161

391,405

BGH, NJW 1993, pag. 721

365

BGH, MDR 1993, pag. 339-340

413

BGH, NJW 1993, pag. 2369-2371

384

BGH, NJW 1993, pag. 2442-2444

391

\section{Oberlandesgericht}

OLG Nürnberg, BB 1978, pag. 1183

421

OLG Hamburg, WM 1978, pag. 1358

437,515

OLG Düsseldorf, NJW 1978, pag. 2512

434

OLG Stuttgart, AGBE I $\$ 22 \mathrm{Nr} .7$

437

OLG Karlsruhe, AGBE I $\& 22$ Nr. 8

437

OLG Saarbrücken, BB 1979, pag. 705

405 
OLG München, BB 1979 , pag. 805

OLG Frankfurt, NJW 1979, pag. 985

OLG Stuttgart, BB 1979 , pag. 1468

OLG Stuttgart, NJW 1979, pag. 2355

OLG Frankfurt, AGBE I $13 \mathrm{Nr}$. 14, WRP 1980, pag. 84

OLG Nürnberg, BB 1980, pag. 179

OLG München, BB 1980, pag. 283-285

OLG Karlsruhe, BB 1980, pag. 599-600

OLG Stuttgart, AGBE I \& 13 Nr. 21, NJW 1980, pag. 1583

OLG Hamburg, WRP 1981, pag. 536/537

OLG Köln, ZIP 1981, pag. 1101-1102

OLG Stuttgart, NJW 1981, pag. 1105-1106, AGBE I \& 13 Nr. 28

OLG Hamburg, NJW 1981, pag. 2420

OLG Köln, BB 1982, pag. 638, WRP 1981, pag. 663

OLG Düsseldorf, DB 1982, pag. 801

OLG Stuttgart, BB 1982, pag. 1753, WRP 1983, pag. 177-178

OLG Frankfurt, NJW 1982, 2200

OLG Karlsruhe, AGBE III § 22 Nr. 1-2

OLG Karlsruhe, BB 1983, pag. 725

OLG Frankfurt, BB 1983, Beilage 11, pag. 7

OLG Köln, NJW 1983, pag. 1002-1003

OLG Koblenz, WM 1983, pag. 1272-1273

405

OLG Hamm, NJW-RR 1986, pag. 927-930

418

OLG Hamburg, NJW-RR 1986, pag. 1440

417

OLG Karlsruhe, NJW-RR 1988, pag. 302-303

418

OLG Düsseldorf, NJW-RR 1988, pag. 884-886

417

OLG Düsseldorf, NJW 1989, pag. 1487

OLG Frankfurt, NJW 1989, pag. 1489

436

OLG Düsseldorf, NJW-RR 1990, pag. 821

378

OLG München, NJW-RR 1993, pag. 736

\section{Landgericht}

LG Konstanz, BB 1981, pag. 1420

LG Frankfurt, AGBE I $\$ 15 \mathrm{Nr} .8$

LG Stuttgart, AGBE I \& $15 \mathrm{Nr} .10$

LG Konstanz, AGBE II $\$ 11 \mathrm{Nr} .5 \mathrm{~b}, \mathrm{Nr} .59$

LG Frankfurt, NJW 1984, pag. 1626

LG Berlin, ZIP 1988, pag. 1311

LG Köln 22 januari 1992, VSV-Info 1992/3, pag. 1-10 


\section{Kammergericht}

KG, OLGZ 80, 400, NJW 1981, pag. 2420, BB 1981, pag. 148. AGBE I $\$ 20 \mathrm{Nr}$. 1

$434,435,443$

KG Berlin, AGBE II $\$ 13$ Nr. 17, WRP 1982, pag. 19

KG Berlin 22 juni 1994, VSV-Info 1994/3, pag. 1-7

231,433

\section{Benelux}

Benelux-Gerechtshof 14 april 1983, NJ 1983, 615 


\section{Lijst van verkort aangehaalde literatuur}

Abas, diss.

P. Abas, Beperkende werking van de goede trouw, dissertatie Amsterdam, Deventer 1972.

Asser-Hartkamp II, 1992

Mr. C. Asser's handleiding tot de beoefening van het Nederlands burgerlijk recht, Verbintenissenrecht, deel II, Algemene leer der overeenkomsten, negende druk bewerkt door A.S. Hartkamp, Zwolle 1993.

Asser-Rutten II, 1979

Mr. C. Asser's handleiding tot de beoefening van het Nederlands burgerlijk recht, Verbintenissenrecht, deel II, Algemene leer der overeenkomsten, vijfde druk bewerkt door L.E.H. Rutten, Zwolle 1979.

Asser-Rutten II, 1982

Mr. C. Asser's handleiding tot de beoefening van het Nederlands burgerlijk recht, Verbintenissenrecht, deel II, Algemene leer der overeenkomsten, zesde druk bewerkt door L.E.H. Rutten, Zwolle 1982.

\section{Asser-Scholten, 1974}

Mr. C. Asser's handleiding tot de beoefening van het Nederlands burgerlijk recht, Algemeen deel, door Paul Scholten, derde druk, met feitelijke gegevens aangevuld door G.J. Scholten, Zwolle 1974.

\section{Axmann}

J. Axmann, Die praktische Bedentung und Effizienz der Verbandsklage nach \$\& 13 ff. AGB-Gesetz, WiRe Verlagsgesellschaft mbH, Göttingen 1986.

Van Baars, diss.

J. van Baars, Point d'interrêt, point d'action, diss. Amsterdam (VU), Amsterdam 1971. 


\section{Balkema en de Groot}

J.P. Balkema en G.R. de Groot, Recht en vertalen, Kluwer, Deventer 1987.

Barendrecht, diss.

J.M. Barendrecht, Recht als model van rechtvaardigheid, diss. Tilburg 1992, Deventer 1992.

\section{Basedow}

J. Basedow, Kollektiver Rechtsschutz und individuelle Rechte, Die Auswirkungen des Verbandsprozesses auf die Inzidentkontrolle von AGB, AcP 1982, pag. 335-371.

Van der Beek, diss.

H.L. van der Beek, Overgangsrecht nieuw Burgerlijk Wetboek, Systematiek, uitgangspunten en toepassingen, diss. Maastricht, Deventer 1992.

\section{Bierbooms en De Vries}

P.F.A. Bierbooms en L.J.A. de Vries, Wetsvoorstell Collectief Actierecht: de rechtspraak aan banden gelegd, NJB 1994, pag. 96-97.

\section{Blankenburg}

E. Blankenburg, Studying the frequency of civil litigation in Germany, 9 Law and Society Review (1975), pag. 307-319.

\section{Blankenburg en Verwoerd}

E.R. Blankenburg en J.R.A. Verwoerd, Vermijden en benutten van civielrechtelijke procedures in Nederland en omringende landen, Justitiële verkenningen 1987.

\section{BMJ I}

BMJ-Arbeitsgruppe, Erster Teilbericht, Vorschläge zur Verbesserung des Schutzes der Verbraucher gegenuber AGB, Reform I, Bonn 1974.

\section{BMJ II}

BMJ-Arbeitsgruppe, Zweiter Teilbericht, Vorschläge zur Verbesserung des Schutzes der Verbraucher gegenüber AGB, Reform II, Bonn 1975.

\section{Boer}

A.N.A.G. Boer, Beslechting van consumentengeschillen naar Nederlands recht, Deventer 1990. 


\section{De Boer}

Th: M de Boer, Vergelijkenderwijs: de inspiratie van buitenlands recht, WPNR 1992, jrg. 123, nt. 6033, pag. 39-48.

\section{Bohle en Micklitz}

W. Bohle en H.W. Micklitz, Erfahrungen mit dem AGB-Gesetz im nichtkaufmännischen Bereich, Eine Zwischenbilanz nach sechs Jahren, Betriebs Berater 1983, Beilage 11 zu Heft 28.

\section{Borck}

H.G. Borck, Ansichten und Argumente zur Erstattungsfähigkeit der Abmahnkosten, WRP 1981, pag. 438-444.

\section{Bourgoignie}

Th. Bourgoignie, Eléments pour une théorie du droit de la consommation, Louvain 1988.

Bourgoignie, JCP 1984

T. Bourgoignie, The Need to Reformulate Consumer Protection Policy, JCP 1984, pag. 307-321;

Brack, diss.

A. Brack, Consument, recht en koopkracht, diss. Twente 1981, Deventer 1981.

Brack, TvC 1987

A. Brack, Consumentenbeleid van de Nederlandse overheid: planning of pragmatiek?, TvC 1987, pag. 243-253

\section{Brack, Kernpunten}

A. Brack, Niet goed .... geld terug? Kernpunten van het consumentenrecht, Alphen aan den Rijn 1975.

\section{Brens}

J.L. Brens, Bescherming van de toetreder tot een adhesiecontract; AA XX, 1971 nr. 5.

Bruinsma en Welbergen

F. Bruinsma en R. Welbergen, De Hoge Raad van onderen, Utrecht 1987. 
Bultmann

F.A. Bultmann, Allgemeine Geschäftsbedingungen: Beseitigung der Wiederholungsgefahr beim Unterlassungsanspruch, BB 1982, pag. 703.

Buitmann, VuR 1994

F.A. Bultmann, Änderungen des AGBG aufgrund der Richtlinie über miBbräuchliche Klauseln?, pag.. 137-145.

\section{Bundesgesetzblatt}

Bundesgesetzblatt 1976, I 3317 .

Bundesrat (nummer)

Bundesrat-Drucksache $360 / 75$ en $443 / 1 / 76$.

Bundestag (nummer)

Bundestag-Drucksache nrs. 7/3200, 7/3919,7/5412, 7/5422 en 7/5617.

Bunte, AGBE (nummer)

H.-J. Bunte, Entscheidungssammlung zun AGB-Gesetz, Band I-VI, 1977-1985.

Bunte, BB 1980

H.-J. Bunte, Zur Kontrolle Allgemeiner Geschäftsbedingungen und Konditionenempfehlungen, BB 1980, pag. 325-332.

Bunte, DB 1980

H.-J. Bunte, Verfahrensrechtliche Fragen der AGB-Kontrollklage, DB 1980, pag. $481-486$.

Bunte, AcP 1982

H.-J. Bunte, Erfahrungen mit dem AGB-Gesetz, Eine Zwischenbilanz nach 4 Jahren, Archiv für die civillistische Praxis 1982, nr. 181, pag. 31-67.

Bunte, Handbuch

H.-J. Bunte, Handbuch der AGB, Beck'sche Verlagsbuchhandlung, München 1982.

Bunte, DB 1982

H.-J. Bunte, Entwicklungen im Recht der Allgemeinen Geschäftsbedingungen, Ein Erfahrungsbericht nach 5 Jahren AGB-Gesetz, DB 1982, Bijlage nr. 13 bij afl. 23. 
Bunte, NJW 1987

H.-J. Bunte, Zehn Jahre AGB-Gesetz, Rückblick und Ausblick; NJW 1987, pag. 921-928.

Bunte, JA 1988

H.-J. Bunte, 10 Jahre AGB-Gesetz - ein Gewinn an Rechtssicherheit?, JA 1988, pag. 311-318.

CCA, Van consument en consumptie

Sociaal Economische Raad, Commissie voor Consumentenaangelegenheden, Van consument en consumptie, 25 jaar advies en overleg door bedrijfsleven en consument, Den Haag 1991.

CCA-advies

Sociaal-Economische Raad, Advies inzake het vraagstuk van de toepassing van standaardvoorwaarden bij transacties met de consument, uitgebracht door de commissie voor consumentenaangelegenheden aan de ministers van justitie en van economische zaken, SER-uitgaven 1978, nr. 7.

\section{Coleman}

J.S. Coleman, Power and the structure of society, New York 1974.

Contractenrecht (VII)

A.R. Bloembergen en W.M. Kleijn, Contractenrecht, Deventer 1972, Losbladig (Hoofdstuk VII, Standaardvoorwaarden, door E.H. Hondius).

Creutzig

J. Creutzig, Das AGB-Register beim Bundeskartellamt - Hilfe für die Praxis?, NJW 1979, pag. 20-22.

Dalhuisen, preadvies NJV

J.H. Dalhuisen, Algemene voorwaarden, preadvies voor de Nederlandse Juristen-Vereniging, HNJV 1979, deel 1, pag. 5-89.

Dalhuisen, NJB 1979

J.H. Dalhuisen, Nogmaals het NJV-onderwerp der algemene voorwaarden, NJB 1979, pag. 619-620.

Van Dam-Lely

J.H. van Dam-Lely, Wetswoorstel regeling bevoegdheid belangenorganisaties tot instellen collectieve acties, S\&V 1992, pag. 39-44. 


\section{Damm}

R. Damm, Privatrechtliche verbandsklagen - Instrument der Wirtschaftskontrolle oder Kontrollersatz, ZRP 1978, pag. 167-171.

Van Delft-Baas

M. van Delft-Baas, Consumentenkoop, Monografieën Nieuw BW B-65b, Deventer 1992.

Demeulenaere, diss.

B. Demeulenaere, Beslechting van consumentengeschillen naar Belgisch recht, Een voorstel voor een consumentengeschillenprocedure vanuit een rechtsvergelijkende analyse, diss. Gent, 1986.

Deutscher Juristentag

Verhandlung 50. Deutscher Juristen Tag, 1974.

Dietlein en Rebmann

M.J. Dietlein en E. Rebmann, AGB Aktuell, Bundesanzeiger Verlagsges.m.b.H., Köln 1976.

Dommering-van Rongen

L. Dommering-van Rongen, Verdediging van collectieve belangen voor de rechter, Consumentenrecht, in: Verdediging van collectieve belangen via de rechter, Congresbundel van De Jonge Balie bij de Hoge Raad der Nederlanden ter gelegenheid van haar 10e lustrum, Zwolle 1988, pag. 134-158.

Van Driel, Regelmaat 1987

M. van Driel, Zelfregulering in het consumentenbeleid, Regelmaat 1987, pag. 158-163.

Van Driel, diss.

M. van Driel, Zelfregulering - Hoog opspelen of thuisblijven, diss. Utrecht, Deventer 1989.

Van Dunné, diss.

J.M. van Dunné, Normatieve uitleg van rechtshandelingen, diss. Leiden, Deventer 1971.

Van Dunne, Verbintenissenrecht

J.M. van Dunné, Verbintenissenrecht, Deel 1, Deventer 1993. 
Van Duyne

P.C. van Duyne, Handel en wandel in civilibus, Civielrechtellike verkenningen in cijfers, Justitiële Verkenningen 1987, nr. 2, pag. 69-89.

\section{Eckert}

H.-W. Eckert, Der Referentenentwurf zur Unsetzung der EG-Richtlinie über mißbräuchliche Klauseln in Verbraucherverträgen, ZIP 1994, pag. 1986-1991.

EG-COM, 1985

Commissie van de Europese Gemeenschappen, De consument en zijn verhaalsmogelijkheden, Memorandum van de Commissie aan de Raad van 4 januari 1985, EG-Bulletin 1985, Supplement 2/85.

Elders, Minnelijke schikking

J.L.M. Elders, Minnelijke schikking als middell ter voorkoming van rechtsgedingen en ter oplossing van rechtsgeschillen, in: Effectieve rechtsbescherming en constitutionele rechtsorde, Zwolle 1984, pag. 55-71.

\section{Elders, preadvies}

J.L.M. Elders, Burgerlijk recht en grondrechten: "een intregatieve benadering", in: Burgerlijk recht en grondrechten, preadviezen uitgebracht voor de vereniging voor burgerlijk recht, Lelystad 1986, pag. 7-40.

\section{Engelen}

B.J. Engelen, Artikel 6.5.2.1 NBW: de standaardregelling, BW-krant jaarboek 1988, pag. 200-212.

\section{Van Erp, diss.}

J.H.M. van Erp, Contract als rechtsbetrekking, Een rechtsvergelijkende studie, diss. Tilburg, Zwolle 1990.

\section{Von Falckenstein}

R. von Falckenstein, Die Bekämpfung unlauterer Geschäftspraktiken durch Verbraucherverbände, Bundesanzieger Verlagsges.mbH., Köln 1977.

Francken, 1982

D.A. Francken, Klachtenbehandeling bij geschillenkommissies, SWOKAonderzoeksrapporten nr. 11, 's-Gravenhage 1982. 
Francken, 1983

D.A. Francken, Consumentenzaken voor het kantongerecht, een case studie, SWOKA-onderzoeksrapporten nr. 20, 's-Gravenhage 1983.

Frenk, RM-Themis 1989

N. Frenk, Het voorontwerp vorderingsrecht belangenorganisaties nader geanalyseerd, RM-Themis 8 (1989), pag. 372-389.

Frenk, TvC 1990

N. Frenk, Het vorderingsrecht voor belangenorganisaties, TvC 1990, pag. 203216.

Frenk, Jaarboek konsumentenrecht 1990

N. Frenk, Kollektieve akties in konsumentenzaken, in Jaarboek konsumentenrecht 1990, Deventer 1990, pag. 321-327.

Frenk, Jaarboek konsumentenrecht $199 \|$

N. Frenk, Kollektieve akties in konsumentenzaken 1990, in Jaarboek konsumentenrecht 1991, Deventer 1991, pag. 307-313.

Frenk, Jaarboek konsumentenrecht 1992

N. Frenk, Kollektieve akties in konsumentenzaken, in Jaarboek konsumentenrecht 1992, Deventer 1992, pag. 327-334.

Frenk, Jaarboek konsumentenrecht 1993

N. Frenk, Kollektieve akties in konsumentenzaken, in Jaarboek konsumentenrecht 1993, Deventer 1992, pag. 199-200.

\section{Frenk, S\&V 1994}

N. Frenk, De informele vereniging: het onwettig kind van het rechtspersonenrecht, S\&V 1994, pag. 35-38.

Frenk, diss.

N. Frenk, Kollektieve akties in het privaatrecht, diss. Utrecht, Deventer 1994.

Galanter, L\&SR 1974

M. Galanter, Why the "haves" come out ahead: speculations on the limits of legal change, 9 Law and Society Review (1974), pag. 95-160. 
Galanter, L\&SR 1975

M. Galanter, Afterword: explaining litigation, 9 Law and Society Review (1975), pag. 347-368.

Galanter, L\&SR 1976

M. Galanter, Delivering legality: some proposals for the direction of research, 11 Law and Society Review (1976), pag. 225-246.

Göbbels

M. Göbbels, Algemene Voorwaarden, AA 1982, pag. 217-226.

Göbel

K. Göbel, Prozeßzweck der AGB-Klage und herkömmlicher Zivilprozeß, Königstein 1980 .

Van der Graaf, Van der Meer en Van Mierlo

H. van der Graaf, H. van der Meer en Th.J.M. van Mierlo, Algemene voorwaarden: CCA-overleg verder met Nieuw BW als basis, TvC 1992, pag. 48-57.

Gras, Standaardkontrakten

F.A.J. Gras, Standaardkontrakten, Een rechtssociologische analyse, Deventer 1979.

Gras, diss.

F.A.J. Gras, De sociale werkelijkheid van het standaardkontrakt, Een rechtssociologisch onderzoek, diss. Amsterdam, Amsterdam 1984.

Van der Grinten

W.C.L. van der Grinten, Collectivering in het privaatrecht, inaugurele rede Nijmegen, Nijmegen 1957.

Groenendijk, diss.

C.A. Groenendijk, bundeling van belangen bij de burgerlijke rechter, diss. Nijmegen, Zwolle 1981.

De Groot, inaug. rede

G.-R. de Groot, Vergelijkt alles en behoudt het goede, inaugurele rede Masstricht, Deventer, 1989. 
Hardieck

T. Hardieck, Die gerichtliche Entscheidungspraxis in Verfahren mach $\$ 13$ AGBG, BB 1979, pag. 708-712.

Hartkamp, Compendium

A.S. Hartkamp, Compendium van het vermogensrecht volgens het nieuwe burgerlijk wetboek, vierde druk, Deventer 1990.

Hartkamp, WPNR 1992

A.S. Hartkamp, Vermogensrecht Aktueel, Het overgangsrecht inzake algemene voorwaarden, WPNR 1992, pag. 327-328.

Hartkamp, inaug. rede

A.S. Hartkamp, Wetsuitleg en rechtstoepassing na de invoering van het nieuwe burgerlijk wetboek, inaugurele rede Utrecht, Deventer 1992.

Hefermehl/Werner, Handkommentar zum BGB

Handkommentar zum Bürgerlichen Gesetzbuch, 7. Auflage, bewerkt door H. Hefermehl ( $\$ 1-12$ ) en $\mathrm{O}$. Werner ( $\$ 13-30$ ), Band 1, Aschendorffsche Verlagsbuchhandlung, Münster 1981 .

\section{Van Heijningen}

J.A.M. van Heijningen, De standaardregeling, een novum in het NBW, WPNR 1985, pag. 369-376.

Heinrichs/Heldrich, BGB (Palandt)

Bürgerliches Gesetzbuch (Palandt), Band 7, 46. neubearbeitete Auflage, bewerkt door H. Heinrichs ( $\$$ 1-11 en 13-30) en A.Heldrich ( $\$ 12)$, C.H. Beck'sche Verlagsbuchhandlung, München 1987.

Heisterkamp

A.H.T. Heisterkamp, Vernietigbaarheid en billijkheid bij algemene voorwaarden, in: CJHB, Brunner-Bundel, Opstellen aangeboden aan prof. mr. C.J.H. Brunner ter gelegenheid van zijn vijfenzestigste verjaardag, Deventer 1994, pag. 163-171.

Hennig en Jarre

W. Hennig en J. Jarre, Die gerichtliche Entscheidungspraxis in Verfahren nach \$13 AGB-Gesetz, BB 1981, pag. 1161-1172. 
Hensen, JA 1981

H-D. Hensen, Das AGB-Gesetz, Juristische Arbeitsblätter 1981, nr. 3, pag. 133 141.

Hijma, diss.

Jac. Hijma, Nietigheid en vernietigbaarheid van rechtshandelingen, diss. Leiden, Deventer 1988.

Hijma, WPNR 1990

Jac. Hijma, Koop en ruil, WPNR 1990, pag. 734-740.

Hijma, WPNR 1992

Jac. Hijma, Consumentenkoop of gewone koop?, WPNR 1992, pag. 387-388.

Von Hippel

E. von Hippel, Verbraucherschutz, 3., neubearbeitete Auflage, J.C.B. Mohr Tübingen, 1986.

Hondius en Rodrigues

E.H. Hondius en P.R. Rodrigues, Actiebevoegdheid voor consumentenorganisaties: een kink in de kabel, NJB 1986, pag. 1206-1214.

Hondius, Konsumentenrecht

Hondius, Konsumentenrecht, preadvies voor de Nederlandse Vereniging voor Rechtsvergelijking, Deventer 1976.

Hondius, diss.

E.H. Hondius, Standaardvoorwaarden, Rechtsvergelijkende beschouwingen over standaardisering van kontraktsbedingen en overheidstoezicht daarop, diss. Leiden, Deventer 1978.

Hondius, preadvies NJV

E.H. Hondius, Naar een wettelijke regeling van algemene voorwaarden, preadvies voor de Nederlandse Juristen-Vereniging, HNJV 1979, deel 1, pag. 91-290.

Hondius, AA 1982

E.H. Hondius, Konsumentenrecht, AA 1982, katern 2, pag. 45-47. 
Hondius, KwNBW 1984, Operatie stofkam

E.H. Hondius, Operatie stofkam: rol van rechter in Nieuw BW wordt teruggedrongen, KwNBW 1984, pag. 2-6.

Hondius, KwNBW 1984, Deregulering

E.H. Hondius, Deregulering en het Nieuw BW, KwNBW 1984, pag. 17-18.

Hondius, KwNBW 1984, Algemene voorwaarden

E.H. Hondius, Algemene voorwaarden, KwNBW 1984, pag. 29-30.

Hondius, JCP 1984

E.H. Hondius, Non-Legislative Means of Consumer Protection: the Dutch Experience, JCP 1984, nr. 7, pag. 137-156.

Hondius, TvC 1985

E.H. Hondius, Van deregulering naar herregulering/ontmanteling van het Nederlandse Consumentenrecht gaat niet door, TvC 1985, pag. 67-76.

Hondius, TVC 1986

E.H. Hondius, De consument en zijn klacht, De toekomst van de geschillencommissies voor consumentenklachten, TvC 1986, pag. 183-187.

Hondius, Unfair Terms In Consumer Contracts

Ewoud Hondius, Unfair Terms In Consumer Contracts, molengraaff instituut voor privaatrecht, Utrecht september 1987.

Hondius, TvC 1991

E.H. Hondius, De rechtspositie van de consument naar nieuw burgerlijk recht, TvC 1991, pag. 324-338.

Hondius, Standaardcontracten

E.H. Hondius, Standaardcontracten, Contractenrecht VII, Kluwer Deventer, losbladig.

Hondius en Van Wassenaer

E.H. Hondius en A.G.J. van Wassenaer, Van standaardvoorwaarden naar standaardregeling?, Preadviezen voor de Vereniging voor Bouwrecht Nr.21, Deventer 1993. 


\section{Hugenholtz/Heemskerk}

W. Hugenholtz, Hoofdlijnen van Nederiands Burgerlijk Procesrecht, zestiende druk, bewerkt door W.H. Heemskerk, Lemma, Utrecht 1991.

\section{Huls}

N.J.H. Huls, Zelf- en Overheidsregulering in het bankwezen, Regelmaat 1987, pag. 9-15.

ICC-eindrapport

Dereguleringsinvloeden op het consumentenbeleid, Een benadering voor toekomstige instrumentkeuze, Rapport van de door de Interdepartementale Coördinatiecommissie voor Consumentenzaken ingestelde werkgroep dereguleringsinvloeden consumentenbeleid, 's-Gravenhage 18 september 1985.

\section{Jansma}

K. Jansma, Is het wenselijk onze burgerlijke wetgeving aan te vullen met bepalingen omtrent "standaard contracten" en zo ja, naar welke beginselen?, Praeadvies, HNJV 1948, III, pag. 125-164.

Jongeneel, Koop en consumentenkoop

R.H.C. Jongeneel, Koop en consumentenkoop, derde herziene druk, Zwolle 1993.

Jongeneel, WPNR 1991

R.H.C. Jongeneel, Vallen door een ander dan partijen opgestelde algemene voorwaarden onder afd. 6.5.3?, WPNR 1991, nr. 6027, pag. 813-816.

Jongeneel, diss.

R.H.C. Jongeneel, De Wet algemene voorwaarden en het AGB-Gesetz, diss. Amsterdam, Deventer 1991.

Jongeneel, TvC 1993

R.H.C. Jongeneel, Een richtlijn die weinig schade aanricht, TvC 1993, pag. 117-130.

Jongeneel en Wessels, NJB 1993

R.H.C. Jongeneel en B. Wessels, Onredelijke bedingen in consumentenovereenkomsten, NJB 1993, pag. 897-899. 
Kabel

J.J.C. Kabel, Zelfregulering en recht, Basiscriteria voor zelfregulering van reclame in Nederland, SEW 1983, nr. 3, pag. 151-165.

\section{Klik}

P. Klik, Het wetswoorstel vorderingsrecht van belangenorganisaties bij de eerste kamer, Terug naar af ..., TMA 1994, pag. 34-42.

\section{Knieper}

R. Knieper, Technokratische Rationalität in allgemeinen Geschäftsbedingungen?, Zeitschrift für Rechtspolitik 1971, Heft 3, pag. 60-73.

\section{Koch en Stübing}

E. Koch en J. Stübing, Allgemeine Geschäftsbedingungen, Luchterhand Verlag, Neuwied Darmstadt 1977.

\section{Kokkini-Jatridou}

D. Kokkini-Iatridou e.a., Een inleiding tot het rechtsvergelijkend onderzoek, Deventer 1988.

Konsumenten-blauwdruk

Konsumenten-blauwdruk No. 2, De consument en de rechter, publikatie van het Konsumenten Kontakt, Rijswijk 1985.

\section{Koopman}

J. Koopman, Consumentenmacht en markt, ontwikkeling in perspectief, Aangeboden door mr. Yvonne C.M.T. van Rooy, staatssecretaris van Economische Zaken, aan de 40-jarige Consumentenbond, 10 spetember 1993, Ministerie van Economische Zaken, Den Haag 1993.

\section{Van Koppen en Malsch, L\&SR 1991}

P.J. van Koppen en M. Malsch, Defendants and one-shotters win after all: compliance with court decisions in civil cases, 25 Law and Society Review (1991), pag. 803-820.

Van Koppen en Malsch, NJB 1992

P.J. van Koppen en M. Malsch, Hoe de verliezer wint, NJB 1992, pag. 11011104. 
Kötz, BB 1982

H. Kötz, Die Rückwirkung von Unterlassungsurteilen gemäß $\S 13$ ff. AGBGesetz, BB 1982, pag. 644-651.

Kötz/Gerlach, Münchener Kommentar

Münchener Kommentar zum Bürgerlichen Gesetzbuch, Band 1, Allgemeiner Teil ( $\& 1-240)$, AGB-Gesetz, 2. Auflage, bewerkt door H. Kötz (\$\$ 1-12) en J.W. Gerlach ( $\$$ 13-30), C.H. Beck'sche Verlagsbuchhandlung, München 1984.

Last

C. Last, De toekomst van de geschillencommissies, Geschillencommissies: een blijvend consumentenbelang, TvC 1986, pag. 237-243.

Loewenheim

U. Loewenheim, Die Erstattung von Abmahnkosten der Verbände in der neueren Rechtsentwicklung, WRP 1987, pag. 286-289.

\section{Lokin}

J.H.A. Lokin, Redactionele kanttekeningen, De wetgever of de wet, RMThemis 1993, pag. 257-259.

Löwe/Graf von Westphalen/Trinkner, Großkommentar zum AGB-Gesetz W. Löwe, F. Graf von Westphalen en R. Trinkner, Großkommentar zum AGBGesetz, Band 2, 2. Auflage, Heidelberg 1983.

\section{Marx}

A.J. Marx, Het euvel der ongeweten en onbegrepen bedingen, NIB 1939, pag 423-430 en pag. 447-453.

\section{Van Mierlo}

Th.J.M. Van Mierlo, Het overleg tussen ondernemers en consumenten in kaart gebracht, TvC 1985, pag. 247-260.

\section{Mincke}

W. Mincke, Die Problematik von Recht und Sprache in der Übersetzung von Rechtstexten, Archiv für Rechts- und Sozialphilosophie 1991, Heft 4, pag. 446465. 


\section{Mölenberg}

L.J.H. Mölenberg, De Wet vorderingsrecht belangenorganisaties in werking getreden, TvC 1994, pag. 275-288.

\section{Mölenberg en Rijken}

L.I.H. Möllenberg en G.J. Rijken, De ervaringen van de Duitse consumentenorganisaties met het AGB-Gesetz, SWOKA-onderzoeksrapporten 1991, nr. 115, SWOKA, Den Haag 1991.

\section{Mölenberg en Van der Sluijs}

L.J.H. Mölenberg en P.T. van der Sluijs, Nieuwe ANVR-reisvoorwaarden: een schoolvoorbeeld van zelfregulering?, TvC 1988, pag. 259-269.

\section{Niebling}

J. Niebling, Die Schranken der Inhaltskontrolle nach $\& 8$ AGB-Gesetz, BB 1984, pag. 1713-1718.

Nieuwenhuis, diss.

J.H. Nieuwenhuis, Drie beginselen van contractenrecht, diss. Leiden, Deventer 1979.

\section{Van Nispen}

C.J.J.C. van Nispen, Onrechtmatige Daad II, losbladige editie, Deventer, nr. 219 a.

Parlementaire Geschiedenis, Boeken 3, 5 en 6

M.M. Olthof en J.W. Du Pont (eindredactie), Parlementaire geschiedenis van het nieuwe Burgelijk Wetboek, Boeken 3, 5 en 6, Deventer 1982.

Parlementaire Geschiedenis, Inv. 3, 5 en 6

C.J. van Zeben en J.W. Du Pont (eindredactie), Parlementaire geschiedenis van het nieuwe Burgelijk Wetboek, Invoering Boeken 3, 5 en 6, Boek 6, Algemeen gedeelte van het verbintenissenrecht, door W.H.M. Reehuis en E.E. Slob, Kluwer, Deventer 1990.

\section{Peeters}

J.A.J. Peeters, Niet meer van repliek gediend! (Een verbeterde kantongerechtsprocedure?), TvC 1988, pag. 3-13. 


\section{Polak}

J.M. Polak, Deponering van algemene voorwaarden en standaardcontracten, WPNR 1971, pag. 95-103.

\section{Prelinger}

D. Prelinger, Ersatz von Abmahnkosten aus Geschäftsführung ohne Auftrag?, AnwBl 1984, pag. 533-535.

Rabe

D. Rabe, Die Auswirkungen des AGB-Gesetzes auf den Kaufmännischen Verkehr, NJW 1987, pag. 1978-1985.

Raiser, diss.

L. Raiser, Das Recht der Allgemeinen Geschäftsbedingungen, diss. Hamburg, Hamburg 1935.

Rammeloo, diss.

S.F.G. Rammeloo, Das neue EG-Vertragskollisionsrecht, diss. Groningen, Carl Heymanns Verlag, Köln-Berlin-Bonn-München 1992.

Rehbinder

M. Rehbinder, Das Kaufrecht in den Allgemeinen Geschäftsbedingungen der deutschen Wirtschaft, 2. Aufl., Berlin 1979.

Reinel

P. Reinel, Die Verbandsklage nach dem AGBG, 1979.

Rijken, diss.

G.J. Rijken, Exoneratieclausules, diss. Utrecht, Deventer 1983.

Rijken, KwNBW 1984

G.J. Rijken, De stand van zaken met betrekking tot het wetsontwerp algemene voorwaarden, KwNBW 1984, pag. 120-129.

Rijken, NJB 1984

G.J. Rijken, De exoneratieclausule toch op de zwarte lijst?, NJB 1984, pag. 1413-1417.

Rijken, KwNBW 1985

G.J. Rijken, Het wetsvoorstel algemene voorwaarden door de Tweede Kamer aanvaard, KwNBW 1985, pag. 79-80. 
Rijken, KWNBW 1986

G.J. Rijken, Wet commissies standaardregelingen, KwNBW 1986, pag. 6-8.

Rijken, TVVS 1986

G.J. Rijken, De komende wettelijke regeling van de algemene voorwaarden, TVVS 1986, 265-270.

Rijken, SR 1987

G.J. Rijken, Het kort geding in het consumentenrecht, Sociaal Recht 1987, pag. 252-256.

Rijken, KwNBW 1988

G.J. Rijken, Boekbespreking B. Wessels / R.H.C. Jongeneel Algemene Voorwaarden, KwNBW 1988, pag. 59-61.

Rijken, inaug. rede

G.J. Rijken, Het consumentenrecht in de jaren negentig: een zware taak voor consumentenorganisaties, inaugurele rede Maastricht, Deventer 1991.

Rijken, NTBR 1993

G.J. Rijken, Boekbespreking: R.H.C. Jongeneel, De Wet algemene voorwaarden en het AGB-Gesetz, NTBR 1993, pag. 65-66.

Rijken, NJB 1994

G.J. Rijken, De Wet algemene voorwaarden na eén jaar: een trieste tussenbalans, NJB 1994, pag. 643-645.

Rijken, Redelijkheid en billijkheid

G.J. Rijken, Redelijkheid en billijkheid, Monografieën Nieuw BW A-5, Deventer 1994.

Rijken, Mölenberg en Verstappen

G.J. Rijken, L.J.H. Mölenberg en J.M.P. Verstappen, Algemene voorwaarden in het toeristisch-recreatieve verkeer, SWOKA-onderzoeksrapporten 1990, nr. 89, SWOKA, Den Haag 1990.

Rodrigues, SEW 1987

P.R. Rodrigues, Beunhazerij, reclameverboden, groepsacties en het consumentenbelang, SEW 6 (1987), pag. 471-480. 
Rodrigues, SWOKA-onderzoeksrapport

P.R. Rodrigues, Collectieve consumentenacties, SWOKA-onderzoeksrapport 1988 nr. 60, Den Haag 1988.

Rodrigues, Procesrecht en collectief actierecht

P.R. Rodrigues, Procesrecht en collectief actierecht, in Verdediging van collectieve belangen via de rechter, Congresbundel van De Jonge Balie bij de Hoge Raad der Nederlanden ter gelegenheid van haar 10e lustrum, Tjeenk Willink, Zwolle 1988, pag. 14-51.

Rodrigues, TvC 1989

P.R. Rodrigues, annotatie bij Rb. 's-Gravenhage 15 februari 1988, TvC 1989, pag. 76

Rodrigues, Ars Aequi Libri

P.R. Rodrigues, Consumentenrecht en collectieve acties, in Coilectieve actie in het recht, Ars Aequi Libri, Nijmegen 1990.

Rodrigues, SR 1992

P.R. Rodrigues, Het wetsvoorstel inzake vorderingsrechten voor belangenorganisaties, Sociaal Recht 1992, 4, pag. 108-113.

Rozemond

Klaas Rozemond, Het wetsvoorstel collectieve acties, een belangrijke stap voorwaarts, Rechtshulp 1992, pag. 13-19.

Rutten-Roos

A. Rutten-Roos e.a., Nederlands recht in kort bestek, 7e druk, Deventer 1988.

Van de Sande Bakhuijzen

N.J. van de Sande Bakhuijzen, Kontrole op standaardvoorwaarden, WPNR 1979, pag. 281-291 en 297-299.

Sarat

A. Sarat, Alternatives in dispute processing: litigation in a small claims court, 10 Law and Society Review (1976), pag. 339-375.

Van Schaick, diss.

A.C. Van Schaick, Contractsvrijheid en nietigheid, diss. Tilburg, Zwolle 1994. 
Schlosser, ZIP 1985

P. Schlosser, Entwicklungstendenzen im Recht der Allgemeinen Geschäftsbedingungen, Zeitschrift für Wirtschaftsrecht und Insolvenzpraxis (ZIP) 1985, nr. 8, pag. 449-462.

Schlosser, JR 1988

P. Schlosser, 10 Jahre AGB-Gesetz, JR 1988, pag. 1-7.

Schlünder

B. Schlünder, AGB-Gesetz in Leitsätzen, C.H. Beck'sche Verlagsbuchhandlung, München 1990.

Schut

G.H.A. Schut, Rechtshandeling, overeenkomst en verbintenis, Zwolle 1987.

Schuyt, Groenendijk en Sloot

C.J.M. Schuyt, C.A. Groenendijk en B. Sloot, De weg naar het recht, een rechtssociologisch onderzoek naar de samenhangen tussen maatschappelijke ongelijkheid en juridische hulpverlening, Kluwer, Deventer 1976.

Seifert, BB 1982

D. Seifert, Gerichtliche Entscheidungspraxis in Verfahren nach $\S 13 \mathrm{AGBG}, \mathrm{BB}$ 1982, pag. 464-471.

Seifert, BB 1984

D. Seifert, Die gerichtliche Entscheidungspraxis in Verfahren nach $\$ 13$ AGBG, BB 1984, pag. 880-887.

Serraris-Perrick, Bouwrecht 1982

G. Serraris-Perrick, Het wetsontwerp Algemene Voorwaarden, afdeling 6.5.2.A van het N.B.W., Bouwrecht 1982, pag. 380-282.

Serraris-Perrick, NJB 1983

G. Serraris-Perrick, Wit, zwart of grijs met een zwart randje?, NJB 1983, pag. $472-478$.

SGC 19 ..

Stichting geschillencommissies voor consumentenzaken, Jaarverslag $19 .$. 
Slagter

W.J. Slagter, Dient de wet ten aanzien van ongeoorloofde mededinging nadere bijzondere regelen te bevatten, en zo ja, welke?, Praeadvies, HNJV 1963, nr 1a, Zwolle 1963.

\section{Sluyter}

H.J. Sluyter, Standaardcontracten, De grenzen van de particuliere wetgever, Deventer 1972.

Snijders, inaug. rede

H.J. Snijders, Troubles en doubles in het burgerijik procesrecht, inaugurele rede Rotterdam, Deventer 1985.

Spier, KwNBW 1984

J. Spier, Het wetsontwerp algemene voorwaarden: voor de praktijk funest, KwNBW 1984, pag. 129-131.

\section{Spier, KwNBW 1985}

J. Spier, Nogmaals het wetsontwerp algemene voorwaarden, KwNBW 1985, pag. 6-10.

Stein, Compendium

P.A. Stein, Compendium van het burgerlijk procesrecht, vijfde druk, Deventer 1981.

Stein, diss.

P.A. Stein, Misbruik van omstandigheden als grond voor ongeldigheid van rechtshandelingen, diss. Leiden, 's-Gravenhage 1957.

Stein, BGB

Bürgerliches Gesetzbuch, Band 2/2, Schuldrecht I/2, Stand: Frühjahr 1986, Verlag W. Kohlhammer, Stuttgart-Berlin-Köln-Mainz 1986.

Stillner

W. Stillner, Praktische Erfahrungen mit dem AGB-Gesetz, Zeitschrift für Verbraucherpolitik 1980, nr. 2, pag. 142-149.

\section{Stumpf}

H. Stumpf, Sand im Getriebe unternehmerischen Handelns. Eine Kritische Betrachtung anhand einiger Beispiele aus der jüngeren Rechtsprechung zum AGB-Gesetz, BB 1985, pag. 963-965. 


\section{Stuyck}

J. Stuyck, Zelfdiscipline inzake Reclame: Kritische evaluatie van de Belgische praktijk, SEW 1981, pag. 81-108;

\section{Tala}

J. Tala, Soft Law as a Method for Consumer Protection and Consumer Influence. A Review with Special Reference to Nordic Experiences, ICP 1978, pag. 341-361

Tjittes, diss.

R.P.J.L. Tjittes, De hoedanigheid van contractspartijen, diss. Groningen, Deventer 1994.

Traub

F. Traub, Der Streitwert der Verbandsklage, WRP 1982, pag. 557-560.

Ulmer, BB 1982

Ulmer P., Erfahrungen mit dem AGB-Gesetz, Zwischenbilanz nach fünfjähriger Geltung, BB 1982, pag. 584-589.

Ulmer/Brandner/Hensen, AGB-Gesetz

P. Ulmer, H.E. Brandner en H-D. Hensen, AGB-Gesetz, 6. neubearbeitete und erweiterte Auflage, Verlag Dr. Otto Schmidt K.G., Köln 1990.

Urbanczyk

R. Urbanczyk, Zur Verbandsklage im Zivilprozeß, Berlin 1981.

H.G. van der Werf, Gebondenheid aan standaardvoorwaarden, Standaardvoorwaarden in het rechtsverkeer met particuliere en professionele contractanten, diss. Nijmegen, Arnhem 1980.

Van der Werf, NJB 1980

H.G. van der Werf, Voorbarige wetgeving inzake standaardvoorwaarden, NJB 1980 , pag. 682-685.

Van der Werf, Advocatenblad 1982

H.G. van der Werf, Vrije standaardvoorwaarden in de ban, Advocatenblad 1982, pag. 113-123. 
Van Westerop

M.G. van Westerop, Deponering van algemene voorwaarden en standaardcontracten, WPNR 1971, pag. 95-103.

Verburgh, inaug. rede

M.J.P. Verburgh, Privaatrecht en kollektief belang: verdediging van kollektieve belangen via de Nederlandse burgerlijke rechter, inaugurele rede Utrecht, Zwolle 1974.

Verburgh, NJB 1979

M.J.P. Verburgh, Naar een wet op standaardvoorwaarden: controle van de particuliere wetgever via de publieke wetgever, NJB 1979, pag. 528-532.

Verburgh, Trechter

M.J.P. Verburgh, Het konsumentenrecht in de 80-er jaren, Trechter 1980.

\section{Verhoeven}

M.A.L. Verhoeven, Algemene voorwaarden getoetst, Deventer 1989.

\section{Vidmar}

N. Vidmar, The small claims court: a reconceptualization of disputes and an empirical investigation, $18 \mathrm{Law}$ and Society Review (1984), pag. 515-550.

\section{Vollebregt}

J.E. Vollebregt, Wetsontwerp algemene voorwaarden, NJB 1984, pag. 809-815.

VSV-Tätigkeitsbericht (jaar)

Verbraucherschutzverein (VSV), Berlin, Tätigkeitsberichte 1977-1992.

VZ-Tätigkeitsbericht (jaar)

Verbraucherzentrale Baden-Württemberg, Stuttgart, Tätigkeitsberichte 19771992.

\section{Wanner, L\&SR 1974}

G. Wanner, The public ordening of private relations, part one: initiating civil cases in urban trial courts, 8 Law an Society Review (1974), pag. 421-440.

\section{Wanner, L\&SR 1975}

G. Wanner, The public ordening of private relations, part two: winning civil court cases, 9 Law an Society Review (1975), pag. 293-319. 
Weermekers

I. Weernekers, De consument en zijn klacht, TvC 1986, pag. 244-247.

Wessels, WPNR 1990

B. Wessels, De vorm van de onherroepelijkheid van een volmacht, WPNR 1990, pag. 722-724.

Wessels en Jongeneel, 1987

B. Wessels en R.H.C. Jongeneel, Algemene voorwaarden, De nieuwe regeling in afd. 6.5.2A toegelicht voor de praktijk, Zwolle 1987.

Wessels en Jongeneel, 1992

B. Wessels en R.H.C. Jongeneel, Algemene voorwaarden, Zwolle 1992.

Wolf/Horn/Lindacher, AGBG Kommentar

M. Wolf, H. Horn en F. Lindacher, Gesetz zur Regelung des Rechts der Allgeme:̈nen Geschäftsbedingungen, Kommentar, 3. völlig neubearbeitete Auflage, C.H. Beck'sche Verlagsbuchhandlung, München 1994.

Wolthers

M.D. Wolthers, De standaardregeling vergeleken met algemene voorwaarden, in Jaarboek konsumentenrecht 1991, Deventer 1991, pag. 27-47.

Yngvesson en Hennessey

B. Yngvesson en P. Hennessey, Small claims, complex disputes: a review of the small claims literature, 9 Law and Society Review (1975), pag. 219-274.

\section{Zehn Jahre AGB-Gesetz}

H. Heinrichs, W. Löwe en P. Ulmer, Zehn Jahre AGB-Gesetz, RWS-Forum 2, Köln 1987.

\section{Zeylemaker}

J. Zeylemaker, Is het wenselijk onze burgerlijke wetgeving aan te vullen met bepalingen omtrent "standaard contracten" en zo ja, naar welke beginselen?, Praeadvies, HNJV 1948, III, pag. 67-124. 


\section{Curriculum Vitae}

De auteur werd geboren op 11 september 1957 te Nuth. In 1976 behalde hij het diploma. Atheneum-B aan het St. Janscollege te Hoensbroek. Van 1976 tot 1982 volgde hij de opleiding Maatschappelijk Werk, eerst aan de Katholieke Sociale Academie te Sittard en vervolgens aan de Sociale Academie "De Dommel" te Eindhoven, alwaar hij in 1982 het diploma Maatschappelijk Werk behaalde. Van 1983 tot 1987 studeerde hij Nederlands Recht aan de Rijksuniversiteit Limburg te Maastricht, alwaar hij in 1987 het doctoral examen behaalde. Vanaf 1987 is hilj werkzaam bij de vakgroep Privatrecht van de Rijksuniversiteit Limburg, eerst als Assistent in Oplleiding en sinds 1992 als universitair docent privaatrecht en consumentenrecht. Sinds 1992 is hij tevens wetenschappelijk medewerker van het "lems. Verburgh Instituut voor Consumentenrecht" aan de Rijksuniversiteit Limburg. 